\title{
National Policy Space in the WTO General Agreement on Trade in Services
}

Citation for published version (APA):

Mendis, N. M. (2020). National Policy Space in the WTO General Agreement on Trade in Services: With Special Reference to Public Health Services. [Doctoral Thesis, Maastricht University]. Maastricht University. https://doi.org/10.26481/dis.20200618nm

Document status and date:

Published: 01/01/2020

DOI:

10.26481/dis.20200618nm

Document Version:

Publisher's PDF, also known as Version of record

\section{Please check the document version of this publication:}

- A submitted manuscript is the version of the article upon submission and before peer-review. There can be important differences between the submitted version and the official published version of record.

People interested in the research are advised to contact the author for the final version of the publication, or visit the DOI to the publisher's website.

- The final author version and the galley proof are versions of the publication after peer review.

- The final published version features the final layout of the paper including the volume, issue and page numbers.

Link to publication

\footnotetext{
General rights rights.

- You may freely distribute the URL identifying the publication in the public portal. please follow below link for the End User Agreement:

www.umlib.nl/taverne-license

Take down policy

If you believe that this document breaches copyright please contact us at:

repository@maastrichtuniversity.nl

providing details and we will investigate your claim.
}

Copyright and moral rights for the publications made accessible in the public portal are retained by the authors and/or other copyright owners and it is a condition of accessing publications that users recognise and abide by the legal requirements associated with these

- Users may download and print one copy of any publication from the public portal for the purpose of private study or research.

- You may not further distribute the material or use it for any profit-making activity or commercial gain

If the publication is distributed under the terms of Article $25 \mathrm{fa}$ of the Dutch Copyright Act, indicated by the "Taverne" license above, 


\section{NATIONAL POLICY SPACE IN THE \\ WTO GENERAL AGREEMENT ON TRADE IN SERVICES: \\ WITH SPECIAL REFERENCE TO PUBLIC HEALTH SERVICES}

\section{DISSERTATION}

to obtain the degree of Doctor at Maastricht University, on the authority of the Rector Magnificus,

Prof.dr. Rianne M. Letschert

in accordance with the decision of the Board of Deans, to be defended in public

on Thursday the 18th day of June 2020, at 12.00 hours

by

Nishara Manique Mendis 
Supervisor:

Prof.dr. Peter LH Van den Bossche

Co-supervisor:

Dr. MD Prévost

Assessment Committee:

Prof.dr. J. Vidmar (Chair)

Prof.dr. P. Delimatsis, Tilburg University

Dr. ND Udagama, University of Peradeniya, Sri Lanka

Dr. I. Westendorp 


\section{ACKNOWLEDGMENTS}

I must begin with expressing my deepest gratitude to my supervisor Prof. Peter van den Bossche for taking a leap of faith in initially choosing me for this $\mathrm{PhD}$ project, and continuing to encourage me during the years I worked on it, with patience and kindness.

I am also extremely grateful for the detailed and meticulous feedback on my writing provided by both Peter and my Academic Co-ordinator and Co-supervisor Dr. Denise Prevost over the years, especially on the first and second drafts of this book. I will always be indebted to both of you for the training I received during this process. Throughout the years, both of you have always responded quickly to my communications and questions, and regularly reminded me to keep on track for completing the project. I greatly appreciate that Denise guided me through the final stages of preparing for the defence.

I would not have been able to begin this journey if not for Maastricht University, IGIR and Peter funding me, and for providing such a good working environment at the initial stages of my research. I am also grateful to the PhD Dean during my stay in Maastricht, Prof Hildegard Schneider, for the special and kind interest in the well-being of us all.

The many friends and colleagues at Maastricht University made it feel like a home away from home during the time I spent there. Arkady, Phyllis, Christina, Katharina, Rogier, Eveline, Kathryn, Su-Mia, Raluca, Jennifer, Florian, Lotte, Djebo, Tania, Daniar, Tamara, Anke, Gustavo and Ana-Maria, Marco, Mira, Renata, Ana-Maria Daza, Dorcas, Marina, Bianca, Siamak, Jasper and many others too - thank you for all the good times we shared. Everyone at IGIR, especially for the lunch meetings and annual seminars where we shared our research and also those I met in the Jus Commune group. Jaqueline Schoonheim, it was lovely to have you as co-ordinator for the UCM courses I tutored, and thank you for all the chats. I also thank all the friendly and supportive staff, both academic and non-academic who made my stay in Maastricht such a comfortable one. Special thanks goes to Esther, Arjie and all the lovely people I met at Tafelstraat 13, and to those I met at PhD Academy events and other informal support and friendship groups.

In terms of the path that finally led me to Maastricht and to this particular $\mathrm{PhD}$ project, there are many people who have had important roles; but it was my father, who, as a medical doctor and educator with a special interest ethics and public policy, first shared with me his interest in the impacts of the WTO and its provisions on health. During my undergraduate days, he gave me the first articles and books I read on the issues of TRIPS and access to medicines and the GATS in relation to public health services. So thank you Thaththi, for the initial motivation in wanting to learn more about the topic of policy space for public health services in the WTO GATS.

I also cannot forget the inspiration of the work of the late Dr. K. Balasubramaniam in the area of health rights, and I am thankful for his invitation to a regional meeting on GATS and Health, which led to the drafting of my $\mathrm{PhD}$ proposal. I must also acknowledge Dr. Krishantha Weerasuriya who firmly advised me to get more involved in health, TRIPS and GATS issues and arranged for me to join several training programmes. I will always be extremely grateful to Dr. Chris Pinto for being my mentor when I was a young academic. His kindness and encouragement has been invaluable to me, not only at a time when I needed guidance generally, but also for being the person who sent me the information on the Maastricht $\mathrm{PhD}$ project that was going to be supervised by Peter, and advising me to accept the offer.

There is much I owe Yale Law School: for funding my Master's degree and for providing me with opportunities through classes, seminars and independent reading to further my interests in international human rights law and policy, the WTO dispute settlement system, and the ethical formation of lawyers. With regard to this $\mathrm{PhD}$ project, perhaps the most important learning 
experience was the reading group on distributive justice with Prof. Daniel Markovitz, which my LL.M classmate Ilan organized, which I am thankful I joined.

I owe so much to the free education system in Sri Lanka. At the background of this research, are the foundations laid during my undergraduate days at the University of Colombo by my brilliant teachers. I am grateful to Rohan Edrisinha for teaching me constitutional law and the interpretation of statues and documents, and for later encouraging me to research and write on globalization and WTO issues as a young graduate; Dr. Deepika Udagama for human rights law and public international law, and giving me opportunities to research and discuss economic and social rights and right to health issues; Malkanthi Abeyratne for first introducing me to analysis of WTO provisions and jurisprudence through TRIPS, in my Intellectual Property Law class; Shyamala Gomez for her kindness, support and setting of goals for me throughout undergraduate days; Dr. Sumudu Atapattu and Dr. 'Suki' Ekaratne for encouragement on PhD applications.

I also thank all my past and current academic colleagues at the Faculty of Law, University of Colombo who wished me well and cheered me on to finish the project. A special word of thanks is owed to my former Head of Department, Prof. Jeeva Niriella, for all her support and kind but stern reminders to focus on completing the first draft of my PhD writing during 2013-2014.

I am grateful to all my family members, at home and abroad, for encouragement, prayers, chats, good wishes and good times together - and for those around Colombo who had open doors to drop by and enjoy home-cooked meals. Special love to my Godmother, Delaine Aunty, for constantly calling and checking up on me, and for proofreading my first draft. A special thank you to close family friends, Aunty Savitri and Uncle Nimal, who were there with kind advice and encouragement and Aunty Mirani, for your support when I needed it.

Thank you to every one of my friends in Sri Lanka who cheered me up with café chats and gifts and made me smile, and my dear friends across the oceans for wishing me well from across the miles, who sent me messages for upliftment over the long years of this project. Sanjeewani $a k k i$ and Pim ayya, thank you for giving me that important confidence boost to finish up the last lap. Special thanks to Samindika for cheerfully assisting me with the references for the WTO Secretariat Notes for Chapter 3, at that time when I was stressed and having a 'writers block' period and needed some friendly support, and for everything since then. Hasini, for all those 'let's do our $\mathrm{PhD}$ writing!' coffee meetings and encouragement and sharing of ups and downs through the many years of our friendship. Shevanthi, for your friendship of 35 years, and for your faith and reassurances: 'A faithful friend is a source of strength; whoever finds one has found a treasure'. Dilum, the first friend I call in both the worst of times and in the best of times: 'If she must know the ebb of your tide, let her know its flood also'. Thank you Dilly, for everything.

At the end of a journey, to look back at the beginning ... I think the seeds for this book began on a lovely sunny day in a garden, in early January 1995, when I was still in secondary school. I had just finished one set of my school exams and was thinking about the subjects I would do for my university entrance exams in almost three years' time, which would be decisive for my future. My mother had just been discussing over breakfast, a long article in the newspaper on the establishment of the World Trade Organization and how this was going to change the way many things were going to be done. So as we were hanging out clothes in the garden that morning, we talked about law and policy and the importance of studying and mastering it; and I settled on choosing subjects for my Advanced Level exams with a future application for a law degree kept in mind. Much later on, it was she who encouraged me to sit down on an over-worked weekend and to finish writing up and sending in that $\mathrm{PhD}$ application to Maastricht University ... and who still encouraged me to go, when I received the acceptance letter during the same week she was diagnosed with Stage 4 cancer.

Well, here are my efforts, at long last ... this book is for you Ammi, even if you are not here now to read it; because in another, different world, you would have been my first and best reader. 


\section{CONTENTS}

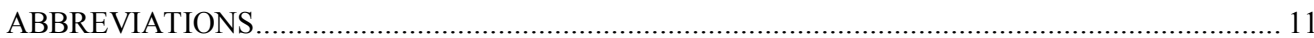

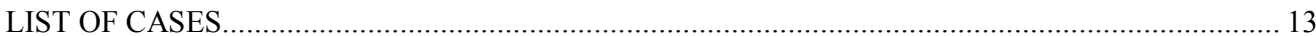

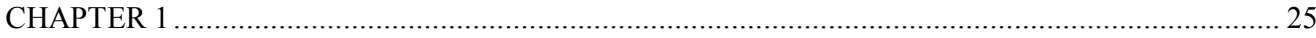

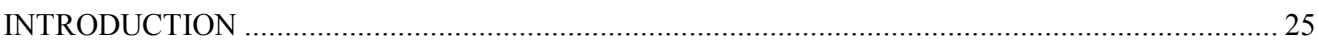

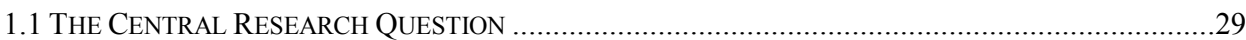

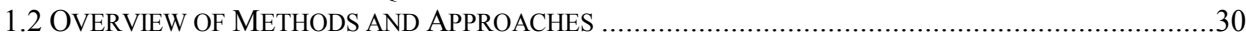

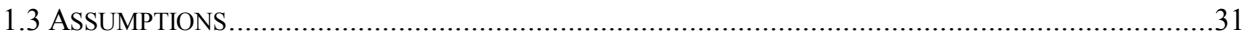

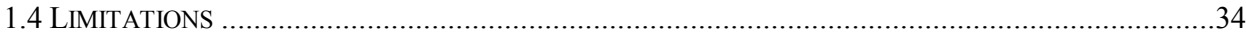

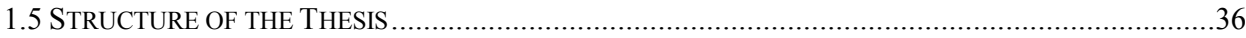

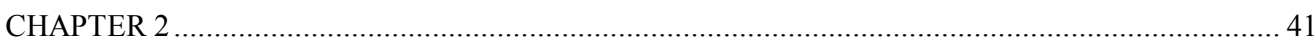

UNDERLYING CONCEPTS, INTERPRETIVE APPROACHES AND THE RIGHT TO

HEALTH

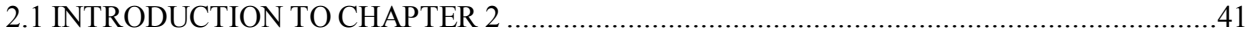

2.2. BACKGROUND AND OBSERVATIONS ON IMPORTANT UNDERLYING

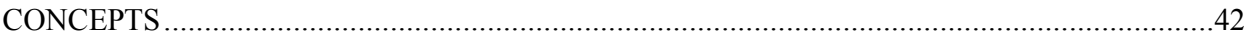

2.2.1. Trade in Services enters the WTO

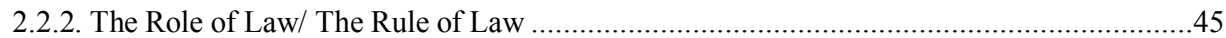

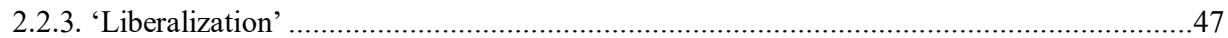

2.2.4. Economic Growth, Human Development and the Right to Development ..........................48

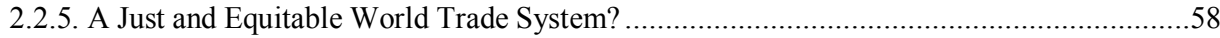

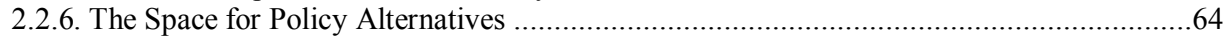

2.2.7. Sovereignty, Democracy and Public Services ................................................................ 71

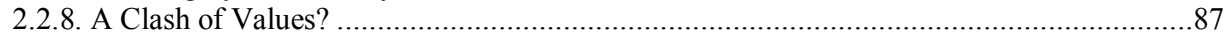

2.2.9. Is there space for a choice between conflicting values in the WTO? ................................102

2.2.10. Values in the GATS: progressive liberalization, national policy and flexibility ..............103

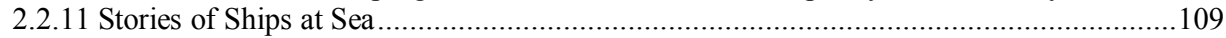

2.3 OVERVIEW OF METHODOLOGY AND OBSERVATIONS ON POSSIBLE

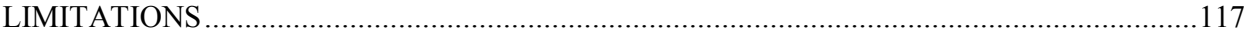

2.3.1. The WTO Dispute Settlement Understanding (DSU) and the Vienna Convention on

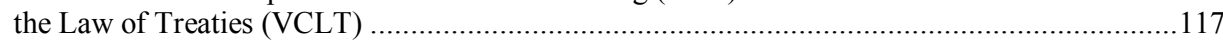

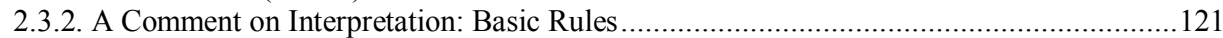

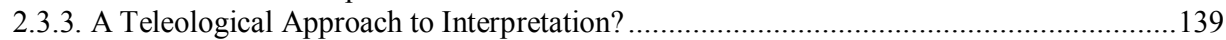

2.3.4. WTO GATS - not to be read in isolation from public international law? .........................149

2.3.5. Article 31(3)(c) of the VCLT: A Doorway or a Dead-end Street? ..................................151

2.3.6. A 'Human Rights Approach' to WTO Interpretation?.....................................................162

2.3.7. Reference to Human Rights in GATT 1947 and WTO Disputes ......................................168

2.3.8. The Challenges of Incorporating Human Rights into WTO law .....................................170

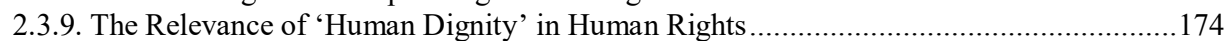

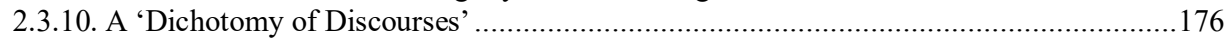

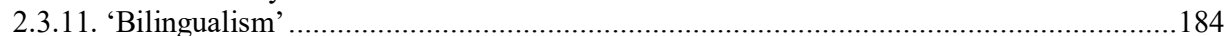

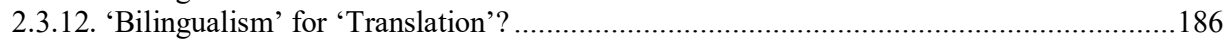

2.4 INTERNATIONAL LAW AND POLICY ON THE RIGHT TO HEALTH ...............................192

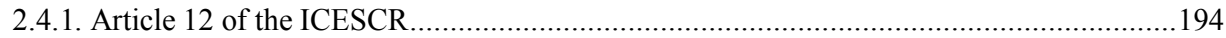

2.4.2. The Status of General Comments in International Law ...................................................197

2.4.3. The Right to Health as elaborated in CESCR General Comment No. 14. ............................204

2.4.4. A Brief Comment on the Right to Health in other International Documents .....................212

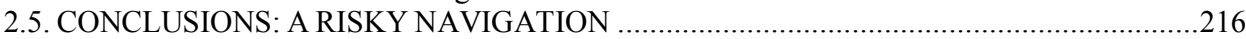




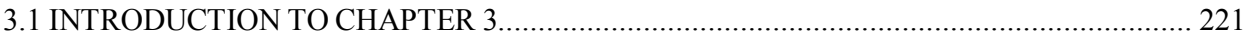

3.2. A REAPPRAISAL OF CONCERNS RELATING TO PUBLIC SERVICES AND THE

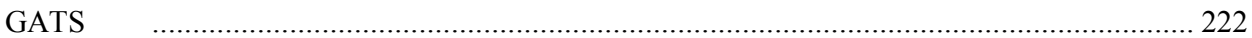

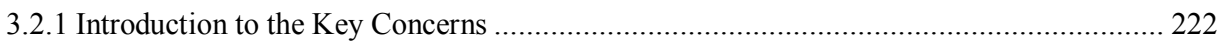

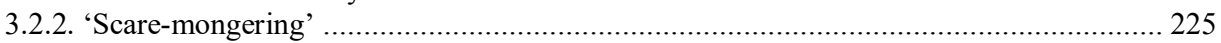

3.2.3. Privatization, Corporatization and Commercialization of Public Services ...................... 227

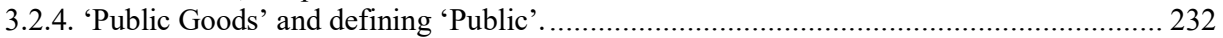

3.3. INTRODUCING KEY TERMS IN ARTICLE I:1 AND 1:2 OF THE GATS: GENERAL

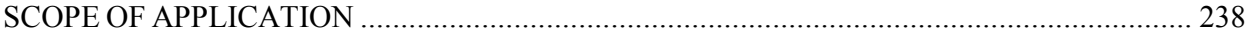

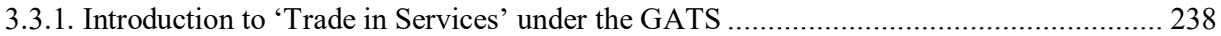

3.3.2. Article I:2 and Article XXVIII: "Trade in services is defined as..." .............................. 242

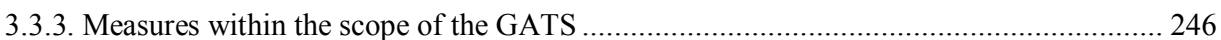

3.3.3.1. Defining 'Measures': the breadth of coverage and the different forms of

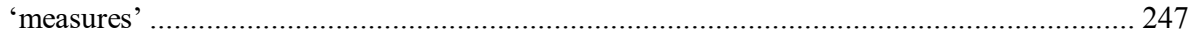

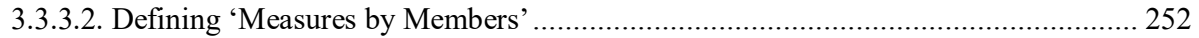

3.3.3.3. Defining "Measures affecting Trade in Services".................................................... 253

3.3.3.4. Public infrastructure and measures within the scope of the GATS ........................... 255

3.3.4. Article I:3 - Obligation of Members to ensure observance within its territory ................. 260

3.3.5. Conclusions on the key terms in Article I:1 and I:2 of the GATS ...................................2. 269

3.4. ARE PUBLIC SERVICES EXEMPTED UNDER ARTICLE I OF THE GATS? ..................... 271

3.4.1. Introduction: Is there a 'Public Services Exemption' in Article 1:3 the GATS? ............... 271

3.4.2. The relevant methods for the interpretation of Article 1 of the GATS ............................ 274

3.4.2.1. The VCLT method for the interpretation of Article 1 of the GATS........................... 274

3.4.2.2. The Relevance, if any, of Secretariat Notes for understanding Public Services ........ 278

3.4.2.3. Using a Human Rights and Human Development Approach to Public Services ....... 281

3.4.3. Defining "Services Supplied in the Exercise of Governmental Authority" (SSEGA). ..... 283

3.4.4. Defining the terms "Supplied on a Commercial Basis" and "...in Competition with"..... 287

3.4.4.1. "Supplied on a Commercial Basis" ...................................................................... 287

3.4.4.1.1. The role of profit in defining "commercial" and "on a commercial basis" ........ 289

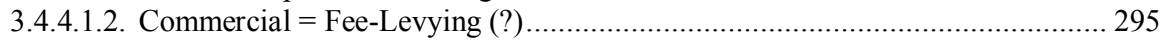

3.4.4.1.3. Public-Private Partnerships = Commercial (?)................................................. 297

3.4.4.1.4. "Commercial" Activity: Views on Benefits and Motivations ............................. 299

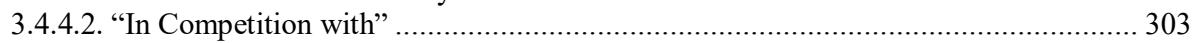

3.4.4.2.1. Competition within the Market or for the Market.............................................. 303

3.4.4.2.2. Public Services facing Private Competition - Dispute Settlement Context ......... 306

3.4.4.2.3. Co-existence, Involvement and Public-Private Partnership ............................... 307

3.4.4.2.4. Expectations on a 'carve-out' or 'ring-fence' of public services ......................... 312

3.4.4.2.5. Regarding the 'likeness' of public and private services .................................... 317

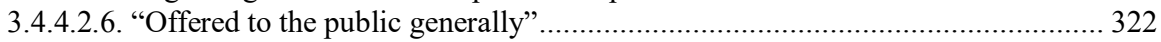

3.4.5. Conclusions on the scope of Article I of the GATS in the context of public services ...... 325

3.5. IMPLICATIONS FOR PUBLIC SERVICES IN OTHER AREAS OF THE GATS ............... 329

3.5.1. Article VIII of the GATS: Monopolies and Exclusive Service Providers .......................... 329

3.5.2. Article XIII of the GATS: Government Procurement ...................................................... 341

3.5.2.1. Government Procurement, Public Health Services and Human Rights ...................... 341

3.5.2.2. The Definition of 'Government Procurement' in the GATS ..................................... 344

3.5.2.3. Relevance of GATT for Interpretation of Article XIII of the GATS ........................ 355

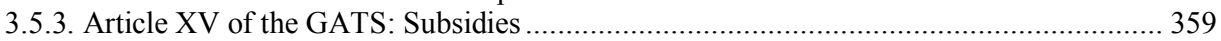

3.5.3.1. Concerns about Funding for Public Services .......................................................... 359

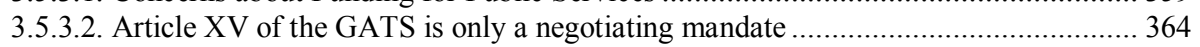

3.5.3.3. Difficulties in Defining Subsidies for the GATS ................................................... 371 
3.5.3.4. Using the WTO SCM Agreement definition of 'subsidy' ........................................374

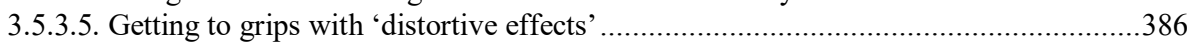

3.5.3.6. Subsidies are already covered by other WTO Provisions and GATS Articles ..............391

3.6. CONCLUSIONS ON THE SCOPE OF ARTICLE I OF THE GATS, RIGHT TO HEALTH

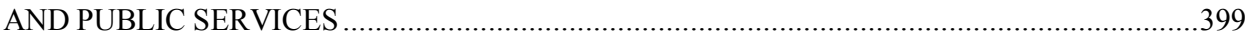

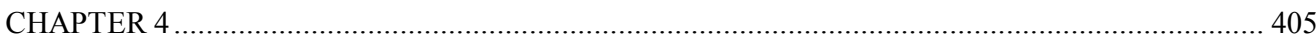

GENERAL OBLIGATIONS, SPECIFIC COMMITMENTS AND PUBLIC HEALTH SERVICES .405

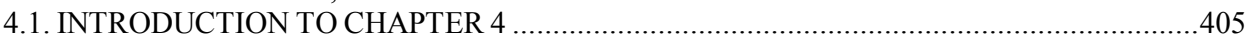

4.2. NON-DISCRIMINATION AS A VALUE IN TRADE AND HUMAN RIGHTS......................408

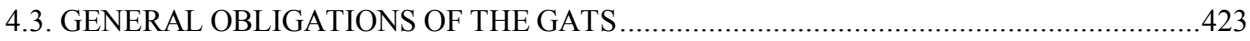

4.3.1. Article III: Transparency (and Article IIIbis: Protection of Confidentiality) .....................423

4.3.2. Article II: The Most Favoured Nation Treatment Obligation..........................................426

4.3.2.1. Introduction to the Most-Favoured-Nation (MFN) Treatment Principle.....................426

4.3.2.2. History of the MFN Treatment Principle................................................................427

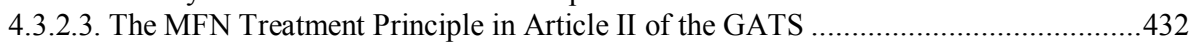

4.3.2.4. Article II:2 and the Annex on Article II Exemptions .................................................435

4.3.2.5. Other MFN Exemptions (Article II:3) and Exceptions (Articles V, VII, XIV and XIVbis)

4.4. ARTICLES XIX, XX AND XXI OF THE GATS - SPECIFIC COMMITMENTS:

NEGOTIATION, SCHEDULING, MODIFICATION - THE POLICY SPACE ..............................446

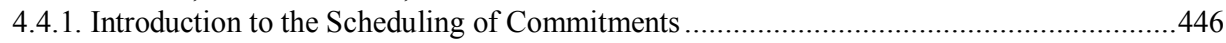

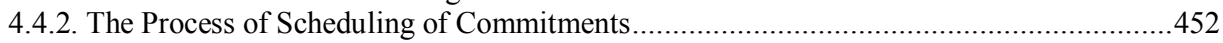

4.4.3. The Services Sectoral Classification System and National Health Policy ........................457

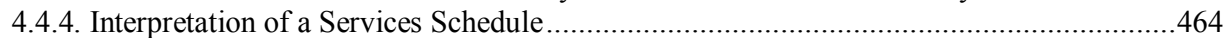

4.4.5. Article XXI of the GATS: Modification of Schedules of Commitments ...........................470

4.4.5.1. Overview of Requirements/Procedure of Article XXI of the GATS .........................471

4.4.6. Additional Commitments - Article XVIII of the GATS..................................................476

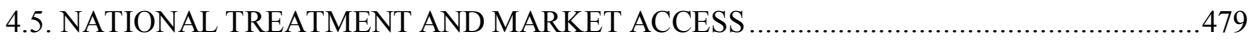

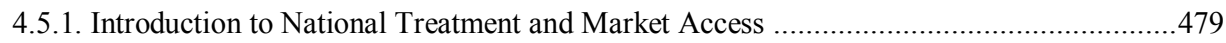

4.5.2. Article XVII of the GATS: National Treatment ...............................................................48

4.5.2.1. Introduction and Comparison with comparable GATT 1994 and TBT Provisions....481

4.5.2.2. Further Comments on the interpretation of Article XVII of the GATS ......................488

4.5.2.3. 'Likeness' of Services and Service Suppliers for National Treatment ........................491

4.5.3. Article XVI of the GATS: Market Access ..................................................................50

4.6. ARTICLE VI OF THE GATS: DOMESTIC REGULATION …..........................................508

4.6.1. The Relationship between Article VI and other GATS Provisions ................................508

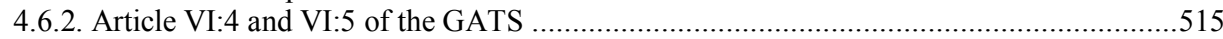

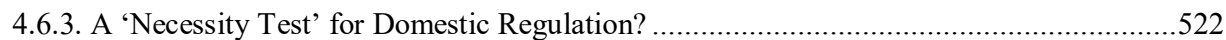

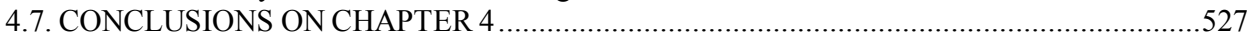

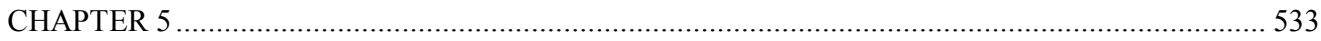

GENERAL AND SECURITY EXCEPTIONS TO OBLIGATIONS UNDER THE GATS.................533

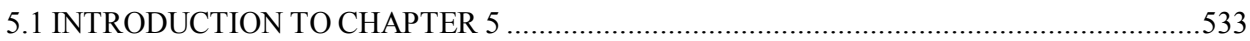

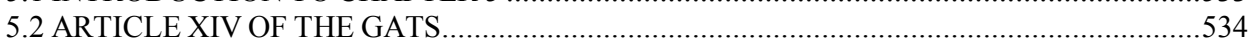

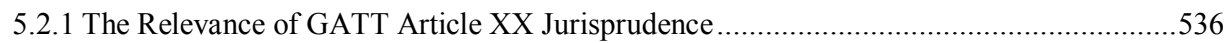

5.2.2. Comparing Article XIV of the GATS with Exceptions Provisions ...................................545

5.2.1. The two-tiered approach to the analysis of Article XIV of the GATS.............................550

5.3 ARTICLE XIV(A) OF THE GATS: "NECESSARY TO PUBLIC MORALS OR TO

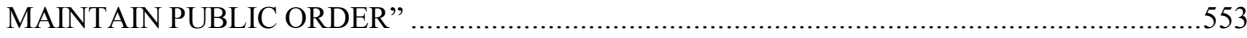

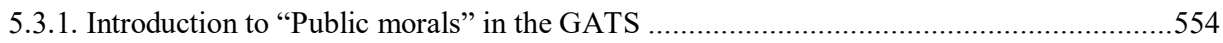

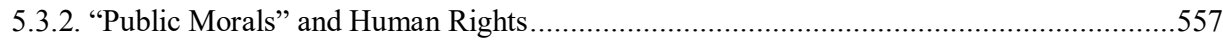

5.3.3. US-Gambling: The Dictionary Approach to "ordinary meaning of the words" ...................566

5.3.4. "Standards of right and wrong conduct...... maintained by or on behalf of a community or nation" 


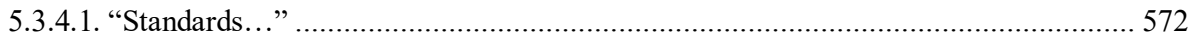

5.3.4.2. "Maintained on behalf of a Community or Nation" ................................................... 577

5.3.4.3. Identification of 'Risk' needed in order to "Protect" Public Morals? ......................... 580

5.3.5. Measures Necessary to Protect Public Order....................................................................... 582

5.4. ARTICLE XIV(B) OF THE GATS: MEASURES NECESSARY TO PROTECT HUMAN, ANIMAL OR PLANT LIFE OR HEALTH ………............................................................. 594

5.4.1. Reviewing the Journey from GATT to GATS in light of the Right to Health................... 595

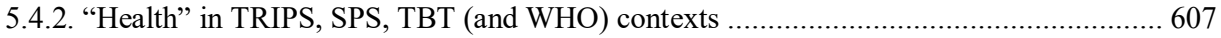

5.4.3. 'Risk', evidence and precaution: SPS and TBT approaches and implications for GATS . 614

5.5. ARTICLE XIV(C) - MEASURES NECESSARY TO SECURE COMPLIANCE WITH

LAWS OR REGULATIONS WHICH ARE NOT INCONSISTENT WITH THE PROVISIONS

OF THE GATS

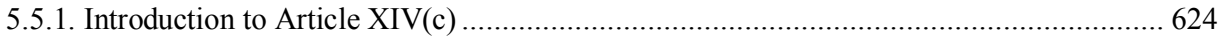

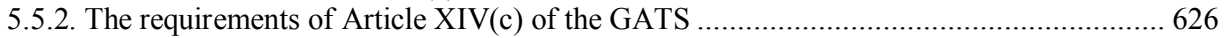

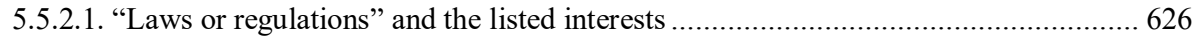

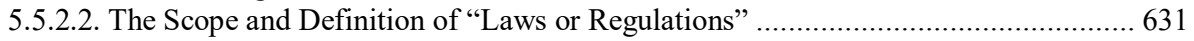

5.5.2.3. "Not inconsistent with the provisions of this Agreement"....................................... 635

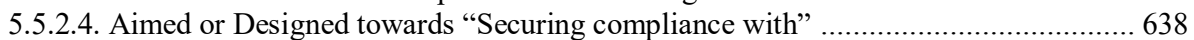

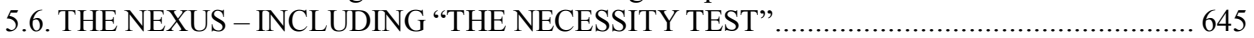

5.6.1. The Existence of a Sufficient Nexus between the Measure and the Interest Protected..... 645

5.6.1.1. Introduction to "the Necessity Test" in WTO Law .................................................. 645

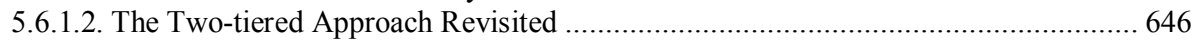

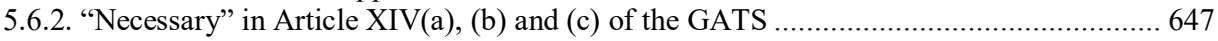

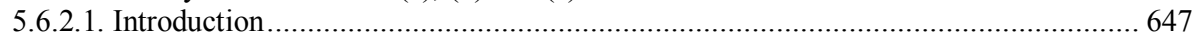

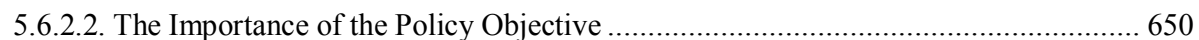

5.6.2.3. Reasonably Available Alternative Measures and the Level of Protection.................. 653

5.6.2.4. A Brief Comment on International Co-operation........................................................ 658

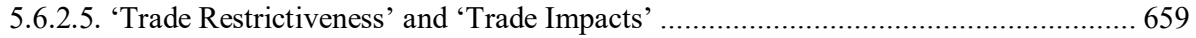

5.6.2.6. Assessing the 'Pass-Mark' for the Necessity Test...................................................... 664

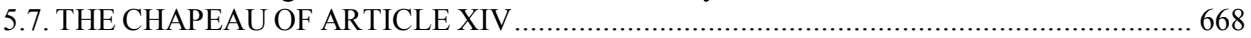

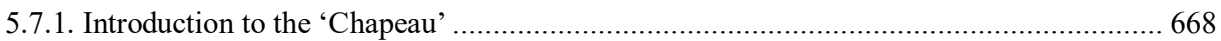

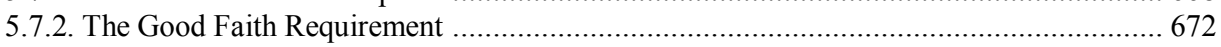

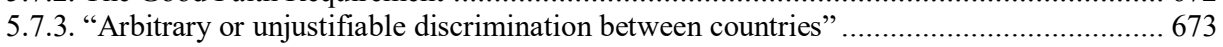

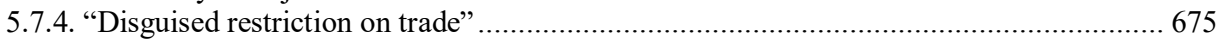

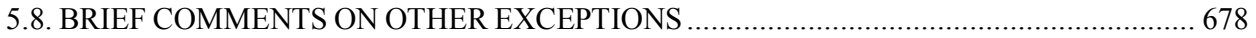

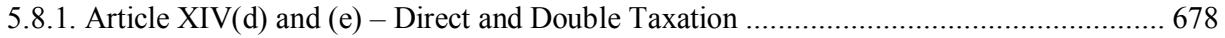

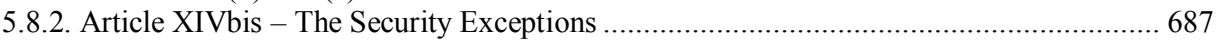

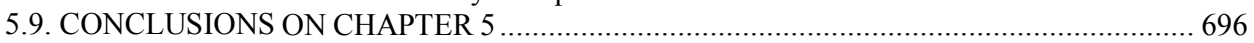

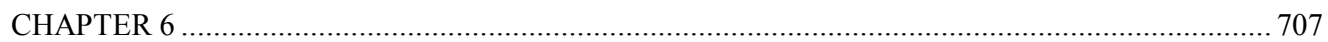

'EXTRA' POLICY SPACE FOR DEVELOPING COUNTRY AND LDC MEMBERS?...................... 707

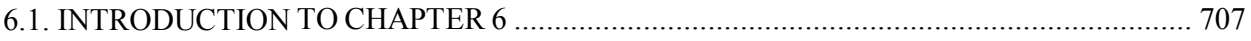

6.2. BACKGROUND AND RELEVANT PROVISIONS ...................................................... 708

6.3. WHAT IS A DEVELOPING COUNTRY OR LEAST DEVELOPED COUNTRY IN WTO

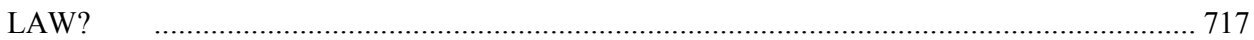

6.4. SPECIAL PROVISIONS FOR DEVELOPING AND LEAST DEVELOPED MEMBERS

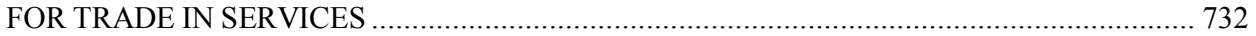

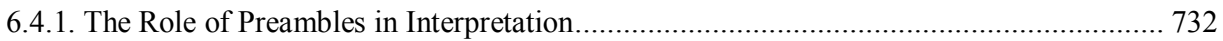

6.4.2. The Preamble of the WTO Agreement establishing the WTO ...................................... 734

6.3.1.1. An interpretation that trade is targeted towards raising standards of living and ensuring full employment within the Members...................................................................... 735

6.3.1.2. An interpretation supportive of environmentally friendly trade - that avoids ecological damage and harm to human, animal and plant life and health. ............................. 735

6.3.1.3. Differential treatment for developing country Members ......................................... 739 
6.3.1.4. Needs of Economic Development - Especially Developing Countries

6.4.3. The Preamble to the GATS

6.4.4. Using the Preamble of the GATS for interpretation of terms in the GATS

6.4.5. Article IV of the GATS: Increasing Participation of Developing Countries

6.3.5.1. Agreements for buying technology from developed country Members on commercial terms.

6.3.5.2. Greater access to information networks and distribution channels. ...........................759

6.3.5.3. Voluntary liberalization of market access by developed country Members. ................760

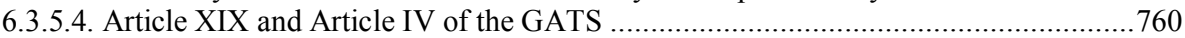

6.4.6. Special Treatment for Least Developed Countries (LDCs).............................................763

6.5 THE ROLE OF SUBSIDIES IN DEVELOPMENT PROGRAMMES.....................................774

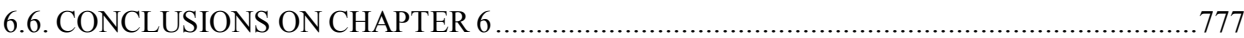

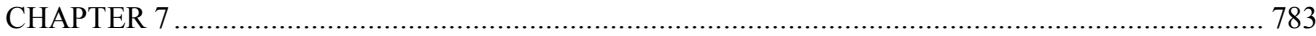

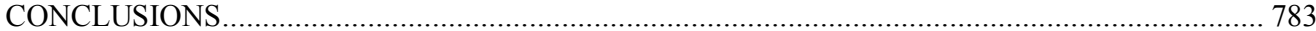

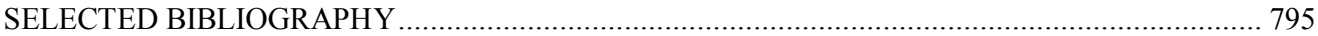

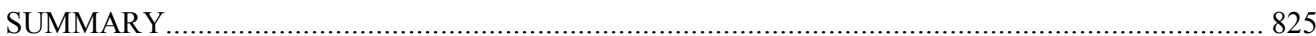

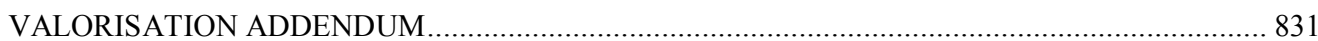

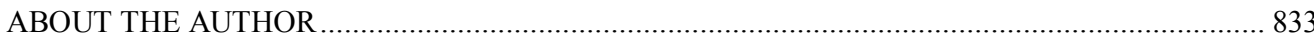




\begin{tabular}{|c|c|}
\hline DSB & Dispute Settlement Body \\
\hline DSU & Dispute Settlement Understanding \\
\hline $\mathrm{EC}$ & European Communities \\
\hline EU & European Union \\
\hline ECHR & European Convention on Human Rights \\
\hline ECtHR & European Court of Human Rights \\
\hline ECOSOC & United Nations, Economic and Social Council \\
\hline GATS & General Agreement on Trade in Services \\
\hline GATT & General Agreement on Tariffs and Trade \\
\hline GSP & Generalized System of Preferences \\
\hline HDI & Human Development Index \\
\hline ICCPR & International Covenant on Civil and Political Rights \\
\hline ICESCR & International Covenant on Economic, Social and Cultural Rights \\
\hline ICJ & International Court of Justice \\
\hline IACtHR & Inter-American Court of Human Rights \\
\hline ILC & International Law Commission \\
\hline MFN & Most Favoured Nation \\
\hline OECD & Organization for Economic Cooperation and Development \\
\hline OHCHR & Office of the High Commissioner on Human Rights \\
\hline $\mathrm{SCM}$ & Agreement on Subsidies and Countervailing Measures \\
\hline SPS & Agreement on the Application of Sanitary and Phytosanitary Measures \\
\hline TBT & Agreement on Technical Barriers to Trade \\
\hline TRIPS & Agreement on Trade-Related Aspects of Intellectual Property Rights \\
\hline TRIMS & Agreement on Trade-Related Investment Measures \\
\hline UN & United Nations \\
\hline UNDP & United Nations Development Programme \\
\hline UNCTAD & United Nations Conference on Trade and Development \\
\hline UN GA & United Nations General Assembly \\
\hline VCLT & Vienna Convention on the Law of Treaties, 1969 \\
\hline WHO & World Health Organization \\
\hline WTO & World Trade Organization \\
\hline
\end{tabular}




\section{LIST OF CASES}

\section{WTO Panel and Appellate Body Reports}

Argentina-Financial Services. Appellate Body Report, Argentina-Measures Relating to Trade in Goods and Services WT/DS453/AB/R and Add.1, adopted 9 May 2016; Panel Report, Argentina - Measures Relating to Trade in Goods and Services, WT/DS453/R and Add.1, adopted 9 May 2016, as modified by Appellate Body Report WT/DS453/AB/R

Argentina-Hides and Leather. Panel Report, Argentina - Measures Affecting the Export of Bovine Hides and the Import of Finished Leather, WT/DS155/R and Corr.1, adopted 16 February 2001

Argentina-Footwear. Appellate Body Report, Argentina - Safeguard Measures on Imports of Footwear, WT/DS121/AB/R, adopted 12 January 2000; Panel Report, Argentina - Safeguard Measures on Imports of Footwear, WT/DS121/R, adopted 12 January 2000, as modified by Appellate Body Report $\mathrm{WT} / \mathrm{DS} 121 / \mathrm{AB} / \mathrm{R}$.

Argentina-Textiles and Apparel. Appellate Body Report, Argentina - Measures Affecting Imports of Footwear, Textiles, Apparel and Other Items, WT/DS56/AB/R and Corr.1, adopted 22 April 1998; Panel Report, Argentina - Measures Affecting Imports of Footwear, Textiles, Apparel and Other Items, WT/DS56/R, adopted 22 April 1998, as modified by Appellate Body Report WT/DS56/AB/R.

Australia-Tobacco Plain Packaging (Cuba). Panel Report, Australia - Certain Measures concerning Trademarks, Geographical Indications and other Plain Packaging Requirements applicable to Tobacco Products and Packaging, WT/DS458/R, Add.1 and Suppl.1, adopted 27 August 2018

Australia-Tobacco Plain Packaging (Dominican Republic). Panel Report, Australia - Certain Measures concerning Trademarks, Geographical Indications and other Plain Packaging Requirements applicable to Tobacco Products and Packaging, WT/DS441/R, Add.1 and Suppl.1, circulated to WTO Members 28 June 2018 [appealed by the Dominican Republic 23 August 2018]

Australia-Tobacco Plain Packaging (Honduras). Panel Report, Australia - Certain Measures concerning Trademarks, Geographical Indications and other Plain Packaging Requirements applicable to Tobacco Products and Packaging, WT/DS435/R, Add.1 and Suppl.1, circulated to WTO Members 28 June 2018 [appealed by Honduras 19 July 2018]

Australia-Tobacco Plain Packaging (Indonesia). Panel Report, Australia - Certain Measures concerning Trademarks, Geographical Indications and other Plain Packaging Requirements applicable to Tobacco Products and Packaging, WT/DS467/R, Add.1 and Suppl.1, adopted 27 August 2018

Brazil-Retreaded Tyres. Appellate Body Report, Brazil - Measures Affecting Imports of Retreaded Tyres, WT/DS332/AB/R, adopted 17 December 2007; Panel Report, Brazil-Measures Affecting Imports of Retreaded Tyres, WT/DS332/R, adopted 17 December 2007, as modified by Appellate Body Report $\mathrm{WT} / \mathrm{DS} 332 / \mathrm{AB} / \mathrm{R}$.

Canada - Renewable Energy/Canada Feed in Tariff. Appellate Body Reports, Canada - Certain Measures Affecting the Renewable Energy Generation Sector / Canada-Measures Relating to the Feed-in Tariff Program, WT/DS412/AB/R / WT/DS426/AB/R, adopted 24 May 2013; Panel Reports, Canada Certain Measures Affecting the Renewable Energy Generation Sector / Canada - Measures Relating to the Feed-in Tariff Program, WT/DS412/R and Add.1 / WT/DS426/R and Add.1, adopted 24 May 2013, as modified by Appellate Body Reports WT/DS412/AB/R / WT/DS426/AB/R

Canada-Aircraft. Appellate Body Report, Canada - Measures Affecting the Export of Civilian Aircraft, WT/DS70/AB/R, adopted 20 August 1999; Panel Report, Canada-Measures Affecting the Export of Civilian Aircraft, WT/DS70/R, adopted 20 August 1999, upheld by Appellate Body Report $\mathrm{WT} / \mathrm{DS} 70 / \mathrm{AB} / \mathrm{R}$,

Canada-Autos. Appellate Body Report, Canada - Certain Measures Affecting the Automotive Industry, WT/DS139/AB/R, WT/DS142/AB/R, adopted 19 June 2000; Panel Report, Canada - Certain Measures Affecting the Automotive Industry, WT/DS139/R, WT/DS142/R, adopted 19 June 2000, as modified by Appellate Body Report WT/DS139/AB/R, WT/DS142/AB/R.

Canada-Continued Suspension. Appellate Body Report, Canada-Continued Suspension of Obligations in the EC - Hormones Dispute, WT/DS321/AB/R, adopted 14 November 2008; Panel Report, Canada - 
Continued Suspension of Obligations in the EC - Hormones Dispute, WT/DS321/R and Add.1 to Add.7, adopted 14 November 2008, as modified by Appellate Body Report WT/DS321/AB/R

Canada-Dairy. Appellate Body Report, Canada - Measures Affecting the Importation of Milk and the Exportation of Dairy Products, WT/DS103/AB/R, WT/DS113/AB/R, and Corr.1, adopted 27 October 1999; Panel Report, Canada - Measures Affecting the Importation of Milk and the Exportation of Dairy Products, WT/DS103/R, WT/DS113/R, adopted 27 October 1999, as modified by Appellate Body Report WT/DS103/AB/R, WT/DS113/AB/R.

Canada-Patent Term. Appellate Body Report, Canada - Term of Patent Protection, WT/DS170/AB/R, adopted 12 October 2000; Panel Report, Canada - Term of Patent Protection, WT/DS170/R, adopted 12 October 2000, upheld by Appellate Body Report WT/DS170/AB/R.

Canada-Periodicals. Appellate Body Report, Canada - Certain Measures Concerning Periodicals, WT/DS31/AB/R, adopted 30 July 1997; Panel Report, Canada - Certain Measures Concerning Periodicals, WT/DS31/R and Corr.1, adopted 30 July 1997, as modified by Appellate Body Report $\mathrm{WT} / \mathrm{DS} 31 / \mathrm{AB} / \mathrm{R}$.

Canada-Pharmaceutical Patents. Panel Report, Canada - Patent Protection of Pharmaceutical Products, WT/DS114/R, adopted 7 April 2000.

Canada-Wheat Exports and Grain Imports. Appellate Body Report, Canada - Measures Relating to Exports of Wheat and Treatment of Imported Grain, WT/DS276/AB/R, adopted 27 September 2004; Panel Report, Canada - Measures Relating to Exports of Wheat and Treatment of Imported Grain, WT/DS276/R, adopted 27 September 2004, upheld by Appellate Body Report WT/DS276/AB/R.

Chile-Alcoholic Beverages. Appellate Body Report, Chile - Taxes on Alcoholic Beverages, WT/DS87/AB/R, WT/DS110/AB/R, adopted 12 January 2000; Panel Report, Chile - Taxes on Alcoholic Beverages, WT/DS87/R, WT/DS110/R, adopted 12 January 2000, as modified by Appellate Body Report WT/DS87/AB/R, WT/DS110/AB/R.

Chile-Price Band System. Appellate Body Report, Chile - Price Band System and Safeguard Measures Relating to Certain Agricultural Products, WT/DS207/AB/R, adopted 23 October 2002; Panel Report, Chile - Price Band System and Safeguard Measures Relating to Certain Agricultural Products, WT/DS207/R, adopted 23 October 2002, as modified by Appellate Body Report WT/DS207AB/R

China-Auto Parts. Appellate Body Reports, China - Measures Affecting Imports of Automobile Parts, WT/DS339/AB/R / WT/DS340/AB/R / WT/DS342/AB/R, adopted 12 January 2009; Panel Reports, China - Measures Affecting Imports of Automobile Parts, WT/DS339/R, Add.1 and Add.2 / WT/DS340/R, Add.1 and Add.2 / WT/DS342/R, Add.1 and Add.2, adopted 12 January 2009, upheld (WT/DS339/R) and as modified (WT/DS340/R / WT/DS342/R) by Appellate Body Reports WT/DS339/AB/R/WT/DS340/AB/R/WT/DS342/AB/R.

China-Electronic Payment Services. Panel Report, China - Certain Measures Affecting Electronic Payment Services, WT/DS413/R and Add.1, adopted 31 August 2012.

China-Intellectual Property Rights. Panel Report, China - Measures Affecting the Protection and Enforcement of Intellectual Property Rights, WT/DS362/R, adopted 20 March 2009.

China-Publications and Audiovisual Products. Appellate Body Report, China - Measures Affecting Trading Rights and Distribution Services for Certain Publications and Audiovisual Entertainment Products, WT/DS363/AB/R, adopted 19 January 2010; Panel Report, China - Measures Affecting Trading Rights and Distribution Services for Certain Publications and Audiovisual Entertainment Products, WT/DS363/R and Corr.1, adopted 19 January 2010, as modified by Appellate Body Report WT/DS363/AB/R.

Colombia-Ports of Entry. Panel Report, Colombia - Indicative Prices and Restrictions on Ports of Entry, WT/DS366/R and Corr.1, adopted 20 May 2009.

Colombia-Textiles. Appellate Body Report, Colombia - Measures Relating to the Importation of Textiles, Apparel and Footwear, WT/DS461/29, adopted 22 June 2016. Panel Report, Colombia - Measures Relating to the Importation of Textiles, Apparel and Footwear, WT/DS461/R and Add.1, adopted 22 June 2016, as modified by Appellate Body Report WT/DS461/AB/R.

Dominican Republic- Import and Sale of Cigarettes. Appellate Body Report, Dominican Republic Measures Affecting the Importation and Internal Sale of Cigarettes, WT/DS302/AB/R, adopted 19 May 2005; Panel Report, Dominican Republic - Measures Affecting the Importation and Internal Sale 
of Cigarettes, WT/DS302/R, adopted 19 May 2005, as modified by Appellate Body Report $\mathrm{WT} / \mathrm{DS} 302 / \mathrm{AB} / \mathrm{R}$.

EC-Asbestos. Appellate Body Report, European Communities - Measures Affecting Asbestos and AsbestosContaining Products, WT/DS135/AB/R, adopted 5 April 2001; Panel Report, European Communities - Measures Affecting Asbestos and Asbestos-Containing Products, WT/DS135/R and Add.1, adopted 5 April 2001, as modified by Appellate Body Report WT/DS135/AB/R.

EC-Bananas III. Appellate Body Report, European Communities - Regime for the Importation, Sale and Distribution of Bananas, WT/DS27/AB/R, adopted 25 September 1997; For a general citation for all 4 Panel Reports in EC - Bananas III above, use: Panel Reports, European Communities - Regime for the Importation, Sale and Distribution of Bananas, WT/DS27/R/ECU (Ecuador) / WT/DS27/R/GTM, WT/DS27/R/HND (Guatemala and Honduras) / WT/DS27/R/MEX (Mexico) / WT/DS27/R/USA (US), adopted 25 September 1997, as modified by Appellate Body Report WT/DS27/AB/R.

EC-Approval and Marketing of Biotech Products. Panel Reports, European Communities - Measures Affecting the Approval and Marketing of Biotech Products, WT/DS291/R, Add.1 to Add.9 and Corr.1 / WT/DS292/R, Add.1 to Add.9 and Corr.1 / WT/DS293/R, Add.1 to Add.9 and Corr.1, adopted 21 November 2006,

EC-Chicken Cuts. Appellate Body Report, European Communities - Customs Classification of Frozen Boneless Chicken Cuts, WT/DS269/AB/R, WT/DS286/AB/R, adopted 27 September 2005; For a general citation for both Panel Reports in EC - Chicken Cuts above, use: Panel Reports, European Communities - Customs Classification of Frozen Boneless Chicken Cuts, WT/DS269/R (Brazil) / WT/DS286/R (Thailand), adopted 27 September 2005, as modified by Appellate Body Report WT/DS269/AB/R, WT/DS286/AB/R.

EC-Computer Equipment. Appellate Body Report, European Communities - Customs Classification of Certain Computer Equipment, WT/DS62/AB/R, WT/DS67/AB/R, WT/DS68/AB/R, adopted 22 June 1998; Panel Report, European Communities - Customs Classification of Certain Computer Equipment, WT/DS62/R, WT/DS67/R, WT/DS68/R, adopted 22 June 1998, as modified by Appellate Body Report WT/DS62/AB/R, WT/DS67/AB/R, WT/DS68/AB/R.

EC-Export Subsidies on Sugar. Appellate Body Report, European Communities - Export Subsidies on Sugar, WT/DS265/AB/R, WT/DS266/AB/R, WT/DS283/AB/R, adopted 19 May 2005.

EC-Hormones. Appellate Body Report, EC Measures Concerning Meat and Meat Products (Hormones), WT/DS26/AB/R, WT/DS48/AB/R, adopted 13 February 1998; For a general citation for both Panel Reports in EC - Hormones above, use: Panel Reports, EC Measures Concerning Meat and Meat Products (Hormones), WT/DS48/R/CAN (Canada) / WT/DS26/R/USA (US), adopted 13 February 1998, as modified by Appellate Body Report WT/DS26/AB/R, WT/DS48/AB/R.

EC-IT Products. Panel Reports, European Communities and its member States - Tariff Treatment of Certain Information Technology Products, WT/DS375/R / WT/DS376/R / WT/DS377/R, adopted 21 September 2010.

EC-Poultry. Appellate Body Report, European Communities - Measures Affecting the Importation of Certain Poultry Products, WT/DS69/AB/R, adopted 23 July 1998; Panel Report, European Communities - Measures Affecting the Importation of Certain Poultry Products, WT/DS69/R, adopted 23 July 1998, as modified by Appellate Body Report WT/DS69/AB/R.

EC-Sardines. Appellate Body Report, European Communities - Trade Description of Sardines, WT/DS231/AB/R, adopted 23 October 2002; Panel Report, European Communities - Trade Description of Sardines, WT/DS231/R and Corr.1, adopted 23 October 2002, as modified by Appellate Body Report WT/DS231/AB/R.

EC-Seal Products. Appellate Body Reports, European Communities - Measures Prohibiting the Importation and Marketing of Seal Products, WT/DS400/AB/R / WT/DS401/AB/R, adopted 18 June 2014; Panel Reports, European Communities - Measures Prohibiting the Importation and Marketing of Seal Products, WT/DS400/R and Add.1 / WT/DS401/R and Add.1, adopted 18 June 2014, as modified by Appellate Body Reports WT/DS400/AB/R/WT/DS401/AB/R.

EC-Tariff Preferences. Appellate Body Report, European Communities - Conditions for the Granting of Tariff Preferences to Developing Countries, WT/DS246/AB/R, adopted 20 April 2004; Panel Report, European Communities - Conditions for the Granting of Tariff Preferences to Developing Countries, WT/DS246/R, adopted 20 April 2004, as modified by Appellate Body Report WT/DS246/AB/R. 
EC-Trademarks and Geographical Indications (Australia). Panel Report, European Communities Protection of Trademarks and Geographical Indications for Agricultural Products and Foodstuffs, Complaint by Australia, WT/DS290/R, adopted 20 April 2005.

EC-Trademarks and Geographic Indications (US). Panel Report, European Communities - Protection of Trademarks and Geographical Indications for Agricultural Products and Foodstuffs, Complaint by the United States, WT/DS174/R, adopted 20 April 2005.

EU-Energy Package. Panel Report, European Union and its member States - Certain Measures Relating to the Energy Sector, WT/DS476/R and Add.1, circulated to WTO Members 10 August 2018 [appealed by the European Union 21 September 2018]

India-Autos. Appellate Body Report, India - Measures Affecting the Automotive Sector, WT/DS146/AB/R, WT/DS175/AB/R, adopted 5 April 2002; Panel Report, India - Measures Affecting the Automotive Sector, WT/DS146/R, WT/DS175/R, and Corr.1, adopted 5 April 2002.

India-Patents (EC). Panel Report, India - Patent Protection for Pharmaceutical and Agricultural Chemical Products, Complaint by the European Communities and their member States, WT/DS79/R, adopted 22 September 1998.

India-Patents (US). Appellate Body Report, India - Patent Protection for Pharmaceutical and Agricultural Chemical Products, WT/DS50/AB/R, adopted 16 January 1998; Panel Report, India - Patent Protection for Pharmaceutical and Agricultural Chemical Products, Complaint by the United States, WT/DS50/R, adopted 16 January 1998, as modified by Appellate Body Report WT/DS50/AB/R.

India-Quantitative Restrictions. Appellate Body Report, India - Quantitative Restrictions on Imports of Agricultural, Textile and Industrial Products, WT/DS90/AB/R, adopted 22 September 1999; Panel Report, India - Quantitative Restrictions on Imports of Agricultural, Textile and Industrial Products, WT/DS90/R, adopted 22 September 1999, upheld by Appellate Body Report WT/DS90/AB/R.

Indonesia-Import Licensing Regimes. Appellate Body Report, Indonesia - Importation of Horticultural Products, Animals and Animal Products, WT/DS477/AB/R, WT/DS478/AB/R, and Add.1, adopted 22 November 2017. Panel Report, Indonesia - Importation of Horticultural Products, Animals and Animal Products, WT/DS477/R, WT/DS478/R, Add.1 and Corr.1, adopted 22 November 2017, as modified by Appellate Body Report WT/DS477/AB/R, WT/DS478/AB/R.

Japan-Agricultural Products II. Appellate Body Report, Japan - Measures Affecting Agricultural Products, WT/DS76/AB/R, adopted 19 March 1999; Panel Report, Japan - Measures Affecting Agricultural Products, WT/DS76/R, adopted 19 March 1999, as modified by Appellate Body Report WT/DS76/AB/R.

Japan-Alcoholic Beverages II. Appellate Body Report, Japan - Taxes on Alcoholic Beverages, WT/DS8/AB/R, WT/DS10/AB/R, WT/DS11/AB/R, adopted 1 November 1996.

Japan-Apples. Appellate Body Report, Japan - Measures Affecting the Importation of Apples, WT/DS245/AB/R, adopted 10 December 2003; Panel Report, Japan - Measures Affecting the Importation of Apples, WT/DS245/R, adopted 10 December 2003, upheld by Appellate Body Report $\mathrm{WT} / \mathrm{DS} 245 / \mathrm{AB} / \mathrm{R}$.

Japan-Film. Panel Report, Japan - Measures Affecting Consumer Photographic Film and Paper, WT/DS44/R, adopted 22 April 1998.

Japan-Taxes on Alcoholic Beverages. Panel Report, Japan - Taxes on Alcoholic Beverages, WT/DS8/R, WT/DS10/R, WT/DS11/R, adopted 1 November 1996, as modified by Appellate Body Report WT/DS8/AB/R, WT/DS10/AB/R, WT/DS11/AB/R.

Korea-Alcoholic Beverages. Appellate Body Report, Korea - Taxes on Alcoholic Beverages, WT/DS75/AB/R, WT/DS84/AB/R, adopted 17 February 1999; Panel Report, Korea - Taxes on Alcoholic Beverages, WT/DS75/R, WT/DS84/R, adopted 17 February 1999, as modified by Appellate Body Report WT/DS75/AB/R, WT/DS84/AB/R.

Korea-Commercial Vessels. Panel Report, Korea-Measures Affecting Trade in Commercial Vessels, WT/DS273/R, adopted 11 April 2005.

Korea-Procurement. Panel Report, Korea - Measures Affecting Government Procurement, WT/DS163/R, adopted 19 June 2000. 
Korea-Various Measures on Beef. Appellate Body Report, Korea - Measures Affecting Imports of Fresh, Chilled and Frozen Beef, WT/DS161/AB/R, WT/DS169/AB/R, adopted 10 January 2001; Panel Report, Korea - Measures Affecting Imports of Fresh, Chilled and Frozen Beef, WT/DS161/R, WT/DS169/R, adopted 10 January 2001, as modified by Appellate Body Report WT/DS161/AB/R, WT/DS169/AB/R.

Mexico-Telecoms. Panel Report, Mexico-Measures Affecting Telecommunications Services, WT/DS204/R, adopted 1 June 2004.

Mexico-Taxes on Soft Drinks. Appellate Body Report, Mexico- Tax Measures on Soft Drinks and Other Beverages, WT/DS308/AB/R, adopted 24 March 2006; Panel Report, Mexico - Tax Measures on Soft Drinks and Other Beverages, WT/DS308/R, adopted 24 March 2006, as modified by Appellate Body Report WT/DS308/AB/R.

Russia-Traffic in Transit. Panel Report, Russia- Measures concerning Traffic in Transit, WT/DS512/R and WT/DS512/R/Add.1 adopted 26 April 2019.

Turkey-Textiles. Appellate Body Report, Turkey - Restrictions on Imports of Textile and Clothing Products, WT/DS34/AB/R, adopted 19 November 1999.

US-Carbon Steel. Appellate Body Report, United States - Countervailing Duties on Certain CorrosionResistant Carbon Steel Flat Products from Germany, WT/DS213/AB/R and Corr.1, adopted 19 December 2002; Panel Report, United States - Countervailing Duties on Certain Corrosion-Resistant Carbon Steel Flat Products from Germany, WT/DS213/R and Corr.1, adopted 19 December 2002, as modified by Appellate Body Report WT/DS213/AB/R.

US-Corrosion-Resistant Steel Sunset Review. Appellate Body Report, United States - Sunset Review of Anti-Dumping Duties on Corrosion-Resistant Carbon Steel Flat Products from Japan, WT/DS244/AB/R, adopted 9 January 2004; Panel Report, United States - Sunset Review of AntiDumping Duties on Corrosion-Resistant Carbon Steel Flat Products from Japan, WT/DS244/R, adopted 9 January 2004, as modified by Appellate Body Report WT/DS244/AB/R.

US-Countervailing Measures on Certain EC Products. Appellate Body Report, United States Countervailing Measures Concerning Certain Products from the European Communities, WT/DS212/AB/R, adopted 8 January 2003; Panel Report, United States - Countervailing Measures Concerning Certain Products from the European Communities, WT/DS212/R, adopted 8 January 2003, as modified by Appellate Body Report WT/DS212/AB/R.

US-Customs Bond Directive. Panel Report, United States - Customs Bond Directive for Merchandise Subject to Anti-Dumping/Countervailing Duties, WT/DS345/R, adopted 1 August 2008, as modified by Appellate Body Report WT/DS343/AB/R/WT/DS345/AB/R.

US-Upland Cotton. Appellate Body Report, United States - Subsidies on Upland Cotton, WT/DS267/AB/R, adopted 21 March 2005; Panel Report, United States - Subsidies on Upland Cotton, WT/DS267/R, Add.1 to Add.3 and Corr.1, adopted 21 March 2005, as modified by Appellate Body Report WT/DS267/AB/R.

US-FSC (Article 21.5- EC). Appellate Body Report, United States - Tax Treatment for "Foreign Sales Corporations" - Recourse to Article 21.5 of the DSU by the European Communities, WT/DS108/AB/RW, adopted 29 January 2002; Panel Report, United States - Tax Treatment for "Foreign Sales Corporations" - Recourse to Article 21.5 of the DSU by the European Communities, WT/DS108/RW, adopted 29 January 2002, as modified by Appellate Body Report WT/DS108/AB/RW

US-Section 211 Appropriations Act. Appellate Body Report, United States - Section 211 Omnibus Appropriations Act of 1998, WT/DS176/AB/R, adopted 1 February 2002; Panel Report, United States - Section 211 Omnibus Appropriations Act of 1998, WT/DS176/R, adopted 1 February 2002, as modified by Appellate Body Report WT/DS176/AB/R

US-Shrimp. Appellate Body Report, United States - Import Prohibition of Certain Shrimp and Shrimp Products, WT/DS58/AB/R, adopted 6 November 1998; Panel Report, United States - Import Prohibition of Certain Shrimp and Shrimp Products, WT/DS58/R and Corr.1, adopted 6 November 1998, as modified by Appellate Body Report WT/DS58/AB/R. 
US-Shrimp (Thailand). Panel Report, United States - Measures Relating to Shrimp from Thailand, WT/DS343/R, adopted 1 August 2008, as modified by Appellate Body Report WT/DS343/AB/R / $\mathrm{WT} / \mathrm{DS} 345 / \mathrm{AB} / \mathrm{R}$

US-Wool Shirts and Blouses. Appellate Body Report, United States - Measure Affecting Imports of Woven Wool Shirts and Blouses from India, WT/DS33/AB/R, adopted 23 May 1997; Panel Report, United States - Measure Affecting Imports of Woven Wool Shirts and Blouses from India, WT/DS33/R, adopted 23 May 1997, upheld by Appellate Body Report WT/DS33/AB/R.

US-1916 Act. Appellate Body Report, United States - Anti-Dumping Act of 1916, WT/DS136/AB/R, WT/DS162/AB/R, adopted 26 September 2000; For a general citation for both Panel Reports in US 1916 Act above, use: Panel Reports, United States - Anti-Dumping Act of 1916, WT/DS136/R and Corr. 1 (EC) / WT/DS162/R and Add.1 (Japan), adopted 26 September 2000, upheld by Appellate Body Report WT/DS136/AB/R, WT/DS162/AB/R.

US-Carbon Steel. Appellate Body Report, United States - Countervailing Duties on Certain CorrosionResistant Carbon Steel Flat Products from Germany, WT/DS213/AB/R and Corr.1, adopted 19 December 2002; Panel Report, United States - Countervailing Duties on Certain Corrosion-Resistant Carbon Steel Flat Products from Germany, WT/DS213/R and Corr.1, adopted 19 December 2002, as modified by Appellate Body Report WT/DS213/AB/R.

US-Certain EC Products. Appellate Body Report, United States - Import Measures on Certain Products from the European Communities, WT/DS165/AB/R, adopted 10 January 2001; Panel Report, United States - Import Measures on Certain Products from the European Communities, WT/DS165/R and Add.1, adopted 10 January 2001, as modified by Appellate Body Report WT/DS165/AB/R.

US-Clove Cigarettes. Appellate Body Report, United States - Measures Affecting the Production and Sale of Clove Cigarettes, WT/DS406/AB/R, adopted 24 April 2012; Panel Report, United States - Measures Affecting the Production and Sale of Clove Cigarettes, WT/DS406/R, adopted 24 April 2012, as modified by Appellate Body Report WT/DS406/AB/R.

US-Continued Suspension. Appellate Body Report, United States - Continued Suspension of Obligations in the EC - Hormones Dispute, WT/DS320/AB/R, adopted 14 November 2008; Panel Report, United States - Continued Suspension of Obligations in the EC - Hormones Dispute, WT/DS320/R and Add.1 to Add.7, adopted 14 November 2008, as modified by Appellate Body Report WT/DS320/AB/R, DSR

US-Continued Zeroing. Appellate Body Report, United States - Continued Existence and Application of Zeroing Methodology, WT/DS350/AB/R, adopted 19 February 2009; Panel Report, United States Continued Existence and Application of Zeroing Methodology, WT/DS350/R, adopted 19 February 2009, as modified as Appellate Body Report WT/DS350/AB/R.

US-Steel Safeguards. Appellate Body Report, United States - Definitive Safeguard Measures on Imports of Certain Steel Products, WT/DS248/AB/R, WT/DS249/AB/R, WT/DS251/AB/R, WT/DS252/AB/R, WT/DS253/AB/R, WT/DS254/AB/R, WT/DS258/AB/R, WT/DS259/AB/R, adopted 10 December 2003; Panel Reports, United States - Definitive Safeguard Measures on Imports of Certain Steel Products, WT/DS248/R and Corr.1 / WT/DS249/R and Corr.1 / WT/DS251/R and Corr.1 / WT/DS252/R and Corr.1 / WT/DS253/R and Corr.1 / WT/DS254/R and Corr.1 / WT/DS258/R and Corr.1 / WT/DS259/R and Corr.1, adopted 10 December 2003, as modified by Appellate Body Report.

US-Export Restraints. Panel Report, United States - Measures Treating Exports Restraints as Subsidies, WT/DS194/R and Corr.2, adopted 23 August 2001.

US-FSC. Appellate Body Report, United States - Tax Treatment for "Foreign Sales Corporations", WT/DS108/AB/R, adopted 20 March 2000; Panel Report, United States - Tax Treatment for "Foreign Sales Corporations", WT/DS108/R, adopted 20 March 2000, as modified by Appellate Body Report WT/DS108/AB/R.

US-FSC (Article 21.5 - EC). Appellate Body Report, United States - Tax Treatment for "Foreign Sales Corporations" - Recourse to Article 21.5 of the DSU by the European Communities, WT/DS108/AB/RW, adopted 29 January 2002; Panel Report, United States - Tax Treatment for "Foreign Sales Corporations" - Recourse to Article 21.5 of the DSU by the European Communities, WT/DS108/RW, adopted 29 January 2002, as modified by Appellate Body Report WT/DS108/AB/RW.

US-Gambling. Appellate Body Report, United States - Measures Affecting the Cross-Border Supply of Gambling and Betting Services, WT/DS285/AB/R, adopted 20 April 2005; Panel Report, United States 
- Measures Affecting the Cross-Border Supply of Gambling and Betting Services, WT/DS285/R, adopted 20 April 2005, as modified by Appellate Body Report WT/DS285/AB/R

US-Gasoline. Appellate Body Report, United States - Standards for Reformulated and Conventional Gasoline, WT/DS2/AB/R, adopted 20 May 1996; Panel Report, United States - Standards for Reformulated and Conventional Gasoline, WT/DS2/R, adopted 20 May 1996, as modified by Appellate Body Report WT/DS2/AB/R.

US-Large Civil Aircraft (2nd complaint). Appellate Body Report, United States - Measures Affecting Trade in Large Civil Aircraft (Second Complaint), WT/DS353/AB/R, adopted 23 March 2012; Panel Report, United States - Measures Affecting Trade in Large Civil Aircraft (Second Complaint), WT/DS353/R, adopted 23 March 2012, as modified by Appellate Body Report WT/DS353/AB/R.

US-Offset Act (Byrd Amendment). Appellate Body Report, United States - Continued Dumping and Subsidy Offset Act of 2000, WT/DS217/AB/R, WT/DS234/AB/R, adopted 27 January 2003; Panel Report, United States - Continued Dumping and Subsidy Offset Act of 2000, WT/DS217/R, WT/DS234/R, adopted 27 January 2003, as modified by Appellate Body Report WT/DS217/AB/R, WT/DS234/AB/R.

US-Oil Country Tubular Goods Sunset Reviews. Appellate Body Report, United States - Sunset Reviews of Anti-Dumping Measures on Oil Country Tubular Goods from Argentina, WT/DS268/AB/R, adopted 17 December 2004; Panel Report, United States - Sunset Reviews of Anti-Dumping Measures on Oil Country Tubular Goods from Argentina, WT/DS268/R and Corr.1, adopted 17 December 2004, as modified by Appellate Body Report WT/DS268/AB/R.

US-Section 301 Trade Act. Panel Report. United States - Sections 301-310 of the Trade Act of 1974, WT/DS152/R, adopted 27 January 2000.

US-Shrimp. Appellate Body Report, United States - Import Prohibition of Certain Shrimp and Shrimp Products, WT/DS58/AB/R, adopted 6 November 1998; Panel Report, United States - Import Prohibition of Certain Shrimp and Shrimp Products, WT/DS58/R and Corr.1, adopted 6 November 1998, as modified by Appellate Body Report WT/DS58/AB/R.

US-Shrimp (Thailand) / US-Customs Bond Directive. Appellate Body Report, United States - Measures Relating to Shrimp from Thailand / United States - Customs Bond Directive for Merchandise Subject to Anti-Dumping/Countervailing Duties, WT/DS343/AB/R / WT/DS345/AB/R, adopted 1 August 2008.

US-Softwood Lumber III. Panel Report, United States - Preliminary Determinations with Respect to Certain Softwood Lumber from Canada, WT/DS236/R, adopted 1 November 2002.

US-Softwood Lumber IV. Appellate Body Report, United States - Final Countervailing Duty Determination with Respect to Certain Softwood Lumber from Canada, WT/DS257/AB/R, adopted 17 February 2004; Panel Report, United States - Final Countervailing Duty Determination with Respect to Certain Softwood Lumber from Canada, WT/DS257/R and Corr.1, adopted 17 February 2004, as modified by Appellate Body Report WT/DS257/AB/R.

US-Underwear. Appellate Body Report, United States - Restrictions on Imports of Cotton and Man-made Fibre Underwear, WT/DS24/AB/R, adopted 25 February 1997; Panel Report, United States Restrictions on Imports of Cotton and Man-made Fibre Underwear, WT/DS24/R, adopted 25 February 1997, as modified by Appellate Body Report WT/DS24/AB/R.

US-Upland Cotton. Appellate Body Report, United States - Subsidies on Upland Cotton, WT/DS267/AB/R, adopted 21 March 2005; Panel Report, United States - Subsidies on Upland Cotton, WT/DS267/R, Add.1 to Add.3 and Corr.1, adopted 21 March 2005, as modified by Appellate Body Report WT/DS267/AB/R.

US-Wheat Gluten. Appellate Body Report, United States - Definitive Safeguard Measures on Imports of Wheat Gluten from the European Communities, WT/DS166/AB/R, adopted 19 January 2001; Panel Report, United States - Definitive Safeguard Measures on Imports of Wheat Gluten from the European Communities, WT/DS166/R, adopted 19 January 2001, as modified by Appellate Body Report $\mathrm{WT} / \mathrm{DS} 166 / \mathrm{AB} / \mathrm{R}$. 


\section{GATT Panel Reports}

Canada-Ice cream and Yogurt. GATT Panel Report, Canada - Import Restrictions on Ice Cream and Yoghurt, L/6568, adopted 5 December 1989, BISD 36S/68.

Canada-Provincial Liquor Boards (EEC). GATT Panel Report, Canada-Import, Distribution and Sale of Alcoholic Drinks by Canadian Provincial Marketing Agencies, L/6304, adopted 22 March 1988, BISD 35S/37.

EEC-Bananas II. GATT Panel Report, EEC - Import Regime for Bananas, DS38/R, 11 February 1994, unadopted.

EEC-Dessert Apples. GATT Panel Report, European Economic Community - Restrictions on Imports of Dessert Apples - Complaint by Chile, L/6491, adopted 22 June 1989, BISD 36S/93.

EEC-Parts and Components. GATT Panel Report, European Economic Community - Regulation on Imports of Parts and Components, L/6657, adopted 16 May 1990, BISD 37S/132.

US-Malt Beverages. GATT Panel Report, United States - Measures Affecting Alcoholic and Malt Beverages, DS23/R, adopted 19 June 1992, BISD 39S/206.

US-Nicaraguan Trade. GATT Panel Report, United States - Trade Measures Affecting Nicaragua, L/6053, 13 October 1986, unadopted.

US-Section 337 Tariff Act. GATT Panel Report, United States Section 337 of the Tariff Act of 1930, L/6439, adopted 7 November 1989, BISD 36S/345.

US-Spring Assemblies. GATT Panel Report, United States - Imports of Certain Automotive Spring Assemblies, L/5333, adopted 26 May 1983, BISD 30S/107.

US-Tobacco. GATT Panel Report, United States Measures Affecting the Importation, Internal Sale and Use of Tobacco, DS44/R, adopted 4 October 1994, BISD 41S/131.

US-Swedish Steel Plate, GATT Panel Report, United States - Anti-Dumping Duties on Imports of Stainless Steel Plate from Sweden, ADP/117 and Corr. 1, 24 February 1994, unadopted.

US-Tuna (Mexico), GATT Panel Report, United States - Restrictions on Imports of Tuna, DS21/R, DS21/R, 3 September 1991, unadopted, BISD 39S/155.

US-Tuna (EEC) GATT Panel Report, United States - Restrictions on Imports of Tuna, DS29/R, 16 June 1994, unadopted.

\section{International Court of Justice Cases}

Anglo-Iranian Oil Company Case (United Kingdom v. Iran) 1952 ICJ Reports 93.

Application of the Convention of 1902 Governing the Guardianship of Infants (Netherlands v. Sweden), 1958 ICJ Reports 55.

Arbitral Award of 31 July 1989 (Guinea-Bissau v. Senegal), 1991 ICJ Reports 53.

Asylum Case (Colombia v. Peru), 1950 ICJ Reports 266.

Avena and other Mexican Nationals (Mexico v. United States of America), 2004 ICJ Reports.

Border and Transborder Armed Actions (Nicaragua v. Honduras), 1987 ICJ Reports 69.

Competence of the General Assembly for the Admittance of a State to the United Nations case, 1950 ICJ Reports.

Continental Shelf (Tunisia v. Libyan Arab Jamahiriya), 1982 ICJ Reports 18.

Dispute regarding Navigational and Related Rights (Costa Rica v. Nicaragua), 2009 ICJ Reports 213.

Gabcikovo-Nagymaros Project (Hungary v. Slovakia) 1997 ICJ Reports 7. 
La Grand, (Germany v United States of America) 2001 ICJ Reports.

Legal Consequences for States of the Continued Presence of South Africa in Namibia (South West Africa) notwithstanding Security Council Resolution 276 (1970), 1971 ICJ Reports.

Legality of the Use by a State of Nuclear Weapons in Armed Conflict, Advisory Opinion of July 8, 1996 (Preliminary Objections), request by the World Health Organization, 1996 ICJ Reports.

Legality of the Threat or Use by a State of Nuclear Weapons, Advisory Opinion, 1996 ICJ Reports 66.

Maritime Delimitation and Territorial Questions (Jurisdiction and Admissibility) (Qatar v. Bahrain) 2001 ICJ Reports 6.

Oil Platforms (Iran v. United States of America), 2003 ICJ Reports 161.

Questions of Interpretation and Application of the 1971 Montreal Convention arising from the Aerial Incident at Lockerbie (Libyan Arab Jamahiriya v. United States of America) 2003 ICJ Reports.

Nuclear Tests Case, (New Zealand v France), 1973 ICJ Reports 457.

Nuclear Tests Case. Request for an Examination of the Situation in Accordance with Paragraph 63 of the Court's Judgment of 20 December 1974 in the Nuclear Tests (New Zealand v. France) Case, 1995, ICJ Reports 288.

Territorial Dispute (Libyan Arab Jamahiriya v. Chad), 1994 ICJ Reports 7.

The Ambatielos Case (Greece v. United Kingdom) (Merits: obligation to arbitrate) 1953 ICJ Reports 5.

Rights of Nationals of the United States of America in Morocco, (France v. United States of America), 1952 ICJ Reports 176.

Whaling in the Antarctic (Australia v. Japan: New Zealand intervening), 2014 ICJ Reports 226.

\section{Other Cases}

Argentina, Federal Chamber of Constitutional and Administrative Proceeding Viceconte v. Ministry of Health and Social Welfare, Case No. 31.777/96, 1998.

Bangladesh, Supreme Court, Dr. Mohiuddin Farooque v. Bangladesh, 48 DLR, 1996, HCD 438.

Committee for the Elimination of All Forms of Discrimination against Women, Alyne da Silva Pimentel Teixeira v. Brazil, Communication No. 17/2008, UN Doc. CEDAW/C/49/D/17/2008, decided in 2011.

Committee for the Elimination of All Forms of Discrimination against Women, A.S. v. Hungary, Communication No. 4/2004, U.N. Doc., CEDAW/C/36/D/4/2004 (July 14, 2006), decided in 2006,

Constitutional Court of South Africa President of the Republic of South Africa v. Hugo, 1997 (4) SA 1.

European Court of Human Rights Al-Adsani v. UK, 123 ILR 24, 2001.

European Court of Human Rights Bankovic v. Belgium 123 ILR 94, 2001.

European Court of Human Rights Fogarty v. UK, 123 ILR 54, 2001.

European Court of Human Rights Loizidou v. Turkey 108 ILR 443, 1996.

European Court of Human Rights McElhinney v Ireland, 123 ILR 73, 2001.

European Court of Human Rights, Golder v. UK 57 ILR 200, 1975.

European Court of Human Rights, Handyside v. The United Kingdom, 5493/72, ECHR 51976.

Human Rights Committee, Views adopted by the Committee under Article 5 (4) of the Optional Protocol, concerning communication No. 2348/2014 (Toussaint v. Canada), CCPR/C/123/D/2348/2014, 30 August 2018

India, Supreme Court, Paschim Banga Khet Mazdoor Samity and others v. State of West Bengal and another, 1996 AIR SC 2426.

India, High Court of Madhya Pradesh (Jabalpur), Sandesh Bansal and others v. Union of India and others, Writ Petition No. 9061/2008, decided on 06 February 2012.

Inter-American Court of Human Rights, Interpretation of the American Declaration of the Rights and Duties of Man Advisory Opinion, 1989.

Inter-American Court of Human Rights, Mayagna (Sumo) Awas Tingni Community v. Nicaragua, No. 79, 2001, Merits, Reparations and Costs, 2001.

Inter-American Court of Human Rights, Ximenes-Lopes v. Brazil, Merits, Reparations and Costs, Series C No. 149, 2006. 
Nepal, Supreme Court, Advocate Prakash Mani Sharma v. Government of Nepal and Others, Writ No.064 WO 0230 (SC), 1999.

PCIJ, Polish Nationals in Danzig, Series A/B No 44.

South Africa, Constitutional Court of South Africa, The State v. Makwanyane and Mchunu, Case No. CCT/3/94, 6 June 1995.

South Africa, Constitutional Court of South Africa, Minister of Health v. Treatment Action Campaign (2002) 5 SA 721 (CC).

Sri Lanka, Supreme Court of Sri Lanka, Bulankulama and six others v. Ministry of Industrial Development and seven others, S.C. Application No 884/99 F.R, 2000

Supreme Court of Canada, Law v. Canada (Minister of Employment and Immigration) 19991 SCR 497,

Uganda, Supreme Court of Uganda at Kampala, Centre for Health, Human Rights and Development and Three Others v. Attorney General of Uganda, 2015 - Constitutional Appeal No. 01 of 2013.

United Kingdom, House of Lords, I Congreso del Partido case, HL (1983) AC 244

United Kingdom, House of Lords, YL v. Birmingham City Council and others (2007) UKHL 27, (2007) 3 All ER 957

United States Supreme Court, New State Ice Co. v. Liebmann, 285 US 262 (1932).

United States, Supreme Court, West Lynn Creamery Inc. v. Healy 114 S. Ct. 2205 (1994). 


\section{CHAPTER 1}

\section{INTRODUCTION}

This Dream is all amiss interpreted

It was a vision fair and fortunate.

Brutus,

Shakespeare's Julius Caesar 
Chapter 1 


\section{CHAPTER 1}

\section{INTRODUCTION}

We live today in a society that is changing perhaps more rapidly than any which preceded it. Such rapid change can instill an enormous range of emotions from fear to hope to confidence... We will have to adapt to change and we will have to manage it as best we can, and in a global economy that means ensuring our rules and practices fit our circumstances. ${ }^{1}$

WTO rules are not so rigid or so inflexible as not to leave room for reasoned judgments in confronting the endless and ever-changing ebb and flow of real facts in real cases in the real world. They will serve the multilateral trading system best if they are interpreted with that in mind. ${ }^{2}$

It is now twenty-five years since the establishment of the World Trade Organization (WTO) and the introduction of a multilateral trade agreement on services for the first time: the WTO General Agreement on Trade in Services (GATS). This research is set in the context of fears which have been expressed by communities and organizations across the world concerning the negative implications of the progressive liberalization obligation in the GATS, especially if the alleged protections for core human rights and societal values are illusory. This study does not aim to either justify or negate these fears by looking for empirical data to prove or disprove actual negative impacts or to make projections of outcomes. What it does aim to do is analyze the provisions of the GATS according to the rules of treaty interpretation, to ascertain where the 'protections' actually fall on a scale where the two extreme views can be described as '(absolutely-nothing-tofear)-all-will-be-well' or '(destructive-evil-conspiracy)-all-will-be-lost'. In such an emotionally charged atmosphere, it is one of the challenges of this study to give a fair hearing to rational arguments on both sides. However, as a person from a developing country, who received the benefits of a democratic socio-political system that invested in free public health and free education, my interest in this research area has a personal history, which will impact my approach to it.

It is also approximately twenty-five years since a strong global network of multidisciplinary scholars on health and human rights began strengthening the conceptual basis of the human rights-based approach to health. ${ }^{3}$ The special focus of this study will

\footnotetext{
${ }^{1}$ Lamy, P., Trade improves the lives of people, Lamy, speech at the Minnesota Economic Club in Minneapolis, United States on 17 April 2012, http://www.wto.org/english/news_e/sppl_e/sppl224_e.htm, last accessed 19.03.2012.

${ }^{2}$ Appellate Body Report, Japan - Alcoholic Beverages II, p31.

${ }^{3}$ Gostin L.O, and J. M. Mann, Towards the development of a human rights impact assessment for the formulation and evaluation of public health policies, Health and Human Rights Journal 1/1 (1994), pp.5980; Gruskin, Sophia, Reflections on 25 Years of Health and Human Rights: History, Context, and the Need for Strategic Action, Health and Human Rights Journal, December 10, 2019, available online at https://www.hhrjournal.org/2019/12/reflections-on-25-years-of-health-and-human-rights-history-contextand-the-need-for-strategic-action/; MacNaughton, Gillian, The Maturing Right to Health: Deeper, Broader and More Complex but Still Unequal, December 16, 2019, https://www.hhrjournal.org/2019/12/thematuring-right-to-health-deeper-broader-and-more-complex-but-still-unequal/; Khosla, Rajat, Health and Human Rights at a Crossroads, December 11 2019, https:/www.hhrjournal.org/2019/12/health-andhuman-rights-at-a-crossroads/. See further Meier B. M. and L.O. Gostin, HUMAN RIGHTS IN GLOBAL
} 
be on health services within the GATS framework. This is because health services are one of the most controversial areas in trade in services and due to this, it is also one of the areas where very few liberalization commitments have been made. There is concern that national policy space for the provision of health services - particularly public health services - may be unduly constrained by the trade liberalization obligations. There are also counter-arguments that more nuanced interpretations of GATS obligations demonstrate that WTO Members retain sufficient policy space for the measures they need to take to protect public services, including public health services. It has been commented that:

The GATS and health debate often reads like a 'tale of two treaties' - it is the best of treaties, it is the worst of treaties. ${ }^{4}$

If the GATS does not allow for sufficient policy space for values such as protection and promotion of public health services, and if there is a limitation of options or 'lock-in' to a particular type of trade liberalization in health services - why should this be considered as a unsatisfactory situation? In broad general terms, it can be argued that allowing for dynamic and evolutionary growth and change can be more beneficial than a 'lock-in' to a specific type of stability - where choices are limited to one type of success or alternately, as may yet be proven, one type of mistake. Constraining policy choice also indicates a lack of trust in the intellectual and ethical capacity and ability of people for economic decision-making in the future. Legal frameworks are necessary for structuring the local and global society, but they need a certain amount of policy space to achieve a healthy balance of stability as well as flexibility. If the legal framework is too rigid and unresponsive to societal needs and values, it may not succeed in even the task of maintaining stability and order, and may thus ultimately undermine itself.

Being more specific to the issue of public health services, a narrowing or loss of policy space is to be deplored because it could constrain possible measures for health and health equity. Accessibility to health services is of special concern, particularly to the poor across the world, as it has an obviously huge impact on the quality of life and the general standard of living. The role of public health services in meeting the health needs of people must not be underestimated, as without such a system, health must be dependent on luck (genetic and circumstantial) and financial resources.

It could be argued that the GATS has not had the adverse impact on public health services that was feared since its inception; but it is difficult to assess and measure the overall constraint that the WTO approach to liberalization of services has had on public health services policy, financing and other measures at national level. Even if the causative link between constraints on national health policy for promotion of public health services and the GATS cannot be clearly made, the GATS is part of the trade liberalization ethos that has influenced global economic, social and trade policy for the past quarter of a century. Thus, it is important to discuss the GATS in light of public health services and vice versa.

Furthermore, there are obligations in international human rights law regarding the ability of a State to protect, promote and fulfill the right to health and related rights. The right to

HEALTH: RIGHTS-BASED GOVERNANCE FOR A GLOBALIZING WORLD, Oxford University Press, 2018.

${ }^{4}$ Fidler, David P., Nick Drager, Carlos Correa and Obijior Aginam, Making Commitments in Health Services under the GATS: Legal Dimensions in Blouin, Chantal, Nick Drager and Richard Smith Eds., INTERNATIONAL TRADE IN HEALTH SERVICES AND THE GATS: CURRENT ISSUES AND DEBATES, The World Bank, 2006, p143. 
health and the nature of the health system that a State should establish are interlinked and are vital to the concept of a just and fair society. As stated by the UN Special Rapporteur on the right to health:

Underpinned by the right to health, an effective health system is a core social institution, no less than a court system or political system. ${ }^{5}$

There are also positive obligations some States are required to carry out according to the domestic conceptions of the responsibilities of the State (e.g. constitutional rights and values or social policy of that domestic system), that tie-in with the obligations in international human rights law. These domestic views may go beyond the narrow partisan confines of politics and be expressed as important societal values with historical and cultural roots.

Thus, it must be noted that the story cannot end with determining the relevant international trade law obligations and associated levels of constraint and/or maneuverability. That trade ought to be subject to the responsibility of the State to achieve progressively the full realization of economic, social and cultural rights and to ensure social justice and protect core societal values will be a main line of argument in this study. This is not merely a question of an assumption that the intervention of the State is necessary for the protection of certain values such as the right to health, but that in international human rights law, and in some instances also for some States according to written or unwritten national constitutional principles, it is the obligation of the State to do so. ${ }^{6}$

However, it must also be noted that the general understanding in public international law is that if a State has ratified an international treaty and taken on an international legal obligation that may be interpreted as conflicting with their domestic law - although it does not trump constitutional rights and principles within the domestic sphere - domestic law cannot be claimed as a justification for non-fulfilment of the international obligation in the international sphere. ${ }^{7}$ It should also be remembered that in a domestic legal order,

\footnotetext{
${ }^{5}$ UN, Economic and Social Council and Commission On Human Rights, Report of the Special Rapporteur on the right of everyone to the enjoyment of the highest attainable standard of physical and mental health, Paul Hunt, E/CN.4/2006/48, 3 March 2006, p2.

${ }^{6}$ When a State ratifies an international treaty, such as the International Covenant on Economic, Social and Cultural Rights (the right to health is Article 12 of the Covenant), the State has agreed to an international legal obligation to enforce this right within their jurisdiction, and to cooperate internationally in this regard (Note however that the customary international law status of the right to health remains a debatable issue). For some States, operationalizing the right to health is an accepted responsibility of the State in longstanding national policy and for some States it can be a legal obligation according to a specific Constitutional provision. See Kinney, Eleanor D., The international human right to health: What does this mean for our nation and world, Indiana. L. Rev. 34 (2000): 1457: Kinney, Eleanor D., and Brian Alexander Clark, Provisions for health and health care in the constitutions of the countries of the world, Cornell Int'l LJ 37 (2004): 285, finding that $67.5 \%$ of constitutions of the world (in 2004, including draft constitutions) had provisions regarding health and healthcare - the provisions are extracted by the authors and included Appendix I of that paper.

7 General public international law theory and practice confirms this (see e.g. Shaw, Malcolm, N., INTERNATIONAL LAW, $6^{\text {th }}$ Edition, Cambridge University Press, 2008, p133-137); see also the cases PCIJ, Polish Nationals in Danzig, Advisory Opinion, Series A/B No 44, p21 and p24; and more recently, the ICJ in Lockerbie (Libyan Arab Jamahiriya v United Kingdom), ICJ Reports, 1992, p3 and p32, and La Grand (Germany v United States), ICJ Reports, 2001 p466 and p497-8 and Avena and Others (Mexico $v$ United States), ICJ Reports, 2004, p12 and p65.

It is also codified in Article 27 of the Vienna Convention on the Law of Treaties: Article 27: Internal law and observance of treaties
} 
treaty obligations may prevail over national policy and over other domestic legal rules which are not constitutional rights or principles.

Thus, a first question to ask is whether there are obligations under the WTO GATS that could come into conflict with domestic policies and measures promoting the right to health. The right to health policies and measures could be based on international law obligations in addition to the societal values relating to health services in certain domestic systems. A glance at the current debates suggests that this is so, but this study will briefly re-address this issue and identify the problem areas. Such domestic values would be a basis for States/WTO Members to desire to maintain a certain policy space for implementing these values, with international human rights law reinforcing their position. The issue in the context of international law is whether there is a conflict between these two relevant regimes of international law, WTO law and human rights law, and the values that are promoted within the separate frameworks.

If it is made evident in the health services context that there is tension between general WTO obligations and the domestic values relating to health services which are also supported by international human rights law, then the next issue is whether it is possible to interpret and apply the GATS to achieve a result which ensures social justice. If so, there could be (optimistically speaking and depending on the conclusions) a chance for progress on two fronts - as it can also be argued that the uncertainty on the extent of available flexibility under the GATS has resulted in deadlock for both the progressive liberalization process and the progressive realization of economic and social rights.

Therefore, the basic question of this research is whether there is space for this balancing of values within the GATS. As part of this balancing process, at times a choice must be made whether to protect a 'trade value' or another conflicting societal value. Who makes this choice? It can be said that the WTO Member does, as it is the Member who must make and implement the decisions and measures. However, the WTO panels and Appellate Body, in their task of interpreting the WTO agreements, also play an important role in the ultimate decision-making of WTO Members. Due to the binding nature of the dispute settlement system of the WTO, which includes the possibility of retaliation in case of non-compliance, it is often pointed out that there are greater pressures upon a WTO Member to change domestic policies, when compared with any other international dispute settlement system. Furthermore, despite not applying a doctrine of binding precedent, the impact of WTO panel and Appellate Body reports are not limited to the

A party may not invoke the provisions of its internal law as justification for its failure to perform a treaty. This rule is without prejudice to Article 46 [Article 46: Provisions of internal law regarding competence to conclude treaties]

Note that with regard to the GATS, only Article VI:2(b) of the GATS specifically recognizes a deviation from this general rule of public international law and treaty interpretation:

Article VI:2(a) and (b) of the GATS

(a) Each Member shall maintain or institute as soon as practicable judicial, arbitral or administrative tribunals or procedures which provide, at the request of an affected service supplier, for the prompt review of, and where justified, appropriate remedies for, administrative decisions affecting trade in services. Where such procedures are not independent of the agency entrusted with the administrative decision concerned, the Member shall ensure that the procedures in fact provide for an objective and impartial review.

(b) The provisions of subparagraph (a) shall not be construed to require a Member to institute such tribunals or procedures where this would be inconsistent with its constitutional structure or the nature of its legal system. 
Members involved in the trade dispute. The interpretation of WTO provisions in previous panel and Appellate Body rulings have a persuasive effect which clearly influences the direction of interpretation in future disputes. It has been accepted that prior reasoning and findings, especially those of the Appellate Body, create legitimate expectations among WTO Members ${ }^{8}$ and cannot be disregarded in the legal interpretation required for deciding later disputes, absent cogent reasons. ${ }^{9}$ Therefore, a decision can impact more than just the specific Member's national policy, it is also an indication that similar policy by other Members can be challenged as not being compliant with their WTO obligations. Thus, national policy choice in general can be constrained by the interpretation of WTO obligations by the panels and Appellate Body - and there must be acknowledgment of the importance of such interpretation in this context. It has to also be acknowledged that the recent crisis concerning the blocking of Appellate Body appointments by the United States has resulted in serious doubts about the future of the WTO dispute settlement system as a whole.

Ultimately, this study concerns the socio-economic policy choices available to us with regard to the services which we require. How free are Members to make these choices within the current framework of WTO GATS - or more specifically, how free are our governments to choose on our behalf? But the purpose of this study is not to justify particular means for the protection of societal values such as building, maintaining and promoting comprehensive public health services - but to see to what extent the WTO GATS provides for the policy space for a variety of bona fide measures for the protection of such societal values.

\subsection{The Central Research Question}

All understand that the GATS represents a complex and multi-faceted compromise between these twin goals of trade liberalization and regulatory autonomy. ${ }^{10}$

As stated earlier, the central question in this study is: 'how much policy space for the protection of non-trade core societal values is available for a WTO Member under the GATS'?

This study will be with special reference to public health services: discussing that the existence of public health services is important for the health and wellbeing of people in a given society, especially considering the benefits for the economically vulnerable, least advantaged in society; and also in the light of the State obligation (in international law

\footnotetext{
${ }^{8}$ Appellate Body Report, Japan -Alcoholic Beverages II, p107-108 stated that adopted reports "...create legitimate expectations among WTO Members, and, therefore, should be taken into account where they are relevant to any dispute".

${ }^{9}$ See Appellate Body Report, US-Stainless Steel (Mexico), paras. 158, 159-162 and Footnote 309, citing also earlier Appellate Body Reports of US-Shrimp (Article 21.5 - Malaysia), paras. 107-109 and US-Oil Country Tubular Goods Sunset Reviews, para.188. Also see Appellate Body Report, US-Softwood Lumber $V$, para.112.

See Appellate Body Report in US-Stainless Steel (Mexico), para.160:

Ensuring "security and predictability" in the dispute settlement system ... implies that, absent cogent reasons, an adjudicatory body will resolve the same legal question in the same way in a subsequent case.

${ }^{10}$ Lang, Andrew, The GATS and Regulatory Autonomy: A Case Study of Social Regulation of the Water Industry, Journal of International Economic Law, 7, 2004, 801, at p804.
} 
and also in certain circumstances, according to national law and policy) to fulfill, protect and promote the right to health.

Thus, the more specific research question is:

How far can the GATS be interpreted to allow for national policy that protects a core societal value such as public health services, in light of the right to health?

This study will be mostly a legal analysis based on the interpretation of certain provisions in the GATS; particularly those which are presented as providing space for the protection of public services. The study hopes to contribute further to the discussion on the available policy space in the GATS by also taking into account the societal values back-cloth of these provisions, while spotlighting the legal interpretation of the provisions according to the rules of treaty interpretation.

It is also hoped that through the analysis of the provisions of the GATS, the study would provide support for the idea of policy space for States to protect and further develop public health services as an important feature of the interaction of rights and responsibilities of citizen and State, and of members of a modern society to each other. In the course of assessing the policy space in the GATS, the measures expected from a modern State, in light of societal values and buttressed by the right to health and the human rights based-approach, could be made evident. Thus, it can be argued that this study has implications beyond the GATS to the consideration of a socio-economic policy framework for supporting public health services in general.

The provisions which will be discussed in depth in this study include Article 1:3 of the GATS, which is sometimes referred to as a 'public services exemption' but which uses the phrase "services supplied in the exercise of governmental authority"; and Article XIV of the GATS, which is the general exceptions provision and includes "public morals" and "life or health" as policy objectives on which an exception can be argued. The discussion will not be limited to these provisions but will also include an analysis of provisions on non-discrimination, the scheduling of commitments and domestic regulation and their implication for national policy space. The study also critically discusses the extent of 'extra' policy space that may be available to developing countries and least developed countries in their implementation of the GATS while also developing their public health services using a right to health-based approach.

\subsection{OVERVIEW OF METHODS AND APPROACHES}

In order to answer the research question, an analysis of specific provisions of the GATS will be carried out. It has often been argued by its proponents that the text of the Agreement has sufficient guarantees of policy space. The provisions that will be focused on in this research are those which are most often referred to as the ones allowing for this space. Thus, the methodology used will be primarily treaty interpretation using the Vienna Convention on the Law of Treaties of 1969 (VCLT) and supplemented by the rulings of panels and the Appellate Body in WTO dispute settlement. It is hoped that this inquiry will lead to a better understanding of the content of the obligations of the specific provisions of the GATS which will be focused on.

There is also the wider issue of the general approach to interpretation of law and international economic law in particular. The legal profession often may wish to appear 
neutral in these matters of interpretation but terminology often has ideology behind it. Ideological positions can influence the drafting, understanding and interpretation of treaty provisions. This study also raises some theoretical and practical questions with regard to the societal values and economic ideologies that influence the drafting, understanding and interpretation of WTO law, and at the outset of the study, identifies some concepts that should be taken note of. There are certain broad concepts and ideas that underlie most of the debates in WTO law, and it is useful to mention them at the outset of Chapter 1. These include the role of economic growth in development and the role of sovereignty and democracy in policymaking. These concepts are mostly ambiguous and their interpretations can lead in opposing directions and may have both normative and positive law implications. The ideological positions taken on these concepts can and do often influence the interpretation that is favoured when dealing with how the liberalization obligations in the WTO will be carried out with 'due regard to national policy' as stated in the Preamble to the GATS.

The role of human rights law (and of other international law and principles such as those in environmental law) in the interpretation of WTO law is a matter of concern for those who believe that the WTO regime has an important role to play in human development. There is also an ideological struggle over the vocabulary and application of human rights for development and the place for human rights within the WTO system. This study aims to look at the GATS from both the trade and human rights perspectives and to assess when, how and whether a common ground can be found and a common language formed. As the two regimes have been identified at times as two distinct legal languages, this study considers the application of the concept of 'bilingualism' and thus, of language translation - in addition to legal interpretation, with the hope that this bring a fresh perspective to the debates and controversies in the area of services, particularly with regard to the issue of the protection of public health services.

The best a lawyer can do with words is sometimes no more than a balancing act - a bit like juggling while on a high wire. The ambiguity of meaning in texts may be what lawyers thrive on; that matters could go either way for the opposing interests involved. But this idea of a clash of interests (and sometimes more than that - a clash of value systems) sounds far too adversarial. Is it possible to find a safe and stable middle ground that is a win-win situation or must there be a choice between extremes? The words used in the GATS can be approached as a tool, and while tools have sometimes been designed for specific purposes, it may be possible not to use it to its full potential or to use it in ways that were not originally conceived. This nature of ideas, concepts and language (the possibility of using them in a variety of sometimes contradictory ways and their possible differing practical results) and the possibility of balancing or accommodating different values - has an impact throughout all the issues discussed in this book.

\subsection{ASSUMPTIONS}

This study rests on the assumption that societies ought to have the freedom to choose the form and nature of government for themselves and that their representatives in government can reflect social values and implement policy choices that are considered best by that society. This study will not make the assumptions that government is inherently less capable than the market of increasing social welfare ${ }^{11}$ or that the

\footnotetext{
${ }^{11}$ Shirley, Mary M., and Patrick P. Walsh, Public Versus Private Ownership, Volume 2420 of Policy
} Research Working Papers, World Bank Publications, 2000, p17, acknowledge that "[c]ontroversy surrounds 
government is inherently economically inefficient when it regulates or provides services. ${ }^{12}$ This study does not make the assumption that a perfect market system is the standard to which health service systems are to be measured. ${ }^{13}$ The views expressed below in the United Nations context, sum-up the basic underlying assumption in this study:

The question of values and ethics must be raised - even if market economics are seen as indispensable, societies are not ruled by the values of the market. Market principles cannot replace the values of solidarity, compassion and equity. ${ }^{14}$

Thus, broadly speaking, peoples, governments acting on their behalf and public institutions ought to be able to retain the choice, even in the context of a market economy, to make decisions that are not based on market values, but other important social values. The creation and continued development of models of public health systems which are 'universal', 'single payer' and free at the point of delivery, are examples of the alternatives which have been and can be implemented. The question is whether international agreements like the GATS, that WTO Members have voluntarily entered into, have retained for governments, the policy space for the choice to make such decisions.

The special interest theory - that special interests can capture the legislature, even in a democracy, and thereby make government ineffectual to implement policies that counter such special interests ${ }^{15}$ - will not be completely ignored, but will not be particularly focused upon for this study. There is also the possibility of 'elite capture' of economic and social policy due to the creation of political and economic elites or oligarchies, which could control law and policy. While there are many varieties of failure of governance possible, in light of the limited and otherwise unsavoury options available to us (dictatorship, oligarchy, aristocracy, monarchy, theocracy etc.) an assumption will be made that deliberative and participatory democracy is to be preferred - and interests legitimately represented thereby ought not be classified together with special interests that wield power through the corruption of the democratic process, to the detriment of the

the idea that public ownership is the best solution to market failure, even with a welfare maximizing government". The authors also comment at p14 and p15 on the idea that where the "political market" works effectively, it is more likely to elect social welfare maximizing governments.

${ }^{12}$ See for example Rothbard, Murray N., MAN, ECONOMY, AND STATE, Scholar's Edition, Ludwig von Mises Institute, 2009, at p952, p1266, p1272.

13 See further, Donaldson, C., Karen Gerard, Stephen Jan, Craig Mitton and Virginia Wiseman, ECONOMICS OF HEALTH CARE FINANCING: THE VISIBLE HAND, Macmillan International Higher Education, $2^{\text {nd }}$ Edition, 2004, p15, stating that "[t]he perfect market system is one which would unequivocally work best for healthcare, but only under certain ideal and strong assumptions". The authors go on to say that "[t]he usefulness of this model of perfect competition is that, even if it cannot be attained," it should be the standard against which the success or failure of other alternatives including public oriented systems should be measured.

${ }^{14}$ United Nations General Assembly (UNGA), Preparatory Committee for Special Session of the GA on Implementing Copenhagen+5 (2000), Note by the Secretary General, Symposium on States, Markets and Social Services: Roles and Co-operation of the Public and Private Sectors, UN.Doc A/AC.253/14 and E/CN.5/2000/5, p8, para.9.

15 "In the idealized democracy, public policy is guided by the principle of 'one man, one vote'. But in all real polities, special interest groups participate actively in the policymaking process." - Grossman, Gene M. and Elhanan Helpman, SPECIAL INTEREST POLITICS, MIT Press, 2001, p1. See further, Grossman, Gene M. and Elhanan Helpman, INTEREST GROUPS AND TRADE POLICY, Princeton University Press, 2002; Persson T., Economic Policy and Special Interest Politics, The Economic Journal, 1998 1;108(447):310-27; Lohmann S., An Information Rationale for the Power of Special Interests, American Political Science Review, 1998, 92(4): 809-27. 
welfare of citizens. However, not all WTO Members are democracies and not all governmental measures can be assumed to be reflect public interest. Nor should one assume that all special interest capture of regulation is done by domestic interests against foreign competitors, since transnational interests can also influence foreign governments to regulate in their favour against both other transnational interests and against domestic competition within that foreign country. The ideal situation is that the protectionist measures which trade law filters out with regard to services are those where there is special-interest capture of regulation which prevents the public from accessing and enjoying the services they require at the best available quality and affordability. In the context of health services and the right to health, this aligns with the standards of international human rights law reflected in the General Comment No.14 on the Right to Health by the Committee on Economic, Social and Cultural Rights. ${ }^{16}$

Furthermore, in general, it is fairly safe to assume at this point in time that the regulation of the market often has benefits over 'governance by the market'/ 'anarchy of the market'. Even with regard to the WTO law context, WTO Members, mainly States, preferred a system of enforceable rules and obligations often requiring re-regulation, rather than divesting of responsibilities of the State. The controversies in international trade law are often over what and how the State should be regulating rather than the fact of the involvement of government in regulating in the first place. Markets are needed for development, but effective governments are needed for well-functioning markets - to maintain political and legal stability through good governance, to regulate commercial activities for maximum social benefit, to correct market failure and to promote both economic growth and development.

With regard to the GATS, the move for international regulation of trade in services was initiated by service suppliers who wanted to expand into new markets and to operate across borders and therefore wanted governments to actively create better conditions for international trade. The interests of such service suppliers and their States of origin could at times conflict with the interests of other States with less developed service sectors, or more highly developed public services, or even cause controversies within a State regarding policy choices. These conflicting interests and controversies could concern government responsibilities regarding issues of right to health, right to education, right to water, environmental issues including climate change policies, development of developing country service industries and infant industry protection, as well as technology transfer, migration and brain-drain, inequitable development within countries, protection and promotion of culture and so on. This study makes the assumption that there is governmental responsibility to retain and use as much policy space as possible in order to carry out policies supporting citizens' rights and benefits, with special reference to the chosen area of public health services. Therefore, it becomes important to study and ascertain the extent of policy space in the GATS and the possibilities and limitations of treaty interpretation in situations where there are competing and conflicting interests.

\footnotetext{
${ }^{16}$ The elements of right to health are described as being: availability, accessibility (including affordability), acceptability (ethical and sensitive to culture, lifestyle and maintaining confidentiality) and quality para.12 of the UN CESCR, General Comment No. 14: The right to the highest attainable standard of health, U.N. Doc. E/C.12/2000/4, 2000.
} 


\subsection{LiMITATIONS}

Although this study concerns the national policy space for economic and social policy choices, it is not a study of economics, economic efficiency or economic analysis of law; nor does it necessarily suggest a 'best path' on the basis of economic theory. It only emphasizes the right and the responsibility of making a choice and examines whether the WTO system, and the GATS in particular, allows for that space. However, even though there will not be a law and economic analysis, there is an obvious underlying question concerning the definition and application of the concepts of welfare maximization (costs and benefits) and efficiency. This underlying question will not be specifically addressed in this study, since the focus will be on the availability of choice or policy space for the protection of a core societal value and the importance of having such space -but not on a cost-benefit or efficiency analysis of the methods employed to achieve such ends.

Neither does the study take on an analysis of the failures of governmental policy and decision-making, whether due to lack of information, manipulation by special interests or corruption. Analysis of case studies of such failures would be a separate exercise altogether, beyond the scope of this study.

It must be noted that this study does not undertake the case study method of presenting national systems or in-depth research into expressions of societal values related to public health services in chosen jurisdictions. However, illustrations from certain jurisdictions will be provided where necessary as evidence that different value systems exist and therefore, to encourage consideration of whether policy diversity regarding services is something that should continue within the GATS framework, and if so, how it can be supported by GATS rules. The references are intended for illustration and chosen for the information richness of the example, to provoke thought and not presented as generalizations or as representative samples. This is inspired by the "snapshot" method used by Gill Walt for illustrating the role of the State in the formation of health policies ${ }^{17}$ and the method generally used by UNDP studies and reports. Illustrations will be based on visibility of the issue in that jurisdiction, the fact that it has been flagged by those Members in trade negotiations or domestic consultations, caught the attention of local or international academia or civil society or led to the formation of organizations dealing with the relevant issues - and in general been a visible topic of debate. The range of illustrations will be also based on availability of publicly accessible information in the English language.

Certain exemptions and exceptions will not be dealt with in this study although they offer some scope for flexibility. These are the special provisions regarding economic integration (Article V of the GATS), labour market integration (Article Vbis), restrictions to safeguard the balance of payments (Article XII of the GATS) and the negotiating mandate for emergency safeguards measures (Article X of the GATS).

This is because, in the case of economic or labour market integration (Articles $\mathrm{V}$ and Vbis), the Articles concern bilateral, regional or other existing or proposed multilateral agreements; and these specific situations and analysis of these specific situations and agreements would be best suited for a separate study. But it is interesting to note that the

\footnotetext{
${ }^{17}$ Walt, Gill, HEALTH POLICY: AN INTRODUCTION TO PROCESS AND POWER, Witwaterstrand University Press, Zed Books, $2^{\text {nd }}$ Edition, 1996. See p11.
} 
economic integration exception is designed for facilitating trade liberalization $^{18}$ and it is a condition for recognition under the WTO system that there shall not be discrimination among the parties to such an agreement nor an overall raising of trade barriers due to such an agreement. Specific conditions listed under Article V:1 include 'substantial sectoral coverage' including that there should not be a prior exclusion of any mode of supply. ${ }^{19}$ Article XIV and XIVbis, as well as Article XII, are exceptions to all obligations under the GATS, including Article V. Article XIV (General Exceptions) and Article XIVbis (Security Exceptions)of the GATS, will be discussed in more depth in this study. Labour market integration is also interesting for the connection with Mode 4 obligations, as it is designed to facilitate greater freedom of movement for service personnel. It is about granting of the right of free entry to the employment markets of the parties and promotes measures concerning conditions of employment and social benefits. ${ }^{20}$ Thus it is a positive article from the point of view of rights and freedoms relating to labour, but that depends on action taken by parties to such a preferential agreement.

Article XII concerns situations where a "serious balance-of-payments and external financial difficulties or threat thereof" 21 has been identified and is thus also a 'special' situation. The most interesting aspect here is that Article XII:2 states that in such a situation:

Members may give priority to the supply of services which are more essential to their economic or development programmes.

It is however specified in Article XII that such restrictions must be temporary and shall not be used for protecting a particular service sector. ${ }^{22}$ The emergency safeguards provision (Article $\mathrm{X}$ ) is a negotiating mandate and is also more suitable for the subject of a separate in-depth inquiry. Article $\mathrm{X}$ is also generally understood to apply to a situation where a Member needs to "temporarily safeguard its domestic industry against serious injury or threats thereof". ${ }^{23}$ Moreover, both safeguards and balance of payments exceptions require that a specific type of short-term economic crisis situation be proven before the exceptions come into play and this study chooses to focus on generally available exemptions, exceptions and 'flexibility' provisions in the GATS, and general special and differential treatment provisions for developing and least developed countries which do not include such a pre-condition.

With regard to the interpretation of the provisions chosen for this study there is a particular limitation that is common for any study of the GATS. That is the fact that there are very few GATS cases in comparison with the goods area; and no cases that shed light

\footnotetext{
${ }^{18}$ See Panel Report, Canada - Autos, para.10.272:

Such economic integration agreements typically aim at achieving higher levels of liberalization between or among their parties than that achieved among WTO Members...In this respect, the purpose of Article $\mathrm{V}$ is to allow for ambitious liberalization to take place at a regional level, while at the same time guarding against undermining the MFN obligation by engaging in minor preferential arrangements.

${ }^{19}$ GATS Article V:1(a) and original footnote 1.

${ }^{20}$ GATS Article Vbis, original footnote 2.

${ }^{21}$ Article XII: 1 of the GATS.

22 Article XII:2(e) states that the restrictions shall be temporary and progressively phased out as the situation of balance-of-payments or external financial difficulties improves. The second sentence of Article XII:3 notes that restrictions "shall not be adopted or maintained for the purpose of protecting a particular service sector".

${ }^{23}$ Working Party on GATS Rules, Communication from ASEAN, Concept Paper: Elements of a Possible Agreed Draft of Rules for Emergency Safeguard Measures for Trade in Services (GATS Article X), S/WPGR/W/30, 14 March 2000, para.3.
} 
on some of the most contentious terms, phrases and issues. Furthermore, some important provisions are only negotiating mandates where Member consensus remains non-existent and no draft documents have been forthcoming due to the conflicting proposals and/or lack of information. Thus, the academic debates in the area of services contain divergent expert opinions presented by WTO lawyers and critics of the system, which may influence, but cannot predict, the direction that the panels and Appellate Body and WTO Members may take in either interpreting the provisions or formulating and developing services disciplines.

Finally, this study does not go into depth concerning two very interesting areas in trade law that are part of the back-cloth or larger picture. These are: the role of diplomacy/international relations and the role of powerful corporations and trade associations in the WTO trade negotiations and 'formation' of both the law and the disputes that result in the interpretation of the law. As powerful corporations and associations may be also playing a role in diplomacy - and even in the formation of the law - the analysis of the role of corporations as 'shadow drivers' of the system would be fascinating one to undertake; but it is one that cannot be included in this study. ${ }^{24}$ However, in the discussion of certain sections such as the scheduling of specific commitments and provisions on developing and least developed Members, the reality of international relations and imbalances of power will be taken into account.

\subsection{STRUCTURE OF THE THESIS}

This study comprises six chapters. Chapter 2 introduces the background to the research question, concepts and methodology. It is intended to set the scene for the legal analysis of the provisions of the GATS that is dealt with in the chapters that follow. The first part of Chapter 2 discusses some basic underlying concepts that should not be ignored; which are the backdrop to the play of the GATS and societal values unfolding on the stage. The concepts of the rule of law, liberalization, democratic participation in policy and lawmaking and human development should be recognized as part of the larger picture behind the focused area of trade in services in the foreground.

The discussion in the first part of Chapter 2, of the importance of national policy space or flexibility, and whether there is a possible clash of values in the WTO system as a whole and in the GATS itself, lead on to the second part of the Chapter. The second part of Chapter 2 deals with the opportunities and limitations of the standard approach to interpretation in the WTO context (based on the General Rule and supplementary rules of the Vienna Convention of the Law of Treaties), which is analyzed together with the suggestions for a 'human rights approach' to the interpretation of WTO law. Bringing human rights into the equation has its own set of challenges, which the second part of the Chapter will discuss. A broad theoretical approach based on language translation theory is suggested as a possible method of bridging the gap between the dichotomies of the trade and human rights regimes, which may not be able to be reconciled through the more conservative interpretative methods. Taken on its own, this Chapter is a general discussion of the difficulties of interpreting WTO Agreements, if one steps out of the 'WTO bubble' and attempts to grapple with the broader context and criticisms of the

\footnotetext{
${ }^{24}$ See for a sector-specific example, Arnold, Patricia J., Disciplining Domestic Regulation: the World Trade Organization and the Market for Professional Services, Accounting, Organizations and Society 30, 2005, 299-330 discusses the role of the international accounting industry (the major international firms and industry associations, located in the United States and in Europe).
} 
system. The third part of Chapter 2 presents the international human rights framework for the right to health, specifically Article 12 of the International Covenant on Economic, Social and Cultural Rights (1977) and its interpretation through the General Comment No. 14 (2000). This discussion of the understanding of the right to health and its relationship with State responsibilities, including the delivery of public health services will flow into the following discussions in the chapters that follow.

Chapter 3 deals with the scope of the GATS, with particular focus on what is often referred to as the 'public services exemption' in Article I of the GATS. Although the focus of the chapter will be legal analysis and interpretation based on the Vienna Convention rules, the discussion will be situated in the broader background of the debates on the protection of public services, particularly public health services. Since State subsidies are of primary importance in the context of protecting public services and exempting them from international trade rules, a part of this chapter will focus on the state of affairs with regard to rules on subsidies for services. Subsidies as well as government procurement are negotiating mandates in the GATS, but brief assessments are necessary with regard to the implications (for public services and development) of developing rules in this area. The scope of 'measures' that come under the GATS, the unclear definition for 'trade in services', the GATS approach to monopolies and government procurement will also be discussed in this Chapter.

Chapter 4 is in three main parts. The first part of Chapter 4 will discuss the nature of the non-discrimination principle in WTO law and compare it with that of the human rights regime. The reason for this analysis is because the application of non-discrimination among trading partners in WTO law is concerned with efficiency and prosperity of the world trading system as a whole; but in human rights law, non-discrimination is concerned with whether individual human beings are protected from negative discrimination, and receive special treatment or positive action if that is necessary in order to redress social injustice. The dissimilarities between these two concepts on nondiscrimination are usually underplayed in the trade law context, and thus attention is drawn to this before moving on to the second part of the Chapter. The second part of the Chapter deals with general obligations under the GATS that are taken on when becoming a WTO Member and any exemptions that may be available in that regard. The obligations regarding transparency and confidentiality in Article III and IIIbis and the Most Favoured Nation Treatment Principle of Article II will be discussed in this part. The third part of the Chapter is on the area that is said to be more flexible and which is also referred to as the special feature of GATS; the Scheduling of Commitments by Members for either/both national treatment (Article XVII) and market access (Article XVI) obligations. A brief discussion of Article VI of the GATS, on domestic regulation, is also part of the third part of Chapter 4. The impact of GATS on domestic regulation is often referred to as the area where GATS could be most intrusive with regard to the domestic policy space.

Even in the situation where specific commitments have been undertaken by Members, there is still the option of using the provisions for general exceptions: Article XIV of the GATS (and probably useful to a lesser extent, Article XIVbis Security Exceptions). The exceptions will be analyzed in Chapter 5. The exceptions are often identified as the entry point for human rights and other values, particularly through the public morals exception in Article XIV(a) of the GATS. The human life and health exception in Article XIV(b) of the GATS may also be relevant for the area of focus, public health services, so this provision will also be given special attention. This Chapter will also discuss the extent to 
which this may be true and also whether it could assist in keeping open or expanding the policy space for Members to follow national priorities that may conflict with WTO obligations. This analysis is conducted taking into account the limitations of the VCLT, the realities of international relations and the challenges of incorporating other international rules, norms and principles such as human rights, particularly the right to health.

Chapter 6 will deal with the issue of whether there is actually more leeway for developing country Members and least developed country (LDC) Members in the GATS framework. The chapter first introduces the background and relevant provisions but then analyzes the definitions for developing country and least developed country within the WTO context, including the issue of self-definition. Thereafter, the special provisions which may provide additional policy space for developing country and LDC Members, and the implementation of these provisions, is analyzed. A brief comment is also made on the role of subsidies for development, linking with the discussion of subsidies earlier in Chapter 3. Can developing countries and LDCs, who are possibly already at a disadvantage with regard to the current state of domestic service industries, ever become competitive in the international services market without some kind of affirmative action that allows for policies that boost their own industries? More importantly, in the context of this study, can these countries retain policy space to develop their public health services, for the benefit of their population? If the GATS framework supposedly addresses these concerns, as proponents say, then the provisions need to be analyzed to see if they actually go beyond lip-service to this idea and are able to deliver results.

The Conclusion will sum up the concerns and the possibilities that have been discussed in the preceding Chapters - explaining the current state of affairs and considering whether policy recommendations can be made, and at which levels.

What this study plans to contribute to the current debate is to see if it is possible to add to clarity and coherence in the aforesaid debatable areas. If the purpose of the WTO is security and predictability, then clarity where there is ambiguity is surely needed. But on the other hand, it can also be questioned whether this is what should be sought, since constructive ambiguity has often been the solution in contentious areas of trade negotiations. It can be wondered whether such an academic exercise will only 'rock the boat' and draw more attention to the contentious areas that negotiators have decided to postpone or avoid addressing and deciding on. Yet, as citizens of WTO Members and of the world, curiosity and the need to know more would lead in a different direction from that taken by cautious negotiators and bureaucrats, to attempt to focus on and clarify these murky areas as soon as possible.

It is hoped that the conclusions of this research will be of relevance for those interested in WTO law and the GATS as well as those interested in right to health and the role of public health services in achieving higher levels of implementation of the right to health. There is a need to 'keep fighting the good fight' promoting the role of public health services, in light of the commitment to the progressive realization of the right to health for all, regardless of the GATS framework. It is also hoped that this discussion of the policy space within the GATS, being placed in the broader context (or backdrop) of protection of socio-economic values and rights in the current framework of international economic law, will also contribute to that wider debate. 


\title{
CHAPTER 2
}

\section{UNDERLYING CONCEPTS, INTERPRETIVE APPROACHES AND THE RIGHT TO HEALTH}

\author{
...to know where sits the wind, \\ Peering in maps for ports and piers and roads ...
}

Salanio,

Shakespeare's Merchant of Venice 
Chapter 2 


\section{CHAPTER 2}

\section{UNDERLYING CONCEPTS, INTERPRETIVE APPROACHES AND THE RIGHT TO HEALTH}

\subsection{INTRODUCTION TO CHAPTER 2}

This Chapter is in three main parts. The first part discusses some of the issues and debates at the backdrop of the action at the foreground. The foreground of this study is the analysis of the rules of the WTO system, particularly the GATS framework. The discussion of the backdrop is for the reason that interpretation of any legal text does not take place in a vacuum and that there are concepts, societal values and ideology to deal with or ignore as may be, which have serious implications for the lives of people. The first part of this Chapter considers these underlying concepts briefly, which include references to the rule of law, liberalization, economic growth, human development, the right to development, sovereignty, democracy, societal values and the space for policy alternatives. These concepts will generally be discussed with regard to the policy choices relating to public services and to public health services in particular.

The second part of the Chapter is an overview of the methodology for the interpretation of the GATS provisions in the other chapters of this thesis. This second part also makes observations on possible limitations and challenges of both the traditional approach to the interpretation of a treaty and the proposed new approaches, in light of the values discussed in the first part of this Chapter. The traditional treaty interpretation approach based on the Vienna Convention on the Law of Treaties of 1969 (VCLT), is discussed first, followed by an analysis of human rights discourse and interpretative approaches in relation to WTO law. Using a human rights approach to WTO interpretation has been proposed by some as a means to bring in a better balance between trade and non-values within the WTO, and the second part of this Chapter makes a general assessment on the extent to which this may be possible.

Part three of the Chapter presents the current understanding of the right to health in the international human rights regime, with special focus on Article 12 of the International Covenant on Economic, Social and Cultural Rights (ICESCR, 1977), but also briefly introducing the other important international human rights treaties. The Committee on Economic, Social and Cultural Rights (CESCR) has interpreted the scope and contours of the right to health in Article 12 of the ICESCR and the obligations of States in this regard, through the General Comment No.14 on the Right to Health (2000). This section also analyzes the status of General Comments in international law before going into more detail on the contents.

The space for national policy in the GATS should not be looked at in isolation of the core societal values upon which such policy choices are being made. In this Chapter, national policy choice will be discussed in light of the core societal value of creating and protecting public health services, with 'snapshots' from several countries to highlight the points discussed. This value is also identified as a part of the obligations of a State under international human rights law to protect, promote and fulfil the right to health of its population. It is intended that this discussion of the background and observations on important underlying concepts will be the basis for the discussion on the methodological 
aspects in the second part of the Chapter and interconnected with the right to health-based approach presented in the third part of the Chapter, as well as providing a foundation for the discussions on values and policy choice in later Chapters of this study.

\subsection{BACKGROUND AND OBSERVATIONS ON IMPORTANT UNDERLYING CONCEPTS}

\subsubsection{Trade in Services enters the WTO}

It is well known that services were not originally conceived as an area that required international regulation, but began to draw the attention, particularly of transnational companies, due to their growing value as a share of international trade. The GATS was intended to expand the opportunities for participation and profit in this area for private entities across borders in an area often described as the largest and fastest growing area in the global economy. ${ }^{25}$ As the potential for profits in this area grew, so did incentives for the opening up of hitherto restricted markets.

For most of those keen on cashing in on this economic opportunity, it is important to have a framework of rules that support trade in services and reduce the risks and costs of entering new markets. The WTO, established in 1995, provides a forum for on-going trade negotiations and a dispute settlement system based on a legal framework for international trade created by its Members. This includes trade in goods, which incorporates the General Agreement on Trade and Tariffs (GATT) of 1947 as GATT 1994 of the WTO, and the new areas of services and trade related aspects of intellectual property rights. The GATS is part of the 'single undertaking', otherwise referred to as the 'WTO package', which every WTO Member accepts on becoming part of the organization.

But in order to begin the process of creating international rules, even the first task - that of defining the concept of services itself for the initial purposes of research and data collection - proved to be challenging. Most efforts focused on the invisibility and immateriality of services and the extent to which they can be comparable to trade in goods. ${ }^{26}$ More recently, the suggestions for fusing the goods and services disciplines in order to reflect a better reflection of market realities of cross-border trade have been deemed unfeasible. ${ }^{27}$ As services are by nature intangible and require supplier and consumer proximity or means of contact by technological methods, this means that services cannot be regulated by the traditional form of regulation at national borders

\footnotetext{
${ }^{25}$ World Bank, GLOBAL ECONOMIC PROSPECTS AND THE DEVELOPING COUNTRIES, World Bank Publications, 2002, p70-74; Organization for Economic Co-operation and Development (OECD), GATS, THE CASE FOR OPEN SERVICES MARKETS, OECD Publishing, 2002, p3; Mattoo, Aaditya, Robert M., Stern and Zanini, Gianni, Eds., A HANDBOOK OF INTERNATIONAL TRADE IN SERVICES, 2007, p3; Johnson, Debra and Colin Turner, Eds. INTERNATIONAL BUSINESS: THEMES AND ISSUES IN THE MODERN GLOBAL ECONOMY, Routledge, 2003, p163.

${ }^{26}$ See Fernandes, Deepali, Twins, Siblings or Friends: The Conceptual Case of Goods and Services, where do we stand and where could we be headed to? in Alexander, Kern and Mads Andenas, THE WORLD TRADE ORGANIZATION AND TRADE IN SERVICES, Martinus Nijhoff Publishers, 2008.

${ }^{27}$ Sauvé, Pierre, To fuse, Not to Fuse, or Simply Confuse? Assessing the Case for Normative Convergence Between Goods and Services Trade Law, Journal of International Economic Law, Volume 22, Issue 3, September 2019, p355-371.
} 
which applies to goods. Travel across borders by consumers, temporary migration by service suppliers who are natural persons as well as supply across borders by suppliers using technological means as well as through investment and establishment of commercial enterprises all come within the ambit of internationally supplied and consumed services. ${ }^{28}$ Therefore liberalization of trade in services needs to deal with the mix of cross-border and local presence of internationally traded services, the intangibility of services and the technological advances which reduce the significance of 'at-theborder' regulation in the case of services.$^{29}$ Footer and George have commented that:

...the GATS influences national domestic laws and regulations in a way that the GATT goods regime never has, simply because it [the goods regime] is largely concerned with border measures. ${ }^{30}$

Of course, it is not that the GATT does not have an effect of restricting domestic law and policy on goods, since there can be disputes on domestic measures that are considered protectionist and thus in violation of GATT obligations; but it is generally commented that a greater degree of intrusion could occur under the new area of trade in services. This perception may be due more to the fact that services were not covered by multilateral trade rules until recently and there is a new intrusion into a more sensitive area of the domestic sphere rather than it being more intrusive than the rules for goods. Footer and George comment that the closest comparison in the new WTO goods regime to the effect that services rules has, is the Agreement on Technical Barriers to Trade (TBT), as the TBT is designed to control the trade distortive effects of domestic regulations and standards for manufactured goods. ${ }^{31}$ The SPS Agreement also constrains regulatory autonomy concerning sanitary and phytosanitary (SPS) measures a Member can take concerning food safety and protection of the life or health of humans, animals or plants. Under GATT 1947, the national treatment obligation meant that such measures had to be distinguished from protectionist measures, but under the TBT and SPS the disciplines go beyond non-discrimination rules to internal regulation including rules on harmonization, the requirement of a risk assessment basis and the least-trade-restrictive measure requirement.

All these Agreements, including the GATS, have provisions for the balancing of the international trade interests of Members with the national policy and regulatory autonomy of Members, ${ }^{32}$ but trade in services is usually seen as a more complex area than trade in

\footnotetext{
${ }^{28}$ The study that is often referred to as most influential in setting out criteria and typology for services is Sampson, Gary P. and Richard H. Snape, Identifying the Issues in Trade in Services, The World Economy 8, June 1985, p171-82. Sampson originally worked at UNCTAD and later became Head of services activities in the GATT Secretariat. See also, Feketekuty, Geza, INTERNATIONAL TRADE IN SERVICES: AN OVERVIEW AND BLUEPRINT FOR NEGOTIATIONS, Ballinger Publishers and |The American Enterprise Institute, 1988, p. 310. Feketekuty worked in the Office of the US Trade representative and was involved in the Uruguay Round Negotiations on services. See further on the definition of services in the Uruguay Round negotiations, Drake, William J and Kalypso Nicolaidis, Ideas, Interests, and Institutionalization: "Trade in Services" and the Uruguay Round, International Organization, Vol. 46, No. 1, Knowledge, Power, and International Policy Coordination (Winter, 1992), p37-100;

${ }^{29}$ Hoekman, Bernard, Liberalizing Trade in Service, a Survey, World Bank Policy Research Working Paper 4030, 2006, p5.

${ }^{30}$ Footer, Mary E. and Carol George, The General Agreement on Trade in Services in Macrory, Patrick, Arthur Appleton and Michael Plummer, THE WORLD TRADE ORGANIZATION: LEGAL, ECONOMIC AND POLITICAL ANALYSIS, VOL. I, Springer, 2005 at p802.

${ }^{31}$ Ibid., (Footer and George).

${ }^{32}$ See further: Marceau, Gabrielle and Joel P. Trachtman, A Map of the World Trade Organization Law of Domestic Regulation of Goods: The Technical Barriers to Trade Agreement, the Sanitary and
} 
goods. It is due to the observation that GATS will be an intrusion into an area formerly subject only to national law and policy that additional sensitivities and controversies come into play.

While there is satisfaction on one hand that there is an international rule-based system to deal with cross-border trade in services, there is also concern that the system has certain in-built biases and is therefore limited in its approach to the complexities in services and that it also creates new problems. It can also be questioned whether the system may even prevent certain solutions to socio-economic problems which WTO Members need to deal with by designing and applying relevant national policy and regulatory measures. Thus, in the context of international trade in services, there is a fear that the GATS will tie the hands of nation states and local authorities, limiting future policy flexibility that is necessary for progress and achieving socio-economic goals. ${ }^{33}$ This fear is especially acute in the case of the GATS because the influence or intrusion on domestic governmental decision-making and action is considered more than was earlier the case in the GATT rules. ${ }^{34}$ Furthermore, there are few who do not find themselves confused and lost in the maze of the GATS provisions, their differing interpretations and the possible loopholes.

In addition, there continue to be suspicions and allegations that the current situation, as well as proposed future developments in most areas of services under the WTO, may be beneficial primarily to a relatively small group of businesses and consumers and that it bypasses other participants in the global economy and other interests and values. Responding to such criticisms, the WTO Secretariat has been keen to clarify that:

... the WTO is not just about liberalizing trade, and in some circumstances its rules support maintaining trade barriers - for example to protect consumers, prevent the spread of disease or protect the environment. ${ }^{35}$

However, the WTO response to these matters has rarely if ever, met with praise by consumer protection, health or environmental groups. This could be because the brief summaries of the more controversial WTO decisions in media releases and news reports which are accessed by the public appear to laypersons to disregard environmental concerns altogether, when the actual basis of the decisions are often a more technical analysis, such as the necessity of a measure or of whether a measure results in unjustifiable discrimination between Members. It may be that the national authorities responsible for the decision-making have not prepared their rules in accordance with the obligations which they have chosen to bind themselves - and thus the outcome is more a matter of ineffective and imprecise formulation of domestic rules in accordance with national policy, rather than being denied the policy space by WTO law.

Phytosanitary Measures Agreement, and the General Agreement on Tariffs and Trade, 48 Journal of World Trade, Issue 2, 2014, p.351-432

${ }^{33}$ As summed up in the words of one critic, citizen activity for:

[a]dvancing crucial non-commercial values that shape living standards will be stifled by the WTO, with bottom-up democratic impulses replaced by pull-down mercantile dictates.

- statement of Ralph Nader at The Uruguay Round of the General Agreement on Tariffs and Trade, Hearing before the Senate Committee on Foreign Relations, 104 ${ }^{\text {th }}$ Congress, June 14, 1994, 1994 WL 266499 cited by Jackson, John, H., SOVEREIGNTY, THE WTO AND CHANGING FUNDAMENTALS OF INTERNATIONAL LAW, Cambridge University Press, 2006, p71.

34 See e.g. Kennedy, Daniel L., and James D. Southwick, THE POLITICAL ECONOMY OF INTERNATIONAL TRADE LAW: ESSAYS IN HONOR OF ROBERT E. HUDEC, Cambridge university Press, 2002, p1-5: noting at p5 that the new WTO agenda controls governmental conduct in a different way from the earlier, simpler choices regarding tariff protection etc.

${ }^{35}$ WTO, UNDERSTANDING THE WTO, $5^{\text {th }}$ Edition, July 2011, p7. 
Thus, on one hand, while there is criticism of the restrictions created by the GATS, there is also on the other hand an indication of some sort of in-built balancing mechanism within the Agreement, where the text offers some hope in facing the fears mentioned above. However, the extent to which it will be possible in practice to freely take measures $^{36}$ according to national policy objectives remains unclear. More importantly, does the balancing mechanism extend to allowing for alternative socio-economic policy choices in the area of services for a WTO Member? The purpose of this study is to analyse such mechanisms in the text of the GATS - what the text promises and whether, in the course of interpretation and application, the text can deliver on its promises.

\subsubsection{The Role of Law/ The Rule of Law}

"All the laws were good laws. For cats.

But, oh, they were hard on the mice." 37

In a sense, the debate on the WTO is part of the larger debate on the benefits and drawbacks of globalization and the even larger picture of the value of law. Those who feel protected by or believe in the protection of a rule-based system - or who see its potential for protection - will see it as vastly superior to the freedom or anarchy of trade without rules wherein the unprotected suffer - a "law which liberates" ${ }^{38}$. But there can be others who feel alienated and vulnerable - that laws are but "spider webs for the rich and mighty, steel chains for the poor and weak" 39 and who therefore do not trust that this system will deliver a better life for them. This distrust does not necessarily go so far as expressing a preference to have no rules at all instead of the present ones, but that the rules can and ought to be critiqued and challenged for not providing desired outcomes. Thus, these attitudes and approaches are not necessarily ideological ones, but can be based on the evaluations of whether there are benefits in the system and in the use of the system for promoting the values that different groups believe should be promoted.

In the middle ground between law as freedom or law as chains (frees the weak and chains the strong or vice versa, depending on the context and the point of view), a more cautious view would be one that appreciates the application of the rule of law in preventing abuses, but is at the same time aware of the realities - the inadequacies of law and the possibility

\footnotetext{
${ }^{36}$ The GATS Agreement Article XXVIII(a)(Definitions):

For the purpose of this Agreement... 'measure' means

....any measure by a Member, whether in the form of a law, regulation, rule, procedure, decision, administrative action, or any other form.

${ }^{37}$ From the famous 'The Story of Mouseland' speech told by Tommy Douglas in 1944, available online at http//:www.dcf.ca /en/mouseland.htm, last accessed 12.03.2012

${ }^{38}$ Van den Bossche, Peter., THE LAW AND POLICY OF THE WORLD TRADE ORGANIZATION, Cambridge University Press, $2^{\text {nd }}$ Edition, 2008, quoting Fr. Lacordaire at p 34:

In relations between the rich and the strong, between the rich and the poor, between the master and the servant, it's liberty that grinds down, and the law which liberates.

Also noting further that international trade rules offer a greater measure of equity in international economic relations and that weaker countries are more likely to benefit from a rules-based system (at p34-35).

39 Proudhon, Pierre-Joseph, GENERAL IDEA OF THE REVOLUTION IN THE NINETEENTH CENTURY, Courier Dover Publications, Reprint, 2013, p133:

Laws: We know what they are, and what they are worth! They are spider webs for the rich and mighty, steel chains for the poor and weak, fishing nets in the hands of government.
} 
of abuses that can be carried out by it or under the cover of legality. In the context of the GATS, the text of the Agreement can create both hopes and fears for the weak in need of the freedom and protection of the law.

Furthermore, the objectives of 'security and predictability" 40 in the WTO dispute settlement system, though laudable from a strict rule of law perspective, may be at the cost of possibilities for diplomatic and flexible solutions. But creating the balance between stability and flexibility is tricky. The former dispute settlement system under GATT 1947 had more flexibility and has been described by Hudec as "designed and operated as an instrument of diplomacy". ${ }^{41}$ Marceau notes "the culture of diplomacy", the "diplomatic culture of confidentiality" and the forging of compromises out of the public eye; which is described as permeating the GATT dispute settlement. ${ }^{42}$ She also notes that the key goal in the old GATT dispute settlement system was to "find a solution, rather than crafting exhausting legal analysis". ${ }^{43}$ However, this flexibility led to the uneven quality of GATT law and underlined the need for stability as expressed in the WTO system. Taking into account the weaker bargaining position of developing countries, it is also possible to argue that having increased space for negotiated diplomatic solutions may not result in better outcomes for all parties to the negotiation. ${ }^{44}$ Yet, the WTO system as a whole and the texts of the covered Agreements are also the result of a negotiated outcome in which developing countries were in a weaker bargaining position. Moreover, even this purported 'security and predictability' of the WTO system is often in doubt. One reason as the "constructive ambiguity' 45 of certain terms that succeeded in garnering agreement on a final text. It is possible to surmise that at least some ambiguous terms were intentionally retained in the text so as to allow for flexibility for national policy objectives. But if there is a dispute which requires that the panels and Appellate Body deal with such ambiguous terms and clarify them in order to promote security and predictability in the system, it cannot be certain that the interpretation would be in favour of national policy flexibility.

\footnotetext{
${ }^{40}$ Article 3.1 of the WTO Dispute Settlement Understanding (DSU):

The dispute settlement system of the WTO is a central element in providing security and predictability to the multilateral trading system...

${ }^{41}$ See Hudec, Robert, The GATT Legal System: A Diplomats Jurisprudence, Journal of World Trade 4, 1970, 615, p665; adding further that what sets the GATT system apart from other (domestic) systems is the "overriding concern for 'flexibility' ... [from] the laws' coercive pressures".

42 Marceau, Gabrielle, A HISTORY OF LAW AND LAWYERS IN THE GATT/WTO: THE DEVELOPMENT OF THE RULE OF LAW IN THE MULTILATERAL TRADING SYSTEM, Cambridge University Press, 2015, p66.

${ }^{43}$ Ibid., (Marceau).

${ }^{44}$ See further Weiler, J.H.H., The Rule of Lawyers and the Ethos of Diplomats: Reflections on the Internal and External Legitimacy of WTO Dispute Settlement, Journal of World Trade 35, 2001, 191-207; who refers to the utility of such dispute settlement being "chilled" for "the meek and economically and politically unequal".

${ }^{45}$ Van Damme, Isabelle, TREATY INTERPRETATION BY THE WTO APPELLATE BODY, Oxford University Press, 2009, p144; refers to constructive ambiguity as 'deliberate silences', but adds that it does not necessarily mean that there is no law.

Sampson, Gary P., THE WTO AND SUSTAINABLE DEVELOPMENT, United Nations University Press, 2005 , p170 refers to the "...legendary penchant of WTO/GATT members to resort to constructive ambiguity in the drafting process"; and further adds at p261 that it is a 'fig leaf' that hides disagreement without actually blocking the negotiations. Also see Sampson, p106, p 260 and p188 for further comments on the results of this ambiguity.
} 


\subsection{3. 'Liberalization'}

It seems that most of these abovementioned fears are ignited by the emphasis on the term and concept of 'liberalization', as much as the concept of 'services as trade'. The WTO is often referred to as 'an organization for liberalizing trade' both in its own publications ${ }^{46}$ and in a less positive tone, by its critics. The concept of trade liberalization is often, controversially, linked with laissez faire in the minds of many observers. Edwards commenting on this matter, notes that while liberalization has been referred to in various ways ranging from merely reducing anti-export bias to laissez faire, by the late 1980's policy debate had become both confusing and ideologically based, due to the inability to clearly define both the concepts of 'trade liberalization' and alternative policies to it. ${ }^{47}$

The Marrakesh Agreement Establishing the World Trade Organization (hereinafter the WTO Agreement) identifies the goals of liberalization primarily in terms of economic growth. The Preamble of the WTO Agreement refers to the objectives of the growth of real income and demand and expanding the production of and trade in goods and services. The Preamble of the GATS refers to the expansion of trade in services and promoting the economic growth of all trading partners through progressive liberalization of service sectors. The underlying assumption, based on classical economic theory, is that these economic objectives can be best achieved by a liberalization framework such as that promoted by the WTO. ${ }^{48}$

There are some obvious short and mid-term benefits both from the point of view of business and consumer interests but at the same time, some doubts raised as to whether the WTO system by itself will lead to longer term benefits of sustainable development of

46 WTO, UNDERSTANDING THE WTO, 5 $5^{\text {th }}$ Edition, July 2011, p. 9. In the WTO Publication UNDERSTANDING THE WTO Chapter 1: The Basics, the section titled 'What is the World Trade Organization?' it is stated that:

There are a number of ways of looking at the WTO. It's an organization for liberalizing trade. It's a forum for governments to negotiate trade agreements. It's a place for them to settle trade disputes. It operates a system of trade rules.

${ }^{47}$ Edwards, S., Openness, Trade Liberalization, and Growth in Developing Countries, Journal of Economic Literature, Vol. 31, No. 3, September 1993, p1358 at p1365; Edwards also cites Cooper (Richard N. Cooper, Why liberalization meets resistance in J. Michael Finger (ed.), THE URUGUAY ROUND, A HANDBOOK ON THE MULTILATERAL TRADE NEGOTIATIONS, World Bank, November 1987. p. 518), who says:

...it is necessary to distinguish between different types of liberalization ....and to disassociate liberalization from laissez-faire.

${ }^{48}$ Lal, Deepak and Sarath Rajpatirana, Foreign Trade Regimes and Economic Growth in Developing Countries, World Bank Research Observatory, 1987, 2(2), p189: argues that free trade is the 'handmaiden of growth', but not necessarily the 'engine of growth' as it: ...indirectly constrains the state from going beyond the bounds of necessary public action for the provision of those domestic public goods that are essential for development

Frankel, Jeffrey A. and David Romer, Does Trade Cause Growth? The American Economic Review, Vol. 89, No. 3, June 1999, p379, examine the question of whether international trade affects income and standards of living. This study also concludes that international trade by itself, while it is to be encouraged, provides no clear evidence of a causal link, while a countries' geographical characteristics, level of internal trade and other policies are also significant in its levels of growth and income.

More Recently, an IMF Staff Paper (Billmeier, Andreas And Tommaso Nannicini, Trade Openness and Growth: Pursuing Empirical Glasnost, IMF Staff Papers 2009 56, at p447) analyzing a number of studies on the effect of trade on growth concluded that:

...we confirm a positive correlation between trade openness and growth in selected regions after $1970 .$. however, we cannot interpret this correlation as a causal effect [emphasis added]. 
developing countries. ${ }^{49}$ Sustainable development is recognized in the opening paragraph of the Preamble to the WTO Agreement. The economic growth which is expected to be achieved should also occur:

...while allowing for the optimal use of the world's resources in accordance with the objective of sustainable development, seeking both to protect and preserve the environment and to enhance the means for doing so in a manner consistent with their respective needs and concerns at different levels of economic development.

The opening sentence of the Preamble to the WTO Agreement also includes the phrase:

Recognizing that their relations in the field of trade and economic endeavour should be conducted with a view to raising standards of living, ensuring full employment...

Thus 'sustainable development' should not be seen merely as a calculation on the optimal use of resources for economic growth objectives but, taking into account the context of the paragraph and the extent to which this concept has evolved since its introduction, it should be recognized as a concept which includes socio-economic equity, a focus on rights and environmental justice. ${ }^{50}$ This aspect is not sufficiently embraced in the context of international trade and WTO law.

\subsubsection{Economic Growth, Human Development and the Right to Development}

...the question of benefits is a highly controversial matter, but one that must be gone into, for our democratic republic sets great store by the discovery of truth in matters of public importance in the market place of ideas by vigorous and uninhibited public debate. In the debate, perhaps, we need to consider whether income and economic growth on which the respondents lay great emphasis are the sole criteria for measuring human welfare. ${ }^{51}$

The focus on economic growth per se without taking other development indicators that take the impact on ordinary human lives into account is also a far too limited approach. Economic growth is important, but only in so far as it is a means to reduce social inequality and directly benefits the poor and marginalized groups in society, not as an end

\footnotetext{
${ }^{49}$ Edwards, S., Openness, Trade Liberalization, and Growth in Developing Countries, Journal of Economic Literature, Vol. 31, No. 3, September 1993, p1358 at p1365, also notes that even creating a liberalized system where all trade distortions are eliminated does not necessarily lead to improved economic performance and such a system may not be the most important policy developing countries need to implement.

${ }^{50}$ See Hopwood, B., Mellor, M. and O'Brien, G., Sustainable development: mapping different approaches, 2005 Sust. Dev., 13: 38-52: on how the concept is being used in attempts to combine environmental justice and human equity, especially to provide a conceptual basis for socio-economic policy for sustainable livelihoods. See also Redclift, M., Sustainable development (1987-2005): an oxymoron comes of age, 2005 Sust. Dev., 13: 212-227, on the emergence of a rights-based approach in sustainable development discourse.

${ }^{51}$ Bulankulama and six others v. Ministry of Industrial Development and seven others, S.C. Application No 884/99 F.R., decided on 2nd June 2000, Sri Lanka (Supreme Court, Fundamental Rights). This landmark Sri Lankan case dealt with a fundamental rights petition against a phosphate mining investment agreement by a subsidiary of the US company Freeport MacMoran that threatened a land area of extreme cultural and ecological importance. The economic benefits presented by the respondents were not considered by the Supreme Court as able to outweigh the damage that would be caused if the project went through.
} 
in itself. ${ }^{52}$ An alternative to the focus on economic growth is the human development approach, which is a broad and complex concept, but it has been defined by the United Nation Development Programme (UNDP) as being about:

...expanding the richness of human life, rather than simply the richness of the economy in which human beings live. It is an approach that is focused on people and their opportunities and choices. ${ }^{53}$

In the context of this study having special reference to public services, it is interesting to note the comments by Anand and Ravallion that:

Advocates of the human development approach tend to attach a higher weight to supplying public services relative to expanding private incomes as instruments of public action - than do proponents of an incomescentered view of the objectives of development...This leads the HDR [UNDP Human Development Report, 1990] to view the public provisioning of social services as a leading instrument for human development, and relatively less emphasis is given to economic growth tout court [emphasis added]. ${ }^{54}$

On the issue of health, the conclusion of Anand and Ravallion's study on public services highlights the positive impact of public health spending; and states with reference to their key case study that:

Sri Lanka's impressive record of progress in human development despite being a poor country also illustrates what the right sort of public action can achieve, independently of income growth [emphasis added] ${ }^{55}$

\footnotetext{
52 Ibid, UNDP HDR website.

${ }^{53}$ UNDP, Human Development Reports, What is Human Development?, http://hdr.undp.org/en/humandev. See also Anand, Sudhir and Martin Ravallion, Human Development in Poor Countries: On the Role of Private Incomes and Public Services, The Journal of Economic Perspectives, Vol. 7, No. 1 (Winter, 1993), p133 at p136:
}

The human development approach focuses on the state of existence of people - the lives they lead - not the detached objects they happen to possess

${ }^{54}$ Anand, Sudhir and Martin Ravallion, Human Development in Poor Countries: On the Role of Private Incomes and Public Services, The Journal of Economic Perspectives, Vol. 7, No. 1 (Winter, 1993), p133, at p136. The authors also contrast the 1990 UNDP Human Development Report (HDR) and the 1990 World Bank World Development Report for the differing emphasis on economic growth/income as poverty reduction instruments. The HDR definition of development, they conclude, is more consistent with the 'capabilities approach' advocated by Sen.

See also The HDR (2010), THE REAL WEALTH OF NATIONS: PATHWAYS TO HUMAN DEVELOPMENT, Chapter 3, Diverse Paths to Progress (hdr.undp.org/en/media/HDR 2010 EN _Chapter3_reprint.pdf) that supports the idea of different means to the goal of human development and presents that:

...one of the most surprising results to come out of human development research in the past few years: the lack of a significant correlation between economic growth and improvements in health and education. Understanding this result is enormously important for development policy...over time progress has come to depend more on how countries exploited these ideas - with differences among countries traceable, in part, to variations in institutions and in the underlying social contract [emphasis added].

55 Anand, Sudhir and Martin Ravallion, Human Development in Poor Countries: On the Role of Private Incomes and Public Services, The Journal of Economic Perspectives, Vol. 7, No. 1 (Winter, 1993), p133 at p136. Further commenting at p147:

We have pointed out a number of caveats to these conclusions; for example, basic health capabilities may well be more responsive to this type of public action than other capabilities, such as those related to education. Nonetheless, our analysis does lend qualified support for the view that certain components of public spending can matter greatly in enhancing human development in poor countries, and that they matter quite independently of what they do or don't deliver in terms of reduced income poverty. It is the latter claim that lies at the heart of the difference in policy implications between the 
A question that could then be framed in the study of the WTO GATS is: to what extent would a human development approach giving a 'greater weight' to public health services find the required 'policy space' within the GATS context?

The human development approach is sometimes linked to the right to development, but it was originally pioneered by Amartya Sen (giving the conceptual basis through the capabilities approach) and Mahbub ul Haq (in launching the first UNDP Human Development Report in 1990). The definition and parameters of human development are flexible and can evolve over time, but central issues contained within the concept include social progress, equity, participation and freedom (equality rights and democratic governance), sustainability (ecological, economic and social) and security (similar to 'freedom from want'). ${ }^{56}$ This concept is now also used by other UN bodies in the context of the right to health. ${ }^{57}$ Although the human development approach is not one which restricts itself to narrow definitions or measurements, a measurement which is often used is the Human Development Index (HDI) which was introduced by the UNDP in its first Human Development Report in 1990. The three indicators assessed in the HDI are (i) literacy and schooling, (ii) life expectancy (and measurement of its related health indicators) and (iii) adjusted income. Therefore, strategies for human development emphasize a three-pronged policy of investing in education and health, and promoting equitable economic growth.

It is sometimes suggested that higher levels of income and higher levels of real expenditure on health (health services being a large and profitable industry) are linked with better health outcomes and that low income and thus low (private) expenditure is a sign of low outcomes. It is important to keep in mind that this is not necessarily true. In fact there are studies and statistics which suggest otherwise: that it is spending effectively targeted towards better outcomes, rather than merely higher income and higher expenditure on health, that has achieved results, especially for the poor. ${ }^{58}$ Fukuda-Parr has also commented that looking at the HDI rankings has made policy-makers consider why countries such as Costa Rica, Sri Lanka, or the state of Kerala in India, "managed to achieve much higher levels of 'human development' in comparison to countries with

human development approach and more traditional income-centered approaches to development.

${ }^{56}$ See UNDP HDR, website, hdr.undp.org/en/humandev/origins/, last accessed 15.03.2012.

${ }^{57}$ For an example of its use in the right to Health context see OHCHR, Human Rights Council, Report of the Special Rapporteur on the right of everyone to the enjoyment of the highest attainable standard of physical and mental health, Anand Grover, 12 April 2011 A/HRC/17/25, paras.4, 8, 11, 12, 13, 19, 31 (also citing Sen and Nussbaum at para.11). At para.12:

When development is perceived in terms of human development and capabilities, it is evident that the right to health has both constitutive and instrumental relevance in respect of development and poverty reduction

58 See also Baldacci, E., B. Clements, S. Gupta and Qiang Ciu, Social Spending, Human Capital and Growth in Developing Countries, World Development, Vol. 3, Issue 6, August 2008, p1317, which also concludes that higher spending alone is insufficient to attain the Millennium Development Goals without effective alternative supportive policies and good governance. See also Gupta, S., M. Verhoeven, and E. Tiongson, Public Spending on Health Care and the Poor, Health Economics 12(8): 685-96, 2003, that statistics prove that public spending on health services have greater outcomes in terms of improved health for the poor. 
similar income levels. ${ }^{59}$ There is evidence that increase in increased government spending on public health services results in better health outcomes for individuals. ${ }^{60}$

The 1998 WTO Secretariat Note on Health and Social Services also cites Sri Lanka with regard to health expenditure stating that:

For example, Sri Lanka recorded an estimated life expectancy of 73 years in 1996, which is several years longer than in some other countries spending 20 or 30 times more on health. With Sri Lanka's per capita expenditure on health estimated at US\$12 per annum. $^{61}$

According to World Bank and WHO data, Sri Lanka's health expenditure was only USD 491 per capita in 2016 and has remained between $4.2 \%$ to $3.7 \%$ of GDP for the period 2000-2016. ${ }^{62}$ Meanwhile life expectancy at birth has increased further to 75.2 years in 2016 (78 years for females). ${ }^{63}$ Ironically, less overall spending on health (but policies that direct benefits to the population, especially the poor) may in certain situations actually achieve higher standards of health - something that needs to be taken into account in policy planning. ${ }^{64}$ Furthermore, several recent studies also note that there is no real correlation between per capita growth or income and non-income goals and indicators e.g. life expectancy and other indicators expressed in development targets like the Millennium Development Goals, without other development-supportive policies. ${ }^{65}$ If progress in terms of indicators such as health has not been proven as directly linked to economic growth, but related to how a national system has formulated its policies, we need to also look at where there has been progress, and what methods were used for improving the level of human development.

But can these kinds of ideas find space for expression within the current framework of rules in the WTO, specifically in the GATS, especially since the human development approach is not always supported by economic theorists advising global institutions ${ }^{66}$ The same Secretariat Note mentioned above stated that:

\footnotetext{
${ }^{59}$ Fukuda-Parr, Sakiko, The Human Development Paradigm: Operationalizing Sen's Ideas on Capabilities, Feminist Economics 9(2-3), 2003, 301 - 317, p305.

${ }^{60}$ Ibid., (Baldacci et al and Gupta et al). See further WHO, Spending on Health: A Global Overview, April 2012, http://www.who.int/mediacentre/factsheets/fs319/en/ or see http://www.who.int/whr/2010/en/;

Esteban Ortiz-Ospina and Max Roser - 'Financing Healthcare (2017)' published online at ourworldindata.org.

(Retrieved from: https://ourworldindata.org/financing-healthcare and https://ourworldindata.org/the-linkbetween-life-expectancy-and-health-spending-us-focus.)

${ }^{61}$ WTO, Secretariat Background Note, Health and Social Services, S/C/W/50, 18 September 1998, para. 12.

62 World Bank, Current health expenditure (\% of GDP) - Sri Lanka (retrieved from https://data.worldbank.org/indicator/).

${ }^{63}$ WHO, https://www.who.int/countries/lka/en/.

${ }^{64}$ Riley, James C., LOW INCOME, SOCIAL GROWTH AND GOOD HEALTH: A HISTORY OF TWELVE COUNTRIES, University of California Press, 2008, notes at p162: the 'archetypical cases' of Sri Lanka, Costa Rica, Cuba and Jamaica who made rapid progress on life expectancy and good health in the mid- $20^{\text {th }}$ century, with low income.

${ }^{65}$ See UNDP Human Development Report (2010), THE REAL WEALTH OF NATIONS: PATHWAYS TO HUMAN DEVELOPMENT, Chapter 3, Diverse Paths to Progress, citing Bourguignon, F., et al, Millennium Development Goals at Midpoint: Where Do We Stand and Where Do We Need to Go? Background paper for the 2009 European Report on Development, European Commission, 2008. The HDR 2010 concludes that impressive long-term gains in HD can and have been achieved even without consistent economic growth.

${ }^{66}$ Interestingly, even with the available facts, economists still rely on the old efficiency arguments to devalue public health services. See e.g. the World Bank study: Filmer, Deon, Jeffrey S. Hammer and L. H. Pritchett, Weak Links in the Chain: A Diagnosis of Health Policy in Poor Countries, The World Bank
} 
Many analysts, especially in OECD countries, may be inclined to see the health sector not predominantly as a "contributor" to GDP but as a drag on economic expansion [emphasis added]. ${ }^{67}$

This ignores the contribution of health services to society and to development as a whole, and as a factor in creating opportunities for further advancement of individual rights, casting it as mostly unnecessary expenditure. Yet, the next three paragraphs in the Note mention the differences in health expenditure across countries including the case of Sri Lanka, where good health indicators did not seem to be linked with the level of expenditure, and the United States, where extremely high levels of health expenditure were notably more due to the private sector than the public sector. It is true that expenditure without positive consequences for the society that is allocating the cost is something that needs to be re-assessed, and health systems can be made more costeffective. However, without drawing any links between the health indicator success and cost-effectiveness of public sector healthcare or the importance of health for development, the Note goes on to promote more private sector involvement, ${ }^{68}$ which seems rather contradictory. Perhaps this is due to extreme fidelity to the liberalization formula promoted by the WTO, rather than an objective assessment.

There may be different views on what development is and what its relationship with economic growth really is. For some, the causal links between trade liberalization to growth and then to development, are unassailable matters of both faith and fact - for others, the causation is debatable and lacking in convincing evidence. Ekins and Voituriez are skeptical, and of the view that knowledge on this linkage is "simply not adequate" to

Research Observer, Vol. 15, No. 2 (Aug., 2000), p199. This study discusses the reports and studies on the 'potentially replicable' (at p204) achievements in healthcare of Sri Lanka, Kerala (a State in India), Costa Rica and China. The public health programs of Jamaica and the Brazilian State of Ceara are also referred to. Interestingly the authors add that;

Although these examples suggest possibilities, it was never very clear whether the success stemmed directly from characteristics of their health systems or was instead a social or political phenomenon.

There often appears to be, for whatever reasons, a drawing back from clear expressions that a public health system coupled with a societal value system that promoted it can or ought to be replicated. But from p213214 the authors note that the studies in Kerala and Ceara indicate that it is a mix of social, political and community motivation which lead to provision of effective public health services. Nevertheless, the authors conclude in the follow-up paper - Filmer, Deon, Jeffrey S. Hammer and L. H. Pritchett, Weak Links in the Chain II: A Prescription for Health Policy in Poor Countries, The World Bank Research Observer, Vol. 17, No. 1 (Spring, 2002), p47 - that intensive public provision of healthcare is inefficient; crowds out private sector opportunities and takes away power and choices from consumers; is not replicable - "Kerala might be able to do it. Bihar certainly cannot" (p 63); is hard for the public sector to manage, so should be left to the market; and that risk pooling (insurance, privately provided?) is key.

${ }^{67}$ WTO, Secretariat Background Note, Health and Social Services, S/C/W/50, 18 September 1998, para.10.

${ }^{68}$ Para.3 appears to bemoan the fact that " $[\mathrm{t}]$ rade-related considerations have not proved a dominant policy concern..." but that:

However, the picture seems to be gradually brightening over time, owing in particular to two complementary developments: first, regulatory regimes in various countries have been moving towards stronger market orientation - opening space for increased private involvement, domestic and foreign

Para.34 notes approvingly that "[g]radual shifts towards systems with private participation may offer interesting business prospects"; and points out trends to "decentralize and/or commercialize the health sector" and introduce competition between public and private or between healthcare providers and private health insurance. WTO, Secretariat Background Note, Health and Social Services, S/C/W/50, 18 September 1998. 
engage in trade liberalization with the objective of promoting development. ${ }^{69}$ Voituriez further posits that the "the absence of consensual knowledge" on this link resulted in the impasse in the so-called 'Doha Development Round' of WTO negotiations ${ }^{70}$ which was based on this "development idea". ${ }^{71} \mathrm{He}$ illustrates this view by drawing attention to the language used by the Indian and US negotiators, whose positions resulted in the impasse at Geneva. Voituriez notes that India spoke of the Development Round as means for developing countries to safeguard livelihood security, whereas the US referred to the reduction of barriers to trade (more market openness) as its essential function. Liberalization of trade can contribute to economic and social development, but it cannot be assumed that all liberalization could automatically achieve this end without being balanced, within the system itself, by the necessary protections from possible negative social impacts. The difficulty of reaching agreement on this fairly obvious issue had dogged the 'Doha Development Round' negotiations from the outset. Since its launch in 2001, there have been only a few tentative steps forward. The $10^{\text {th }}$ WTO Ministerial in Nairobi in 2015 was seen by some as a fresh opportunity to push for the implementation of the 2013 Bali package. ${ }^{72}$ But problems of implementation continue, mainly because of this continuing divergence of views on achieving the best balance of having both trade liberalization and social goals for development. The most recent Ministerial Conference in Buenos Aires in 2017 did not further the development agenda in any significant manner, except perhaps for a decision to conclude negotiations on fisheries subsidies by preparing an agreement (which would also implement the UN Sustainable Development Goal 14.6 on sustainable fishing) for the next Ministerial in 2019. ${ }^{73}$

The snapshot of Sri Lanka discussed earlier highlights the problem of economic globalization that is usually inadequately addressed in the literature by trade experts addressing need for trade liberalization and the WTO legal framework. There is obviously no simple formula for trade and development that will work for all countries and for everyone within that country - additional efforts must be taken to ensure benefits for the most disadvantaged the marginalized. There are several different reasons why such additional efforts are not successfully designed and implemented, but overall, it is the failure of domestic politics and policy (both at local and national level) to respond to the needs of the disadvantaged and marginalized. Yet, an excuse that is sometimes given for these failures of responsibility is that there is a constriction of domestic policy space due to international trade and economic law, including WTO and policy. It is fair and honest

\footnotetext{
${ }^{69}$ Ekins, Paul and Tancredi Voituriez, Overview and General Introduction in Ekins, Paul and Tancredi Voituriez Eds., TRADE, GLOBALIZATION AND SUSTAINABILITY IMPACT ASSESSMENT: A CRITICAL LOOK AT METHODS AND OUTCOMES, Earthscan 2009/ Routledge 2012. The editors went on to state that, therefore,

The whole idea of a 'development round' of trade negotiations was fundamentally misconceived.

70 The Doha Development Round was launched at the WTO Ministerial Conference in Doha in 2001 and by the Ministerial Conference in Geneva in 2009 it was clearly seen that there was a difficulty for Members to move forward.

71 Voituriez, Tancredi, why did 'Development' Entrap the Doha Round in Ekins, Paul and Tancredi Voituriez Eds., TRADE, GLOBALIZATION AND SUSTAINABILITY IMPACT ASSESSMENT: A CRITICAL LOOK AT METHODS AND OUTCOMES, Earthscan 2009/ Routledge 2012.

72 The Bali Package is an informal way to refer to the Bali Ministerial Declaration and accompanying ministerial decisions adopted at the WTO Ministerial Conference on 7 December 2013, which was held in Bali. One of the key achievements in Bali was the Trade Facilitation Agreement (WT/MIN(13)/36 or WT/L/911), which was further 'cleaned up' by a November 2014 decision which also included a Protocol for adding it to the WTO agreements (WT/L/940).

${ }^{73}$ See WTO, Fisheries Subsidies, Ministerial Decision Of 13 December 2017 WT/MIN(17)/64, WT/L/1031 18 December 2017.
} 
to say that concerted efforts need to be made to craft policies and work towards the best possible result, and that while trade liberalization is one of the possible tools, it should not be considered the only tool which can be used. WTO law and policy does not assert that no other tools can be used, only that their use by Members should not be incompatible with the rights of other WTO Members under the relevant agreements.

There are natural questions on the outcomes of trade liberalization, which neither Members during negotiations nor members of the public should be expected to ignore; nor be pressured to accept economic dogma without critical analysis of the situation. One of the issues recognized by the Doha Ministerial Declaration of 2001 is the need to:

...improve dialogue with the public...continue to promote better public understanding of the WTO and to communicate the benefits of a liberal, rules-based multilateral trading system. ${ }^{74}$

The trading system promises prosperity, but in addition to promoting the possible benefits, the WTO and its Members need to address the possibility of harm being caused, even if it is unintentional harm. A serious consideration of all the consequences, including both benefits and harm, is necessary to build trust in a dialogue with the public. Discussing how harm can be mitigated, including the support and space within the system itself for such measures, would go a long way to improve the understanding of the WTO. Furthermore, the discussion should also be more inclusive of the work being done to understand the goal of development.

There are other sources to turn to in trying to define 'development' and to identify the framework in which to achieve it. In order to attempt to clarify the concept of development and whether there is a framework of international legal obligations of States to achieve it, one can turn to the Declaration on the Right to Development, ${ }^{75}$ adopted by UN General Assembly in 1986. The principles contained in this Declaration include the State obligation towards a process of development wherein economic, social, cultural, civil and political rights can all be realized and most importantly, reminds that:

The human person is the central subject of development and should be the active participant and beneficiary of the right to development [emphasis added]. ${ }^{76}$

It is unfortunate that sometimes the real effects on the lives of human persons are overlooked in statistics on trade and economic growth, but the human rights regime is there to redirect our focus back to this and remind us that trade should be seen merely as a means to improve the lives of all human beings. Article $8(1)$ of the Declaration specifically notes that:

States should undertake, at the national level, all necessary measures for the realization of the right to development and shall ensure, inter alia, equality of opportunity for all in their access to basic resources, education, health services, food, housing, employment and the fair distribution of income [emphasis added].

The Declaration was passed with only one dissenting vote (the United States) and eight abstentions including the United Kingdom. However, differing ideologies gave the

\footnotetext{
74 WTO Doha Ministerial Declaration 2001, WT/Min.(01)/Dec/1, 20 November 2001 (adopted on 14 November 2001), para.10.

${ }^{75}$ UN General Assembly Declaration on the Right to Development, Resolution A/RES/41/128, 4 December 1986.

${ }^{76}$ Ibid., Article 2(1).
} 
concept of a right to development an inauspicious beginning and has continued to hampered its legitimacy and justiciability. ${ }^{77}$

However, in the quarter century since then, the Right to Development (RtD) has been included in all major UN documents, and made a part of human rights. It was included in paragraph 10 the Vienna Declaration and Programme of Action of 1993, where it was unanimously affirmed ${ }^{78}$ (the United States also participated) ${ }^{79}$ - and Paragraph 24 of the Millennium Declaration of $2000^{80}$ which specifically identified the right to development

77 Justiciability refers to the fact that a legal right is that which is capable of being adjudicated upon.
However, a human right is not always a justiciable or legal right in all legal systems, which can be invoked
in judicial and quasi-judicial proceedings. Notwithstanding the lack of justiciability in certain legal systems,
this does not take away from the recognition of something as a human right within the international human
rights regime. Thus, the right to development and the right to health, even if non-justiciable in most
contexts, are recognized as human rights. See UN Committee on Economic, Social and Cultural Rights
(CESCR), General Comment No. 3: The Nature of States Parties' Obligations (Art. 2, Para. 1, of the
Covenant), 14 December 1990, E/1991/23, especially paras. 5 and 6 . See also with special reference to the
right to development, Sengupta, Arjun, On the Theory and Practice of the Right to Development, Human
Rights Quarterly 24.4 (2002): 837-889; Sengupta, Arjun. Right to Development as a Human Right,
Economic and Political Weekly (2001): 2527-2536; Alston, Philip. Making space for new human rights:
The case of the right to development, Harv.Hum.Rts.YB 1 (1988):3; OHCHR, Realizing the Right to
Development: Essays in Commemoration of 25 Years of the United Nations Declaration on the Right to
Development, 2013 , ravailable at Development,
thttp://www.ohchr.org/Documents/Publications/RightDevelopmentInteractive_EN.pdf.

${ }^{78}$ Also known as the Vienna Declaration on Human Rights or the Declaration at the World Conference of Human Rights. It was adopted by consensus of the 171 States which participated in the World Conference (there were also more than 800 non-governmental organizations, a majority of them being grassroots organizations).

10. The World Conference on Human Rights reaffirms the right to development, as established in the Declaration on the Right to Development, as a universal and inalienable right and an integral part of fundamental human rights.

As stated in the Declaration on the Right to Development, the human person is the central subject of development.

...The international community should promote an effective international cooperation for the realization of the right to development and the elimination of obstacles to development.

Lasting progress towards the implementation of the right to development requires effective development policies at the national level, as well as equitable economic relations and a favourable economic environment at the international level.

The Right to Development is also affirmed at Paragraph 72 and cited in Paragraphs 11 and 73. The Vienna Declaration was endorsed by the UN General Assembly Resolution 48/121, of 1994.

${ }^{79}$ As can be noticed, the United States rejection of the Declaration on the Right to Development (RtD) was under the Reagan Administration, but the concept was supported during the Clinton Administration. See further, Marks, Stephen P., The Human Right to Development: Between Rhetoric and Reality, Harvard Human Rights Journal, Vol. 17, 2004, 137 - on the "residual ideological hostility" (p146) to RtD from the United States. Marks also notes that during the George W. Bush Administration in 2003, the United States was one of only three votes against the Resolution of the Commission on Human Rights UN.Doc E/CN.4/RES/2003/83, which requested the Sub Commission of the Promotion and Protection of Human Rights to prepare a concept document for binding international standards for RtD (p140).

${ }^{80}$ UNGA, Millennium Declaration, A/RES/55.2 adopted by the UN General Assembly on 8 September 2000, paras. 11 and 24:

11. We will spare no effort to free our fellow men, women and children from the abject and dehumanizing conditions of extreme poverty, to which more than a billion of them are currently subjected. We are committed to making the right to development a reality for everyone and to freeing the entire human race from want [emphasis added].

24. We will spare no effort to promote democracy and strengthen the rule of law, as well as respect for all internationally recognized human rights and fundamental freedoms, including the right to development [emphasis added]. 
was adopted by the UN General Assembly. The Millennium Development Goals specifically identify health targets to be achieved (MDG 4: reduce child mortality; MDG 5: improve maternal health, MDG 6: combat HIV/AIDS, malaria and other diseases). In 2015, the Millennium Development Goals (MDGs) based on the Millennium Declaration were replaced by the Sustainable Development Goals (SDGs) and 2030 Agenda $^{81}$.

The SDGs extend beyond the Millennium Development goals in that it introduces 17 sustainable development goals for all countries, not only limiting itself to developing countries like the MDGs. The UN General Assembly Resolution introducing the 2030 Agenda noted that sustainable development agenda is informed by instruments such as Declaration on the Right to Development and based on respect for human rights including the right to development. ${ }^{82}$ Goal 3 the SDGS, which is broadly worded as "Ensure healthy lives and promote well-being for all at all ages", includes:

SDG 3.8 Achieve universal health coverage, including financial risk protection, access to quality essential health-care services and access to safe, effective, quality and affordable essential medicines and vaccines for all.

In September 2019, the United Nations High Level Meeting on Universal Health Coverage (UHC) was convened to mobilize political support for action on UHC to advance SDG 3.8. However, it is important to note that the right to health was not mentioned in the UHC (nor was anything said about public health services), leading to critical commentary that the UHC requires a robust 'right to health-based' conceptual and accountability framework in order to achieve its aims. ${ }^{83}$

The Declaration on the Right to Development is of course 'soft' law but it can be read with binding obligations found in the Covenants; the International Covenant on Civil and Political Rights and the International Covenant on Economic, Social and Cultural Rights (ICCPR and ICESCR). The Declaration on the Right to Development itself "recalls" the ICCPR and ICESCR in recital 4 of its Preamble. As mentioned above, the resolutions

Recital 9 of the concluding resolutions in Paragraph 30 also add that the GA resolves to:

To ensure greater policy coherence and better cooperation between the United Nations, its agencies, the Bretton Woods Institutions and the World Trade Organization, as well as other multilateral bodies, with a view to achieving a fully coordinated approach to the problems of peace and development [emphasis added].

${ }^{81}$ UNGA, Resolution adopted by the General Assembly on 25 September 2015: Transforming our world: the 2030 Agenda for Sustainable Development, A/RES/70/1, 21 October 2015

${ }^{82}$ Ibid., paras. 10 and 35.

${ }^{83}$ Nygren-Krug contends that the potential for UHC is limited "by its own ambiguity", since it lacks conceptual and operational clarity concerning a human rights perspective. She also critiqued the importance given to the private sector in shaping public health agendas, including the pressure made for privatization of health services. (Nygren-Krug, Helena, The Right (s) Road to Universal Health Coverage, Health and Human Rights 21.2, 2019, 215). Flavia Bustreo and Curtis Doebbler highlight the specific important failure of the UHC to prioritize women's and children's health and primary health care, which is a significant feature of the right to health approach promoted by the WHO and the OHCHR since the Alma Ata Declaration on Primary Healthcare of 1978 (Bustreo, Flavia, and Curtis Doebbler, Perspective - Universal Health Coverage: Are We Losing Our Way on Women's and Children's Health?, Health and Human Rights Journal November 21, 2019, available at https://www.hhrjournal.org/2019/11/universal-health-coverageare-we-losing-our-way-on-womens-and-childrens-health/\#_ednref18. Hammonds et al comment that the UHC needs to be "anchored in the right to health care", without which the UHC process would be risking "mirroring the global and national patterns of exclusion and injustice that flow from the colonial era" (Hammonds, Rachel, Gorik Ooms, Moses Mulumba, and Allan Maleche, UHC2030's Contributions to Global Health Governance that Advance the Right to Health Care: A Preliminary Assessment, Health and Human rights Journal, November 21, 2019). 
creating the MDGs and SDGs recognize the role played both by binding human rights instruments as well as the normative foundations laid by the concept of the right to development, and the fact that they should be read together.

Meier and Fox comment that there are underlying determinants of health "that can only be achieved by the provision of public goods through public health systems" and that the interrelationship between collective right to development and the individual right to health becomes important, since when read together they:

offer public health actors an opportunity to work through development discourses to obligate and empower states to allocate public goods for the public's health. ${ }^{84}$

The binding obligation with regard to the right to health in international law, which is discussed in this study, is expressed in Article 12 of the ICESCR (currently ratified by 170 of the 194 United Nations member States); but the goals and values with regard to health are recognized also in other non-legally binding UN documents. Thus, the importance of right to health, a binding obligation, in the context of a broader right to development, which is a normative statement and goal, is highlighted. The contours and requirements of the right to health are presented in more depth at the beginning of Chapter 3 of this study.

In 2004, a Background Note of the UN Secretariat to the Commission on Human Rights identified the right to development as conveying "a set of definite and powerful normative messages" and discussed how the right could be mainstreamed into the WTO ${ }^{85}$ This included looking at where and how the interpretation of WTO law could be affected by including a right to development perspective. However, the extent to which the Note analyzed this approach and offered suggestions was limited. It focused on the references to development policy and measures to protect balance of payments in the India-Quantitative Restrictions dispute, acknowledging that the right to development was apparently not raised during the dispute and suggesting that governments and civil society need to be "sensitized" on this matter as much as the WTO dispute settlement panels or the Appellate Body. ${ }^{86}$

It would be interesting to see what a right to development analysis of existing WTO law would reveal and what a better consideration of the concept - a true mainstreaming would change or be able to accomplish. It is possible that the rights-based approach would effectively link different approaches to development and direct the focus onto the ends to be achieved.

\footnotetext{
${ }^{84}$ Meier, Benjamin Mason, and Ashley M. Fox, Development as Health: Employing the collective right to development to achieve the goals of the individual right to health, Human Rights Quarterly, 30 (2008): 259293, p261.

${ }^{85}$ UN, Commission on Human Rights, Sub-Commission on the Promotion and Protection of Human Rights, Note by the Secretariat, Economic, Social and Cultural Rights - Mainstreaming the right to development into international trade law and policy at the World Trade Organization, E/CN.4/Sub.2/2004/17, 9 June 2004, first sentence of Report Summary and para.6. thereof. This report was authored by Robert Howse, acknowledging the assistance of Ana Frischtak and thanking Oona Hathaway and Harold Koh.

${ }^{86}$ Ibid, para. 49.
} 


\subsubsection{A Just and Equitable World Trade System?}

For the making of public policy, it is important not only to assess the demands of justice and the reach of values in choosing the objectives and priorities of public policy, but also to understand the values of the public at large, including their sense of justice. ${ }^{87}$

'Justice' and 'equity' are difficult concepts to grapple with, and some may question whether such notions play any useful role or any role at all in the 'law' and 'rules' that have to be dealt with in the WTO agreements. More recently, Linarelli, Salomon and Sornarajah have presented a philosophically influenced argument in support of international trade law being subject to the moral demands of justice, although international law in general admittedly "remains trapped in a power-based notion of justice". ${ }^{88}$ Howse has noted how questions of justice or redistribution are not usually made part of the training of the majority of young lawyers in the field of international economic law; ${ }^{89}$ and Sakr has commented that this is a creation of disciplinary boundaries which results in a marginalization of "relevant questions related to social justice and economic redistribution by setting humans rights and development policies outside the field's domain". 90

Notions of justice play an important role in understanding the differences between an approach to development that focuses merely on numbers to judge success (volume of trade, increase in profit margins, GDP per capita) and an approach that prioritises people in society as the participants in prosperity (human development, universal health care, public education, social mobility, reduction of inequality and the gap between highest and lowest economic percentile etc.) - and this needs to be reiterated. Yet it has been commented that:

As far as the theory of free trade is concerned, it has to be borne in mind that it refers to the prosperity of a society as a whole. It does not address questions about the distribution of this prosperity and the priorities of economic development [emphasis added]. ${ }^{91}$

The issues of taxation in order to provide for social welfare programmes and public services is thus left out of free trade theory, and even cast by some as a threat to free trade values, which really need not be the view to take on how prosperity ought to be shared by the whole community.

In the context of health services, a high expenditure can result in the health services sector recording a high percentage of GDP, but in terms of actual persons benefiting from health services and the positive impact on their lives, the result can be measured differently. For example, in 2015, health spending in the United States accounted for a staggering $17.8 \%$

\footnotetext{
${ }^{87}$ Sen, Amartya, DEVELOPMENT AS FREEDOM, Oxford University Press, 1999, p274.

88 Linarelli, John, Margot E. Salomon, M. Sornarajah, Chapter 2: Confronting the Pathologies of International Law: From Neoloberalism to Justice in THE MISERY OF INTERNATIONAL LAW: CONFRONTATIONS WITH INJUSTICE IN THE GLOBAL ECONOMY, Oxford University Press, 2018, p41.

${ }^{89}$ Howse, Robert, Economics for Progressive International Lawyers: A Review Essay, 5 London Review of International Law 2017, 187-196, p188.

${ }^{90} \mathrm{Sakr}$, Rafael Lima, Beyond History and Boundaries: Rethinking the Past in the Present of International Economic Law, Journal of International Economic Law, Volume 22, Issue 1, March 2019, 57-91, p63.

${ }^{91}$ Stoll, Peter-Tobias and Frank Schorkopf, WTO: WORLD ECONOMIC ORDER, WORLD TRADE LAW, Max Planck Commentaries on World Trade Law, Martinus Nijhoff Publishers,2006, p33.
} 
of GDP and the per capita cost per year is nearly $\$ 10,000$ - on the surface these numbers suggest wealth and capability of citizens to pay since even publicly financed healthcare is provided privately in the United States. And yet there is a huge problem of unaffordability, with millions of citizens without access to healthcare due to inability to pay for services, which includes inability to afford health insurance. ${ }^{92}$ There are a number of studies assessing the relationship between healthcare expenditure, bankruptcy and mortality in the United States, issues which have been raised by political figures and policy-makers who want to reform the current healthcare system. ${ }^{93}$

Thus, the actual benefits of free trade and liberalization for particular countries or individual human beings within countries in the current framework of international rules and the benefits of a just and equitable framework of international rules applicable for all WTO Members, may turn out to be two different things. Does the WTO have anything at all to do with reducing social inequalities either inside or between countries? The preambles of the WTO Agreement and the GATS both acknowledge a range of objectives, including the development of developing countries, but to what extent do the binding rules allow for national measures that are aimed at equitable development? What are the benefits of these rules if the rules do not create greater equity and opportunities for individual human beings as opposed to greater opportunities and benefits primarily for corporate bodies? In the words of one civil society group:

Defenders of the system keep reassuring us that if we can just get economic growth rates high enough, these problems will be solved. We regularly hear the refrain, 'a rising tide floats all boats'. But for those who don't own boats or have leaky boats, a rising tide means greater inequality between them and the more fortunate. ${ }^{94}$

There may be debate even on this point, but supposing that there is agreement that overall living conditions have improved across the world with the reduction of trade barriers, the issue is the extent of inequality that is present (whether created by these policies or merely remaining unchanged by them) and how much of it will be tolerated as inevitable or acceptable. Thus, it is relevant to discuss the extent to which the existing structures have a place for policy aimed at raising those without boats or with leaky boats.

Former WTO Director-General Pascal Lamy, noting that public opinion has become 'considerably more anxious about the effects of globalization' admitted that:

\footnotetext{
92 Jost, Timothy, Affordability: The most urgent health reform issue for ordinary Americans, Health Affairs Blog, February 29, 2016, http://healthaffairs.org/blog/2016/02/29/affordability-the-most-urgent-healthreform-issue-for-ordinary-americans/ ; Osborn, Robin, David Squires, Michelle M. Doty, Dana O. Sarnak and Eric C. Schneider, In New Survey Of Eleven Countries, US Adults Still Struggle With Access to and Affordability Of Health Care, Health Affairs, December 2016, Vol.35 No.12 2327-2336; Schoen, Cathy, Robin Osborn, David Squires and Michelle M. Doty, Access, Affordability, and Insurance Complexity are often worse in the United States compared to ten other countries, Health Affairs, December 2013 Vol. 32, No.12, 2205-2215.

${ }^{93}$ For example, see Scott, John W., et al., Cured into destitution: catastrophic health expenditure risk among uninsured trauma patients in the United States, Annals of Surgery 267.6 (2018): 1093-1099; Himmelstein, David U., et al., The US health care crisis continues: A data snapshot, International Journal of Health Services 48.1 (2018): 28-41; Kulkarni, Sandeep C., et al., Falling behind: life expectancy in US counties from 2000 to 2007 in an international context, Population Health Metrics 9.1 (2011): 16.

${ }^{94}$ Danaher, Kevin, Seven Arguments for Reforming the Global Economy, available online at www.globalexchange.org/campaigns/econ 101/sevenArguments.html, accessed 07.04.2011.

The Global Exchange website is a resource for critical perspectives of the global economy set up by a group of civil society activists
} 
Indeed, it can be argued that in some instances, globalization has reinforced the strong economies and weakened those that were already weak... The issue of global trade imbalances has also been taken up in similar terms. Some people are no longer convinced that a rising tide of trade will lift all boats. ${ }^{95}$

But he also pointed out that:

The WTO does not produce equity, in the meaning given to the term by public international law - rather, it produces legality. ${ }^{96}$

The attempt to provide legality as an alternative to anarchy is indeed the great thing about the WTO. But who amongst us actually wishes to exchange anarchy for international trade law without fairness? As Denis Lloyd has analysed it, an unjust law is a law which is valid in itself, but "conflicts with the scale of values by which we choose to judge it" an idea that can be applied not only to individual laws, but to a whole legal system. ${ }^{97} \mathrm{~A}$ concept that tempers the rigidity of formal law with 'mercy' and 'substantial justice' is 'equity'. 98

The concept of equity is on one hand a philosophical one, discussed by Aristotle and St. Thomas Aquinas as being required when the letter of the law should not be strictly followed in a particular situation, as it would be unjust to do so. ${ }^{99}$ The concept of equity in international law has been defined as justice attained through what is fair. ${ }^{100}$ It is a general principle applicable as law, and according to the interpretation of International Court of Justice, applies to both the means and the result to be achieved, the Court adding furthermore that:

It is, however, the result which is predominant; the principles are subordinate to the goal. ${ }^{101}$

\footnotetext{
${ }^{95}$ WTO News, Completing the Doha Round is a "political must" - Lamy, Director-General Pascal Lamy, in a speech in Kuala Lumpur on 17 August 2007, www.wto.org/english/news_e/sppl_e/sppl65_e.htm, accessed 21.07.2011.

${ }^{96}$ Lamy, P., The Place and Role of the WTO (WTO Law) in the International Legal Order, Address before the European Society of International Law, 19 May 2006, Sorbonne, Paris, www.wto.org/english/news_e/ sppl e/ sppl26 e.htm, accessed 21.07.2011

${ }^{97}$ Lloyd, Denis, THE IDEA OF LAW, Penguin Books, first published 1964, p131.

${ }^{98}$ Ibid., p132-133.

${ }^{99}$ Aristotle, Book 5, Chapter 10 (on Equity) in NICHOMACHEAN ETHICS, translated by W.D. Ross;
} And this is the nature of the equitable, a correction of law where it is defective owing to its universality...It is evident also from this who the equitable man is; the man who chooses and does such acts, and is no stickler for his rights in a bad sense but tends to take less than his share though he has the law oft his side...

Aquinas, Question 120: Epikeia or Equity in THE SUMMA THEOLOGICA OF ST. THOMAS AQUINAS, 2nd Revised Edition, translated by the Fathers of the English Dominican Province, 1920, http://www.newadvent.org/summa/3120.htm;

Legislators in framing laws attend to what commonly happens: although if the law be applied to certain cases it will frustrate the equality of justice and be injurious to the common good, which the law has in view... [then] it is bad to follow the law, and it is good to set aside the letter of the law and to follow the dictates of justice and the common good. This is the object of "epikeia" which we call equity. Therefore, it is evident that "epikeia" is a virtue.

${ }^{100}$ Walker, D., THE OXFORD COMPANION TO LAW, Clarendon Press, 1980 at p424 - discussed by Rosenne, S., The Position of the International Court of Justice on the Foundations of the Principle of Equity in International Law in Bloed and Van Dijk (Eds) FORTY YEARS OF THE INTERNATIONAL COURT OF JUSTICE, Europa Institute, 1988, p85.

${ }^{101}$ The ICJ in the Continental Shelf(Tunisia v, Libyan Arab Jamahiriya), 1982 ICJ Rep. 18, para.70-71, stated: 
In this, the International Court of Justice gives priority to equity in the result which is being sought, while the evaluation of equity in the means used is of less importance.

In this respect, there may be a prima facie difference ascertained in the comparison with the emphasis on means in the WTO, which has been created as a complex structure for doing particular things in a particular way. There are supposed to be overarching goals for the WTO, and briefly mentioned in Recital 1 of the Preamble to the WTO Agreement is the statement that "the field of trade and economic endeavour should be conducted with a view to raising the standards of living..." and the Preamble to the GATS mentions "economic growth for all trading partners and development for developing countries" in Recital 2. Liberalization per se, although in reality only one of several possible tools to achieve these ends, appears to be given higher priority than the results the method can and will be likely to achieve. It can be argued that the fairer the rules themselves are, the greater the benefits will be - but fairness of the rule is inextricably linked with the fairness of the result. How worthwhile is global economic growth without sustainable economic and social development and justice? This is of course, not an argument against economic growth, but an emphasis on the nature of the economic growth and the equity of its outcomes.

Paul Wolfowitz, former President of the World Bank, has said that equity (in the context of development) is defined in terms of two basic principles:

...equal opportunity ...[and] avoidance of deprivation in outcomes, particularly health, education and consumption levels [original emphasis] ${ }^{102}$

The World Bank study on Equity and Development, in which Wolfowitz made his abovementioned comments, argues that there is a central place for equity in the interpretation of the experiences of development as well as for the design of policies for development. ${ }^{103}$ Drawing on the contributions of Rawls, Sen, Dworkin and Roemer, ${ }^{104}$ this study adds that reducing inequity:

[Equity] was often contrasted with the rigid rules of positive law, the severity of which had to be mitigated in order to do justice. In general, this contrast has no parallel in the development of international law; the legal concept of equity is a general principle directly applicable as law.

The result of the application of equitable principles must be equitable. This terminology, which is generally used, is not entirely satisfactory because it employs the term equitable to characterize both the result to be achieved and the means to be applied to reach this result. It is, however, the result which is predominant; the principles are subordinate to the goal.

102 Wolfowitz, Paul D., Foreword to the WORLD DEVELOPMENT REPORT 2006: EQUITY AND DEVELOPMENT, World Bank and Oxford University Press, 2005.

103 World Bank, THE WORLD DEVELOPMENT REPORT 2006: EQUITY AND DEVELOPMENT, World Bank and Oxford University Press, 2005.

104 Rawls, John., A THEORY OF JUSTICE, Harvard University Press, 1971; Sen, Amartya., COMMODITIES AND CAPABILITIES, Oxford University Press, 1985; Dworkin, Ronald, What is Equality? Part 1: Equality of Welfare, 1981 Philosophy and Public Affairs 10 (1981), pp. 185-246, reprinted in: Dworkin, Ronald, SOVEREIGN VIRTUE: THE THEORY AND PRACTICE OF EQUALITY, Harvard University Press 2000, pp.11-64; Dworkin, Ronald, What is Equality? Part 2: Equality of Resources, Philosophy and Public Affairs 10 (1981), pp. 283-345, reprinted in Dworkin, Ronald, SOVEREIGN VIRTUE: THE THEORY AND PRACTICE OF EQUALITY, Harvard University Press 2000, pp.65-119; Roemer, John E., EQUALITY OF OPPORTUNITY, Harvard University Press, 1998. 
...may be perfectly consistent with - perhaps even necessary for - greater efficiency and prosperity in the long run. ${ }^{105}$

The 2015 IMF Staff Discussion Note, Causes and Consequences of Income Inequality: A Global Perspective, estimated that increases in the income share of the poor and middle class contributes towards increasing growth, whereas concentration of income and wealth in the top $20 \%$ of a country results in lower growth, rejecting the 'trickle down' of benefits argument. ${ }^{106}$ The OECD (Organization for Economic Cooperation and Development), in its 2015 report, In It Together: Why Less Inequality Benefits All, notes that growth has disproportionally benefited higher income groups and that rising income inequality is an economic concern as well as a social and political concern since the encumbrance on GDP and human capital potential has a negative impact on the economy. ${ }^{107}$

Using the language of Nobel Prize winner in economics, Amartya Sen, it is important to ask whether the process of economic growth and development can be directed towards improving 'human capabilities ${ }^{108}$ across the world in an equitable way, not merely as an aggregation of benefits to limited geographical areas or limited social classes or communities or limited sectors in the economy. The role of equitable services delivery in advancing these 'human capabilities', especially equitable public health services, cannot be overstated. The World Development Report (WDR) 2004, Making Services Work for Poor People, identifies market failure and equity as the rationales from economics and also the normative justifications for public responsibility (which is not necessarily fully public provision) for health and education services in particular. ${ }^{109}$ Public responsibility can be linked with public provision when the market cannot or will not supply the needs of people, especially the poor. A study of health equity in Peru has provided support for the view that increases in the amount of public expenditure on social programmes resulted in reduced infant and overall mortality rates (a standard measurement for health) - and that there was a sharp increase in infant mortality rates when public expenditure on health was cut during the 1988-1992 Latin American economic crisis. ${ }^{110}$

105 World Bank, THE WORLD DEVELOPMENT REPORT 2006: EQUITY AND DEVELOPMENT, World Bank and Oxford University Press, 2005, p78. Marks, Stephen P., The Human Right to Development: Between Rhetoric and Reality, Harvard Human Rights Journal, Vol. 17, 2004, 137, p165 on work by the UN system, particularly independent experts, on the linkage between equity and economic growth. See also

What we should have learned over the last half century is that growth doesn't trickle down from the top. It percolates upward from working people who are adequately educated, healthy, sufficiently rewarded, and who feel they have a fair chance...Fairness isn't incompatible with growth. It's necessary for it.

(Reich, Robert, Fairness isn't Incompatible with growth, http//:readersupportednews.org/opinion2/27982/10975-fairness-isnt-incompatible-with-growth. Reich is a professor at UC Berkeley and former Secretary of Labour under the Clinton Administration).

${ }^{106}$ IMF, Staff Discussion Notes - Cross-country analysis, Dabla-Norris, Era, Evridiki Tsounta, Frantisek Ricka, Kalpana Kochhar and Nujin Suphaphiphat, Causes and Consequences of Income Inequality : A Global Perspective, Staff Discussion Notes No. 15/13, June 15, 2015.

${ }^{107}$ The OECD, in its 2015 report, In It Together: Why Less Inequality Benefits All, OECD Publishing, 2015.

${ }^{108}$ See Sen, Amartya, DEVELOPMENT AS FREEDOM, Oxford University Press, 1999 and Sen, Amartya, Development as Capability Expansion, Journal of Development Planning 19: 41-58. Also see Martha Nussbaum, Human Rights and Human Capabilities, 20 Harvard Human Rights Journal 21, 2007.

${ }_{109}$ World Bank, THE WORLD DEVELOPMENT REPORT 2004: MAKING SERVICES WORK FOR POOR PEOPLE, World Bank and Oxford University Press, 2003 p33.

${ }^{110}$ Paxson, Christina H. and Norbert Schady, Child Health and Economic Crisis in Peru, World Bank Policy Research Working Paper Series 3260, 2004. This study drew on multiple rounds of DHS 
Liberalization of health services by itself would not lead to negative effects on health services, but liberalization or proposals for liberalization have often been coupled in practice with government spending cuts, divesture of assets and privatization, and thus there is concern on whether liberalization would be this sort of 'package deal'. It is possible to envisage a scenario where liberalization allows for the government to increase spending in certain necessary areas, while allowing for certain profitable areas to be provided for by the private sector, with an overall increase in welfare across the board. But reducing the involvement of government in health services is not part of this bestcase scenario.

Public responsibility was identified in the WDR 2004 as based on "social justice reasons" as well as international human rights and national constitutional guarantees. ${ }^{111}$ The UN Special Rapporteur on the right to health has emphasized that the international right to health is a firmly established feature of binding international human rights law and has also identified that over 100 countries have constitutional provisions on the right to right to health, the right to health care or health-related rights. ${ }^{12}$ Even the supporters of the world trade system admit that 'not all shall have cake' and that the beneficial impact of services liberalization varies greatly among countries and even within countries. ${ }^{113}$ Hoekman argues that the extent to which countries will benefit from open services regimes also depends on the quality of economic governance, something which is "particularly significant for services trade". ${ }^{114}$ With regard to health services and developing countries in particular, it has been noted that the benefits of liberalization are most likely to be confined to a small minority of developing country suppliers of health services. ${ }^{115}$ There is no global system to correct imbalances or compensate the losers from trade liberalization - thus it can be argued that any rigidity that causes or exacerbates inequity should be dealt with within the system itself through allowing for flexibilities.

(Demographic and Health Survey) data. This study was also cited in the WORLD DEVELOPMENT REPORT 2006: EQUITY AND DEVELOPMENT.

${ }^{111}$ Ibid., (WDR 2004).

${ }^{112}$ UN Economic and Social Council, Commission on Human Rights, Report of the Special Rapporteur Paul Hunt, The right of everyone to the enjoyment of the highest attainable standard of physical and mental health, Addendum, Mission to the World Trade Organization, E/CN.4/2004/49/Add.1, 1 March 2004, para.15.

${ }^{113}$ World Bank, GLOBAL ECONOMIC PROSPECTS AND THE DEVELOPING COUNTRIES, Trade In Services: Using Openness to Grow, World Bank, 2002 noting that "estimates of benefits vary for individual countries - from under 1 percent to over 50 percent of gross domestic product (GDP)" (p77) and that "liberalization could increase prices of some services for the poor" (p80).

See also: Ackerman, Frank, and Kevin P. Gallagher, The shrinking gains from global trade liberalization in computable general equilibrium models: a critical assessment, International Journal of Political Economy 37.1 (2008): 50-77; Francois, J., H. van Meijl and F. van Tongeren (2003). Trade Liberalization and Developing Countries Under the Doha Round. Tinbergen Institute Discussion Paper 2003-060/2; Anderson, K., W. J. Martin and D. van der Mensbrugghe (2005b). Global impacts of the Doha Scenarios on poverty. Putting Development Back into the Doha Agenda: Poverty Impacts of a WTO Agreement. T. W. Hertel and L. A. Winters. Washington, D.C., the World Bank: Chapter 17.

${ }^{114}$ Hoekman, Bernard, Trade in services Opening markets to create opportunities, WIDER Working Paper 2017/31 February 2017, p6. See further, Eschenbach, F., and B. Hoekman Services Policy Reform and Economic Growth in Transition Economies, (2006) Review of World Economics, 142(4): 746-64.

${ }^{115}$ Drabek, Zdenek and Sam Laird, Can Trade Policy Help Mobilize Financial Resources For Economic Development? Staff Working Paper ERAD-2001-02, WTO Economic Research and Analysis Division, 29 August, 2001, at p18, citing WTO Document S/C/W/50. 
There could be a role for a 'human rights approach' in this process, as shall be discussed later in this Chapter. The abovementioned 2006 World Bank Study agrees that equity in international law encompasses notions of both corrective and distributive justice; and also recognizes that the legal understanding of equity has also "influenced individualised justice", the foremost example of which is identified as the international human rights regime of the United Nations system and regional legal instruments on human rights. ${ }^{116}$ In order to achieve these various international (and also national) obligations; the legal system, the political system and the economic system of a State all need to be committed to delivering equitable results. According to international law, the State is the primary duty bearer in terms of fulfilling human rights obligations, but when international organizations and systems such as the WTO are created by States, that duty is not transferred to these structures. States must collectively use these systems as tools in their toolbox of providing better lives for individuals across the world, but have the States failed to design these systems so as to assist them in this endeavor?

\subsubsection{The Space for Policy Alternatives}

Would you tell me, please, which way I ought to go from here?' That depends a good deal on where you want to get to,' said the Cat.

From Lewis Carroll's Alice in Wonderland

The WTO system is not necessarily designed for an equitable sharing of benefits - and this is a cause for concern, especially as there seems at first glance to be limited space in international trade for alternative approaches to what is promoted by this system, that take equity into account. Therefore, Members and the citizens they represent need to know whether there is indeed sufficient space for the written rules to provide for alternative policy choices where a real need is perceived. At the same time, it is important to keep in mind that 'flexibility = fairness' is an assumption that can be countered with the allegation that flexibility can also be applied sometimes as freedom from necessary rules, related to corruption or used as unfair advantage or leverage. Thus, the rules need to be framed as to allow for 'good flexibility' and prevent misuse and abuse - and this is where it can get complicated. These real needs, where 'good flexibility' in rules is required, can be with regard to groups of people as well as important subject matter such as healthcare. Some groups of people may want to do things differently and some issues may need to be tackled differently and the international trade rules ought to allow for this. This study will assess the extent to which such choices are possible.

It is true that there is a limitation of flexibility for WTO Members, in so far as they agree to the main general principle of most favoured nation treatment (MFN) that applies to all Members and to all services covered by the Agreement (unless Members have used Article II to exempt certain services in their Annex on Art II exemptions); and undertake specific commitments for national treatment and market access for services in the individualized country schedules. ${ }^{17}$ It is understandable that a Member ought to be

\footnotetext{
${ }^{116}$ World Bank, The World Development Report 2006, EQUITY AND DEVELOPMENT, World Bank and Oxford University Press, 2005 p79.

${ }^{117}$ National treatment and market access in the GATS depend upon the scheduling of commitments each Member makes for particular sectors and sub-sectors. In contrast, national treatment in the GATT 1994 is a general obligation under Article III and market access issues or border measures fall under Article II
} 
controlled from taking action that harms the global economy and what may in the long run harm itself. This attitude of combined common interest and self-interest recalls the spirit of the "mutually advantageous arrangements" directed towards reduction of trade barriers and discrimination in international trade, expressed in the Preamble of the Marrakesh Agreement Establishing the World Trade Organization. The limitations on flexibility for WTO Members should then, theoretically and in practice, be interpreted in dispute settlement context and in how it is applied, to benefit the global economy as a whole and also benefit each Member.

It seems that the WTO system is not so rigid as to prevent opportunities for the protection of non-trade societal values, and this was probably not the intention of the drafters of the WTO agreements either. ${ }^{118}$ As stated during the Uruguay Round negotiations, in the Ministerial Declaration of 20 September 1986:

Negotiations in this area shall aim to establish a multilateral framework of principles and rules for trade in services... Such framework shall respect the policy objectives of national laws and regulations applying to services and shall take into account the work of relevant international organizations [emphasis added]. ${ }^{119}$

The preamble of the WTO Agreement also refers to the social objectives of raising standards of living and ensuring full employment and the Preamble of the GATS refers to "due respect to national policy objectives" and the desire to the strengthen of developing country domestic services capacity and their efficiency and competitiveness. The issue taken up in this study is whether this respect translates into something concrete in legal terms within the framework of the GATS. Is it possible, within the available flexibilities, to take measures ${ }^{120}$ according to national policy objectives, which run counter to the overall GATS-based efforts to liberalize trade in services? Are the available flexibilities limited to ones that can be taken within the ranks of the forward-march of 'progressive liberalization' - is there only one road or can there be parallel roads and returns to 'roads not taken'? What alternative economic policy choices in the area of services are still available for a WTO member? In the dispute settlement context, the Panel in ArgentinaFinancial Services stated broadly that:

It is our understanding that Members' right to regulate in accordance with their national policy objectives, as enshrined in the Preamble to the GATS, confirms the relevance of the regulatory framework established to meet these objectives in the area of trade in services... ${ }^{121}$

Appellate Body in Argentina-Financial Services commenting on the above statement of the Panel elaborated that:

(custom duties and other duties or charges imposed on or in connection with importation) and Article XI (quantitative import prohibitions or restrictions).

118 WTO, Ministerial Declaration of 20 September 1986 (Punta Del Este Declaration), GATT Doc No. MIN.DEC. Also see Stewart, Terence P., Ed., THE GATT URUGUAY ROUND: A NEGOTIATING HISTORY (1986-1992) Volume II: Commentary, Kluwer Law and Taxation Publishers, 1993, p2425 concluding the commentary on services noting that the abovementioned were the objectives of the services negotiations.

119 GATT, Ministerial Declaration on the Uruguay Round (Punta del Este Declaration), 20 September 1986, Part II Negotiations on trade in services.

${ }^{120}$ The GATS Agreement Article XXVIII(a)(Definitions)

For the purpose of this Agreement: ... "measure" means any measure by a Member, whether in the form of a law, regulation, rule, procedure, decision, administrative action, or any other form.

121 Panel Report, Argentina-Financial Services, para.7.217 - also cited at Appellate Body Report, Argentina-Financial Services, para.6.116. 
...the pursuit of a Member's national policy objectives is not equivalent to violation of Member's GATS obligations, and can be accommodated without the need to invoke exceptions. ${ }^{122}$

However, the Appellate Body pointed out that if a Member's policies discriminate between like services or service suppliers or modify the conditions of competition to the detriment of like services or service suppliers of any other Member, then the Member must rely on the GATS exceptions. ${ }^{123}$

It is also important to consider whether economic and social development of WTO Members, especially developing countries, can occur without national policy formulation in the services sector for the growth and development of domestic services capacity. Opening up domestic markets does not necessarily translate into overall higher living standards for developing countries, as their limited purchasing power suggests that, in many cases, the elite are more likely to benefit from service liberalization than the general population. This may not be the case for all service sectors: for example, greater competitiveness in the telecommunications market may drive down prices and make telecom services accessible to a larger proportion of the population than before, but with other services, more vital ones such as health or education, the market may not work the same way and have the same benefits. This is because not all services are alike nor will the result of market forces have similar results. Creating a health care market where there was previously a public health service is unlikely to result in universal access to better quality services at a lower price. More private competitors in the health services market will not necessarily lead to more choice and thus better quality services at a lower price as there are other factors at play with profit-oriented private health services providers such as; focusing on high-cost specialized services or even non-essential services (e.g. cosmetic surgery) over primary or essential healthcare, private companies holding patents on medicines and being free to charge extremely high prices and the design of health insurance systems which can serve to drive up costs. Just as it is argued that the essential medicines should be treated differently from other goods by the intellectual property regime, because of the magnitude and importance of its impact on those deprived of it, health services should arguably be looked at in a different light than most other services.

In the area of special focus, it should be noted that the values and ideology that underpin the provision of State-subsidized or free public health services are not reconcilable with a view that health services are merely another commodity. ${ }^{124}$ Analyzing the healthcare 'rights-commodity dialectic' through history, Adam Gaffney comments that healthcare has "never functioned as a pure market commodity" and that the idea of an ethical or

\footnotetext{
${ }^{122}$ Appellate Body Report, Argentina-Financial Services, para.6.117.

${ }^{123}$ Ibid (para.6.117).

${ }^{124}$ See e.g. Frank, Arthur, W., What's Wrong with Medical Consumerism? in Henderson, Saras, and Alan Petersen, Eds., CONSUMING HEALTH: THE COMMODIFICATION OF HEALTH CARE, Routledge, 2002, p25:
}

In neoliberal society, an increasingly fragile public consensus supports the idea that medical goods are different from other goods traded in the market and the government has some responsibility to protect all citizens' access to these goods.

This analysis can be said to also apply to the health services context. It is further commented by the same author that:

...a collective sense of responsibility for the vulnerable seems essential to sustaining the idea that society has common goods.

This collective sense of responsibility has been translated in some societies to free public healthcare systems (e.g. the British NHS) and has also evolved into a human rights approach to health services provision. 
egalitarian-religious obligation to provide healthcare (and a corresponding right) clearly has deep roots in a number of different cultures" (referring to Greek, Roman, Chinese, Indian, medieval European, Byzantine and Arab-Islamic contexts). ${ }^{125}$ Thus, for many countries, the modern domestic policy approach to the provision of health would be different from a neoliberal view of health services as just another of the services which need to be liberalized.

The belief that there are rights and duties with regard to the provision of health services exists in a number of societies and this has become endorsed by both international and domestic law and policy. Reference to international human rights law can strengthen the case for national policy alternatives and the retention of policy space for the implementation of different economic policy options when it comes to health services. The overall State obligation on improving socio-economic conditions under international human rights law - specifically the International Covenant of Economic Social and Cultural Rights (ICESCR, 1977) - is to:

...take steps...to the maximum of its available resources, with a view to achieving progressively the full realization of [economic, social and cultural] rights. ${ }^{126}$

Furthermore, it is the obligation of States to co-operate with each other in achieving the aim of full realization of economic, social and cultural rights. ${ }^{127}$ The obligations under the ICESCR includes the right of everyone to the enjoyment of the highest attainable standard of physical and mental health', ${ }^{128}$ the full realization of which includes:

Article 12(2)d. The creation of conditions which would assure to all medical service and medical attention in the event of sickness. ${ }^{129}$

Is there still flexibility to choose the method by which to achieve this? The Committee on Economic, Social and Cultural Rights (CESCR) has noted in 1991 that the undertaking to take all appropriate steps,

...neither requires nor precludes any particular form of government or economic system being used as the vehicle for the steps in question - only that it is democratic and respects all human rights. ${ }^{130}$

\footnotetext{
125 Gaffney, Adam, TO HEAL HUMANKIND: THE RIGHT TO HEALTH IN HISTORY, Taylor \& Francis, 2017, p26-27.

${ }^{126}$ International Covenant on Economic, Social and Cultural Rights (1976), Article 2(1).

${ }^{127}$ Paragraph 14 of the CESCR General Comment No.3, The Nature of States parties' obligations (Art. 2, par. 1 of the Covenant on Economic Social and Cultural Rights, E/1991/23, 14/12/90:

The Committee wishes to emphasize that in accordance with Articles 55 and 56 of the Charter of the United Nations, with well-established principles of international law, and with the provisions of the Covenant itself, international cooperation for development and thus for the realization of economic, social and cultural rights is an obligation of all States.

${ }^{128}$ Ibid., Article 12(1).

${ }^{129}$ Ibid., Article 12(2)d.

${ }^{130}$ Office of the High Commissioner of Human rights, Paragraph 8 of the General Comment No.3: The Nature of States parties Obligations (Art. 2, para.1 of the Covenant on Economic Social and Cultural Rights), E/1991/23, 14/12/90. The Committee further notes in this paragraph that taking steps under the Covenant:
}

...neither requires nor precludes any particular form of government or economic system being used as the vehicle for the steps in question, provided only that it is democratic and that all human rights are thereby respected. Thus, in terms of political and economic systems the Covenant is neutral and its principles cannot accurately be described as being predicated exclusively upon the need for, or the desirability of a socialist or a capitalist system, or a mixed, centrally planned, or laissez-faire economy, or upon any other particular approach. In this regard, the Committee reaffirms that the rights recognized in 
This view was reiterated in the Limburg Principles on the Implementation of the ICESCR (1986), which stated that:

...the achievement of economic, social and cultural rights may be realized

in a variety of political settings. There is no single road to their full realization. ${ }^{131}$

Thus, there is no specified economic system promoted in the context of international human rights, it appears that a 'non-aligned' position was adopted in the context of the Cold War period.

This recognizes the freedom for States to choose their own economic policy, but places that decision in the context of needing to achieve all human rights objectives, preferably through democratic participation in the political system. The question is not the economic system itself but the results in terms of achieving socio-economic rights, and therefore, if a chosen economic model in a particular sector of the economy in a particular State has proven to be less successful in achieving human rights objectives such as the right to health, then there should be questions asked about better methods for achieving those results. Thus, the international human rights system has avoided taking an ideological or dogmatic stance on economic policy, with the focus being on results or outcomes - and unlike in international trade, this leaves open and encourages continuous engagement with and justification of the consequences of socio-economic policy choices in light of human rights.

Does the old argument of Justice Brandeis in New State Ice Co. v Liebman, ${ }^{132}$ that different, autonomous jurisdictions serve an important role as 'experimenting laboratories', still hold true (at least to some extent), for international economic law when applied to national jurisdictions across the world? Justice Brandeis noted that while a statute which is "arbitrary, capricious, or unreasonable" may be struck down by the Supreme Court, all those with the power to "stay experimentation in things social and economic" bear a "grave responsibility" and "must ever be on our guard lest we erect our prejudices into legal principles". ${ }^{133}$ Commenting on Brandeis' vision of 'experimenting

the Covenant are susceptible of realization within the context of a wide variety of economic and political systems, provided only that the interdependence and indivisibility of the two sets of human rights, as affirmed inter alia in the preamble to the Covenant, is recognized and reflected in the system in question. The Committee also notes the relevance in this regard of other human rights and in particular the right to development [underlined in original].

131 The Limburg Principles on the Implementation of the International Covenant on Economic, Social and Cultural Rights, E/CN.4/1987/17. This is an analysis by human rights experts on the principles of implementation of ESCR and of persuasive value in the interpretation of the rights. The Limburg Principles influenced the later General Comment No. 3 of the Committee on Economic, Social and Cultural Rights and are said to have been "very influential" in the preparation of that document (UN, OHCHR, ECONOMIC, SOCIAL AND CULTURAL RIGHTS: HANDBOOK FOR NATIONAL HUMAN RIGHTS INSTITUTIONS, Professional Training Series No. 12, Un, 2005, p7)

${ }^{132}$ New State Ice Co. v Liebmann, 285 US 262 (1932).

133 Justice Brandeis of US Supreme Court, dissenting in New State Ice Co. v. Liebmann, 285 U.S. 262 (1932):

To stay experimentation in things social and economic is a grave responsibility. Denial of the right to experiment may be fraught with serious consequences to the nation. It is one of the happy incidents of the federal system that a single courageous State may, if its citizens choose, serve as a laboratory; and try novel social and economic experiments without risk to the rest of the country. This Court has the power to prevent an experiment. We may strike down the statute which embodies it on the ground that, in our opinion, the measure is arbitrary, capricious, or unreasonable. We have power to do this, 
laboratories', Bednar makes the interesting comparison with the idea of 'adaptive efficiency' as applied in evolutionary theory on the genetic diversity of biological organisms. ${ }^{134}$ Bednar comments that, just as greater genetic variation makes it more likely that an biological organism can survive complex environments, it is also more likely that social systems which can implement diverse ideas will be more "efficiently adaptive'. ${ }^{135}$ Thus, "experimentation is a useful way to explore policy space" and "the more diverse the experimentation, the more like the system will encounter a modification that improves it". ${ }^{136}$ If this is the case, then it is important to continually engage in comparative study of national systems and their sub-units, to glean the best policies in light of the best outcomes. Of course, what is considered as an 'improvement' needs to be defined and identified and that is where an analysis based on the progressive realization of economic and social rights can assist in recognizing solutions and improvements.

However, different ideology can still hold sway, and not all trade experts would agree on this freedom to choose a non-trade means to the end. For example, Chauffour decries the 'agnosticism' of the Declaration on the Right to Development, which is closely tied to the objectives of the ICESCR, and argues that:

...the Right to Development depends on the extent to which a market economy is in place. ${ }^{137}$

Chauffour goes on to emphasize the importance of limited government intervention in the economy and limited government ownership, regulations, taxation and expenditure being required for the Right to Development to be fulfilled. ${ }^{138}$ This shows that there can be a dogmatic emphasis on the market as means coupled with a lesser consideration of

because the due process clause has been held by the Court applicable to matters of substantive law as well as to matters of procedure. But, in the exercise of this high power, we must be ever on our guard lest we erect our prejudices into legal principles. If we would guide by the light of reason, we must let our minds be bold.

${ }^{134}$ Bednar, Jenna, Building the Adaptive Efficiency of Federal Systems in Fleming, James E. and Jacob T. Levy, Eds., FEDERALISM AND SUBSIDIARITY: NOMOS LV, NYU Press, 2014, p239, applying the ideas of evolutionary theorist R.A. Fisher to an analysis of subsidiarity and policy diversity in governance.

${ }^{135}$ Ibid., (Bednar).

136 Ibid., (Bednar).

137 Chauffour, Jean-Pierre, THE POWER OF FREEDOM: UNITING HUMAN RIGHTS AND DEVELOPMENT, Cato Institute, 2009, p48. The same extract is available online as Pro-Human Rights Growth Policies, Development Outreach, October 2006, http://www1.worldbank.org/devoutreach /october06 /article.asp?id=381.

Chauffour was formerly IMF Representative to the WTO, Geneva Office and is currently economic adviser and lead economist in the World Bank, International Trade Department.

${ }^{138}$ Chauffour also classifies "development policies" with Nozickian classical liberalism and contrasts this with "humanitarian policies", welfare-state egalitarianism and Rawls (Ibid, p45) - although it is more common to also classify development policies with Rawlsian theory. John Morijn (in Morijn, John, Conflicts between Fundamental Rights or Conflicting Fundamental Rights Vocabularies?: An Analysis of Diverging Uses of 'Fundamental Rights' in the Context of International and European Trade Law in Brems, Eva Ed., CONFLICTS BETWEEN FUNDAMENTAL RIGHTS, Intersentia 2008) notes that the UNDP Human Development Report 2000 and Phillip Alston have rebutted the notion put forward by Chauffour that social rights are handouts (the sense in which Chauffour uses the term "humanitarian"), but that they are actually:

...claims to a set of social arrangements - norms, institutions, laws, and an enabling economic environment - that can best secure the enjoyment of these rights ... it is thus the obligation of governments and others to implement policies to put these arrangements in place [emphasis added].

(Morijn citing the UNDP, Human Development Report 2000, p73 as cited in P. Alston, Ships Passing in the Night: The Current State of the Human Rights and Development Debate Seen Through the Lens of the Millennium Development Goals, 27(3) Human Rights Quarterly 755-829, 2005, p789). 
the results - although such faith in the market should be required to be coupled with evidence of results that no other system can successfully provide.

In the case of health services, there is evidence that health indicators and equitable access have a correlation to the health system that is in place. ${ }^{139}$ A well-known statement from Sir Michael Marmot of the Institute of Health Equity on the social determinants of health inequalities emphasizes that:

The health of a population is a measure of whether, in the end, that population is benefitting as a result of a set of its social arrangements. ${ }^{140}$

The Marmot Review Report of $2010^{141}$ highlights the 'social gradient of health inequalities' - the fact that research has shown that it is likely that as one's social and economic status lessens, health worsens, but at the same time these health inequalities are not inevitable, but largely preventable. It is further argued in a World Health Organization (WHO) study, that:

Health systems promote health equity when their design and management specifically consider the circumstances and needs of socially disadvantaged and marginalized populations ... Despite the increasingly plural nature of health systems (especially with respect to health care provision), the public sector plays the primary role in working towards health equity and should be strengthened to achieve this function. ${ }^{142}$

Therefore, a rush to a worldwide single liberalized model of health services seems undesirable, especially since studies of the comparative outcomes in the current plurality of health systems recognize the importance of public health services for health equity. The debate continues on the issue of choice of economic model for the provision of services (particularly essential services such as health services) and an automatic adoption of identical free market-type profit-oriented models in every sector cannot be presupposed. It cannot be assumed that the ideological tussle has somehow been won by default; on the other hand, it can be said it has merely entered a new phase.

Another interesting point is that the area of health services does not have a single specific liberalization regime in the GATS such as there is for e.g. financial services and no

139 For example, the I2SARE project has produced health profiles for 265 regions in the European Union (see www.i2sare.eu). Prof. John Wilkinson, Chair, Association of Public Health Observatories of the United Kingdom and member of the research team stated during a presentation at the EUREGIOII Conference, Maastricht November 2011, that preliminary data preliminary finding show that health determinants match country borders and regions (in case of decentralized healthcare) and the standard of health is related to national health systems. This idea is intuitively accepted, but it can be supported by data.

See also The UK government commissioned Strategic Review of Health Inequalities in England ('Fair Society, Healthy Lives' - also known as The Marmot Review Report, 2010); and research for the Review of Social Determinants of Health and the Health Divide for the WHO European Regional Office - ongoing research and follow-up currently carried out by the UCL Institute of Health Equity, information available at www.instituteofhealthequity.org/.

${ }^{140}$ Marmot, M., Social Determinants of Health Inequalities, 365 The Lancet (2005a) 1099. See further the website http://www.instituteofhealthequity.org/about-us - for the Marmot Review report, 'Fair Society Healthy Lives (2011)' and for the work of the Members of the WHO Commission on Social Determinants of Health (Sharon Friel, Michael Marmot, Ruth Bell, Tanja A.J. Houweling, Sebastian Taylor).

${ }^{141}$ The Marmot Review Report, 2010: 'Fair Society Healthy Lives', commissioned by the British Secretary of State for Health in 2008. See further at the website http://www.instituteofhealthequity.org/ or http://www.parliament.uk/documents/fair-society-healthy-lives-full-report.pdf.

${ }^{142}$ WHO Commission on the Social Determinants of Health, (lead authors Lucy Gilson, Jane Doherty, Rene Loewenson and Victoria Francis with inputs and contributions from the members of the Knowledge Network), CHALLENGING INEQUITY THROUGH HEALTH SYSTEMS, Final Report Knowledge Network on Health Systems, June 2007, Recommendations. 
negotiating proposals had been submitted on the matter. It is not even under one heading in the services sectoral classification; instead, health services are distributed under different areas and headings, from insurance to professional services. The reason for this, it has been suggested by Krajewski, is the fundamental differences in health services regulatory frameworks in different countries and the insistence of many countries to maintain their current trajectories, resulting in the unlikelihood of agreement on a single model for liberalization; ${ }^{143}$ assuming that is, that some level of liberalization will occur in this sector.

It can alternatively be argued that health services could more easily be liberalized in a piecemeal manner if health was distributed under various different areas and headings rather than only under one. This situation can be criticized as making it practically difficult for a country to synchronize its trade commitments on health with its national policies on health services - especially if there had earlier been a single coordinated national health policy that covered different aspects of health services delivery or if there is an intention to make this kind of national health service a possibility in the future. The classification is, naturally, looked at from an international trade perspective and not from a national public health services perspective. The current classification means that deciding on commitments would require that a Members trade and health experts must work together extensively at some point to make sure that national health policy and trade policy and GATS commitments do not contradict each other. This issue is discussed in more detail under scheduling of specific commitments in Section 4.4 of Chapter 4 of this study.

\subsubsection{Sovereignty, Democracy and Public Services}

While development is the primary responsibility of each country, domestic efforts should be facilitated and complemented by an enabling international environment based on multilaterally agreed and applied rules. It is for each Government to evaluate the trade-off between the benefits of accepting international rules and commitments, and the constraints posed by the loss of policy space. ${ }^{144}$

On the issue of the importance of the kinds of policy divergence discussed above (or flexibility, policy space, room to manoeuvre, or whatever term one may chose) - the fact that it relates to specific groups of people and political expressions of their will, cannot be ignored. While there is talk of policy in a vacuum, by experts and analysts, in a modern society, the choice and implementation of policy is most often done through political party representation within WTO Members (however the details of this may differ). Other than China and Cuba, which are one-party political systems; Saudi Arabia, UAE, Bahrain, Oman, Qatar and Brunei Darussalam which do not have political party representation; and Thailand which is being governed by the military following two coup d'états in 2006 and 2014 - other WTO Members are in two-party or multi-party democracies. However, a closer look at the political systems of Members would raise serious doubts as to how representative, participatory and deliberative each of them actually is as a democracy. The

\footnotetext{
${ }^{143}$ Krajewski, M., NATIONAL REGULATION AND TRADE LIBERALIZATION IN SERVICES, Kluwer Law International, 2003, p185-186.

${ }^{144}$ United Nations Conference on Trade and Development (UNCTAD), The Accra Declaration, TD/L.413, Accra, Ghana, 25 April 2008, para.16, available online at http://unctad.org/en/Docs/tdl413_en.pdf.
} 
extent of trust in elected representatives and perceptions of corruption are also relevant. ${ }^{145}$ The Economists' 'Intelligence Unit' Democracy Index makes an assessment that less than half the world's population lives in a democracy of some sort, and less than $5 \%$ reside in the 19 countries which they categorize as a "full democracy". ${ }^{146}$ It can be argued that these debates on the pros and cons of the WTO system are often also debates within the larger context of the importance of national sovereignty, democracy, good governance and subsidiarity in the modern age.

Even with some countries granting significant powers to federal, provincial or other devolved units and local government - or even de facto ceding aspects of governmental power to major corporations ${ }^{147}$ - nation-states still remain the most important actor and 'grouping' of persons in international law and WTO Members are predominantly ${ }^{148}$ nation states. Most WTO Members are also democratic States according to their constitutions and political systems, where sovereignty is often termed (and sometimes explicitly identified in national constitutions) as the expression of the will of the people. ${ }^{149}$ The binding obligations agreed to in international trade law by the governments representing the people affect the will and freedom of the citizens of that Member in future decision-making and thus it is natural that citizens would ask questions about the extent of the limitation of sovereignty. And contrary to those who say that the 'Westphalian' concept of sovereignty is obsolete ${ }^{150}$ or that the 'economic sovereignty' of the New International Economic Order (NIEO) has lost much of its meaning ${ }^{151}$ - it

145 See for example, the Transparency International, Corruption Perception Index 2016, available online at: https://www.transparency.org/news/feature/corruption_perceptions_index_2016\#table.

146 The Economist, Democracy Index, updated yearly and available online at http://www.eiu.com/ topic/democracy-index.

${ }^{147}$ This is nothing new - as evident by the power wielded by the VOC and British East India/ British West India Companies in the past. Parts of Sri Lankan territory were 'governed' by the VOC from 1640-1796 and by the British East India Company headquartered in Madras (now part of India) in the period 1795-1798. Parts of what is now India, Pakistan and Bangladesh were 'governed' by the British East India Company for almost a hundred years from 1757-1858 during what is referred to as the 'Company-Raj'.

${ }^{148}$ Except for the Separate Customs Territories, e.g. Taiwan, Penghu, Kinmen and Matsu (Chinese Taipei) and the EU.

${ }^{149}$ For Example, THE SRI LANKAN CONSTITUTION (1978) states in Article 3 that:

In the Republic of Sri Lanka sovereignty is in the people and is inalienable. Sovereignty includes the powers of government, fundamental rights and the franchise

150 See Henkin, L, The Mythology of Sovereignty, American Society of International Law Newsletter, March-May 1993, p1-2.

Also see e.g. Nichols, Philip M., Sovereignty and Reform of the World Trade Organization in Shan, Wenhua, Penelope Simon and Dalvinder Singh Eds., REDEFINING SOVEREIGNTY IN INTERNATIONAL ECONOMIC LAW, Hart Publishing, 2008, p149-150 and the assertion that: Sovereignty is not a sacred condition of statehood: sovereignty is simply a tool for making order of relationships, including relationships among polities...

Nichols continues on to discuss the United States polities - federal States (including the Kingdom of Hawaii), Native American tribal governance, and other situations such as US trusteeships under the United Nations, American Samoa, Northern Mariana Islands and Puerto Rico, concluding that only a 'sophist' would suggest that the only polity with sovereignty in this group is the United States (p151). The kind of approach to defining sovereignty undermines the international law principle of sovereign equality of States and the concepts of internal and external sovereignty which are included in the principle. It also ignores the public international law criteria of Statehood (requiring ability to enter into international relations) and the doctrine of recognition of States - probably because a part of Nichols argument deals with entities such as California - that it ought to be seen as suitable for WTO membership on its own, as it has the important criteria of control over customs border and territory and makes decisions as 'a sovereign polity'.

${ }^{151}$ McRae, Donald, The WTO in International Law: Tradition Continued or New Frontier?, Journal of International Economic Law, 2000, 27-41, p29-30. McRae also says, at p29 that: 
remains a matter of vital importance for nations emerging from centuries of domination by Empire and/or 'Company', ${ }^{152}$ who are wishing to finally make free choices concerning the provision of their own welfare and to be equal partners in the community of nations. ${ }^{153}$ Qureshi, explains this in the following manner:

...sovereignty can facilitate development, self-help and self-determination among developing nations. Such sovereignty may be coined as 'development sovereignty' [emphasis added]. ${ }^{154}$

The outcome document of the 1993 World Conference on Human Rights - The Vienna Declaration and Programme for Action (which was later endorsed by the UN General Assembly) - is one of the many human rights documents that recognize and describe the right to self-determination, which is connected to sovereignty. Paragraph 2 of Vienna Declaration states that:

All peoples have the right of self-determination. By virtue of that right they freely determine their political status, and freely pursue their economic, social and cultural development.

As mentioned in the introduction to this study, an assumption will be made that deliberative and participatory democracy would be the best system under which the aforesaid economic, social and cultural development can take place in a sovereign state. The description of democracy in Paragraph 8 of the Vienna Declaration of 1993 (at the World Conference on Human Rights) is also a useful one. It states as follows:

Democracy, development and respect for human rights and fundamental freedoms are interdependent and mutually reinforcing. Democracy is based on the freely expressed will of the people to determine their own political, economic, social and cultural systems and their full participation in all aspects of their lives. ${ }^{155}$

It is this relationship between the full participation of people in economic and social decision-making and the interdependence of democracy, development and respect for human rights that underlies the questions in this study.

International trade law appears to require states to do precisely the opposite of what a sovereignty-based regime would require them to do.

${ }^{152}$ For example, countries such as India, Sri Lanka etc., were governed (partially, some provinces) by the Dutch India Company (VOC) and the British East India Company before being governed as occupied territories by the British Empire. India became an independent democratic republic on August 151947 but Sri Lanka became a self-governing dominion on February 41948 and a republic only on May 221972. Thus, many countries have only had a very brief taste of sovereignty and ability to decide on their economic and social policy independently. Both India and Sri Lanka became founding Members of GATT on 30 October 1947; Sri Lanka was at the time still a non-independent entity officially known as Ceylon.

${ }^{153}$ See Lowe, Vaughan, Sovereignty and International Economic Law in Shan, Wenhua, Penelope Simon and Dalvinder Singh Eds., REDEFINING SOVEREIGNTY IN INTERNATIONAL ECONOMIC LAW, Hart Publishing, 2008, stating that sovereignty, as a concept, identifies a framework of inquiry within which more specific debates about rights, duties and rules must take place, and concluding at p84:

It is not the precise meaning of sovereignty, its denotation that is important. It is what sovereignty signifies, what it connotes [which is] independence; and independence has a precise meaning; it denotes "in regard to a portion of the globe, the right to exercise therein, to the exclusion of any other State, the functions of a State" [italics in original, quote from earlier in the text, Netherlands $v$ USA, Island of Palmas case, 1928, 2 UNRIAA 829].

${ }_{154}$ Qureshi, Asif H., Sovereignty Issues in the WTO Dispute Settlement - A Development Sovereignty Perspective, in Shan, Wenhua, Penelope Simon and Dalvinder Singh Eds., REDEFINING SOVEREIGNTY IN INTERNATIONAL ECONOMIC LAW, Hart Publishing, 2008, p159.

${ }^{155}$ UN General Assembly, Vienna Declaration and Programme of Action, 12 July 1993, A/CONF.157/2, endorsed by General Assembly Resolution 48/121, 20 December 1993. 
Furthermore, there is no justifiable reason that this freedom to make decisions on one's own future should be limited to only a national level, as it can also be extended to subnational level. A WTO Member's decision-making relating to international trade matters is often concentrated at national level, usually not involving the concerns of a state or province a federal structure or involving local governance and participation. It is also usually conducted by a small group of elites within departments of trade, commerce and/or foreign affairs, and often influenced by effects on major industries and sectors of the economy (perhaps also the major corporations representing those industries and sectors). While this kind of decision-making is normally presented as an expression of sovereignty, it can be questioned whether the roots of this sovereignty can go deeper and be more enriched by participation of different levels of representative governance and the knowledge and support of the ordinary citizen. The distribution of decision-making power within the State, the expressions of grassroots needs at higher administrative levels and the accountability of representatives of the people for decisions taken, are also important matters for discussion by citizens in a properly functioning democracy. Some examples of de-centralization of power (particularly on the subject of healthcare) in different legal systems which take into account the principle of subsidiarity, have shown correlation with better governance and better outcomes for local populations, usually when accompanied by greater transparency of government, reduced corruption and community participation. ${ }^{156}$

Thus subsidiarity connotes on one hand a sharing of power at different levels of government and on the other hand both a limit on higher authority to intervene when intervention is seen as a limit of rights and freedoms and at the same time a duty to intervene when rights need to be upheld. ${ }^{157}$ Vandana Shiva explains the principle of subsidiarity (which she also refers to as 'localization') as a test for both justice and sustainability. ${ }^{158}$ It is not suggested that all decisions are best made at local level, but that decision-making at national and global level should "have to constantly pass the screen of living democracy" 159 ... a 'bottom up' process where there is active participation of all stakeholder groups including the underprivileged and marginalized at the grassroots. There is still a considerable amount of criticism that the world trade system fails in this aspect since it ignores these processes - but this can also be seen as more a failure of national democracies. But it is clear that ultimately, ones' views on the interconnected concepts of democracy, sovereignty and subsidiarity will underlie one's vision of how WTO law ought to be negotiated, interpreted and applied - even though there are doubts to what extent these concepts are currently recognized or respected in WTO law and policy.

The interconnected concepts mentioned above are of course also the focus of a lot of debate, both pro and con. Yet it can still be convincingly argued that it has often been free democratic choice initiated by the needs and demands of ordinary people that has shaped

\footnotetext{
${ }^{156}$ See the examples of Kerala (India) and Ceara (Brazil) mentioned later in this chapter.

${ }^{157}$ See the useful discussion on the definition of subsidiarity in the European context - Delcamp, Alain, Definition And Limits of The Principle of Subsidiarity: Report Prepared for The Steering Committee on Local and Regional Authorities (CDLR), Steering Committee on Local and Regional Authorities, Council of Europe, 1994, p10

158 Shiva, Vandana, EARTH DEMOCRACY: JUSTICE, SUSTAINABILITY AND PEACE, Zed Books, 2006, p64

159 Ibid., (Shiva). Similarly, Krajewski refers to the 'legitimacy chain' that links democratic decisionmaking with negotiations at the WTO level, see Krajewski, Markus, Democratic Legitimacy and Constitutional Perspectives of WTO Law, 35 Journal of World Trade 167, 2001, p175-176.
} 
progressive economic and social decision-making. With regard to services, Sri Lanka is an interesting 'snapshot' to look at. Currently Sri Lanka has a universal public healthcare system, free at the point of delivery, supplemented by a rapidly expanding private health care sector. Sri Lankans therefore, have the freedom, to directly access either government or private medical facilities (if they can afford the fees of the latter). Unlike some other countries, it is not compulsory for patients to obtain referrals from general physicians in order to meet specialists, so a patient can directly access a specialist at a government hospital or clinic. The public health services are also accessible to anyone, anywhere in the country without discrimination, and this was applied even during the decades-long armed conflict, which ended in 2009. Data from the Ministry of Health shows that there is a public medical health-care facility within $4.8 \mathrm{~km}$ of every household and a health-care facility can be found, on average, not further than $1.4 \mathrm{~km}$ from any home. ${ }^{160}$

Sri Lanka has a long tradition of 'free health'. Free public health services and free public education were implemented in Sri Lanka in the years following the introduction of universal adult franchise for all citizens over 21 years of age and a limited degree of selfrule from the British via an 'Executive Committee' of elected representatives under the Donoughmore Constitution of 1932. ${ }^{161}$ Universal adult franchise was introduced to Sri Lanka only three years after its introduction in Britain and resulted in indigenous elected officials becoming answerable to the needs of their electorate, particularly in terms of social welfare such as health services and public education. There was also a parallel indigenization of the bureaucracy, including in the field of medicine and health policy planning which led to better health outcomes for the population. ${ }^{162}$ Interestingly, the actions taken in the post-Donoughmore context for implementing free healthcare and free education were originally taken prior to the development of a political party system in the country, and remain to a large extent ingrained social values (with roots in Sri Lanka's Buddhist history) which have not been significantly affected by the alternating left-orright or other economic ideological differences of successive governments.

160 Ministry of Health, Sri Lanka, Annual Health Bulletin 2016, available online at http://www.health.gov.lk/moh_final/english/public/elfinder/files/publications/AHB/2017/AHB_2016.pdf.

${ }^{161}$ See further for overview of the results of these early policies; Bjorkman, James Warner, Health Policy and Politics in Sri Lanka: Developments in the South Asian Welfare State, Asian Survey, Vol. 25, No. 5, May, 1985, p537. Bjorkman comments at p551;

Under periodic electoral pressure from an increasingly literate and politically articulate population, successive governments adopted interventionist policies directed towards the achievement of social equality. Over a forty-year period, Sri Lanka diverted nearly $30 \%$ of its budgetary resources into developing one of the most extensive welfare systems to be found anywhere in the Third World. And the result is a quality of life that gives hope against the inevitable perpetuation of poverty and ignorance.

It is also noted by Bjorkman that despite the liberalization of the economy in 1978, the new government did not dismantle the network of social services that had been created earlier.

See also Gunatilleke, Godfrey, The Right to Development in Sri Lanka, in Sengupta, Arjun, Archna Negi and Moushumi Basu Eds., REFLECTIONS ON THE RIGHT TO DEVELOPMENT, SAGE Publications India, 2005:

Some of the essential elements in the right to development such as access to health care, universal primary education and adequate nutrition were already realised in large measure in the first three decades after independence. Average life expectancy which was in the region of 42 years in the mid-1940s had reached approximately 68 years of age in the mid-1970s. The current life expectancy is over 75 years of age and almost 80 years for females.

162 See further for more details; Jones, Margaret, HEALTH POLICY IN BRITAINS MODEL COLONY: CEYLON (1900-1948), New Perspectives in South Asian History, Orient Longman and the Wellcome Trust Center for the History of Medicine at the University College London, 2004. 
Looking back over the past decades, the results of the free public health services and national health programmes on communicable diseases, maternal and child mortality and overall life expectancy are striking. In the 1934-35 malaria epidemic in Sri Lanka, 1.5 million people were affected and 60-80,000 deaths were apparently recorded in a population of 5.8 million people. ${ }^{163}$ Although the Anti-Malaria campaign was initially launched under the British after the epidemic of 1911, the Malaria Eradication Programme of the Ministry of Health was launched only in 1958 in an independent Sri Lanka, and consequently the deaths due to malaria went down in the post-independence period to only 17 cases in 1963, with only six of those being indigenous cases (others were infections occurring while abroad). ${ }^{164}$ There have been no cases of indigenous infection of malaria (as opposed to travelers who were infected abroad) since 2012 and the World Health Organization (WHO) has declared Sri Lanka malaria free in $2016^{165}$ - a remarkable achievement for a malaria endemic country. Furthermore, in 2019, the WHO certified Sri Lanka as a country that has eliminated transmission of HIV and Syphilis from mother to child. ${ }^{166}$ The country has previously eliminated polio, measles, maternal and neonatal tetanus and lymphatic filariasis. The basic immunization coverage for infants is at $99 \%$ in Sri Lanka, with e.g. the last case of measles caused by an indigenous virus being in May $2016^{167}$ and the last case of a virologically confirmed poliomyelitis patient reported in 1993. ${ }^{168}$ Furthermore, 99\% of births occur with the assistance of a trained health professional, and more than $94 \%$ of registered live births occur in government health institutions. ${ }^{169}$ The current life expectancy at birth in Sri Lanka is calculated at 74.95 years, with it being higher for females at 78.6 years. ${ }^{170}$ It should be noted that these achievements in public health were achieved despite of a civil war that went on in the country from 1983 to 2009 , in addition to other severe social and political instability and unrest, and the devastating 2004 tsunami; which were all responsible for causing immense burdens for the public healthcare system.

\footnotetext{
163 WHO-SEARO (WHO-South-East Asia Regional Office), Sri Lanka Defeats Malaria and Reaches Zero Cases, 2013, http://www.searo.who.int/srilankadefeatsmalaria.pdf?ua=1; The Malaria Epidemic in Ceylon 1934-1935: (Section of Epidemiology and State Medicine with Section of Tropical Diseases and Parasitology), Joint Discussion No. 1. Proceedings of the Royal Society of Medicine. 1936;29(5):537-562.

${ }^{164}$ See Sri Lanka Anti-Malaria Campaign, http://www.malariacampaign.gov.lk/Precentation/AboutUs.aspx 165 Sri Lanka Anti-Malaria Campaign, http://www.malariacampaign.gov.lk/Precentation/AboutUs.aspx; WHO-SEARO, Sri Lanka Defeats Malaria and Reaches Zero Cases, 2013, http://www.searo.who.int/ srilankadefeatsmalaria.pdf?ua=1; WHO, Sri Lankans vigilant after bidding farewell to malaria, Bulletin of the World Health Organization, 2017;95(3):170-171.

166 WHO, WHO congratulates Sri Lanka for eliminating mother-to-child transmission of HIV, Syphilis, SEAR/PR/1713, 10 December 2019, https://www.who.int/southeastasia/news/detail/10-12-2019-whocongratulates-sri-lanka-for-eliminating-mother-to-child-transmission-of-hiv-syphilis.

167 WHO, Sri Lanka eliminates measles, SEAR/PR/1712, 9 July 2019, https://www.who.int/southeastasia/ news/ detail/09-07-2019-sri-lanka-eliminates-measles

${ }^{168}$ Sri Lanka, Ministry of Healthcare \& Nutrition, Epidemiology Unit, Eradication of Poliomyelitis: $A$ comprehensive guide for Medical Officers, Second Edition 2005,

http://www.epid.gov.lk/web/images/pdf/Publication/polio_guide.pdf. Also see WHO-SEARO, WHO SouthEast Asia Region is officially certified polio-free, 2014, http://www.searo.who.int/entity/campaigns/poliocertification/en/.

${ }^{169}$ See Sri Lanka, Department of Census and Statistics, http://www.statistics.gov.lk/page.asp?page=Health.

${ }^{170}$ See Sri Lanka, Department of Census and Statistics, http://www.statistics.gov.lk/page.asp?page=Health.
} 
The 2003 Health Master Plan of the Sri Lankan government reiterates a firm political commitment to equity in healthcare more than once ${ }^{171}$ - and referring to the culturalhistorical idea that health is a responsibility of King and State, adds that:

During the pre-colonial period, the monarchs had four fundamental responsibilities, namely, attending to their people's spiritual growth, providing water, ensuring security, and responding to their health needs. In fact, the strength of a king was measured by his ability to fulfill these four obligations... ${ }^{172}$

...For historical and cultural reasons, no matter which party is in power, health services seem to receive priority in Sri Lanka. ${ }^{173}$

The National Health Policy of the Ministry of Health also reiterates equity and accessibility and providing basic healthcare free of cost at the point of delivery through State institutions. ${ }^{174}$ The National Strategic Framework for Development of Health Services 2016-2025 continues to emphasize the need for a "people-centered" health system using the tools of "Universal Health Coverage" (described as "equity of distribution of services to all patients; accessibility for each patient; quality of services provided to each patient; financial protection of the patients"). ${ }^{175}$ The Sri Lanka-WHO Country strategy for 2018-2023 identifies four strategic priorities, with the first being "strategic priority policy support for service delivery"; reiterating that the ongoing success of Sri Lanka's health system must be based on the continuation of a good national health policy. ${ }^{176}$

\footnotetext{
${ }^{171}$ Ministry of Health, Sri Lanka, Master Plan Study For Strengthening Health System in the Democratic Socialist Republic of Sri Lanka, Supporting Document I: Situational Analysis, Final Report 2003 (still applicable for the Health Plan 2007-2016), pviii and p2-1. See for all Health Master Plan 2007-2016 documents: www.health.gov.lk/HMP-07-16.htm. A new plan for 2017-2025 was being drafted.

${ }^{172}$ See further, Rannan-Eliya, Ravi P. and Lankani Sikurajapathy, Sri Lanka: 'Good Practice' in Expanding Health Care Coverage, Institute for Health Policy and The World Bank, 2009, p23:

Unlike in pre-modern Europe, most hospitals were built in Sri Lanka not through private charitable action, but as state initiatives.

The earliest references to public hospitals in Sri Lanka are from the $4^{\text {th }}$ Century BC, and historical and archaeological records are available concerning hospital and medical services provided under the patronage of various kings over the centuries; see Uragoda, C. G., A History of Medicine in Sri Lanka, The Sri Lanka Medical Association, 1987, p21-41 (Chapter 3: Medicine Under Sri Lankan Kings).

Also see the ancient manuscript of Sri Lanka's written history since the $6^{\text {th }}$ Century BC to the $5^{\text {th }}$ Century AD, MAHAVAMSA: THE GREAT CHRONICLE, Chapter 10: The Consecration of Pandukabhaya, which records that King Pandukabhaya, a pre-Buddhist king of Sri Lanka, built 'halls for the sick' during his reign, which is estimated as ending in $367 \mathrm{BC}$.

Codrington notes the stories concerning the reign of King Buddhadasa, in the $4^{\text {th }}$ Century AD, that the King "provided dispensaries, throughout the kingdom, and ordained that there should be physicians for every ten villages, the first mention of this ancient grouping (gandahaya) which still survives in name in certain districts... [and he] composed in Sanskrit a work on medicine, the Sarartha-sangraha" (Codrington, H.W., A SHORT HISTORY OF CEYLON, Macmillan and Co., 1926).

173 Op cit., Ministry of Health, Sri Lanka, Master Plan 2003, p2-2.

${ }^{174}$ Ministry of Health, Sri Lanka, National Health Policy - Sri Lanka, policy overview available online at www.health.gov.lk/HealthPolicy.htm, last accessed 20.07.2011; Ministry of Health, Sri Lanka, Health Master Plan 2016-2025, available online at: http://www.health.gov.lk/enWeb/index.php?option=com_content\&view=article\&id=327\&Itemid=102, last accessed 17.08.2019.

${ }^{175}$ Ministry of Health, Sri Lanka, National Strategic Framework for Development of Health Services 2016-2025, p2-3, available online at: http://www.health.gov.lk/enWeb/HMP20162025/National\%20\%20Strategic\%20\%20Framework\%20 $\% 20 . p d f$,

176 SRI LANKA - WHO: COUNTRY COOPERATION STRATEGY 2018-2023, available online at http://www.searo.who.int/ srilanka /9789290226345-eng.pdf
} 
In 2010, the then Sri Lankan President, Mahinda Rajapaksha, highlighted the connection of the values of the past with future goals at the UN Summit on the Millennium Development Goals, referring to the Buddhist traditions which guide the Sri Lankan approach to economic and social policy making:

In Sri Lanka, social development goals, such as free healthcare, access to education were embedded from independence, in the country's overall policy framework...It is our deep conviction that the well-springs of our civilization, nurtured by the Buddhist tradition should guide our approach to economic and social policy making. At the core of this, there must be a sound scale of values ${ }^{177}$

The positive results of these policies in Sri Lanka have been used as examples by Amartya Sen in several instances, including in the seminal work DEVELOPMENT AS FREEDOM. ${ }^{178}$ Setting the background for his arguments, Sen explains in the preface that: ...social opportunities of education and healthcare, which may require public action, complement individual opportunities of economic and political participation and also help to foster our own initiatives in overcoming our respective deprivations. ${ }^{179}$

The author's personal interest in services in international trade is a result of being a beneficiary of these public services in Sri Lanka and to wondering what the future holds for both this particular national system as well as others. ${ }^{180}$

Other studies show similar correlations between democratic good governance and healthcare, for example, in the State of Ceara in Brazil. Brazil was under military government between 1964 and 1986 and Ceara one of the poorest regions. However, following a new federal constitution in 1988 and the reforms for improved preventive health programs and community health workers introduced by an elected state government in Ceara, dramatic improvements in health indicators were to be seen in as short a period as 5 years, resulting in the region being studied for the success of its health system. ${ }^{181}$ Article 196 had been introduced in the 1988 Constitution of Brazil, which states that:

177 Government of Sri Lanka, Sri Lanka already attained, or on track to attain MDGs - President tells MDGs Summit, 2010.09.22, available online at the official website:

www.president.gov.lk/speech_New.php?Id=99, last accessed 19.03.2012.

178 Sen, Amartya, DEVELOPMENT AS FREEDOM, Oxford University Press, 1999. See also the references to the experience of Sri Lanka in Sen, A., INEQUALITY RE-EXAMINED, Harvard University Press, 1995; Sen, Amartya, Sri Lanka's Achievements: How and When in T. Srinivasan and P. Bardhan Eds. RURAL POVERTY IN SOUTH ASIA, Columbia University Press, 1988; Sen, Amartya, The Sir John Crawford Memorial Lecture, held in Washington D.C., October 29th 1987, available online at http://www.worldbank.org/html/cgiar/publications/crawford/craw3.pdf, last accessed 20.01.2012.

${ }_{179}$ Sen, Amartya, DEVELOPMENT AS FREEDOM, Oxford University Press, 1999, Preface, pxii.

180 See further McGuire, James William, WEALTH, HEALTH, AND DEMOCRACY IN EAST ASIA AND LATIN AMERICA, Cambridge University Press, 2010; for the argument that democracy has contributed to the provision and use of public health care services, which has in turn led to rapid results even in difficult economic conditions.

${ }^{181}$ UNDP Human Development Report 2010, THE REAL WEALTH OF NATIONS: PATHWAYS TO HUMAN DEVELOPMENT, Chapter 3, Diverse Paths to Progress, available online at hdr.undp.org/en/media/HDR 2010_EN_Chapter3 reprint.pdf, last accessed on 15.03 .2012 and World Bank, WORLD DEVELOPMENT REPORT 2004: MAKING SERVICES WORK FOR POOR PEOPLE, 2003, p201-202. Also Svitone, Ennio Cufino, Richard Garfield, Maria Ines Vasconcelos and Villane Araujo Craviero, Primary Health Care Lessons From The Northeast Of Brazil: The Agentes De Saude Program, Rev Panam Salud Publica 2000, Vol.7, N.5 pp. 293-301, 2000; Atkinson, Sarah, Regianne Leila Rolim Medeiros, Paulo Henrique, Lima Oliveira and Ricardo Dias de Almeida, Going Down to the Local: Incorporating Social Organization and Political Culture into Assessments of Decentralized Health Care, 
Health is the right of all persons and the duty of the State and is guaranteed by means of social and economic policies aimed at reducing the risk of illness and other hazards and at universal and equal access to all actions and services for the promotion, protection and recovery of health.

This firmly established health a fundamental right as well as a duty of the State and laid the foundation for progressive reform of Brazil's health system.

The State of Kerala in India is notable due to the achievement of very high life expectancy and literacy and low infant mortality (the best indicators within India) despite low per capita income and low health expenditure - as well as for the fact that the results it achieved have not been matched by other States within India. ${ }^{182}$ This was also highlighted in the UNDP Human Development Report 2016 as "extreme geographic differences in health services" but without making any comment on the factors such as differences in governance and policy that may have led to these differences. ${ }^{183}$ The State of Kerala was formed in 1956 following a 'States Reorganization Act' which re-drew former State boundaries. There are many reasons given for the success of Kerala in terms of health indicators, including the social welfare policies of pre-independence kingdoms, a strong tradition of ayurveda, siddha and other indigenous medicine practices - and the democratic election of leftist governments. Kerala was the first Indian state where a communist party-led coalition was voted to power and has continuously returned to power since then in alternate election cycles. ${ }^{184}$ If Kerala has achieved much higher indicators in health and "extreme" differences in terms of the quality of health services provided, it is important to pay attention to the cultural and ideological factors that led to these progressive differences in health governance and health outcomes for the population.

Another example for the link between good governance and health is Costa Rica, the only Latin American country to have continuously been a democracy in second half of the $20^{\text {th }}$ century, with stability and regular elections since 1948. The Social Insurance Administration System of 1941 and the constitutional amendment that required Costa Rica to implement universal healthcare in 1961, created dramatic improvements in health indicators within a short period, that have continued to be maintained since then to levels equal to or higher than developed country levels, at a fraction of the cost. ${ }^{185}$ The UNDP

Social Science \& Medicine 51 (2000) 619; Atkinson, Sarah, Political Cultures, Health systems and Health Policy, Social Science \& Medicine 55 (2002) 113-124.

See further for an assessment of Brazillian reforms: Gragnolati, Michele, Magnus Lindelow, Bernard Couttolenc, TWENTY YEARS OF HEALTH SYSTEM REFORM IN BRAZIL: AN ASSESSMENT OF THE SISTEMA ÚNICO DE SAÚDE, World Bank Publications, 2013.

${ }^{182}$ Franke, Richard W. and Barbara H. Chasin, Kerala State, India: Radical reform as development, International Journal of Health Services 22.1 (1992): 139-156; Panikar, Puthenveetil Govinda Kesava, and C. R. Soman, Health status of Kerala: The paradox of economic backwardness and health development, Centre for Development Studies, 1984.

${ }^{183}$ UNDP, HUMAN DEVELOPMENT REPORT 2016: HUMAN DEVELOPMENT FOR EVERYONE, p62. The report gave the wide variation in the statistics for child immunization rates, health professional attendance at births and the number of hospital beds per population in Kerala as compared with the Indian State of Uttar Pradesh.

${ }^{184}$ Nabae, Koji, The health care system in Kerala: its past accomplishments and new challenges, Journal of the National Institute of Public Health 52.2 (2003): 140-5.

${ }^{185}$ United Nations Research Institute for Social Development (UNRISD), Chapter 6: Universal Provision of Social Services in COMBATING POVERTY AND INEQUALITY: STRUCTURAL CHANGE, SOCIAL POLICY AND POLITICS, UNRISD, 2010, p173-174, citing Trejos, Juan Diego, UNRISD Background Paper - Basic Social Services: Achievements and Bottlenecks since 1950, UNRISD, 2008. See also Azevedo, Mario J., Africa's Health System(s) Performance on the Millennium Development Goals (MDGs) 
Human Development Report of 2010 reiterated that countries such as Costa Rica, Sri Lanka, Cuba and the State of Kerala have attained higher human development than other countries with the same income due to their development policy-making directly tackling issues such as health services in manner that was 'decoupled' from economic growth ${ }^{186}$ and cited a number of studies that have shown that health services are better provided and health outcomes improve when governments are more democratic (not merely formal democracy but when there are higher rates of popular participation). ${ }^{187}$

Botswana is a politically stable, democratic country with uninterrupted democratic elections since independence from the British in 1966 and a low corruption index. From being one of the poorest countries in the world at the time of independence, it is now one of the fastest growing economies in the world, with high HDI as well as high GDP for an African nation. It is cited as having "one of the most developed social service systems in Africa", which includes a State-funded health services sector that succeeded in achieving "virtually universal access to primary healthcare". ${ }^{188}$ The UNRISD study on 'Combating Poverty and Inequality', studying examples such as Botswana, comes to the conclusion that public involvement is an effective and affordable method to achieve universal social services in the health and education sectors. ${ }^{189}$ Furthermore, Botswana is also one of six African Union countries which has been identified by the African Union Commission as achieving the pledge (made in Abuja in 2001) to commit at least $15 \%$ of their national budget for health expenditure. ${ }^{190}$ Botswana also faces a major health crisis with adult HIV prevalence estimated at between $22 \%-25 \%$, the $2^{\text {nd }}$ highest in the world next to Swaziland. However, the effects of this epidemic are mitigated since the public health system services in Botswana provides free sexual reproductive health services and antiretroviral therapy (ART) services for HIV patients - and was deemed likely to achieve universal access to ART by 2017 (and in 2019 the government also extended free HIV treatment to foreign residents). ${ }^{191}$ In addition, the public health system has successfully tackled malaria and achieved targets to reduce malaria cases to less than $1 \%$ prevalence. $^{192}$

in HISTORICAL PERSPECTIVES ON THE STATE OF HEALTH AND HEALTH SYSTEMS IN AFRICA, VOLUME II. Springer International Publishing, 2017, p.75-111.

186 UNDP, HUMAN DEVELOPMENT REPORT 2010: THE REAL WEALTH OF NATIONS: PATHWAYS TO HUMAN DEVELOPMENT, $\mathrm{p} 5$ and $\mathrm{p} 49$.

${ }^{187}$ Ibid (UNDP 2010), p51.

${ }^{188}$ United Nations Research Institute for Social Development (UNRISD), Chapter 6: Universal Provision of Social Services in COMBATING POVERTY AND INEQUALITY: STRUCTURAL CHANGE, SOCIAL POLICY AND POLITICS, UNRISD, 2010, p173-174, citing Trejos, Juan Diego, UNRISD Background Paper - Basic Social Services: Achievements and Bottlenecks since 1950, UNRISD, 2008, p.177-178. It is also noted that even in the face of serious setbacks to health indicators and development due to the HIV and AIDS epidemic, the government of Botswana continues to provide free, non-discriminatory treatment to HIV and AIDS patients.

${ }^{189}$ Ibid., (UNRISD, 2010), p180. See further for country studies on right to health, universal healthcare and national health systems of Brazil, the United Kingdom, South Africa, The United States, the Philippines, Peru, Mexico, Japan, Haiti, Ghana India and China: Zuniga, Jose, M., Stephen P. Marks and Lawrence O. Gostin, ADVANCING THE HUMAN RIGHT TO HEALTH, Oxford University Press, 2013.

${ }^{190}$ Partners in Population and Development Africa regional Office (PPD ARO), Meeting the Abuja Promise by African Governments to Commit $15 \%$ of Total National Budgets to health, available at http://www.ppdafrica.org/docs/policy/abuja-e.pdf.

${ }^{191}$ See the WHO statistics and UNAIDS statistics for Botswana for further details, available online at https://www.who.int/countries/bwa/en/ and https://www.unaids.org/en/keywords/botswana.

${ }^{192}$ Chihanga, Simon, et al. Malaria control in Botswana, 2008-2012: the path towards elimination, Malaria journal 12.1 (2013): 458; Chihanga, Simon, et al., Malaria elimination in Botswana, 2012-2014: Achievements and challenges, Parasites \& Vectors 9.1 (2016): 99. 
Another interesting illustration of economic and social rights coming to the forefront following a period of undemocratic government - is South Africa. South Africa's National Health Act of 2004 was enacted as part of the policy for creating a more egalitarian health services system for a country emerging from a long period of apartheid and injustice. The Preamble of the National Health Act recognizes this history and also the fact that health is a right under the post-apartheid Constitution of South Africa (1996). ${ }^{193}$ The constitutional rights include the overall State responsibility to take reasonable legislative and other measures within its available resources to achieve the progressive realization of the right of the people of South Africa to have access to health care services (including reproductive health care); as well as stating specifically that no one may be refused emergency medical treatment and that every child has the right to basic health care services. ${ }^{194}$

South Africa's 1996 Constitution was the first Constitution in the world to include justiciable socio-economic rights, ignoring the division and hierarchy between civil and political versus economic and social rights; and to incorporate the indivisibility principle in the Vienna Declaration and Programme of Action (1993), that states:

All human rights are universal, indivisible and interdependent and interrelated...it is the duty of States, regardless of their political, economic and cultural systems, to promote and protect all human rights and fundamental freedoms. ${ }^{195}$

Some of these constitutional rights were later the basis of public interest litigation before the Constitutional Court and are part of an ongoing debate on the direction of State policies, the implementation of social programmes and people's hopes for a just society. On the other hand, the GATS commitments of South Africa, it is pointed out, were those negotiated by the apartheid regime in 1994 during the transitional period of handing over of power to democratic government. Some see this apartheid era context as a reason to describe GATS accession as 'illegitimate' (although it is in fact legally binding) as compared with the health rights that are 'both morally and constitutionally justified' within the South African legal system. ${ }^{196}$

There are always counter-arguments against democracy, which we cannot ignore, and the first is that it does not always benefit all those within that particular 'grouping' (subnational region or nation) - and that it can perhaps harm those who stand 'outside' of the majority view within the group. Therefore, one turns to law as a tool that is a 'counterweight against majority view' or one that which balances the scales against a

${ }^{193}$ CONSTITUTION OF SOUTH AFRICA (1996), Section 27(2).

${ }^{194}$ CONSTITUTION OF SOUTH AFRICA (1996), Section 27(3) and Section 28(1)(c).

195 United Nations General Assembly, The Vienna Declaration and Program of Action adopted by the World Conference on Human Rights on $25^{\text {th }}$ June 1993, A/CONF.157/23, para.5:

All human rights are universal, indivisible and interdependent and interrelated. The international community must treat human rights globally in a fair and equal manner, on the same footing, and with the same emphasis. While the significance of national and regional particularities and various historical, cultural and religious backgrounds must be borne in mind, it is the duty of States, regardless of their political, economic and cultural systems, to promote and protect all human rights and fundamental freedoms.

196 Sinclair, Scott, GATS and South Africa's National Health Act: A Cautionary Tale, Canadian Centre Policy Alternatives, 2005, p10-11. 
harmful 'majority consensus'. ${ }^{197}$ In the legal-political context, the argument is usually raised in relation to the representation of minority interests or groups with proportionately less political power than others, or groups without political power within that system (usually meaning those who do not have the vote). An obvious example is that many of the progressive steps taken for civil rights in the United States were based on reasoning by judges on constitutional principles or principles of human dignity and not due to majority vote (especially when minorities could not fully exercise their voting rights) ${ }^{198}$ and it was not done with reference to evolving social attitudes as supported by opinion polls. In fact, such judicial decisions often went against popular opinion and far from being simply a reflection of social reality, has re-fashioned social reality.

Similarly, the Constitutional Court of South Africa, rejected the argument that what is cruel, inhuman or degrading depends to a large extent upon contemporary attitudes within society. Noting that that South African society does not regard capital punishment for extreme cases of murder as a cruel, inhuman or degrading form of punishment, the Court stated that:

...The question before us, however, is not what the majority of South

Africans believe a proper sentence for murder should be. It is whether the

Constitution allows the sentence. ${ }^{199}$

Thus, the reasoning by judges, on the basis of constitutional principles, to find the death penalty unconstitutional, went against public opinion at the time, and remains the legal basis for the rejection of public submissions to reinstate the death penalty. ${ }^{200}$

In the context of international law, the question of whether there are similar principles of a 'constitutional nature' is a whole other debate. For example, Doyle states that the international system has no single constitution, but the closest candidate to a constitution that it does have is the UN Charter. ${ }^{201}$ Cass analyzes the international trade 'constitutionalization project' but argues that the WTO is not and should not be described as 'a constitution', although she uses 'constitutionalization' as a concept to discuss

\footnotetext{
197 Smits, Jan M. Redefining Normative Legal Science: Towards an Argumentative Discipline in Fons Coomans, Fred Grunfeld and Menno T. Kamminga Eds., METHODS OF HUMAN RIGHTS RESEARCH, Intersentia, 2009, p52.

198 The Voting Rights Act of 1965, a federal legislation, was required to overcome the legal barriers at the state and local levels that prevented African Americans from exercising their right to vote. Thus, although the 15th Amendment to the US Constitution, which was passed in 1870, stated that the rights of citizens to vote shall not be denied or abridged "on account of race, color, or previous condition of servitude", the practical reality was that there was widespread disenfranchisement of African Americans. It can be argued that there continues to be barriers to participation of minorities in American democracy, due to the effects of 'racial gerrymandering' and felony disenfranchisement (See with regard to racial gerrymandering, Bethune-Hill et al. V. Virginia State Board of Elections et al., 580 U. S. 15-680 (2017) and Alabama Legislative Black Caucus v. Alabama, 575 U. S. 13-895 (2015); with regard to felony disenfranchisement see further, http://www.sentencingproject.org/issues/felony-disenfranchisement/ and Franqui Melissa, Felony disenfranchisement: The untold story of the 2016 election, 28.11.2016, http://www.salon.com/2016/ 11/28/felony-disenfranchisement-the-untold-story-of-the-2016-election_partner/.

199 The Constitutional Court of South Africa in The State v Makwanyane and Mchunu, Case No. CCT/3/94, (6 June 1995), paragraph 87. For a more nuanced analysis of the political context of the decision, see Fowkes, James, BUILDING THE CONSTITUTION: THE PRACTICE OF CONSTITUTIONAL INTERPRETATION IN POST-APARTHEID SOUTH AFRICA, Cambridge University Press, 2016, p625.

${ }^{200}$ Ibid., (Fowkes), p9, footnotes 21-22 - on submissions to parliament by the public and private members Bills.

${ }^{201}$ Doyle, Michael W., Dialectics of a global constitution: the struggle over The UN Charter, European Journal of International Relations, Volume: 18 Issue: 4, Page(S): 601-624.
} 
realigning the direction of the WTO more towards development goals. ${ }^{202}$ But supposing that there $i s$ a strong argument for looking at multilateral agreements in the same manner that domestic law judges look at constitutional principles and values, the power imbalances of the global community that lie behind the creation of the relevant multilateral agreements and the complexity and non-heterogeneity of values held by the various States are such that it could be a far more problematic endeavor than domestic constitutional interpretation. Milewicz's suggestion is that global constitutionalism is a "process of continuous development" rather than a "final good" like domestic constitutions. ${ }^{203}$ This highlights the importance of being engaged with the process of the development of WTO law, and the question as to the extent to which it could be directed or whether it has a telos or end toward which it is heading. But it also gives an impression that domestic constitutions are more static and do not evolve through constitutional interpretation. It would be more true to say that 'global constitutions' do not have the same foundations, structure and features of a domestic constitution, but that both could be in the process of continuous development.

Furthermore, an important feature of a national constitution is that it is often a social contract with a Bill of Rights that takes human dignity into account. This latter, most vital feature, which a trade constitution does not have, can be said to be the reason that there is distrust expressed about the idea of a global 'trade constitution' or "de facto kind of economic constitutionalism" 204 that constrains policy options that would otherwise have been available. What is available in the WTO context in place of a Bill of Rights are mechanisms such as exceptions, some of which will be discussed in this study. This study also looks at whether concepts such as human rights and dignity are necessary to supplement these mechanisms and whether they can be brought into the WTO through legal interpretation. Ooms and Hammonds propose a global constitutionalism project in light of international human rights "that ensures at the very least universal health coverage anchored in the right to health". ${ }^{205}$ Is it possible that there could there be a combination between Cass's arguments for a WTO constitutionalization which is more development-oriented and the Ooms and Hammonds version of a global constitutionalization of universal health coverage and right to health?

It is clearly too simplistic to conclude whether the concepts of sovereignty or democracy should or should not continue to be prioritized and respected in themselves, because these concepts can only be judged in their outcomes. There are studies that identify correlations between gains in health when countries are democracies with free and fair elections, ${ }^{206}$ and such outcomes are worth valuing and supporting. In the context of international

\footnotetext{
${ }^{202}$ Cass, Deborah, THE CONSTITUTIONALIZATION OF THE WORLD TRADE ORGANIZATION, Oxford University Press, 2005.

203 Milewicz, Karolina, Emerging Patterns of Global Constitutionalization: Toward a Conceptual Framework, 16 IND. J. GLOBAL LEGAL STUD. 413, 422 (2009)

${ }^{204}$ Tamanaha, Brian, The Dark Side of the Relationship between the Rule of Law and Liberalism, 33 NYU Journal of Law and Liberty, Volume 3, 2008, 516, p546.

205 Ooms, Gorik and Rachel Hammonds, Global constitutionalism, responsibility to protect, and extraterritorial obligations to realize the right to health: time to overcome the double standard (once again), International Journal for Equity in Health (The official journal of the International Society for Equity in Health) 2014, 13:68.

206 Thomas J. Bollyky, Tara Templin, Matthew Cohen, Diana Schoder, Joseph L. Dieleman, Simon Wigley, The relationships between democratic experience, adult health, and cause-specific mortality in 170 countries between 1980 and 2016: an observational analysis, The Lancet, Volume 393, Issue 10181, 20-26 April 2019, Pages 1628-1640.
} 
economic law, the greater emphasis on the smooth functioning of international trade can result in placing less importance on sovereignty and democracy and the popular choices that are driven by voter constituencies. From a pro-liberalization point of view, democratic expressions that do not support liberalization policies cause harm to both groupings outside the democracy (international business and ordinary people in other nations benefiting from reduction of trade barriers) and in the long run, those within the democracy, if they continue to close themselves off to reciprocal and mutually beneficial international trade opportunities. As Buddhist monks in ancient Sri Lanka wrote down as they concluded one of the chapters of the written record of Sri Lankan history, it can still be said today that:

Thus, reflecting that sovereignty, being the source of manifold works of merit, is at the same time the source of many an injustice, a man of pious heart will never enjoy it as if it were sweet food mixed with poison. ${ }^{207}$

Law does indeed have a balancing role to play against popular will or majoritarian democracy, especially if there are rights and interests of minorities or the marginalized that should be taken into account that will contribute to progress in both that society and other societies internationally. But at the same time, going to another extreme; giving an impression of disregarding popular or democratic will through decision-making by a distant, albeit erudite, elite - whether international trade scholars, lawyers or technocrats seems like an unhappy retrogression to systems of concentrated, distant power that in the past often caused, and sometimes did not survive, violent revolution. It is safe to say that the international trade system does not want future turmoil and upheaval, but aims for stability and prosperity. Therefore, the perceived distance between the grassroots aspirations and international decision-making must be narrowed. If both sovereignty and internationalism are 'preconceived mantras' 208 , not always supplying the best or more righteous position, the international trade system should be attempt to identify and apply methods that achieve a fair and rational balance between these positions.

In other areas of international law, there may be more of an understanding of the synergy between promoting national sovereignty and promoting international standards and action. In certain situations, in human rights and environmental law, where both popular will at local level, long term benefits for the international community as a whole and the implementation of international law and policy are considered, the global and local can come together in a positive manner. For example, Robert Howse notes that "a national interest model of sovereign regulation" will not solve a problem such as climate change that needs a "coordinated global response". ${ }^{209}$ A new way of thinking in education, politics, media, policy, law-making and governance is needed to inform citizens of the interconnections between local and global concerns, to empower them and to harness the resulting political will for meaningful change that benefits both the local and global. It

\footnotetext{
207 THE MAHAVAMSA (The Great Chronicle), Chapter XXXVI: Thirteen Kings (English translation by George Turnour, 1826), available online at http://mahavamsa.org/mahavamsa/original-version/36-thirteenkings/. The Mahavamsa is an official record of Sri Lankan history from the 6th Century BC to the 4th Century AD.

${ }^{208}$ Jackson, John H., Sovereignty, Subsidiarity and Separation of Powers in Kennedy, Daniel L. and James D. Southwick, THE POLITICAL ECONOMY OF INTERNATIONAL TRADE LAW: ESSAYS IN HONOR OF ROBERT E. HUDEC, Cambridge University Press, 2002, p15.

${ }^{209}$ Robert Howse, The End of the Globalization Debate in Meredith Kolsky Lewis, Susy Frankel, Eds., INTERNATIONAL ECONOMIC LAW AND NATIONAL AUTONOMY, Cambridge University Press, 2010, p12 Howse further emphasizes that the state can continue to be a progressive force, by working with global actors. See also Howse, Robert, and Kalypso Nicolaidis, Toward a global ethics of trade governance: subsidiarity writ large, Law \& Contemporary. Problems 79 (2016): 259.
} 
also seems that many citizens worldwide, especially young people, are eager for international agreement and action on climate change which would involve greater selfregulation by States, both individually and as a collective, for the benefit of the global community. ${ }^{210}$ The question is, how exactly is this popular will to be transformed into local, national and global action.

If citizens groups see that the State is also a progressive force for local as well as global change, what is sometimes confusingly referred to as the 'anti-globalization' position of defending state sovereignty, can in many situations actually mean defending the capacity of the state to advance what is sometimes termed as global or universal values. ${ }^{211}$ Thus, 'anti-globalization' protest actions are not necessarily undertaken merely on behalf of exclusivist nationalistic (group identity-based and inward-looking) ideology per se, but to defend the national and local capacity to take coordinated action on global issues such as climate change, exploitation of labour, humanitarian assistance and defence of human rights - and also to preserve national policy space in trade negotiations, in order to defend these non-trade values. ${ }^{212}$

${ }^{210}$ See for example the initiatives and co-ordination with other agencies carried out by the Secretariat for the UN Framework Convention on Climate Change (UNFCCC), United Nations Joint Framework Initiative on Children, Youth and Climate Change, launched in 2008 - which is linked to the implementation of Article 6 of the UNFCCC and in particular the implementation of the Doha work programme on Article 6 of the Convention.

See further: Worthington, Richard, Mikko Rask, and Lammi Minna, eds., CITIZEN PARTICIPATION IN GLOBAL ENVIRONMENTAL GOVERNANCE, Routledge, 2013; Finger, Matthias, and Thomas Princen, ENVIRONMENTAL NGOS IN WORLD POLITICS: LINKING THE LOCAL AND THE GLOBAL, Routledge, 2013; Dryzek, John, Global Deliberative Democracy in Morin, Jean-Frédéric, ED., THE ESSENTIAL GUIDE TO GLOBAL ENVIRONMENTAL GOVERNANCE, Earthscan/Routledge (2014): 76-79; Scannell, Leila, and Robert Gifford, Personally relevant climate change: The role of place attachment and local versus global message framing in engagement, Environment and Behavior 45.1 (2013): 60-85; Devine-Wright, Patrick, Think global, act local? The relevance of place attachments and place identities in a climate changed world, Global Environmental Change 23.1 (2013): 61-69; DevineWright, Patrick, Jennifer Price, and Zoe Leviston, My country or my planet? Exploring the influence of multiple place attachments and ideological beliefs upon climate change attitudes and opinions, Global Environmental Change 30 (2015): 68-79.

211 Robert Howse, The End of the Globalization Debate in Meredith Kolsky Lewis, Susy Frankel, Eds., INTERNATIONAL ECONOMIC LAW AND NATIONAL AUTONOMY, Cambridge University Press, 2010. Referring to the confusion that is caused by the term 'anti-globalization' since 'globalization' is often used as synonymous with economic neo-liberalism, and not in the wider sense of international action or solidarity.

${ }^{212}$ In their preliminary report to the Economic and Social Council, United Nations Special Rapporteurs on Globalization and Human Rights, Oloko Onyango and Udagama, included a quote from the then Brazilian President Fernando Enrique Cardoso that captures this:

In addition to its classic functions in the area of law enforcement, health, education, and foreign policy, the State must now meet increasing demands for more equity, more justice, a sound environment, and a greater respect for human rights. A more demanding society has to be matched by a more sophisticated State. A well-organized and efficient State will be better placed to meet those demands, many of them springing from globalization itself. Furthermore, the State must also be well equipped so that, in negotiating the rules within which globalization is to take place, national interests are preserved [emphasis added].

-UN, ECOSOC, Globalization and its Impact on the Full Enjoyment of Human Rights - Preliminary report submitted by J. Oloka-Onyango and Deepika Udagama, in accordance with Sub-Commission resolution 1999/8, E/CN.4/Sub.2/2000/13, 15 June 2000, para.11, citing Cardoso, Fernando Enrique, Globalization and International Relations, Public Address to the South African Institute of International Affairs, Johannesburg, 26 November 1996. Cardoso's address is also included in Cardoso, Fernando Enrique, CHARTING A NEW COURSE: THE POLITICS OF GLOBALIZATION AND SOCIAL TRANSFORMATION, Rowman \& Littlefield, 2001, p254. See further, UN, ECOSOC, Globalization and 
Howse also suggests that the intuitive leap some international lawyers make, from the idea of universal norms or values to an idea of 'global constitutionalism' enforced by international law and institutions, is an unwarranted one. ${ }^{213}$ In the context of human

rights, Howse says that the normative force of human rights is generally:

...today thought to imply a commitment to democracy, and democracy tends to imply popular sovereignty within a closed political community, the nation-state. [Human rights] need not be interpreted as at odds with national sovereignty rather than enhancing of it. For example, the Office of the High Commissioner for Human Rights has published a number of studies or papers on globalization where it is shown how some human rights such as the right to health, imply the need to protect national sovereignty against rules on economic globalization... [emphasis added] ${ }^{214}$

Thus, universal values can be used to support the right to choose national and local law policy and legal measures that benefit individual human rights and the environment at national and local level. It can also be 'globalization at the local level' in that there can be understanding and recognition by those at the grassroots, of the global solidarity of needs and rights held in common.

Yet it is important to note that perhaps this common understanding is more likely in the context of economic and social rights such as the right to health, than civil and political rights, where the experiences of gender, race, class, age, ability etc. offer different narratives and perspectives to the human rights struggles of different peoples. David Kennedy says that human rights "encourages a false solidarity" and that:

As a vocabulary for progressive elite solidarity, human rights is particularly ham-handed, making it more difficult to articulate differences. ${ }^{215}$

But it could be that Kennedy is focusing on a small sub-set of civil and political rights and not acknowledging that most economic and social rights do not have the same connotation of 'global elite solidarity'. Activist forums and movements on labour rights, right to form trade unions, water rights, land rights, farmer's rights, patient's health rights, access to medicines, right to food, and such are usually launched and spread at grassroots levels.

Poverty, living standards and economic and social rights are not always what comes to mind when the phrase 'human rights' crops up. Economic and social rights are after all referred to as the 'second generation' rights, often relegated to the shadows. As noted by Del Mar:

its Impact on the Full Enjoyment of Human Rights - Final report submitted by J. Oloka-Onyango and Deepika Udagama, E/CN.4/Sub.2/2001/10.

${ }^{213}$ Howse, Robert, Sovereignty, Lost and Found in Shan, Wenhua, REDEFINING SOVEREIGNTY IN INTERNATIONAL ECONOMIC LAW, Hart Publishing, 2008, p62

${ }^{214}$ Ibid., (Howse in Shan et al) p74-75. Howse in this instance refers specifically to intellectual property and the right to health. He further suggests at p75 that these rules are ...not really a surrender of sovereignty to the WTO as an institution but a transfer of sovereignty from some countries to others [emphasis added]

- which is an important idea to keep in mind, especially in the context of countries emerging from a history of domination by others or are independent states for the first time in history and have negligible international political power.

215 Kennedy, David, The International Human Rights Movement: Part of the Problem?, Harvard Human Rights Journal, Volume 14, 2002, 101, p120. 
...the very dubbing of social concerns as "second-generation norms" is symptomatic of the cleavage between the political and economic sphere, and the disavowal of responsibility for the effects of economic governance ${ }^{216}$

It may also be that there is an attitude of 'but the poor are always with us' and that there are other priorities and interests to take care of in matters of governance. After all, the international obligation in the International Covenant on Civil and Political Rights (ICCPR), is for the State not to interfere in 'freedoms' and to immediately guarantee those CPR, whereas the obligations in the International Covenant on Economic, Social and Cultural Rights (ICESCR) is to "achieve progressively...to the maximum of available resources" those rights spelt out in the ICESCR. What is at the root of all these issues is the question 'what do we believe that systems of governance should be created for and committed to provide'. This is a question that needs to be asked and answered at all levels of governance; local, national and international.

\subsubsection{A Clash of Values?}

These concerns about sovereignty, democracy, rights and the WTO, other than being broad general concerns, are tied to concerns about important subject matter ...or at the very least, subject matter that is important in a particular democracy. ${ }^{217}$ The importance given to a particular subject in a particular democracy can also be linked in that democracy to a particular set of rights and a particular use of sovereign power and particular approach to governance with regard to that issue. The example of public health services highlights this need to sometimes retain certain powers at certain levels of governance - and to resist 'cosmopolitan governance' through trade institutions (this does not refer to global co-ordination of public health responses through the WHO and other UN agencies). Although some examples have been already been presented, this can be gone into in further depth. The subject matter of health services can be seen through different lenses of society, history and political economy and is tied up with what is considered important in a given society.

For example, the healthcare debate in the United States is fundamentally different from that of Canada, although the two countries may share at first glance, many similarities. Canada has a strong public healthcare system with a core principle of free and universal access to publicly insured health care, and the United States does not. The government of Canada has stated that "no issue touches Canadians more deeply than health care" and that the healthcare system "is a practical expression of the values that define us as a country". ${ }^{218}$ In 2018, the UN Special Rapporteur on the Right to Health, Dainius Puras,

\footnotetext{
${ }^{216}$ See Del Mar, Maksymilian T. and Oche Onazi, The Moral Quality of Work in International Economic Institutions: Resisting Complacency, International Journal of Law in Context, Vol. 4, No 4, 2008, 337-377. Also available at SSRN, http://ssrn.com/abstract=1089488, p41.

217 See Jackson, John H., Sovereignty, Subsidiarity and Separation of Powers in Kennedy, Daniel L. and James D. Southwick, THE POLITICAL ECONOMY OF INTERNATIONAL TRADE LAW: ESSAYS IN HONOR OF ROBERT E. HUDEC, Cambridge University Press, 2002, p21:

...the controversy where to place government decision-making powers is sometimes actually over the substance of the issue.

${ }^{218}$ Cited in Footnote 4 of Van Duzer, J. Anthony, Health, Education and Social Services in Canada: The Impact of the GATS, Curtis, J.M., and D. Ciuriak, Eds., TRADE POLICY RESEARCH 2004, International Trade Canada, (Independent Report commissioned for the Government of Canada), 2004, p287-518, p305 (original source: Governor-General of Canada, Speech from the Throne to Open the Thirty-Seventh Parliament of Canada, 2003).
} 
visited Canada (on invitation) to how the right to health is realized in the country. While the shortcomings in the health service system were identified and critiqued, the report of the Special Rapporteur strongly commended the human rights-based approach to health and recommended that Canada further strengthen the justiciability of the right to health and continue to be a role model for other countries in that regard. ${ }^{219}$ The report explicitly stated that:

Canadian health-care systems are firmly rooted in values of equity and fairness and the overall notion that access to health care should be based on need and not on the ability to pay. Those values are embedded in single-payer public health-care systems partially funded by the Federal Government and implemented in each province and territory. ${ }^{220}$

While Canada needs to improve in terms of formulating better national health policy plans and in areas such as the right to health of indigenous peoples and providing nondiscriminatory access to health services regardless of immigration status, the overall review of the system was positive.

The difference between the two jurisdictions is due to the different choices taken by political actors and voters in Canadian history. It was the electoral success of the Cooperative Commonwealth Federation (CCF) party in the Saskatchewan, whose universal healthcare plan (first suggested in the 1930's) was later taken on by the Federal Government. ${ }^{221}$ The current legislation, the Canada Health Act (1985) is the federal legislation that sets out the principles and conditions under which provinces and territories in Canada receive federal funding for health care services they provide to citizens. The five main principles in the Canada Health Act include universality, accessibility, comprehensiveness, portability and public administration. This last principle, also used in combination with the concept of 'single payer', maintains that:

...the health care insurance plan of a province must be administered and operated on a non-profit basis by a public authority appointed or designated by the government of the province 222

Interestingly it is stated that:

...the original policy objective with regard to this principle was to prevent provinces and territories from using federal contributions to subsidize the coverage of provincial and territorial residents by private insurance companies [entirely bold in original] ${ }^{223}$

Supporters of the Canadian system are thus wary of the suggestions that public-private partnerships are the way forward for health services, as it undermines the principles of the national system currently in place. It also can be problematic in terms of GATS and other trade obligations, as will be looked into in Chapter two of this study.

\footnotetext{
${ }^{219}$ UNGA and HRC, Report of the Special Rapporteur Dainius Puras on the right of everyone to the enjoyment of the highest attainable standard of physical and mental health: Visit to Canada, A/HRC/41/34/Add.2, 19 June 2019, paras.16-19.

${ }^{220}$ Ibid., (Puras, 2019), para.26.

221 See Duncan, R. Paul, Michael E. Morris and Linda E. MacCarey, Canada (Chapter 4) in James A. Johnson and Carleen Harriet Stoskopf Eds., COMPARATIVE HEALTH SYSTEMS: GLOBAL PERSPECTIVES, Jones \& Bartlett Learning, 2010.

${ }^{222}$ Canada Health Act (R.S.C., 1985), Section 8(1)a.

${ }^{223}$ Madore, Odette, The Canada Health Act: Overview and Options, Economics Division, Parliamentary Information and Research Service of the Library of Parliament, CIR 94-4E, revised 16 May 2005. Accessed on 08.03.2011, available at www.parl.gc.ca/content/lop/researchpublications/944-e.htm.
} 
Overwhelming support for Canada's public health system and the belief that it is the highest priority issue in governance has been clearly expressed in surveys and reports on public opinion. ${ }^{224}$ An interesting example is that when in 2004, a nationwide debate and vote organized by the Canadian Broadcasting Corporation (CBC) was held, it resulted in Former Saskatchewan Premier Tommy Douglas (1904-1986), the 'Father of Medicare', being voted as 'The Greatest Canadian of All Time'. ${ }^{225}$ Reiterating the social vision behind the health system, another former Saskatchewan Premier, Roy Romanow, current Chair of the Commission on the Future of Health Care in Canada, said that:

The Medicare debate is not even just about basic Canadian values like equity and fairness for all citizens. Yes, it is about all these things. But it is also about much more. For, Medicare holds such a central role in our narrative of 'shared destiny', that how we deal with our social programs may determine the future progress of our nation - or whether, in fact, we do make progress. ${ }^{226}$

This history means that in relation to the context of international trade today, it is not uncommon to find expressions such as the one below by the Canadian Center for Policy Alternatives, that:

Medicare's creation required governments to take decisive, principled action - often despite intense opposition and powerful commercial interests - to serve the broader public interest. Today, Canadian health care reform demands the same decisive, principled action to meet Canadians' key priorities - despite the powerful commercializing bent of trade treaties - by putting health first. ${ }^{227}$

\footnotetext{
224 See Nanos Research for the Canadian Health Coalition, Canadians Views on Public Healthcare Solutions, November 2011, available online at healthcoalition.ca/wp-content/uploads/2011/11/NANOSEN.pdf, accessed on 12.03.2012. Across the political spectrum, over $80 \%$ of those polled supported, with another additional 10-14\% somewhat supporting.

See also Mendelsohn, Matthew, Canadians' Thoughts on Their Health Care System: Preserving the Canadian Model through Innovation, report submitted to the 'Romanow Commission' (Commission on the Future of Health Care in Canada), available at www.hc-sc.gc.ca/english/care/romanow/hcc0383.html.

See further, building on the Mendelsohn Report: Soroka, Stuart N., A Report to the Health Council of Canada: Canadian Perceptions of the Health Care System, 2007, available online at http://www.queensu.ca/cora/_files/ PublicPerceptions.pdf, accessed 12.03.2012.

${ }^{225}$ See archives.cbc.ca/society/celebrations/topics/1455/ last accessed 12.03.2012.

${ }^{226}$ Romanow, Roy, stated in a keynote address at a Canadian Health Coalition event titled 'Secure the Future of Medicare: A Call to Care', November $11^{\text {th }}$ 2011, last accessed 12.03.2012. - speaking notes available online at:

www.healthcoalition.ca/wp-content/uploads/2011/12/Romanow.pdf,

See also 'The Romanow Report', Building on Values: The Future of Health Care in Canada (2002), available online at: publications.gc.ca/site/eng/237274/publication.html, last accessed 12.03.2012.

227 Canadian Centre for Policy Alternatives and the Consortium on Globalization and Health, Principle Author, Campbell, Bruce, Authors Chantal Blouin et al, Summary Report, Globalization and Health Putting Health First: Canadian Health Care Reform, Trade Treaties and Foreign Policy, October 2002, last accessed 19.11.2011, available online at:

http:/www.policyalternatives.ca/sites/default/files/uploads/publications/National_Office_Pubs/putting_healt h_first.pdf

Ālso see Van Duzer, J Anthony, Health, Education and Social Services in Canada: The Impact of the GATS, Curtis, J.M., and D. Ciuriak, Eds., TRADE POLICY RESEARCH 2004, International Trade Canada, (Independent Report commissioned for the Government of Canada), 2004, p287-518, p305, available online at SSRN: http://ssrn.com/abstract=747545.
} 
The official position of the Canadian Government is that no GATS commitments for health have been taken. ${ }^{228}$ However, questions have been raised on the commitments in the insurance sector, to which the official reply has been that:

Commitments made on private health insurance do not undermine or require us to change our public health insurance system. ${ }^{229}$

But to the question 'What if the Government decides to expand public health insurance?' - The official response is that:

Should Canadian governments decide to expand public health insurance to areas previously covered by private health insurance, the GATS has procedures to modify our commitments as necessary. ${ }^{230}$

The procedures for the modification of commitments is an area that will be discussed further in Chapter 4 of this study, but suffice to say for now that modifying commitments is not an easy matter and these procedures are not simple. This raises some concerns for the future development of the current single-payer public health service system and the promotion of the objectives of the Canada Health Act, as mentioned above. The further expansion of the public system to provide for needs such as homecare, physiotherapy, prescription drugs, dental and eye care without provincial differences are currently being discussed - can this be done in the context of GATS commitments on health insurance? There is also some overlap with NAFTA obligations in this regard, so it is not only GATS commitments that need to be considered. It has been noted that there is possibility of 'regulatory chill' on policy flexibility and that there is a narrowing window of opportunity for public health service reforms to be done without the consequences being international trade disputes, if more and more foreign service providers enter the market. $^{231}$

In contrast, the United States, although sharing a geographical border with Canada and being similar in many other ways in socio-economic matters, could not be further apart with regard to the approach to universal public health services. Anyone following the debates around 'Obamacare', as the Patient Protection and Affordable Care Act 2010 or 'Affordable Care Act' is usually referred to, would realize this. ${ }^{232}$ Those who want to expand the access to affordable healthcare have to deal on one hand with arguments on whether it would be a proper exercise of federal constitutional authority; ${ }^{233}$ and on the

${ }^{228}$ Foreign Affairs and International Trade - Canada, Canada's Commitments to the GATS, last accessed 13.03.2012, available online at: www.international.gc.ca/trade-agreements-accords-commerciaux/services /gats_agcs/gatscommitment.aspx?lang=eng \&view=d,

${ }^{229}$ Ibī.

${ }^{230}$ Ibid.

231 See further, Grieshaber-Otto, Jim and Scott Sinclair, BAD MEDICINE: TRADE TREATIES, PRIVATIZATION, AND HEALTH CARE REFORM IN CANADA, Canadian Centre for Policy Alternatives, 2004, p146-148; and Crawford, Mark, Interactions: Trade Policy and Healthcare Reform After Chaoulli v. Quebec, Research Paper, Healthcare Policy, 2006 January; 1(2): 90-102, available online at:www.ncbi.nlm.nih.gov/pmc/articles/PMC2585326/pdf/policy-01-90.pdf, last accessed 15.03.2012.

${ }^{232}$ See further, Jacobs, Lawrence R. and Theda Skocpol, HEALTH CARE REFORM AND AMERICAN POLITICS: WHAT EVERYONE NEEDS TO KNOW, Oxford University Press, (Revised), 2012.

${ }^{233}$ See Amar, Akhil Reed, The Lawfulness of Health-Care Reform, Yale Law School Research Paper \#228, available online ssrn.com/abstract=1856506, accessed 22.06.2011. Amar presents six theories (five with binding Supreme Court case law) which support the constitutional nature of President Obama's healthcare plan. These arguments mostly deal with tax issues, interstate commerce and corporations; but also with the post-Civil War rights Amendments. Amar notes in his conclusion at p28 (in relation to civil rights) that:

A person who is unable to get necessary health care to save his life or to make his life livable is, in many ways, a slave. He is utterly dependent on the will or whim of others, as many an antebellum slave was utterly dependent on his master's will or whim. $\mathrm{He}$ 
other hand to engage with the politically polarized public who are usually confused as to what a law for expanded access to healthcare would aim to do or what it ought to do. ${ }^{234}$ The lack of an economic and social rights ethos, the complexity of the US legal system's approach to healthcare and the division of power between Federal and State authorities is part of this confusion. Until recently, the most commonly expressed viewpoint, such as presented by the Heritage Foundation - which describes itself as the most broadly supported think tank in America - was that there is already too much unnecessary interference by government in the health sector and that (as expressed in their Statement of Purpose on healthcare):

The result of so much government control is that health care is one of the most highly regulated sectors of the American economy. Government financing means government control, and government control means less personal freedom. 235

Interestingly, the attempted measures for universal health service coverage in the United States such as Medicaid which was introduced in 1965 (which was what was expanded under 'Obamacare'), Medicare, which was introduced in 1966 and military veterans' healthcare, have all been initiated at the federal level and thus are linked with particularly American fears on taxation, 'big government' and 'socialized medicine'. Therefore, despite the conceptual groundwork laid by Roosevelt's New Deal, ${ }^{236}$ the efforts of Truman to introduce compulsory health insurance ${ }^{237}$ and the 'Great Society' legislation

does not have the minimum autonomy and control over his life needed to be truly free.

Or so Congress might properly believe.

234 Sage, William M., Brand New Law! The Need to Market Health Care Reform, University of Pennsylvania Law Review, Vol. 159, 2011; U of Texas Law, Public Law Research Paper No. 190; U of Texas Law, Law and Econ Research Paper No. 198. Available online ssrn.com/abstract=1759555, accessed 09.03.2011.

235 The Heritage Foundation, Statement of Purpose (healthcare) on www.heritage.org/Initiatives/HealthCare, last accessed 13.03.2012. See also (as representative of the views of similar think-tanks) the comments on the ICESCR by Andre J. Cowin, the current Chairman of the Yankee Institute, Connecticut, former Jay Kingham Fellow for International Trade at The Heritage Foundation:

Four years after the fall of the Berlin Wall symbolized the fall of Communism, the Clinton Administration intends to present for ratification a treaty shelved at the height of the Cold War because of its embrace of socialist principles. The International Covenant on Economic, Social and Cultural Rights establishes the rights to housing, food, a fair wage, paid vacations, health care, and other expensive benefits.... Abundant health care, housing, and food are byproducts of wealth created by private individuals pursuing a profit.... Activist judges use broadly worded documents like the International Covenant to achieve a variety of social goals.... Clinton's proposal to ratify this treaty ignores centuries of Western intellectual and economic history, while at the same time embracing the theories of Karl Marx and Vladimir Lenin... Ratification of this treaty could be a costly disaster. It would violate the intellectual spirit of freedom and individual liberties that has characterized America since its founding.

(Cowin, Andrew, J., Human Rights Treaty Poses Dangers For America, Backgrounder No. 961 on Political Thought, Heritage Foundation, 29 July, 1993, http://www.heritage.org/research/reports/1993/ 07/humanrights-treaty-poses-dangers-for-america?renderforprint=1, last accessed 09.07.2014)

${ }^{236}$ See Transcript of President Franklin Roosevelt's Annual Message (Four Freedoms) to Congress , 1941, available online at http:/www.ourdocuments.gov/doc.php?flash=false\&doc=70\&page=transcript: In the future days, which we seek to make secure, we look forward to a world founded upon four essential human freedoms...The third is freedom from want - which, translated into world terms, means economic understandings which will secure to every nation a healthy peacetime life for its inhabitants-everywhere in the world ...We should widen the opportunities for adequate medical care.

${ }^{237}$ See Ameringer, Carl F., THE HEALTHCARE REVOLUTION: FROM MONOPOLY TO MARKET COMPETITION, University of California Press, 2008, p38: 
for civil rights and public services introduced under Johnson (including the introduction of Medicaid and Medicare), access to affordable healthcare remains problematic ${ }^{238}$ for tens of millions of (uninsured) Americans and it remains a divisive political issue.

This does not mean that there are no grassroots initiatives for rights regarding public health services in the United States. However, such efforts have not yet successfully introduced and implemented an entirely new system at Sub-State level that has gone on to galvanize and inspire a transformation of the federal system, like the CCF in Saskatchewan managed to do as the guiding force for health services reform in Canada. So, the parameters of the 'trade in health services' debate have been thus far on a completely different planet to the debate in Canada, which is about securing existing public health services in the context of international trade agreements and the commodification and privatization of public health services. In the United States, the issues of right to health and public health services which deliver free, universal services, has not really been raised until very recently. An example of grassroots activism for health reform in the United States is the Healthcare is a Human Right campaign by the Vermont Workers' Center, which has been active for a number of years and aims for a single-payer system with healthcare recognized as a public good. ${ }^{239}$ Vermont was the first US State which proposed universal healthcare legislation (Bill H.202: An Act relating to a universal and unified health system, passed into law on signature of the Governor of Vermont on $26^{\text {th }}$ of May 2011 as Act 48 of 2011). ${ }^{240}$ Vermont Senator, Bernie Sanders, an 'independent' candidate, was allowed by the Democratic Party to participate in the 2015/16 primaries for the Democratic Party presidential election nomination and he promoted the idea of universal, federally administered, single payer healthcare and right to health as a core policy proposal of his primary campaign - bringing this issue to the forefront of American national politics and raising support for the idea. ${ }^{241}$ Public opinion

Antisocialist rhetoric clouded the debate over access to health care...And in 1949, President Truman placed compulsory health insurance on the national agenda. Vehemently opposed to Truman's initiative, the AMA [American Medical Association] engaged Whitaker and Baker, a public relations firm, to stigmatize the president's plan. "The doctors of this country are in the front lines today of a basic struggle between socialism and private initiative," [Footnote: Campion 1984:159].

${ }^{238}$ See Franks, Peter, Carolyn M. Clancy and Martha R. Gold, Health Insurance and Mortality Evidence from a National Cohort, Journal of the American Medical Association, 1993;270(6):737-741. This study provided evidence for the assumption that that lack of health insurance is associated with "an increased risk of subsequent mortality".

${ }^{239}$ Vermont Workers' Center, Healthcare is a Human Right campaign, htttp://www.workerscenter.org /healthcare, last accessed 13.03.2012. Also see the campaign support site: vermontcareforall.org/presskit.html, last accessed 13.03.2012, where activist-musician Scott Ainslie sums up the campaign using human rights language:

The premise here is simple: when we agree that healthcare is a human right, public policy will move toward a healthcare delivery system that is based upon medical need rather than corporate greed. The campaign's goal is to gain widespread agreement that healthcare is a public good, not a commodity; a component of the commonwealth, not private wealth; and a human right, not an economic privilege.

Also see Vermont Workers' Center, Healthcare is a Human Right: Testimony on H.559 [an Act to implement the universal healthcare bill H.202, Act 48 of 2011], February 7, 2012, available at https://www.workerscenter.org/news/testimony-h559-healthcare-human-right.

${ }^{240} \mathrm{http}: / /$ legislature.vermont.gov/bill/status/2012/H.202. Further details on the healthcare reform process in Vermont available online at http://hcr.vermont.gov/legislation. See also: MacNaughton, Gillian, F. Haigh, M. McGill, K. Koutsioumpas and C. Sprague, The Impact of Human Rights on Universalizing Health Care in Vermont, USA, Health and Human Rights Journal 17/2 (2015), pp. 83-95;

${ }^{241}$ See Bernie Sanders' official website on his healthcare position:

https://berniesanders.com/issues/medicare-for-all/ 
polls in 2017 identified Sanders as the most popular politician in the United States ${ }^{242}$ and indicate rising approval rates for federally funded, single payer, universal healthcare. ${ }^{243} \mathrm{In}$ the context of the Trump administration proposal to repeal 'Obamacare', some Democratic Party representatives in the State of California, publicly supported by Sanders, made an attempt to introduce a single payer, universal healthcare bill in June 2017 (Senate Bill 562). This initiative was supported by the activism of the California Nurses Association and other labour organizations and was introduced in the California Senate by two Democratic senators; but it has stalled in the California Assembly without sufficient political support of politicians. ${ }^{244}$

As continuing evidence for the changing values regarding healthcare provision, it can be noted that in late 2018, Alexandria Ocasio-Cortez campaigned and was elected to the US House of Representative from New York's $14^{\text {th }}$ District on a platform which included support for single-payer healthcare system and the right to health. Pramila Jayapal, the Democratic representative from Washington State, proposed a bill in the House of Representatives for the transition of the U.S. healthcare system to a single-payer "Medicare for All" program which has so far gained 100 co-sponsors. ${ }^{245}$ Polls continue to show a rise in support for single-payer healthcare in 2018 and 2019, most likely boosted by Senator Bernie Sanders' continuing popularity and campaigning on the right to healthcare as part of his second bid for Democratic Presidential candidacy in $2020 .^{246}$ Meanwhile tens of millions of Americans have neither access to public health services nor the capacity to pay for private health insurance and thus left with neither freedom nor

Also see comments on continuing efforts: Loffredo, Nicholas, Bernie Sanders to sponsor single payer healthcare bill, Newsweek, 17 March 2017, http://www.newsweek.com/bernie-sanders-sponsor-singlepayer-healthcare-bill-574403:

Sanders' support for a single-payer system was a centerpiece of his unsuccessful run for the Democratic presidential nomination.

${ }^{242}$ Easley, Jonathan, Poll: Bernie Sanders country's most popular active politician, The Hill, 18 April 2017, http://thehill.com/homenews/campaign/329404-poll-bernie-sanders-countrys-most-popular-activepolitician:

Sanders is viewed favorably by 57 per cent of registered voters, according to data from a Harvard-Harris survey.

See also Bernie Sanders Favorable Rating, 57\%, in June 2017, available online at: http://elections.huffingtonpost.com/pollster/bernie-sanders-favorable-rating.

${ }^{243}$ Gallup: Newport, Frank, Majority in U.S. Support Idea of Fed-Funded Healthcare System, May 16, 2016, available at http://www.gallup.com/poll/191504/majority-support-idea-fed-funded-healthcaresystem.aspx.

Pew: Kiley, J., Public support for 'single payer' health coverage grows, driven by Democrats, June 23, 2017, available at http://www.pewresearch.org/fact-tank/2017/06/23/public-support-for-single-payerhealth-coverage-grows-driven-by-democrats/.

${ }^{244}$ Cadelago C. and Taryn Luna, Why universal health care died in California, The Sacramento Bee, June 27 2017, http://www.sacbee.com/news/politics-government/capitol-alert/article158363674.html; Bartolone, Pauline, The Union That Roars: Nurses Aren't Giving Up On California's Single-Payer Push, California Healthline, June 12 2017, http://californiahealthline.org/news/the-union-that-roars-nurses-arent-giving-upon-californias-single-payer-push; also see National Nurses United, Medicare for all: News, http://www.nationalnursesunited.org/site/entry/medicare-for-all.

${ }^{245}$ Abutaleb, Y., U.S. House Democrats introduce sweeping 'Medicare for All' bill, Reuters, February 26, 2019, https://www.reuters.com/article/us-usa-congress-medicare/u-s-house-democrats-introduce-sweeping -medicare-for-all-bill-idUSKCN1QF2TA.

246 Yoni Blumberg, 70\% of Americans Now Support Medicare-For-All - Here's How Single-Payer Could Affect You, CNBC, August 28 2018, https://www.cnbc.com/2018/08/28/most-americans-now-supportmedicare-for-all-and-free-college-tuition.html. 
choice despite health expenditure being among the highest in the world at over $17 \%$ of GDP according to the available data (2014-16). ${ }^{247}$

The example of Canada, as contrasted with the United States, shows that countries that otherwise may have much in common in terms of society and culture can still have stark differences in terms of certain expressed values and it may be stated that those societal values have influenced the legal and institutional structures of that society. However, it can also be seen that values can evolve and change in a short period of time, as is clear in the case of changes seen in the US public polls on health reform within the last several years. The standard definition for the noun 'values' is rather broad, being:

life $^{248}$

Principles or standards of behaviour; one's judgement of what is important in

This definition recalls the tricky question of who is the creator of these principles or standards - anyone, just someone or the other, someone important or almost everyone? The possible answers connect with the significance of the concept of democracy, as discussed earlier. Regardless of one's views on democracy and its imperfections, it is possible to say that decision-making in democratic societies can be often seen as an aggregation of values. These values are those expressed in political choices and that shape socio-economic and other policy.

There can be various arguments on how rational or not these decisions based on values are, and how they are made with insufficient information; but in the case of issues such as public health services delivery, it can often be seen that societies which have developed a system that protects the weakest among them do it quite regardless of economic efficiency or economic rationality arguments. It can be seen as a situation of what Weber would term value-rational action: a conscious attempt to realize certain values, 'come what may' - a form of behavior:

...determined by a conscious belief in the value for its own sake...independently of its prospects or success. ${ }^{249}$

\footnotetext{
247 WHO Department of Health Statistics, 2010-2014. World Bank data 1995-2014 and 2000-2016 and the OECD Health Division, Health Data November 2011. This is equal to the health expenditure rate for the Marshall Islands, which faces particular difficulties as a pacific island facing climate change, pollution and transportation linkage problems and well as ongoing severe health issues due to the nuclear bomb testing conducted in the Marshall Islands by the US Department of Defence in the 1950s-1960s. The next highest expenditure in an industrialized country is less than $12 \%$ GDP, with the highest expenditure in the world according to WHO data for 2012 being Sierra Leone at 20.8\%; a country emerging from serious conflict which devastated their infrastructure. Sierra Leone, which has initiated a Free Health Care Initiative in 2010, had a life expectancy of only 56 years and the worst child and maternal mortality rate in the world according to WHO data (WHO, TRENDS IN MATERNAL MORTALITY: 1990 TO 2010 - WHO, UNICEF, UNFPA AND THE WORLD BANK ESTIMATES, 2012). Thus, there was a need for rebuilding their destroyed health sector to maintain minimum core standards of health services provision, and this is reflected in the high GDP percentage. The GDP percentage was back down to $11 \%$ for Sierra Leone in 2014 but rose again to $16.5 \%$ in 2016 according to WHO and World Bank data (see http://data.worldbank.org/indicator/ ). World Bank data places the Marshall Islands, a territory formerly 'administratively controlled' by the United States following World war II and now under a Compact of Association with them since 1983, as one of the highest in terms of health expenditure, fluctuating between $19 \%$ and $27 \%$ of GDP during 2000-2016. Notably, this continues to be a location for a US Military base and was formerly a testing area for atomic bombs.

248 THE NEW SHORTER OXFORD DICTIONARY, Clarendon Press, 1993: "The principles or moral standards of a person or group".

249 Swedberg, Richard and Ola Agevall, THE MAX WEBER DICTIONARY: KEY WORDS AND CENTRAL CONCEPTS, Stanford Social Sciences Series, Stanford University Press, 2005, p287-288 referencing Weber, Max, ECONOMY AND SOCIETY, p24-25
} 
The proponents of national public health systems thus do not often focus primarily on efficiency, effectiveness and the results which can be achieved. The positive results justify the action, but the reason that the system is chosen is more than merely the probable result. Rubin analyzes this kind of situation in the following manner:

The political rationale for insisting that policymaking must remain within government control is fairly obvious, at least in a democracy. But we must also know the theoretical rationale for the principle...Policy formation represents a choice of goals or values; implementation can then be understood as a form of instrumental rationality designed to achieve the defined goal in an effective manner. The goals are deontological, that is, they are chosen for their own sake, independent of their prospects for success, but they define success for implementation programs. $^{250}$

This is not just a matter of a theoretical explanation, but can be seen in words and deeds in societies who have made such value choices. The justifications are often along these lines, which found in the opening paragraph of the National Health Service (NHS) Constitution for England:

The NHS belongs to the people... It touches our lives at times of basic human need, when care and compassion are what matter most. It is founded on a common set of principles and values that bind together the communities and people it serves - patients and public - and the staff who work for it... [emphasis added] ${ }^{251}$

As Jane K. Seymour emphasizes, it was the shared values concerning the responsibilities of citizenship and reciprocal social obligations that were the foundations of the policy and statutes on public health that were introduced in the early part of the $20^{\text {th }}$ Century in Britain; and which ultimately led to the creation of the NHS after World War II. ${ }^{252}$ The underlying ethos of the duty of community and the State in bearing the cost of health services was captured in the justification for a national health service for Britain given by Aneurin Bevan, the Minister of Health who was responsible for the National Health Service Act of 1946:

Illness is neither an indulgence for which people have to pay, nor an offence for which they should be penalised, but a misfortune, the cost of which should be shared by the community. ${ }^{253}$

These social values have been a fundamental feature of British society and national identity in the post-World War II period. There have been continuous expressions of support for the NHS across the political spectrum and the NHS is considered the result of national consensus. ${ }^{254}$

\footnotetext{
${ }^{250}$ Rubin, Edward L., The Possibilities and Limitations of Privatization, 2010 Harvard Law Review, Vol. 123, No.890, p18

${ }^{251}$ THE NATIONAL HEALTH SERVICE CONSTITUTION FOR ENGLAND, 08 $8^{\text {th }}$ March 2010 , www.dh.gov.uk/prod_consum_dh/groups/dh_digitalassets/@dh/@en/@ps/documents/digitalasset/dh_1136 45.pdf, last accessed on 13.04.2011

${ }^{252}$ Seymour, Jane K., Not Rights but Reciprocal Responsibility: The Rhetoric of State Health Provision in early Twentieth Century Britain in Alex Mold and David Reubi Eds., ASSEMBLING HEALTH RIGHTS IN GLOBAL CONTEXT: GENEALOGIES AND ANTHROPOLOGIES, Routledge, 2013.

${ }^{253}$ Campbell, Alastair V., MEDICINE, HEALTH, AND JUSTICE: THE PROBLEM OF PRIORITIES, Churchill Livingstone, 1978, p9.

${ }^{254}$ See Rintala, Marvin, CREATING THE NHS: ANEURIN BEVAN AND THE MEDICAL LORDS, Routledge, 2003, p3-6; Webster, Charles, THE NHS: A POLITICAL HISTORY, Oxford University Press, 1998.
} 
However, despite election promises to the contrary, the Conservative and Liberal Democrat coalition government took a number of measures to reorganize and commercialize the NHS by enacting the Health and Social Care Act of 2012. The new approach of creating a privatized 'internal market' for supply of health services through the NHS and other amendments, have been severely criticized for removing the 'duty to provide comprehensive healthcare' and undermining the concept of free universal health services - both of which were fundamental features of the NHS since its inception in $1946 .{ }^{255}$ These controversies have led to the establishment of a small new political party by some concerned citizens: the National Health Action Party. The NHA Party campaigns for awareness of the effects of the 2012 Act and other measures which have been observed to damage the NHS and to call into account the major parties, on their failure to abide by prior election promises to protect the NHS. ${ }^{256}$ In the context of more recent elections dominated by 'Brexit' and immigration, the NHS has been one of the most important issues in the elections, at least in terms of election promises by all parties to safeguard it and the acknowledgement of its importance to the British public. ${ }^{257}$

Interestingly, it has been often commented that the values and ideology of the NHS, as well as the response to it by its supporters, is comparable to a religious faith. A wellknown saying is that the NHS is the closest that the English have to a religion. ${ }^{258} \mathrm{~A}$ statement in a British Parliamentary debate in 2011 recalled another famous saying by Aneurin Bevan:

Bevan said: "The NHS will last as long as there are folk left with the faith to fight for it". The NHS does have folk willing to fight for it [emphasis added]. ${ }^{259}$

\footnotetext{
${ }^{255}$ See further, Davis, Jacky and Raymond Tallis, Eds., NHS SOS: HOW THE NHS WAS BETRAYED AND HOW WE CAN SAVE IT, One World Publications, 2013.

${ }^{256}$ See for further information: http://nhap.org/. Note that the UK has a 'first-past-the-post' electoral system instead of proportional representation, which means that a constituency (electoral area or seat) is represented by a single elected representative, who does not need to receive a majority $(50 \%+1)$ vote, only more votes than the nearest competitor. This makes it extremely difficult for $3^{\text {rd }}$ parties or new political parties to win seats in the UK system which is dominated by the Conservatives and Labour parties. Yet the formation of a new political party like the NHA Party is important as an organization for public awareness and action which can help in highlighting matters of public interest and influencing the two main parties likely to win, Conservative and Labour, to respond to the policy issues surrounding the protection of the NHS.

${ }^{257}$ See for example: Colchester, Max, Health Care Joins Brexit as Big Issue in British Election, Wall Street Journal, 10 December 2019, https://www.wsj.com/articles/health-care-joins-brexit-as-big-issue-in-britishelection-11576009396; Sturgeon, Nicola, An election to define and shape the UK - and the NHS, 30 November 2019, Financial Times, https://www.ft.com/ content/94ba0076-12b9-11ea-a7e6-62bf4f9e548a.

See also Boris Johnson being quoted as stating after the 2019 election victory that:

I know, because I have heard it loud and clear from every corner of the country - that the overwhelming priority of the British people now is that we should focus above all on the NHS."

(Mason, Rowena and Kate Proctor, Boris Johnson pledges to prioritise NHS after election victory, The Guardian, Fri 13 Dec 2019, https:/www.theguardian.com/politics/2019/dec/13/boris-johnson-pledges-toprioritise-nhs-after-election-victory).

${ }^{258}$ See Catterall, Peter (Series Editor), in Preface to Rintala, Marvin, CREATING THE NHS: ANEURIN BEVAN AND THE MEDICAL LORDS, Routledge, 2003. Catterall refers to the famous statement by Nigel Lawson MP, that the NHS is the closest that the English have to a religion (from Lawson, N., THE VIEW FROM NUMBER ELEVEN, Doubleday, London, 1992) and also adds that:

Bevan's chapel flavoured rhetoric may have given his creation a religious glow which has remained ever since.

259 Thornberry, Emily, Member for Islington South and Finsbury (Labour), The House of Commons Hansard Debates for 30th March 2011, available online at:
} 
Faith commonly refers to something that stands by itself, without reference to supportive evidence. A value system can thus be like a religion and get a life of its own, quite apart from reference to any actual good sense reason for it or any requirement of justification.

Raymond Boudon, discussing different theories of values, refers to the notion that values are 'unjustified' ${ }^{260}$ However, Boudon also refers to John Rawls as a theorist of values and Rawls' theory of justice as a rationalistic explanation of values (of what people would do faced with distributive inequalities) which escapes the relativism of values taken alone (that we all have our own values, each equally valid). This suggests that, if it is possible to say that certain values can be rationalistically explained, then they can also be justified - and to take a step forward in that argument, that those values can be identified with justice. A Rawlsian 'behind the veil' approach would justify as rational, a social decision to have a health service system that protects all members of society in case of ill-health, regardless of their ability to purchase healthcare.

The writings of Norman Daniels of the Harvard School of Public Health link the Rawlsian concept of justice to healthcare. Daniels says that the questions posed by a general theory of justice and health must guide our thinking on social obligations and fairness in healthcare provision, health policy and the design of institutions. ${ }^{261}$ However, Daniels acknowledges that his theory of 'just health' fails to be specific about international obligations to promote health or reduce international inequalities. ${ }^{262}$ Indeed, the issue of global justice is also one of the criticisms of Rawls' theory, and one which was not satisfactorily answered in his later work, The Law of Peoples. ${ }^{263}$ Therefore, it has to be admitted the ability to make Rawls' theory of justice relevant to the WTO-led new world order, seems rather limited, and a great deal of stretching of the original arguments is required. Rawls can even be criticized as creating a theory that ultimately does not challenge and perhaps even defends the status quo. Although Rawls has not developed a comparable idea of global justice, his original theoretical approach remains useful for discussions on just social order at the domestic level.

Democratic choice in establishing and advancing rights and services such as health services, guided by core societal values, can be identified as the closest in real life to this hypothetical 'behind the veil' situation described by Rawls. These core values could be

http://www.publications.parliament.uk/pa/cm201011/cmhansrd/cm110330/halltext/110330h0002.htm.

${ }^{260}$ Boudon, Raymond, THE ORIGIN OF VALUES: SOCIOLOGY AND PHILOSOPHY OF BELIEFS, Transaction Publishers, 2001, p2.

${ }^{261}$ Daniels, Norman, JUST HEALTH: MEETING HEALTH NEEDS FAIRLY, Cambridge University Press, 2007, p2, building upon his earlier work - Daniels, Norman, JUST HEALTH CARE, Series: Studies in Philosophy and Health Policy, Cambridge University Press, 1985.

262 Daniels, Norman, JUST HEALTH: MEETING HEALTH NEEDS FAIRLY, Cambridge University Press, 2007, p8.

${ }^{263}$ Rawls, John, THE LAW OF PEOPLES: WITH, THE IDEA OF PUBLIC REASON REVISITED, Harvard University Press, 2001.

For engagement and critical responses to Rawls, see Brock, Gillian., GLOBAL JUSTICE: A COSMOPOLITAN ACCOUNT, Oxford University Press, 2009; Pogge, Thomas., An Egalitarian Law of Peoples, 1994 Philosophy \& Public Affairs, 23: 195-224; Pogge, Thomas, Moral Universalism and Global Economic Justice, 2002 Philosophy, Politics and Economics 1:1; Beitz, Charles R., Justice and International Relations, Philosophy \& Public Affairs Vol. 4, No. 4, Summer, 1975, pp. 360-389; Beitz, Charles R., Cosmopolitanism and Global Justice in Brock, Gillian and Darrel Moellendorf, Eds., CURRENT DEBATES IN GLOBAL JUSTICE, Series: Studies in Global Justice, Vol. 2, 2005 reprinted from 2005, The Journal of Ethics 9:1, Special Volume; Costa, M. Victoria., Human Rights and the Global Original Position Argument in The Law of Peoples, 2005 Journal of Social Philosophy, 36: 49-61. 
linked to any general theory of justice or even to a 'love thy neighbor as thyself' attitude based on spiritual values. Even if many modern States are secular or do not overtly refer to ethical or religious values in formulation of law and policy, the influence of such values cannot be denied. It has been commented by Neergard in the context of health services being an essential element of the European welfare state, that:

[The] parable of the Good Samaritan may be claimed to have worked itself deeply into the European consciousness ${ }^{264}$

The same underlying values can be identified and shared by other societies, although they do not share the same religio-historical background - as the 'snapshots' in this Chapter demonstrate.

Yet, at the same time, we can see that there are different social models; and the idea that there can really be universal values is doubted by both theorists and observers of reality. It can be said that a form of universal values can be seen in norms and principles of international law; especially, as mentioned earlier, in certain areas of human rights and environmental law and other areas where jus cogens, customary international law or other norms on the verge of acceptance as customary international law, exist. The existence of many of these values will often not be denied outright by different societies worldwide, although they may deny the rights in practice or try and find (or create, new) legal loopholes. Thus, there is a need in some cases for legal and policy frameworks that go beyond merely acknowledging particular social values and recognize that some of these values form the basis of binding obligations in international law. For some States or regions within States with a strong domestic value basis for universal healthcare and public health services, such as the UK, Canada, Sri Lanka, Kerala etc., there is not much of a need for citizens to rely upon international obligations such as the right to health or health as a part of the right to development, in order to promote and protect universal public health services. In most of the countries mentioned in the 'snapshots', the domestic values are strong despite not even having an explicit right to health provision in their national constitutions, to support the value. But for citizens of countries such as the United States, which does not have a strong domestic tradition of the same kind, referencing the international right to health would be an important part of the participatory democratic debate on the nature of health services, as well as a basis for discussing how the United States should position itself in terms of international trade in services.

Thus, there may be a role for human rights to play in values protection in the context of the health services debate. Reference to human rights may be useful to ensure that the use of 'values' in the debate are guided by the concept of human dignity. This has been suggested in the UN context, that:

Human rights, as a code of values juridically accepted at the international level, can legitimately signal the ethically acceptable or unacceptable limits

\footnotetext{
${ }^{264}$ Neergard, Ulla, EU Healthcare Law in a Constitutional Light: Distribution of Competences, Notions of 'Solidarity' and 'Social Europe', in J.W. van der Gronden, E. Szyszczak, Ulla Neergard and M. Krajerski Eds., HEALTH CARE AND EU LAW, T.M Asser Press and Springer, 2011.

See also Hervey, Tamara, EUROPEAN SOCIAL LAW AND POLICY, Longman, 1998, p8-10. Hervey identifies two European social justice models; one which is conservative, with roots in Roman Catholicism of Germany and Austria and the other being more radical and associated with Scandinavian and French Socialist ideas of 'solidarity'.
} 
of economic policy measures and economic functioning [emphasis added]. ${ }^{265}$

But even this remains an area to tread carefully - as this too is open to abuse and sophistry - and using language which is as yet evolving to justify (even good) motivations may lead to other problems, including a different level of values-clashes within the human rights arena. This issue will be discussed further in this Chapter in Section 2.3 on guidelines for the interpretation of the GATS and the use of human rights language. Section 2.4. will provide further details on the contours of the right to health in international human rights law and the relevance of the right to health-based approach for the protection of public health services.

Norman Daniels, although a proponent of a theory of justice that could link and create a balance between equity and efficiency, assumes that the right to health or to healthcare is not an appropriate starting point for inquiring into justice in the context of healthcare. While admitting that members of the public claim 'rights' whenever strong interests are felt and that there is a "pragmatic appeal" in using the right to health with the hope that it will assist in uniting people to support reform of existing systems - Daniels believes that we should look to general theories of justice, because rights are not clear about what is owed and are unable to resolve practical disputes on obligations. ${ }^{266}$ This is interesting in that it ignored the existence of, and the role played by, the international, regional and constitutional legal frameworks on the right to health in shaping policy and adjudicating disputes and problems in this area. It is puzzling how Daniels can argue that a general theory of justice can be more useful to clarify and justify claims for the right to health or healthcare than specific binding international and regional legal obligations or constitutional fundamental rights obligations on the right to health. Perhaps this is explained by the context of the United States legal system, which does not acknowledge the right to health in any of the latter ways, and therefore a general theory is apparently more acceptable to propose in academic circles within the United States.

Furthermore, the linkage of social values and rights, especially the use of emotion-laden terms such as 'values', can be a double-edged sword. Although this study posits social values and rights as concepts that are inclusive of the disadvantaged and marginalized, values-language can also be used to create division and ostracize those who are critical of the existing order. ${ }^{267}$ It can also be used to impose unacceptable ideas upon unwilling groups of people, to prevent discussion on choice of policy and other even worse forms of abuse of power. ${ }^{268}$ Therefore, open and ongoing democratic discourse is vital for true

$265 \mathrm{UN}$ Economic and Social Council, The relationship between the enjoyment of human rights, in particular economic, social and cultural rights, and income distribution, Final Report of José Bengoa, Special Rapporteur to the Sub -Commission on Prevention of Discrimination and Protection of Minorities, E/CN.4/Sub.2/1997/9, 30 June 1997, para 4. The paragraph continues, adding that

The human rights system has the legal obligation to observe the economic system and to signal the greater or lesser impact it is having in meeting the needs of individual human beings and on their enjoyment of essential civil, economic, social, political and cultural rights [emphasis added].

266 Daniels, Norman, JUST HEALTH: MEETING HEALTH NEEDS FAIRLY, Cambridge University Press, 2007, p15.

${ }^{267}$ Boudon, Raymond, THE ORIGIN OF VALUES: SOCIOLOGY AND PHILOSOPHY OF BELIEFS, Transaction Publishers, 2001 at p89-90. Boudon refers also to Russel Hardin, who discusses 'particularist', community values vs universal values and uses the Antigone myth to illustrate this clash. (See Hardin, Russel ONE FOR ALL: THE LOGIC OF GROUP CONFLICT, Princeton University Press, 1997)

${ }^{268}$ For example, the former US President George W. Bush has been quoted as stating in 2002 with regard to what underlies his/US foreign policy, that 
societal values, which should be organic and not imposed. Continuing the example of the NHS Constitution for England, it is also stated therein (and important to quote fully) that:

The Constitution will be renewed every 10 years, with the involvement of the public, patients and staff. It is accompanied by the Handbook to the NHS Constitution, to be renewed at least every three years, setting out current guidance on the rights, pledges, duties and responsibilities established by the Constitution. These requirements for renewal are legally binding. They guarantee that the principles and values which underpin the NHS are subject to regular review and recommitment; and that any government which seeks to alter the principles or values of the NHS, or the rights, pledges, duties and responsibilities set out in this Constitution, will have to engage in a full and transparent debate with the public, patients and staff [emphasis added] ${ }^{269}$

Furthermore, Section 3 of the Health Act of 2009 also sets out the legal obligation for this continuous review of the NHS constitution. However, as mentioned briefly earlier, the Health and Social Care Act of 2012, and the process by which it became law, is obviously contrary to the clear principles and processes required by the NHS Constitution, and a betrayal of public trust.

Thus, while it is important to bear in mind that values can be weapons and well as shields, and that weapons can wound, perhaps we should not set aside the concept of values as $a$ sword that defends, merely because it is double-sided. As St Augustine said:

Since, then, the faculty of eloquence is available for both sides, and is of very great service in the enforcing either of wrong or right, why do not good men study to engage it on the side of truth, when bad men use it to obtain the triumph of wicked and worthless causes, and to further injustice and error? $?^{270}$

In conclusion, the perspective of this research on the issue of societal values can be summed up by the following statements on the relevance of values to law and policymaking:

- Societal values are still relevant to economic and social policy-making;

- Values can and have been chosen and continue to be chosen through continuous and dynamic democratic process;

- Values are translated into policy - locally, nationally and internationally;

- Values are translated into law - both normative 'soft law' and binding obligations; and

- Values are also contained in non-legally-binding expressions nationally and internationally.

...there is a value system that cannot be compromised...And if the values are good enough for our people, they ought to be good enough for others, not in a way to impose because these are God-given values. These aren't United States-created values. These are values of freedom and the human condition and mothers loving their children.

(Woodward, Bob, A Course of 'Confident Action': Bush Says Other Countries Will Follow Assertive U.S. in War on Terrorism, Washington Post, November 19 2002, www.washingtonpost.com/wp-dyn/articles /A7596-2002Nov18_2.html, accessed 17.03.2011).

${ }^{269}$ The National Health Service Constitution for England, 8 March 2010, available online at the following official website: www.dh.gov.uk/prod_consum_dh/groups/dh_digitalassets/@dh/@en/@ps/documents/ digitalasset/dh_113645.pdf.

${ }^{270}$ St Augustine, DOCTRINA DE CHRISTIANA, Book IV:3. This particular translation is available online at the following website: www9.georgetown.edu/faculty/jod/augustine/ddc.html, accessed on 18.03.2011. 
Although they are intuitive statements, evidence can be found to support them and some illustrations have been provided in this section.

It is also clear that there is a link between societal values and human rights - and within human rights there exists the concept of the right to health. Therefore, the issue of health services in national systems is not merely about a relativistic argument ${ }^{271}$ of allowing for divergence of societal values and economic policy, but also one which has implications for international legal obligations in the area of human rights law, which have been agreed upon by States and developed with the participation of citizens and civil society groups. While human rights promote a bottom-up approach based on national values and democratic processes, the values that come out of these national processes are not free from being critiqued from a human rights perspective. Human rights are also a framework for challenging 'national values' which violate the rights and dignity of some members of a society, whether they are women, children, the disabled, irregular migrants or refugees, people discriminated due to their sexual orientation, persons in need of healthcare or any other group who suffers under the system which denies them equality, equity and humanity.

Moreover, the best measures which should be taken to promote the right to health do not really have a great deal of variation of implementation methods, but require specific targeted plans and activities. As commented on by the former Special Rapporteur on the Right to Health, Paul Hunt:

...progressive realization [of the right to health] does not mean that a State is free to adopt any measures that are broadly going in the right direction. States have a legal obligation to take "deliberate, concrete and targeted" steps towards the realization of the right to health for all... Health research and experience confirm that some measures work better than others. States are obliged to take those measures that are the best available to them [emphasis added]. ${ }^{272}$

Gunilla Backman et al (including Paul Hunt), in a 2008 study on the right to health features of national health systems (e.g. comprehensive national health plans), proposed 72 indicators that reflect some of these features, and assessed data for 194 countries with regard to these indicators, recommending that they be used for monitoring the progressive realization of the right to health. ${ }^{273}$ The overall approach of that study was that right to health features are central to the creation of equitable health systems, and not merely features of good management but legal obligations under international human

\footnotetext{
${ }^{271}$ Note that relativist arguments arise most often in the context of defending violations of the rights of women and children, who are vulnerable in patriarchal societies to genital mutilation, child marriage/rape, denial of reproductive health services etc. Can human rights be considered as culturally relative if human rights are based upon 'human-ness', which is the same everywhere regardless of culture? It is argued that right to health is not subject to a 'radical cultural relativism'. As defined by Donnelly, 'radical cultural relativism' posits culture as the sole source of morality of a right or rule. In contrast, a "weak cultural relativism' according to Donnelly, recognizes basic human rights as fundamentally universal, but with some cultural variations of methods of implementation (not rejection of the right itself) - See Donnelly, Jack, Cultural relativism and universal human rights, Human rights Quarterly, 6 (1984): 400, p400 and p419.

${ }^{272}$ UNGA, Human Rights Council, Implementation of General Assembly Resolution 60/251 Of 15 March 2006 , Report of the Special Rapporteur on the right of everyone to the enjoyment of the highest attainable standard of physical and mental health, Paul Hunt, A/HRC/4/28, 17 January 2007, para.66, citing CESCR, General Comment No. 3, para.2, and General Comment No. 14, para. 30.

273 Backman, Gunilla, et al., Health systems and the right to health: an assessment of 194 countries, The Lancet 372.9655 (2008): 2047-2085.
} 
rights. The question before us is: whether or not the GATS limits the ability of Members to give effect to the national policy choices to opt for the best measures which are targeted towards achieving something of value, such as public health services for attaining the right to health. It is relevant to note that such policy choices for right to health are supported by the framework of the rights and obligations States have under international human rights law and are thus not a limitation on sovereign policy-making giving effect to national values.

\title{
2.2.9. Is there space for a choice between conflicting values in the WTO?
}

\author{
Trade is not a value, it is only an instrument ${ }^{274}$
}

In the WTO, as in any other legal and political system, value choices are reflected in the legal order. ${ }^{275}$

Following from the issue of identifying values within societies, the next question is whether the WTO recognizes the role of values and values choices in the system. It seems that there is such recognition of the importance of values within the system:

Although far from being a perfect model, the WTO is nevertheless a laboratory for harnessing globalization and contributing to the construction of a system of global governance. A place where evolving global governance can find some roots in ensuring legitimate decisionmaking... A fora where values can be discussed, and this is crucial as trade restrictions will become more and more value-based. ${ }^{276}$

So, is the WTO merely a neutral place where values are discussed, or is it a place that values that do not fit into the system have to be justified? It is hard to be convinced that the WTO provides a value-neutral forum for discussion. It is true that values are mostly brought up in the context of trade restrictions which are based on certain societal values; but there is also a value system underlying the faith in what the WTO promises to deliver, that has been referred to as a 'trade bias' or 'embedded liberalism'. ${ }^{277}$ It seems that values can be of two classifications, even for trade experts - those values that underlie trade restrictions (some of which may be considered WTO-compatible) and those that underlie the 'trade bias/liberalization'. It can be argued that the WTO system is one that seeks to balance these two different, at times conflicting, values of national policy objectives which may lead to trade restriction and liberalization of trade - and that both values are part of the system itself. Others can argue that it is not an issue of a balancing scale, but a

\footnotetext{
${ }^{274}$ Pauwelyn, Joost, CONFLICT OF NORMS IN PUBLIC INTERNATIONAL LAW: HOW WTO LAW RELATES TO OTHER RULES OF INTERNATIONAL LAW, Cambridge University Press, 2003, p73.

275 Andenas, Mads and Stefan Zleptnig, Proportionality and Balancing in WTO Law: A Comparative Perspective, EAIEL Policy Paper No. 2, November 2006, p1.

${ }^{276}$ Lamy, P., The World Trade Organization: a Laboratory for Global Governance, The Malcolm Wiener Lecture, John F. Kennedy School of Government, Harvard University, $1^{\text {st }}$ November 2006, available online at http://www.wto.org/english/news_e/sppl_e/sppl47_e.htm, accessed 21.07.2011

277 See on Trade Bias, Guzman, Andrew T., Global Governance and the WTO UC Berkeley Public Law Research Paper No. 89, August 2002, available at ssrn.com/abstract=321365; Lang, Andrew T. F., Reconstructing Embedded Liberalism: John Gerard Ruggie and Constructivist Approaches to the Study of the International Trade Regime, Journal of International Economic Law, Vol. 9, No. 1, pp. 81-116, March 2006; See further Lang, Andrew T.F., WORLD TRADE LAW AFTER NEOLIBERALISM: REIMAGINING THE GLOBAL ECONOMIC ORDER, Oxford University Press, 2011, Chapter 7: Embedded Liberalism and Purposive Law.
} 
more complex interaction. Pauwelyn, for example, stresses that liberalization of trade is only an instrument and not a value in itself, unlike the protection of human rights and the environment, ${ }^{278}$ yet goes on to talk of WTO obligations giving States "an instrument to achieve certain other 'nobler' goals". ${ }^{279}$

The lack of clarity in trade-related academic and public discussions on these references to such 'nobler' goals of the WTO raises many doubts and questions. Although sustainable development is referred to in the first recital of the Preamble to the WTO Agreement, it has not been placed front and center in these discussions. Is there more to the WTO than neo-liberal economic policy - does it involve sustainable development in its most balanced and inclusive form? With the launch of the Doha Round negotiations, there has been a shift of emphasis in the language used, with greater acknowledgement of 'development' in general rather than the narrower stance more focused on antiprotectionism. ${ }^{280}$ With regard to the WTO, the values it purportedly and actually supports and promotes is an area of (often heated) debate. Some of these issues regarding language used in the WTO context will be analyzed further in the next part of this Chapter, Section 2.3 , but taking the problem one step at a time, it is necessary to first ask the following questions.

- Does the WTO system embody any values, and if so, what are these?

- Do the values embodied in the WTO system complement or clash with other values expressed by or within democratic nations that are Members, that make up the WTO system?

The next issue, which may be the most contentious one, is:

- Are there any other important values left outside of the WTO legal regime that need to be brought in?

This research was initiated with the intuitive view that there are values that seem to be left out, and that this matter needs to be further investigated. There may be some clearly marked entry points for social values such as the right to health to enter into the WTO system, but like Alice trying to get into the garden in Wonderland, WTO Members protecting a non-trade societal value may find themselves unable to find the key that opens the loophole or unable to fit through the small legal doorway. Like Alice, they need to be able to think ahead, get the key and make themselves the right fit, and do it in correct order. By assessing how a certain value can be brought into the WTO, specifically to the GATS, through the legal means of interpretation of the treaty, light may be shed on the mystery of these doors and keys.

\subsubsection{Values in the GATS: progressive liberalization, national policy and flexibility}

The GATS, as we know, is part of the WTO single undertaking. But unlike the WTO Agreement and the GATT 1994, the Preamble of the GATS specifically deals with the

\footnotetext{
${ }^{278}$ See e.g. Pauwelyn, Joost, CONFLICT OF NORMS IN PUBLIC INTERNATIONAL LAW: HOW WTO LAW RELATES TO OTHER RULES OF INTERNATIONAL LAW, Cambridge University Press, 2003, p73.

${ }^{279}$ Ibid, (Pauwelyn), p75.

${ }^{280}$ Note that 'protectionism' can cut in both ways. An analysis of the background of the EC-Asbestos dispute concluded that the actual protectionism (favouring of a domestic industry) was on the part of Canada, the complainant, and not France, the respondent (Howse, Robert and Elizabeth Tuerk, The WTO Impact on Internal Regulation - A case study of Canada-EC Asbestos Dispute in De Burca G., and J. Scott Eds., THE EU AND THE WTO: LEGAL, CONSTITUTIONAL ISSUES, Hart Publishing 2001, p291.
} 
possible clash of national policy with the objectives of the international trade system. There is a point of view that the reason that there is such a focus on policy flexibility in the GATS is because of the impression that services liberalization influences internal laws and regulation to a much greater extent than the multilateral Agreements on goods, and that therefore it is even more important to leave a larger policy space. It is also often commented that leaving market access and national treatment to be subject to the negotiation of commitments rather than as part of the general obligations of the GATS was a conscious result of the negotiators intent to make the GATS more palatable for countries with doubts as to the impact of trade rules on internal services policy and regulation. The reference to national policy objectives in the Preamble of the GATS can thus be seen as recognition of national sovereignty and respect for autonomy and policy space that is not expressed in the Preambles to the WTO Agreement and the GATT $1994 .^{281}$

The parts of the Preamble of the GATS, that describe the objectives of the agreement, which are relevant for this matter, are the expressions of:

Desiring the early achievement of progressively higher levels of liberalization of trade in services ... while giving due respect to national policy objectives;

...Recognizing the right of Members to regulate, and to introduce new regulations, on the supply of services within their territories in order to meet national policy objectives and...the particular need of developing countries to exercise this right

The terms 'national', 'policy' or 'national policy' are mentioned only in the Preamble and negotiation of specific commitments. The terms used in connection with national policy are 'due respect' and 'recognition of the right'. But do these particular mentions have the same legal force and effect as the references to 'progressive liberalization'? As progressive liberalization is the gradual extension of commitments by Members, there is also another reference to national policy in that section of the Agreement, under the heading of Part IV: Progressive Liberalization:

Article XIX(2): Negotiation of Specific Commitments:

The process of liberalization shall take place with due respect for national policy objectives and the level of development of individual Members, both overall and in individual sectors.

This goal of progressive liberalization is described in the Preamble of the GATS as part of the context and condition under which trade expansion is likely to occur:

Wishing to establish a multilateral framework of principles and rules for trade in services with a view to the expansion of such trade under conditions of transparency and progressive liberalization

\footnotetext{
${ }^{281}$ Hestermeyer, H., Preamble GATS in Wolfrum, Rudiger, Peter-Tobias Stoll and Clemens Feinaugle Eds., WTO - TRADE IN SERVICES, Max Planck Commentaries on World Trade Law, Martinus Nijhoff Publishers, 2008, p 26.

Note however that the SPS and TBT Agreements also affect internal policy and regulation by imposing international standards on such goods as are covered by these Agreements. The Preambles of both agreements as well as their provisions recognize the need for national policy measures and protection of national regulatory interests. However, since the GATT text (of 1948) already existed prior to the Final results of the Uruguay Round, national treatment and market access in goods was already covered for GATT 1994. In the case of the GATS, it was possible to negotiate the exclusion of national treatment and market access from the general obligations of the GATS.
} 
And furthermore, the basis upon which negotiations should be conducted under the GATS framework;

\section{Article XIX(1) of the GATS}

In pursuance of the objectives of this Agreement, Members shall enter into successive rounds of negotiations... with a view to achieving a progressively higher level of liberalization

Article XIX(4) of the GATS

The process of progressive liberalization shall be advanced in each such round through bilateral, plurilateral or multilateral negotiations directed towards increasing the general level of specific commitments undertaken by Members under this Agreement.

What does it mean for Members' national policy objectives, that they would be respected or given recognition in the process of liberalization? Do both of these ideas - the importance of liberalization of trade and the importance of national policy objectives, stand as equals and will they be balanced given equal weight? Or does national policy merely have the chance of getting taken into account (briefly considered whether it has any relevance) in a dispute, the substance of which is the failure to comply with an obligation that is part of the liberalization agenda?

Other than Article XIX(2), which is on negotiation of specific commitments, the reference in the Preamble is the only other reference to national policy objectives in the GATS. The Preamble by itself is not much of a 'leg to stand on' if one relies only on that in a dispute. The panels and Appellate Body have made clear that the objectives of a trade agreement according to preambular language cannot override the provisions of the agreement, and that measures promoting preambular objectives which are however incompatible with one or more provisions need to be justified under exceptions provisions. The WTO Appellate Body in EC-Tariff Preferences states:

We note...that WTO objectives may well be pursued through measures taken under provisions characterized as exceptions. The Preamble to the WTO Agreement identifies certain objectives that may be pursued by Members through measures that would have to be justified under the "General Exceptions" of Article XX [of the GATT 1994] ] $^{28}$

However, there has also been recognition that the Preamble of a WTO Agreement can play a role in balancing different interests. The Appellate Body in US-Clove Cigarettes used the Preamble of the TBT Agreement to interpret the non-discrimination obligation in

\footnotetext{
${ }^{282}$ Appellate Body Report, EC-Tariff Preferences, para.94 (agreeing with the Panel Report, para 7.52). Note that the Preamble to the 1971 Waiver Decision and the Preamble to the European Council Regulation (EC) No. 2501/2001 are cited in paras. 116 and 144 of the Appellate Body Report, but only for purposes of ascertaining the objectives of the Waiver and Regulation.

See also, the NAFTA Mexico Trucking dispute, where the Panel concluded that: ...language in the Preamble of NAFTA, which states that the Parties 'resolve to...preserve their flexibility to safeguard the public welfare' cannot be relied upon by the United States as an independent basis for failing to comply with its obligations under the various provisions found in the NAFTA text and Annex I. Under Article 31 of the Vienna Convention, as mentioned earlier, the preamble is part of the 'context' to be considered in interpreting the treaty. However, there is no suggestion in NAFTA that the preambular language was intended to override the textual obligations. Rather, the language used in the Preamble - 'resolve' rather than 'agree to', 'shall', or 'must'indicate that the Preamble is aspirational and hortatory [emphasis added].

- In the Matter of Cross-Border Trucking Services, Secretariat File No.USA-MEX-98-2008-01, para.277.
} 
Art 2.1 in manner that allowed for national regulation pursuing societal policy objectives, remarking on:

...the balance that the preamble of the TBT Agreement strikes between, on the one hand, the pursuit of trade liberalization and, on the other hand, Members' right to regulate... ${ }^{283}$

The Appellate Body adds further in the same paragraph that unlike the balancing in the GATT 1994, which is between national treatment in Article III and the general exceptions in Article XX,

....in the TBT Agreement, this balance is to be found in Article 2.1 itself, read in the light of its context and of its object and purpose.

As will be discussed further in Section 2.3 of this Chapter, Article 31 of the Vienna Convention on the Law of Treaties (VCLT), which relates that the interpretation of a provision, states that such interpretation should be with regard to the text, in its context and in the light of the object and purpose of the agreement. Therefore, interpretation is not a purely text-based exercise, but can take into account the societal policy being pursued, which underlies a legitimate regulatory distinction.

Furthermore, due respect for national policy plays a more important role in the negotiation and scheduling processes in the GATS, when Members wish to avoid making a commitment or to maintain limitations. It could be a diplomatic miss-step on the part of another Member to question limitations that are related to national policy objectives, if they do not want their own schedules and their own national policy objectives to be called into question outside of an actual dispute settlement proceeding. But perhaps this also depends on the ability of a Member to withstand influence or to be influenced by another Member who questions their choices. This matter will be looked into in more detail in Chapter 4, when discussing negotiation of commitments.

Other than the mentions of national policy objectives, the reference to the term 'flexibility' can also be a tool for maintaining policy space. However, despite the assertions of the GATS being the most flexible of WTO agreements and the view that flexibility can be seen as a key feature of the Agreement in so far as the variations in commitments concerning market access and national treatment undertaken by Members, the contexts in which the term flexibility is used does not seem to present this as a general principle of the GATS. 'Flexibility' is mentioned more times than national policy is, but only in the context of special consideration for developing country Members. Furthermore, except for the broader reference to 'appropriate flexibility' for developing country Members with regard to specific commitments, reference to specific instances of flexibility is in limited contexts of transparency, economic integration agreements and negotiations on subsidies.

The provision regarding the general obligation on transparency is Article II of the GATS. Article II:4 of the GATS, a provision including reference to flexibility, is not particularly significant as it only refers to the process of establishing enquiry points for information and states:

[A]ppropriate flexibility with respect to the time-limit within which such enquiry points are to be established may be agreed upon for individual developing country Members.

\footnotetext{
${ }^{283}$ Appellate Body Report, US-Clove Cigarettes, para. 109.
} 
The provision on negotiation of specific commitments, Article XIX:2 of the GATS, seems more significant as the flexibility is about something more important, namely the extent of a Member's national treatment and market access obligations for services, and is linked with the abovementioned 'due respect for national policy objectives and the level of development of individual Members'. However, this Article is contained in the section on progressive liberalization, as also pointed out earlier. The Article states:

There shall be appropriate flexibility for individual developing country Members for opening fewer sectors, liberalizing fewer types of transactions, progressively extending market access in line with their development situation and, when making access to their markets available to foreign service suppliers, attaching to such access conditions aimed at achieving the objectives referred to in Article IV [Increasing Participation by Developing Countries] [emphasis added].

The inclusion of the term 'appropriate' suggests at first glance that there could be a limitation on the exercise of flexibility - and that there could be something more than the Members own judgment involved in the choice if the matter comes before a panel or the Appellate Body in a dispute. However, it is difficult to imagine a dispute regarding only the negotiation process and lack of commitments, so it makes this provision seem more like an expression of a political or ideological stance, and not particularly credible as either an incentive or threat. There is no explicit obligation to make commitments in the GATS or other WTO Agreements, and therefore it is not possible that the slow rate of liberalization of a developing or least developed country will ever become the basis of an actual dispute. But it is possible that the pressure from trading partners to liberalize may have a greater effect on some governments, compared with adopting and maintaining a policy of retaining flexibility to liberalize fewer sectors and types of transactions.

Moreover, on second glance, the flexibility in Article XIX:2 with reference to delaying liberalization seems to be only to allow a slower speed and not for a pit-stop, as it also states that Members have the flexibility to progressively extend market access according to their development situation. On one hand, this seems to indicate an optimistic view of countries simultaneously developing and liberalizing, but on the other hand, practically speaking, it makes one wonder how the increased efficiency of the domestic service industry is to be achieved without a pit-stop, and how competitiveness in the race can be achieved at all. In the case of developing countries, achieving the Millennium Development Goals (and now the Sustainable Development Goals), raising their standards of health and living conditions for their entire population with a special focus on the disadvantaged, while simultaneously progressively liberalizing the health services sector for foreign suppliers, seems a daunting task and could be problematic in terms of cost of regulation and priorities in development policy. While raising standards of health can be achieved in the context of liberalization of trade in health services if the economy is already developed, income is high and there are less economic disparities, in cases of low income and when even basic primary healthcare is lacking, introduction of a 'forprofit' health market is less likely to be effective in raising general welfare and certainly less of a 'development priority'. This has led to the reality that developing countries have made very limited commitments under the GATS, especially in areas such as health; choosing to remain in the pit-stop instead of participating in the race for international trade in health services.

Article XIX can be read with Article IV of the GATS, which specifically refers to developing country Members. The usefulness of Article IV of the GATS for flexibility 
will be discussed in more detail in Chapter 6 of this study, but suffice to say at this point that Article IV:1 makes clear increased participation of developing countries "... shall be facilitated through negotiated specific commitments", with a number of market access measures to be offered by developed countries (access to technology, distribution channels, information sectors - and liberalization of sectors and modes of export interest to developing countries).

The next mention of flexibility in the GATS text is in the context of Article V of the GATS - Economic Integration Agreements. Article V:3(a) refers to situations

Where developing countries are parties to an agreement of the type referred to in paragraph 1 , flexibility shall be provided for regarding the conditions set out in paragraph 1, particularly with reference to subparagraph (b) thereof, in accordance with the level of development of the countries concerned, both overall and in individual sectors and subsectors [emphasis added].

Cottier and Molinuevo commenting on this provision, note the mandatory language that is used, ${ }^{284}$ which is stronger than other references to national policy or flexibility. According to the sub-paragraphs of Article $\mathrm{V}: 1$, several conditions including substantial sectoral coverage are required. The meaning of substantial sectoral coverage is explained in footnote 1 of the GATS as a condition

...understood in terms of number of sectors, volume of trade affected and modes of supply. In order to meet this condition, agreements should not provide for the a priori exclusion of any mode of supply.

So, this appears to rule out removal of, for example, the health services sector; whether taken as a whole, in terms of the economic importance of this sector in international trade or according to the separate sub-sectors relating to health in the services sectoral classification list. ${ }^{285}$ More detail on this classification system for the GATS will be discussed in Chapter 4 of this study in relation to scheduling. Cottier and Molinuevo note that the exclusion of major sectors of the (local or global) economy would not be compatible with the obligation of substantial sectoral coverage; but also refer to primary education and public health care as 'sensitive services'. ${ }^{286}$ In light of the current text, the authors do not go so far as suggesting that these sensitive areas are exempted under this provision, but this reference highlights the fact that public services are a matter of concern.

The other conditions in Article V of the GATS provide for the absence or elimination of substantially all discrimination, in the sense of Article XVII (national treatment), between or among the parties, in the sectors covered under subparagraph 3(a), except for measures permitted under Articles XI, XII, XIV and XIVbis. Article XI and XII deal with Payments and Transfers and Restrictions to Safeguard the Balance of Payments; Articles $\mathrm{XIV}$ and XIVbis are the general exception provisions, which can in any case, be used by a

\footnotetext{
${ }^{284}$ Cottier, Thomas and Martin Molinuevo, Article V GATS in Wolfrum, Rudiger, Peter-Tobias Stoll and Clemens Feinaugle Eds., WTO - TRADE IN SERVICES, Max Planck Commentaries on World Trade Law, Martinus Nijhoff Publishers, 2008, p141.

285 The GATS does not define 'service sector' - but Article 22.3(ii) of the Dispute Settlement Understanding defines sector according to the Services Sectoral Classification List, Note by the Secretariat, MTN.GNS/W/120, $10^{\text {th }}$ July 1991.

${ }^{286}$ Cottier T. and M. Molinuevo, Article V GATS in Wolfrum, Rudiger, Peter-Tobias Stoll and Clemens Feinaugle Eds., WTO - TRADE IN SERVICES, Max Planck Commentaries on World Trade Law, Martinus Nijhoff Publishers, 2008, p132.
} 
Member in any dispute that may arise concerning measures allegedly inconsistent with the GATS.

Article V:3(b) of the GATS, although it does not use the term flexibility, mentions the possibility to grant 'more favourable treatment' to 'juridical persons owned or controlled by natural persons of the parties' to an economic integration agreement between developing countries - notwithstanding the proviso in Paragraph 6 that it 'engages in substantive business operations in the territory of the parties to such agreement'. What is significant is of course, that these agreements, according to paragraph 1 aforementioned are deemed GATS-consistent because they must be agreements "liberalizing trade in services between or among the parties to such an agreement".

Thus, it seems possible to conclude that these provisions on economic integration agreements (EIA) are not primarily, flexibility provisions with regard to GATS obligations in general, but provisions that grant a limited exception to Article II of the GATS (MFN treatment) and which are designed to ensure that, while such agreements are possible, they should conform to other provisions of the WTO GATS, to the principle of progressive liberalization and do not leave out specific service sectors.

The next mention of flexibility is with regard to the negotiation of disciplines on services subsidies in Article XV:1 of the GATS, with particular reference to developing countries. This provision states that:

Such negotiations shall recognize the role of subsidies in relation to the development programmes of developing countries and take into account the needs of Members, particularly developing country Members, for flexibility in this area.

This provision is only a negotiating mandate and only requires that developing country Members' need for flexibility be 'taken into account' in negotiations. Thus, the impact of this provision on the actual service subsidies negotiations, if and when they begin in earnest, and the outcomes in terms of a final text on service subsidies remain to be seen. The issue of subsidies and their relation with public services will be discussed in further depth in Chapter Two of this study.

\subsubsection{Stories of Ships at Sea}

From the above brief discussion of the values of liberalization and national policy flexibility expressed in the GATS, it appears that there is recognition that there may be policies that conflict with the GATS liberalization ethos, which ought to be respected. But what does 'respect' for 'value $\mathrm{X}$ ' in the process of liberalization translate into in actual practice? Is there an actual possibility to choose a non-trade value over the trade values within this framework? There is a broad objective of trade liberalization in the GATS, and the system is designed for Members to undertake commitments for market access and national treatment, but it is also possible that no commitments are undertaken for the time being due to national policy. In situations where commitments have been undertaken, the GATS provides for exceptions for important instances when Members are justified, even according to trade law, in taking steps which conflict with their trade obligations. The flexibilities available in these instances need to be analyzed to see how effective they would be in real instances of need. As some of these instances, such as the obligation to progressively achieve economic and social rights e.g. the right to health, are backed by 
international law in addition to domestic law and values; it is also a question whether the non-trade values in the GATS can be given strength and support with reference to international law regimes outside of the WTO trade bubble. The WTO recognizes the existence of other values to some extent, but to what extent and would there be a hierarchy involved for a value that is more or less an outsider in the trade regime? This will be discussed in the next section in this Chapter.

This study is about a basic question of values and choice of values - what are the choices available to us, as citizens of WTO Members, and how free are we (or our governments on our behalf) to choose to follow the values that are important to our way of life? If there are conflicting values, how is the choice between them to be made? If one's view of law is that it is a system of constraints, whether for better or for worse, then this idea can be extended to the new international trade constitution. Two stories come to mind, that of Odysseus/Ulysses and that of Antigone, which highlight the matter of constraints and moral choice.

The metaphor of 'Ulysses tied to the mast' and resisting the lure of the sirens of special interests is often referred to in the trade law context. ${ }^{287}$ In the context of services, it is interesting that the Schedules of Specific Commitments use the terminology of 'unbound' to refer to lack of commitments to liberalize and 'binding' or being 'bound' is associated with accepting treaty obligations. Ulysses needs the constraints, as it keeps him from abandoning his obligation of guiding his sailors (whose ears have been plugged so as not to hear the sound of the sirens) and this prevents the ship from being led astray by the sirens and crashing the rocks. Ulysses (the WTO Member) is grateful for the bonds (WTO law) as it saves him from giving in to the sirens (special interests) that would have destroyed the ship (the national economy) due to protectionist policies (probably the rocks) and drowned the sailors (us, the citizens; some of us, the representatives of the citizens, the policy makers and decision makers - who need to have our ears closed too, so that we cannot be lured by the sirens and instead follow the instructions of the legally bound captain).

\footnotetext{
${ }^{287}$ One of the early references to the Ulysses metaphor in relation to trade is in Hauser, Heinz, Foreign Trade Policy and the Function of Rules for Trade Policy Making, in Detlev, Christian D. and Ernst-Ulrich Petersmann Eds., FOREIGN TRADE IN THE PRESENT AND THE NEW INTERNATIONAL ECONOMIC ORDER, Series: Progress and Undercurrents in Public International Law, Vol. 4, University of Fribourg Press, 1988 p18 at p32.

But in the comparative constitutions field, there was a previous publication: Elster, Jon, ULYSSES AND THE SIRENS: STUDIES IN RATIONALITY AND IRRATIONALITY, Cambridge University Press, 1979; recently followed up in Elster, Jon, ULYSSES UNBOUND: STUDIES IN RATIONALITY, PRECOMMITMENT, AND CONSTRAINTS, Cambridge Univ. Press, 2000.

Ernst-Ulrich Petersmann uses the story to comment that:

Governments know very well...that by 'tying their hands to the mast' (like Ulysses when he approached the island of the Sirens), reciprocal international pre-commitments help them to resist the siren-like temptations from 'rent-seeking' interest groups at home.

(Petersmann, E-U., The GATT/WTO Dispute Settlement System: International Law, International Organizations and Dispute Settlement, Kluwer Law International, 1997, p36-37 cited in Van den Bossche, Peter, THE LAW AND POLICY OF THE WORLD TRADE ORGANIZATION: TEXT, CASES AND MATERIALS, Cambridge University Press, Second Edition, 2008, p33)

Rudolf Adlung also uses the term 'Ulysses effect' for the "gains in transparency, stability and predictability" that Members get in exchange for "relinquishing some 'policy space', and the related scope for satisfying protection-seekers" (Adlung, R., Services Liberalization from a WTO/GATS Perspective: In Search of Volunteers, WTO Staff Working Papers, Economic Research and Statistics Division, ERSD2009-05, February 2009, p1).
} 
This is an interesting metaphor, perhaps even ironic, as it underestimates, ignores or misinterprets the influence of private stakeholders in both the creation of WTO law and as originators of WTO disputes. It can also be argued, contra to the position that the WTO rules free governments from political pressure of interest groups, ${ }^{288}$ that, as it is interest groups that often frame the rules in the first place, it only frees governments from political pressures of the democratic voter base. Even if some could categorize the voters themselves as a type of 'special interest group' or sirens instead of being the sailors, it cannot be ignored that a democratic government exists to protect the interests of this group as a whole, and not to serve specific corporate interests over public interest. If this basis for government is criticized as narrowly nationalistic, in comparison to the benefits of global trade, it can also be argued that there are many instances where specific corporate interests run counter to global public interest (the concerns of the public across different nations) which governments have promised to protect, such as climate change mitigation, environmental protection, labour rights and human rights concerns.

Many WTO disputes are not 'Member driven' in the manner that is assumed, but are drafted by private law firms (sometimes by individual lawyers who were former WTO negotiators or consultants) on behalf of private corporations and passed on to governments. ${ }^{289}$ Although only governments have formal access to WTO dispute settlement, private parties, particularly multinational companies, can 'shop for governments' and for legal firms in various countries, to bring cases when they and the government have complementary interests. An example for this is the challenge against Australia's labeling law on cigarette packages (Australia-Plain Packaging), where US And European tobacco companies funded law firms in Cuba, Dominican, Republic, Honduras, Indonesia, and Ukraine - and their interests coincided with the State's economic interests, particularly the Dominican Republic, Cuba, and Indonesia, who have their own significant tobacco exports. While such private parties are involved in the initiation of specific disputes, elected politicians in the WTO Member government must make the decision on whether proceedings are initiated. Sometimes these disputes are only backed by powerful individual politicians in relation to their private interests and not necessarily by political parties after broad internal agreement on its public interest value. Therefore, Members could be led at times to act against even their own governmental or public interest. At other times where action is needed, it is possible that Members cannot obtain high quality legal advice as corporations already have hired the major firms which have the necessary expertise, to represent their interests. ${ }^{290}$

An extremely useful and interesting project would be to trace the no doubt significant role and influence of these private interests behind WTO negotiations and disputes. The $E C$ Bananas disputes and the 'large civil aircraft disputes' (EC-Measures Affecting Trade in Large Civil Aircraft and US-Measures Affecting Trade in Large Civil Aircraft) often referred to in the media as 'Boeing vs Airbus' are well known examples. As Shaffer et al comment, the United States was the lead complainant in EC-Bananas even though it did not export bananas because Chiquita, an American multinational, had investments in

\footnotetext{
${ }^{288}$ See e.g. Maggi, G. and A. Rodriguez-Clare, The Value of Trade Agreements in the Presence of Political Pressures, Journal of Political Economy, 106(3), 1998, 547-601.

${ }^{289}$ Observations of a lawyer in a major international law firm, in private conversation with the author, Maastricht 13 October 2009.

${ }^{290}$ Ibid., this lawyer further commented that the serious ethical issues which trade lawyers had to face while working in such legal firms had led to a number of resignations and efforts to work pro bono for public interest on some of these matters (which included health-related issues and rights).
} 
Latin America, and had hired their own lawyers to develop the factual and legal arguments. ${ }^{291}$ Shaffer et al also comment on the interest shown by the legal profession to prepare briefs for private clients to influence governments to consider filing cases.

The real landscape behind this fog of 'special interest' theory - or if sticking to the metaphor, the seascape - is far more complicated than a simplistic 'protectionism is bad, trade rules are good' story. There could even be 'lighthouses' representing important social values which are necessary for economic, social and cultural development, that are mistakenly identified as sirens.

Another problem with the metaphor is being tied to the mast, which creates the idea of a fixed point of agreement that is unquestionably good. There are two issues here, one is whether such a fixed point today will be acceptable tomorrow, and the other issue is to what extent the texts we are dealing with in the WTO context reflect actual points of agreement, particularly in the case of the ambiguities of the GATS and the supposed room for flexibility. And just as an aside, being tied with ropes to this fictional point of agreement (even assuming that it is self-inflicted and for one's own safety) does not create a comfortable mental image, as it recalls the image of a psychiatric patient in a strait jacket, and not of a rational decision-maker. An alternative way of looking at the mast, that does not create an uncomfortable mental image, is to remember that the ship itself is in motion, and that if the mast is the language of the texts, the context in which the words are interpreted and applied changes and progresses, and so can the interpretation of the rules.

However, it is not only trade law that is a system of constraints, some aspects of human rights-related law are also about binding governmental power and preventing 'wrong choices' once it has been decided that a certain direction is the wrong direction to lead the ship of state. Constitutions set limits and bind future generations of a State to a broadly described course of action that is pre-judged as the best course. Some will ask whether this is foolishly agreeing to be bound to a particular set of words, even when there is no clear agreement what these words may mean in practice and if they will continue to be acceptable in terms of evolving society. Waluchow, commenting on constitutional rights (human rights), refers to the Ulysses metaphor as an appealing one for proponents of constitutional Charters or Bills of Rights. Waluchow also adds the counter-argument that proponents of such a 'binding' must face - that it can be said that:

Only an idiot would think we can intelligibly pre-commit to limits upon which we cannot agree in advance... We will be led to ask why the people now should be hamstrung in their pursuit of sound, morally responsible public policy by decisions made earlier... ${ }^{292}$

But Waluchow disagrees with the assumption that Charters aspire to embody fixed points of agreement and pre-commitment, and brings in the metaphor of a 'living tree' used in Canadian constitutional jurisprudence to counter the metaphor of the 'mast' to which

\footnotetext{
291 Shaffer, Gregory, Manfred Elsig and Sergio Puig, The Extensive (but Fragile) Authority of the WTO Appellate Body, Law and Contemporary Problems, Vol. 79:237, No. 1 2016, p250-251.

${ }^{292}$ Waluchow, Wil Constitutions as Living Trees: An Idiot Defends in Dyzenhaus David, Sophia Reibetanz Moreau and Arthur Ripstein Eds., LAW AND MORALITY: READINGS IN LEGAL PHILOSOPHY University of Toronto Press, $3^{\text {rd }}$ Edition, 2007, p549-550; also published as Waluchow, Wil, Constitutions as Living Trees: An Idiot Defends 2005, 18 Canadian Journal of Law and Jurisprudence, 207. Waluchow is here referring to the position of Jeremy Waldron in two books, THE DIGNITY OF LEGISLATION and LAW AND DISAGREEMENT, to which his article is a response.
} 
Ulysses is bound. This discussion can be drawn upon for the interesting comparison that can be made about approaches in constitutional interpretation that are verbally rigid and obsessed with formulas and semantics (e.g. United States) and a less verbally constrained common law approach to interpretation. ${ }^{293}$

The approach to interpretation of the text of the agreements in the WTO system will be discussed in further detail in a following section of this Chapter, but it is interesting to keep in mind to what extent the WTO will be rigid and unyielding to evolving values in society that ought to be taken into account, yet are not referred to in the text. Are the texts of the WTO system a tree with the ability to grow stronger - or has the system left out some important supporting moral roots? If it is assumed that certain moral roots are lacking in the system, then can a support post be provided by recognizing alternative values or parallel regimes in international law and even by bringing them in through interpretation of the exemptions or exceptions available in the texts? A step such as introducing human rights such as the right to health to support interpretation of certain GATS provisions could be considered too radical at the present time. However, it should be noted that the Appellate Body in Japan-Alcoholic Beverages II held that while the provisions of the covered agreements are meant to be reliable and achieve predictability:

WTO rules are not so rigid or so inflexible as not to leave room for reasoned judgements in confronting the endless and ever-changing ebb and flow of real facts in real cases in the real world. They will serve the multilateral trading system best if they are interpreted with that in mind. ${ }^{294}$

It can be said that it is not necessarily the rules that are inflexible, but that interpreters must leave room in their minds and their decisions, for the complexities of the real world. There is more than the mast and the sirens, there is the sea - and the imagery of the sea is recalled in the words of "endless and ever-changing ebb and flow" in the Appellate Body report in Japan-Alcoholic Beverages II. There is also the destination, where does this ship wish to journey to, and how should this journey be accomplished?

The Ulysses as referred to in the WTO context, is a heroic tale without nuances, but this may not reflect the original story, where Ulysses, the Sirens, and their relationship have been presented as more complex by both ancient and modern philosophers - including as the rejection of knowledge that distracts from goals that have been pre-determined. ${ }^{295}$ The story of Antigone moves beyond the simpler version of the Ulysses story of fear, selfprotection and 'good-vs.-evil' - and addresses the grey area of a clash of values and the call to higher norms. Hegel has described Antigone as the model for (Greek) tragedy: a conflict of two opposing principles, rights or values, both of which are valid, both of which pursue a legitimate end, but at the same time infringe upon the 'legitimate ethical

${ }^{293}$ Ibid, (Waluchow in Dyzenhaus et al, Eds., 2007), p548. In conclusion, Waluchow says:

If we reject the view of Charters as confident, hubristic attempts to establish (illusory) fixed points of agreement and pre-commitment, and view them instead as the living trees whose roots are fixed (by precedent and the terms chosen to express the Charter's moral commitments) but whose branches can develop over time through a developing common law jurisprudence of moral rights, we stand a better chance of satisfying both of Hart's two fundamental needs, and of reconciling Charters with our self-image as selfgoverning, autonomous rights holders who, alas, don't have all the answers.

See further, Waluchow, Wil, A COMMON LAW THEORY OF JUDICIAL REVIEW: THE LIVING TREE, Cambridge University Press, 2007.

${ }^{294}$ Appellate Body report, Japan-Alcoholic Beverages II, 1996, p. 122-3.

${ }^{295}$ Montiglio, Silvia, FROM VILLAIN TO HERO: ODYSSEUS IN ANCIENT THOUGHT, University of Michigan Press, 2011, especially p132-138, 145-146, 88-89. 
power' of the other and thereby violate what each ought to honor. ${ }^{296}$ Of course it is also commented - as it is in the WTO and 'other values' context - that in contrast to Hegel's view, 'the tragic collision' between values is not necessarily always between equally justified values, but that both values can be justified. ${ }^{297}$ Helpfully for the continuation of the previous metaphor in the context of Antigone, although the actual action takes place on land, one of our protagonists also uses a nautical metaphor. Creon, just before ordering that the body of his nephew remain unburied for his crimes against the State, says:

... I know well

our country is a ship which keeps us safe,

and only when it sails its proper course

do we make friends. These are the principles

I'll use in order to protect our state. ${ }^{298}$

This recalls the positive view of the WTO system, as a system of rules that create conditions for stability and mutually beneficial trade between Members. Nussbaum, analyzing the drama, says that Creon has "made himself a deliberative world into which tragedy cannot enter" and apparently has achieved stability: it is his tragedy that he cannot see that the world is more complicated, that justice also lies outside of his straight and narrow conception and that the ship is after all, only a tool, for the benefit of the sailors. ${ }^{299}$

Upon considering the moral objections to Creon's application of law, Antigone, in defying his order, says as many human rights or environmental activists may say with reference to higher universal norms and natural law that could protect interests of individual persons or the eco-system, ${ }^{300}$ that

...I did not think

anything which you proclaimed strong enough

to let a mortal override the gods

and their unwritten and unchanging laws. ${ }^{301}$

The clash of these values and the inability for either party to compromise ends in heartbreak and/or death for everyone involved in this story. ${ }^{302}$ It is a very different ending

296 Williams, Robert R., TRAGEDY, RECOGNITION AND THE DEATH OF GOD: STUDIES IN HEGEL AND NIETZSCHE, Oxford University Press, 2012, p135-136, p138; Kaufman, Walter Arnold, TRAGEDY AND PHILOSOPHY, Princeton University Press 1979, reprinted in 1992, p201-202; Houlgate, Stephen, HEGEL, NIETSCHE AND THE CRITICISM OF METAPHYSICS, Cambridge University Press, 2004, p198-199; Cascardi, Anthony J., Chapter 5: Values, Contingencies, Conflicts in THE CAMBRIDGE INTRODUCTION TO LITERATURE AND PHILOSOPHY, Cambridge University Press, 2014, p71.

${ }^{297}$ Ibid., Kaufman, p280 and Williams p135.

298 Johnston, Ian C, SOPHOCLES' ANTIGONE, Richer Resources Publications, 2007.

${ }^{299}$ Nussbaum, Martha C., Sophocles; Antigone: Conflict, Vision and Simplification IN THE FRAGILITY OF GOODNESS: LUCK AND ETHICS IN GREEK TRAGEDY AND PHILOSOPHY, Revised Edition, Cambridge University Press, 2001, p58-60.

${ }^{300}$ See e.g. reference to the Antigone analogy relating to health rights, Annas, George, J., Human Rights and Health: The Universal Declaration of Human Rights at 50 in Gruskin, Sofia, Michale A. Grodin, George J. Annas and Stephen P. Marks (Eds.) PERSEPCTIVES OF HEALTH AND HUMAN RIGHTS, Routledge, 2005 at p63-64.

${ }^{301}$ Johnston, Ian C, SOPHOCLES’ ANTIGONE, Richer Resources Publications, 2007.

${ }^{302}$ As noted by Del Mar:

Neither Creon nor Antigone are capable of seeing the limitations of the rules they feel

bound to follow ... Both Creon and Antigone, then, are victims of excessive rulefollowing; of an inability to step outside their rule-defined roles...

(Del Mar, Maksymilian T. and Oche Onazi, The Moral Quality of Work in International Economic Institutions: Resisting Complacency, International Journal of Law in Context, Vol. 4, No 4, 2008, 337-377, p353) 
from that of Ulysses and his companions in that chapter of their journey; and this difference can be said to underline the importance of narrative perspective. ${ }^{303}$ With regard to the WTO, some see themselves in the context of players in a brave adventure and others see themselves being drawn into an inevitable tragedy. Both of these versions are sincere and there may be other perspectives also.

But one thing that the proponents of the acknowledgement of diverse narratives would hope to achieve is to morally improve the law and advance the interests of subordinated groups, whose version of the story is often not the one that is privileged in legal discourse. ${ }^{304}$ Benvenisti, in criticizing the manner in which the consensus doctrine and the margin of appreciation doctrine are coupled in the jurisprudence of the European Court of Human Rights (ECHR) to the detriment of "minority values", also uses a nautical metaphor with regard to the trust expected towards the judges who have created these doctrines, that:

...the judges are portrayed as holding firm the compass of morality, guiding the communal ship towards more enlightened standards, yet taking into account the prevailing wind and sea conditions. ${ }^{305}$

Yet, he argues that although the ECHR method is portrayed as a

...sophisticated mechanism to prod nations to update their policies gradually to emerging new standards while still respecting their domestic processes $^{306}$...the doctrines are harmful from both theoretical and practical perspectives, in that this judicial policy cannot be said to promote human rights, especially those of minority or subordinate groups. ${ }^{307}$

It is possible that a similar conclusion could be reached in looking at the sophisticated processes and power imbalances of the WTO system.

Alternatively, it can be wondered whether there is a balance that is expressed in the GATS, a new story that does not go to either extreme of stifling mutually beneficial international trade or of preventing progressive social policies that raise the standards and quality of life for ordinary people. If thinking optimistically, it could be asked - how can a balance be achieved between the obligation to progressively liberalize services and the protection of national policy concerns within the framework of the GATS? Some doubt that a balancing process can happen within the WTO; for example, Fred L. Morrison comments that:

The WTO is not a neutral entity in which to balance the claims of economic efficiency against those of moral imperative, because it knows only the imperative of economics. ${ }^{308}$

\footnotetext{
${ }^{303}$ See e.g. Delgado, Richard, Storytelling for Oppositionists and Others: A Plea for Narrative, Michigan Law Review, Vol. 87, No. 8, Legal Storytelling, August 1989, p2411.

${ }^{304}$ Binder, Guyora and Robert Weisberg, LITERARY CRITICISMS OF LAW, Chapter Three: Narrative Criticism of Law, Princeton University Press, 2000, p201: referring to Delgado (Ibid), the symposium on 'Legal Storytelling' at the University of Michigan and the recurring claims in narrative legal scholarship.

305 Benvenisti, Eyal, Margin of Appreciation, Consensus and Universal Standards, International Law and Politics, Vol.31, 1999,843, p852.

${ }^{306}$ Ibid., p851-852.

${ }^{307}$ Ibid., p851-853.

${ }^{308}$ Morrison, Fred L., Its Elementary, My Dear Abbot, in Kennedy, Daniel L. M. and Southwick, James D.,THE POLITICAL ECONOMY OF INTERNATIONAL TRADE LAW, Cambridge University Press, 2002.
} 
While agreeing that the WTO is not a neutral entity, it is still possible to cast the problem in a less polarizing manner. Chimni, in the context of asking whether there should be attempts to realize non-trade values through the instrument of trade says that:

...often a false opposition is set up between the defenders and critics of

free trade [italics in original] ${ }^{309}$

It is true that there can be a positive role for trade in promoting development, rights, the environment and progressive social values - it is just that the rules are not specifically designed or applied for that end. It is not entirely impossible to conceive of wresting the interpretation of the rules away from narrow ends to apply them to broader goals of development or to achieve a balance. Chimni does not refer to finding a balance in the WTO (in the text or structures of the institution), but draws attention to what he identifies as the 'real issues': the historic role of free trade in economic development (used after protectionist policies assisted domestic industries to prosper), the selective adherence to free trade norms (promoted only when it suits the powerful classes and resisted otherwise e.g. agriculture subsidies) and the inattention to differences in levels of development. ${ }^{310}$ In agreeing with Chimni, it can be said that it is therefore not helpful to identify the existing debates as pro-WTO and anti-WTO; but that it can be recognized that there is $a$ misconstruction in trade law on identifying tools and goals. Can there be a different story of communication and conflict resolution - one that replaces the flaws in both the Ulysses and Creon/Antigone stories? Perhaps that is for us - citizens, scholars, lawmakers, policy makers and interpreters - to find out and to write - and perhaps it will be a re-discovery rather than a discovery, of co-operation.

${ }^{309}$ Chimni, Bhupinder, WTO, Democracy and Development: A View from the South in Lee, Yong-Shik Ed., ECONOMIC DEVELOPMENT THROUGH WORLD TRADE: A DEVELOPING WORLD PERSPECTIVE, Kluwer Law International, 2008, p75.

${ }^{310}$ Ibid., (Chimni), p74-75. 


\subsection{OVERVIEW OF METHODOLOGY AND OBSERVATIONS ON POSSIBLE LIMITATIONS}

\subsubsection{The WTO Dispute Settlement Understanding (DSU) and the Vienna Convention on the Law of Treaties (VCLT)}

The focus of this study is identifying the scope for national policy space and flexibility in specific provisions of the GATS. For this purpose, the main method is treaty interpretation relying on the rules of the Vienna Convention on the Law of Treaties (VCLT), 1969. ${ }^{311}$ This is in line with the approach taken by WTO dispute settlement bodies, which is to interpret the text by following the guidelines of the WTO Dispute Settlement Understanding (DSU) and the Vienna Convention on the Law of Treaties (VCLT). The relevant articles are as follows:

\section{Article 3.2 of the WTO DSU:}

The dispute settlement system of the WTO is a central element in providing security and predictability to the multilateral trading system. The Members recognize that it serves to preserve the rights and obligations of Members under the covered agreements, and to clarify the existing provisions of those agreements in accordance with customary rules of interpretation of public international law. Recommendations and rulings of the DSB cannot add to or diminish the rights and obligations provided in the covered agreements.

\section{Article 31 of the VCLT: The General Rule of Interpretation of the VCLT}

1. A treaty shall be interpreted in good faith in accordance with the ordinary meaning to be given to the terms of the treaty in their context and in the light of its object and purpose.

2. The context for the purpose of the interpretation of a treaty shall comprise, in addition to the text, including its Preamble and annexes:

(a) any agreement relating to the treaty which was made between all the parties in connexion with the conclusion of the treaty;

(b) any instrument which was made by one or more parties in connexion with the conclusion of the treaty and accepted by the other parties as an instrument related to the treaty.

3. There shall be taken into account, together with the context:

(a) any subsequent agreement between the parties regarding the interpretation of the treaty or the application of its provisions;

(b) any subsequent practice in the application of the treaty which establishes the agreement of the parties regarding its interpretation;

(c) any relevant rules of international law applicable in the relations between the parties.

4. A special meaning shall be given to a term if it is established that the parties so intended.

${ }^{311}$ Done at Vienna on 23 May 1969 and entered into force on 27 January 1980. 


\section{Article 32 of the VCLT: Supplementary means of interpretation}

Recourse may be had to supplementary means of interpretation, including the preparatory work of the treaty and the circumstances of its conclusion, in order to confirm the meaning resulting from the application of article 31 , or to determine the meaning when the interpretation according to article 31:

(a) leaves the meaning ambiguous or obscure; or

(b) leads to a result which is manifestly absurd or unreasonable.

With regard to customary rules of interpretation of public international law' in Article 3.2 of the DSU, it has been recognized by the Appellate Body on US-Gasoline that Article 31, the "general rule of interpretation" of the Vienna Convention on the Law of Treaties has attained customary international law status ${ }^{312}$. In Japan-Alcoholic Beverages II, the Appellate Body also observes that Article 32 of the VCLT, on supplementary means of interpretation, has also achieved the same status. ${ }^{313}$ In this the WTO system is in line with the views of the International Court of Justice, which has stated that certain provisions of the VCLT are declaratory of pre-existing customary international law and that the drafting process of other provisions helped develop and codify customary international law. ${ }^{314}$

This interpretive path of relying on the VCLT has been established early on and met with approval from WTO Members and experts alike ${ }^{315}$ and can be said to have added to the

312 Appellate Body Report, US-Gasoline, para.15-17. It is at this point that the Appellate Body adds that objections concerning the use of the Vienna Convention rules of interpretation - such as the fact that some WTO members are not parties to the Vienna Convention - are overruled by the customary international law status of Article 31. Furthermore, even the United States, which is not party to the Vienna Convention, has invoked the rules of interpretation e.g. Panel Report, US-Underwear, para. 5.185.

The text of the VCLT is based on draft articles prepared by the ILC during 1949-1966 under the eminent international legal scholars James Brierly, Hersch Lauterpacht, Gerald Fitzmaurice and Humphrey Waldock (special rapporteurs). The United Nations Conference on the Law of Treaties is described by the UN legal information website as:

...the last great codification conference that successfully used voting as its working method and could adopt the draft articles by substantial majorities.

(available online at http://legal.un.org/avl/ha/vclt/vclt.html, last accessed 29.01.2014).

The voting on the final text of the VCLT was 79-1, with 19 abstentions and as of 2013 there are 113 Parties and 45 Signatories. This lends credence to the view that the VCLT is overall a treaty where few Articles are still argued as controversial or contested. However, it should be noted that not all provisions of the Vienna Convention have attained customary status.

313 Appellate Body Report, Japan-Alcoholic Beverages II, p.104.

314 The customary status of VCLT Articles have been discussed in the ICJ cases of Territorial Dispute Case (Libyan Arab Jamahiriya v Chad) 1994 ICJ Reports 6, at paras.38-51; Maritime Delimitation and Territorial Questions between Qatar and Bahrain (Jurisdiction and Admissibility) 2001 ICJ 6, paras.24-42 (note the dissenting opinion of Vice-President Schwebel). Also see the Gabcikovo-Nagymaros (Hungary $v$ Slovakia) 1997 ICJ at para.46:

The Court has no need to dwell upon the question of the applicability in the present case of the [VCLT 1969]. It needs only to be mindful of the fact that it has several times had occasion to hold that some of the rules laid down in the Convention might be considered as a codification of existing customary law...

The ICJ in the Arbitral Award of 31 July 1989 (Guinea-Bissau v. Senegal), 1991 I.C.J., 53, para.48, has also stated:

...Articles 31 and 32 of the Vienna Convention on the Law of Treaties...may in many respects be considered as a codification of existing customary international law...

${ }^{315}$ See further, Ehlermann, C-D., Six Years on the Bench of the "World Trade Court", in Ortino, Federico and Ernst-Ulrich Petersmann, Eds. THE WTO DISPUTE SETTLEMENT SYSTEM 1995-2003, Kluwer Law International, 2004, p449-529. 
'security and predictability' 316 of the multilateral trading system as envisioned in Article 3.2 of the DSU. It is interesting that commentators point out that this departs from the earlier approach under the GATT 1947, which had a less legalistic, less 'judicial' process, ${ }^{317}$ but also had the requirement of mutually acceptable outcomes, which has been described as a looser approach dominated by the search for general consensus among the 'trade policy elite'. 318

But, in the context of this study, it can be argued that this VCLT methodology can be relied on only partially, due to the following issue that ought to be given special consideration. This is that the VCLT method is satisfactory for the interpretation of the final text of agreement that specifies the existing substantive rights and obligations as well as their exemptions or exceptions - however, in the GATS, there are also provisions on the negotiations of commitments, provisions that are only mandates for further negotiations on certain subjects, or are provisions whose interpretation will be influenced by the aforementioned negotiations. The GATS is in this way a work in progress, an agreement that is still in the process of forming. This makes it different from the GATT 1947 being made into GATT 1994 and becoming one of the covered agreements of the WTO, because the changes the GATS will bring to the law on international trade in services are not yet fully clear. Thus, interpretation with regard to GATS disputes would be conducted in the context of ongoing negotiations concerning new commitments for market access and national treatment and possible draft texts for areas where consensus could not be reached during the Uruguay Round and which remained as negotiating mandates in the GATS text. Although this context is unlikely to affect the interpretation of the currently available texts (GATS provisions, Schedules of Commitments, Annexes) by the panels and Appellate Body in a dispute, it would be interesting to be able to ascertain whether or not such interpretations could have an impact on the ongoing negotiations of commitments and new texts.

The provisions on negotiating commitments abovementioned are: Article XIX on the negotiations of specific commitments, Article XX on the scheduling of specific commitments and Article XVIII on additional commitments. The provisions that are negotiating mandates are: Article $\mathrm{X}$ on emergency safeguard measures, Article XV on subsidies and Article XIII on government procurement. Thus, taking the 'unfinished business' and the power imbalances between negotiating Members into account, the ability of a Member without much influence to participate in determining the scope of coverage of the GATS in these areas - and the actual policy space it can reserve to itself may be less than what is apparent. ${ }^{319}$ For example, there are terms and phrases whose

\footnotetext{
${ }^{316}$ This aspect was stressed upon by the Panel in US-Section 301 Trade Act, para.7.75:

Providing security and predictability to the multilateral trading system is another central object and purpose of the system...the DSU is one of the most important instruments [to carry out this object and purpose].

317 The basis for dispute settlement in the GATT 1947 is Article XXII (Consultation) and Article XXIII (nullification or impairment), which refer the matter to the CONTRACTING PARTIES (GATT) for settlement.

${ }^{318}$ Howse, Robert., Adjudicative Legitimacy and Treaty Interpretation in International Trade Law: The Early Years of WTO Jurisprudence, in Weiler, Joseph H. H. Ed, THE EU, THE WTO, AND THE NAFTA: TOWARDS A COMMON LAW OF INTERNATIONAL TRADE?, Oxford University Press, 2000, at p57-58.

319 Note however, that even if the scope of GATS coverage and the issues currently under negotiation are clarified in a manner restrictive of national policy space - and relevant commitments undertaken, if any - the exceptions provided for in Article XIV and Article XIVbis of the GATS will be available to defend a challenged measure.
} 
interpretation and application can be influenced by the results of subsequent negotiations, such as 'services supplied in the exercise of governmental authority' in Article I (scope). This can also be influenced by the negotiations on service subsidies and government procurement. This is because the interpretation of 'services in the exercise of governmental authority' depends on the definition of 'commercial' and 'competition' according to Article I:3(b) of the GATS, and although this has not been done yet in the Article I context, whether and if so, how, the concepts of public services, commercial service delivery and competition are dealt with in the context of subsidies and government procurement can have an impact on the exemption in Article I. This issue is discussed in more depth further in Chapter Two of this study. Furthermore, there are additional annexes to the final text, on specific service sectors and the possibility of further future annexes, that may indeed have an effect on the original text.

John H. Jackson refers to the concept of 'rule orientation' - a system of rules (including a dispute settlement process) that yet retains a fluidity that accords with practical realities and the bargaining and negotiation that is accommodated in the WTO system. ${ }^{320} \mathrm{He}$ contrasts this with 'power orientation' of diplomatic negotiations outside of a rule structure such as the WTO. Can this rule-oriented WTO system be seen as a one that adjusts the power imbalances to also benefit weaker Members? Or is it merely one that just misleads the Members as to the realities of the power orientation or postpones it temporarily, giving an impression of greater equality at the outset, but having the same result? Jackson, in adding up the advantages of a more evolved rule-oriented approach versus a power-oriented approach, refers to the:

...fairer treatment of the smaller countries, or at least a perception of greater fairness [emphasis added]. ${ }^{321}$

Matthew Dunne, analyzing Jackson's rule-power paradigm, stresses that the international trade system cannot be characterized as one where there are level playing fields and where asymmetries of power can be largely ignored - instead, it is suggested that while power-oriented negotiations are primary, "rule-oriented regimes provide the yardsticks by which behaviour is measured". ${ }^{322}$

There is nothing objectionable about a rule-oriented regime if it takes fairness into account in the substance, interpretation and applications of the rules. This brings us to the significant shift of power to the hands of the interpreters in a rule-oriented regime and the focus of this thesis. Yet meanwhile, there remains a need to take into account the realities of international power imbalances in the context of WTO negotiations of unfinished areas and of specific commitments - and of who can make use of these negotiations to protect their national policy interests and to what extent. Although this is a legal study, it is important that legal scholars be able to lift their heads from the text and take into account the limitations of an approach emphasizing the text to the exclusion of the realities of international relations, internal politics, the power of large corporations and enterprises

\footnotetext{
320 Jackson, John H., SOVEREIGNTY, THE WTO AND CHANGING FUNDAMENTALS OF INTERNATIONAL LAW, Cambridge University Press, 2006, p89

${ }^{321}$ Jackson, John H., Perspectives on the Jurisprudence of International Trade: Costs and Benefits of Legal Procedures in the United States, 82 Michigan Law Review, 1984, 1570, p1571.

${ }^{322}$ Dunne, Matthew, S. III, Redefining Power Orientation: A Reassessment of Jackson's Paradigm in Light of Asymmetries of Power, Negotiation, and Compliance in the GATT/WTO Dispute Settlement System, Law and Policy in 34 International Business, 2002-2003, 277, p342. See also Howse, R., The House That Jackson Built: Restructuring the GATT System, Michigan Journal of International Law, 1999, Vol. 20 p107, for an analysis of Jackson, John H., RESTRUCTURING THE GATT SYSTEM, Royal Institute of International Affairs, 1990.
} 
and even the significance of individuals and organizations who can shape international trade law.

The methodology for answering the research question therefore includes interpretation of the text, but also takes into account the limitations of this approach, as abovementioned. The main guidelines for interpretation of the GATS will be the WTO DSU and the VCLT, but the key issues discussed in the following section of this chapter are the identification of the specific tools which are available for interpretation and their application in the context of the wider debates. Firstly, the more technical aspects of the law of treaty interpretation will be discussed and then this will be placed in the larger picture of the place of WTO law within the context of public international law and the relationship of WTO law with other specialized areas of international law, particularly with international human rights law.

\subsubsection{A Comment on Interpretation: Basic Rules}

As mentioned earlier at the beginning of this section, the interpretation of 'flexibilities' (the availability and extent of domestic policy space) in a WTO agreement depends primarily on the text of the treaty and the application of the Vienna Convention on the Law of Treaties (VCLT) by the dispute settlement bodies (panels and Appellate Body) of the WTO. The principle of good faith is also a guiding and overarching principle of treaty interpretation and has also been identified as a "core principle of interpretation of the WTO Agreement". ${ }^{323}$ The following section present a more detailed discussion of the technical aspects of treaty interpretation in the WTO context.

It ought to be mentioned at the outset that recourse to the dispute settlement procedures are not the only method of interpreting provisions of the WTO Agreements. Article 3.9 of the Dispute Settlement Understanding of the WTO (DSU) reiterates the rights of Members to seek authoritative (also known as 'definitive') interpretation of provisions of a covered agreement under the WTO. Article IX:2 of the WTO Agreement states that exclusive authority to adopt interpretations of this Agreement and of the Multilateral Trade Agreements is with the Ministerial Conference and the General Council and such interpretations need to be adopted by a three-fourths majority of the Members. ${ }^{324}$ In the case of an interpretation of any of the Agreements on goods, services and intellectual property, this needs to be based on a recommendation by the Council overseeing that Agreement e.g. the Services Council for the GATS. ${ }^{325}$ Such adopted authoritative interpretations have been understood as binding upon all Members, as opposed to a nonbinding declaration or an adopted dispute settlement report, which is technically only binding on the parties to the dispute. ${ }^{326}$

\footnotetext{
${ }^{323}$ Panel Report, US-Gambling, para.6.50.

${ }^{324}$ The Appellate Body in Japan-Alcoholic Beverages II, p13, clarified with reference to Article IX:2 of the WTO Agreement that:

The fact that such an 'exclusive authority' in interpreting the treaty has been established so specifically in the WTO Agreement is reason enough to conclude that such authority does not exist by implication or by inadvertence elsewhere [such as the panels and Appellate Body or the Dispute Settlement Body (DSB)]

${ }^{325}$ Note that According to Article X:2 of the WTO Agreement, Article IX of the same Agreement is one of only four provisions in WTO Agreements which cannot be amended without acceptance by all members. The others are Article II:1 of GATS (MFN), Articles I and II of GATT 1994 and Article 4 of TRIPS.

326 The Appellate Body Report, US-Clove Cigarettes, para.257 confirmed this, stating:
} 
As can be seen, the authoritative interpretation of WTO provisions is given into the hands of the political and not the 'judicial' bodies of the WTO. It has been suggested that the political organs, could perhaps change or modify WTO rights and obligations through such interpretation - but others disagree, convinced that there can only be a clarification of rights and obligations. ${ }^{327}$ However, as this provision has not been used in practice, ${ }^{328}$ the implications of dispute settlement become more significant with regard to interpretation of the WTO texts by the panels and Appellate Body.

Changing or modifying through waivers and/or amendments could be the answer to resolve certain controversies. Although not yet specifically resorted to for the GATS, the Kimberly waiver concerning trade in conflict diamonds, ${ }^{329}$ the waiver of TRIPS Agreement obligations (implementing the Doha Declaration on TRIPS and Public Health regarding compulsory licensing) ${ }^{330}$ and the Amendment to the TRIPS Agreement concerning compulsory licensing and parallel importing of essential medicines (new Article 31 bis) are examples of such responses in the trade in goods and intellectual property regimes.

With regard to the legal effect of adopted dispute settlement reports, the situation in the WTO dispute settlement system is a little complicated. The official position is that interpretations by panels or the Appellate Body are authoritative only for the dispute brought before them and do not affect other disputes. Yet, even though there is no official doctrine of precedent, a 'precedent-like' effect exists with regard to earlier dispute decisions and of the Appellate Body decisions on panels. Basically, the ratio decidendi of adopted WTO dispute settlement reports are not binding beyond the parties to the dispute, but will generally still be followed - although when they are followed, they will not be

Multilateral interpretations under Article IX:2 of the WTO Agreement provide a means by which Members - acting through the highest organs of the WTO - may adopt binding interpretations that clarify WTO law for all Members. Such interpretations are binding on all Members, including in respect of all disputes in which these interpretations are relevant.

${ }^{327}$ See Ehlermann C-D., and L. Ehring, The Authoritative Interpretation Under Article IX:2 of the Agreement establishing the World Trade Organization: Current Law, Practice and Possible Improvements, 8 JIEL 803, 2005, 812; Stoll, Peter-Tobias, Article 3 DSU in Wolfrum, Rüdiger , PeterTobias Stoll and Karen Kaiser Eds. WTO: INSTITUTIONS AND DISPUTE SETTLEMENT, Max Planck Commentaries on World Trade Law, Brill, 2006 at p312 and Pauwelyn, J., CONFLICT OF NORMS IN PUBLIC INTERNATIONAL LAW: HOW WTO LAW RELATES TO OTHER RULES OF INTERNATIONAL LAW, Cambridge University Press, 2003, p112 for the view that there can be modification. See Van Damme, Isabelle, TREATY INTERPRETATION BY THE WTO APPELLATE BODY, Oxford University Press, 2009, p28 (citing Appellate Body Report, EC-BANANAS III (Article 25.1 Ecuador II/US, para.383) and Gazzini, Tarcisio, Can Authoritative Interpretation Under Article IX: of the Agreement Establishing the WTO Modify the Rights and Obligations of Members?, International and Comparative Law Quarterly 57(1), 2008, 169, p175, for the view that there can only be clarification.

See Nottage H. and T. Sebastian, Giving Legal Effect to the Results of WTO Trade Negotiations: An Analysis of the Methods of Changing WTO Law, 9 JIEL 989, 2006, 1003 and Gazzini, Tarcisio, Can Authoritative Interpretation Under Article IX:2 of the Agreement Establishing the WTO Modify the Rights and Obligations of Members, International and Comparative Law Quarterly, Volume 57, Number 1, January 2008, p169 for the view that it can only be a clarification.

${ }^{328}$ The EC had put forward a Request of an Authoritative Interpretation pursuant to Article IX:2 of the Treaty Establishing the WTO (25 Jan 1999) WT/GC/W/133, but there was no outcome.

${ }^{329}$ Kimberly Process Certification Scheme for Rough Diamonds, WTO Documents WT/L/518 of $27^{\text {th }}$ May 2003, WT/L/676 of $19^{\text {th }}$ December 2006 and WT/L/876 of $14^{\text {th }}$ December 2012.

${ }^{330}$ WTO Documents WT/L/540 of $2^{\text {nd }}$ September 2003 and WT/L/540.Corr. 1 of $29^{\text {th }}$ July 2009. 
called 'precedent'. If something is to be decided differently in later disputes, then cogent reasons have to be given for this different conclusion. In practice, Appellate Body findings have made extensive cross-references to prior Appellate Body interpretations. Parties to later disputes would also cite heavily from previous panel and Appellate Body findings in their submissions and arguments; and Members may even adjust their policy, unilaterally or during dispute consultations, on the basis of previous Appellate Body interpretations. ${ }^{331}$ This was explained by the Appellate Body in US-Stainless Steel (Mexico) in the following manner:

Dispute settlement practice demonstrates that WTO Members attach significance to reasoning provided in previous panel and Appellate Body reports [emphasis added]. ${ }^{332}$

The reason is the importance given to ensuring 'security and predictability' of the system through the development of a 'coherent and predictable' body of jurisprudence. ${ }^{333}$ Thus, due to this practice, each adopted dispute settlement report has an effect of creating binding law for all WTO Members - what has been described as and seems to be agreed to be 'de facto finality as interpretation of law'. ${ }^{334}$

However, such interpretations by the panels or Appellate Body are constrained by the generally accepted view in dispute settlement, that such interpretation can only 'clarify the meaning of existing obligations' but not modify their content, ${ }^{335}$ and that neither panels nor the Appellate Body may add to or diminish rights and obligations provided in the WTO Agreement. ${ }^{336}$ These findings are in accordance with Article 3.2 of the DSU which states that:

The dispute settlement system of the WTO is a central element in providing security and predictability to the multilateral trading system. The Members recognize that it serves to preserve the rights and obligations of Members under the covered agreements, and to clarify the existing provisions of those agreements in accordance with customary rules of interpretation of public international law. Recommendations and rulings of the DSB cannot add to or diminish the rights and obligations provided in the covered agreements [emphasis added].

Article 19.2 of the DSU also reiterates the phrase "cannot add to or diminish the rights and obligations provided in the covered agreements". Van den Bossche, a member of the WTO Appellate Body, notes that these two provisions:

...explicitly cautions the WTO dispute settlement system against judicial activism i.e. taking on the role of legislator ${ }^{337}$

\footnotetext{
331 Shaffer, Gregory, Manfred Elsig and Sergio Puig, The Extensive (but Fragile) Authority of the WTO Appellate Body, Law and Contemporary Problems, Vol. 79:237, No. 1 2016, p260-261.

${ }_{332}$ Appellate Body Report, US-Stainless Steel, para.160. See further paras.159-162.

${ }^{333}$ See Appellate Body Report, US-Stainless Steel, para.159-162

${ }^{334}$ Howse, R., The Most Dangerous Branch? WTO Appellate Body Jurisprudence on the Nature and Limits of Judicial Power in Cottier, Thomas and Petros Mavroidis Eds., THE ROLE OF THE JUDGE IN INTERNATIONAL TRADE REGULATION - EXPERIENCE AND LESSONS FOR THE WTO, World Trade Forum, IV, 11, 2003, at p15, quoted also by Van Damme, Isabelle, Treaty Interpretation by the WTO Appellate Body, European Journal of International Law, Vol.21, No. 3, 2010, 605, p 611.

${ }^{335}$ Appellate Body Report, EC-Bananas III (Article 21.5), para. 383; also see Appellate Body Report, USFSC, para. 112, footnote 127.

${ }^{336}$ Panel Report, India-Patents, para.45.

${ }^{337}$ Van den Bossche, Peter., THE LAW AND POLICY OF THE WORLD TRADE ORGANIZATION: TEXT, CASES AND MATERIALS, Cambridge University Press, $2^{\text {nd }}$ Edition, 2008, p174.
} 
Van den Bossche in providing support for this conclusion, in addition to Article IX:2 of the WTO Agreement and other Appellate Body reports, ${ }^{338}$ refers to the following statement by the Panel in India-Patents, that the dispute settlement bodies:

... simply cannot make a ruling ex aequo et bono to address a systemic concern divorced from the explicit language of the DSU. ${ }^{339}$

In EC-Hormones, the Appellate Body paraphrased the statement from India-Patents, above, in the following terms:

The fundamental rule of treaty interpretation requires a treaty interpreter to read and interpret the words actually used by the agreement under examination, not words the interpreter may feel should have been used. ${ }^{340}$

While this approach is respectful of the Members' authority and control over the Covered Agreements, and places a limit on panels and the Appellate Body acting independently of the text of the agreements, it also has its drawbacks and therefore its critics.

Abi-Saab, formerly a member of the WTO Appellate Body, is critical of what he identifies as this "obsession with words" 341 and a strict constructivist interpretation that the Appellate Body has often been said to have followed. He rather picturesquely compares the interpretive approach of the Appellate Body to a description in Article 77(4) of the United Nations Convention on the Law of the Sea (UNCLOS), as having:

.... a tendency to stick the reasoning very close to, and keep it in constant contact with the words (the interpreter proceeding in a manner reminiscent of the definition of 'sedentary species' in the United Nations Convention on the Law of the Sea, as being "unable to move except in constant physical contact with the seabed or the subsoil") ... ${ }^{342}$

Perhaps Abi-Saab's experiences of also being a judge on the Appeals Chamber of the International Criminal Tribunals for the Former Yugoslavia and for Rwanda as well as having been a former judge ad hoc on the ICJ, where there has been a less literal approach in interpretation, have informed his criticism. After all, the ad hoc International Criminal Tribunals are widely known for the creative development of international criminal law and humanitarian law, a view that is reflected in recent publication titles such as "Judicial Creativity at the International Criminal Tribunals". ${ }^{343}$ Furthermore, the Statute of the International Court of Justice states the following (after Article 31(1), which lists the sources of international law that the ICJ shall apply to disputes before it) in Article 38(2):

This provision shall not prejudice the power of the Court to decide a case ex aequo et bono, if the parties agree thereto.

\footnotetext{
338 Appellate Body Report, Chile-Alcoholic Beverages, para 79; Appellate Body Report, US-Certain EC Products, para.92.

${ }^{339}$ Panel Report, India-Patents (EC), para.7.23.

${ }^{340}$ Appellate Body Report, EC-Hormones, para. 181.

${ }^{341}$ Abi-Saab, G., The Appellate Body and Treaty Interpretation in Fitzmaurice, M., Olufemi A. Elias and Panos Merkouris Eds., TREATY INTERPRETATION AND THE VCLT; 30 YEARS ON, BRILL Publishers, 2010, p107 (reprinted from Sacerdoti et al, Eds., THE WTO AT 10; THE CONTRIBUTION OF THE DISPUTE SETTLEMENT SYSTEM, Cambridge University Press, 2006, p453-64). Abi-Saab also adds, what many readers of panel and Appellate Body Reports would have surely thought, that the language of many Reports is such that "the reasoning seems to disappear in a maze of words".

${ }^{342}$ Ibid., (Abi-Saab) p106-107.

${ }^{343}$ Darcy, Shane and Joseph Powderly Eds., JUDICIAL CREATIVITY AT THE INTERNATIONAL CRIMINAL TRIBUNALS, Oxford University Press, 2010. Also see e.g. article such as Powles, Steven, Joint Criminal Enterprise Criminal Liability by Prosecutorial Ingenuity and Judicial Creativity?, Journal of International Criminal Justice 2004, 2(2), 606-619.
} 
This kind of solution is obviously not possible in the WTO system, as is made clear by the DSU provisions (and the Panel report in India-Patents cited above).

In attempting to avoid the criticism of judicial activism, the debate with regard to the role of the dispute settlement bodies of the WTO has evolved to the consideration of different understandings of the phrase "add to or diminish the rights and obligations provided in the covered agreements", as this signals the limitations upon panels and the Appellate Body. Pauwelyn has argued, gathering support from other scholars, that a non-WTO norm (such as a human rights obligation) can prevail over WTO law, but only so far as it can be identified as applicable law in a specific dispute and even then only as a defence for a breach of WTO obligations. ${ }^{344}$ Marceau is one of the scholars that are more cautious about bringing in non-WTO norms into interpretation, stressing that any interpretation that turns into, in effect, an amendment or otherwise adds to or diminishes rights and obligations under the covered agreements is not acceptable. ${ }^{345}$ In practice, WTO Members follow the cautious approach in their understanding of WTO rights and obligations and have not recognized a role for non-WTO norms within the system. Even in the case of the amendment of the TRIPS Agreement and insertion of Article 31 bis to the TRIPS, there were no references to human rights approaches and right to health, but only to "public health problems" and public health purposes". ${ }^{346}$ This is despite the fact that the human rights and the right to health in particular, were the foundations upon which the global efforts to amend the rules concerning compulsory licensing for pharmaceutical products were built. ${ }^{347}$

Tancredi makes an interesting comment, especially in light of the current crisis with Appellate Body appointments, that the 'mantra' of the WTO being a 'Member-driven' organization makes it more exposed to the direct influence and decisional power of its Member States (and the governments of the Members) than other systems such as those created by human rights treaties. ${ }^{348}$ It is true that the individuals and various nongovernmental actors, both local and international, play a very active role in the development and maintenance of the international human rights system; but the involvement and decision-making power of States has a direct influence on the human rights system. The primary responsibility for the creating international treaties and soft law standards and for domestic implementation of human rights, remains in the hands of the State, with support of the other actors. Whether human rights are upheld or violated is ultimately a matter of the influence and decisional power of States, much like the WTO system. It is only that the various human rights bodies (judicial and monitoring bodies),

344 Pauwelyn, J., CONFLICT OF NORMS IN PUBLIC INTERNATIONAL LAW: HOW WTO LAW RELATED TO OTHER NORMS OF INTERNATIONAL LAW, Cambridge University Press, 2003, p491.

${ }_{345}$ Marceau, Gabrielle, Conflicts of Norms and Conflicts of Jurisdictions: The Relationship between the WTO Agreement, MEA's and Other Treaties, Journal of World Trade, 2001, 1130.

346 WTO General Council Decision on the Amendment of the TRIPS Agreement, 2005; The Protocol amending the TRIPS Agreement and the Annex (Article 31 bis), available online at https://www.wto.org/ english/tratop_e/trips_e/wtl641_e.htm.

${ }^{347}$ UN Committee on Economic, Social and Cultural Rights, Human Rights and Intellectual Property: Statement by the Committee on Economic Social and Cultural Rights, UN doc. E/C.12/2001/15, 14 December 2001; UNGA, Report of the Special Rapporteur on the right of everyone to the enjoyment of the highest standard of physical and mental health, Paul Hunt, UN doc. A/61/338, 13 September 2006; Human Rights Council, Access to Medicine in the context of the right of everyone to the enjoyment of the highest attainable standard of physical and mental health, UN doc. A/HRC/RES/12/24, 12 October 2009.

348 Tancredi, Antonello, Trade and Inter-Legality in Klabbers, Jan. and Gianluigi Palombella Eds., THE CHALLENGE OF INTER-LEGALITY, ASIL Studies in International Legal Theory, Cambridge University Press, 2019, p187. 
once set up, appear to have much more autonomy and space for judicial activism and interpretive creativity than the dispute settlement bodies of the 'Member-driven' WTO system.

In light of criticisms against the 'judicial activism' of the WTO Appellate Body, Chang-fa Lo's recommendation that the Appellate Body should avoid anything approaching activism in the context of technical or purely commercial matters, but still retain a role of carefully exercising judicial activism where it is necessary to maintain important human values, has some merit. ${ }^{349}$ Lo situated this in the context of the Appellate Body's important role in ensuring a proper international legal order, with respect for other international obligations and legal frameworks which are also created by the WTO Members themselves - and emphasized that this was part of the Appellate Body's responsibility in the Member-driven WTO system (contrasting the collective-Membersdriven ideal, as opposed to a single-Member-driven deadlock, ${ }^{350}$ which has currently occurred).

While there is controversy on the relationship between the WTO regime and other regimes of substantive international law, there is no problem with the application of principles of international law for treaty interpretation to the WTO context, as the relevant Articles of the Vienna Convention on the Law of Treaties (Articles 31 and 32) are generally accepted in WTO law as embodying customary international law on treaty interpretation. ${ }^{351}$ Abi-Saab, has even commented that Articles 31 and 32 of the VCLT have been treated by the Appellate Body with such esteem:

....as if they were substantive provisions of the covered agreements that are directly applicable as such, and themselves interpreted literally... ${ }^{352}$

Abi-Saab also notes that Article 3.2 of the DSU refers to "customary rules of interpretation of public international law" and not specifically to Articles 31 and 32 of the $V C L T$. The significance of this is that Articles 31 and 32 of the VCLT codify customary international law as it stood at a certain moment in time, but "customary rules of interpretation of public international law" continue to evolve. ${ }^{353}$ For example, the role of

${ }^{349}$ Lo, Chang Fa, A Proper Balance between WTO's Members-Driven Nature and the Appellate Body's Role as an Adjudicator - Careful Exercise of Judicial Activism in Lo, Chang-fa, Junji Nakagawa and Tsaifang Chen Eds., THE APPELLATE BODY OF THE WTO AND ITS REFORM, Springer, 2019, p125140.

${ }^{350}$ Petersmann notes that all the concerns of judicial overreach raised by the United States in relation to the blocking of Appellate Body appointments during 2017-2019 are political claims without any supporting evidence, and that the activities complained of are on the contrary, "long-standing legal interpretations and judicial practices" based on the customary rules of treaty interpretation, the quasi-judicial mandates given by the DSU to WTO panels, the AB and to WTO arbitrators, and had been accepted in the legal practices of the WTO Dispute Settlement Body (see Petersmann, E-U., How should WTO members respond to the WTO Appellate Body crisis?, International Economic Law and Policy Blog, posted by Simon Lester on December 13, 2018, available online at https:/ielp.worldtradelaw.net/2018/12/ulli-petersmann-on-how-should-wtomembers-respond-to-the-wto-appellate-body-crisis.html\#comments).

${ }^{351}$ One of many examples of the acceptance of this customary status in WTO law, is the statement by the Appellate Body in US-Gambling, para.159, referring to:

...the customary rules of interpretation of public international law, codified in Articles 31 and 32 of the Vienna Convention.

${ }^{352}$ Abi-Saab, G., The Appellate Body and Treaty Interpretation in Fitzmaurice, M., Olufemi A. Elias and Panos Merkouris Eds., TREATY INTERPRETATION AND THE VCLT; 30 YEARS ON, BRILL Publishers, 2010, p103-104 (reprinted from Sacerdoti et al, Eds., THE WTO AT 10; THE CONTRIBUTION OF THE DISPUTE SETTLEMENT SYSTEM, Cambridge University Press, 2006, p453-64).

${ }^{353}$ Ibid., (Abi-Saab), p104. 
General Comments of human rights treaty bodies in the interpretation of international human rights treaty obligations seems to be beyond the classic VCLT interpretive framework for multilateral agreements that the WTO fits into. This is something that will be discussed further in this study, since the General Comment No 14 on the Right to Health (Article 12 in the ICESCR) is relevant for interpretation of the obligations of States under the right to health.

Article 31(1) of the VCLT states that there is recourse to: (i) ordinary meaning of terms (ii) context and (iii) object and purpose of the treaty for the purposes of interpretation.

It was debated at one time whether this indicates a hierarchy of separate approaches or a holistic approach, but this is theoretically not an issue any longer. With regard to the usual WTO treaty interpretation situation, the Panel in US-Section 301 Trade Act stated that

...the elements referred to in Article 31 - text, context and object-andpurpose as well as good faith - are to be viewed as one holistic rule of interpretation rather than a sequence of separate tests to be applied in a hierarchical order [emphasis added]. ${ }^{354}$

This was also the view of the Appellate Body in EC-Chicken Cuts, which stated that: Interpretation pursuant to the customary rules codified in Article 31 of the $\mathrm{VC}$ is ultimately a holistic exercise that should not be mechanically subdivided into rigid components. ${ }^{355}$

The Appellate Body in US-Continued Zeroing added that:

The principles of interpretation that are set out in Articles 31 and 32 are to be followed in a holistic fashion. The interpretative exercise is engaged so as to yield an interpretation that is harmonious and coherent and fits comfortably in the treaty as a whole so as to render the treaty provision legally effective. ${ }^{356}$

This view is in line with the commentaries of the International Law Commission (ILC) on the (then) Draft Articles of the Vienna Convention. The ILC reiterated that the abovementioned elements 'form a single closely integrated rule', 'a single combined operation' and 'cannot be regarded as laying down a legal hierarchy of norms'. ${ }^{357}$ The process of interpretation was further described as 'a unity' wherein

...[a]ll the various elements, as they were present in any given case, would

be thrown into the crucible, and given their interaction would give the legally relevant interpretation. ${ }^{358}$

And so that there would be no confusion on that point, it was also added that the decision to term the Article "General Rule of Interpretation" was to leave no doubt that it was a single rule and not General rules ${ }^{359}$.

\footnotetext{
${ }^{354}$ Panel Report, US-Section 301 Trade Act, para.7.22.

${ }^{355}$ Appellate Body Report, EC-Chicken Cuts, para.176.

${ }^{356}$ Appellate Body Report, US-Continued Zeroing, para.268

357 Reports of the International Law Commission to the UN General Assembly, GA Doc. A/6309/Rev.1, also as Draft Articles of the Law of Treaties with Commentaries, Yearbook of the International Law Commission, 1966, Vol. II at p219-220.

358 Ibid., (ILC).

359 Ibid., (ILC). See also McDougal, Myers S., H.D. Lasswell and James M. Miller, THE INTERPRETATION OF INTERNATIONAL AGREEMENTS AND WORLD PUBLIC ORDER: PRINCIPLES OF CONTENT AND PROCEDURE, Martinus Nijhoff Publishers, 1994 (Reprint), p65; Gardiner, Richard, TREATY INTERPRETATION, Oxford University Press, 2008, p36; Sinclair, Ian, THE
} 
Article 31(2) is a further clarification on "context" - and therefore also becomes part of the holistic approach, if that is the way to read the Article. The Appellate Body in USContinued Zeroing explained that the identification of the different shades of meanings of a term "only commences the process of interpretation" and that the "logical progression" of interpretive analysis requires recourse to context and object and purpose as "connected and mutually reinforcing components of a holistic exercise". ${ }^{360}$ Therefore, it must be determined what sources can be looked at as "context".

Article 31(2) states that in addition to the text, including its Preamble and annexes, "context" shall comprise of:

(a) any agreement relating to the treaty which was made between all the parties in connexion with the conclusion of the treaty;

(b) any instrument which was made by one or more parties in connexion with the conclusion of the treaty and accepted by the other parties as an instrument related to the treaty.

The Appellate Body in China-Auto Parts, stated that in order to take something into consideration as context, it:

...must also have some pertinence to the language being interpreted that renders it capable of helping the interpreter to determine the meaning of such language. ${ }^{361}$

According to the Panel in China-Electronic Payment Services, it appears that "context" as codified in Article 32(2) of the VCLT includes the text, including the Preamble and Annexes for the purposes of interpreting an Article and a different, longer list for the purposes of interpreting a GATS Schedule. For the purposes of interpreting an entry in a GATS schedule, the Panel listed the following as "context":

(i) the rest of the subsector

(ii) the relevance of the sectoral heading at stake the remainder of the Member's schedule

(iii) market access, national treatment and additional commitments under the subsector at stake

(iv) subsectors adjacent to the services at stake

(v) commitments scheduled under another related sector

(vi) the structure of the schedule

(vii) the GATS schedules of other WTO Members

(viii) the substantive provisions of the GATS

(ix) the structure of the GATS

(x) any relevant GATS Annex

(xi) the provisions of covered agreements other than the GATS. ${ }^{362}$

Even this longer list does not draw the parameters of the "context" beyond the documents considered integral to the GATS or within the 'covered agreements'. Even documents that assist Members in making their commitments such as the W/120 and the 1993 Scheduling Guidelines which were drafted by the GATT Secretariat on behalf of

VIENNA CONVENTION ON THE LAW OF TREATIES, 2nd Ed., Manchester University Press, 1984, p116.

${ }^{360}$ Appellate Body Report, US-Continued Zeroing, para.268.

${ }^{361}$ Appellate Body Report, China - Auto Parts, para.151.

362 Panel Report, China-Electronic Payment Services, paras.102-104, citing the Appellate Body Reports in US-Gambling and China-Publications and Audiovisual Products. 
negotiating States were not accepted by the Appellate Body (in the earlier dispute of USGambling) as falling within the definition of Article 31(2) of the VCLT, since both the negotiators and the Secretariat refer to them as non-binding and non-authoritative. ${ }^{363}$

Context could be looked at broadly, since the interpretation of terms and phrases in a treaty need not be limited to the confines of the treaty and yet in the WTO context this is usually limited to the context of the relevant provision within the Agreement, and if necessary other relevant WTO agreements. It is not clear if this makes the task of the interpreter easier or more difficult. Thus, it is commented that according to the VCLT, 'context' is seen in a very technical and limited way which does not include factual, social or historical context, ${ }^{364}$ which may be what would immediately be supposed by a lay person seeing the term 'context'. It is usually limited to the context of the words of that Agreement; where the words are placed within it and its relationship to the context of the surrounding words.

Subsequent agreement on interpretation or practice between the parties or any relevant rule of international law applicable to the relations between the parties can also be taken into account together with context, under Article 31(3) of the VCLT. ${ }^{365}$

3. There shall be taken into account, together with the context:

(a) any subsequent agreement between the parties regarding the interpretation of the treaty or the application of its provisions;

(b) any subsequent practice in the application of the treaty which establishes the agreement of the parties regarding its interpretation;

(c) any relevant rules of international law applicable in the relations between the parties

This provision has rarely been referred to explicitly by judicial or decision-making bodies - although it seems at first glance to have a lot of potential. However, it has been commented that the Appellate Body has adopted a strict approach to subsequent agreement and practice, ${ }^{366}$ whereas in contrast, it has been commented that the International Court of Justice (ICJ), and the European Court of Human Rights have adopted "radically expansive" approaches to subsequent practice. ${ }^{367}$ Does "subsequent

363 Appellate Body Report, US-Gambling, paras.175, 176 and 178: stating that the Panel erred in categorizing W/120 and the 1993 Scheduling Guidelines as "context" for the interpretation of the United States' GATS Schedule.

${ }^{364}$ Shaffer, Gregory C. and Trachtman, Joel P., Interpretation and Institutional Choice at the WTO, Oñati Socio-Legal Series, Vol. 1, No. 4, 2011, p115.

365 See further for comments on a project on "subsequent agreements and subsequent practice in relation to the interpretation of treaties" begun by the International Law Commission (ILC) in May 2012 with the appointment of special rapporteur, Georg Nolte - see Nolte, Georg Second Report for the ILC Study Group on Treaties over Time, in Nolte Ed., TREATIES AND SUBSEQUENT PRACTICE, Cambridge University Press, 2013 and in particular, Murphy, Sean D., The Relevance of Subsequent Practice, GWU Law School Public Law Research Paper No. 2013-102 and Nolte Ed., TREATIES AND SUBSEQUENT PRACTICE, Cambridge University Press, 2013.

366 See Appellate Body Report, US-Gambling, para.175-178, which stated that the Panel erred in identifying the W/120 Document and the 1993 Scheduling Guidelines as context - they were not to be considered context since

Such documents can be characterized as context only where there is sufficient evidence of their constituting an "agreement relating to the treaty" between the parties or of their "accept[ance by the parties] as an instrument related to the treaty"(para.175)

The Appellate Body added that although Members have used these documents, it was never meant to be binding.

${ }^{367}$ Arato, Julian, Treaty Interpretation and Constitutional Transformation: Informal Change in International Organizations, Yale Journal of International Law, Vol. 38, No.2, 2013. 
practice' have to be a common position or a majority position of the parties? The recent ICJ Judgment in Whaling in the Antarctic (2014) stated that:

...while unanimous or consensus resolutions of a supervisory treaty body might be considered subsequent agreements or practice relevant to the interpretation of the underlying convention, resolutions adopted by disputed majority will not count under the general rule of interpretation. ${ }^{368}$

This contradicts earlier ICJ interpretive practice, especially in Certain Expenses, 1962 and Construction of a Wall (2004), where the General Assembly resolutions adopted by majority vote with strong dissentions, were relied upon. ${ }^{369}$ It may be that the ICJ is also moving back to a cautious approach towards 'disputed majority' resolutions that is comparable to the Appellate Body approach; but unlike the WTO well-established practice to arrive at decisions by consensus - which is based on Articles IX (DecisionMaking) of the WTO Agreement - there is not such a strong basis for insistence on consensus in decision-making in the UN system.

The problem with regard to requiring consensus would not only lead to deadlock or prolonged delay in negotiations or decision-making, but can retard the evolution of binding international law and formation of legal norms. An unreasonable or 'rogue' member of an international institution can prevent the development of international law meant to control their unacceptable behavior. On the other hand, requiring consensus can be said to allow for even the weakest Member to defend its own interests against the majority. However, the practical reality is that the outcomes of consensus decision making and majority voting are both likely to benefit powerful States. In the WTO context, decisions are deemed to have been made by consensus unless a Member "formally objects". ${ }^{370}$ Therefore, even if there has not been a transparent, inclusive process of deliberation, there is a presumption of consensus in the absence of a formal objection. Thus, it is difficult to make a value judgement merely on the procedure for the recognition of subsequent agreement, subsequent practice or relevant rules applicable between the parties. It is useful only according to the consequences of taking such practice into account, based on who benefits and what kind of progress can be achieved. If Article 31(3)(c) can be a way for bringing in progressive parallel developments in areas such as environmental law and human rights into trade law, it can be a useful tool for those particular reasons.

Article 31(3)(c) seems to be a promising provision from the point of view of bringing in norms from other international law regimes into the WTO system. This provision will be discussed in more detail later on in this Chapter at Section 2.3.5. Broader socio-historical context and policy issues, even though relevant from a layman's point of view, do not seem to be able to enter into the interpretation exercise according to the accepted rules and principles of interpretation. Most interpreters would not agree that such wider issues can be referred to with regard to the object and purpose that is discernible from the text but there is no knowing whether or not such considerations play a part in the mind of an

368 ICJ, Whaling in the Antarctic, Australia v. Japan: New Zealand intervening, ICJ Reports, 31 March 2014, para.83.

369 Arato, Julian, Treaty Interpretation and Constitutional Transformation: Informal Change in International Organizations, Yale Journal of International Law, Vol. 38, No.2, 2013

${ }^{370}$ Footnote 1 of the WTO Agreement:

The body concerned shall be deemed to have decided by consensus on a matter submitted for its consideration, if no Member, present at the meeting when the decision is taken, formally objects to the proposed decision. 
individual interpreter, consciously or subconsciously. While this can affect any party to a dispute, it may be said that developing countries have a particular interest in interpretation that takes socio-historical circumstances into account and acknowledges development differences in implementing their obligations.

Even if this is not specific to rules of treaty interpretation that are to be applied, it may be that consideration of the situation of developing country Members is recognized in the WTO system through Article 8.10 of the DSU, which states that when a dispute is between a developing country Member and a developed country Member, if the developing country Member so requests, the panel must include at least one panelist from a developing country Member.

There is also a limited opportunity where negotiations and circumstances at the time of conclusion of the treaty can be considered under the abovementioned Article 32 of the VCLT, and some socio-historical factors can be taken into account in the VCLT. Asif Qureshi argues that this is a point at which, if it has not been done earlier in the consideration of Article 31 factors, the power imbalance between developing and developed countries during the creation of the WTO agreements and the overall objectives of development can be brought into interpretation. ${ }^{371}$

In practice, it is natural that interpretation begins with the text and then moves on to the other aspects. For example, in Japan-Alcoholic Beverages II, it is stated by the Appellate Body that:

Article 31 of the Vienna Convention provides that the words of the treaty form the foundation for the interpretive process: 'interpretation must be based above all upon the text of the treaty'. ${ }^{372}$

But the Appellate Body continues in the next sentence adding that:

[t]he provisions of the treaty are to be given their ordinary meaning in their context...

and further that:

[t] he object and purpose of the treaty are also to be taken into account in determining the meaning of its provisions [emphasis added].

In US-Shrimp, the Appellate Body seems to refer to a hierarchy, where:

A treaty interpreter must begin with, and focus upon, the text of the particular provision to be interpreted ${ }^{373}$.

But it is added that such words must be "read in their context" and that object and purpose must be first sought in words. Thus, context is the context of the relevant agreement and does not appear to take into account any additional information about the wider setting of the trade regime in the global context, for an understanding of the limitations or the breadth of the terms and phrases in the agreement. It was further added that looking at the object and purpose of the treaty as a whole was identified as only useful for confirmation of the correctness of the reading of the text, or if the meaning imparted by the text itself is "equivocal or inconclusive".

\footnotetext{
371 Qureshi, Asif H., INTERPRETING WTO AGREEMENTS: PROBLEMS AND PRSPECTIVES, Cambridge University Press, 2006.

372 Appellate Body Report, Japan-Alcoholic Beverages II, p105-106. The phrase in inverted commas which indicates primacy of the text is found in the ICJ case Territorial Dispute (Libyan Arab Jamahiriya v. Chad), 1994 ICJ Reports, p19-20, para.41; and followed in the Case Concerning Maritime Delimitation and Territorial Questions (Qatar v. Bahrain)(Jurisdiction and Admissibility), 1995, ICJ 6 at p18.

${ }^{373}$ Appellate Body Report, US-Shrimp, para.115
} 
The text is of course the logical starting point, with the context allowing for consideration of Preamble, Annexes of the Agreement, and under specific conditions, for related subsequent agreements or instruments and relevant rules of international law applicable between the parties. It is only if continued ambiguity or an absurd or unreasonable outcome result from the application of Article 31, that supplementary means provided for in Article 32 of the VCLT can be resorted to; and that is also limited to preparatory work of the treaty and the circumstances of its conclusion. Basically, it is only if the textcontext-object-and-purpose fail to provide an unambiguous result, that one would need to look to other means. It is also possible that recourse to Article 32 can be used merely to confirm the result reached through the application of Article 31 of the VCLT. Irwin and Weiler have referred to this strict VCLT approach as a "textual fetish and policy phobia" of the WTO dispute settlement system. ${ }^{374}$

A plain reading of Article 31 suggests that importance is given to object and purpose as well as text, which is read in context - in the holistic exercise discussed above. Object and purpose are often the overlooked aspects in a WTO approach that is strongly focused on text, but it has become important in some instances. The problem is that a holistic exercise should take it into account as a matter of course, and it is arguable whether this is apparent in a majority of WTO disputes. The above WTO dispute extracts suggest that while the starting point is the text, and context is to be read with text in a manner which suggests a more integrated approach, 'object and purpose' does not have equal status with 'text and context'. Yet it has been commented that Article 31(1) of the VCLT does not refer to object and purpose of the provision at issue being found within the provision itself, but that object and purpose of the treaty as a whole is part of the process of finding the ordinary meaning of the terms of the provision in the first instance ${ }^{375}$. The Panel in US-Section 301 Trade Act seems to have understood and expressed more clearly that context and object and purpose need to integrated and stating that:

...[i]n reality it is always some context, even if unstated, that determines which meaning is to be taken as 'ordinary' and frequently it is impossible to give meaning, even 'ordinary meaning', without looking also at objectand-purpose $\mathrm{s}^{376}$.

In sum, it has been argued by commentators such as Ortino that although the Appellate Body does not seem to be supporting a rigorous textual approach, it has perhaps not fully

\footnotetext{
${ }^{374}$ Irwin, Douglas A. and Joseph Weiler Measures Affecting the Cross-Border Supply of Gambling and Betting Services (DS 285), World Trade Review 7: 1, 2008, 71-113, p95. They focused on the interpretive methods of the Appellate Body.

${ }^{375}$ Gardiner, Richard, TREATY INTERPRETATION, Oxford University Press, 2008, p118, commenting further at p1 19 that what the Appellate Body actually did in US-Shrimp was correct and in line with Article 31 of the Vienna Convention, but the description of what it thought should be done creates a wrong impression of the general rule.

${ }^{376}$ Panel Report, US-Sections 301-310, para.7.22. See also, the Panel in Canada-Autos, para.10.12: ...understanding of these rules of interpretation is that, even though the text of a term is the starting-point for any interpretation, the meaning of a term cannot be found exclusively in that text; in seeking the meaning of a term, we also have to take account of its context and to consider the text of the term in light of the object and purpose of the treaty...The three elements referred to in Article 31 - text, context and object and purpose - are to be viewed as one integrated rule of interpretation rather than a sequence of separate tests to be applied in a hierarchical order. Of course, context and object and purpose may simply confirm the textual meaning of a term. In many cases, however, it is impossible to give meaning, even 'ordinary meaning', without looking also at the context and/or object and purpose.
} 
and openly embraced a holistic approach that is said to be more in line with Article 31(1) of the VCLT. ${ }^{377}$ Ortino is focusing on a critique of US-Gambling, when making these comments. However, it should be noted that in TBT disputes, the Appellate Body has expressed a more holistic approach, stating that interpretation is "a holistic exercise in which the components of the definition are to be considered together" ${ }^{\text {"378 }}$ in US-Tuna II (Mexico) and referring to "an interpretation that properly canvasses the text, context, and object and purpose" ${ }^{379}$ in US-Clove Cigarettes.

It has also been commented that Article 31 of the VCLT is not merely representative of a single approach, as argued by some interpreters and commentators but in fact "embodies something of a compromise (or oscillation perhaps)" 380 between a textual approach and a wider approach.

However, the wider approach can be an entry point for discussion of an array of issues relating to policy choices relating to 'object and purpose' of a treaty - and to some issues that may be beyond that, and are trying to enter in, such as human rights, environmental, labour and cultural concerns. It is natural that a dispute settlement body may wish to avoid involving any controversial issues in the decision-making as much as possible and stay within the area of competence and expertise. The caution generally shown by the Appellate Body, and what has been called its current unwillingness to:

...situate its legal analyses within a framework which firmly articulates

both the normative and policy considerations and consequences of its decisions $^{381}$

- can perhaps be understood better in this light. But considering the impact of WTO rules on so many different areas of law and policy-making and ordinary life, such avoidance, although justifiable, can also met with criticism as just going along with blinders, ignoring vital policy matters and their implications. ${ }^{382}$ This caution towards a holistic approach does not however, completely preclude a more purposive and teleological approach to the interpretation of the treaty provisions, although it seems to give it less significance. ${ }^{383}$ The problem with this is if this goes to the extreme of becoming, as described by Irwin and Weiler:

\footnotetext{
377 See, Ortino, Federico, Treaty Interpretation and the WTO appellate Body Report in US - Gambling: A Critique, Journal of International Economic Law 9(1), 117-148, 2006.

378 Appellate Body Report, US-Tuna II (Mexico), para.359: "The interpretation of the term "international standardizing body" is therefore a holistic exercise in which the components of the definition are to be considered together."

${ }^{379}$ Appellate Body in US-Clove Cigarettes para.286.

${ }^{380}$ Klabbers, Jan, AN INTRODUCTION TO INTERNATIONAL INSTITUTIONAL LAW, Cambridge University Press 2003, p 96.

${ }^{381}$ Horn, Henrik and Joseph Weiler, European Communities-Trade Description of Sardines: Textualism and its Discontent, in Horn Henrik and Mavroidis Petros C. Eds., THE WTO CASE LAW OF 2002, Cambridge University Press, 2005, at 253.

382 Recalling the comment by renowned environmentalist David Suzuki:

We must reinvent a future free of blinders so that we can choose from real options

- from Suzuki, David T., INVENTING THE FUTURE: REFLECTIONS ON SCIENCE, TECHNOLOGY AND NATURE, Adamantine, 1992.

${ }^{383}$ Gardiner, Richard, TREATY INTERPRETATION, Oxford University Press, 2008, p189-190 states that ... 'object and purpose' brings in the teleological element into the general rule, but adds that the precise nature, role and application of the concept is uncertain.

See for further discussion on the topic - Buffard, I. and Zemanek K., The 'Object and Purpose' of a Treaty: An Enigma?, Australian Review of International and European Law, 311, 1998.
} 
Over-textualized decisions deracinated from the policy objectives of the law [which] leave the loser with the impression of having 'lost on a technicality' 384

Interpreters ought to be mindful that the choice of interpretive approach in the WTO has social consequences and that the overall impression that has been created for the public and concerned stakeholders who are not trade lawyers is indeed that the system is often excessively technical and does not give due consideration to other important and relevant matters of public policy.

It is clearly expressed by the Appellate Body, that restraint in interpretation is the best path to follow in dealing with controversial subjects, emphasizing in India-Patents that:

[The Vienna Convention] principles of interpretation neither require nor condone the imputation into a treaty of words that are not there or the importation into a treaty of concepts that were not intended [emphasis added $]^{385} \ldots$

However, words by themselves may acquire meanings and become attached to concepts that were indeed not originally intended, due to developments in other settings where these words are used. An 'originalist' interpretation is not the direction to take if the WTO is to avoid being stuck in a time-warp and unable to respond to rapidly changing and evolving situations and concerns of the modern world. Why should Members be bound by the intention or understanding of a matter expressed by the GATT negotiators in 1947 or even the WTO negotiators of 1994? It is also difficult to support 'originalism' as there is no 'official' negotiating history or travaux preparatoires to turn to in order to decide original intention in the Uruguay Round, only various different compilations of material and a commonsense estimation of what probably was or was not in the minds of the framers. Furthermore, preparatory documents relating to the negotiating history are only supplementary means of interpretation under Article 32 of the Vienna Convention, and therefore given less importance. The use of such preparatory documents was referred to in several instances in dispute contexts, but not always relied upon. ${ }^{386}$ Marceau comments that while the GATT 1947 negotiations had been carefully recorded and important parts were highlighted in publications including the GATT Analytical Index; the negotiations of the Uruguay Round did not have an official record. ${ }^{387}$ Marceau explains that the emphasis was on the final text itself, and rather than an official

\footnotetext{
${ }^{384}$ Irwin Douglas A., and Joseph Weiler, Measures Affecting the Cross-Border Supply of Gambling and Betting Services (DS 285), 7 World Trade Review, 2008, 71, p94-95. This also described by the same authors less restrainedly as the Appellate Body's 'textual fetish and its policy phobia'.

385 Appellate Body Report, India-Patents (US), para.45.

${ }^{386}$ E.g. Panel Report, US - Carbon Steel paras.89-90: ... we do not consider it strictly necessary to have recourse to the supplementary means of interpretation identified in Article 32 of the Vienna Convention. In any event, we consider that recourse to the negotiating history of the SCM Agreement tends to confirm our view as to the meaning of Article 21.3;

Panel Report, US - Upland Cotton, para.623:

The Panel did not think it necessary to resort to negotiating history for purposes of its interpretation of Article 10.2. Even if the negotiating history were relevant for our inquiry, we do not find that it supports the United States' position.

However, the Panels in Canada-Dairy at para.138 and Korea-Procurement at para.7.74 resorted to examination of the negotiating history with regard to specific negotiated commitments under the Agreement on Agriculture and the Agreement of Government Procurement.

387 Marceau, Gabrielle, A HISTORY OF LAW AND LAWYERS IN THE GATT/WTO: THE DEVELOPMENT OF THE RULE OF LAW IN THE MULTILATERAL TRADING SYSTEM, Cambridge University Press, 2015, p231 and footnote 26 and p431.
} 
negotiating history, "the memories of those who were there are all that remains of the process". 388 This was explained as being influenced by both the downgrading of the importance of negotiating history in the 1969 Vienna Convention on the Law of Treaties and changes in GATT panel practice, of less reliance on negotiating history, by the time of the Uruguay Round.

There are no official travaux preparatoire on the debates of the WTO agreements and there was practically no debate on the meaning of certain important provisions requiring interpretation such as Article XX(a) of the GATT 1947 - which was incorporated by reference in the GATT 1994 - or on Article XIV of the GATS. It is suggested that there was consensus on what the terms meant as there were commonly accepted meanings in prior trade treaties. Another common view is that the negotiators decided that the best method in coming to agreement on the provisions was to frame the terms and phrases broadly and leave room for varied and variable interpretations, which would be decided upon in dispute settlement contexts if necessary. Or at least, if they did not consciously decide this, they

...should have realized that the vagueness of these terms would result in their meaning being open to discussion and variation depending on the context and times [italics in original]. ${ }^{389}$

This latter view also allows for panels and the Appellate Body to be flexible and does not bind them to a rigid and time-bound textual interpretation. The suggestion is: that the interpretation of terms and phrases need not rely on the intention at the time of drafting, fixed in time at 1947 or 1994.

If an evolutionary approach is applied, it may solve the problem of balancing flexibility and respect for original intent by embracing both to a certain extent. In fact, both the Appellate Body report in US-Shrimp and analysis by commentators can be seen as support for this view on the matter. The Appellate Body in US-Shrimp pointed out that the words, 'exhaustible natural resources' in Article XX(g) of GATT, although crafted more than 50 years ago, must be:

...read by a treaty interpreter in the light of contemporary concerns of the community of nations about the protection and conservation of the environment. ${ }^{390}$

Notably, the travaux preparatoires were not relied upon and the Appellate Body also added that, the words 'exhaustible natural resources' were in any case not 'textually' limited to mineral resources, even if it was intended as such by the negotiators. The result was that 'exhaustible natural resources' was taken as covering living resources such as sea turtles. So, it is possible to interpret this result as textual-evolutionary, taking into account the ordinary meaning of the words in the present-day context as opposed to being circumscribed by either plain text or original intent.

Evolutionary interpretation was also an issue with regard to the interpretation of phrases in China's GATS Schedule in the China-Publications and Audiovisual Products dispute. China submitted that their GATS Schedule should be based on "definitions

\footnotetext{
${ }^{388}$ Ibid (Marceau), p231 and 431.

389 Pauwelyn, Joost, The Nature of WTO Obligations, Jean Monnet Working Paper No. 1/02, available online at http://www.jeanmonnetprogram.org/papers/02/020101.rtf, accessed 03.06.2009.

${ }^{390}$ Appellate Body Report, US -Shrimp, para.129.
} 
contemporaneous to the conclusion of the treaty" ${ }^{391}$ but the Appellate Body was of the view that an evolutionary approach should be followed, giving the entry a "contemporary meaning" for 2009, when the dispute was decided. ${ }^{392}$ It was further explained by the Appellate Body that the GATS schedules have "continuing obligations that WTO Members entered into for an indefinite period of time" and the term at issue being a generic one, the meaning which ought to be given is the meaning at the time of interpretation, and not meaning at the time of making the entry. ${ }^{393}$ If China's submission would have been accepted, DVDs would not be included in the term "videos", as there were no DVDs in existence in 2001 when China's commitments were undertaken. While these interpretations are not problematic, and largely common sense, Lennard has cautioned that such evolutionary interpretation could overstep and become 'disguised teleological analysis', which he contrasts with the mere recognition of room for growth allowed by the VCLT rule. ${ }^{394}$

Some domestic constitutional courts or regional special regimes have clearly chosen to distance themselves from 'original intention' and have adopted a more evolutionary or teleological view of the normative framework for interpretation. For example, the European Court of Human Rights when interpreting the European Convention on Human Rights in Tyrer $v$ UK, 1978, stated that:

The Court must also recall that the Convention is a living instrument which ... must be interpreted in the light of present-day conditions ... the Court cannot but be influenced by the developments and commonly accepted standards ... of the member States of the Council of Europe in this field. ${ }^{395}$

The Tyrer case initiated the 'living instrument' approach to interpretation of ECHR. This was developed further in Loizidou v. Turkey, 1997, which stated

That the Convention is a living instrument which must be interpreted in the light of present-day conditions is firmly rooted in the Court's caselaw.... It follows that these provisions cannot be interpreted solely in accordance with the intentions of their authors as expressed more than forty years ago. ${ }^{396}$

The Inter-American Court of Human Rights, in the matter of the Interpretation of the American Declaration of the Rights and Duties of Man, stated that

...international legal instruments should always be interpreted in light of the normative framework in force at the moment the interpretation is done $^{397}$

The Inter-American Court further stated in Mayagna (Sumo) Awas Tingni Community v. Nicaragua 2001, has stated that:

\footnotetext{
${ }^{391}$ Appellate Body Report, China-Publications and Audiovisual Products, para.47 and 390, citing China's appellant's submission, paras. 170 and 173.

${ }^{392}$ Appellate Body Report, China-Publications and Audiovisual Products, para.83 and footnote 150.

${ }^{393}$ Appellate Body Report, China-Publications and Audiovisual Products, para.396.

394 Lennard, Michael, Navigating by the Stars: Interpreting the WTO Agreements, 5(1) Journal of International Economic Law, 17, p75-76.

${ }^{395}$ Tyrer $v$ UK, EHRR 2 1978, 1, p15.

${ }^{396}$ Loizidou v. Turkey, EHRR 23, 1997.

${ }^{397}$ Inter-American Court of Human Rights, in the matter of the Interpretation of the American Declaration of the Rights and Duties of Man, Advisory Opinion, 1989, para.37 (referring also to the South West Africa Advisory Opinion, ICJ Reports, 1971).
} 
...human rights treaties are live instruments whose interpretation must adapt to the evolution of the times and, specifically, to current living conditions. ${ }^{398}$

Evidently, this is a more teleological and less conservative approach to Article 31(1) of the VCLT, with less caution about the restrictions on interpretation and/or less fear about over-stepping than in the WTO context. The subject matter being dealt with by the other courts and systems (such as human rights) may also play a part in such less restrictive interpretive approaches. The European Court of Human Rights has not always adhered strictly to the rules of interpretation, especially where they conflict with the "ideals and values of a democratic society" or the 'European standard'. In Golder v UK, 1975:

In interpreting the Convention, regard must be had to its special character as a treaty for the collective enforcement of human rights and fundamental freedoms [...]. [T]hus the object and purpose of the Convention as an instrument for the protection of individual human beings require that its provisions be interpreted and applied so as to make its safeguards practical and effective [emphasis added]. ${ }^{399}$

It has been commented that Golder is "undoubtedly one of the most important cases in the history of the ECHR", not just for its extensive discussion of the VCLT but for taking a stance on the general theory of interpretation to be applied by the ECHR and the rejection of originalism, which was followed in later cases. ${ }^{400}$

However, the idea is often expressed that the WTO system is unlike other national or supra-national systems which may allow for greater activism in interpretation and extension of rights and duties of written covenants or constitutions. Therefore, when the issue of teleology is raised in connection with interpretation, it is looked at with some concern about overreach. Is this view related to the idea that the power of dispute settlement panels and the Appellate Body should be more limited? But to what extent is the role of a WTO panelist or Appellate Body member different in practice from Supreme Court judges, judges of a European Court or International Court of Justice or other international tribunals? This may be related to the role of the 'judiciary' in each of these systems. In some legal systems, the sovereignty of the people is expressly vested in the judiciary through the national constitution, and part of the task of the judiciary is to uphold constitutional fundamental rights and to be a check and balance on the powers of the executive and legislature. It is difficult to make a similar connection regarding experts appointed to panels and the Appellate Body, since they are not vested with any form of 'sovereignty of the people' (neither with regard to any particular nationality nor representative of the people of the world in general) and such experts are not expected to carry out the similar balancing of power functions, but a more mechanical task of interpreting the relevant agreements in the context of a dispute. Therefore, it can be argued that their role should be restricted and not extended any further from what it already is.

\footnotetext{
${ }^{398}$ Mayagna (Sumo) Awas Tingni Community v. Nicaragua, Inter-American Court of Human Rights, No. 79, 2001, Merits, Reparations and Costs. Judgment of January 31, 2001. Series C No. 79, para.146.

${ }^{399}$ Golder v United Kingdom, EHRR 1, 1975, 574.

${ }^{400}$ Letsas, George, Intentionalism and Interpretation of the ECHR in Fitzmaurice, M., Olufemi A. Elias and Panos Merkouris Eds., TREATY INTERPRETATION AND THE VCLT; 30 YEARS ON, BRILL Publications, 2010, p259. See further Letsas, George, A THEORY OF INTERPRETATION OF THE ECHR, Oxford University Press, 2007.
} 
This also opens up a further debate on the nature of the WTO agreements; whether they have a constitutional character and whether there can or ought to be compared with national or European Union constitutional structures. The WTO system has been referred to as an effort at constitutionalizing international trade. ${ }^{401}$ What different commentators mean by a 'WTO constitution' will differ; but one view, that of Deborah Cass, is that the Appellate Body is involved in something that is like a constitution-building exercise through its decisions. ${ }^{402}$ If indeed the WTO intends to have such a nature, one should not disagree with a general statement such as:

.... a treaty of a 'constitutional' character should be subject to somewhat different rules of interpretation so as to allow for the intrinsically evolutionary nature of a constitution. ${ }^{403}$

In a 'constitutional interpretation approach', teleology, the balancing of powers and the recognition of fundamental human rights would play a larger role in in interpretation. The lack of WTO text for fundamental rights and the difficulties in finding support for the inclusion of fundamental rights is being looked at in this study. The difference in judicial role of WTO panels and the Appellate Body that does not allow for either the text-based creativity of the European system or the English Common Law approach of interpreting rights into an "unwritten constitution", is a limitation that seems insurmountable. However, even if the comparison with other constitutional systems, their roots and their growth, will be side-stepped for the most part, it is likely that the interpretation of the terms of the WTO agreements will be, at least to some extent, evolutionary and contemporary.

It has been suggested by ICJ jurisprudence that while certain categories of treaties can be interpreted according to original intent, there are other categories of treaties that require an evolutionary approach. An example of a category of treaties that require an evolutionary approach are treaties that relate to environmental obligations. Judge Weeramantry in his Separate Opinion in the Danube Case argued that environmental issues being "live and continuing concerns" must be judged by current environmental standards, and not those of an earlier time when such treaty was created. ${ }^{404}$ Should the WTO Agreements be seen as within this category of treaties that require an evolutionary interpretation, like environmental treaties? Do WTO Agreements have any commonalities with environmental treaties? A very broad generalization could be put forward that trade

\footnotetext{
${ }^{401}$ See e.g. Jackson, John, H., The WTO 'Constitution' and Proposed Reforms: Seven 'Mantras' Revisited, Journal of International Economic Law (2001) 4 (1): 67-78; Ruggiero, R., The Multilateral Trading System at Fifty', Address to the Royal Institute of International Affairs in London, United Kingdom, 16 January 1998, available at www.wto.org/english /news e/sprr e/london e.htm last accessed 20.04.2012. See also Trachtman, Joel P., The Constitutions of the WTO, The European Journal of International Law Vol. 17 no.3, 2006, 623. See contra Howse, Robert and Kalypso Nicolaidis, Legitimacy and Global Governance: Why Constitutionalizing the WTO is a Step Too Far in Porter Roger B. et al., Eds., EFFICIENCY, EQUITY, AND LEGITIMACY: THE MULTILATERAL TRADING SYSTEM AT THE MILLENNIUM, Brookings, 2001.

402 Cass, Deborah, THE CONSTITUTIONALIZATION OF THE WORLD TRADE ORGANIZATION, Oxford University Press, 2005; Cass, Deborah, The 'Constitutionalization' of International Trade Law: Judicial Norm Generation as the Engine of Constitutional Development in International Trade, 12 European Journal of International Law 39, 2001.

403 Jennings, R. And Watts, A., OPPENHEIM'S INTERNATIONAL LAW, VOL.I, (9 ${ }^{\text {th }}$ Ed.) Oxford University Press, 2008, p1268.

${ }^{404}$ ICJ, Gabcikovo-Nagymaros (Danube) Case (Hungary v Slovakia) 1997 ICJ Reports para.114. See further, Greig, Don, The Time of Conclusion and the Time of Application of Treaties as Points of reference in the Interpretive Process in Craven, Matthew, Malgosia Fitzmaurice and Maria Vogiatzi Eds., TIME, HISTORY AND INTERNATIONAL LAW, Martinus Nijhoff Publishers, 2007, p205-206.
} 
treaties, being based on economic ideology, give an impression of being more fixed and rigid than science-and-value-based environmental treaties, which give an impression of growing along with new scientific knowledge and progressive societal values.

The issue is whether this broad generalization becomes a self-fulfilling prophesy for the WTO or whether it can be subverted through application of different interpretative approaches. The Appellate Body in Japan - Alcoholic Beverages II stated that the WTO rules are not entirely "rigid or inflexible", but need to be interpreted keeping in mind that "reasoned judgements" are needed for "confronting the endless and ever-changing ebb and flow of real facts in real cases in the real world". ${ }^{405}$ This ability to respond to the needs of the real world would not only serve the interests of the WTO system surviving and adapting into the future, but would address the concerns expressed about its negative consequences.

\subsubsection{A Teleological Approach to Interpretation?}

As can be inferred from the above, a debate that is related to the 'hierarchy-or-holistic' views on the Vienna Convention, is what can be named the 'textual-or-teleological' debate. Gardiner, for example, notes that the words of Article 31 of the VCLT itself can be seen as one that 'nicely balanced' the literal and teleological elements. ${ }^{406}$ Shaw has also noted that the VCLT rule of interpretation takes into account some measure of all three major doctrines of interpretation of international treaties, including the teleological approach. ${ }^{407}$ However, it has been noted by Ehlermann, a former member of the Appellate Body, that preference for a primarily textual or literal interpretation has been a feature of the WTO dispute settlement system, rather than a teleological approach which looks more to goals and purposes of the law and grants greater scope for judicial activism and creativity. ${ }^{408}$ Ehlermann's comments on the role of creative interpretation were in the context of European economic integration and the elaboration of the 'four freedoms' as showing greater scope for judicial activism. Commentators have noted that the European judicial organs have been less inclined than the WTO dispute settlement organs to rely on a textual interpretation - though they both say that they rely on the VCLT Rules. ${ }^{409}$

The International Court of Justice in one of its early cases also commented that:

\footnotetext{
${ }^{405}$ Appellate Body Report, Japan - Alcoholic Beverages II, p31.

406 Gardiner, Richard, TREATY INTERPRETATION, Oxford University Press, 2008, p80. See also Lennard, Michael, Navigating by the Stars: Interpreting the WTO Agreements, 5 (1) Journal of International Economic Law 2002, 17, p21-22 who says that while 'fundamentally textual', the VCLT approach attempted to balance stability with the flexibility of a teleological approach.

407 Shaw, Malcolm N., INTERNATIONAL LAW, 6 ${ }^{\text {th }}$ Edition, Cambridge University Press, 2008, p932933.

408 Ehlermann, C-D., Six Years on the Bench of the "World Trade Court", in Ortino, Federico and Petersmann, Ernst-Ulrich Eds. THE WTO DISPUTE SETTLEMENT SYSTEM 1995-2003, Kluwer Law International, 2004.

${ }^{409}$ See e.g. Slotbloom, Marco, A COMPARISON OF WTO AND EC LAW: DO DIFFERENT OBJECTS AND PURPOSES MATTER FOR TREATY INTERPRETATION?, Cameron May, 2006, p92.

It has been further elaborated that:

Teleological interpretation in EU law does not refer exclusively to a purpose driven interpretation of the relevant legal rules. It refers to a particular systemic understanding of the EU legal order that permeates the interpretation of all its rules.

(Poiares Maduro, Miguel, Interpreting European Law: Judicial Adjudication in a Context of Constitutional Pluralism, European Journal of Legal Studies, Vol.1, Issue 2, pg. 5, December 2007).
} 
...the first duty of a tribunal which is called upon to interpret and apply provision of a treaty is to endeavor to give effect to them in their natural and ordinary meaning in the context in which they occur. ${ }^{410}$

Irwin and Weiler also claim that in practice, text-and-context is privileged over teleology in the WTO context, which is only "grudgingly and sparingly" analyzed. ${ }^{411}$ Van Damme feels that this view is "too much of an abstraction" and thinks that teleology is expressed in the text and what is relevant is how the different elements "interact and are weighed against each other' ${ }^{412}$ These more recent analyses do not show any major change in the understanding of treaty interpretation since Sir Gerald Fitzmaurice identified three main schools of thought on the subject ${ }^{413}$ more than half a century ago and stated that

The ideas of these schools are not necessarily exclusive of one another, and theories of treaty interpretation can be constructed (and indeed are normally held) compounded of all three [emphasis added]. ${ }^{414}$

Of course, the interpretation must be based on the text, and is in the first instance at least, a literal interpretation of the text. It is reasonable to begin with a definition of the terms at issue. For reasons of objectivity, language dictionaries, ${ }^{415}$ or if necessary, dictionaries of a technical nature, ${ }^{416}$ are consulted.

Schaffer and Trachtman in a 2011 paper noted that 70\% (67 of the first 96) of Appellate Body rulings that they searched cited a dictionary with regard to the ordinary meaning of a term. ${ }^{417}$ Van Damme points out that there is no need to think that this is problematic, as dictionaries "represent an objective standard to counteract impressions of

${ }^{410}$ ICJ, The Competence of the General Assembly for the Admittance of a State to the United Nations case, ICJ Reports, 1950, p4, 8.

${ }^{411}$ Irwin Douglas A., and Joseph Weiler, Measures Affecting the Cross-Border Supply of Gambling and Betting Services (DS 285), 7 World Trade Review, 2008, 71, p90.

412 Van Damme, Isabelle, Treaty Interpretation by the WTO Appellate Body, European Journal of International Law, 2010, Vol. 21, no. 3, 605, p618.

${ }^{413}$ Fitzmaurice, G., The Law and Procedures of the International Court of Justice: Treaty Interpretation and Certain Other Points (1951) 28 B.Y.I.L. 1, the following schools of thought:

1 .'intention of the parties' or 'founding fathers'

2. 'textual' or 'ordinary meaning of the words'

3. 'teleological' or 'aims and objectives'

${ }^{414}$ Fitzmaurice, G., The Law and Procedures of the International Court of Justice: Treaty Interpretation and Certain Other Points (1951) 28 B.Y.I.L. 1

415 Usually the SHORTER OXFORD DICTIONARY, leading to some comments, in particular by Mavroidis, that it has become one of the covered agreements: (Mavroidis, P., No Outsourcing of Law? WTO Law as Practiced by WTO Courts, 102 American Journal of International Law, 2008, 421). Most recently the Appellate Body in China-Publications and Audiovisual Products, paras.354-356 discussed the Panel's references to dictionaries including reference in the Panel Report to THE AMERICAN HERITAGE DICTIONARY OF THE ENGLISH LANGUAGE.

416 Technical dictionaries were looked at in e.g. Panel Report, Mexico-Telecoms, paras.7.81-7.83 (NEWTON'S TELECOM DICTIONARY); Panel Report, China-Auto Parts, paras.7.660-7-661 (DICTIONARY OF AUTOMOBILE ENGINEERING, DICTIONARY OF TRADE POLICY TERMS (WTO, 2003), THE DICTIONARY OF INTERNATIONAL TRADE: THE HANDBOOK OF THE GLOBAL TRADE COMMUNITY and the Agency for International Trade Information and Cooperation (AITIC) GLOSSARY OF COMMONLY USED INTERNATIONAL TRADE TERMINOLOGY WITH PARTICULAR REFERENCE TO THE WTO; Panel Report on EC-Approval and Marketing of Biotech Products, para.7.372 (GLOSSARY OF BIOTECHNOLOGY FOR FOOD AND AGRICULTURE); Appellate Body Report, EC-Poultry, para.92 (DICTIONARY OF TRADE POLICY TERMS and the DICTIONARY OF INTERNATIONAL TRADE).

${ }^{417}$ Shaffer, Gregory C. and Trachtman, Joel P., Interpretation and Institutional Choice at the WTO, Oñati Socio-Legal Series, Vol. 1, No. 4, 2011, p115 (published November 28, 2011) 
arbitrariness". ${ }^{418}$ However, the Appellate Body has acknowledged that a dictionary is "is a useful stating point" and not the whole story - and that it can "leave many interpretive questions open". ${ }^{419}$ The reliance only on dictionary meanings has been criticised by the Appellate Body in US-Gambling as being too mechanical. ${ }^{420}$ Further, on the over-reliance on dictionaries the Appellate Body also noted in US-Gambling that dictionaries "cannot resolve complex questions of interpretation" as they typically aim to catalogue all meanings of words common or rare, universal or specialized - and that 'ordinary meaning' cannot therefore be equated with the dictionary meaning. ${ }^{421}$ In another dispute, the Appellate Body recalled that

...dictionaries are important guides to, not dispositive statements of, definitions of words appearing in agreements and legal documents. ${ }^{422}$

Thus, this exercise, which begins with recourse to dictionaries to first ascertain the 'plain meaning' of the text and then moves on to the 'ordinary meaning' in light of context, object-and-purpose, is explained by the Panel in EC-IT Products in the following manner:

...understanding the plain meaning of the text is the beginning of our inquiry and not the end. While we may organize our analysis of the ordinary meaning into different sections, for the sake of convenience, we remain cognizant that we are conducting an holistic analysis of the ordinary meaning and that the text of the terms cannot be divorced from the context and the object and purpose of the treaty ${ }^{423}$

It appears that the larger picture that would be seen in a more 'holistic' analysis should include identifying the goals of the relevant Agreement, taking into account even the broader goals of the WTO system itself.

For terms in WTO Agreements that have a parallel definition in human rights or environmental law contexts, and which can be relevant in the context of the exceptions, reference to specialized dictionaries, and glossaries could be done if the dictionary approach is to take account of specialized terminology. This would probably not be a case of application of Article 31(1) of the VCLT, but that of Article 31(4) of the VCLT:

A special meaning shall be given to a term if it is established that the parties so intended.

Since WTO Members also meet in other international conferences and negotiate agreements or prepare statements, declarations and outcome documents in other nonWTO contexts, ignorance of the other specialized areas and the terms used cannot be pleaded by Members. There ought to be some evidence that the particular special meaning of a term was intended by the parties to the WTO Agreement at issue.

It is relevant to point out that terms which developed in the human rights and environmental law context may be more clearly and authoritatively explained through a variety of other documents and expert analysis, than through a dictionary approach. For

\footnotetext{
418 Van Damme, Isabelle, Treaty Interpretation by the WTO Appellate Body, European Journal of International Law, 2010, Vol. 21, no. 3, 605, p624.

${ }^{419}$ Appellate Body Report, Canada-Aircraft, para. 153 and Appellate Body Report, EC-Asbestos, paras.9192.

${ }^{420}$ Appellate Body Report, US-Gambling, para.166.: ...to the extent that the Panel's reasoning simply equates the "ordinary meaning" with the meaning of words as defined in dictionaries, this is, in our view, too mechanical an approach.

${ }^{421}$ Appellate Body Report, US-Gambling, paras 164 and 166

${ }^{422}$ Appellate Body Report, US-Offset Act (Byrd Amendment), para.248.

${ }^{423}$ Panel Report, EC-IT Products, para.7.621.
} 
example, the General Comments by specialized treaty bodies, Special Rapporteurs Reports and Reports of specialized agencies such as the United Nations Development Programme (UNDP) or the World Health Organization (WHO) on the scope, content and application of certain human rights are more relevant than a dictionary on human rights terminology if a human right such as the right to health is to be defined for use in a trade law context (whether in general discussion or in the context of a dispute). With regard to principles of international environmental law and terms such as "sustainable development" that were created and evolved their meaning through The Brundtland Report, Our Common Future (1987), the Stockholm (United Nations Convention on the Human Environment, 1972) and Rio Declaration (United Nations Conference on Environment and Development 1992) and Agenda 21. Direct reference to these documents is the usual method of definition used by environmental law specialists, and not reference to dictionaries or even specialized legal dictionaries. The term 'right to health' is not specifically used in the WTO context, only 'public health' but 'sustainable development' is found in the Preamble to the WTO agreement. The holistic and teleological approach to interpretation, as opposed one that is reluctant to venture too far beyond the dictionary-based approach, is much more obviously relied on in contexts outside of the WTO (domestic courts, regional human rights courts or UN Committees with individual human rights complaints procedures) where human rights or environmental disputes have been raised and resolved.

An approach that takes teleology into account from the outset, and not as an afterthought, can be said to be closer to the ideal of a dynamic holistic approach as it takes object-andpurpose into account simultaneously with text-and-context. However, some commentators have doubted whether the VCLT method allows for a teleological interpretation as such, but only for the possibility of a more constrained teleological approach to 'object and purpose'. ${ }^{424}$ Yet this teleological approach can still go beyond an 'original intent' based interpretation to decide that the true interpretation of a treaty is what exists at the time of interpretation rather than at the time of its conclusion. This is referred to as 'the doctrine of emergent purpose', which is gathered from other evidence of change - such as other socio-legal developments outside of the treaty at hand. ${ }^{425}$

However, despite the attractiveness of such a teleological approach, it is also not without problems relating to its significance for alternate policy choices and other international legal regimes. Telos means a specific and goal, aim or purpose of a treaty or international organization, held in common by the state parties or members - and therefore a clear understanding of what the telos is essential for both the effective functioning of the organization as well as for the interpretation of the provisions of related agreements. Tomer Broude further adds that:

In a cooperative, 'Member driven' organization like the WTO, telos is doubly important because it provides a collective guiding beacon for the actions of disparate institutions and a diversely composed membership, a

\footnotetext{
${ }^{424}$ See Trachtman, Joel, The Domain of WTO Dispute Resolution, 40(2) Harvard international Law Journal 1999, 333, p360; Lennard, Michael, Navigating by the Stars: Interpreting the WTO Agreements, 5(1) Journal of International Economic Law, 17 p28-29. Lennard calls the object and purpose the entry point for a teleological approach and

... a headlight for illuminating and guiding the textual analysis, not a motor for driving its interpretation.

425 This has been acknowledged for some time already, see Jacobs, F. L., Varieties of Approach to Treaty Interpretation: With Special Reference to the Draft Convention on the Law of Treaties Before the Vienna Diplomatic Conference, 18 ICLQ 318, 1969, p319-320.
} 
general principle (if not a constitution) against which all positions, measures and decisions must be evaluated and justified. ${ }^{426}$

An explanation for the lesser acknowledgement of telos identified by Ehlermann and others who were comparing the WTO with experiences of the European Union or other more 'activist' courts, is that embracing creativity and new developments is related to the fact that a teleological approach or a teleological interpretation presupposes general agreement on telos - on a specific goal. Agreement on this specific goal e.g. European integration etc., is then a basis for interpretation. Thus, it can be said that agreement and clarity on the content of telos provides both stability and opportunity for growth. But it is questionable to what extent there was and is consensus on the telos of WTO agreements and whether the telos has actually shifted (in expression if not in actual intent) after the intense criticism against organization in its first few years.

Some commentators such as Broude, Howse and Nicolaides state that there is no doubt of the (original) pro-economic liberalization telos of the WTO. ${ }^{427}$ Howse also refers to a "telos of deep or ever deepening integration" but adds that Members' right to regulate, while limited, has been retained, and that its contours can be ascertained by reading the relevant provisions and exceptions as a whole. ${ }^{428}$ Cho comments that the GATT system had an anti-protectionist telos which was influenced by "[i]nternational Lochnerism freedom to trade without any local interference" but that the WTO goal of increased quality of life and prosperity also needs national regulation on behalf of non-trade social values. $^{429}$ Whether this 'original telos' which gives primacy to liberalization is satisfactorily balanced by other emerging social policy considerations that are also recognized within the WTO framework - and whether it is understood that opening of markets is a means to enhancing human welfare by contributing to equitable and

${ }^{426}$ See Broude, Tomer, The Rule(S) of Trade and the Rhetos of Development: Reflections on the Functional and Aspirational Legitimacy Of The WTO, 27(4) Columbia Journal of Transnational Law, 2006 at p26 citing the International Court of Justice, ICJ, Legality of the Threat or Use by a State of Nuclear Weapons, Advisory Opinion of July 8, 1996 (Preliminary Objections), request by the World Health Organization, at para. 19.

${ }^{427}$ Ibid Broude, p26:

The telos of the GATT/WTO has traditionally been quite clear - the goal of trade liberalization. Even when confronted with growing tensions with other legitimate policy goals, the centrality of this historical telos has never been questioned in earnest - indeed, the distinctiveness of the telos of trade in the GATT/WTO is the lightning rod that attracts much of the popular criticism raised against it by proponents of non-trade interests. The trade liberalization telos has so far also proven resilient in the face of claims that development and trade expansion are decidedly not one and the same.

Howse Robert and Kalypso Nicolaidis, Enhancing WTO Legitimacy: Constitutionalization or Global Subsidiarity? in Verweij, Marco and T. Josling Eds., DELIBERATELY DEMOCRATIZING MULTILATERAL ORGANIZATION, special issue of Governance Vol. 16, No. 1, 2003:

Economic freedom is understood as the telos of the WTO. Competing human values enter into the picture as narrow and carefully policed exceptions or limits to the overall constitutional project of freer trade.

See also Cho, Sungjoon. FREE MARKETS AND SOCIAL REGULATION: A REFORM AGENDA OF THE GLOBAL TRADING SYSTEM, Kluwer Law International, 2003, citing the strong 'pro-trade bias 'of the international trading system.

${ }^{428}$ Robert Howse, The World Trade Organization 20 Years On: Global Governance by Judiciary, 27 European Journal of International Law, 9 (2016), p45-46.

${ }^{429}$ Cho, Sungjoon, FREE MARKETS AND SOCIAL REGULATION: A REFORM AGENDA OF THE GLOBAL TRADING SYSTEM TOWARD A NEW INTERNATIONAL ECONOMIC LAW, Kluwer Law International, 2003, p68-70, citing Shell, G. Richard, Trade Legalism and International Relations Theory: An Analysis of the World Trade Organization, 44 Duke Law Journal 829, 906-7 for the term 'international Lochnerism'. 
sustainable development and not an end in itself - remains a matter of debate. There is a general concern that the focus on open markets elbows a development dimension that is more inclusive of other policy considerations out of the way. Supposing that it is agreed that the 'original telos' (if we can use such a term) is indeed so limited, does this mean that its interpretation necessarily has to be restricted thereby, or is it possible for the understanding of the telos to change with time? To what extent could the understanding be adjusted according to evolving understanding? It could be and is fairly often argued that 'development' is also a goal of the WTO, that Members agree on. Qureshi, for example, says that a telos of development already exists in the WTO, when reading the Preamble of the WTO Agreement together with other development-friendly text and provisions: and that therefore a restrained (not overly political) teleological approach supportive of development may be possible. ${ }^{430}$ As any 'ends and means' discussion relating to trade would have ideological implications, a teleological approach to interpretation of the WTO texts is commented on as justified more on political and philosophical grounds than on legal grounds. ${ }^{431}$ This makes it at the same time more attractive to activists and more problematic for the interpreter trying to figure out the boundaries of his task.

It can also be added that the mere acceptance of the term 'development' in the trade context does not presuppose an agreement on the definition or content of it. That is something that can be defined under other regimes of international law. The UN Declaration on the Right to Development of $1986^{432}$ has been followed by over a quarter century of work on the topic. The recent reaffirmation of the declaration by the Human Rights Council also called for the WTO to contribute further to the work of the Working Group and to cooperate with the High Commissioner on Human Rights with regard to the implementation of the right to development. ${ }^{43}$ However, working with other organizations and reference to these other regimes is an area where the WTO treads carefully and what extent there will be co-operation with and recognition of such parallel work in WTO interpretation is yet to be seen. A step made in that direction recently was when the WTO endorsed the Statement made by agencies of the United Nations system and other international organizations in support of policy coherence in the implementation of the right to development. ${ }^{434}$

An area where we might see a change in attitude about the telos of the WTO is the rhetoric surrounding the Doha Round. The Doha Ministerial Declaration (2001) linked

\footnotetext{
430 Qureshi, Asif H., INTERPRETING WTO AGREEMENTS, Cambridge University Press, 2006, especially P17-18, 44-46 and 117-159

${ }_{431}$ See Klabbers, Jan, AN INTRODUCTION TO INTERNATIONAL INSTITUTIONAL LAW, Cambridge University Press 2003.

${ }^{432}$ UN General Assembly, Declaration on the Right to Development, adopted by Resolution 41/128 of 4 December 1986.

${ }^{433}$ UN Human Rights Council, The Right to Development, Resolution A /HRC/RES/19/34, 11 April 2012, para.7.

${ }^{434}$ UN, Statement made by agencies of the United Nations system and other international organizations in support of policy coherence in the implementation of the right to development, 14 September 2011, Annex $\mathrm{V}$ of The Right to Development, Report of the Secretary-General and the United Nations High Commissioner for Human Rights, , 8 December 2011,A /HRC/19/45. Of particular interest is this statement: An effective global partnership for development, underpinned through human rightsbased policy coherence and coordination at all levels, is the very foundation for achieving the Millennium Development Goals and other internationally agreed development goals in an equitable and sustainable manner.
}

The red-line of the entire report is a rights-based policy coherence with regard to development. 
the Preamble of the WTO Agreement with positive efforts for sharing the benefits of the world trade system and recognizing the role of "balanced rules". Indeed, the Declaration even went so far as to say that:

The majority of WTO members are developing countries. We seek to place their needs and interests at the heart of the Work Programme adopted in this Declaration. ${ }^{435}$

The WTO Doha Ministerial Declaration of 2001 recalls the Preamble of the WTO Agreement and reiterates the need to make positive efforts such as "enhanced market access, balanced rules, and well-targeted, sustainably financed technical assistance and capacity-building programmes" 436 for developing and least developed Members. The Doha Ministerial Declaration is interesting in that it takes over the language of pro-poor development and absorbs it into the WTO regime.

With regard to services, the right of Members to regulate and introduce new regulations on the supply of services was reaffirmed in paragraph 7 of the Declaration. There is no specific reference to the role of services in development. Instead, paragraph 15 (services) of the Declaration refers, as expected, to the broad goals of economic growth and development that are the objectives of the WTO GATS as is "stipulated in the Preamble, Article IV and Article XIX of that Agreement". This could be read with paragraph 22 which mentions the work plan for the Working Group on the Relationship Between Trade and Investment and which notes that any framework should:

....reflect in a balanced manner the interests of home and host countries, and take due account of the development policies and objectives of host governments as well as their right to regulate in the public interest.

Investment can fall under GATS Mode 3 (commercial presence) when it concerns the establishment of a business by a service supplier from one Member in the territory of another Member. ${ }^{437}$ For future rules in this particular investment situation, the guidelines in the Declaration which highlight that development and public interest should be taken into account, could apply. There is no recognition of the importance of health services, but other matters which had garnered a lot of attention - environment and trade issues, core labour standards and access to medicine - are recognized in the Declaration. It is recognized in paragraph 6 , that Members have a right to protect health in the context of sustainable development and environmental protection - perhaps suggesting issues which would fall under GATT, SPS and TBT. Paragraph 17 stresses the importance attached to the implementation and interpretation of the TRIPS Agreement "in a manner supportive of public health"; something tackled in more detail in the Doha Declaration on TRIPS and Public Health ${ }^{438}$ and which ultimately led to a TRIPS amendment. Recognition of the importance of public services or public health services in the GATS context has not been articulated as clearly in the Declaration.

The promise of this round of negotiations has dulled by now and the Doha Round is criticized for providing only the rhetoric of 'development' and not providing any progress

435 WTO, Doha Ministerial Declaration 2001, WT/MIN(01)/Dec/1, 20 November 2001 (adopted on 14 November 2001), para.2.

436 Ibid.

${ }^{437}$ See further: De Meester, Bart and Dominic Coppens, Mode 3 of the GATS: A Model for Disciplining Measures Affecting Investment Flows?, in Drabek, Zdenek and Petros Mavroidis Eds., REGULATION OF FOREIGN INVESTMENT: CHALLENGES TO INTERNATIONAL HARMONIZATION, World Scientific Publishing Co. Pte. Ltd., 2013, p99-151.

438 WTO, Doha Declaration on TRIPS and Public Health, WT/MIN(01)/DEC/2, 20 November 2001 (adopted on 14 November 2001). 
or adaptation of the institution in support of broader development goals. ${ }^{439}$ The naming of the negotiations as the "Development Round" or "Development Agenda" has also been criticized as suggesting a developing Member-friendly image to an undeserved degree. Former World Bank Chief Economist Joseph Stiglitz has commented that:

Both as it was conceived, and even more as it has evolved, today's Development Round does not deserve its name. Many of the issues that it has addressed should never have been on the agenda of a genuine development round, and many issues that should have been on the agenda have not been ${ }^{440}$

The July Framework Package ${ }^{441}$ for future negotiations which followed in 2004 reiterated many of the same statements as the Doha Ministerial Declaration, but also confirmed processes such as the request-offer approach for GATS, which is seen as subjecting developing countries to increased bilateral pressure. There was also additional pressure created by calling for moving the process forward faster - despite the acknowledgment that developing and least developed countries do not have the same capacity to respond quickly to offers and develop their negotiating positions. ${ }^{442}$

At the $8^{\text {th }}$ WTO Ministerial Conference, (Geneva, December 2011) it seemed that negotiations were at a stalemate. The Trade Facilitation Agreement ${ }^{443}$ concluded at the $9^{\text {th }}$ WTO Ministerial Conference (Bali, December 2013) focused on Articles V, VIII and X of GATT 1994. Trade facilitation was not originally part of the Doha mandate but was included in the so-called 'Bali Package', where the issues of importance were identified as: public stockholding for food security and a set of issues of special interest to least developed countries including trade preferences, terms for operationalizing the LDC services waiver agreed at the 2011 Geneva ministerial and cotton subsidies. While one hand, the success of Bali in dealing with some development issues has been lauded, it has also been commented that beyond revitalizing WTO negotiations, the results have been overall disappointing on development issues and the path for their implementation. ${ }^{44}$ After more than a decade, it remains uncertain whether the Doha Round and the Bali developments have contributed or will contribute in the future towards re-evaluation and progress regarding a sustainable development telos of the WTO.

\footnotetext{
${ }^{439}$ See further for criticism of the gap between rhetoric and results, Broude, Tomer, The Rule(S) of Trade and the Rhetos of Development: Reflections on the Functional and Aspirational Legitimacy Of The WTO, 27(4) Columbia Journal of Transnational Law, November, 2006 at p28.

${ }^{440}$ Stiglitz, Joseph, The Development Round that Wasn't, Project Syndicate, 2005.12.07 available at: http://www.projectsyndicate.org/commentary/stiglitz65.

${ }^{441}$ The General Council Decision on the Doha Agenda Work Programme (The "July package"), as agreed on 1 August 2004,WT/L/579.

442 Oliva, Maria Julia, The Doha Work Programme: Still the Development Agenda?, CIEL Geneva, available at http://www.ciel.org/Publications/Doha_SDI12.pdf.

${ }^{443}$ WTO, Agreement on Trade Facilitation, Ministerial Decision of 7 December 2013, WT/MIN(13)/36, WT/L/911, $11^{\text {th }}$ December 2013.

${ }^{444}$ Bellmann, Christophe, The Bali Agreement: Implications for Development and the WTO, International Development Policy/Revue internationale de politique de développement 5.2 (2014), 20 May 2014, available online at http://poldev.revues.org/1744; Jatkar, Archana and Chenai Mukumba, Unpacking the Bali Package: A Snapshot of the Bali Ministerial Decisions of the WTO Members, Discussion Paper has researched and written for CUTS Centre for International Trade, Economics \& Environment (CUTS CITEE), CUTS International 2014, available online at http://www.cuts-citee.org/pdf/ Unpacking _ the_Bali_Package-A_Snapshot_of_the_Bali_Ministerial_Decisions_of the_WTO_Members.pdf.
} 
There is of course the example of the Appellate Body reference to the use of 'sustainable development' (from the Preamble of the WTO Agreement) in US-Shrimp, which is promising as a first step. It represents how WTO dispute settlement bodies could react to a situation where new meanings and concepts have become attached to words in the WTO agreements, due to those words being part of non-WTO law and practice between the parties. However, sustainable development was defined somewhat narrowly in a particular environmental sense only - the use of exhaustible natural resources - as that was all that was required in that context; and reference to the broader socio-economic development aspects of sustainable development were avoided.

The Appellate Body was not changing the trade-telos of the WTO agreements nor diluting it, nor expanding it to include new concerns not envisioned by the WTO negotiators. This is confirmed by the statement in US-Shrimp that such interpretation was only to add "colour, texture and shading" to the interpretation of WTO provisions, but not to add to their substance. ${ }^{445}$ It is also confirmed by the fact that the reference to the important international environmental law instruments - the Rio Declaration 1992 and Agenda 21 - were based on their being noted by the Decision on Trade and Environment and the Committee on Trade and Environment, and thus already had some measure of recognition in the system. ${ }^{446}$ In addition, the references in US-Shrimp to the CITES (the Convention on International Trade in Endangered Species of Wild Fauna and Flora, 1973) as support for the endangered nature of species of sea turtle was not contested by parties to the dispute, nor were the other references to international agreements: the UNCLOS (United Nations Convention on the Law of the Sea, 1982), the CBD (Convention of Biodiversity, 1992) and the Resolution on Assistance to Developing Countries, adopted in conjunction with the CMS (Convention on the Conservation of Migratory Species of Wild Animals, 1979). ${ }^{447}$ Thus it is fair to say that the step forward was regarding the evolutionary approach to interpretation of a term in the text ('exhaustible natural resources'); and that US-Shrimp is not evidence of the evolution of the 'sustainable development' telos in the WTO system.

It is perhaps also relevant that international human rights law and policy, which contains a core teleological view of 'human flourishing' ${ }^{448}$ can perhaps also be brought in to the interpretive exercise in the same manner - for an evolutionary approach to interpreting terms in the WTO agreements and perhaps also regarding the reevaluation of the development goals of the WTO. For example, the Preamble of the WTO Agreement recognizes that:

...relations in the field of trade and economic endeavour should be conducted with a view to raising standards of living.

This could be an entry point for other international law and principles relating to development, human rights and human flourishing. Furthermore, terms that require interpretation under Article XIV of the GATS, such as public morals or health, are also

\footnotetext{
${ }^{445}$ Appellate Body Report, US-Shrimp, para.153 and 155.

${ }^{446}$ Appellate Body Report, US-Shrimp, paras.153-154.

${ }^{447}$ Panel Report, US-Shrimp, para.7.58; Appellate Body Report, US-Shrimp, paras.25, 130 and 132.

448 See the views of Amartya Sen expressed in Sen, Amartya, INEQUALITY REEXAMINED, Oxford University Press, 1992. See further, Pogge, Thomas, Human Flourishing and Universal Justice, in Paul, E.F., F.D., Miller and J. Paul Eds.., HUMAN FLOURISHING, Cambridge University Press, 1999; Todd Peters, Rebecca, IN SEARCH OF THE GOOD LIFE: THE ETHICS OF GLOBALIZATION, Continuum International Publishing Group, 2006; Schwenke, Chloe, RECLAIMING VALUE IN INTERNATIONAL DEVELOPMENT: THE MORAL DIMENSIONS OF DEVELOPMENT POLICY AND PRACTICE IN POOR COUNTRIES, ABC-CLIO, 2009.
} 
used in non-WTO contexts and thus have a range of meanings that should be taken into account in interpretation by WTO dispute settlement bodies.

However, there can be another view on whether teleological interpretation or approaches would be useful. Some of those who wish to retain flexibility for choosing the end (e.g. sustainable human development) and the means (national policy) may actually prefer to keep teleological approaches out of the reckoning in WTO interpretation, as it could also be used to advance one particular type economic policy and governance and lessen space for alternative economic policy. Even if it is often stated that liberalization and the particular forms of economic policy proposed by the WTO system are only tools and not goals, both supporters and detractors would agree that the focus of the texts of WTO Agreements are on liberalization first and foremost. For example, if a teleological or purposive approach to interpretation of the GATS is applied, one is limited by the telos expressed for the WTO in general ${ }^{449}$ - and for the GATS in particular - which is primarily the desire to achieve the progressive liberalization of services. Sustainable development does not have a strong position in the WTO system as a goal: while it is included in the Preamble to the WTO Agreement, it is rarely supported by clear, enforceable provisions and lacks special institutional structures for promoting it or assessing its implementation. The final substantive Chapter of this study discusses this further and unpacks the special and differential treatment provisions for developing countries and LDCs and their operationalization. It can be argued that respect for national policy is not goal of the WTO as such but may be seen as a 'taking-into-account' aspect of methods of implementation; ${ }^{450}$ and this can suggest to some observers that there is an inherent incapability to balance it with trade liberalization.

Thus it is commented that a teleological approach is more relevant to the European context, where there is supposedly greater socio-political and economic policy commonality and where it has been relied upon less controversially and more creatively. ${ }^{451}$ The European system also has its own fundamental rights and social solidarity regime to balance the pro-market policies of the internal market regime, which

${ }^{449}$ See the Marrakesh Declaration of 15 April 1994, that the Ministers, representing the 124 Governments and the European Communities participating in the Uruguay Round are:

Determined to build upon the success of the Uruguay Round through the participation of their economies in the world trading system, based upon open, market- oriented policies and the commitments set out in the Uruguay Round Agreements and Decisions [emphasis added]

${ }^{450}$ It is also possible to argue that the since the Preamble to the WTO Agreement states that "the field of trade and economic endeavor...[should be done] in manner consistent with their respective needs and concerns at different levels of development" (Recital 1) as "objectives" (Recital 3) - that respect for national policy is an objective of the WTO system. However, the Preamble to the GATS only recognizes the "right of Members to regulate" (Recital 4) and takes particular account of "serious difficulties" faced by LDC Members (Recital 6).

451 Ehlermann, C-D., Six Years on the Bench of the "World Trade Court", in Ortino, Federico and Petersmann, Ernst-Ulrich Eds. THE WTO DISPUTE SETTLEMENT SYSTEM 1995-2003, Kluwer Law International, 2004; and Klabbers, Jan, AN INTRODUCTION TO INTERNATIONAL INSTITUTIONAL LAW, Cambridge University Press 2003. Also see Delmas-Marty, Mireille, THE EUROPEAN CONVENTION FOR THE PROTECTION OF HUMAN RIGHTS: INTERNATIONAL PROTECTION VERSUS NATIONAL RESTRICTIONS, Martinus Nijhoff Publishers, 1992, pp 290 and 292, citing the following statements by Judge Pescatore: ...the treaties establishing the Communities are steeped in teleology; and Judge Kutcher:

An interpretation based on the situation at the time of inception is totally ill-adapted to community law which looks to the future. 
the WTO does not have. National constitutions also have an inbuilt balance which the WTO system does not have except for perhaps the Preamble and exceptions clauses - that is, national constitutions usually have fundamental rights chapters to balance other rights and obligations. Furthermore, international human rights law provides a vision of individual human dignity and human flourishing - balanced by the limits necessary for a democratic society - and this has an innate teleological aspect.

Thus, teleological interpretation or approaches can be seen as both wings and a cage. Wings are clear for the above situations where there is, to mix metaphors slightly, a runway from which to take off. But the telos can also be a cage if the aims are too narrow, and thus it prevents the possibility of creative interpretation. If it is agreed that the WTO agreements have a limited view of development and means to achieve it, it can be cage rather than give wings to progressive interpretations.

\subsubsection{WTO GATS - not to be read in isolation from public international law?}

The WTO system is a specialized system focusing on international trade law as codified in the relevant WTO agreements, but it is part of the wider area of international law and has considerable overlap with and consequences for other aspects of international law. ${ }^{452}$ The nature of the relationship between these other areas of international law, especially international human rights law, and WTO law has been the subject of debate and disagreement. It is in the sharper details that the matter becomes problematic, although the larger picture, being a little blurred, shows greater congruence.

As former WTO Director General Pascal Lamy has put it:

...how could the WTO, created in 1994 by an international legal instrument, be immune to the rules of the general international law from which it derives its mission and its very existence ${ }^{453}$

And also, that:

...this integrated legal system [of the WTO] is not 'clinically isolated': there is a presumption of validity in international law and the rules of its treaties must therefore be read in harmony with the principles of international law...The WTO respects general international law, while at the same time adapting it to the realities of international trade. In joining the international legal order, the WTO has ended up producing its own unique system of law. ${ }^{454}$

Yet in the same paragraph, Lamy notes only some basic (it could be said, 'foundational') general concepts and impliedly, the VCLT rules on interpretation of treaties, as those that the WTO accepts as general public international law, and not anything from parallel regimes:

\footnotetext{
${ }^{452}$ See generally, Pauwelyn, Joost, CONFLICT OF NORMS IN PUBLIC INTERNATIONAL LAW: HOW WTO LAW RELATES TO OTHER RULES OF INTERNATIONAL LAW, Cambridge University Press, 2003.

${ }^{453}$ Lamy, P., Lamy: Globalization and trade opening can promote human rights, Speech given at the University of Geneva, 5 June 2009, available online www.wto.org/english/news_e/sppl_e/sppl128_e.htm, last accessed on 05.06.2009

${ }^{454}$ Lamy, P, The Place and Role of the WTO (WTO Law) in the International Legal Order Address before the European Society of International law, 19 May 2006, Sorbonne, Paris, available at www.wto.org/ english/news_e/sppl_e/sppl26_e.htm, last accessed 21.07.2011.
} 
Thus, the WTO legal order respects, inter alia, the sovereign equality of States, good faith, international cooperation, and the obligation to settle disputes peacefully, not to mention the rules of interpretation of conventions which the Appellate Body, for example, applies without hesitation.

However, there seems to be agreement, consolidated in the International Law Commission (ILC), that there cannot be 'self-contained regimes' immune to other aspects of international law, only specialized regimes within the larger system. ${ }^{455}$

An interesting metaphor of the modern situation of multilateral treaty-making and the reality of the work of government negotiators describes the interactions as "akin to a continuous dialogue in an open-plan office". ${ }^{456}$ McLachlan, in using this metaphor, says that therefore, modern treaty interpretation must also reflect this reality and have 'dialogue' between regimes. This metaphor is in the context of its comparison to the bilateral treaty-making process, which is described as "a series of distinct conversations in separate rooms". ${ }^{457}$ Whether this describes the realities of negotiation and bilateral and multilateral treaty-making is open for argument; but it at least underlines the element that it should not be possible in this open-plan office for international legal professionals to block their ears to areas of law beyond their particular specialization, even if one takes into account the possibility of 'office rivalries'.

Lamy's abovementioned statement also recognizes the trend that has already been acknowledged in the dispute settlement context of the WTO. The Appellate Body has clearly stated (in the context of the GATT 1994) that there is:

...a measure of recognition that the General Agreement is not to be read

in clinical isolation from public international law [emphasis added] ${ }^{458}$.

This has been usually applied in the context of interpretation of WTO law and cannot, according to Article 3.2 of the DSU be used to change substantive WTO rights and obligations. The latter is clearly rejected in Article 3.2 of the DSU, which states:

Recommendations and rulings of the DSB cannot add to or diminish the

rights and obligations provided in the covered agreements.

Yet the implications of this statement lead to speculation on possibilities of interactions between WTO law and other areas in public international law in general. ${ }^{459}$ The ILC has recognized that although a tribunal may have jurisdiction only with regard to a specific instrument or instruments,

\footnotetext{
${ }^{455}$ See, ILC/Koskenniemi, M., Study on the Function and Scope of the Lex Specialis Rule and the Question of 'Self-Contained Regimes, UN Doc. ILC (LVI)/SG/FIL/CRD.1/Add.1, 2004 at para.134; commenting that no such entities as "self-contained international legal regimes outside the framework of general international law" exist; also suggesting that 'special regimes' are a more appropriate term to be used for individual regimes. See also, Lindroos, Anja and Mehling, Michael, Dispelling the Chimera of 'SelfContained Regimes', International Law and the WTO, European Journal of International Law 2005 16(5):857-877.

${ }^{456}$ McLachlan, Campbell, The Principle of Systemic Integration and Article 31(3)(c) of the Vienna Convention, ICLQ 54 (2005): 279, p284 and at footnote 28 acknowledging indebtedness to William Mansfield for the metaphor.

457 Ibid (McLachlan).

458 Appellate Body Report, US-Gasoline, para. 16.

${ }^{459}$ See Ehlermann, C-D., Six Years on the Bench of the "World Trade Court", in Ortino, Federico and Petersman, Ernst-Ulrich Eds. THE WTO DISPUTE SETTLEMENT SYSTEM 1995-2003, Kluwer Law International, 2004, p510.
} 
...it must always interpret and apply that instrument in its relationship to its normative environment - that is to say 'other' international law [original emphasis]. ${ }^{460}$

The 'other areas' considered here are primarily environmental law and human rights, because these are the areas where there is most concern about the impact of trade rules and where a recognition of these other international rules and norms would be considered important by those who express these concerns. The recent Separate Opinion of Judge Trindade in the ICJ Whaling in the Antarctic case is an example for the recognition of the inter-relationship between different international agreements in the context of interpretation of international environmental obligations:

With the growth in recent decades of international instruments related to conservation, not one single of them is approached in isolation from the others: not surprisingly, the co-existence of international treaties of the kind has called for a systemic outlook, which has been pursued in recent years. [italics in original] ${ }^{461}$

A 'systemic outlook' on development in the WTO is a lot to hope for, and perhaps utopian. However, theoretically, if WTO law is not isolated from the rest of public international law, there should be some methods of achieving this or something similar.

It must be stressed at the outset, that the WTO dispute settlement will not decide on a violation of human rights, that being outside their mandate, but on violations of WTO law. But when deemed necessary for interpretation of WTO rules, it is argued by some, including Pauwelyn and Marceau, that relevant non-WTO rules of international law may be taken into account. ${ }^{462}$ Furthermore, the Preamble of the VCLT also notes that the State parties to the VCLT agree to those rules of treaty interpretation,

Having in mind the principles of international law embodied in the Charter of the United Nations, such as...universal respect for, and observance of, human rights and fundamental freedoms for all. ${ }^{463}$

Thus, other basic international law principles, such as human rights, can be described as backdrops to the trade narrative in the foreground. The suggestion is that this aspect should not be overlooked or forgotten and that the interpretation of trade rules should not ignore their existence nor should the interpreters become too shortsighted to see this larger context.

\subsubsection{Article 31(3)(c) of the VCLT: A Doorway or a Dead-end Street?}

When considering the relationship of WTO Law to public international law in general and more specifically, the relationship with other specialized regimes in international law, it

\footnotetext{
${ }^{460}$ ILC/ Koskenniemi, M., Report of the ILC Study Group, Fragmentaton of International Law: Difficulties Arising from the Diversification and Expansion of International Law. Doc.A/CN.4/L.682 and Add.1. and Corr. 1, 2 May 2006, para.423.

${ }^{461}$ ICJ, Whaling in the Antarctic (Australia v. Japan: New Zealand intervening), International Court of Justice, 31 March 2014 (separate opinion of Judge Trindade).

${ }^{462}$ See Pauwelyn, Joost, CONFLICT OF NORMS IN PUBLIC INTERNATIONAL LAW: HOW WTO LAW RELATES TO OTHER RULES OF INTERNATIONAL LAW, Cambridge University Press, 2003; Marceau, WTO Dispute Settlement and Human Rights, 2002, European Journal of International Law Vol. 13, No.4, p753.

${ }^{463}$ Preamble, Vienna Convention on the Law of Treaties, 1969 entered into force 1980.
} 
would be useful to look a little closer at Article 31(3)(c) of the VCLT. This has been sometimes referred to as a 'systemic integration clause'. ${ }^{464}$

31(3). There shall be taken into account, together with the context:

...(c) Any relevant rules of international law applicable in the relations

between the parties.

This can be considered an entry point for international law other than WTO law, in the WTO dispute settlement context. Howse says that:

In the context of "fragmentation" it is 31(3)(c) that is of most interest

since (a) and (b) refer to norms internal to the regime of which the treaty

being interpreted is part whereas (c) is clearly much broader. ${ }^{465}$

Koskenniemi, writing as part of the International Law Commission (ILC) Study Group on the Fragmentation of International Law, notes that Article 31(3)(c) of the VCLT requires an interpreter of a treaty to consider other treaty rules "so as to arrive at a consistent meaning", particularly where parties to a dispute are both also parties to another different treaty or treaties. ${ }^{466}$ This has been confirmed by the Appellate Body in EC and certain member States- Large Civil Aircraft. ${ }^{467}$

However, not all commentators on WTO interpretation seem to consider this Article of that much importance or that it should be given importance; and some commentators have noted its usefulness only more recently. Qureshi, for example, does not discuss the possibilities of Article 31(3)(c) in his 2006 study on WTO treaty interpretation. ${ }^{468}$ However, he includes a section identifying it as "an important focal point of an integrating mechanism" in his 2015 edition of the same book. ${ }^{469}$ Van Damme states that "the appeal" of the Article is "greater in theory than in practice" and of "limited value". ${ }^{470}$ Bruno Simma and Theodore Kill comment that "the impact of the rule on the interpretation of the treaty in dispute should be low" unless it supplies "operational guidance" for the interpretation of the terms of the treaty. ${ }^{471}$

There has also been up until recently, apparent reluctance by judicial bodies to use Article 31(3)(c) and there are only a few cases. ${ }^{472}$ The different approaches for using Article

${ }^{464}$ See e.g. Lim, C.L., Trade Law and the Vienna Treaty Convention's Systemic Integration Clause in Julien Chaisse, Tsai-Yu Lin Eds., International Economic Law and Governance: Essays in Honour of Mitsuo Matsushita, Oxford University Press, 2016, p107; McLachlan, Campbell, The Principle of Systemic Integration and Article 31(3)(c) of the Vienna Convention, ICLQ 54 (2005) 279.

465 Howse, Robert, The use and abuse of other "relevant rules of international law" in treaty interpretation: insights from WTO trade/environment litigation, NYU, IILJ Working Paper 2007/1, p2-3.

466 International Law Commission, Report of the Study Group of the International Law Commission, finalized by Martti Koskenniemi: Fragmentation of International Law: Difficulties Arising from the Diversification and Expansion of International Law, UN Doc. A/CN.4/1682, 13 April, 2006.

${ }^{467}$ Appellate Body Report, EC and certain member States-Large Civil Aircraft, paras.844-855.

${ }^{468}$ Qureshi, Asif H., INTERPRETING WTO AGREEMENTS, Cambridge University Press, 2006.

${ }^{469}$ Qureshi, Asif H., INTERPRETING WTO AGREEMENTS, Cambridge University Press, $2^{\text {nd }}$ Edition, $2015, \mathrm{p} 46$.

470 Van Damme, Isabelle, TREATY INTERPRETATION BY THE WTO APPELLATE BODY, Oxford University Press, 2009, p361-367.

${ }^{471}$ Simma, Bruno and Theodore Kill, Harmonizing Investment Protection and International Human Rights: First Steps Towards a Methodology in C. Binder et al Eds., INTERNATIONAL INVESTMENT LAW FOR THE 21ST CENTURY: ESSAYS IN HONOUR OF CHRISTOPH SCHREUER, Oxford University Press, 2009, p 696.

${ }^{472}$ The International Court of Justice considered Article 31(3)(c) of the VCLT in the Case Concerning Oil Platforms (Iran v US,) ICJ 2003; and the European Court of Human Rights did so in the following cases: Golder v UK 57 ILR 200, 1975 and more recently in Loizidou v Turkey 108 ILR 443, 1996, Al-Adsani v UK, 123 ILR 24, 2001, Fogarty v UK, 123 ILR 54, 2001, McElhinney v Ireland, 123 ILR 73, 2001 and 
31(3)(c) by the judges of the International Court of Justice in the Oil Platforms Case, which has been described as the probably the most "proactive" use of this provision, ${ }^{473}$ exemplify the that there is no agreement on the breadth of Article $31(3)(\mathrm{c}){ }^{474}$

A review of the approach to Article 31(3)(c) of the VCLT in WTO dispute settlement may give an idea of the direction in which panels and the Appellate Body could head towards with regard to the use of this Article. The Appellate Body in US-Anti-Dumping and Countervailing Duties (China), noted that Article 31(3)(c) of the Vienna Convention contains three elements:

1. "rules of international law";

2. the rules must be "relevant";

3. such rules must be "applicable in the relations between the parties". 475

It can be seen that the usefulness of Article 31(3)(c) for WTO interpretation would be limited by the fact that the precise nature of all of the above terms and phrases, as well as the phrase "take into account" - can be construed in a number of different ways. However, there is only minimal guidance on what these terms may encompass.

The Appellate Body in US-Anti-Dumping and Countervailing Duties (China) clarified some of the meanings for the purposes of WTO law, stating that "rules of international law" corresponds to the sources of international law listed in Article 38(1) of the Statute of the International Court of Justice. ${ }^{476}$ "Relevant" is identified as a requirement of concerning the "same subject matter" 477 - the latter of which is also a phrase which would also require a separate interpretation. ${ }^{478}$ It has been commented that there can be a wide scale of what is identified as "relevant" since "any rule of international law will be "relevant" when considered with the proper degree of abstraction". ${ }^{479}$ Thus, "same subject matter" is one way of limiting the possible scope of "relevant".

Bankovic v Belgium 123 ILR 94, 2001. The US-Iran Claims Tribunal also used the Article in Esphahanian v Bank Tejarat 2 US-ICTR 1983, 57.

473 Pulkowski, Dirk, THE LAW AND POLITICS OF INTERNATIONAL REGIME CONFLICT, Oxford University Press, 2014, p287-293.

${ }^{474}$ See the analysis of McLachlan, Campbell, The Principle of Systemic Integration and Article 31(3)(c) of the Vienna Convention, ICLQ 54 (2005) 279, p307-309,

${ }^{475}$ Appellate Body Report, US-Anti-Dumping and Countervailing Duties (China), paras.307-308

${ }^{476}$ Ibid., (US- $A D C D(C)$.

477 Ibid., (US- $A D C D(C)$. Also see approval for this in Appellate Body Report, EC and certain member States-Large Civil Aircraft, paras. 846-847; and Appellate Body Report, Peru-Agricultural Products, para.5.101. In Peru-Agricultural Products, it was raised during the appeal by Peru that the FTA between Peru and Guatemala and ILC Articles 20 and 45 were "relevant rules of international law applicable in the relations between the parties" under Article 31(3)(c) of the VCLT. The Appellate Body did not agree with Peru that the Panel had made an error in not considering these rules. The decision was based on the relevancy of the rules to the interpretation carried out by the panel and Appellate Body.

478 See Merkouris, Panagiotis, ARTICLE 31(3)(C) OF THE VCLT AND THE PRINCIPLE OF SYSTEMIC INTEGRATION, PhD Thesis, 2010, p152-153; commenting on the lack of clarity on the meaning and scope of "same subject matter" and discussing for comparison the travaux preparatoires of Article 30 of the VCLT, which has the title "Application of successive treaties relating to the same subject". Full text of the Thesis is available online at https://qmro.qmul.ac.uk/.../MERKOURIS Article\% 2031(3)(c)2010.pdf; also see Merkouris, Panagiotis, ARTICLE 31(3)(C) VCLT AND THE PRINCIPLE OF SYSTEMIC INTEGRATION: NORMATIVE SHADOWS IN PLATO'S CAVE, BRILL, 2015, p2122 .

${ }^{479}$ Simma, Bruno and Theodore Kill, Harmonizing Investment Protection and International Human Rights: First Steps Towards a Methodology in C. Binder et al Eds., INTERNATIONAL INVESTMENT LAW FOR THE 21ST CENTURY: ESSAYS IN HONOUR OF CHRISTOPH SCHREUER, Oxford University Press, 2009, p 696. 
The Appellate Body in US-Anti-Dumping and Countervailing Duties (China) also states that "applicable" means "cited as containing similar provisions to those in certain areas of the WTO Agreement" or "cited by way of contrast with the provisions of the WTO Agreement", and that if such a process had been carried out by panels and the Appellate Body in disputes, then the other rules had been "taken into account" in the sense of Article 31(3)(c). ${ }^{480}$ In another WTO dispute, EC and certain member States-Large Civil Aircraft, the Appellate Body states that the phrase "taking into account" represents the "normative weight to be ascribed" to the relationship between the WTO agreement being interpreted and the other rules of international law which are being considered. ${ }^{481}$ Hernandez notes that the validity of the result of interpretation is not limited to the factual situation that is being dealt with, "but carried normative repercussions for the legal order as a whole" including both the international and domestic plane. ${ }^{482}$ The Appellate Body recognizes this in EC and certain member States-Large Civil Aircraft referring to:

...the fact that Article 31(3)(c) of the Vienna Convention is considered an expression of the "principle of systemic integration" which, in the words of the ILC, seeks to ensure that "international obligations are interpreted by reference to their normative environment" in a manner that gives "coherence and meaningfulness" to the process of legal interpretation. ${ }^{483}$

The Appellate Body also specifically commented on the implications of recourse to a non-WTO rule for the purposes of interpreting a provision of a WTO Agreement as " $a$ delicate balance" which must be struck between:

...on the one hand, taking due account of an individual WTO Member's international obligations and, on the other hand, ensuring a consistent and harmonious approach to the interpretation of WTO law among all WTO Members. ${ }^{484}$

However, when "applicable in the relations between the parties" is interpreted, the significance given to an individual WTO Members' non-WTO international obligations, such as economic and social rights under the ICESCR, will need to be balanced with consistency in the interpretation of WTO law as applicable among all Members. As confirmed by the Appellate Body in EC-Chicken Cuts, this is because interpretation in the light of Articles 31 and 32 of the VCLT "must focus on ascertaining the common intentions of the parties". ${ }^{485}$

The phrase "applicable in the relations between the parties" was further interpreted in USAnti-Dumping and Countervailing Duties (China) as meaning a binding treaty obligation or a provision which reflects customary international law or general principles of law. ${ }^{486}$ In that dispute what was being considered was the applicability of several provisions of the ILC Articles on the Responsibility of States for Internationally Wrongful Acts.

\footnotetext{
${ }^{480}$ Appellate Body Report, US-Anti-Dumping and Countervailing Duties (China), paras.312-313.

481 Appellate Body Report, EC and certain member States-Large Civil Aircraft, para.841.

${ }^{482}$ Hernandez, Gleider, Interpretative Authority and the International Judiciary in Andrea Bianchi, Daniel Peat, Matthew Windsor, Eds., INTERPRETATION IN INTERNATIONAL LAW, Oxford University Press, 2015, p179.

${ }^{483}$ Appellate Body, EC and certain member States-Large Civil Aircraft, para.845.

${ }^{484}$ Appellate Body Report, EC and certain member States-Large Civil Aircraft, para. 845.

485 Appellate Body Report, EC-Chicken Cuts, para.240. See also Appellate Body Report, EC-Computer Equipment, para.109: "The purpose of treaty interpretation is to establish the common intention of the parties to the treaty". Also see Appellate Body Report, US-Anti-Dumping and Countervailing Duties (China), para,313; Appellate Body Report, US-Gambling, para. 160 Appellate Body Report, ChinaPublications and Audiovisual Products, para. 405.

${ }^{486}$ Appellate Body Report, US-Anti-Dumping and Countervailing Duties (China), paras.307-308.
} 
However, as noted by several commentators, there is no basis to insert an concept of' 'binding', which suggests a precise legal content, into the concept of 'applicability'. ${ }^{487}$ As noted by Broekhuijsen, several cases of the European Court of Human Rights (ECtHR)have applied non-binding, soft law instruments under Article 31(3)(c) of the VCLT, in interpreting rights and obligations under the European Convention on Human Rights (ECHR). ${ }^{488}$ The cases explicitly using Article 31(3)(c) in this manner referred to by Broekhuijsen are: Demir and Baykara v. Turkey (2008), which used soft law materials of the International Labour Organization (ILO), European Union recommendations and the European Social Charter; and Saadi v. United Kingdom (2008), which referred to the United Nations High Commissioner for Refugees (UNHCR) guidelines, Council of Europe recommendations and a recommendation of the UN Working Group on Arbitrary Detention. ${ }^{489}$ In Demir and Baykara it was specified by the Grand Chamber that use of such non-binding material and practice of States is allowed in so far as it reflects the parties" "common values" and "denote a continuous evolution" in the norms and principles and practices of a majority of member States "and show, in a precise area, that there is common ground in modern societies". ${ }^{490}$ Thus an evolutionary and teleological approach appears to be taken by the ECtHR, rather than a possibly time-bound 'common intention of the parties' approach.

Other ECtHR cases which suggest similar use, without explicit reference to Article 31(3)(c), are: Öneryildiz v. Turkey (2004), which used various non-binding instruments of the Council of Europe; and Oluic v. Croatia (2012), which used the non-binding WHO Guidelines for Community Noise. ${ }^{491}$ In a different paper, Tzevelekos, notes that $V v$. United Kingdom (1999) impliedly used Article 31(3)(c) by referring to the UN General Assembly's 'Beijing Rules' concerning the 'Standard Minimum Rules for the Administration of Juvenile Justice'; and Sigurjonsson v. Iceland (1993) used the UDHR, the Community Charter of the Fundamental Social Rights and the practice of the International Labour Office. ${ }^{492}$

Tzevelekos, comments that the critics of the ECtHR would "fear that the Court stimulates the so-called 'humanization' of international law"; but argues in favour of the Court's communication of its "humanistic telos" and its use of Article 31(3)(c) as an "anti-

\footnotetext{
487 Broekhuijsen, Dirk M., A Modern Understanding of Article 31(3)(c) of the Vienna Convention (1969): A New Haunt for the Commentaries to the OECD Model?, Bulletin for International Taxation, 2013 (Volume 67), No. 9, p4. See also Simma, Bruno and Theodore Kill, Harmonizing Investment Protection and International Human Rights: First Steps Towards a Methodology in C. Binder et al Eds., INTERNATIONAL INVESTMENT LAW FOR THE 21ST CENTURY: ESSAYS IN HONOUR OF CHRISTOPH SCHREUER, Oxford University Press, 2009, p 696.

${ }^{488}$ Ibid., (Broekhuijsen), p5-7.

489 Demir and Baykara v. Turkey, ECtHR, Judgement No. 34503/97, 12 November 2008; Saadi v. The United Kingdom, ECtHR, Judgement No. 13229/03, 29 Jan. 2008. Note however, that in Saadi the outcome was not favourable for the applicant and did not uphold his rights, since an exception was applied. The facts concerned whether there was arbitrary deprivation of liberty of an asylum seeker or whether a State is authorized to detain such persons under the ECHR. Also see Al-Adsani v. United Kingdom, ECtHR, Judgement 35763/97, 21 November 2001, where the ECtHR interpreted state immunity as legitimately restricting the applicant's right of access to justice under the ECHR.

${ }^{490}$ Demir and Baykara v. Turkey, ECtHR, Grand Chamber, 2008, para.85-86.

491 Öneryildiz v. Turkey, ECtHR, Judgement No. 48939/99, 30 Nov. 2004; Oluic v. Croatia, ECtHR, Judgement No. 61260/08, 20 May 2012.

492 Sigurjonsson v. Iceland, ECtHR, Judgement No. 24/1992/369/443, 30 June 1993.
} 
fragmentation tool". ${ }^{493}$ The approach of the ECtHR can also be criticized in that it does not appear to apply this provision consistently in favour of the human rights telos and that it has gone far beyond the accepted contours of "applicability" by including non-binding instruments created by human rights experts and used practice of other States which are not parties to the dispute at hand, as well as the practices of international organizations.

Linderfalk has commented generally on the scope of Article 31(3)(c) and the debates about its use, stating that only the stricter interpretation agrees with the clear ordinary meaning as well as with other data of interpretation, such as the context, the object and purpose of the treaty, and the preparatory work. ${ }^{494}$ However, it can be noted that the Shorter Oxford Dictionary, often cited by the panels and Appellate Body of the WTO, defines "applicability" as meaning:

1. able to be applied (to a purpose etc.)[original emphasis];

2. having reference, relevant;

3. suitable; appropriate. ${ }^{495}$

This would be a broader definition than the narrowing down that has been carried out by bodies such as the Appellate Body of the WTO in interpretation of this term thus far. Such a broader definition would allow for a wider range of international instruments to be referred to as pertinent in a WTO dispute and would not perhaps lead to the problems of the thorny issue of identifying "parties" since there would be less emphasis on the binding nature of "applicable". A broad interpretation based on the "evolving common values of modern society' would not require precise identification of the specific parties who have agreed to a specific binding rule. But this approach, while being possible to apply for the interpretation of provisions containing normative values in human rights treaties, would not be considered acceptable for the more precise obligations in a WTO Agreement.

It is the aspect of "applicable between the parties" which has been subject to most scholarly debate, particularly in the WTO context. The question is, if there is an assumption of "applicable" meaning binding law; whether applicable to the "parties" mean that the other treaty being applied for an interpretation under Article 31(3)(c) is (i) also ratified by the parties to the dispute or (ii) whether it requires that all parties which have ratified the first treaty being interpreted must also have ratified the second one or (iii) whether all parties can be bound because the second treaty rule is customary international law. The Panel in EC-Approval and Marketing of Biotech Products commented that since consideration of Article 31(3)(c) (other applicable rules of international law) "may prompt a treaty interpreter to adopt one interpretation rather than another", it "makes sense" to interpret that those other rules are those which are "applicable in the relations between all parties to the treaty which is being interpreted". 496

The Appellate Body in EC and certain member States-Large Civil suggested exercising caution with regard to "drawing from an international agreement to which not all WTO

\footnotetext{
493 Tzevelekos, Vassilis P., The Use of Article 31(3)(C) of the VCLT in the Case Law of the ECtHR: An Effective Anti-Fragmentation Tool or a Selective Loophole for the Reinforcement of Human Rights Teleology?, 31 Michigan Journal of International Law 621 (2010), p624-625.

494 Linderfalk, Ulf, 'Who are 'the parties'? Article 31(3)(c) of the 1969 Vienna Convention, and the 'Principle of Systemic Integration' Revisited, Netherlands International Law Review Vol. 55 Issue 3 (2008).

${ }^{495}$ NEW SHORTER OXFORD ENGLISH DICTIONARY, Clarendon Press, 1993.

${ }^{496}$ Panel Report,_EC-Approval and Marketing of Biotech Products, paras. 7.69-7.70.
} 
Members are a party" ${ }^{497}$ But the Appellate Body did not definitively state what "parties" suggested. Referring to academic debate on the term "parties" in Article 31(3)(c) it was noted that:

...the Appellate Body has made no statement as to whether [it] refers to all WTO Members, or rather to a subset of Members, such as the parties to the dispute. ${ }^{498}$

But, if the term comes to mean 'parties = all parties' to both the treaties being considered, this would mean, as commented by the ILC Study on Fragmentation, that the larger the membership of the multilateral treaty being interpreted, the less likely it is that other international law would be taken into account. ${ }^{499}$ Such an interpretation would be isolating the WTO, with its an increasingly larger Membership, from other international law. The following paragraphs discuss in more detail, the approaches taken by the panels and Appellate Body in instances where other non-WTO international agreements were referred to in the interpretation of WTO Agreements.

The Appellate Body in US-Shrimp seems, at first glance, to take a broad approach to the relevance of other international law in interpreting WTO law, in stating that it is:

...pertinent to note that modern international conventions and declarations

make frequent references to natural resources as embracing both living and non-living resources. ${ }^{500}$

The Convention on Biodiversity (CBD), the United Nations Convention on the Law of the Sea (UNCLOS), the Convention on the Preservation of Migratory Species of Wild Animals (Bonn Convention), Agenda 21 of the United Nations Conference on Environment and Development (the Rio Conference) and the Inter-American Convention for the Protection and Conservation of Sea Turtles were referred to by the Appellate Body. ${ }^{501}$ The fact that the Rio Conference, a significant milestone in the development of international environmental law and policy and the concept of sustainable development occurred in 1992, just prior to the conclusion of the Uruguay Round in 1993 and the Marrakesh Declaration and WTO Agreement of 1994, was obviously taken into consideration by the Appellate Body. However, Article 31(3)(c) of the Vienna Convention was not invoked. Instead, the interpretation was under Article 31(1), an evolutionary interpretation of the ordinary meaning of the words "exhaustible natural resources", taking into account the abovementioned developments that occurred since GATT 1947. Using Article 31(1) in this way makes Article 31(3)(c) somewhat superfluous. It should be noted however, that the panel in US-Shrimp (Article 21.5 Malaysia) expressly referred to Article 31(3)(c), and stated that other than the Bonn Convention, to which neither the US nor Malaysia were parties, all the above mentioned other agreements could be considered relevant rules of international law applicable between the parties. ${ }^{502}$

In EC-Hormones, the precautionary principle was raised by the $\mathrm{EC}$ as a general customary rule of international law or at least a general principle of law to be kept in

\footnotetext{
${ }^{497}$ Appellate Body Report, EC and certain member States-Large Civil Aircraft, para.845.

${ }^{498}$ Appellate Body Report, EC and certain member States-Large Civil Aircraft, para.844.

499 International Law Commission, Report of the Study Group of the International Law Commission, finalized by Martti Koskenniemi: Fragmentation of International Law: Difficulties Arising from the Diversification and Expansion of International Law, UN Doc. A/CN.4/1682, 13 April, 2006, para.237.

${ }^{500}$ Appellate Body Report, US-Shrimp, para.130.

${ }^{501}$ Appellate Body Report, US-Shrimp, para.168.

${ }^{502}$ Panel Report, US-Shrimp (Article 21.5 Malaysia), para.5.57.
} 
mind for the interpretation of obligations in the SPS Agreement. ${ }^{503}$ The Appellate Body disagreed with this approach and noted that the precautionary principle was not of such general application since it was explicitly expressed in Article 5.7 of the SPS Agreement, and therefore of more limited application and did not override the provisions of 5.1 and 5.2 of the SPS Agreement. ${ }^{504}$ The United States, in contrast to the EC, only conceded that the precautionary 'approach' existed and not that it was a principle of customary international law. But the Appellate Body did not refer to Article 31(3)(c) or even determine whether the precautionary principle was a customary or general principle of international law. The Appellate Body had only accepted that:

The precautionary principle is regarded by some as having crystallized

into a general principle of customary international environmental law [emphasis in original]. ${ }^{505}$

Thus, there was doubt cast on its general customary law status. Almost all international legal environmental law instruments since the Rio Declaration on Environment and Development of 1992 specifically include the precautionary principle, in the body of their text or at least in their preamble. ${ }^{506}$ These 'environmental' instruments are issues that impact the world in which we live, and emphasize that precautions must be taken in varied issues such as biosafety, conservation of fish stocks, use of certain chemicals (CFCs and POPs), anthropogenic climate change and generally for impact assessment in development planning. Limiting the precautionary principle to 'environmental law' is ignoring the fact that reference to the principle and the relevance of it for policy-making overlaps into broader development law and policy, technology, manufacturing and trade issues. Furthermore, the Appellate Body in EC-Hormones did not consider it necessary to specifically link biosafety or food safety with the environmental regime, which would have supported the use of a customary international environmental law principle for the issue of biosafety. This can be explained by the fact that the case was decided under the SPS Agreement, which deals with regulation aimed to address food safety risks and risks from plant and animal pests and diseases, not with environmental risks in general. But it is relevant to be aware that in terms of environmental treaty law, the Cartagena Protocol on Biosafety, which is founded on the precautionary principle (and includes it in the Preamble, Article 1, Articles 10.6, 11.8 and Annex III on risk assessment), is after all, a protocol to the Convention on Biological Diversity, an international environmental agreement.

\footnotetext{
${ }^{503}$ Appellate Body Report, EC-Hormones, para. 16.

${ }^{504}$ Appellate Body Report, EC-Hormones, paras.120-125. Note that Article 5.7 only allows for Members to "provisionally adopt" precautionary measures and requires seeking of "additional information necessary for a more objective assessment of risk [emphasis added]" and based on this, a review of the precautionary SPS measure "within a reasonable period of time".

${ }^{505}$ Appellate Body Report, EC-Hormones, para.123.

${ }^{506}$ Atapattu, Sumudu, EMERGING PRINCIPLES OF INTERNATIONAL ENVIRONMENTAL LAW, Transnational Publishers, 2006, p234-241. The relevant examples are Principle 11 of the World Charter for Nature (1982); the preamble of the Montreal Protocol on Substances that Deplete the Ozone Layer (1987); Principle 11 of the Rio Declaration on Environment and Development (1992); Principle 3 of Article 3 of the UN Framework Convention on Climate Change (1992); Article 6 of the Fish Stocks Agreement of 1995 (The United Nations Agreement for the Implementation of the Provisions of the United Nations Convention on the Law of the Sea of 1982 relating to the Conservation and Management of Straddling Fish Stocks and Highly Migratory Fish Stocks); the preamble and Article 1 (which specifically cites Principle 15 of Rio) of the Cartagena Protocol to the Convention on Biological Diversity (2000); Article 1 of the Stockholm Convention on Persistent Organic Pollutants (2001). See further at p242-266 for the acceptance of the precautionary principle in international and regional judicial bodies.
} 
The EC in their submission in EC-Approval and Marketing of Biotech Products, referred to the Cartagena Protocol on Biosafety and the precautionary principle. However, the Panel in this dispute did not take this major international agreement on biosafety into account, even if it was directly relevant to the subject matter of the dispute, genetically modified organisms. But, unlike the earlier disputes, Article 31(3)(c) was looked at. The Panel interpreted the words "applicable in relations between the parties" in Article $31(3)$ (c) of the Vienna Convention as requiring that if such a rule of international law is raised for interpretation, it should be one that is binding between all the parties of the treaty being interpreted. ${ }^{507}$ This is not an entirely satisfactory result from the view of this study, as it means that if the customary international law status of such 'other rule' is disputed or there is a consistent objector or if it is a treaty and a single WTO Member has not ratified it, that rule of international law cannot be considered in interpretation under Article 31(3)(c) of the VCLT.

The International Law Commission Study Group on Fragmentation has also criticised the narrow interpretation of the Panel in EC-Approval and Marketing of Biotech Products. ${ }^{508}$ While the ILC study group report approves that the Panel accepted Article 31(3)(c) as applying to rules of general international law and other treaties, it criticised the Panel's interpretation of "parties" in "applicable in the relations between the parties" as limited to all WTO members instead of just the parties to the dispute ${ }^{509}$ The ILC study group noted that the panel had justified this interpretation in order to ensure and enhance consistency and avoid conflict (in the WTO context) ${ }^{510}$ but that such an interpretation:

...makes it practically impossible ever to find a multilateral context where reference to other multilateral treaties as aids to interpretation under article 31(3)(c) would be allowed. The panel buys what it calls the "consistency" of its interpretation of the WTO Treaty at the cost of the consistency of the multilateral treaty system as a whole [emphasis added]. ${ }^{511}$

The ILC study group report also noted that such an interpretation had an "ironic effect", since the larger the membership was of a multilateral treaty such as the WTO, the less likely it would be that all Members/parties would have ratified another multilateral agreement, resulting in "the isolation of multilateral agreements as 'islands'..." . 512 The ILC study group report stated that this would have an "inappropriately restrictive effect" in precluding reference to treaties with a very wide acceptance (but not accepted in all

\footnotetext{
${ }^{507}$ Appellate Body Report, EC-Approval and Marketing of Biotech Products, paras. 7.67-7.71. See also Linderfalk, Ulf, Who Are 'The Parties'? - Article 31, Paragraph 3(C) of the 1969 Vienna Convention and the 'Principle of Systemic Integration' Revisited, Netherlands International Law Review, Volume 55, Issue 03, December 2008. Discussing the meaning of the term "the parties" in Article 31(3)c of the VCLT, Linderfalk notes that this has always been interpreted in the sense of all parties to the interpreted treaty. He reviews the literature on the alternative, broader interpretation of 'the parties' meaning the two or more parties to a specific dispute and concludes that only the former, stricter interpretation can be defended as being correct. Linderfalk argues that the ordinary meaning, context, the object and purpose of the treaty, and the preparatory work all support the stricter interpretation.

${ }^{508}$ International Law Commission, Report of the Study Group of the International Law Commission, finalized by Martti Koskenniemi: Fragmentation of International Law: Difficulties Arising from the Diversification and Expansion of International Law, UN Doc. A/CN.4/1682, 13 April, 2006.

509 Ibid., (ILC Report on Fragmentation, 2006), para.448, citing the Panel report, EC-Approval and Marketing of Biotech Products, para. 7.68.

510 Ibid., (ILC Report on Fragmentation, 2006), para.448, citing the Panel Report EC-Approval and Marketing of Biotech Products, para.7.70.

${ }^{511}$ Ibid., (ILC Report on Fragmentation, 2006), para.450.

512 Ibid., (ILC Report on Fragmentation, 2006), para.471
} 
respects as customary international law) and those which represent "the most important elaboration of the content of international law on a specialist subject matter". 513

The ILC study group report does not provide an argument on how and why a party to a treaty should be treated as bound by a non-customary rule they have not agreed to (e.g. a WTO Member such as the United States, which has not ratified the Cartagena Protocol) since they refer to the US-Shrimp example as one where the United States was bound by provisions of UNCLOS which were accepted as customary international law. ${ }^{514}$ Furthermore, the ILC study group's discussion on this issue is somewhat confused/confusing as in a later paragraph the US-Shrimp approach is described a takinginto-account of the extent of implicit acceptance or tolerance of the rule by the parties "in the sense that it can reasonably be considered to express the common intentions or understanding of all members as to the meaning of the ... term concerned". ${ }^{515}$ These argument could have been elaborated in further depth and clarity, but have remained vague in the ILC report. However, it is interesting that there is a comment on normative conflict and the weight which should be given to rights and obligations brought in under Article 31(3)(c): it is noted that this can only be argued on a case-by-case basis and that international law seeks the "accommodation" of values and not "the triumph of one norm over another". ${ }^{516}$ It has been commented that the ILC study group relied heavily on Pauwelyn's analysis of conflict of norms in its own analysis of fragmentation issues in international law and the WTO. ${ }^{517}$

The consequences of the EC-Approval and Marketing of Biotech Products approach on "parties" being 'all WTO Members', can affect consideration and accommodation of human rights in the WTO context, especially economic and social rights such as right to health. As the United States has not ratified the ICESCR, CEDAW or the Child Rights Convention (being one of very few countries in the world to refrain from doing so), then that would automatically exclude the right to health and the special consideration for women and children's health from WTO interpretation, if basing the reference to these rights on Article 31(3)(c). However, as seen in US-Shrimp, agreements to which some WTO Members are not a party can still be used for an evolutionary interpretation of terms according to Article 31(1) of the VCLT. The use of Article 31(1) or 31(3)(c) to integrate human rights norms into WTO law has not yet been tested but it remains a possibility that human rights norms can be considered 'applicable in the relations between the parties'. The role of soft law or non-binding norms is significant in both international environmental law and international human rights law, but there would be a narrower application if only 'binding' norms can be taken into account in the WTO context for an Article 31(3)(c) application.

\footnotetext{
${ }^{513}$ Ibid., (ILC Report on Fragmentation, 2006), para.471

514 Ibid., (ILC Report on Fragmentation, 2006), para.443 citing the Appellate Body Report, US-Shrimp, para. 130 .

${ }^{515}$ Ibid., (ILC Report on Fragmentation, 2006), para.472.

${ }^{516}$ Ibid., (ILC Report on Fragmentation, 2006), para.474, citing ICJ, Case concerning the Arrest Warrant of 11 April 2000 (Democratic Republic of the Congo v. Belgium) I.C.J. Reports 2002 (Joint separate opinion of Judges Higgins, Kooijmans and Buergenthal) pp. 86-87, para. 79.

Note that the ILC Study Group Report

${ }^{517}$ Pauwelyn, Joost, ILC Report on "Fragmentation" is out and favors close WTO-International law link, IELP Blog, September $28^{\text {th }} 2006$, http://worldtradelaw.typepad.com/ielpblog/2006/09/ilc_report_on_f.html.
} 
Howse, in contrast to Pauwelyn, ${ }^{518}$ says that the better interpretation is that the phrase "applicable in relations between" in Article 31(3)(c) of the VCLT is not about binding nature of the rule, but "the appropriateness of the norm to the matters in dispute". 519 Howse also refers to the ICJ Oil Platforms case ${ }^{520}$ in support of his view, noting that when the Court (Majority Judgement) made a brief mention of Article 31(3)(c) of the VCLT, it referred to rules "applicable to the question". This is a much preferable approach from a human right (and environmental) perspective. In making his argument, Howse brings out an interesting point that the panels and Appellate Body, in interpreting the SPS and TBT Agreements, have given "considerable legal force" to voluntary international standards created by bodies that are "often largely private in nature" and where not all WTO Members are participants and which could have different methods of arriving at decisions than in other multi-lateral forums. ${ }^{521}$ In contrast, international human rights (and environmental) law, both soft law and binding law have wide participation of a majority of States and often arise in large assemblies and conferences, usually also with NGO and civil society participation. The difference in the level of acceptance can be explained as due to the SPS and TBT Agreements including preambular recitals and provisions which explicitly refer to the importance of certain other international standards for harmonizing SPS measures and technical barriers to trade, ${ }^{522}$ whereas other international standard setting is not explicitly recognized in other WTO agreements in this manner.

One of the difficulties that need to be resolved, perhaps on a case-by-case basis if it ever arises, is the weight that is to be given to 'other' international rules, principles or norms. With regard to the issue of public health services, as mentioned earlier, a human rights approach and specifically, a right to health perspective can add weight to arguments in support of a Members' policies that promote these objectives. While there is reference to 'due respect for national policy objectives' within the GATS, it can be reasonably assumed that an additional human rights justification - national policy supported by international human rights law and norms - and brought through either Article 31(1) ('evolutionary ordinary meaning') or Article 31(3)(c) of the VCLT ("any relevant rules of international law applicable in the relations between the parties"), would put such policies in a stronger position. However, it may need to be kept in mind that, the other "relevant rules" looked at under Article 31(3)(c) have been described as rules that only have a "certain bearing on interpretation"" and "cannot possibly stand in the way" of the treaty

\footnotetext{
518 Pauwelyn, Joost, CONFLICT OF NORMS IN PUBLIC INTERNATIONAL LAW: HOW WTO LAW RELATES TO OTHER RULES OF INTERNATIONAL LAW, Cambridge University Press, 2003, p258262.

519 Howse, Robert, The use and abuse of other "relevant rules of international law" in treaty interpretation: insights from WTO trade/environment litigation, NYU, IILJ Working Paper 2007/1, p25.

With regard to the relevance of accepting economic and social rights as norms in domestic law when binding international rules are not available due to non-ratification of the ICESCR, see Piccard, Ann, The United States' Failure to Ratify the International Covenant on Economic, Social and Cultural Rights: Must the Poor Be Always with Us? Stetson University College of Law Research Paper No. 2011-04, also available online at SSRN: http://ssrn.com/abstract=1794303.

${ }^{520}$ ICJ, Case Concerning Oil Platforms (Iran v. United States), Merits, November 6, 2003 at para.42.

521 Howse, Robert, The use and abuse of other "relevant rules of international law" in treaty interpretation: insights from WTO trade/environment litigation, NYU, IILJ Working Paper 2007/1, p26.

${ }^{522}$ SPS Agreement: Preamble, recital 5 and 6; Article 3(Harmonization); Article 5.8. (Risk assessment); Article 12 (Administration). See also Annex A (Definitions), 3 and Annex B (Transparency of SPS Regulations) 5.c.

TBT Agreement: Preamble, recital 2, 3, 4 and 8; Articles 2, 4, 5, 6, 10, 12 and Annex 3.
} 
rules that are being interpreted. ${ }^{523}$ This was not stated by a WTO panel or Appellate Body but by the ICJ in the Djibouti case. Whether within WTO interpretation or in other areas of international law, achieving a balance between the different interests of parties to a treaty can be exceedingly difficult. In the WTO context, the Appellate Body in EC and certain member States-Large Civil Aircraft described this as a "delicate balance" to be achieved between an individual Members non-WTO obligations and consistency and harmony in the interpretation of the WTO obligations of all Members. ${ }^{524}$

Thus, ultimately, the impact of human rights on trade discourse depends on what exactly one means when one says that the GATS 'not to be read in clinical isolation' from the human rights regime. It is also important to consider whether human rights principles and standards can play a role in on-going trade negotiations, specifically in the development of human rights approaches in discussing the protection of non-trade objectives in the context of trade negotiations and how it may be applied in future disputes if such issues are raised. In the absence of reference to human rights in the process of negotiations of 'unfinished business' and no dispute where the current text has been tested and balanced $v i s-a$-vis a human right, the situation remains vague and open for conflicting arguments.

\subsubsection{A ‘Human Rights Approach’ to WTO Interpretation?}

Thus far there has been insufficient direct guidance and support at the international level and a lack of concrete suggestions with regard to how to bring in human rights into the interpretation of WTO law. Additionally, on closer observation, there are some further challenges facing proponents of a human rights approach to interpretation of WTO law. Some of the challenges, which will be termed in this study as problems of language, discourse or 'bilingualism' will be looked into in more detail later in this Chapter. The position that has been suggested at present is a 'human rights approach' to the interpretation and application of WTO rules. The idea of a 'human rights approach' sounds a little vague and fuzzy (or as Sen has said, 'soft' and 'mushy') ${ }^{525}$ compared to the (solid) mechanical and technical task of WTO interpretation.

The 'human rights approach' is a conceptual framework, normatively based upon international human rights standards and usually applied in the context of development. But it is often seen as a weak, fairly fluid, legal frame that can become dominated by variety of different political or ideological development models. Not all these models are compatible with each other, as there are different views on development: development as modernization, as dependency or non-dependency, Marxist theories on capital and labour or the neo-liberal view of development focusing on 'economic efficiency'.

Every organization in the field of development can have its own view of a human rights approach that has evolved in the context of its applied knowledge in its own field. ${ }^{526}$

\footnotetext{
523 ICJ, Certain Questions of Mutual Assistance in Criminal Matters (Djibouti v France), 2008, ICJ Reports, 177, para.114.

524 Appellate Body, EC and certain member States-Large Civil Aircraft, para.845.

${ }^{525}$ Sen, Amartya, Elements of a Theory of Human Rights, Philosophy \& Public Affairs, 32: 2004, 315-356, p315.

${ }_{526}$ The author is indebted to a number of discussions and seminars held over the years in Colombo, Sri Lanka - by the Marga Institute - Center for Development Studies, the Center for the Study of Human Rights (CSHR) - University of Colombo, the Center for Policy Alternatives, the Law and Society Trust, Health Action International Asia-Pacific, the Center for Womens Research (CENWOR), the International Center
} 
Alston has even noted a different 'ships passing in the night' situation with regard to human rights and the development model of the Millennium Development Goals (MDGs), which one would assume to be more aligned. ${ }^{527}$ In an attempt to link theory to practice, the Stamford Principles for UN Inter-Agency Common Understanding of 2003 mainstream human rights within the $\mathrm{UN}$ by emphasizing that all programmes of development in the UN system should further the realization of human rights. Meier and Gostin have recently critiqued the mainstreaming efforts within the UN, stating that there were inconsistent and varied approaches to human rights implantation and public health. ${ }^{528}$ Stephen P. Marks has identified a number of different categories to a human rights framework to development, one of them being the 'human rights approach'. The other approaches identified by Marks are based on: capabilities, responsibilities, social justice, the right to development, a human rights education approach and a holistic approach to development. ${ }^{529}$

What gives a human rights approach some structure and clarity is that making the fulfillment of human rights obligations the objectives of development means that it can be measurable: i.e. the indicators and data on nutrition, literacy, morbidity and mortality can be checked to measure how far the rights to food, education, health have been achieved. But a human rights approach to development can be defined as more complex than one that merely attends to such 'needs' - but can also have a broader approach that engages with more complex relationships of power structures and dynamics, and with formulating strategic development impact assessments that are both holistic and inclusive. ${ }^{530}$ The human rights approach thus moves away from looking at the underprivileged and disadvantaged in society as weak links needing 'charity' from the privileged and successful, to rights-holders who are participants, decision-makers and beneficiaries of

for Ethnic Studies, Environmental Foundation Limited, the Movement for National Land and Agricultural Reform (MONLAR) and the Weeramantry International Center for Peace Education and Research.

${ }^{527}$ See Alston, P., Ships Passing in the Night: The Current State of the Human Rights and Development Debate Seen Through the Lens of the Millennium Development Goals, Human Rights Quarterly 27(3), 2005, 755-829. Alston uses the same metaphor as Jackson (see Jackson, John H., Reflections on the Possible Research Agenda for Exploring the Relationship between Human Rights Norms and International Trade Rules in Frederick M. Abbott, Christine Breining-Kaufmann and Thomas Cottier Eds., INTERNATIONAL TRADE AND HUMAN RIGHTS: FOUNDATIONS AND CONCEPTUAL ISSUES, University of Michigan Press, 2006). Yet Alston does not discuss the dichotomies of human rights and trade discourse but that of human rights and the Millennium Development Goals (MDGs). Furthermore, he notes that although the MDGs have a great deal in common with human rights, the two agendas resemble ships passing in the night, even though they are both headed for very similar destinations.

${ }_{528}$ Meier, Benjamin Mason, and Lawrence O. Gostin, Human Rights for Health across the United Nations, Health and Human Rights 21.2 (2019): 199.

${ }^{529}$ Marks, Stephen P., The Human Rights Framework for Development: Seven Approaches, 2003 and The Human Rights Framework for Development: Five Approaches, 2001, published in the Working Paper Series of the Francois-Xavier Bagnoud Center of the Harvard School of Public Health (of which Marks was the Director).

See also, Marks, Stephen P., The Human Right to Development: Between Rhetoric and Reality, Harvard Human Rights Journal, Vol. 17, 2004, p137.

${ }^{530}$ However, note also the comments by Stephen Marks on regulatory objectives with regard to development in general, that:

The US is firmly opposed to the idea of regulating state behaviour to conform to the RTD

[Right to Development] or any elements thereof.

(Marks, Stephen P., The Human Right to Development: Between Rhetoric and Reality, Harvard Human Rights Journal, Vol. 17, 2004, 137, p150) 
development. A human rights-based society is one "which consciously chooses to respect the dignity of every human being so that none is left out". 531

Thus, the human rights approach also moves away from the utilitarian view that some must sacrifice in the same process by which some will benefit. In the trade context it seems that everyone must have faith that the WTO system will somehow reward this sacrifice, by bestowing economic gains from trade, which could, if there are appropriate government policies, perhaps be distributed (or 'trickle down'). Anne Orford, describing this attitude as "the theological form of trade agreements" that requires faith in the market and the choosing of WTO rules over societal values (and at times, over human life and health) - recalls the story of Abraham being willing to sacrifice his son Isaac to his God: and concludes that this represents the "tragic nature of responsibility in the face of the call to sacrifice". 532

An example of such 'sacrifice' with regard to health services can be found in the discussion by Preker and Harding of marketization and corporatization reform of hospital services. ${ }^{53}$ Preker and Harding respond to criticism of these reforms as being based in a "deep-rooted 'anti-market' value system" that expects "short-term wins". 534 While admitting that there are negative consequences of reforms on the poor without mitigating policies such as subsidies and that the corporatization of hospitals have a:

...high risk of being associated with some serious health, efficiency, equity and quality trade-offs,

- marketizing reforms are described as "subtle and not easily perceived by the public". 535 Again, there appears to be a view that the poor must make sacrifices based on faith in a market system that will perhaps someday provide an unknown, unexplained, indeterminate future benefit (probably to other indeterminate individuals), while corporations benefit monetarily, today. It is not even acknowledged in the above study

531 George, Susan, Globalizing Rights? in Gibney, Matthew J., Ed., GLOBALIZING RIGHTS: THE OXFORD AMNESTY LECTURES 1999, Oxford University Press, 2003, p17.

532 Orford, Anne, Trade, Human Rights and the Economy of Sacrifice in Orford, Anne, Ed., INTERNATIONAL LAW AND ITS OTHERS, Cambridge University Press, 2009, p175. The author is also indebted to a discussion conducted by Dr. Morag McDougall at the Institution for Globalization and International Regulation (IGIR), Faculty of Law, Maastricht University on 23.09.2008. Orford in her paper discusses the Appellate Body Report, EC-Hormones, where there was a discussion in the context of risk assessment under Article 5.1 of the SPS Agreement on whether there was a justification for constraining the market by regulating hormones in beef. The EC had (unsuccessfully) argued that even a risk evaluated by the US and Canada at one in a million, was sufficient justification to protect their population (Appellate Body Report, EC-Hormones, para.29). Orford's argument is that the results of the dispute show that faith in the benefits of non-regulation is prioritized over faith in the benefits of regulation (in the public interest) of private profit-seeking enterprises. However, it should be noted that in this particular dispute, it does not appear that sufficient evidence on the carcinogenic risks of beef hormones was placed before the Appellate Body.

Martti Koskenniemi also discusses 'Abraham's Lesson' in the context of a different issue, the legality of nuclear weapons: but what he says concerning the attitude of international lawyers' loyalty to the law and the courts and their bureaucratic attachment to legal technique as perpetuating "the illusion of the existence of a privileged (legal) rationality that is able to resolve any political conflict without becoming political itself" while abdicating personal responsibility, is relevant for trade law as well (Koskenniemi, M., THE POLITICS OF INTERNATIONAL LAW, Hart Publishing, 2011, p217).

${ }^{533}$ Preker, Alexander S, and April Harding Eds., INNOVATIONS IN HEALTH SERVICES DELIVERY: THE CORPORATIZATION OF PUBLIC HOSPITALS, World Bank, 2003, Introduction, p7-8. See also Harding, April and Alexander S. Preker Eds., PRIVATE PARTICIPATION IN HEALTH SERVICES, World Bank, 2003.

${ }^{534}$ Ibid., (Preker and Harding).

${ }^{535}$ Ibid., (Preker and Harding). 
that 'anti-market values' are not necessarily focusing on selfish short-term benefits, but could be based on a vision of a long-term, efficient and equitable system that provides a quality service. However, in the same volume, another chapter refers to 'anti-market' criticisms in a different way, noting that radical overhaul to health services in times of recession (referring here to Conservative/Republican-led reforms in UK, New Zealand and the United States during 1980s-1990s), was not followed in Western Europe "where social democratic values remained resilient". ${ }^{536}$ These values undoubtably include those of solidarity and human dignity, which requires that civilized societies create social welfare systems which ensure that everyone if cared for in situations of need and vulnerability.

In this context, how can the human rights approach, which would include these social values, be used for a more specific task - treaty interpretation; and within non-human rights treaties such as the WTO agreements? The WTO does not deny an overall development aspect and objective (it is included in the Preamble to the WTO Agreement and in the GATS), and this can be informed by the human rights approach to development. Can the human rights approach offer any specific solutions to interpretation of specific provisions of the WTO agreements? If a human rights or human dignity approach is used in interpreting the relevant provisions of an Agreement, could 'trade freedoms'/'freedom from regulation' be balanced with a human right such as the right to health - and could this lead to different outcomes in disputes?

This study focuses on instances where a human rights approach may be useful for the interpretation of the GATS - as human rights may reflect or confirm societal values and thus be useful support in a dispute where such an interpretation is key. In the context of services, with special emphasis on services such as health and education services, the Reports of the UN High Commissioner for Human Rights (UNHCHR) notes that a human rights approach to trade would, in determining whether a measure is trade-restrictive, seek for:

...consistency between the progressive liberalization of trade and the progressive realization of human rights...[and] encourages interpretations of GATS that are compatible with human rights ${ }^{537}$

The optimistic references to consistency between trade and human rights objectives gloss over methodology to achieve this as well as the possibility of un-resolvable conflict of disparate choices or the complex policies that may be needed for regulation that can provide a measure of both trade freedoms and health rights. A joint WTO SecretariatWHO (World Health Organization) study in 2002 on trade and health focusing on 'coherence' accepted that:

Policy coherence is easy to support in principle but hard to achieve in practice... Two divergent perspectives underlie the interface between trade considerations and health interests... These perspectives may cause

\footnotetext{
${ }^{536}$ Ham, Chris and Lorraine Hawkins, Implementing Organizational Reforms to Hospitals in the Public Sector in Preker, Alexander S, and April Harding Eds. INNOVATIONS IN HEALTH SERVICES DELIVERY: THE CORPORATIZATION OF PUBLIC HOSPITALS, World Bank, 2003, p85-86, commenting on 'dominant values' and citizens attachment to public health care.

${ }^{537}$ UN, Reports of The High Commissioner for Human Rights, Liberalization of Trade in Services and Human Rights, E/CN.4/Sub.2/2002/9, 25 June 2002.
} 
tension between 'trade people' and 'health people', and render coherence difficult. ${ }^{538}$

The study gives the example of Canadian inter-departmental work and the collaborations on the international level between the WTO and WHO as examples of how the problems raised by NAFTA and the WTO Agreement can be dealt with. The conclusions stressed the critical importance of 'constructive engagement'. Thus, the approach to 'coherence' did not extend much further than the idea that communication between agencies and institutions is a good thing; and this seems to be the common approach. ${ }^{539}$

The 1998 Background note on Health Services by the WTO Secretariat also stated clearly that:

Delegations are recommended to read it in conjunction with more detailed studies issued by international organizations such as the World Health Organization (WHO), UNCTAD, World Bank and OECD. ${ }^{540}$

Yet, despite this, the WHO, which applied for observer status at WTO General Council in June $1997^{541}$, only has ad hoc observer status in the Council for Trade in Services and the TRIPS Council (as well as observer status in the SPS Committee and the TBT Committee) ${ }^{542}$ In contrast, FAO and WIPO have observer status in the General Council and the International Telecommunication Union and the Universal Postal Union have been granted observer status in the Council for Trade in Services and the International Union for the Protection of New Varieties of Plants (UPOV) has observer status in the Council for TRIPS.

However, communication per se will not solve problems - it is the outcome of communication that could possibly do so. This first collaboration between the WTO and WHO was, quite fairly, criticized by Howse as 'disappointing' and 'misleading' with regard to the presentation of WTO law and the right to health. ${ }^{543}$ Furthermore, in this particular context, it is important to note that policy 'coherence' merely for its own sake can have the effect of diminishing the importance of the right to health, if the right to health is not prioritized by the parties involved in the collaboration. The above WTO/WHO joint study, although it ought to have set to rest the concerns about the WTO impacts on public health, refers to the need for trade-consistency of international health rules and that:

\footnotetext{
${ }^{538}$ WTO/WHO, The WTO Agreements and Public Health: A Joint Study by the WHO and WTO Secretariat, authored by Drager, N. and Miguel Rodríguez Mendoza et al., 2002, WTO Secretariat, para.282.

${ }^{539}$ See comments by Mary Robinson, former UN High Commissioner on Human Rights, that coherence is about 'reconciling distinct bodies of international law' as well as 'reconciliation of institutional divisions at a national level' - which 'sometimes amount to a virtual 'lobotomy', (Robinson, Mary, The Fifth Annual Grotius Lecture Shaping Globalization: The Role of Human Rights, American University International Law Review 19, no. 1 (2003): 1-26, p23). See also Wouters, Jan and Bart De Meester, Safeguarding Coherence in Global Policy-Making on Trade and Health: The EU-WHO-WTO Triangle, 2005, 2 International Organizations Law Review, p295.

${ }^{540}$ WTO, Background Note by the Secretariat, Health and Social Services, S/C/W/50, 18 September 1998, para.1.

${ }_{541}$ WHO, International Trade and Health, Report by the WHO Secretariat, EB 116/4, $28^{\text {th }}$ April 2005, para.5:

... but for reasons unrelated to WHO, to date this designation has not been made.

542 See www.wto.org/english/thewto_e/igo_obs_e.htm for the list of international intergovernmental observers. Last accessed 02.04.2012.

${ }^{543}$ Howse, R., The WHO/WTO Study on Trade and Public Health: A Critical Assessment, Journal of Risk Analysis, Vol.24, Issue 2, 2004, 501.
} 


\section{[t]rade input into health policy making could also increase policy} coherence [emphasis added]. ${ }^{544}$

Why not the other way around? It was also a matter of concern that the Report did not mention human rights at all, and the only mention of 'rights' was with regard to intellectual property. Compromising on health rights for the sake of 'free trade', without even an acknowledgement of the right to health or the health rights impacts of trade rules and negotiations does not reflect well on the possibilities for "coherence in policymaking' suggested by the joint study. The other WHO studies on the GATS that followed the joint study ${ }^{545}$ give more in-depth review of the law and assessments of policy options and negotiating positions as well as maintaining a right to health approach.

It is not a surprise that there is not much enthusiasm for a human rights approach from trade experts, and that the idea of 'coherence' slips into the realm of trade prioritization. Andrew Lang comments that framing the trade and human rights debate as a problem of coherence does little to change how trade policy is decided; instead, it assumes an understanding of the meaning and goals of the two regimes and adds another layer of policies to the established trade policies. ${ }^{546}$ This, when and if it happens, would be piecemeal and patchy, and having no effect on the status quo, rather than a radical resetting of the understanding on trade, human rights and development that can lead to any sort of dynamic and progressive change in the relationship between these concepts and their practical implementation.

Petersmann has noted in 2004 that:

WTO diplomats and WTO bodies have so far avoided official positions on proposals by the UN High Commissioner to adopt a 'human rights approach' to international trade. ${ }^{547}$

Petersmann rightly notes that even the Doha Declaration on TRIPS and Public Health makes no reference to human rights, although it was concerns about the right to health and its component access to medicines that had driven this political position and the move for amendment to the TRIPS Agreement. ${ }^{548} \mathrm{He}$ also adds that a 'human rights approach' would unduly complicate WTO negotiations' - essentially because more than 30 WTO Members including the United States have not ratified the ICESCR. The risk that human

\footnotetext{
${ }^{544}$ WTO/WHO, The WTO Agreements and Public Health: A Joint Study by the WHO and WTO Secretariat, authored by Drager, N. and Miguel Rodríguez Mendoza et al., 2002, WTO Secretariat, para.304.

545 WHO, David P. Fidler, Carlos Correa, Obijiofor Aginam, DRAFT LEGAL REVIEW OF THE GENERAL AGREEMENT ON TRADE IN SERVICES (GATS) FROM A HEALTH POLICY PERSPECTIVE, WHO, 2005; WHO, Chantal Blouin, Nick Drager, Richard Smith Eds., INTERNATIONAL TRADE IN HEALTH SERVICES AND THE GATS: CURRENT ISSUES AND DEBATES, World Bank and WHO, 2005.

${ }^{546}$ Lang, Andrew, WORLD TRADE LAW AFTER NEOLIBERALISM: RE-IMAGINING THE GLOBAL ECONOMIC ORDER, Oxford University Press, 2011.

${ }^{547}$ Petersmann, E-U., The 'Human Rights Approach' advocated by the UN High Commissioner for Human Rights and by the International Labour Organization: is it relevant for Law and Policy?, Journal of International Economic Law, 2004, Vol. 7, No. 3, 605, p607.

548 The Declaration on Public Health at the WTO Doha Ministerial in 2001 recognized that public health should have primacy over trade and that medicines cannot be treated like any other commercial product (WTO Doha Declaration on the TRIPS Agreement and public health, WT/MIN(01)/DEC/2, adopted on 14 November 2001 during the Doha Ministerial Conference, Ministerial Conference, Fourth Session, Doha, 9 14 November 2001, WT/MIN(01)/DEC/2). It was a political win which led to the WTO General Council Decision (2003) to allow export of pharmaceuticals under compulsory license and to the Amendment of the TRIPS Agreement (December 2005). This Amendment is not yet in force, as it still requires the minimum ratifications.
} 
rights could be abused for protectionist trade restrictions, resulting in less developed country Members preferring to keep labour and other rights separate from trade matters is also mentioned. But the most important point in Petersmann's analysis is probably the statement that just as 'market freedoms etc.,' are not referred to as essential conditions for the enjoyment of human rights in UN human rights conventions,

...so WTO law does not explicitly refer to respect and protection of

human rights as necessary means for realizing WTO objectives. ${ }^{549}$

However, it is admitted that human rights may be legally relevant context for the interpretation of WTO rules and further, that:

...rights of WTO Members to regulate, may be duties to regulate under

human rights law [original emphasis]. ${ }^{550}$

This is often true - but if the basis of measures contested under WTO law are in fact duties under human rights law, how will this be given due consideration in a dispute and are the available entry-points and pathways for this sufficient for a justification of such measures? This question is one that underlies much this particular study of the WTO GATS.

\subsubsection{Reference to Human Rights in GATT 1947 and WTO Disputes}

So far, panels and the Appellate Body have been able to avoid the phrase 'human rights' altogether in rulings, and the term itself is only mentioned in the text of a Report in ten disputes and only in particular types of situations. The usual circumstances where 'human rights' is referred to in WTO Reports is mainly two-fold: when the European Union refers to European Court of Human Rights decisions to support its arguments, usually analogies to matters of procedure and not substantive rights (in US-Continued Suspension, CanadaContinued Suspension, EC and certain member States-Large Civil Aircraft and USStainless Steel) and the references to unsolicited amicus curiae briefs presented by organizations with names containing the term - the Center for Human Rights and Environment and Conectas Human Rights in Brazil-Retreaded Tyres ${ }^{51}$ and the Center for Human Rights and the Environment in EC-Approval and Marketing of Biotech Products. ${ }^{552}$ There is also a convoluted situation where the Panel in Thailand in ThailandCigarettes (Philippines) ${ }^{553}$ refers to the International Law Commission (ILC) work on the lex specialis rule wherein the ILC cited Bankovic v Belgium from the European Court of Human Rights.

There are two situations which are different from the rest. The first is the unusual instance where the US mentions a European Court of Human Rights case in the un-adopted USTuna (EEC) (GATT Panel) citing Jens Soering $v$ United Kingdom, in support of a principle of extraterritorial interpretation of treaty provisions, ${ }^{554}$ which the EEC and the

\footnotetext{
${ }^{549}$ Petersmann, E-U., The 'Human Rights Approach' advocated by the UN High Commissioner for Human Rights and by the International Labour Organization: is it relevant for Law and Policy?, Journal of International Economic Law, 2004, Vol. 7, No. 3, 605, p608.

${ }^{550}$ Ibid., (Petersmann), p615.

${ }^{551}$ Panel Report, Brazil-Retreaded Tyres, footnote 4.

${ }^{552}$ Panel Report, EC-Approval and Marketing of Biotech Products, footnote 222.

${ }_{553}$ Panel Report, Thailand-Cigarettes (Philippines), footnote 1760.

554 The Soering case concerned a rule of extradition against sending persons to jurisdictions which impose the capital punishment, as well as Article 3 of the European Convention on Human Rights (to ensure that no one should be subjected to inhuman or degrading treatment or punishment). This was relevant for the arguments against extraditing a person from the United Kingdom to the United States, where the charge
} 
Netherlands denied, stating that the case only applied to a specific and long-standing rule of extradition law. ${ }^{555}$ This reference may be relevant for the reason that the possible extraterritorial application of human rights is a source of controversy, as will be discussed further below and in later Chapters in this study. The second situation is also a GATT dispute, Japan - Leather III, but this case was adopted. The dispute concerned quantitative restrictions on imported leather and the sole reason claimed by Japan was the desire to protect the Dowa people, a group that had been discriminated in Japanese society and for whom tanning was a traditional and symbolic industry. Japan in explaining the historical, cultural and socio-economic background of the case, refers to democratic reforms, particularly the Law on Special Measures for Dowa Projects and the Law on Special Measures for Area Improvement Project that was aimed at

...improvement of the living environment, enhancement of social welfare and public health, promotion of district industries, promotion of employment, improvement of education and cultural activities and protection of human rights. ${ }^{556}$

Although the Panel found that Japan's arguments were not sufficient to rebut the presumption that the quantitative restrictions on leather imports had nullified or impaired benefits to the United States under Article XI of the GATT, the panel 'took into account'

...the difficult socio-economic situation of the Japanese leather industry and the particularly sensitive problem of the Dowa population ${ }^{557}$

and suggested that, in light of this, the Council might wish to consider progressively eliminating these import restrictions. ${ }^{558}$

Broadly speaking, even from a human rights perspective, affirmative action measures for a disadvantaged group are expected to be phased out at some future date; but this phasing out should be associated with the disadvantaged group achieving social equality. It has been commented that Japan in this instance took a non-legalistic approach in relying on the facts about the Dowa population and expected this to have an effect on the outcome. The approach of Japan to trade disputes up to that time had been bilateral settlement of disputes and this was the first and only dispute to end up in a GATT Panel report. ${ }^{559}$

What happened in this particular instance may also have implications for how events will unfold in future WTO disputes. It may still be possible to come to an understanding outside of the existing trade rules based on the other trading partner accepting the importance of a domestic socio-economic arrangement. However, no Member can rely on this, especially as different societies may not subscribe to the same values or same respect for particular measures to implement particular values, and therefore they should be

was for a capital offence. This highlighted what is regarded by European law as lower standards regarding human rights in the United States, particularly the application of capital punishment. It is ironic that the US in US-Tuna (EEC) was citing Soering in support of the US position on extraterritoriality of environmental regulations.

${ }^{555}$ See para.3.17 and para.3.38 of GATT Panel report, US-Tuna II (EEC), for the arguments.

${ }^{556}$ GATT Panel Report, Japan-Leather III, para 21(v).

${ }^{557}$ GATT Panel Report, Japan-Leather III, para.43 and para.60.

${ }^{558}$ Interestingly, one of the members of the Panel in this dispute was the Sri Lanka representative to GATT and the United Nations, Mr. D. Jayasekera.

559 See Araki, Ichiro, Beyond Aggressive Legalism: Japan and the GATT/WTO Dispute in Matsushita, Mitsu and Dukgeun Ahn Eds., WTO AND EAST ASIA: NEW PERSPECTIVES, Cameron May, London, 2004; Gao, Henry S., Aggressive Legalism: The East Asian Experience and Lessons for China in Gao, Henry S. and Donald Lewis Eds. CHINA'S PARTICIPATION IN THE WTO, Cameron May, 2005. The above articles both discussed Pekkanen, Saadia M., Aggressive Legalism: The Rules of the WTO and Japan's Emerging Trade Strategy, The World Economy 24, 2001, p707. 
prepared with effective legal arguments and familiarize themselves with the available 'flexibilities'.

\title{
2.3.8. The Challenges of Incorporating Human Rights into WTO law
}

\author{
Rights of course are paradoxical things ${ }^{560}$
}

Whenever conversation turns to the ethics of globalization, it is not long before the language of human rights comes into play. It is however, language fraught with ambiguity. ${ }^{561}$

The broader canvas of the globalization debate begs the question whether an evolution from a 'rule-based Rule of Law' to a more 'value-based Rule of Law' is needed and whether at the heart of it, we can place the idea of an inherent human right to dignity. ${ }^{562}$ It is the age old tug between positivism and natural law perspectives on obedience to and the shaping of, existing law. At a more focused level, there are several challenges to be faced in incorporating specific human rights into WTO law. The major challenge for the purposes of this study is that, although recourse to human rights is an attractive argument to make, there is insufficient understanding and critique of the methods by which human rights can be brought into another specialized legal regime like the WTO system.

The other challenges are more theoretical, but also have an impact on the application of human rights or a human rights approach to WTO interpretation. The role of human rights in societal values protection could be a tool to ensure that values are guided or moderated by reference to 'higher', 'universal' norms and standards. This, it is hoped, could prevent societal values justifications being used by governments to further repressive and/or unfair policies that cause hardship for both their own citizens and others. For example: using societal values justifications to support censorship and/or blasphemy laws or to continue gender or other forms of discrimination which would be violations of the international legal standards on freedom of expression and right to information or the right to equality, equal protection of the law and non-discrimination, respectively. But even using human rights as a basis for policies can also have a different effect if it is with the motive of protectionism and/or used for political pressure in order to gain advantages in another area or for other geopolitical considerations. There is a problem between the idea of human rights as a tool for peace, security and human dignity - and the possibility of human rights being used as the basis for measures that, by restricting trade, may at the same time put these goals in doubt.

Thus, the ambiguity of human rights itself, in definition and application, can further confuse the situation because from a practical point of view human rights values can be seen as a double-sided sword and may not always cut the way one wants it to. In

\footnotetext{
${ }^{560}$ Schneiderman, David, Realising Rights in an Era of Economic Globalization in Shan, Wenhua, Penelope Simon and Dalvinder Singh Eds., REDEFINING SOVEREIGNTY IN INTERNATIONAL ECONOMIC LAW, Hart Publishing, 2008, p429.

${ }^{561}$ Lee, Daniel E., and Elizabeth J. Lee, HUMAN RIGHTS AND THE ETHICS OF GLOBALIZATION, Cambridge University Press, 2010, p3.

562 Tung, Ko-Yung, Shaping Globalization: The Role of Human Rights - Comment on the Grotius Lecture by Mary Robinson, International Law Review 19, no. 1 (2003): 27, p42-43. Also available as American Society of International Law's (ASIL) 97th Annual Meeting on April 2, 2003, available online at www.auilr.org/pdf/19/19-1-2.pdf, last accessed 02.04.2012.
} 
international affairs, there is always a possibility that human rights will be used as an excuse for furthering other political or economic goals. Human rights violations could also be used as a basis for trade sanctions, and in the WTO context, use of such sanctions by a Member could be justified as an application of the public morals exceptions available under Article XX(a) of the GATT or Article XIV(a) of the GATS. For example, human rights violations in the territories of other Members, such as restrictions on freedom expression (especially media freedom), the right of peaceful assembly, electionrelated violence or racial, religious, political opinion, gender or sexual orientation-based discrimination, have been brought into matters of trade negotiations. ${ }^{563}$ If such human rights violations are used as a basis of differential treatment to other WTO Members and such use is deemed acceptable in WTO law as an extraterritorial application of public morals, the consequences can also be deemed undesirable from a human rights perspective. The result may be both a denial of trade freedoms as well as a violation of economic and social rights of citizens of that WTO Member when a particular industry or that national economy has to face with inability or difficulty to trade. It can even have a spill-over effect to other 'innocent' economies, as is normal in global trade.

In the UN context, the Committee on Economic, Social and Cultural Rights (CESCR) in General Comment No. 8 (1997) on The Relationship between Economic Sanctions and Respect for Economic, Social and Cultural Rights noted that while the UN Charter authorizes sanctions for violations of international law (including serious violations of human rights), human rights can in turn be violated through the imposition of sanctions and that it is necessary:

\footnotetext{
563 Regarding gender in trade negotiations, see: Zarrilli, Simonetta, The Gender Chapters in Trade Agreements: A True Revolution?, 14 November 2017, https:/www.ictsd.org/opinion/the-gender-chaptersin-trade-agreements-a-true-revolution commenting on the mainstreaming of gender equality and inclusion of gender-related capacity-building mechanisms features in FTAs such as EU-Mexico global agreement and calls for promotion of gender equity in fisheries in the EU-EAC economic partnership agreement (The East African Community - Burundi, Kenya, Rwanda, Tanzania, and Uganda). She also notes gender chapters of the recent Chile-Uruguay FTA (2016) and the Canada-Chile FTA (2017) which refer to the implementation of gender equality obligations under international conventions. (Zarrilli is Chief, Trade, Gender and Development Programme, UNCTAD). Also see Frohman, Alicia, An opportunity for a gender equality focus in trade policy?, 16 November 2018, https://www.ictsd.org/opinion/an-opportunity-for-a-genderequality-focus-in-trade-policy,who in addition to the abovementioned trade agreements also noted the gender chapter in the Canada-Israel FTA (2018). See further: Frohman, Alicia, Gender Equality and Trade Policy, World Trade Institute Working Paper No. 24/2017, December 2017; Kenny, Charles and Megan O'Donnell, Making Global Trade More Gender-Inclusive, February 6 2017, Center for Global development, https://www.cgdev.org/publication/making-global-trade-more-gender-inclusive, commenting that "[c]ountries seeking to enter into bilateral trade agreements can negotiate pre-ratification reforms and treaty language related to women's rights".

See further on LGBT issues: the new proposed United States-Mexico-Canada Agreement (2018) included provisions (Articles 23.9 and 23.1(5)(1)(i))on employment discrimination on the basis of sexual orientation and gender identity, which were resisted by conservatives in both countries; and the Declaration of the ACP Parliamentary Assembly on Recent Proposals adopted by the European Parliament with regard to Uganda and Nigeria (2014) condemning the European Parliament Resolution of 13 March 2014 on initiating consultations to suspend Uganda and Nigeria from the Cotonou Agreement in view of new legislation in those two countries further criminalizing homosexuality (http://www.acp.int/content/declaration-acpparliamentary-assembly-recent-proposals-adopted-european-parliament-regard-u). The EU and ACP countries began negotiations on a successor to the Cotonou Agreement in 2018 and the issue of inclusion of provisions on LGBT rights continues. In 2018 a Joint Motion for a Resolution on Tanzania was tabled at the European Parliament (2018/2969(RSP)), condemning recent repression and calling on Tanzania to repeal laws criminalizing homosexuality and making reference to obligations under the Cotonou Agreement.
} 
...to draw attention to the fact that the inhabitants of a given country do not forfeit their basic economic, social and cultural rights by virtue of any determination that their leaders have violated norms relating to international peace and security. The aim [of this General Comment] ....is to insist that lawlessness of one kind should not be met by lawlessness of another kind which pays no heed to the fundamental rights that underlie and give legitimacy to any such collective action. ${ }^{564}$

The use of human rights language can thus be seen to cause a different set of problems if we accept that there is an imbalance of power in international relations and the power to create, use and interpret human rights rules and norms - similarly to trade rules - would be in the hands of a limited number of States, non-governmental groups and individuals. In a personal conversation the author had with a developing country trade representative, there was immediate recoil against the suggestion of using human rights as a basis for national policy flexibility, as the immediate assumption was that using human rights language is of no advantage in furthering a developing country's interests. Instead, human rights/morals, especially their extraterritorial application, is what developed countries are thought to do, to attempt to deprive a developing country of any preferential treatment under existing trade rules, to neutralize any small comparative advantage or to generally undermine the ability to compete in the international market. Whether this is truth or paranoia, in practice this assumption undermines the recourse to human rights language in instances where such language could have been used to advance rights-supportive national policies. But, the fear of domestic politics using such a linkage between human rights and trade to advance other agendas should be placed in the context that there is no trade-related agenda that is free from "priorities with political significance". 565

The application of the broader interpretative approaches mentioned above could allow for extending national law and policy measures beyond the national territory to be applied extraterritorially to other Members. While this is seemingly a violation of the sovereignty of such other WTO Members, justification for this may be sought in emerging norms of international law in non-WTO contexts such as human rights and the environmental law, as well as within the WTO context itself. The desirability of this is in question and it also something that is debated in the non-WTO context as well as in the discussion on the relationship between the WTO and other international law. In the WTO context, there is no explicit prohibition on extraterritorial measures, but in instances where a disputed measure was applied extraterritorially, the panels and Appellate Body have not supported the position that extra-territorial measures can be justified under the exceptions. ${ }^{566}$

Another matter that complicates the issue of recourse to human rights is that what a particular human right means in practice in one national jurisdiction may be different from how it is in another. But at the same time human rights aspire for universalism. In

\footnotetext{
564 The Committee on Economic, Social and Cultural Rights, General Comment No. 8 (1997), The Relationship between Economic Sanctions and Respect for Economic, Social and Cultural Rights, E/C.12/1997/8, para.16.

${ }^{565}$ Leader, Sheldon, Trade and Human Rights II in Macrory, Patrick, F. J., Arthur E. Appleton and Michael G. Plummer Eds., The WORLD TRADE ORGANIZTION: LEGAL ECONOMIC AND POLITICAL ANLAYSIS, VOLUME II, Springer, 2005, p695.

${ }^{566}$ See Van den Bossche, Peter, THE LAW AND POLICY OF THE WORLD TRADE ORGANIZATION: TEXT, CASES AND MATERIALS, Cambridge University Press, 2nd Edition, 2008, p619, noting that the Appellate Body in US-Shrimp avoided answering the question whether there is an implied jurisdictional limitation in Article XX(g) of the GATT (para.133) and that the Panel in EC-Tariff Preferences implied that extraterritorial measures could not be justified under Article XX(b) of the GATT (para.7.210).
} 
the European context, the 'margin of appreciation' doctrine, developed from administrative law concepts in European civil law systems, has been resorted to for this issue in the jurisprudence of the European Court of Human Rights (ECHR) and in EU law. The criteria for the application of the margin of appreciation (and the related principle of proportionality) have been developed over time through the cases before the ECHR, the first of which was Handyside v. The United Kingdom, ${ }^{567}$ decided in 1976. However, the margin of appreciation doctrine is given less significance in other international human rights contexts outside of Europe. Benvenisti states firmly that:

Margin of Appreciation, with its principled recognition of moral relativism, is at odds with the concept of the universality of human rights. ${ }^{568}$

Explicit use of the doctrine has generally been avoided by the committees of human rights bodies such as the decisions of Human Rights Committee (HRC) of the ICCPR in individual complaints procedures, and in their General Comments (interpretive guidance on implementation of the rights in the relevant Covenant or Convention). Keller and Grover note that the margin of appreciation in HRC decisions has been only in the case of the interpretation of the scope of the 'public morals' limitation on freedom of expression, the regulation of the presence of non-citizens on a territory and the scope of the right to family. ${ }^{569}$ As can be noticed, there may be similar issues raised about the extent of national policy space with regard to the first two instances, in WTO law as well. The 'public morals' exception in Article XIV of the GATS shall be discussed in further detail in Chapter 5 of this study.

Thus, it seems that asking how much divergence is possible or desirable in a national context ${ }^{570}$ is similar to the question about how much policy flexibility ought to be allowed in the WTO context. An interesting example with regard to investor-State relations is presented by David Schneiderman regarding South Africa's program of building up indigenous economic empowerment as part of their constitutional commitment to socioeconomic rights and to correct the inequalities created by apartheid. Schneiderman refers to this policy as a 'promotion-of-equality exception' and adds that States 'should be entitled to experiment in these ways' to 'generate a modest counter-narrative' to dominant economic models. ${ }^{571}$ This example includes an important exception from constitutional equality in human rights (affirmative action to correct past systemic injustice), as well as suggesting that international economic law ought to recognize this kind of exception in

\footnotetext{
${ }^{567}$ Handyside v. The United Kingdom, 5493/72, ECHR 5, 7 December 1976, para 48-49. Note that this doctrine is essentially judge-made

${ }^{568}$ Benvenisti, Eyal, Margin of Appreciation, Consensus and Universal Standards, International Law and Politics, Vol 31, 1999,843, p844.

${ }^{569}$ Keeler, H. and Leena Grover, General Comments of the Human Rights Committee and their Legitimacy in Keller, H. and Geir Ulfstein Eds., UN HUMAN RIGHTS TREATY BODIES: LAW AND LEGITIMACY, 2012, Cambridge University Press, p125 and footnote 51.

Benvenisti (op cit) cites Hertzberg et al v Finland, UN HRC Doc A/37/40, 1982 where the issue was a national media broadcasting limitation on the discussion of homosexuality. Another case from the Inter American Court of Human Rights is mentioned, which concerns the requirements on the acquisition of nationality in the Naturalization Provisions of the Constitution of Costa Rica, Advisory Opinion OC-484 of January 19, 1984.

${ }^{570}$ See further McCarthy, T, On Reconciling Cosmopolitan Unity and National Diversity in de Greiff P. and C. Cronin Eds., GLOBAL JUSTICE AND TRANSNATIONAL GOVERNANCE, The MIT Press, 2002, p267.

${ }^{571}$ Schneiderman, David, Realising Rights in an Era of Economic Globalization in Shan, Wenhua, Penelope Simon and Dalvinder Singh Eds., REDEFINING SOVEREIGNTY IN INTERNATIONAL ECONOMIC LAW, Hart Publishing, 2008, p444.
} 
human rights equality law as an exception in the national treatment principle in international trade relations as well.

However, as a note of caution, it is very important to realize that not all values expressed in human rights can be transposed to a trade law setting. In this context, it is important to draw attention to the role of 'human dignity' in the development of human rights; which can highlight why it can be argued that human rights does not in general share the same values as trade.

\subsubsection{The Relevance of 'Human Dignity' in Human Rights}

An overarching concept such as human dignity appears to suggest for more judicial creativity than would be acceptable in the WTO system - although it makes sense in some domestic jurisdictions. A human dignity approach has not been suggested in the WTO context, although it has been raised as explaining differences in issues of 'mistranslation' or 'bilingualism'. There can be different ways of explaining what 'human dignity' is. For some, 'dignity' is a value that is at the basis of all human rights; for others, it is just another way of saying 'human rights' and the two are synonymous; for another it is seen as a substantive right in itself; yet others may see dignity as a method of setting limitations on the exercise of human rights. According to McCrudden, it is the first view abovementioned, which he calls the "thicker view of dignity" that is used in judicial decisions on human rights to help identify and clarify the scope of specific rights. ${ }^{572}$

The origins of the concept of human dignity in western and other philosophy can be traced quite far back in time, but the current concept is the one that was crystallized in the Universal Declaration on Human Rights (UDHR) and is now considered a central concept in human rights discourse. The Preamble of the UDHR uses 'dignity' twice, in the sense of "inherent dignity... of all members of the human family" and "the dignity and worth of the human person". The very first Article of the UDHR underscores the importance of dignity:

Article 1 of the UDHR

[a]ll human beings are born free and equal in dignity and rights. They are endowed with reason and conscience and should act towards one another in a spirit of brotherhood.

There are also specific mentions of dignity in the context of Article 22. This Article, which is on the right to social security, provides:

'[e]veryone, as a member of society, has the right to social security and is entitled to realization, through national effort and international cooperation and in accordance with the organization and resources of each State, of the economic, social and cultural rights indispensable for his dignity and the free development of his personality'.

Article 23(3) in the context of right to work, provides that:

'[e]veryone who works has the right to just and favourable remuneration ensuring for himself and his family an existence worthy of human dignity, and supplemented, if necessary, by other means of social protection'.

\footnotetext{
572 McCrudden, Christopher, Human Dignity and Judicial Interpretation of Human Rights, European Journal of International Law 19, 4, 2008. See further, Kretzmer D. and E. Klein, Ed., THE CONCEPT OF HUMAN DIGNITY IN HUMAN RIGHTS DISCOURSE, Kluwer Law International, 2002 and Malpas, J. and Norelle Lickis, PERSPECTIVES ON HUMAN DIGNITY: A CONVERSATION, Springer, 2007.
} 
As can be seen, dignity has a close connection with economic and social rights and the responsibility of States to provide a social security and social protection system that is "indispensable for dignity" and for "an existence worthy of human dignity". The subsequent frequent use of the phrase 'human dignity' in modern international and regional human rights treaties and texts (substantive provisions as well as preambles) originated from this use of the phrase in the UDHR.

The concept of dignity gave human rights theory a foundation that is coherent, universal, timeless, non-ideological, humanistic (not based upon, but consistent with religious principles), originates independently from the State and places the individual within a social dimension. ${ }^{573}$ McCrudden calls such a theory the 'Holy Grail of human rights' that dignity has "undoubtedly played a pivotal political role" in bridging different viewpoints and ideologies to agree on the nature and context of human rights. ${ }^{574}$ This is also reflected in the Vienna Declaration on Human Rights, 1993, which attempted to bridge the ideological divide of the two Covenants. The second recital to the Preamble of the Vienna Declaration states that:

Recognizing and affirming that all human rights derive from the dignity and worth inherent in the human person, and that the human person is the central subject of human rights and fundamental freedoms, and consequently should be the principal beneficiary and should participate actively in the realization of these rights and freedoms,

But despite this consensus as to its importance at the level of international human rights there will be differences in the interpretation and application of the concept of human dignity on closer inspection of different domestic jurisdictions - and in some it may even be ignored. For example, the Constitutional Court of Canada and the Constitutional Court of South Africa have relied upon the concept of human dignity, ${ }^{575}$ but it has not been raised before the Supreme Court of the United States, as the latter does not have a tradition of reference to this concept.

McCrudden comments that:

...to speak of human dignity is a shorthand way of summing up how a complex, multi-faceted set of relationships involving Man is, or should be, governed: relationships between man and man, man and God, man and animals, man and the natural environment, man and the universe. ${ }^{576}$

The central point in dealing with the concept of human dignity, is that it deals with human relationships as the core of human rights. The entry of 'legal persons' into the conversation on human rights greatly confuses the matter - and can be accommodated only so far as the fundamental differences between humans and legal persons and the foundational concept of human dignity which underlies human rights, are kept at the forefront. Otherwise the conversation becomes an attempt, and naturally a failure, at building a 'tower of Babel'.

\footnotetext{
${ }^{573}$ Ibid., McCrudden, p 677 citing Weisstub, David, Honor, Dignity, and the Framing of Multiculturalist Values in Kretzmer D. and E. Klein, Ed., THE CONCEPT OF HUMAN DIGNITY IN HUMAN RIGHTS DISCOURSE, Kluwer Law International, 2002 p 263.

${ }^{574}$ Ibid., (McCrudden), p677 and p722.

${ }^{575}$ See e.g. Law v. Canada (Minister of Employment and Immigration) 19991 SCR 497, Supreme Court of Canada and President of the Republic of South Africa v. Hugo, 1997 (4) SA 1, Constitutional Court of South Africa.

${ }^{576}$ Op cit., (McCrudden), p675.
} 


\subsubsection{A 'Dichotomy of Discourses'}

Even when thinking like lawyers dealing with a legal text, and leaving aside the sociopolitical realities and worldviews and difficulties of balancing universalism and relativism in human rights protection discussed above, there is another problem to contend with, that needs to be taken into account but is often overlooked, and which this next section will discuss in further depth.

This concerns the problem that human rights can become overwhelmed in trade discourse. Overall, this can be called the 'translation' or 'bilingualism' problem. Trade and human rights discourse have what can be termed two 'language' problems. One can be called the 'human rights vs. trade' problem where the distance between human rights and trade is seen as unbridgeable. The other can be called the 'human rights = trade' problem where rights granted by rules in trade treaties are often (wrongly, as it shall be argued in this study) equated with similar-sounding principles in human rights. Either of these issues - which deal with the use of language in the trade and human rights debate would be a major barrier in the attempt to search for a balance where both types of rules (human rights promoting and trade promoting) can be used where needed for progress and development.

It appears that there is something that both sides agree upon in the trade-human rights discourse - that is that it is very difficult to understand each other, let alone come to an agreement on a matter of importance. But since there has been in recent years a great deal of effort for co-operation with regard to human rights issues in trade law, perhaps 'human rights $v s$. trade' has become less of a problem than before, even if, on both sides of the debate there are statements that:

The two communities are so far apart that they do not even use the same vocabulary, let alone share a common philosophy. ${ }^{577}$ ...or that:

The language in the literature regarding human rights on the one hand and trade on the other presents a dichotomy of discourses, like ships passing in the night. ${ }^{578}$

Progress in talking to each other does not mean that the nature of the relationship between trade and human rights is no longer an issue, but that integrating human rights into the WTO system is seen as a reasonable possibility and no longer appears to be viewed as a radical and unrealistic challenge to the world trade system. It is the methodology and the extent of integration that remain subjects of debate. While there is potential in the interpretation of the WTO agreements, those engaged in this task must contend with the constraints of the General Rule of Interpretation of the Vienna Convention on the Law of Treaties (VCLT) and with the fact that they are attempting to the balance values rooted in two different regimes within the context of one of them.

\footnotetext{
577 Allmand Warren, (President, Rights and Democracy), Preface to Howse, Robert and Makau Mutua, Protecting Human Rights in a Global Economy: Challenges for the World Trade Organization, International Centre for Human Rights and Democratic Development, 2000.

578 Jackson, John H., Reflections on the Possible Research Agenda for Exploring the Relationship between Human Rights Norms and International Trade Rules in Frederick M. Abbott, Christine Breining-Kaufmann and Thomas Cottier Eds., INTERNATIONAL TRADE AND HUMAN RIGHTS: FOUNDATIONS AND CONCEPTUAL ISSUES, Studies in International Economics, University of Michigan Press, 2006, p19.
} 
It is important, in taking on this task, to acknowledge the existence of two different legal languages - those of trade liberalization and human rights - expressed in the context of different 'legal cultures'. If this is acknowledged, then there exists along with the task of treaty interpretation according to the General Rule, the task of translation of human rights language into the language and context of trade - and doing so in such a manner that human rights language retains its essential nature of defending human dignity.

It is here that the 'human rights = trade' problem can be a hindrance. If the exercise is seen as a two-way street, where one could also imagine the translation of trade law or WTO law into human rights language, there is a possibility of the dilution or substitution of some key features of the human rights regime, especially that of the defence of human dignity and the individual human person against dominant power structures. Furthermore, with reference to the example of South African policy abovementioned, Schneiderman notes how cross-border trade freedoms are often 'framed in the language of rights' and that therefore 'democratic self-government is viewed as untrustworthy according to the logic of this rights regime'. ${ }^{579}$ This kind of 'translation' problem, whether intentional or a bona fide misunderstanding due to a lack of 'bilingualism' (the expertise in and use of both the languages of trade and human rights), is what the 'human rights = trade' problem is referring to.

The role of language in human rights and trade discourse should not be underestimated because "language and text can create, shift, or maintain ideologies". ${ }^{580} \mathrm{As}$ is common with language when it links with power - whether the power of ideas or power in society the same language can be used in different ways by those who see themselves on opposing sides of an issue, to wrest control of it to themselves.

Trade rights and human rights may even share the same cradle, though they have matured differently, grown apart and are perhaps now attempting, with some difficulty, to reconcile. Micheline Ishay, points out that;

While the development of capitalism in Europe contributed to the circumstances necessary for the development of a secular and universal language of human rights, the early European liberal agenda inadvertently taught that very language to its challengers. Thus, the international language of power and the language of resistance were simultaneously born in the cradle of the European enlightenment. ${ }^{581}$

The development of human rights language has since been part and parcel of revolt against authority or reorganizing of social structures. The most important developments

\footnotetext{
${ }^{579}$ Ibid., (Schneiderman, 2008) p430.

580 Collins, Christopher S., A General Agreement on Higher Education: GATS, Globalization, and Imperialism, Research in Comparative and International Education, 2(4), pp. 283-296, 2007. Collins adds further that

In the case of GATS, the ideology reflects a new imperialism where more powerful countries retain developing countries as markets in which they continue to rule intellectually.

While this seems a harsh criticism, it is in the context that the benefits of liberalization of services has been predominantly reaped by transnational service industries from developed countries.

581 Ishay, Micheline, THE HISTORY OF HUMAN RIGHTS: FROM ANCIENT TIMES TO THE GLOBALIZATION ERA, University of California Press, 2008, p8.

See for another perspective, the editorial comment by Odinkalu, C.A., Trade and Human Rights, Interights Bulletin Vol.13(4), 2001, p141 (a Review of the International Center for the Legal Protection of Human Rights, London): that "the international human rights movement began as an initiative against a form of trade - the slave trade" by English Quakers in 1783.
} 
occurred during the turmoil of $20^{\text {th }}$ century and at this time human rights became a more universal language. Ishay notes that the language of human rights was added to by the socialists and the labour movement (though this is not often taken notice of) and points out that the composition of the Human Rights Commission in 1945 consisted of persons of widely differing philosophical backgrounds and further that UNESCO had carried out a study to support worldwide support for principles of human rights in different cultural and philosophical contexts. ${ }^{582}$ Therefore it is important to remember that the human rights regime contains and is nourished by far more than a 'life, liberty and property' concept.

Thus, it can be argued that when trade experts such as Petersmann, speak of fundamental rights of 'freedom of trade', contract, property rights (of investors and companies), 'producer rights' and 'liberty rights', ${ }^{583}$ such expressions are not taking into account postWorld War II developments in human rights terminology and the text and commentary of the Covenants (ICCPR and ICESCR), but focus on a more limited and outdated liberal/libertarian view. Similarly Chauffour criticizes the content and definition of economic, social and cultural rights according to UN debates as "ironic" and fundamentally misinformed since they "have little relation to the actual process of economic development" and are essentially an output of the development process rather than an input". ${ }^{584}$ In observing this he ignores the role played by rights such education and health that are necessary for a person to have the capability to become an independent economic agent. Chauffour offers a "completely different set of economic, social and cultural rights" from those developed at UN level, which focuses "first and foremost" on a concept of "economic freedom", which would include:

...personal choice, voluntary exchange (both domestically and internationally), the freedom to compete and protections of persons and property. Institutions and policy that are consistent with economic freedom would thus provide and infrastructure for voluntary exchange (i.e. a market economy... 585

He thus argues that "economic freedom [including property rights] is a largely forgotten human right" that must be "prioritized" in practice as opposed to the indivisibility and interdependence of rights promoted by the Vienna Declaration of $1993 .{ }^{586}$ Chauffour is not unaware of the reaction to his interpretation of economic rights and notes that "many human rights specialists will find many points objectionable" in his writings. ${ }^{587}$

\footnotetext{
${ }^{582}$ Ibid., (Ishay), p8 and p16-17.

See also Waltz, Susan, Reclaiming and Rebuilding the History of the Universal Declaration of Human Rights, Third World Quarterly, 2002, 23:3, 437- 448: discussing the input to the UDHR from different individuals and traditions across the world.

${ }^{583}$ See Petersmann, E-U., Constitutionalism and WTO law: From a State Centred Approach towards a Human Rights Approach in International Economic Law in Kennedy, Daniel L. M. and Southwick, James D.,THE POLITICAL ECONOMY OF INTERNATIONAL TRADE LAW, Cambridge University Press, 2002; also see Petersmann, E-U., The 'Human Rights Approach' advocated by the UN High Commissioner for Human Rights and by the ILO: Is it Relevant for WTO Law and Policy?, Journal of International Economic Law 605, 2004.

584 Chauffour, Jean-Pierre, THE POWER OF FREEDOM: UNITING HUMAN RIGHTS AND DEVELOPMENT, Cato Institute, 2009, p47-48. The same extract is available online as Pro-Human Rights Growth Policies, Development Outreach, October 2006, http://wwwl.worldbank.org/devoutreach/october06/article.asp?id=381.

${ }^{585}$ Ibid., (Chauffour), p47-48.

${ }^{586}$ Ibid., (Chauffour), p42, 44.

${ }^{587}$ Ibid., (Chauffour). P4.
} 
Pauwelyn states firmly that unlike e.g. the protection of human rights or the environment, the liberalization of trade is not a value, only an instrument. Yet even he goes on to refer to the 'freedom of trade', the 'right to set up an enterprise' (as a human right and hence a 'special value') and the 'human right to trade' (of individuals). ${ }^{588}$ None of these 'rights' mentioned by Petersmann, Chauffour or Pauwelyn are included in the ICCPR or ICESCR. There is 'property' mentioned in the context of non-discrimination in Article 2 of both ICCPR and ICESCR alongside "race, colour, sex, language, religion, political or other opinion, ...". It is a right not to be discriminated based upon property status, but not a 'right to property'. There is a right to form trade unions under Article 8 of the ICESCR, but no 'right to trade'.

Within the international human rights regime, a definition of human rights would include: ...civil, cultural, economic, political and social rights, as set forth in the International Bill of Human Rights and other human rights treaties, as well as the right to development and rights recognized by international humanitarian law, international refugee law, international labour law, and other relevant instruments adopted within the United Nations system. ${ }^{589}$

Using the ejusdem generis rule of interpretation, ${ }^{590}$ 'other relevant instruments' would not include trade treaties, let alone other documents in trade law or usage of trade experts. Note however, that ejusdem generis is not a principle of treaty interpretation codified in the VCLT - but the more laborious VCLT method ought not to come up with a different conclusion when using the holistic 'text-context-object and purpose'. The Office of the High Commissioner on Human Rights (OHCHR) has the list of human rights documents on its website and this lists the International Bill of Human Rights, the Core International Human Rights Instruments (core treaties with monitoring bodies) and a non-exhaustive list of other conventions, declarations, principles, rules and guidelines. ${ }^{591}$ In none of these documents is there to be found a 'human right to trade' or 'economic freedoms' as referred to by some trade lawyers, as mentioned above. Furthermore, when the concept of 'trade freedoms' are often referred to as if equal with or even sometimes as superior to human rights (especially social rights), without reference to the specialized regime in international law that deals with both the definition of particular human rights and the relationship between different rights, this only adds to the frustration of the human rights community and to the serious 'mis-translation' problem. ${ }^{592}$

\footnotetext{
${ }^{588}$ See e.g. Pauwelyn, Joost, CONFLICT OF NORMS IN PUBLIC INTERNATIONAL LAW: HOW WTO LAW RELATES TO OTHER RULES OF INTERNATIONAL LAW, Cambridge University Press, 2003, p73-74.

${ }^{589} \mathrm{UN}$, Norms on the Responsibilities of Transnational Corporations and other Business Enterprises with regard to Human Rights, U.N. Doc. E/CN.4/Sub.2/2003/12/Rev.2 2003, para.23 (Approved August 13, 2003, by U.N. Sub-Commission on the Promotion and Protection of Human Rights Resolution 2003/16, U.N. Doc. E/CN.4/Sub.2/2003/L.11 at 52).

${ }^{590}$ Garner, Bryan A., BLACK'S LAW DICTIONARY, 8th edition, West Group, 2004: the 'ejusdem generis rule' is that where general words follow an enumeration of persons or things, by words of a particular and specific meaning, such general words are not to be construed in their widest extent, but are to be held as applying only to persons or things of the same general kind or class as those specifically mentioned.

${ }^{591}$ See http://www2.ohchr.org/english/law/, last accessed 02.06.2012.

592 Howse in Human Rights in the WTO: Whose Rights, What Humanity?: Comment on Petersmann, Jean Monnet Working Paper No.12/02, Symposium: Trade and Human Rights: An Exchange, 2002, mentions 'the enormous skepticism' on human rights in the WTO and refers in footnote 7 to an experience At the World Trade Forum in Berne last August, where many of the leading traditional WTO experts gathered to address the question of WTO law and human rights, several of the most eminent of them even questioned whether any human rights were sufficiently
} 
If we take the example of property rights - a main feature of the liberal/libertarian rights discourse - the Universal Declaration of Human Rights 1948 (UDHR) does not include the freedom to trade or rights of producers or investors, or refer to contractual rights as fundamental rights. The right to property is included in Article 17 of the UDHR:

Article 17 UDHR

(1) Everyone has the right to own property alone as well as in association with others

(2) No one shall be arbitrarily deprived of his property

This Article is subject to Article 29(2), that

In the exercise of his rights and freedoms, everyone shall be subject only

to such limitations as are determined by law solely for the purpose of securing due recognition and respect for the rights and freedoms of others and of meeting the just requirements of morality, public order and the general welfare in a democratic society.

This recognizes property rights to some extent, but does not prevent appropriation of private property for public purposes. ${ }^{593}$ However, this was a controversial inclusion, and the justiciable right to property was not included in the International Bill of Rights (in neither the ICCPR nor the ICESCR). Considering both the ideological conflict of the Cold War and the nationalization measures of countries emerging from a period of occupation or colonization, this is an understandable outcome. Therefore, while the UDHR recognizes some level of property rights, the Human Rights Committee has not found any individual complaint about property rights admissible, unless it was related to another violation of a human right e.g. non-discrimination. ${ }^{594}$

well understood or clearly embodied in international law so as to be relevant to the operation of the WTO!

It is to be hoped that there may have been some progress in the last few years, and that this is no longer the case.

${ }^{593}$ The original draft of the UDHR (June 1947) read:

Everyone has a right to own personal property. His right to share in the ownership of industrial, commercial and other profit-making enterprises is governed by the laws of the State of which he is a citizen.

(from Hobbins, A.J., Rene Cassin and the Daughter of Time: The First Draft of the Universal Declaration of Human Rights, Fontanus Vol. 2 (1989) p7 at p16.)

It is clear that at this point in the drafting process, the right to property was for the right of a person to own personal (non-commercial) property. It was definitely not seen as extending to the right of legal persons to own property. The changes in the final draft, as seen above, extended the human right to a person holding property in association with others. In contrast, The European Convention on Human Rights (ECHR) includes the right to property in its First Protocol (1952), Article 1:

added]

Every natural or legal person is entitled to the peaceful enjoyment of his possessions [emphasis

While legal persons are included, the right is of 'enjoyment' rather than of 'ownership' of property, giving the State more powers to deprive an individual of possessions 'in the public interest and subject to conditions provided for by law' and 'in accordance with the general interest or to secure the payment of taxes or other contributions or penalties'.

594 The First Optional Protocol to the ICCPR gives the Human Rights Committee competence to examine individual complaints with regard to alleged violations of the Covenant by States parties to the Protocol. The Office of the High Commissioner on Human Rights in explaining the procedure for complaints by individuals under the human rights treaties, makes clear that:

If you have filed a complaint under the Optional Protocol to the International Covenant on Civil and Political Rights, for example, you cannot claim a violation of the right to property since the Covenant does not protect that right. In such a case, your claim would be, in legal terms, inadmissible ratione materiae. 
This is evident in the Convention on the Elimination of All Forms of Discrimination against Women, 1979 (CEDAW), wherein property rights are included in the context of equal rights for women with regard to contracts and property. Article 15(1) on equality of men and women before the law is followed by Article 15 (2):

States Parties shall accord to women, in civil matters, a legal capacity identical to that of men and the same opportunities to exercise that capacity. In particular, they shall give women equal rights to conclude contracts and to administer property ...

Furthermore, Article 16 includes:

(1) States Parties shall take all appropriate measures to eliminate discrimination against women in all matters relating to marriage and family relations and in particular shall ensure, on a basis of equality of men and women:

(h) The same rights for both spouses in respect of the ownership, acquisition, management, administration, enjoyment and disposition of property, whether free of charge or for a valuable consideration.

Similarly, Article 5 of the International Convention on the Elimination of All Forms of Racial Discrimination (CERD) protects the right to own and inherit property without discrimination as to race, colour and national or ethnic origin. As can be seen, international human rights law does value property - but in the context of equality and non-discrimination, rather than as a 'right to property', in itself.

The trend of arguing that human rights, meaning particularly property rights and due process rights, apply to both corporations and human individuals is a use of rights language in a context which lacks the same equality and non-discrimination basis and rationale. For corporations, property rights are clearly not means to redress historic inequality and discrimination, but to protect capital, investments and profits. If there is discrimination due to the characteristics of property owners (race, ethnicity, nationality, religion, gender, sexual orientation etc., of the owners) - that can be seen in some instances as a more direct human rights violation of the rights of those individuals to peacefully enjoy their property - and is thus a different matter. There can be some connections drawn here with trade law, with regard to the non-discrimination principles in MFN and national treatment - being based on 'nationality'. However, this view must also take into account the differences between legal persons and 'human persons' and the different connotations of 'rights' and 'human rights'. ${ }^{595}$ The trade lawyers focus on

(from the official website at http://www2.ohchr.org/english/bodies/petitions/individual.htm, last accessed 02.05.204)

Note also that the individual complaints procedure is not available in the case of the ICESR, where the Optional Protocol for individual complaints was only opened for signatures in December 2009 and still has not acquired the necessary 10 ratifications in order to come into force. However, there is an individual complaints procedure for relevant treaty bodies under the Optional Protocol to the Convention on the Elimination of Discrimination Against Women (CEDAW) and the Optional Protocol to the Convention on the Rights of Persons with Disabilities; and where States parties have made the necessary declaration under the relevant articles of the Convention Against Torture or the Convention on the Elimination of Racial Discrimination.

${ }^{595}$ Note that regional human rights approaches complicate this issue, since there are difference between Latin American, African and European regional human rights instruments. Latin American and African approaches attempt to balance individual human rights, social justice and public interest (see the American Declaration of the Rights and Duties of Man, (Bogota Declaration) 1948, Article 23 and the American Convention on Human Rights (Pact of San Jose), Article 21; the African Charter on Human and Peoples' 
rights such as property or due process may obscure the issue, but it becomes clearer when we take a human right such as the right to health, which cannot apply to corporate entity or other legal person, but only to a human being.

Another illustration of what is termed 'mis-translation' in this study, is the use of the term 'non-discrimination' in human rights and trade contexts. Non-discrimination, together with equality before the law and equal protection of the law, is a basic and general principle of international human rights law. The international covenants (ICCPR and ICESCR) and other human rights conventions refer to the right of 'all persons', that is, to all real persons with human dignity - not to corporations, and not to customs territories or States as WTO Members. In WTO law, non-discrimination does not directly claim to give either natural or legal persons rights, but sets obligations on Members not to discriminate between like products or services/service providers. If Members take measures which can be defined as discriminatory under WTO law, producers and service providers can lobby their WTO Member governments to initiate consultations, which may lead to a WTO dispute. These two types of 'non-discrimination' are not the same, despite suggestions that they are the same concept or similar concepts. ${ }^{596}$

Some can argue that the non-discrimination principle in WTO law will also extend to individuals within WTO Members, and that it is thus similar to the human rights concept of non-discrimination. But this does not deny the fact that WTO law is commonly used to defend the interests of legal persons such as corporations in that territory, and that the 'non-discrimination' sought is for corporations to compete for market shares and profits. $^{597}$ It only indirectly concerns the wellbeing of the general public within a Member. The extension of 'human rights' to corporations in some jurisdictions is a controversial departure from the concept of fundamental human rights being about the human person. ${ }^{598}$ In the context of trade law, UN Reports have highlighted the difference

Rights (Banjul Charter), 1981, Article 14). The European human rights system also recognizes limitations on property rights due to public interest or other legal principles, but there is a significant difference since the relevant provision (Article 1 of Protocol I of the European Convention on Human Rights) recognizes that:

Every natural or legal person is entitled to the peaceful enjoyment of his possessions [emphasis added]

${ }^{596}$ See further, Section 4.2 of this study, titled 'Non-Discrimination as a Value in Trade and Human Rights'.

${ }^{597}$ Sarah Joseph states this more strongly, that:

...international economic law focuses on the rights of a privileged few, namely foreign traders and investors, which may lead to the inevitable prioritisation of their rights when they clash with or otherwise detract from the human rights of others. Such a prioritisation is unfortunate if it adds to the capacity for powerful entities to override the interests of the powerless and marginalised.

(Joseph, Sarah, Human Rights and International Economic Law, in Bungenberg M., C. Herrmann, M. Krajewski, J. Terhechte. eds., EUROPEAN YEARBOOK OF INTERNATIONAL ECONOMIC LAW, Vol 7., Springer, 2016).

598 See generally, Kinley, David, Ed., HUMAN RIGHTS AND CORPORATIONS, Ashgate Press, 2009. See further, Emberland, Marius, THE HUMAN RIGHTS OF COMPANIES; EXPLORING THE STRUCTURE OF ECHR PROTECTION, Oxford University Press, 2006. The author highlights that while there is in principle protection of persons related to profit-based enterprises under the European Convention on Human Rights, that it is 'doctrinally problematic'. The United States Supreme Court in a long series of cases including the 5:4 decision Citizens United v. Federal Election Commission 558 U.S. 310 (2010), has extended to corporations, legal personhood for constitutional rights litigation. However, this is being seriously questioned and challenged now by some US citizens groups e.g. the coalition of organizations involved in movetoamend.org/. On the other side of the coin, it is also debated whether corporations ought to be held liable for human rights violations, the same way individuals can, since rights should be 
in the principle of non-discrimination used in human rights and trade contexts. With reference to the GATS, the 2002 Report of the High Commissioner on Human Rights has stated:

Both GATS and human rights law include the principle of nondiscrimination; however, there are distinctions in the application of the principle. The High Commissioner highlights the need to ensure that the application of trade law takes into account the human rights principle of non-discrimination [emphasis added]... ${ }^{599}$

Furthermore, as discussed earlier in this Chapter, the international economic system is targeted towards general prosperity through 'free trade' and more efficient markets and the disputes deal with treatment of firms, companies, industries, service sectors and not directly concerned with the impacts on the lives of ordinary individual people (unless one considers the interests of particular individuals who own or manage the firms and companies). Of course, on a larger canvas, it could be seen that trade rules can have both direct and indirectly positive (or negative) outcomes on the lives of ordinary individuals living within WTO Members and that since trade affects such individual persons it can also affect their human rights.

But the extent to which the WTO system takes into account the impact on ordinary individual human beings appears to be insignificant compared to the attention towards the dignity and rights of the individual human being and towards disadvantaged or discriminated groups or communities that is found in human rights law. The 2004 study of the High Commissioner on Human Rights on the fundamental principle of nondiscrimination in the context of globalization emphasises that the two principles of nondiscrimination used in trade law and human rights should not be confused, as the goals are "in many ways quite different" 600 and can contradict each other. ${ }^{601}$ The main difference identified in the report is that the human rights principle of non-discrimination is intrinsically linked with the principle of equality, which includes the achievement of substantive equality through:

... positive measures to redress the structural biases that lead to discrimination. The trade principle of non-discrimination is primarily directed towards reducing trade protectionism and improving international competitive conditions rather than achieving substantive equality. ${ }^{602}$

complemented by obligations in the same legal regime. Currently, hearings are being held in the United States Supreme Court on several cases under the Alien Tort Claims Act on serious human rights violations committed by multinational corporations in other territories. See further, Ratner Steven R., Corporations and Human Rights: A Theory of Legal Responsibility, 111 YALE L.J. 443, 2001.

See also, Ruggie, J., Special Representative of the Secretary-General, Guiding Principles on Business and Human Rights: Implementing the United Nations 'Protect, Respect and Remedy' Framework, U.N. Doc., A/HRC/17/31. March 21, 2011.

${ }^{599}$ UN Economic and Social Council, Commission on Human Rights, Report of the High Commissioner, Liberalization of trade in services and human rights, E/CN.4/Sub.2/2002/9, 25 June 2002, p4; UN Economic and Social Council, Commission on Human Rights, Report of the High Commissioner Analytical study of the High Commissioner for Human Rights on the fundamental principle of non-discrimination in the context of globalization E/CN.4/2004/40, 15 January 2004, para.5-6.

${ }^{600}$ UN Economic and Social Council, Commission on Human Rights, Report of the High Commissioner Analytical study of the High Commissioner for Human Rights on the fundamental principle of nondiscrimination in the context of globalization E/CN.4/2004/40, 15 January 2004, para.26.

601 Ibid., para.27. The Report discusses three examples of such contradiction or conflict: the use of government procurement to promote affirmative action, the application of the principle of nondiscrimination in the context of agricultural trade and the question of social labelling.

${ }^{602}$ Ibid, para.26. See also para.51, Report Conclusions: 
And yet, it is often argued by trade experts that human rights and trade rules are based on the 'same values', especially when it comes to the concept of non-discrimination. Chapter 4 of this study will comment further on the 'non-discrimination' concept in the context of the human rights and trade regimes. It is important not to gloss over differences, because saying that concepts and terms in two different legal regimes are identical without a real attempt at comparison means that in the end there is an understanding of neither.

\subsubsection{1. 'Bilingualism'}

It was all very well to say 'Drink me,'

but the wise little Alice was not going to do that in a hurry.

'No, I'll look first,' she said,

'and see whether it's marked "poison" or not'.

\section{From Lewis Carroll's Alice in Wonderland}

For a translator to re-express meaning from source to receptor language, it is obvious that a competence in both is needed. This situation recalls a 'word-play' in the Sinhala language about the translation of the word 'water' in a globalized context of Sinhala speakers meeting German tourists in Sri Lanka. ${ }^{603}$ The German word for water is 'wasser' and the informal Sinhala word for water is 'wathura' - which both sound similar to the English word 'water', and probably all three had common Indo-European language roots. However, 'wasser' means 'poison' in Sinhala. Thus, it is not true to say that 'wasser' and 'wathura' mean the same thing to a Sinhala speaker communicating in Sinhala; but 'wasser' and 'wathura' are the same thing to a German speaker learning Sinhala (or vice versa) and to an English speaker asking for the translation for 'water' in both Sinhala and German.

The same care needs to be applied if referring to concepts in trade law as being similar to concepts in human rights. There is a need to check if it means the same in the context of each different regime and in comparison to each other; and in order to that, 'bilingualism' is needed. ${ }^{604}$ Terms and concepts may not be identical, even if both international trade

While the principle under human rights is directed towards protecting the weak and vulnerable and removing the structural barriers to achieving greater equality in society, the principle under trade law is focused more closely on combating trade protectionism and improving international competitive conditions

${ }^{603}$ Source: a discussion the author participated in during high school language and literature class, a long time ago.

${ }^{604}$ Grant, Stephanie, Functional Distinction or Bilingualism: Human Rights and Trade - the UN Human rights system in Abbot, Frederick M., Christine Breining-Kaufman and Thomas Cottier (Eds.) INTERNATIONAL TRADE AND HUMAN RIGHTS: FOUNDATIONS AND CONCEPTUAL ISSUES, University of Michigan Press, 2006. See also Robinson, Mary. The Fifth Annual Grotius Lecture Shaping Globalization: The Role of Human Rights, American University, International Law Review 19, no. 1 (2003): 1-26, where Robinson, the former UN High Commissioner on Human Rights refers to this 'bilingualism'.

See additionally, Tung, Ko-Young, Shaping Globalization: The Role of Human Rights - Comment on the Grotius Lecture by Mary Robinson, American University International Law Review 19, no. 1 (2003): 27 on the dichotomy of discourses with reference to the language of politics or human rights in the UN and the language of economics or development in the World Bank and IMF. The author also refers to his personal experience using the term human rights in the World Bank: 
law and human rights are regimes within public international law and share a common origin in the European enlightenment. But to wrest control of terms and concepts in human rights and use them in the context of trade law without acknowledging the original 'context-object-and-purpose' of human rights has been referred to by critics of this practice (human rights activists) by terms such as 'trade creep', 'colonization' and 'highjacking' ${ }^{605}$

How language is controlled and used in the rights-trade debate becomes a matter of great importance if it is believed that:

...discourse is not simply that which translates struggles or systems of domination, but is the thing for which and by which there is struggle; discourse is the power which is to be seized ${ }^{606}$

In the academic sphere, the tussle for control of human rights language in the context of trade can be illustrated by what could be called the 'Petersmann-Alston/Howse exchanges', where a number of articles were written by the said authors in the form of an open debate on the understanding of the role of human rights in the context of international trade. ${ }^{607}$ Alston has particularly stressed that rights in WTO law are "not analogous to human rights" and "have a fundamentally different ideological underpinning". ${ }^{608}$ Desierto has commented on this exchange of views, emphasizing that there are "vast qualitative, normative, institutional, legal, policy and contextual differences" between international human rights law and international economic law that "cannot be glossed over easily". ${ }^{609}$ The original Petersmann-Alston debate was described by Cottier as being between contenders who were:

...not on the same page as they talk in different words and worlds. ${ }^{610}$

Which again highlights the need for 'bilingualism', an understanding of both languages, both worlds, from the inside, in order to translate accurately and effectively. Cottier also highlights justifiable fears on the 'merger and acquisition of human rights by the trading

A year ago, at an internal conference at the World Bank, I used the 'HR' word - human rights. I was immediately taken to task by some Executive Directors and some staff members of the World Bank as they said that human rights were political and, therefore, outside our mandate.

${ }^{605}$ See for the specific example of health services policy: Koivusalo M. J., World Trade Organization and Trade-Creep in Health Services, Health Services Research and Policy, April 6(2):65-7, 2001; Benatar, Solomon, and Gillian Brock, GLOBAL HEALTH AND GLOBAL HEALTH ETHICS, Cambridge University Press, 2011, p150.

${ }^{606}$ Fairclough, Norman, DISCOURSE AND SOCIAL CHANGE, Wiley Blackwell, 1993 p51, citing Foucault, M, The Order of Discourse in Shapiro, Michael J. (Ed.) LANGUAGE AND POLITICS, New York University Press, 1984, p110.

${ }^{607}$ See Alston, Phillip, Resisting the Merger and Acquisition of Human Rights by Trade Law: A Reply to Petersmann, European Journal of International Law (EJIL), Vol.13, No. 4, 2002, 815; Petersmann, E-U., Taking Human Dignity, Poverty and Empowerment of Individuals More Seriously: Rejoinder to Alston, EJIL, Vol. 13, No 4, 2002, 845; Petersmann, E-U., Human Rights, International Economic Law and Constitutional Justice, EJIL, Vol.19, 2008, 769; Howse, Robert, Human Rights, International Economic Law and Constitutional Justice: A Reply, European Journal of International Law Vol. 19, No. 5, 945; Petersmann, E-U., Human Rights, International Economic Law and Constitutional Justice: A Rejoinder, EJIL, Vol.19, No.5, 2008, 955.

608 Alston, Phillip, Resisting the Merger and Acquisition of Human Rights by Trade Law: A Reply to Petersmann, European Journal of International Law (EJIL), Vol.13, No. 4, 2002, 815, p826 and 844.

${ }^{609}$ Desierto, Diane A., PUBLIC POLICY IN INTERNATIONAL ECONOMIC LAW: THE ICESCR IN TRADE, FINANCE, AND INVESTMENT, Oxford University Press, 2015, p158 after more detailed discussion on the Petersmann-Alston/Howse debate at p152-158.

${ }^{610}$ Cottier, Thomas, Introduction in Cottier, Thomas, Joost Pauwelyn and Elizabeth Burgi Bonanomi Eds., HUMAN RIGHTS AND INTERNATIONAL TRADE, Oxford University Press, 2005, p7. 
system' and the question of the ability of WTO dispute settlement bodies to refer to or even construe human rights. In the larger context just discussed, this integration of two regimes, of two ways of speaking and thinking, goes beyond the technical matters of jurisdiction of a WTO body to consider other international law, norms and principles.

However, this need for 'bilingualism' in the integration exercise, although discussed academically, will probably be postponed for a while longer in the WTO dispute settlement context, because the approach in dispute settlement has been restrained, avoiding the terminology of human rights. As noted by Del Mar et al:

The key to seeing the limitations of human rights discourse is to see how that discourse is being used in international economic institutions. ${ }^{611}$

In the case of health in the WTO, it has been limited to the acknowledgment of public health as a legitimate policy objective, but not as a human right. In light of the muddied waters of current academic debates, this is probably the best course of action, at least in the short term. Yet, some positive steps with regard to recognizing rights language need to be taken at some point of time.

Taking this into account, this study will discuss the possible entry points for the right to health in the GATS and the possibilities and limitations of the VCLT. It is suggested that an approach that takes 'bilingualism' into account may offer more scope for policy space promoting and protecting the right to health in the GATS, than basing GATS interpretation on the assumption that there is a common language between trade and human rights.

\subsubsection{2. 'Bilingualism' for 'Translation'?}

Like the translator, who despite his best efforts to be faithful to the meaning of the original always changes it, the lawyer seeks to do something that it is impossible to achieve with perfection, without flaw, but something that it is nonetheless necessary to attempt: to create effective and comprehensible working relations between different systems of language and thought. ${ }^{612}$

Even if there is a 'taking into account' of the human rights regime and the idea that trade and human rights are 'different languages' - is that enough? Perhaps there is an additional conceptual step that should be acknowledged. If there are two 'languages', is not the task of interpretation of an international treaty also similar to the task of a translator of languages? Larson, in defining translation, has stated that:

Translation is a process based on the theory that it is possible to abstract the meaning of a text from its forms and reproduce that meaning with the very different forms of a second language. ${ }^{613}$

'Translation' requires understanding, and to interpret is to apply knowledge and understanding - yet at the same time, interpretation can be implicit in the task of

\footnotetext{
${ }^{611}$ Del Mar, Maksymilian T. and Oche Onazi, The Moral Quality of Work in International Economic Institutions: Resisting Complacency, International Journal of Law in Context, Vol. 4, No 4, 2008, 337-377, also available online at http://ssrn.com/abstract=1089488, p45.

${ }^{612}$ Boyd White, James, Establishing Relations Between Law and Other Forms of Thought and Language, Erasmus Law Review, Vol. 01, Issue 03, 2008, p10.

${ }^{613}$ Larson, Mildred L., MEANING-BASED TRANSLATION: A GUIDE TO CROSS-LANGUAGE

EQUIVALENCE, 2nd Edition, University of America Press, 1998 (first published 1984), p3.
} 
translation. Perhaps the superimposition of the theories relating to translation of languages may clarify some of the problems faced by a legal professional in the current international arena, when dealing with WTO law and while perhaps also being 'bilingual', meaning being competent in the 'language' of another regime of international law such as human rights (or international environmental law).

Larson has identified that even when we are referring to bilingualism; there can be translators that work from their first language to their second language (or vice versa) ${ }^{614}$ She further states that the task can be directed towards either the source language community or the receiving/target community and that therefore at times the 'audience' becomes relevant. For example, an individual trained initially in international human rights law and then learning international trade law, who addresses international trade lawyers on human rights law concepts could be said to be working from their own 'first language' to their 'second language' and to a 'receiving community' or audience. The intention is for the trade lawyers to understand human rights terms and concepts. But if the same individual translator explains how human rights is perceived and applied by trade lawyers in trade contexts, then the audience being addressed is the 'source community'. But for a successful translation, translators need to "switch from source to target audience and back again within the same text", a capability that Larson calls "dual orientation'. Thus, according to Larson, the ideal translation should be accurate, natural and communicative. That is, reproducing meaning of the source text as accurately and faithfully as possible and using the "natural forms" of the receiving language to fit the source text while communicating the fullest meaning in a way that is readily understandable to the intended audience.

However, this task may not be one that can be achieved one hundred per cent. Translation theorists have discussed in depth the concept of 'equivalence' in translation and generally seem to agree that equivalence in translation is one of a matter of degree (similarity) and not of absolute symmetry (sameness) between the source and receiving languages, with the latter considered as an impossible point for the translator to reach. This idea is expressed in an oft-cited statement by Jakobson that:

There is ordinarily no full equivalence between code units ${ }^{615}$

Nida's seminal theory on the distinction between two types of equivalence: formal equivalence (the message itself, same form and meaning) and dynamic equivalence (reception of the message, aiming at the same effect), ${ }^{616}$ has been the basis of work by other scholars, although they used different terminology. ${ }^{617}$ Nida suggests that it is possible that the natural and dynamic translator is more faithful than a literal translator, since a dynamic translator may be able to grasp the meaning of the original text "more fully and satisfactorily". The aspect of dynamic equivalence can be useful in 'translating' human rights, as Nida says that this type of equivalence is based on "the principle of equivalent effect", that:

\footnotetext{
614 Ibid., (Larson).

${ }^{615}$ See Roman Jakobson, SELECTED WRITINGS: WORD AND LANGUAGE, VOLUME II, Walter de Gruyter, 1971, p261. See further for analysis of Jakobson's approach: Munday, Jeremy, INTRODUCING TRANSLATION STUDIES, THEORIES AND APPLICATIONS, Routledge, 2001, p37. Also Mehrach, who considers equivalence "an impossible aim in translation"; Mehrach, Mohamed., A TEXT-BASED MODEL FOR TRANSLATION EVALUATION, Ridderkerk: Ridden Print, 1977, p16.

${ }^{616}$ Nida, Eugene A., TOWARD A SCIENCE OF TRANSLATING, Brill Publishers, 1964, p159.

${ }^{617}$ Chesterman, Andrew, MEMES OF TRANSLATION: THE SPREAD OF IDEAS IN TRANSLATION

THEORY, Vol, 22 of John Benjamins Translation Library, John Benjamins Publishing, 1997, p9.
} 
...the relationship between receptor and message should be substantially the same as that which existed between the original receptor and the message. ${ }^{618}$

Thus, the 'heart', 'spirit' or 'core' (or whatever term represents the idea) of human rights must be retained even when a human rights term or concept is 'translated' into the trade regime. The concept of human dignity as the basis for rights and the legal protection of vulnerable or marginalized must be part of that understanding. Devoid of that, it can be argued that the task of 'translating' fails in successfully communicating the message of human rights into another regime.

Chesterman identifies 'equivalence' as one of the 'super-memes' of translation theory and adds that translation has the same source as metaphor, in that they both state that two things are the same, $\mathrm{X}=\mathrm{Y}$, when they are in fact, not identical. ${ }^{619}$ Chesterman proposes in his book that a translation itself is a theory or hypothesis concerning the source text, which is subject to testing just like any other hypothesis. He suggests that translation. ${ }^{620}$

...the only true test of equivalence would therefore be invariable backApplying this theory to human rights law and trade agreements, there should be 'testing' by 'back-translation' carried out to confirm if the concepts have been translated to the greatest possible degree of equivalence between the two 'languages'/regimes.

Does this task of translating seem insurmountable in light of the theorizing on 'equivalence'? Some translation theorists take a slightly different approach that takes into account the possible conflicts and tensions that cannot be resolved in translating between two languages. Mehrach proposes that, because no two languages share the same linguistic structures, and social or cultural aspects, it is better to use a standard of 'adequacy' that is, to accept as appropriate if a translation -

$\ldots$ has achieved the required optimal level of inter-language communication under certain given conditions. ${ }^{621}$

Ferran Larraz has elaborated that such adaptation to the receiving language and culture should preserve loyalty to the original document and the "basic human motivation and needs" that led to the conclusion of the document. ${ }^{622}$ She adds that this motivation is sometimes not made explicit in the text, and may even be an "untranslatable trait" but operates as an element that "inspires and disciplines" the translator.

Ferran Larraz highlights the importance of appreciating the prior motivation of a legal text, as necessary in order to place two texts in parallel and adapt the ideas of one into another. Bayar further adds that it is important to preserve the source ideology if the translation is to be qualified as equal to the source text. ${ }^{623}$ She draws comparison between

\footnotetext{
${ }^{618}$ Nida, Eugene A., TOWARD A SCIENCE OF TRANSLATING, Brill Publishers, 1964, p159.

${ }^{619}$ Chesterman, Andrew, MEMES OF TRANSLATION: THE SPREAD OF IDEAS IN TRANSLATION

THEORY, Vol. 22 of John Benjamin's Translation Library, John Benjamin's Publishing, 1997, p9-10.

${ }^{620}$ Ibid., (Chesterman), p10.

${ }^{621}$ Mehrach, Mohamed, A TEXT-BASED MODEL FOR TRANSLATION EVALUATION, Ridderkerk: Ridden Print, 1977, p14.

${ }^{622}$ Ferran Larraz, Elena, Breu resum de principis bàsics sobre traducció juridica (A Brief Summary of Basic Principles for Legal Translation), Grup d'Estudis, Dret i Traduccio, Papers Lextra, No. 1, 2005, available online at http://www.lextra.uji.es/papers/ 2005/Ferran05.pdf.

${ }^{623}$ Bayar, Monia, TO MEAN OR NOT TO MEAN, Kadmous Cultural Foundation Khatawat, 2007, p163 and pp186-203; see further Bayar, Monia, INTENTIONALITY IN TRANSLATION: (WITH A SPECIAL REFERENCE TO ARABIC/ENGLISH TRANSLATION), University of Edinburgh, 1992.
} 
the easy 'cultural equivalence' if the words under translation are universally known and not culture-based - and difficulties that are exacerbated with cultural differences (her example being Arabic and English). How far is it possible to retain faithfulness and loyalty to a source motivation or ideology when translating into a different language and culture (e.g. human rights to trade)? One view, often repeated in this field of study and springing from the idea of the impossibility of exact equivalence, is that translation is a "betrayal". ${ }^{624}$ And yet, it is necessary and useful to participate in this process, with awareness of its difficulties, failures and 'betrayals'. As Maggiori states:

To translate is to betray, needless to say, but it is this betrayal which, like misunderstanding, provides the best guarantee for the ongoing pursuit of translation, discussion, exchange and "dialogical thought"...If translation were to succeed completely, the spectre of the lone language would reemerge, and the towers would begin wobbling again. In Babel and everywhere else [emphasis added]. ${ }^{625}$

What is this "spectre of lone language" in the context of this study? It is the concern that, considering the enforceability of WTO law through the dispute settlement system and the influence of powerful interests, the language of trade law would become the 'lone language' in which the issues of diverse policy measures and aims can be discussed. The idea of a lone language evokes the ambition of the builders of the Babel tower and its fall. The communication between languages through attempting bilingual translation that does not focus on creating a singular coherence or harmony - may avoid the fragmentation of international law into regimes which are not only conflicting, but ultimately, noncommunicative.

In response to this kind of problem, "the agnostics that make a drama of the translators' task" 626 , Paul Ricoeur, has developed a concept known as "linguistic hospitality". This came about in Ricoeur's search for a policy synthesis between seemingly irreconcilable positions in ideology. James Taylor, assessing the concept of 'linguistic hospitality', describes it as:

$\ldots$ the practice of bringing two languages into communication with oneanother without violating the integrity of either one. ${ }^{627}$

Taylor believes that linguistic hospitality is not content with "utterly separate, sequestered selves" and that is:

...patiently and carefully works toward a common ground, forging a meaningful site for interaction that didn't previously exist...It insists, even through great difficulty, that understanding of and hospitality toward the other is possible and desirable.

\footnotetext{
See also Ricoeur, Paul, ON TRANSLATION, translated by Eileen Brennen, Routledge, 2006, p15: "...beneath the diversity of languages, there are hidden structures".

${ }^{624}$ Weinberger, Eliot, Anonymous Sources (on Translators and Translation), in Allen, Esther and Susan Bernofsky Eds., IN TRANSLATION: TRANSLATORS ON THEIR WORK AND WHAT IT MEANS, Columbia University Press, 2013, p21-22 and at p21: "All discussions of translations, like nineteenthcentury potboilers, are obsessed with fidelity and betrayal".

Also Ricoeur, Paul, ON TRANSLATION, translated by Eileen Brennen, Routledge, 2006, p24, how translation is "... a task that is at the risk of serving and betraying two masters".

${ }^{62}$ Maggiori, Robert, Review of 'Traduire: Defense et illustration du multilinguisme' by François Ost (2009), available online at http://www.presseurop.eu/en/content/article/18351-ost-translation.

${ }^{626}$ Ricoeur, Paul, ON TRANSLATION, translated by Eileen Brennen, Routledge, 2006, p10.

${ }^{627}$ James Taylor, Translating Hospitality: Paul Ricoeur's Ethics of Translation, The New Arcadia Review, Vol. 4, 2011, available at http://www.bc.edu/publications/newarcadia/archives/4/translating_hospitality/.
} 
In the midst of difficulties and criticism, and perhaps the 'betrayal of two masters', those working at the crossroads of trade and human rights or other 'trade and ...' values are making a few attempts at forging a common ground. More work needs to be done, and 'Babel tower' avoided. Morijn, also using a Babel metaphor for the conflicting, misunderstood voices, sets out the difficult task for human rights advocates when he writes that:

...the Babel of diverging fundamental rights vocabularies also implies many challenges for fundamental rights protection. A first challenge is creating a better awareness among human rights advocates of the institutional setting of the EC and WTO when they call for greater fundamental rights sensitivity. ${ }^{628}$

Thus, the skill of 'bilingualism' - in understanding WTO law as well as understanding how the institution works - needs to be built up by specialists in the human rights field, so they can identify spaces for 'linguistic hospitality'.

The recent endorsement by the WTO of the Statement in support of policy coherence in the implementation of the right to development, ${ }^{629}$ which was also mentioned earlier in this chapter, could be looked at as a positive improvement with regard to recognizing rights language, something that has usually avoided in the system and referred to a:

...global partnership for development, underpinned through human rights-

based policy coherence.

It cannot be said that there is as yet, a "human rights-based policy coherence" in the WTO system; and in most trade policy documents, the policy coherence aimed at has not been overtly with reference to a human rights "underpinning". Rather, 'policy coherence' has lacked that aspect, and has often been criticized, especially by writers such as Howse, the author of the Note for the UN Commission on Human Rights on 'Mainstreaming the Right to Development into International Trade Law and Policy at the World Trade Organization' as:

...redefinition and reordering of diverse human interests or rights in light

of trade liberalization. This is "mainstreaming" done backwards. ${ }^{630}$

In fact, this could be seen as an attempt to build a tower of Babel, rather than a 'linguistic hospitality'.

Rosalyn Higgins also uses the metaphor of the tower of Babel for the unharmonious voices of different international judicial bodies. ${ }^{631}$ While admiring the ILC work on the

\footnotetext{
${ }^{628}$ Morijn, John, Conflicts between Fundamental Rights or Conflicting Fundamental Rights Vocabularies?: An Analysis of Diverging Uses of 'Fundamental Rights' in the Context of International and European Trade Law in Brems Eva Ed., CONFLICTS BETWEEN FUNDAMENTAL RIGHTS, Intersentia 2008, $\mathrm{p} 20$.

${ }^{629}$ UN, Statement made by agencies of the United Nations system and other international organizations in support of policy coherence in the implementation of the right to development 14 September 2011 (Annex $\mathrm{V}$ of The Right to Development, Report of the Secretary-General and the UNHCHR, 8 December 2011, A /HRC/19/45.

${ }^{630}$ UN, ECOSOC, Commission On Human Rights, Sub-Commission on the Promotion and Protection of Human Rights, Note by the Secretariat, Mainstreaming the right to development into international trade law and policy at the World Trade Organization, E/CN.4/Sub.2/2004/17, 9 June 2004, para.23; see further para.15-23 and particularly the criticisms of the lack of a right to development approach in the Trade Policy Review Mechanism, see para 25-30. Also see further Howse's criticisms of the WTO-WHO Joint study in Howse, R., The WHO/WTO Study on Trade and Public Health: A Critical Assessment, Journal of Risk Analysis, Vol.24, Issue 2, 2004, 501.

${ }^{631}$ Higgins, Rosalyn, A Babel of Judicial Voices? Ruminations from the Bench, The International and Comparative Law Quarterly, Vol. 55, No. 4, October 2006, pp. 791- 804.
} 
fragmentation of international law, she doubts whether Article 31 of the VCLT or any idea of hierarchy can offer a solution and instead suggests something less technical and more 'human' as guidance for international judges:

We judges are going to have to learn how to live in this new, complex world, and to regard it as an opportunity rather than a problem:

We must read each other's judgments.

We must have respect for each other's judicial work.

We must try to preserve unity among us unless context really prevents this. ${ }^{632}$

It is part of this difficult task of dialogue and search for means and methods, that translation theory can offer some insight. That is the imaginative beauty of Ricoeur's term 'linguistic hospitality', a vision of a time and space:

...where the pleasure of dwelling in the other's language is balanced by the pleasure of receiving the foreign word at home, in one's own welcoming house $\mathrm{e}^{633}$

Human rights (and environmental law and policy) is not yet accurately recognized in the WTO system, let alone dwelling within it with pleasure - and the WTO system cannot yet be called a 'welcoming house' for words and concepts from other regimes. And without acknowledging that the conceptual foundations of both 'languages' differ and require 'translation' and 'hospitality', it is dangerous to suggest, as Petersmann has, that perhaps WTO law can serve "constitutional functions" for the protection of human rights in the global economy. ${ }^{634}$

\footnotetext{
${ }^{632}$ Ibid., (Higgins), p803-804.

${ }^{633}$ Ricoeur, Paul, ON TRANSLATION, translated by Eileen Brennen, Routledge, 2006, p10.

${ }^{634}$ Petersmann, Ernst-Ulrich, Time for a United Nations "Global Compact” for Integrating Human rights into the Law of Worldwide Organizations: Lessons from European Integrations Law for Global Integration Law, in George A. Bermann and Petros C. Mavroidis Eds., TRADE AND HUMAN HEALTH AND SAFETY, Volume 1 of Columbia Studies in WTO Law and Policy, Cambridge University Press, 2006, 271-326, p325.
} 


\subsection{INTERNATIONAL LAW AND POLICY ON THE RIGHT TO HEALTH}

In the previous sections there was an analysis on the concepts of 'translation' and 'bilingualism', which were introduced to highlight certain 'mis-translations' between human rights law and trade law. In exploring the meaning of the right to health, it could be possible to achieve a greater understanding of the necessity of a 'bilingual' approach to GATS obligations, where the human rights approach to health and public health services can be more correctly compared with the conservative trade law approach.

The 'right to health' has not been acknowledged in the WTO context. However, 'public health' has been recognized in the Doha Declaration on TRIPS and Public Health and been the basis for the amendment of the TRIPS Agreement. WTO dispute settlement reports have acknowledged 'public health' as a legitimate interest of Members. ${ }^{635}$ While the concept of 'public health', has a very long history, ${ }^{636}$ the right to health is a postWorld War II development. The Universal Declaration of Human Rights of 1948 included, in Article 25(1), the following right:

Everyone has the right to a standard of living adequate for the health and well-being of himself and of his family, including food, clothing, housing and medical care and necessary social services, and the right to security in the event of unemployment, sickness, disability, widowhood, old age or other lack of livelihood in circumstances beyond his control.

The World Health Organization (WHO), which was also established in 1948, was preceded by and took over the powers of the Health Organization of the League of Nations and the work of the International Office of Public Health. ${ }^{637}$ The Preamble to the WHO Constitution went further than the UDHR, as the State Parties declare that:

...The enjoyment of the highest attainable standard of health is one of the fundamental rights of every human being without distinction of race, religion, political belief, economic or social condition [emphasis added].

...Governments have a responsibility for the health of their peoples which can be fulfilled only by the provision of adequate health and social measures.

These are not binding obligations upon States. The binding obligation on the right to health is in the International Covenant on Economic, Social and Cultural Rights (ICESCR), which came into force in 1976.

The gap in time between the expression of the right to health in the UDHR and WHO Constitution, and the coming into force of a treaty for the legal enforceability of the right

\footnotetext{
${ }^{635}$ See Section 2.3.7. of this study, titled "Reference to Human Rights in GATT 1947 and WTO Disputes". ${ }^{636}$ See Rosen, George, A HISTORY OF PUBLIC HEALTH, first published 1958, reprinted John Hopkins University Press, 1993 - this is the classic treatise on the topic, covering Greek, Roman, Western European and US history.

See also Chapter 1 - Public Health History of the contemporary textbook, Tulchinsky, Theodore H. and Elena A. Varavikova, THE NEW PUBLIC HEALTH: AN INTRODUCTION FOR THE 21ST CENTURY, 3rd Edition, Academic Press, 2014, p1-42 for the long history of public health in other regions of the world. Also see Bangdiwala, Shrikant I., Tucker, Joseph D., Li, Li-Ming, and K. Srinath Reddy et al, Public Health Education in India and China: History, Opportunities, and Challenges, Public Health Reviews, Vol.33, No. 1, 204-224.

${ }^{637}$ Ibid., (Rosen), p460. The WHO Constitution, adopted by the representatives of 61 States during the International Health Conference held in New York, 22 July 1946, entered into force on 7 April 1948.
} 
is often explained as the result of 'Soviet Bloc vs West' ideological divide, with the USSR being pro-ESCR and the 'West' being in favour of civil and political rights. This is a simplification of the story, but the Cold War debate did affect the chances of success with regard to a single covenant. Thus, when the UDHR was ultimately transformed, it was ideologically partitioned into two Covenants: the International Covenant on Civil and Political Rights (ICCPR) and the International Covenant on Economic and Social and Cultural Rights (ICESCR). According to Article 2 of the ICCPR, the rights in the ICCPR are to be respected and ensured within the territory of the State immediately upon ratification. However, with the rights in the ICESCR, the obligation in its Article 2 is only to:

...take steps, individually and through international assistance and cooperation, especially economic and technical, to the maximum of its available resources, with a view to achieving progressively the full realization of the rights recognized in the present Covenant by all appropriate means, including particularly the adoption of legislative measures [emphasis added].

Thus, economic and social rights such as the right to health are only to be achieved "progressively". But it also means that the implementation of rights identified in the ICESCR require positive governmental action and cannot be achieved merely by a 'negative obligation' of 'respect', refraining from violation by inaction, non-interference with the enjoyment of the right or a general 'hands-off' approach by governments. ${ }^{638}$

In contrast, the ICCPR does not refer to a right to health at all. It only mentions the term 'health' in the context of 'public health' being a legitimate restriction to certain rights (the freedoms of speech, movement, assembly, association and the freedom to manifest one's religion). Thus, health is not referred to as a right in the ICCPR, but is specified as a right to be achieved by progressive realization in Article 12 of the ICCPR. States which have ratified the ICESCR thus have a specific obligation, which should not be seen as isolated from the obligations under international trade law and their interpretation and application in dispute settlement bodies. As emphasized by Desierto:

The interpretation of the normative content of the right to health under article 12 of the ICESCR may be useful to WTO tribunals, not just for purposes of understanding the legal parameters of the responding Member's duties under the ICESCR, but more so to be able to map how the responding Members policy measures for responding to threats to human life and health would, in turn, be programmatically shaped and circumscribed by these ICESCR duties... ${ }^{639}$

If it is recognized that international trade has a role to play in improving the standards of living across the world, then the reduction of social inequality through the legal and policy measures according to international human rights law, cannot be ignored. In the case of international trade and health services, the obligations of the right to health under the ICESCR should be clearly understand and 'bilingualism', as discussed in the previous chapter of this study, should be encouraged.

\footnotetext{
${ }^{638}$ See further on the characteristics of 'negative' obligations: UN Human Rights Committee, Human Rights: Civil and Political Rights, Fact Sheet No. 15 (Rev.1), available at https://www.ohchr.org/Documents/Publications/FactSheet15rev.1en.pdf; Tomuschat, C., International Covenant on Civil and Political Rights (1966), Encyclopaedia of Public International Law, Vol.IV, p639650, at p643, para.15, Oxford University Press, 2012.

${ }^{639}$ Desierto, Diane A., PUBLIC POLICY IN INTERNATIONAL ECONOMIC LAW: THE ICESCR IN TRADE, FINANCE, AND INVESTMENT, Oxford University Press, 2015, p195.
} 


\subsubsection{Article 12 of the ICESCR}

The right to health is explicitly recognized in the ICESCR. Article 12 of the ICESCR describes the right to health, which includes some specific rights considered priorities in the field of public health, that is maternal and child health, hygiene and disease control and medical services. Article 12 of the ICESCR states as follows:

1. The States Parties to the present Covenant recognize the right of everyone to the enjoyment of the highest attainable standard of physical and mental health.

2. The steps to be taken by the States Parties to the present Covenant to achieve the full realization of this right shall include those necessary for:

(a) The provision for the reduction of the stillbirth-rate and of infant mortality and for the healthy development of the child;

(b) The improvement of all aspects of environmental and industrial hygiene;

(c) The prevention, treatment and control of epidemic, endemic, occupational and other diseases;

(d) The creation of conditions which would assure to all medical service and medical attention in the event of sickness [emphasis added].

The ICESCR is sometimes downplayed as a treaty that does not have broad global support, but it has 165 State parties as of June 2017. The United States is one of the few countries which have signed but have not ratified the Convention. Article 12 of the ICESCR requires that the State parties must take steps within their territory so that conditions are conducive towards the achieving the highest attainable standard of health by each citizen.

Following the end of the Cold War, the view that the separation of the rights into the two Covenants, the differences in justiciability and the resulting implication that this had caused a hierarchy of 'First Generation' (civil and political) and 'Second Generation' (economic, social and cultural) rights, could seemingly be put to rest. A very important result of the World Conference on Human Rights held in 1993 was the Vienna Declaration and Programme of Action. ${ }^{640}$ Article 5 of the Vienna Declaration stated that:

All human rights are universal, indivisible and interdependent and interrelated. The international community must treat human rights globally in a fair and equal manner, on the same footing, and with the same emphasis. While the significance of national and regional particularities and various historical, cultural and religious backgrounds must be borne in mind, it is the duty of States, regardless of their political, economic and cultural systems, to promote and protect all human rights and fundamental freedoms. [emphasis added]

Thus, the right to health cannot be treated as any less important than any right in the ICCPR, such as the freedom of expression or the right to vote, even if there is that difference between them in terms of immediate and progressive justiciability. ${ }^{641}$ As Marks correctly notes:

\footnotetext{
${ }^{640} \mathrm{UN}$, The Vienna Declaration and Programme of Action, UN Doc. A/CONF.157/23, 12 July 1993.

${ }^{641}$ See for example of interdependence and indivisibility, 3 of the General Comment no 14 on the Right to Health:
} 
...building a fair and effective justice and law enforcement system is not fundamentally different from building a fair and effective health system. ${ }^{642}$

Both these endeavours need serious efforts in terms of policy planning, legislation, training of personnel and resource allocation by the State. Both affect the lives of individuals in profound ways. What exactly is the justification for prioritizing one over the other conceptually, other than habit, tradition or ideology of governance?

On closer inspection, even some of the ICCPR rights have socio-economic aspects and implementation of the right requires that the State 'take steps'. For example, the following Articles of the ICCPR, for the protection of children, suggest that the State has to have in place a robust system of child protection laws, legal services and social service institutions:

\section{Article 23 (4) of the ICCPR}

States Parties to the present Covenant shall take appropriate steps to ensure equality of rights and responsibilities of spouses as to marriage, during marriage and at its dissolution. In the case of dissolution, provision shall be made for the necessary protection of any children.

Article 24(1) of the ICCPR

Every child shall have, without any discrimination as to race, colour, sex, language, religion, national or social origin, property or birth, the right to such measures of protection as are required by his status as a minor, on the part of his family, society and the State [emphasis added].

It seems in the context of the ICCPR, that resource constraints could not be raised by a State as justifications for the failure to provide the required social services for children or opt-out of the role of what is described in the private law context of some legal systems as being 'upper guardian of children' to act in a child's best interest. Often these protections for children are lacking, even in developed countries, due to underfunding of required public legal and social services sectors. But a child's right to health is subject to "progressive realization" under the ICESCR and thus a resource constraint argument can be raised and replacement by other budgetary priorities can be justified. A large number of children die each year all across the world from preventable and treatable illness caused by the lack of basic healthcare, nutrition, sanitation and basic, safe living conditions. The idea that the protection of a child in the case of dissolution of the marriage of the parents, is somehow a 'First Generation' right with the connotations of somehow being more important - and that a child's right to health is not given the same legal consideration, is fascinating, to say the least. These two types of child protection requirements are being distinguished by the artificial hierarchy of a "civil rights vs social rights' paradigm.

It is difficult to maintain this division of civil and social rights conceptually, even within the context of interpretation and clarification of the ICCPR itself. Article 24(1) of the

The right to health is closely related to and dependent upon the realization of other human rights, as contained in the International Bill of Rights, including the rights to food, housing, work, education, human dignity, life, non-discrimination, equality, the prohibition against torture, privacy, access to information, and the freedoms of association, assembly and movement.

${ }^{642}$ Marks, Stephen P., The Human Right to Development: Between Rhetoric and Reality, Harvard Human Rights Journal, Vol. 17, 2004, 137, p148. 
ICCPR abovementioned is a non-discrimination provision, and although it does not specifically refer to the discrimination faced by children due to socio-economic status or poverty, it is implied. In clarifying Article 24, even the General Comment 17 of the UN Human Rights Committee has recognized this, stating that:

The Committee notes in this regard that such measures, although intended primarily to ensure that children fully enjoy the other rights enunciated in the Covenant, may also be economic, social and cultural. For example, every possible economic and social measure should be taken to reduce infant mortality and to eradicate malnutrition among children... ${ }^{643}$

Of course, the legal status of the General Comment 17 can be debated, but the issue remains that even some civil and political rights appear to require more than a 'hands-off' acknowledgement of 'freedom' by the State, and require that resources are used and budget allocations are provided for the relevant social services.

In the context of budgeting, it can also be pointed out that the most obvious civil and political right, the right to vote at "genuine periodic elections" requires a large expenditure and creation of national institutions and monitoring mechanisms. However, no State would argue that the requirements of holding an election according to the standards of Article 25 of the ICCPR: with universal and equal suffrage, secret ballot, "guaranteeing the free expression of the will of the electors" needs to be achieved 'progressively' due to economic constraints. This is because it is seen as clearly the responsibility of the State and must be included in the national budget as a public expenditure; but historically, very few countries have looked at any economic and social right such as the right to health in the same manner. Moreover, the "highest attainable standard of physical and mental health" for everyone, is a standard that keeps moving out of reach with the increase in scientific and social knowledge. Thus, the argument can be more easily made that rights such as the right to health are 'unaffordable' whereas the right to vote has to borne by the Treasury without question.

The right to health in the ICESCR has been further developed through the General Comment no 14 on the Right to Health of the Committee on Economic, Social and Cultural Rights and is supported by many other international and regional standards and obligations as well as by a number of political commitments. While the interconnectedness of these other specific treaties, norms and political commitments can each be discussed in depth, that is beyond the scope of this study. This section will focus on the general right to health provision of Article 12 of the ICESCR and its elaboration through the General Comment no 14. Several General Comments have been cited in this study for the purposes of explaining views and positions of the human rights regime on a number of issues. ${ }^{644}$ At this point, as the right to health is given special attention in this study, and General Comment 14 has been cited at length, a brief comment is necessary regarding the status of General Comments in international law.

\footnotetext{
${ }^{643}$ UN, Office of the High Commissioner of Human Rights, UN Human Rights Committee, General Comment No. 17: Article 24 (Rights of the child), Adopted at the Thirty-fifth session of the Human Rights Committee, on 7 April 1989.

${ }^{644}$ The HRC General Comment No. 17 (1989) on Article 24 (rights of the child), was cited just on the previous page of this study and CESCR General Comment No. 8 (1997) on The Relationship between Economic Sanctions and Respect for Economic, Social and Cultural Rights was cited earlier at section 2.3.8. At Sections 2.2.4. and 2.2.6., the CESCR General Comment No.3: The Nature of States parties Obligations (Art. 2, para.1 of the Covenant on Economic Social and Cultural Rights), E/1991/23, 14/12/90 was referred to.
} 


\subsubsection{The Status of General Comments in International Law}

'General Comments' and 'General Recommendations' are documents issued by independent specialist committees of the nine UN treaty bodies that have been set up to supervise the implementation of the major human rights treaties by the State Parties. ${ }^{645}$ The Committee on the Elimination of Racial Discrimination (CERD) and the Committee on the Elimination of Discrimination against Women (CEDAW) use the term 'General Recommendation', but the seven other committees use the term 'General Comment'. Other than the Committee on Economic, Social and Cultural Rights (CESCR) which implements the International Covenant on Economic, Social and Cultural Rights (ICESCR), all the other treaty bodies are created in accordance with the provisions of the treaties which they monitor. The CESCR was established by the Economic and Social Council of the United Nations (ECOSOC), as the ICESCR itself does not have a specific provision for the establishment of a treaty body to monitor compliance with its provisions. The CESCR reports to ECOSOC, since it is a subsidiary organ of ECOSOC.

Currently, over 100 General Comments and General Recommendations have been issued and adopted. Some of these documents address procedural obligations under the relevant treaties (reporting obligations, reservations, derogations) but a majority of them address the interpretation of substantive provisions (the rights themselves). The issues which are covered by these documents are as varied as 'self-determination' and 'children's rights in juvenile justice'.

Although the rights are written down quite plainly and concisely in the human rights conventions, there is still a need to interpret and clarify the nature of the State obligation in more detail and to have some oversight on the implementation of the rights. The General Comments have often been based on the reports of the State Parties on their implementation of the rights to the relevant Committees. The Committee for the ICESCR has noted that the General Comments are a means of making the experiences of States as expressed in their reports,

...available for the benefit of all State parties in order to assist and promote their further implementation of the Covenant [emphasis added]. ${ }^{646}$

The General Comments are therefore explanatory documents, which gather evidence of State practice and add analysis of expert opinion, to be used as an aid by State parties in implementing their obligations.

The General Comments are often described as having a 'soft law' character. Alston has described 'soft law' as a source of law which human rights law is more welcoming of, and which contains a "a much broader or looser range of sources", but despite this, soft law can still "reasonably be taken into account in legal analysis". ${ }^{647}$ It has also been said

\footnotetext{
${ }^{645}$ Human Rights Committee (for the ICCPR), Committee on Economic, Social and Cultural Rights, Committee on the Elimination of Racial Discrimination, Committee on the Elimination of Discrimination against Women, Committee against Torture, Committee on the Rights of the Child, Committee on Migrant Workers, Committee on the Rights of Persons with Disabilities, Committee on Enforced Disappearances.

${ }^{646}$ Committee on Economic Social and Cultural Rights (CESCR), Report in the 8th and 9th Session, 1994, UN Doc. E/1994/23 and E/C.12/1993/19, p20, para.51; see also CESCR, Report on Fortieth and FortyFirst Sessions, 2009, UN.Doc E/2009/22, para.56.

${ }^{647}$ Alston, Phillip, The Historical Origins of the Concept of 'General Comments' in Human Rights Law in Boisson da Chazournes, L., and V. Gowland Debbas Eds., THE INTERNATIONAL LEGAL SYSTEM IN QUEST OF EQUITY AND UNIVERSALITY: LIBER AMICORUM GEORGES ABI SAAB, Martinus
} 
that General Comments are "central to understanding human rights treaty obligations" and can even be called indispensable to interpretation. ${ }^{648}$ The view is that not only do the General Comments "carry considerable weight" but they are "quasi-legislative in nature" even if they are not legally binding. ${ }^{649}$

Thus, the General Comments are generally seen as 'authoritative' interpretations of individual human rights and the related State obligations. ${ }^{650}$ 'Authoritative' in this context is not always meant in the same way when it is used by different writers, but it is usually described by human rights academics as something on a scale between positive law and a mere technical guideline. Chinkin and Turner support the view that 'soft' norms expressed in the work of human rights treaty bodies can crystallize over time, through progressive interpretation, into 'hard norms' which have more legal content and can be interpretive guidance for international 'hard law'. ${ }^{651}$

The Committees themselves have publicly referred to their work as being' authoritative': for example, with reference to the procedure for the General Discussion on the Draft General Comment on Article 7 (Right to just and favorable conditions of work) of the ICESCR $^{652}$ and for the Procedure for the Adoption of the General Comment on Article 6 (Right to life) of the ICCPR ${ }^{653}$ - it was declared on the official websites of both the Committees that:

The purpose of the general comment is to provide authoritative guidance to State Parties on the measures to be adopted to ensure full compliance with the rights under this article [emphasis added].

Of course, it is possible to critique the reference to these statements, as probably referring to the fact that the Committees have been given an official mandate to carry out this work, which is accepted by the State parties to the relevant treaties - and not that the Committees are necessarily commenting on the legal nature of their General Comments. It should also be noted that the extent to which the General Comments are 'authoritative' is questioned at times, with some expressing doubt as to whether they should be given

Nijhoff, 2001, p763-775, in particular p764 and footnote 6. See also D'Aspremont, Jean, Softness in International Law: A Self Serving Quest for New Legal Materials, 19 European Journal of International Law, 2008, 1075.

${ }^{648}$ Keller, H. and Leena Grover, General Comments of the Human Rights Committee their Legitimacy in Keller, H. and Geir Ulfstein, Eds., UN HUMAN RIGHTS TREATY BODIES: LAW AND LEGITIMACY, Cambridge University Press, 2012, p1 17-118.

${ }^{649}$ Urfan Khaliq and Robin Churchill, 2012, 'The Protection of Economic and Social Rights: A Particular Challenge' in Keller, H. and Geir Ulfstein, Eds., UN Human Rights Treaty Bodies: Law and Legitimacy, Cambridge University Press, p205.

${ }^{650}$ See Russel, S. (eds), CORE OBLIGATIONS: BUILDING A FRAMEWORK FOR ECONOMIC, SOCIAL AND CULTURAL RIGHTS, Intersentia, 2002, p3; Sepúlveda, Magdalena M., , THE NATURE OF THE OBLIGATIONS UNDER THE INTERNATIONAL COVENANT ON ECONOMIC, SOCIAL AND CULTURAL RIGHTS, Intersentia, 2003, p211; Khalfan, Ashfaq, , Division of responsibilities among States in Langford, Malcolm Ed., GLOBAL JUSTICE, STATE DUTIES: THE EXTRATERRITORIAL SCOPE OF ECONOMIC, SOCIAL, AND CULTURAL RIGHTS IN INTERNATIONAL LAW, Cambridge University Press, 2013, p300.

${ }^{651}$ Chinkin, Christine, Normative Development in the International Legal System, in Dinah Shelton Ed., COMMITMENT AND COMPLIANCE: THE ROLE OF NON-BINDING NORMS IN THE INTERNATIONAL LEGAL SYSTEM, 2000, p21 and p33; Turner, Catherine, Human Rights and the Empire of (International) Law, (2011) 29 Law \& Inequality, 313, p330.

${ }^{652}$ Notice of the 56th session of the Committee on Economic, Social and Cultural Rights, to be held in Geneva from 1 to 19 June 2015, http://www.ohchr.org/EN/HRBodies/CESCR/Pages/Discussion2015.aspx.

${ }^{653}$ Notice of the 114th session of the Human Rights Committee, to be held in Geneva from 29 June to 24 July 2015, http://www.ohchr.org/EN/HRBodies/CCPR/Pages/GC36-Article6Righttolife.aspx. 
any weight. They can even be seen as a double-edged sword since they are just tools and could be used either to extend the scope of human rights or to limit it. ${ }^{654}$

But even if they are not accepted as authoritative, they could still be identified as important "interpretive instruments" due to the practice of States and others of referring to them and using them in such a manner. ${ }^{655}$ Blake adds that the result is that:

States communicate in the language and normative frameworks set forth in General Comments. ${ }^{656}$

Keller and Grover argue that General Comments therefore have 'normative legitimacy' as they are sufficiently persuasive to induce compliance with the norms expressed in them. ${ }^{657}$ Desierto points out that despite questions being raised on the "degree of interpretative and authoritative weight" of the General Comments and the scope of the rights concerned, no State party has disputed the institutional practice of issuing the comments. ${ }^{658}$ It can be additionally argued that this is not a situation of mere acquiescence on the part of State Parties, but a situation where State Parties themselves have delegated authority through the treaties to the Committees, to assist them in the interpretation of their international obligations. Some experts have said that this means that General Comments have a role in developing customary international law since they take into account State practice and opinion juris in their interpretation of human rights standards and in recommending State implementation. Gerber et al have said that the General Comments "play a substantive legal role in the elaboration of standards and possible future custom", 659

Blake, in a thorough exposition of the status of General Comments, clarifies that this role of the General Comments as interpretive instruments is not based on any mandate in the text of the relevant treaties, but is something that came about through the evolving practice of the human rights treaty bodies acting as "members of an interpretive community". ${ }^{660}$ Blake adds that:

\footnotetext{
${ }^{654}$ McCall-Smith K.L., 2016, Interpreting International Human Rights Standards: Treaty Body General Comments as a Chisel or a Hammer, in Lagoutte, S., T Gammeltoft-Hansen and John Cerone Eds., TRACING THE ROLES OF SOFT LAW IN HUMAN RIGHTS. Oxford University Press.

${ }^{655}$ Alston, Philip, The Historical Origins of 'General Comments' in Human Rights Law in Boisson De Charzournes, Laurence and Vera Gowlland-Debbas Eds., THE INTERNATIONAL LEGAL SYSTEM IN QUEST OF EQUITY AND UNIVERSALITY, 2001, p764.

${ }^{656}$ Blake, Conway, Normative Instruments in International Human Rights Law: Locating the General Comment, NYU School of Law, Center for Human Rights and Global Justice Working Paper Number 17, 2008, p22 available online at http://chrgj.org/wp-content/uploads/2012/07/blake.pdf (also available as 50 Harvard International Law Journal Volume 1, No.50, 2009, 1).

${ }^{657}$ Keller, H. and Leena Grover, General Comments of the Human Rights Committee their Legitimacy in Keller, H. and Geir Ulfstein, Eds., UN HUMAN RIGHTS TREATY BODIES: LAW AND LEGITIMACY, Cambridge University Press, 2012, p117-118.

${ }^{658}$ Desierto, Diane A., PUBLIC POLICY IN INTERNATIONAL ECONOMIC LAW: THE ICESCR IN TRADE, FINANCE, AND INVESTMENT, Oxford University Press, 2015, p101.

659 Gerber, Paula, Joanna Kyriakakis and Katie O'Byrne, General Comment 16 on State Obligations regarding the impact of the Business Sector on Children's Rights: What is the Standing, Meaning and Effect?, 14 Melbourne Journal of International Law, 1, 2013, p9. See also D'Aspremont, Jean, Softness in International Law: A Self-Serving Quest for New Legal Materials, 19 European Journal of International Law, 2008, 1075, p1082.

660 Blake, Conway, Normative Instruments in International Human Rights Law: Locating the General Comment, NYU School of Law, Center for Human Rights and Global Justice Working Paper Number 17, 2008, p36, available online at http://chrgj.org/wp-content/uploads/2012/07/blake.pdf (also available as 50 Harvard International Law Journal Volume 1, No.50, 2009)
} 
Therefore, these groups by virtue of their place and function in the international legal process constitute communities of interpreters. ${ }^{661}$

In this situation, the relevant Committees are both guided by and guiding the practice of States in a joint exercise to clarify and interpret the scope of the legal obligations contained in human rights treaties and the broader normative framework that human rights is placed in. Blake invokes Koh's theory of the transnational legal process ${ }^{662}$ when referring to this process wherein laws emerge through discourse and persuasion and are interpreted and internalized collectively over time.

According to Blake, the role of General Comments has been most striking in the area of economic, social and cultural rights, in developing a "standard language to describe and evaluate the normative content" of the ICESCR. ${ }^{663}$ As Blake stated:

The contemporary function of the General Comment is nowhere more vividly demonstrated than in the practice of the Committee on Economic, Social and Cultural Rights (CESCR). Indeed, the single most significant contribution of that Committee to the promotion of the Covenant, has been its bold and innovative General Comments. ${ }^{664}$

$\mathrm{He}$ also notes that this active and creative role of the Committee on Economic, Social and Cultural Rights (CESCR) was a necessary outcome of the need to address the "imbalance" created by the skepticism and relegation to secondary status of economic, social and cultural rights (ESCR). ${ }^{665}$

The historically different treatment meted out to ECSR meant that in practice, ESCR did not have justiciability at the international level until very recently. The UN General Assembly adopted an Optional Protocol to the ICESCR for complaints and inquiry procedures in December 2008, opening it for ratification in September 2009. On the other hand, the First Optional Protocol to ICCPR, which allows for an individual complaints procedure, came into force at the same time as that Covenant, in 1977, and has been ratified by 116 State parties (out of 169 State Parties to the ICCPR) as of 2017. In contrast, the Optional Protocol to the ICESCR came into force only in May 2013 after the deposit of the $10^{\text {th }}$ ratification. There are currently 165 State parties to the ICESCR and 22 for the Optional Protocol as of 2017. Individual, Inter-State and inquiry procedures can now be undertaken with regard to rights under the ICESCR. So, until May 5th 2013, the ESCR did not have the formal complaints procedure and standing for individuals that was available since 1977 for violations of civil and political rights by State Parties under the Human Rights Committee of the ICCPR. However, unlike the ICCPR procedure, the final views of the ICESCR procedure will not be considered formally binding upon the State parties.

As can be seen, there was no opportunity until recently for international case law that interprets the provisions and develops the normative content of the rights in the ICESCR, as it is done for the ICCPR. Even national case law is rare as few States grant justiciability for ESCR within their domestic jurisdictions. Therefore, if wanting to

\footnotetext{
${ }^{661}$ Ibid., (Blake).

${ }^{662}$ Ibid., (Blake) citing Koh, Harold H., How is International Human Rights Law Enforced, Indiana Law Journal, 74:4, 1999, 1397-1417.

${ }^{663}$ Ibid., (Blake), p8.

${ }^{664}$ Ibid., (Blake), p10.

665 Ibid., (Blake), p10-11 - at p10 Blake comments that ESCR is often seen as 'the normatively underdeveloped stepchild of the human rights family'.
} 
develop the law in this area, the CESCR needs to take proactive steps and has had to adopt a different path to clarifying the content of the specific rights in the ICESCR. One of these novel approaches and innovations is to hold a Day of General Discussion (DGD) as part of the process of the formulating and generating the concepts and norms that would underlie a General Comment. A DGD is a public meeting where representatives of governments, UN bodies, specialized agencies and human rights mechanisms, national human rights institutions, non-governmental organizations and academia meet. ${ }^{666}$

Thus, it can be argued that the authoritative character of the General Comments can be justified because they are the outcomes of a participatory process with inputs from a wide variety of relevant stakeholders, including the State parties themselves, non-governmental organizations and civil society. Nolte has referred to the State party reporting process in particular, as a "constructive dialogue". ${ }^{667}$ In addition, using a sound reasoning technique, transparent drafting process, clear language and avoidance of overbreadth can be identified as inputs that support the persuasiveness of the General Comments. Blake notes that by including a wide variety of actors, the process of creating a General Comment:

... has not only altered the substance of human rights norms, but has in some ways transformed the processes of norm generation... ${ }^{668}$

Alston highlights how the 2002 CESCR General Comment 15 on the Right to Water ${ }^{669}$ which takes up a right that is not mentioned in the ICESCR (and the word 'water' is also not referred to at any point in the ICESCR) - led to widespread acceptance of the right to water within a few years following its publication. ${ }^{670}$ Expanding the scope of rights in this manner can be seen as provocative but also as controversial in some quarters.

Blake comments further that "the reach and utility of General Comments" have gone beyond UN Committees or NGO advocacy and have:

...become important tools in human rights enforcement at both the national and supra-national level ...[being] frequently invoked before tribunals, particularly by litigants seeking a progressive interpretation of the law [and] tribunals when interpreting treaties, constitutions and statutes or when searching for general jurisprudential guidance... ${ }^{671}$

In the areas of ESCR, the General Comments are often the only source of interpretation of ESCR that is available, and through repetition and general consensus have gained significant status. Blake comes to the conclusion that, even if the General Comments are non-binding, they are not non-legal: as the results of modern international law-making

\footnotetext{
666 See further the CESCR webpage on DGD: http://www.ohchr.org/EN/HRBodies/CESCR/Pages/ DiscussionDays.aspx

${ }^{667}$ Nolte, Georg, Report 3 of Reports for the ILC Study Group on Treaties over Time in George Nolte, Ed., TREATIES AND SUBSEQUENT PRACTICE, Oxford University Press, 2013, p380.

668 Blake, Conway, Normative Instruments in International Human Rights Law: Locating the General Comment, NYU School of Law, Center for Human Rights and Global Justice Working Paper Number 17, 2008, p14, available online at http://chrgj.org/wp-content/uploads/2012/07/blake.pdf (also available as 50 Harvard International Law Journal Volume 1, No.50, 2009).

${ }^{669} \mathrm{UN}$, Committee on Economic, Social and Cultural Rights, General Comment no. 15 on the Right to Water, 2002, UN.Doc. E/C.12/2002/11.

${ }^{670}$ Alston, Philip and Ryan Goodman, INTERNATIONAL HUMAN RIGHTS, Oxford University Press, 2013, p287-290.

${ }^{671}$ Blake, Conway, Normative Instruments in International Human Rights Law: Locating the General Comment, NYU School of Law, Center for Human Rights and Global Justice Working Paper Number 17, 2008, p16 and see further for examples - available online at http://chrgj.org/wpcontent/uploads/2012/07/blake.pdf (also available as 50 Harvard International Law Journal Volume 1, No.50, 2009).
} 
processes cannot be confined within the "outdated terms of Article 38(1) [of the ICJ Statute]". ${ }^{672}$ Therefore he stresses that the General Comments have legal significance

... by virtue of their content and their iterative and persuasive character, rather than privileging considerations of form. ${ }^{673}$

This may seem odd to a trade lawyer used to the WTO context, who may be astonished at the use of the General Comments for interpretation, whereas for an individual trained in human rights, especially economic, social and cultural rights, their invocation is common and it may even be said, required. In the (currently) unlikely event of references to such instruments in WTO dispute settlement, perhaps to provide support for reliance on an exception, it is safe to say that the reaction to the General Comments would depend on familiarity/'bilingualism' and 'hospitality' (the concepts and methodology issues discussed earlier in Chapter 2.2).

While these are practical common-sense arguments for accepting that the General Comments play an important role, from an international lawyers' point of view, especially in the context of WTO law, there must be a clearer legal basis for reliance upon such documents. The members of the Committees which issue General Comments or General Recommendations are mostly lawyers, but there are also economists, political scientists and social scientists. ${ }^{674}$ Such an interdisciplinary representation in the committees is because an assessment of obligations and implementation of human rights treaties requires a broad assessment of laws, policies, and administrative practices of States that goes beyond just legal knowledge and expertise. ${ }^{675}$ However, legal methods of interpretation of treaties have a particularly important role to play in the work of the committees. As commented by Tobin, who has written extensively on the international right to health:

Simply clothing an assertion about the content of an internationally recognized human right with the apparel of humanity may satisfy a moral or political urge, but it does not necessarily accord with the nature of the legal obligations actually assumed by a state under a human rights treaty. ${ }^{676}$

If General Comments fall within the framework of and follow the rules of treaty interpretation, there is a legal basis for accepting their interpretations, in addition to the idea that "interpretive communities" 677 could generate meaning for terms in a text through various processes that express a shared understanding of the rights at issue.

\footnotetext{
${ }^{672}$ Ibid., (Blake), p33, citing Baxter, R., International Law in "Her Infinite Variety, (1980) 29 International and Comparative Law Quarterly 549 - and citing for support for the same position earlier at p26; Hollis, Duncan, Why State Consent Still Matters-Non-State Actors, Treaties, and the Changing Sources of International law, (2005) 23 Berkley Journal of International Law, p. 137, 141.

${ }^{673}$ Ibid., (Blake), p37.

${ }^{674}$ The number of individuals in a committee is between 10 and 23 (the highest number is for CEDAW). Committee members are usually nominated by their own States and elected by the State parties to the relevant treaty. Again, the CESCR is different because its members are elected by ECOSOC.

${ }^{675}$ Mechlem, Kerstin, Treaty Bodies and the Interpretation of Human Rights, 2009, Vanderbilt Journal of Transnational Law, Vol. 42:905, p918.

${ }^{676}$ Tobin, John, Seeking to Persuade: A Constructive Approach to Human Rights Treaty Interpretation, 2010, Harvard Human Rights Journal, Vol. 23, 1, p2.

${ }^{677}$ As mentioned by Blake (Supra p37) and also by Tobin (Ibid, p8-11), who cites Fish for introducing the idea of 'interpretive communities' (Fish, Stanley, IS THERE A TEXT IN THIS CLASS?: THE AUTHORITY OF INTERPRETIVE COMMUNITIES, Harvard University Press, 1980; Fish, Stanley Doing what comes naturally: Change, Rhetoric, and the Practice of Theory, Literary and Legal Studies 1989, p141-42).
} 
Keller and Grover argue that unless State parties to a human rights convention or covenant contest a General Comment, and as long as it is accepted by the State parties, it could be considered as subsequent practice under Article 31(3)(b) of the Vienna Convention on the Law of Treaties (VCLT), even if States themselves are not directly the producers of the documents. ${ }^{678}$ Article 31(3)(b) of the VCLT states that in addition to the general rule of treaty interpretation in Article 31 of the VCLT, "There shall be taken into account, together with the context...":

(b) any subsequent practice in the application of the treaty which establishes the agreement of the parties regarding its interpretation.

Thus, it can be argued that according to Article 31(3)(b) of the VCLT; these expert comments, based upon input from the State parties and various stakeholders to the treaties, can be considered as "subsequent practice" which shall be taken into account in treaty interpretation. However, it should be noted that ordinarily it has been States which have been the originators of 'subsequent practice' and not expert committees. In response to this, it could be in turn argued that the States usually participate to a certain degree in the creation of the documents and at the very least acquiesce to the expert opinion. ${ }^{679}$ It could also be argued either that States have delegated their powers of developing subsequent practice to these treaty bodies or that the experts are merely identifying the subsequent practice. This lack of clarity on the matter has led Georg Nolte, the Special Rapporteur to the ILC on 'Subsequent Agreements and Subsequent Practice in relation to interpretation of treaties', to disagree that the work of treaty monitoring bodies are subsequent practice under Article 31(3)(b) ${ }^{680}$ However he makes it a point to add that this does not diminish the importance of their role in interpretation of the relevant human rights treaties.

As can be seen from the above discussion, the interpretive practice ${ }^{681}$ with regard to human rights treaties appears to place less importance on form and formality than the interpretation of trade law agreements. The scope of the right to health as clarified in the General Comment 14 on the Right to Health (Article 12 of the ICESCR) will be addressed in the next part of this Chapter. This assessment is a useful one to engage in before going on to discuss whether the GATS framework allows for sufficient national policy space to implement the obligations of States to protect, promote and fulfill the right to health. This discussion has specific importance to the exception of public health services from the GATS but also has general relevance for the other chapters of the study.

\footnotetext{
${ }^{678}$ Keller, H. and Leena Grover, General Comments of the Human Rights Committee their Legitimacy in Keller, H. and Geir Ulfstein, Eds., UN HUMAN RIGHTS TREATY BODIES: LAW AND LEGITIMACY, Cambridge University Press, 2012, p127,130 and 131.

${ }^{679}$ Ibid., (Keller and Grover), p131-132. The authors also note that the United States, United Kingdom and Australia have made submissions to the treaty bodies disagreeing with the 'authoritative' nature of their findings and that their Comments cannot be taken as 'subsequent practice'. The United States is not a party to the ICESCR or CRC

${ }^{680}$ Nolte, Georg, Report 3 of Reports for the ILC Study Group on Treaties over Time in George Nolte, Ed., TREATIES AND SUBSEQUENT PRACTICE, Oxford University Press, 2013, p381. See also First report of the Special Rapporteur, Mr. Georg Nolte (65th session of the ILC (2013).

${ }^{681}$ There is the interpretive practice of the drafters of the General Comments when interpreting the ECSR and also the practice of the human rights adjudicators in using the General Comments when interpreting the ECSR.
} 


\subsubsection{The Right to Health as elaborated in CESCR General Comment No. 14.}

The concerns over what kind of governance system can be chosen and sustained in light of liberalization of services is a legitimate one. The legal obligations in international human rights instruments concerning health services provision are founded on State responsibility to realize the right to health, and obviously not on the vagaries of free market supply. When it comes to the international human rights approach to health services provision, it is not merely a right for countries to have a national policy according to their traditions and internal political processes, it is also a duty to progressively implement positive policies and to prevent retrogressive actions for those countries that have accepted the right. ${ }^{682}$

The General Comment No.14 on the right to health (2000) reiterates that "health is a fundamental human right indispensable for the exercise of other human rights", which is also a legally enforceable. ${ }^{683}$ It is added that:

Every human being is entitled to the enjoyment of the highest attainable standard of health conducive to living a life in dignity. ${ }^{684}$

The General Comment focuses on the normative content of Article 12 of the ICESCR, the State parties' obligations and implementation at the national level, violations of the right to health and the obligations of actors other than States parties. ${ }^{685}$ The obligations of parties other than States has been a debated area in international human rights law, ${ }^{686}$ and the primary focus is on the actions or inactions of the State. The General Comment is "based on the Committee's experience in examining States parties' reports over many years" ${ }^{687}$ and it is prepared so as to assist State parties' implementation and the fulfilment of their reporting obligations.

Some aspects of the right to health refer to non-discrimination (based on the usual clearly non-legitimate criteria such as race, ethnicity, religion or gender) in the provision of health services. ${ }^{688}$ It should be noted that the indivisibility ${ }^{689}$ of civil and socio-economic

\footnotetext{
${ }^{682}$ The customary international law status of the right to health is debated since it is argued by some authors that it is still not achieved this status since there is no consistency in State practice and opinion juris (see Clarke, Lisa, PUBLIC-PRIVATE PARTNERSHIPS AND RESPONSIBILITY UNDER INTERNATIONAL LAW: A GLOBAL HEALTH PERSPECTIVE, Routledge Research in International Law, Routledge, 2014, p156-157) but on the other hand there are others who state that the core content of the right to health has already achieved customary status (see Vadi, Valentina, PUBLIC HEALTH IN INTERNATIONAL INVESTMENT LAW AND ARBITRATION, Routledge research in international economic law, Routledge, 2013, p174 and p189).

${ }^{683}$ CESCR (Committee on Economic, Social and Cultural Rights), General Comment 14, The right to the highest attainable standard of health (Twenty-second session, 2000), U.N. Doc. E/C.12/2000/4 (2000) hereinafter, General Comment No 14 on the Right to Health - para.1.

${ }^{684}$ General Comment No 14 on the Right to Health para.1.

${ }^{685}$ General Comment No 14 on the Right to Health para. 6

${ }^{686}$ See further Clapham, Andrew and Mariano Garcia Rubio The Obligations of States with Regard to NonState Actors in the Context of the Right to Health, Health and Human Rights Working Paper Series No 3, Graduate Institute of International Studies, Geneva and WHO, Graduate Institute of International Studies, Geneva, 2002, available online at http://www.who.int $/ \mathrm{hhr} / \mathrm{Series} 3 \% 20 \mathrm{Non}-$ State_Actors_Clapham_Rubio.pdf; Weissbrodt, D., Non-State Entities and Human Rights within the Context of the Nation- State in the 21st Century, M. Castermans, F. van Hoof and J. Smith, eds The Role of the Nation State in the 21st Century, Kluwer, 1998.

${ }^{687}$ General Comment No 14 on the Right to Health, para.6.

${ }^{688}$ General Comment No 14 on the Right to Health, para. 18 notes the prohibited grounds as:
} 
discrimination is clearly recognized by the CESCR. Non-discrimination based on criteria such as race appear on the surface to be less problematic to implement than tackling discrimination due to either poverty by itself, or a combination of poverty with other grounds such as race, religion and gender. The General Comment notes that the violation of the obligation to respect the right to health includes:

...the denial of access to health facilities, goods and services to particular individuals or groups as a result of de jure or de facto discrimination.

An example of this is the Communication Alyne da Silva Pimentel Teixeira $v$. Brazil, ${ }^{690}$ where the Committee on the Elimination of Discrimination against Women ${ }^{691}$ concluded that Brazilian authorities discriminated against a woman who died of poor healthcare facilities, based not only on her sex, but also on the basis of her socioeconomic status and her African ethnicity; and recommended that Brazil ensure the right to affordable access to emergency obstetric care for all women on a nondiscriminatory basis. The Committee noted (and Brazil did not refute the argument) that Ms. da Silva Pimentel Teixeira suffered from multiple layers of de facto discrimination; being a woman, being of African descent and on the basis of her socio-economic background, with the discrimination exacerbated by regional disparities in health services provision. ${ }^{62}$

The state responsibility on the right to health is classified in three ways as the obligations to respect, protect and fulfill the right to health:

Paragraph 33. The right to health, like all human rights, imposes three types or levels of obligations on States parties: the obligations to respect, protect and fulfil. In turn, the obligation to fulfil contains obligations to facilitate, provide and promote.

These obligations are further described as

1. respect requires States to refrain from interfering directly or indirectly with the enjoyment of the right to health.

2. protect requires States to take measures that prevent third parties from interfering with Article 12 guarantees.

...race, colour, sex, language, religion, political or other opinion, national or social origin, property, birth, physical or mental disability, health status (including HIV/AIDS), sexual orientation and civil, political, social or other status, which has the intention or effect of nullifying or impairing the equal enjoyment or exercise of the right to health. Para.34 adds:

In particular, States are under the obligation to respect the right to health by, inter alia, refraining from denying or limiting equal access for all persons, including prisoners or detainees, minorities, asylum seekers and illegal immigrants, to preventive, curative and palliative health services; abstaining from enforcing discriminatory practices as a State policy; and abstaining from imposing discriminatory practices relating to women's health status and needs.

689 Article 5 of the Vienna Declaration on Human Rights (Vienna Declaration and Programme of Action, 1993) which states that all human rights, whether civil and political rights or economic, social and cultural rights are "universal, indivisible and interdependent and interrelated".

${ }^{690}$ Committee for the Elimination of All Forms of Discrimination against Women, Alyne da Silva Pimentel Teixeira v. Brazil, Communication No. 17/2008, UN Doc. CEDAW/C/49/D/17/2008, decided in 2011. This decision is significant for being the first decision of an international human rights treaty body to hold a state accountable for its failure to prevent an avoidable death in childbirth.

${ }^{691}$ The Committee on the Elimination of Discrimination against Women is a treaty body with an individual complaints mechanism which interprets the rights under the Convention on the Elimination of Discrimination against Women (CEDAW). A woman's' right to health comes under Article 12 of CEDAW as well as the right to health in Article 12 of the ICESCR

${ }^{692}$ Ibid., (Alyne da Silva Pimentel Teixeira v. Brazil), para.7.7. 
3. fulfil requires States to adopt appropriate legislative, administrative, budgetary, judicial, promotional and other measures towards the full realization of the right to health. ${ }^{693}$

These three levels of obligations are also clarified further in the General Comment.

'Respect' refers mostly to non-interference in right to health - by not undertaking actions or creating policies or laws that violate the right to health or suspending laws that are required for its protection. ${ }^{694}$ But it also includes taking of measures that would deny or limit equal access to health services. Significantly, it is also noted that a violation of the obligation to respect would also occur if there is:

...failure of the State to take into account its legal obligations regarding the right to health when entering into bilateral or multilateral agreements with other States, international organizations and other entities, such as multinational corporations. ${ }^{695}$

Thus, this obligation remains present in the context of negotiation of WTO commitments and other bilateral, regional or multilateral agreements on trade. For example, in the Concluding Observations of the CRC: Ecuador, the Committee on the Rights of the Child has issued expressed concern that the intellectual property standards in a proposed free trade agreement between Ecuador, Colombia, Peru and the United States undermined the ability of Ecuador to ensure access to low cost medicines and thereby affected their obligations under the CRC (Article 24, child's right to health). ${ }^{696}$ Ecuador was urged to make full use of the flexibilities available in the WTO TRIPS Agreement to provide generic medicines and enable the universal enjoyment of the right to health in Ecuador.

It is clearly stated in the General Comment No. 14 on the right to health, with regard to international obligations, that:

States parties should ensure that the right to health is given due attention in international agreements and, to that end, should consider the development of further legal instruments. In relation to the conclusion of other international agreements, States parties should take steps to ensure that these instruments do not adversely impact upon the right to health. Similarly, States parties have an obligation to ensure that their actions as members of international organizations take due account of the right to health [emphasis added]. ${ }^{697}$

There is a corresponding obligation on the part of actors or bodies other than State parties. The General Comment notes that in order for coordinated efforts for the realization of the right to health, there must be effective co-operation from bodies such as the WTO, as well as the World Bank and IMF. ${ }^{698}$ Although only State parties have legal obligations under the ICESCR, other actors, including inter-governmental organizations and the private business sector are considered as having 'responsibilities' towards that achievement of the right to health, which the State parties must facilitate. ${ }^{699}$ The obligation of State parties with regard to third party behaviour is not limited to facilitation of their normative responsibilities, but includes 'influencing' them by "legal or political

\footnotetext{
${ }^{693}$ General Comment No 14 on the Right to Health, para.33.

${ }^{694}$ Ibid., para.50.

${ }^{695}$ Ibid.

${ }^{696}$ Concluding Observations CRC: Ecuador, CRC/C/15/Add.261 of 3 June 2005.

${ }^{697}$ General Comment No 14 on the Right to Health, para.39

${ }^{698}$ Ibid., para.64.

${ }^{699}$ Ibid., para.42.
} 
means" ("in accordance with the Charter of the United Nations and applicable international law") to prevent them from violating the right to health in other countries. ${ }^{700}$ Respecting the right to health within other States is also part of the Article 12 obligations.

'Protect' requires States to take legislative and other measures to ensure that even when third parties are providing healthcare, equality of access is maintained. It also includes the duty to ensure that privatization of the health sector "does not constitute a threat" to the availability, accessibility, acceptability and quality of health facilities, goods and services. ${ }^{701}$ Private provision of health services does not change the role of the State in terms of human rights obligations, but it has been commented that implementation of a State's responsibilities can be affected due to the additional and complicated regulatory and oversight required and difficulties in promoting of a national rights-based approach to health in the context of having profit-motivated health service enterprises. ${ }^{702}$

Of course, it should be noted that there can be private health service providers which are non-profit, charitable organizations, catering to the underprivileged on the basis of need, in which case it is more likely that the right to health in terms of affordability is protected by such organizations but the State is still responsible for maintaining quality and nondiscrimination. The key problem in the context of how health services are supplied currently, is that the human rights regime does not have interpretations or any clear guidelines on mixed health systems where the provision of services and financing of said services are divided into public and private sectors, which are at times inter-linked or in public-private partnerships.

An example for the extent to which a State can be held legally responsible under such a human rights standard can be seen in the Inter-American Court of Human Rights (IACtHR) case of Case of Ximenes-Lopes v. Brazil. ${ }^{703}$ This case addressed State responsibility with regard to the provision of health care services by private actors within the context of a public health system in Brazil. Ximenes-Lopes, an individual with mental illness, was hospitalized at a private psychiatric clinic that operated within Brazil's public health system and died three days later, apparently while undergoing 'psychiatric treatment'. In its conclusions, the Court observed that a private health institution engaged by the State (through outsourcing) to render mental health services under the coverage of public health legislation, provided public services and the State continued to be responsible for protecting the public interest concerned in such a situation. ${ }^{704}$ The court

\footnotetext{
${ }^{700}$ Ibid, para.39.

${ }^{701}$ Ibid., para.35.

${ }^{702}$ See Chapman, Audrey, The Impact of Reliance on Private Sector Health Services on the Right to Health, Vol 16, No.1, Health and Human Rights 2014.

See also contra, Bloche, M. G., Is privatisation of health care a human rights problem? in De Feyter, Koen and F. Gómez Isa Eds., PRIVATISATION AND HUMAN RIGHTS IN THE AGE OF GLOBALISATION, Intersentia, 2005, pp. 207-228: who gives a "qualified endorsement" for privatization of health services on the basis that privatization has "the potential to enhance human rights compliance" because private health decision-makers can be "more attuned and responsive to patients concerns" and since centralized public health services would be seen by caregivers of patients who buy healthcare as "more imperious" and less subject to the pressures of human rights compliance.

${ }^{703}$ IACtHR, Ximenes-Lopes v. Brazil, Judgment of July 4, 2006 (Merits, Reparations and Costs), IACtHR, Series C No. 149. The IACtHR deals with the rights under the regional Inter-American Convention on Human Rights and also applies the standards of international human rights law.

${ }^{704}$ Ibid., (Ximenes-Lopes v. Brazil), paras.92 and 96.
} 
also observed that States have a duty to regulate and supervise all health service activities regardless of the public or private nature of the entity giving such health care. ${ }^{705}$

The UN Committee on the Elimination of Discrimination against Women, also dealt with the State responsibility for health, even when the services were supplied by a private actor, in the Communication Alyne da Silva Pimentel Texeira v. Brazil, and cited the previous IACtHR decision of Ximenes-Lopes $v$. Brazil in support. ${ }^{706}$ The Communication Alyne da Silva Pimentel Texeira v. Brazil concerned a woman who died from pregnancyrelated causes due to inadequate care in a private health care facility. The Committee found that the unsatisfactory medical practices of the private institution were imputable to the State because the State was directly responsible for exercising due diligence in regulating and monitoring private healthcare institutions when medical services were outsourced to such institutions. Another Communication cited in support of this decision was A.S. v Hungary, which also recommended that a State party take steps to ensure that all relevant healthcare personnel in public and private health facilities adhere to human rights standards relating to health. ${ }^{707}$ Both these decisions emphasized that State parties to a human rights convention which includes the right to health have a legally binding obligation to ensure that private health care facilities comply with such standards.

'Fulfill' requires that States adopt appropriate legislative, administrative, budgetary, judicial, promotional and other measures towards the full realization of the right to health. It is added that there must be "sufficient recognition" of the right to health in the national political and legal systems as well as a detailed national health policy plan for achieving health goals. ${ }^{708}$ Some countries have constitutional, and legislative recognition of the right to health, but the lack of a specific constitutional right to health or legislation specifically on the right to health is no barrier to implementing right to health-based policies in the national health system. Sri Lanka, for example, does not have any constitutional or legislative recognition of the right to health, but the national health policy has long been carried out on a conceptual foundation that has the same effect. Brazil has the protection of the right to health included in Articles 6 and 196 of its current Federal constitution, identifying public health services as the State apparatus which is responsible for such the right to health. With regard to financing of health services, it was discussed in Alyne da Silva Pimentel Texeira v. Brazil, that while Brazil's goals in its health policies and its constitutional protections were laudable, these needed to be "backed up by adequate funding which is equitably allocated"; and furthermore, the financing of the health system was identified as "not linked to results [the fulfillment of the right to health], which in turn are not sufficiently evaluated". ${ }^{709}$

\footnotetext{
${ }^{705}$ Ibid., (Ximenes-Lopes v. Brazil), para. 89, pp, 108-109.

${ }^{706}$ Committee on the Elimination of Discrimination against Women, Alyne da Silva Pimentel Teixeira $v$. Brazil, Communication No. 17/2008, UN Doc. CEDAW/C/49/D/17/2008, decided in 2011, para.5.12. The Committee on the Elimination of Discrimination against Women is a treaty body with an individual complaints mechanism which interprets the rights under the Convention on the Elimination of Discrimination against Women. A woman's' right to health comes under both this convention as well as the right to health in Article 12 of the ICESCR.

${ }^{707}$ Committee on the Elimination of Discrimination against Women, A.S. v. Hungary, Communication No. 4/2004, U.N. Doc., CEDAW/C/36/D/4/2004 (July 14, 2006), decided in 2006, para.11.5

${ }^{708}$ General Comment No 14 on the Right to Health, para.36.

${ }^{709}$ Committee on the Elimination of Discrimination against Women, Alyne da Silva Pimentel Teixeira $v$. Brazil, Communication No. 17/2008, UN Doc. CEDAW/C/49/D/17/2008, decided in 2011, para.5.8, also see para.5.6
} 
One of the significant contributions of the General Comment No 14 of the CESCR is the identification of four elements of the Right to Health: availability, accessibility, acceptability and quality, which are listed out in paragraph 12 of the document.

'Availability' is the requirement that:

...public health and health care facilities, goods and services, as well as programmes, have to be available in sufficient quantity within the State party. ${ }^{710}$

Thus, even if the provision of health services is mostly private or a mix of public-private, the State still has a responsibility to take steps so that a health goods and services are available in sufficient quantity. In the Argentine case of Viceconte v. Ministry of Health and Social Welfare, ${ }^{711}$ the courts (a Federal Chamber of Constitutional and Administrative Proceedings) ordered the government to produce a WHO-certified vaccine for Argentine haemorrhagic fever (which is endemic, of epidemic proportions and has a high fatality rate), which was not being produced and supplied by the private sector as it was not considered sufficiently profitable ("not a commercially attractive proposition"). ${ }^{712}$ The court specifically cited Article 12 of the ICESCR and remarked that its principles were also enshrined in provisions of the Constitution of Argentina, adding that the right to health means that individuals can claim benefits from the State, which has an obligation to meet the healthcare needs of the public and provide the necessary resources. $^{713}$

'Accessibility' includes non-discrimination in the provision of health services, the health services being available within safe physical distance and the right to seek, receive and impart information with regard to health issues. It can be said that the most importance aspect of accessibility is affordability: the requirement that that health facilities, goods and services must be affordable for all:

Economic accessibility (affordability): health facilities, goods and services must be affordable for all. Payment for health-care services, as well as services related to the underlying determinants of health, has to be based on the principle of equity, ensuring that these services, whether privately or publicly provided, are affordable for all, including socially disadvantaged groups. Equity demands that poorer households should not be disproportionately burdened with health expenses as compared to richer households [emphasis added]..$^{714}$

Thus, while the choice of public or private provision is not mandated, the State responsibility includes 'ensuring' affordability of health services, for which they must take suitable measures. Such measures need not necessarily to be limited to competition policy measures in a free market economy. ${ }^{715}$ "Affordable health care, including sexual

\footnotetext{
${ }^{710}$ Ibid., para.12(a).

${ }^{711}$ Viceconte, Mariela Cecilia v. Ministry of Health and Social Welfare, Case No. 31.777/96, 1998.

712 Ibid., Viceconte, para.XI(d) of the judgment. This was also referred to in UNGA, Human Rights Council, Implementation of General Assembly Resolution 60/251 Of 15 March 2006, Report of the Special Rapporteur on the right of everyone to the enjoyment of the highest attainable standard of physical and mental health, Paul Hunt, A/HRC/4/28, 17 January 2007, para.70.

${ }^{713}$ Ibid., (Viceconte), paras.V-X.

${ }^{714}$ General Comment No 14 on the Right to Health, para.12(b).

715 For a comparison with the European context see Prechal, Sacha, Fundamental Rights and the Liberalization of Service Markets in van de Gronden, Johan, Ed., EU AND WTO LAW ON SERVICES: LIMITS TO THE REALIZATION OF GENERAL INTEREST POLICIES WITHIN THE SERVICES MARKETS, Kluwer Law International, 2008, p67-68 and 71. Prechal argues that access to 'services of
} 
and reproductive services" is specifically highlighted in the case of women's right to health in Paragraph 21 of the General Comment 14. Paragraph 36 adds that the obligation to 'fulfill' the right to health requires State Parties to provide "a public, private or mixed health insurance system which is affordable for all". In the case of public health services free at the point of delivery and funded from general taxation, this aspect of affordability can be said to be fulfilled without the need for a separate and more complicated health insurance system.

'Acceptability' means that health facilities, goods and services must be "respectful of medical ethics and culturally appropriate" and 'Quality' requires that 'health facilities, goods and services must also be "scientifically and medically appropriate and of good quality". ${ }^{716}$ It is possible that there could be situations where acceptability and quality requirements which may involve domestic regulation of health services; and while there should not be a conflict with the trade rules on the matter of quality and qualifications, States would need to be aware of potentially conflict with future trade disciplines and commitments in their design of such domestic regulations.

The key obligation (for the purposes of this study) is the right to health facilities, goods and services as expressed in Article 12.2 (d) of the ICESCR. The General Comment clarifies this obligation in Paragraph 17, as follows:

The creation of conditions which would "assure to all medical service and medical attention in the event of sickness" (art. 12.2 (d)), both physical and mental, includes the provision of equal and timely access to basic preventive, curative, rehabilitative health services and health education; regular screening programmes; appropriate treatment of prevalent diseases, illnesses, injuries and disabilities, preferably at community level; the provision of essential drugs; and appropriate mental health treatment and care. A further important aspect is the improvement and furtherance of participation of the population in the provision of preventive and curative health services, such as the organization of the health sector, the insurance system and, in particular, participation in political decisions relating to the right to health taken at both the community and national levels.

Thus, the element of accessibility is stressed upon as well as the right to participate in political decision-making on health services at community and national levels. At the same time, the possibility that the organization of the health sector and insurance system may be done at regional or international level in context of bilateral or multilateral trade negotiations has not been taken into account. Yet it can be assumed that the participation of the population in matters that affect their health and their right to health facilities, goods and services can be extended to any level of decision-making.

The CESCR has also further developed for the health context, the concept of 'minimum core obligations' of human rights, which identifies the minimum level of rights that the State party must ensure, without which the right to health would be meaningless. The

general interest' is an emerging fundamental principle in EU law that can be construed as a guarantee that services of general economic interest are provided - either by public authorities or private operators (applying a combination of Article 36 of the Charter and Article 16 of the EC Treaty) . Although probably not an enforceable right, it can be seen as guidance for the orientation and interpretation of other legal norms in the EU; and one which "can counter, through interpretation, the fact that in various directives relative priority is given to competition" (p68).

${ }^{716}$ General Comment No 14 on the Right to Health, para.12(c) and para.12(d). 
Committee, reading the right to health in conjunction with General Comment No 3 , the Programme of Action of the International Conference on Population and Development (Cairo, 1994) and the Alma-Ata Declaration (1978), was of the view that the minimum core obligations of the right to health include the responsibility:

To ensure the right of access to health facilities, goods and services on a nondiscriminatory basis, especially for vulnerable or marginalized groups ${ }^{717}$

Thus, minimum core obligations are focused on the standards to be maintained even for the most disadvantaged in society.

Furthermore, all ICESCR rights including the right to health include:

....a strong presumption that retrogressive measures taken in relation to the right to health are not permissible. ${ }^{718}$

If a State has taken any "deliberately retrogressive measures" the General Comment notes that the State has the burden of proving that the "most careful consideration of all alternatives" was carried out and that they are:

...duly justified by reference to the totality of the rights provided for in the Covenant in the context of the full use of the State party's maximum available resources. ${ }^{719}$

Thus, it appears that the only justification for retrogressive measures concerning the right to health would be economic hardship in the context of the State doing its best with the maximum of available resources to cover all ICESCR rights. A general trend to avoid obligations on the progressive realization of economic, social and cultural rights (due to a change in governmental economic policy towards neo-liberalism, for example) would not be acceptable under the interpretation of the Covenant. The Report of the High Commissioner for Human Rights on Liberalization of Trade in Services has in addition identified the need of a human rights approach to assess the current and potential impacts and to avoid possible retrogressive measures under WTO law and policy. ${ }^{720}$ Moreover, as States parties to the ICESCR are also required to take steps to realize the rights in the Covenant through international assistance and co-operation to the maximum of their available resources using all appropriate means, ${ }^{721}$ the WTO ought not to be a forum that promotes retrogressive measures, but for discussing how trade can realize the right to health.

A point that should be reiterated is that the General Comment No.14 is not limited to commenting on State obligations only. Paragraph 64 refers to the need for "coordinated efforts" at the international level for the realization of the right to health, calling upon the WTO (among other international organizations and agencies) to:

...cooperate effectively with States parties, building on their respective expertise, in relation to the implementation of the right to health at the national level, with due respect to their individual mandates.

When States parties act as members of international organizations, which do not specifically include human rights or the Right to Health in their mandates, they do not shed their obligations and take on a different identity. Within organizations such as the WTO and with regard to agreements such as the GATS, States must ensure that the right

\footnotetext{
${ }^{717}$ Ibid, para.43(a).

718 Ibid., para 32.

${ }^{719}$ Ibid.

${ }^{720}$ Commission on Human Rights, Liberalization of Trade in Services (Report of the High Commissioner), UN doc. E/CN.4/Sub.2/2002/9, 25 June 2002, para.12.

${ }^{721}$ Article 2(1) of the ICESCR.
} 
to health is given due regard and that the available policy space or flexibilities in the GATS are used to respect, protect and fulfil the right.

It can be argued vice versa that States acting in human rights contexts must give due regard to their GATS obligations; but as discussed above, the right to health must be progressively realized and the General Comment notes that there is a "strong presumption" that taking retrogressive measures would be a violation of a State's human rights obligations. Thus, a State cannot justify, within the human rights context, measures which are consistent with their GATS obligations, but which also violate State responsibilities under human rights law. There is no argument here for an equivalent importance for WTO law within the human rights framework in exchange for due regard for human rights in the WTO system. It is only posited that the WTO system and its Members should give due regard to human rights in the context of WTO obligations, since the system declares an objective of benefitting human beings in general by raising standards of living; and that the positive link of human rights with services, that services provision play a vital part in the fulfillment of human rights, can be strengthened within the GATS, if the existing policy space in the GATS is utilized with that objective in mind.

There is no benefit in discussing a right in the abstract without the means and ability of procuring and administering and promoting it. Thus, if public health services are important for the right to health, the doubts as to whether the GATS gives free rein or binds the hands of Members - or if it falls somewhere in-between and allows for a conditional and limited policy space with regard to the protection of public health services - is an important issue that needs clarification.

\subsubsection{A Brief Comment on the Right to Health in other International Documents}

International soft law in support of the right to health includes Article 1 of the Declaration of Alma-Ata (Declaration at the International Conference on Primary Health Care, 1978):

The Conference strongly reaffirms that health...is a fundamental human right and that the attainment of the highest possible level of health is a most important world-wide social goal...

Commitment $1(\mathrm{f})$ of the Copenhagen Declaration for Social Development and its Programme of Action, made at the World Summit for Social Development 1995, reaffirms the right to health in the ICESCR and makes over one hundred references to health. Commitment 6 also states that:

We commit ourselves to promoting and attaining the goals of universal and equitable access to ...the highest attainable standard of physical and mental health, and the access of all to primary health care ... ${ }^{722}$

There is also support for the right to health in the Copenhagen Plus 5 Declaration (2000); as well as a number of other declarations including the Declaration on the Right to Development, 1986, the Rio Declaration on Environment and Development and Agenda

\footnotetext{
722 UN, Copenhagen Declaration for Social Development, A/CONF.166/9, 19 April 1995. See also Commitments 2(b), 2(d) and 5(d), which state as follows:

We commit ourselves to...the provision of...primary healthcare services, including reproductive health care...Develop and implement policies to ensure that all people have adequate economic and social protection during ...ill health, maternity...disability...

Take appropriate measures to ensure, on the basis of equality of men and women, universal access to the widest range of health-care services...
} 
21 of 1992; and the International Conference on Population and Development (ICPD), Cairo, 1994.

At regional level, the statements are a mix of binding obligations and persuasive norms and political commitments. Article 11 of the European Social Charter, ${ }^{723}$ Article 33 of the American Declaration on the Rights and Duties of Man and Article 10 of the Additional Protocol to the American Convention on Human Rights (Protocol of San Salvador) ${ }^{724}$ Article 16 of the African Charter on Human and Peoples' Rights ${ }^{725}$, and the Preamble and several Principles/Articles of the SAARC Social Charter ${ }^{726}$ all acknowledge the right to health. In addition, there is also Article 17 of the Cairo Declaration on Human Rights in Islam. ${ }^{727}$ These regional standards and obligations all either recognize health as a human right and/or a State obligation or as a vital public good that creates a legal and/or political responsibility upon States.

Understanding the challenges of accessibility of healthcare services also requires acknowledgement of the challenges people face in real-life, including race, gender and other vulnerabilities. International legal obligations on addressing various forms of social discrimination or exclusion also take special note of the right to health of special groups of people. The prohibition and elimination of racial discrimination takes into account "the right to public health, medical care, social security and social services"728 in Article 5 of the International Convention on the Elimination of All Forms of Racial Discrimination (CERD) of 1963.

Development and population health goals and indicators focus particularly on maternal and child health. Thus, the right to health of both women and children has also attracted special attention. Women's right to health is focused on in Article 12 of the Convention on the Elimination of All Forms of Discrimination against Women (CEDAW) of 1979,

${ }^{723}$ Article 11 of the European Social Charter - The right to protection of health:

..... the Contracting Parties undertake, either directly or in co-operation with public or private organisations....

- $\quad$ to remove as far as possible the causes of ill-health;

- to provide advisory and educational facilities for the promotion of health and the encouragement of individual responsibility in matters of health;

- to prevent as far as possible epidemic, endemic and other diseases.

${ }^{724}$ Article 10 of the Additional Protocol to the American Convention on Human Rights (Protocol of San Salvador):

In order to ensure the exercise of the right to health, the States Parties agree to recognize health as a public good ...

${ }^{725}$ Article 16 of the African Charter on Human and Peoples' Rights (Banjul Charter) 1981:

States parties to the present Charter shall take the necessary measures to protect the health of their people and to ensure that they receive medical attention when they are sick.

${ }^{726}$ The South Asian Association for Regional Co-operation (SAARC) Social Charter includes health under Principle 13 (Health goals); Article III (Poverty alleviation); Article IV (Health); Article VII (Children includes health); Article X (Population stabilization).

${ }^{727}$ Article 17 of The Cairo Declaration on Human Rights in Islam:

Everyone shall have the right to medical and social care, and to all public amenities provided by society and the State within the limits of their available resources... The States shall ensure the right of the individual to a decent living that may enable him to meet his requirements and those of his dependents, including food, clothing, housing, education, medical care and all other basic needs...

${ }^{728}$ International Convention on the Elimination of All Forms of Racial Discrimination, Article 5 states that compliance with the fundamental obligations laid down in Article 2 of the Convention requires this. 
which establishes the obligation to adopt adequate measures to guarantee women access to health and medical care, including adequate maternal health care, with no discrimination whatsoever, including access to family planning services. ${ }^{729}$ An international political commitment on women's health rights was achieved as a result of the Fourth World Conference on Women, Beijing, 1995 and with its follow-up, Beijing +5 , in 2000. The Beijing Declaration and Platform for Action of the Fourth World Conference on Women of 1995 includes as a Strategic Objective (C) the area of Women and Health. ${ }^{730}$ It is possible that if liberalization of services is done without the necessary social welfare protections also in place, it could contribute towards further marginalization of the poor in society. It also possible with regard to liberalization of health services, that various gender issues may arise. It has been generally noted that if liberalization of health services is carried out in such a manner that affects the availability and accessibility of public services, poor women who depend on public health systems for reproductive care and medical care of children would be particularly affected - and so would their children. Articles 23 and 24 of the Convention on the Rights of the Child of 1989 recognize the right to health for all children and identify several steps for its realization. As mentioned earlier, development cannot neglect the improvement of standards of health, especially for women, children and other particularly vulnerable communities.

In addition to the abovementioned international standards and obligations there are also either right to health provisions or basic health obligations in: the Convention relating to the Status of Refugees 1954 (and as amended); the Geneva Conventions of 1949 and their Additional Protocols of 1977; the International Convention on the Protection of the Rights of All Migrant Workers and Members of Their Families of 1990 (entered into force 2003); the Standard Minimum Rules for the Treatment of Prisoners of 1955; the Declaration on the Rights of Disabled Persons of 1975; the Principles for the Protection of Persons with Mental Illness and the Improvement of Mental Health Care of 1991 as well as a number of other commitments and binding international obligations.

The comments on these other international right to health documents is for the purpose of reiterating that the right to health is a well-developed and widely accepted right. There is extensive work done over a long period of time on its content and implementation, both as political commitments and binding obligations. The references to 'public health' in trade contexts do not fully reflect the depth of the right to health and its importance for sovereign national policy-making. But at the same time, it should be acknowledged that:

\footnotetext{
${ }^{729}$ See further Sellin, J. and N. Mendis, Women's Right to Health and International Trade - Special Reference to the GATS and the TRIPS Agreement in Westendorp, Ingrid Ed., THE WOMEN'S CONVENTION TURNED 30: ACHIEVEMENTS, SETBACKS, AND PROSPECTS, Intersentia, 2012.

See also for a communication to the CEDAW Committee on Article 12, Alyne da Silva Pimentel v. Brazil (Communication No. 17/2008). This was the first case on maternal mortality (the case also related also to poverty and race, as the mother was an impoverished woman of African descent) to be brought before CEDAW under the individual complaints procedure available through the Optional Protocol to CEDAW. The petition was filed by the Center for Reproductive Rights and Advocacia Cidadã pelos Direitos Humanos. The CEDAW Committee in this case also referred to Article 12 of ICESCR and General Comment 14 on the Right to Health of the ESCR Committee, and it is considered an important step forward in increasing coherence in international human rights law on women's economic, social and cultural rights.

${ }^{730}$ See Paragraph 106 of the Beijing Platform for Action on the commitment towards universal access to healthcare, especially reproductive healthcare for women.
} 
Rights alone are not panacea for global health and never will be. But they are a reflection of our collective common conscience. ${ }^{731}$

As discussed earlier in Chapter 2, human rights language is ambiguous and comes with its own set of inherent problems, but if we are to seek to establish a 'value-based Rule of Law' for global interactions, human rights such as the right to health are useful tools for describing and for setting standards for the achieving of the kind of society and world that could be created. 


\subsection{CONCLUSIONS: A RISKY NAVIGATION}

Navigation was always a difficult art, Though with only one ship and one bell;

And he feared he must really decline for his part, Undertaking another as well.

\section{From Lewis Carroll's The Hunting of the Snark}

This Chapter brings together three key stands: (i) the concepts underlying the GATS and trade in services and policy choice; (ii) the methodology for the interpretation of GATS provisions including the VCLT and the inclusion of a human rights approach; and (iii) the relevance of the right to health of the international human rights regime for the protection of public services.

The first part of the Chapter discussed the backdrop and justifications for an international legal framework for trade in services and the arguments in favour of retaining national policy space and flexibility. The underlying assumption of the WTO Services regime is that the objective of the economic growth of all trading partners can be achieved through progressive liberalization of service sectors. However, there is an alternative to the focus on economic growth, which is the human development approach. The 'snapshot' of Sri Lanka's health expenditure was referred to as an oft-cited example that good health indicators are not necessarily linked with the level of expenditure. The experiences with several other countries referred to in 'snapshots' regarding the outcomes of strengthening public health services also emphasizes that health services should probably not be looked at in the same manner as other services - and that trade liberalization is not a panacea for all ills.

The nature of the health system that a State should establish are vital to the concept of a just and fair society, and are preferably formulated and implemented through democratic participation in the political system. Snapshots of Sri Lanka, The United Kingdom, The State of Kerala in India, among other countries, were presented in support of the linkage between political representation of the people's will and the development of strong public health services. The contrasting approaches to public health services in United States and Canada were discussed in light of the importance of social values being represented through the democratic political process and being absorbed by domestic legal and policy frameworks.

WTO Members have shown a desire to maintain a certain policy space for implementing their domestic non-trade societal values. It is generally argued that the WTO system is not so rigid as to prevent opportunities for the protection of non-trade societal values. Recognizing national policy space flexibility is part of the attempt to balance sovereignty with the uniformity needed for the international system. There are also responsibilities of the State according to constitutional rights and values or social policy of that domestic system, that tie-in with the obligations in international human rights law. For most of the countries mentioned in the 'snapshots', the domestic values are strong despite not even having an explicit right to health provision in their national constitutions, to support the value. Thus, international human rights law on the responsibility of the State to protect, promote and fulfill the right to health can reinforce the local values that support the creation and promotion of a national public health service. A synergy can be identified 
between promoting national sovereignty and promoting international standards and action when it comes to the right to health.

The Preamble of the GATS has the recognition of national sovereignty and respect for policy space and appropriate flexibility. But there is also the goal of the progressive liberalization of services. What space is there in the GATS for the exercise of sovereignty and for acceptance of national interpretations which align with differing economic and social policies to that of services liberalization? It is generally accepted that WTO rules are not so rigid or so inflexible that they cannot be interpreted according to the needs of the 'real world'. As discussed in this chapter, the starting point for treaty interpretation would be the text of the relevant agreement. The VCLT suggests a holistic approach to text-context-object and purpose and the WTO dispute settlement bodies have recognized an evolutionary approach. A restrained teleological approach could be applied if there was greater clarity on the goals of the agreement with regard to the balancing of conflicting interests and values.

Judicial activism is discouraged in the WTO context and it is the responsibility of the dispute settlement bodies not add to or diminish the rights and obligations provided in the covered agreements. There is debate and disagreement on the relationship between the WTO regime and other regimes of substantive international law, especially international human rights law. Yet there should not be 'self-contained regimes' in the international system, immune to other aspects of international law, only specialized regimes within the larger system. With this in mind it was useful to look a little closer at how Article 31(1) ('evolutionary ordinary meaning') or Article 31(3)(c) of the VCLT was addressed is the dispute settlement context, particularly to integrate human rights norms into WTO law. Regarding Article 31(3)(c) of the VCLT ("any relevant rules of international law applicable in the relations between the parties"), it would depend on whether a narrow or broad interpretation is given. It is also not clear as yet what weight can be given to other international rules, principles or norms within the interpretive exercise. A balance must be achieved between an individual Members societal values or non-WTO obligations and maintaining consistency and harmony with regard to the in the interpretation of the WTO obligations of all the Members.

The chapter also discusses the various challenges in promoting a human rights approach to interpretation of WTO law. These are not only limited to treaty interpretation but can be also political problems including bad faith use and making it a tool for other objectives. The doubts regarding how far the interpretation can and should be stretched are also related to sovereignty concerns, especially the realities of international relations and the ability of some countries to influence others. There is also a point raised in the chapter concerning the importance of 'human dignity' for bridging different viewpoints and ideologies that may not agree on the nature and context of legally binding and justiciable human rights.

The Chapter also addresses the existence of two different legal languages of human rights and trade - and the resulting 'the dichotomy of discourses'. On reviewing the human right approach to WTO interpretation, it was noted that the idea of 'policy coherence' between these two areas often slips into the realm of trade prioritization, when the core differences in the two concepts are not acknowledged. These challenges are termed in this study as problems of language, discourse or 'bilingualism'. 
As in the exercise of language translation, lawyers discussing and applying human rights and trade law must be 'bilingual' in both their discourse and in the application of human rights in the interpretation of trade rules. The sections on the right to health in international human rights law, and the methods of human rights interpretation have been included so as to assist in developing this bilingualism for the purposes of this study. Understanding the limitations of 'language competency' (or incompetency) should lead to a better understanding of your own 'language' or area of expertise in attempting an 'accurate, natural and communicative translation' into another regime. An even more optimistic view is that this can lead to something like 'linguistic hospitality' between human rights and trade law. But as Ricoeur has said, "translation remains a risky operation, which is always in search of its theory". ${ }^{732}$ Interpretation of the provisions in the GATS which may or may not allow for policy space and entry of non-trade concerns and values through 'translation', also seems like a risky business in search of its theory.

${ }^{732}$ Ricoeur, Paul, REFLECTIONS ON THE JUST, University of Chicago Press, 2007, p108. 


\section{CHAPTER 3}

THE SCOPE OF THE GATS, THE RIGHT TO HEALTH AND PUBLIC SERVICES

What do you prate of service?

- I talk of that, that know it.

From Shakespeare's Coriolanus 
Chapter 3 


\section{CHAPTER 3}

\section{THE SCOPE OF THE GATS, PUBLIC SERVICES AND THE RIGHT TO HEALTH}

\subsection{INTRODUCTION TO CHAPTER 3}

This chapter is on the scope of coverage of the GATS, focusing on Article I of the GATS. At the heart of the Chapter is the question of the extent of policy space in the GATS for Members to protect and promote public services, with special emphasis on public health services. This is the core specific research question of this study. If public services are excluded from the scope of the GATS, the concerns about the extent of available policy space for public health services can be addressed and, for the purposes of the GATS coverage at least, laid to rest to a great extent. The problem is that the issue of scope of coverage of the GATS is not unequivocally clear on the exclusion of public services.

The first part of this Chapter, section 3.2, introduces and summarizes the controversies and broader context, particularly on how the possibility of inclusion in the GATS has been seen as having potentially negative consequences for public health services. This section also sets out the text and terminology of Article 1, which requires interpretation and application in order to answer the question of "what is covered by the GATS?".

This section is followed by a more in-depth analysis of the sub-sections of Article 1 of the GATS in sections 3.3 and 3.4. Section 3.3 looks at some of the key terms for understanding the scope of the GATS, beginning with "trade in services". This section includes discussion of the definition of "measures" in WTO law and with regard to "measures affecting trade in services" and "measures by Members" in Articles I:1, I:2 and XXVIII of the GATS. Section 3.4 deals with the exemption for "services supplied in the exercise of governmental authority" in Article I:3(b) of the GATS. This concept of "services supplied in the exercise of governmental authority" is clarified and defined further in Article I:3(c) of the GATS, by reference to the terms "supplied on a commercial basis" and "...in competition with". The aim of the discussion in this section is to establish whether the breadth of this exemption creates a sufficient safe harbour for public health services.

Section 3.5 of this Chapter discusses the implications for public services of Articles VIII, $\mathrm{XIII}$ and XV of the GATS; that is, the provisions dealing with monopolies and exclusive service providers, government procurement and the negotiating mandates for services subsidies. The reference to these additional issues is due to their link with public services provision and the question of their relationship with the exemption for "services supplied in the exercise of governmental authority".

This study does not aim to classify and discuss types of national policy measures regarding public health services that ought to be beyond scope of the GATS or make detailed justifications of such possible measures - however the issue of subsidies will be looked into in some detail as relevant to the scope of coverage. This Chapter will focus on whether it is possible to determine the extent of the freedom to take measures for the continued provision and protection of public health services. In this regard, the basic question yet to be answered is whether the interpretation of the scope of the GATS, in 
particular the exemption from the scope of application of the Agreement in Article I:3(b) and (c), will allow for national policy divergence in order to protect public health services.

The questions that are discussed in this Chapter relating to the scope of the agreement are:

1. The interpretation of 'measures affecting trade in services' and the breadth of the Agreement with regard to both:

a. the definition of trade in services for the GATS and

b. the types of measures that fall within its scope.

2. Whether Article I of the GATS, the Article on the scope of application of the Agreement, exempts public services from the scope of application (The interpretation of 'services supplied in the exercise of governmental authority').

3. Whether the regulation of monopolies and exclusive service providers (Article VIII) would affect public services even if they are outside the scope of Article I of the GATS.

4. Whether it is possible to determine the extent of coverage in the GATS of public services subsidies (Article XV of the GATS), rules on government procurement of services (Article XIII of the GATS) and the impact of domestic regulation rules on public services (Article VI of the GATS). The fact that these are negotiating mandates for GATS future disciplines further complicates the matter, as does the fact that subsidization of public services may come under other Articles of the GATS than Article XV.

\subsection{A REAPPRAISAL OF CONCERNS RELATING TO PUBLIC SERVICES AND THE GATS}

\subsubsection{Introduction to the Key Concerns}

There are several key concerns with regard to the scope of the GATS that underlie this Chapter. They can be summarized as concerns about sovereign decision-making, concerns about services commoditization in general and concerns about the impact of commoditization of services on provision of and access to public services which are necessary for the general welfare of society. McMichael and Beaglehole comment how although public health systems remain the responsibilities of national governments, the fundamental socio-economic and environmental determinants of population health are "increasingly supranational" - the result being a "global combination of liberal economic structures and domestic policy constraint" causing an adverse effect on political stability, socio-economic equality and therefore also, population health. ${ }^{733}$ More directly, Delimatsis has commented that "the GATS was the culmination of the erosion of the public service tradition which had already happened in most of the " 80 s". 734

Would the GATS limit the extent of freedom a WTO Member retains with regard to services policy-making and regulation? To what extent would a Member be free to promote and protect both the concept of public services and the actual provision of

\footnotetext{
${ }^{733}$ McMichael Anthony J., and Robert Beaglehole, The Changing Global Context of Public Health, 356 Lancet (2000), 495, p497.

${ }^{734}$ Delimatsis, P., Coherence and Divergence in Agreements on Trade in Services: A Drama in Three Acts, TILEC Discussion Paper, DP 2019-019, 2019, p10.
} 
services by governments? These are the questions that this Chapter on the scope of the Agreement attempts to answer, with special reference to public health services.

Article I of the GATS sets out the scope of the Agreement, but it is not entirely clear whether public services are exempt from the scope of the GATS, even though Article I exempts "services in the exercise of governmental authority" from coverage. With regard to the area of focus of this study, there is concern that the liberalization of health and related services under the GATS would result in restrictions of national policy space for the development of public health services. The concern is that these restrictions on national policy could result in the possibility of downgrading (in terms of national prioritization etc.) and reduction in funding (such as State financing and subsidies for public health services) leading to increased costs and the inability to maintain and improve existing public health services. ${ }^{735}$ As the burden of increased healthcare costs will disproportionately be upon the poorest and most disadvantaged segments of society, ${ }^{736}$ questions have been asked of governments on how they intend to balance their domestic obligations in terms of constitutional aspirations or the right to health with their general or specific commitments to liberalize the health sector.

In the context of economic globalization, it has been commented that:

Private markets [in health services], unconstrained and inadequately regulated, are perhaps the most powerful globalizing force driving inequities in health. ${ }^{737}$

But it also should be stressed at the outset that the GATS per se is not necessarily the cause of the problems and failures in public health service provision. It is argued that properly regulated, liberalized international trade should be no barrier to universal and equitable public services provision and that all these fears actually relate to shortcomings in 'governance issues' such as national democratic accountability, citizen participation in policy formulation, transparent and responsible national budgeting and public spending on health services. These governance issues are also political issues relating to policy decisions in relation to services; and arguably not directly influenced by or an inevitable result of GATS obligations, which are, other than MFN and transparency obligations, the result of negotiations by Members. ${ }^{738}$ However, while not necessarily a cause of problems

\footnotetext{
${ }^{735}$ See e.g. the views expressed by the International Human Rights Internship Program (IHRIP) and Asian Forum for Human Rights and Development, The Right to Health in CIRCLE OF RIGHTS: ECONOMIC, SOCIAL AND CULTURAL RIGHTS ACTIVISM: A TRAINING RESOURCE, IHRIP, 2000, p. 267:

Economic policies that result in the underfunding of public services and the fragmentation of the regulatory role of the government tend to reduce the threshold of what is considered an acceptable minimum standard of health-care provision for the population at large. Access to health care becomes dependent on the individual's capacity to pay; patients are turned from citizens who have rights and responsibilities into clients or consumers...

${ }^{736}$ See e.g. the work of the United Nations Research Institute for Social Development (UNRISD) Project on Commercialization of Health Care: Global and Local Dynamics and Policy Responses (2001-2004). The Project cast healthcare systems as a "key arena for redistribution and social inclusion" where unfortunately, some current systems act as "powerful drivers of impoverishment and exclusion". See further the research available online at http://www.unrisd.org/unrisd/website/projects.nsf/(httpProjectsForProgrammeAreaen) /E90A28B15B255697 C1256DB4004B2D63?OpenDocument, last accessed 03.05.2014.

737 Chen, Lincoln, and Giovanni Berlinguer, Health Equity in a Globalizing World in Evans, Timothy, Margaret Whitehead, and Finn Diderichsen, eds. CHALLENGING INEQUITIES IN HEALTH: FROM ETHICS TO ACTION. Oxford University Press, 2001, p40.

738 See further, Chapter 4 of this study, which discusses both the general obligations and specific commitments under the GATS in further detail.
} 
in health services delivery, universal access and progressive realization of the right to health, the GATS can be described in general as a symptom of the neo-liberal economic philosophy towards public services or in its possible specific impacts, as a carrier of the neo-liberal epidemic.

Thus, according to the above view of the importance of governance, it is up to each Member to assure its citizens that public health services of good quality with universal coverage will be maintained and to take steps to do so. Until trade in services and the GATS created a framework of rules in this area, the design of the domestic health services system and the relationship between the public sector and the nature and extent of involvement of private suppliers in health services were only a matter of domestic debate and policy choices. Now this has changed and the interests of foreign private health service providers could have a greater influence on the domestic space, but the matter of equitable and effective public health services still remains a domestic social and political choice. It can be an easy way out for some Member governments unwilling to take these steps, to say when facing their constituencies, that the GATS does not allow for such steps and that their hands are tied, when this is not true in every instance. Still, a public debate on the ambiguities of the GATS and its possible negative outcomes can have a positive outcome of drawing attention to the abovementioned governance issues and to the fact that inability to improve or maintain public health services, whether GATS-induced or not, will disproportionately burden the poor.

Whether the GATS is viewed with suspicion as an insidious part of a broader program of libertarian lock-in for economic and social policy or whether failures of governance in areas such as public health services occur quite independently of the GATS, the stage is set for a post-Cold War reassessment of societal values when it comes to public health services. This re-assessment needs to take into account the policy space available in the framework of the GATS for taking measures for the protection of public health services. The best-case scenario is one where WTO Members, freed from the capitalist-orcommunist paradigm that dominated the Cold War era, can take the measures relating to health services that their society thinks most suitable for achieving human development. This possibility to take health measures unhampered by GATS does not automatically guarantee better health governance, but it empowers the citizens in any efforts they may initiate to hold their governments responsible for improvements in the provision of public health services and health indictors, and denies the governments the excuse of declaring that their hands are tied due to GATS obligations or pressures from negotiating partners.

With regard to the governance issues abovementioned there is also an issue of what citizens expect from the State and government and relate to the rights and responsibilities of both citizenship and of State power. In international law, a highly developed and detailed exposition of the relationship between people (not just citizens) and the State is found in international human rights law and policy. This was mentioned previously in the Chapter 1 and 2 in relation to concepts underlying this study, with reference to the State responsibility for health and health services provision and the human right to health. The following sections will go into further detail on the interaction between the right to health and the GATS in the context of public services. The relationship between the international law and policy on the right to health and the delivery of public health services discussed earlier in Section 2.4. of Chapter 2 can explain why Article I of the GATS was the focus of attention for persons concerned about the consequences for public health services. 


\subsection{2. 'Scare-mongering'}

Civil society criticism and protests, especially those that occurred at the time of the Seattle Ministerial Conference, have forced Member governments and WTO officials to respond to the issue of whether the GATS affects the ability of governments to provide public services. Although Member governments have responded with promises to protect public interests in liberalization negotiations and the WTO published official responses that refuted allegations made by organizations and in various demonstrations, the burning questions were left unanswered and the rebuttals were not convincing. The responses of WTO officials have ranged from scoffing at the fears as 'scare mongering' or 'scare stories', to contradictory statements as to what the scope of coverage of the GATS really is. Rudolf Adlung, at the time the senior economist in the Trade in Services Division in the WTO Secretariat, referred to "scare mongering" by those who were concerned about the effect of the GATS on public services, ${ }^{739}$ and David Hartridge, former Director of Trade in Services Division of the WTO Secretariat has stated that:

[s]ince the right to maintain publicly-funded governmental services is vital

to all WTO, members, and questioned by none, this is one scare story

which can be shown up for what it is. ${ }^{740}$

However, Hartridge also admitted that an interpretation of Article 1:3 of the GATS and the term "services supplied in the exercise of governmental authority" (SSEGA) in Article I:3(b) is 'might be worthwhile'. For an example of contradictory statements or confusing signals: Adlung says in a 2001 response to critical articles published in The Lancet, that under Article I:3 public services are fully and unconditionally exempt from the scope of the GATS i.e. from all subsequent rules and disciplines ${ }^{741}$ - however, in a 2006 publication Adlung says that "Article 1:3 is not only relatively narrow but subject to uncertainties". ${ }^{742}$ There have been no clarifications in the intervening years since these statements were made, which have settled the issues of the scope of coverage or exemption for public services. These issues are analyzed in further depth in part two and part three of this Chapter.

Similarly, the trend in Background Notes on services by the WTO Secretariat from 19982001 as analyzed by Krajewski ${ }^{743}$ show that the position oscillated from doubts about the extent of coverage in 1998, to confident responses to subsequent civil society concerns that the position is very clear and needs no additional interpretation. Overall, Krajweski comes to a fair conclusion when he says that:

...it is safe to say that there is no coherent use of the meaning of this provision [Article I of the GATS] throughout the Secretariat publications.

\footnotetext{
${ }^{739}$ Adlung, R., Health-Care Systems and the WTO: No Grounds for Panic, 27.03.2001, available online at www.wto.org/english/tratop_e/serv_e/comments_lancet_e.doc, last accessed 20.03.2012.

${ }^{740}$ Hartridge, David, Director of Trade in Services Division, WTO Secretariat, WTO Secretariat hits false attacks against GATS, 27 November 2000, available online at http://www.wto.org/english/news_e/ news00_e/gats2000neg_hartridge_e.htm.

The term 'scare story' is also used in the publication WTO, GATS: FACT AND FICTION, 2001, p10, available online at http://www.wto.org/english/tratop_e/serv_e/gatsfacts1004_e.pdf.

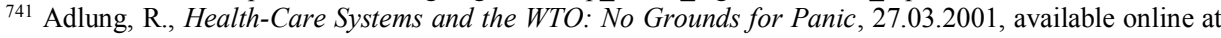
http://www.wto.org/english/tratop_e/serv_e/comments_lancet_e.doc, last accessed 20.03.2012.

742 Adlung, R., Public Services and the GATS, WTO Staff Working Paper No. ERSD-2005-03.

743 Krajweski, Markus, Public Services and the Scope of the General Agreement on Trade in Services (GATS), A Research Paper written for the Center for International Environmental Law (CIEL), 2001, p7-8.
} 
The reference to Background Notes here is merely to trace the position of trade officials working in the WTO System. It is hoped that they would be able to explain some of these issues to those without their level of expertise and experience in trade matters. But these are matters that trade negotiators have left unclear, and which may not be authoritatively interpreted for some time to come - something that ought to be admitted at the outset.

Thus, these kinds of explanations have not increased faith in the ability of the GATS framework to protect public services, but rather added fuel to the fire of doubt and suspicion. As former WTO Director General Lamy has said:

Ensuring factual clarity is essential when talking about trade because there is a great deal of mist surrounding the topic, some of it deliberately generated by those with an anti-trade agenda. ${ }^{74}$

Factual clarity and more information definitely would lead to 'more informed debate and better policy decisions' as pointed out in this speech. But if it was not such a serious topic, it would be amusing that the concerns raised due to the ambiguity of WTO provisions are blamed on 'those with an anti-trade agenda', when much of it was due to deliberate constructive ambiguity ${ }^{745}$ on the part of the WTO negotiators intending to postpone decisions on controversial issues and the lack (or avoidance) of subsequent authoritative interpretation. At the same time, it is admitted that:

We at the WTO accept our share of the blame. We can and will do better at explaining how trade improves the lives of most people around the world. ${ }^{746}$

There is further comment that governments, universities and businesses 'need to do more' and 'need to lift their play' to spread the story that trade is good for us. ${ }^{747}$ On the other hand, it can also be argued that the alleged 'scare-mongering' is not the preserve of only the critics of liberalization of trade, but also the proponents. Tamanaha notes that the warnings by liberal economic theorists that modern social welfare programmes would threaten (the sacrosanct concept of) 'liberty' "has the feel of scaremongering". ${ }^{748}$

Something that can be agreed upon by anyone, regardless of the side or stand taken in these issues is that narrative voice is important. ${ }^{749}$ It is also important the way the story is told:

${ }^{744}$ Lamy, P., 'Trade improves the lives of people'- Lamy, speech at the Minnesota Economic Club in Minneapolis, United States on 17 April 2012, www.wto.org/english/news_e/sppl_e/sppl224_e.htm, last accessed 19.03.2012.

745 Panel Report, Mexico-Telecoms, para.7.2 citing Moore, Mike, A WORLD WITHOUT WALLS FREEDOM, DEVELOPMENT, FREE TRADE AND GLOBAL GOVERNANCE, Cambridge University Press, 2003, p. 111:

WTO negotiators sometimes praise the political wisdom of resorting to "constructive ambiguity" as a diplomatic means of enabling consensus on WTO rules.

746 Lamy, P., 'Trade improves the lives of people'- Lamy, speech at the Minnesota Economic Club in Minneapolis, United States on 17 April 2012, http://www.wto.org/english/news_e/ sppl_e/sppl224_e.htm, last accessed 19.03.2012.

${ }^{747}$ Ibid., (Lamy)

748 Tamanaha, Brian, The Dark Side of the Relationship between the Rule of Law and Liberalism, NYU Journal of Law and Liberty, 33, 2008, 516, p545.

${ }^{749}$ Lamy, P., 'Trade improves the lives of people'- Lamy, speech at the Minnesota Economic Club in Minneapolis, United States on 17 April 2012, http://www.wto.org/english/news_e/sppl_e/sppl224_e.htm, last accessed 19.03.2012:

There is another important part of the trade agenda for which change is urgently required how we tell the story of trade. In the communication age, you cannot persuade people without a compelling narrative. 
Stories and counter-stories, to be effective, must be or must appear to be non-coercive. They invite the reader to suspend judgment, listen for their point or message, and then decide what measure of truth they contain ${ }^{750}$

It can be argued that it is the responsibility of trade experts to provide a non-coercive yet convincing narrative on the benefits of the WTO system and the ability of the rules to provide fair solutions for difficult problems. And that it is not the moral duty of critics to be less emotive in their reactions, only to avoid spreading incorrect or unsubstantiated information. It is not only the critics of the trade regimes who can be "incoherent and selfcontradictory [and full of] righteous indignation" and the justifiable concerns cannot be easily dismissed even by the trade experts. ${ }^{751}$ Since much of the criticism is about areas where there is no authoritative interpretation as yet, this cannot be said to be a matter of the critics deliberately generating confusion about something that is absolutely clear in facts and interpretation. Ultimately, both trade experts and critics are 'scaring' or appealing to, not each other, but the public, who may by their stance also influence national decision-makers. Judging the success of trade law and policies will include not just which policies were successfully promoted but how these choices are presented and justified and the extent to which there is public support.

\subsubsection{Privatization, Corporatization and Commercialization of Public Services}

It is also is necessary to briefly mention of the issue of privatization of existing public services, which is also feared as being part of the liberalization agenda. At times privatization has consisted of clear transfer of ownership from public to private, but at times the changes have been more subtle, involving a change of operational goals rather than change of ownership. Observers such as Chapman warn of countries like Canada slowly moving away from their prior commitment to the right to health and the 'single payer universal coverage health system' as a "core social institution existing for the benefit of society" based on a social citizenship model - towards accepting health as a commodity and business opportunity within relationships of classical liberal 'market citizenship'. ${ }^{752}$ Chapman also highlights that the experience of the United States is to be taken as a cautionary example, since, as "the most thoroughly privatized and

${ }^{750}$ Delgado, Richard, Storytelling for Oppositionists and Others: A Plea for Narrative, Michigan Law Review, Vol. 87, No. 8, Legal Storytelling, August 1989, p2415.

${ }^{751}$ Hartridge, David, Speech at the ECOSOC High-Level Segment, Geneva, 5 July 1999, available online at http://www.wto.org/english/thewto_e/minist_e/min99_e/english/press_e/ecosoc_e.htm, last accessed 04.05.2013:

Even though the opposition is often incoherent and self-contradictory, and even though we must be suspicious of those who surrender too easily to the sheer pleasure of righteous indignation, we cannot ignore the fact that there are real concerns about the impact of globalization, concerns felt by many good people - the kind of people you would prefer to have on your side in any argument.

752 Chapman, Audrey R., HUMAN RIGHTS, GLOBAL HEALTH, AND NEOLIBERAL POLICIES, Cambridge University Press, 2016, p139, drawing together conclusions from: Flood, Colleen, and Aeyal Gross, THE RIGHT TO HEALTH AT THE PUBLIC/PRIVATE DIVIDE: A GLOBAL COMPARATIVE STUDY, Cambridge University Press, 2014; Armstrong, Pat, and Hugh Armstrong, The context for health care reform in Canada in Armstrong, Pat, Carol Amaratunga, and Jocelyne Bernier Eds., EXPOSING PRIVATIZATION: WOMEN AND HEALTH CARE REFORM IN CANADA, University of Toronto Press, 2001; Cameron, Barbara, Accounting for rights and money in the Canadian Social Union in Young, Margot, Susan Boyd, Gwen Brodsky, and Shelagh Day, eds. POVERTY: RIGHTS, SOCIAL CITIZENSHIP, LEGAL ACTIVISM, UBC Press, 2007. 
commercialized health system among developed countries" it ranks last among developed countries for on a number of measures including efficiency and equity. ${ }^{753}$

There has also been a trend that international institutions have strongly promoted increased private participation in the supply of public services. With regard to health policy, Walt says that with the involvement of international economic institutions in health policy planning and financing, a shift towards 'cost-effectiveness' and an increased role of the market alongside a reduced role for the State in places where the State played a greater role in health service delivery has been promoted. ${ }^{754}$ Walt cites in particular, the World Bank documents - Financing Healthcare: An Agenda for Reform Report (1987) and the World Development Report (1993). ${ }^{755}$

A more recent publication by the World Bank in 2003 titled Innovations in Health Services Delivery: The Corporatization of Public Hospitals presents an overview of reforms in the sector. This publication, in its glossary of terms, distinguishes "privatization" (also referred to by the editors as "outright divesture of the organization from the public sector" ${ }^{\prime 756}$ ) from other market-oriented reforms as "...the most extreme version of marketizing organizational reform". ${ }^{757}$ This highlights the fact that there can be other forms of marketization that may have privatization-like effects, although not as obvious or extreme. The glossary further defines "marketizing reforms" - also known as "new public management" - as including the concepts of "corporatization", "privatization" and "autonomization". The exposure of public services to "market pressures" or "market-like pressures" is emphasized. ${ }^{758}$ Further, "corporatization" is defined separately as:

A reform of a public organization that reproduces some elements of private sector business structure in an attempt to engender the efficiency of private corporations while assuring continued emphasis of social objectives through public ownership [emphasis added]. ${ }^{759}$

However, there is contradiction in the publication since "New Public Management" is referred to by the Editors (Preker and Harding) as follows:

Application of private sector management principles to the public sector...

[including] emphasis on monetary rather than non-monetary incentives [emphasis added]. ${ }^{760}$

In a sector like health services, this trend of emphasizing monetary incentives and promoting exposure to market pressures without satisfactorily or consistently

\footnotetext{
753 Chapman, Audrey R., HUMAN RIGHTS, GLOBAL HEALTH, AND NEOLIBERAL POLICIES, Cambridge University Press, 2016, p138.

${ }^{754}$ Walt, Gill, HEALTH POLICY: AN INTRODUCTION TO PROCESS AND POWER, $2^{\text {nd }}$ Edition, Witwatersrand University Press and Zed Books, 1996, p 127. Walt makes reference to Buse, K, Spotlight on International Agencies: The World Bank, Health Policy and Planning 9:95-9.

755 Akin, John S., Nancy Birdsall, David M. De Ferranti, FINANCING HEALTH SERVICES IN DEVELOPING COUNTRIES: AN AGENDA FOR REFORM, World Bank Publications, 1987; Berkley, Seth, Jose-Luis Bobadilla, Robert Hecht, Kenneth Hill, Dean T. Jamison, Christopher J. L. Murray, Philip Musgrove, Helen Saxenian and Jee-Peng Tan, WORLD DEVELOPMENT REPORT 1993 : INVESTING IN HEALTH, World Bank Publications, 1993.

WORLD DEVELOPMENT REPORT 1993: INVESTING IN HEALTH, Oxford University Press, 1993.

${ }^{756}$ Preker, Alexander S, and April Harding Eds. INNOVATIONS IN HEALTH SERVICES DELIVERY: THE CORPORATIZATION OF PUBLIC HOSPITALS, World Bank, 2003, p2.

${ }^{757}$ Ibid., (Preker and Harding), p556.

${ }^{758}$ Ibid., (Preker and Harding), p554, 551 and p2.

${ }^{759}$ Ibid., (Preker and Harding), p551.

${ }^{760}$ Ibid., (Preker and Harding), p2.
} 
acknowledging and assessing the social objectives, is troubling for those concerned with the effects of such reforms on the health of people. Using certain private sector management principles within the public service can assist in more efficient use of public resources in terms of preventing waste, improving productivity and assessing both health worker and public satisfaction levels. However, the incentives for attempting these improvements should be social objectives related to the right to health and not monetary objectives; since prioritizing monetary objectives over the social objectives can negatively impact public health and the right to health (e.g. reduction of funding in areas not considered cost effective such as counselling and mental health services). ${ }^{761}$

The diversity of opinion in the area of how best to provide services has not gone completely un-noticed at World Bank level as a year later, the World Development Report (WDR) for 2004 was titled Making Services Work for Poor People and acknowledging the link between services delivery and the Millennium Development Goals, several goals of which concern health indicators. ${ }^{762}$ The report also recognized that "growth alone will not be enough to reach the goals" $" 763$ and services that contribute to health and education outcomes are a "public responsibility and fundamental human right" that "the private sector left to its devices will not achieve". ${ }^{764}$ There is no argument against more effective and better managed public services, this indeed needed. Furthermore, the need for efficient public services provision does not preclude efficient private providers supplying health services alongside the public health sector. Creating the right national and local institutional frameworks to achieve "development effectiveness" $" 765$ is a huge challenge - and the question was asked in the WDR 2004, with regard to the role of GATS, whether or not it deprives governments of the freedom to

\footnotetext{
${ }^{761}$ See Saxena, Shekhar, Graham Thornicroft, Martin Knapp and Harvey Whiteford, Resources for mental health: scarcity, inequity, and inefficiency, The Lancet, Volume 370, Issue 9590, 8-14 September 2007, pp.878-889;

Young, Suzanne, Outsourcing in public health: a case study of contract failure and its aftermath, Journal of Health Organization and Management, Vol. 22 Issue: 5, 2008, pp.446-464. See further Andrews, Rhys, George A. Boyne, and Richard M. Walker, Dimensions of publicness and organizational performance: A review of the evidence, Journal of Public Administration Research and Theory 21. suppl 3, 2011. The authors review the research on public and private services provision, including health services. They critique the notion of 'New Public Management' as well as the discussions of 'publicness' (nature, funding and control) in research, noting in their conclusion that most studies which have been carried out examine effects on efficiency without paying much attention to equity, although equity is a fundamental rationale of public services provision.

762 World Bank, WORLD DEVELOPMENT REPORT 2004: MAKING SERVICES WORK FOR POOR PEOPLE, 2003, p2. UNGA, Millennium Declaration, A/RES/55.2 adopted by the UN General Assembly on 8 September 2000. The Millennium Goals to be reached by 2015 are:

1. Halving the proportion of people living in extreme poverty and suffering from hunger.

2. Achieving universal primary education.

3. Promote gender equality and empower women

4. Reduce by two-thirds the under-5 child mortality rate.

5 . Reduce by three-quarters the maternal mortality ratio.

6. Combat (halt and begin to reverse the spread) of HIV/AIDS, malaria and other diseases.

7. Ensure environmental sustainability (includes halving by 2015, the proportion of people without sustainable access to safe drinking water and basic sanitation and achieving a significant improvement in the lives of at least 100 million slum dwellers).

8. Create a global partnership for development with targets for aid, trade and debt relief.

${ }^{763}$ Ibid, (WDR 2004).

${ }^{764} \mathrm{Ibid}$, (WDR 2004), Box 2 and p2.

${ }^{765}$ Ibid, (WDR 2004), Wolfensohn, James. D. in the Foreword, pxvi.
} 
choose and implement the 'pro-poor' domestic policies necessary for development or to reverse inappropriate policy choices. ${ }^{766}$

The Millennium Development Goals referred to above were targets to be achieved by 2015, therefore they were replaced by the UN General Assembly Resolution on the post2015 development agenda, with the new targets for 2030 being named as the Sustainable Development Goals (SDGs). ${ }^{767}$ There are 17 "integrated and indivisible" Sustainable Development Goals and 169 targets listed in this document. The SDG vision is based upon international human rights treaties, informed by the Declaration on the Right to Development and identifies the importance of:

...equitable and universal access to...health care and social protection, where physical, mental and social well-being are assured. ${ }^{768}$

Goal 3 of the SDGs is to "ensure healthy lives and promote well-being for all at all ages", which is clarified further in 3.8 as a target to:

Achieve universal health coverage, including financial risk protection, access to quality essential health-care services and access to safe, effective, quality and affordable essential medicines and vaccines for all.

The SDG Resolution mentions the importance of access to affordable essential medicines and vaccines in accordance with the Doha Declaration on the TRIPS Agreement and Public Health. ${ }^{769}$ However there is no specific mention of GATS in the context of public health services, although the importance of both public financing of essential services and the role of a "diverse private sector" are acknowledged. ${ }^{770}$ The World Bank WDR of 2017 was titled "Governance and the Law", and highlighted the instrumental value of SDG 16 (building effective, accountable and inclusive institutions). ${ }^{771}$ There is no specific mention of the WTO or GATS in relation to attaining the SDGs, but the role of publicly provided services in reducing inequality as well as the effect of the democratic participation of disadvantaged communities on improving public health services is discussed at several points in the Report. ${ }^{772}$

Privatization is not necessarily an outcome of GATS obligations, but publications supporting GATS liberalization, including Background Notes by the WTO Secretariat also often refer to terms such as "commodification", "corporatization",

\footnotetext{
${ }^{766}$ Ibid (WDR 2004), Box 6.9 Is the GATS a help or hindrance?, p105.

767 The Sustainable Development Goals are identified in the UNGA Resolution, Transforming our world: the 2030 Agenda for Sustainable Development, A/RES/70/1, 21 October 2015.

768 UNGA Resolution, Transforming our world: the 2030 Agenda for Sustainable Development, A/RES/70/1, 21 October 2015, para.7 (the vision), para10 and 11 (shared principles and commitments) and para. 18 and 26 (the new Agenda).

769 UNGA Resolution, Transforming our world: the 2030 Agenda for Sustainable Development, A/RES/70/1, 21 October 2015, para.3b.

770 UNGA Resolution, Transforming our world: the 2030 Agenda for Sustainable Development, A/RES/70/1, 21 October 2015, para.41:

Public finance, both domestic and international, will play a vital role in providing essential services and public goods and in catalysing other sources of finance. We acknowledge the role of the diverse private sector, ranging from micro-enterprises to cooperatives to multinationals, and that of civil society organizations and philanthropic organizations in the implementation of the new Agenda.

${ }^{771}$ Ibid (UNGA Res. 70/1, 2015), para SDG 16 in full is

Promote peaceful and inclusive societies for sustainable development, provide access to justice for all and build effective, accountable and inclusive institutions at all levels.

772 World Bank, WORLD DEVELOPMENT REPORT 2017: GOVERNANCE AND THE LAW, p12, Box

2.11 at $\mathrm{p} 67, \mathrm{pp} 167,179$ and 192
} 
"commercialization" of public service provision and "greater market orientation" of services such as health services. ${ }^{773}$ "Commercialization" has also been used in the context of health services where there has been:

... the introduction of monetary incentives in hitherto tightly regulated areas (commercialization of hospital functions) $\ldots{ }^{774}$

These terms suggest increasing profitability and efficiency through greater private sector involvement in services supply, more public-private partnerships, introducing private sector management attitudes in the public sector or changes in the formerly non-feelevying nature of some public services.

A quick perusal of Background Notes of the WTO Secretariat illustrates the changing attitudes towards public services over the last two decades, in several different sectors. For example, "corporatization" is mentioned in the context of policies promoting "remunerative activities" to supplement public funding for public universities is mentioned in the Background Note on Education Services of $1998 .{ }^{775}$ The Note also recognizes the importance of education for "human and social" development and that primary and secondary education is seen as "basic entitlement"776 (the term 'right' or 'human rights' is avoided). As basic (primary and secondary) education is often provided as free by public authorities, the Secretariat is willing to categorize it as "services supplied in the exercise of governmental authority" (SSEGA) ${ }^{777}$ and focus on the areas (mainly tertiary education) where private participation is occurring and is profitable. The updated Note on Education Services of 2010 discusses the structural changes in the education market and emphasizes that "non-tertiary education is usually perceived as public good" where governments intervene in order to ensure "equitable access". ${ }^{778}$

"Corporatization" is also used in conjunction with "privatization" in the context of postal services. ${ }^{779}$ The Background Note on Postal and Courier Services also adds that as a result of corporatization and/or privatization:

...the traditional dividing line between private and public operators has become much less clear. ${ }^{780}$

It is increasingly suggested that public services are seen merely as a type of service, including those such as health, education, water and sanitation or transport, that carry out a public good and can be supplied in different ways by different suppliers including private companies. Therefore:

Public services can and are carried out either by public or by private undertakings. ${ }^{781}$

\footnotetext{
${ }^{773}$ For example, WTO Secretariat, Health and Social Services, Background Note by The Secretariat, S/C/W/50, 18 September 1998, paras.3 and 8.

${ }_{774}$ WTO Secretariat, Health and Social Services, Background Note by the Secretariat, S/C/W/50, 18 September 1998, para.8; also see para.34, the phrase "commercialize the health sector".

775 WTO Secretariat, Education Services, Background Note by the Secretariat S/C/W/49, 23 September 1998, para 20.

${ }^{776}$ Ibid., (S/C/W/49), para.12.

${ }^{777}$ Ibid., (S/C/W/49), para.12-13. See further the discussion on the definition of SSEGA at Section 3.4.3. of this Chapter.

778 WTO Secretariat, Education Services, Background Note by the Secretariat, S/C/W/313, April 2010, para.12.

${ }_{779}$ WTO Secretariat, Postal and Courier Services, Background Note by the Secretariat, S/C/W/39 12 June 1998, Introduction, p1 and p7 and the Postal and Courier Services, Background Note by the Secretariat, S/C/W/319 11 August 2010, paras. 2, 45, 47.

${ }^{780}$ Postal and Courier Services, Background Note by the Secretariat, S/C/W/319 11 August 2010, para.45.

${ }^{781}$ Lamy. P., GATS: Pascal Lamy responds to Trade Union Concerns on Public Services, Brussels, 7 June 2002, available online at trade.ec.europa.eu/doclib/docs/2004/april/tradoc_116645.pdf, last accessed
} 
Following this view, the term 'public' is used as meaning merely the provision of something that relates to the wider needs of the community in general, rather than referring to something that should be provided by the government in situations of 'market failure'.

However, in contradiction to the above use of the term 'public services', the WTO Secretariat has made reference to 'public goods' as services that private suppliers do not have sufficient incentive to provide and would only become involved with if there was a specific opportunity to obtain a benefit or profit. ${ }^{782}$ They have further been defined as being "goods" financed by general taxation and provided free for those who cannot afford to pay for them. ${ }^{783}$

\subsection{4. 'Public Goods' and defining 'Public'.}

Ronald Coase and his seminal work on public goods ${ }^{784}$ - which analyzes the relationship between public and private in the provision of public goods - resulted in changes of outlook with regard to the funding of public goods. The idea that they can be and have been funded by user fees opened up policy options for private provision or private-public combinations. It can be argued that one of the extensions of this view is support for a certain type of government regulated private monopoly in the supply of a public service. Whether and if so, how, this kind of service provision is dealt with in the GATS is a point that will be addressed further later in this Chapter at Section 3.5.1.

Cooter and Ulen in their classic textbook on "Law and Economics" make a distinction between private and public goods by focusing on the roles played by efficiency, availability of property rights and the low cost of enforcing such property rights. Using the concept of "rivalrous and excludable goods" (consumption by x excludes y and the owner is able to enforce exclusion of others from use), Cooter and Ulen come to the conclusion that "private goods must be used and consumed by individuals, not enjoyed

20.10.2011. This document is a letter in reply to a previous letter from Emilio Gabaglio, General Secretary, European Trade Union Confederation (ETUC), dated 23 May 2002.

${ }^{782}$ See for example, the Council for Trade in Services, Background Note on Environmental Services, $\mathrm{S} / \mathrm{C} / \mathrm{W} / 320,20$ August 2010 at para.1 referring to opportunities in divesture of assets or delegation of tasks - and also at para.15, referring to the involvement of the private sector in waste management through management or lease, build-own-operate, build-operate-transfer, or concession contracts as well as direct provision of services to private companies in certain specialized manufacturing and service sectors as well as to households.

${ }^{783}$ Ibid., citing www.businessdictionary.com/, at para.1 and footnote 3 .

${ }^{784}$ Coase, Ronald H., The Lighthouse in Economics, Journal of Law and Economics 17, 1974. See for more recent analysis: Van Zandt, David E., The Lessons of the Lighthouse: 'Government' or 'Private' Provision of Goods, Journal of Legal Studies 22, January p47-72 and October, p357-376, 1993 and Bertrand, Elodie, The Coasean analysis of lighthouse financing: myths and realities, Cambridge Journal of Economics, Volume 30, Issue 3, May 2006, p389-402.

However, see WTO, Secretariat, Background Note on Environmental Services, S/C/W/320, 20 August 2010 (it provides background information and updates a previous Background Note on Trade in Environmental Services, S/C/W/46, 6 July 1998) - public goods are defined in the footnote to para.5:

A public good can be defined as an "[i]tem whose consumption is not decided by the individual consumer but by the society as a whole, and which is financed by taxation. A public good (or service) may be consumed without reducing the amount available for others, and cannot be withheld from who do not pay for it.". See http://www.businessdictionary.com/, consulted on 12 July 2010. [emphasis added].

This is an example that the view of public goods being funded by taxation is not entirely out-of-date. 
equally by everyone"785 - but they do not identify the role of private provision of public goods in any detail. Other than noting that if it is not fully public funded (the main examples given being national defence, government-funded scientific research and court trials), it is noted that State should subsidize private providers of public goods though the tax system, including encouraging of voluntary charitable donations by granting tax deductions. ${ }^{786}$ There is no mention of the term "public services" nor of "public health services" in this textbook, and health is only dealt within the context of the economics of tort liability (medical malpractice, product liability, insurance). However, a review question for microeconomic theory, where the concept of "public goods" was introduced, expects students to be able to come to a conclusion on whether (i) a heart transplant and (ii) a vaccination against a highly contagious disease - are private goods which "might, therefore, be provided in socially optimal amounts by private profit-maximizers" or public goods which "should, therefore, be provided by the public sector or by the private sector with public subsidies". ${ }^{787}$ Although understandable that the expected answer must be based on microeconomic theory in the context of this field of study, in actual public policy situations the human development approach and the right to health ought to play a more significant role in decision-making. The answer in the latter situation would be easy: health is a public good and both heart transplants and vaccinations should be provided as far as possible by public health services through general taxation, with subsidizing of private providers also undertaken if necessary to ensure universal service coverage or to provide specialized services not available in the public sector.

In the globalized context, another matter, which can be raised is the emerging concept of 'global public goods'. ${ }^{788}$ This is the idea that neither the global market nor the efforts of nations on their own can be successful to provide for certain 'global public goods' such as a clean environment, financial stability, security, dissemination of knowledge and information, education and health. The UNDP work on this issue takes into account both traditional economic analysis, as well as development theory and concepts of equity in discussing the provision and prioritization of global public goods. ${ }^{789}$ These developments are occurring parallel to the WTO negotiations and also have implications for law and policy on both the international and domestic levels - and offer another approach to the challenges in the provision of public goods.

In the area of health, this has been analyzed as where a 'good' or service in the area of health which will not be produced or disseminated globally due to lack of market incentives, but where there is the possibility of government intervention at the national level. ${ }^{790}$ But defining a public service as merely any service that is not provided due to market failure or that the private sector does not provide due to the lack of economic

${ }^{785}$ Cooter, Robert and Ulen, Thomas, LAW AND ECONOMICS, 6th edition, Berkeley Law Books, 2016, p103.

${ }_{786}^{78}$ Ibid (Cooter and Ulen), p115, also see p40, 41, 104.

${ }^{787}$ Ibid (Cooter and Ulen), p53-54.

788 See Kaul Inge, Isabelle Grunberg and Mark A. Stern Eds., Global Public Goods: International Cooperation into the 21st Century, Oxford University Press and United Nations Development Program,1999. Also see Woodward, David, Nick Drager, Robert Beaglehole and Debra Lipson, Globalization, Global Public Goods and Health in TRADE IN HEALTH SERVICES: GLOBAL, REGIONAL AND COUNTRY PERSPECTIVES, Pan American Health Organization, 2002.

${ }^{789}$ Ibid., (Kaul et al Eds., Global Public Goods).

${ }^{790}$ See Smith R., R., Beaglehole D. Woodward and N. Drager Eds., GLOBAL PUBLIC GOODS FOR HEALTH: HEALTH ECONOMICS AND PUBLIC HEALTH PERSPECTIVES, Oxford, Oxford University Press, 2003 
incentives, is a viewing of even public health services from a narrow, market-centered view of services. Moreover, it does not capture how public-private partnerships provide health services or the many instances where government intervention can create lucrative domestic and cross-border economic opportunities for the private health services industry.

In contrast, the content of 'Global Public Goods for Health' has been identified as knowledge and technologies, policy and regulatory regimes and the role of health systems as 'access goods' not just for 'health as a public good' itself, but also for a range of other public goods. ${ }^{791}$ This language to describe the role of health systems recalls the human rights language of accessibility - including non-discriminatory and affordable access - as well as equality of opportunity. Petersmann has specifically acknowledged that a public health system protecting the right to health can be seen as a public good under international law:

Modern UN law prioritizes universal recognition of "inalienable" and "indivisible" civil, political, economic, social and cultural rights of citizens and multilateral protection of corresponding PGs [public goods] (like a public health system protecting the human right to health, judicial remedies protecting rule of law) [emphasis added]. ${ }^{792}$

But he goes on to add that "value preferences" of different economic actors, public and private, national and international, would mean there are different priorities for and conceptions of the role of international economic law in governing public goods. Whatever the extent of domestic policy capability and the tools and measures that can be used for creating and developing these global public goods for health, it now also requires compatibility with the international trade regime - and this is something that health policymakers need to include in their plans and assessments.

Thus, although the definition of 'public' may seem to a layman's eye uncomplicated and relating to government provision through taxation, both the theory and the application is often the cause of debates, controversies and misunderstandings. Thus, important questions that arise are whether the current concept of 'public' is something that is equally possible to be provided by government, privately or in partnership, covers every type of service which is a useful service from the point of view of the community in general - and in particular, whether it does or does not recognize the importance of some services over others. Are some public services like health and education, 'more public than others'? - meaning, would some services require a greater governmental responsibility, a different mind-set, a different approach? This question is raised because neither the nature of the service in relation to economic and social development and the related scope of the responsibility of the suppliers, nor the rights or expectations of the recipients is embedded in the concept of public services as usually addressed in the trade and international economic law context. In a sense, it is basically taking the 'public' out of public services or watering down the concept of 'public' to a type of service which can be provided in any manner by any type of provider, rather than using it to identify a specific nature and importance of a service and its manner of provision.

\footnotetext{
${ }^{791}$ Woodward, D., and R. Smith, Global Public Health: Concepts and Issues in Smith R., R. Beaglehole, D. Woodward and N. Drager Eds., GLOBAL PUBLIC GOODS FOR HEALTH: HEALTH ECONOMICS AND PUBLIC HEALTH PERSPECTIVES, Oxford, Oxford University Press, 2003.

792 Petersmann, Ernst-Ulrich, Reforming Multilevel Governance of Transnational Public Goods through Republican Constitutionalism: Legal Methodology Problems in International Law, Asian J. WTO \& Int'1 Health L \& Pol'y 12 (2017): 33, p39.
} 
In the WTO context, there is very little attention to the concept of public services and whether there are any public services-related concerns with regard to interpretation and implementation of GATS rules. The concept of public health services and their role in social welfare and development is rarely alluded to in the WTO context. The WTO Secretariat Note on Health and Social Services of 1998 recognizes with regard to public services that:

...such services may be core instruments in the pursuit of social and distributional justice or could be viewed as important contributors to, or preconditions for, economic development [emphasis added]. ${ }^{793}$

The rest of this Note does not satisfactorily discuss the implications of health services being governed by international trade rules or being affected by privatization and commodification. It is not really a matter of debate that the private sector is driven by profit (while contributing to economic development as an outcome of this profit-driven enterprise) and not driven by the "pursuit of social and distributional justice", which is mainly a governmental responsibility (and which can also be pursued by organizations whose guiding principle is not profit). If this is so, then there needs to be more discussion of the governmental role in using particular services such as health services as "core instruments" for social justice and economic development - since it is strange and difficult to imagine the private sector in such a role, unless we are talking of visionary private co-operative community organizations and not the usual corporate business models.

In the WTO dispute settlement context, the definition of 'public' is primarily a dictionary definition. The Panel in US-Gambling cited the ubiquitous Shorter Oxford Dictionary (2002):

In determining the ordinary meaning of the terms "public morals" and "public order", we turn to the Shorter Oxford English Dictionary. "Public" is defined therein as:

Of or pertaining to the people as a whole;

belonging to, affecting, or concerning the community or nation. ${ }^{794}$

The Panel in US-Gambling also noted that the word "public" (in the context of the "public morals" and "public order" exceptions) means a measure aimed at protecting the interests of the people within a community or nation as a whole. ${ }^{795}$ This suggests that public services have a broader objective than a commercial services venture, and that they are designed with the idea of people/the public as the beneficiaries.

In the context of interpreting Article 1.1(a)(1) of the SCM Agreement in US-AntiDumping and Countervailing Duties (China), the meaning of the term "public body" was debated with the parties to the dispute offering different approaches. The Appellate Body took a middle ground in not favouring "either a broad or a narrow interpretation of the term..." 796 and went on to elaborate that a 'public body' shares certain attributes with the concept of 'government' and that:

\footnotetext{
${ }^{793}$ WTO Secretariat Note, Health and Social services, S/C/W/50 of 18 September 1998, para.7.

${ }^{794}$ Panel Report, US-Gambling, para.6.463.

795 Panel Report, US-Gambling, para.6.463

The Panel believes that a measure that is sought to be justified under Article XIV(a) must be aimed at protecting the interests of the people within a community or a nation as a whole. This is the case whether the measure is asserted to be necessary to "protect public morals" or to "maintain public order" since both terms contain the word "public" [emphasis added].

${ }^{796}$ Appellate Body Report, US-Anti-Dumping and Countervailing Duties (China), para.303.
} 
A public body within the meaning of Article 1.1.(a)(1) of the SCM Agreement must be an entity that possesses, exercises or is vested with governmental authority. Yet, just as no two governments are exactly alike, the precise contours and characteristics of a public body are bound to differ from entity to entity, State to State, and case to case. ${ }^{797}$

In the approach to defining "public" in US-Anti-Dumping and Countervailing Duties (China), the Appellate Body stated that the Panel's notion of control and ownership, in which the Panel referred to "the everyday financial concept of a 'controlling interest' in a company" 798 was "not sufficient to establish that an entity is a public body". ${ }^{799}$ Although reversing the Panel's finding that the term "public body" in Article 1.1(a)(1) of the SCM Agreement meant "any entity controlled by a government", it was not necessary in the context of the dispute for the Appellate Body to offer an alternative legal interpretation for the term 'public'. Thus, the broader issue of the role of the system of governance in a State and its relationship with the community which is governed, was not commented upon. However, it is suggested in the Appellate Body report that a public body exercising governmental authority indicates something more than mere financial control or majority shareholding of an entity. ${ }^{800}$

Indeed, the comparison of "public body" with merely a notion of a government-owned company highlights only the commercial role which can be played by it and undermines the importance of the relationship of the concept of 'public' to 'community', 'nation' or 'people as a whole'. These references in WTO jurisprudence remain too vague and too narrow to assist in understanding fully the nature of public services in the current global context, which play a key role in welfare, opportunities and human rights. Thus, broader outlooks than trade disputes and dictionaries should be considered to understand the nature of 'public services' more fully. However, it is important to direct attention towards the use of 'public' and its relationship to the term 'public services' in the context of trade disputes and dictionaries; since the use of the phrase 'services in the exercise of governmental authority' in place of 'public services' in the GATS should not completely obscure the larger picture of the interpretations of 'public' and 'public services' being an ideological battleground.

The dictionary definitions of 'public' as an adjective state that it means:

Of or provided by the state rather than an independent, commercial company: public spending, public services. ${ }^{801}$

And more specifically:

Also (of a service, fund, amenity, etc.) provided by local or central government for the community and supported by rates or taxes...

\footnotetext{
${ }^{797}$ Appellate Body Report, US-Anti-Dumping and Countervailing Duties (China), para. 317.

${ }^{798}$ Panel Report, para. 8.134.

${ }^{799}$ Appellate Body Report, US-Anti-Dumping and Countervailing Duties (China), para.320.

${ }^{800}$ Appellate Body Report, US-Anti-Dumping and Countervailing Duties (China), para.318: ...the mere fact that a government is the majority shareholder of an entity does not demonstrate that the government exercises meaningful control over the conduct of that entity, much less that the government has bestowed it with governmental authority.

${ }^{801}$ See oxforddictionaries.com/definition/public, last accessed 23.04.2012. The origin of the term is also explained as

late Middle English: from Old French, from Latin publicus, blend of poplicus 'of the people' (from populus 'people') and pubes 'adult'
} 
Public Service (a) government employment (b) a service provided for the community, esp. under the direction of local or central government or other official agency. ${ }^{802}$

With the involvement of the private sector in the provision of core public services, there is now a blurring of the lines between public and private in both theory and practice. And one of the results of this approach towards services is that it can and does influence the interpretation of legal rights and obligations - both domestic and international - of the state and private actors as well as the individuals as consumers or beneficiaries. The relevant international rights and obligations include the economic and social rights angle as well the basic substance of the scope of the GATS, which is the focus of this Chapter. Furthermore, what the concept of public services is, and whether there can be agreement on this (as it is a concept in the process of either expansion or contraction depending on the political climate of the time and place) is a vexed issue that underlies the other questions of a more technical nature that will be dealt with in this Chapter.

${ }^{802}$ THE NEW SHORTER OXFORD ENGLISH DICTIONARY, Clarendon Press, 1993. 


\subsection{INTRODUCING KEY TERMS IN ARTICLE I:1 AND 1:2 OF THE GATS: GENERAL SCOPE OF APPLICATION}

\subsubsection{Introduction to 'Trade in Services' under the GATS}

The first, most obvious, question any person faced with a document called 'The General Agreement on Trade in Services' would ask is; how does the Agreement define what 'services' are? Although it seems a simple question to answer at first glance, the answer is not a straightforward one. To begin with, the term "services" is not expressly defined in the provisions of the GATS. The attempts to get to grips with the concept of services had not, by the time of the Uruguay Round, resulted in a clear-cut definition. The starting point during the negotiations was usually a comparison with goods and whether services differed from or were similar to goods became the basis of whether or not similar rules could be applied. ${ }^{803}$ Many of the scholars dealing with this particular area would agree with the writer who said (in 1989):

In a paradoxical way, the more intensely services are studies, the less certainty there is about how they can be defined and classified. ${ }^{804}$

The provisions of the final GATS text did not clear up this uncertainty for WTO Members taking on obligations for the liberalization of services.

Article I:1 of the GATS is the provision on the 'scope and definition' of the Agreement.

Article I: 1 of the GATS:

This Agreement applies to measures by Members affecting trade in services

But this Article is not as helpful to those trying to identify the parameters of national policy flexibility as it perhaps could have been. Article I and its sub-sections only state that 'trade in services' refers to the 'supply of services' (see further below) and that the agreement applies to 'measures affecting' such trade.

As indicated above, there are reasons behind the existing wording and lack of clear definition of what we are supposed to be dealing with, not the least being that 'trade in services' is a fairly new concept. Ron Shelp, one of the key early advocates for multilateral rules on trade in services, noted that a few decades ago academic discussion was on the basic question of the differences between goods and services and whether services can be 'traded' in the first place. ${ }^{805} \mathrm{He}$ pointed out that neither capitalist nor communist economic theory included services in the calculation of trade value. ${ }^{806}$ The practical problems of identifying and defining services separately from goods trade adds to the difficulties.

\footnotetext{
${ }^{803}$ See generally Fernandes, Deepali, Twins, Siblings or Friends: The Conceptual Case of Goods and Services, Where do we stand and where could we be headed to?, in Alexander, Kern and Mads Andenas, THE WORLD TRADE ORGANIZATION AND TRADE IN SERVICES, Martinus Nijhoff Publishers, 2008. Also, Nicolaides, Phaedon, LIBERALIZING SERVICE TRADE: STRATEGIES FOR SUCCESS, Routledge, 1989, p8.

${ }^{804}$ Nicolaides, Phaedon, LIBERALIZING SERVICE TRADE: STRATEGIES FOR SUCCESS, Routledge, 1989, p8.

${ }^{805}$ Shelp, Ronald K., Trade in Services, Foreign Policy, No. 65 (Winter, 1986-1987), p64 at p66-67. See further, Shelp, Ronald, K., BEYOND INDUSTRIALIZATION: ASCENDANCY OF THE GLOBAL SERVICE ECONOMY, Praeger, 1981.

${ }^{806}$ Ibid., (Shelp, Trade in Services).
} 
In dealing with this issue of differentiating more recently, the WTO Appellate Body in EC-Bananas III, reasoned that some measures could affect trade in goods as goods, falling within the scope of the GATT 1994, other measures could affect services as services and be exclusively within the scope of the GATS, but a third category can straddle the two types of trade and be scrutinized under both WTO Agreements. This can only be decided on a case by case basis. ${ }^{807}$ The Appellate Body clarifies that the third category relates to:

...measures that involve a service relating to a particular good or a service

supplied in conjunction with a particular good...

Another aspect raised in China-Publications and Audiovisual Products was with regard to whether the term 'distribution' in relation to 'sound recording distribution services' in the relevant entry in China's GATS Schedule covered the distribution of both tangible (goods) and intangible (services) products; a question which was answered in the affirmative. ${ }^{808}$ Thus, even now, a services dispute has to sometimes first untangle this kind of basic identification and confirm which WTO Agreement is applicable.

Another relevant question raised by Shelp is whether liberalization of services would lead to gains from comparative advantage, the traditional rationale for international trade. ${ }^{809}$ $\mathrm{He}$ also asks what the intellectual foundation for services liberalization actually is. Nusbaumer's partial answer to this question was that some services, the ones requiring specialized knowledge for specific needs, would be more likely to be determined by absolute advantage conferred by specialized knowledge. ${ }^{810}$ The fact that intellectual property protection under the WTO TRIPS adds to cost and limits the transfer of knowledge and technology also needs to be taken into account when analyzing the nature of the advantages of liberalized international trade in services. Thus, it is also a matter for debate whether the benefits are weighed more towards those who are poised in a position of absolute advantage, yet without access to potentially lucrative services markets. It seems by all accounts that it was not economic theory but the practical needs of certain multinational enterprises at that point in time that led to the inclusion of services in multilateral trade negotiations. ${ }^{811}$ Marchetti and Mavroidis also highlight this lack of an economic theory to explain the GATS as well as the role of certain US companies and trade lobbies in promoting a services agreement. ${ }^{812}$

\footnotetext{
${ }^{807}$ Appellate Body Report, EC-Bananas III, para.221.

${ }^{808}$ Appellate Body Report, China-Publications and Audiovisual Products, para. 379.

${ }^{809}$ Shelp, Ronald K., Trade in Services, Foreign Policy, No. 65 (Winter, 1986-1987), p68.

${ }^{810}$ Nusbaumer, J., SERVICES IN THE GLOBAL MARKET, Kluwer Academic Publishers, 1987, p51-65.

${ }^{811}$ Shelp, at the time he was promoting multilateral rules for international services trade was vice president of international relations at the American International Group (AIG), one of the biggest multinationals and had previously been with the International Department of the U.S. Chamber of Commerce, where he worked on international trade issues. See Feketekuty, Geza, INTERNATIONAL TRADE IN SERVICES: AN OVERVIEW AND BLUEPRINT FOR NEGOTIATIONS, Ballinger for The American Enterprise Institute, 1988; who mentions, in addition to Shelp's background at AIG, that other services organizations such as the Air Transport Association, the American Institute of Marine Underwriters, the American Institute of Merchant Shipping, and the National Constructors Association initially supported Shelp and AIG's position. However, these were later either opposed or a lot less enthusiastic about a multilateral framework.

${ }_{812}$ Marchetti J.A. and Petros C. Mavroidis, The Genesis of The GATS (General Agreement on Trade in Services) EJIL (2011), Vol. 22 No. 3, 689-721 at p689 and 692-694.
} 
The literature also points to a report of an OECD group of experts in 1972 as the source for the term "trade in services ${ }^{813}$ and for the first attempts at creating a conceptual framework for multilateral negotiations in services ${ }^{814}$. This conceptual framework for trade in services was a new approach, as opposed to the earlier approach of the United States to offer trade concessions for removal of non-tariff barriers to trade in services and to promote the inclusion of services issues in government procurement and subsidies negotiations in the GATT Tokyo Round. The work of the OECD has been referred to as being the basis for the inclusion of services in the multilateral negotiations that led to the establishment of the $\mathrm{WTO}^{815}$. The approach of the group of experts was to try and extend the concepts such as national treatment, already understood in the GATT context, and to apply it to services. In the negotiations leading up to the WTO, the inclusion of services in this manner was promoted mostly by US trade representatives with the backing of certain powerful companies as it was projected that would help their economy. ${ }^{816}$ But it was resisted by both other developed countries with strong service exports (countries in Western Europe, especially France) and developing countries led by Brazil and India. ${ }^{817}$

Other than BRIC countries (Brazil, Russia, India and China), the service sectors of most developing countries do not have companies with global reach and competitiveness in international services trade. Inadequately developed human capital and infrastructure in most developing countries mean that they would have to import knowledge and capital intensive services, and this may exacerbate balance of payments and debt. ${ }^{818}$ While

${ }^{813}$ Drake, William J. and Kalypso Nicolaidis, Ideas, Interests, and Institutionalization: 'Trade in Services' and the Uruguay Round, International Organization, Vol. 46, No. 1, Winter, 1992 , p37 at p38: citing OECD, Report of the High Level Group on Trade and Related Problems, Paris, OECD, 1973, p63. Marchetti and Mavroidis focus on the role of Citibank, American Express, Bechtel and Peat Marwick (which were also part of the Coalition of Service Industries or CSI) as well as AIG.

814 See Feketekuty, Geza, INTERNATIONAL TRADE IN SERVICES: AN OVERVIEW AND BLUEPRINT FOR NEGOTIATIONS, Ballinger for The American Enterprise Institute, 1988. Feketekuty says Jean Rey, the former president of the Commission of the European Community, issued a report on the long-term trade issues facing the world economy: The Report by the High-Level Group on Trade and Related Problems, OECD, 1973, which provided the intellectual underpinnings for the Tokyo Round of multilateral trade negotiations. It contained a short chapter on trade in services and was the first published document of any kind to discuss trade in services as 'trade in services'. Feketekuty also refers to the work of Hugh Corbet of the Trade Policy Research Center in London who commissioned Brian Griffiths, an economist at the London School of Economics, to undertake a study of international flows of services and restrictions on transactions in the services sector. The resulting book, INVISIBLE BARRIERS TO INVISIBLE TRADE, was published by the Trade Policy Research Center in 1975. The decision to include a chapter on trade in services was largely due to several individuals associated with the preparation of the report which consisted of both businessmen and economists.

${ }^{815}$ See Footer, Mary E. and Carol George, The General Agreement on Trade in Services in Macrory, Patrick F. J, Arthur Edmond Appleton and Michael G. Plummer, Eds., THE WORLD TRADE ORGANIZATION: LEGAL, ECONOMIC AND POLITICAL ANALYSIS, VOL. II, Springer 2005, p806 - referring to the Report by the High level Group on Trade and related Problems,(OECD,1972) which led to the work programme Elements of a Conceptual Framework for Trade in Services (OECD, 1987).

${ }^{816}$ See further Dunning, John H. Multinational Enterprises and the Growth of Services: Some Conceptual and Theoretical Issues, The Service Industries Journal, Volume 9, Issue 1, 1989, p5-39. Also see regarding key players: Marchetti Juan A. and Petros C. Mavroidis, The Genesis of the GATS (General Agreement on Trade in Services), The European Journal of International Law Vol. 22 no. 3, 689-721, 201.

${ }^{817}$ Shelp, Ronald K., Trade in Services, Foreign Policy, No. 65 (Winter, 1986-1987), p64 at p73. Also see for the evolving European position in the run up to the Uruguay Round: Marchetti J.A, and Petros C. Mavroidis, The Genesis of the GATS (General Agreement on Trade in Services), EJIL (2011), Vol. 22 No. 3, 689-721 at p695-699. Marchetti and Mavroidis also comment on the role of G-5 (Gang of Five Argentina, Brazil, Egypt, India, and Yugoslavia) at p698.

${ }^{818}$ Gibbs, Murray and Mina Mashayekhi, Elements of a Multilateral Framework for Trade in Services, 14 N.C.J. Int'l L. \& Com. Reg. 1, 1989, p1 
temporary migration ${ }^{819}$ offers opportunities for developing countries to gain remittances and reduce poverty, there are practical problems that have not been resolved, including the need for protection of the rights of migrant workers and their families and there are growing critiques of the migration-development model which has thus far been promoted. ${ }^{820}$ It is often argued that in order to be competitive on the global level, developing countries need to develop their domestic industries until they reach a level where international competition may be possible. Without a chance to compete, there is no vested interest in creating a level playing field where one is forever sitting on the sidelines. UNCTAD also noted that services liberalization without infant industry protection was not in the interests of developing countries. ${ }^{821}$

Yet, despite the initial strong opposition by developing countries, developed countries were looking forward to exporting services and thus services became part of the Uruguay Round negotiations. Even now, the definition of 'trade in services' remains vague and some of the purported economic benefits of the liberalization of all service sectors are still seen as unconvincing in some quarters. At the same time, it is difficult to argue that developing country economies benefit from denying foreign services suppliers access to their markets. Allowing for foreign suppliers in telecommunications and financial services can boost development in other domestic sectors and foreign competition in general could push domestic suppliers to achieve higher standards than if they were protected from competition. Developing country consumers would also benefit from more open markets in many service sectors, as opposed to more protectionism and lesser accessibility to those services. There may be other public policy reasons for limiting liberalization of service sectors such as education, health, legal services, audiovisual services etc., which would be less about infant industry protection and more about protection of a societal value, custom or practice of coordinating matters in that particular field. A human rights-based approach to the provision of these services (right to health, right to education, access to justice, right to culture, freedom of information, etc.) would also emphasize and prioritize a different set of policy objectives and values.

Although developed countries took the position in negotiations that a definition of trade in services is not necessary, ${ }^{822}$ a definition is important for developing countries for several theoretical and practical reasons. This includes the role of such a definition in establishing of parameters for negotiations for liberalization (particularly the need to clarify what will not fall within the scope of the WTO) and preventing powerful countries from using the vagueness for applying and/or imposing unilateral and subjective

\footnotetext{
${ }^{819}$ See further the discussions relating to 'movement of natural persons' or Mode 4 supply of services in this chapter.

${ }^{820}$ See Delgado Wise, Raúl, Humberto Márquez Covarrubias, and Ruben Puentes, Reframing the debate on migration, development and human rights, Population, space and place, 2013, 19.4, 430-443; de Haas, H., The Migration and Development Pendulum: A Critical View on Research and Policy, International Migration, 2012, 50:, 8-25; Ratha, Dilip, Soonhwa Yi, and Seyed Reza Yousefi, Migration and Development: The Asian Experience in Anna Triandafyllidou (Ed.) THE ROUTLEDGE HANDBOOK OF IMMIGRATION AND REFUGEE STUDIES 1.3 (2015): 260.

${ }^{821}$ Shelp, Ronald K., Trade in Services, Foreign Policy, No. 65 (Winter, 1986-1987), p74; Footer, Mary E. and Carol George, The General Agreement on Trade in Services in in Macrory, Patrick, Arthur Appleton and Michael Plummer, THE WORLD TRADE ORGANIZATION: LEGAL, ECONOMIC AND POLITICAL ANALYSIS, VOL. I, Springer 2005, p806, on the role of UNCTAD and the US International Chamber of Commerce.

${ }^{822}$ Gibbs, Murray and Mina Mashayeki Elements of a Multilateral Framework for Trade in Services, 14 N.C.J. Int'l L. \& Com. Reg. 1, 1989, p11.
} 
definitions that are difficult to resist due to the weaker bargaining position and lack of expertise.

Other than these practical concerns in the context of current and future negotiations within the WTO, the implications of terminology and the breadth of the scope and definitions on future law and policy should also be kept in mind. The acceptance of a very broad concept of 'trade in services' establishes the liberalization of trade in services as the norm and may lead to the commoditization of services that have national strategic, cultural or values-related importance that needs a different policy approach from other tradable services. This would suggest that either such services should be clearly outside the scope of the GATS (perhaps using Article 1:3 of the GATS) or that there are exemptions or exceptions (such as Article XIV and XIVbis of the GATS) relating to such services. The first option (exclusion) draws a clearer line between what is included and what is not, but is unsatisfactory from the view of those wanting to expand international trade opportunities through the WTO system. The availability of some flexibility, while retaining the service sector or sub-sector within WTO rules would be more attractive. But this may not be the fairest way of balancing interests in sensitive areas such as health services, as it has the drawback highlighted by Drake and Nicolaidis that:

The very act of defining services transactions as 'trade' established normative presumptions that 'free' trade was the yardstick for good policy against which regulations, redefined as non-tariff barriers (NTBs), should be measured and justified only exceptionally. ${ }^{823}$

A specific example in the area of health is the stance of Health Action International - Asia Pacific, a civil society organization that promotes the concept of health as a fundamental human right and not something that is treated as a marketable commodity. ${ }^{824}$

Feketekuty comments that as the definition of a transaction as 'trade in services' and the scope of the agreement will have to be debated in the context of the major policy implications in the area of services, the definition ought therefore to include acknowledgement of and adjustment to that policy context. ${ }^{825}$

\subsubsection{Article I:2 and Article XXVIII: "Trade in services is defined as..."}

Keeping the above issues in mind and returning to the text of the GATS, the relevant provisions are as follows. The definition for 'trade in services', in Article I:2 of the GATS, is:

Trade in services is defined as the supply of a service (emphasis added).

According to the subsections of the same provision, 'supply of a service' covers the four modes of supply specified in the GATS:

a) from the territory of one Member into the territory of any other Member;

\footnotetext{
${ }^{823}$ Drake, William J. and Kalypso Nicolaidis, Ideas, Interests, and Institutionalization: 'Trade in Services' and the Uruguay Round, International Organization, Vol. 46, No. 1, Winter, 1992, p40.

${ }^{824}$ See HAI, Balasubramaniuam, Dr. K., The General Agreement on Trade in Services and Public Health, HAI News, Number 141, April-June 2007. The author was also rapporteur for the discussions during HAIAP, Regional Seminar on GATS and Public Health, Sri Lanka, August 27-29 $9^{\text {th }}$,2007, where the approach to health as a right, public good and governmental responsibility, was reiterated.

825 See Feketekuty, Geza, INTERNATIONAL TRADE IN SERVICES: AN OVERVIEW AND BLUEPRINT FOR NEGOTIATIONS, Ballinger for The American Enterprise Institute, 1988, Chapter 4.
} 
b) in the territory of one Member to the service consumer of any other Member;

c) by a service supplier of one Member, through commercial presence in the territory of any other Member;

d) by a service supplier of one Member, through presence of natural persons of a Member in the territory of any other Member.

This can be simplified, with examples from the health sector as:

(a) Mode 1 - Cross-border supply, e.g. 'tele-medicine'

(b) Mode 2 - Consumption abroad e.g. 'health tourism'

(c) Mode 3 - Commercial presence e.g. establishing a foreign-owned hospital

(d) Mode 4 - Presence of natural persons e.g. temporary movement of foreign medical professionals from abroad to supply services in local hospitals.

This explains how a service is supplied for purposes of the concept of 'trade in services' relevant for the coverage of the GATS.

The Technical Note by the Secretariat (WT/ACC/5) provides a "common understanding" on what is covered by each mode of supply. ${ }^{826}$ Cross border supply is described as a situation where the service supplier is not present on the territory where the service is delivered. Examples given are international transport, telecommunications, mail and services "embodied" in exported goods. Consumption abroad is described as the "movement of the consumer", such as for an individual travelling for tourism or a ship repair done abroad. Commercial presence according to the Technical Note, includes corporations, joint ventures, partnership, representative offices and branches. The movement of natural persons is described as their presence as service suppliers or as employees of service suppliers of the home State only. The Appellate Body in CanadaAutos drew attention to the fact that 'commercial presence' is also defined by Article XXVIII(d) (the interpretation provision of the GATS), as:

.... any type of business or professional establishment including through

(i) the constitution, acquisition or maintenance of a juridical person... ${ }^{827}$

In the case of health services, cross-border services refer usually to services such as consultations and diagnosis supplied via telecommunications technology while the consumer and provider physically remain with their own state borders and consumption abroad refers to consumers physically travelling to another country to purchase health services, sometimes referred to as 'health tourism'. Commercial presence refers to the local establishment of a foreign-owned health services supplier such as a hospital or clinic. Movement of natural persons refers to the temporary migration of health workers. Migration could refer to either individuals independently moving to another country seeking employment, which is not an area covered by the GATS; or to individuals moving to another country to provide services in order to fulfill contractual duties on behalf of a foreign supplier to a local client. This latter situation is covered by the GATS and requires Members to undertake specific commitments under Mode 4 for the application of market access and national treatment obligations. There could also be another type of situation where individuals migrate temporarily as a part of a transfer of employees of a trans-national health service supplier established under Mode 3. It is notable that Members have been cautious about making specific commitments under

${ }^{826}$ WTO, Technical Note by the Secretariat, Accession to the World Trade Organization - Information to be Provided on Policy Measures Affecting Trade in Services, WT/ACC/5, 31 October 1996, para.5.

${ }^{827}$ Appellate Body Report, Canada-Autos, para.155 
Mode 4 and even when doing so have often made reservations that connect the temporary migration to more restrictive Mode 3-type intra-corporate transfers. ${ }^{828}$

Taking into account the different modes of supply, the impacts of GATS on health services can be varied. With regard to the impact on the poor and prospects for economic and social development, it has been noted even by trade experts that liberalization of services may lead to marginalization of the poor and that with regard to health services, different issues may arise in relation to the different modes of supply involved. ${ }^{829}$

Telemedicine that provides consultations for rural poor sounds like a great idea - but it is obviously not a profitable business proposition per se for private health service suppliers, since the rural poor most likely could not afford to pay for such services, unless the government funded or subsidized such suppliers. Telemedicine can thus be a part of an innovative development of public health services for the rural poor, which remains part of governmental duties under a right to health approach.

Another obvious point is that the poor are unlikely to be able to participate in 'health tourism' - unless they are funded and/or subsidized by public healthcare or public health insurance schemes. Such public healthcare schemes are issues of national governance, which would become WTO issues only so far as there is an MFN treatment dispute if there is different treatment for service suppliers from different WTO Members; or national treatment or market access issues if commitments have been have been undertaken regarding health services.

Increased $\mathrm{FDI}^{830}$ in the health sector suggests no particular gains for health of the poor who are unlikely to access these services without government policies to redistribute the benefits to the disadvantaged. Design and implementation of distributive justice measures is a task for domestic governance and not an issue that concerns the GATS. The point at which the GATS may come into contact with the issue is if governments actually take the effort to draft such measures and realize that they must additionally spend time and resources upon assessing the GATS compliance of such redistribution schemes.

Other issues that may arise with regard to Mode 3 is whether GATS would have a negative effect on subsidy policies for provision of health services to the poor, an issue referred to in more detail later in this Chapter at Section 3.5.3. With regard to Mode 4 issues, from a developing country perspective, a main one is that of the impact on the quality of health services due to the brain-drain of skilled health workers from developing to developed economies balanced with the benefits of free movement of persons for skills training and remittances. GATS liberalization covers only temporary free movement, which can be said to be prima facie a beneficial outcome for developing countries. Issues

\footnotetext{
${ }^{828}$ Carzaniga, A., The GATS, Mode 4, and Pattern of Commitments in Mattoo, Aaditya and A. Carzaniga Eds., MOVING PEOPLE TO DELIVER SERVICES, World Bank and Oxford University Press, 2003, p2126.

${ }^{829}$ Footer, Mary E. and Carol George, The General Agreement on Trade in Services in Macrory, Patrick, Arthur Appleton and Michael Plummer, THE WORLD TRADE ORGANIZATION: LEGAL, ECONOMIC AND POLITICAL ANALYSIS, VOL. I, Springer 2005, p727: referring to the reports of the UN High Commission for Human Rights.

${ }^{830}$ Foreign Direct Investment - a Mode 3 (commercial presence) issue in GATS, but also under the Agreement on Trade related Investment Measures (TRIMS) that promotes market access and national treatment principles in relation to investment in the area of trade in goods. See further Krajewski, Markus Investment Law and Public Services, April 1 2012, available at SSRN: http://ssrn.com/abstract=2038514.
} 
in each of the modes of supply can be gone into in depth, but will not be done for the purposes of this particular Chapter.

The definition in Article I:2 specifies that the GATS is concerned with services that are supplied across borders in the modes described. The suggestion is that the GATS is focused on international transactions and does not affect domestic trade in services. But this second point is something that needs to be looked at more closely, in light of other provisions of the agreement, including Article XXVIII of the GATS (Definitions). However, it ought to be kept in mind, as Feinaugle comments, that the definitions in Article XXVIII of the GATS must have been intended to give a "broad meaning in the interest of trade liberalization" and also that they "seem to provide flexible guidance rather than sharp and clear-cut explanations". ${ }^{831}$

While the definition of 'trade in services' is not further clarified, at least not directly, Article XXVIII, the "Definitions" provision of GATS can also be referred to for what is included in 'trade in services'. Article XXVIII(c) is an open-ended provision which identifies 'measures' in the context of 'measures by Members affecting trade in services' to include measures in respect of:

i. the purchase, payment or use of a service;

ii. the access to and use of, in connection with the supply of a service, services which are required by those Members to be offered to the public generally;

iii. the presence, including commercial presence, of persons of a Member for the supply of a service in the territory of another Member;

This definition provides illustrative examples and a general definition which indicates a wide scope of 'trade in services'. Subsection iii seems to be identifiable with Modes 3 and 4 (commercial presence and movement of natural persons) in Article 1:2 of the GATS, ${ }^{832}$ while subsections $\mathrm{i}$ and ii seem to indicate a connection with Article I:1 and I:3(a) of the GATS on "measures affecting trade in services" and "measures by Members" respectively.

Furthermore, Article XXVIII(b) states that:

...'supply of a service' includes the production, distribution, marketing, sale and delivery of a service.

This definition is open ended, and does not specifically identify the modes of supply like the definition of the same phrase in Article I:2.

\begin{tabular}{|l|l|}
\hline \multicolumn{1}{|c|}{$\begin{array}{c}\text { Article 1:2 of the GATS } \\
\text { (Scope and Definition) }\end{array}$} & Article XXVIII(b) (Definitions) \\
\hline $\begin{array}{l}\text { Trade in services } \\
=\text { supply of a service in one of four } \\
\text { modes of supply }\end{array}$ & $\begin{array}{l}\text { Supply of a service } \\
\text { = production, distribution, marketing, } \\
\text { sale and delivery of a service }\end{array}$ \\
\hline
\end{tabular}

${ }^{831}$ Feinaugle, C., Article XXVIII GATS in Wolfrum, Rudiger, Peter-Tobias Stoll and Clemens Feinaugle Eds., WTO - TRADE IN SERVICES, Max Planck Commentaries on World Trade Law, Martinus Nijhoff Publishers, 2008, p564.

832 'Person' according to Article XXVIII(j) of the GATS means a natural or a juridical person. 
The same phrase "supply of a service" is there in both Article I:2 and Article XXVIII(b). When organized in the manner shown above, it appears that "supply of a service" could be expressed either as the four modes of supply or in the nature of the activity (production, sale etc.).

\subsubsection{Measures within the scope of the GATS}

The Panel stated in EC-Bananas III that:

$[\mathrm{N}] \mathrm{o}$ measures are excluded a priori from the scope of the GATS as defined by its provisions. ${ }^{833}$

This and subsequent reports as well as academic analysis have usually focused not on the creation of a classification of types of measures and whether the disputed measures fall within such a categorization, but on the connection between the disputed measure, the Member and the GATS obligation.

As stated by the Appellate Body in US-Gambling:

To the extent that a Member's complaint centers on the effects of an action taken by another Member, that complaint must nevertheless be brought as a challenge to the measure that is the source of the alleged effects [emphasis added.$^{834}$

Accordingly, the main points are whether the Member bears responsibility for such a measure and whether the disputed measure affects trade in services. In Canada-Autos, the Appellate Body pointed out that the obvious step, that:

...the fundamental structure and logic of Article I:1, in relation to the rest of the GATS, require that determination of whether a measure is, in fact, covered by the GATS must be made before the consistency of that measure with any substantive obligation of the GATS can be assessed... the measure at issue must be found to be a measure 'affecting trade in services' within the meaning of Article I:1, and thus covered by the GATS, before any further examination of consistency with Article II can logically be made. ${ }^{835}$

The issue of whether a disputed measure affects trade in services is usually what is focused on in dispute settlement, but the first point of the relationship between a Member and the challenged measure is also relevant. The following section of this Chapter deals with both these issues and any interpretations that are currently available

According to the provisions on definition of terms in the GATS, the term "measure" is defined in the following manner:

\footnotetext{
${ }^{833}$ Panel Report, EC-Bananas III, para. 7.285; reiterated by the Panel in Canada-Autos, para. 10.234.

${ }^{834}$ Appellate Body report, US-Gambling, para.123.

${ }^{835}$ Appellate Body Report, Canada-Autos, para 151-152, citing the prior Appellate Body Report of USShrimp (at para. 119) where it was stated in the context of Article XX of the GATT 1994, that the fundamental structure and logic of a provision cannot be ignored in deciding the proper sequence of steps in its analysis, save at the peril of reaching flawed results.
} 


\begin{tabular}{|c|c|c|}
\hline $\begin{array}{c}\text { Article } 1: 1 \text { of the } \\
\text { GATS } \\
\text { (Scope and Definition) }\end{array}$ & $\begin{array}{l}\text { Article XXVIII(a) } \\
\text { (Definitions) }\end{array}$ & $\begin{array}{l}\text { Article XXVIII(c) } \\
\text { (Definitions) }\end{array}$ \\
\hline $\begin{array}{l}\text { This Agreement applies } \\
\text { to measures by } \\
\text { Members affecting } \\
\text { trade in services }\end{array}$ & $\begin{array}{l}\text { "Measure" means any } \\
\text { measure by a Member, } \\
\text { whether in the form of } \\
\text { a law, regulation, rule, } \\
\text { procedure, decision, } \\
\text { administrative action } \\
\text { or any other form }\end{array}$ & $\begin{array}{l}\text { Measures by Members affecting } \\
\text { trade in services include measures } \\
\text { in respect of: } \\
\text { (i) purchase, payment or use } \\
\text { of a service } \\
\text { (ii) access to and use of } \\
\text { services offered to the } \\
\text { public generally } \\
\text { includes commercial } \\
\text { presence. }\end{array}$ \\
\hline
\end{tabular}

The Appellate Body in US-Gambling stated that there are two important points with regard to the understanding of the term "measures" in this context, that:

1. a 'nexus' must exist between the responding Member and the 'measure', such that the 'measure' - whether an act or omission - must be 'attributable' to that Member.

2. the 'measure' must be the source of the alleged impairment, which is in turn the effect resulting from the existence or operation of the 'measure'. 836

The first point relates to the question whether there is a 'measure by a Member'. The second point appears to be referring back to the Appellate Body in Canada-Autos, that a specific measure, such as the import duty exemption in that case, has to be identified as the measure "affecting trade in services".

\subsubsection{Defining 'Measures': the breadth of coverage and the different forms of 'measures'}

This section of this Chapter addresses the breadth of coverage of 'measures', including the different forms these measures take and the relationship between the definition and interpretation of 'measure' and the policy space available for Members. Article XXVIII(a) of the GATS defines a measure as "any measure by a Member, whether in the form of a law, regulation, rule, procedure, decision, administrative action or any other form". Among the questions that could be asked are the following: do the WTO disputes shed any further light on the extent of coverage and the different forms of measures which are covered by the GATS?; is it possible to identify any type of measure which could be considered as not covered by the GATS?; what implications does this have for measures concerning public health services?

\footnotetext{
${ }^{836}$ Appellate Body Report, US-Gambling, para.121.
} 
"Measures" are not limited to the types specifically listed in Article XXVIII(a) of the GATS, as Article XXVIII(a) is an open-ended provision. But if a ejusdem generis ${ }^{837}$ rule of interpretation is applied, the terms 'any other form' would mean any other form of the same class as 'law, regulation, rule procedure, decision [or] administrative action'. And it may also be questioned in this context whether "decision" would mean something more akin to 'procedure' or 'administrative action', since the ordinary meaning of the words 'any other form' can be extremely broad. According to the Appellate Body in USCorrosion-Resistant Steel Sunset Review, an instrument containing rules or norms could also constitute a 'measure'. The Appellate Body identified the Sunset Policy Bulletin (SPB), a pre-established rule for the conduct of an anti-dumping investigation, as being an 'administrative procedure' within the meaning of Article 18.4 of the Anti-Dumping Agreement. ${ }^{838}$

It should also be noted that unwritten norms and rules and ongoing conduct can be 'measures' within the meaning of WTO law (and thus subject to challenge in WTO dispute settlement). The inclusion of 'unwritten norms or rules' is interesting from the point of view of societal values and policy concerning matters such the support for a national health service, since these can have a powerful socio-political influence on decision-making. However, the WTO disputes have not thus far dealt with such societal values issues. Van Den Bossche and Zdouc list six different types of measures that "have raised complex questions about whether they can be subject to WTO dispute settlement", including unwritten norms and rules and practices or policies of Members. ${ }^{839}$ Van Den

${ }^{837}$ Ejusdem Generis is a Latin term meaning "of the same kind", which is part of the broader rule of interpretation known as Noscituur a Sociis which means 'a thing is known by its allies'/'a word is known by the company it keeps'. Ejusdem Generis is a canon of statutory construction, where general words follow the enumeration of particular classes of things, the general words will not be construed in their widest sense, but be construed as applying only to things of the same general class as those specifically enumerated - see BLACK'S LAW DICTIONARY, 8th edition, 2004.

Ejusdem Generis has been applied in the context of international treaty interpretation, e.g., the PCIJ in the Advisory Opinion on the Competence of the ILO for Agriculture case in the context of the ILO statute and the US-Iran Claims Tribunal in Grimm v Government of the Islamic Republic of Iran, Award 25-71-1 (22 $2^{\text {nd }}$ February 1983) in the context of the US-Iran Claims Settlement Declaration. See further Linderfalk, Ulf, ON THE INTERPRETATION OF TREATIES: THE MODERN INTERNATIONAL LAW AS EXPRESSED IN THE 1969 VIENNA CONVENTION ON THE LAW OF TREATIES, Springer, 2007, p303-310.

With regard to WTO dispute settlement, in Japan-Agricultural Products II, the term 'measure' in context of footnote 5 to the first paragraph of Annex B of the SPS Agreement, was interpreted by the Appellate Body in a manner that suggests the ejusdem generis rule. The footnote lists 'laws, decrees and ordinances' as three examples of relevant "measures"( The text of the original Footnote 5: Sanitary and phytosanitary measures such as laws, decrees or ordinances which are applicable generally) The Appellate Body held that this term also included "other instruments which are applicable generally and are similar in character to the instruments explicitly referred to" and found that the Japanese "varietal testing requirement" was a "measure" within the meaning of Annex B of the SPS Agreement (Appellate Body Report on Japan Agricultural Products II, para. 105-108). But the Appellate Body additionally takes into account the object and purpose of paragraph 1 of Annex B as one that enables members to 'become acquainted' with the sanitary and phytosanitary regulations of other members and 'thus to enhance transparency regarding these measures' (Appellate Body Report on Japan-Agricultural Products II, para. 106). Therefore, the interpretation in this instance is not merely related to a rule of language, but follows the text-context-objectand-purpose approach of the Vienna Convention on the Law of Treaties.

${ }^{838}$ Appellate Body Report, US-Corrosion-Resistant Steel Sunset Review, Footnote 87 and para 98.

${ }^{839}$ Van den Bossche, Peter and Werner Zdouc, THE LAW AND POLICY OF THE WORLD TRADE ORGANIZATION: TEXTS, CASES AND MATERIALS, Cambridge University Press, Revised edition, $2017, \mathrm{p} 174$. The other four types of measures are; action or conduct by a private party attributable to a Member, measures no longer in force, ongoing conduct, "legislation as such" (independent from its application), discretionary (as opposed to mandatory) legislation. 
Bossche and Zdouc highlight that the Appellate Body has recognized that unwritten measures such as "administrative practice" 840 or "zeroing methodology" can be challenged in WTO dispute settlement based on its "content and substance" 841 but that the panels are at the same time cautioned that they should not "lightly assume" 842 the existence of such a rule or norm. ${ }^{843}$ There are several criteria for proving an "unwritten norm or rule'. The Appellate Body in US-Zeroing (EC) required the establishment of the precise content of the norm or rule and its general and prospective application as well as being attributable to the responding Member. ${ }^{844}$ More recently the panel in USCountervailing Measures (China) added two more requirements: that the policy had normative value and had been applied consistently for a considerable period of time. ${ }^{845}$ This may cover health policy relating to public health services, which have been implemented for decades by Members and could be interpreted as falling within 'measures' under the GATS.

A practice as such need not have a normative value. In EC and certain member StatesLarge Civil Aircraft, the United States challenged the launch aid/ member State financing (LA/MSF) "programme" as a whole, in addition to particular instances of aid/financing. The Appellate Body noted that such a challenge is possible under WTO law:

As a general proposition, we do not exclude the possibility that concerted action or practice could be susceptible to challenge in WTO dispute settlement... When a challenge is brought against an unwritten measure, the very existence and the precise contours of the alleged measure may be uncertain. We would therefore expect complaining parties to identify such measures in their panel requests as clearly as possible [emphasis added]. ${ }^{846}$

As long as unwritten rules or norms or ongoing conduct can be clearly identified, they could be separate ground for challenge in dispute settlement proceedings. In the specific example of EC and certain member States-Large Civil Aircraft, the Appellate Body noted that they were "unable to discern in the United States' panel request" a separate challenge to an alleged LA/ MSF Programme, and this was considered a "defect" in the panel request which could not cured by later submissions on the issue. ${ }^{847}$ Therefore, if a Member wishes to raise such an issue of an ongoing practice that is not found in a document, it should clearly identify the practice as measure which is being challenged, in the request for the establishment of the panel.

The Panel in China-Publications and Audiovisual Products, also first looked at the measures in question to consider whether they were attributable to China. Subsequently, the relationship of the measure to the harm or impairment was considered. It was also

\footnotetext{
${ }^{840}$ Appellate Body Report, US-Countervailing Measures on Certain EC Products, para. 151.

${ }^{841}$ Appellate Body Report, US-Zeroing (EC), para.192, referring to Appellate Body Report, US-CorrosionResistant Sunset Steel Review, Para.87.

${ }^{842}$ Appellate Body Report, US-Zeroing (EC), para.192,

${ }^{843}$ Van Den Bossche, Peter and Werner Zdouc, THE LAW AND POLICY OF THE WORLD TRADE ORGANIZATION: TEXTS, CASES AND MATERIALS, Cambridge University Press, Revised edition, 2017, p174-175.

${ }^{844}$ Appellate Body Report, US-Zeroing (EC), para.198.

${ }^{845}$ Panel Report, US-Countervailing Measures (China), para.7.111-7.119.

846 Appellate Body Report, EC and certain member States-Large Civil Aircraft, paras.792-794 (citing Appellate Body Report, US-Corrosion-Resistant Steel Sunset Review, para. 81; Appellate Body Report, USSoftwood Lumber IV (Article 21.5-Canada), para. 67; Appellate Body Report, EC-Bananas III, para. 143; Appellate Body Report, US-Carbon Steel, para. 127).

${ }^{847}$ Appellate Body Report, EC and certain member States-Large Civil Aircraft, para. 794.
} 
clarified by the Panel that measures should establish rules or norms intended to have general and prospective application to fall under Article 3.3 of the DSU. The Panel went on to state that the "Several Opinions" raised in this dispute, being rules or norms of general and prospective application was thus a 'measure' that could be subject to dispute settlement, but the "Importation Procedure and the Sub-Distribution Procedure" was not a 'measure', as it did not establish rules or norms intended to have general and prospective application. ${ }^{848}$ The Panel in China-Publications and Audiovisual Products relied upon US-Corrosion-Resistant Steel Sunset Review for this position ${ }^{849}$ and also cited the same Report for the position that:

A determination of whether something is a 'measure' must be based on the content and substance of the instrument, and not merely on its form or nomenclature. ${ }^{850}$

The reference to substance rather than form and to 'rules or norms' suggests that 'measures' can be defined more broadly than legislation passed by a national legislative body, and can extend to different forms of regulatory instruments.

The Panel report in US-Export Restraints, supports the view that a 'practice' cannot be considered as something that would independently give rise to a WTO violation. ${ }^{851}$ The Panel in US-Steel Plate cited US-Export Restraints stating that in order to be identified as a measure there should be "independent operational status" of the challenged practice. ${ }^{852}$ However, it should be noted that in a later case, US-Continued Zeroing, the Appellate Body stated that 'ongoing conduct', or concerted/systematic action or practice of Members can be a 'measure' subject to WTO settlement proceedings. ${ }^{853}$

In the GATS context, the Appellate Body in US-Gambling discussed whether a 'practice' can mean the same as a 'measure'. The Panel report cited several prior Appellate Body decisions ${ }^{854}$ in support of the view that 'practice' can be considered as an autonomous measure that can be challenged in and of itself. ${ }^{855}$ The Appellate Body in US-Gambling disagreed with the Panel in US-Gambling, stating that there had not been any pronouncement to date on whether a "practice" may be challenged as a "measure" in dispute settlement. ${ }^{856}$ Reasons for why a "practice" should not be considered a measure can be connected with the fact that the terms of reference for the establishment of a panel, the identification of the specific measure, the evidence that can be presented for this

\footnotetext{
${ }^{848}$ Panel Report, China-Publications and Audiovisual Products, para.7.226.

${ }^{849}$ Panel Report, China-Publications and Audiovisual Products, para.7.172 citing Appellate Body Report, US-Corrosion-Resistant Steel Sunset Review, para.82.

${ }^{850}$ Panel Report, China-Publications and Audiovisual Products, para.7.172; citing Appellate Body Report, US-Corrosion-Resistant Steel Sunset Review, footnote 87.

${ }^{851}$ Panel Report, US-Export Restraints, para. 8.126:

US 'practice' [of treating export restraints as meeting the "financial contribution" requirement of Article 1.1(a)(1)(iv) of the SCM Agreement] therefore does not appear to have independent operational status such that it could independently give rise to a WTO violation as alleged by Canada.

${ }^{852}$ Panel Report,_US-Steel Plate, para. 7.14

${ }^{853}$ Appellate Body Report, US-Continued Zeroing, para, 171.

${ }^{854}$ Appellate Body Report, US-Corrosion-Resistant Steel Sunset Review, para. 97; Appellate Body Report, US-Carbon Steel, para.157; and Appellate Body Report, US-Countervailing Measures on Certain EC Products, para. 162

${ }^{855}$ Panel Report, US-Gambling, para.6.197 referred to in Appellate Body report at para 129.

${ }^{856}$ Appellate Body Report, US-Gambling, para.132. in the footnote to that paragraph the Appellate Body cites the prior Appellate Body Report in US-Oil Country Tubular Goods Sunset Reviews, para 220 for explicit mention of the fact that there has not been a pronouncement on this issue so far.
} 
identification and the preparation of the defence of the respondent will be difficult without a "specific measure" to deal with. In its analysis, the Appellate Body referred to 'measures' in the context of the Dispute Settlement Understanding, and to Article 3.3 and Article 4.2 of the DSU that were mentioned earlier. It was pointed out that the complaint must be brought as a challenge to the measure that is the source of the alleged negative effects on trade of the complainant. ${ }^{857}$ The Appellate Body suggests that a measure must be a "single and autonomous 'measure' that can be challenged in and of itself" 858 - as the complaining party must fulfil its obligation under Article 6.2 of the DSU to identify the 'specific measure at issue' so that the responding party can adequately prepare its defence. ${ }^{859}$

Article 6.2 of the DSU (Establishment of Panels)

The request for the establishment of a panel shall be made in writing. It shall indicate whether consultations were held, identify the specific measures at issue and provide a brief summary of the legal basis of the complaint sufficient to present the problem clearly... [emphasis added]

In EC-Bananas III, the Appellate Body stressed upon the importance of carefully examining the request for the establishment of a panel, since:

1. ...first, it often forms the basis for the terms of reference of the panel pursuant to Article 7 of the DSU; and,

2. second, it informs the defending party and the third parties of the legal basis of the complaint. 860

The Appellate Body stated that in the instance of the Gambling dispute, the 'total prohibition' on cross-border internet gambling which was raised by the complainant was:

...the collective effect of...an imprecisely defined list of legislative provisions and other instruments [italics in original] $]^{861}$ ....and as such did not constitute a 'measure' per se.

While the types of measures that are acts and omissions of the branches of government or their delegated agencies would obviously be quite varied, we already know some of the types of 'measures' that have already been identified in dispute settlement as being covered or not being covered by the scope and definition of 'measures' - and Members can have some idea of their level of success with regard to similar measures in future dispute contexts.

While laws, regulations, rules, procedures, decisions, and administrative actions are more clearly within the scope of measures, when it comes to "any other form", the situation is more complex. There is a possibility that health policy of a normative nature and a Members' ongoing systemic practices regarding health services could be regarded as measures under the GATS, if such policy or practices are identifiable as being the legal basis for a complaint.

\footnotetext{
${ }^{857}$ Appellate Body report, US-Gambling, Para. 123.

${ }^{858}$ Appellate Body report, US-Gambling, para 126.

${ }^{859}$ Appellate Body report, US-Gambling, para.125.

${ }^{860}$ Appellate Body Report, EC-Bananas III, para.142, reiterated in Appellate Body Report, US-Carbon Steel, para. 126.

${ }^{861}$ Appellate Body report, US-Gambling, para 124-126, upholding the findings of the Panel Report at para. 6.175 .
} 


\subsubsection{Defining 'Measures by Members'}

It is important to identify the link between a WTO Member and a measure taken by such a Member. "Measures" can be decisions taken at all the different levels of governance and cover the exercise of delegated governmental power. "Measures by Members" is defined in Article I:3(a) of the GATS for the purposes of the GATS, as:

...measures taken by:

(i) central, regional or local governments and authorities; and

(ii) non-governmental bodies in the exercise of powers delegated by

central, regional or local governments or authorities.

In a broad sense, it suggests that "measures" could refer to executive, administrative and legislative measures taken as various levels of government and by non-governmental bodies with delegated powers. With regard to health, this can cover not merely governmental decision-making but also the delegated authority exercised by medical associations and medical boards.

The Appellate Body in US-Gambling cites the Appellate Body in US-Corrosion-Resistant Steel Sunset Review, which stated that Article 3.3 of the DSU identifies the relevant nexus between the 'measure' and a 'Member' for purposes of dispute settlement proceedings broadly, as:

... situations in which a Member considers that any benefits accruing to it directly or indirectly under the covered agreements are being impaired by measures taken by another Member (emphasis in original). ${ }^{862}$

In US-Gambling, the measures found to violate obligations under the GATS were both Federal and State measures. The Federal measures that were the Wire Act; the Travel Act; and the Illegal Gambling Business Act, read together with the State measures found in the laws of Louisiana, Massachusetts, South Dakota and Utah. ${ }^{863}$

As can be seen, the measures in question could be by different branches of government, not only the legislative branch and outcomes of delegated legislative powers. The Appellate Body in US-Corrosion-Resistant Steel Sunset Review has noted in the context of trade in goods, that:

...[i]n principle, any act or omission attributable to a WTO Member can be a measure of that Member for purposes of dispute settlement proceedings ${ }^{864} \ldots$

and that those

....acts or omissions that are so attributable are, in the usual case, the acts or omissions of the organs of the state, including those of the executive branch. ${ }^{865}$

The original footnote at this point in the report referred to both specific determinations and regulations issued by the executive branch of government, citing as example, the Panel Report in US-DRAMS, where the measures included a United States Department of Commerce determination in an administrative review as well as a regulatory provision issued by it.

\footnotetext{
${ }^{862}$ Appellate Body Report, US-Corrosion-Resistant Steel Sunset Review, para.81.

${ }^{863} \S 14: 90.3$ of the La. Rev. Stat. Ann.; $\$ 17$ A of chapter 271 of Mass. Ann. Laws; $\S 22-25$ A-8 of the S.D. Codified Laws; $§ 76-10-1102$ (b) of the Utah Code.

${ }^{864}$ Appellate Body Report, US-Corrosion-Resistant Steel Sunset Review, Footnote 87

${ }^{865}$ Appellate Body Report, US-Corrosion-Resistant Steel Sunset Review, Footnote 87
} 


\subsubsection{Defining "Measures affecting Trade in Services"}

As mentioned at the start of this Chapter, Article I: 1 of the GATS states that:

[t]his Agreement applies to measures by Members affecting trade in services.

If the matter of whether the issue is one of 'trade in services' has already been decided in the affirmative, then the next key question then is the nexus between the measure and trade in services. Thus, it has to be asked whether the measure in question affects trade in services and therefore falls under the scope of application of the GATS.

The term 'affecting' has been interpreted broadly in dispute settlement, going even beyond measures taken by a Member that are designed for the regulation of trade in services. The Panel in EC-Bananas III held that:

The scope of the GATS encompasses any measure of a Member to the extent it affects the supply of a service regardless of whether such measure directly governs the supply of a service or whether it regulates other matters but nevertheless affects trade in services [emphasis added]. ${ }^{866}$

The Appellate Body in EC-Bananas III, upheld the Panel, stating that:

In our view, the use of the term 'affecting' reflects the intent of the drafters to give a broad reach to the GATS. The ordinary meaning of the word 'affecting' implies a measure that has 'an effect on', which indicates a broad scope of application. ${ }^{867}$

The Appellate Body reasoning relied on the following arguments:

- There is nothing in these provisions to suggest a limited scope of application for the GATS. ${ }^{868}$

- Article XXVIII(b) of the GATS (Definitions) provides that the 'supply of a service' includes 'the production, distribution, marketing, sale and delivery of a service'

- Article XXVIII(c) of the GATS (Definitions) does not narrow the meaning of the term 'affecting' to 'in respect of'.

- This interpretation is reinforced by the conclusions of previous panels that the term 'affecting' in the context of Article III:4 of the GATT is wider in scope than such terms as 'regulating' or 'governing', 869

The measures at the heart of the dispute, the EC banana import licensing procedures, were recognized by both the Panel and the Appellate Body as subject to both the GATT 1994 and the GATS.

The EC submissions on appeal were that the Panel's interpretation was not supported by preparatory work of the GATS and that the negotiators wanted to create an instrument of limited coverage that was distinct from the GATT 1994, were not accepted by the Appellate Body. ${ }^{870}$

\footnotetext{
${ }^{866}$ Panel Report, EC-Bananas III, para. 7.285

867 Appellate Body Report, EC-Bananas III, para. 220; applied by the Panel in US-Gambling, paragraph 6.251 .

${ }^{868}$ Appellate Body Report, EC-Bananas III, para. 7.285

${ }^{869}$ Appellate Body Report, EC-Bananas, para 220.

The Appellate Body further adds that former GATT and WTO Panel Reports reinforce this position. This position is also cited by the Appellate Body Report, Canada-Autos, para 158.

See also, Panel Report, China-Publications and Audiovisual Products, para. 7.971; also stating that 'affecting' in Article 1:1 of the GATS is wider in scope than 'regulating' or 'governing'.

${ }^{870}$ Appellate Body Report, EC-Bananas III, para. 42 and para. 43.
} 
It was also argued by the EC that:

...there is no indication that the broad interpretation given to the term

'affecting' in a Note by the Secretariat, which is referred to by the Panel in

support of its interpretation, was shared by the negotiators of the GATS. ${ }^{871}$

The EC also added that using a specific meaning of 'affecting' from a Panel report interpretation of Article III:4 of the GATT 1947 would be taking things out of context; and further that the Preamble of GATS and other provisions such as Articles VI:4 and XVI of the GATS, gives no indication that the GATS is concerned with the indirect effects on trade in services of measures relating to trade in goods. ${ }^{872}$

It is possible to have some sympathy for the EC argument here because the relevant GATS provision deals only with "measures affecting trade in services" and with regard to GATT it specifically deals with the avoidance of protectionism in the application of internal tax and regulatory measures. The Appellate Body in Japan-Alcoholic Beverages II further explained that such regulatory measures include all measures:

...in respect of all laws, regulations and requirements affecting internal

sale, offering for sale, purchase, transportation, distribution or use [of imported products]. ${ }^{873}$

In Canada-Periodicals, the Appellate Body added:

The fundamental purpose of Article III of the GATT 1994 is to ensure equality of competitive conditions between imported and like domestic products. $^{874}$

The GATS do not have the same kind of general obligations with regard to domestic regulation and equality of competitive conditions for 'like' imported services would fall mostly under the commitments negotiated and scheduled under national treatment.

With regard to Article III:4 of GATT 1994 the Appellate Body has stated in US-FSC (Article 21.5-EC) (also citing EC-Bananas III, which had extended the reasoning also to Article I:1 of the GATS), that the term "affecting" has a "broad scope of application" and that it "operates as link between identified types of government action" which fall within the Agreement and commercial transactions and activities. ${ }^{875}$ Thus, without the link of "affecting" between the measure and the commercial activity, the measure would not be a relevant measure falling within the scope of the trade agreement. The Panel in ChinaPublications and Audiovisual Products added that 'affecting' covers measures which "create incentives or disincentives" with respect to the sale, offering for sale, purchase, and use of an imported 'like' product, and not merely measures that directly regulate or govern such a sale. ${ }^{876}$

\footnotetext{
${ }^{871}$ Ibid. para 42.

872 Ibid.

${ }^{873}$ Appellate Body in Japan-Alcoholic Beverages II, citing Panel Report on US - Section 337 Tariff Act, para. 5.10.

${ }^{874}$ Appellate Body Report, Canada-Periodicals, para.464. The original footnote also cited a number of Panel Reports in support: US-Tobacco, para 99; US-Malt Beverages, para 5.6; Canada-Provincial Liquor Boards (EEC), para 5.6; US-Section 337 Tariff Act, para 5.13; US-Superfund, para 5.1.9; and BrazilInternal Taxes, para. 15.

${ }^{875}$ Appellate Body Report, US-FSC (Article 21.5-EC), paras.208-209

${ }^{876}$ Panel Report, China-Publications and Audiovisual Products, para.7.1450 - citing Panel Report, ECBananas III, para.7.175; Panel Report, India-Autos, paras.7.196-7.197; Panel Report, Canada-Wheat Exports and Grain Imports, para.6.267.
} 
The Appellate Body in US-Gambling has also pointed out that there is a distinction between 'measures' and their effect; further adding that the "measures" themselves must "affect" the operation of a covered agreement in order for a dispute to arise. ${ }^{877}$ The Appellate Body in Canada-Autos also considered the definitions under Article XXVIII(c) of the GATS (Definitions), an open-ended provision which identifies 'measures' in the context of 'measures by Members affecting trade in services'. This suggests that the measures have to be taken in respect of services per se and not as services related to trade in goods. With regard to Article I:1 of the GATS, Canada had claimed that the effect of the measure in question (according the advantage of duty-free treatment to motor vehicles originating in certain countries) on the supply of distribution services was so tenuous that the measure should be scrutinized exclusively under the GATT $1994 .{ }^{878}$ Although the Appellate Body in Canada-Periodicals did not find it relevant to pronounce on the issue of potential overlaps between the GATT 1994 and the GATS, it was accepted by the Appellate Body in both EC-Bananas III and China-Publications and Audiovisual Products that a measure can regulate both goods and services and that, as a result, the same measure can be subject to obligations affecting trade in goods and obligations affecting trade in services. ${ }^{879}$ This is particularly the case where the services in question are concerned with the wholesale or retail supply of goods. In China-Publications and Audiovisual Products, one of the measures at issue was the different treatment of Chinese-owned and foreign-invested enterprises supplying the service of wholesale importing of reading materials. ${ }^{880}$

\subsubsection{Public infrastructure and measures within the scope of the GATS}

With regard to Article XXVIII(c) of the GATS, it is noticeable that "use of a service" is included as well as the more obvious "purchase" and "payment" within the definition of "measures by Members affecting trade in services". What does the reference to "use of a service" in Article XXVIII(c)(i) actually suggest? When comparing with 'purchase' and 'payment' which are clearly referring to commercial transactions that are part of 'trade in services', it seems to mean that situations that deal with fees or taxes or other procedures for and rights regarding access, without either 'purchase' and 'payment' for the use of certain services, are still part of 'trade in services' and fall within the scope of the GATS. If compared with Article III:4 of the GATT 1994, there is "use" of goods mentioned Article III:4 in the context of national treatment on internal taxation and regulation. The Appellate Body in EC-Seal Products has clarified the scope of national treatment in this context:

Article III:4 does not require the identical treatment of imported and like domestic products, but rather the equality of competitive conditions between these like products [original emphasis]. ${ }^{881}$

In the context of trade in goods this means that while Members could have different regulatory regimes for imported and domestic services, these measures should not unfavourably modify conditions of competition for the foreign service suppliers. ${ }^{882}$ However, as pointed out by the Appellate Body in US-FSC (Article 21.5-EC), although

\footnotetext{
${ }^{877}$ Appellate Body Report, US-Gambling, para 122.

${ }^{878}$ Appellate Body Report, Canada-Autos, para.20 and para.162-164.

879 Appellate Body Report, EC-Bananas III, para.221; China-Publications and Audiovisual Products, paras.193-195.

${ }^{880}$ Panel Report, China-Publications and Audiovisual Products, paras. 7.975-7.976.

${ }^{881}$ Appellate Body Report, EC-Seal Products, para.5.108.

882 Ibid., (EC-Seal Products), referring to Appellate Body Report, Korea-Various Measures on Beef, para.137.
} 
Article III:4 of the GATT 1994 can be compared with Article I:1 of the GATS, the GATS provision "does not in itself impose any obligation". ${ }^{83}$ The national treatment obligation is a limited one in GATS, narrower than the general scope of application of the agreement.

A related point is whether use of public infrastructure by private entities is somehow covered by 'trade in services' according to this definition, although the initial reaction is that it would not be. However, the inclusion of the subsection that follows, Article XXVIII(c)ii, may be connected with the interpretation of 'use', and it is also significant from the angle of interest in public services issues. According to Article XXVIII(c)ii, measures that are covered by the GATS include those in respect of "access to and use of services which are required to be offered to the public generally". This can be generally identified as public infrastructure, and that therefore use and access to public infrastructure can also be covered by the scope of the GATS. The reason for this to be covered is that use of such public infrastructure is essential for foreign services and service suppliers to provide their services, and thus denying them equal access as domestic service suppliers would be an issue affecting the non-discrimination obligations of the GATS, if there is a national treatment commitment.

This idea is included more clearly in the documents on the telecommunications sector. The text of Article XXIX of the GATS states that:

The Annexes to this Agreement are an integral part of this Agreement.

Therefore, the provisions of the Annex on Telecommunications ${ }^{884}$, if relevant, can also shed light on the definition of 'trade in services' and the matter of measures in respect of access and use of services which are required to be offered to the public generally. It is important to note that the definitions and interpretations of the text of the Annex itself only applies to telecommunications services and not all services covered by the GATS.

Paragraph 1(Objectives) of the Annex on Telecommunications states that WTO Members have agreed that this Annex elaborates upon and 'provides notes and supplementary provisions ${ }^{885}$ to the provisions of the GATS with respect to

...measures affecting access to and use of public telecommunications transport networks and services. ${ }^{886}$

Paragraph 2(a) of the Annex (Scope) provides that

This Annex shall apply to all measures of a Member that affect access to and use of public telecommunications transport networks and services (14) (original footnote retained)

The original footnote 14 states:

This paragraph is understood to mean that each Member shall ensure that the obligations of this Annex are applied with respect to suppliers of public telecommunications transport networks and services by whatever measures are necessary.

Paragraph 3(b) defines a 'public telecommunications transport service' (PTTS) as $\ldots$ any telecommunications transport service required, explicitly or in effect, by a Member to be offered to the public generally

\footnotetext{
${ }^{883}$ Appellate Body Report, US-FSC (Article 21.5-EC), para.209.

${ }^{884}$ Also known as the Fourth Protocol to the GATS, adopted 30 April 1997 and entered into force 5 February 1998.

${ }^{885}$ GATS Annex on Telecommunications, Paragraph 1 (Objectives).

886 Ibid.
} 
And Paragraph 3(c) defines 'public telecommunications transport network'(PTTN) as $\ldots$ the public telecommunications infrastructure which permits telecommunications between and among defined network termination points.

Thus, it can be seen that public services and public infrastructure is clearly included in 'trade in services' with regard to the telecommunications sector. ${ }^{887}$ Furthermore, Paragraph 5(b) of the Annex also says that Members shall ensure access and use to PTTN and PTTS within or across borders of the said Member, 'including private leased circuits' to foreign service suppliers have if they have made telecommunications commitments (for national treatment and market access) in their Schedule ${ }^{888}$

The scope of obligations is not limited to the extent of commitments made in the telecommunications sector. Paragraph 5(a) of the Annex on Telecommunications, states that:

Each Member shall ensure that any service supplier of any other Member is accorded access to and use of public telecommunications transport networks and services on reasonable and non-discriminatory terms and conditions, for the supply of a service included in its Schedule [emphasis added].

Paragraph 5(a) ought to be read in light of Article XXVIII(c)ii which, as mentioned above, defines measures within the scope of the GATS as including access to and use of services offered to the public generally, in connection with the supply of a service. In an explanation of the Annex on Telecommunications on the official website of the WTO, it is stated that public telecommunications transport networks and services means essentially basic public telecommunications and also adds that

Members incur these obligations whether or not they have liberalized or scheduled commitments in the basic telecommunications sector. ${ }^{889}$

The reason given for this is that the Annex addresses access to telecommunication services by service suppliers of sectors that have already been liberalized rather than market access in telecommunication services, the former being what is included in the obligations of the Annex and the latter being what may or may not be addressed in the Schedules of Commitments. It is further elaborated that the main beneficiaries of the Annex on Telecommunications can be firms that supply services in other service sectors where commitments have been made and which would benefit from a right of access and use of the public telecommunications services and networks of that Member for expansion and competitiveness in their service sector.

The Panel in Mexico-Telecom stated that they consider Paragraph 5(a) as an indication that the Annex is not limited in application but applies to:

\footnotetext{
887 The other relevant sub-paragraphs list the areas exempted from the scope as; radio and television broadcast or cable services (Paragraph 2(b)) and the limitations or lack of telecommunications commitments in the Schedule (Paragraph 2(c)).

${ }^{888}$ Paragraph 5 is titled:

Access to and Use of Public Telecommunications Transport Networks and Services.

This was a matter at issue in the Panel Report for Mexico-Telecoms, where the Panel stated that since Mexico had undertaken commitments on the supply of telecommunications services by commercial agencies through commercial presence, for which access to and use of private leased circuits is not only relevant but, by Mexico's own definition in its schedule, is essential. It was found that Mexico had failed to ensure access to and use of private leased circuits in a manner consistent with Section 5(b).

${ }^{889}$ Available at http://www.wto.org/english/tratop_e/serv_e/telecom_e/telecom_annex_expl_e.htm
} 
... measures ensuring the access to and use of public telecommunications transport networks and services for the supply of any service, including basic telecommunications services [emphasis added]. ${ }^{890}$

The importance of public infrastructure for private investment is recognized in the objectives of the Annex, Paragraph 1, which states that the telecommunications sector is "...the underlying transport means for other economic activities". It could be said that what this Annex is attempting to provide is pressure or incentive for Members to assure that their public telecommunication sector will be available to be accessed by foreign service suppliers. Paragraph 2(c) of the Annex gives a certain amount of flexibility by not imposing an obligation for a Member to authorize foreign service suppliers to provide telecommunication services if there is no telecommunications commitment made in the Schedule: and there is no obligation to ensure that private telecommunications service providers within their jurisdiction develop and extend their services.

The above provisions are geared towards providing for foreign investment. The governmental obligations that would be relevant in the context of public telecommunications service provision such as universal service obligations for the domestic population or other development goals are not explicitly taken into account. It could be argued that while ensuring that foreign service suppliers in committed sectors have access to the existing national basic telecommunications network, at the same time the obligation for universal services should also be achieved. Paragraph 3 of the 1996 Telecoms Reference Paper of the Working Group on Basic Telecommunications (which is binding on those Members that have committed to it, currently being 82 Members) states that:

Any Member has the right to define the kind of universal service obligation it wishes to maintain. Such obligations will not be regarded as anti-competitive per se, provided they are administered in a transparent, non-discriminatory and competitively neutral manner and are not more burdensome than necessary for the kind of universal service defined by the Member.

This leaves open the definition of the nature of the universal services obligation and allows for governmental policy to define its scope so long as the requirements abovementioned are followed in its administration. Transparency is fairly unproblematic but the interpretation and application of the other terms; non-discriminatory, administered in a "competitively neutral manner" and "not more burdensome than necessary", which reflect standards used in WTO law, remains to be seen. It is interesting to note the preamble of the Constitution and Convention of the International Telecommunication Union (ITU, 1992), which is a specialized agency of the United Nations and has 193 State parties includes obligations of States with regard to universal services provision. While recognizing "the sovereign right of each State to regulate its telecommunication" the preamble to the Constitution and Convention states that the ITU has the objective of facilitating "economic and social development by means of efficient telecommunication services". 891

\footnotetext{
${ }^{890}$ Panel Report, Mexico - Telecoms, para. 7.281

891 See https://treaties.un.org/doc/Publication/UNTS/Volume\%201825/volume-1825-I-31251-English.pdf. Note that the 1992-1994 period during which the Constitution and Convention came into force means that States parties were negotiating and ratifying this parallel to the Uruguay Round and the coming into force of the WTO Agreement and GATS.
} 
Human rights implications of access to telecommunications networks are also not discussed in the WTO context, but that is entirely understandable as WTO law avoids any direct references to human rights and this became an important issue within the human rights context only recently. A first step to link telecommunications investment and human rights was taken in 2003 with the 'Geneva Declaration of Principles: Building the Information Society' which was built upon the principles of the UN Charter and the Universal Declaration on Human Rights. The Geneva Declaration noted in paragraph 23 that:

Policies that create a favourable climate for stability, predictability and fair competition at all levels should be developed and implemented in a manner that not only attracts more private investment for ICT infrastructure development but also enables universal service obligations to be met in areas where traditional market conditions fail to work. In disadvantaged areas, the establishment of ICT public access points in places such as post offices, schools, libraries and archives, can provide effective means for ensuring universal access to the infrastructure and services of the Information Society [emphasis added]. ${ }^{892}$

It is also interesting to note recent developments in the international human rights law approach to access to basic telecommunications networks, particularly the access to the internet, under the theme of 'freedom of opinion and expression in the digital age'. In 2011, the UN Special Rapporteur on the promotion and protection of the right to freedom of opinion and expression issued a report which noted that:

Given that the Internet has become an indispensable tool for realizing a range of human rights, combating inequality, and accelerating development and human progress, ensuring universal access to the Internet should be a priority for all States [emphasis added] ${ }^{893}$

This report also noted that several countries have initiated programmes for public access points, which were recognized as "particularly important to facilitate access for the poorest socio-economic groups"; and some countries have recognized internet access as a fundamental right or human right. ${ }^{894}$ The 2017 Report of the Special Rapporteur on the promotion and protection of the right to freedom of opinion and expression comments on the responsibilities of both government and private 'digital access' providers to respect human rights; also highlighting that (i) access providers supply a public good (ii) restrictions on internet access affect freedom of expression globally, and (iii) the industry is vulnerable to State pressure against freedom of expression...but also uniquely situated to ensure respect for users' rights. ${ }^{895}$

\footnotetext{
${ }^{892}$ ITU, World Summit on the Information Society (2003-2005), Declaration of Principles: Building the Information Society - a global challenge in the new Millennium Document WSIS-03/GENEVA/DOC/4-E, 12 December 2003, para.23.

${ }^{893}$ UN GA and Human Rights Council, Report of the Special Rapporteur on the promotion and protection of the right to freedom of opinion and expression, (Frank La Rue), A/HRC/17/27, 16 May 2011, para.85 (under Recommendations: Access to the Internet and the necessary infrastructure).

${ }^{894}$ Ibid., (La Rue), paras.64-65, referring to programmes in India and right to internet being recognized in the 2000-2010 period in France, Estonia, Costa Rica and Finland.

${ }^{895}$ UN GA and Human Rights Council, Report of the Special Rapporteur on the promotion and protection of the right to freedom of opinion and expression, (David Kaye), A/HRC/35/22. 30 March 2017, paras.4549. See especially para. 47 on access providers supplying a public good:

Since privately owned networks are indispensable to the contemporary exercise of freedom of expression, their operators also assume critical social and public functions. The industry's decisions, whether in response to government demands or rooted in
} 
This section is focused on what is included in 'trade in services', and from what has been discussed so far it can be concluded that the scope and definition could go beyond what would naturally be supposed, to matters of access and use of domestic public infrastructure. The Annex on Telecommunications is intended to go further than the GATS in this specific area, but it can be said that there are basic minimum obligations which are contained in Article XXVIII(c)(ii) of the GATS, since it provides a definition that "Measures by Members affecting trade in services include measures in respect of...access to and use of services which are required to be offered to the public generally". If there are rights of access and use of public infrastructure for foreign private service suppliers under the GATS, the question also arises whether the rights of the domestic public have been taken into account. The official WTO website abovementioned also recognizes this by stating that:

The Annex obligations strike a fragile balance between the needs of users for fair terms of access and the needs of the regulators and public telecommunications operators to maintain a system that works and that meets public service objectives. ${ }^{896}$

However, this matter needs to be and will be further analyzed later in this Chapter, to determine to what extent this balance has been struck.

\subsubsection{Article I:3 - Obligation of Members to ensure observance within its territory}

Article 1:3 of the GATS makes it clear that:

For the purposes of this Agreement:

(a) "measures" by members means measures taken by

(i) central, regional or local governments or authorities; and

(ii) non-governmental bodies in the exercise of powers delegated by central, regional or local governments or authorities;

In fulfilling its obligations and commitments under the Agreement, each Member shall take such reasonable measures as may be available to it to ensure their observance by regional and local governments and authorities and non-governmental bodies within its territory...

Zacharias points out that this is an obligation that accords with general public international law and cites Articles 4 and 5 of the 2001 ILC Draft Articles on State Responsibility. ${ }^{897}$ These two Articles are on the attribution of conduct to a State and provide that the conduct of any state organ (whether central or of a territorial unit ${ }^{898}$ ) or a

commercial interests, can directly impact freedom of expression and related human rights in both beneficial and detrimental way [emphasis added].

See further, recent publication by Kriangsak Kittichaisaree, former member of the International Law Commission (2012-2016): Kittichaisaree, Kriangsak, PUBLIC INTERNATIONAL LAW OF CYBERSPACE, Springer, 2017.

${ }^{896} \mathrm{http} / /$ www.wto.org/english/tratop_e/serv_e/telecom_e/telecom_annex_expl_e.htm

${ }^{897}$ Zacharias, Diana, Article I GATS in Wolfrum, Rudiger, Peter-Tobias Stoll and Clemens Feinaugle Eds., WTO - TRADE IN SERVICES, Max Planck Commentaries on World Trade Law, Martinus Nijhoff Publishers, 2008, p57: citing UN General Assembly, International Law Commission, Draft Articles on the Responsibility of States for Internationally Wrongful Acts,, A/CN.4/L.602/Rev.1.

898 International Law Commission Draft Articles on the Responsibility of States for Internationally Wrongful Acts, A/CN.4/L.602/Rev.1, Article 4 (Conduct of organs of a State):

1. The conduct of any State organ shall be considered an act of that State under international law, whether the organ exercises legislative, executive, judicial or any other functions, whatever position it holds in the organization of the State, and whatever its character as an organ of the central Government or of a territorial unit of the State. 
body empowered to exercise governmental authority ${ }^{899}$ shall be considered to be an act of the State. The Panel in Korea-Procurement cited Article 5 and the Commentary on the Draft Articles on State responsibility when noting that:

The actions and even omissions of State organs acting in that capacity are attributable to the State as such and engage its responsibility under international law. ${ }^{900}$

The Panel in US-Gambling, referred to Article 4 of the Draft Articles as reflecting "customary principles of international law concerning attribution" when concluding that the actions of the United States International Trade Commission (USITC) were attributable to the United States. ${ }^{901}$

Furthermore, as recognized by the Panel in US-Section 301 Trade Act, it is important to:

Consider, first, the overall obligation of Members concerning their internal legislation. Under traditional public international law, a State cannot rely on its domestic law as a justification for non-performance. ${ }^{902}$

When the Panel made the above statement, it cited Article 27 of the VCLT in support. Article 27 of the Vienna Convention on the Law of Treaties clearly states that:

A party may not invoke the provisions of its internal law as justification for its failure to perform a treaty.

Thus, a Member must take action concerning domestic/internal law which impacts its treaty obligations. But when must this action be taken? Should it pre-empt a dispute or should action be taken only upon a panel or Appellate Body decision or WTO arbitration which is not in the responding Member's favour and which makes recommendations for compliance? Of course, even then there is the possibility of facing retaliation rather than "ensuring observance" - but when does the obligation to ensure compliance arise?

It should be noted that it has been recognized by the Panel in US-Section 301 Trade Act that under traditional public international law, State responsibility is not usually raised merely due to the undertaking of an obligation and the creation of legislation which may cause a future violation of that obligation - but when a violation has actually occurred.$^{903}$ This was stated as a general comment on State responsibility in public international law, although the Panel eventually held that a statute which "reserves the right for the Member concerned to do something which it has promised not to do" was a violation of its WTO obligations. ${ }^{904}$ This also seems to be addressed by Article XVI:4 of the WTO Agreement which describes the obligation on a Member to ensure compliance of its laws, regulations and administrative procedures with its obligations as provided in the annexed Agreements in, and with regard to dispute settlement findings, by the reference to "prompt

2. An organ includes any person or entity which has that status in accordance with the internal law of the State.

${ }^{899}$ Ibid (ILC), Article 5 (Conduct of persons or entities exercising elements of governmental authority):

The conduct of a person or entity which is not an organ of the State under article 4 but which is empowered by the law of that State to exercise elements of the governmental authority shall be considered an act of the State under international law, provided the person or entity is acting in that capacity in the particular instance.

${ }^{900}$ Panel Report, Korea-Procurement, para. 6.5, also citing ICJ, Corfu Channel Case (UK v Albania), 1949 ICJ Reports, p. 23; US Diplomatic and Consular Staff in Tehran (US v Iran), ICJ Reports 1980, pp. 30-31 and 33.

${ }^{901}$ See Panel Report, US -Gambling, paras. 6.127-6.130.

${ }^{902}$ Panel Report, US-Section 301 Trade Act, para. 7.80.

${ }^{903}$ Panel Report, US-Section 301 Trade Act, para. 7.80.

${ }_{904}$ Panel Report, US-Section 301 Trade Act, para.7.63. 
compliance" (Art 21.1 of the DSU) and "immediate withdrawal" (Art 3.7 of the DSU), unless impracticable, in which case a reasonable period for compliance is agreed or decided in arbitration. Despite the traditional public international law approach and the provisions of the WTO Agreement, the Panel in US-Section 301 Trade Act noted that even in prior GATT panel reports, "legislation as independent from its application" was considered to be a violation because of the "indirect... 'chilling effect' on the economic activities of individuals". ${ }^{905}$

It is clear that measures taken by central, regional or local governments or authorities come within the scope of the GATS under Article I:3(a)(i). This is supported by the analysis in the Panel in the SPS dispute, Australia-Salmon (Article 21.5-Canada), where a ban by Tasmania was regarded as a measure taken by Australia. The Panel noted that this is because the Tasmanian ban is a measure Australia is responsible for "under both general international law and relevant WTO provisions". ${ }^{906}$ The Panel cited in respect of general international law, Article 27 of the VCLT and Article 6 of the ILC Draft Articles on State Responsibility, the latter of which states that:

The conduct of an organ of the State shall be considered as an act of that State under international law, whether that organ belongs to the constituent, legislative, executive, judicial or other power, whether its functions are of an international or an internal character, and whether it holds a superior or a subordinate position in the organization of the State. ${ }^{907}$

The Panel also noted in the same paragraph that the Tasmanian measure was one that "that directly affects international trade", and thus was subject to the SPS Agreement according to Article 1.1 and Paragraph 1 of Annex 1 of the SPS Agreement. However, in these Article 21.5 proceedings the Panel noted that their task was not to decide on "the enforcement or compliance by Australia with any findings of inconsistency of the Tasmanian measure" but to decide on the consistency of the Tasmanian measure with the SPS Agreement and of Australia's obligations with regard to the enforcement of DSB recommendations. ${ }^{908}$ The Panel also noted that Australia's statements before the Panel that the Australian Federal government also objected to Tasmania's measures, are not relevant for the issue of whether those Tasmanian measures are inconsistent with SPS Agreement obligations of Australia. ${ }^{909}$

The extent to which a Member must, prior to recommendations of a DSB, 'ensure observance' of their WTO obligations and commitments by regional or local governments or delegated authorities within its territory is not so clear - and this also applies for Article I:3(a) of the GATS. It is ultimately the DSB which would be able to interpret the extent of the obligation, although the Member may decide on how it would choose to implement what it understands as its obligations under the GATS. Art I:3(a) (ii) GATS appears to suggest that local/regional government measures should be considered as measures by Members, in the sense that these measures are attributable to Members. Any

\footnotetext{
${ }^{905}$ Panel Report, US-Section 301 Trade Act, para. 7.80-7.81. The Panel in footnote 666 of the report refers to the GATT Panel Report, US-Superfund, paras. 5.2.1 and 5.2.2) where tax legislation which had not yet entered into effect was found to violate GATT obligations; GATT Panel Report, US-Malt Beverages, paras.5.39, 5.57, 5.60 and 5.69 where the legislation imposing the tax discrimination was not being enforced by the authorities.

${ }^{906}$ Panel Report, Australia-Salmon (Article 21.5-Canada, para.7.12

907 Panel Report, Australia-Salmon (Article 21.5-Canada), footnote 146 to para.7.12.

${ }^{908}$ Panel Report, Australia-Salmon (Article 21.5-Canada), para.7.13 and footnote 147.

${ }^{909}$ Panel Report, Australia-Salmon (Article 21.5-Canada), para.7.126 and footnotes 252-253.
} 
other interpretation would mean that WTO obligations would be easy to evade by delegating authority to take trade restrictive measures to lower levels of government, and the lower levels of government deciding not to implement the WTO obligations. This would also be contrary to the public international law basic principle of pacta sunt servanda. It may be implied that the central government of a Member must assure within their own domestic legal system that the lower levels of government do not take measures that would violate WTO obligations. Yet some Members have federal or other systems of devolution of powers from the center, where there may be internal restrictions on the ability of the center to overturn decision-making at the sub-national level. The obligation of a Member to ensure the observance of the GATS within its territory involves both problems of policy and constitutional structure for Members; and may require internal discussions and constitutional interpretation by courts or constitutional amendments, if the WTO obligations are to be carried out by the central government. Broadly speaking, such steps to restrict the lower levels of government also undermine the concept of subsidiarity and the choices of economic and social policy that devolved political units could 'experiment' with. ${ }^{910}$ The example of the CCF in Saskatchewan introducing a public health system (Medicare) that was later adopted by the Canadian Federal Government is an example of how the 'experimenting laboratory' view of devolution has led to positive results for the general public.

It is interesting to note that the dissenting judgement of Justice Brandeis in the 1932 case of New State Ice Co $v$ Liebmann, ${ }^{911}$ which is the source for the "experimenting laboratories' metaphor, was in the context of public interest, competition and monopoly concerns. The issue in the case was the constitutionality (violation of due process) of legislation passed by the US State of Oklahoma requiring that manufacture and distribution of ice could only be done with a license, which was to be based on necessity of supply at the relevant location of the business. The effect of this was to create a "network of local ice monopolies protected by the state from price competition". ${ }^{912}$ Six Supreme Court Justices felt that the legislation was an unwarranted interference with the right to engage in private business in a lawful occupation. However, Justice Brandeis argued that the Oklahoman legislation was reasonable and not a violation of due process. It is possible to assess the dissenting judgement and conclude the basis of Justice Brandeis' argument went beyond a mere broad endorsement of just any experimentation at lower levels of government, but that it was justified by Justice Brandeis on a socioeconomic basis. The dissenting judgement by Brandeis highlights the context of the suffering of the 'Great Depression' and that "rightly or wrongly, many persons think that one of the major contributing causes has been unbridled competition" as well as production which is not balanced with consumption - and which now needs "economic control" and "proposals for stabilization" in order to increase employment. ${ }^{913}$ Making a comparison with scientific experimentation wherein knowledge is advanced through trial and error, he notes that:

Some people assert that our present plight is due, in part, to the limitations set by courts upon experimentation in the fields of social and economic science ... There must be power in the States and the Nation to remould,

\footnotetext{
910 See Chapter 2, section 2.2.7 of this study (Sovereignty, Democracy and Public Services).

${ }^{911}$ New State Ice Co. v. Liebmann, 285 U.S. 262 (1932)

912 James A. Gardner, The "States-as-Laboratories" Metaphor in State Constitutional Law, 30 Valparaiso University Law Review 475 (1996).

${ }^{913}$ New State Ice Co. v. Liebmann, 285 U.S. 262 (1932) at p306-09
} 
through experimentation, our economic practices and institutions to meet changing social and economic needs. ${ }^{914}$

Gardner analyzes this dissenting judgement as being an argument, not for economic protectionism or protection of the powers of the Federal State per se, but for rational policy which is response to a socio-economic need. ${ }^{915}$ Gardner states that in comparison the majority of the Supreme Court does not come to a conclusion which take into account the socio-economic effects of the challenged measure or the legal impacts of restricting State powers, but merely focuses on interpretation of fixed due process limits on government power. ${ }^{916}$

In a way, this approach would be similar to how WTO law would usually approach a matter of limiting the possibility of State or sub-State authorities from 'experimenting'. The 'experimenting laboratories' metaphor has been used in a number of cases by the US Supreme Court and lower courts in the intervening decades, but many of them did not have a direct link to socio-economic flexibility. However, it may be relevant to note that in a case decided more than 60 years after Liebmann, Chief Justice Rehnquist in a dissenting judgment (with Justice Blackmun joining) in West Lynn Creamery Inc. v. Healy, ${ }^{917}$ used the 'experimenting laboratory' metaphor and quoted Brandeis in the context of a Massachusetts state tax which subsidized local milk producers. Chief Justice Rehnquist mentions the "values of federalism" in his dissenting judgment but also comments negatively on the "messianic insistence on a grim sink-or-swim policy of laissez-faire economics" which rejected state-level flexibility. ${ }^{918}$ However, the majority of the Court noted that the tax (which was non-discriminatory and on milk dealers) and subsidy program (which was for local milk producers) imposed what was in effect a 'tariff' on out-of-state competitors. If a similar situation was transferred to a WTO dispute context, would the WTO Member be bound to take steps against sub-State level measures intended to preserve a local industry and prevent prices falling lower due to competition from outside the state? This can only be answered by examining the specific measure against the obligations and exceptions of the relevant WTO agreement. Can a charge of an "insistence on a grim sink-or-swim policy of laissez-faire economics" be avoided in such a situation? Unreasonable measures and policies are not demanded by the GATS. Article 1:3(a) of the GATS only says that:

...each Member shall take such reasonable measures as may be available to it to ensure that measures taken by the regional and local governments and authorities and non-governmental bodies with delegated authority within its territory [do not violate the GATS obligations and commitments of that Member] [emphasis added]

How are "reasonable measures" to be defined and applied? There is nothing specific so far in GATS jurisprudence on "reasonable measures" available to Members for ensuring such internal conformity to WTO obligations. The TBT Agreement also has Article 3.1 on taking "reasonable measures" to ensure compliance "with respect to their local government and nongovernmental bodies within their territories" (and a similar provision in Article 7.1 and 8.1): but there are no decisions of a competent WTO body on this phrase.

\footnotetext{
${ }^{914}$ Ibid., (New State Ice Co. v. Liebmann), p31.

915 James A. Gardner, The "States-as-Laboratories" Metaphor in State Constitutional Law, 30 Valparaiso University Law Review 475 (1996), p476-477.

${ }^{916}$ Ibid., (Gardner), p480.

${ }^{917}$ West Lynn Creamery Inc. v. Healy 114 S. Ct. 2205 (1994).

${ }^{918}$ Ibid., (West Lynn Creamery Inc. v. Healy), p 217.
} 
However, arbitrators' findings with regard to "reasonable period of time", pursuant to the terms of Article 21.3 of the DSU, to implement the recommendations and rulings of the DSB in a dispute, appear to be useful to look at for the broad understanding of "reasonable" in the WTO context and the factors that may or may not be considered relevant. One of the reasons it is suggested that this be looked at is because thus far all the arbitrators who have been chosen or appointed for this purpose have been members of the Appellate Body of the WTO, and their approach to reasonableness in this context may give some indication on what could be considered reasonable with regard to Article I:3(a) of the GATS. In the report of the arbitrator in US-Offset Act (Byrd Amendment)(Article 23.1(c), it was noted that:

The final sentence of Article 21.3(c), [which refers to "particular circumstances] moreover, makes clear that the "reasonable period of time" cannot be determined in the abstract... "reasonable" should be interpreted as including "the notions of flexibility and balance", in a manner which allows for account to be taken of the particular circumstances of each case [emphasis added]. ${ }^{919}$

The arbitrator notes (but does not comment further) on the submission by the complaining parties, that factors such as "domestic 'contentiousness' of implementing measures" and "hardship of an economic and social nature", are not relevant for the determination of the reasonable period of time. ${ }^{920}$ In the Article 21.3 arbitration in Canada-Patent Term, Canada's main argument for a "reasonable period of time" (of 14 months and two days) was that:

... the required amendment of its Patent Act will have an economic impact on Canada's health care system, so that it can be expected that there will be significant debate which is likely to be divisive, and that, therefore, the Government of Canada will have to carefully manage the legislative process... ${ }^{921}$

The arbitrator was "very reluctant to take these factors into account" noting that they are "political factors" which vary depending on the country and constitution, and even change over time within a given country. ${ }^{922}$ The arbitrator also noted that their "evaluation will often be difficult and highly speculative" and that "such factors have never been considered as 'particular circumstances' in any of the earlier awards under Article 21.3(c) of the DSU. ${ }^{923}$

These arbitrations concern "reasonable period of time" not "reasonable measures" and Article I:3(a) of the GATS does not refer to the term "particular circumstances", which was considered significant in the context of the above arbitrations, for determining "reasonable". However, the attitude of the complaining parties and arbitrators on factors which affect what is "reasonable" suggest that similar objections (towards

\footnotetext{
${ }^{919}$ Award of the Arbitrator, US-Offset Act (Byrd Amendment), para. 42, citing Award of the Arbitrator, USHot Rolled Steel, para. 25, quoting with approval the Appellate Body in US-Hot-Rolled Steel, para. 85.

${ }^{920}$ Award of the Arbitrator, US-Offset Act (Byrd Amendment), para.30.

${ }^{921}$ Award of the Arbitrator, Canada-Patent Term (Article 23.1(c)), para. 49.

${ }_{922}$ Award of the Arbitrator, Canada-Patent Term (Article 23.1(c)), paras.59-60.

${ }^{923}$ Award of the Arbitrator, Canada-Patent Term (Article 23.1(c)), paras.59-60.

See also Award of Arbitrator, US-Section 110(5) Copyright Act (Article 23.1(c)), paras. 41-42:

The United States refers to the "controversy" surrounding the legislation, and the "divergent views of stakeholders" ... any argument as to the "controversy", in the sense of domestic "contentiousness", regarding the measure at issue is not relevant [as a factor for determining "reasonable period of time].
} 
"contentiousness" and/or "hardship" of measures) could be raised if Article I:3(a) of the GATS would become an issue in a dispute settlement context.

Something that comes to mind when considering both reasonableness and ensuring compliance in Article I:3(a) of the GATS is that the Member must follow its national constitution in such a matter of domestic power arrangements and delegation. However, according to both Article I:3(a) of the GATS and Article 22.9 of the DSU, dispute settlement provisions can be invoked in respect of measures taken by regional or local governments or authorities within a Member. Even in public international law, the nature and limitations of a national constitution would not be a justification for the violation of an international obligation nor an escape from its consequences. For example, it has been noted that the implementation of the decision in the Canada-Renewable Energy/CanadaFeed-in Tariff Program dispute by Canada is problematic, since the Canadian federal authorities have no constitutional power of compelling the Province of Ontario to change its disputed feed-in tariff programme. ${ }^{924}$ So even if there is no constitutional authority to compel a sub-State authority, the matter can still be a basis for a WTO dispute. It cannot be assumed that if a GATS Member has taken "reasonable measures as may be available to it" in such circumstances, the matter of its obligations under GATS ends there. Article 22.9 of the DSU also goes on to state that when the DSB has ruled that a provision of a covered agreement has not been observed "the responsible Member must take such reasonable measures as may be available to it to ensure its observance". ${ }^{925}$ Yet there are still consequences for the failure to secure observation, since the last sentence of Article 22.9 emphasizes that such failure would result in the application of provisions in covered agreements and the DSU relating to "compensation and suspension of concessions or other obligations". 926

As Julia Qin points out, there is ultimately no practical difference whether or not a Member has taken what it thinks are reasonable measures to ensure local compliance, as

${ }^{924}$ It can also be noted that this means that Ontario could not represent/defend its programme before the WTO since a 'Member' before the DSB means the relevant federal authority (see International Center for Trade and Sustainable Development (ICTSD), WTO Appellate Body rules against Canada in renewable energy case, Bridges News (Biores), Vol. 7, No.2, 27 May, 2013, available online at http://www.ictsd.org/ bridges-news/biores/news/wto-appellate-body-rules-against-canada-in-renewable-energy-case-0)

925 The consequences of failure to assure compliance within the Members territory in the context of WTO law, can be seen in 22.9 of the WTO DSU titled Compensation and the Suspension of Concessions:

The dispute settlement provisions of the covered agreements may be invoked in respect of measures affecting their observance taken by regional or local governments or authorities within the territory of a Member. When the DSB has ruled that a provision of a covered agreement has not been observed, the responsible Member shall take such reasonable measures as may be available to it to ensure its observance. The provisions of the covered agreements and this Understanding relating to compensation and suspension of concessions or other obligations apply in cases where it has not been possible to secure such observance [emphasis added]

${ }^{926}$ According to Footnote 17 to Article 22.9 of the DSU, this sentence applies unless the provisions of the relevant covered Agreement (e.g. GATS) have different provisions from Article 22.9, but that issue does not arise in this case.

Footnote 17 states:

Where the provisions of any covered agreement concerning measures taken by regional or local governments or authorities within the territory of a Member contain provisions different from the provisions of this paragraph, the provisions of such covered agreement shall prevail. 
non-observance of WTO obligations will ultimately have consequences. ${ }^{927}$ She also draws attention to the fact that there are additional obligations taken on by certain Members including China (which is not a Federal country) in its Accession Protocol, to ensure full WTO compliance by their political subdivisions. These include obligations to annul WTO-inconsistent local rules, apply uniform administration and, in the special case of China only, to establish a national complaints mechanism regarding such nonuniformity. ${ }^{928}$

Article I:3(a)(ii) of the GATS provides that Members the responsibility to ensure that measures by the following bodies also comply with GATS obligations:

non-governmental bodies in the exercise of powers delegated by central, regional or local governments or authorities...

Thus, delegated authority is not limited to governmental bodies. Krajewski notes that Article 1:3(a) has a wide scope and applies not only to governmental departments and public entities but also to independent regulatory bodies, non-governmental associations, institutions or entities which are empowered with "regulatory competence". 929 A Secretariat Note on definitions of the draft GATS text comments that:

As in the GATT, actions taken by private persons or associations, if in the exercise of public authority, could constitute measures [under Article $\mathrm{I}: 3(\mathrm{a})]^{930}$

As can be seen from the wording of Article I:3(a)(ii) of the GATS, it is also possible that a private action may be considered a governmental measure, but this depends on the details of the specific measure. Krajewski comments that "delegated" could be interpreted narrowly as requiring formally and expressly delegated regulatory powers. ${ }^{931}$

In the Panel report, Japan-Film, it was stated more broadly that:

$[\mathrm{P}]$ ast GATT cases demonstrate that the fact that an action is taken by private parties does not rule out the possibility that it may be deemed to be governmental if there is sufficient government involvement with it. It is difficult to establish bright-line rules in this regard, however. Thus, that possibility will need to be examined on a case-by-case basis. ${ }^{932}$

Thus, a private action can be considered if there is 'sufficient governmental involvement'. This goes beyond the context of Art I:3(b) GATS, which refers to delegation, and relates to attribution more generally even when there is no delegation. Vidigal, in an assessment of Panel and Appellate Body Reports posits that the dispute settlement bodies are more likely to attributability in the context of "affirmative" governmental conduct in measures consisting of actions, rather than mere omissions to regulate private actors. ${ }^{933}$ Delimatsis

\footnotetext{
${ }^{927}$ Qin, Julia Ya, “WTO-Plus” Obligations and Their Implications for the World Trade Organization Legal System: An Appraisal of the China Accession Protocol, Journal of World Trade 37(3): 483-522, 2003, p498.

${ }_{928}^{9}$ Ibid., citing Section 2(A) of China's Accession Protocol.

929 Krajewski, Markus, NATIONAL REGULATION AND TRADE LIBERALIZATION IN SERVICES: THE LEGAL IMPACT OF THE GENERAL AGREEMENT ON TRADE IN SERVICES (GATS) ON NATIONAL REGULATORY AUTONOMY, Kluwer Law International, 2003, p63.

${ }^{930}$ WTO, Secretariat, Definitions in the Draft GATS, Note by the Secretariat, MTN.GNS/W/139, 15 October 1991, para.7, citing GATT Document BISD 36S/93 paras.12.8, 12.9.

931 Krajewski, Markus, NATIONAL REGULATION AND TRADE LIBERALIZATION IN SERVICES: THE LEGAL IMPACT OF THE GENERAL AGREEMENT ON TRADE IN SERVICES (GATS) ON NATIONAL REGULATORY AUTONOMY, Kluwer Law International, 2003, p63.

${ }^{932}$ Panel Report, Japan-Film, paras.10.55-10.56.

${ }^{933}$ Vidigal, Geraldo, Attribution in the WTO: The Limits of 'Sufficient Government Involvement', 6 Journal of International Trade and Arbitration Law (2017) 133-160.
} 
is of the view that non-governmental bodies with delegated regulatory powers, including "all self-regulated professions that set conditions for access to and practice of a profession" come under the GATS. ${ }^{934}$

It would be interesting to consider if the actions of medical associations or councils which are non-governmental bodies but play important 'public' roles as well, could come under the GATS. Such associations in some countries have played a role in deciding on acceptable professional standards and qualifications or even sometimes influence governments by making recommendations on national health policy and the nature of the health system.

For example, in Sri Lanka, the Sri Lanka Medical Association (SLMA) is an professional body independent of the government, with membership open to all medical practitioners registered with the Sri Lanka Medical Council (SLMC) ${ }^{935}$ On occasions of health issues of national importance, the SLMA makes policy recommendations to the Sri Lankan government through the Ministry of Health. The Sri Lanka Medical Council (SLMC) is also a body which acts independently of the government, but is established by a parliamentary statute ${ }^{936}$ and is empowered by the relevant statute to register medical practitioners and maintain their quality and standards. The SLMC can also recommend recognition or prevent recognition of medical education institutions within the country and foreign medical qualifications. ${ }^{937}$ The Medical Council Ordinance stipulates that the President of the Sri Lanka Medical Council (SLMC) is appointed by the Executive President of the Republic on the recommendation of the Minister of Health. ${ }^{938}$ The Minister of Health also has powers to appoint some members to the governing body of the SLMC. The other members of the governing council are elected or nominated in various ways, including by the registered medical practitioners of the country and one representative each elected by the teachers of the Faculties of Medicine of the eight State universities. Although the government is involved in appointments, the decisions of the SLMC are made independently.

From the perspective of trade law, it would be interesting if such decisions would be considered as independent powers, delegated powers or as 'governmental' or as 'attributable' because of 'sufficient governmental involvement'. It is more likely that this link could be more easily drawn with regard to the actions of the SLMC than the SLMA. However, with regard to even the status of the SLMA, it is relevant that the Panel in USGambling has stated that:

\footnotetext{
${ }^{934}$ Delimatsis, P., Coherence and Divergence in Agreements on Trade in Services: A Drama in Three Acts, TILEC Discussion Paper, DP 2019-019, 2019, p11.

935 This Association was first initiated 1887 under colonial rule as the Ceylon Branch of the British Medical Association. Following independence in 1948, the name of the association was changed to the Ceylon Medical Association in 1951, and its relationship as a branch of the British Medical Association was ended in 1957. It has been known as the 'Sri Lanka Medical Association' since the country became a republic in 1972 (see http://slma.lk/about-us/history-of-slma/).

936 The Sri Lanka Medical Council was established by the Medical (Amendment) Act No. 40 of 1998 when its name was changed from 'Ceylon Medical Council'. The Ceylon Medical Council (CMC) was established by the Medical Council Ordinance No. 24 of 1924.

${ }^{937}$ According to the powers granted under the Medical (Amendment) Act No. 30 of 1987.

See further, http://www.srilankamedicalcouncil.org/.

938 Medical Ordinance No. 26 of 1927 as Amended (Section 12(1) of the Ordinance as substituted by Section 2 of the Medical (Amendment) Act No. 30 of 1987).
} 
...[ $\mathrm{t}$ ]he fact that certain institutions performing public functions and exercising public powers are regarded in internal law as autonomous and independent of the executive government does not affect their qualification as a state organ. ${ }^{939}$

It should be noted that if an issue relating to GATS obligations comes up, the current domestic legal framework would not allow the Sri Lankan government to "ensure observance" of GATS obligations and commitments by the SLMC by interfering with its independent decision-making procedures. Such steps are unlikely to be considered as allowable under current domestic law and new legislation curbing the mandate of the SLMC may be required. Such attempts would be controversial and politically unfeasible, and from the domestic viewpoint 'unreasonable': but the final decision on whether 'reasonable' measures to ensure observance have been taken or not would be a decision within WTO dispute settlement, not domestic law. It can be concluded from prior Appellate Body reports, that a responding Member's law will be treated as WTOconsistent until proven otherwise by appropriate evidence produced by the complainant. $^{940}$

\subsubsection{Conclusions on the key terms in Article I:1 and I:2 of the GATS}

Understanding the scope of the GATS requires defining the breadth of the terms 'trade in services', 'measures' and 'affecting' - which the Appellate Body has suggested will be defined broadly; and there is nothing in the GATS that suggests otherwise. It also requires an understanding of 'supply of services' and the four modes of supply. One issue that has been cleared up is that it is possible that the obligations with regard to trade in goods and trade in services can overlap depending on the circumstances.

The type of domestic measures which are covered by the GATS can be decided by the link or nexus of 'affecting' and whether the 'measure' can be clearly identified, rather than being limited by a specific definition of 'measure'. The type of measure can and has been defined broadly to include a wide range of measures.

The obligation of a Member to ensure the observance of the GATS within its territory can be seen to undermine the concept of subsidiarity and the 'experimenting laboratory' view of devolution, which has led to positive results for the general public when new governance structures, services provision or regulatory measures have been tested first at a lower level of government. However, it is clear that the central or federal authorities, regardless of national constitutional structures, have obligations in the international sphere under WTO law to ensure WTO conformity of their subdivisions. The scope of the application of the GATS could also include activities of private actors within a Member, whose actions can be attributed to the Member if there is 'sufficient government involvement'.

Dealing with an Agreement where the basic scope of the area it covers is not explicitly defined in either a technical or conceptual manner leaves the scope open for future

\footnotetext{
${ }^{939}$ Panel Report, US-Gambling, para. 6.128.

${ }^{940}$ See Appellate Body Report, US-Carbon Steel, paras. 156-157; Appellate Body Report, US-Oil Country Tubular Goods Sunset Reviews, para. 173.
} 
expansion. This may have been intentional with regard to the GATS, so that as technology and economic models evolve, these emerging areas of trade in services could be covered by the Agreement. The other possibility is that this is an area that, to begin with, was too broad to be defined in terms of scope of coverage and can only be defined by what it is not: by explicit exemptions from the scope of application. The GATS is being understood more clearly due to the practical application of the GATS rules and framework to the changing circumstances of trade in services. While this has some positive implications for those who would wish to expand the scope of the GATS according to their view of emerging needs and developments in international trade, it has negative implications for others who would wish to clearly identify the limitations or boundaries of the intrusion of WTO rules into domestic law and policy-making. This latter concern is particularly in the case of public services, and in sensitive sectors such as health services. The following part of the Chapter will go into more detail about this aspect, with special reference to public health services, and discuss whether or not these concerns may be justifiable. 


\subsection{ARE PUBLIC SERVICES EXEMPTED UNDER ARTICLE I OF THE GATS?}

'Be what you would seem to be' - 'or if you'd like it put more simply' -

'Never imagine yourself not to be otherwise than what it might appear to others that what you were or might have been was not otherwise than what you had been would have appeared to them to be otherwise.'

'I think I should understand that better,' Alice said very politely, 'if I had it written down: but I can't quite follow it as you say it.'

'That's nothing to what I could say if I chose,' the Duchess replied, in a pleased tone.

From Lewis Carroll's Alice in Wonderland

\subsubsection{Introduction: Is there a 'Public Services Exemption' in Article 1:3 the GATS?}

As discussed in the beginning of this Chapter, the scope of coverage of the GATS is 'Trade in Services' as defined in Article I of the GATS. A Member's obligations under the GATS include MFN and transparency (as well as most probably the future disciplines under Article VI:4 on domestic regulation), plus the scheduled commitments of individual Members in the areas of market access and national treatment (if any) and the domestic regulation requirements of the other sub-sections of Article VI that arise with regard to committed sectors.

The first consequence of GATS coverage is the applicability of the general GATS obligations like MFN and that if a Member opens a service sector to another Member's service suppliers, it must apply MFN and also open it in the same way to all other WTO Members. A Member may still choose not to provide market access or national treatment so as to exclude all foreign service suppliers, or to limit national treatment to allow regulatory standards that could have discriminatory effect, but these decisions have to be carefully included in the Members' schedule of commitments. An exclusion of public services generally from the GATS will assist Members to retain their policy space regarding public services without additional efforts, because the MFN obligation (as well as other general obligations) would not apply and explicit exclusion of public services with regard to market access and national treatment in the schedules would not be required.

The relevant provisions that appear to acknowledge the importance of State/public provision of services and which have potential for protecting the policy space for public services by excluding them from the GATS, are Article 1:3(b) and Article 1:3(c) of the GATS.

Article I:3(b) of the GATS:

'services' includes any service in any sector except services supplied in the exercise of governmental authority.

Article I:3(c) of the GATS

'a service supplied in the exercise of governmental authority' means any service which is supplied neither

- on a commercial basis,

- nor in competition with one or more service suppliers 
The first thing that can be observed is that the term 'public services' is not used in the above definition. Some concerns regarding public services provision and the GATS were discussed earlier in the Chapter, with special reference to public health services. If those issues are kept in mind, one of the first questions that would arise is whether "services supplied in the exercise of governmental authority" (SSEGA) in Article I:3(b) is equivalent to that of 'public services'. It could be seen as identical to, broader or narrower than what a particular Member would consider 'public services'. The attitude towards public services can also be different in different jurisdictions for social, political and historical reasons. Where on the spectrum "SSGEA" in the GATS falls, is something that is not clear from the text of Article I:3(b) and on which there is as yet no authoritative interpretation.

For the purposes of analyzing the scope of the GATS according to Article I, it cannot be assumed that Article I:3(b) can be used to neatly carve out 'public services' from the GATS, as Article I:3(c) needs to be taken into account. Although at first glance it seems that the politically sensitive area of public services can be interpreted as exempted from the scope of coverage under Article I:3(b), the definition given in Article 1:3(c) casts doubt on this possibility. For example, the WTO Secretariat discussing the notarial services, noted that it is a public role performed in some countries by public officials, which would make them "services supplied in the exercise of governmental authority": however if notaries supply their services "on a commercial basis" they would be subject to the provisions of the GATS. ${ }^{941}$ This was contrasted with judges, court clerks and public prosecutors, "who are civil servants". ${ }^{442}$ It seems a case-by-case approach would be recommended, relying on Article I:3(c). This is confirmed with regard to the Secretariat approach to legal services, as the updated Note of 2010 refers to the activities relating to the administration of justice (judges, prosecutors etc.) as excluded from the GATS as:

....in most countries it is considered a "service supplied in the exercise of governmental authority" according to Article I:3(c) of the Agreement [emphasis added $]^{943}$

There is also nothing in the GATS Article XXVIII (Definitions) for "services supplied in the exercise of governmental authority" (hereinafter SSEGA), and this is probably another reason that the reliance is on Article I:3(c). Yet the crucial terms "commercial basis" and "in competition with one or more service suppliers" in Article I:3(c) have also not yet been interpreted authoritatively in the GATS context and has been the subject of much discussion and analysis. ${ }^{944}$

${ }^{941}$ WTO Secretariat, Legal Services Background Note by the Secretariat, S/C/W/43, 6 July 1998, para.13 and its footnote.

See also WTO Secretariat, Legal Services Background Note by the Secretariat, S/C/W/318 14 June 2010, para.40, with regard to Members specifically excluding from the scope of their commitments, the activities of notaries and bailiffs as being persons entrusted with public functions:

It should be noted that these activities would not fall outside the scope of the GATS in line with Article I:3 of GATS, as this Article does not exclude services on the basis of their public function, but only where they are supplied neither on a commercial basis nor in competition with one or more service suppliers.

${ }^{942}$ Ibid (Legal Services Note, 1998).

${ }^{943}$ WTO Secretariat, Legal Services Background Note by the Secretariat, S/C/W/318 14 June 2010, para.7.

944 See further (to be discussed in this Chapter): Krajweski, M., Public Services and the Scope of the General Agreement on Trade in Services (GATS), A Research Paper written for the Center for International Environmental Law (CIEL), 2001; Krajewski, M., Public Services and Trade Liberalization: Mapping the Legal Framework, Journal of International Economic Law 6(2), 341-367 2003; Adlung, R., Public Services and the GATS, Journal of International Economic Law 9(2), 455-485, 2006; Chandra, R., GATS and its 
There have not as yet been any disputes involving the interpretation of Article I:3 nor have Members pushed for other methods of clarifying the scope. If Members wish for a clarification on Article I:3(c) they could use Article IX:2 of the WTO Agreement. Article IX:2 of the WTO Agreement states that an authoritative interpretation of multilateral agreements in Annex 1, including the GATS, can be adopted by the Ministerial Conference and General Council. In fact, these bodies have, according to Article IX.2 abovementioned, the "exclusive authority" to adopt such interpretations. The Ministerial Conference and General Council are required to exercise their authority on the basis of a recommendation by the Council overseeing the functioning of the relevant Agreement. In the case of the GATS it is the Services Council that must take the step of referring the matter of the interpretation of Article I. Thereafter, the Membership of the WTO also would have a role to play, as the adoption of the interpretation shall be taken by a threefourths majority of Members (although it should be noted that WTO Members vote extremely rarely and in practice there would be a 'consensus decision'). ${ }^{945}$ However, this system has not yet been used. The only request was by the European Communities with regard to Articles 3.7, 21.5, 22.2, 22.6, 22.7 and 23 of the DSU, but which was never followed up. ${ }^{946}$

An alternative path is the recourse to Article X of the WTO Agreement (Amendments), which was what was done in relation to public health concerns in the area of intellectual property (compulsory licensing exception for patents on essential medicines). Initially, there was an interim waiver under paragraphs 1,3 and 4 of Article IX of the WTO Agreement ${ }^{947}$ and later an Amending Text (insertion of Article 31 bis to the TRIPS Agreement) which was carried out under Article X:3 of the WTO Agreement. ${ }^{948}$ The effectiveness of taking the path of Article IX or X to assist in an interpretation and/or amendment that takes into account public health concerns in services is an interesting issue which could be looked into further, but this could only be possible with the consensus of Members.

The current problem of the interpretation of Article I:3 has been acknowledged even by the officials of the WTO. Back in 2000, then Director of Trade in Services Division, WTO Secretariat, David Hartridge, responded strongly to criticisms and 'misinterpretations' of the GATS, yet admitted that although there is nothing to fear concerning the impact of the GATS on public services, that

...it might be worthwhile for the Services Council to develop an understanding on the interpretation of Article I:3 which would make it

\footnotetext{
Implications for Developing Countries: Key Issues and Concerns, DESA Discussion Paper 25, November 2002, p16-19.

945 Article IX. 2 of the DSU adds that such an interpretation should not be used in a manner that would undermine the amendment provisions in Article X.

${ }^{946}$ WTO, Request for an Authoritative Interpretation pursuant to Article IX:2 of the Marrakesh Agreement establishing the World Trade Organization: Communication by the European Communities, WT/GC/W/133, 25 January 1999.

${ }^{947}$ See WTO, Declaration on the TRIPS agreement and Public Health, WT/MIN(01)/DEC/2, Adopted on 14 November 2001 and WTO, GENERAL COUNCIL, Implementation of paragraph 6 of the Doha Declaration on the TRIPS Agreement and public health, Decision of the General Council of 30 August 2003, WT/L/540 and Corr.1.

${ }^{948}$ WTO GENERAL COUNCIL, Amendment of the TRIPS Agreement, 6 December 2005, WT/L/641.
} 
even more clear that there is a ring-fence around non-commercial public services. ${ }^{949}$

As there has been no authoritative interpretation, either by the Services Council nor an interpretation in dispute settlement context by the Appellate Body, doubts as to the existence of this 'ring-fence' have not been assuaged and continue persist.

This is comparable to ignoring the elephant in the room. A clear legal interpretation of the scope of an Agreement is a fundamental issue and the lack of such makes it more difficult to answer to critics and doubters of the GATS. This essentially means that Members cannot depend entirely upon on the provision and ought to look to other methods of 'carve-out' or 'ring-fencing' of public services, usually by careful scheduling of commitments in sensitive sectors. A report by the UK government exemplifies the current approach.

There has been public comment that these conditions are ambiguous. The Government has been exploring with other WTO Members the desirability of seeking a clarification of this provision. However, so far, most WTO Members seem content not to re-open this article and no Members are currently questioning any other Member's interpretation. Moreover, the bottom-up approach means that WTO Members can choose not to make commitments in any sector where this ambiguity could compromise a country's reliance on this exclusion. ${ }^{950}$

Avoidance of the issue will only last as long as no Member 'rocks the boat' by bringing the attention of the dispute settlement system to the issue. As is pointed out in the publication GATS: Facts and Fiction,

...the issue could arise if a specific measure, which had been challenged in dispute settlement, were to be defended on the ground that it applied only to services supplied in the exercise of governmental authority. ${ }^{951}$

If no commitments in sensitive areas such as health services are made, the only GATS obligations with regard to that sector would be most favoured nation treatment and transparency. If a Member has made commitments, and even if they have tried to include protections for their public health services in their Schedules, there is the possibility of a dispute arising regarding market access and national treatment obligations. So what guidance is available on interpreting the phrase "supplied in the exercise of governmental authority"?

\subsubsection{The relevant methods for the interpretation of Article 1 of the GATS}

\subsubsection{The VCLT method for the interpretation of Article 1 of the GATS}

The VCLT rules discussed earlier in Chapter 2 would be the basis for the interpretation of the GATS text. Reduced to a simple formula, the method in Article 31(1) of the VCLT is to look at (in good faith) the interaction of 'text + context + object \& purpose'. This holistic approach was discussed in more detail in Chapter 2. Issues to keep in mind

\footnotetext{
${ }^{949}$ Hartridge, David, WTO Secretariat hits false attacks against GATS, Speech at the European Services Forum, Brussels 27th November 2000, WTO News, available at http://www.wto.org/english/news_e /news00_e/gats2000neg_hartridge_e.htm, last accessed 13.05.2013.

${ }_{950}$ UK HM Government and the Department of Trade and Industry, LIBERALISING TRADE IN SERVICES: A NEW CONSULTATION ON THE WORLD TRADE ORGANISATION GATS NEGOTIATIONS, London, October, 2002, para.6.25, p71, available online at http://webarchive. nationalarchives.gov.uk/ tna/+/http://dti.gov.uk/ ewt/gatscons.pdf/.

${ }^{951}$ WTO, GATS: FACT AND FICTION, 2001, p10.
} 
include that the context includes subsequent agreement or practice on interpretation and any relevant rules applicable between the parties and that ordinary meaning of the text can evolve with time. While from a broader perspective there are unresolved issues about the nature of public services and the best methods of their provision, the VCLT method focuses attention on the text and provides a clear framework for the terms that need to be interpreted.

It is generally accepted that according to Article 31(2) of the VCLT, the context includes the entire text, including Preamble and Annexes - as well as any agreement between all the parties made in connection with conclusion of treaty or even an instrument entered into by less than all the Members, yet accepted by the others as related. ${ }^{952}$ Thus, it is possible to search for guidance in sector-specific Annexures to the GATS and try to find out if there is anything that is related or can influence the interpretation of terms of the main Agreement. If this approach is taken there is a question whether there can be generalizations applicable across service sectors and also whether this would be desirable. Each sector-specific Annex of the GATS clarifies the obligations for that sector in particular, so applying any interpretation of terms in an Annex back to the provisions of the GATS so as to apply to other sectors as well, is a position one should be very cautious about. With regard to the Annex on Telecommunications, the Panel in Mexico-Telecoms, the first Panel proceeding to deal solely with trade in services under the GATS, noted that:

...the Annex recognizes that its provisions relate to and build upon the obligations and disciplines contained in the Articles of the GATS - the Annex states expressly that it "provides notes and supplementary provisions to the Agreement [emphasis added]. ${ }^{953}$

The reference to being "supplementary" means that the Annex adds to (rather than diminishes or provides exceptions to) its obligations in respect of basic telecoms. Can the Annex also be used as a supplementary means of interpretation as per Article 32 of the VCLT, which includes the preparatory work of the treaty and the circumstances of its conclusion within the interpretive exercise? Even if it is used as such, the Annex could be used only to confirm the meaning of Article 31 application or to determine the meaning when the interpretation according to Article 31:

(a) leaves the meaning ambiguous or obscure; or

(b) leads to a result which is manifestly absurd or unreasonable.

This view of context in Article 31(2) or even Article 32 of the VCLT does not appear to place the text in a broader context or backdrop which was presented earlier with regard to public services and health services. Another point to comment on with regard to context and object and purpose is the usefulness of the Preamble (or lack of usefulness) for interpretation of the terms focused on in this Chapter. The Preamble of the GATS can be said to be a balance of liberalization and national policy objectives - but it is obvious that

\footnotetext{
952 Van Damme, Isabelle, TREATY INTERPRETATION BY THE WTO APPELLATE BODY, Oxford University Press, 2009, p215.

${ }_{953}$ Panel Report, Mexico-Telecoms, para 7.332. The Panel goes on to note in the same paragraph, a similar role for the Telecommunications reference Paper:

Similarly, many of the provisions of the Reference Paper also draw from and add to existing obligations of the GATS, such as Articles III, VI, VIII and IX and the Annex on Telecommunications. Accordingly, there is a degree of overlap between the obligations of the Annex and the Reference Paper, despite their differences in scope, level of obligations, and specific detail provided [emphasis added].
} 
simultaneous objectives may clash or result in difficulty in terms of deciding on priority. ${ }^{954}$

Article 31(3)(a) and (b) may be more relevant for a broad interpretation, as it takes into account, together with the context, any subsequent agreement between parties or subsequent practice in the application and interpretation of the relevant Agreement. In 2012, the International Law Commission (ILC) appointed a special rapporteur, Georg Nolte, to complete a project on "subsequent agreements and subsequent practice in relation to the interpretation of treaties." Nolte's overview of the use of subsequent agreement and subsequent practice in various different international tribunals shows that it is not commonly used and is not applied in a systematic manner. ${ }^{955}$ However, if focusing on WTO dispute settlement, there are several disputes where Article 31(3) was referred to, and the approach of the Appellate Body can be discerned.

Regarding what kind of item has been considered "subsequent agreement" in WTO dispute settlement, it was noted by the Appellate Body in US-Clove Cigarettes that: ...paragraph 5.2 of the Doha Ministerial Decision ${ }^{956}$ can be characterized as a "subsequent agreement" within the meaning of Article 31(3)(a) of the Vienna Convention provided that it clearly expresses a common understanding, and an acceptance of that understanding among Members $\ldots$ [and its terms] constitute an interpretative clarification ...957

Thus, according to the Appellate Body, Declarations of a Ministerial Conference plus evidence that there is an acceptance of the common understanding expressed in the Declaration, is an accepted example of "subsequent agreement". This means that statements in such Declarations have potential to be more than mere political statements, and could play a role in the interpretation of terms of the relevant Agreement In the case of US-Clove Cigarettes it was a relatively innocuous term: "reasonable interval" in 2.12 of the TBT Agreement.

In US-Tuna II(Mexico) the Appellate Body agreed that the 'TBT Committee Decision on Principles for the Development of International Standards, Guides and Recommendations with Relation to Articles 2, 5, and Annex 3 to the Agreement' (the 'TBT Committee Decision') can be considered subsequent agreement under Article 31(3)(a) of the VCLT. Unlike the earlier situation. The Appellate Body took into account the role and mandate of the TBT Committee and the activities it undertook leading up to the adoption of the Decision. ${ }^{958}$ It is interesting to note that meetings of the TBT Committee are open to international intergovernmental organizations (including standardizing bodies) to

\footnotetext{
954 See also Zleptnig, Stefan, NON-ECONOMIC OBJECTIVES IN WTO LAW: JUSTIFICATION PROVISIONS OF GATT, GATS, SPS AND TBT AGREEMENTS, Nijhoff International Trade Law Series, 2010, p68.

${ }_{955}$ Nolte, Georg, Report 3 of Reports for the ILC Study Group on Treaties over Time in George Nolte, Ed., TREATIES AND SUBSEQUENT PRACTICE, Oxford University Press, 2013. See also Murphy, Sean D., The Relevance of Subsequent Agreement and Subsequent Practice for the Interpretation of Treaties in George Nolte, Ed., TREATIES AND SUBSEQUENT PRACTICE, Oxford University Press, 2013.

${ }^{956}$ WTO, Doha Ministerial Conference, Implementation-Related Issues and Concerns, Decision of 14 November 2001.

${ }_{957}$ Appellate Body Report, US-Clove Cigarettes, para. 267 and 269.

${ }^{958}$ Appellate Body Report, US-Tuna II (Mexico), paras.371-372
} 
participate as observers on the invitation of the Committee. ${ }^{959}$ Currently the WHO and UNCTAD are among the intergovernmental organizations which have been granted observer status. The WHO only has ad hoc observer status in the Council on Trade in Services and the Council for TRIPS, as opposed to being granted observer status for all meetings in the TBT Committee and SPS Committee. ${ }^{960}$

Article 31(3)(c) of the VCLT could also be useful for interpretation of Article I of the GATS. This Article states that:

31(3). There shall be taken into account, together with the context:

...(c) Any relevant rules of international law applicable in the relations between the parties.

The use of this provision in the WTO context was discussed earlier in section 2.3.5. of Chapter 2. The concept and role of public services generally has been discussed in nonWTO contexts and with regard to health services, there have been linkages made between public health services and the right to health. The nature of governmental responsibility in other areas of international law has broad relevance for how States approach 'services in the exercise of governmental authority'. The question is whether this has relevance as context for the interpretation of Article I of the GATS, as being "relevant", being "rules of international law" and also "being applicable in the relations between the parties".

The Appellate Body in US-Anti-Dumping and Countervailing Duties (China) made the following observations on the above points:

(i) "rules of international law" corresponds to the sources of international law in Article 38(1) of the Statute of the International Court of Justice and thus includes customary rules of international law as well as general principles of law.

(ii) In order to be "relevant", such rules must concern the same subject matter as the treaty terms being interpreted.

(iii) In order to be considered "applicable in the relations between the parties", the relevant rules must be binding upon the parties. ${ }^{961}$

Thus, if all Members concerned in a dispute are not bound by the rules on the basis of both of them being part of a treaty, the status of the rules as customary international law can be taken into account to determine whether it is binding upon the parties. Moreover, if concerning the same subject matter and referring to binding rules of international law, Members could possibly raise their obligations concerning the right to health before WTO dispute settlement bodies. However, this will not be an easy argument to uphold. In PeruAgricultural Products, Peru argued that the FTA between Peru and Guatemala and ILC Articles 20 and 45 were "relevant rules of international law applicable in the relations between the parties" under Article 31(3)(c) of the VCLT. However, the Appellate Body did not agree with Peru that the Panel had made an error in not considering these rules.

\footnotetext{
${ }^{959}$ Rule 11 and Annex 2 of the Rules of Procedure for the Meetings of the WTO Committee on Technical Barriers to Trade and Guidelines for Observer Status for Governments and International Intergovernmental Organizations, G/TBT/W/4.

${ }^{960}$ See WTO, International intergovernmental organizations granted observer status to WTO bodies, lists available online at: https://www.wto.org/english/thewto e/igo obs e.htm\#tbt.

${ }^{961}$ See Appellate Body report, US-Anti-Dumping and Countervailing Duties (China), paras. 307-308, 311, and Footnote 222.
} 
The decision was based on the relevancy of the rules to the interpretation carried out by the panel and Appellate Body. ${ }^{962}$

As the most of the terms of the GATS are not yet clearly defined in WTO Dispute Settlement, the interpretation of these terms will remain a matter for speculation until there are more disputes. But there are several directions to which can be looked to make a guess at the possible outcomes - and (from the point of view of Members) to thereby prepare strategy. Unfortunately, the possibilities are also combined with a great deal of ambiguity and contradiction, which is carried through in WTO documents to the practice of members and into the academic discussion. The official statements and national documents of WTO Members on their intentions with regard to the interpretation and application of Article 1:3(b) and (c) and the practices of Members (including scheduling practices) can also either spread some light - or confuse matters further. Yet there could be indications of understandings of the terms that need definition, which may be useful to note. Furthermore, it would be important to see whether a particular Member's approach to disputed definitions would be followed by the panels and Appellate Body, if submitted in a dispute.

\subsubsection{The Relevance, if any, of Secretariat Notes for understanding Public Services}

Comparing across different Agreements, if there are similar or related terms that have been defined in the text or that have been interpreted by dispute settlement is a possibility, with regard to GATT 1994 and GATS, as discussed in Chapter 2. But, as to be expected, there are few such terms for comparison in the GATT with regard to Article I of the GATS. The exception would be 'affecting' (Article III:4 of the GATT 1994, as discussed in Section 3.3.3 above and 'commercial' where 'commercial sale' in Article III:8(a) GATT could be discussed, which is dealt with in Section 3.4.4. below).

But reference to the terms in Article I of the GATS is most commonly found in scholarly writing and the Background Notes of the WTO Secretariat. Adlung replying to the Pollock and Price article in the Lancet that discussed the content of several WTO Secretariat Notes ${ }^{963}$ clarifies that:

The Secretariat has no mandate to initiate policy or interpret WTO law. ${ }^{964}$

This is true according to the provisions of the WTO covered Agreements. However, in the context of the scarcity of services disputes and authoritative interpretations, the observations and interpretations in Background Notes have been analyzed by scholars such as Krajewski and been presented as evidence for the lack of coherent approach to the interpretation of Article I:3 of the GATS, ${ }^{965}$ but it can also be seen as evidence of a changing and evolving approach to the issues. Thus, it can be argued that although the

\footnotetext{
${ }^{962}$ Appellate Body Report, Peru-Agricultural Products, para.5.101. See further discussion at section 2.3.5. of this Study.

963 Pollock A. M. and D. Price, Rewriting the Regulations: How the World Trade Organization Could Accelerate Privatisation in Health-Care Systems, Lancet, 2000; 356: 1995-2000.

964 Adlung, Rudolf, Health-Care Systems and the WTO: No Grounds for Panic, WTO News published 27.03.2001, available at http://www.wto.org/english/tratop e/serv e/comments lancet e.doc, last accessed 11.10.2010.

Rudolf Adlung was at the time working in the Trade in Services Division, WTO Secretariat. But his views in the abovementioned article come with the proviso that they are "those of the author and should not be attributed to the WTO Secretariat".

${ }^{965}$ See Krajweski, Markus, Public Services and the Scope of the General Agreement on Trade in Services (GATS), A Research Paper written for the Center for International Environmental Law (CIEL) 2001.
} 
Secretariat Notes are not 'interpretations of WTO law', they can be used to confirm an interpretation of WTO law and/or to suggest a clarification of an interpretation of WTO law. Thus, discussion and analysis of these documents is relevant.

The use of Secretariat notes in disputes began in the GATT era even before the establishment of the WTO. In EEC-Dessert Apples the GATT Panel recalled and endorsed the views contained in a 1965 GATT Secretariat Note. ${ }^{966}$ In the GATT Panel Report US-Tuna (EEC), the EEC thought that a Secretariat Note to the Working Group on the relevant provisions in GATT and MTN Agreements" 967 was "relevant" for interpretation of Article XI:2(b) of the GATT in that dispute. In US-Swedish Steel Plate, Sweden had referred to a 1977 Secretariat Note which was in turn discussed by the other party to the dispute (the United States) and who had an alternate interpretation of the implications of the same document. ${ }^{968}$

Secretariat Notes have been referred to several times by parties in their arguments during WTO dispute settlement proceedings. The complaining parties in the EC-Bananas dispute referred to a Note by the Secretariat issued to negotiating parties with regard to the interpretation of Article III of the GATS. ${ }^{969}$ Mexico also referred to a Secretariat Background Note ${ }^{970}$ as "confirming" a certain view it was asserting in the MexicoTelecoms dispute. ${ }^{971}$ However the Panel in Mexico-Telecoms gives its own analysis which is not same as Mexico's. ${ }^{972}$ The dispute settlement bodies have found that recourse to Secretariat Notes in complicated technical matters was very useful. The Panel in MexicoTelecoms highlighted that the

...assistance granted by the Secretariat pursuant to Article 27.1 of the DSU, have ensured that this Panel was fully aware of the legal and technical complexity of the regulation of telecommunications services, including their rapid technological evolution and the drafting history of GATS provisions to which both parties to this dispute referred extensively (original footnote deleted) ${ }^{973}$

More recently, there is a reference to work of the Secretariat in the Panel Report, ChinaElectronic Payment Services, in a non-controversial reference to the preparation of GATT Schedule of Concessions on market access. ${ }^{974}$

\footnotetext{
${ }^{966}$ GATT Panel Report, EEC-Dessert Apples, paras.12.35-12.36 referring to 1967 GATT Secretariat Note COM.TD/5, March 1965.

${ }^{967}$ Secretariat Background Note on the relevant provisions in GATT and MTN Agreements (DPG/W/6).

968 GATT Panel Report, US-Swedish Steel Plate, para.44 - referring to the 1977 Agreement containing the inventory of problems and issues arising under the Anti-Dumping Code, COM.AD/W/68, 8 March 1977.

${ }^{969}$ Appellate Body Report, EC-Bananas, para.75:

The Complaining Parties also maintain that this broad ordinary meaning is confirmed by the broad interpretation of Article III of the GATT by previous panels. The Complaining Parties maintain that the drafters of the GATS were generally familiar with such basic GATT concepts, and that this includes the Note by the GATT Secretariat issued to the GATS negotiators.

The original footnote to the second sentence in the above paragraph refers to the WTO Secretariat, Definitions in the Draft General Agreement on Trade in Services, Note by the Secretariat, MTN.GNS/W/139, 15 October 1991.

${ }^{970}$ In this instance it was WTO Secretariat, Additional Commitments Under Article XVIII of the GATS: Note by the Secretariat, S/CSC/W/34, 16 July 2002, para.8.

${ }^{971}$ Panel Report, Mexico-Telecoms, para.7.369.

${ }_{972}$ Panel Report, Mexico-Telecoms, paras.7.369-7.370.

973 Panel Report, Mexico-Telecoms, para.7.2.

${ }^{974}$ Panel Report, China- Payment Services, footnote 853:
} 
References to Secretariat Notes are usually raised as supplementary means to confirm meaning of a term in the relevant Agreement according to Article 32 of the VCLT. That is, supplementary and only to confirm meaning or to clarify where recourse to Article 31 leaves the interpretation ambiguous, obscure, manifestly absurd or unreasonable. Under Article 32:

Recourse may be had to supplementary means of interpretation, including the preparatory work of the treaty and the circumstances of its conclusion...

The Appellate Body in US-Gambling referred to the WTO Secretariat Note on Economic Needs Tests to support their interpretation of that phrase. ${ }^{975}$ The Appellate Body in USGambling rejected looking at certain GATT Secretariat documents relating to services classification and scheduling ${ }^{976}$ under Article 31 of the VCLT, but was of the opinion that they could also be seen as supplementary means of interpretation under Article 32 of the VCLT. ${ }^{977}$ The view of the Panel in US-Gambling that the relevant documents could be seen as constituting agreement or acceptance of the parties as an instrument relating to the treaty was rejected. ${ }^{978}$ However the possibility of specific documents authored by a delegated body such as a Secretariat falling within the scope of Article 31(2) was not wholly barred. ${ }^{979}$ In that specific situation, the Secretariat documents related to services classification and scheduling which were prepared during the negotiations for the GATS and could be considered to be either part of the preparatory work of the treaty and or related to the circumstances of its conclusion. These documents were and continue to be relied upon by parties for making commitments, but Secretariat Notes issued after the conclusion of the GATS are a different matter. Acceptance and reliance upon Secretariat interpretations in later Notes by Members is not a common practice, even if the Notes are analyzed by scholars.

The Dominican Republic also relied on "a Secretariat note on the negotiation of the Understanding during the Uruguay Round" in its submissions in the Dominican RepublicImport and Sale of Cigarettes dispute. ${ }^{980}$ The Panel in Dominican Republic-Import and Sale of Cigarettes referred to the Secretariat Note on Article II:1(b) of the General Agreement (GATT) ${ }^{981}$ as having the nature of preparatory work or travaux preparatoires as it was circulated during the process of negotiation. ${ }^{982}$ This would also put Secretariat Notes used by WTO negotiators on the level of Article 32 VCLT sources. The view that they could be seen as travaux preparatoires would not necessarily apply for all Secretariat Notes, as many (especially in the services sector) were written after the

The structure of a WTO goods schedule is described generally in a Secretariat Note on

"Preparation of the Uruguay Round Schedules of Concession on Market Access", MTN.GNG/MA/W/25 of 22 December 1993.

${ }^{975}$ Appellate Body Report, US-Gambling, footnote 269 states:

See WTO Secretariat Note on "Economic Needs Tests", S/CSS/W/118, 30 November 2001, para.4.

976 WTO GATT Secretariat, Services Sectoral Classification List ("The W/120”), Note by the GATT Secretariat, MTN.GNS/W/120, 10 July 1991and Scheduling of Initial Commitments in Trade in Services: Explanatory Note ("1993 Scheduling Guidelines"), MTN.GNS/W/164, 3 September 1993.

977 Appellate Body Report, US-Gambling, para.175-178.

${ }^{978}$ Ibid., (US-Gambling), para.175.

979 Ibid.

${ }^{980}$ Panel Report, Dominican Republic-Import and Sale of Cigarettes, para.7.42.

981 WTO Secretariat, Article II:1(b) of the General Agreement - Additional Note by the Secretariat, Negotiating Group on GATT Articles, MTN.GNG/NG7/W/53, 2 October 1989.

982 Panel Report, Dominican Republic-Import and Sale of Cigarettes, para.7.58 and 7.114. 
conclusion of the Final Agreements. However, there may be ways in which Secretariat Notes may be used as 'other' supplementary means, since 'supplementary means' in Article 32 include, but are not limited to preparatory work and circumstances of conclusion of a treaty.

Marchetti and Mavroidis have noted with regard to the role of the GATT Secretariat in negotiating the GATS, that:

It is worth recalling that, with few exceptions, there was hardly any embedded expertise, either within national governments and delegations or within international bureaucracies regarding trade in services in 1986. It is lack of expertise in many national capitals that led to reliance on the GATT Secretariat. ${ }^{983}$

Does this same practical argument apply in the WTO GATS context, as it did for the preWTO/Uruguay Round context that Marchetti and Mavroidis are commenting on? General lack of expertise or experience gives an explanation for why Members in a dispute setting or researchers interested in issues of services trade would access and rely on the explanations or opinions in Secretariat Notes. The complexity of the covered Agreements and in particular, the structure of the GATS means that there may be heavy reliance on the opinions of such Notes. However, in the past few years, there has been a significant increase of persons with expertise in WTO law, so the Uruguay Round period and the current situation of WTO Members is not identical.

Therefore even if not always useful for or possible to rely upon for interpretation of the terms, the Secretariat Notes can still be evidence of the development of a certain area of trade law, explanation of the current state of affairs and possibly also an indication of the direction that interpretation may take - even if it is not possible to rely on them as authoritative interpretations. The following sections will make reference to WTO Secretariat Notes in the context of building an interpretation of the exemption in Article I:3(c) of the GATS, keeping in mind both the usefulness and limitations of reference to these documents.

\subsubsection{Using a Human Rights and Human Development Approach to Public Services}

Previously in Section 2.3.6. of Chapter 2 of this study, the relevance of a human rights approach for WTO interpretation in general was discussed. Sections 2.3.11-12 then proposed the concept of 'bilingualism' in relation to whether human rights can be 'translated' into and trade law and vice versa. It was mentioned that translation theorists have proposed 'equivalence' in translation (similarity, not symmetry) as the meeting point for languages: and similarly, it could be speculated whether there can be such a point for human rights and trade to meet and agree on 'equivalence'. In the context of interpreting Article I:3(c) of the GATS, it is important to revisit those prior discussions, to propose a human rights approach to public services.

The measurability of human rights objectives in terms of achieving certain standards of quality of life is part of the human rights approach to formulating strategic development plans involving public services. In terms of right to health this can include improvements

983 Marchetti J.A. and Petros C. Mavroidis, The Genesis of The GATS (General Agreement on Trade in Services), European Journal of International Law Vol. 22 No. 3, 2011, 689-721. 
in nutrition, immunizations, reduction of preventable disease and affordable access to medicines and medical services. The human rights approach also changes terminology (and the associated attitudes of policy planners) from that of providing services for consumers with purchasing power to inclusive structural planning and services delivery with the participation of rights-holders.

In 2013, a Report of the United Nations High Commissioner for Human Rights on the "role of the public service as an essential component of good governance in the promotion and protection of human rights" noted that:

There is no universally recognized definition of "public service". Public service is often broadly bracketed with public administration and public sector governance. ${ }^{984}$

While affirming the role of public administration and public sector governance in the delivery of and equitable access to public services, the report notes from a previous publication on good governance that:

Notably, "in the realm of delivering State services to the public, good governance reforms advance human rights when they improve the State's capacity to fulfil its responsibility to provide public goods which are essential for the protection of a number of human rights, such as the right to education, health and food."..$^{85}$

The report also states that good governance should "ideally be defined and guided by existing normative interpretations" 986 of human rights principles and standards; and further that:

A human rights-based approach to public services is integral to the design, delivery, implementation and monitoring of all public service provision ${ }^{987}$

Four important features were identified in the implementation of a human rights-based approach:

a) A human rights-based approach being an important legal yardstick for measuring how well public service is designed and delivered and whether the benefits reach rights-holders;

b) A contribution to guiding and improving public service, complementing existing public services value systems and ethos, leading to improved outcomes and better quality of service;

c) Assuring respect for human rights would in turn build public trust, morale and public perception;

d) A human rights-based approach provides protection against discrimination, particularly to the vulnerable and marginalized (whether due to poverty, disability or other forms of exclusion).

Thus, there is a close linkage acknowledged in the UN human rights context with good governance, public services delivery and human rights. The report also cites international legal obligations (Articles 21 and 28 of the UDHR, Article 2 of both the ICCPR and ICESCR) and interpretative guidance for these obligations (CESCR General Comment No. 3 (1990) on the nature of States parties' obligations, No. 14 (2000) on the right to the

\footnotetext{
${ }^{984}$ UN, Human Rights Council, Report of the United Nations High Commissioner for Human Rights on the role of the public service as an essential component of good governance in the promotion and protection of human rights, $\mathrm{A} / \mathrm{HRC} / 25 / 27,23$ December 2013, para.5.

${ }^{985}$ Ibid, (UN HRC, 2013), para.7, citing Good Governance Practices for the Protection of Human Rights (United Nations publication, Sales No. E.07.XIV.10), p. 3.

${ }^{986}$ Ibid, (UN HRC, 2013), para. 10.

${ }^{987}$ Ibid, (UN HRC, 2013), para.12.
} 
highest attainable standard of health, No. 13 (1999) on the right to education, No. 12 (1999) on the right to adequate food, among others). The public services obligations under Article 2 of the Convention on the Rights of the Child, Article 7 of the International Convention on the Protection of the Rights of All Migrant Workers and Members of Their Families and Article 5 of the Convention on the Rights of Persons with Disabilities are also among the other international human rights obligations of States which are mentioned in the report. Part IV of the report is titled "Major public service challenges that affect human rights", and mentions the challenges in maintaining a human rightsbased approach to public services delivery in situations of decentralization, privatization and public-private partnerships, corruption, conflicts and disasters.

In terms of best practices gleaned from UN Member countries, "creating a culture of human rights" and the training and monitoring role played by National Human Rights Commissions is recognized by the 2013 Report. ${ }^{988}$ The report in its conclusions noted that international treaty regimes relating to the improvement of public services are "fragmented", with international financial and trade institutions having "a significant impact on public service provision through their policies and rules" and that there should be a better synergy between these institutions and UN human rights mechanisms for a "human rights-based policy coherence and coordination to support public service improvements globally". 989

If applying these broad recommendations to the current GATS issues on the interpretation of Article I:3(c) of the GATS, the question is whether there is any space for a human rights-based approach to public services delivery to enter into the interpretation of "a service supplied in the exercise of governmental authority"? Can the VCLT method be used, nevertheless with the human rights approach at the back of the minds of the interpreters? The WTO Members have to apply their international obligations in human rights and trade simultaneously, but the task of interpretation is usually restricted to the language of the specialized area concerned not a 'bilingual' exercise. It can be argued if the interpreter is aware of the human rights approach to public services, the bilingualism is present and therefore could play a subtle role within the trade context.

\subsubsection{Defining "Services Supplied in the Exercise of Governmental Authority" (SSEGA).}

Article I:3(c) of the GATS:

"a service supplied in the exercise of governmental authority" means any service which is supplied neither on a commercial basis, nor in competition with one or more service suppliers.

Attempting to get a clearer understanding of unclear terms in the GATS is a bit like wiping the condensation from a mirror in a sauna, a glimpse of something clear and recognizable and then the matter seems to get fogged up again. This section attempts to 'un-fog' the matter of Article I:3(b) of the GATS based on the interpretive guidelines and sources currently available.

\footnotetext{
988 Ibid. (UN HRC, 2013), para.67 and para.71.

${ }^{989}$ Ibid. (UN HRC, 2013), para.78 and para. 79.
} 
There is no interpretation for "Services Supplied in the Exercise of Governmental Authority" (hereinafter "SSEGA") of Article I:3(b) in the GATS Agreement other than being defined as meaning non-commercial and non-competitive services according to Article I:3(c). It is interesting that the concept of 'exercise of governmental authority' was not defined in the GATS even though it is at first glance the key to understanding SSEGA. A 1991 Secretariat Note comments with reference to the draft GATS text that:

The term 'service' is not directly defined in the GATS, reflecting the lack of a generally-accepted economic definition. The term is however defined to include all service sectors, with the possible exception, not yet agreed, of government functions [emphasis added] ${ }^{990}$.

Ultimately, the terminology used for the GATS is an exception for "services supplied in the exercise of governmental authority" (SSEGA) but only if such services are also noncommercial and non-competitive.

The GATS Annex on Financial Services ${ }^{91}$ in its Paragraph 1(b) on scope and definition also refers to "SSEGA", "for the purposes of" Article I:3(b) of the GATS as meaning the following in the context of Financial Services ${ }^{992}$ :

(i) activities conducted by a central bank or monetary authority or by any

other public entity in pursuit of monetary or exchange rate policies;

(ii) activities forming part of a statutory system of social security or public retirement plans; and

(iii) other activities conducted by a public entity for the account or with

the guarantee or using the financial resources of the Government.

And adds further in Paragraph 1(c) that

990 WTO, Secretariat, Definitions in the Draft GATS, Note by the Secretariat, MTN.GNS/W/139, 15 October 1991, para.8.

${ }^{991}$ Also known as the Fifth Protocol to the GATS. Article 1(a) of the Annex on Financial Services states:

This Annex applies to measures affecting the supply of financial services. Reference to the supply of a financial service in this Annex shall mean the supply of a service as defined in paragraph 2 of Article I of the Agreement.

992 "Financial services" is defined in Paragraph 5(a) as: ... any service of a financial nature offered by a financial service supplier of a Member.

This is then further classified into two main areas; insurance and insurance related areas and banking and other (non-insurance) financial services. Note that health services are divided among different service sectors, with health insurance falling within financial services.

See further paras.9-10 of the WTO Secretariat, Financial Services: Background Note by The Secretariat, $\mathrm{S} / \mathrm{C} / \mathrm{W} / 72,2$ December 1998, for the differences in the classification of health insurance according to the Services Sectoral Classification List (MTN.GNS/W/120 of 10 July 1991) and the United Nations CPC classification (Statistical Papers, Series M, No.77, 1991).

There is also a possibility that a health insurance scheme that is defined as part of a statutory system of social security may fall under 'SSEGA'? This is something that could be looked into further, especially because of the separation in WTO services classification of financial (including insurance) services and health (hospital) services.

The definition of mandatory health insurance (MHI) is quite simple: it is a system that pays the costs of health care for those who are enrolled and in which enrollment is required for all members of a population. It is quite distinct from systems in which health insurance is largely voluntary and from those in which out-of-pocket payments predominate. It is a little more difficult to distinguish MHI systems from those in which government services are provided at little or no cost to the population (for example, the national health services of Malaysia or the United Kingdom), except that in MHI systems the insurance function is generally explicit and provision is often separated from financing [emphasis added].

- Savedoff, William D., and Pablo Gottret, Eds, GOVERNING MANDATORY HEALTH INSURANCE: LEARNING FROM EXPERIENCE, The World Bank, 2008, p1. 
For the purposes of subparagraph 3(b) of Article I of the Agreement, if a Member allows any of the activities referred to in subparagraphs (b) (ii) or (b) (iii) of this paragraph to be conducted by its financial service suppliers in competition with a public entity or a financial service supplier, "services" shall include such activities.

Paragraph 1(d) clarifies that Article I:3(c) of the GATS does not apply to services covered by the Annex on Financial Services. ${ }^{993}$

Therefore, the definition of "SSEGA" for the purposes of financial services is limited to three specific situations and even those situations would be outside the scope of the GATS only if there is no "competition". The term "competition" is not defined in the Annex, although some other relevant terms are. The 1998 WTO Secretariat Background Note on Financial Services discusses the importance of increasing or enhancing competition and on competition policy ${ }^{994}$ but again, no definition is given. The Secretariat does of course state that the Background Note on Financial Services:

... should not be interpreted as an indication of any particular interpretation of the GATS. ${ }^{995}$

However, these Background Notes are looked at, for the reasons discussed earlier in this Chapter.

The term "commercial" used in Article I:3(c) of the GATS is not referred to in this Annex except in context of defining the nature of a "public entity". The reference to "public entity" first appears in the Annex in Paragraph 5 on definitions.

In 5(b) it is clarified regarding the scope of the Annex that

A financial service supplier means any natural or juridical person of a Member wishing to supply or supplying financial services but the term "financial service supplier" does not include a public entity [emphasis added].

"Public entity" is then further clarified in Paragraph 5(c) as meaning:

(i) a government, a central bank or a monetary authority, of a Member, or an entity owned or controlled by a Member, that is principally engaged in carrying out governmental functions or activities for governmental purposes, not including an entity principally engaged in supplying financial services on commercial terms; or

(ii) a private entity, performing functions normally performed by a central bank or monetary authority, when exercising those functions [emphasis added].

Taking into account the above definitions, it can be concluded that in the financial services sector, a similar standard of non-commercial and non-competitive provision of services applies as in other sectors that are covered by Article I:3 of the GATS. One of the differences is that the concept of "public" is elaborated further in the Annex on Financial Services, in that there is reference to both the nature of a "public entity" and the possibility of private entities carrying out "public" functions. This emphasizes that the approach of WTO officials which was referred to earlier in this Chapter that

\footnotetext{
993 The text of Paragraph 1(d) of the Annex on Financial Services:

Subparagraph 3(c) of Article I of the Agreement shall not apply to services covered by this Annex.

994 WTO Secretariat, Financial Services: Background Note by The Secretariat, S/C/W/72, 2 December 1998, paras.24, 29, 30, 33, 39-41, 44-46, 49-51 and 56.

${ }^{995}$ Ibid para.5.
} 


\author{
Public services can and are carried out either by public or by private \\ undertakings. ${ }^{996}$ \\ ....is reflected in the text of the Annex on Financial Services.
}

How relevant or significant are the definitions in the Annex on Financial Services, a specific type of services, for the interpretation of Articles I:3(b) and (c) of the GATS, which apply to all types of services? Some could argue that this is context under Article 31(2) of the VCLT, which states that:

The context for the purpose of the interpretation of a treaty shall comprise, in addition to the text, including its preamble and annexes...

However, the counter-argument is that the Annex applies only to financial services under the GATS and therefore plays no role for interpretation of Article I:3 in general.

An additional point is that while the Annex suggests that a pro-market approach to public services prevails in the WTO context, it is interesting to note that the Background Note on Financial Services also recognizes the importance of the role of the public sector in this area of "basic infrastructure of the economy" despite a "clear trend towards privatization". ${ }^{997}$ The Secretariat cautiously put forward that this sector provides services considered as "public goods" while also being a sector where "market failure is an acute problem". ${ }^{998}$ Many other service sectors can also be looked at in the same manner, although some, such as e.g. tourism services, are obviously seen differently, as predominantly a private sector-supplied service.

In terms of a human rights-based approach to public services, it may be relevant to mention a recommendation of the UK House of Commons Public Administration Select Committee in 2008, that when it comes to the perspective of the human rights of 'public service users', their rights should not be affected by the identity of the service provider (particularly in the case of privatization or private management) and that "all organizations delivering public services should be considered to be public authorities for the purposes of the Human Rights Act 1998". ${ }^{999}$ This was in response to concerns that courts were narrowing the scope of coverage of the Human Rights Act and excluding from it the human rights obligations of non-public sector authorities which were carrying out public functions such as health care and nursing services on behalf of the State. The other side of this is that if under WTO law, a public body is supplying services on a commercial basis and in competition with other suppliers, it would fall under the scope of coverage of the GATS.

Thus it is more likely that public service providers of Members would be under the coverage of both their human rights and trade law liberalization obligations while private suppliers would not be directly under human rights obligations (since domestic law may exclude them, and they are only indirectly covered by the State obligation for oversight of

\footnotetext{
${ }^{996}$ Lamy. P., GATS: Pascal Lamy responds to Trade Union Concerns on Public Services, Brussels, 7 June 2002, available online at trade.ec.europa.eu/doclib/docs/2004/april/tradoc_116645.pdf, last accessed 20.10.2011. This document is a letter in reply to a previous letter from Emilio Gabaglio, General Secretary, European Trade Union Confederation (ETUC), dated 23 May 2002.

997 WTO Secretariat, Financial Services: Background Note by The Secretariat, S/C/W/72, 2 December 1998, para 28.

${ }_{998}$ Ibid., para.31.

${ }^{999}$ UK, House of Commons, Public Administration Select Committee, Public Services and the Third Sector: Rhetoric and Reality, Volume 112 of HC (Series) Great Britain. Parliament. House of Commons, HC 112-i, Eleventh Report of Session 2007-08 - Volume I: Report, Together with Formal Minutes, p70.
} 
non-State actors under international human rights law). Thus, attention is drawn to what could be a public services exemption from the scope of the GATS, the opportunity presented with the interpretation of the terms 'commercial' and 'in competition'.

\subsubsection{Defining the terms "Supplied on a Commercial Basis" and "...in Competition with".}

Keeping in mind the issues discussed in the preceding section concerning "services supplied in the exercise of governmental authority" (SSEGA) and setting aside for now the larger context ideological debates on public services, we must turn to the interpretive guidance given by the GATS in the following paragraphs:

"...supplied on a commercial basis" and

"... in competition with"

It is these two phrases that must be looked at in in a more technical manner in order to define SSEGA for the GATS.

These two criteria are clearly cumulative. But there are two ways to look at the relationship between the two criteria: that they are distinct, and could be looked at separately, in different spheres or that the line between them is always blurred and likely to overlap since commercial activity is likely to also be carried out in competition with other suppliers. Those supporting the first view could argue that there is no blurring of lines if, for example, a government entity could have a monopoly but charge rates above cost (not competitive, but commercial) or that there could be both governmental and private providers but the government provide services below cost (apparently competitive situation but non-commercial on the part of the government). Adlung takes the second point of view, stating that commercial and competitive' behaviour "may be viewed as two facets of the same concept". ${ }^{1000}$ That is true if applying a broad approach to SSEGA and the two criteria in Article I:3(c), which would "blur the distinction between 'commercial' and 'competitive' behaviour". ${ }^{1001}$ Adlung refers to a broad approach that considers "strategic economic behavior" of public entities as relevant for the interpretation of commercial and competitive behavior, ${ }^{1002}$ but it is also possible to have a different type of broad approach that looks at the purposes and nature of public services and the difference in the motivation behind public and private economic activity when interpreting "commercial" and "in competition with". These two contrasting 'broad approaches' are likely to have different results, with the latter more likely to retain greater policy space.

However, the focus in the next few pages will be narrower and take each criterion separately, although acknowledging the interconnection between commercial and competitive behavior.

\subsubsection{1. "Supplied on a Commercial Basis"}

In the context of 'public goods' and market orientation, the term 'commercial' and what it means for public services under Article I:3(c) of the GATS needs to be looked at in closer detail. It is also relevant to see if jurisprudence on Article III:8(a) of the GATT 1994 on

\footnotetext{
1000 Adlung, R., Public Services and the GATS, Staff Working Paper ERSD-2005-03, World Trade Organization Economic and Statistical Division, 2005, p9.

${ }^{1001}$ Ibid., (Adlung).

1002 Ibid.
} 
procurement for governmental purposes, which includes the terms 'commercial sale' and 'commercial resale', will be useful for the interpretation of Article I:3(c) of the GATS. The interpretation of "supply" for the purposes of the GATS has already been discussed earlier in this Chapter. Therefore, attention will be focused more on the term "commercial" in this section, although, of course the terms of the phrase have to be read together.

The term "commercial" has not as yet been interpreted with regard to Article I:3(c) of the GATS. However, it has been discussed in the context of different WTO Agreements, and may give some insight into how the interpretation could be likely to be if there is a GATS dispute where the term would need to be interpreted. The term "commercial scale" in Article 61 of the TRIPS Agreement and "commercial resale" in Article III:8(a) of the GATT 1994 have been discussed by the Panel in China-Intellectual Property Rights and by the Appellate Body in Canada-Renewable Energy/Canada-Feed-in Tariff Program respectively. While these interpretations are in the context of those particular phrases and Agreements, it may be useful to see the framework for interpretation that has been set out thus far in dispute settlement.

It may also be relevant to note that in a recent contentious case in the International Court of Justice (Costa Rica v Nicaragua, 2009), it was noted that an evolutionary interpretation should be given to the term term "commercio". ${ }^{1003}$ The case concerned the phrase "con objectos de commercio" in a 1858 Treaty between Nicaragua and Costa Rica, the point being argued was that Nicaragua said that the phrase only covered trade in goods, while Costa Rica argued it included trade in goods and services. The International Court of Justice (ICJ) stated that the term "commercio", must be understood to have the meaning they bear on each occasion on which the Treaty is to be applied (e.g. 2009), and not necessarily their original meaning (at the date of 1858 Treaty). It has only been approximately 20 years since the entry into force of the GATS, and thus the evolutionary interpretation of terms of the GATS may not necessarily arise in the same sense. The ICJ case highlights how the term "commercial" may not originally have included services, but that services are now considered to be an important and lucrative commercial activity.

It is relevant that the issue of evolutionary interpretation of certain types of services arose in the China-Publications and Audiovisual Products dispute in 2009. China submitted in the context of this dispute, that the meaning of the phrases "sound recording distribution services" and "videos...distribution services" in China's GATS Schedule should be based on "definitions contemporaneous to the conclusion of the treaty" - basically, to refer to dictionaries edited at the time of the conclusion of China's accession negotiations. ${ }^{1004}$ However, the Appellate Body approved the position taken by the Panel, that an evolutionary approach should be followed, giving the entry a "contemporary meaning". They agreed that the interpretation should not be limited to the dictionary definition of 2001. ${ }^{1005}$ Notably, the Appellate also referred at footnote 705, to the interpretation of the

\footnotetext{
${ }^{1003}$ ICJ, Dispute regarding Navigational and Related Rights (Costa Rica v. Nicaragua), Judgment, ICJ Reports, 13 July 2009, p213.

${ }^{1004}$ Appellate Body Report, China-Publications and Audiovisual Products, para.47 and 390, citing China's appellant's submission, paras. 170 and 173 - and further at para.83 of the Appellate Body Report, citing the United States' appellee's submission, para. 91.

1005 Appellate Body Report, China-Publications and Audiovisual Products, para.83 and footnote 150. DVDs would not be included if the term "videos" was interpreting according to the dictionary meaning ascribed to the term in 2001 when China's commitments were undertaken. Despite the non-inclusion of the term under 'video' in dictionaries at the time, it was noted by the United States that DVDs had already
} 
term "commercio" in the Costa Rica v. Nicaragua judgement, when stating that terms used in China's GATS Schedule ("sound recording" and "distribution") are "sufficiently generic that what they apply to may change over time". ${ }^{1006}$

\subsection{The role of profit in defining "commercial" and "on a commercial basis"}

Why is it important to determine whether "on a commercial basis" includes the profit motivation? The scope of the GATS - the extent to which it covers a variety of different activities - could depend on this definition. If a service is not supplied on a commercial basis, that fulfills one part of the requirement for being a SSEGA and thus it could be excluded from the scope of the GATS. If "on a commercial basis" is defined as primarily profit seeking activities, then services where the primary motivation is non-profit could be excluded. If "commercial" is defined as including profit-seeking, then the definition could cover activity which is not primarily profit-seeking or even not profit-seeking at all, that could otherwise have been seen as beyond the scope of GATS. If these types of services, which are not primarily profit seeking are included in the scope of the GATS, then the protection for measures relating to such activities must then rely on whether they fall within the exemptions, exceptions or other leeway provided by those Agreements. Thus, the definition of the term "commercial" in Article I of the GATS could cover a much broader range of activities than assumed at first glance and also cover public services, depending on the role of profit in different models of public services. It is important to note that public health services are not overall modelled on a profit motivation, even if there would be aspects of 'commercialization' in some areas of service delivery; such as certain fee levying hospital wards or clinics existing alongside non-fee levying wards and clinics. Similarly, public universities could be non-fee levying for undergraduate programmes and fee levying for postgraduate programmes.

In China-Intellectual Property Rights, the term "commercial scale" in Article 61 of the TRIPS Agreement was looked at by the Panel in the context of the China's obligation to have criminal procedures and penalties for commercial scale counterfeiting and piracy (of intellectual property). The main arguments by the parties (United States and China) and third parties (Argentina, the European Communities, Japan, Mexico, Chinese Taipei, Australia, Brazil, Canada, India, Korea, Thailand and Turkey) reveal a difference in approach by WTO Members concerning the interpretation of "commercial". This was recognized by the Panel ${ }^{1007}$ which went on to assess all the different approaches that were submitted.

The Panel in interpreting this phrase looked at "commercial" separately and individually, at first referring to the Shorter Oxford Dictionary 1993, especially focusing on the following two definitions, as those that were the ones raised by parties in this dispute:

1. Engaged in commerce; of, pertaining to, or bearing on commerce...

2. Interested in financial return rather than artistry; likely to make a profit; regarded as a mere matter of business. ${ }^{1008}$

become the primary medium for distributing films by then, and highlighted that the "editing of a dictionary lags behind the evolution of the ordinary meaning of a term" (footnote 150).

${ }^{1006}$ Appellate Body Report, China-Publications and Audiovisual Products, para.396 and footnote 705.

${ }^{1007}$ Panel Report, China- Intellectual Property Rights, paras.7.532-7.537.

1008 The New Shorter Oxford English Dictionary, Oxford University Press, 1993. 
The Panel considered the first definition more appropriate than the second, and appeared to align with the approach of the United States that "commercial" activity does not require a profit motive. ${ }^{1009}$ This position is clarified in footnote 522 , which states that:

[T] he Panel is not required, for the purposes of this claim, to express a view as to whether "commercial" also indicates certain qualitative factors, such as a profit-seeking purpose. ${ }^{1010}$

The Panel thus avoided making a specific statement on whether profit motivation was a requirement. However, it must be noted that the Panel disagreed with China and their reference to the explanatory observation on the terms "commercial scale" in the Draft Model Provisions for National Laws by International Bureau of WIPO for the WIPO Committee of Experts on Measures against Counterfeiting and Piracy in 1988 that was contemporaneous with the negotiations of the TRIPS Agreement. This WIPO explanatory observation accompanied the term "commercial scale" stating that "the will to make profit" was a factor that courts would need to take into account in interpreting the term. ${ }^{1011}$ The basis of the Panel's rejection of the Draft Model Provisions was that they were controversial, never agreed upon and thus not acceptable as ordinary meaning 1012

Despite initially avoiding direct commentary on the issue, the Panel contradicts its own position at a later point in the report by stating that:

The distinguishing characteristic of a commercial activity is that it is carried out for profit [emphasis added] ${ }^{1013}$

The footnote to this sentence adds somewhat unnecessarily, that:

At the same time, some activities - such as experimentation - may be conducted in the course of business or in connection with a business without a specific profit-making purpose. ${ }^{1014}$

Since this refers to a minor activity that is conducted within the broader business (forprofit) activity, it could not change the overall approach or classification of for-profit activities. In any case, as earlier stated, it had been deemed that it was not necessary to assess the relevance of profit-seeking for the definition of "commercial".

The result of the Panel's interpretation is a circular and rather unhelpful definition where "commercial" means engaged in commerce, and being contradictory on the whether and to what extent the motivation for commercial activity must be looked into and whether it must include a profit motivation. Furthermore, it ignores the fact that the Shorter Oxford Dictionary also goes on to define "commercialism" as:

...the principles and practices of commerce; excessive adherence to financial return as a means of worth. ${ }^{1015}$

It is also added that "commercialize" is defined to "render (merely) commercial" implying that there can be other motivations in engaging in supplying goods or services,

\footnotetext{
${ }^{1009}$ Panel Report, China-Intellectual Property Rights, paras.7.532-7.537.

${ }^{1010}$ Panel Report, China- Intellectual Property Rights, footnote 522.

1011 Para 7.562: that explanatory observation in full (footnote 539 of the Panel Report):

Commercial scale' is a notion which will have to be applied taking into consideration the circumstances accompanying the manufacture. The quantity of the goods manufactured, the way in which they were, are or are intended to be used and the will to make profit are among the factors that the courts will have to take into consideration [emphasis added].

See WIPO document C\&P/CE/2 of 18, 19 February 1988, para. 17, set out in Exhibit CHN-43

1012 Panel Report, China- Intellectual Property Rights, para.7.567.

1013 Panel Report, China- Intellectual Property Rights, para 7.545.

1014 Panel Report, China- Intellectual Property Rights, footnote 523.

1015 The New Shorter Oxford English Dictionary, Oxford University Press, 1993.
} 
as of course there are many. For example, there can be fundraising or subscriptions - for causes, non-profit bodies, promotion of an idea or skill, support of groups of persons or animals, sharing of information or talents, sharing of a personal passion or hobby, voluntary political or social activism, non-profit awareness-raising activities and many other motivations. The world is a more interesting place - and much larger one in terms of ideas and imagination - than one in which all these individual and community activities would be classed together as "commercial" alongside profit-oriented activities just because they involve buying and selling in some form.

It can thus be seen as disappointing from such a point of view, that although the Panel stated that:

...commercial is qualitative, in the sense that it refers to the nature of

certain acts. Some acts are in fact commercial, whilst others are not, ${ }^{1016}$

...the next immediate sentence states that:

...any act of selling can be described as commercial in this primary sense...

[emphasis added]

It can be argued that perhaps ordinary people would not agree to such an "ordinary meaning" of "commercial", as there can be "selling" associated with charitable or cooperative fund-raising and entirely non-profit activities that ordinary people would not connect with the term "commercial". It could be argued that the ordinary meaning of commercial, divorced from a trade dispute context, recognizes that "commercial" implies profit-making motives as central to the definition.

Some of the third parties in China-Intellectual Property Rights appear to agree with the centrality of the profit motivation for the term "commercial". Brazil refers to the "profitseeking motivation"1017; Canada refers to "the pursuit of profit"1018; the EC argues that "pertaining to a business or profit generation" takes into account "factors such as indications of business organization or profit orientation of an activity;" 1019 and Korea refers to "the purpose of gaining financial return" 1020 as defining "commercial". Chinese Taipei submitted that "commercial scale":

...is an abstract legal concept that involves multiple factors of local circumstances, such as nature of the infringed rights, value and price in the market, motive and purpose of act, method and scale of infringement, damage caused, profit gained, cultural background, advancement of modern technology and living standards, that need to be considered on a case-by-case basis [emphasis added]. ${ }^{1021}$

It is a valid argument that motivation and purpose, as well as profit seeking behaviour should be considered when looking at a public service and the criteria of 'commercial' for SSEGA in Article I:3(c). However, the Canada-Renewable Energy/Canada-Feed in Tariffs dispute appears to be unhelpful in supporting this position.

\footnotetext{
${ }^{1016}$ Panel Report, China-Intellectual Property Rights, para.7.538.

1017 Panel Report, China-Intellectual Property Rights, para.7.486.

${ }_{1018}$ Panel Report, China-Intellectual Property Rights para.7.487.

1019 Panel Report, China-Intellectual Property Rights para.7.488 citing the EC third party oral statement, paras.10, 14.

${ }^{1020}$ Panel Report, China-Intellectual Property Rights, para.7.490

${ }^{1021}$ Panel Report, China-Intellectual Property Rights, para.7.492, citing Chinese Taipei's third party written submission, para.21; Chinese Taipei's third-party oral statement, para.11.
} 
In Canada-Renewable Energy/Canada-Feed-in Tariff Program the agreements dealt with were the Agreement on Subsidies and Countervailing Measures (SCM), the Agreement on Trade-Related Investment Measures (TRIMs) and the GATT 1994. Canada invoked Article III:8(a) of the GATT 1994, arguing that the measures at dispute were not subject to the obligations of Article III because the relevant measures governed the procurement of renewable electricity for governmental purposes and were

...not with a view to commercial resale or with a view to use in the production of goods for commercial sale.

The findings of the Panel and Appellate Body did not support Canada's position and found that Canada needed to bring its measures into conformity with its obligations under the TRIMs Agreement and the GATT 1994. For the purposes of this section, the arguments relating to the interpretation of the term "commercial" in the above dispute will be discussed.

Canada argued that the term "commercial" in "commercial resale" means resale with "underlying intent to profit". ${ }^{1022}$ In support of this Canada cited the interpretation of the word "commercial" by the Panels in China-Intellectual Property Rights and CanadaWheat Exports and Grain Imports; and the Appellate Body in US-Anti-Dumping and Countervailing Duties. The parties to the dispute presented different meanings to the above phrase with the complainants submitting that it meant:

...with a view to being sold or introduced into the stream of commerce,

trade or market, regardless of any profit. ${ }^{1023}$

Japan and the European Union specifically rejected the argument that the intent to profit $^{1024}$ is a required element. It can be agreed that activity that can be classed as "commercial" is not necessarily activity that is in actual fact, profitable. But it can be also submitted that Canada's argument - that the profit-making intention or motivation behind the activity is relevant to decide whether something is a commercial activity - was not properly assessed. Instead the Panel and Appellate Body both focused on actual profit in this dispute, rather than the intent to profit - and the existence of competition, in order to determine that the government (in this dispute, the Provincial Government of Ontario) was carrying out a "commercial resale". The Appellate Body discussed "commercial resale" as a something that must be assessed having regard to the entire transaction:

... assessing the transaction from the seller's perspective and at whether

the transaction is oriented at generating a profit for the seller...

- and with the seller acting in a "self-interested manner". ${ }^{1025}$ The Appellate Body noted further in the same paragraph, that sometimes the seller's long terms strategy may be different but still commented that "a rational seller would be expected to be profitoriented in the long term". This does not fully encapsulate the motivations of a government acting in the public interest in a situation where profit is not part of the motivation or long term strategy (such as providing public healthcare or implementing environmental policies).

Krajewski identifies two approaches to the definition of the term "commercial", one that includes the profit motivation and the other that includes all acts of buying and selling

\footnotetext{
1022 para.2.4.

1023 Panel Report, Canada-Renewable Energy / Canada-Feed-in Tariff Program, para.7.146, cited in the Appellate Body Report, Canada-Renewable Energy / Canada-Feed-in Tariff Program, para.5.44.

${ }_{1024}$ Panel Report, Canada-Renewable Energy / Canada-Feed-in Tariff Program, para.7.146, cited in the Appellate Body Report, Canada - Renewable Energy, para.5.70.

${ }^{1025}$ Appellate Body Report, Canada-Renewable Energy / Canada-Feed-in Tariff Program, para.5.71.
} 
without seeking profit, and states that the GATS definition should only include profit. ${ }^{1026}$ Adlung disagrees with Krajewski's rationale and basis for this conclusion and says that "commercial" for GATS purposes cannot be limited to 'profit' or 'profitseeking'. ${ }^{1027}$ Adlung has also correctly pointed out that even if commercial was equated with profit, there are further definitional problems that would need to be resolved, including services that are not 'profit-seeking' but turn out to be unintentionally profitable. ${ }^{1028}$ The implication seems to be that if governmental bodies acting for public purposes introduce something into the "stream of commerce" they could find themselves open to challenges under WTO law, especially considering the size and attractiveness of that market for foreign competitors. ${ }^{1029}$ Whether the governmental bodies make actual profits or not could be relevant from the point of view of the potential foreign competitors, as it shows the potential of the market. If the situation can be seen as having potential for commercial profits for foreign competitors, the intentions and motivations of the governmental bodies themselves may not be considered relevant in a context that is supportive of increased marketization and commercialization.

However, there is also another matter that probably would not be considered relevant in the context of WTO trade disputes, but perhaps ought to be, which is that these profits belong to the public (for utilization for further public purposes) ${ }^{1030}$ and not to shareholders of a company. It is an interesting question for further research, whether these two types of profit-making ought to be considered the same thing and connected with the notion of "competition". It essentially means that private companies could have a share in what could otherwise belong to the public and be used (if there is no corruption and if good policies are formulated) for general public purposes and maintaining and improving that particular public service or other public services. It can also be linked with limitations on cross-subsidization in WTO law, which could discourage the use of profits in a certain public sector, sub-sector or mode of supply in a sub-sector, from being used to

${ }^{1026}$ Krajewski, M., Public Services and Trade Liberalization: Mapping the Legal Framework, Journal of International Economic Law, Vol. 6, No. 2, 341-367, p351 referring to Article XXVIII(d) - "Commercial presence [Mode 3] means any type of business or professional establishment..." - suggesting that "commercial" is meant to cover a particular type of profit-seeking body.

See also Leroux, Eric, What is a 'Service Supplied in the Exercise of Governmental Authority' Under Article I:3(b) and (c) of the General Agreement on Trade in Services?, Journal of World Trade, 40, 2006, p345, who also identifies the intent to have financial gains as key to whether a service is "commercial" or not.

${ }^{1027}$ See further, Adlung, R., Public Services and the GATS, Working Paper ERSD-2005-03, World Trade Organization Economic and Statistical Division, 2005, p8-9 and footnote 21. Adlung's counter-argument against Krajewski's interpretation refers to the definition of juridical person in Article XXVIII:(l):

.... any legal entity constituted or otherwise organized under applicable law, whether for profit or otherwise(!), and whether privately-owned or governmentally-owned ... [emphasis by Adlung].

1028 Adlung, R., Public Services and the GATS, Working Paper ERSD-2005-03, World Trade Organization Economic and Statistical Division, 2005.

${ }^{1029}$ See Appellate Body Report, Canada-Renewable Energy / Canada-Feed-in Tariff Program, paras.2.30 and 2.32: Japan in its submissions noted in particular the existence of both profit and of private sector competition.

1030 Japan in the Canada-Renewable Energy / Canada-Feed-in Tariff Program dispute submitted that the Panel correctly found that the Government of Ontario "earns financial returns" from its "resale" of electricity to consumers in Ontario, thereby making the transaction a "commercial" one, even if it did not intend to make a profit (Appellate Body Report, Canada-Renewable Energy, para.2.29, footnote 129 quoting Panel Reports, para.7.150). That the ultimate beneficiaries of these "financial returns" were also the consumers/public who made payments, rather than bonuses for CEOs and Shareholders if it had been a private company, was not factored into the analysis by either the Panel or the Appellate Body. 
cross-subsidize another public sector that is not similarly 'profitable'. The argument against making the differentiation based on the beneficiaries of the profits is that such an argument can be extended to exempting all government provision of services from the scope of the GATS, even when an entity acts as a commercial profit-seeking entity in competition with others. Therefore, the argument should be on whether profit-motivation is the primary motivation is the supply of services by the government.

It can be argued that there was not sufficient consideration by the Panel and Appellate Body in the above dispute of the public purposes of ensuring a "sufficient and reliable supply of electricity for Ontarians and to protect the environment". ${ }^{1031}$ Neither does it appear that the constitutional mandate to act nor the traditional role of government, "focusing on the history, constitution, and legislation of a particular government", ${ }^{1032}$ was given consideration in this dispute. Of course, the disputes often turn on very technical interpretations of terms and a question is - under which terms or provisions could these considerations have been given weight? The outcome is that governmental activities, even if actually without a profit motivation, but making a profit in fact, in the context of the existence of a market (and therefore with the possibility of competition) - are considered commercial activities. From the point of view of competitors attempting to enter this market, it is the best result. The effects on cost and access by the public and environmental impacts (whether positive or negative) remains to be seen. A question that could be posed is to what extent the WTO system is weighted towards the possibility of profit-making through increased marketization and competition rather than other societal motivations. Whether a fair balancing of these interests exists in the system, particularly with regard to the GATS, is indeed one of the threads connecting all the issues in this thesis.

As a last point on the role of profit in 'commercial', it is interesting to note that the 2015 text of the Trans Pacific Partnership (TPP - revised and renamed in January 2018 as the Comprehensive and Progressive Agreement for Trans-Pacific Partnership or CPTPP), which uses the same definition of SSEGA in its Article 10.1 as is used in Article 1:3 of the GATS, also includes a chapter 17 on "state-owned enterprises and designated monopolies". This chapter 17 begins with a provision on definitions, which defines "commercial activities" and "commercial considerations" for the purposes of the chapter. Article 17.1 of the text of the TPP defines these terms as follows: ${ }^{1033}$

commercial activities mean activities which an enterprise undertakes with an orientation toward profit-making and which result in the production of a good or supply of a service that will be sold to a consumer in the relevant market in quantities and at prices determined by the enterprise

commercial considerations mean price, quality, availability, marketability, transportation, and other terms and conditions of purchase or sale, or other factors that would normally be taken into account in the commercial decisions of a privately owned enterprise in the relevant business or industry. [emphasis added]

Two footnotes to chapter 17 of the text of the TPP add clarifications to the terms "profit making" and "prices determined by the enterprise" in the definition of "commercial

\footnotetext{
${ }^{1031}$ Appellate Body Report, Canada-Renewable Energy / Canada-Feed-in Tariff Program, para.2.3.

1032 Appellate Body Report, Canada-Renewable Energy / Canada-Feed-in Tariff Program, para.2.8.

1033 See Office of the US Trade representative, TPP Full Text, available online at https://ustr.gov/tradeagreements/free-trade-agreements/trans-pacific-partnership/tpp-full-text.
} 
activities" by adding footnotes to these terms in the paragraph defining "commercial activities".

Footnote 1 of chapter 17 - "profit making":

For greater certainty, activities undertaken by an enterprise which operates on a not-for-profit basis or on a cost-recovery basis are not activities undertaken with an orientation toward profit-making.

Footnote 2 of chapter 1 - "prices determined by the enterprise":

For greater certainty, measures of general application to the relevant market shall not be construed as the determination by a Party of pricing, production, or supply decisions of an enterprise.

Thus, the States who are also WTO Members, when negotiating in the context of the TPP, have made some clarifications on what is commercial and included profit making as part of the definition. The debates on whether or not profit making is a relevant consideration for the interpretation of "commercial" in the WTO context would not have been unknown to these TPP negotiators.

\subsubsection{2. $\quad$ Commercial $=$ Fee-Levying (?)}

Another criterion for determining the commercial nature of an activity is the nature of payment. Whether payment is at market rates or a nominal fee or the service is free, may also connect with both the intention to profit and actual profit that could be gained. Adlung comments that it "might go too far" to suggest that any service for which a price is charged is to be considered "commercial" and states that a distinction could be drawn between "symbolic dues" and "deliberate pricing strategies with a view to maximizing revenue" which includes "an element of strategic economic behavior". ${ }^{1034}$ It is possible to question the commercial nature of even the second category, as it is possible that maximizing revenue may be an intention, but one that is low on the list of priorities, after other more important public policy considerations. Maximizing revenue and the strategic economic behavior in energy or transport sectors that are given as examples by Adlung, can be for the purposes of maintenance, improvement and re-investment of the services for the benefit of the public and the environment, and thus not about maximizing revenue just for the sake of it.

The pattern in WTO Secretariat Notes is that a service where there is a fee charged is considered as service supplied "on a commercial basis". The only services identified as clearly non-commercial are the judiciary, prosecutorial and court services and privatized local monopoly for environmental services that is paid for by government funds and not user fees. It could be argued that these are non-commercial since the above services are carried out without directly charging from the individual consumer, although the funding ultimately comes from the 'public'/national budget. ${ }^{1035}$ It should be noted that fees could

\footnotetext{
${ }^{1034}$ Adlung, R., Public Services and the GATS, Working Paper ERSD-2005-03, World Trade Organization Economic and Statistical Division, 2005, p9.

1035 WTO, Secretariat, Background Note, Legal Services, S/C/W/43, 6 July 1998, para.13 and footnote 34, refer to services in the administration of justice not being covered by the GATS, but also comment that although notarial Services play a "public role", they are not exempt from the GATS since they are provided for a fee. See also WTO, Secretariat Background Note, Environmental Services, S/C/W/320, 20 August 2010, para.53.

See further WTO, Secretariat, Background Note, Education Services, S/C/W/313, 1 April 2010, paras.17-18 notes that "[G]iven its importance for human and social development", primary and secondary education can be considered as a basic entitlement, even when a "nominal fee" is charged - but tertiary education is
} 
be charged for court services in many countries. But the attitude towards this service that justice cannot be seen as 'paid for' or 'bought' - results in court services continuing to be seen as "non-commercial" even if a court fee is required. If public health services would be seen in the same way as court services, minor user fees should not change its basic characteristic as a non-commercial service.

However, the WTO Secretariat Background Note on Health and Social Services of 1998 suggests that any form of fee-levying, whether directly from the patient or through insurance means that an entity operates "on a commercial basis" and that it becomes "unrealistic" to argue that Article I:3 would continue to apply in such a case. ${ }^{1036}$ Thus it is only if the service is provided free at the point of delivery and funded through general taxation (or perhaps even local and foreign aid, grants and charitable donations), that it would be considered non-commercial. Thus, according to this line of argument, innovative health insurance schemes which many countries have introduced, that have to be purchased by or for the consumer, would be considered 'fee-levying' and therefore "commercial" and within the scope of the GATS. A fair point is raised for liberalization, since health insurance is a profitable sub-sector. Yet health insurance falls under Financial Services (Insurance) and not Health and Social Services according the Services Sectoral Classification List that is followed by WTO Members. This means that Members who wish to retain policy space for the funding of public services must be aware of the interconnections and ramifications of commitments and limitations in the area of health insurance, and the apparent limitations of an Article I exemption, when they are negotiating in Financial Services. This is because, although Health is a sector with very low levels of commitments, financial services are a sector where many Members have made commitments. It is also pertinent to note that there is a difficult relationship between private health insurance and the right to health, with one argument being that private health insurance is detrimental to a State achieving its right to health and universal coverage goals, with another supportive view of it only so far as it contributed towards sharing the burden of costs and providing the ability for the State to focus on the most vulnerable who are in need of public insurance or free public health services. ${ }^{1037}$ There is also the ambitious, long term, right to health-based plan for a type of 'global health insurance', which has been implemented through the Global Fund to Fight AIDS, Tuberculosis and Malaria ("the Global Fund"), and which has been described as taking the concept of health insurance out of the traditional private and/or public domestic box

assumed to be open for market competition. But although this suggests a 'carve-out' under Article 1:3 (b) and (c) for primary and secondary education, it is noted that some Members have additionally "specifically excluded publicly-provided or funded education services from their commitments" (para.62 and Box 1). This exclusion often covers tertiary education as well.

1036 WTO Secretariat, Health and Social Services: Background Note by the Secretariat, S/C/W50, 18 September 1998, para.39.

${ }^{1037}$ Bodenheimer, Thomas, Should we abolish the private health insurance industry?, International Journal of Health Services 20.2 (1990): 199-220; Bodenheimer, Thomas, Steven Cummings, and Elizabeth Harding, Capitalizing on illness: The health insurance industry, International Journal of Health Services 4.4 (1974): 583-598; Kinney, Eleanor D., The International Human Right to Health: What does this mean for our nation and world?, Ind. L. Rev. 34 (2000): 1457; Stuckler, David, et al, The Political Economy of Universal Health Coverage, Background Paper for the Global Symposium on Health Systems Research, World Health Organization, Vol. 2010, 2010; Hacker, Jacob S., Medicare Expansion as a Path as well as a Destination: Achieving Universal Insurance through a New Politics of Medicare, The Annals of the American Academy of Political and Social Science, Volume: 685 issue: 1, page(s): 135-153, September 10, 2019. 
into an international funding initiative. ${ }^{1038}$ This funding could be used in ways similar to how international financial institutions currently fund and support national health systems to either expand coverage or implement new models of efficiency, including recommendations for health insurance schemes. These complex interactions between financing of health and health services must be taken into account by GATS Members when developing national policy and during trade negotiations.

Another related issue of concern is that there is a general trend where entities and institutions providing public services have also been encouraged to develop alternate sources of revenue rather than depend entirely on Treasury allocations. In his 2005 working paper, Adlung dismissed the fears expressed that developing parallel new sources of revenue could affect the applicability of the exclusion to other services provided by the same supplier. ${ }^{1039}$ The specific context Adlung addressed was commercial activities of public universities, where this trend is clearly obvious with feelevying executive diplomas and Masters Programmes being introduced; but there is a possibility that other public services may also be encouraged to develop such alternative sources of revenue. Some public hospitals providing free services also sometimes have a few rooms or wards where patients can pay and get an upgrade to slightly better room or bed facilities, but should this affect the status of the health service as a 'public' one? This kind of situation suggests that partial competition or some commercial activities should not affect the position of the entire public service and whether it falls within or outside the protection of the Article I exemption. It could be argued that a public service may be excluded it from the exemption only if the entirety of that public service is supplied in a commercial and competitive manner.

It is yet to be decided clearly whether the coverage of Article I:3(c) would be decided in this manner, but it is a reasonable interpretation to apply the GATS only if the entirety of the service in question is supplied in a commercial (and competitive) manner. In the examples of public universities and public hospitals mentioned above, a different interpretation would leave them open to the GATS unless no commitments have been undertaken on education and health services or in the case that commitments have been undertaken, that a specific limitation is written into the Schedule after negotiations which deemed such a limitation as acceptable.

\subsection{Public-Private Partnerships = Commercial (?)}

International financial institutions and economic advisers have generally promoted public-private partnerships (PPPs) "as tools to finance the rehabilitation or development of public facilities". ${ }^{1040}$ The implications of such arrangements for the scope of the GATS

\footnotetext{
1038 Ooms, Gorik, Katharine Derderian, and David Melody, Do we need a world health insurance to realise the right to health?, PLoS Medicine 3.12 (2006): e530; Jürgens, Ralf, et al, Human Rights and the Global Fund to Fight AIDS, Tuberculosis and Malaria: How Does a Large Funder of Basic Health Services Meet the Challenge of Rights-Based Programs?, Health and Human Rights 19.2 (2017): 183; Sachs, Jeffrey D. and Guido Schmidt-Traub, Global Fund lessons for sustainable development goals, Science 356.6333 (2017): 32-33; Fan, Victoria Y., Feng-Jen J. Tsai, Zubin C. Shroff, Branden Nakahara, Nabil Vargha, and Scott Weathers, Dedicated health systems strengthening of the Global Fund to fight AIDS, tuberculosis, and malaria: an analysis of grants, International health 9, no. 1 (2017): 50-57.

${ }^{1039}$ Adlung, R., Public Services and the GATS, Working Paper ERSD-2005-03, World Trade Organization Economic and Statistical Division, 2005, p9.

${ }^{1040}$ WTO, Secretariat Background Note, Environmental Services, S/C/W/320, 20 August 2010, para.21, which also cites Cossy M., Water Services at the WTO in Brown Weiss, E., L. Boisson de Chazournes and
} 
has not been made sufficiently clear. The Background Note on Health and Social Services, 1998, states that:

The legal status of such arrangements under the GATS may vary, depending

on the rights and obligations conferred in individual cases. ${ }^{1041}$

The Note does not make any reference to Article I of the GATS in the context of PPPs, but states that Build-Operate-Transfer (BOT) arrangements, ${ }^{1042}$ may be viewed as a "form of government-regulated commercial activity or as government procurement of the services". The latter would fall under Article XIII of the GATS (government procurement). If a BOT is a "government-regulated commercial activity" there is no suggestion of an exemption under Article I of the GATS; the Note states that MFN would apply - and that it could also be scheduled and covered by Article VI:4 of the GATS on domestic regulation. The possibility that it would alternatively be considered under Article VIII of the GATS (monopolies and exclusive service providers) was also mentioned in a footnote.

With regard to scheduling of commitments for environmental infrastructure services provided by PPPs, a group of Members presented three questions for debate among Members. It is noteworthy that there is no suggestion of public-private partnerships remaining covered by the Article I exemption. The three questions were:

(a) In which subsectors of environmental services are these forms of PPPs particularly relevant? ...

(b) For those countries wishing to make commitments in services provided through various forms of public-private partnerships, what should such commitments look like? How can Members clearly indicate the existence of exclusive rights contracts while also indicating that foreign service providers can be granted national treatment for such contracts?

(c) Which types of activities or public-private partnerships are to be considered as government procurement under GATS Article XIII? ${ }^{1043}$

One thing that is clear from the literature is that PPPs do not suggest a lesser role for the public sector, but may in fact entail greater, although different responsibilities for the State. It has been stated that:

N. Bernasconi-Osterwalder Eds., FRESH WATER AND INTERNATIONAL ECONOMIC LAW Oxford University Press, 2005.

${ }^{1041}$ WTO, Secretariat Background Note, Health and Social Services, S/C/W50, 18 September 1998, para.40.

${ }^{1042}$ Build Operate Transfer (BOT) Project s are defined in the following manner according to the World Bank Public-Private-Partnership Legal Resource Center (see https://ppp.worldbank.org/public-privatepartnership/agreements/concessions-bots-dbos):

A Build Operate Transfer (BOT) Project is typically used to develop a discrete asset rather than a whole network and is generally entirely new or greenfield in nature (although refurbishment may be involved). In a BOT Project the project company or operator generally obtains its revenues through a fee charged to the utility/ government rather than tariffs charged to consumers. In common law countries a number of projects are called concessions, such as toll road projects, which are new build and have a number of similarities to BOTs.

1043 WTO, Secretariat Background Note, Environmental Services, S/C/W/320, 20 August 2010, para.80 citing the Joint Report on Informal Discussion on Environmental Services in the Context of the DDA, Communication from Australia, the European Union, Japan, New Zealand, The Separate Customs Territory of Taiwan, Penghu, Kinmen and Matsu and the United States, TN/S/W/28, 11 February 2005. Hong Kong, China later added its name to the list of co-sponsors (TN/S/M14, para. 126). 
PPPs demand a strong public sector, which is able to adopt a new role with new abilities... asking private partners to deliver government services places more, not less, responsibility on public officials ${ }^{1044}$

While PPPs may benefit public services that need an injection of funds and private sector management skills, it is suggested that PPPs are more likely to be successful where there is a strong public sector in place, which can provide leadership through policy and regulatory guidance and oversight. Considering the 'public goods' nature of what is sometimes referred to in WTO context as 'infrastructure services', the public trust and promotion of human rights through universal service provision, the public sector cannot divest itself of responsibilities through PPPs. This has been affirmed recently within the international human rights regime. General Comment 24 (2017) of the Committee on Economic, Social and Cultural Rights called on States to develop strict regulations that prohibit private providers from denying access to affordable and adequate services, treatments, or information. ${ }^{1045}$

The question is whether the WTO framework will provide for measures taken by Members in a PPP context to be brought within and challenged under the GATS framework. This is an area that can benefit from further detailed research and interpretation. In the current context it appears that there could be an inclusion of PPPs and application of GATS rules to PPPs, as this is an area where foreign service providers can see an opportunity of entering new markets and benefitting from the application of GATS rules. In this context, Members must stay aware of the criticisms of the role of private sector actors in health services, particularly with regard to the negative impact on the right to health-based policy for health services and their "shaping the public health agenda, often under the umbrella of public-private partnerships or in more subtle but sophisticated ways". ${ }^{1046}$

\subsubsection{4. “Commercial” Activity: Views on Benefits and Motivations}

A final point regarding the understanding of the term "commercial" in the WTO context is that wider economic policy considerations seem to be excluded in favour of a narrow definition of commercial benefits.

The Canada-Wheat Exports and Grain Imports dispute included a reference to the term commercial in the context of Article XVII:1 of the GATT 1994 and its Ad note. These provisions concerned the obligations of State Trading Enterprises (STE) to act "solely in accordance with commercial considerations" in purchases and sales and to charge different prices only for "commercial reasons". The meaning of the term "commercial considerations" in Article XVII:1(b) was assessed by the Panel in this context as:

...meaning considerations pertaining to commerce and trade, or considerations which involve regarding purchases or sales "as mere matters of business". ${ }^{1047}$

\footnotetext{
1044 United Nations Economic Commission for Europe, Guidebook on Promoting Good Governance in Public-Private Partnerships, United Nations, UNECE, 2008, cited in the WTO, Secretariat Background Note, Environmental Services, S/C/W/320, 20 August 2010, para.2.

${ }^{1045}$ CESCR, General Comment No. 24, State Obligations under the International Covenant on Economic, Social and Cultural Rights in the Context of Business Activities, UN Doc. E/C.12/GC/24 (2017).

1046 Nygren-Krug, Helena, The Right (s) Road to Universal Health Coverage, Health and Human Rights 21.2, 2019, 215, citing Richter J., Public-private partnerships for health: A trend with no alternatives?, Society for International Development. 2004;47(2):43-48.

${ }^{1047}$ Panel Report, Canada-Wheat Exports and Grain Imports, para.6.85.
} 
The Panel goes on to say that this also implies trade on "economically advantageous" terms. ${ }^{1048}$ However it is stated that it would not be in accordance with its obligations to act "solely in accordance with commercial considerations" under the relevant provision if the STE also acted on the basis of:

...the policies pursued by their governments, or the national (economic or political) interest of the Member maintaining the STE (footnote omitted $)^{1049}$

This is a narrow view of economic advantage and does not recognize the position and role of these activities in the larger economic context, nor the national responsibility of a government to take such considerations into account. The Panel explains that this is because these considerations:

...do not relate to, and are not characteristic of, commerce and trade, and they are not consistent with regarding purchases or sales as mere matters of business ${ }^{1050}$

While there is justification for the application of the non-discrimination principle in international trade, such a contraction of the right of governments to carry out their obligations to their national economy in the trade context to this extent is a cause for concern. In short, according to the GATT provision, a STE must operate on solely commercial considerations:

Solely "commercial considerations"

= "purchases or sales "as mere matters of business" (implies trade on

"economically advantageous" terms)

$\neq$ based on policies pursued by governments, or the national (economic or

political) interest of a Member

The Panel has further commented that non-commercial considerations include "political" considerations ${ }^{1051}$. While the Panel is not entirely clear what political concerns are, the suggestion is that it involves patriotism, whereas private commercial activities do not. ${ }^{1052}$ This is not to argue that there ought to be in general a broad interpretation of 'commercial' in the WTO, in order for governments to have more freedom to act through STEs in providing 'public goods'. It is that a critique should be raised as to why governmental activities involving trade and commerce have been artificially disconnected from the national interest (and the provision of public goods) under the WTO system. Furthermore, the provision of public goods is not solely or even primarily a commercial activity but an activity in the national interest which may also include a commercial aspect. Public health services are a case in point.

With regard to whether the interpretation of commercial for STEs in the GATT has any implications for the interpretation of the term "commercial basis" for SSEGA in the GATS; does the outcome of Canada-Wheat Exports and Grain Imports suggest that any mere business activities ("economically advantageous" purchase and sales of services) could be seen as commercial, but policy planning or national interest ("patriotic"?) matters are not? Does this mean that as long as (and only to the extent that) governmental

\footnotetext{
${ }^{1048}$ Ibid., para.6.87.

1049 Ibid., para.6.88.

${ }^{1050}$ Ibid., para.6.89.

${ }^{1051}$ Ibid., para.6.94 and footnote 175 .

1052 Ibid., footnote 177 . Indeed, as Jacob Viner aptly put it:

Private enterprise, as such, is normally non-patriotic, while government is automatically patriotic.

(Jacob Viner, International Relations between State-Controlled National Economies, American Economic Review, no. 34, supplement March 1944, p439).
} 
authority regarding public services is limited to implementing governmental policy but stays out of the business of supplying services generally (unless it is entirely devoid of user fees) can it be retained as SSEGA (not supplied on a commercial basis) and left out of the GATS scope?

It should also be noted that if looking towards an end result of retaining space for governments to provides public goods and public services while also being able to engage in trade and commerce through public institutions and corporations, there is a contradiction that could arise regarding the interpretation of 'commercial' in Article XVII:1 of the GATT 1994 and its Ad note as compared with Article I:3 of the GATS. If, for STEs, a wide interpretation of 'commercial' could include reasons of national (economic and political) interest; that would allow for the recognition of more policy space for STEs under the GATT. But if similar arguments are applied for SSEGA, that would bring more public services within the scope of the GATS, thereby reducing the available policy space.

When the government supplies a service, does that create a presumption as to a noncommercial nature of the service or does it create a contrary presumption of the commercial nature of the service? Unless there is other evidence to support a noncommercial nature of the service, it appears that it would be considered "commercial". The Appellate Body in US-Anti-Dumping and Countervailing Duties (in the context of supply of financial loans and Article 14(b) of the SCM Agreement):

We see nothing to suggest that the notion of "commercial" is per se incompatible with the supply of financial services by a government. Therefore, the mere fact that loans are supplied by a government is not in itself sufficient to establish that such loans are not "commercial" ... ${ }^{1053}$

There is also a suggestion in the literature that 'corporatization', which can sometimes refer to public institutions transforming into state owned enterprises as a means of becoming more efficient, also suggests profit motivation ${ }^{1054}$ and services supplied by such bodies can therefore be considered "commercial" in nature.

As a final point, a question could be raised as to whether the theories on understanding the nature of sovereign and non-sovereign acts in public international law (in the context of State immunities) could be of any relevance to this situation. It may seem to be a bit of a stretch to relate sovereign immunity to exemption from the scope of the GATS, but general public international law in this area also has ways of approaching the definition of activities as either commercial or non-commercial. It is an interesting matter to look into.

The UN Convention on Jurisdictional Immunities of States and their Property, 2004, Article 2(1)b; defines 'State' as including units and entities that are entitled to perform

1053 Appellate Body Report, US-Anti-Dumping and Countervailing Duties, para.479.

1054 See for example, Ham, Chris and Lorraine Hawkins, Implementing Organizational Reforms to Hospitals in the Public Sector in Preker, Alexander S, and April Harding Eds. INNOVATIONS IN HEALTH SERVICES DELIVERY: THE CORPORATIZATION OF PUBLIC HOSPITALS, World Bank, 2003; Harding, April and Alexander S. Preker Eds., PRIVATE PARTICIPATION IN HEALTH SERVICES, World Bank, 2003; Akin, John S., Nancy Birdsall, David M. De Ferranti, FINANCING HEALTH SERVICES IN DEVELOPING COUNTRIES: AN AGENDA FOR REFORM, World Bank Publications, 1987; Berkley, Seth, Jose-Luis Bobadilla, Robert Hecht, Kenneth Hill, Dean T. Jamison, Christopher J. L. Murray, Philip Musgrove, Helen Saxenian and Jee-Peng Tan, WORLD DEVELOPMENT REPORT 1993 : INVESTING IN HEALTH, World Bank Publications, 1993. 
and are actually performing acts in the exercise of the sovereign authority of the State. Shaw notes that:

With the adoption of the restrictive theory of immunity, the appropriate test becomes whether the activity in question is of itself sovereign (jure imperii) or non-sovereign (jure gestionis). In determining this, the predominant approach has been to focus upon the nature of the transaction rather than its purpose. ${ }^{1055}$

In the footnote to the above statement, Shaw gives the examples of a number of domestic cases as well as an analysis of Section 1603(d) of the US Foreign Sovereign Immunities Act of 1976, that,

...the fact that goods or services to be procured through a contract are to be used for a public purpose is irrelevant; it is the initially commercial nature of an activity or transaction that is critical. ${ }^{1056}$

However, Shaw goes on to add that Article 2(2) of the UN Convention, 2004, also needs to be taken into account as in determining whether a transaction is a "commercial transaction", this Article notes that:

...reference should be made primarily to the nature of the contract or transaction, but its purpose should also be taken into account if the parties to the contract have so agreed, or if, in the practice of the state of the forum, that purpose is relevant to determining the non-commercial character of the contract or transaction [emphasis added].

Shaw explains that the reason that this modification to the 'nature' of the transaction was included in the Convention was in order to:

...provide an adequate safeguard for developing countries, particularly as

they attempt to promote national economic development. ${ }^{1057}$

In the context of sensitive services such as health services, it can be argued that this policy space should not be limited to developing countries, and indeed, the Article does not do so; it only notes that that in determining the non-commercial nature of a transaction the practice of the domestic jurisdiction should play a part. Shaw, citing the International Law Commission Report of 1991, gives "procurement of medicaments for fighting epidemics" as an example for State practice relating to non-commercial purposes. Government procurement of health services in such an emergency situation of an epidemic should be exempt from the WTO GATS under Article XIII of the GATS (as government procurement that is not for commercial use in the supply of goods and services for sale or commercial resale) - so this example is not particularly helpful. There is government procurement for public health services that is not for commercial sale or resale and is part of the normal, non-emergency situations on a daily basis. Immunization services, primary health care, accident services, preventive and palliative care for communicable and noncommunicable diseases and all necessary health services are all situations that could be defined within 'non-commercial' in the public health system. It is the issue of transactions and measures for the maintenance and development of a public health services as $a$ general aspect of development that is the question.

The dicta of a number of cases in the public international law context, particularly the $I$ Congreso case, discuss further the nature of sovereign acts, the relevance of state policy, the mixed public and private characteristics of the context and the overlap between the

\footnotetext{
1055 Shaw, Malcolm N., INTERNATIONAL LAW, $6^{\text {th }}$ Edition, Cambridge University Press, 2008, p709

${ }^{1056}$ Ibid., (Shaw), footnote 64 at p709.

${ }^{1057}$ Ibid., (Shaw), p710
} 
activity and the motive and purpose of the act. ${ }^{1058}$ Shaw sums up this area of international law referring to the dicta of Lord Wilberforce in the I Congreso case, that the ultimate test of what constitutes jure imperii is not just concerned with having a public/State purpose or motive but whether the act in question is:

...of its own character a governmental act, as opposed to an act which any private citizen can perform ${ }^{1059}$

Considering that private actors are now considered capable of performing almost all of the governmental acts that can be called 'public' and often carry out such activities, ${ }^{1060}$ these developments in public international law greatly narrow the scope of jure imperii and make it possible that most services can be jure gestionis or commercial in nature. Thus it seems that while public international law draws greater attention to the purpose of governmental activities and the practice of States in determining whether an activity is non-commercial; this 'taking-into-account' approach may not in the end be of much assistance, if the crucial feature is that public services can also be carried out by private actors.

\subsubsection{2. "In Competition with"}

\subsection{Competition within the Market or for the Market}

As seen earlier in the context of Canada-Renewable Energy/Canada-Feed-in Tariff Program, the existence of competition is linked with the understanding of what is "commercial". The definition of SSEGA in Article I:3 of the GATS includes both these aspects.

There is an economic and political connotation to the idea of competition as a good that should be promoted, and that can be said to also underlie (at least some parts of) the WTO system. But in this particular situation, if we focus on the interpretation of the above term "in competition with" and turn to the trusty dictionary definition of competition, we can find the following:

The action of competing or contending with others (for supremacy, a position, a prize etc.) specially striving for custom between rival traders in the same commodity ${ }^{1061}$

The general impression of competition is that it is competition within the same market. Moreover, if it is also part of the understanding of the term "competition" that each competitor is striving against the other for a greater share in the market, a question can be

1058 Ibid., (Shaw) see p710-714.

${ }^{1059}$ Ibid., (Shaw). I Congreso del Partido case, HL (1983)AC 244

${ }^{1060}$ Note that in the United States, even services that may have been seen as inherently governmental, such as fire services, prison services, military and intelligence services are being or have been privatized. The judiciary, public prosecution and police remain the only officially non-privatized services - that is, only to the extent that it is not seen as overtly corrupt and seen as truly carrying out public functions. Police tasks could be done in the future by private security firms, especially since their origins were not always public in the Anglo-American context, their origins were as security for landlords, the latter being the local judicial officers as well (See e.g. Waxman, Olivia B, How the U.S. Got Its Police Force, Time, May 18 2017, http://time.com/4779112/police-history-origins/ - on the historical origins of the police in the United States as privately funded organizations for benefit of private interests, including the 'slave patrols' in the American South; Langbein, John, The Origins of Public Prosecution at Common Law, The American Journal of Legal History, Vol. XVII, 1973, 313). Legislators would then be the only public service, but the public nature of legislators would depend on the nature of the political system - participatory and deliberative democracy, not oligarchy, theocracy, monarchy, autocratic etc.

${ }^{1061}$ New Shorter Oxford Dictionary, Oxford University Press, 1993. 
asked in the services context, whether most public service suppliers, particularly in the case of public health services, could be seen as inherently non-competitive. It is difficult to argue that public health service suppliers would want a greater share in the market or want to deprive private suppliers of business when it is economically more efficient if the public health sector provided services only for those who could not afford the higher private fees. This section of the market would not be participating in the health services sector of the economy as they would be unable to pay the higher private fees or private insurance - and are thus not really part of the market that private suppliers or foreign suppliers would be competing for. ${ }^{1062}$ There also seems little point in public services extending costs and burdening the taxpayer and Treasury by 'competing' for a greater share of the 'cream' of the market without attending to universal service obligations. However, it is possible that if fee-levying services were offered at lower cost, some portion of consumers may opt for the public option and it could thus be a source of revenue. Yet public and private health services often co-exist side by side without stepping on each other's toes, so to speak. Delimatsis comments that the fact that even when there is low priced public health services available, private health services "get a stable market share" and that could be taken to mean that they do not actually compete in the same market and that therefore these services perhaps ought not to be considered as comparable services which compete against each other. ${ }^{1063}$

However, the promotion of 'health tourism' using public facilities or better facilities for patients paying higher fees in order to raise revenue to cross-subsidize the services for the poor, can be seen as problematic - since there is an intention to profit, the possibility of making profit and a possible 'eating in to' the share of the market that could have been left to private suppliers (more on this is the section further below on subsidies). Is this competition - because there is an identifiable area of overlap between the public and private health services market? It seems easier to classify this kind of action as competition on the part of the public sector than the case of providing public health services to those who cannot otherwise afford it - and the private sector offering an additional option for those who can. However, should this particular aspect colour the entire public health services as "in competition with" private suppliers?

Competition can also be looked at from the viewpoint of the private suppliers and their market share. 'Those who can afford' private health services is not a static data-set. If government programmes for national development - health, education, employment and overall economic growth - start showing results in terms of across-the-board increases in income, the numbers of people that could access private health services will also increase. If the public health services are of good quality and availability, this can be seen as making it difficult for the private sector to access a potential market or a section of the newly expanding market (as consumers have the choice to opt for the public sector).

\footnotetext{
${ }^{1062}$ See WTO Secretariat, Health and Social Services: Background Note by the Secretariat, S/C/W50, 18 September 1998, para 38. The WTO Secretariat has commented that even where there is co-existence of private and public hospitals it has been argued that public hospitals can nevertheless be deemed to fall under Article I:3 because:

...public hospitals (and their services) constitute a sector distinct from, and not in competition with, private hospitals (and their services) [emphasis added].

However, the Note does not go on to discuss the nature of competition, but only as to whether they are "like" services.

${ }^{1063}$ Delimatsis, P, GATS and Public Healthcare: Reflecting an Uneasy Relationship in Van Calster, Geert and Marie Denise Prévost, Eds., RESEARCH HANDBOOK ON ENVIRONMENT, HEALTH AND THE WTO, Edward Elgar Publishing, 2013, p384.
} 
Whereas the public sector is not competing with the private sector to retain as many consumers as possible and to prevent the private sector entering a potential market, the private sector can be said to be unilaterally competing with the public sector (a one-sided competition), and also competing amongst themselves (different private suppliers), with an eye on increasing profits. One could say that competition is not merely about the consumers who already exist, but the consumers who potentially exist. This is competition for the market or the potential market. Profit-seeking entities would be having their eye on long-term possibilities and future consumers.

Thus, the question is not only whether the public and private suppliers are supplying the same service for the same group of consumers ${ }^{1064}$ (current consumers) but also whether "in competition with" covers situations of a unilateral or one-sided competition by private suppliers for potential consumers in a partial market overlap situation. This is a situation where there are comparable services available in a segment of the market, thus giving the patient/consumer the right to choose either the public or private service. From a proliberalization and pro-private enterprise point of view, it is unlikely that such a situation would not be considered as "in competition with". But if the intention is to carve out public services from the scope of the GATS entirely so that governments retain greater policy space over public services; then "in competition with" should at least be looked at as rivalry/competition for the same consumers by both public and private suppliers, and not as unilateral competition from the private sector. Telecommunications services and financial services such as banking could perhaps be seen as such a rivalry/competition, as the public service suppliers also act intentionally to increase their market share and make profits. The Panel in Mexico-Telecoms also referred to the notion of "rivalry in the market" as part of the definition of competition. ${ }^{1065}$ Adlung also points out that it should be the actions of the supplier concerned and not of other (cross-border) suppliers, which would decide whether there was a in that instance a situation of competition or not. ${ }^{1066}$ For example, if there is a public health service with universal services obligations being met in a certain country, with intentions of expanding services or coverage of services to any excluded communities or categories of patients, this should not be seen as competitive behavior of the public service with either domestic or foreign private health services providers. Similarly, the foreign health service suppliers such as health insurance or private hospitals who are intending to enter such a market should not be considered as somehow creating a rivalry or competition on the part of the public health service, through their own unilateral intention.

Basic services ${ }^{1067}$ such as health, education, water and sanitation services are also not of the same nature, as the public service does not make an effort to increase customers, but

${ }^{1064}$ Zacharias, Diana, Article I GATS in Wolfrum, Rudiger, Peter-Tobias Stoll and Clemens Feinaugle Eds., WTO - TRADE IN SERVICES, Max Planck Commentaries on World Trade Law, Martinus Nijhoff Publishers, 2008, p66; Krajewski, M., Public Services and Trade Liberalization: Mapping the Legal Framework, Journal of International Economic Law, Vol. 6, No. 2, 2003, 341-367,p352.

1065 Panel Report, Mexico-Telecoms, para. 7.230.

1066 Adlung, R., Public Services and the GATS, Working Paper ERSD-2005-03, World Trade Organization Economic and Statistical Division, 2005, p10-11.

1067 The term 'Basic Services' is used here in the way that it is used in UNICEF documents (see e.g. Mehrotra, Santosh, Jan Vandermoortele and Enrique Delamonica, Basic Services for All? Public Spending and the Social Dimensions of Poverty, UNICEF Innocenti Research Centre, 2000, available at https://www.unicef-irc.org/publications/pdf/basice.pdf. Also see The Report of the World Summit for Social Development (also includes the Copenhagen Declaration and Programme of Action), 1995, A/CONF.166.9, para 19: refers to manifestations of poverty including "lack of access to education and 
to provide a necessary public welfare/support system. It is submitted that maintaining and improving the extent and quality of these latter types of public services (which can unintentionally lure a few of those who could afford the alternate private services), should not be seen as competitive behaviour, but as carrying out the obligations on the progressive realization of those rights under the ICESCR and the relevant General Comments, on the availability, accessibility and quality of the services which are part of core rights of the Covenant. Using such an argument that is based on human rights obligations for the interpretation of competitive behavior is the type of 'translation' from the human rights understanding to the interpretation of provisions in the GATS which would be makes use of the 'bilingualism' approach that was discussed in the previous Chapter. Of course, unless Members raise such arguments, one cannot know of the possibility of such views being taken into consideration in WTO dispute settlement.

\subsection{Public Services facing Private Competition - Dispute Settlement Context}

Although not in a services context, the Canada-Renewable Energy/Canada-Feed-in Tariff Program dispute is relevant for the concept of competition, especially the situation of public services facing private competition. Furthermore, the nature of energy, although considered a 'good' can be a good analogy for supply of services; as well as this dispute being one concerning public interest in terms of also being about renewable energy subsidies. In this dispute, Japan made submissions that argued for the existence of competition if:

a. Public entities (in this case the energy distributers) "face private sector competition". ${ }^{1068}$

b. There is consumer choice regarding whom to purchase from. ${ }^{1069}$

The information relied upon by Japan in its arguments refers to the Panel's finding that four private companies own and operate $3 \%$ of the transmission system, and three out of 80 distributors are private companies. ${ }^{1070}$ Thus the extent of private involvement can be very minor, but there may still be arguments that these private entities are competing for a greater market share and thus the public entities are "facing competition". Therefore, based on the fact that they are facing competition, even if they are not themselves taking steps to compete with private suppliers, it is possible to argue that the public service providers "may compete" with the private suppliers. This was also the view of the EU. ${ }^{1071}$

other basic services" and para.74: "Governments should promote equality and social justice by:... (c) Expanding and improving access to basic services with the aim of ensuring universal coverage". However, the UN-Habitat Guidelines - International guidelines on decentralisation and access to basic services for all, 2009, Resolution 22/8 of 3 April 2009, extends basic services in urban areas to public spaces, transportation, sustainable energy, telecommunications and public cultural activities and heritage. The UNHabitat use of 'basic services' covers sectors which could be provided by both public and private suppliers, and especially in the case of telecommunications and transport, in competition with each other.

1068 Appellate Body Report, Canada-Renewable Energy/Canada-Feed-in Tariff Program, para.2.26

1069 Appellate Body Report, Canada-Renewable Energy/Canada-Feed-in Tariff Program, para.2.27.

${ }^{1070}$ Appellate Body Report, Canada-Renewable Energy/Canada-Feed-in Tariff Program, para.2.28: Japan recalls the Panel's finding that four private companies own and operate $3 \%$ of the transmission system127, and three out of 80 distributors are private companies. Thus, Japan submits that Ontario has established an electricity system in which Hydro One and municipally owned distributors may compete with private transmission and distribution companies in the resale of electricity to consumers [footnote omitted]

${ }^{1071}$ Appellate Body Report, Canada-Renewable Energy/Canada-Feed-in Tariff Program, para.2.50-2.53. 
Canada submitted that the Panel erred on this point and argued that there was competition between 'retailers' but not between retailers and distributers. ${ }^{1072}$ But although Japan directly requested the Appellate Body to conclude that distributors face private-sector competition, including from private-sector electricity retailers, in the resale of renewable electricity ${ }^{1073}$ and although it is an issue raised in the appeal, ${ }^{1074}$ the Appellate Body did not directly address the interpretation of public entities 'facing competition'. The Appellate Body only noted that the Panel had previously stated that the purchases of electricity by the Government of Ontario were undertaken "with a view to commercial resale", because (a the Government of Ontario and municipal governments profit from the resale of electricity under the FIT Programme and Contracts, and (b) because the resales of electricity are made "in competition with licensed electricity retailers...". ${ }^{1075}$ There is insufficient discussion on whether there would be a difference in the understanding of competition when the issue is that a public body is facing competition from private bodies that are trying to gain a stronger foothold in the market dominated by the public body/bodies. This is particularly significant in services situations where the public body, such as public health services, has been a dominant supplier, uninterested in competition, since that is not part of its motivation or strategy; and private bodies are attempting to enter the market or expand their much smaller presence.

\subsection{Co-existence, Involvement and Public-Private Partnership}

It can be argued that the mere co-existence of public and private sectors, without competition by both for shares of the same market and consumers, should not be considered as "in competition" for the purposes of the interpretation of Article I:3(c) of the GATS. Luff is also of this view, commenting that the question should not be whether the market is divided but whether there are competitive conditions in the market. ${ }^{1076}$ But Luff's criteria for competitive and commercial conditions appear to be interconnected and fairly stringent, suggesting that the situations that fall within the exemptions are situations such as health services that are fully governmentally-funded and provided free of cost, without patient choice in access (such as being compelled by geographical 'zoning') and provider income being fixed and not dependent on number of patients treated. ${ }^{1077}$

If it is someday decided that the mere co-existence of public and private in a market opens up the service sector to WTO rules, then does it mean that only monopoly and

\footnotetext{
1072 Ibid., para.2.15-2.16. See also at para.5.47:

Canada challenges the Panel's finding that Hydro One Inc. and distributors sell electricity in competition with private-sector licensed retailers.

1073 Ibid., para.2.32.

1074 Ibid., para.3.1(c):

[The Panel] failed to make an objective assessment of the matter before it, contrary to Article 11 of the DSU, when finding that the measures at issue involve purchases "with a view to commercial resale".

More specifically, whether the Panel acted inconsistently with Article 11 of the DSU in finding that:

- Hydro One Inc. and Local Distribution Companies sell electricity in competition with 1075 ...para.5.44 private-sector licensed retailers (raised by Canada) [emphasis added].

${ }^{1076}$ Luff, David, Regulation of Health Services and International Trade Law in Mattoo, A. and P. Sauvé Eds., DOMESTIC REGULATION AND SERVICES TRADE LIBERALISATION, The World Bank/Oxford University Press, 2003, p191-221, p195.

1077 Ibid, p191-195.
} 
exclusive supply situations could be exempt from the scope of the GATS? Would it still be possible for some situations of co-existence within the market to fall within the Article I:3 exemption? In light of the fact that the situation in most jurisdictions is not of monopoly situations, but of co-existence, private involvement in public services provision and public-private partnerships, a broad interpretation of competition that covers unilateral competition would exclude a majority of public services from the exemption and place them within the GATS framework. Although there is no direct statement on this in the WTO Background Notes, the matter has been mentioned indirectly.

The WTO Secretariat Background Note on Environmental Services of $2010^{1078}$ comments on the "infrastructure" features of this service "which may give rise to natural monopolies", the public provision and "characteristics of public goods", the "important social, public health and environmental policy dimensions" and "insufficient incentive" for private provision of these services. ${ }^{1079}$ It is accepted that the policy dimensions cause controversies over liberalization of such sectors and it is added that:

Liberalization of monopolistic-type industries normally requires a strong regulatory framework and ongoing surveillance in order to ensure consumer protection and the quality of the service. ${ }^{1080}$

The note goes on to comment on specific sub-sectors of environmental services, notes the importance of the role of the public sector in municipal waste management which it is claimed has not been fully privatized in any country, and the different forms of outsourcing and contracting of such services to the private sector. ${ }^{1081}$

There is a vague suggestion in the Note that a distinction can be made between collection and disposal of municipal waste produced by homes (not commonly carried out by private firms, except in certain countries like Netherlands, Belgium and Switzerland) and the solid and hazardous waste which is produced mainly by private industry and sometimes disposed of also through private services. It is possible that it may be economically efficient to allow for private environmental services to deal with solid and hazardous waste produced by private industry so long as it is regulated in terms of quality and environmental protection measures. If it is possible to regulate this effectively, the public revenue could be directed towards public services focusing on the needs of the general public in municipal household and small industry waste disposal, while the cost of industrial waste disposal can be borne by industries themselves while also creating opportunities for more private environmental services. The focus of low-cost public services that serve the needs of the general public and SMEs (small and medium enterprises) would be the main issue with regard to policy space.

The Background Note comments that the private sector can be involved in waste management through various contractual forms including divestiture of assets, service contracts, management, lease, build-own-operate (BOO), build-operate-transfer (BOT), build-own-operate-transfer (BOOT), joint ownership or concession contracts, as well as Buy-Build-Operate (BBO), Build-Lease-Operate-Transfer (BLOT), Design-Build-

\footnotetext{
1078 WTO, Secretariat, Background Note on Environmental Services, S/C/W/320, 20 August 2010 - it provides background information and updates a previous Note on Trade in Environmental Services, S/C/W/46, dated 6 July 1998.

${ }^{1079}$ Ibid., (S/C/W/320), para.5.

${ }^{1080}$ Ibid.

${ }^{1081}$ Ibid., para. 15 .
} 
Finance-Operate (DBFO). ${ }^{1082}$ The Appendix to the Background Note does not refer to Article I of the GATS, but states in relation to the categorization of private involvement or public-private partnership in environmental infrastructure services that:

From a GATS point of view, an important question is whether some of these contractual arrangements would fall under the definition of government procurement (Article XIII) and, thus, would not be covered by specific commitments and the MFN obligation.

Thus, there is an oblique suggestion that some such private involvement or public-private partnership may be exempt from certain GATS obligations (Articles II, XVI and XVII), but that private-public partnerships could otherwise fall within the scope of the GATS.

Thus, a question to consider is whether it could therefore be more beneficial for WTO Members wanting to retain policy space to enter into public private partnerships than to exclude private suppliers from the contracts available within the 'public internal market'. In an area such as health services, the 'public internal market' refers to the commercialized aspects of public health service delivery which could be carried out by private suppliers. It is relevant to flag at this point the debates surrounding the 'NHS internal market' or the introduction of competition and marketization into the National Health Service in Britain following the reforms brought in initially during the Thatcher government in the 1980s and later through the Health and Social Care Act of 2012. ${ }^{1083}$ For example, as early as 1997, Hughes et al, in studying the impact of NHS internal market reforms on equity within the system, particularly on services for the mentally ill, disabled and elderly conclude that it is not a good model to emulate. ${ }^{1084}$ Tom Sorell, in critiquing consumerist reforms of the NHS (privatizing public sector activity by either selling publicly-owned businesses or contracting out publicly-supplied services) as being objectionable both within and beyond the health care market, argues that there are rights and responsibilities of both users and the new competing private providers that can be expressed by 'solidarity', which includes respect for the humanity of patients and the moral basis of the health system. ${ }^{1085}$ Some authors have noted that while neoliberal managerial and marketization reforms to the NHS has been accompanied by the attempts to avoid political culpability and responsibility for health care more generally, the public has continued to raise the issue of governmental responsibility and the democratic deficit relating to policy changes and decision-making affecting the NHS. ${ }^{1086}$ These concerns can also be framed through a right to health-approach, based on the ICESCR, which would limit the abdication of responsibility of the State in provision of health services and

\footnotetext{
1082 Ibid., para. 15 and Appendix 1.

${ }^{1083}$ For early use of the term 'internal market' for NHS reforms, see: Enthoven A.C. National Health Service: Some Reforms that Might Be Politically Feasible, The Economist, 22 June 1985: 61 - 64: Enthoven, Alain C., Internal Market Reform of the British National Health Service, Health Affairs Vol.10, No. 3, Fall 1991.

1084 Hughes, David, Siobhan McClelland, and Lesley Griffiths, Cinderella Services in the NHS Internal Market: Does Contracting Make a Difference, Dalhousie LJ 20 (1997): 400.

1085 Sorell, Tom, Morality, consumerism and the internal market in health care, Journal of Medical Ethics 23.2 (1997): 71-76.

${ }^{1086}$ Benbow, David I., With Great Power Comes Great Responsibility”: Democracy, the Secretary of State for Health and Blame Shifting Within the English National Health Service, International Journal of Health Services 48.3 (2018): 461-481; Maybin, Jo, et al., Accountability in the NHS: Implications of the government's reform programme, (2011); Moyes, W., J. Wood, and M. Clemence, Nothing to do with me? Modernising ministerial accountability for decentralised public services, Institute for Government (2011); Pollock, Allyson M., et al., NHS and the Health and Social Care Bill: end of Bevan's vision?, BMJ 327.7421 (2003): 982-985.
} 
imposes obligations to assure that private actors do not cause retrogression in the progressive achievement of the right to health.

WTO Members should consider the benefits and harm of such commercialization of health and other public services, both in the context of their national law and policy and well as for international trade consequences. Competition for contracts in the "public internal market' may be excluded from the definition of "competition" depending on the interpretation of the provision on monopolies and exclusive service suppliers and the results of the negotiating mandate for government procurement. These provisions and their implications will be discussed in further detail in the next section of this Chapter.

Before moving on to analysis of these other provisions, a look at the Secretariat Background Notes on Health and Social Services may be useful. The 1998 Background Note acknowledges that medical, health and social services:

...may be core instruments in the pursuit of social and distributional justice or could be viewed as important contributors to, or preconditions for, economic development...

...health and social services have long been considered as (a) nontradeable to be provided by (b) public institutions... ${ }^{1087}$

However, it is added "there has been a change in policy perception" and initiatives that "may lead to greater market orientation" in many countries. ${ }^{1088}$ The Note goes on to focus on these policy changes and what it identifies as the "one common denominator" in health research: "efficiency considerations". ${ }^{1089}$ It is explained that "more prudent resource use" can come through introduction of

...organizational changes... monetary incentives in hitherto tightly regulated areas (commercialization of hospital functions) or reforms in public insurance and subsidy schemes to encourage more prudent resource use. ${ }^{1090}$

With the 'commercialization' emphasis already in place, the Note goes on to discuss the overall conditions of the public-private relationship in the health systems. It is noted that with the "gradual shifts towards systems with private participation", there is also "competition between private and public health care providers" and "competition between integrated systems". ${ }^{1091}$ It seems that co-existence and competition are considered as possibly connected, perhaps causally linked. For Article I:3 to be given any weight, there should not be an automatic assumption of 'competition' merely due to co-existence in the market. The Note also considers this, commenting that:

The co-existence of private and public hospitals may raise questions, however, concerning their competitive relationship and the applicability of the GATS: in particular, can public hospitals nevertheless be deemed to fall under Article I:3?

It is stated that Article I:3 of the GATS would cover situations where there is "medical and hospital treatment directly through the government, free of charge"1092 - but that it

1087 WTO Secretariat, Background Note, Health and Social Services, S/C/W/50, 18 September 1998, paras.7 and 9 .

${ }^{1088}$ Ibid., para.9.

${ }^{1089}$ Ibid., para. 8 .

${ }^{1090}$ Ibid.

1091 WTO Secretariat, Background Note, Health and Social Services, S/C/W/50, 18 September 1998, para.34. The original footnote to this paragraph cites U.S. Department of Commerce/International Trade Administration Report of 1998.

${ }^{1092}$ Ibid., para.37. 
"seems unrealistic" to argue that Article I:3 would continue to apply were both public and private hospitals "charge the patient or his insurance", since this would suggest a competitive relationship. ${ }^{1093}$ It is explained that the result of such competition would be that, "subsidies and any similar economic benefits" conferred on public services would be subject to the national treatment obligation under Article XVII, if the sector is scheduled.

A quick perusal of Secretariat Notes on various sectors suggests that the overall view is that if fee-levying public services exist alongside private services, there is an assumption of the commercial and competitive nature of such public services. But this approach makes an assumption that does not go deeper into the nature of 'what is commercial?' and 'what is competition?'. ${ }^{1094}$

Thus, it appears that what exactly Article I covers on the following scale is not possible to clearly identify, except to say that one extreme end of the scale, a completely public monopoly, would be exempted:

Completely public monopoly $\leftarrow---------------\rightarrow$ Completely market oriented health sector

Another measurement including whether fees are charged or not may be needed, since the Article I:3 exemption may still cover some situations of a co-existence, where fees are not charged. The Background Note on Education, also noting health services as another sector which features "an important public service aspect" states that with regard to Article I:3 of the GATS:

The coverage of the carve-out will thus have to be determined on a case-bycase basis. ${ }^{1095}$

A quick perusal of the Background Notes by the Secretariat published from1998 onwards shows several varieties of models of public services being discussed. It appears that the following situations are covered by Article I:3:

- Provision by the government only, directly and free of charge - yes, since within exemption (non-commercial and no competition)

- Privatized former public monopoly - yes, since no competition)

Whereas the following would not be covered:

- Full private participation without access controls, apart from quality and qualification-related regulation, at freely negotiated prices.

- Commercial revenue generation by public sector not fully dependent on government funding (e.g. with regard to education). ${ }^{1096}$

But there is still some doubt about the following situations, although they are most likely not covered by the exemption and fall within the GATS:

- Fee levying public monopolies (subsidized or not) - may be considered as 'facing potential competition' from the private sector which want a market share.

- Co-existence of private and public sectors, where competition is assumed due to the co-existence.

- Direct private-public cooperation agreements. ${ }^{1097}$

\footnotetext{
1093 Ibid., para.39.

${ }^{1094}$ See further the previous discussion in this study under Sections 3.4.4.1.1.(The role of profit in defining "commercial" and "on a commercial basis") and 3.4.4.1.2. (Commercial = fee levying?).

1095 WTO Secretariat, Background Note, Education Services, S/C/W/313, 1 April 2010, Box.1.

${ }^{1096}$ Ibid., it is commented in the Note that Members could exercise scheduling flexibility to exempt public universities, which are "increasingly engaged in commercial revenue generation activities and may not be fully dependent on government funding". This suggest that engaging in "commercial revenue generation" could risk the non-application of Article I:3 exemption.
} 
- Public-private partnerships within a public monopoly

The nature of the health sector across different jurisdictions is that it is usually a case of co-existence of public and private. Delimatsis comments that "it bears noting" that in a dispute settlement context, it is the complaining party that bears the burden of proof and has to provide evidence of either the existence of 'competition' or the 'commercial' nature of the public service/SSEGA at issue. The DSU does not include a specific rule on the burden of proof, but it is a generally-accepted rule of evidence in most jurisdictions, that the burden of proof rests upon the party, whether complaining or defending, who asserts the affirmative of a particular claim or defence. If that party presents sufficient evidence to raise a presumption that what is claimed is true, the burden then shifts to the other party, to present sufficient evidence to rebut the presumption. ${ }^{1098}$ This underlines the fact that the text by itself may not be able to resolve this lack of clarity and a case-bycase approach is needed, which may ultimately depend on the skill of the disputing parties to bring relevant factors to the attention of the panel. However, proving "commercial and competitive nature of the service may not be as difficult requests proving the contrary, if the general trend in the trade literature of assuming coverage extends to the dispute settlement context.

After assessing the issues with regard to the definition of the terms 'commercial' and 'in competition with' in Article I:3 of the GATS and the human rights based-approach to public services, one can agree with the comment by Adlung that:

... a broader interpretation of the terms tends to blur the distinction

between 'commercial' and 'competitive' behavior... They may be viewed as two facets of the same concept ${ }^{1099}$

However, in practice, WTO panels usually followed a more literal interpretation of the terms in the text. A broader view which would bring in wider societal considerations and a grappling with the concept of public services does not seem likely as of now, but is not entirely impossible.

\subsection{Expectations on a 'carve-out' or 'ring-fence' of public services}

The VCLT general rule of treaty interpretation refers to the 'object and purpose' of the treaty concerned - and it can be argued that while some negotiators argued for the broadest possible scope and coverage by the GATS, there was also argument for limiting the scope and coverage and leaving out 'public services' by other negotiators. Although the term ultimately used was not 'public services', the intention to have some form of a carve-out was clear. Responding to the criticisms of the WTO in the Lancet in late 2000,

1097 WTO Secretariat, Background Note, Health and Social Services, S/C/W/50, 18 September 1998, para.40 comments that the legal status of Build-Operate-Transfer (BOT) arrangements, where governments may invite private investors, including foreign investors, to build hospitals through offering them certain exclusivity rights on a temporary basis, would depend on rights and obligations conferred in individual cases. It is noted that BOT arrangements

...may be viewed as some form of government-regulated commercial activity or as government procurement of the services involved.

Both these situations would be covered by the scope of the GATS (Article II and VI:4 or XIII). On the other hand, it could also be seen as temporary monopolies subject to Article VIII (non-abuse of monopoly position).

${ }^{1098}$ Appellate Body Report, US-Wool Shirts and Blouses, p14. Also see Panel Report, China-Auto Parts, para. 7.92 .

1099 Adlung, R., Public Services and the GATS, Working Paper ERSD-2005-03, World Trade Organization Economic and Statistical Division, 2005, p9. 
including those by authors Pollock and Price, ${ }^{1100}$ Adlung notes that the suggestion of a 'narrow interpretation' of the Article I:3 carve-out in the minutes of a Council for Trade in Services meeting was referring to an informal discussion of the 1998 Secretariat Background Note on Health Services. ${ }^{1101}$ Adlung points out that these were views of individual delegations and do not have any legal force, and were not suggesting an interpretation or decision for the inclusion of public services in the GATS.

Would it be possible for panels and the Appellate Body not to take the narrowest interpretation, and to affect a fair compromise between the different intentions of negotiators (for a narrow or broad exemption), if called upon to interpret Article I:3 of the GATS? Such a compromise would be particularly relevant in the case of sensitive sectors such as health where governments have made repeated promises to their general public, to maintain the supposed 'carve-out' or 'ring-fence', and where WTO officials have also reiterated that there is no move to disturb this balance. It has been suggested that some activities within the health sector could be considered non-marketable or nontradeable. ${ }^{102}$ WTO Members who become respondents in a relevant dispute could suggest such an interpretation. The question is whether any panel or the Appellate Body will have a legal basis to accept such an interpretation, if given the opportunity to do so. Can such a compromise be interpreted within the search for 'common intention' of the parties, which is the usual method used?

The promises that Members have made to their general public, a fair compromise taking into account the expectations and objectives of some Members (or more precisely the expectations and objectives of their general public) and the statements of WTO officials are not generally accepted as relevant for interpretation based on Article 31 of the VCLT in WTO law. What is considered are the legally binding promises which Members have made each other and included in the text of the Agreements (in GATS, the GATS Text, Protocols, Annexures and Schedules of Commitments). What Members have communicated to each other is the basis of the 'common intention' of the parties that a panel or the Appellate Body will try to ascertain. Political promises made within the domestic jurisdiction of a Member, between elected representative and their constituents or the members of the general public, play no direct role in interpretation of international agreements, although it is a responsibility of Members themselves to take those promises into account in negotiating the text. In a much broader sense, it can be argued that the object-and-purpose of the text of modern international agreements is to represent the broad interests of the public, but this is difficult to do this in the VCLT framework of legal interpretation, when there is not sufficient guidance in the text itself.

With regard to taking into account the different intentions of Members with regard to Article 1:3 of the GATS - meaning in particular, Members whose societal values are strongly supportive of protecting public health services and Members where there is no

\footnotetext{
${ }^{1100}$ Pollock A. M. and D. Price, Rewriting the Regulations: How the World Trade Organization Could Accelerate Privatisation in Health-Care Systems, Lancet, 2000; 356: 1995-2000.

1101 Adlung, Rudolf, Health-Care Systems and the WTO: No Grounds for Panic, 27.03.2001, available online at www.wto.org/english/tratop e/serv e/comments lancet e.doc.

1102 Delimatsis, P., GATS and Public Healthcare: Reflecting an Uneasy Relationship in Van Calster, Geert and Marie Denise Prévost, Eds., RESEARCH HANDBOOK ON ENVIRONMENT, HEALTH AND THE WTO, Edward Elgar Publishing, 2013, p365, citing Krajewski, M., Commodifying and Embedding Services of General Economic Interest in Transnational Contexts -The example of healthcare liberalization in the $E U$ and the WTO in Jorges, Christian and Joseph Falke Eds., KARL POLANYI - GLOBALIZATION AND THE POTENTIAL OF LAW IN TRANSNATIONAL MARKETS, Hart Publishing, 2011.
} 
such explicit societal value - it should be noted that the WTO Agreements are seen as representing the 'common intention' of the Members, and that is what is taken into account for interpretation. This was stated clearly by the Appellate Body in EC-Computer Equipment, when discussing tariff concessions under GATT 1994:

The purpose of treaty interpretation under Article 31 of the Vienna Convention is to ascertain the common intentions of the parties. These common intentions cannot be ascertained on the basis of the subjective and unilaterally determined "expectations" of one of the parties to a treaty. ${ }^{1103}$

The Appellate Body also stated with regard to a Members "classification practice that "the prior practice of only one of the parties may be relevant", "... in fact, may be of great importance" but that it cannot "justify exclusive reliance" on that practice. ${ }^{1104}$ This position was approved by the Appellate Body in EC-Chicken Cuts. ${ }^{1105}$ It is significant that in both these disputes, the comments on common intention related to an individual Member's argument that there was a specific intention or practice by them with regard to their tariff schedules under GATT 1994. In the context of services, the Appellate Body in both US-Gambling and China-Publications and Audiovisual Products took the same position on the common intention of Members, Members' schedules and practices, and the rules in Article 31 and 32 of the VCLT. The Appellate Body in US-Gambling stated:

Here, too, the task of identifying the meaning of a concession in a GATS

Schedule, like the task of interpreting any other treaty text, involves identifying the common intention of Members. ... we consider that the meaning of the United States' GATS Schedule must be determined according to the rules codified in Article 31 and, to the extent appropriate, Article 32 of the Vienna Convention. ${ }^{1106}$

The Appellate Body in China-Publications and Audiovisual Products noted that: ...the purpose of treaty interpretation under Articles 31 and 32 of the Vienna Convention is to ascertain the "common intention" of the parties, not China's intention alone. ${ }^{1107}$

Therefore, the same argument applies, with even greater force to the interpretation of Article I of the GATS - since it was the text agreed by the all the negotiators and not a schedule entry of an individual Member - that the different intentions of Members, even if they are relevant, cannot be the basis of an Article 31 or 32 VCLT interpretation of the Agreement.

There is still a small space for bringing in the importance of public services: that is the submission of relevant material under Article 32 of the VCLT. In EC-Chicken Cuts, the Appellate Body noted that:

... not only "multilateral" sources, but also "unilateral" acts, instruments, or statements of individual negotiating parties may be useful in ascertaining "the reality of the situation which the parties wished to regulate by means of the treaty" and, ultimately, for discerning the common intentions of the parties [emphasis added]. ${ }^{108}$

\footnotetext{
${ }^{1103}$ Appellate Body Report, EC-Computer Equipment, para.84. Also see para.109.

${ }^{1104}$ Appellate Body Report, EC-Computer Equipment, para.93

${ }^{1105}$ Appellate Body Report, EC-Chicken Cuts, paras.238-240 and paras.265-266.

${ }^{1106}$ Appellate Body Report, US-Gambling, para.160.

1107 Appellate Body Report, China-Publications and Audiovisual Products, para.405.

1108 Appellate Body Report, EC-Chicken Cuts, para.291:
} 
Thus, individual Members' position on public health services, particularly if they reflect their position and practice around the time of the conclusion of the Uruguay Round and shortly after accession to the WTO Agreements, can be considered 'relevant' and 'of great importance' to interpretation, as mentioned in EC-Computer Equipment. ${ }^{1109}$ However, it remains doubtful to what extent the distinctions and differences between Members the Appellate Body with regard to their attitudes toward a specific public services such as health services could be taken into account, since it is stated further in EC-Chicken Cuts, that events, documents which are considered to form part of the "historical background against which the treaty was negotiated" and subsequent practice may be taken into account so far as they "continue to influence or reflect the common intentions of the parties at the time of conclusion [emphasis added]" ${ }^{1110}$ Since this evaluation of common intention "would have to be determined on a case-by-case basis", ${ }_{1111}$ it remains to be seen whether there will be a dispute and whether the panels and/or Appellate Body would decide that societal values on protection of public health services are irrelevant for common intention for the reason that there are some Members who see health services primarily as commercial and did/do not support a 'carve-out' or 'ring-fence' - or whether the position will be that there was/is common intention that certain valued services such public health services would not be subject to the GATS, and that that was the reason to include Article I:3 in the text. Furthermore, the expectations of some Members that there would be a 'commercialization' and 'commodification' of the public health services of other Members due to the GATS, can also be taken as an individual, unilateral approach, rather than a reflection of the 'common intention' of all the Members.

On the issue of whether there could be a 'legitimate expectation' concept within WTO law, the common opinion among scholars is that the application of this concept in the context of disputes on WTO violations is not recognized. ${ }^{112}$ However, it has been generally stated that Members could have legitimate expectations about the way the system as a whole functions. In Japan-Alcoholic Beverages II it was said with regard to the legal status of adopted panel and Appellate Body reports that the decisions:

...create legitimate expectations among WTO Members, and, therefore,

should be taken into account where they are relevant to any dispute. ${ }^{1113}$

This is in accordance with the security and predictability concept in Article 3.2 of the Dispute Settlement Understanding, which seems to have become almost a 'constitutional principle' or of normative value within the WTO.

We can conceive of a number of objective factors that may be useful in determining the degree of relevance of particular circumstances for interpreting a specific treaty provision. These include the type of event, document, or instrument and its legal nature; temporal relation of the circumstance to the conclusion of the treaty; actual knowledge or mere access to a published act or instrument; subject matter of the document, instrument, or event in relation to the treaty provision to be interpreted; and whether or how it was used or influenced the negotiations of the treaty.

${ }^{1109}$ Appellate Body Report, EC-Computer Equipment, para.93 (as mentioned earlier in this discussion)

${ }^{1110}$ Appellate Body Report, EC-Chicken Cuts, para.293 and 305.

1111 Appellate Body Report, EC-Chicken Cuts, para.305.

1112 See Cottier, Thomas and Nadia Schefer, Good Faith and the Protection of Legitimate Expectations in the WTO, in M. Bronckers and R. Quick (eds), NEW DIRECTIONS IN INTERNATIONAL ECONOMIC LAW, 2000.

1113 Appellate Body Report, Japan-Alcoholic Beverages II, p107-108 
However, although the Panel in India-Patents(US) stated that a good faith interpretation under Article 31 required "the protection of legitimate expectations", ${ }^{114}$ the Appellate Body in the same dispute disagreed. At least the Appellate Body disagreed that Article 31 of the VCLT allowed for legitimate expectations of the parties to be sought outside the treaty text to determine the intention of the parties and that words or concepts which were not intended could be imputed in that manner. ${ }^{1115}$ The Appellate Body in EC-Computer Equipment also denied that "legitimate expectations" of a Member are relevant for the purposes of interpreting the terms in a schedule of concessions under GATT 1994. ${ }^{1116}$

There are also expressions by panels and Appellate Body in WTO disputes that the Agreements create 'expectations' that Members would act in a manner that promotes trade and competition and not impair concessions. The Appellate Body in EC-Seal Products refers to Article I:1 of GATT 1994 as protecting "expectations of equal competitive opportunities for like imported products from all Members" - and cites a long line of previous decisions supporting the fact that the content of specific obligations protect not only actual (currently existing opportunities) but also potential trade and the 'expectation' of ongoing equal competitive opportunities. ${ }^{1117}$ It seems unproblematic for Members to have expectations on the market access opportunities but raising expectations on restricting the scope of an Agreement, appears less likely.

'Expectations' remain relevant in the case of a non-violation claim under GATT Art. XXIII:1(b), although the retention of the concept there has been commented on as "controversial and problematic". ${ }^{118}$ In EC-Asbestos it was questioned whether there can still be a nullification or impairment of benefits when reasonable expectations of continued market access are affected by a measure restricting market access for products posing a serious health risk. ${ }^{1119}$ While the Appellate Body acknowledged the importance of arguments made by the EC that there cannot be an expectation for market access if an Article XX(b) defence has succeeded - the appeal of the EC was dismissed on the basis that it did not address the panels' findings on the threshold issues of the scope of application of Article XXIII:1(b). Thus, the issue of whether or not market access expectations can be the basis for a non-violation complaint even if the restrictions are measures based on risks to life and health, was not decided.

The it is difficult to argue that panels or the Appellate Body would consider in the course of interpretation, the possibility of a 'legitimate expectation' or 'expectation' that sectors such as health would be treated with special sensitivity, taking into account the subjective societal values of a particular Member or even the expectations of a number of Members that Article I:3 would be interpreted restrictively.

\footnotetext{
${ }^{1114}$ Panel Report, India - Patents, para. 7.18.

1115 Appellate Body Report, India-Patents (US), para. 45 and 48.

1116 Appellate Body Report, EC-Computer Equipment, para.97.

1117 Appellate Body Report, EC-Seal Products, para.5.87 and footnote 1013 - citing Panel Report, USCOOL, para.7.571, Panel Report, Colombia-Ports of Entry, para.7.236, Panel Report, Argentina-Hides and Leather, para.11.20, Appellate Body Reports, Japan-Alcoholic Beverages II, p.109 and Korea - Alcoholic Beverages, paras.119, 120, and 127.

1118 Carmody, Chios, Great Expectations: the Treatment of Expectations in WTO and International Investment Law, Western University Scholarship, Law Publications, Summer 6-2017. Also see Staiger, Robert W., and Alan O. Sykes, Non-violations, Journal of International Economic Law, 16.4 (2013): 741775: “...'non-violation nullification or impairment' doctrine is among the more unique and perplexing features of WTO Law".

${ }^{111}$ Appellate Body Report, EC-Asbestos, para.190.
} 


\subsection{Regarding the 'likeness' of public and private services}

Another way of differentiating public services from private services is in the interpretation and application of a concept of 'likeness' of public and private services, or more specifically domestic public services and foreign private services. While 'likeness' is a concept in MFN and national treatment, the following section discusses whether it also could provide an opportunity for a public services exemption from the scope of the Agreement, rather than only in the application of the provisions.

The Panel in EC - Bananas III stated that "to the extent that entities provide these like services, they are like service suppliers". ${ }^{1120}$ The question of whether the entities (or service suppliers) are 'like' is not usually looked into, instead the comparison is usually made between the services offered. The approach is that the nature of the entities providing the services are subsumed into the comparison of the services provided. The Appellate Body in Argentina-Financial Services made a clarification that there is no requirement to make separate findings with respect to the "likeness' of "services", on the one hand, and the 'likeness' of "service suppliers", on the other hand, and that "like services and service suppliers" was seen as an "integrated element for the likeness analysis under Articles II:1 and XVII:1, respectively [original emphasis]". ${ }^{1121}$ The Appellate Body emphasized that:

In any event, in a holistic analysis of "likeness", considerations relating to both the service and the service supplier will be relevant, albeit to varying degrees, depending on the circumstances of each case [emphasis added]. ${ }^{1122}$

This appears to focus attention away from the nature of the entities providing the services, but also leaves room for considerations relating to the service supplier depending on relevant circumstances. It can be argued that there can be circumstances such as the importance of the protection of public health services, which may require a less "holistic" view of service and service supplier.

While the concept of 'likeness' would normally arise in the GATS context under Articles II and XVII of the GATS, it could also come in indirectly in the context of Article I:3 of the GATS. According to Article I:3(c) of the GATS, the competition referred to relates to that which is present between service suppliers. There is an element of substitutability or 'likeness' of the public and private services that comes into the understanding and discussion of 'competition'. This would mean that similar considerations to 'likeness' could be used for defining the scope of the Agreement and not only for Articles II and XVII of the GATS.

The arguments for public and private hospitals not to be considered to provide 'like' services is acknowledged in the WTO discussion, with the Secretariat commenting that:

${ }^{1120}$ Panel Report, EC-Bananas III, para. 7.322; affirmed by the Panel Report, Canada-Autos, para. 10.248.

${ }^{1121}$ Appellate Body Report, Argentina-Financial Services, para.6.29.

1122 Ibid. (Appellate Body Report, Argentina-Financial Services) 
Given the perceived advantages of private over public hospitals - the absence of waiting periods, use of modern equipment, etc. - the two groups might not be considered to provide "like" services. ${ }^{1123}$

Being in competition is therefore linked to the 'likeness' of a service, particularly matters such as quality, technology and waiting lists. Unfortunately, this also suggests that there is an assumption that these public health services cannot compete because they are of lower quality in terms of 'customer service' and technology. While this may be true in the comparison of some public and private providers, it is not necessarily true across the board. The reality might be that while there are different basic comfort levels, with private facilities spending and charging more for unessentials which are nevertheless better for marketing and promoting their services, the actual service provided in terms of quality of the health service (e.g. experience and expertise of health professionals) could be higher in the public sector. ${ }^{124}$ Therefore, there could be situations where the public hospitals are not providing 'like' services, since they in fact provide superior services in terms of quality of care.

The ICESCR obligation for the protection of the Right to Health also includes progressive realization of better quality of health services, which are scientifically and medically appropriate. ${ }^{1125}$ This raises the question whether the public service can fall within the GATS as soon as the quality of the service is improved and becomes comparable to the private suppliers. Of course, it can be argued that there could be an actual 'likeness' in so far as substitutability of the services - where affluent clientele may choose the public option since they could think that it is of equal quality, while being cheaper (since there would not be the same approach to overheads and profit maximization).

This approach does not take into account the difference in the nature of either 'public services' nor of public health services (services supplied by the State)- as being different from standard commercial and competitive services, whose providers' actions are not essentially targeting human development, but which may also indirectly benefit it. In effect, treating both public and (foreign) private health services suppliers as 'like' in the WTO context could protect the foreign private suppliers from a possible loss of profit (including subsidies or other benefits which would be granted if national treatment applied). At the same time, it would draw public monies away from other public infrastructure investment and channel them into private shareholder benefits. It is not usual in the trade law context to suggest that the objectives of the service suppliers should be relevant in considering the 'likeness'/competitive relationship between services and service suppliers. However, in reality, the core of the difference $i s$ in the objectives.

On a scale of values, the cost to the public of this expected loss of private profit can hardly be compared with the gain to the public if the public health services are provided to such a high standard that may discourage entry of private health service suppliers, even in the niche areas that they would enter. It must be admitted that private health service

1123 WTO Secretariat, Background Note, Health and Social Services, S/C/W/50, 18 September 1998, para.38.

${ }^{1124}$ For example, the choice between physical and psychological comfort (private sector) and better quality medical care (public sector) is one that often faces patients in the Sri Lankan healthcare system. A more detailed example is that in the Western Province of Sri Lanka which has many private hospitals, when a patient has been diagnosed with dengue fever, the best quality services are provided by the government Infectious Diseases Hospital which has the most qualified and experienced medical staff and best record of patient care.

${ }^{1125}$ CESCR, General Comment No 14, para.12(d). 
suppliers are not going to be spearheading national programmes for immunization; prevention of non-communicable disease; tackling sanitation, clean water, diarrhoea, cholera; child malnutrition reduction through promotion of breast-feeding and healthy nutritional supplements; carrying out anti-malaria programmes, HIV prevention or antituberculosis activities; dealing with parasitical diseases such as Guinea worm/Tape worm; carrying out primary health education and treatment campaigns - all of which need to be carried out by public health services, particularly in developing country health systems. It has been analysed that the creation of space for profit-oriented private health suppliers within or in place of some of these national programmes dilutes not just the ethos of the public health system but also diverts focused attention away from the achievement of such health goals. ${ }^{1126}$ It is obvious that exempting public services from trade rules would allow for a greater extent of policy space to implement State responsibilities on public health than otherwise and a strengthening of public health services. Whether sufficient space will continue to exist which allows a State to take all the measures that it needs to meet its public health responsibilities, if public services are deemed as covered under the GATS, is a different matter. Foreign service suppliers can and do enter health services markets across the world even in the absence of Members' explicit acknowledgement of general or specific commitments under the GATS, and it is possible that these activities can be done at a small scale without significantly affecting State responsibilities on public health and right to health. It is the tension between the explicit promotion of the objectives of large private foreign health service suppliers and the objectives of public health services, which brings attention to the relationship of the GATS and health services (and raises red flags).

Adlung is of the view that Article I:3 of the GATS does not use 'likeness' at all, unlike Article II and XVII of the GATS. It is suggested that 'competition' for the purposes of the GATS refers to:

...the supply of any service in competition between one or more suppliers, rather than to competition between like services or like suppliers [original emphasis] ${ }^{1127}$

Adlung suggests that it is therefore possible that services which are 'unlike' can be thought of as in competition or that "seemingly like services" can be supplied by 'unlike' suppliers for different clienteles. By that logic, public health services suppliers supplying primary healthcare e.g. immunization and private health service suppliers specialized in cosmetic surgery can thus be described as being in competition with each other - which is an unreasonable conclusion. It may also be that services can compete across different modes of supply. ${ }^{1128}$ There seems to be something wrong or at least incomplete in such a picture. Thus, concepts of direct competition and substitutability could be used to acknowledge the differences in such services. ${ }^{1129}$ Delimatsis, as mentioned earlier, noted

\footnotetext{
${ }^{1126}$ See for example the discussions concerning the impacts of the changes in policy that led to greater private sector participation in the British NHS: Frith, L., The changing face of the English National Health Service: new providers, markets and morality, British Medical Bulletin, 2016, 119(1), p5-16; Relman, A., Medical professionalism in a commercialized healthcare market, JAMA. 2007;298, p2668-70; Caton P., At What Cost? Paying the Price for the Market in the English NHS, CHPI, 2014.

${ }^{1127}$ Adlung, R., Public Services and the GATS, Working Paper ERSD-2005-03, World Trade Organization Economic and Statistical Division, 2005, p9.

${ }^{1128}$ Panel Report, Canada-Autos, p417, stated in the context of Article XVII (national treatment), that 'like' services may be supplied through various modes

${ }^{1129}$ Krajewski, M., Public Services and Trade Liberalization: Mapping the Legal Framework, Journal of International Economic Law, Vol. 6, No. 2, 2003, 341-367, p353; Marchetti, Juan A. and Petros C.
} 
that the private sector maintaining a stable market share despite lower-priced public healthcare would suggest that there is no 'likeness' or competition between the two services. ${ }^{1130}$ But the application of such concepts in a way that governments can determine the scope of "in competition with" in Article I:3 remains unclear.

Adlung states that it can be argued that an element of competition exists even with regard to "a country like Canada, where education and health services are normally provided for free by the government without parallel private supplies" - because there can be considered to be 'cross-border' competition with the United States since Canada offers a cheaper substitute for identical yet more expensive US healthcare. This will appear even stranger if applied to another US neighbor, Cuba (which also has cheaper health services) - since such an approach would mean that Cuban public health services can be considered "in competition with" US private health services. ${ }^{1131}$ Thus, if "(cross-border) coexistence and substitutability were equated" the fact that there is a domestic monopoly would not be sufficient to exclude such a service from the scope of the GATS. ${ }^{1132}$ The same argument can be raised in this instance which was raised earlier under 'competition for the market' and the relevance of 'rivalry' and wanting to attract these cross-border clients. There would probably be a difference if there was active 'poaching' for the purposes of profiting from health tourism as a primary goal of the service, but should not otherwise be considered as 'like' and "in competition with"

Cossy comments that Members have shown limited interest for discussing such issues of 'likeness' in services in the abstract, and have preferred to determine 'likeness' on a caseby-case basis. ${ }^{1133}$ The reference by Cossy in this instance is to 'likeness' in Article XVII of the GATS. Article XVII:1 of the GATS provides for the application of the principle of national treatment to a sector which has been scheduled in a Members schedule of specific commitments. Thus, it can be argued that the same process can also apply to the possibility of a 'likeness-type' test for the general scope of the Agreement provided for in Article I:3(c); in particular for the concept of 'competition'.

The Panel in Canada-Autos, although following EC-Bananas III, did not make a general interpretation for 'likeness' for the GATS nor comment on the nature of the producers/suppliers. ${ }^{1134}$ Thus the issue was raised anew in US-Gambling, and the parties

Mavroidis, What are the Main Challenges for the GATS Framework? Don't Talk about Revolution, European Business Organization Law Review, No. 5, 2004, p511-562, p531.

${ }^{1130}$ Delimatsis, P., GATS and Public Healthcare: Reflecting an Uneasy Relationship in Van Calster, Geert and Marie Denise Prévost, Eds., RESEARCH HANDBOOK ON ENVIRONMENT, HEALTH AND THE WTO, Edward Elgar Publishing, 2013, p384.

${ }^{1131}$ See for example the controversial documentary film 'Sicko' (1997) directed by US film-maker and social activist Michael Moore (not to be confused with the former WTO-DG Mike Moore), where a group of US patients were taken to Cuba to highlight the differences in access and affordability of the same healthcare in the two countries. The documentary compares the US health system with the nonprofit universal health care systems of Canada, the United Kingdom, France and Cuba.

1132 Adlung, R., Public Services and the GATS, Working Paper ERSD-2005-03, World Trade Organization Economic and Statistical Division, 2005, p10.

${ }^{1133}$ Cossy, M., Determining "likeness" under the GATS: Squaring the circle, WTO Staff Working Paper, Economic Research and Statistics Division, ERSD-2006-08 September 2006, p1.

${ }_{1134}$ Note that there is a concept of 'likeness' similar in the SCM Agreement, which may be relevant for services subsidies if negotiations in services subsidies take over some of the SCM rules.

Van den Bossche, Peter, THE LAW AND POLICY OF THE WORLD TRADE ORGANIZATION: TEXT, CASES AND MATERIALS, Cambridge University Press, $2^{\text {nd }}$ Edition, 2008, p578 notes that footnote 46 to the SCM seems narrower than Art. I and III of GATT 1994 (as well as the concept of 'likeness' in the 
and third parties expressed very different views on whether 'likeness' needed to be assessed for both services and service suppliers. ${ }^{1135}$ The United States argument that their state monopolies of gambling services are not 'like' non-state private suppliers was not really decided in that dispute. The issues which were raised by the United States as differences in state monopolies and private ('remote' or internet) suppliers included those "relating to law enforcement and consumer protection, protection of youth, and health" and the "intense regulatory control" of the state gambling monopolies was contrasted with private/internet gambling. ${ }^{1136}$

The United States also highlights the difference in 'risk' (including risk to health via addiction) of the different modes of supply of gambling as playing a role in them not being 'like' services, citing the Appellate Body in EC-Asbestos (which was with regard to 'likeness' in Article III:4 of the GATT 1994) that:

$[\mathrm{w}] \mathrm{e}$ are very much of the view that evidence relating to the health risks associated with a product may be pertinent in an examination of 'likeness'...1137

Thus, it is possible to argue that differences in the extent of health risks or consequences can be relevant criteria for identifying services as not being 'like' services. Yet is it possible to compare the differences between public and private and different modes of supply in health services in a similar manner? It is possible to make an analogy with the gambling dispute situation comparing the differentiation of unregulated foreign private health services under Mode 1 and Mode 2 from domestic public and private regulated health services. Since most Members have not made commitments in the health sector, such a dispute may be less likely - but it is not impossible.

In such a situation, the issue of 'likeness' or the nature of the competitive relationship, may be raised again, either in a non-standard manner with regard to the scope of the GATS under Article I:3 or in the usual way, with regard to the non-discrimination principle in Article II (MFN treatment) or Article XVII (national treatment). Further discussion on national treatment and the possibility of using the 'likeness test' for making a differentiation between foreign service suppliers and domestic public services will be presented in Section 4.5.2 of Chapter 4 of this book.

If unsuccessful in differentiating public services or measures protecting public services in both instances (with regard to domestic private suppliers or foreign private suppliers), the path which remains open is that of using exceptions to defend the measure that makes a differentiation between these types of services as 'necessary' for the protection of human life or health under Article XIV(b) of the GATS. However, if the 'likeness' issue is resolved at an earlier stage of such a dispute, such as determining the scope of the Agreement, it becomes obviously unnecessary to assess the application of exceptions.

Agreement on Safeguards), but that the approach to establishing in it is similar. See Panel Report, Indonesia-Autos, paras. $14.174-14.175$ which refer to the criteria of physical characteristics, end users, consumer habits and preferences, tariff classification, the degree of substitutability and analysis of price undercutting. The same sort of criteria could be used for services.

${ }^{1135}$ Panel Report, US-Gambling, para. 3.154.

1136 Ibid., para.3.156.

${ }^{1137}$ Ibid., citing the Appellate Body Report, EC-Asbestos, para.113. 


\subsubsection{6. "Offered to the public generally"}

The problem with the definitions in Article I:3(b) and (c) is that it is like a game where the most important concept 'public services' cannot be said aloud, but everyone has to dance around it. The negotiators of the Agreement have settled for "services supplied in the exercise of governmental authority" (SSEGA), which raised all the interpretive problems discussed so far.

Is it useful to look at the concept of "offered to the public generally" to understand the concept of public services? Adlung, noting that Article I:3 does not use 'public services', comments that the "closest match" to that concept is the definition in Article XXVIII(c)(ii) of the GATS: ${ }^{1138}$ which is:

(c ). "measures by Members affecting trade in services" include measures in respect of

(ii) the access to and use of, in connection with the supply of a service, services which are required by those members to be offered to the public generally.

"Measures by Members affecting trade in services" is phrase not in Article I:3 but in Article I: 1 of the GATS referring broadly to its scope of coverage. Article XXVIII(c)(ii) refers to 'measures' (listed as (ii) and (iii) - not to 'services' or the nature of services. There is no suggestion in the text of the GATS that Article XXVIII(c)(ii) would apply to and be read with Article I:3(b) and (c), except that the scope of "services" in Article I:1, is limited by Article I:3(b) and (c). Thus, measures in respect of "services... offered to the public generally" in the context of use, access and supply of a (different) service, fall within the GATS. This seems to mean that under the GATS, public infrastructure services should be accessible for all service suppliers. It could be said that this highlights the importance of public services (as "services... offered to the public generally") for trade in services, whether or not the said public services (if they are "services supplied in the exercise of governmental authority"), fall within or outside the scope of the GATS

The phrase "offered to the public generally" is also used in the 1998 Annex on Telecommunications, with regard to the scope of the GATS telecommunications sector. Thus, we can look at what it may mean in the context of telecommunication services. This also has relevance for health services as well, but generally speaking, the extent of access to telecommunication networks could either facilitate or preclude cross-border trade in health services (telemedicine). ${ }^{139}$ According to Paragraph 2 of the Annex on Telecommunications, its scope is with regard to:

... all measures of a Member that affect access to and use of public telecommunications transport networks and services.

The definitions provided for in Paragraph 3(b) and (c) state that:

\footnotetext{
${ }^{1138}$ Adlung, R., Public Services and the GATS, Working Paper ERSD-2005-03, World Trade Organization Economic and Statistical Division, 2005, p1 and footnote 2.

${ }^{1139}$ Butkeviciene, Jolita and David Diaz, Chapter 9: GATS commitments in the health services sector and the scope for future negotiations in INTERNATIONAL TRADE IN HEALTH SERVICES A DEVELOPMENT PERSPECTIVE, UNCTAD-WHO Joint Publication, UNCTAD/ITCD/TSB/5 WHO/TFHE/98, 1998, p142 -(http://unctad.org/en/Docs/po9he98.pdf). Also see Mattoo, A. and P. Sauvé, Domestic Regulation and Trade in Services: Looking Ahead in Mattoo, A. and P. Sauvé Eds., DOMESTIC REGULATION AND SERVICES TRADE LIBERALISATION, The World Bank/Oxford University Press, 2003 p202
} 
(b) "Public telecommunications transport services" means any telecommunications transport service required, explicitly or in effect, by a Member to be offered to the public generally... [emphasis added]

(c) "Public telecommunications transport network" means the public telecommunications infrastructure which permits telecommunications between and among defined network termination points.

Paragraph 5(b) further adds that access and use of the above include "private leased circuits" - and this is confirmed by the Panel in the Mexico-Telecoms dispute. ${ }^{140}$

Telecommunications can be considered a public good ${ }^{141}$ which requires nondiscriminatory access for consumers - and with regard to telecommunications infrastructure maintained as a monopoly, requires non-discriminatory access for suppliers of other services that need access to telecommunications to provide their services. Here the term "public" appears to focus on that characteristic of being a public good (which can also be supplied by private suppliers). "Public" may also refer to universal service obligations ${ }^{1142}$ or concepts of the role of public services as benefitting the public/people/general population, since Paragraph 3(e)(i) states that no restrictions shall be placed on access and use other than those necessary:

...to safeguard the public service responsibilities of suppliers of public telecommunications transport networks and services, in particular their ability to make their networks or services available to the public generally [emphasis added]

Krajewski comments that universal service obligations are:

...firmly rooted in the social consensus of most societies. They can also be based on fundamental legal principles, such as basic human rights and equal access to communication and information. ${ }^{1143}$

However, the concept of "public service responsibilities" was not defined or mentioned any further in the Annex. But although there is no direct reference to government ownership of 'public' telecommunications networks and services, the connection of a particular role of governmental services and their relationship to the public/people in general is generally suggested. Both Secretariat Background Notes on Telecommunications refer to an idea that basic and value-added services may be relevant for defining or implementation of "public or universal service objectives", ${ }^{1144}$ but do not explain any further what is meant by any of these concepts or what is meant by 'public'.

\footnotetext{
1140 Panel Report, Mexico-Telecoms, para.7.381: confirms that 'public' includes private leased facilities "offered to the public generally".

1141 Gao, Henry, Annex on Telecommunications in Wolfrum, Rudiger, Peter-Tobias Stoll and Clemens Feinaugle Eds., WTO - TRADE IN SERVICES, Max Planck Commentaries on World Trade Law, Martinus Nijhoff Publishers, 2008, p687.

1142 Note that the WTO Telecommunications Glossary available online at the official WTO website http://www.wto.org/english/tratop_e/serv_e/telecom_e/tel12_e.htm, states:

Universal services - The concept that every individual within a country should have basic telephone service available at an affordable price. The concept varies, among countries, from having a telephone in every home and business in the wealthier countries to most inhabitants' being within a certain distance or time away from a public telephone in developing countries.

${ }^{1143}$ Krajewski, M., Sectoral Examples: Telecommunications and Health Services in NATIONAL REGULATION AND TRADE LIBERALIZATION IN SERVICES: THE LEGAL IMPACT OF THE GENERAL AGREEMENT ON TRADE IN SERVICES (GATS) ON NATIONAL REGULATORY AUTONOMY, Kluwer Law, 2003, p173.

1144 WTO, Secretariat, Background Note, Telecommunications Services, S/C/W/74 8 December 1998, para7 and WTO, Secretariat, Background Note, Telecommunications Services, S/C/W/29910 June 2009, para.8.
} 
The 1996 Reference Paper on Basic Telecommunications ${ }^{1145}$ adds a bit more to these definitions, stating that "essential facilities" mean ...

... facilities of a public telecommunications transport network or service that

(a) are exclusively or predominantly provided by a single or limited number of suppliers; and

(b) cannot feasibly be economically or technically substituted in order to provide a service.

Again, it is not clear whether such "essential facilities" mean services "provided by the government', although there may be an underlying suggestion.

It is unfortunate that the connections between 'public services', 'offered to the public generally', 'available to the public generally', 'public infrastructure', 'public service responsibilities', 'universal service obligations' and 'essential facilities' are left unclear. The important link between the role of the State in providing for access to services and taking necessary measures for the development of the domestic service sector and for development in general could perhaps be made clearer if these terms and their linkages were not written so obscurely.

Paragraph 5(g) ("reasonable conditions" on access and use necessary for a developing country to strengthen domestic telecommunications infrastructure) and Paragraph 6 (technical cooperation for developing country and least developed country Members) also link to the role of the State in developing the telecommunications services sector and indirectly suggest the important role of public telecommunications services infrastructure. However, the opportunity for exploring this further was not really followed up in the Mexico-Telecoms dispute, although it presented itself. ${ }^{1146}$

Another issue is that a method that is used for bearing and spreading the cost of universal service obligations (and general development objectives) is cross-subsidization. It appears that there are limitations on the use of cross-subsidization according to paragraph 1.1 and 1.2 of the reference Paper on Telecommunications. Paragraph 1.1 refers to "competitive safeguards" and the prevention of "anti-competitive practices" in telecommunications. "Anti-competitive practices" are specifically described in Paragraph 1.2 as including "engaging in anti-competitive cross-subsidization".

\footnotetext{
1145 The Reference Paper is described as

... a set of regulatory principles that is legally binding for those WTO governments which have committed to it by appending the document, in whole or in part, to their schedules of commitments ... [and] a blueprint for sector reform that largely reflects "best practice" in telecoms regulation.

(WTO official website - http://www.wto.org/english/tratop_e/serv_e/telecom_e/telecom_e.htm).
}

See also the Panel Report, Mexico-Telecoms, paras. 7.331-7332. The Panel comments that the Annex provisions relate to and build upon the obligations and disciplines contained in the Articles of the GATS and provides notes and supplementary provisions to the Agreement; the provisions of the Reference Paper on Telecom draw from and add to existing obligations of both the GATS and the Annex on Telecommunications. However, although the obligations in the Annex and the Reference Paper may overlap the Annex is applicable to all Members and all sectors in which specific commitments have been undertaken. The Reference Paper obligations are additional commitments undertaken by Members.

1146 See for detailed analysis on the dispute, its background and the disregarded development dimension: Kelsey, Jane, SERVING WHOSE INTEREST: THE POLITICAL ECONOMY OF TRADE IN SERVICES AGREEMENTS, Routledge, 2008, p165-167. 
Gao argues that cross-subsidization is not per se illegal, as some may think, but only when it can be deemed an anti-competitive practice by a major supplier, as per Paragraph 1.1. ${ }^{1147}$ But this assessment also suggests that public telecommunications services can be easily covered by the rules in the Reference Paper, as one of the features of a "major supplier" as defined in the Reference Paper is "control over essential facilities". The only element which then remains to be proven is whether the cross-subsidization is anticompetitive in the specific instance. Gao comments more specifically in a different text that "universal service is possible only by way of cross subsidization [emphasis added]" and further that such cross subsidization is possible "only if one operator i.e., a monopoly, provides services to all markets". ${ }^{148}$ Therefore, cross-subsidization seems targeted towards 'large'/'monopoly providers, most likely to be public providers. The tip-toeing around the issue of cross-subsidization as if it is not necessarily concerning public services is a waste of time in services such as telecommunications and others where until recently, they were considered 'public goods' provided by a public provider.

Although this particular interpretation of cross-subsidization applies only to the additional commitments undertaken in the telecommunications sector, there is the issue of whether similar provisions would be included in the 'unfinished business' of Article XV of the GATS. Since Article XV of the GATS would apply to subsidies regulation to all service sectors, it is important to be vigilant with regard to the matter of cross-subsidization and its link with universal service obligations as well as its possible use for promoting economic and social rights such as the right to health. Competition policy can also be used to promote better quality services and more access and universal coverage, so a balance must be struck within future subsidies disciplines with an eye to such favourable outcomes. There may be a need to protect particular service sectors such as health and education, and as discussed elsewhere, WTO Members have made such political promises to the members of the public in their jurisdictions.

\subsubsection{Conclusions on the scope of Article I of the GATS in the context of public services}

In sum, the situation with regard to the scope and definition of services in the GATS with regard to Article I of the GATS is not entirely favourable from the point of view of those hoping that the interpretation of "SSEGA", "commercial" and "in competition with" in Article I would give sufficient policy space for measures pertaining to public services such as health services. "SSEGA" under Article I are a different concept from the broad understanding of public services and there are contrary views on the breadth of the scope of application resulting in considerable uncertainty.

Recognizing of the existence of an issue or problem and steps towards dealing with the issue could reduce anxiety and mistrust. The terms that are used are 'services supplied in the exercise of governmental authority', which is in turn defined as not being

${ }^{1147}$ Gao, Henry, Telecommunications Services: Reference Paper in Wolfrum, Rudiger, Peter-Tobias Stoll and Clemens Feinaugle Eds., WTO - TRADE IN SERVICES, Max Planck Commentaries on World Trade Law, Martinus Nijhoff Publishers, 2008, p743. See also Krajewski, M, NATIONAL REGULATION AND TRADE LIBERALIZATION IN SERVICES: THE LEGAL IMPACT OF THE GENERAL AGREEMENT ON TRADE IN SERVICES (GATS) ON NATIONAL REGULATORY AUTONOMY, Kluwer Law, 2003, p174, commenting on why private suppliers are unlikely to contribute towards universal service obligations.

1148 Gao, Henry, Annex on Telecommunications in Wolfrum, Rudiger, Peter-Tobias Stoll and Clemens Feinaugle Eds., WTO - TRADE IN SERVICES, Max Planck Commentaries on World Trade Law, Martinus Nijhoff Publishers, 2008, p687 
'commercial' and 'in competition with'. However, there is no 'official' general definition of what constitutes "services supplied in the exercise of governmental authority", and so far, such an interpretation does not appear to be forthcoming. If limiting the interpretation to these words in the GATS text, the purported 'public services exception 'does not look like a protective 'ring-fence' at all. Even if a 'ring-fence' for public services exists in Article I the GATS, that fence does not appear to enclose much ground.

There is also no single model of public supply of services within the WTO membership: the understanding of what is "public" varies according to different services sectors, national traditions and legal conditions in different jurisdictions. The scope can be delineated by a wide range of factors and influences including broad politico-economic ideology on the role of the State in the economy, the human rights obligations of the State for public services provision, universal services obligations, as well as the definition of a number of terms - those within the WTO texts, raised by the dispute settlement context and those to which attention has been drawn in expert and academic commentary. These include the terms 'public', 'governmental authority', governmental functions, public purpose and 'offered to the public'; 'competition', 'non-commercial', lack of or existence of market overlap; fees, profit; exclusive, predominant or monopoly supplier; and whether a service can feasibly be economically or technically substituted. The aspects of what is considered 'public infrastructure' and the consequences of 'public-private partnerships' can also play a role.

The implications of the choice of interpretation would be the extent to which national policy space for the protection of national public services from WTO GATS rules can be allowed to be maintained. The panels and Appellate Body of the WTO, although not unaware of the larger picture, would be expected to focus on only the interpretation of the terms in Article I:3 of the GATS. An interpretation of the terms such as "...on a commercial basis" and "... in competition with one or more service suppliers" in a manner that widens the scope of coverage of the GATS and narrows the scope of the SSEGA exemption seems more likely. But a broader approach remains a possibility, considering some aspects of the interpretation of 'public body' in Article 1.1 of the SCM Agreement by the Appellate Body Report in US-Anti-Dumping and Countervailing Duties (China).

An alternative broader 'interpretation' in light of human rights and universal services obligations may expand the protection for public services and narrow the scope of application of the GATS. This is if the idea of the role of the state and the state obligations concerning the provision of public services under international human rights law as well as national policy, can be brought into both the debate and the interpretation of the GATS. It is also possible to argue for an interpretation specific to health services, considering the special features and consequences of a successful public health system towards increasing human development. The right to health may be useful in this context to support the societal values that envision a successful and compassionate society. The "bilingual" approach or "linguistic hospitality" argued for in Chapter 2 could provide a starting point for including human rights language and the interpretation of the scope of the right to health in relation to public health services. Such an approach could suggest a synthesis between State responsibility for public services and a WTO Members' obligations relating to trade in services. However, it would appear that such an approach goes beyond the limits of an interpretation of Article I of the GATS according to the VCLT, and a rewriting or amendment which adds additional words to the existing text, may be required. 
If such an approach to Article I is a stretch too far and there is no general exemption of public services such as health services from the GATS, these services will be within GATS general obligations; and if Members have made commitments in their schedules, also fall under specific commitments. The inclusion of public services such as health services within the GATS does not mean that a GATS dispute on the subject would invariably occur. If a dispute occurs between Members and is not settled through consultations, the next step could be to inquire if a human rights (and particularly a right to health) approach can be brought in under exceptions to the GATS. This will be discussed further in Chapter 5 of this study, which goes into more depth with regard to the available exceptions of the GATS.

Members have not asked for an authoritative interpretation of Article I and the 'public services exemption' of Article I:3, probably because they would rather not 'rock the boat' and end up with a more unsatisfactory result. Could this be interpreted in a future WTO dispute? In light of how panels and the Appellate Body have approached interpretation thus far, it is likely that they will try to avoid a definition for very controversial terms unless it is directly necessary for resolving the dispute. Panels and the Appellate Body have not generally been seen as activist judicial bodies (except by US commentators) ${ }^{1149}$ but usually step forward very cautiously, case by case. But till there is an interpretation on the scope of the GATS, either by the Appellate Body or through an authoritative interpretation under Article IX:2 of the WTO Agreement, the situation will be like that story about several blind (or blindfolded) people trying to describe an elephant ('SSGEA') by identifying different body parts, but unable to say anything about the appearance and nature of the entire animal (the concept of public services). To mix metaphors, but stick to the same creature, ignoring the issue of the lack of clarity about the scope of the GATS is ignoring the elephant in the room. Even when WTO lawyers admit to seeing this elephant, we seem blinded by or using blindfolds of ideology when trying to describe its scope and purpose, without taking an objective step back and taking a look at the larger picture.

What is the 'larger picture'? It is argued here that the 'slightly larger' picture is that this lack of clarity is not good for the future of the GATS and its objective of progressively making commitments to liberalize services. The whole vision of the WTO as a system for bringing stability via a rule-based system will be undermined. It is doubtful whether there is ultimately much of a role for Article I to play, for the purposes of 'ring-fencing' public services, especially health services, as a societal value. As long as the doubts as to the scope of Article I remain, liberalization of services, especially services sectors such as health, will (and should be) undertaken very cautiously. The 'larger picture', it is argued, is that the WTO system must be placed within the vision of future, developed and civilized societies that can be created through innovation, enterprise and compassion. The GATS framework for liberalization of services is not and should not be seen as the only (or even as the primary) defining framework for services in these future societies, and must not be interpreted in such a way as to restrict the forms of public services provision that contribute to human development especially, as argued in these first substantive Chapters, the key role of public health services.

1149 See the overview of such criticisms in Barton, John H., THE EVOLUTION OF THE TRADE REGIME: POLITICS, LAW, AND ECONOMICS OF THE GATT AND THE WTO, Princeton University Press, 2006, p86-87. The 
It can be argued that allowing access to foreign private health service suppliers increases the diversity of forms of services provision and does not 'restrict' public health services provision, and this is correct in that particular sense. However, in the context of public health services in countries facing privatization, de-funding and overturning of the principles on which they have operated, in order to open the health services market to private providers, including private foreign entities, the restrictions that have occurred have usually concerned restrictions upon public health services continuing their role. That is, the changes that have been observed have been restrictions upon maintaining or expanding public health services and not any further restrictions on the entry of private providers into a market. Also included in the background of the discussion is the idea that there could be a perception of restrictions on introducing public health services which are universal and free at the point of delivery to countries which do not have such a system at present, due to prioritization of a model of competitive private health suppliers and the entrenchment of this model through legal frameworks such as the GATS. As stated in the Declaration on the Centrality of Health in Social Development issued by the WHO Task Force on Health in Development:

Market forces and profit-making enterprises on their own are unlikely to ensure equitable health outcomes. There has to be a fair share of public responsibility for health guided by a caring value system based on social justice. ${ }^{1150}$

It is possible to argue that excluding public services from the scope of application of the GATS removes the sphere of public health services from the pressures of commodification and makes it easier to ensure that national health policy and health services would be guided by equity, social justice and public responsibility. The actual role that will be played by the interpretation of Article I of the GATS in supporting such value systems is yet to be seen. It is not only a question of the viability of the WTO system, but of the kind of world we envision for ourselves.

${ }^{1150}$ Gunatilleke, Godfrey and Aleya El Bindari Hammad, Eds., HEALTH: THE COURAGE TO CARE, WHO/HPD/97.3, WHO, 1997, p60 (Annex 2). The text of this Declaration was adopted on 17 Februry, 1995 in Paris (shortly after the entering into force of the WTO in January 1995), during a meeting held at the initiative of the WHO Task Force on Health in Development. 


\subsection{IMPLICATIONS FOR PUBLIC SERVICES IN OTHER AREAS OF THE GATS}

There are some additional issues and GATS provisions related to public services that should be touched upon in considering the impact of GATS on public services. These additional issues are linked to the fact that the scope of Article I and the exemption of "services supplied in the exercise of governmental authority" - which is usually assumed to refer to public services - is unclear and unlikely to be definitively and authoritatively interpreted. There is some doubt as to whether certain public services of Members, which they may believe are outside the scope of the GATS and covered by the SSEGA exemption according to Article I, may still be subject to GATS rules under the provision on 'Monopolies and Exclusive Service Providers' (Article VIII of the GATS). In addition, the impact of future disciplines on 'Government Procurement' (Article XIII of the GATS), 'Subsidies' (Article XV of the GATS) and 'Domestic Regulation' (Article VI of the GATS), may also have significance for public services.

The following sections will briefly discuss monopolies and government procurement, while going into a little more detail about subsidies. Lastly, domestic regulation under Article VI and national treatment under Article XVII will also be briefly mentioned in connection with scope of public services, but these latter obligations will be looked at in more detail in the next Chapter of the study.

\subsubsection{Article VIII of the GATS: Monopolies and Exclusive Service Providers}

And affecting one sole throne

Without assistance

\section{From Shakespeare's Coriolanus}

Article VIII of the GATS deals with monopoly and exclusive service suppliers. The GATS does not rule out the continued existence of monopolies or exclusive service providers, whether they be public or private, but through Article VIII provides that these service suppliers generally act according to the GATS obligations (MFN treatment and specific commitments). Article VIII also creates obligations for Members on taking certain steps to prevent or minimize abuse of monopoly position, anti-competitive practices and restrictive business practices.

It is relevant to discuss Article VIII since some monopolies and exclusive service suppliers may also be public services or services supplied in the exercise of governmental authority (SSEGA) as defined in Article I:3 of the GATS. If the monopoly or exclusive service supplier is recognized as providing a service covered under Article I, as an SSEGA, then is it the case that the entirety of the GATS does not apply to such a service, including the provisions of Article VIII. There could still be other public services which are monopolies and exclusive service suppliers and which may fall within the scope of the GATS if they would not be recognized as SSEGA due to being supplied on a commercial and competitive basis. Thus, in light of the lack of clarity on Article I, could some public 
services which Members may believe are excluded under Article I, nonetheless fall under Article VIII?

The general complexity of trade in services, the nature of the suppliers and whether they are covered by GATS obligations and disciplines, the classification of services and the manner of scheduling all cause a lot of uncertainty for Members. Natens notes that the EU schedule of specific commitments shows a cautious approach because of the sensitive nature of European public services such as health and education services and their related universal service obligations. ${ }^{151} \mathrm{He}$ also comments that the EU's 2006 Consolidated Schedule 306 has a horizontal market access limitation for Mode 3 on "public utilities", which are defined by them in a footnote as including health services; and which are described as services which "may be subject to public monopolies or to exclusive rights granted to private operators". ${ }^{1152}$ This kind of limitation in the schedule can be seen as an attempt by a Member to clarify that particular public services such as health services should not be considered under any of the GATS provisions; and if not being covered by the exemption in Article I, that it should be made clear that it should also not be covered by Article VIII. Using the schedule in this manner is because of the lack of clarity on the scope of both Article I and Article VIII.

The first issue is to understand if and how monopolies or exclusive service suppliers are defined in the Agreement. Article VIII:1 and VIII:2 of the GATS, although they are about monopoly service suppliers, do not define what a monopoly is, but only specifies what a monopoly supplier cannot be allowed to do according to a Members' obligations under the GATS. The definition is in the interpretation provision of the Agreement, Article XXVIII of the GATS, which states that a monopoly supplier of a service (MSS) means:

Article XXVIII(h)

Any person public or private which in the relevant market of the territory of a member is authorized or established formally or in effect by that Member as the sole supplier of that service [emphasis added].

Article VIII:5 of the GATS, which defines exclusive service suppliers (ESS) states as follows:

The provisions of this Article shall also apply to cases of exclusive service suppliers, where a Member, formally or in effect, $(a)$ authorizes or establishes a small number of service suppliers and $(b)$ substantially prevents competition among those suppliers in its territory.

This is where the relevance to the matter of public services is obvious. How does this relate to SSEGA in Article I:3 of the GATS? It is only public services which fulfill the criteria under Article I:3(b) and (c) which would be exempted from the GATS. The existence of Article VIII means that even a public service which is not clearly exempted as an SSEGA under Article I of the GATS can be authorized or established formally or in effect by a Member as a MSS or ESS and thus come within the scope of certain GATS obligations. It is only if in a certain service sector in a certain market there is a SSEGA (service supplied in the exercise of governmental authority) that can also be unequivocally recognized as non-commercial and non-competitive as defined by Article I:3 - that it would be considered as falling outside of the scope of the GATS. Thus, it is still possible that obligations under Article VIII of the GATS apply to a public service if it is not clearly SSEGA and is an MSS or ESS as defined above.

\footnotetext{
${ }^{1151}$ Natens, Bregt, REGULATORY AUTONOMY AND INTERNATIONAL TRADE IN SERVICES: THE EU UNDER GATS AND RTAS, Edward Elgar Publishing, 2016, p83-86.

${ }^{1152}$ Ibid., (Natens), p84-85.
} 
It should also be kept in mind that if a service sector is scheduled under Article XVI (market access), that unless a limitation is entered according to Article XVI:2(a) on the number of service suppliers "in the form of monopolies or exclusive service suppliers", a Member cannot maintain or adopt such measures either on a regional or national basis. Yet it was further clarified by the Appellate Body in US-Gambling that such a measure need not be aimed at maintaining a "monopoly "or "exclusive service" but should be read to "include limitations that are in form or in effect", monopolies or exclusive service suppliers. ${ }^{1153}$ The Appellate Body hastened to add that they were not ignoring the words "in the form of" and replacing it with the words "that have the effect of", but that in viewing the text of the subparagraph as a whole its "thrust" can be seen as "not on the form of limitations, but on their numerical, or quantitative, nature [original emphasis]"1154 Thus the interpretation by the Appellate Body has widened the scope to include measures that create such conditions only in effect.

Note also the following in the Understanding on Commitments in Financial Services, which is specific to that sector:

B. Market Access: Monopoly Rights

1. In addition to Article VIII of the Agreement, the following shall apply:

Each Member shall list in its schedule pertaining to financial services existing monopoly rights and shall endeavour to eliminate them or reduce their scope. Notwithstanding subparagraph 1(b) of the Annex on Financial Services, this paragraph applies to the activities referred to in subparagraph 1(b)(iii) of the Annex.

Subparagraph1(b) of the Annex on Financial Services refers to SSEGA of Article I:3(b) of the GATS and subparagraph 1(b)iii of the Annex on Financial Services refers to:

Other activities conducted by the public entity for the account or with the guarantee or using the financial resources of the government.

"Other activities" is a phrase that can cover any type of activity relating to financial services and thus will be covered by Article VIII of the GATS - but activities under subparagraph 1(b)(i) and (ii) of the Annex are excluded (as SSEGA, but only so long as not commercial nor in competition with other suppliers). These latter activities thus excluded from Article VIII of the GATS are those related to central bank/monetary authority monetary or exchange rate policies; and activities forming part of a statutory system of social security or public retirement plans.

With regard to examples of services to which the general rules of the GATS could apply, Bigdeli and Rechsteiner believe that public monopolies such as health 'do not function on a commercial basis' and are therefore outside the scope of Article I:3 - but services such as transport services, which may be 'commercial' and 'in competition with' will fall under the GATS and under Article VIII. ${ }^{1155}$ But as discussed earlier, there cannot be complete confidence that a public health service which is a national health service and has some monopoly features, would definitely be exempted by Article I:3 of the GATS if it has some commercial or competitive features. If that is the case, and it is also a MSS or ESS as defined in the GATS, then Article VIII would apply.

1153 Appellate Body Report, US-Gambling, para.230.

1154 Ibid., para.232.

1155 Bigdeli, S.Z. and S. Rechsteiner, Article VIII GATS in Wolfrum, Rudiger, Peter-Tobias Stoll and Clemens Feinaugle Eds., WTO - TRADE IN SERVICES, Max Planck Commentaries on World Trade Law, Martinus Nijhoff Publishers, 2008, p209. 
What are these obligations? The first two paragraphs of Article VIII describe the obligations as follows:

\section{Article VIII of the GATS}

1. Each Member shall ensure that any monopoly supplier of a service in its territory does not, in the supply of the monopoly service in the relevant market, act in a manner inconsistent with that Member's obligations under Article II and specific commitments.

2. Where a Member's monopoly supplier competes, either directly or through an affiliated company, in the supply of a service outside the scope of its monopoly rights and which is subject to that Member's specific commitments, the Member shall ensure that such a supplier does not abuse its monopoly position to act in its territory in a manner inconsistent with such commitments

The obligation of a WTO Member is to see to it that monopoly service suppliers (MSS) which could be a public service - do not violate MFN and specific commitments in national treatment, market access or any other additional commitments made in the Schedules. This includes situations where the supplier competes in another area outside of its monopoly area and could thereby have 'abused its monopoly position'. This could include a public service monopoly that has diversified into a competitive market in a different service sector or sub-sector. The obligation not to violate MFN may be linked with procurement policies of a public service, where international tenders are called for supply of goods or services needed by the monopoly. If specific commitments have been made in that sector, then there cannot be more favourable treatment for domestic suppliers and violation of market access commitments.

Thus, it can be seen that while the existence of monopolies is not per se inconsistent with the GATS, but it is the manner in which the MSS acts that can be deemed to be violation of the GATS obligations. This acceptance of monopolies appears to be prima facie inconsistent with the idea of greater competition in a market, which is also usually assumed to be an important part of liberalization and free market ideology. Article IX of the GATS ("Business Practices") which follows immediately after this provision recognizes that certain 'business practices' can be a restriction on competition and trade in services - and therefore something that should be eliminated:

Article IX of the GATS

1. Members recognize that certain business practices of service suppliers, other than those falling under Article VIII, may restrain competition and thereby restrict trade in services.

2. Each Member shall, at the request of any other Member, enter into consultations with a view to eliminating practices referred to in paragraph $1 \ldots$

However, as can be seen, Article VIII business practices (practices of monopolies and exclusive service suppliers that are NOT deemed 'abuse of monopoly position') are exempt from the general rule recognizing the importance of competition. Bigdeli and Rechsteiner note that this can be compared to the concept of 'abuse dominant position' that is used in European law, but that the GATS provision is narrower ${ }^{1156}$ (since

1156 Bigdeli, S.Z. and S. Rechsteiner, Article VIII GATS in Wolfrum, Rudiger, Peter-Tobias Stoll and Clemens Feinaugle Eds., WTO - TRADE IN SERVICES, Max Planck Commentaries on World Trade Law, Martinus Nijhoff Publishers, 2008, p214-215.

Article 82 (former Article 86) of the European Union Treaty states: 
'monopoly' is defined more narrowly than 'dominant position', in that large firms in competitive conditions can have a 'dominant position').

Article VIII appears to also cover service suppliers which are broadly speaking providing public services or carry out what is broadly identified as public service responsibilities. Members may have assumed that public services generally would fall outside the scope of the GATS; but it is only "services supplied in the exercise of governmental authority" which are exempted. Article VIII would cover some public monopolies (which are not "SSEGA" and exempted under Article I:3), privatized former public monopolies, private monopolies with state recognition and state trading enterprises set up with monopoly position. However, as Adlung points out, private monopolies emerging without government interference are exempt from Article VIII. ${ }^{1157}$ It may be that such private monopolies are covered by Article IX of the GATS (abovementioned) as this provision clearly states that it covers business practices that restrain competition and trade "other than those falling under Article VIII".

However - unlike the obligation in Article VIII, where the WTO Member "shall ensure" that the MSS or ESS shall not act inconsistently with the MFN and specific commitments obligations and the 'abuse of monopoly' obligation in Article VIII paragraphs 1 and 2 Article IX:2 only requires Members, on request of another Member, to "enter into consultations with a view to eliminating [anti-competitive] practices". Article IX:2 continues on to say:

The Member addressed shall accord full and sympathetic consideration to such a request and shall cooperate through the supply of publicly available non-confidential information of relevance to the matter in question. The Member addressed shall also provide other information available to the requesting Member, subject to its domestic law and to the conclusion of satisfactory agreement concerning the safeguarding of its confidentiality by the requesting Member.

This obligation of co-operation and sharing of information is such that a violation of Article IX does not seem to provide a strong enough basis for a dispute. There is no obligation to eliminate the restrictive business practices and failure to do so is not a violation of the GATS. Bigdeli and Burri Nenova describe Article IX:2 disciplines as "soft law" provisions that cannot be subject to dispute settlement. ${ }^{158}$ The language in Article IX:2 is similar to the consultations provisions in Article 4 of the WTO DSU, in particular, the following:

\section{2 of the DSU}

Each Member undertakes to accord sympathetic consideration to and afford adequate opportunity for consultation regarding any representations made by another Member concerning measures affecting the operation of any covered agreement taken within the territory of the former

... any abuse by one more undertakings of a dominant position within the common market or in a substantial part of it shall be prohibited as incompatible with the common market in so far as it may affect trade between Member States.

1157 Adlung, R., Public Services and the GATS, Working Paper ERSD-2005-03, World Trade Organization Economic and Statistical Division, 2005, p473.

${ }^{1158}$ Bigdeli, S.Z., and Mira Burri Nenova, Article IX GATS in Wolfrum, Rudiger, Peter-Tobias Stoll and Clemens Feinaugle Eds., WTO - TRADE IN SERVICES, Max Planck Commentaries on World Trade Law, Martinus Nijhoff Publishers, 2008, p230-231. 
Article 4.7 of the DSU further states that if the consultations fail to settle a dispute within 60 days from the date of the request for consultations or if both parties jointly consider that consultations have failed within the 60-day period, the complaining party may request the establishment of a panel. Yet it is arguable that the obligation to "enter into consultations with a view to eliminating practices referred to [Article IX:1]" is not the same as consultations regarding "measures affecting the operation of any covered agreement" that are inconsistent with obligations under the covered agreements - as there is no defined obligation with regard to eliminating "certain business practices". It is only 'recognition' of the fact that it is 'trade restrictive' and that there should be co-operation, if requested. However, a panel (which can be requested upon refusal to enter into Article 4 DSU consultations) could find that a Member acted inconsistently with Article IX GATS if it would refuse to enter into consultations with a view to eliminating business restrictive practices. But it may be unlikely that a Member would think it worthwhile to have recourse to dispute settlement on these kinds of matters.

This difference with regard to the effect of MSS or ESS "authorized or established formally or in effect" by the government and those private monopolies that come into being in other ways, highlights that the GATS is primarily directed towards changing governmental regulatory measures and structures and what may be perceived as trade barriers caused by governmental action or inaction.

The GATS does not really engage with the importance of public provision of services where public MSS or ESS exist due to market failure in certain service sectors or where public provision is the most successful method of universal service provision (which is an obligation of the State according to other regimes of international law). National public health services immediately come to mind. It is possible that Art VIII can be used in a manner restrictive of these public services provided by public MSS or ESS. Nor does the GATS deal with situations where there are private MSS or ESS have control of the market causing competition and trade restrictions.

The Havana Charter of 1948 for the failed ITO, had a Chapter on this topic. It is suggested by Hufbauer and Kim that the US rejection of the Havana Charter was partly because:

...leading US business firms feared that limitations on restrictive business practices might be used as a club against their commercial interests. ${ }^{1159}$

Much more recently, it can be seen that US firms have come to appreciate that anticompetitive practices, monopolies and control by state enterprises in important markets such as China, India and Brazil are restricting their opportunities and are therefore becoming more open to the idea of an international agreement on competition. At the time of the Havana Charter, developing countries supported inclusion of competition rules, but now are more cautious on the matter. Hufbauer and Kim explain this change in the following manner:

Bluntly speaking, many countries want "policy space" to nurture monopolistic practices in selected industries. In 1948, at Havana, most developing countries favored competition rules because they viewed

\footnotetext{
${ }^{1159}$ Hufbauer, Gary Clyde and Jisun Kim (Peterson Institute for International Economics), International Competition Policy and the WTO, Paper presented at a conference titled "One Year Later: The Antitrust Modernization Commission's Report and the Challenges that Await Antitrust", New York University, April 11, 2008, http://www.piie.com/publications/ papers/ print.cfm?ResearchId=930\&doc=pub.
} 
themselves as powerless hewers of wood and drawers of water, subject to the predatory behavior of US and European industrial firms. Sixty years later, the same countries enthusiastically support infant industry policies for selected manufactured products and business services - including limits on competition. ${ }^{1160}$

But at the same time, developing countries have also seen that they are made vulnerable to the increasing market power of developed country export 'cartels' and cross-border mergers and acquisitions by transnational corporations. ${ }^{1161}$ Balancing these two needs, policy space including support for infant industry and allowing for competition that can support manufacturers and consumers, is the high-wire act that is expected of international trade law and policy - but can it deliver?

Competition policy was not included as an issue during the time of the negotiations for the WTO. Mavroidis, referring to GATT 1947, notes that it was a "political decision" (and not an economic one) to focus on governmental practices that affect competition and not to include private business practices, which would be dealt with under domestic competition laws. ${ }^{1162}$ Domestic competition policies (mostly existing in developed countries) which focus on creating and maintaining fair and efficient domestic markets, have used different approaches and methods and usually concern private anti-competitive practices. These may not be transposable to a single international agreement that expect States to regulate both public and private sector behavior under competition policy. Furthermore, existing national laws on anti-competitive practices usually do not have a cross-border application, the US being an exception, as well as the EU. Article VIII:1 of the GATS as it now stands does not cover extraterritorial application of anti-competitive behavior of MSS/ESS as it only requires that the Member regulate the behaviour "in its territory". However, there is no such limitation for Article IX business practices.

Creating a common agreement on competition policy for a large number of countries, based on extending existing domestic understanding on competition policy is a difficult task (although the EU has done so for its member States), and this is one reason it has not been successfully tackled at WTO level. Thus, while there are some provisions, there is no proper framework for competition law in the covered Agreements. The Working Group on the Interaction between Trade and Competition Policy (WGITCP) was created after the 1996 Singapore Ministerial Conference and paragraph 25 of the Doha Ministerial Declaration in 2001 mentions its future work plan. However, there have not been any further negotiations on competition policy since 2004 and WGITCP is inactive. In addition to the WTO, the OECD and UNCTAD have also worked on this area. UNCTAD and OECD studies have noted that a significant number of bilateral and regional agreements now incorporate competition policy provisions. ${ }^{1163}$ A 2014 note by the UNCTAD Secretariat commented that consumer law enforcement can strengthen competition law by addressing unfair commercial practices, and gave examples from

\footnotetext{
1160 Ibid (Hufbauer and Kim)

${ }^{1161}$ Levenstein, Margaret C., and Valerie Y. Suslow, Private International Cartels and their Effect on Developing Countries, Background paper for the World Bank's World Development Report 2001.

${ }_{1162}$ Mavroidis, Petros C., Market Access in the GATT, Sant'Anna Legal Studies Research Paper 7/2008, transcript of lecture at Sant'Anna School of Advanced Studies, Pisa, 28 May 2006, http://www.stals.sssup.it/ files/stals_Mavroidis.pdf.

1163 UNCTAD (United Nations Conference on Trade and Development), Competition Provisions in Regional Trade Agreements: How to Assure Development Gains. 2005; OECD (Organization for Economic Cooperation and Development), Competition Provisions in Regional Trade Agreements, OECD Trade Policy Working Paper No. 31. COM/DAF/TD(2005)3/FINAL, 2006.
} 
Chile on State regulation of 'pharmaceutical cartels' by pharmacies and of ex-post abusive billing of patients by private medical clinics. ${ }^{1164}$ Both examples refer to the regulation of the private health industry in the public interest. The study did not assess the relevance of consumer law and competition law with regard to public health services in detail, although the executive summary mentions that it discusses "policy coherence in ensuring benefits for consumers, including in public utilities in a post-liberalization period".

It is obvious from the discussion earlier in this Chapter that there is no common understanding on the definition and value of public services and that the WTO GATS 'public services exemption' which is actually a more specific SSEGA exception cannot be relied upon with confidence. Neither is there clarity on the position of public services in the context of MSS/ESS in international trade law. Since in some jurisdictions, there can be important public services that are MSS/ESS, the WTO approach towards monopolies also needs to be taken into account. Natens and Wouters commenting on the EU approach in GATS Scheduling towards MSS/ESS, have found that the uncertainty of the exemption appears to have clearly influenced certain limitations in the schedule which refer to monopolies. In particular, reference is made to the horizontal market access limitation in Mode 3, titled 'public utilities', which states that:

...services considered as public utilities at a national or local level may be subject to public monopolies or to exclusive rights granted to private operators

....and its explanatory note states that this covers the following sectors, but not telecommunications and computer and related services:

Public utilities exist in sectors such as related scientific and technical consulting services, R\&D services on social sciences and humanities, technical testing and analysis services, environmental services, health services, transport services and services auxiliary to all modes of transport. Exclusive rights on such services are often granted to private operators, for instance operators with concessions from public authorities, subject to specific service obligations ... [footnotes omitted]. ${ }^{1165}$

This limitation also highlights the point that private operators can get opportunities to operate public utilities, and that the status of the public utility (whether exempted under Article I:3 of the GATS or governed by Article VIII or IX) is unclear.

Liberalization of services includes the incursion of private management and publicprivate partnerships, which could cause a change in market structure and/or ownership that affect the categories of services that would fall under Article I:3 and Article VIII. The regulation of private operators and service suppliers that manage to get hold of these public utilities and the maintenance of competition and/or universal service obligations is not something that WTO law deals with. It is an area that needs to be dealt with more clearly in the GATS and the relationship between monopolies or dominant suppliers

1164 UNCTAD, The benefit of competition policy for consumers: Note by the UNCTAD secretariat, Intergovernmental Group of Experts on Competition Law and Policy at Geneva on 8-10 July 2014, TD/B/C.I/CLP/27, 29 April 2014, para.8, 20 and Box 4, https://unctad.org/meetings/en/ SessionalDocuments/ciclpd27 en.pdf.

${ }^{1165}$ Natens, Bregt and Jan Wouters, The Scope of GATS and of its Obligations Working Paper 117 - August 2013, Leuven Centre for Global Governance Studies and the Institute for International Law, KU Leuven, p18-19. 
(particularly with regard to the significant public services such as health services) and the possible market access obligations a Member takes on, needs to be studied further.

The current rules do not create any direct obligations to change the market structure or ownership of any public services in favour of foreign service suppliers. ${ }^{1166}$ But (according to the definition of MSS/ESS that includes public or private legal persons) the current rules also allow for continuing privileges for the private operators of 'public' services monopolies, which are established by the government as MSS or ESS. In light of the fears about privatization of existing public services and suspicions about the implications of the GATS, this provision suggests that the most profitable course for a TNC would be to get themselves into this position. Then, if there isn't a well-developed domestic competition law, there could be the possibility of avoiding both competition rules and GATS rules and maintaining a secured market position with control over pricing and profit - or get government contracts that pay directly from the Treasury/tax-payer to the private monopoly, leaving them to carry out cost-cutting in the name of 'efficiency'. This can be particularly disastrous in the context of public health service delivery, where there is the possibility of misguided cost-cutting decisions impacting the right to health (and even the right to life).

Does the GATS have any space for raising questions about such an issue? Articles VIII:3 and VIII:4 have a process for monitoring whether a MSS or ESS has acted inconsistently with MFN and specific commitments or abused its monopoly position. However, this is limited to when an MSS/ESS competes "directly or indirectly through an affiliated company" in an area outside of its monopoly rights.

Article VIII paras 3 and 4

3 The Council for Trade in Services may, at the request of a Member which has a reason to believe that a monopoly supplier of a service of any other Member is acting in a manner inconsistent with paragraph 1 or 2, request the Member establishing, maintaining or authorizing such supplier to provide specific information concerning the relevant operations.

4 If, after the date of entry into force of the WTO Agreement, a Member grants monopoly rights regarding the supply of a service covered by its specific commitments, that Member shall notify the Council for Trade in Services no later than three months before the intended implementation of the grant of monopoly rights and the provisions of paragraphs 2,3 and 4 of Article XXI shall apply.

Paragraph 3 abovementioned is only a right for the Council for Trade in Services to request (upon the request of a Member) for information concerning a monopoly supplier acting inconsistently with Paragraphs 1 and 2 of Article VIII. Paragraph 4 is only an obligation to notify the Council for Trade in Services of granting of monopoly rights regarding a service covered by specific commitments. It does not appear that these Paragraphs can be the basis for any further action than this, with regard to monopolies that affect trade in services. In any case this seems to be more related to anti-crosssubsidization than the kind of situation mentioned above. There is specific reference to cross-subsidization in the Reference Paper on Telecommunications, but this does not mean that it applies to all other services in the same manner. A brief comment on cross-

${ }^{1166}$ Mattoo, Aaditya, Dealing with Monopolies and State Enterprises: WTO Rules for Goods and Services, WTO Research and Analysis, Staff Working Paper No: TISD-98-01, January 1998, p1. 
subsidization as it has been handled in the context of telecommunications services may be useful at this point.

The special GATS negotiations on basic telecommunications were concluded after the WTO came into force and ended in 1997. Members made market access and national treatment commitments in telecommunications and also took additional commitments under Article XVIII of the GATS for pro-competition regulatory principles in the telecommunications sector. Members could insert entire or modified provisions of the negotiated Reference Paper on (Basic) Telecommunications into their schedules. The Panel in Mexico-Telecoms found that Section 1.2(a) of the Reference Paper on Telecommunications refers to cross-subsidization as an example of anti-competitive practices that must be prevented by Members who take up additional commitments to liberalize the telecommunications sector. The Panel stated:

Cross-subsidization was and is a common practice in monopoly regimes, whereby the monopoly operator is required by a government to cross subsidize, either explicitly or in effect, usually through government determination or approval of rates or rate structures. Once monopoly rights are terminated in particular services sectors, however, such crosssubsidization assumes an anti-competitive character. This provision, therefore, provides an example of a practice, sanctioned by measures of a government, that a WTO Member should no longer allow an operator to 'continue'...[and] would be obliged to revise or terminate ... [emphasis added $]^{1167}$

The Panel further notes the provisions of the Reference Paper draws from and add to the existing GATS obligations such as Articles III, VI, VIII and IX of the GATS and the Annex on Telecommunications, including Section 5 of the Annex which requires additional obligations regarding 'major suppliers'. ${ }^{1168}$ The Annex on Telecommunications expressly states that it "provides notes and supplementary provisions to the Agreement". ${ }^{1169}$ The relationship between the obligations in the Reference Paper and in the Annex of Telecommunications was also noted by the Panel in Mexico-Telecoms, which stated that although there is overlap in the obligations, the Reference Paper obligations are additional commitments applying only to "major suppliers" of basic telecommunications (focusing on 'interconnection' and specific 'competitive safeguards') whereas the Annex sets out general obligations for "access to and use of public telecommunications transport networks and services", applicable to all Members and all sectors in which specific commitments have been undertaken. ${ }^{1170}$ This approach to cross-subsidization, being sector-specific, does not apply other services, and if further developments occur in the area of subsidies disciplines, it would be relevant to also clarify the position on cross-subsidization, and whether some areas such as health services and the other related services that impact public health services delivery should be excluded from any future cross-subsidization disciplines (since this issue is also related to SSEGA, the special nature of public health services and the argument that it should not be considered as "competitive" with the private health sector and thus cannot engage in anti-competitive practices.

1167 Panel Report, Mexico-Telecoms, para.7.242. Also see paras.7.230 and 7.232. The context of this determination was whether or not the actions by the major supplier of telecommunications services in Mexico constituted "anti-competitive practices".

${ }_{1168}$ Panel Report,_Mexico-Telecoms, paras.7.331-7.332

${ }^{1169}$ Section 1 (Objectives) of the Annex on Telecommunications

${ }^{1170}$ Panel Report, Mexico-Telecoms, para.7.331. 
Article VIII:1 and Article XIII of the GATS can also overlap where a public MSS/ESS procures services for its own consumption - and it appears that there is no application of government procurement rules in this situation. ${ }^{1171}$ But would GATS rules apply to situations where the procured goods and services would be passed on to consumers - and should it? Does it matter whether there is a clearly identifiable commercial resale or if there is no fee charged for the consumer? It is interesting to consider to what extent this question can be relevant in situations such as the change in the NHS after the Health and Social Care Act of 2012 was passed by British Parliament. Reports by organizations such as NHS Support Federation (NHSSF) and National Health Action Party (NHA) ${ }^{1172}$ draw attention to the granting of contracts - which appears to be like procurement of services to 'outsource' parts of the management, running or clinical services of the NHS to commercial private healthcare companies resulting in what appears to be 'small internal private monopolies' for specific health services within the larger public NHS monopoly otherwise referred to an the 'NHS internal market'. Once again, the interpretation of 'commercial' and 'competition' in Article I:3 would be the pivotal factor in interpreting GATS coverage for such activities.

A separate, but connected question is the purpose of such contracts, outsourcing and partnerships in terms of benefits for the public. The purpose is stated as 'efficiency' through increased competition by allowing private providers to offer tenders for the provision of services alongside the other components of the existing public provider. The benefits for private enterprise that can profit from contracts with public monopolies is obvious. It has been widely commented with regard to the NHS that the proportion of public funds spent on non-NHS providers including for-profit private health service providers has increased in the past several years from $6 \%$ to the current level of $10 \%$ in 2017 and more than doubled since $2009 / 10 .{ }^{1173}$ This is $10 \%$ of the total NHS budget of over 120 Billion pounds. In 2016-2017, media in Britain also drew attention to the fact that billions of pounds of public funds earmarked for the NHS had been used to buy health care from private, non-NHS providers instead of directly injected into necessary maintenance and development of the public NHS system. ${ }^{1174}$

${ }^{1171}$ Bigdeli and Rechsteiner Article VIII GATS in Wolfrum, Rudiger, Peter-Tobias Stoll and Clemens Feinaugle Eds., WTO - TRADE IN SERVICES, Max Planck Commentaries on World Trade Law, Martinus Nijhoff Publishers, 2008, p210.

1172 See http://www.rcpbml.org.uk/wwie-14/ww14-04.htm\#sthash.9qRwpp3T.dpuf, last accessed 05.06.2014:

A report of the NHS Support Federation (NHSSF) points out that in excess of $£ 5$ billion worth of contracts to run, or manage, clinically related NHS services have been advertised in the first 9 months since the competition regulations (section 75) of the Health and Social Care Act 2012 were passed by Parliament.

See more at: http://www.rcpbml.org.uk/wwie-14/ww14-04.htm\#sthash.9qRwpp3T.dpuf, last accessed 05.06.2014:

A report by the National Health Action Party (NHA) points out that the TTIP US-EU Transatlantic Trade and Investment Partnership (TTIP) negotiations "goes way beyond previous trade agreements", opening up the NHS and other public services to these global health monopolies.

An issue raised in social media surrounding these campaigns is the extent to which awarding of these contracts are transparent and free from corruption, nepotism and personal gain at public expense.

1173 The UK Government, Office of National Statistics, Health Care System: Expenditure, available online at https://www.ons.gov.uk/peoplepopulationandcommunity/healthandsocialcare/healthcaresystem

1174 Campbell, Dennis, How much is the government really privatizing the NHS?, The Guardian, 15 August 2016, available online at https://www.theguardian.com/society/2016/aug/15/creeping-privatisation-nhsofficial-data-owen-smith-outsourcing; Forster, Katie, Half of $£ 2 b n$ NHS cash injection spent on outsourced 
But benefits to the public in terms of better quality and more affordable or accessible services is not necessarily guaranteed. Rubin has commented on the government outsourcing done in US Executive Departments and Agencies, that:

....it casts the entire process of government in the efficiency-based, private market framework [while] ignoring or minimizing public values... for relatively little gain in efficiency. ${ }^{175}$

Rubin also refers to a Memorandum issue by President Obama which states that ...the line between inherently governmental activities that should not be outsourced and commercial activities that may be subject to private sector competition has been blurred and inadequately defined. As a result, contractors may be performing inherently governmental functions. Agencies and departments must operate under clear rules prescribing when outsourcing is and is not appropriate. ${ }^{1176}$

According to Rubin's analysis, the result of the Circular was to require every government agency to justify in writing any designation of governmental personnel performing "inherently governmental activities", demonstrating that they could perform these functions more efficiently than private firms and make these documents available to lobbyists for companies that wanted to make offers to obtain contracts from the federal government to carry out these activities. Thus, in the United States, it has been recognized that there is such a concept as 'inherently governmental functions' and there can be line that separates appropriate and inappropriate outsourcing to the private sector. Not knowing exactly where to draw that line and there being insufficient national debate on the issue is unfortunately a problem for many countries. For WTO Members, the legal framework that binds them internationally, and the obligations they may have to take on in the future, will further complicate their national political debate, if there is one.

The next section of this chapter will discuss government procurement in the GATS framework and the implications, if any for public services, particularly public health services.

private care providers labelled a 'disgrace', The Independent, Monday 27 March 2017; available online at http:/www.independent.co.uk/news/uk/politics/nhs-cash-injection-2-billion-spent-outsourcing-private-careproviders-disgrace-healthcare-service-a7651531.html; Campbell, Dennis, Virgin Care wins £700m contract to run 200 NHS and social care services, The Guardian, 11 November 2016, available online at https:/www.theguardian.com/society/2016/nov/11/virgin-care-700m-contract-200-nhs-social-care-servicesbath-somerset; Taylor, Matthew, Surge in privatization threatening free NHS treatment, unions say, The Guardian, $8^{\text {th }}$ February 2016, available online at https://www.theguardian.com/society/2016/feb/08/surgein-privatisation-threatening-free-nhs-treatment-unions-say.

1175 Rubin, Edward L., The Possibilities and Limitations of Privatization, Harvard Law Review, Vol. 123, No. 890, 2010 (also available as Vanderbilt Public Law Research Paper No. 11-09; Vanderbilt Law and Economics Research Paper No. 11-14). Rubin reviews Freeman, Jody and Martha Minow, Eds., GOVERNMENT BY CONTRACT: OUTSOURCING AND AMERICAN DEMOCRACY, Harvard University Press, 2009 - and is commenting on their analysis in his paper.

1176 United States Government, Memorandum for the Heads of Executive Departments and Agencies, Subject: Government Contracting, March 4 2009, issued by President Barack Obama, available at http://www.govexec.com/pdfs/030409e1.pdf, last accessed 03.07.2011. The memorandum refers to Circular A-76 which defines an inherently government activity as "an activity that is so intimately related to the public interest as to mandate performance by government personnel." 


\title{
3.5.2. Article XIII of the GATS: Government Procurement
}

\author{
...you shall find \\ No public benefit which you receive \\ But it proceeds or comes from them to you \\ And no way from yourselves...
}

From Shakespeare's Coriolanus

\subsubsection{Government Procurement, Public Health Services and Human Rights}

Government procurement in the context of governmental responsibilities for public services and the protection of human rights has gained attention in recent years. This can be looked at in at least two ways. One is that actual or potential human rights violations by public bodies and private providers should be an issue that is taken into account in procuring of goods and services by public bodies. The second is how public procurement of services from private suppliers could impact the human rights of the public to whom those services are provided. Entering into procurement contracts for services provided by human beings for other human beings is distinct from procurement for goods, and such interactions can have either positive or negative effects on the consumers of the services depending on the policies implemented for service delivery. It is especially important in public health services, where non-discrimination, accessibility and other rights concerns should not be ignored.

The first aspect abovementioned requires designing and implementing policy and legislation, particularly on labour rights and standards. The second aspect relates to protecting the rights of the public both when the governmental authorities supply services or when they contract out to private entities to supply the services. In the UK parliament, this aspect has been raised by the 2017 report by the Joint Committee on Human Rights, explaining the current government advice on human rights in public procurement. ${ }^{1177}$ The Joint Committee report refers in passing to a number of human rights reports including the UN Committee on the Rights of the Child - General Comment No.16 (on child labour), ${ }^{1178}$ the UN Human Rights Committee Concluding Observations to the UK, ${ }^{1179}$

${ }^{1177}$ UK Parliament, Joint Committee on Human Rights, Human Rights and Business 2017: Promoting responsibility and ensuring accountability, paras.72-78 -Available online at:

https://publications.parliament.uk/pa/jt201617/jtselect/jtrights/443/44307.htm\#footnote-148-backlink.

1178 Committee on the Rights of the Child, General comment No. 16 (2013) on State obligations regarding the impact of the business sector on children's rights, CRC/C/GC/16, 17 April 2013. See for example, para.27:

The obligation to respect also implies that a State should not engage in, support or condone abuses of children's rights when it has a business role itself or conducts business with private enterprises. For example, States must take steps to ensure that public procurement contracts are awarded to bidders that are committed to respecting children's rights

${ }^{1179}$ UN Committee on the Rights of the Child, Concluding observations on the fifth periodic report of the United Kingdom of Great Britain and Northern Ireland, CRC/C/GBR/CO/5, 3 June 2016, para.18(b) (recommendations):

Establish and implement regulations to ensure that the business sector, including in the context of public procurement, complies with the rights of the child. 
and evidence submitted to it by the Equality and Human rights Commission, Institute for Human Rights and Business, the International Corporate Accountability Roundtable, Amnesty International UK and the British Medical Association (a report on procurement of medical goods) and the International Learning Lab on Public Procurement and Human Rights. This shows that governments are being encouraged by both international and domestic bodies to create government procurement policies and legislation which takes human rights into account, and they have initiated assessments of their own activities in this light.

A study completed in 2016 by the International Learning Lab on Public Procurement and Human Rights (hereinafter Learning Lab) carried out a survey and assessment of 20 jurisdictions with regard to issues where public procurement and human rights intersect. ${ }^{1180}$ Public procurement for essential goods and services is categorized separately for the purposes of the Learning Lab study and with regard to human rights impacts of public procurement, the State responsibility for the right to health is highlighted. ${ }^{1181}$ It is particularly noted that the UK Equality and Human Rights Commission and the Scottish Human rights Commission have worked on integrating human rights into the commissioning of health and social care at local governmental level. ${ }^{1182}$ The UK case of $Y L v$ Birmingham City Council and others ${ }^{1183}$ was cited in the above study, and this is an interesting case to look at how public procurement of services might affect public interest and individual human rights.

$Y L v$ Birmingham City Council and others considered whether private care homes for the elderly under a contract with a local authority were exercising "functions of a public nature" within section 6(3)(b) of the Human Rights Act 1998, ${ }^{1184}$ and accordingly had a statutory duty to act compatibly with ECHR rights. The House of Lords, held by a majority of 3 to 2 that such contracting out to private institutions meant that the private institution was not carrying out public functions. The majority did not agree that a function which is performed by a private body, is one of a public nature merely because it

\footnotetext{
${ }^{1180}$ International Learning Lab on Public Procurement and Human Rights, Public Procurement and Human Rights: A Survey of Twenty Jurisdictions, 2016, available online at http://www.hrprocurementlab.org/wpcontent/uploads/2016/06/Public-Procurement-and-Human-Rights-A-Survey-of-Twenty-JurisdictionsFinal.pdf.

The Learning Lab is given leadership by the Danish Institute for Human Rights, the International Corporate Accountability Roundtable (ICAR, which is a coalition of human rights, environmental, labour, and development organizations and The Harrison Institute of Public Law of the Georgetown University Law Center. It describes itself as a network of non-governmental organizations, national human rights institutions, academics, representatives of central and local government procurement agencies, government purchasing officers, representatives of other relevant government bodies, and procurement professional associations.

${ }^{1181}$ International Learning Lab on Public Procurement and Human Rights, Public Procurement and Human Rights: A Survey of Twenty Jurisdictions, 2016, p18.

1182 International Learning Lab on Public Procurement and Human Rights, Public Procurement and Human Rights: A Survey of Twenty Jurisdictions, 2016, p22 (see further Equality and Human Rights Commission, Procurement Guidance for Scottish Public Authorities, http://www.equalityhumanrights.com/aboutus/devolved-authorities/commission-scotland/public-sector-equality- duty-scotland/procurement-guidancescottish-public-authorities).

${ }^{1183}$ YL v Birmingham City Council and others [2007] UKHL 27, [2007] 3 All ER 957 -available online at: https://publications.parliament.uk/pa/ld200607/ldjudgmt/jd070620/birm.pdf.

See also an earlier case on similar facts: Court of Appeal in $R$ (Heather) $v$ Leonard Cheshire Foundation [2002] 2 All ER 936

${ }_{1184}$ Under this provision, an otherwise private body may be regarded as a public authority for the purposes of Human Rights Act of 1998 if, per section 6(3)(b), it performs "functions of a public nature".
} 
is commissioned by a public authority. It is interesting that a distinction was drawn in one of the majority opinions between care homes and private prisons or private hospitals which exercise powers of detention under the Mental Health Act 1983; arguing that if a public power such as a coercive power to detain, is handed to a private body by statute, it would suggest that the function performed is one of a public nature. ${ }^{1185}$ This House of Lords decision was later superseded by new legislation enacted by the UK Parliament in 2008 with the specific aim of extending human rights protection (under the Human Rights Act and ECHR) to individual users of 'contracted-out' health and social care. ${ }^{1186}$ It is pertinent that the facts in YLv Birmingham City Council and others were that family had been given notice to remove their mother, an 84 year old woman with Alzheimer's disease, from the care home where the her stay was being funded through a contract with the local authority of the area of her residence. It has been commented on how the Health and Social Care Act 2012 has created a framework for a competitive market for health and care services in England, and places requirements on local commissioners to put many NHS-funded services out to competitive tender, a matter which has been criticized for the negative impact on the public and the future of the NHS. ${ }^{1187}$ It is with the backdrop of the issues discussed above, which have been affecting public health services, that the interpretation of Article XIII of the GATS will be discussed.

Other than the two specific ways in which government procurement, public health services and human rights interact with each other which are discussed above, it is also important to consider the larger picture that government procurement is an essential part of public services delivery, including public health services delivery, and that:

...well designed procurement systems can promote good governance and

...has a broader developmental significance that transcends its magnitude

as an aspect of economic activity. ${ }^{1188}$

Zacharias comment how procurement measures are often directed to non-economic policies and Anderson et al note that the development dimension to government procurement in services is particularly strong in relation to health-related services. ${ }^{189}$ A well designed government procurement framework at the WTO level, which is built upon best practices and allows for national policy flexibility could simultaneously achieve the ambitious goals of: providing global minimum standards of non-discrimination, transparency and procedural fairness, helping governments and their citizens to get the best available services at the best price and also contribute towards stimulating economic growth and development. However, States have often preferred to retain their flexibility by excluding health services and health related services from coverage in their trade

1185 Baroness Hale of Richmond in YL v Birmingham City Council and others [2007] UKHL 27, [2007] 3 All ER 957, para.63, citing $R$ (A) v Partnerships in Care Ltd [2002] 1 WLR 2610, 2619 on the issue of mental health detention by private hospital managers; and HL v United Kingdom (2004) 40 EHRR 761 for the fact that the State would still be held responsible for persons who have been detained (Article 5 of the ECHR - right to liberty)

${ }^{1186}$ Section 145 of Health and Social Care Act of 2008.

1187 See: The Centre for Health and the Public Interest (Marianna Fotaki, Sally Ruane and Colin Leys) THE FUTURE OF THE NHS? LESSONS FROM THE MARKET IN SOCIAL CARE IN ENGLAND, CHPI, 2013: "Lesson Four: Provider failure is an inevitable consequence of any care market, with significant implications for patients, care users and their families".

${ }^{1188}$ Anderson, Robert D., Claudia Locatelli, Anna Caroline Müller, and Philippe Pelletier, The Relationship Between Services Trade and Government Procurement Commitments: Insights from Relevant WTO Agreements and Recent RTAS, WTO Working Paper ERSD-2014-21, 18 November 2014, p1.

${ }^{1189}$ Ibid., (Anderson et al), p10; Zacharias, Diana, Article XIII GATS in Wolfrum, Rudiger, Peter-Tobias Stoll and Clemens Feinaugle Eds., WTO - TRADE IN SERVICES, Max Planck Commentaries on World Trade Law, Martinus Nijhoff Publishers, 2008, p274. 
bilateral and regional trade agreements. Under the GATS, the provision on government procurement on one hand appears to exempt government procurement from the core GATS obligations, but at the same time indicates that there could be more liberalization in the future, as Members are expected to engage in negotiations for a multilateral agreement for government procurement in services.

\subsubsection{The Definition of 'Government Procurement' in the GATS}

Article XIII of the GATS (Government Procurement), states as follows:

1. Articles II, XVI and XVII shall not apply to laws, regulations or requirements governing the procurement by governmental agencies of services purchased for governmental purposes and not with a view to commercial resale or with a view to use in the supply of services for commercial sale.

2. There shall be multilateral negotiations on government procurement in services under this Agreement within two years from the date of entry into force of the WTO Agreement.

The definition for the government procurement of services in the GATS is - services which are:

...purchased for governmental purposes and not with a view to commercial resale or with a view to use in the supply of services for commercial sale.

Thus, the definition of government procurement is tied to the understanding of the terms "governmental purposes" and "not with a view to commercial resale or with a view to use in the supply of services for commercial sale" (hereinafter 'commercial sale/resale'). The latter was also discussed under the sections on Article I:3(c) of the GATS) in section 3.4.4 of this Chapter. The interpretation of these terms in Article XIII and Article I:3(c) need to be clarified and their interpretation can also be influenced by results negotiations on government procurement. 'Governmental purposes' can be interpreted narrowly within the context of trade and WTO law, but as discussed in the previous section, actual governmental decision-making needs to take into account a wider range of obligations, including human rights-based approaches to public procurement relating to public services.

Article XIII of the GATS clearly states that MFN, national treatment and market access obligations of the GATS (the rules in Articles II, XVI and XVII of the GATS) shall not apply to government procurement, as defined above in Article XIII. So, a WTO Member is free to discriminate among foreign tenders and favour national service suppliers, at least in so far as the area is not covered by plurilateral trade agreements (e.g. the WTO Agreement on Government Procurement or GPA) and/or regional trade agreements. The most recent report of the Working Party of GATS Rules highlighted the fact that a large part of services trade is thus excluded from the coverage of the GATS. Research gathered by the WTO Secretariat estimates that the share of government procurement may be as share is as high as $30 \%$ of services trade, with a service supplier's largest contract often being with government entities. ${ }^{190}$ However, note that financial services are not exempt from government procurement disciplines, as Section B.2 of the Understanding on Financial Services applies MFN and national treatment for purchase and acquisition of

\footnotetext{
1190 WTO, Note by the Secretariat, Working Party on GATS Rules, Report of the Meeting held on 29
} October 2013, S/WPGR/M/82, 24 January 2014, para.3.2. 
financial services by 'public entities' (as defined in the GATS Annex on Financial services). ${ }^{191}$ There is also no exclusion of the general obligation of transparency in Article III of the GATS, and thus this obligation continues to apply. This can be seen to link with the overall objectives of (and which are also methods for) liberalization of government procurement: transparency and competitiveness. ${ }^{192}$

It may seem at first that this section is redundant if 'public services' or SSEGA is beyond the scope of the GATS in the first place. However, procurement/purchasing of services for governmental purposes can be of two types: those that don't fall within the scope of the GATS and those that could fall within the GATS but do not yet have to deal with the government procurement disciplines for services, which are yet to be negotiated.

The first type is what is under Article I:3 of the GATS and probably means inter-agency procurement within a government, which is not open to private competitive bidding. If procurement of services by a government is open to private competitive bidding, then it may be that these situations fall within the GATS and such sectors could face national treatment and market access rules - therefore, Article XIII specifically exempts this, until a multilateral agreement is negotiated. Situations of a competitive 'internal market' for private service supply within a major public service such as the NHS comes to mind. The 2010 Secretariat Background Note on Environmental Services suggests that publicprivate partnerships used as tools to finance public service facilities (carrying out tasks from maintenance to control and management) introduce, through the bidding/tender process, "competition for the market, for want of competition in the market". ${ }^{193}$ The Note goes on to add that

Some of these contracts may fall within Article XIII:1 of the GATS... However, in the range of contractual arrangements between public and private entities, it is not easy to draw the line between contracts which amount to government procurement within the meaning of GATS Article XIII, and other types of transactions which would remain subject to GATS Articles XVI and XVII, and the MFN obligation. ${ }^{1194}$

Thus, there is some evidence in support of the view that such public-private partnerships and 'competition for the market' are not generally perceived as being covered by the Article I:3 exemption from scope of the GATS, although it concerns a public service or "services supplied in the exercise of governmental authority" (SSEGA) that may be providing services in a manner that is non-commercial.

The issue of whether the mere fact of government procurement/purchasing "facing" (rather than engaging in) competition by private service suppliers who wish to enter into

${ }^{1191}$ Section B. 2 of the Understanding on Commitments in Financial Services:

Financial Services purchased by Public Entities

Notwithstanding Article XIII of the Agreement, each Member shall ensure that financial service suppliers of any other Member established in its territory are accorded mostfavoured-nation treatment and national treatment as regards the purchase or acquisition of financial services by public entities of the Member in its territory.

1192 See Arrowsmith, Sue, GOVERNMENT PROCUREMENT IN THE WTO, Kluwer Law International, 2003; Trepte, P., Regulating Procurement: Understanding the Ends and Means of Public Procurement Regulation in Arrowsmith, Sue, J. Linarelli and D. Wallace, REGULATING PUBLIC PROCUREMENT: NATIONAL AND INTERNATIONAL PERSPECTIVES, Kluwer Law International, 2000.

1193 WTO, Council for Trade in Services, Note by the Secretariat, Background Note on Environmental Services, S/C/W/320, 2010 para.77-78.

1194 Ibid., (S/C/W/320), para.79. 
that governmental market means that the Article I:3 exemption no longer applies, was discussed earlier. ${ }^{195}$ But the specific exemption from government procurement disciplines in the GATS suggests that, even in a case of doubt about the status of public services (whether SSEGA or not), if a procurement is "by government agencies...for governmental purposes" and not for "commercial sale/resale" according to Article XIII, it can be an escape from being covered by Articles II, XVI and XVII of the GATS. Free provision of services, including free public health services, could be outside the scope of 'commercial sale/resale'. But there may be procurement by public health services which have mixed non-fee levying and fee levying parts (like certain hospital wards or certain medical testing services) - using the fees to fund or cross-subsidize other parts of the same broad service. The difference with a service such as health is that the ultimate recipients of such services are the public, and not the governmental agency as such. Is this a relevant factor and should this be taken into account when negotiating disciplines and creating a clearer definition of what procurement 'for governmental purposes' means? There ought to be recognition that the purposes of procurement of such services are very different from a mere transaction in trade and commerce, since it has to be carried out for the furtherance of a public policy objective and not merely for profit and efficiency requirements.

So, it is a curious and circular argumentation with regard to whether services such as public health services could be considered exempt from the GATS or not. A future work programme may be able to clarify these points, and make sure that a 'governmental purposes' definition includes purposes that are for the general welfare of the public and specifies protection for important public services such health and education, as well as other important responsibilities such as taking measures to promote environmentally sustainable services. The procurement of services by a government agency can have other non-trade policy implications and should not be judged only by trade values. The existence of Article XIII of the GATS in the form it is in, suggests that these concerns are recognized to a certain extent. What the ultimate outcome will be is still being decided.

The EC recognized that the relevant procuring entities for the purposes of the proposed Agreement or Annex on government procurement could be defined as encompassing all entities listed in Article I: 3 (a) GATS; but suggested that there should be recognition of ... the right for a WTO Member to limit the scope of its government procurement commitments to a limited group of procuring entities, which could be listed in the Schedule, sector by sector, on the basis of either a positive-list or negative-list approach [emphasis added]. ${ }^{1196}$

If such a proposal is turned into text and not merely kept as a concept, it could mean that sector specific government procurement policies could still be implanted by Members and there could be flexibility to not include sensitive sectors.

While Article XIII as it stands provides a broad exemption from the core obligations of the GATS, it is arguable as to whether it is meant to be a permanent exemption. Article XIII:2 provides a negotiating mandate, confirming that there was a vision of future multilateral rules on government procurement at the time of the negotiations leading up to the WTO Agreement. The idea seems to have been that a future Agreement or Annex to the GATS could be negotiated after the establishment of the WTO. However, since even

\footnotetext{
${ }^{1195}$ See earlier in Chapter 3 - section 3.3.4.2.

${ }^{1196}$ WTO, WPGR, Communication from The European Communities S/WPGR/W/52, 15 June 2005, para.9.
} 
the government procurement of goods had only a plurilateral agreement at the time, a multilateral agreement on services in this area was clearly deemed premature.

An interesting issue regarding the scope of the negotiating mandate, which is ambiguous in the text of Article XIII, is whether future disciplines can include MFN, national treatment and market access regarding government procurement. The Report of the Chairperson of the Working Party on GATS Rules noted in 2003, that there was disagreement among Members on the scope of the mandate for negotiations and whether Article XIII represented an exclusion of these obligations from future negotiations. ${ }^{1197}$ The model with regard to the current plurilateral WTO Agreement on Government Procurement (GPA) 1994/and revised is of reciprocal commitments according to entries made by the Parties to the GPA - and not general MFN, national treatment and market access obligations. But the model for a multilateral GPA on services need not follow that model, and there is no limitation to that effect in Article XIII. Even in the case of the negotiations for the GPA it was commented in the WTO Briefing Notes for the 2003 Cancun Ministerial Conference, that some Members want a broader mandate in general for government procurement negotiations, which would "in the long term... mean exploring the possibility of market access at a multilateral level". ${ }^{1198}$

In general, government procurement of services refers to the purchase services required by various government bodies. In the context of the GATS, the aspect of 'international trade' that enters into the transaction is that the purchase of services is from foreign service suppliers; and issue is whether this must be liberalized, and to what extent. This is not an area where a majority of States have been willing to open up, as government procurement in certain service sectors often have non-economic motives of promoting domestic industries and of national security. As of 2019 there are 48 parties to the plurilateral Agreement on Government Procurement, although all WTO members are eligible for accession. Zacharias notes that the support for the Agreement was mainly from the United States and the EU, as this would increase market opportunities for their own firms ${ }^{1199}$ which are more likely to have the capacity to be at an advantage in international bidding in a 'level playing field'.

According to Zacharias, the opposition to a multilateral agreement on government procurement has been mainly from developing countries such as India (as well as certain organizations such as Oxfam). ${ }^{1200}$ The reasons include the disadvantages to domestic

${ }^{1197}$ WTO, Report by the Chairperson of the Working Party on GATS Rules, Negotiations On Government Procurement, S/WPGR/11, 30 June 2003, paras.14, 17, 18 - noting at para.18 that the Members who oppose the inclusive interpretation are "not convinced that such disciplines would yield any benefit, in particular for developing country Members". Another group of Members are neither for nor against an inclusion but merely suggest a postponement of the negotiations on the matters pressed by the pro-inclusion group, particularly market access.

1198 WTO, Cancún WTO Ministerial 2003 Briefing Notes, Transparency in Government Procurement Ready to Negotiate an Agreement, Or Not Yet?, available online at http://www.wto.org/english/thewto_e /minist_e/ min03_e /brief_e/brief09_e.htm, last accessed 21.02.2014

1199 Zacharias, Diana, Article XIII $\bar{G}$ ATS in Wolfrum, Rudiger, Peter-Tobias Stoll and Clemens Feinaugle Eds., WTO - TRADE IN SERVICES, Max Planck Commentaries on World Trade Law, Martinus Nijhoff Publishers, 2008, p286, citing Linarelli J., The WTO Transparency Agenda: Law, Economic and International Relations Theory in Arrowsmith, S. and M. Trybus Eds., PUBLIC PROCUREMENT: THE CONTINUING REVOLUTION, Kluwer Law International, 2003. p235, 237.

${ }^{1200}$ Zacharias, Diana, Article XIII GATS in Wolfrum, Rudiger, Peter-Tobias Stoll and Clemens Feinaugle Eds., WTO - TRADE IN SERVICES, Max Planck Commentaries on World Trade Law, Martinus Nijhoff Publishers, 2008, p286. 
industries and balance of payments issues as well as the possibility of encouraging a 'race to the bottom' (motivated by increasing margin of profit) among bidders since governments are likely to fail to include clear provisions in such an agreement to promote and maintain standards on human rights, labour and environmental issues as requirements for granting procurement.

The counter to this argument is that a multilateral agreement can include these concerns if they are made part of the negotiated draft text, which can be better than having no text/agreement at all. However, the ability of developing countries - or even interested groups in civil society in developed countries - to bring these matters to the negotiating table and to push them through as part of an Agreement, is somewhat doubtful. The strategy so far (or perhaps the only feasible option?) has been for less powerful negotiators to try and block proposals but not to bring alternative proposals forward.

However, these concerns are additional to the fact that there are also economic and social down-sides to a government procurement system that is neither open nor transparent. The cost of the nepotism and corruption that goes on in unsatisfactorily regulated government procurement ultimately negatively impacts the quality of service provision and thus also economic development and the quality of individual lives. Transparency International (TI), a key non-governmental organization working in this area, identifies government procurement as one of the main areas in which corruption occurs in many countries. ${ }^{1201}$ TI promotes tackling the problem mainly through various domestic measures discouraging bribery and corruption, but also played an important role in the creation of two important treaties, the United Nations Convention against Corruption ${ }^{1202}$ and the OECD Anti-Bribery Convention (Convention on Combating Bribery of Foreign Public Officials in International Business Transactions). At the international level there is also the United Nations Commission on International Trade Law (UNCITRAL) Model Law on the Procurement of Goods, Construction and Services of 1995 and its' 2011 version, which reflects procurement principles used by the World Bank. ${ }^{1203}$ In addition to the UNCITRAL Model Law; the World Bank Guidelines on Procurement under IBRD

\footnotetext{
${ }^{1201}$ See Transparency International, HANDBOOK FOR CURBING CORRUPTION IN PUBLIC PROCUREMENT, TI, 2006 and http://www.transparency.org/topic/detail/public procurement. See further on the structure and mandate of the organization: http://www.transparency.org/whoweare/organisation 1202 Note the Preamble to the Revised GPA 1996/2014 recital 7:

Recognizing the importance of transparent measures regarding government procurement, of carrying out procurements in a transparent and impartial manner and of avoiding conflicts of interest and corrupt practices, in accordance with applicable international instruments, such as the United Nations Convention Against Corruption [emphasis added]

In this instance the WTO has expressly recognized a UN Convention (which has 171 State Parties as of April 2014) and suggested that other international instruments may also be relevant. This makes interpretation of the Revised GPA in coherence with other relevant international standards (according to the ejusdem generis rule it would be standards relating to corruption) a much easier exercise - and not one where there needs to be a struggle to apply Article 31 of the VCLT or resort to Article 31(3)(c). This is unfortunately not the case with other UN Conventions and Covenants on human rights which have never been expressly acknowledged in WTO Agreements.

1203 Arrowsmith, Sue and Geo Quinot, PUBLIC PROCUREMENT REGULATION IN AFRICA, Cambridge University Press, 2013, p16-17: notes that while the WTO procurement agreements have not influenced African countries, with zero participation in WTO GPA; the UNICTRAL model has been used extensively.
} 
Loans and IDA Credits and the APEC Non-Binding Principles on Government Procurement have also been noted in WTO work on the area. ${ }^{1204}$

Thus, depending on the final text which is decided, a multilateral agreement on government procurement can be an opportunity for improving good governance, protecting progressive societal values and contributing to sustainable development.

There are also other ways to look at the problem. It would not be beneficial for economic development and social welfare if government procurement policies and practices discriminate in favour of protected domestic suppliers when competitive imported goods are cheaper and/or of better quality. This kind of inefficiency and distortion of trade is of no overall benefit to anyone but the protected suppliers, and the cost is ultimately borne by the public. An OECD study has concluded that there is sufficient evidence that there are considerable savings to the Treasury through open and transparent bidding processes. ${ }^{1205}$ 'Cost' can also have a wider connotation, as described by Aman:

Costs are not just expenses on the part of the service provider but distributions relative to values, monetary and otherwise, among the public at large, requiring and understanding of various relationships in the management process. Therefore, social values that inform our judgments about costs should be central issues for public debate. The selection of cost reduction is a political concern of broad public relevance, even if the service provider is a public entity [emphasis added]. ${ }^{1206}$

Thus, both avoiding and promoting public procurement disciplines can be based on political choices about the nature of 'cost' and its social impact.

The narrowest approach towards government procurement is that the lack of liberalization can be seen merely as an issue of 'trade-restrictive' effects of the exclusion of foreign suppliers of goods and services from the lucrative procurement market or of allowing a chosen few and not others in a discriminatory manner. Thus, the necessity for increasing transparency and competitiveness in the framework for government procurement can be looked at from either or both the point of view of interests of the domestic public ('good governance') and interests of foreign suppliers ('free trade'). Increased competitiveness can also be looked at from the viewpoint of domestic suppliers - some may fear that competition will be harmful since they may not be able to be successful alongside foreign competition; some others may welcome the competition from foreign service suppliers as an incentive to improve their own services. The overarching issue for governments is, even taking into account these trade/welfare concerns, the need for retention of policy flexibility to respond to different non-trade concerns remains.

Trade negotiators have attempted to balance these concerns or at least postpone creation of rules until the facts and needs were understood better. Government procurement for purely governmental ('not for commercial sale/resale') purposes was excluded from the

\footnotetext{
1204 See references in the following WTO documents: WT/WGTGP/W/1, WT/WGTGP/W/2, WT/WGTGP/W/11, WT/WGTGP/W/22 and WT/WGTGP/W/24.

1205 OECD, Transparency in Government Procurement: The Benefits of Efficient Governance, TD/TC/WP/(2002)31/Rev2/14, April 2003.

${ }^{1206}$ Aman Jr., Alfred, C., Privatization and Democracy: Resources in Administrative Law in Freeman, Jody and Martha Minow Eds., GOVERNMENT BY CONTRACT, Harvard University Press, 2009, p274. Also available as Indiana Legal Studies Research Paper No. 145, 2009.
} 
GATT 1947 under Article III:8(a) and XVII:2 of the GATT (thus not covering national treatment in trade in goods). But there was a re-thinking of government procurement and what international trade rules can be introduced to make it more open to international trade and less 'trade restrictive'.

The Tokyo Round thus introduced the first agreement on government procurement (the GATT GPA) in 1979 which came into force in 1981 (it was also later amended). This was on the awarding of governmental contracts for the supply of goods to government agencies but also included some services such as construction services ${ }^{1207}$ after an amendment in 1987. The value of large infrastructure projects would have been the reason behind this inclusion. ${ }^{1208}$ This aspect is further increasing in importance with the rapid growth and spending on public infrastructure projects in countries such as India, China and Brazil.

The WTO GPA is the updated version of the GATT GPA, negotiated during the Uruguay Round and which came into force in 1996. In December 2011, the GPA was successfully re-negotiated, resulting in the Decision on the Outcomes of the Negotiations under Article XXIV:7 of the Agreement on Government Procurement, 2012. Continuing the GATT and WTO legacy, all goods are covered but services and construction services, procurement at the sub-central level (provinces, departments etc.), and procurement by public utilities are also covered. ${ }^{1209}$ This greatly expanded the coverage from that of the GATT GPA. Unlike the GATT 1994 and GATS, the GPA is (and always has been) a plurilateral agreement with a limited number of Members opting for it. ${ }^{1210}$ The covered services must be included in the relevant Annexes by Parties. Annexes 4 and 5 to Appendix I specify each Party's covered services and construction services. The GPA Annexes and GATS schedules both refer to the United Nations Provisional Central Product Classification (CPC) List and to the Services Sectoral Classification List (also referred to as the "W/120") ${ }^{1211}$. But the GPA and RTAs with government procurement provisions do not refer to 'Modes of Supply' like the GATS schedules. The reason for this has been explained as being that "the GPA's domain was "procurement policy as such" and that it

${ }^{1207}$ According to the Revised GPA Article 1(c) (Definitions)

Construction service means a service that has as its objective the realization by whatever means of civil or building works, based on Division 51 of the United Nations Provisional Central Product Classification (CPC).

1208 Chen, Hejing and John Whalley, The WTO Government Procurement Agreement and its Impacts on Trade, National Bureau of Economic Research (NBER) Working Paper 17365, August 2001, p16, available online at http://www.nber.org/papers/w17365.

${ }^{1209}$ What is covered by the GPA is determined by three factors:

1. whether the particular government entity responsible for the procurement is included in the list provided by the Party's schedule to the agreement;

2. whether the procurement contract is for goods, services or construction works, and

3. whether the value of the particular procurement is above the "threshold" agreed under the Agreement, as provided by each Party in its schedule.

(Malumfashi, G. Ibrahim., 'GREEN' PUBLIC PROCUREMENT POLICIES, CLIMATE CHANGE MITIGATION AND INTERNATIONAL TRADE REGULATION: AN ASSESSMENT OF THE WTO AGREEMENT ON GOVERNMENT PROCUREMENT, PhD Thesis, University of Dundee, 2010, available online at http://discovery.dundee.ac.uk/portal/ files/1288540/Malumfashi phd 2010.pdf.)

${ }^{1210}$ Except for government procurement and 3 other areas (trade in civil aircraft, dairy products and bovine meat) all other Tokyo Round agreements became multilateral obligations in the covered Agreements and apply to all WTO members since 1995 . The plurilaterals on bovine meat and dairy agreements were terminated in 1997. The Agreement on Trade in Civil Aircraft of 1980 is still in force.

1211 United Nations CPC classification List (Statistical Papers, Series M, No.77, 1991) and the Services Sectoral Classification List (document MTN.GNS/W/120 of July 1991, a GATT Secretariat document) 
therefore did not regulate modes of supply or provide rights of establishment or rights relating to cross-border supply of services. ${ }^{1212}$ GPA Parties' current services sector commitments are mostly on business services (e.g. professional and computer services), telecommunications, construction, aspects of environmental services, financial, tourism and travel. ${ }^{1213}$

The current GPA entered into force in April 2014. Ratification by 10 WTO Members out of the 43 WTO Members (including 28 EU member States) who are parties to the 1996 GPA, were required for it to enter into force. By 2014, the United States, the European Union, Japan, Liechtenstein, Norway, Canada, Chinese Taipei, Hong Kong (China), Iceland, Singapore and Israel became parties. ${ }^{1214}$ As can be seen, the first Parties to join are all industrialized or newly industrialized ${ }^{1215}$ At present, the Agreement has 48 parties (including the EU, consisting itself of 28 States). About 10 other WTO Members have either applied to join or have provision regarding joining in their WTO accession protocols, including China and the Russian Federation. ${ }^{1216} 34$ WTO Members participate in the GPA Committee as observers. Many of these observers are developing countries and their services suppliers would benefit from greater access and transparency in government procurement.

Of the major developing countries, China (if it can still be called a 'developing country'), has shown interest in joining and has attempted to negotiate their accession, but so far, India has not shown much interest in doing more than observing, although that may be slowly changing. However, neither China nor India appear to be willing to open up their large domestic government procurement market to the extent that the industrialized trading partners currently party to the Revised GPA would wish; and have shown they would want to maintain considerable policy space for non-trade objectives. ${ }^{1217}$ At the most recent WPGR in October 2013, the Indian representative "regretted" that the existing work and research presented in the WPRG had a "very narrow focus" on service procurement coverage provided by developed-country RTAs and:

...did not address the development challenges of public procurement liberalization, and notably the high compliance costs that could affect

\footnotetext{
1212 See WTO, Note by the Secretariat, Report of the meeting held on 29th October 2013, S/WPGR/M/82, para.3.2 and 3.4. Also see para. 3.5., which clarifies that most Parties used positive lists to define services coverage under the GPA (with the United States noted as an exception.

1213 WTO, Note by the Secretariat, Working Party on GATS Rules, Report of the Meeting held on 29 October 2013, S/WPGR/M/82, 24 January 2014, para.3.5-3.6.

1214 WTO, 2014 News Items, Revised WTO Agreement on Government Procurement enters into force, 7 April 2014, http://www.wto.org/english/news_e/news14_e/gpro_07apr14_e.htm.

1215 Chen and Whalley note that GATT GPA Parties Korea, Singapore, Hong Kong and Israel, can be now be called new industrialized countries not typical developing countries - although they were considered developing countries during the Uruguay Round. (Chen, Hejing and John Whalley, The WTO Government Procurement Agreement and its Impacts on Trade, National Bureau of Economic Research (NBER) Working Paper No. 17365, 2011, p6, footnote 2 available online at http://www.nber.org/papers/w17365, last accessed 06.06.2014.)

1216 Albania, China, Georgia, Jordan, Kazakhstan, Kyrgyz Republic, North Macedonia, Oman, Russian Federation, Tajikistan.

1217 See further, the following chapters in Arrowsmith, Sue and Robert D. Anderson Eds., THE WTO REGIME ON GOVERNMENT PROCUREMENT: CHALLNGES AND REFORM, Cambridge University Press, 2011: Wang, P., Accession to the Agreement on Government Procurement: the Case of China and Chakravarthy, S. and Kamala Dawar, India's Possible Accession to the Agreement on Government Procurement: What are the Pros and Cons?.
} 
developing countries and LDCs (notably the prohibition to use preferences to promote certain national policy objectives. ${ }^{1218}$

China submitted a formal application to become party to the GPA in December 2007. However, China's initial offer was not considered sufficient and acceptable by other GPA Members. Wang comments that the GPA, even with its recent revisions, remains unequipped to deal with countries with a large state sector. ${ }^{1219}$ The Chinese situation is also complex, especially with regard to the relationship between the Chinese central government and sub-entities including state enterprises. Wang also notes that there is not much political support for GPA accession, especially with the continued use of procurement policy to promote national industrial and environmental policies. Despite this, China has made six more bids since then, the latest offer being in 2019.

There are special and differential treatment provisions in the Revised GPA that could benefit developing economies. According to these special and differential treatment provisions, developing countries which accede to it can enjoy immediate MFN privileges (Article V:2 of the Revised GPA) and can negotiate with the bigger developed countries for them to offer concessions without asking for reciprocal commitments from the developing countries (Article V:4 and V:5 of the Revised GPA). This latter flexibility for specific obligations is not permanent, but only a "delayed application" for either "five years after its accession to this Agreement" (for an LDC, Article V:5a) or "only the period necessary to implement the specific obligation and not to exceed three years" (for a developing country, Article V:5b). However, these transitional measures can be extended and new transitional measures can be approved in "special circumstances that were unforeseen during the accession process" (Article V:6b).

Furthermore, Article XXIII of the GPA provides for exceptions to the GPA which are similar to Article XIV and XIVbis of the GATS. This may protect the policy space for such non-trade concerns. Article XXIII:1 of the GPA, similar to Article XIVbis of the GATS, allows for a Party to take any action or refrain from disclosing information

... which it considers necessary for the protection of its essential security interests relating to the procurement of arms, ammunition or war materials, or to procurement indispensable for national security or for national defence purposes.

Article XXIII:2 of the Revised GPA, is similar to the chapeau and exceptions of Article XIV of the GATS, except that it only lists the following exceptions, that is those measures that are deemed necessary:

1. to protect public morals, order or safety

2. to protect human, animal or plant life or health or intellectual property

\footnotetext{
1218 WTO, Working Party on GATS Rules, Note by the Secretariat, Report of the Meeting held on 29 October 2013, S/WPGR/M/82, 24 January 2014, para.3.11.

1219 Wang, P., China's Accession to the WTO Government Procurement Agreement - Challenges and The Way Forward, Journal of International Economic Law, 2009, 12 (3): 663-706. See also Wang, P., Coverage of the WTO's Agreement on Government Procurement: Challenges of Integrating China and Other Countries with a Large State Sector, Journal of International Economic Law 2007, 10: 887. See further for an assessment of Chinese political leadership, organizational arrangements, academic and public involvement on government procurement: Xinquan, Tu, Organizational Aspects of China's GPA Accession Negotiation and Their Implications, Indiana University Research Center for Chinese Politics and Business, Working Paper No.6, October 2011.
} 
3. relating to the products or services of handicapped persons, of philanthropic institutions or of prison labour.

Thus, the arguments for including concerns such as right to health in public morals, order and safety and human, animal, plant life or health in Article XX of the GATT 1994 and Article XIV of the GATS could apply here as well. Chapter 5 of this study looks at these exceptions and those arguments can be extended to the WTO GPA as well. The inclusion of intellectual property protection as well as the grouping of prison labour together with the other products and services in the third type of exception is very interesting. The implications of this provision can be gone into in more detail, but will not be done at present. This is because of the focus of this section being on Article XIII of the GATS and the fact that the GPA is at present only a plurilateral. What needs to be looked at first is the impact of the GPA, if any on the negotiations for a multilateral agreement under the GATS Article XIII mandate. The area of government procurement in the WTO is complicated by the fact that it is being carried out in three different settings:

1. The plurilateral GPA discussed above which includes goods and services, entered into force in April 2014.

2. The Work Group on Transparency in Government Procurement (set up following the Singapore Ministerial Conference, 1996 including all WTO members) currently on hold.

3. The multilateral negotiations on services procurement under Article XIII:2 of GATS and the work of the Working Party on GATS Rules.

While it is obviously difficult to disentangle services procurement from the larger picture and limit it only to the tasks of the WPGR, this section of the study will focus on the interpretation of Article XIII of the GATS.

The targeted outcome of Article XIII was an Annex in the GATS on government procurement. But very little progress and participation with regard to a text has occurred since 1995/1996 when the Working Party of GATS Rules (WPGR) and the Working Group on Transparency in Government Procurement (WPTGP) was established. There have been some formal and informal meetings on the topic as well as information gathering and notes by the Secretariat and by Members. No action has been taken during 2016-2019. The 2003 WPGR notes that two broad options have been suggested:

1. Applying horizontal disciplines to all services sectors included in a Member's schedule

2. Undertaking general disciplines on a sectoral basis (perhaps with some modifications, following models such as the Telecommunications Reference Paper). ${ }^{1220}$

The last meeting where there was a discussion on government procurement in services was in October 2015, where the suggestions tabled by the European Union on information exchange among Members were discussed.

${ }^{1220}$ WTO, Note by the Secretariat, Interpretation of Procurement-Related Provisions in GATT-Possible Application to Article XIII of GATS, Background S/WPGR/W/29, para.12, citing WPGR, Note from the Chairperson, Job No. 782, 11 February 2000. Also noted in WTO, Report by the Chairperson of the Working Party on GATS Rules, Negotiations on Government Procurement, S/WPGR/11, 30 June 2003.

The European Communities tabled an informal paper and communications noting non-discrimination and transparency issues for a possible framework (see EC, Government Procurement of Services - Possible Development of Multilateral Disciplines, Communication from the European Communities and Their Members States, Job No. 4021, 26 June 2000; Government Procurement of Services, Communication from the European Communities, S/WPGR/W/39; and Government Procurement of Services, Communication from the European Communities, S/WPGR/W/42). 
So far there have been no concrete proposals for separate sectoral government procurement disciplines nor have there been any for general disciplines with modification for particular sectors. If following the model of the Telecommunications Reference Paper (which outlines competition policy principles), it is relevant to note the recognition in the Reference Paper of a Members' right regarding maintenance of universal service obligations. This is in Paragraph 3 of the Reference Paper:

Any Member has the right to define the kind of universal service obligation it wishes to maintain. Such obligations will not be regarded as anti-competitive per se, provided they are administered in a transparent, non-discriminatory and competitively neutral manner and are not more burdensome than necessary for the kind of universal service defined by the Member.

Thus, if following this model, an Agreement or Annex on government procurement in services can include a similar provision. This would allow for Members to define universal service obligations with regard to e.g. health services and retain flexibility for government procurement for the promotion of e.g. health services. The limitations transparency, non-discrimination and competitive neutrality in carrying out universal service obligations is certainly less onerous than the limitation of being "not more burdensome that necessary". This phrase is not defined in the reference Paper but if it will be interpreted similarly to the interpretation of "necessary" in dispute settlement concerning Article XIV of the GATS, it might be considered a (problematically) strict standard. Gao doubts that such a strict standard would be applied since Paragraph 3 concerns a Member's right to define universal service obligations and that the legitimacy of the definition and discretionary authority of the Member is implied. ${ }^{1221}$

Gao also notes the overlap in this area of universal service obligations with the prohibition of anti-competitive cross subsidization and the Article VI requirement that domestic regulation should be "administered in an objective and impartial manner". ${ }^{1222}$ These issues will also be touched upon in the following sections of this Chapter. This shows that any multilateral services procurement text should be created in tandem with subsidies and domestic regulation disciplines. Another area of overlap that can be looked into is Article $V$ of the GATS on economic integration. The WPGR has shifted a lot of its attention to the various government procurement provisions in Economic Integration Agreements (EIAs) as it had been noticed that virtually all of those notified to the WTO under Article V of the GATS had such provisions. ${ }^{1223}$

It can also be noted that the Agreement on Trade in Civil Aircraft of 1980, which is a plurilateral from the Tokyo Round that is still in force, contains disciplines on government procurement of civil aircraft. Considering that negotiations are usually driven by demandeurs and not by those interested in protecting non-trade concerns (and that some Members just follow an 'I agree' or a 'wait and see' approach) - it is unlikely that there will be a suggestion to actively promote concerns such as protection of public health services through a sector specific proposal. Theoretically, there is nothing to

\footnotetext{
${ }^{1221}$ Gao, Henry, Telecommunications Services: Reference Paper in Wolfrum, Rudiger, Peter-Tobias Stoll and Clemens Feinaugle Eds., WTO - TRADE IN SERVICES, Max Planck Commentaries on World Trade Law, Martinus Nijhoff Publishers, 2008, p742-743.

${ }^{1222}$ Ibid., (Gao).

${ }^{1223}$ WTO, Note by the Secretariat, Working Party on GATS Rules, Overview of Government ProcurementRelated Provisions in Economic Integration Agreements, S/WPGR/W/44, 24 June 2003.
} 
prevent such a proposal being made, which suggests the scope, exemptions and exceptions relating to government procurement in the public health sector.

If there is such a step taken, it is important that the procurement rules take into account the human rights-based approaches to public procurement, especially the framework of the right to health. It may also be useful to refer to the WHO 'Procurement Process Resource Guide' (2011) which states that "Procurement is a vital element of equitable access to health care" mentions how "social aspects of procurement (e.g. labour conditions and human rights) are also factors to consider". ${ }^{1224}$ The WHO guidance also refers to national health policies as being the starting-point for planning and that assistance can be sought for the procurement plan and the social aspects of procurement from the relevant UN procurement guidances. The UN 'Procurement Practitioner's Handbook' promotes the concept of 'Sustainable Procurement', which "involves looking beyond the traditional economic parameters" and making decisions based also on "implications for society" and "social aspects" including human rights. ${ }^{1225}$ It is further stated that Sustainable Procurement should "incorporate a number of safeguards and checks in the procurement process" to positively assist in human rights. ${ }^{1226}$ Thus, there is already a framework which takes into account the role of human rights-based approaches in policy, planning and implementation of public procurement, which can be implemented even without further GATS developments.

\subsubsection{Relevance of GATT for Interpretation of Article XIII of the GATS}

There are some differences between the how government procurement has been dealt with under the GATT and the GATS, such as the fact that there is no equivalent of Article XXVII of GATT on State trading enterprises ${ }^{1227}$ - but there are other similarities. The WTO Secretariat Note on interpretation of Article XIII deals with the lack of definition of the term "governmental purposes" and the phrases on 'commercial sale/resale' in Article XIII by suggesting that interpretation given to similar provisions under GATT might provide some useful guidance. ${ }^{1228}$ It is also noted that Article III of GATT served as a model for the drafting of Article XIII of GATS, which means the terms and phrases are essentially the same. ${ }^{122}$ With regard to 'commercial sale/resale' the Secretariat Note refers to the GATT Analytical Index for explanation of the term and finds that it was meant only for the continued application of the national treatment exemption to goods procured through 'tied loans ${ }^{1230}$, and which might sell such goods later to private entities after use (e.g. auctioning of used government equipment). ${ }^{1231}$

\footnotetext{
1224 WHO, Procurement Process Resource Guide, 2011, p8 and p21, available online at: https://apps.who.int/medicinedocs/ documents/s21563en/s21563en.pdf.

1225 Interagency Procurement Working Group (IAPWG), UN PROCUREMENT PRACTITIONERS HANDBOOK, November 2006, updated September 2012, Section 4.5.

${ }^{1226}$ Ibid, Section 4.5 .

${ }^{1227}$ See further for detailed discussion: Wang, P., Procurement of State Trading Enterprises Under the GATS in Arrowsmith, Sue and Robert D. Anderson Eds., THE WTO REGIME ON GOVERNMENT PROCUREMENT: CHALLENGE AND REFORM, Cambridge University Press, 2011, p231.

${ }^{1228}$ WTO, Background Note by the Secretariat, Interpretation of Procurement-Related Provisions in GATT

- Possible Application to Article XIII of GATS, S/WPGR/W/29, 31 March 1999, para.2.

${ }^{1229}$ Ibid., (S/WPGR/W/29), para.4.

${ }^{1230}$ Loans granted to purchase equipment from the country granting the loan. A feature of the dependency created through some loan and aid measures.

It can also be noted that Article II:3(e)i-iii of Revised GPA (Scope) states
} 
There were Four GATT disputes from the pre-WTO period under the Tokyo Round Code on Government Procurement. ${ }^{1232}$ For definitional matters, US-Sonar Mapping has some relevance as it commented on the definition "governmental use" and "governmental purposes" but the facts of the case were such that it was the government (not the public) which was the "ultimate beneficiary of the system". It was therefore not necessary to assess whether it was possible to define the terms any wider than that; and it is a narrow definition that does not cover the issues of public services addressed in this study. There have been three disputes under Article XXII of the GPA ${ }^{1233}$ but the only adopted Panel report is Korea-Government Procurement. The issue of 'commercial re-sale' looked at earlier in this Chapter, particularly with regard to the Canada-Renewable Energy / Canada-Feed-in Tariff Program dispute.

Finally, it is good to pause and consider what would be the benefit of a multilateral government procurement agreement on services? Some indications can be found in the study by Chen and Whalley assessing the potential impacts of the plurilateral GPA on trade among contracting parties (covering 20 OECD countries of which 17 are GPA members and 3 are non-members. The sample period is 1996-2008 for bilateral trade in goods, and 1999-2008 for bilateral trade in services.) The findings were that:

1. GPA membership plays more important role in promoting bilateral trade in services than for trade in goods. A possible reason: services account for the majority of the government procurement market for most GPA parties.

2. Service transactions tend to be repeated and based on reciprocal trust and satisfaction attained in previous deals. Switching costs for either service consumer or service producer are typically higher than for tangible goods

Except where provided otherwise in a Party's annexes to Appendix I, this Agreement does not apply to: procurement conducted:

i. for the specific purpose of providing international assistance, including development aid;

ii. under the particular procedure or condition of an international agreement relating to the stationing of troops or relating to the joint implementation by the signatory countries of a project; or

iii. under the particular procedure or condition of an international organization, or funded by international grants, loans or other assistance where the applicable procedure or condition would be inconsistent with this Agreement.

Questioning this from a developing country or LDC viewpoint, this exemption sound unfortunately paternalistic (re: development aid instead of developmental policy space) and 'neo-imperialist' (re: foreign military presence). Why cannot the obligations (and exemptions/exceptions) in the WTO clearly allow/encourage developing countries to take charge of their own destiny to develop in the way most industrialized nations gained economic growth and development in the first place? That is, by protecting and promoting their domestic industries (both public and private) through governmental measures until they became competitive internationally? That would create, in terms of capacity to benefit, the true 'level playing field' conditions suitable for free trade competition. A GPA on goods and services after conditions are improved closer to a 'level playing field' would be much more popular.

1231 Ibid., (S/WPGR/W/29), para.15 - GATT ANALYTICAL INDEX GUIDE TO GATT LAW AND PRACTICE, p. 192.

1232 Belgium-Family Allowances (BISD 1S/59), EEC-Value-added tax (BISD 31S/247), United States Procurement of a Sonar Mapping System (GPR.DS1/R), Norway-Tendering procedures on Trondheim toll ring project (BISD 40S/319).

1233 Japan-Procurement of a Navigation Satellite DS73; United States-Measures Affecting Government Procurement (Massachusetts State Law prohibiting contracts with firms doing business with or in Myanmar) brought by EC and Japan, DS88 and DS95 but later suspended by the complainants; Korea Measures affecting Government Procurement (procurement practices of the Korean Airport Construction Authority) DS163 Panel report adopted: 15 June 2000. 
consumer and producer, so trade with existing service trade partners tend to intensify.

3. Countries with competitiveness in services will gain and may have strong incentive to increase the number of GPA parties and the degree of openness in government procurement market.

4. The high threshold for the GPA makes foreign affiliates/local commercial presence preferable since interests of procurer to have lower supervision costs. Both the threshold and these preferences will also deter developing countries from entering the GPA. ${ }^{1234}$

If these findings also apply to a multilateral setting, then the incentives for broad participation in creating and acceding to such an Agreement/Annex are not sufficient, especially for developing countries. Furthermore, the many and complicated objectives of the Revised GPA, as expressed in its Preamble, represent the issues that need to be balanced in a GATS procurement text, if ever there is one:

Revised GPA Preamble (extracts, summarized)

1. ...integrity and predictability of government procurement systems are integral to the efficient and effective management of public resources [and] the performance of the Parties' economies ...

2. [No] affording of protection to domestic suppliers, goods or services, or to discriminate among foreign suppliers, goods or services...

3. Recognizing the need to take into account the development, financial and trade needs of developing countries, in particular the least developed countries...

4. The procedural commitments under this Agreement should be sufficiently flexible to accommodate the specific circumstances of each Party...

Adding to this difficulty in balancing all these objectives is the fact that, as the 2011 WPGR Chairperson has also commented, even the problems and benefits have not been sufficiently identified in terms of facts and the discussions have been:

... "essentially conceptual in nature" and without a working text...no draft text or results seem likely to ensue in the near future. ${ }^{1235}$

Sauvé comments that progress is hampered due to the "somewhat schizophrenic" approach of having multilateral negotiations for services procurement under the GATS parallel to the plurilateral disciplines already existing in the GPA and the separate calls for multilateral transparency and due process rules. ${ }^{1236}$

Poretti has drawn attention to another complication, in noting that government procurement can also be seen as a form of subsidization. ${ }^{1237}$ Indeed Article 1.1(a)1.iii of the Agreement on Subsidies and Countervailing Measures (SCM) states that a subsidy shall be deemed to exist where there is a financial contribution through the government purchase of goods, and 1.1.(b) adds that that if a benefit is thereby conferred - a subsidy shall be deemed to exist. The situation of purchase/procurement of services is not

${ }^{1234}$ Chen, Hejing and John Whalley, The WTO Government Procurement Agreement and its Impacts on Trade, National Bureau of Economic Research (NBER) Working Paper No. 17365, 2011, p27-29.

${ }^{1235}$ See WTO, Report by The Chairperson of The Working Party on GATS Rules, S/WPGR/21, 14 April 2011.

1236 Sauvé, Pierre, Completing the GATS Framework: Addressing Uruguay Round Leftovers, Aussenwirtschaft, 57, Jahrgang 2002, Heft III, Zürich: Rüegger, 301-341, p305.

${ }^{1237}$ Poretti, P. REGULATION OF SUBSIDES WITHIN THE GENERAL AGREEMENT ON TRADE IN SERVICES OF THE WTO: PROBLEMS AND PROSPECTS, Kluwer Law International, 2009, Chapter 7. 
Chapter 3

expressly covered in the SCM, although the government provision of "services other than general infrastructure" is in the same category as government purchase of goods. The issue of service subsidies disciplines and their relationship with public services and the scope of the GATS - in particular the negotiating mandate for services subsidies in Article XV of the GATS is an issue of vital importance that will be discussed in further detail in the next, final, section of the Chapter. 


\subsubsection{Article XV of the GATS: Subsidies}

...I will go root away

The noisome weeds, which without profit suck

The soil's fertility from wholesome flowers

The Gardner,

Shakespeare's Richard II

\subsubsection{Concerns about Funding for Public Services}

Due to the ambiguity of the Article I:3 exemption, and taking into account the attitude of caution expressed by Members regarding reliance on the provision a reassessment of tactics regarding public services and GATS coverage becomes necessary. The concerns expressed regarding the impact of GATS on public health services are primarily about continued government funding and support and whether there will be constraints on how government subsidies can be granted.

The discussions on subsidies to the public services sector are relatively new in the context of international trade rules, as earlier definitions of subsidies focus on government payment to private manufacturing bodies. ${ }^{1238}$ The original attitude towards subsidies has therefore been that of 'unfair/distortive benefits' to some manufacturers who are protected at the expense of healthy market competition. But even in that context, many studies, including the work of the UNDP, highlight the fact that large direct and indirect export subsidies played an essential role in the rapid growth of the economies that later became the 'Asian Tigers'. ${ }^{1239}$ The fact that subsidies are not necessarily harmful for trade, growth and economic development and that, rather than inhibit these objectives, can actually play an important role in development of developing countries is acknowledged in many instances, including in Article XV of the GATS, as shall be discussed further on.

The standard view of subsidies is that they are protective of national interests or national industries but at the same time would be harmful to the interests of other nations and their people. Agricultural subsidies of developed countries causing harmful impacts to smallscale farmers in developing countries is the most common example that comes to mind. However, subsidies may play a positive role in promoting common global interests. Several authors have commented on the interactions between WTO law and renewable energy subsidization, noting that there needs to be space in the WTO for acknowledging that the positive externalities are not only to the domestic economy but also to the global environment. Multilateral disciplines are for greater efficiency at the level of international trade, but in some areas, national policy of using subsidies may reach overall national developmental objectives in a quicker ('more efficient'?) manner. Thus, the

1238 See Schwartz, Warren F. and Eugene W. Harper, Jr., The Regulation of Subsidies Affecting International Trade, Michigan Law Review, Vol. 70, No. 5, April 1972, p842-843; Sykes, Alan O., Subsidies and Countervailing Measures in Macrory, Patrick F. J, Arthur Edmond Appleton and Michael G. Plummer, THE WORLD TRADE ORGANIZATION: LEGAL, ECONOMIC AND POLITICAL ANALYSIS, Vol. II, Springer, 2005, p85.

${ }^{1239}$ UNDP, Making Global Trade Work for People, UNDP/Earthscan, 2003, p197, Box 10.1, referring to the Republic of Korea, Malaysia, Singapore and Taiwan. 
approach towards subsidies as harmful merely because they are 'trade-distortive' (usually of global trade) - without considering the objectives of the 'distortion' is too narrow a view to take in the broader context of sustainable development.

These former parameters on subsidies as 'trade-distortive' have shifted and become even more complicated with the entry into force of the GATS. The issue of subsidies is one of the most contentious in services - at least from a civil society point of view. The question is whether the situation of services, particularly public services, should be seen through the same lens through which subsidies for goods/manufacturing have been seen. There are some other factors that make public services subsidies different from the general view towards goods subsidies (and even in the case of goods, food security concerns of some countries such as India lend a different character to certain agricultural subsidies, which are dealt with separately under the Agreement on Agriculture).

It must be pointed out that it is not necessarily subsidies themselves as tools, but what ends the tools are used for, that would decide the extent of 'harmfulness' to trade or other social goals. Schwartz and Harper note that it is "curious" that there is "no distinction drawn among subsidies on the basis of the [specific social] policy objectives they are designed to implement", although it is recognized that a subsidy is a policy instrument. ${ }^{1240}$ For example, subsidies can be harmful for environmental protection if they are directed towards subsidizing polluting industries; but there can also be 'green subsidies' that promote environmentally friendly technologies and industries. The obligations of States with regard to measures to limit climate change and environmental damage and pollution can also require the use of subsidies for the use of 'green technology' or for offering incentives to existing enterprises to take up environmentally sustainable practices. ${ }^{1241}$

Similarly subsidies that are supportive of public health services delivery and are made for the purpose of raising and maintaining higher standards of healthcare are an entirely different matter from subsidies that are diverting tax payer/treasury finances towards certain chosen private healthcare providers or private health insurance providers (who are also often, but not necessarily always, domestic service suppliers). The former situation may arguably not even be strictly defined as a 'subsidy' and the latter form of expenditure is not be the best way to achieve public health and right to health goals, since the combined cost of the diversion of public money is likely to be more costly than if the funds were invested in improving public health services. Furthermore, subsidies and funding for the public sector and the obligation to provide universal services have been discussed in the human rights context as part of both the right and the duty to regulate and part of the right to development. ${ }^{1242}$

\footnotetext{
1240 See Schwartz, Warren F. and Eugene W. Harper, Jr., The Regulation of Subsidies Affecting International Trade, Michigan Law Review, Vol. 70, No. 5, April 1972, p842, footnote 11; and UNDP, MAKING GLOBAL TRADE WORK FOR PEOPLE, UNDP and Earthscan, 2003, p197 and Box 10.1. Also note that there was a category of non-actionable subsidies under Article 8 of the SCM, for research activities, regional development or adaptation to new environmental regulations - however, it is no longer used.

${ }^{1241}$ ICTSD (International Center for Trade and Sustainable Development), Mark Benitah with David VivasEugui and Mahesh Sugathan, Subsidies, Services and Sustainable Development, Issue Paper No.1, ICTSD Programme in Trade in Services and Sustainable Development, February 2005, p1.

${ }^{1242}$ UN, OHCHR, Liberalization of Trade and Human Rights: Report of the High Commissioner of Human Rights, E/CN.4/Sub.2/2002/9, June 25 2002, para.55:
} 
Subsidies are clearly an important policy tool for maintaining effective public services. Subsidies can also provide much needed incentives for developing domestic services capacity, both for large scale development programmes as well as for small and medium enterprises. Even in the trade context, the 1998 Background Note by the WTO Secretariat on subsidies for services acknowledges that some measures may have been intended "primarily to promote public policy or infrastructural objectives", and particularly note the health sector. ${ }^{1243}$ Footnote 2 this paragraph states:

For example, the provision of basic health services may be ensured through: (a) cost-free treatment in state-owned hospitals; (b) the extension of public funds to commercially independent hospitals; or (c) government sponsored premiums for basic health insurance. While conferring the same benefits to the same target group, such measures might be defined, respectively, as the provision of infrastructural services, subsidies for the health sector, social transfers and/or subsidies for insurers

Subsidies are described here as related to "the extension of public funds to commercially independent hospitals" and not to financial transfers to public hospitals. The footnote to that paragraph defines free treatment in public hospitals as "infrastructure services" and not specifically as subsidies. Such services may in any case be exempt from the scope GATS under Article I:3. The footnote also defines government sponsored premiums for basic health insurance as subsidies. There is no mention of subsidies as relating to national public health services in the Background Note, but general subsidized loan repayment (Czech Republic), tax incentives for investments (Paraguay) and tariff reductions (Benin) for health services are mentioned from Trade Policy Reviews (TPR).

In the most one of the recent Secretariat Note on subsidies in TPRs (2014, revised 2015), it is noted that there are a number of different forms of financial assistance granted to health services as recorded in eight TPRs, including tax incentives and other unspecified measures mentioned by India in its $5^{\text {th }}$ TPR in $2011 .{ }^{1244}$ However, the Note states that this information from TPRs has been provided merely for facilitating discussion and that there is no judgement on the objectives pursued in granting this assistance, on whether these types of financial contributions should be considered subsidies. ${ }^{1245}$ Both the 2014 version and 2015 revision of the Note commented that:

... some of the subsidies mentioned in TPR reports may be financial contributions to services which are beyond the scope of the GATS, i.e.,

Subsidies [and] the obligation to provide universal services...are other forms of governmental regulation that can be important to the services sector... In human rights terms, the Declaration on the Right to Development [Article 2 (3)] declares that "States have the right and the duty to formulate appropriate national development policies that aim at the constant improvement of the well-being of the entire population and of all individuals ...". Indeed, what is referred to as a right under GATS is in fact a duty to regulate under human rights law.

1243 WTO, Background Note by the Secretariat, Working Party on GATS Rules, Subsidies for Services Sectors: Information Contained in WTO Trade Policy Reviews, S/WPGR/W/25, 26 January 1998, para.5 and footnote 2 .

${ }^{1244}$ WTO, Working Party on GATS Rules, Background Note by The Secretariat, Subsidies for Services Sectors: Information Contained in WTO Trade Policy Reviews, S/WPGR/W/25/Add.7, 17 April 2014, p17.

1245 Ibid., (S/WPGR/W/25/Add.7), para.2.4. Also repeated in WTO, WPGR, Background Note by The Secretariat, Subsidies for Services Sectors, Information Contained in WTO Trade Policy Reviews, Addendum, Revision, S/WPGR/W/25/Add. 7/Rev.1., 13 January 2015, para.2.4. 
services provided in the exercise of governmental authority (Article $\mathrm{I}: 3(\mathrm{~b})) .{ }^{1246}$

The Notes have not explicitly recognized that when considering subsidies, financial contributions and public services, there is a wider policy context than mere trade and commercial aspects for services such as health services, but it can be read between the lines or read into it by Members if they rely on this information for developing subsidies disciplines for services. It is relevant to connect these attempts to classify health services assistance - whether financial contributions or subsidies - with the fact that these public policy and infrastructure objectives for basic health services could align with the State's obligations under domestic constitutional arrangements and right to health and right to development-based obligations under international law, discussed in earlier sections of this study. ${ }^{1247}$

In the WTO Publication GATS: Facts and Fiction, released in 2001 to counter the criticisms that were expressed both during the controversial Seattle Ministerial and subsequently, the concerns regarding the effect of the GATS on public funding was mentioned as 'unfounded'. But the categorical statement that:

The GATS has no implications for the funding or subsidy of services provided in the exercise of governmental authority. ${ }^{1248}$

...is undermined by the sentences that follow it, which say that whatever future disciplines developed through the negotiations on subsidies:

... will not apply to governmental services, because these are simply outside the scope of the GATS.

Thus, the same familiar circular argument that there is no need to be concerned about the exclusion of 'subsidies'/government funding for public health services from the GATS, 'since everything is very clear', is based on two problematic definitions: SSEGA and subsidies for services. SSEGA under Article I of the GATS does not precisely clarify the status of an exemption of public health services and subsidies for public services comes under Article XV which does not have an actual text on services subsidies, but only a negotiating mandate that has not yet been negotiated by Members.

As discussed earlier in Section 3.4 of this Chapter, the matter of this exemption is not as simple as it may seem at first and the concerns of protestors and critics are valid. As the exemption is too vague to be relied upon, the issue of clarifying which WTO rules, if any, could impact upon funding of public services such as health services and how they may influence national policy, become very important. Furthermore, confusion on these matters (on the actual position taken and in statements to allay concerns) is not only seen in official statements of the WTO as an institution, but also in the domestic statements of its Members. As an illustration of the latter point is the public consultation held in the UK and the government responses to the issues raised. Thanks to the level of public participation in the process of governance and policy-making in the UK, there is access to publicly available documents that affirm the position of a WTO Member in this matter.

In 2002, the UK Department of Trade and Industry, in a consultation document open for public comment, acknowledged that recently expressed public concerns about the GATS negotiations were primarily focused on the issues of:

\footnotetext{
${ }^{1246}$ Ibid.

${ }^{1247}$ See in particular Sections 2.4 and 5.3.2. and 5.4.2.

1248 WTO, GATS: FACT AND FICTION, 2001, p10.
} 
...governments' ability to maintain public services where they choose to do so [and] the right and ability of governments to regulate services in order to meet national policy objectives ${ }^{1249}$

It was also stated later in the document that:

One of the key concerns for all Members will be to ensure that the provision of public funding or subsidy to key public services can be maintained without question. ${ }^{1250}$

However, what is cited for support of this right and ability regarding public services protection is the Preamble of the GATS ${ }^{1251}$ and not Article I:3(b) and I:3(c). It is admitted that

There has been public comment that these conditions are ambiguous. The Government has been exploring with other WTO Members the desirability of seeking a clarification of this provision. However, so far, most WTO Members seem content not to re-open this article and no Members are currently questioning any other Member's interpretation. ${ }^{1252}$

Therefore, the emphasis is laid wholly on the ability to choose not to make commitments, especially in the sensitive area of public health services ${ }^{1253}$ - stating that

The Government has made clear that it does not intend to take

commitments that could lead to the continued provision of public services

via the NHS being called into question. ${ }^{1254}$

That this is the most reliable option may also be the conclusion of this Chapter, but before coming to that point, it is necessary to analyze in more detail, the provisions on subsidies in the GATS.

\footnotetext{
${ }^{1249}$ UK Government, Department of Trade and Industry, Liberalizing Trade in Services: A new consultation on the World Trade Organization GATS negotiations, October 2002, at para.1.5 and again at para.6.28, specifically mentioning universal service and affordable prices as examples of national policy objectives. Document available online at webarchive.nationalarchives.gov.uk/tna/+/http://dti.gov.uk/ewt/gatscons.pdf/. Last accessed 27.10.2011.

1250 Ibid para.5.8

${ }^{1251}$ Ibid, para.6.29, citing the following sentence from the Preamble of the GATS: Recognizing the right of Members to regulate, and to introduce new regulations, on the supply of services within their territories in order to meet national policy objectives ...
}

Note also that the Preamble of the GATS was also what was cited for support of 'the right to regulate' by the Commission on Human Rights, Report of the High Commissioner of Human Rights, Liberalization of Trade and Human Rights: Report of the High Commissioner of Human Rights, E/CN.4/Sub.2/2002/9, June 252002 , para. 55.

1252 Ibid., (UK Govt), para.6.24.

${ }^{1253}$ Ibid., para.6.25:

Moreover, a bottom-up approach means that WTO Members can choose not to make commitments in any sector where this ambiguity could compromise a country's reliance on this exclusion.

${ }^{1254}$ Ibid, page 43. Also repeated at para.6.26:

The Government has repeatedly stated that it does not intend to make commitments that could call into question the continued provision of public services through the National Health Service or the state education system.

The section on health services at page 43 further explains that the EC has reserved the right to limit eligibility for subsidies to nationals of a Member State of the EC when it comes to establishment, R\&D and any subsidies granted to natural persons.

Note that since the Conservative-Liberal Democrat coalition government came into power and new legislation and policy was put in place 2012 (as mentioned in Chapter 2) some major changes have occurred in both the overt and implied position of the UK Government on the NHS and on funding for the NHS. This is the first time since the establishment of the NHS that there has been such a significant shift in law and policy. 
In 2003 the UK Government published the response to the DTI's consultation document and set out the main messages from almost 800 submissions and responded to them briefly. It was stated that there was little to add to the consultation document on the matter of subsidies, other than the expression of concerns as to public funding. This is not altogether surprising, considering that the questions asked were

1. What kinds of domestic subsidies might be considered trade distortive and why?

2. What exclusions from any GATS disciplines might be necessary or desirable? ${ }^{1255}$

These questions are matters which do not have a clear solution as yet, and certainly, if no clear solution has been offered either by expert economists taking all the externalities into account, nor by trade lawyers and WTO Member representatives in negotiations, it is expecting quite a lot from political groups, trade unions, civil society organizations and the general public, that they could provide this. In the end, the UK Government position on subsidies was reiterated thus:

The Government supports the development of multilateral disciplines on subsidies, which provide an opportunity to prevent trade distortions while at the same time clarifying the exclusion of essential public services from any subsidy rules that may be developed. ${ }^{1256}$

So, what is the situation with regard to developing multilateral disciplines on subsidies? The relevant provision is Article XV of the GATS, which will be discussed below in the next section.

\subsubsection{Article XV of the GATS is only a negotiating mandate}

'When will it be done?' she eagerly asked.

'If there's any chance of it in my time,

I think I'll leave off reading, and wait for it!'

'Well, perhaps in another thousand years or so...'

From Lewis Carroll's Sylvie and Bruno

Article XV of the GATS, on subsidies states as follows:

1. Members recognize that, in certain circumstances, subsidies may have distortive effects on trade in services. Members shall enter into negotiations with a view to developing the necessary multilateral disciplines to avoid such trade-distortive effects. ${ }^{1257}$ The negotiations shall also address the appropriateness of countervailing procedures. Such negotiations shall recognize the role of subsidies in relation to the development programmes of developing countries and take into account the needs of Members, particularly developing country Members, for

\footnotetext{
${ }^{1255}$ UK Department of Trade and Industry, Liberalising Trade in Services: A New Consultation on the WTO GATS Negotiations (Summary of Responses and Government's Reply), para.116, $18^{\text {th }}$ December 2003, available at http://webarchive. nationalarchives.gov.uk/tna/+/http://dti.gov.uk/ewt/gats2000.doc/, last accessed 27.10.2011.

${ }^{1256}$ Ibid., para.117.

${ }^{1257}$ At this point - The Original Footnote 7 of the GATS.
} 
flexibility in this area. For the purpose of such negotiations, Members shall exchange information concerning all subsidies related to trade in services that they provide to their domestic service suppliers.

2. Any Member which considers that it is adversely affected by a subsidy of another Member may request consultations with that Member on such matters. Such requests shall be accorded sympathetic consideration.

Footnote 7 of the GATS adds that

A future work programme shall determine how, and in what time-frame, negotiations on such multilateral disciplines will be conducted

As can be seen from the above, Article XV:1 is only a negotiating mandate for future disciplines and not a substantive provision. Unlike Article XIII of the GATS on government procurement, which allows for exemption from GATS rules, there is no exemption or protection for existing subsidies but neither is there specific prohibition.

Under Article XV:2, there is an opportunity for consultations when adversely affected by subsidies of another Member, but this has not been made use of. One possibility is that Members do not want to rock the boat before the basic issues regarding service subsidies have been negotiated. Other reasons for inaction could be; uncertainty of actual damaging effects of service subsidies, lack of service industry pressure to ask for consultations and also that the efforts under Article XV:2 are merely discussions and not even preliminaries to a dispute settlement process. ${ }^{1258}$

The Article XV of the GATS negotiating mandate is for the development of future disciplines in subsidies and requires the identification of trade distortive effects and creating the necessary rules. The issues left incomplete in the final text of the GATS in this manner, fall under the work of the Working Party on GATS Rules (WPGR). ${ }^{1259}$ The progress on this matter has been very slow progress, if at all. The recent reports of the discussions in the Working Party meetings show that there is very little momentum on services subsidies. This is hardly surprising as the last sentence of the Article XV:1 states that:

For the purpose of such negotiations, Members shall exchange information concerning all subsidies related to trade in services that they provide to their domestic service suppliers.

Rather than focus on the conceptual work of defining services subsidies and clarifying the sensitive issues of balancing legitimate non-trade socio-economic goals with the overbroad concept of trade distortion, Members are asked to voluntarily provide all the information on their domestic subsidies. ${ }^{1260}$ This is - even taking into account the general obligation on transparency - something that is hardly likely to happen. ${ }^{1261}$ In 2010 , the Annual Report of the WPGR noted that since the launch of the Work Programme, only 15 Members (counting the EU as one) had submitted information on their subsidy programmes. ${ }^{1262}$ In 2011, the Report by the WPGR Chairperson stated that the number of

${ }^{1258}$ Poretti, P., Article XV GATS in Wolfrum, Rudiger, Peter-Tobias Stoll and Clemens Feinuagle Eds., WTO -TRADE IN SERVICES, Max Planck Commentaries on World Trade Law, Martinus Nijhoff Publishers, 2008, p.360-361.

${ }^{1259}$ Working Party on GATS Rules, established on 30 March 1995 by the Council for Trade in Services 1260 .

${ }^{1261}$ See also Grosso, Massimo Geloso, Analysis of Subsidies for Services: The Case of Export Subsidies, OECD Trade Policy Working Paper No. 66, TAD/TC/WP(2007)15/FINAL, OECD, 2008, para.5-6.

1262 WTO, Annual Report of the Working Party on GATS Rules to the Council for Trade in Services, S/WPGR/20, 8 November 2010, para.7. 
submissions was 18 (covering 44 WTO Members) ${ }^{1263}$ Furthermore, there is also no timeline for completing the negotiations, which means that no urgency is created and Members can postpone this issue indefinitely. However, this section will present the framework that has been put in place so far, as it is useful to be aware of the foundations that may be built upon later.

The first version of the Checklist on Subsidies was circulated by the Chairman of the Working Party in July 2000 (revised in September 2000 and in February 2003) ${ }^{1264}$ was intended to assist Members to address the subject of subsidies in a systematic manner during the Meetings. It was thought that the WPGR would take one issue from the checklist per meeting. Two changes were included in the Checklist $(\operatorname{JOB}(03) / 57)$ in February 2003:

1. Explicitly spelling out the issue of the definition of a subsidy in trade in services.

2. Adding a new issue: concepts relevant to what should be regarded as tradedistortive subsidies.

These are also the two issues that will be focused on in this section of the study. The Checklist also acknowledges the following:

- The wider role of subsidies, including to pursue public policy objectives.

- The role of subsidies in relation to development, and

- the needs of developing countries Members for flexibility, including special and differential treatment.

But there is nothing to suggest how this is to be implemented in the GATS - whether it is to be through Article XIV exceptions, through the provisions that take note of the special needs of developing countries or whether this role should be recognized in the definition for services subsidies and the concept of 'trade distortion'. On the last item, the possibility seems to be considered as the Checklist also notes that:

Concepts relevant to what should be regarded as trade-distortive subsidies, including specificity, public policy objectives, nature of the subsidies, and permissible or non-actionable subsidies [emphasis added].

This will be discussed in more detail further on. But it must be only speculation, as the negotiations have not resulted so far in any draft text on definitions for services subsidies.

The WPGR Meeting in 2011 noted no progress in the area of subsidies, merely advising Members to exchange information and to continue using the revised Checklist as a guide for identifying the content of possible disciplines and to discuss the possibility of multilateral disciplines in the area. There has been a session of dedicated discussions in 2010 on the information provided by Members ${ }^{1265}$ but later Notes and Reports on subsidies meetings mainly refer to the proposals by Switzerland for disciplines on export subsidies (JOB/SERV/36), and the questions submitted by the United States on tradedistortive effects of subsidies in services (S/WPGR/W/59). It was noted that there was a proposal from India, Chile and Mexico suggesting a flexible roadmap for future

\footnotetext{
1263 WTO, Report by the Chairperson of the Working Party on GATS Rules, S/WPGR/21, 14 April 2011, para.9.

The footnote lists that submissions were received from Australia; Brazil; Canada; China; European Union; Chile; Colombia; Hong Kong, China; India; Japan; Korea; Mexico; New Zealand; Norway; Peru; Turkey; Chinese Taipei; and the United States and were circulated in JOB/SERV/1/Add. 1 to 12.

1264 WTO, Note from the Chairperson of Working Party on GATS Rules, Checklist on Subsidies, Negotiations on Subsidies (Article XV of the GATS), JOB(03)/57 17 March 2003.

${ }^{1265}$ WPGR meeting of 24 November 2010 , see S/WPGR/M/71.
} 
discussions (JOB/SERV/37), but this has not produced any changes in the negotiations. Since 2011, consultations on subsidies have been mostly informal, due to the insufficiency of conceptual and technical work and information on whether there are existing trade-distortive subsidies in services. There have been a number of documents circulated since then, which build upon the 1998 Secretariat Background Note ${ }^{1266}$ that attempted to gather and explain information on subsidies from Trade Policy Reviews.

The minutes of the Meeting of October 2013 consisted mostly of an exchange between the trade representatives of the United States and Switzerland. The United States expressed concern on the lack of consensus on the definition of subsidy for services and while Switzerland observed that there was a level of global coherence, there was no agreement on how to move forward. ${ }^{1267}$ The issue of subsidies was postponed once again. In February 2014, it was noted by the Chairman of the WPGR that discussions were "at an impasse", not because of lack of inputs but because of lack of "convergence on how to move forward". ${ }^{1268}$ It was however stated that there was a consensus decision that the existing information on subsidies would be re-organized on a sectoral basis, to allow Members to make searches on subsidy measures on a sectorial basis. ${ }^{1269}$ In 2014 and 2015, the WTO Secretariat issued an Addendum and Revision to its Background Note on subsidies for service sectors, which reviewed the sectoral-based mention of subsidies in Member's Trade Policy Reviews. ${ }^{1270}$ It was mentioned that the information is not to be considered complete nor to assume that the document prejudges the measures listed as subsidies. It is also stated that the highest number of subsidies noted by Members was for tourism services and travel-related services ( 81 Members), with only 8 Members making specific mention of health services-related subsidies. ${ }^{1271}$

A WTO Member or anyone trying to make sense of subsidies in the GATS is once again faced with vagueness and contentious issues, as subsidies may or may not be sorted out at some later date. Having a coherent discussion, let alone a widely acceptable global set of rules on services subsidies as an outcome of current WTO discussion and negotiations, is a very ambitious project. There has not even been any suggestion as to the broad contours of possible disciplines on services subsidies; and which rules, if any, may be necessary, desirable or even feasible, have not been clearly identified, let alone agreed upon. ${ }^{1272}$

\footnotetext{
${ }^{1266}$ Background Note by the Secretariat, Working Party on GATS Rules, Subsidies for Services Sectors: Information Contained in WTO Trade Policy Reviews, S/WPGR/W/25, 26 January 1998.

Also see Results of the Meeting of 29 October 2013 (see WTO/AIR/4220 and JOB/SERV/166) and the Working Party's Annual Report (S/WPGR/W/63)

1267 WTO, Note by The Secretariat, Working Party on GATS Rules, Report of the Meeting Held on 29 October 2013, S/WPGR/M/82, 24 January 2014.

1268 WTO, Note by The Secretariat, Working Party on GATS Rules, Report of the Meeting Held on 25 February 2014, RESTRICTED, S/WPGR/M/83, 17 April 2014, para.3.1.

1269 The reorganization of information referred to a new version of the Secretariat's Background Note, Subsidies for Services Sectors - Information contained in WTO Trade Policy Reviews, (S/WPGR/W/25/Add.6).

1270 WTO, Note by The Secretariat, Working Party on GATS Rules, Report of the Meeting Held on 25 February 2014, RESTRICTED, S/WPGR/M/83, 17 April 2014; WTO, Background Note By The Secretariat, Subsidies for Services Sectors, Information Contained in WTO Trade Policy Reviews, Addendum, Revision S/WPGR/W/25/Add. 7/Rev.1., 13 January 2015.

1271 The countries with health services subsidies in there TPR's are Jordan, Oman, Barbados, Antigua, India, Republic of Korea, Mozambique and Brunei Darussalam.

1272 ICTSD (International Center for Trade and Sustainable Development), Mark Benitah with David VivasEugui and Mahesh Sugathan, Subsidies, Services and Sustainable Development, Issue Paper No.1, ICTSD Programme in Trade in Services and Sustainable Development, February 2005, p3.
} 
So, on one hand Members are left with insufficient information on the types and level of service subsidization currently happening and whether it can be controlled through creation of trade rules. On the other hand, there is also no coherent discussion on the basic issue of whether disciplines on subsidies are in general a desirable outcome for services, especially taking into account the case of improving and maintaining public services. In this author's opinion, the basic conceptual issues on the differentiation of public services, particularly the inability of the market to ensure universal provision of certain essential services such as healthcare services need to be addressed before there can be transparency of information about current services subsidies and negotiations on how to reduce 'distortive' services subsidies.

Until then, Article XV:2 of the GATS only says that Member adversely affected by subsidy may request consultations - which shall be accorded sympathetic consideration. So far there have not been any consultations under Article XV:2. Poretti offers as explanation, the "risk of a glasshouse effect that a first request for consultation may trigger". ${ }^{1273}$ Sauvé comments that there is a "decidedly limited political appetite for forward movement" in subsidies negotiations, particularly as Members would want to avoid questions on subsidies in politically sensitive areas (Sauvé notes audiovisual services and health - presumably the main European areas of concern in services). ${ }^{1274}$

Although it may be viewed as a defeat of sorts, Member positions on subsidies negotiations could be seen as a strategic withdrawal and preparation for siege, to protect one's borders either through exclusion of health-related services from commitments or careful use of limitations in Members' schedules of commitments to allow for measures such as subsidies and leave public services funding unaffected. From a human rights approach, this strategy is in line with the High Commissioner on Human Rights position on subsidies negotiations, which (while commenting that negotiations on subsidies have so far been "superficial"),

...encourages all WTO members to acknowledge in any such [subsidies] negotiations the responsibility of all countries to respect human rights [and] underlines that it will be important for States to take a cautious approach when making commitments to open services markets in their schedules. ${ }^{1275}$

WTO Members are certainly not being hasty in this area of negotiations, but neither are there any signs that disciplines in subsidies that take a human rights approach to economic development. More comprehensive discussions and negotiations are necessary at some point of time if there is to be any progress on the issue. Of course, some would find the alternative of deadlock preferable to a 'hurriedly pushed through' subsidies

\footnotetext{
1273 Poretti, P., Article XV GATS in Wolfrum, Rudiger, Peter-Tobias Stoll and Clemens Feinaugle Eds., WTO - TRADE IN SERVICES, Max Planck Commentaries on World Trade Law, Martinus Nijhoff Publishers, 2008, p360.

1274 Sauvé, Pierre, Completing the GATS Framework: Addressing Uruguay Round Leftovers, Aussenwirtschaft, 57, Jahrgang 2002, Heft III, Zürich: Rüegger, 301-341, p332. See also Sauvé, Pierre and Marta Soprana, Learning by Not Doing: Subsidy Disciplines in Services Trade, International Centre for Trade and Sustainable Development (ICTSD) and World Economic Forum, E15Initiative, 2015, https://www.wti.org/media/filer_public/fa/32/fa32afa517d84e35a93f07d39bca94b8/e15_subsidies_sauve_a nd soprana_final.pdf.

${ }^{127 \overline{5}}$ UN, Commission on Human Rights, Report of the High Commissioner of Human Rights, Liberalization of Trade and Human Rights: Report of the High Commissioner of Human Rights, E/CN.4/Sub.2/2002/9, June 252002 at para. 62.
} 
agreement that ties the hands of democratic governments in implementing measures providing for welfare of the people that elected them.

Additionally, Sauvé also notes that there is a lack of pressure from the services industry for the adoption of such discipline and that it is only an issue that "a few trade economists... worry from time to time". ${ }^{1276}$ Perhaps this is because the pressure from services industries would relate to their practical desires in entering new markets or expanding their market share, and the concern with subsidies would be higher if there is already intense competition or the potential of competition. If the practical situation is such that there is either little or no practical opportunity to compete globally (certain developing country and LDC lethargy towards developing the multilateral disciplines can be explained this way) or if the lack of real competition means that the major profitable foreign markets have already been captured (by developed country TNCs holding monopolies or large market shares), there would not be sufficient pressure on reducing subsidies affecting international trade in services.

On the other hand, Sauvé and Soprana commented in 2015 that the "alignment of political economy forces" now in play are no longer those that were present at the conclusion of the Uruguay Round, and note the new factors such as:

... the emergence of developing countries, including those where SOEs play a major role in key service sectors...[and]... vastly more questioning attitudes that pervade public policy debates on trade and investment liberalization relative to those characterizing the heyday of the Washington Consensus. ${ }^{1277}$

In 2018, the authors further updated their conclusions, noting the importance of preserving policy space and the increasing opportunities for Members in the global services market as reasons why services subsidies negotiations are unlikely to go ahead. ${ }^{1278}$ Thus, the outlook does not seem encouraging for Members to work further in the WPGR to develop subsidies disciplines for services, since developing country Members would hope to build their domestic services capacity through using subsidies as a policy tool.

This brings us to the Chinese market, which is obviously a very large one where there is potential for profit through trade in services. But the special case of China and its State trading enterprises or State-owned enterprises led, not to developing multilateral rules for subsidies, but to the inclusion of special rules on subsidies in China's Accession Protocol for the purposes of applying Articles 1.2 and 2 of the SCM Agreement. The SCM definition of 'subsidy' is a financial contribution by a government that confers a benefit to a recipient. According to Section 10.2 of China's Accession Protocol, subsidies to State owned enterprises (SOEs) are identified as 'specific' if SOEs are the predominant beneficiaries or receive disproportionately large amounts of such subsidies. This apparent targeting of State-owned enterprises suggests pressure to privatize, to open the economy

\footnotetext{
1276 Ibid, (Sauvé).

1277 Sauvé, Pierre and Marta Soprana, Learning by Not Doing: Subsidy Disciplines in Services Trade, Think Piece: E15 Task Force on Rethinking International Subsidies Disciplines, E15Initiative, International Centre for Trade and Sustainable Development (ICTSD) and World Economic Forum, April 2015, http://e15initiative.org/wp-content/uploads/2015/04/E15_Subsidies_Sauve-andSoprana_final.pdf.

1278 Sauvé, Pierre and Marta Soprana, Disciplining Service Sector Subsidies: Where Do We Stand and Where Can We (Realistically) Go?, Journal of International Economic Law, Volume 21, Issue 3, September 2018, Pages 599-619.
} 
and allow for more private enterprises including foreign ones. Qin notes that this is against the basic international law principle of the right to freely chose one's own political and economic system ${ }^{1279}$ and is also discriminatory as it "singles out China's state ownership as a special target for trade remedies" without a basis of sufficient economic or other legitimate rationale. ${ }^{1280}$ Qin also notes that the fear of China's role as a new economic power may have led to stricter rules on subsidies for SOEs, but that there should have been a more balanced approach that took into account China's "responsibility for the welfare of $20 \%$ of the world's population" and its needs for legal framework that supports social stability. ${ }^{1281}$ This applies with probably even more relevance for areas such as health services. China's Accession Protocol notes "health related services" as being 'service sectors subject to government guidance pricing' in Annex 4 of its Accession Protocol, but there is nothing explicitly noted about service subsidies.

As can be seen, the Uruguay Round did not deal with services subsidies and there are both basic conceptual and definitional problems as well as practical problems that have been left for later - which have still not been negotiated. There are some good arguments supporting multilateral disciplines in subsidies, especially in goods, but these do not necessarily transfer themselves to services. It is difficult to agree with Sykes' recent suggestion that the difficulty of formulating rules of general applicability in the WTO means that the solution can be found by transposing a "laissez-faire approach to subsidies" as it is in the U.S. Federal system. ${ }^{1282}$ Services need to be looked at differently, taking into account the importance of public services. This seems to have been understood by Members, in that the WTO Agreement on Subsidies and Countervailing Measures (SCM Agreement) relating to goods was not thought to be easily transformable into a services version. To begin with, there are conceptual problems relating to the negative impact of subsidies on international trade in services. Even in the case of the existence of negative impacts, these could be offset by the positive gains in national development objectives.

Thus, the next problem is how to define and categorize subsidies for services and whether the SCM Agreement is a good starting point for a discussion on services subsidies. From a European viewpoint, the EU State aid regime and the role played by public services in European law may be useful for the purposes of defining services subsidies in WTO law, particularly since Rubini notes that the EU State aid rules are more lenient towards government subsidies than WTO law. ${ }^{1283}$ However, as there are many other factors and conditions that make the context of European law different, as well as the fact that

\footnotetext{
${ }^{1279}$ Qin, Julia Ya, WTO Regulation of Subsidies to State-Owned Enterprises (SOEs) - A Critical Appraisal of the China Accession Protocol, Journal of International Economic Law, 7(4), 2004, 863-899, p899 citing the UNGA Resolution 2625 of 1970 (Declaration on Principles of International Law Concerning Friendly Relations and Co-operation Among States in accordance with the Charter of the United Nations)

${ }^{1280}$ Ibid., (Qin), p902.

${ }^{1281}$ Ibid., (Qin), p914.

${ }^{1282}$ Sykes, Alan O., The Questionable Case for Subsidies Regulation: A Comparative Perspective, Stanford Law and Economics Olin Working Paper No. 380. Sykes come to this conclusion after comparing subsidization in the U.S. Federal system, the WTO, and the European Union ('State aid' in the latter case).

${ }_{1283}$ Rubini, Luca, THE DEFINITION OF SUBSIDY AND STATE AID: WTO AND EC LAW IN COMPARATIVE PERSPECTIVE, Oxford University Press, 2009, p17. See also Luja, R. H. C, The WTO Subsidies Regime: Are there Lessons to be Learnt from Recent EC State Aid Issues? in Lang, Michael, Judith Herdin, Ines Hofbauer Eds., WTO AND DIRECT TAXATION, Kluwer Law International, 2005, p434.
} 
transposing those rules into the WTO removed from their context may not be suitable, this section will be focused on WTO law, especially the GATS and SCM.

\subsubsection{Difficulties in Defining Subsidies for the GATS}

Supposing that there is sufficient data available to come to a clear understanding about the negative consequences of certain services subsidies and the need for GATS disciplines, the next problem we encounter is that there is no definition of subsidy in Article $X V$ of the GATS. This may be because it is often expressed that on the conceptual level there is still a difficulty in defining precisely what a subsidy is and what kind of subsidy should be prohibited or controlled. ${ }^{1284}$ It is also a circular problem, as the lack of information on services subsidies makes it difficult to formulate a definition, but it is also difficult to search for relevant information without the guidance of a definition.

There is some broad general agreement that export subsidies for goods create can create unfairness in international trade, but even where it is relatively simple to analyze the causation in trade terms, the politics of negotiations can be complex. For example, with regard to the negotiations on agricultural subsidies in the Doha Development Round, which were supposed to result in agreement on the phasing out of export subsidies relating to agricultural goods, particularly by developed countries, Sykes notes that:

It is ironic that the one sector considered to be the most subsidized [by developed nations] is subject to the least degree of discipline on subsidies... ${ }^{1285}$

It is possible that most developing countries would not agree to moving forward on negotiations in services subsidies, an area which may not bring them any benefits without any reduction in subsidies on agricultural goods by developed countries, which is an area that is seen as harming developing country export interests. New disciplines for subsidies in services would also mean that developing country governments would have to restrict one of their most effective policy tools for supporting domestic services capacity by developing human capital and physical infrastructure and communications systems in competitive areas of services.

Important questions to be answered in dealing with subsidies disciplines in the GATS include:

Firstly, can the same concepts be applied to services that are applied for subsidies for goods in international trade?

Secondly, if all public services are broadly not exempt from the scope of coverage of the GATS under Article 1:3(b) and (c), does this mean that public services need to be specifically protected by provisions in future GATS rules on subsidies - if they are not to be treated the same as private provision of services?

\footnotetext{
1284 Sykes, Alan O., Subsidies and Countervailing Measures in Macrory, Patrick F. J, Arthur Edmond Appleton and Michael G. Plummer, THE WORLD TRADE ORGANIZATION: LEGAL, ECONOMIC AND POLITICAL ANALYSIS, Vol. II, Springer, 2005 at p87:

In sum, it is far easier to conceptualize a "subsidy" in simple economic models than it is to identify a subsidy in practice... Any administrable rules for deciding whether a particular government program is a subsidy or not will no doubt result in serious errors of 1285 Ibid., p105.
} 
Theoretically speaking, the standard approach to defining subsidies focuses on government transfer of money, goods or services to private entities, that confer a 'benefit' and thereby result in 'distorting' competition. The definition can also include government policies that could favourably affect the competitiveness of certain private entities over others.

The Subsidies and Countervailing Measures (SCM) Agreement applies defines subsidy for the purpose of the Agreement (with respect to trade in goods), as a financial contribution by a government that confers a benefit. The SCM Agreement applies only to subsidies which are also "specific subsidies" within the meaning of Articles 1 and 2 of the SCM Agreement; broadly speaking that is subsidies which are being specifically provided to an enterprise or industry or group of enterprises or industries. The SCM Agreement creates two basic categories of specific subsidies: those that are prohibited (under Article 3 of the SCM Agreement) and those that are actionable (under Article 5 and 6 of the SCM Agreement). The Appellate Body in Canada-Aircraft described and contrasted these two categories as: "prohibited export subsidies for which the adverse effects are presumed" and actionable subsidies, which "may be illegal if they have certain trade effects". ${ }^{1286}$ Initially, there was a third category of subsidies, namely non-actionable subsidies under Article 8 of the SCM Agreement but this category is now defunct; as under Article 31 it is clear that this category applied only for 5 years since the date of entry into force of the WTO Agreement and a decision was needed if it was to be extended for a further period.

Article 3 of the SCM Agreement identifies two types of prohibited subsidies:

1. Subsidies contingent on export performance ("export subsidies") - a list of which is annexed to the SCM Agreement.

2. Subsidies contingent upon the use of domestic over imported goods ("local content subsidies").

It is clear that these types of subsidies are prohibited because they are designed to directly affect international trade. It is also more likely that if such subsidies were granted by a Member, the trade interests of other Members would be adversely affected. ${ }^{1287}$ It has also been noted early on that there are "few if any" examples of direct export subsidies in services and that services subsidization is mostly import-displacing subsidies, ${ }^{1288}$ which could be based on public policy objectives and therefore have an argument for being seen as legitimate. As Poretti points out, import-displacing subsidies could be used for generating positive externalities, generating innovation and employment, maintaining important service sectors (the financial sector in particular has received support in times of crisis) and for non-economic objectives. ${ }^{1289}$ Strengthening the domestic public health services capacity through direct financial benefits, so as to have the effect of being

\footnotetext{
${ }^{1286}$ Appellate Body Report, Canada-Aircraft, para.202.

${ }^{1287}$ It has been commented that the Working Party on GATS Rules should focus export subsidies since: Export subsidies distorted competition in third markets; suppliers from such markets faced unfair competition from abroad, as did exporters from other countries...trade distortive effects were inherent to export subsidies
}

(WTO, Note by the Secretariat, Working Party on GATS Rules: Report of the meeting of 23 June 2004, S/WPGR/M/48 2004, 20 July 2004, para.8, comments by the Representative for Switzerland).

1288 Feketekuty, Geza, Trade in Services - Bringing Services in the Multilateral Trading System in Bhagwati, J. and Mathias Hirsch, THE URUGUAY ROUND AND BEYOND, ESSAYS IN HONOUR OF ARTHUR DUNKEL, University of Michigan Press, 1998, p89.

${ }^{1289}$ Poretti, P. REGULATION OF SUBSIDES WITHIN THE GENERAL AGREEMENT ON TRADE IN SERVICES OF THE WTO: PROBLEMS AND PROSPECTS, Kluwer Law International, 2009, p80. 
'import-displacing' - of not giving the opportunity for foreign private health companies should not be seen as something that should be regulated by the GATS. On the contrary, such support should not be seen as coming under either prohibited or actionable subsidies, due to having a positive benefit for persons in need of health services.

The types of adverse effects, which are included as actionable subsidies in trade law, are of three main types:

1. Those that cause injury to the domestic industry of another country

2. Those that cause nullification or impairment of benefits accruing to other countries under rules covering international trade

3. Those that cause serious prejudice to the interests of other countries. ${ }^{1290}$

This standard view of (goods) subsidies (as found in Articles 5 and 6 of the Subsidies and Countervailing Measures (SCM) Agreement) does not of course refer to anything specific covering public services subsidies - but that does not mean that public services subsidies will not be included in a future definition of services subsidies. It can be pointed out that if the same format of the subsidies definition in goods is to be applied, it would be limited to government subsidies to private suppliers, and thus cross-subsidization within the public services or direct subsidies to poor consumers will not be covered, mitigating any concerns about issues such as funding and access to public health services. However, this needs to be looked into more carefully, before it is possible to be satisfied that there are no negative implications.

The way an economist would approach a subsidy involves the concept of 'hypothetical market equilibrium', which imagines a situation without the government involvement as a way of identifying subsidization. This hypothetical 'competitive equilibrium' is not real and cannot be observed. Poretti comments critically that it isn't a coherent hypothesis and that other benchmarks are needed for ascertaining existence of a subsidy. ${ }^{1291}$ Other benchmarks/methods suggested by Poretti are:

1. Whether the government program in isolation confers benefits on a private entity.

2. That generally applicable tax rates do not confer a subsidy - only special tax rates could do so.

3. The relative impact on private entities compared to public entities (that similar benefits could cancel each other out in international trade, so they do not need to be subject to multilateral trade disciplines)

Poretti's analysis brings out further problems, and highlights that the definition and scope of subsidies needs to have some basic conceptual issues clarified about the positives and negatives of subsidies as a tool for adjustment of the market. This needs to go beyond a gut-reaction that any government intervention in the market is suspect $a b$ initio, to an analysis of the expected societal benefit and not merely limit it to the harm to competitors in a market.

There is some general agreement that subsidies can be classified as

- Export enhancing,

- Import displacing and

${ }^{1290}$ Davey William J., NON-DISCRIMINATION IN THE WORLD TRADE ORGANIZATION: THE RULES AND EXCEPTIONS, Hague Academy of International Law and Martinus Nijhoff Publishers, 2012, p32-33 - this is what is included in Article 5 of the SCM, and which would result in countervailing duties if subsidized imports cause 'material injury' to the Members domestic industry.

${ }^{1291}$ Poretti, P. REGULATION OF SUBSIDES WITHIN THE GENERAL AGREEMENT ON TRADE IN SERVICES OF THE WTO: PROBLEMS AND PROSPECTS, Kluwer Law International, 2009, p86. 
- Investment diverting. ${ }^{1292}$

But this definition does not cover all types of measures that can be seen as subsidies for services Public services subsidies in particular would not have the objective of affecting exports, imports or investment, but only promoting accessibility and universal service obligations. It depends of course whether the objective is relevant or whether it is only the means and the result.

The SCM definition is that a subsidy is a financial contribution by a government that confers a benefit to a recipient. Yet the financial contribution by government may cause such effects as abovementioned, to foreign suppliers. Sauvé notes that borrowing a subsidies definition from SCM would not cover the "subsidy-like effects of regulatory interventions". ${ }^{1293}$ Following this view, some Members may want to have a broader definition than the GATT/SCM definition. On the other hand, it is possible that some these other 'subsidy-like' regulations could be dealt with under Article VI:4 disciplines on domestic regulation instead of Article XV of the GATS.

\subsubsection{Using the WTO SCM Agreement definition of 'subsidy'}

Comparison with the goods regime and reference to the SCM definition of subsidy is often a starting point for discussion of services subsidies. The Working Party of GATS Rules (WPGR) has commented that the subsidy definition generally used for Trade Policy Reviews in services are based on the definition of the SCM Agreement ${ }^{1294}$ The SCM Agreement is on goods: thus, the question is how well it can be transferred to the services context, taking into account the particular sensitivities in services policy. It is submitted that a wider definition for services subsidies than for goods subsidies is not desirable, especially if the goal is to allow for as much policy space as possible for the implementation of legitimate policy objectives of the State, such as progressively realizing the right to health. ${ }^{1295}$ A note of caution in using the SCM definition of subsidy is also pertinent. Robert Howse for example, critiques the SCM as a whole, stating that it has a more neoliberal orientation than some other WTO documents, and "is indifferent to policy objectives". ${ }^{1296}$

1292 UNCTAD, Document TD/B/COM.1/62, cited by Mashyekhi, Mina, Martine Julsaint and Elisabeth Tuerk, Strategic Considerations for Developing Countries: The Case of GATS and Health Services in Chantal Blouin, Nick Drager and Richard Smith Eds., INTERNATIONAL TRADE IN HEALTH SERVICES AND THE GATS: CURRENT ISSUES AND DEBATES, The World Bank, 2006 at p41.

1293 Sauvé, Pierre, Completing the GATS Framework: Addressing Uruguay Round Leftovers, Aussenwirtschaft, 57, Jahrgang 2002, Heft III, Zürich: Rüegger, 301-341, p328.

1294 Working Party on GATS Rules, Background Note by the Secretariat, Subsidies for Services Sectors: Information Contained in WTO Trade Policy Reviews, Concepts and Definitions S/WPGR/W/25, 26 January 1998, para.4.

1295 Sauvé (Ibid., p328), terms this differently, presumably from a pro-trade negotiators view (focusing only on the criticisms that NGOs may raise concerning an over-broad definition):

Adopting an all-encompassing definition ....would also certainly raise, particularly in today's more transparent negotiating environment characterised by vocal NGO advocacy, difficult issues in terms of perceived loss of regulatory sovereignty in the pursuit of legitimate public policy objectives.

${ }^{1296}$ Howse Robert, The World Trade Organization 20 Years On: Global Governance by Judiciary, EJIL (2016), Vol. 27 No. 1, 9-77, p63-64. 
The SCM Agreement provides a detailed and comprehensive definition for 'subsidy' for the first time in the international trade system. ${ }^{1297}$ WTO panels have commented that this was "one of the most important achievements of the Uruguay Round in the area of subsidies" 1298 and "one of the most important achievements in the development of the law on subsidies". 1299

Article 1 of the SCM Agreement (Definition of a Subsidy) states as follows:

1.1 For the purpose of this Agreement, a subsidy shall be deemed to exist if:

(a)(1) there is a financial contribution by a government or any public body within the territory of a Member (referred to in this Agreement as "government"), i.e. where:

(i) a government practice involves a direct transfer of funds (e.g. grants, loans, and equity infusion), potential direct transfers of funds or liabilities (e.g. loan guarantees);

(ii) government revenue that is otherwise due is foregone or not collected (e.g. fiscal incentives such as tax credits) ${ }^{1300}$;

(iii) a government provides goods or services other than general infrastructure, or purchases goods;

(iv) a government makes payments to a funding mechanism, or entrusts or directs a private body to carry out one or more of the type of functions illustrated in (i) to (iii) above which would normally be vested in the government and the practice, in no real sense, differs from practices normally followed by governments; or

(a) (2) there is any form of income or price support in the sense of Article XVI of GATT 1994; and

(b) a benefit is thereby conferred.

1.2 A subsidy as defined in paragraph 1 shall be subject to the provisions of Part II or shall be subject to the provisions of Part III or V only if such a subsidy is specific in accordance with the provisions of Article 2.

As can be seen, the SCM Agreement definition of the term "subsidy" contains three basic elements:

(i) a financial contribution

(ii) by a government or any public body within the territory of a Member

(iii) which confers a benefit.

All three of the above elements must be satisfied in order for a subsidy to exist.

Furthermore, the SCM rules only apply to 'specific' subsidies granted to an enterprise, industry or group of enterprises or industries. ${ }^{1301}$ Thus the definition of subsidy requires

\footnotetext{
1297 Van den Bossche, Peter., THE LAW AND POLICY OF THE WORLD TRADE ORGANIZATION: TEXT, CASES AND MATERIALS, Cambridge University Press, $2^{\text {nd }}$ Edition, 2008, p560.

1298 Panel Report, US-FSC, para.7.80.

${ }^{1299}$ Panel Report, US-Softwood Lumber III, para.7.24.

${ }^{1300}$ Original footnote 1 of the SCM Agreement:

In accordance with the provisions of Article XVI of GATT 1994(Note to Article XVI) and the provisions of Annexes I through III of this Agreement, the exemption of an exported product from duties or taxes borne by the like product when destined for domestic consumption, or the remission of such duties or taxes in amounts not in excess of those which have accrued, shall not be deemed to be a subsidy.
} 
further clarification of 'government or public body', 'benefit', 'financial contribution', and 'specificity'.

The definition of government or public body in Article 1.1(a) 1 of the SCM Agreement has been discussed in a number of disputes. The Panel in Korea-Commercial Vessels, stated with regard to 'public body' that:

[A]n entity will constitute a 'public body' if it is controlled by the government (or other public bodies). If an entity is controlled by the government (or other public bodies), then any action by that entity is attributable to the government, and should therefore fall within the scope of Article 1.1(a)(1) of the SCM Agreement. ${ }^{1302}$

However, the Appellate Body in US-Anti-Dumping and Countervailing Duties (China) did not agree with the focus being on 'control' by the government and found instead that a public body should by identified by looking at whether the entity has 'governmental authority':

A public body within the meaning of Article 1.1.(a)(1) of the SCM Agreement must be an entity that possesses, exercises or is vested with governmental authority. ${ }^{1303}$

The Appellate Body in this dispute went on to comment that "the precise contours and characteristics of a public body are bound to differ", depending on a number of factors which must be properly evaluated, including:

- the core features of the entity,

- its relationship with the government and State (possibly including evidence of "meaningful control"),

- whether or not there is a legal instrument expressly vesting authority (easier to identify if there is express vesting), and

- other evidence pointing to a sustained and systematic practice of exercising governmental authority. ${ }^{1304}$

It was stressed that the "existence of mere formal links between an entity and government in the narrow sense" - such as the government being a majority shareholder - is not likely to be sufficient to establish that the entity at issue has 'governmental authority'. ${ }^{1305}$ However, it should be noted that the mere finding that an entity is not a public body does not mean that the conduct of that entity is excluded from the scope of the SCM Agreement, since a private body can be entrusted or directed by a government or by a public body. ${ }^{1306}$

Article 1.1(a)(1)iv of the SCM Agreement classifies under "financial contribution by government or any public body", situations where a government "makes payments to a funding mechanism, or entrusts or directs a private body" to carry out a direct or potential transfer of funds or liabilities, forego government revenue or provide or purchase goods and services that are not general infrastructure. It is noted in the same provision that such a practice of delegation of authority "in no real sense, differs from practices normally

\footnotetext{
${ }^{1301}$ Van den Bossche, Peter., THE LAW AND POLICY OF THE WORLD TRADE ORGANIZATION: TEXT, CASES AND MATERIALS, Cambridge University Press, $2^{\text {nd }}$ Edition, 2008, p560.

1302 Panel Report, Korea-Commercial Vessels, para.7.50, noting that state owned enterprises can be considered public bodies.

${ }^{1303}$ Appellate Body Report, US Anti-Dumping and Countervailing Duties (China), para.317.

1304 Appellate Body Report, US Anti-Dumping and Countervailing Duties (China), paras.317.-318.

${ }^{1305}$ Ibid., (US Anti-Dumping and Countervailing Duties (China)).

${ }^{1306}$ Ibid., (US Anti-Dumping and Countervailing Duties (China)), para.302.
} 
followed by governments". With regard to identifying "governmental functions" carried out by a private entity on behalf of a public body the Appellate Body has considered "whether the functions or conduct are of a kind that are ordinarily classified as governmental in the legal order of the relevant Member" and "the classification and functions of entities within WTO Members generally". ${ }^{1307}$

The Appellate Body observed in US-Countervailing Duty Investigation on DRAMS that Article 1.1(a)(1)(iv) is "in essence, an anti-circumvention provision" which is "is intended to ensure that governments do not evade their obligations under the SCM Agreement by using private bodies to take actions that would otherwise fall within Article 1.1(a)(1), were they to be taken by the government itself". ${ }^{1308}$ The Appellate Body, noted that a government can entrust or direct a private body and use it as proxy to make a financial contribution as listed in Article 1.1 of the SCM $^{1309}$ Thus, according to panel and Appellate Body decisions, 'government or public body 'covers situations ranging from State-owned enterprises to private proxies of a government.

With regard to what a government or public body is conferring - a 'financial contribution' and 'benefit' - these have been identified by the Appellate Body as two separate legal elements in Article 1.1 of the SCM Agreement, which together determine whether a subsidy exists. ${ }^{1310}$ The Appellate Body in US-Softwood Lumber IV noted (agreeing with the Panel's discussion of the SCM negotiating history in US-Export Restraints) that the requirement of 'financial contribution' limits the scope of subsidies falling within Article 1.1(a), since if it were otherwise, "all government measures conferring benefits per se, would be subsidies". ${ }^{1311}$

The definition in Article 1.1 of the SCM Agreement contains an exhaustive list of practices that constitute financial contributions by a government or public body. These are:

- direct transfer of funds e.g., grants, loans, equity infusions,

- potential direct transfer of fund or liabilities e.g. loan guarantees

- government revenue that is otherwise due and foregone or not collected e.g.

fiscal incentives such as tax credits

- the provision of goods or services by the government (other than general infrastructure) and the purchase of goods. ${ }^{1312}$

\footnotetext{
1307 Appellate Body Report, US-Carbon Steel (India), para.4.9 citing Appellate Body Report, US-AntiDumping and Countervailing Duties (China), para. 297.

1308 Appellate Body Report,_US-Countervailing Duty Investigation on DRAMS, para. 113.

${ }^{1309}$ Appellate Body Report, US-Countervailing Duty Investigation on DRAMS, para.116.

${ }^{1310}$ Appellate Body Report, Brazil-Aircraft, para.157 and Appellate Body Report, US-Softwood Lumber IV, para.51.

1311 Appellate Body Report, US-Softwood Lumber IV, para 52 and original footnote 35.

1312 Note that this may be a possible point of overlap for subsidies and government procurement disciplines. Japan, in the Canada-Renewable Energy/Canada-Feed-in Tariff Program dispute raised the question of whether the Panel had correctly identified the measures at issue as "procurements" or "purchase of goods" when they could also have been characterized as "direct transfer of funds" (see Appellate Body Report, Canada-Renewable Energy/Canada-Feed-in Tariff Program, paras.2.86-2.92). The European Union also submitted that the Panel failed properly to consider the link between the words "procurement" and "products purchased" (Ibid., para.2.121). The Panel had stated that, when interpreted in its immediate context, the term 'procurement' in Article III:8(a) of the GATT ("procurement by governmental agencies of products purchased") should be understood to have the same meaning as the term 'purchase' and added that this was similar to its analysis of the phrase "a government ... purchases goods" in Article 1.1(a)(1)(iii) of the SCM Agreement (See Ibid., para.5.41 and the Panel Report, paras.7.131 and 7.135-6). However, the
} 
- any form of income or price support in the sense of Article XVI of the GATT 1994

In the dispute settlement context, financial contributions were deemed to exist in the cases of interest reductions and deferrals, interest or debt forgiveness, debt for equity swaps, timber harvesting programmes, export insurance guarantees, purchase of corporate bonds, user marketing payments, marketing loan programme payments, crop insurance and seed payments. ${ }^{1313}$

With regard to the definition of 'benefit', it is not difficult to confirm the existence of a benefit and its exact value in the case of a cash grant. But the SCM Agreement is not entirely clear whether all loans, equity infusions, government purchases etc., which are listed as 'financial contributions' (see below) also confer a 'benefit' in every instance, as Article 1.1. criteria are cumulative (financial contribution plus benefit). The Appellate Body in Canada-Aircraft has discussed the element of 'benefit' at some length. The argument of Canada, that 'cost to government' was a way of approaching 'benefit' was rejected, with the Appellate Body approaching the issue from the opposite direction, focusing on the beneficiary, not on the granting authority. This would mean that the inquiry must proceed to 'who receives' and 'what is received'. The Appellate Body deemed a 'benefit' to exist if

- Something has been received and enjoyed by a beneficiary or recipient. ${ }^{1314}$

- That 'something' must make the recipient 'better off' than it would otherwise have been without the contribution. ${ }^{1315}$

- The marketplace provides an appropriate basis for comparison in determining whether a benefit has been conferred - whether received on terms more favourable than those available in the market. ${ }^{1316}$

Thus, receiving something on commercial terms and paying fair market value would suggest that it is not a subsidy. ${ }^{1317}$ The Canada-Renewable Energy dispute was an opportunity to clarify the interpretation of 'benefit'. However, the Appellate Body in Canada-Renewable Energy ultimately found that they cannot determine whether the challenged measures confer a benefit within the meaning of Article 1.1(b) of the SCM Agreement and whether they constitute prohibited subsidies inconsistent with Articles 3.1(b) and 3.2 of the SCM Agreement. The reason the Appellate Body gave was insufficient factual findings and uncontested evidence upon which to base their determination.

\footnotetext{
Appellate Body disagreed and stated that 'the concepts of 'procurement' and 'purchase' are not to be equated" - as procurement is not just any type of acquisition or purchase, but the process by which a government does so (Ibid., para.5.59). Furthermore, with regard to services, there is also the analysis of the Panel in US-Large Civil Aircraft ( $2^{\text {nd }}$ Complaint) wherein Articles XIII:2 and XV of the GATS were both referred to in the context of interpreting the definition of a subsidy found in Article 1 of the SCM Agreement. Since Article 1 of the SCM Agreement excludes the purchases of services, and since parallel negotiations on trade in services had not been successful in reaching an agreement on services subsidies and services procurement the Panel concluded that the omission of services purchases was intentional (Panel Report, US-Large Civil Aircraft (2 ${ }^{\text {nd }}$ Complaint), para.7.968 and para.7.969).

${ }^{1313}$ Van den Bossche, Peter, THE LAW AND POLICY OF THE WORLD TRADE ORGANIZATION: TEXT, CASES AND MATERIALS, Cambridge University Press, $2^{\text {nd }}$ Edition, 2008, p563-564, referring to the disputes Korea-Commercial Vessels, Japan-Drams, US-Softwood Lumber III, EC-Countervailing Measures on DRAMS Chips and US-Upland Cotton.

1314 Appellate Body report, Canada-Aircraft, para.154.

1315 Appellate Body report, Canada-Aircraft, para. 157.

${ }^{1316}$ Ibid.

${ }^{1317}$ Van den Bossche, Peter., THE LAW AND POLICY OF THE WORLD TRADE ORGANIZATION:

TEXT, CASES AND MATERIALS, Cambridge University Press, $2^{\text {nd }}$ Edition, 2008, p567.
} 
Article 14 of the SCM Agreement provides some further guidance with respect to determining whether certain types of measures confer a benefit. Although Article 14 concerns guidelines for countervailing measures, the Appellate Body in Canada-Aircraft stated that it was relevant for the interpretation of 'benefit' in Article 1.1(b). ${ }^{1318}$ The Appellate Body in EC and certain member States-Large Civil Aircraft also considered the interpretation of "benefit" in Article 1.1(b) of the SCM Agreement. According to a 1992 Agreement between the EEC and the United States, certain quantitative limitations were imposed on the amount of government support which could be provided for large civil aircraft development programmes. The Appellate Body did not accept that Article 4 of this 1992 Agreement was relevant to the interpretation of "benefit" because, it did not:

....speak to the market-based concept of 'benefit' as reflected in Article

1.1(b) of the SCM Agreement and the market-based benchmark reflected in Article 14(b). ${ }^{1319}$

This was because Article 4 of this 1992 Agreement did not differentiate between an advantage conferred by government support and one that only conferred terms which were also available on the market.

Part VIII, Article 27 of the SCM is on special and differential treatment of developing country Members and allows for some leeway for the use of prohibited subsidies. Subsidies contingent on export performance and other export subsidies in Annex 1 are allowed for Least developed countries (LDCs), which are excluded from the application of Article 3.1(a) of the SCM as well as a specific list of countries of 20 countries (including India and Indonesia) whose GNP per capita was less than $\$ 1000$ per year at the time of the Agreement according to World Bank data. But when any of this latter group of countries' GNP goes above that limit, they would only have the same protection of the 8 -year period (ending in 2003) that all other developing countries had, which was also subject to the conditions of phase out of export subsidies in Article 27.4 of the SCM. Subsidies contingent on the use of domestic over imported goods (Article 3.1(b) of the SCM) were allowed for LDCs for a period of 8 years and other developing countries for a period of 5 years from the entry into force of the WTO Agreement - a time period that has also now lapsed.

At times, the term 'general infrastructure' which is used in Article 1.1 of the SCM has been used to refer to basic services. As mentioned earlier in Chapter 2 of this study, the WTO Secretariat Background Note on Financial Services recognized the importance of public services as "basic infrastructure of the economy". ${ }^{1320}$ However, even if provision of such infrastructure services is not to be considered as a subsidy, it does not mean to say that it would be excluded from the scope of the GATS under Article I:3. In the Annex relevant to the telecommunications services sector, it can be seen that 'public infrastructure' in telecommunications is clearly included in 'trade in services'. ${ }^{1321}$ Thus the reference to provision of 'services...other than general infrastructure' as subsidies

${ }^{1318}$ Ibid., p566 and its footnote 260, citing Appellate Body report, Canada-Aircraft, para. 155.

1319 Appellate Body Report, EC and certain member States - Large Civil Aircraft, para. 851. This was also cited in the Appellate Body Report, Peru-Agricultural Products, para.5.101, in the context of the use of Article 31(3)(c) of the VCLT.

${ }^{1320}$ WTO Secretariat, Financial Services: Background Note by The Secretariat, S/C/W/72, 2 December 1998, para.28 and para.31.

${ }^{1321}$ See Paragraph 3(b) and 3(c) of the Annex on Telecommunications and the definition of 'public' in the Telecommunications Reference Paper, which includes 'public infrastructure'. See also the Panel Report, Mexico-Telecoms, para.7.381. 
could mean that provision of some public services may be seen in the SCM context as a subsidy and some can be considered 'general infrastructure'. But it is not clear what 'general infrastructure' is - it can differ depending on the services sector in question, and may not be a concept that will be applied outside of financial services. But if by any chance it is used in other services sectors as well, it may be possible that such 'services...other than general infrastructure' could be considered prohibited or actionable subsidies if it is accessible to some and not other service suppliers. The issue of crosssubsidization of other public services or of chosen suppliers (from e.g. underprivileged areas, vulnerable groups, only domestic suppliers with nationality etc.) may also be an issue in this context.

This connects with the issue of specificity of a subsidy as defined in Article 2 of the SCM. If a subsidy is generally available for enterprises within an economy and not specific only to a few or only to a selected set of enterprises, it is not considered as a distortion of the market. The subsidy as defined in Article 1.1 of the SCM shall become an actionable subsidy that countervailing measures can be taken against, only if it falls within the definition of a 'specific' subsidy as defined in Article 2 of the SCM. The first principle which applies for determining specificity is that a subsidy is specific if it explicitly limited to certain enterprises. According to Article 2.1(b) of the SCM, the use of objective criteria or conditions for eligibility for a subsidy can avoid specificity, but the application of such criteria must be transparent and strictly adhered to. Article 2.1(c) adds that even if a subsidy appears to be non-specific on the first two principles, if there are "reasons to believe" that a subsidy may in fact be specific, other factors shall be considered such as:

- a limited number of enterprises using a subsidy programme

- predominant use by certain enterprises

- disproportionate granting of subsidies to certain enterprises

- the exercise of discretion by granting authorities (the frequency of refusal or approval of applications)

and these matters also taken into account:

- the diversification of economic activities within the jurisdiction of the granting authority

- length of time a subsidy programme has been in operation

Finally, a subsidy that is limited to certain enterprises within a "designated geographical region within the jurisdiction of the granting authority" shall also be deemed 'specific' so shall all prohibited subsidies according to Article 3.

This means that specificity is of four main types, targeting specific enterprises, industries (sectors), regions of the Members' territory and export goods. Note that it is debatable whether subsidies for regions would necessarily be considered specific subsidies. Subsidies for regions for the purpose of "assistance to disadvantaged regions" and "pursuant to a general framework of regional development"1322 are non-actionable under Article 8(2)(b) of the SCM Agreement. Sykes points out that regional development subsidies as may "be part of a reasonable and democratically legitimate strategy for addressing income inequality" but also cautions that both the true rationale for a subsidy

\footnotetext{
1322 Footnote 31 of the SCM Agreement further explains that a "general framework of regional development" should be part of an internally consistent and general applicable policy which is not fore "isolated geographical points" having little impact on regional development.
} 
"is often unknowable". ${ }^{1323}$ This thought on reasonability, democratic legitimacy and yet 'unknowability' of the true rationale for a subsidy applies not just for non-actionable subsidies identified under Article 8(2) of the SCM (research and development incentives, regional development policy, compliance with environmental regulations), but also for the specific subsidies in Article 2. One would need to look behind the surface appearance of the particular subsidy policy and look at the evidence on which the policy is based on, as well as who benefits, in order to make any kind of assessment. When it comes to services, the aspects of universal services provision at affordable cost would also play a role in certain sectors, including health services.

What the SCM Agreement prohibits are specific export subsidies and import substitution subsidies. Looking at the issue of specificity in the context of services, there is an added complication of modes of supply as well. A subsidy in a particular sector may also target a particular mode of supply, but the 'losses' may be felt in a different mode of supply, that may be either present on the territory through Mode 3 (commercial presence) or competing across the border. Would this still be covered by future services subsidy disciplines is the question - or would disciplines have to be limited to trade-distortions within a single mode of supply? This may also depend on whether the classification of prohibited and actionable subsidies would be adopted.

The SCM approach divides subsidies into prohibited, actionable and non-actionable, each with own procedure. The three types of subsidies have different outcomes:

- Export enhancing and importation substitution subsidies are prohibited in goods trade.

- Actionable subsidies are not prohibited but can be subject to challenge if it can be proven that adverse trade effects have resulted from the government assistance

- Non-actionable subsidies. Originally, Article 8 of the SCM identified both nonspecific subsidies as well as a listed type of specific but non-actionable subsidies. The specific but non-actionable subsidies were of three types, with narrowly defined criteria: assistance for research activities by firms and higher education facilities; assistance to disadvantaged regions; and assistance to promote legally required environmental adaptation of existing facilities. But Article 31 of SCM limited the application of Article 8 to a limited period of 5 years from the entry into force of the WTO Agreement and therefore it is non-effective since Jan 1 2000.

This classification in the SCM Agreement has been referred to as a "traffic light" approach. 'Red Light Subsidies' are the prohibited types, 'Amber Light Subsidies' are actionable and 'Green Light Subsidies' were the temporary non-actionable ones. Prohibited or actionable subsidies causing injury can also have countervailing measures (duties) used against them unilaterally as an anti-subsidy measure. ${ }^{1324}$ It has been stated that:

1323 Sykes, Alan O., The Limited Economic Case for Subsidies Regulation, International Centre for Trade and Sustainable Development (ICTSD) and World Economic Forum, 2015, available online at http://e15initiative.org/wp-content/uploads/2015/09/E15-Subsidies-Sykes-FINAL.pdf.

${ }^{1324}$ Van den Bossche, Peter, THE LAW AND POLICY OF THE WORLD TRADE ORGANIZATION: TEXT, CASES AND MATERIALS, Cambridge University Press, $2^{\text {nd }}$ Edition, 2008, p585, footnote 365. 
...the object and purpose of the SCM Agreement is "to increase and improve GATT disciplines relating to the use of both subsidies and countervailing measures". ${ }^{1325}$

Therefore, it can be seen that the SCM Agreement intended for a phase-out of the specific non-actionable subsidies, and the possibility of prohibiting or making actionable a wide variety of subsidies, if they are deemed as falling within the fuzzy definition of 'governmental financial contributions that confer a benefit'.

Supposing that a Member intends to maintain its policy space for public health services, perhaps subsidies for it should be clearly identified as "green light" type subsidies in a services text? Can this be done following the SCM model or is a different model needed? Sauvé comments that services subsidies for social services such as education and health services, should not be at issue in principle due to the carve-out under Article I:3(b) of the GATS. ${ }^{1326}$ However, he adds that these services can also be "commercially tradable" and have been listed in schedules - and that therefore attention should be given to a 'green light' approach such as the non-actionable subsidies in the SCM. Sauvé does not comment on the limited 5-year period for the green light/green box subsidies. Definitely, the limited 5-year period for non-actionable subsidies would not work if the intention is to maintain funding for public services, so such a time limitation should not be copied in a future services subsidies text.

What is the approach of the Agreement on Agriculture on non-actionable subsidies? Domestic support such as subsidies within the 'green box' of the Agriculture Agreement are non-actionable for disputes and are not subject to countervailing measures. For the issue of exempting public health services from services subsidies disciplines, a permanent 'green box' model as a 'ring-fencing' method is suggested. The Decision on General Services at the 2013 Bali Ministerial Conference expanded the list of general services which qualify for 'green box' support to programmes related to land reform and rural livelihood security, since Members have highlighted the importance of their contribution towards rural development, food security and poverty alleviation. ${ }^{1327}$ Support for public health services could also be 'green-boxed' based on the importance of its contribution towards achieving and maintaining health goals in national policy and in relation to SDGs.

A majority of total trade distorting export subsidies are agricultural export subsidies implemented by developed country Members who originally had no obligation to completely eliminate them. Article 9 of the Agreement on Agriculture only had an obligation to reduce the existing subsidies according to the schedules agreed upon. This was finally changed in 2015, when Members adopted a Decision at the Nairobi Ministerial conference for developed country Members to immediately abolish their scheduled agricultural export subsidies. ${ }^{1328}$ Developing country and least development country (LDC) Members also agreed to eliminate export subsidy entitlements, but were

\footnotetext{
1325 Appellate Body Report, US -Carbon Steel, footnote 65 to para.73, quoting Ministerial Declaration on the Uruguay Round, GATT Doc. No. MIN.DEC, 20 September 1986, p7.

1326 Sauvé, Pierre, Completing the GATS Framework: Addressing Uruguay Round Leftovers, Aussenwirtschaft, 57, Jahrgang 2002, Heft III, Zürich: Rüegger, 301-341, p329

${ }^{1327}$ Ministerial Decision on General Services, 07 DECEMBER 2013, WT/MIN(13)/37-WT/L/912.

${ }^{1328}$ Ministerial Decision of 19 December 2015, WT/MIN(15)/45-WT/L/980, para.6:

Developed Members shall immediately eliminate their remaining scheduled export subsidy entitlements as of the date of adoption of this Decision
} 
given some flexibility regarding different deadlines, with LDC Members receiving time until 2030. In the Nairobi Decision, Members agreed that where an agricultural exporting state trading enterprises has monopoly powers, they would "make their best efforts" to ensure that such powers are exercised "in a manner that minimizes trade distorting effects and does not result in displacing or impeding the exports of another Member". ${ }^{1329}$ Transposing this kind of agreement to a service context would mean acknowledging that public services could have monopolies in certain areas, and that Members' can continue with them, but that there would be an obligation not to "displace or impede" exports of another Member. If there is an efficient public health service, this could be seen as displacing or impeding exports of another Member, since market entry and market share would be reduced.

But for overall services negotiations, although there are ideas to be drawn and developed from these GATT instruments, there are other complicated areas to unravel due to the nature of services trade. The SCM Agreement prohibits export subsidies and import substitution subsidies - but can this be applied in the same manner for services? Subsidies with regard to trade in services and the four modes of supply of services may require a different approach. Even in the case of cross-border supply, which is Mode 1; the services themselves are intangible and do not physically cross borders so it is different from goods. The mere fact of having an efficient services sector with technological capacity to supply cross-border services ('telemedicine'), involves a blurring of the line between domestic and international market. Subsidies for the development of a high-quality health service for the local population could thus be seen as having a 'trade-distortive effect' in relation to international trade. Trade in services can additionally take place when consumers move abroad (Mode 2) or when a service supplier sets up a base in foreign market (Mode 3) or when labour, both skilled and semi-skilled, temporarily move abroad (Mode 4). This has several implications. The first is that where domestic suppliers are subsidized within a domestic market, the 'distortion of competition' can occur across different modes and across subsectors within the domestic market as well as the global market in terms of a service supplier located abroad. Related to this is the fact that the movement and tracking of such services trade is far more complex than trade in goods and many types of service transactions may be 'invisible'.

This leads to another issue: the identification of 'what is trade distortion?' and the linkage of this to distortion of conditions of competition - and therefore whether a subsidy would be a type of market intervention that should be curtailed in the larger context of trade in services. This issue may be compared with the examination of detrimental impact on the conditions of competition under Article XVII:3 of the GATS. In situations where national treatment obligations have been undertaken, the standard applicable would be that which was described by the Appellate Body in Argentina-Financial Services:

In our view, while Article XVII:3 refers to the modification of conditions of competition in favour of domestic services or service suppliers, the legal standard set out in Article XVII:3 calls for an examination of whether a measure modifies the conditions of competition to the detriment of services or service suppliers of any other Member. Less favourable treatment of foreign services or service suppliers and more favourable

${ }^{1329}$ Ministerial Decision of 19 December 2015, WT/MIN(15)/45-WT/L/980, para. 21. 
treatment of like domestic services or service suppliers are flip-sides of the same coin [italics in original]. ${ }^{1330}$

Thus, it could be that subsidies measures taken for the maintenance and development of domestic services such as public health services, could be seen as, on the flip-side, always to the detriment of services and service suppliers of another Member, since it modifies the conditions of competition.

Due to the possibility that the supply of one service can be interconnected to another service sector, subsector or mode of supply, practical difficulties are created in calculating the cost-benefit/effect of subsidies. This means that if a subsidy is considered prohibited or actionable, the remedy through countervailing measures becomes problematic, as it too cannot be correctly calculated. In any case it not easy to apply, since cross-border services are not always subject to border measures. The response to this difficulty in identifying, classifying and calculating services subsidies is to either give up on services subsidies in frustration, as too complicated - or more harshly, to prohibit all services subsidies at one fell swoop. Another approach would be to give up on the existing GATTtype countervailing measures for services, and have different remedies for services subsidies - but most forms of retaliation will still need a calculation.

As a compromise, in order to allow for social policy measures, it is possible to include certain exceptions from the general prohibition. These exceptions could be worded broadly or as specific well-defined goals for social, cultural and environmental protection. The negotiating mandate under Article XV of the GATS does not acknowledge the role of subsidies for public services or issues such as social, cultural and environmental protection, but Members are not prevented from raising such matters in the Working Party context.

In addition, services subsidies may have a 'downstream' effect on goods production. Is this to be taken into account as something undesirable and a distortion - especially if it is not generally available services subsidy? This seems to be taken into account in SCM because the financial contribution element in the SCM Agreement subsidy definition includes Article 1.1(a)(1)(iii) - provision of goods or services other than general infrastructure. However, Article 14 (d) of the SCM gives guidelines that the provision of goods and services by a government shall not be considered as conferring a benefit unless the provision is made for less than adequate remuneration (or the purchase for more than adequate remuneration). Adequate remuneration is to be determined in relation to prevailing market conditions for the good or service in the country of provision or purchase - including price, quality, availability, marketability, transportation and other conditions of purchase or sale. The SCM Agreement already provides scope for remedies through countervailing measures against such subsidisation of services embodied in goods, and thus this issue of services subsidies affecting goods seems to have already been covered by the existing GATT and SCM framework. ${ }^{1331}$

More practically, with regard to the approach of Members to defining services subsidies, one can look at the information given in Trade Policy Reviews. The 1998 Background Note by the WTO Secretariat refers the following types of measures: direct grants,

\footnotetext{
${ }^{1330}$ Appellate Body Report, Argentina-Financial Services, paras. 6.103-6.104. See also Panel Report, EUEnergy Package, para. 7.744.

1331 Sauvé, Pierre, Completing the GATS Framework: Addressing Uruguay Round Leftovers, Aussenwirtschaft, 57, Jahrgang 2002, Heft III, Zürich: Rüegger, 301-341, including footnote 40.
} 
preferential credit and guarantees, equity injections, tax incentives, duty-free inputs and duty-free zones as well as other and unspecified measures. But as a concrete example, Chile's TPR identifies as "subsidies", those granted to transportation services operating "in isolated areas, where the State has a responsibility to provide public transportation". ${ }^{1332}$ This is clearly a type of services subsidy that is linked with the State responsibility to improve the standards of living for its population through improved public services and a universal service obligation.

This type of State intervention is also done for health services, and is a possible indication that Members may refer to such measures as 'subsidies'. If that is the case, it is possible that Members (central or devolved levels of government) may have justifiable reasons to limit these subsidies to the services suppliers in the public health sector. For example, special incentives could be offered by either central or provincial governments for public health personnel volunteering to work in areas that are geographically difficult to access or where working conditions are considered 'difficult' due to lack of sufficient/acceptable public infrastructure, poverty or other reasons such as conflict, crime rates or even that of being areas populated by linguistic, religious or ethnic minorities (which result in communication difficulties and the need to fulfil the obligation of providing for culturally "acceptable" 1333 health services). Thus, depending on the local situation, it is possible that it may not be either suitable or feasible to offer the same incentives to local private suppliers, foreign suppliers or suppliers from any foreign country on an MFN basis, as are given to domestic service suppliers. It is more likely that such subsidies could violate national treatment - for example, foreign health professionals who may be able to work in urban areas using (a global language such as) English to communicate with their patients, but they are unable to communicate with non-English speakers in rural areas, and would not be suitable for and not included in an incentive/subsidy programme for rural healthcare. But this measure can be implemented without a GATS violation, if a justifiable language requirement is included in order for an individual to qualify for a subsidy programme, instead of excluding services suppliers on the basis that they are foreign. But the foreign ownership or management of a private company would not be reason to discriminate, if domestic private companies are granted incentives.

Therefore, especially in important public services such as healthcare services, it is vital to identify the effects of a 'subsidy' in this area. The response could be to deal with the negotiating mandate for subsidies for services in one of the following ways:

- to define 'subsidies' for services under Article XV disciplines as clearly not covering such measures for legitimate social policy and clearly exclude anything touching the public health sector subsidies from the GATS;

- to include public health services subsidies as a 'Green Light' subsidies; or

- to classify under a clear exception in future services subsidies disciplines.

The discussion that follows on 'distortive effects' adds more support to this argument - as the justification for prohibition of subsidies is that it is an unfair 'distortion' of trade that absorbs resources that should be spent elsewhere and prevents benefits that would otherwise accrue to the public.

\footnotetext{
${ }^{1332}$ WTO, Background Note by the Secretariat, Working Party on GATS Rules, Subsidies for Services Sectors: Information Contained in WTO Trade Policy Reviews, S/WPGR/W/25, 26 January 1998.

1333 Recalling the requirement of "acceptability" of the CESCR General Comment No. 14 on the Right to Health.
} 


\subsubsection{Getting to grips with 'distortive effects'}

The reason for including subsidies in the GATS is stated in the first sentence of Article $\mathrm{XV}: 1$ of the GATS:

Members recognize that in certain circumstances, subsidies may have

distortive effects on trade in services. ${ }^{1334}$

As suggested by this first sentence, subsidies may have distortive effects on trade, but this does not necessarily apply to all subsidies in all circumstances and this distortion need not necessarily be always seen as unacceptable.

As discussed in the previous section, the idea of the 'distortive effects' of subsidies in is used in the context of a subsidy being a financial contribution that confers a benefit. The assumption is that such a benefit which changes the state of play in the market. The Appellate Body in Canada-Aircraft adds that:

...the trade-distorting potential of a 'financial contribution' can be identified by determining whether the recipient has received as 'financial contribution' on terms more favourable than those available to the recipient in the market [emphasis added] ${ }^{1335}$

Therefore, if the subsidy is available to every supplier without violating MFN and national treatment - it could not be argued that there is a 'trade-distorting' effect. However, applying the same ground rules for everyone may mean that not everyone can join the game and be able to play effectively.

There are differences in capacity to play among the players (suppliers) in the game, the purpose of playing the game (trade) is different for public and private players and there are different, sometimes conflicting long-term goals from the point of view of the umpires (Members of the WTO/Governments). If the game is to be played in a 'gentlemanly' manner, the rules created by the umpires must allow for what is seen as a fair chance for everyone to score. In this game, sometimes umpires can give a 'green card' to a player that can be a protection or advantage. From a team perspective, sometimes the players are in a position to present an offensive play and sometimes they must be on the defensive. The 'green card' can be a defence from another players' offensive play or an added competitive advantage to the existing offensive play. Watching all of this, there are the people who bought tickets to the game (the domestic public; voters and tax payers), who want to see their team score points, but may also want a 'clean' game. It appears that neither the umpires nor the audience would want to ban the 'green card' entirely, as long as the overall game is played well and appears not to treat players unfairly. Subsidies disciplines must deal with the rules for when it is legitimate for a 'green card' to be used - and the umpires must negotiate this on the field, while the game is being played.

Government subsidy measures can be seen as correcting faults in the market and/or providing for greater social welfare rather than simply and merely 'distorting' the market

\footnotetext{
${ }^{1334}$ Compare with the Panel Report, Brazil-Aircraft, para.7.26:

The object and purpose of the SCM Agreement is to impose multilateral disciplines on subsidies which distort trade.

1335 Appellate Body Report, Canada-Aircraft, para.157.
} 
and leading to overall decrease in welfare. ${ }^{1336}$ In fact, subsidies to public services such as health and education services cause positive externalities and increase in welfare for the overall economy as well as for individual human beings. Larger numbers of healthy and educated workers and consumers, with their tax contributions and savings diverted to the creation and maintenance of social welfare systems by the democratic State are more likely to be more efficient economic actors. Subsidies in services can also be used to protect and promote domestic services capacity in developing and least developed countries, which is apparently an acceptable policy goal according to the Preamble of the GATS $^{1337}$ as well as Article XV above, which clearly states that

...negotiations shall recognize the role of subsidies in relation to the development programmes of developing countries and take into account the needs of Members, particularly developing country Members, for flexibility in this area

Subsidies and cross-subsidization in the domestic context can also promote greater equality in service delivery from a human rights point of view. ${ }^{1338}$ In the context of health services, Chanda highlights the use of cross-subsidization from private to public via tax revenues or other mechanisms including government-subsidized specialist services for patients in private hospitals and other incentives or programs to channel specialized services to the public health system where expertise is needed. ${ }^{1339}$

Furthermore, since subsidies have been used by some developed countries in the past to assist their domestic industries and services, making them more competitive and able to contribute to national economic growth and development, implementing restrictions on the use of subsidies as a development tool can be argued as a case of "kicking away the ladder" that developed countries used. Such restrictions on the use of subsidies, especially for the case of health services which play such a vital role for maintaining a healthy population, can also be said to negatively impact the right to development of developing countries. ${ }^{1340}$ Any discussion on subsidies first needs a step away from an instinctive negative response to subsidies and consider that subsidies could be required for certain public purposes. In the services context, it is necessary to deal with the more complex

1336 See Schwartz, Warren F. and Eugene W. Harper, Jr., The Regulation of Subsidies Affecting International Trade, Michigan Law Review, Vol. 70, No. 5, April 1972, p831-858, p833:

In fact, however, much (perhaps all) government support can be defended as being a "correction" rather than a "distortion" of the market process.

See also in conclusion at $\mathrm{p} 857$ :

Invocation of a "free trade" ideal as providing a self-evident answer to questions of this kind serves to obfuscate the difficult issues that must be faced.

1337 The Preamble of the GATS:

Desiring to facilitate the increasing participation of developing countries in trade in services and the expansion of their service exports including, inter alia, through the strengthening of their domestic services capacity and its efficiency and competitiveness; Taking particular account of the serious difficulty of the least-developed countries in view of their special economic situation and their development, trade and financial needs...

${ }^{1338}$ Commission on Human Rights, Report of the High Commissioner of Human Rights, Liberalization of Trade and Human Rights: Report of the High Commissioner of Human Rights, E/CN.4/Sub.2/2002/9, June 25 2002, para.60; draws attention to ...government schemes ensuring that wealthy people subsidize access to health care for the poor...can be a means of reducing poverty, assisting the development of local infant service suppliers, increasing universal access to essential services...

${ }^{1339}$ Chanda, Rupa, Trade in Health Services in TRADE IN HEALTH SERVICES: GLOBAL, REGIONAL AND COUNTRY PERSPECTIVES, Pan American Health Organization, 2002, p43-44.

${ }^{1340}$ Ibid., (Chanda), para.61. 
issue of identifying what kind of services subsidy should or should not fall under WTO rules and why. It is not only an issue of identifying and balancing beneficial subsidies against harmful subsidies - but it is also necessary to keep in mind whom to think of as recipients when benefit and harm are being considered.

What needs balancing in the WTO services context can be described as - the use of subsidies as a:

...key instrument in implementing governmental policy goals and in bringing about distributional effects by means of public funding ${ }^{1341}$ ...against the distortion of conditions of competition in the market for private profitseeking businesses of other WTO members. A successful balancing of public funded services and private service suppliers should lead to consumers having more access to a greater choice of better and more affordable services. In the health services context, this would also mean fulfilling the State obligation on the right to health in the components of availability, accessibility, acceptability and quality, as described by the General Comment on the right to health. ${ }^{1342}$ Optimal benefits can be gained by having both competition and public funding - and different jurisdictions can have different but successful methods of achieving this. Therefore, the flexibility to experiment ought to be retained, especially considering the lack of information on the harm that is caused in international trade terms by services subsidies and the doubt as to whether multilateral trade rules are the most suitable forum ${ }^{1343}$ to deal with most of the services subsidy issues. Thought should be given to whether subsidies with important social objectives should be considered as requiring prohibition or restriction under multilateral rules that can be created within the mandate of Article $\mathrm{XV}$, and if not, how to formulate language that make sure that they can be excluded. Commentators focused on health rights have been clear that such social objectives should be clearly excluded, ${ }^{1344}$ but the formulation of appropriate language - the job of negotiators and lawyers - has not been tackled. In this matter, the UK Government document mentioned at the beginning of this section certainly asked the right questions, even if answers were not forthcoming.

In fact, some WTO members and trade experts have even raised what is a preliminary question as to whether subsidies in services actually result in adverse trade effects ${ }^{1345}$ in the same way as for goods, and even if so, whether they are "sufficiently pervasive in services trade to warrant rule making". ${ }^{1346}$ Even the 2011 Report of the Working party on GATS rules states that

\footnotetext{
1341 Cottier, Thomas, in the preface to Poretti, Pietro, REGULATION OF SUBSIDIES WITHIN THE GENERAL AGREEMENT ON TRADE IN SERVICES, Kluwer Law International 2009.

${ }^{1342}$ See Chapter 3 of this study, section 3.1.5.

1343 Ibid, Cottier (2009) also notes that disciplines in subsidies "may eventually be closer to unfair competition rules than classical trade remedies".

1344 Mashyekhi, Mina, Martine Julsaint and Elisabeth Tuerk, Strategic Considerations for Developing Countries: The Case of GATS and Health Services in Chantal Blouin, Nick Drager and Richard Smith Eds., INTERNATIONAL TRADE IN HEALTH SERVICES AND THE GATS: CURRENT ISSUES AND DEBATES, The World Bank, 2006, p41-42

1345 Sauvé, Pierre, Completing the GATS Framework: Addressing Uruguay Round Leftovers, Aussenwirtschaft, Vol. 57, No. 3, 2002, p.324.

1346 Ibid. p331-332. Also Poretti, Pietro Waiting for Godot: Subsidy Disciplines in Services Trade, in Marion Panizzon, Nicole Pohl and Pierre Sauvé, Eds., GATS AND THE REGULATION OF INTERNATIONAL TRADE IN SERVICE Cambridge University Press, 2008 at p478 admits that the limited data available means that answering the question of whether there is a need for disciplines on service subsidies 'implies a fair amount of guesswork'.
} 
On subsidies, some Members hoped to see continued discussions towards a better understanding of any trade-distortive effects of subsidies and whether any multilateral disciplines to address such effects were needed. ${ }^{1347}$

In the February 2014 WPGR meeting it was commented by the US representative that they:

...felt that they had not yet been sufficiently debated to determine whether or not there was a problem with subsidies in services [emphasis added]. ${ }^{1348}$

The Report of the meeting does not give further information on whether this point was discussed in the meeting, but it strange if Members would try and make rules for something they have not clearly identified and accepted as a problem to begin with.

On the other hand, it is also argued that the basic economic justifications for controlling services subsidies do not differ from those relating to the use of agricultural and industrial goods subsidies ${ }^{1349}$ and that therefore the same kind of rules apply. This is doubtful, since it is difficult to see the argument of trade distortion causing artificial overproduction of subsidized goods can apply in the same way for services, when there are infrastructure and essential services to be taken into account. The lower cost of subsidized infrastructure and essential services does not result in the same kind of competition problem as with trade in ordinary consumer goods ${ }^{1350}$ although sometimes equated by trade experts ${ }^{1351}$. Removing subsidies to services required for increasing the level of development in a country does not necessarily 'render markets more contestable"1352 as subsidies are often required in order for there to be service delivery in underprivileged rural areas or for underprivileged individuals in urban areas, where there is in reality no profit-making capacity for private service providers and no incentive for supplying unless subsidized. But because of the profit margin that needs to be kept by private suppliers, it is possible that public service delivery would be more cost efficient, especially if there was already a public service system in place, such as a national health service. This would of course mean that the State is both capable of and dedicated to investing in development of services such as health services and subsidizing or delivering these services for free. The political-historical values prevalent in that society would greatly influence these actions.

Where the financial capacity is just not there, such as in low income developing countries and least developed countries, then foreign aid would become necessary, but foreign investment may just not occur. As a certain standard of infrastructure, trained service personnel and consumers will be required to make investment attractive; there is a minimum level of development needed before investment becomes an option. And even

\footnotetext{
1347 WTO, Report by the Chairman of The Council on Trade in Services (Ambassador Fernando De Mateo) to the Trade Negotiations Committee, TN/S/36, 21 April 2011, para.81.

${ }^{1348}$ Ibid., para.3.2.

1349 Poretti, P., Waiting for Godot: Subsidy Disciplines in Services Trade, in Marion Panizzon, Nicole Pohl and Pierre Sauvé, Eds., GATS AND THE REGULATION OF INTERNATIONAL TRADE IN SERVICE Cambridge University Press, 2008 at p478.

${ }^{1350}$ It is important to note that a difference should be made regarding subsidized production and distribution of essential medicines, whether patented or generic, as this is clearly not the same as trade in non-essential consumer items. The same can be argued for subsidized food and shelter for the economically underpriviledged.

${ }^{1351}$ Poretti, P., Waiting for Godot: Subsidy Disciplines in Services Trade, in Marion Panizzon, Nicole Pohl and Pierre Sauvé, Eds., GATS AND THE REGULATION OF INTERNATIONAL TRADE IN SERVICE Cambridge University Press, 2008 at p478

${ }^{1352}$ Ibid., (Poretti).
} 
then, the drawback is that it will be targeted to more privileged sections of society and not the most needy. ${ }^{1353}$ Foreign investment, public-private partnerships or privatized monopoly can still fall within GATS rules (depending on other factors such as future negotiations and commitments as well as interpretation of provisions if a dispute occurs), but the key questions of access and affordability of health care are unfortunately not usually thought to be of interest or relevance in the GATS negotiating context.

Another conceptual justification for subsidies regulation is that a level playing field will be fairer. The situation in trade in agricultural goods is a relevant example, with the continuing efforts by developing country Members to have developed country Members reduce or remove their agricultural subsidies so that there can be better opportunities and competitiveness in global agricultural goods trade. However, developing countries are not yet the major players in international trade in services. In order to have a level playing field, the players ought to have their handicaps taken into account. Services subsidies may be a necessary part of developing an internationally competitive services industry, which should of course be a lesser priority than developing domestic capacity to provide for all members of their society. Clearly, subsidies may be needed for this latter objective as well. Furthermore, contrary to the idea of a level playing field, multilateral rules that limit domestic services subsidies based on legitimate public policy can actually be against the principle of non-discrimination in human rights terms ${ }^{1354}$, which also recognize the need for affirmative action (which could well be in the form of subsidies and crosssubsidization) to realize basic economic and social rights.

Finally, it can be argued that the kind of subsidies for health services that need to be protected and should be outside of multilateral rules are not primarily concerned with giving an 'artificial competitive advantage' to exporters or import competing industries. At least, it can be argued that it should not be seen as intending such, even if it occurs. If it so happens that subsidies are given to national public health services provide a high standard of care that creates a competitive disadvantage to foreign private providers entering the domestic market, why should this be disallowed? It seems to be only from a dogmatic economic justification of free market competition and not considering the human and development dimension. It is admitted by experts that the classic economic models used to understand subsidization are hypothetical situations without a public sector and can therefore be very difficult to apply practically. ${ }^{1355}$ Government expenditure in infrastructure services including financial and telecommunication services, public

\footnotetext{
${ }^{1353}$ Blouin, Chantal, Economic Dimensions and Impact Assessment of GATS to Promote and Protect Health in Chantal Blouin, Nick Drager and Richard Smith eds., INTERNATIONAL TRADE IN HEALTH SERVICES AND THE GATS: CURRENT ISSUES AND DEBATES, The World Bank, 2006 at p194 Box 6.5 Foreign Private Investment in Health in Low Income countries.

${ }^{1354}$ Commission on Human Rights, Report of the High Commissioner of Human Rights, Liberalization of Trade and Human Rights: Report of the High Commissioner of Human Rights, E/CN.4/Sub.2/2002/9, June 252002 at para. 62

If the application of trade law, or even trade liberalization policies generally, threatens "cross-subsidization" or other policies guaranteed to ensure universal service supply or raises prices of services for the poor, the reduction in quality and quantity of services to the poor, isolated or vulnerable might result in de facto discrimination under human rights law.

1355 Sykes, Alan O., Subsidies and Countervailing Measures in Macrory, Patrick F. J, Arthur Edmond Appleton and Michael G. Plummer, THE WORLD TRADE ORGANIZATION: LEGAL, ECONOMIC AND POLITICAL ANALYSIS, Vol. II, Springer, 2005, p85-87.
} 
education ${ }^{1356}$ and healthcare can create the groundwork and maintain conditions for an attractive trade and investment climate for transnational business. If the multilateral trade rules are concerned about the long-term stability of international markets, a country with a good infrastructure and educated and healthy workforce ought to be a better option than one where there is significant inequality and sense of injustice, which could lead to political (and therefore economic) instability.

Thus, there seems to be a 'disconnect' between certain variations of economic theory and practice when it comes to the idea of subsidies causing distortion. Sauvé even states that Apart from a few trade economists that worry from time to time about the potentially trade-and-investment-distorting effects of [service] subsidies, not even the service industry has lobbied much for the adoption of such disciplines. ${ }^{1357}$

It can therefore be suggested that the stress in the debate should be laid on the 'unfair' in any unfair competition caused by government funding and subsidies, not merely on 'distortion' - which can cause a fog around the notion that changing market dynamics can be beneficial to both the consumer and the standard of health of the society as a whole.

\subsubsection{Subsidies are already covered by other WTO Provisions and GATS Articles}

The negotiations under Article XV seem to be at a standstill, without timetable or deadline for conclusion, and further held back by the general lack of information and understanding on how service subsidies affect international trade, as well as unwillingness of Members to observe the requirement for transparency and information sharing on national services subsidies. The Article XV mandate is worded broadly enough that it does not necessarily lead to a particular result. It remains in the hands of Members to decide on the nature and scope of multilateral disciplines on services subsidies - and so far, Members have expressed different and conflicting views on both the need and the feasibility for it. ${ }^{1358}$

A number of provisions in other WTO Agreements may nevertheless cover subsidies, even if the negotiating mandate under Article XV never results in a workable text. Special measures similar to subsidization taken by a government on behalf of public health services may also still be covered under other provisions of the GATS, relating to both general obligations and voluntary commitments. Several authors point out that although there are no specific disciplines on subsidies for services developed under Article XV, other provisions in the GATS can impact a Member's rights and obligations in this regard.

\footnotetext{
${ }^{1356}$ Interestingly, Sykes states that public education can be seen as increasing cost to industries that use lower skilled workers by lowering the supply of such workers (Ibid, P.87) - but of course this issue ought to be seen in a Right to Education and development perspective, not merely as a labour supply problem caused by a 'subsidy conferred by generally applicable programs' that does not have a neutral impact relating to all industries (Sykes also points out the opportunities and rights angle at p88-89).

1357 Sauvé, Pierre, Completing the GATS Framework: Addressing Uruguay Round Leftovers, Aussenwirtschaft, Vol. 57, No. 3, 2002, p.332.

${ }^{1358}$ See further, ICTSD (International Center for Trade and Sustainable Development), Mark Benitah with David Vivas-Eugui and Mahesh Sugathan, SUBSIDIES, SERVICES AND SUSTAINABLE DEVELOPMENT, Issue Paper No.1, Programme in Trade in Services and Sustainable Development, February 2005, p1 and p3.
} 
Government procurement at higher than market rates could be seen as form of subsidization that may overlap with SCM (provision of services as a financial benefit, with specificity) and the negotiating mandate in Article XIII of the GATS. The SCM Agreement includes the situation of services subsidies for goods, which cause tradedistortion.

Under Article I:1 of the GATS, subsidies can be considered "measures by Members affecting trade in services" and since Article I:3(b) and (c) may not necessarily exempt all public service subsidies - therefore Article II (MFN) ${ }^{1359}$ and Article III (transparency) provisions could apply. ${ }^{1360}$ The MFN requirement is not likely to cause any major problems regarding public health service objectives - and this obligation will be discussed in further detail in the next Chapter (in the section on General Obligations). The general obligation of transparency is also connected with the obligation for exchanging information on subsidies under Article XV, but neither obligation has borne results in terms of more information on domestic subsidies for purposes of the current negotiations.

Subsidies are regulated under Article XVII of the GATS (national treatment), even in the absence of Article XV disciplines. If Members have taken on specific commitments of national treatment under Article XVII, this results in equal treatment in granting of subsidies for both domestic and foreign service suppliers, even without specific subsidies disciplines being in place. This is probably the most important issue with regard to policy space for subsidies, as Members would usually wish to avoid subsidizing foreign suppliers in the same manner as domestic suppliers. Also note that with regard to subsidies, there is a question as to whether the national treatment obligation applies to the supply of services in all four modes of supply. Paragraph 10 of the WTO Explanatory Note on the scheduling of commitments ${ }^{1361}$ suggests that commitments in national treatment are limited to territorial jurisdiction, which would mean Modes 3 and $4 .{ }^{1362}$ Furthermore there is similar language in Paragraph 15 of the Guidelines for the Scheduling of Specific Commitments under the GATS, ${ }^{1363}$ that there is no obligation that a Member must apply national treatment outside its jurisdiction. In relation to national treatment there is also the issue of how 'likeness' will be interpreted with regard to services suppliers, especially when the 'same' service is supplied through different modes of supply. This will be looked at further in Chapter 4. But it could also play a part in the concept of 'distortion' if services supplied by public suppliers and private suppliers are not deemed 'like'.

\footnotetext{
1359 Sauvé, Pierre, Completing the GATS Framework: Addressing Uruguay Round Leftovers, Aussenwirtschaft, Vol. 57, No. 3, 2002, p326 notes that:

MFN obligations are particularly relevant to the subsidy issue when there is no domestic service supplier. In such instances, MFN treatment requires that a Member is not allowed to discriminate between other Members' service suppliers.

1360 Poretti points out that a subsidy can clearly come within the meaning of "measures by Members affecting trade in services" in Article I: 1 (Poretti, Pietro, Waiting for Godot: Subsidy Disciplines in Services Trade, in Marion Panizzon, Nicole Pohl and Pierre Sauvé Eds., GATS AND THE REGULATION OF INTERNATIONAL TRADE IN SERVICES, Cambridge University Press, 2008, p467; Poretti, P., Article $X V$ GATS in Rudiger Wolfrum, Peter-Tobias Stoll and Clemens Feinuagle Eds., WTO - TRADE IN SERVICES, Max Planck Commentaries on World Trade Law, Martinus Nijhoff Publishers, 2008, p365.

${ }^{1361}$ WTO Doc. MTN.GNS/W/164, 1993.

1362 See Poretti, Pietro, Waiting for Godot: Subsidy Disciplines in Services Trade, in Marion Panizzon, Nicole Pohl and Pierre Sauvé Eds., GATS AND THE REGULATION OF INTERNATIONAL TRADE IN SERVICES, Cambridge University Press, 2008, p469, citing WTO Doc MTN.GNS/W/164, 1993.

${ }^{1363}$ WTO Doc. S/L/92, 2001.
} 
If the public services at issue are deemed not exempt under Article I:3 and commitments have been made, national treatment will apply to public services subsidies, unless sectoral or horizontal limitations with regard to public services have been made. While this has been identified as "a potentially strong discipline on the use of subsidies", ${ }^{1364}$ many WTO Members, in sectors and modes that have been committed, have often taken care to include national treatment limitations on subsidies for public services in their schedule. It is generally commented that many Members have included horizontal national treatment limitations with regard to subsidies, and some Members have done so for specific sectors, especially for R\&D. ${ }^{1365}$ Poretti notes additionally that Members' schedules reveal that the sectors where it is deemed that high levels of subsidization exist, are also the sectors that are the least committed - including health. ${ }^{1366}$

It has been commented that what was envisioned was that negotiations under Article XV would be concluded prior to negotiations on commitments ${ }^{1367}$ - and this would indeed make sense, since uncertainty on Article XV may deter undertaking commitments in subsidized sectors as the WTO compatibility of such measures is unclear. There may be also an overall lack of public support for marketization reforms, resulting in Member governments making political promises not to make commitments, such as the UK government had done with regard to health services/the NHS (mentioned at the beginning of this section). If there is enthusiasm for "progressive liberalization", it occurs without knowing the exact effects of the provisions and future disciplines on subsidies. This lack of legal certainty and predictability can affect the progress and stability of the entire framework for services liberalization, as it appears to have a dampening effect on commitments. So those in the pro-liberalization side of the ring should perhaps offer clear exclusion of the sensitive areas in services subsidies during the negotiations, if anything is to move forward, even in the area of making commitments.

Article VIII of the GATS on monopolies and exclusive service suppliers can also impact upon subsidies as these must be consistent with MFN and specific commitments. Monopolies and exclusive service suppliers may include public/national health services, their funding and cross-subsidization. Poretti says that cross-subsidization from activities within the scope of monopoly rights to activities not within the scope would not be acceptable as it would be detrimental to the interests of competitors. ${ }^{1368}$ The language of Article VIII:2 relating to the prohibition on abuse of monopoly position is referred to, but this has not yet been interpreted. It applies only to services subject to commitments:

\footnotetext{
1364 Sauvé, Pierre, Completing the GATS Framework: Addressing Uruguay Round Leftovers, Aussenwirtschaft, Vol. 57, No. 3, 2002, p326.

${ }^{1365}$ See e.g. WTO Secretariat document S/WPGR/W/13/Add.2, 30 August 2004. (Poretti, P., Waiting for Godot: Subsidy Disciplines in Services Trade, in Marion Panizzon, Nicole Pohl and Pierre Sauvé, Eds., GATS AND THE REGULATION OF INTERNATIONAL TRADE IN SERVICE Cambridge University Press, 2008, p468)

${ }^{1366}$ Poretti, P., Waiting for Godot: Subsidy Disciplines in Services Trade, in Marion Panizzon, Nicole Pohl and Pierre Sauvé, Eds., GATS AND THE REGULATION OF INTERNATIONAL TRADE IN SERVICE Cambridge University Press, 2008, p468.

1367 Sauvé, Pierre, Completing the GATS Framework: Addressing Uruguay Round Leftovers, Aussenwirtschaft, Vol. 57, No. 3, 2002, p 331; Poretti, P., Article XV GATS in Wolfrum, Rudiger PeterTobias Stoll and Clemens Feinuagle Eds., WTO -TRADE IN SERVICES, Max Planck Commentaries on World Trade Law, Martinus Nijhoff Publishers, 2008, p365.

1368 Poretti, P., Article $X V$ GATS in Wolfrum, Rudiger Peter-Tobias Stoll and Clemens Feinuagle Eds., WTO -TRADE IN SERVICES, Max Planck Commentaries on World Trade Law, Martinus Nijhoff Publishers, 2008, p364.
} 
Where a Member's monopoly supplier competes, either directly or through an affiliated company, in the supply of a service outside the scope of its monopoly rights and which is subject to that Member's specific commitments, the Member shall ensure that such a supplier does not abuse its monopoly position to act in its territory in a manner inconsistent with such commitments.

Is cross-subsidization an 'anti-competitive practice'? It seems that the answer is 'yes, but not always'; since there may be situations where cross-subsidization could be seen as 'anti-competitive'. Such an interpretation can be followed by recalling Paragraph 1.2 of the Reference Paper on Basic Telecommunications, under which cross-subsidization can be seen as a prohibited 'anti-competitive' practice:

1. Competitive safeguards

1.1 Prevention of anti-competitive practices in telecommunications

Appropriate measures shall be maintained for the purpose of preventing suppliers who, alone or together, are a major supplier from engaging in or continuing anticompetitive practices.

1.2 Safeguards

The anti-competitive practices referred to above shall include in particular:

(a) engaging in anti-competitive cross-subsidization;

Although this is specific to the telecommunications sector, it suggests that crosssubsidization is something that could be interpreted as an abuse of monopoly position in Article VIII:2 of the GATS. In this regard, it may be relevant to note that the Panel in Mexico-Telecoms commented that the meaning of 'anti-competitive practices' is "informed by the use of this term in Members' own competition legislation". ${ }^{1369}$

Article XXIII:3 of the GATS on nullification or impairment of benefits due to measures that do not conflict with GATS, may also be relevant for subsidies. Article XXIII:3 states that:

If any Member considers that any benefit it could reasonably have expected to accrue to it under a specific commitment of another Member under Part III of this Agreement is being nullified or impaired as a result of the application of any measure which does not conflict with the provisions of this Agreement, it may have recourse to the DSU. If the measure is determined by the DSB to have nullified or impaired such a benefit, the Member affected shall be entitled to a mutually satisfactory adjustment on the basis of paragraph 2 of Article XXI, which may include the modification or withdrawal of the measure. In the event an agreement cannot be reached between the Members concerned, Article 22 of the DSU shall apply.

This provision may allow Members to have recourse to the DSU with regard to subsidization of a public service sector that has been scheduled or even the crosssubsidization from a non-committed sector to a committed sector. Poretti notes that although there have been no GATS non-violation complaints on subsidies, the GATT system saw the use of non-violation complaints mechanism as a means to challenge subsidization of domestic companies under Article XXIII:1(b) of the GATT. ${ }^{1370}$ Using

1369 Panel Report, Mexico-Telecoms, para.7.235, citing WTO, Note by the Secretariat, Overview of Members' National Competition Legislation, WT/WGTCP/W/128/Rev.2, 4 July 2001.

1370 Poretti, P., Waiting for Godot: Subsidy Disciplines in Services Trade, in Marion Panizzon, Nicole Pohl and Pierre Sauvé, Eds., GATS AND THE REGULATION OF INTERNATIONAL TRADE IN SERVICE 
Article XXIII:3 of the GATS to challenge subsidies and cross-subsidization in services may be favourable to a complainant, especially since specific information on the effect, as well as a precise definition of a service subsidy is still lacking - and this provision (Article XXIII:3 of the GATS) does not seem to require that for the determination of a nullification or impairment.

It is worth mentioning two other areas which may also overlap with subsidies, and could be looked into further. The first, which will only be briefly mentioned here, is that service subsidies could also be related to investment in TRIMs as well as Mode 3 (commercial presence). Although they are not dealt with clearly in either context subsidies regulation overlaps with the idea of investment incentives and GATS Mode 3 (commercial presence) is recognized as an indirect way of introducing multilateral rules on investment. ${ }^{1371}$ The second area is that certain domestic regulation may also be deemed to have a similar effect to a trade distorting subsidy, so there could be an overlap with Article VI negotiating mandate. Although regulation by itself does not fit in with the SCM definition of subsidy that requires a 'financial contribution', it has been suggested that 'implicit subsidies' resulting from regulatory measures should be included in the negotiations under Article VI:4 of the GATS. ${ }^{1372}$ Article VI on domestic regulation will be discussed further in Chapter 4.

However, a brief mention of domestic regulation in financial services may be relevant in connection with domestic regulation. Financial institutions bailouts issue which came to the forefront during the financial crisis of recent years (particularly during 2008-2009), is an area where State support could be defined as subsidization. Large injections of capital or guarantees on bank liabilities were made to specific financial institutions in the United States and Europe, ostensibly for the stabilization of national financial systems as a whole, rather than as support to individual financial institutions. Delimatsis notes that in conferring a benefit and distorting conditions of competition and conferring an unfair comparative advantage, such governmental measures can be regarded as subsidies, and would in principle be challengeable under the SCM, but are however "shielded" since the GATS does not have explicit subsidies disciplines as yet. ${ }^{1373}$

On a related note, the taking of prudential policy measures to protect domestic financial services also came to the forefront in the same context. The financial sector has separate rules under the Annex on Financial Services. There appears to be a "prudential carve-out" provision under Paragraph 2(a) of the Annex on Financial Services, that caters to the requirement of maintaining the "integrity and stability" of the financial system, through State action. This Paragraph is titled "Domestic Regulation" and states:

Notwithstanding any other provisions of the Agreement, a Member shall not be prevented from taking measures for prudential reasons, including

Cambridge University Press, 2008, p471, citing Australia-Subsidy, Working Party Report BISDII/188 (1950) and EC-Oilseeds I, GATT Panel Report L/6627, BISD 37S/86 (1990).

1371 Sauvé, Pierre, Completing the GATS Framework: Addressing Uruguay Round Leftovers, Aussenwirtschaft, Vol. 57, No. 3, 2002, p330; Chandra, Rupa, GATS and Its Implications for Developing Countries, ST/ESA/2002/DP.25, DESA Discussion Paper of the United Nations Department of Economic and Social Affairs, November 2002, p13.

1372 Ibid., (Sauvé, 2002), p328 and Poretti, P., Waiting for Godot: Subsidy Disciplines in Services Trade, in Marion Panizzon, Nicole Pohl and Pierre Sauvé, Eds., GATS AND THE REGULATION OF INTERNATIONAL TRADE IN SERVICE Cambridge University Press, 2008, p477-478.

1373 Delimatsis, Panagiotis, Of Bailouts and Rescue Measures: Subsidies in Financial Services, NCCR Trade Regulation Working Paper No 2012/24, April 2012, p17. 
for the protection of investors, depositors, policy holders or persons to whom a fiduciary duty is owed by a financial service supplier, or to ensure the integrity and stability of the financial system. Where such measures do not conform with the provisions of the Agreement, they shall not be used as a means of avoiding the Member's commitments or obligations under the Agreement.

Chapter Two of the GATS Training Module available on the WTO official website identifies the above provision as "one of the central elements" of the Annex. ${ }^{1374}$ As can be seen, the "prudential carve-out" should not be used as a means of avoiding GATS obligations, but only as a response to needs of integrity and stability of the sector. The exact extent of the scope of the carve-out is therefore somewhat vague. It has been commented that:

...developed countries appear to favour a tighter definition of its permissible scope, while many developing countries prefer to keep the carve-out broad and unconstraining. ${ }^{1375}$

In the context of the uncertainty on the scope of the carve-out and the possibility of disputes, if such measures could be seen as "avoiding" GATS obligations and commitments, some Members have included horizontal limitations that refer to prudential measures in their Schedules of Commitments. ${ }^{1376}$ Moreover, the difference between financial services and another sector such as health is that there are high levels of commitments in financial services, perhaps due to the "external pressure" to liberalize, ${ }^{1377}$ possibly including pressure applied by other international institutions such as the IMF. Indeed, without clarification by panels or the Appellate Body or an authoritative interpretation of the scope of the provision, the scope of Paragraph 2(a) of the Annex on Financial Services raises similar problems to Article I:3(b) and (c) of the GATS.

$1374 \mathrm{http} / / /$ www.wto.org/english/tratop_e/serv_e/cbt_course_e/c2s1p1_e.htm, last accessed 04,06,2014. See further, Yokoi-Arai, Mamiko, GATS' Prudential Carve-Out in Financial Services and Its Relation with Prudential Regulation, International and Comparative Law Quarterly, Vol.57, July 2008, p613-614.

1375 Cornford, Andrew, The WTO Negotiations on Financial Services: Current Issues and Future Directions, UNCTAD Discussion Paper, No.172, June 2004, p3, available online at http://unctad.org/en/docs/osgdp20046_en.pdf. Cornford notes at p16, footnote 24 that during the Uruguay Round the SEACEN group of countries (the Central Banks and monetary authorities of Indonesia, Malaysia, Thailand, Nepal, Sri Lanka, the Republic of Korea, Philippines, Singapore and Myanmar) opposed allowing prudential measures being subject to dispute settlement under the GATS.

${ }^{1376}$ For example: the Republic of Korea and Japan have included horizontal limitations in their schedules. Following the 1997 Asian Financial Crisis, Korea needed to take a number of measures regarding financial restructuring and support for sectors needing State support. These measures were not challenged under the Annex on Financial Services, but the support for the ship building sector was successfully challenged under the SCM Agreement as actionable subsidies in Korea-Shipbuilding (Panel).

1377 International Monetary Fund (IMF), Reference Note on Trade in Financial Services, prepared by the Strategy, Policy, and Review and Legal Departments and Approved by Tamim Bayoumi and Sean Hagan, September 3, 2010, p8, available online at https://www.imf.org/external/np/pp/eng/2010/090310.pdf : ...under significant external pressure, latecomers - 25 emerging markets and low-income WTO accession countries - have made substantial commitments, either binding the status quo or, in some cases, using those commitments to motivate domestic reform programs.

But see also at p12, Box 1 (The 2009 IEO Evaluation of IMF Involvement in International Trade Policy Issues), with regard to trade in financial services:

...the Fund needed to move beyond what it characterized as uncritical support for liberalization of trade in financial services - a position that had at times been inconsistent with the IMF's more cautious approach to more general risks from inadequate financial supervision and prudential control. 
Argentina-Financial Services was the first dispute where Paragraph 2(a) of the Annex on Financial Services was raised. The Panel in this case stated that Argentina's measures could not be justified as measures taken for 'prudential reasons' under paragraph 2(a) of the GATS Annex, ${ }^{1378}$ but Appellate Body reversed the Panel's finding of an MFN violation and therefore the Panel's finding on the prudential exception was rendered 'moot'. ${ }^{1379}$ Mitchell et al offer an analysis that the Appellate Body had deemed that the Panel had not erred in recognizing the policy space necessary for countries to determine their own prudential reasons for taking measures, but that this finding by the Appellate Body was obiter dicta. ${ }^{1380}$ It remains unclear which kind of domestic policies and measures relating to financial services would be inconsistent with the GATS and yet be covered by the prudential carve-out.

As a final point for this section on subsidies, it is emphasized that, considering the importance of subsidies for sectors such as health, that subsidies for public health services and for domestic health service suppliers ought to be clearly excluded from subsidies disciplines. After all, in air transport services, which is a heavily subsidized sector, all measures including subsidies which affect air traffic rights and services directly related to the exercise of traffic rights are exempt from the provisions of the GATS and the dispute settlement system by Paragraph 2 of the Annex on Air Transport Services. According to Article 6(d) of the Annex, "traffic rights" is defined fairly broadly. ${ }^{1381}$ Air transport is not an unimportant service sector considering its profitability - but health has such huge significance for development and the betterment of the lives of millions of people. The attention to air transport over issues such as health suggests the interests of specific industries and service suppliers have been given priority, perhaps due to lobbying power, with the effect of leaving out some larger public concerns. Health services, particularly domestic public health services, should be exempt from subsidies disciplines. Subsidies for private domestic health providers may play specific roles in the health policy of a

\footnotetext{
1378 Panel Report, Argentina-Financial Services, para 7.949.

1379 Appellate Body Report, Argentina-Financial Services, para 6.83.

1380 Mitchell, Andrew D., Jennifer K. Hawkins and Neha Mishra, Dear Prudence: Allowances under International Trade and Investment Law for Prudential Regulation in the Financial Services Sector, Journal of International Economic Law, 2016, 19, 787-820, referring to paras.6.262 and 6.272 of the Appellate Body Report.

${ }^{1381}$ Paragraph 2 of the Annex on Air Transport Services:

The Agreement, including its dispute settlement procedures, shall not apply to measures affecting:

(a) traffic rights, however granted; or

(b) services directly related to the exercise of traffic rights, except as provided in Paragraph 3 of this Annex.

Paragraph 6(d) (Definitions)

"Traffic rights" mean the right for scheduled and non-scheduled services to operate and/or to carry passengers, cargo and mail for remuneration or hire from, to, within, or over the territory of a Member, including points to be served, routes to be operated, types of traffic to be carried, capacity to be provided, tariffs to be charged and their conditions, and criteria for designation of airlines, including such criteria as number, ownership, and control.
}

Paragraph 3:

The Agreement shall apply to measures affecting:

(a) aircraft repair and maintenance services;

(b) the selling and marketing of air transport services;

(c) computer reservation system (CRS) services. 
country and these also should be exempt from subsidies disciplines. There are also other sensitive sectors like culture and education which should be exempted from subsidies disciplines in a similar manner to exempting health services. Culture also has a close connection with the lives of people - and local culture being negatively affected due to the global market strength of foreign services suppliers is an issue for many WTO Members. Citizens as taxpayers and voters would want and have a right to expect and demand that their governments would protect their social and cultural rights through the national budget, including by funding and subsidizing sectors such as public health, public education and cultural services in particular (but also encouraging domestic private enterprises - and not necessarily excluding foreign suppliers in every instance) and promoting national services (by both public and private (domestic) suppliers). Imposition of pro-market WTO rules contrary to these rights and interests, particularly in these 'sensitive' service sectors, appears to have few real (as opposed to theoretical) benefits in return for the costs and losses. 


\subsection{CONCLUSIONS ON THE SCOPE OF ARTICLE I OF THE GATS, RIGHT TO HEALTH AND PUBLIC SERVICES}

Public services are not merely matters of economics and trade, they are also an issue of societal values and moral choices. It has been argued that only limited areas such as justice, the police, the military, public infrastructure such as roads and bridges should be outside of the scope of the GATS. But in some jurisdictions, it can be seen that there is privatization of services that are seen as undoubtably inherently public in other jurisdictions. For example, fire services, prison services, the police, the military and even national intelligence gathering have been partly or completely privatized in some parts of the United States or at Federal level - resulting in a reassessment of what is inherently governmental, what should be delegated and what should be retained as public responsibilities.

Studies have also shown detrimental impacts on health indicators due to privatization and corporatization of health. An additional issue is whether, if delegated to private service suppliers, governmental authority is retained with regard to the implementation of the right to health through providing public health services (there are also other international obligations related to health in areas such as international human rights, labour and the environmental law). International human rights law does not absolve a State of responsibility regarding the right to health, even if vital services are carried out by the private sector.

Health services are also not seen by many societies as a sector where profit and economic efficiency per se are the guiding factors in the design of policies for the service sector. With regard to health, it has been said that:

...commercial interests must be subject to higher values that impede the providers of health services from functioning as any other economic agent. $^{1382}$

These 'higher values' can be societal values that some societies have confirmed through their domestic legal and or political process - which have developed through a historical/cultural process. It can be argued that there must be within the GATS, appropriate methods for allowing the application of such higher values.

Furthermore, private supply and competition are not necessarily relevant to the attainment of the objectives of higher standards of health for the population according to legal obligations taken on in the international human rights regime (the ICESCR) or aspirations such as the Millennium Development Goals or Sustainable Development Goals. Private supply and competition may give certain consumers with sufficient purchasing power more choice and perhaps, in certain circumstances, the option for 'better quality' services, but these are issues of individual privilege, not human rights. While there need not be any conflict at all between public health services and the private supply of more expensive services for the more privileged, there will be situations which create controversy. Unfortunately, potential private health service providers sometimes see the existence of

${ }^{1382}$ Luff, David, Regulation of Health Services and International Trade Law, in Mattoo, Aaditya and Sauvé, Pierre, Eds. DOMESTIC REGULATION AND SERVICE TRADE LIBERALIZATION, World Bank Publications, 2003, p194. 
universal public health services as a barrier to market entry, a competitor and a prevention of potential profits. The issue is whether GATS could be interpreted and applied in a manner which aligns with such views of private health service providers or not.

Taking a human rights approach to health services and their role in development leads to a different view on whether a public health service can be deemed to be provided in a manner that is "commercial" and "in competition" with private suppliers. The application of 'bilingualism' discussed in Section 2.3 of this study would require that the role of public services as providing for basic minimum core obligations and the progressive realization of economic and social rights under the international human rights framework is acknowledged. In this acknowledgement, there could also be evidence and arguments presented that in the primary motivation and manner in carrying out their tasks, the public bodies are not providing services in a way that could be deemed "commercial" or "in competition with" private providers. But the interpretation of the terms according to the trade context and the Vienna Convention on the Law of Treaties, would not capture this value-laden view of health services nor take into account the national policy viewpoint on whether that service is considered to be "commercial" and "in competition" with other suppliers in that socio-economic context. The argument which has to be made is that interpretation and application of the provisions of the GATS would not preclude the result of treating public health services as different from private health service providers.

Members have so far avoided coming out of cover to take a stand on public services protection (from the viewpoint of its protection and exclusion from GATS rules) in the multilateral context of searching for consensus on interpretation of the so-called exemption in the current GATS text nor in the negotiation of the important areas of subsidies and government procurement in services. The ambiguity of the terms can also be said to give a (perhaps temporary) room for discretion and flexibility ${ }^{1383}$ regarding measures that can be taken without challenge. Since Members are not willing to lead an attack nor expose their vulnerabilities when it comes to public services protection, it becomes a matter for each Member to deal with alone, defending their own domestic interests and avoiding conflict on this issue while trying to maintain sovereign policymaking as far as possible.

As the line between public and private provision of health services is being blurred with changes in management, funding, fragmentation and commercialization of certain existing activities in the public health sector in some countries - these new management systems can come under the GATS disciplines. Therefore, this battle needs to be tackled on other fronts, including the subsidies negotiations, if the exemption of public services as a whole from the scope of the GATS is too weak a protection. The intention would be to maintain funding and support for public health services in the interests of the beneficiaries (the members of the public), and either exclude subsidies for public services from the WTO disciplines on services subsidies or allow for specific exemptions or exceptions for public health services.

As can be seen from the preceding analysis in this Chapter, it is not satisfactory to let the matter of public services protection rely on the Article I:3 exemption, as there are contrary views on the breadth or the scope of application. The actual utility of the so-

1383 Chandra, Rupa, GATS and Its Implications for Developing Countries, ST/ESA/2002/DP.25, DESA Discussion Paper of the United Nations Department of Economic and Social Affairs, November 2002, p17. 
called 'public services exemption' provision is thus a matter of debate since the text can easily support a very limited reading of what could be excluded from the scope. In light of the economic opportunities available in trade in services, especially if former public services are opened up for competition, it is not likely that there will be consensus on an interpretation that clarifies that the scope of the Agreement will be limited by a broad exclusion of public services. Thus, the options available in using other means for policy flexibility increase in importance for Members who have particular concerns about the protection of their public services.

Furthermore, reading Article I with other provisions on monopolies, government procurement and subsidies suggests that a GATS system which is interpreted and applied as a fully liberalized world trade system on services would be one which leans towards privatized monopolies, increased private use of public funds and may not include antitrust law. The GATS does not effectively engage with the situations where public provision is the most successful method of universal service provision - such as national public health services. If there is a need for maintaining public health services monopolies, the role of government procurement is not linked with enough clarity to the SSEGA 'carve-out' and the area has been instead dealt with as a plurilateral. Members can make the link between government procurement, policy formation for services, public services, right to health and human rights-approaches on their own, but this has not been effectively linked at the multilateral level for trade in services. There is also no explicit acknowledgment yet that subsidies or subsidy-like payments are an important policy tool for maintaining effective public services and developing domestic services capacity in areas such as public health services; and the existing negotiating mandate for services is at a standstill. As the analysis in this Chapter shows, it is possible that the policy space for developing such public services could be facing a 'chill effect', since the GATS is obviously more representative of market-oriented approaches and has not been able to make progress in defining and classifying subsidies for services and developing an understanding of 'trade-distortion' that encourages space societal values such as the protection of public health services.

What is apparent from this Chapter is that the scope of application of the GATS is not sufficiently clear. If there was a clear line protecting public services, which a Member could identify and know not to step over, perhaps some of the unease concerning the effect of the GATS on national policy autonomy would have been dealt with at the outset. But even on this fundamental matter of the scope of the Agreement, there is a lack of clarity, which may have resulted in Members drawing back from making voluntary commitments to liberalize through the WTO system. Yet this 'fuzziness' in the dividing line can be seen positively by some, as an opportunity for an interpretation that is predisposed towards broad coverage of the Agreement and that can include new areas in services as they develop through multilateral and plurilateral negotiations in the future. From the point of view of those wanting to retain as much national policy space as possible, the 'fuzzy' line is cause for concern. Political representatives and national policy-makers cannot reassure the public on protection of and continued improvement in the quality and reach of public services, even though this may have been included in election pledges and political party manifestos. The lack of clarity of the scope of the GATS may thus also have spill-over effects of erosion of public trust in national political systems, provided of course, that the national political system is a deliberative democracy. The hesitance on the part of Members who have such a distrustful public could ultimately have an adverse effect on their engagement with the GATS and on the 
Chapter 3

continuing relevance of the GATS for the future of world trade in services. There could also be the reverse effect of the multilateral system; that the lack of a clear 'carve-out' for public services such as health services, without constant reiteration of its value at political, policy-making, policy-implementing and academic level, would mean a gradual erosion of the protection of domestic public services and shift in national policy towards market-approaches to public services. 


\section{CHAPTER 4}

\section{GENERAL OBLIGATIONS AND SPECIFIC COMMITMENTS}

It is your former promise.

$\mathrm{Sir}$, it is;

And I am Constant.

From Shakespeare's Coriolanus 
Chapter 4 


\section{CHAPTER 4}

\section{GENERAL OBLIGATIONS, SPECIFIC COMMITMENTS AND PUBLIC HEALTH SERVICES}

\subsection{INTRODUCTION TO CHAPTER 4}

The discussion on right to health and public services which was presented in the previous chapter raises issues which are at the heart of this study and flow on to the chapters that follow. If public services are not excluded from the scope of the GATS, the available space for divergent progressive policy on public health services need to be rechecked in relation to the implications of GATS obligations. These obligations are usually classified as two types, general obligations and specific commitments:

1. Those general obligations of the GATS which are applicable to all parties upon becoming Members of the WTO - mainly the most favoured nation (MFN) treatment principle (Article II of the GATS) and the transparency obligation in Article III; and

2. The specific commitments taken on by Members, which are expected to be progressively extended. These specific obligations are those that are inscribed in the member's schedules and which consist of market access (Article XVI), national treatment (Article XVII) and other additional commitments (Article XVIII), if any.

In order to clearly see which GATS obligations have been undertaken by a WTO Member and for which service sectors (and whether there are conditions or MFN exemptions), one must refer to the Member's schedule and MFN exemption list. The interpretation of the relevant Articles of the GATS as well as these other documents is necessary to get a better picture of the available policy space for any Member.

But before discussing the general obligations and specific commitments of the GATS, the second part of this Chapter will take a critical look at the underlying value of nondiscrimination that is said to be present in the international trading system and the WTO GATS and what role this value may be playing in the framing and application of GATS obligations. The principle of non-discrimination is embodied in both the MFN treatment and national treatment obligations - conversely it could be said that there are two principles of non-discrimination in WTO law: MFN and NT. The concept of nondiscrimination is also to be found in the human rights regime. Could the nondiscrimination concept therefore become a common ground, a common language in which to discuss the balancing of international trade rules (in particular MFN and NT) with national policies on topics such as protection and promotion of public health services? Or this common terminology masking a dissimilarity which needs 'translation', as discussed earlier in Chapter 2 of this study? ${ }^{1384}$

The third part of this Chapter will look briefly at the transparency obligation and in more detail at the MFN treatment principle in the GATS. This part would address whether there is, and whether there should be, space for flexibility with regard to the MFN principle, in light of the values choices discussed in the earlier chapters of this book. To what extent are trade and human rights lawyers speaking the same language when they talk about

${ }^{1384}$ See 'Bilingualism' for 'Translation' - Section 2.3.12 of Chapter 2 of this study. 
non-discrimination ${ }^{1385}$ Taking into account the manner in which equality and nondiscrimination is conceptualized and applied in the human rights regime, an issue that will be discussed is whether it is even the same principle that is being dealt with. If there are doubts about this, then the next step would be to consider if it would it be possible to take a 'human rights approach' to the application of the MFN treatment principle in the trade regime.

The fourth part of the Chapter will discuss the specific commitments and the procedures regarding scheduling of such commitments. Unlike the GATT 1994, national treatment and market access obligations in the GATS are applicable to trade in services between members only if they are included in a member's schedule of commitments. This is the basis for the assertion that GATS is a very flexible Agreement that allows for WTO Members to liberalize at their own pace or perhaps even to decline to 'open up' certain service sectors to foreign competition. The relevant Articles that triggered this assumption of flexibility will be looked at critically in this Chapter. It has to also be noted that the accuracy of that assumption will depend on how commitments are made, whether and how they can be unmade if there is a national policy justification for change and if there is sufficient flexibility even in a commitment made. The rules, processes and procedure concerning scheduling of commitments will be discussed before introducing the national treatment and market access principles in this fifth part of the Chapter. The scheduling of commitments is also an issue of policy space, and the discussion in the fourth part of the chapter will be with particular regard to a developing country view on the negotiation of specific commitments and the modification of schedules. This is because, firstly, it can be important to acknowledge the realities of international relations and power-politics in negotiating and making commitments and secondly, commitments are in general less easy to get out of than get into, because once commitments have been made the WTO GATS may have additional restrictions that need to be taken into account if any modifications are to be attempted.

Part five of this Chapter will focus on Article XIX and Article XXI of the GATS to ascertain to the extent possible, how far there is appropriate respect and flexibility for national policy objectives, especially for developing country Members, and to what extent hands are tied (or 'how strongly Ulysses is bound' - to use a phrase discussed in Chapter One) with regard to the possible modification of schedules after commitments have been undertaken.

The sixth part of this Chapter looks at another significant area in the GATS that is different from GATT 1994: the rules on domestic regulation. Although GATT 1994 is indicated as less flexible in comparison to the GATS, it is also commented that the GATS has greater potential to limit domestic policy alternatives through provisions such as Article VI on domestic regulation. Article VI supplements the non-discrimination provisions (MFN and national treatment) and market access provision by limiting domestic regulations that affect trade in services although these regulations are not in themselves discriminatory or impeding market access. ${ }^{1386}$ Some of the obligations under Article VI on domestic regulation apply only where specific commitments have been undertaken, but some are General obligations that apply regardless of specific

\footnotetext{
${ }^{1385}$ See 'A Dichotomy of Discourses' - Section 2.3.10 of Chapter 2 of this Study.

${ }^{1386}$ Krajewski, Marcus, Article VI GATS in Wolfrum, Rudiger, Peter-Tobias Stoll and Clemens Feinaugle Eds., WTO - TRADE IN SERVICES, Max Planck Commentaries on World Trade Law, Martinus Nijhoff Publishers, 2008, p165.
} 
commitments. Thus, the issue of domestic regulation and whether it could result in significant restrictions on national policy space, especially regarding public services, is a complicated area that overlaps with several other obligations. This final part of the Chapter intends to draw attention to these overlaps between these provisions and assesses the extent to which they may restrict a Member's policy space. 


\subsection{NON-DISCRIMINATION AS A VALUE IN TRADE AND HUMAN RIGHTS}

The notion of non-discrimination is a complex one. Its content is highly elastic and context dependent. ${ }^{1387}$

The principle of non-discrimination in the GATS is found in Article II (MFN treatment) and in Article XVII (national treatment) - which are discussed in this Chapter, along with the scheduling of commitments, market access and domestic regulation. This section of the Chapter includes a brief discussion of non-discrimination in a broad sense, going beyond merely MFN and national treatment principles of non-discrimination as understood in WTO law. This is deemed necessary in the context of statements made by trade lawyers and scholars that the principle of non-discrimination in the trade and human rights regimes are 'the same'. These include Lamy, the former Director-General of the WTO, who has stated that:

HR and trade rules are based on the same values... [including] nondiscrimination... ${ }^{1388}$

and Petersmann who has said that:

Human rights and liberal trade rules (including WTO rules) are based on the same values: [including] non-discrimination... ${ }^{1389}$

If this is really the case, there should be no conflict arising regarding the concept and its application in these two regimes. However, the approaches and the outcomes may not be as harmonious as suggested. In fact, it is even possible that trade liberalization rules could result in causing discrimination that is in violation of human rights principles of nondiscrimination. The 2002 Report of the High Commissioner of Human Rights on Liberalization of trade in services and human rights stated that if liberalization raises prices or impedes policies such as subsidization and cross-subsidization that ensure universal service supply, it could be seen as de facto discrimination against the poor, isolated or vulnerable under human rights law, as the principle of non-discrimination in human rights supports such policies as mechanism that promote equality of access to services. ${ }^{1300}$ Therefore, if we are to consider whether a 'human rights approach' to the interpretation of WTO law is possible, it is important to first consider the definition of the concept of non-discrimination in WTO law and how far it actually aligns with the definition of non-discrimination in human rights law, and how far it needs to change and how far it actually could change in the current framework.

This issue of non-discrimination was already briefly discussed in Chapter 1, under the subsection 'The Role of Language', as an example of 'mis-translation' between trade and human rights languages. The 2002 report of the High Commissioner on Human Rights mentioned in that discussion clearly states that:

\footnotetext{
1387 Qin, Julia Ya, Defining Non-discrimination under the Law of the World Trade Organization, 2005 Boston University International Law Journal Vol. 23:215 at p218.

1388 WTO NEWS: Speeches, Lamy: "Trade and human rights go hand in hand", Speech at the United Nations Institute for Training and Research UNITAR, 26th September 2010, available online at www.wto.org/english/news_e/ sppl_e/sppl172_e.htm.

${ }^{1389}$ Petersmann, E-U., The WTO Constitution and Human Rights, Journal of International Economic Law 3 (1), 2000, 19-25.

${ }^{1390}$ UN Economic and Social Council, Commission on Human Rights, Report of the High Commissioner, Liberalization of trade in services and human rights, E/CN.4/Sub.2/2002/9, 25 June 2002, Executive Summary, p4 and para.60-61.
} 
Both GATS and human rights law include the principle of nondiscrimination; however, there are distinctions in the application of the Principle. ${ }^{1391}$

To begin with, in human rights, non-discrimination is a right of individual human beings - and in trade law it is usually a question of WTO Members or more precisely, of firms, companies, industries in the same manufacturing, trading or service sectors of different WTO Members. It is true that behind these, ultimately there are individual human beings engaging in economic activities. However, it is not entirely correct to equate the rights of WTO Members (and through them those of legal persons and possibly down the line, to natural persons) to the more direct rights of individual human beings, not to be discriminated against. Charnovitz describes this as following, saying that:

...the WTO connects in some ways to the individual, which inhabit the states [through substantive and procedural disciplines of the trading system and other means, ${ }^{1392}$ but...] ...does not accord rights directly to individuals, but rather mandates that member governments do so. ${ }^{1393}$

Even in the case when individual human beings are directly involved, such as movement of natural persons in Mode 4 of the GATS, the rules are not declared in any WTO text as being based on any human right or fundamental freedom. Mode 4 limitations on market access can include differential treatment of foreign workers, requiring citizenship or residency even where the sector is liberalized. So in a situation concerning the nondiscrimination principle in the MFN or national treatment obligations, where it concerns legal persons and not directly individuals or natural persons, it is difficult for a human rights lawyer to reconcile the idea that a 'human rights' concept of non-discrimination of human beings retains its original character and can be directly equated with the nondiscrimination applied to non-human commercial entities. The argument in support of it being the same principle refer to the discrimination or unequal treatment towards individuals who own the foreign commercial entities - and perhaps extends also to its employees and broadly speaking, the many foreign individuals who are indirectly affected and who may benefit from the liberalized trade.

European law is often compared and contrasted with WTO law, and in this instance of Mode 4 too, it can be referenced. But the economic aspects of EU law are balanced by its acknowledgment of individual rights in a way that is absent in the WTO texts. In the context of European integration and the EU single market, freedom of movement within the EU by citizens of EU Member States is a fundamental right under Article 18 of the EC Treaty. Furthermore, Articles 39, 43 and 49 cover free movement of labour including right of access to employment, right of establishment including self-employment and freedom to provide services (on a temporary basis, under the same conditions as for nationals). ${ }^{1394}$

\footnotetext{
${ }^{1391}$ Ibid., Executive Summary, p4.

1392 Charnovitz, Steve, Economic and Social Actors in the World Trade Organization, ILSA Journal of International and Comparative Law, Vol. Spring 2001, Florida, p259. See also Steve Charnovitz, The WTO and The Rights of Individual, Journal of Intereconomics Vol. March/April 2001, Springer -Verlag, p1-15.

${ }^{1393}$ Charnovitz, Steve, The WTO and The Rights of Individual, Journal of Intereconomics Vol. March/April 2001, Springer -Verlag, p1- 15

${ }^{1394}$ Nielson Julia, Joint WTO - World Bank Symposium on Movement of Natural Persons (Mode 4) Under The GATS: Current Regimes for Temporary Movement of Service Providers - Labour Mobility in Regional Trade Agreements, Trade Directorate OECD, 2002.
} 
International human rights law plays an important role in the protection of migrants outside of the trade regime. ${ }^{1395}$ The international human rights and labour rights regimes' protect the rights of migrant workers without citizenship in the country of residence with regard to core labour standards (including ILO Conventions, especially Conventions no. 97 and 143) and non-discrimination vis-à-vis citizens with regard to labour rights and conditions. ${ }^{1396}$ There is also recognition that migrants can become vulnerable groups in some societies, and that special attention is needed to protect their basic human rights. The International Convention on the Protection of the Rights of All Migrant Workers and Members of Their Families (1990, entered into force 2003) states that migrant workers are to be treated as equal to the nationals of the host country in respect of remuneration and conditions of work, social security benefits and emergency medical care. The Convention reaffirms the link with the key human rights documents, the Universal Declaration of Human Rights, the International Covenants on Human Rights, the International Convention on the Elimination of All Forms of Racial Discrimination and the Convention on the Elimination of All Forms of Discrimination against Women. Migration is also seen in the context of the right to an adequate standard of living, as expressed the ICESCR, Article 11. Thus, the human rights regime looks at discrimination in different manner than the trade regime; in terms of the conditions of work, rather than the conditions to enter into an employment market. While the former is cast as rights in the context of international human rights and labour law, the latter is not. The human rights regime also goes beyond non-discrimination in employment, to concern itself with the human reasons behind migration, including the connection or causation of disparities in development and the coercion of poverty, conflict and instability - and the need to address these root causes. ${ }^{1397}$

This is a fundamental difference, wherein human rights are concerned with the effects of laws and regulations or the lack of protective laws and regulation on the lives of individual human beings and their personal dignity and welfare. WTO law is concerned with efficiency of the world trading system taken as a whole and prosperity as reflected in the increased value and volume of international trade - and assumes that the economic benefits would result in social benefits, while not actively assessing or directly pursuing those social benefits. The first sentence of the Preamble to the WTO Agreement recognizes the objective of conducting trade with a view to "raising standard of living" but in the trade regime, the means to this end are limited to the reduction and elimination of tariffs and other barriers to trade. The elimination of discrimination between Members through the application of WTO law and policy is also described as being necessary to further the goals of sustainable development. Although there is acknowledgment that there are different "needs and concerns" of Members at different levels of development, this study argues that the necessarily more nuanced understanding of discrimination and

\footnotetext{
${ }^{1395}$ IHR is not the only other regime relevant for international migration law. According to the International Organization for Migration (IOM) the international legal framework governing migration covers a broad range of principles and rules across different branches of international law including human rights law, humanitarian law, labour law, refugee law, consular law and maritime law - see the IOM Homepage at http://www.iom.int/cms/ en/sites/iom/home/what-we-do/migration-law.html, last accessed 02.05.2014.

1396 Aleinikoff, Thomas Alexander, INTERNATIONAL LEGAL NORMS AND MIGRATION: AN ANALYSIS, Issue 3 of International Dialogue on Migration, International Organization for Migration, United Nations Publications, 2002, p51. See further, Aleinikoff, Thomas Alexander and Vincent Chatail Eds., MIGRATION AND INTENRAIONAL LEGAL NORMS, T.M. Asser Press, 2003.

${ }^{1397}$ See in general the work of the United Nations Research Institute for Social Development (UNRISD): specifically, De Haan, Arjan and Shahin Yaqub, Migration and Poverty: Linkages, Knowledge Gaps and Policy Implications, PP-SPD-40, UNRISD, 15 July 2009.
} 
its effects on individual human beings is not included and is difficult to include in this current WTO framework.

In human rights law, non-discrimination is the right not to be discriminated against based upon personal characteristics, except so far as different treatment can be made according to justifiable criteria. That is why it is possible to have affirmative action for historically disadvantaged groups, without violating the principle of equality. According to the analysis by the Committee on Civil and Political Rights in the General Comment No 18 on Non-Discrimination,

...the Committee believes that the term 'discrimination' as used in the Covenant should be understood to imply any distinction, exclusion, restriction or preference which is based on any ground such as race, colour, sex, language, religion, political or other opinion, national or social origin, property, birth or other status, and which has the purpose or effect of nullifying or impairing the recognition, enjoyment or exercise by all persons, on an equal footing, of all rights and freedoms. ${ }^{1398}$

It is probably the reference to "national origin" that leads trade experts to compare this concept with non-discrimination in the national treatment principle or MFN treatment principle in international trade law. However, the human rights concept of nondiscrimination is also further elaborated as follows in the General Comment:

The enjoyment of rights and freedoms on an equal footing, however, does not mean identical treatment in every instance... ${ }^{1399}$

...The Committee also wishes to point out that the principle of equality sometimes requires States parties to take affirmative action in order to diminish or eliminate conditions which cause or help to perpetuate discrimination prohibited by the Covenant. For example, in a State where the general conditions of a certain part of the population prevent or impair their enjoyment of human rights, the State should take specific action to correct those conditions. Such action may involve granting for a time to the part of the population concerned certain preferential treatment in specific matters as compared with the rest of the population. However, as long as such action is needed to correct discrimination in fact, it is a case of legitimate differentiation under the Covenant. ${ }^{1400}$

...Finally, the Committee observes that not every differentiation of treatment will constitute discrimination, if the criteria for such differentiation are reasonable and objective and if the aim is to achieve a purpose which is legitimate under the Covenant. ${ }^{1401}$ [Emphasis added]

The 2002 Report of the High Commissioner on Human Rights on Liberalization of trade in services and human rights highlights the distinction between "national treatment as non-discrimination' and the human rights concept, stating that:

Under human rights law, the principle of non-discrimination goes beyond this in nature and substance...Importantly, the human rights

\footnotetext{
1398 Office of the High Commissioner of Human Rights, Committee on Civil and Political Rights, General Comment No. 18: Non-discrimination, Thirty-seventh session, 10 November 1989, para. 7.

${ }^{1399}$ Ibid., (CCPR, General Comment 18) para.8.

${ }^{1400}$ Ibid., (CCPR, General Comment 18) para.10.

${ }^{1401}$ Ibid., (CCPR, General Comment 18) para.13.
} 
principle...supports affirmative action in the interests of promoting the human rights of the poor and vulnerable. ${ }^{1402}$

It is doubtful whether the broad understanding of non-discrimination in human rights is matched by similar principles of legitimate differentiation in trade law. What is recognized in the WTO system is limited to provisions on preferential treatment of developing or least developed countries in derogation of MFN, such as the Enabling Clause for goods and the Services Waiver for least developed countries. ${ }^{1403}$

An analytical study by the office of the High Commissioner on Human rights in 2004, on the concept of non-discrimination in the context of globalization has compared the principle in human rights and WTO law, noting that "the two principles should not be confused" and that "that the goals of the two principles are, in many ways, quite different". ${ }^{1404}$ The reason is explained as due to the intrinsic link of the human rights principle of non-discrimination with the principle of equality - which includes both formal equality and substantive equality, the latter of which is illustrated by the obligation under human rights treaties to "take positive measures to redress the structural biases that lead to discrimination". ${ }^{1405}$ The analytical study notes that:

The trade principle of non-discrimination is primarily directed towards reducing trade protectionism and improving international competitive conditions rather than achieving substantive equality...As international trade rules expand their scope into new areas of government regulation, understanding how the human rights imperatives of reducing the structural biases that lead to discrimination and promoting substantive equality within the trade principle of non-discrimination is a crucial question in the debate on globalization. ${ }^{1406}$

The analytical study also highlights that basis of the human rights principle is protecting the weak and vulnerable and removing structural barriers to equality, both within and between countries, whereas the goal of the trade principle is described as focusing on reducing protectionism and enhancing competition. ${ }^{1407}$

Exceptions to identical treatment have been introduced in the trade context, but in a more limited manner. The generalized system of preferences (GSP) for trade in goods was promoted by developing countries through UNCTAD and was introduced to counter the results of the application of the MFN principle under the GATT 1947. ${ }^{1408}$ The argument was that there should be a system that allows at times for a non-application of the MFN treatment obligation with regard to tariffs on goods, by taking into account the differences

${ }^{1402}$ UN Economic and Social Council, Commission on Human Rights, Report of the High Commissioner, Liberalization of trade in services and human rights, E/CN.4/Sub.2/2002/9, 25 June 2002, para.59.

${ }^{1403}$ This will be briefly mentioned in this chapter but the operationalization and application of these mechanisms will be discussed in further detail in Chapter 6 of this study, which assesses the extent of 'extra policy space' available for developing and least developing countries under the GATS.

${ }^{1404}$ UN Economic and Social Council, Commission on Human Rights, Report of the High Commissioner Analytical study of the High Commissioner for Human Rights on the fundamental principle of nondiscrimination in the context of globalization E/CN.4/2004/40, 15 January 2004, para.26

1405 Ibid., para.26.

1406 Ibid., para.26 and 51 (conclusions).

1407 Ibid., para.51.

${ }^{1408}$ See further for the process that resulted in the GSP: Yusuf, Abdulqawi, LEGAL ASPECTS OF TRADE PREFERENCES FOR DEVELOPING STATES: A STUDY IN THE INFLUENCE OF DEVELOPMENT NEEDS ON THE EVOLUTION OF INTERNATIONAL LAW, BRILL, 1982; Keck, Alexander and Patrick Low, Special and Differential Treatment in the WTO: Why, When and How? Economic Research and Statistics Division Staff Working Paper, ERSD-2004-03, WTO, May, 2004. 
in the economic strength of different countries. The legal basis for the GSP system was the Waiver approved by the parties to GATT 1947 in 1971, which was later replaced by the 'Enabling Clause' in 1979. The Enabling Clause, integral part of the GATT 1947, states as follows:

Notwithstanding the provisions of Article I of the General Agreement, contracting parties may accord differential and more favourable treatment to developing countries, without according such treatment to other contracting parties. ${ }^{1409}$

At first glance, this seems to be something similar to affirmative action in domestic jurisdictions. Yet it is only a special system for trade in goods and the same mechanism is not available for developing countries in trade in services. However, the GATS has several provisions, including Article IV, which allow for treatment that takes into account the economic situation and capacity of developing countries and/or least developed countries. The operationalization of the 2011 LDC Waiver brings in a special and differential treatment mechanism into the GATS. ${ }^{1410}$ It can be argued that the consideration of special needs of developing and least developed countries in the GATS can be compared with affirmative action. Chapter 6 of this study will look into the matter as to whether there is extra policy space for developing and least developed countries in the GATS, through implementation of Article IV of the GATS or through the interpretation of the Preamble or other means.

However, even though the GSP and provisions for special treatment can be compared to affirmative action, the next question that arises is how well-developed this concept is in the WTO system and how it is applied. Is 'affirmative action'/special and differential treatment in the WTO applied in the context of either a human rights approach or a broad acceptance of the need for supporting social development efforts of developing and least developed states? To what extent is the WTO system one which requires that Members take action to "...diminish or eliminate conditions which cause or help to perpetuate discrimination" by "...granting for a time to the part of the population concerned certain preferential treatment" - as stated in the abovementioned General Comment No. 18 on Non-discrimination? It is admitted that although non-discrimination is a fundamental principle of WTO law "...the precise interpretation of these rules has long been rife with difficulties". ${ }^{1411}$ Unlike in the international human rights regime, where there is in effect a centralized system of 'Reports' and 'General Comments' clarifying the interpretation of Articles relating to non-discrimination. The WTO system deals with disputes relating to non-discrimination on a case-by-case basis, therefore, it is to the cases that WTO scholars must turn, in order to analyze how the concept is interpreted and applied in the WTO.

\footnotetext{
${ }^{1409}$ General Agreement on Tariffs and Trade (GATT), 'Enabling Clause', Decision of 28 November 1979 (Document L/4903)

1410 The GATS MFN principle can be departed from by using the least developing country (LDC) Services Waiver, which was adopted at the WTO Ministerial Conference in 2011. The waiver allows non-LDC Members to grant preferences to provide LDCs greater access to their markets. At the Ministerial Conference in Bali in 2013, Members decided to take further action to operationalize the LDC Waiver and grant preferential treatment to LDC services and service suppliers.

See further discussion in Chapter 6 of this study.

1411 Davey William J., NON-DISCRIMINATION IN THE WORLD TRADE ORGANIZATION: THE RULES AND EXCEPTIONS, Hague Academy of International Law, 2012.
} 
The Panel in EC-Tariff Preferences had to interpret "non-discrimination" in footnote 3 of the Enabling Clause (regarding GSP). ${ }^{1412}$ This was not about the special and differential treatment of developing countries as a group different from developed countries, but the differentiation between different developing countries to which the EC was granting GSP. It seems that this is prima facie inconsistent with a "mutually acceptable system of generalized, non-reciprocal and non-discriminatory preferences beneficial to developing countries". ${ }^{413}$ The issue in EC-Tariff Preferences was whether the EC had linked this with their own concerns (on drug production and trafficking and perhaps other political motivations) and not with the needs of the developing countries. ${ }^{1414}$ It is alleged that in application, the GSP was often conditional and discriminatory and used by some preference-giving countries for influencing areas outside the area of trade. ${ }^{1415}$ The Panel in this dispute agreed with the position taken earlier in Canada-Pharmaceutical Patents that discrimination could have many different meanings. The Panel in CanadaPharmaceutical Patents had further stated (with regard to the term "discrimination" in Article 27.1 of the TRIPS) that:

Discrimination' is a term to be avoided whenever more precise standards are available, and when employed, it is a term to be interpreted with caution, and with care to add no more precision than the concept contains. ${ }^{1416}$

The Panel in EC-Tariff Preferences mentioned other Articles in WTO agreements which have a non-discrimination principle, but this matter was not considered significant for interpretation of the term 'non-discriminatory' in that dispute. ${ }^{1417}$ The Panel avoided

\footnotetext{
${ }^{1412}$ General Agreement on Tariffs and Trade (GATT), 'Enabling Clause', Decision of 28 November 1979 (Document L/4903)

${ }^{1413}$ Footnote 3 of the Enabling Clause. Decision of 28 November 1979 (L/4903) refers to this wording in the Decision of the Contracting Parties of June 25 1971, (BISD 18S/24). Davey and Pauwelyn note that developing countries had expressed the view that no developing country should be excluded from a GSP, but that no complaint of discriminatory GSP grants could successfully be made as developed countries implemented GSP in a unilateral manner. (Davey, William J., and Joost Pauwelyn, MFN Unconditionality: A Legal Analysis of the Concept in View of its Evolution in the GATT/WTO Jurisprudence with Particular Reference to the Issue of "Like Product" in Cottier, Thomas and Petros C. Mavroidis Eds., REGULATORY BARRIERS AND THE PRINCIPLE OF NON-DISCRIMINATION IN WORLD TRADE LAW, World Trade Forum Vol.2, Studies in International Economics, University of Michigan Press, 2000, p24-25 and footnote 64).

1414 The EC-Tariff Preferences dispute: the complainant (India) considered that the tariff preferences accorded by the EC under the special arrangements (for combating drug production and trafficking and for the protection of labour rights and the environment) create undue difficulties for India's exports to the EC, including for those under the general arrangements of the EC's GSP scheme, and nullify or impair the benefits accruing to India under the most favoured nation provisions of Article I:1 of the GATT 1994 and Paragraphs 2(a), 3(a) and 3(c) of the Enabling Clause (for GSP).

1415 Sutherland, Peter et al, The Future of the WTO: Addressing the Institutional Challenge in the New Millennium, Report of the Consultative Board to the Director-General Supachai Panitchpakdi , 2005, p24; Mckenzie, Michael, European Communities - Conditions for The Granting Of Tariff Preferences to Developing Countries, (2005) 6(1) Melbourne Journal Of International Law 118; Noordhoek, Willemijn, Human Rights in the Law of the World Trade Organization: The Case of the European Generalized System of Preferences, Maastricht Faculty of Law Working Paper 2010/2.

1416 Panel Report, Canada-Pharmaceutical Patents, para.7.94.

1417 Panel report, EC-Tariff Preferences, para.7.153. GATT 1994 and the GATS both have such provisions. But there is perhaps more similarity that can be assumed between these two agreements than in comparing them to the TRIPS. Julia Qin points out the MFN and National Treatment obligations of TRIPS incorporate and are limited by norms and rules of other international agreements on intellectual property. The Panel Report, EC-Trademarks and Geographic Indications (Australia) at paras.7.181-7.187, 7.241-7.248 and the Panel Report, EC-Trademarks and Geographic Indications (US), paras.7.131-7.137, 7.205-7.212 discuss the relationship between the NT obligation of TRIPS Article 3.1 and that of GATT Article III:4. See Qin,
} 
looking at other international law for the interpretation of discrimination and considered the VCLT rules as sufficient guidance. ${ }^{1418}$ The Appellate Body in EC-Tariff Preferences referred only to the 'ordinary meaning' of the term 'non-discrimination' without reference to an international human rights law definition, which was not raised by the parties either. However, Footnote 318 of the Report mentions of the EC submission of international law textbooks for definitions of non-discrimination.

Ultimately, the Appellate Body in EC-Tariff Preferences took a stance similar that that of the Committee on Civil and Political Rights, and interpreted "non-discriminatory" as not treating similarly-situated countries differently. The Appellate Body discerned the content of the 'non-discrimination' obligation based on the ordinary meanings of that term, which suggest that distinguishing among similarly-situated beneficiaries is discriminatory. ${ }^{1419}$ It was also added that 'non-discriminatory' does not necessarily mean that there should be 'identical' tariff preferences to 'all developing countries'. ${ }^{1420}$ It should follow that, if the countries concerned are not "similarly situated", it is possible that the general obligation of nondiscrimination (and the national treatment requirement) under WTO law would not be violated even if there is differential treatment. The Appellate Body noted that Members are not merely allowed but are also encouraged to deviate from MFN in the pursuit of 'differential and more favourable treatment' for developing countries. ${ }^{1421}$

However, the focus in WTO law is not merely on the nature of the economy of the WTO Member/s concerned in a dispute, but also on the 'likeness' of the competing products or services etc.:

Identifying the concept of "similarly situated" in the non-discrimination provisions of the WTO, however, is merely the first step towards defining nondiscrimination under WTO law. The critical issue remains as to the basis or criteria for determining similarity or likeness. ${ }^{1422}$

Therefore, in disputes on MFN treatment or national treatment, there is an important role for the WTO dispute settlement bodies to play, in that they will be formulating the criteria for similarity or likeness - for Member economies and/or for competing goods and services etc. In a general sense, all Members are initially assumed to be similar for the purposes of MFN treatment and national treatment. It is clear that the similarly situated must be treated alike and that this is a fundamental principle of the WTO system; the difficulties arise when it is questioned whether the situation of Members actually are similar and therefore actually should be treated the same. If differences are acknowledged, what are the criteria for different treatment?

In EC-Tariff Preferences the Appellate Body identified certain criteria as implicit in the Enabling Clause, in paragraphs 163, 164 and 167 of the findings:

1. All GSP beneficiaries which are similarly-situated in terms of "development, financial and trade needs" should be treated identically.

Julia Ya, Defining Non-discrimination under the Law of the World Trade Organization, 2005 Boston University International Law Journal Vol. 23:215 at p221.

${ }_{1418}$ Panel Report, EC-Tariff Preferences, para.7.152.

1419 Appellate Body Report, EC-Tariff Preferences, para.153.

${ }^{1420}$ Appellate Body Report, EC-Tariff Preferences, para. 156.

${ }^{1421}$ Appellate Body Report, EC-Tariff Preferences, para. 111.

1422 Qin, Julia Ya, Defining Non-discrimination under the Law of the World Trade Organization, 2005 Boston University International Law Journal Vol. 23:215 at p222. 
2. When assessing the existence of a need for different treatment, an objective standard should be used, which can be a "broad-based recognition of a particular need, set out in the WTO Agreement or in multilateral instruments adopted by international organizations...'

3. This need must be such "that it can be effectively addressed through tariff preferences" and there should be "a sufficient nexus" between the preferential treatment and the alleviation of such need.

4. The conditions for special arrangements should not place any 'unjustifiable burdens' on any of the Members such as overly bureaucratic and/or costly application methods.

5. Any differential and more favourable treatment shall be designed to facilitate and promote the trade of developing countries and not to raise barriers to or create undue difficulties for the trade of any other contracting parties (Paragraph 3(a) of the Enabling Clause).

The Appellate Body concludes its analysis on non-discrimination and preferential and more favourable treatment by making an assessment that their interpretation is consistent with the object and purpose of the WTO Agreement, the GATT 1994 and the 1971 Waiver Decision, as expressed in the relevant preambles. ${ }^{1423}$ Thus, the WTO context has a particular identification and criteria for non-discrimination and special and differential treatment. However, in practice it can be difficult to apply as country situations are varied and asymmetrical.

In comparing different goods or services, the 'likeness' concept appears in Articles I:1, III:2 and III:4 of the GATT 1994 and Articles II:1 and XVII:1 of the GATS. The analysis of the concept of "like products" has resulted in considerable volume of GATT and WTO jurisprudence. However, the criteria are not set in stone as yet and the Appellate Body in Japan-Taxes on Alcoholic Beverages, has suggested that what constitute "like products" can only be determined on a case-by-case basis, subject to the individual, discretionary judgment of the treaty interpreter, and that there isn't a standard, single approach appropriate for all cases. ${ }^{1424}$ If this view of differences in understanding and applying 'discrimination' and 'non-discrimination' in different WTO contexts will continue to be agreed upon in dispute settlement, it appears that there are slightly different meanings and different criteria for judging it when non-discrimination is applied to the GATT 1994, GATS or TRIPS or other covered Agreements. With regard to 'likeness' in the GATS, this issue will be discussed in more detail later in other sections in this Chapter, but a discussion of the concept in the GATT 1994 follows in the paragraphs below.

The concept of 'like products' in Articles I, III:2 and III:4 of GATT 1994 has the same meaning in the sense that the determination of 'likeness' of products is a determination of the nature and extent of the competitive relationship between these products, which is established by looking at factors such as the physical characteristics of the goods, common end uses, tariff classifications and consumers' tastes and habits. What differs from provision to provision is the scope/width of the concept of 'likeness', meaning that products can be 'like' under Article III:4 while they are not considered 'like' under Article III:2.

\footnotetext{
${ }^{1423}$ Appellate Body Report, EC-Tariff Preferences, paras.168-169.

${ }^{1424}$ Appellate Body Report, Japan-Taxes on Alcoholic Beverages, p.19.
} 
With regard to the GATT 1994, Article I, which involves a comparison of the treatment of like products; Article III, which in addition has the objective of avoiding protection of domestic production; and the chapeau of Article XX, which involves a comparison of the treatment of countries where the same conditions prevail - can each theoretically be interpreted differently in the absence of a single overarching principle of nondiscrimination. One concerns products, the other concerns products and producers and the last is a comparison of countries where the same conditions prevail. It is clearly difficult to apply a single concept across these differences, unlike in human rights law, where nondiscrimination is applied to all human beings, and the equality of human beings is a constant foundation across all the different human rights treaties.

Note however that in the context of the close relationship between GATT 1994 and the TBT Agreement, the Appellate Body in US-Clove Cigarettes has found that the nondiscrimination obligation of Article 2.1 of the TBT Agreement is expressed in the same terms as that of Article III:4 of the GATT 1994. ${ }^{1425}$ The Appellate Body further stated that although they are mindful of the specific context of Article 2.1 of the TBT, they find the previous Appellate Body findings in the context of Article III:4 of the GATT 1994 "to be instructive in assessing the meaning of 'treatment no less favourable'..." in Article 2.1 of the TBT. ${ }^{1426}$ Article 2.1 of the TBT states that Members shall ensure that their central government bodies shall accord "no less favourable" treatment in respect of technical regulations to "like products originating in any other country" as they do to "like products of national origin".

TBT case law is also instructive in differentiating between 'legitimate regulatory distinction' and 'discrimination'. This issue arose under the 'less favourable treatment' element of the non-discrimination obligation of Article 2.1 of the TBT, which assesses whether there is detrimental impact on the conditions of competition. As there is no Article XX of the GATT-like exception in the TBT Agreement, the Appellate Body looked at 'legitimate regulatory distinction' from the prohibition in Article 2.1 of the TBT. The Appellate Body in US-Tuna II (Mexico) emphasized that in that dispute the question was whether the difference in labelling conditions was:

... a legitimate regulatory distinction, and hence whether the detrimental impact of the measure stems exclusively from such a distinction rather than reflecting discrimination [emphasis added]. ${ }^{1427}$

The Appellate Body in US-COOL elaborated that regulatory distinctions should be designed and applied in an even-handed manner, not to constitute a means of arbitrary or unjustifiable discrimination - and that in assessing even-handedness, the design, architecture, revealing structure, operation, and application of the technical regulation at issue is relevant. ${ }^{1428}$ It may be interesting to note that through this interpretation of Art 2.1 TBT, the Appellate Body has made something that in other Agreements (Article XX of

\footnotetext{
${ }^{1425}$ Appellate Body Report, US-Clove Cigarettes, para.176.

${ }^{1426}$ Appellate Body Report, US-Clove Cigarettes, para.180.

${ }^{1427}$ Appellate Body Report, US-Tuna II (Mexico), para. 284.

${ }^{1428}$ Appellate Body Report, US-COOL, para. 271:

In contrast, where a regulatory distinction is not designed and applied in an even-handed manner - because, for example, it is designed or applied in a manner that constitutes a means of arbitrary or unjustifiable discrimination - that distinction cannot be considered "legitimate", and thus the detrimental impact will reflect discrimination prohibited under Article 2.1. In assessing even-handedness, a panel must "carefully scrutinize the particular circumstances of the case, that is, the design, architecture, revealing structure, operation, and application of the technical regulation at issue".
} 
the GATT 1994) is an 'exception' allowing for regulatory measures that serve a public policy purpose, become an integral part of the obligation of non-discrimination.

Commenting further on the relationship between exceptions and integral features of nondiscrimination, the interpretation of the 'Enabling Clause' of the GATT is also interesting. The Appellate Body in EC-Tariff Preferences agreed with the Panel that the Enabling Clause is an "exception" to Article I:1 of the GATT. ${ }^{1429}$ Unlike in the human rights regime, where there is a view that affirmative action is integral to the clear, general and substantive principle of equality and non-discrimination, which requires action ${ }^{1430}$ to be taken by States - special and differential treatment in trade law is clearly identified as only an exception to the rules which must be justified if action is taken by Members. ${ }^{1431}$ The former view, one that is held by a majority of commentators on human rights law, is that human rights recognizes such affirmative action as an essential "means to a more equal society" which must nevertheless be justified; while the latter view starts out in assuming that it is a 'reverse discrimination' that must be justified in order to be applied. ${ }^{1432}$ Bacchi has summed up this situation with regard to affirmative action in human rights being posited by some critics as an exception rather than an integral part, but the following can also be applied to the trade system:

Positioning affirmative action as an exception to anti-discrimination law means that affirmative action measures are in principle 'suspect' of being discriminatory and need special justification...This in turn means

${ }^{1429}$ Note that there are general exceptions provisions which provide certain identified exceptions from the obligations of GATS and GATT - these general exceptions provisions are Article XIV of the GATS and Article XX of the GATT. Article XIV of the GATS will be discussed in detail in the next Chapter of this study, Chapter 5 .

1430 The Human Rights Committee has clearly stated this obligation in General Comment 18, para.10;

The Committee also wishes to point out that the principle of equality sometimes requires

States parties to take affirmative action in order to diminish or eliminate conditions which cause or help to perpetuate discrimination prohibited by the Covenant.

(Office of the High Commissioner of Human Rights, Committee on Civil and Political Rights, General Comment No. 18: Non-discrimination, Thirty-seventh session, 10 November 1989). Furthermore, the Committee on Economic, Social and Cultural Rights frequently refers to the duty to take affirmative action in its Concluding Observations.

${ }^{1431}$ It has been noted that the 'liberal view' of affirmative action, such as applied in the constitutional rights framework in the United States, is in line with the liberal trade regime, in that affirmative action is seen as an exception in both systems. However, the opposite position is taken regarding the South African constitution, where affirmative action is now seen as integral to equality and non-discrimination. During the period of transition from apartheid, it was seen as an exception according to Section 8(3)a of the INTERIM CONSTITUTION - something which has changed since, as Section 9(2) of the current SOUTH AFRICAN CONSTITUTION has made clear that affirmative action is an integral part of the right to equality. See further Rabe, Johan, EQUALITY, AFFIRMATIVE ACTION AND JUSTICE, Books on Demand, 2001, p360.

1432 See further, for discussion of the 'integral vs exception' debate in the context of women's rights: Freeman, Marsha A., Beate Rudolf and Christine Chinkin Eds., THE UN CONVENTION ON THE ELIMINATION OF ALL FORMS OF DISCRIMINATION AGAINST WOMEN: A COMMENTARY (Article 4), Oxford University Press, 2012; Bacchi C., The Practice of Affirmative Action Policies: Explaining Resistances and How These Affect Results in Boerefijn, Ingrid, F. Coomans, J. Goldschmidt, R Holtmaat and R. Wollesewinkel Eds., TEMPORARY SPECIAL MEASURES: ACCELERATING DE FACTO EQUALITY OF WOMEN UNDER ARTICLE 4(1) UN CONVENTION ON THE ELIMINATION OF ALL FORMS OF DISCRIMINATION AGAINST WOMEN, Volume 1 of Maastricht Series in Human Rights, Intersentia 2003. Also contrast the approach of Marc Bossuyt, Special Rapporteur on the subject (UNCHR, Prevention of Discrimination, the Concept of Affirmative Action, Final Report, UN.Doc.E/CN.4/Sub2/2002/21, para.113.) with the CEDAW Committee General Recommendation No. 25 on Temporary Special Measures (elaboration on Article 4.1), UN Doc.HRI/GEN/1/Rev.7 (2004) at 282. The former report has been criticized for non-acceptance of the 'integral' approach. 
accepting that the current social rules, which tend to exclude the targeted groups are not suspect of being discriminatory and are accepted as fair. ${ }^{1433}$

In practical terms, if this kind of approach is used in trade law, it will only put an additional burden on WTO Members trying to justify measures that are intended to bring about greater social equality (between Members or within their national boundaries). It could be assumed that the burden of proof for justifying a measure as an 'exception measure' that violates MFN or national treatment could be higher than that of proving something that is acknowledged as an 'integral affirmative action' measure. It is useful to note that the Appellate Body in EC-Tariff Preferences emphasized the special nature of the Enabling Clause as an exception (from MFN in Article I:1 of the GATT 1994) ${ }^{1434}$ and also that Members are "encouraged to deviate from Article I in the pursuit of 'differential and more favourable treatment' for developing countries" [original emphasis]. ${ }^{1435}$ Therefore the burden to indicate the conditions in the Enabling Clause that have not been met ought to be on the complainant.

It can be questioned whether there is such a thing as an integral affirmative action measure' in WTO law. There are various special and differential treatment provisions in the different WTO Agreements, but perhaps it can be said that there is an understanding that special and differential measures are exceptions, and not an integral part of a general non-discrimination principle underlying WTO law? Contrary to this position, it can be pointed out that Member delegates at the 2005 Hong Kong Ministerial reaffirmed that special and differential treatment is an integral part of the WTO agreement. ${ }^{1436}$

Special and differential treatment provisions like the GSP Waiver and the subsequent Enabling Clause of GATT and the LDC Waiver in GATS were introduced later and not part of the original text of the Agreements. ${ }^{1437}$ In the case of services, the GATS originally had only exemptions, general exceptions and Article IV of the GATS on special treatment for developing and least developed countries. Does the GATS framework put developing and least developed countries at a greater disadvantage when it comes to protection of domestic services capacity and maintaining policy space for the

${ }^{1433}$ Bacchi C., The Practice of Affirmative Action Policies: Explaining Resistances and How These Affect Results in Boerefijn, Ingrid, F. Coomans, J. Goldschmidt, R Holtmaat and R. Wollesewinkel Eds., TEMPORARY SPECIAL MEASURES: ACCELERATING DE FACTO EQUALITY OF WOMEN UNDER ARTICLE 4(1) UN CONVENTION ON THE ELIMINATION OF ALL FORMS OF DISCRIMINATION AGAINST WOMEN, Volume 1 of Maastricht Series in Human Rights, Intersentia 2003, p75,79.

${ }^{1434}$ Appellate Body Report, EC-Tariff Preferences, para.126

${ }^{1435}$ Appellate Body Report, EC-Tariff Preferences, para.111:

Furthermore, the history and objective of the Enabling Clause lead us to agree with the European Communities that Members are encouraged to deviate from Article I in the pursuit of "differential and more favourable treatment" for developing countries. This deviation, however, is encouraged only to the extent that it complies with the series of requirements set out in the Enabling Clause, requirements that we find to be more extensive than more typical defences such as those found in Article XX.

1436 WTO, Hong Kong $6^{\text {th }}$ Ministerial Conference, Ministerial Declaration, WT/MIN(05)/DEC, adopted on 18 December 2005, 22 DECEMBER 2005, para.35. See also: Hudec, Robert E., (first edition), Joel P. Trachtman and Chantal Thomas (Eds.), DEVELOPING COUNTRIES IN THE GATT/WTO LEGAL SYSTEM, Rowman \& Littlefield /Cordell Hull Institute and Gower Publishing, (First Edition 1987 revised Edition 2009), p170.

${ }^{1437}$ Note that while the Enabling Clause in respect of GATT 1947 and the LDC Waiver in respect of the GATS where not in the original text, special and differential treatment provisions are included in the original text of WTO agreements in the case of the SCM, AD, TBT and SPS Agreements and most recently the Trade Facilitation Agreement. 
needs of their citizens, as compared to the waiver and preferences which are available for goods? It is argued that the GATS gives more flexibility and policy space than the GATT in the case of national treatment and market access, which require scheduling of commitments and are not automatic obligations. The extent of this flexibility in the GATS, which was negotiated for services instead of the GATT options, which only allow for possibility of non-application of the MFN treatment obligation with regard to tariffs, will be discussed further in the Chapter.

In addition to these Articles of the GATS, consideration of the Preamble to the WTO Agreement may be relevant. The Preamble states that:

There is a need for positive efforts designed to ensure that developing countries and especially the least developed among them, secure a share in the growth of international trade commensurate with the needs of their economic development.

This somewhat vague wording does however suggest that "positive efforts" need to be taken to ensure that developing and least developed countries too get 'a share of the cake' in addition to a 'seat at the table' when it comes to the international trading system. Davey believes this clause in the Preamble gives "added prominence" to the concerns and needs of developing countries and the special provisions in this regard included in the WTO agreements. ${ }^{1438}$ This will depend upon the reference to this clause in dispute contexts by Members and the weight that panels and the Appellate Body will be willing to give to it in interpreting both non-discrimination and special and differential treatment provisions of the WTO agreements.

In conclusion, the non-discrimination concept in trade law is very different from the concept in human rights law and it is not even 'the same' in different contexts within the WTO system as it applies to different issues and objects/subjects. Trade law does not acknowledge or follow the definitions or criteria set out in the human rights regime, which has a well-developed concept of non-discrimination. Thus, it follows that the mere fact of an identical term "non-discrimination" being used in different contexts in trade as well as in human rights, does not mean that in all these cases the application of the principle of non-discrimination would be the same. Neither can it be assumed that the result of the application of non-discrimination in the trade context would result in the protection and promotion of human rights - as it cannot be assumed that both have the same objective nor that both intend to protect the 'same value'.

From a human rights lawyers' point of view there can be said to be a single underlying "spirit" in non-discrimination: the creation of a fair and equitable society for individual human beings to live in dignity and with rights. The idea of universal norms in human rights also means that the interpretation of human rights principles such as nondiscrimination ought not to have different meanings in different human rights contexts or different human rights treaties. Further, it seems that the exceptions to non-discrimination in trade law are not usually an integral part of the non-discrimination principle itself ${ }^{1439}$ in the same manner as in the case of human rights law - because, it can be argued, the

\footnotetext{
1438 Davey William J., NON-DISCRIMINATION IN THE WORLD TRADE ORGANIZATION: THE RULES AND EXCEPTIONS, Hague Academy of International Law and Martinus Nijhoff Publishers, 2012, p28.

${ }^{1439}$ However, it could be said that this is too broad a generalization since it could be stated that the exceptions to non-discrimination are an integral part of Article 2.1 of the TBT and are also integral to the MFN and national treatment obligations in the SPS Agreement.
} 
interpretation of non-discrimination and its exceptions in human rights law is for the purpose or the goal of 'true non-discrimination' and that of improving equitable access to other human rights.

It appears that in the trade context, the defence of the current framework of nondiscrimination not always done with a view to the consequences. If concerning 'like' goods and services, The MFN treatment clauses prescribes that all WTO Members are in the same class (except for developing country Members and LDCs under the Enabling Clause) and the national treatment clauses prescribes that imported and domestic goods and services are also in the same class. But there are wide disparities in economic development between Members and between their respective domestic capacity, which should suggest varied pathways including 'positive' discrimination to achieve development goals. In the case of the GATS there is room for varied pathways as identified in terms of exemptions to MFN, flexibility for not scheduling national treatment or inscribing limitations to national treatment where a service sector has been committed and certain exceptions for when national treatment has been scheduled. However, in comparison to human rights law, non-discrimination in trade law is not itself directly linked in its legal analysis with equitable development and improved standards of living in the same manner. It is not argued strongly enough in the WTO system that both non-discrimination in trade and its exceptions together should have the same purpose of improving the standards of living. Despite the difficulties of definition, the human rights regime remains strongly committed to the principle of non-discrimination and to understanding and applying legitimate differentiation within this regime in a manner that brings benefits to the lives of individual human beings and creates a better society. Since the States within the human rights regime are the same as the WTO Members of the trade regime, there should be more positive cohesion between regimes and enrichment of the trade regime thereby. It could be proposed that the rules need to be renegotiated to make exceptions an integral part of the non-discrimination rules and that dispute settlement also needs to interpret the agreements more in light of the preambular statements across all Agreements. To do so would be to develop an understanding of the spirit of such a principle and not to give an impression of sometimes throwing cows, goats and rabbits in the arena with tigers and wolves while attempting to convince the cows, goats and rabbits that something other than what is natural will happen.

Non-discriminatory treatment of health service suppliers, pharmaceutical companies holding patents on essential medicines, or goods that have impacts on human health, animal, plant life or health - could possibly run counter to the principles supportive of a human right to health or a society that values the health of all, including the most vulnerable and disadvantaged. There is still the availability of General Exception clauses (Article XIV of the GATS and Article XX of the GATT 1994) to justify difference in treatment and as a defense against violations of WTO obligations, if the nondiscrimination clauses do not allow for such aims as mentioned above. Yet even in that situation, the interpretation of the chapeau - which prohibits the application of measures "in a manner constituting arbitrary or unjustifiable discrimination between countries where the same conditions prevail" can play a role in that it judges whether discrimination is 'arbitrary' or 'unjustifiable'. The chapeau is meant to prevent the abuse of the exceptions; it is hoped that it would not limit the beneficial use of the exceptions. The exceptions will be discussed in more detail in Chapter 5 of this study. The discussion that follows in this Chapter will go deeper into the issues of non-discrimination in the MFN treatment and the policy space available in the GATS mechanism of scheduling of 
Chapter 4

commitments regarding national treatment and market access. If this Chapter finds the current framework to be insufficient for the needs of Members to protect core services such as public health services, we must turn to the assessment of the last 'safety net' of the exceptions, which will follow in the next chapter of this study. 


\subsection{GENERAL OBLIGATIONS OF THE GATS}

\subsubsection{Article III: Transparency (and Article IIIbis: Protection of Confidentiality)}

Something that is often overlooked but should not be completely ignored with regard to WTO obligations is the general obligation of transparency, expressed as an objective of the Agreement in the Preamble of the GATS and provided for in Article III of the GATS. Transparency is, along with MFN treatment, one of the general obligations in the GATS, applicable to all Members regardless of the level of commitments. However, the general obligation of transparency ${ }^{1440}$ (regarding mainly the publication of laws, measures, rules and regulations, the establishment of enquiry points and notification of changes in such law etc.) will not be discussed in depth in this Chapter. In any case the definition and implications of the transparency provision of the GATS and its exception has not been the subject of dispute settlement so far.

Yet it should be kept in mind that Article III is relevant not only on its own but also as it is to be read with other provisions of the GATS including the due process requirements of Article VI on domestic regulation and also with regard to sector-specific disciplines such as telecommunications and accountancy services which reiterate transparency in the relevant sectoral Annexures and related texts. ${ }^{1441}$ In particular it is important to remember that transparency also plays a role in scheduling of commitments, which will be discussed in Section 4.4 of this Chapter. The reference to transparency in the Preamble of the GATS has been linked to the need for "clarity and precision" in Members' schedules by the dispute settlement bodies. ${ }^{1442}$

It may also be relevant to draw attention to the exception that follows the transparency obligation which is Article IIIbis of the GATS. It concerns the disclosure of confidential information:

Nothing in this Agreement shall require any Member to provide confidential information, the disclosure of which would impede law enforcement, or otherwise be contrary to the public interest, or which would prejudice legitimate commercial interests of particular enterprises, public or private.

Since it is drafted using fairly broad language, this indicates considerable discretion for the Members when deciding whether or not to disclose certain information - unless the matter is raised in a dispute context. ${ }^{1443}$ This provision is interesting, in light of the focus

1440 See further Delimatsis, Panagiotis, Article III GATS: Transparency, WTO - TRADE IN SERVICES, Rüdiger Wolfrum, Peter-Tobias Stoll, Clemens Feinäugle, Eds., Max Planck Commentaries on World Trade Law Vol. 6, Martinus Nijhoff Publishers, 2008.

${ }^{1441}$ See Disciplines on Domestic Regulation in the Accountancy Sector, adopted by the Council for Trade in Services at its meeting of 14 December 1998, S/L/64.

1442 Appellate Body Report in US-Gambling at paras.188-189 agreed with the following statement made by the Panel in the Panel Report, US-Gambling, para.6.107:

The need for clarity and precision in Members' schedules referred to in the 1993 Scheduling Guidelines is consistent with the preamble to the GATS which stipulates, inter alia, that, in establishing the GATS, Members sought the expansion of trade in services "under conditions of transparency". This requirement of transparency is undoubtedly an object and purpose of the GATS - and the WTO in general - and applies equally to GATS schedules of specific commitments... It is, therefore, important that schedules be readily understandable by all other WTO Members, as well as by services suppliers and consumers.

${ }^{1443}$ Appellate Body Report, Canada - Aircraft, para.187, quoting Article 13.1 of the DSU: 
of this thesis, for the reference to "public interest" and the "legitimate commercial concerns' of public enterprises. A more thorough inquiry into the scope and definition of these terms and what kinds of information could fall under the provision is beyond the scope of this Chapter.

However, with regard to public health services, it could be ventured that privacy rights with regard to health information of patients could come under this exception, if "public interest" is defined so as to cover such matters. Although there is also a possibility that this information can be seen as part and parcel of the commercial interests of health service suppliers (confidential information the disclosure of which would prejudice legitimate commercial interests), other domestic legal rights including constitutional fundamental rights and human rights concerns, would not define it thus. Weber notes that from a trade perspective, "privacy rules can contain the risk of jeopardizing the crossborder delivery of electronic services" and highlights that differences in privacy regulation in different countries would particularly be of concern for suppliers of financial and health services. ${ }^{1444}$ Whether such differences would be in violation of GATS obligations would depend on market access commitments and if such commitments have been made, it would be balanced by the exception in Article XIV(c)(ii) of the GATS which mentions "privacy of individuals in relation to the processing and dissemination of personal data and the protection of confidentiality of individual records and accounts".

Furthermore, although this confidentiality provision is numbered Article IIIbis and an assumption can be made that it relates to Article III Transparency only, the language does not so limit it, and it has been identified as a general exception to the GATS ${ }^{1445}$ and not merely an exception to Article III transparency requirements. Delimatsis notes the connection between Article IIIbis with Article XIV (General Exceptions) and in particular Article XIVbis1(a) (Security Exceptions) ${ }^{1446}$ which will be discussed in Chapter 5 (Section 5.8.2). It is interesting to see that Delimatsis is of the opinion that the level of the protection of confidentiality should be increased, but only refers to commercial interests (and the pro-confidentiality views raised in EC-Approval and Marketing of Biotech Products) and not to public interest reasons for protecting confidential information. The

A Member should respond promptly and fully to any request by a panel for such information as the panel considers necessary and appropriate. Confidential information which is provided shall not be revealed without formal authorization from the individual, body, or authorities of the Member providing the information.

This clearly provides that confidential information should be provided to the Panels on request. The Appellate Body has further commented that Members have the duty to respond to requests for information by Panels and that the Panels retain the discretion to draw negative inference by the refusal to do so (See Appellate Body Report, Canada - Aircraft, paras.202-205; Appellate Body Report, US-Wheat Gluten, paras.173-176). So the exception works well as long as there is satisfactory mutual co-operation, but in the case of a dispute, it may be advisable to provide the confidential information that is requested in order that the dispute settlement bodies can carry out their duties.

${ }^{1444}$ Weber, Rolf H., Regulatory Autonomy and Privacy Standards Under the GATS, Asian Journal of WTO \& International Health Law and Policy, Vol. 7, No. 1, pp.25-48, March 2012, p31-32.

1445 Delimatsis, Panagiotis, Article IIIbis GATS: Disclosure of Confidential Information in Wolfrum, Rudiger, Peter-Tobias Stoll and Clemens Feinaugle Eds., WTO - TRADE IN SERVICES, Max Planck Commentaries on World Trade Law, Martinus Nijhoff Publishers, 2008, p108, citing the WTO Secretariat, Working Group on the Relationship between Trade and Investment, Note by the Secretariat, WT/WGTI/W/109, 27 March 2002, para.43.

${ }^{1446}$ Ibid. See Article XIVbis 1(a):

Nothing in this Agreement shall be construed:

(a) to require any Member to furnish any information, the disclosure of which it considers contrary to its essential security interests... 
inclusion of these two protected interests could be also seen as a balancing exercise in the GATS: recognition that there are other values than commerce and trade that should be recognized and protected. Article IIIbis also has interesting implications for the relationship between government and private business at both domestic and international level with regard to the handling of confidential information. The role that the WTO can play in this sensitive area, and how well the system can balance the conflicting concerns regarding the handling of information, remains to be seen.

The backdrop of the discussions in this Chapter thus includes issues of transparency and confidentiality, although the main focus is on the extent of national policy flexibility and in particular, the extent to which such flexibility can be achieved in tandem with the goal of non-discrimination as understood and applied in the WTO GATS context. 


\subsubsection{Article II: The Most Favoured Nation Treatment Obligation}

'I've a sceptre in hand, I've a crown on my head; Let the Looking-Glass creatures, whatever they be, Come and dine with the Red Queen, the White Queen, and me.'

From Lewis Carroll's Through the Looking Glass

\subsubsection{Introduction to the Most-Favoured-Nation (MFN) Treatment Principle.}

[MFN treatment is] ...treatment accorded by the granting State to the beneficiary State, or to persons or things in a determined relationship with that State, not less favourable than treatment extended by the granting State to a third State or to persons or things in the same relationship with that third State. ${ }^{1447}$

The MFN treatment principle can be described as a non-discrimination principle, in that State A agrees to treat all its trading partners with MFN treatment status in the same manner. Originally found in bilateral treaties, it has been commented that the use of MFN treatment in multilateral trade treaties and the WTO agreements has 'multilateralized bilateral relations' and that this intends to make the future fragmentation of trade relations into bilateral ones less likely. ${ }^{1448}$ Despite this, the current data shows that there has been an enormous proliferation of bilateral trade agreements after the entry into force of the WTO Agreement. ${ }^{1449}$ Some of these bilateral investment treaties could be said to overlap with the GATS in that they have the effect of liberalizing areas that could fall under Mode 3 of the GATS (commercial presence of service supplier). ${ }^{1450}$ Furthermore, there is an increased interest in preferential trade agreements and in regional trade agreements and regionalization. ${ }^{1451}$ The impasse of the Doha Development Round and the changing

1447 ILC, Draft Articles on MFN Clauses with Commentaries (1978), Yearbook of the International Law Commission, 1978, vol. II, Article 5.

${ }_{1448}$ Wolfrum, R., Article II GATS in Wolfrum, Rudiger, Peter-Tobias Stoll and Clemens Feinaugle Eds., WTO - TRADE IN SERVICES, Max Planck Commentaries on World Trade Law, Martinus Nijhoff Publishers, 2008, p73.

${ }^{1449}$ See Adlung, Rudolf and Martin Molinuevo, Bilateralism in Services Trade: is there Fire Behind the (Bit)Smoke, Staff Working Paper ERSD-2008-01, World Trade Organization, Economic Research and Statistics Division, 16 January 2008; Lee, Y.S., Bilateralism under the World Trade Organization, 26 North Western University Journal of International Law and Business, 357, 2006.

${ }^{1450}$ Ibid., (Adlung) p4-6.

${ }^{1451}$ Matsushita, Mitsuo, Proliferation of Free Trade Agreements and Development Perspectives, Law and Development Institute Inaugural Conference, Sydney, Australia, October 2010, available online at http://www.lawanddevelopment.net/ img/matsushita.pdf, last accessed 07.08.2013. An earlier version of this paper is available in The Law and Development Review, Vol. 1, No. 1 (2008), 23-49. Matsushita notes that the EU, NAFTA, the MERCOSUR and the ASEAN account for a majority of international trade. However, the most recent UNCTAD statistics (2012) for services trade show have a growing share of the services market gained by developing economies in Asia (25\% of exports). Furthermore, APEC (the forum for Asia Pacific Economic Cooperation) is the most economically powerful grouping after the EU and it is also formally considering a Free Trade Area of the Asia-Pacific. 
power structure of the WTO Membership, particularly the increasing power of China, India and Brazil have been identified as contributing to this situation. ${ }^{1452}$

The impact of such increased bilateralism and regionalism on the less powerful developing countries is being observed with concern. This is because a multilateral trading system can be argued as more likely to protect the interests of developing economies and provide small developing economies with opportunities for beneficial trade on a non-discriminatory basis than bilateral trade negotiations or trade negotiations with regional associations where they face significant inequalities of bargaining power. On the other hand, multilateral agreements were often "more likely to meet political resistance", ${ }^{1453}$ so it can also be argued that bilateral, regional or other preferential agreements can carry out in practice, and with less reaction and protest, the liberalization process that is stalling under the WTO. However, even in this regard, increasing public awareness of negotiations for bilateral and regional agreements and their possible draft provisions - which may involve deeper integration than in multilateral trade agreements, and thus stronger public resistance - means that signing and adopting such agreements is no longer a simple matter. Increasing public resistance to bilateral agreements could be seen when they may affect services such as health and education services. For example, Sri Lanka and Singapore entered into a bilateral agreement referred to as the Sri LankaSingapore Free Trade Agreement (SLSFTA) in 2018 amidst expressions of protest by sections of the public and the political opposition, and even ultimately the President (who is part of the coalition government and not of the same political party as the Prime Minister or the Ministers of Finance and Foreign Affairs). Sri Lanka has not made commitments in either its GATS or SLSFTA schedules in health and education but there were public assumptions about indirect negative effects of the SLSFTA, which led to several token strikes by the Government Medical Officers Association (GMOA) during 2018.

\subsubsection{History of the MFN Treatment Principle}

The MFN treatment principle has an interesting history with regard to its role in peaceful trade relations between nations, although it is argued that its 'non-discrimination' aspect is a much more recent development of the GATT and WTO. Earlier, it was a form of favourable discrimination for preferred trading partners, although its meaning now is that no trading partner will be treated more negatively than others who have also joined the same international or regional legal framework for trade. The International Law Commission has been studying the MFN treatment principle for some time now, and the findings are thought-provoking in the context of understanding more fully the MFN treatment principle in the GATS. The origins of the MFN treatment principle have been traced to grants and privileges given between trading cities to foreign traders in the

1452 Nakagawa Junji, Serious Efforts Necessary to Reinvigorate the WTO, AJISS - Commentary, The Association of Japanese Institutes of Strategic Studies, No. 177, 4 June 2013, available online at http://www2.jiia.or.jp/ en commentary/201306/04-1.html, last accessed 08.07.2013. See further, Mansfield, Edward D., and Eric Reinhardt, Multilateral Determinants of Regionalism: The Effects of GATT/WTO on the Formation of Preferential Trading Arrangements, International Organization 57, No. 4 (Fall), 829-62, 2003 arguing that the uncertainty in multilateral negotiations pushes countries into smaller trading blocs or regional blocs in order to improve their bargaining position.

${ }_{1453}$ Tobin, Jennifer L and Marc L. Busch, A Bit Is Better Than A Lot Bilateral Investment Treaties and Preferential Trade Agreements, World Politics 62, No. 1, January 2010, p30. 
middle ages. ${ }^{1454}$ It is said to have arisen as a second best option in cases where it was not possible to obtain and enforce a monopoly in a foreign market. ${ }^{1455}$ If unable to exclude competitors, an equal chance to compete was better than no opportunity at all. By the $15^{\text {th }}$ century, it has been observed that the clauses in bilateral treaties began taking a form more like the modern MFN clauses, in that the privileges no longer were limited to certain named trading cities or specific nations, but equal treatment of different foreign traders. ${ }^{1456}$ This more modern form of the MFN clause was used in treaties drawn up by European trading companies that went East in search of new markets from the $16^{\text {th }}$ Century onwards, when they could not obtain trade monopolies or territorial control. ${ }^{1457}$ The use of the actual term "most-favoured-nation" is traced as first appearing at the end of the $17^{\text {th }}$ Century. ${ }^{1458}$

Interestingly, unilateral MFN clauses were also used in capitulation treaties in Europe in the $17^{\text {th }}$ and $18^{\text {th }}$ centuries $^{1459}$, thus having also a sense of the more powerful nation asserting itself to profit from the peace, as much as it was often part of treaties of friendship. In the early $20^{\text {th }}$ century, views were divided with regard to the removal of trade barriers, which would result in trading with (past and future) enemies but which could also be seen as trade for promotion of peace. The peace treaties of $1919^{1460}$ unilaterally imposed temporary unconditional MFN treatment obligations on the defeated nations and the Covenant of the League of Nations, in Article 23 paragraph (e) called for "equitable treatment of the commerce of all Members of the League".

However, the continued economic instability of the post-World War I period resulted in an overall raising of trade barriers in practice, while at the same time the MFN principle (particularly the unconditional form that did not rely on reciprocal benefits for the granting state) was being studied and promoted by international lawyers and economists. In practical terms, the emergence of the Soviet Union, with a different political and economic system, was another complicating factor, as were the actions of Germany to reject the terms of peace and focus on economic self-sufficiency and rearmament. ${ }^{1461}$ An

\footnotetext{
${ }^{1454}$ See Davey, W.J., and Joost Pauwelyn, MFN Unconditionality: A Legal Analysis of the Concept in view of its Evolution in the GATT: WTO Jurisprudence with Particular reference to the Issue of "Like Product", in Cottier, Thomas and Petros C. Mavroidis Eds. REGULATORY BARRIERS AND THE PRINCIPLE OF NON-DISCRIMINATION IN WORLD TRADE LAW, University of Michigan Press, 2000, p13.

${ }^{1455}$ ILC, Ustor, Endre, First Report of the Special Rapporteur to the ILC, The MFN Clause: History of the most-favoured nation clause up to the Second World War, 21st session of the ILC 1969, U.N. Doc. A/CN.4/213. Also available online at http//:untreaty.un.org/ilc/documentation/english/a_cn4_213.pdf.

${ }^{1456}$ Ibid., (Ustor).

1457 Ibid., (Ustor).

${ }^{1458}$ Jackson, John H., THE WORLD TRADING SYSTEM: LAW AND POLICY OF INTERNATIONAL ECONOMIC RELATIONS, $2^{\text {nd }}$ Edition, 1997, p158 cited by Davey, William J., and Joost Pauwelyn, MFN Unconditionality: A Legal Analysis of the Concept in View of its Evolution in the GATT/WTO Jurisprudence with Particular Reference to the Issue of "Like Product" in Cottier, Thomas and Petros C. Mavroidis Eds., REGULATORY BARRIERS AND THE PRINCIPLE OF NON-DISCRIMINATION IN WORLD TRADE LAW, World Trade Forum Vol.2, Studies in International Economics, University of Michigan Press, 2000, p13.

${ }^{1459}$ ILC, Ustor, Endre, First Report of the Special Rapporteur to the ILC, The MFN Clause: History of the most-favoured nation clause up to the Second World War, 21st session of the ILC 1969, U.N. Doc. A/CN.4/213. Also available online at untreaty.un.org/ilc/documentation/english/a_cn4_213.pdf.

${ }^{1460}$ Treaty of Versailles, Article 267; Treaty of Saint-Germain, Article 220; Treaty of Neuilly, Article 150; Treaty of Trianon, Article 203.

${ }^{1461}$ ILC, Ustor, Endre, First Report of the Special Rapporteur to the ILC, The MFN Clause: History of the most-favoured nation clause up to the Second World War, 21st session of the ILC 1969, U.N. Doc. A/CN.4/213.
} 
alternate perspective on today's international trade environment and legal framework could also see a continued underlying mistrust of different political and economic systems and self-sufficiency. The WTO can be seen as an attempt at homogeneity in the acceptance of free market economics and global trade interconnectedness.

The history of the MFN treatment principle with regard to peaceful relations and 'free trade'- that the application of this principle to prevent different treatment had motives of both profit and avoidance of conflict - has interesting implications for the modern WTO context. There could be an inbuilt suspicion of differences of policy, perceived protectionism and different treatment of trading partners, as causing otherwise avoidable instability ${ }^{1462}$ - a reaction that occurs regardless of the reasons, justifications or values underlying such divergences. Differential treatment, it can be argued, would not help any party in the long run. In a system where the basis is not that of maintaining monopolies in closed markets (like with trading Companies or Empire), but the chance to enter markets and compete within them, reduction of tariff and non-tariff barriers may be the best way to go. In addition, modern economic rationale supports equal treatment of trading partners on the grounds of efficiency and growth, lowering the cost of entering new markets and increasing consumer choice.

The unconditional MFN treatment principle came to the fore again post World War II, with it being a defining principle of the multilateral General Agreement on Tariffs and Trade (GATT 1947) and being discussed by International Court of Justice in three important cases ${ }^{1463}$ in the early 1950 's. The International Law Commission (ILC) also prepared The Draft Articles on MFN Clauses (1978) which they recommended for adoption as a convention by the UN General Assembly - but which did not occur. A significant observation was made in this document that has been quoted in many later commentaries on the MFN treatment clause, which is that:

All that the most-favoured-nation clause promises is that the contracting party concerned will treat the other party as well as it treats any third State - which may be very badly. It has been rightly said in this connexion that, in the absence of any undertakings to third States, the clause remains but an empty shell. ${ }^{1464}$

The purpose of an MFN treatment clause is to abolish differences in treatment by discouraging more favourable treatment to a particular trading partner but nothing in the principle specifies which standards will be set in trading relations. A treaty should then also include provisions to maintain levels of openness and not let there be steps backwards, as well as incentivize increased openness of markets. Thus, in the WTO GATS context, implementation of MFN treatment with progressive liberalization commitments in services - and both advancing together, would be the ideal. The ILC also continues with its work on MFN treatment through an open-ended Working Group established again in 2007.

1462 See Van den Bossche, Peter., THE LAW AND POLICY OF THE WORLD TRADE ORGANIZATION: TEXT, CASES AND MATERIALS, Cambridge University Press, $2^{\text {nd }}$ Edition, 2008, p321 - noting that historians regard the discriminatory/protectionist policies of the 1930's contributing to the resentment among countries and the economic and political crisis that led to the outbreak of war.

1463 Anglo-Iranian Oil Company Case (Jurisdiction) ICJ Reports 1952, p93; The Case concerning the Rights of Nationals of the United States of America in Morocco, ICJ Reports 1952, p176; and The Ambatielos Case (Greece v. United Kingdom) (Merits: obligation to arbitrate) 5 ICJ Reports 1953, p10.

1464 ILC Draft Articles on MFN Clauses with Commentaries (1978), Yearbook of the International Law Commission, 1978, vol. II, commentary to draft Article 4, para.8. 
In another development that came in response to the formal and unconditional equality of the GATT 1947 provision on MFN treatment, the United Nations Conference on Trade and Development (UNCTAD) began working in the 1960's on creating more equity in international trade (from the view of developing countries) through a generalized system of preferences (GSP). ${ }^{1465}$ Presented at the very first UNCTAD Conference of 1964, the GSP idea was adopted at UNCTAD II in New Delhi in 1968 and implemented by the GATT contracting parties, initially as a waiver in 1971 and finally as the Enabling Clause in 1979. ${ }^{1466}$ The role of GSP in promoting de facto equality and non-discrimination was discussed earlier in this Chapter. The UNCTAD still works on the issue of MFN treatment, the most recent report on it being published in $2010 .{ }^{1467}$ In fact the UNCTAD works with the WTO on many issues, signing a Memorandum of Understanding for cooperation in 2003 and jointly sponsoring the International Trade Center. ${ }^{1468}$

However, the principle supported by UNCTAD, that treating un-equals equally exacerbates inequalities, ${ }^{1469}$ and therefore that another additional arrangement is needed to promote fairness and economic development, is reflected mainly in the case of goods and to a lesser degree in the other WTO Agreements. More recently, the Trade Facilitation Agreement which entered into force in 2017 is described as benefiting the developing and least developed country Members in the way it will be implemented. The WTO website comments that it "broke new ground" because:

It is the first WTO agreement in which these WTO members can determine their own implementation schedules and in which progress in implementation is explicitly linked to technical and financial capacity. In addition, the Agreement states that assistance and support should be provided to help them achieve that capacity. ${ }^{1470}$

The TRIPS Agreement already recognizes the special needs and requirements for national policy flexibility for least developed country Members in Recital 6 of its Preamble and in Article 66. Flexibility for transitional arrangements for least developed countries is recognized in Article 65 and technical co-operation for developing and least developed countries in Article 67 of the TRIPS. The GATS has recognition of developing country and least developing country interests in several recitals of its Preamble, Articles II:4, IV, XII, XV, XIX and XXV. Thus, for GATS, we have what seems to be at first glance a number of options for flexibility. The options open under the non-discrimination

\footnotetext{
1465 See further, ILC, Ustor, Endre, Second Report of the Special Rapporteur to the ILC, The MFN Clause: Analytical survey of the views expressed in some cases dealt with by the International Court of Justice pertaining to the clause; information supplied by the international organizations, 22nd session of the ILC 1970, U.N. Doc. A/CN.4/228 and Add.1.

${ }^{1466} \mathrm{See}$ unctad.org/en/Pages/DITC/GSP/About-GSP.aspx, last accessed 03.06.2012. The Enabling Clause is otherwise known as the Decision of the Contracting Parties of 28 November 1979 (BISD 26S/203) entitled Differential and more favourable treatment, reciprocity and fuller participation of Developing countries. Paragraph 1 of the Enabling Clause reads:

Notwithstanding the provisions of Article I of the General Agreement, contracting parties may accord differential and more favourable treatment to developing countries without according such treatment to other contracting parties.

${ }^{1467}$ UNCTAD, Most-Favoured-Nation Treatment: A Sequel, UNCTAD Series on Issues in International Investment Agreements II, UNCTAD/DIAE/IA/2010/1, p xii-xiv.

${ }^{1468}$ Interestingly, former WTO Director General Supachai Pantichpakdi is the current Secretary-General of UNCTAD.

1469 Also reiterated in UNCTAD, Beyond Conventional Wisdom in Development Policy: An Intellectual History of UNCTAD (1964-2004), UNCTAD/EDM/2004/4.

${ }^{1470}$ WTO, Trade facilitation - Cutting "red tape" at the border, last accessed 03.07.2017, available online at: https://www.wto.org/english/tratop_e/tradfa_e/tradfa_introduction_e.htm.
} 
obligations, domestic regulation and scheduling will be looked at further in the following sections of this Chapter. Chapter 6 discusses the GATS recognition of developing country needs in further detail.

Ultimately, by the time the WTO system came into force, the MFN treatment principle became known as a 'cornerstone' or 'a pillar' of the international trading system, a sentiment that was included in the Preamble to the WTO Agreement and reiterated by the Appellate Body in more than one dispute settlement context. ${ }^{1471}$ What is insufficiently addressed in most discussions in the WTO law context is the question of the role played by MFN treatment, if any, in the development dimension and how it could assist developing country trading partners. The UNCTAD approach was to acknowledge that equal treatment of trading partners has its failings, and the ILC study group recently recognized that the economic rational of MFN are "controversial" and its benefits, particularly for developing countries, remains "unresolved" in the field of trade. ${ }^{1472}$ While the abovementioned 2015 ILC report noted that MFN was born of a "more pragmatic desire to prevent competitive advantage in the economic sphere" 1473 for trade and also to protect investors' rights, it is unfortunate that a deeper analysis of the question of the economic rationale for MFN provisions and the question of its contribution towards economic development was purposely avoided. ${ }^{1474}$ A previous 1999 UNCTAD study, (reiterated in a 2010 update), noted that GATS allows developing countries to "make MFN exceptions for which a "policy of selective intervention" or a policy to "favour foreign investors of a particular nationality" could apply. ${ }^{1475}$ It is commented that policies of selective intervention, with strategically identified economic partners, could relate to activities in which a developing country can reasonably expect to acquire a comparative advantage, but the report did not go into an analysis of why/whether such strategic trade partnerships may be useful for a developing country, over an 'open-door' policy. ${ }^{1476}$ In practical terms, if looking at application to health services, it is possible for choices to be made for a developing country like Sri Lanka to choose limited strategic partnerships with neighbouring India or Singapore with regard to health services, rather than with the

${ }^{1471}$ Appellate Body Report, U.S - Section 211 Appropriations Act, para 297; ...the obligation to provide most-favoured-nation treatment has long been one of the cornerstones of the world trading system.

Appellate Body Report, Canada-Autos, para.69;

...the 'most-favoured-nation' ('MFN') principle that has long been a cornerstone of the GATT and is one of the pillars of the WTO trading system.

Appellate Body Report, EC-Tariff Preferences, para.101;

It is well settled that the MFN principle embodied in Article I:1 is a 'cornerstone of the GATT' and 'one of the pillars of the WTO trading system', which has consistently served as a key basis and impetus for concessions in trade negotiations. However, we recognize that Members are entitled to adopt measures providing 'differential and more favourable treatment' under the Enabling Clause.

1472 ILC, Most-Favoured-Nation clause: Final Report of the Study Group on the Most-Favoured-Nation clause, Yearbook of the International Law Commission, 2015, Vol. II (Part Two), http://legal.un.org/ilc/ texts/instruments/english/reports/1_3_2015.pdf, para.39.

1473 Ibid, ILC, para.37.

${ }^{1474}$ Ibid, ILC, para.40. Also, para.70, with reference to whether an investor is provided with MFN for the purpose of contribution to the host States economic development.

${ }^{1475}$ UNCTAD, Most-Favoured-Nation Treatment, UNCTAD/ITE/IIT/10 (Vol. III), 1999, p26, available online at https://unctad.org/en/Docs/psiteiitd10v3.en.pdf. See further the update/reiteration: UNCTAD, Most-Favoured-Nation Treatment: A Sequel, UNCTAD/DIAE/IA/2010/1, 2010, available online at https://unctad.org/en/Docs/diaeia20101_en.pdf.

${ }^{1476}$ Ibid, UNCTAD, p38-39. 
United States, with which we do not share a common set of values towards health services provisions.

\subsubsection{The MFN Treatment Principle in Article II of the GATS}

\section{Article II: 1 of the GATS: Most Favoured-Nation Treatment}

With respect to any measure covered by this Agreement, each Member shall accord immediately and unconditionally to services and service suppliers of any other Member treatment no less favourable than that it accords to like services and service suppliers of any other country.

The MFN treatment obligation in the GATS is a 'horizontal obligation', which applies across essentially all service sectors covered by the Agreement. The importance of the first part of Article II of the GATS and of the MFN treatment principle in international trade law is reflected in the provision on amendments to the WTO agreements, Article X (Amendments) of the Marrakesh Agreement Establishing the World Trade Organization (WTO Agreement). Article X:2 of the WTO Agreement states that

Amendments to the provisions of this Article [Article X] and to the provisions of the following Articles shall take effect only upon acceptance by all Members whereas for other amendments a three-fourths or two-thirds majority suffices:

Article IX of this Agreement;

Articles I and II of GATT 1994;

Article II: 1 of GATS;

Article 4 of the Agreement on TRIPS.

Article IX of the WTO Agreement concerns the WTO principle of 'decision making by consensus'. But more importantly, in connection with this section on MFN treatment, it can be seen that Articles I and II of the GATT 1994 are on general MFN treatment and schedules of concessions and Article 4 of the TRIPS is also on MFN treatment. Thus, of all the provisions in these three agreements on goods, services and intellectual property, the MFN treatment principle has been recognized as the one that should be the most difficult to alter, as an amendment can only take effect upon acceptance of all Members.

The Appellate Body in EC-Bananas III has stated that Article II of the GATS should be interpreted in light of Article I of the GATT 1994. ${ }^{1477}$ Wolfrum also notes that Article II of the GATS is modeled on Article I:1 of the GATT 1947 but there are also significant differences. ${ }^{1478}$ The Article II of the GATS has a wider scope as it refers to "any measure covered by this Agreement" whereas the equivalent Article of the GATT 1994 is applicable to certain matters only: customs duties and charges, rules and formalities in connection with importation and exportation and matters covered by Articles III:2 and III:4 (national treatment on internal taxation and regulation) of the GATT 1994. Thus, while it is possible to look at WTO jurisprudence on Article I of the GATT 1994 with regard to the interpretation of Article II of the GATS, these differences need to be kept in mind.

\footnotetext{
1477 Appellate Body Report, EC-Bananas III, paras.231-234.

1478 Wolfrum, R., Article II GATS: Most-Favoured Nation Treatment in Wolfrum, R., Peter-Tobias Stoll and Clemens Feinaugle Eds., WTO-TRADE IN SERVICES, Max Planck Commentaries on International Trade Law, Martinus Nijhoff Publishers, 2008, p74.
} 
Article II:1 of the GATS also includes the term "treatment no less favourable" which is not there in the equivalent Article I:1 of the GATT 1994 which reads:

...any advantage, favour, privilege or immunity granted by any contracting party to any product originating in or destined for any other country shall be accorded immediately and unconditionally to the like product originating in or destined for the territories of all other contracting parties.

The term 'no less favourable' seems to be taken from Article III of the GATT 1947 (national treatment). The same term is used in Article XVII:1 of the GATS, which is the national treatment provision in the GATS. Both Article II and XVII of the GATS also share a concept in the 'likeness' of services and service providers. These terms and their interpretation and application for trade in services will be discussed in more detail under the national treatment provision (section 4.5.2.3.) later in this Chapter.

The question is whether the same term used in two provisions of the same Agreement (Article II and XVII of the GATS) mean the same in the interpretation of both Articles. The Panel in EC-Bananas III dealt with this matter, stating that there was no justification to apply a different 'ordinary meaning' to the same term that is used in different provisions. ${ }^{1479}$ However, the Appellate Body argued that since national treatment and MFN treatment pursue different objectives, national treatment provisions (Article XVII of the GATS or Article III of the GATT 1994) or previous GATT practice "are not necessarily relevant" for the interpretation of the MFN treatment obligation under Article II of the GATS. ${ }^{1480}$

The setting in the GATS - wherein MFN treatment is a general obligation applicable to "any measure covered by this Agreement" 1481 and in contrast Members retain the right to choose to take on specific commitments on national treatment - may also be relevant in whether it is advisable to interpret these two GATS provisions with reference to each other. Furthermore, during the Uruguay Round negotiations on services some countries believed that national treatment should be looked at differently in services for a number of reasons including the reluctance of their legislatures to accept it as an unconditional principle. ${ }^{1482}$ As a result, national treatment is not a general obligation in the GATS unlike MFN treatment. Arguably, MFN treatment has generally been a less controversial matter in international trade than national treatment, and the same can be said with regard to services. Moreover, MFN treatment is far less likely to cause problematic restrictions on domestic policy space as compared to national treatment obligations, since MFN is about treating trading partners equally - which has less impact on the domestic sphere: and national treatment is to treat foreign suppliers the same as domestic suppliers, which has obvious impacts for competition among foreign and domestic suppliers in the domestic sphere.

The breadth of the GATS provision on MFN treatment and the fact that it is an unconditional horizontal obligation applying across almost all service sectors, whether specific commitments are made or not, means that there would be limited scope for

\footnotetext{
${ }^{1479}$ Panel Report, EC-Bananas III, para.7.301

${ }^{1480}$ Appellate Body Report, EC-Bananas III, para.231

1481 The interpretation of "measures" covered by the GATS was discussed earlier in Chapter Two.

1482 Croome, John, RESHAPING THE WORLD TRADING SYSTEM: A HISTORY OF THE URUGUAY ROUND, Diane Publishing, 1996, p125 (Also available $2^{\text {nd }}$ (Revised) Edition, from Kluwer Academic Publishers, 1999).
} 
national policy flexibility. In contrast, market access and national treatment obligations are dependent on the flexibilities Members may use in the scheduling of commitments. Therefore, explicit exemptions or exceptions to MFN treatment ought to be identified in the Agreement. The effect of such exemptions from Article II MFN treatment obligations would not affect the national treatment and market access commitments made under Articles XVII and XVI of the GATS. Mattoo states that negotiators in the Uruguay Round realized that exemptions were necessary in order to prevent "wholesale sectoral exclusions from the GATS" to avoid MFN treatment rule applying to sensitive sectors. ${ }^{1483}$

Exemptions to the general obligation of MFN treatment as expressed in Article II: 1 are provided for in Article II:2 (measures listed in and meeting the conditions of the Annex on Article II Exceptions) and in Article II:3 (the facilitation of exchange of locally produced and consumed services across contiguous frontier zones). Also note that if an MFN treatment obligation is included in any other Article of the GATS, the Article II exemptions would not apply to that specific MFN treatment obligation, only to the general obligation under Article II.

Wolfrum points out that these MFN treatment exemptions only allows 'upward discrimination' or 'positive discrimination' that is more favourable than the minimum requirements in the Members Schedule of Commitments but not less favourable treatment. ${ }^{1484}$ However, Adlung and Carzaniga suggest that the MFN treatment exemptions available under Article II:2 and the related Annex, as well as through Economic and Labour Market Integration Agreements (Articles V and Vbis of the GATS) and recognition measures related to standards etc (Article VII of the GATS) may also allow for:

...targeted denials of market access or other benefits vis- $a$-vis countries

whose trade regimes do not meet prescribed conditions ('MFNminus'). ${ }^{1485}$

They give the example of reciprocity clauses governing access to markets by foreign services or service suppliers, that could be less favourable than other trading partners, if that particular Member had a less liberalized services market. These limitations can be horizontal (applying to all sectors) or sector specific. For example, the scheduled Article II:2 MFN treatment exemption of the Dominican Republic only allows for foreign health professionals (doctors, dentists, physiotherapists, paramedical personnel and nurses) to exercise their profession on the basis of reciprocity. ${ }^{1486}$ Similarly, Jordan issues licenses for non-Jordanians for medical testing and laboratory administration only if Jordanian

1483 Mattoo, Aaditya, MFN and the GATS in in Cottier, Thomas and Petros C. Mavroidis Eds., REGULATORY BARRIERS AND THE PRINCIPLE OF NON-DISCRIMINATION IN WORLD TRADE LAW, World Trade Forum Vol.2, Studies in International Economics, University of Michigan Press, 2000, p55.

${ }^{1484}$ Wolfrum, R., Article II GATS: Most-Favoured Nation Treatment in Wolfrum, Rudiger, Peter-Tobias Stoll and Clemens Feinaugle Eds., WTO - TRADE IN SERVICES, Max Planck Commentaries on World Trade Law, Martinus Nijhoff Publishers, 2008, p91. See also Group of Negotiations on Services, Uruguay Round, Listing of Article II Exemptions, Explanatory Note by the Secretariat, MTN.GNS/Job.2061, 15 September 1993.

${ }_{1485}$ Adlung, Rudolf and Antonia Carzaniga, MFN Exemptions Under the General Agreement on Trade in Services: Grandfathers Striving for Immortality?, Journal of International Economic Law 12(2), 2009, 357392, p358.

${ }^{1486}$ WTO, Dominican Republic - Final List of Article II (MFN) Exceptions, GATS/EL/28, 15 April 1994. 
nationals are granted reciprocal treatment (with the possibility of an exception to the reciprocity requirement to foreign directors of private hospital labs). ${ }^{1487}$

Bulgaria, before joining the EU, also refers to reciprocity based on bilateral agreements and its MFN exemption is quite detailed and covers the following:

Medical and dental services, public medical insurance, subsidization and compensation plans and programs, which cover the cost and expenses relating to medical and dental services provided to foreign citizens in the territory of the Republic of Bulgaria, are granted on the basis of reciprocity in the framework of bilateral agreements. ${ }^{1488}$

Countries to which the above measure applies are "countries with which such bilateral agreements are or will be concluded". This was intended in 1997, the date of the scheduling, to be of indefinite duration. If such healthcare facilities are provided by the public sector and by taxation, the question of course arises whether the benefits should be limited to citizens. However, it can be pointed out that the international obligations of a State with regard to the right to health are not limited to citizens, but include migrants, both legal and undocumented. ${ }^{1489}$ In theory, public health services cannot be limited to citizens if the current international human rights standards with regard to nondiscrimination of migrants, refugees, the Roma etc. are complied with. ${ }^{1490}$ There is no condition of bilateral reciprocity would affect the obligations of Bulgaria under e.g. the ICESCR (which it ratified in 1970) or other human rights obligations. Interestingly, the "conditions creating the need for the exemption" were specified by Bulgaria as "obligations under international agreements"; however, the specific agreements were not identified by Bulgaria in the schedule. So, in the absence of reciprocal public health services policies in other jurisdictions, this seems to be an example of using MFN treatment exemptions to limit the right to health rather than to promote it for all, without discrimination.

\subsubsection{Article II:2 and the Annex on Article II Exemptions}

At the point that GATS came into force, a Member was given an opportunity for making exemptions from the general MFN treatment principle of Article II:1 of the GATS. It is a one-time opportunity for these Members. According to Article II:2, a Member "may

${ }^{1487}$ WTO, Hashemite Kingdom of Jordan - Final List of Article II (MFN) Exceptions, GATS/EL/128, 15 December 2000.

${ }^{1488}$ WTO, Republic of Bulgaria - Final List of Article II (MFN) Exceptions, GATS/EL/122, 21 May 1997.

Note there is a new draft Consolidated Schedule of 25 EU Members (draft Consolidated GATS Schedule, 9 October 2006, S/C/W/273) but Bulgaria was not included in that grouping.

${ }^{1489}$ See International Organization for Migration (IOM), MIGRATION AND THE RIGHT TO HEALTH: A REVIEW OF INTERNATIONAL LAW, International Migration Law, No. 19 (complied by Paola Pace), IOM publications, 2009.

${ }^{1490}$ See the International Convention on the Protection of the Rights of All Migrant Workers and Members of Their Families, 1990; the International Convention on the Elimination of all Forms of Racial Discrimination (CERD) 1965; CERD General Recommendation XX on non-discriminatory implementation of rights and freedoms 1996 (Article 5); CERD General Recommendation XXX on discrimination against non-citizens, 2004 and CERD General Recommendation XXVII on discrimination against Roma 2000; CERD General Recommendation XI on non-citizens 1993, (Article 1); 1993; CERD General Recommendation XXX on discrimination against non-citizens, 2004; HRC General Comment No. 15: the position of aliens under the Covenant, 1986; HRC General Comment No. 31: the nature of the general legal obligation imposed on States parties to the Covenant, 2004; Declaration on the Human Rights of Individuals Who are Not Nationals of the Country in which They Live, 1985, World Health Assembly Resolution WHA61.17: 7. 'Health of migrants', 2008; Convention relating to the Status of Stateless Persons, 1954. 
maintain a measure inconsistent with paragraph 1" of the same Article, if such a measure has existed prior to the entry into force of the WTO Agreement and has been listed in and meets the conditions of the Annex on Article II Exemptions. The member who is to receive the more favourable treatment and the duration of the exemption needed to be listed in the exemption list as well as other requirements that make the terms of the exemption clear. ${ }^{1491}$ This exemption list is considered an integral part of the GATS, according to Article XXIX of the GATS. ${ }^{1492}$ When a country is making preparations to accede to the WTO, exemptions can be made part of the accession negotiations. In this sense, the opportunity available for original Members and new WTO Members differs.

Article II:2 is a 'self-selecting exemption' ${ }^{1493}$ as original Members must have sought the exemption themselves. These exemptions were expected to be a one-time opportunity granted "at the entry into force" 1494 of the WTO Agreement, which Members could not use again. It was not expected to last more than 10 years "in principle"1495 and ought to be terminated on changes in the conditions that required the exemption to be granted. But as the language seems only persuasive, Members have usually inscribed the duration of their MFN treatment exemptions as "indefinite", "unspecified" or "unlimited" as the time duration. ${ }^{1496}$ Thus, for original Members, the exemption under Article II:2 has in practice been broader than it looks at first glance. Furthermore, new Members have also been given an opportunity to use the exemption when acceding to the WTO Agreement, although the wording of the Annex on Article II Exemptions is that:

Any new exemptions applied for after the date of entry into force of the WTO Agreement shall be dealt with under [Article X:3 of the WTO Agreement].

${ }^{1491}$ Group of Negotiations on Services, Uruguay Round, Listing of Article II Exemptions, Explanatory Note by the Secretariat, MTN.GNS/Job.2061, 15 September 1993 - discusses five entries which are necessary for the complete and precise listing of an exemption:

(i) Description of the sector or sectors in which the exemption applies

(ii) Description of the measure, indicating why it is inconsistent with Article II.

(iii) The country or countries to which the measure applies.

(iv) The intended duration of the exemption.

(v) The conditions creating the need for the exemption

${ }^{1492}$ See further, Wolfrum, R., Annex on Article II Exemptions in Wolfrum, Rudiger, Peter-Tobias Stoll and Clemens Feinaugle Eds., WTO - TRADE IN SERVICES, Max Planck Commentaries on World Trade Law, Martinus Nijhoff Publishers, 2008.

Note also: If the procedure and requirements of the Annex on Article II Exemptions has not been followed Members could only seek a waiver under procedures of Article IX:3 of the WTO Agreement. A waiver request must be one where there are 'exceptional circumstances' to justify it and a three-fourths majority approval of WTO Members. The result would only be a one-year waiver, to be reviewed (regarding the continuing existence of the 'exceptional circumstances'). The description of this clause by Adlung and Carzaniga as more of a "a narrow winding path" than an "escape route" is more than justified, as they note that it has only been used once with regard to services (Adlung, Rudolf and Antonia Carzaniga, $M F N$ Exemptions Under the General Agreement on Trade in Services: Grandfathers Striving For Immortality? Journal of International Economic Law 12(2), 2009, 357-392, p365-366).

${ }^{1493}$ Wang, Y., Most-Favoured-Nation Treatment under the General Agreement on Trade in Services and its application in Financial Services, Journal of World Trade, 30, 1996 1, p99.

${ }^{1494}$ Paragraph 1 of the Annex on Article II Exemptions.

1495 Paragraph 6 of the Annex on Article II Exemptions.

1496 Adlung, Rudolf and Antonia Carzaniga, MFN Exemptions Under the General Agreement on Trade in Services: Grandfathers Striving for Immortality? Journal of International Economic Law 12(2), 2009, 357392, Table 4, showing that only a handful of exemptions are for lesser, defined time periods. Also see OECD Working Party of the Trade Committee (Author: Martin Roy) Trade in Services: A Roadmap to GATS MFN Exemptions, TD/TC/WP (2001)25/FINAL, 29 October 2001. 
The date of entry into force of the WTO Agreement for new Members is the date of their accession to the WTO, thus their exemptions, if any, would begin from the date of their accession. Taking into account both the way in which original Members have used it as well as the fact that new Members can also use the MFN exemption, it is clearly much broader in practice that the text would lead one to assume.

The available data on exemptions show that there are over 400 exemptions listed by over 90 WTO Members. ${ }^{1497}$ Martin Roy in his report on behalf of the OECD Working Party of the Trade Committee notes that more than half (51\% according to the report) of all MFN treatment exemptions are taken in sectors such as audiovisual services and maritime, air and road transport services where there are low levels of commitments by WTO Members. ${ }^{1498}$ Financial services, which have a comparatively higher level of commitments accounted for a third of MFN exceptions according to this study.

These MFN treatment exemptions are part of current services negotiations and are to be reviewed. The GATS Council carries out 5 yearly reviews of the exemptions but it is also time for new in-depth studies and statistical analysis of the exemptions. Adlung and Carzaniga discussing the role of the MFN exemptions have called it a 'grandfathering clause', which has been retained by governments long after it was originally envisioned to have been phased out. ${ }^{1499}$ Members may have not realized that they should have sought an exemption earlier, and as there is no process for new exemptions, other alternative methods would be tried, including retaining existing exemptions and interpreting their application very broadly. The review of the MFN exemptions has not yielded any concrete results.

A quick search of MFN treatment exemptions reveals that there are five Members with MFN treatment exemptions in health and health-related professional services: Jordan, Bulgaria, Cyprus, Tunisia and the Dominican Republic. Two of these Members, Bulgaria and Cyprus, have joined the EU in the meantime (in 2007 and 2004 respectively), so this would affect their earlier commitments and exemptions made in the 1990s. The exemptions in the schedules of three of these countries (the Dominican Republic, Jordan and Bulgaria) were mentioned above in the preceding section, in relation to reciprocity. In addition, Tunisia has an MFN exemption for measures extending social security health benefits to citizens of other countries with which Tunisia has signed bilateral social security agreements. ${ }^{1500}$ The exemption in the Cyprus schedule dated 1994 concerns current and future bilateral agreements regarding the provision of medical treatment not available in Cyprus to Cypriot citizens. ${ }^{1501}$ This is an obvious MFN treatment exemption that would come to mind for a small country, wherein it is not always feasible (for either public or private providers) to supply all the necessary healthcare facilities within their territory, but where there are neighbouring countries with the facilities to which patients can travel (and perhaps also a particular history of good relations between those countries). For Cyprus, there has been a practice of accessing medical centers in Greece,

\footnotetext{
${ }^{1497}$ Ibid., (Adlung and Carzaniga; OECD (Roy)).

1498 OECD Working Party of the Trade Committee (Author: Martin Roy), Trade in Services: A Roadmap to GATS MFN Exemptions, TD/TC/WP (2001)25/FINAL, 29 October 2001.

1499 Adlung, Rudolf and Antonia Carzaniga, MFN Exemptions under the General Agreement on Trade in Services: Grandfathers Striving for Immortality? Journal of International Economic Law 12(2), 2009, p357-392.

${ }^{1500}$ WTO, Tunisia; Final List of Article II (MFN) Exemptions, GATS/EL/87, 15 April 1994.

${ }^{1501}$ WTO, Cyprus, Final List of Article II (MFN) Exemptions, GATS/EL/25, 15 April 1994.
} 
UK and Israel. ${ }^{1502} \mathrm{~A}$ similar situation applies to Sri Lanka, where certain medical testing and treatment is done more economically in healthcare facilities in India and Singapore.

It can be argued that there should be flexibility in the GATS to give preference to particular trading partners based on common experiences (historical, cultural and economic). Although it can be argued that this would be trade-restrictive, there may be situations where further encouraging a relationship that already exists is a better option for consumers, at least in the medium term. The economic rationale for MFN treatment is for the most efficient service provider or best service to have access to a foreign market and to provide an opportunity for those consumers to be able to choose these service suppliers. Yet it could be in certain contexts, such as health services, that the preferred trading partners could have developed a relationship wherein provision of services more suitable to the needs of the relevant country would have developed over time, and application of MFN across the board does not really add value for the consumers. The Sri Lankan consumer's preferred option for India or Singapore as trading partners for health services in the four modes of supply, is a relevant example to recall again at this point.

A final point on Article II Exemptions is that the sector-specific issues covered by the Protocols to the GATS and subsequent decisions should not be forgotten. These are:

- The Fourth Protocol to the GATS, adopted by the Council for Trade in Services at its meeting of 30 April 1996, on exemptions in basic telecommunications.

- The Fifth Protocol to the GATS, adopted by the Committee on Trade in Financial Services on 14 November 1997, deals with exemptions from Article II of the GATS with regard to financial services.

- The Decision on Maritime Transport Services adopted by the Council for Trade in Services at its meeting of 28 June 1996, suspends negotiations on maritime transport services; but adds that when negotiations resume and are concluded at some later date, Article II of the GATS will enter into force with respect to "international shipping, auxiliary services and access to and use of port facilities".

However, it is relevant that in the report of the Trade Negotiations Committee in preparation for the Sixth Ministerial meeting in Hong Kong in 2005, it is stated that Members have identified the need to eliminate MFN exemptions for telecommunications and maritime transport during discussions. ${ }^{1503}$ Thus, sector-specific MFN exemptions are not issues which the GATS Members have paid much attention to and are unlikely to develop or expand. However, if there was interest in protecting certain sectors such as health or education from MFN coverage, it possible to develop a decision on a Protocol or decision for MFN exemptions for Health Services.

1502 See further, Note by the Secretariat, Council for Trade in Services, Council Review of MFN Exemptions, Report of the Meeting held on 5 July 2000 WTO.Doc S/C/M/45 of 18 August 2000, para.40, for replies by Cyprus to questions on its health services MFN exemption.

1503 WTO, Council for Trade in Services, Report by the Chairman to the Trade Negotiations Committee, TN/S/23, 28 November 2005. 


\subsubsection{Other MFN Exemptions (Article II:3) and Exceptions (Articles V, VII, XIV and XIVbis)}

The alternative MFN treatment exemption available in the GATS is Article II:3, which is an exemption for adjacent countries with contiguous frontier zones:

Article II:3 of the GATS

The provisions of this Agreement shall not be so construed as to prevent any Member from conferring or according advantages to adjacent countries in order to facilitate exchanges limited to contiguous frontier zones of services that are both locally produced and consumed.

This can be helpful with regard to services produced and consumed in frontier zones and to promote regional trade. This provision has not been interpreted in the GATS context, and has not gained any serious attention. This is possibly due to the 'exchanges' abovementioned being considered as only a minor aspect of overall trade in services between Members as they are "locally produced and consumed". Article II:3 of the GATS is similar to Article XXIV:3(a) of the GATT which states:

The provisions of this Agreement shall not be construed to prevent:

(a) Advantages accorded by any contracting party to adjacent countries in order to facilitate frontier traffic...

This provision had also not gained any attention under the GATT system either, in terms of commentary or disputes. Mavroidis comments on Article XXIV:3(a) of the GATT as being of historic interest only, since GATT framers included this specifically to protect arrangements made between Yugoslavia and Italy to facilitate trade and maintain ethnic harmony with the Free Territory of Trieste, which was established by a peace treaty in 1947, but has legally ceased to exist since $1975 .{ }^{1504}$ It is curious then why such a provision was retained in the GATS two decades after is ceased to be relevant for the GATT 1947. Munin explains that Article II:3 of the GATS was a result of a controversy concerning whether or not a provision equivalent to Article XXIV:3 of the GATT could be included within Article V of the GATS - and that is was resolved by narrowing down the scope to the contiguous frontier zones and including the phrase "being locally produced and consumed". ${ }^{1505}$ Van den Bossche and Zdouc give an example of taxi services between Geneva and neighbouring France as services to which Article II:3 would apply. ${ }^{1506}$ A similar application for health services in frontier zones could make this a useful exemption from the viewpoint of patients in such areas, especially if this increases choice and options for higher quality and expertise in health services. From a domestic trade policy perspective, this exemption could provide an opportunity to develop trade in health services in all four modes of supply, especially in relation to encouraging Mode 2 (health tourism) between adjacent countries. Yet this provision has been ignored in analysis of policy space in trade in services. ${ }^{1507}$

\footnotetext{
${ }^{1504}$ Mavroidis, Petros C., THE REGULATION OF INTERNATIONAL TRADE: GATT, MIT Press, 2015, p292.

${ }_{1505}$ Munin, Nellie, LEGAL GUIDE TO GATS, Kluwer Law International, 2010, p114.

1506 Van den Bossche and Werner Zdouc, THE LAW AND POLICY OF THE WORLD TRADE ORGANIZATION, Cambridge University Press, Revised 3rd edition, 2013, p342.

${ }^{1507}$ Bregt Natens even states that "its relevance for regulatory autonomy seems to be non-existent". (Natens, Bregt, Natens, Bregt, REGULATORY AUTONOMY AND INTERNATIONAL TRADE IN SERVICES: THE EU UNDER GATS AND RTAS, Edward Elgar Publishing, 2016, p143).
} 
Other situations where MFN treatment would not apply could be defined, not as exemptions but instead as exceptions to the GATS. These include Article V of the GATS which provides exceptions for economic integration agreements and Article VII which allows Members to take note of differences when they are granting recognition to education, experience obtained, standards, licenses, requirements or certification. The general exceptions provisions of Article XIV and XIVbis could also provide MFN exceptions in case of an MFN-related dispute arising between Members.

Article $V$ of the GATS is said to be modeled on Article XXIV of the GATT, but Mattoo clarifies that it improves on the GATT equivalent as it covered "substantial sectoral coverage" more carefully. ${ }^{1508}$ The Panel in Canada-Autos acknowledges that Article V of the GATS provides legal coverage for measures "which would otherwise be inconsistent with the MFN obligation in Article II" since such measures were "taken pursuant to economic integration agreements". ${ }^{1509}$ The Panel was also of the opinion that this provision was intended to "aim at achieving higher levels of liberalization" between parties to economic integration agreements (EIA) than what was otherwise achieved among WTO Members, and also that the provision would also not allow for preferential treatment of only some parties among those in the EIA. ${ }^{1510}$ The dispute concerned certain Canadian measures which the panel identified as not granting more favourable treatment to all services and service suppliers of NAFTA members, but giving preferential treatment to only certain firms. The Panel's interpretation of Article V of the GATS was not commented on by the Appellate Body, and therefore this is the only reference to Article V of the GATS in the context of dispute settlement.

The regional agreements that have been notified according to the requirement of transparency in Article V:7 include NAFTA and the EC Treaty. Other regional economic integration associations and agreements include the ASEAN (Association of South East Asian Nations) Free Trade Area (AFTA) and the Common Market of the Eastern and Southern Africa (COMESA). The text of the Trans Pacific Partnership (TPP) which was concluded in 2015 states in Article 1.1 that it is a free trade area established in accordance with Article V of GATS. ${ }^{1511}$ The 12 participating countries: Australia, Brunei, Canada, Chile, Japan, Malaysia, Mexico, New Zealand, Peru, Singapore, the United States, and Vietnam need to ratify the TPP text in order for it to come into force; but this was affected by the US elections of 2016, as the current US government announced that it would not be participating any further. The texts have been revised and renamed in January 2018 as the Comprehensive and Progressive Agreement for Trans-Pacific Partnership or CPTPP.

Some of these RTAs include political (peace, stability and cultural co-operation) as well as economic agendas, the EU being the foremost example of such a combination of objectives. There are different approaches towards the liberalization of trade through regional arrangements and it is debated whether there is an increase in international trade

1508 Mattoo, Aaditya, MFN and the GATS in in Cottier, Thomas and Petros C. Mavroidis Eds., REGULATORY BARRIERS AND THE PRINCIPLE OF NON-DISCRIMINATION IN WORLD TRADE LAW, World Trade Forum Vol.2, Studies in International Economics, University of Michigan Press, 2000, p57.

1509 Panel Report, Canada-Autos, para.10.272

${ }^{1510}$ Ibid., (Canada Autos).

1511 See Office of the US Trade representative, TPP Full Text, available online at https://ustr.gov/tradeagreements/free-trade-agreements/trans-pacific-partnership/tpp-full-text. 
as a whole or just a diversion to trade within the region. All WTO Members have joined some form of RTA. Mongolia was the only WTO Member which had not entered into an RTA until that changed in June 2016, with an RTA between Japan and Mongolia. As of 5 May 2017, 274 RTAs were in force, which rose to 302 by 1 September $2019 .{ }^{1512}$ In a study by Carzaniga et al, as of January 2019, out of 284 RTAs notified to the WTO, 149 had a services component. ${ }^{1513}$

Since parties agree to grant preferential treatment to (goods or) services traded between the parties, RTAs introduce "discriminatory" treatment which is inconsistent to the overall MFN treatment in the trading system. However, even in such situations, it remains accurate to say that any special treatment RTA Members grant each other is inconsistent with the general obligation of MFN treatment under the WTO Agreements, unless it falls within MFN treatment exemptions such as Article $V$ of the GATS. Mathis has recently surveyed the provisions on transparency, dispute settlement and selected topics of customs cooperation, product and food safety standards, intellectual property protection, public procurement and state aid in recent EU and US RTAs. ${ }^{1514} \mathrm{He}$ finds that the regional processes are often 'decidedly bilateral and preferential in character' and do not always appear to fall within the scope of the WTO's regional trade agreement exceptions provided in Article XXIV of the GATT and Article V of the GATS. ${ }^{1515}$ The RTA that fails to comply with Article V of the GATS remains legally valid in international law, but for the purposes of WTO law, the MFN treatment obligation means that special treatment granted therein should be extended to all WTO Members. ${ }^{1516}$ Pauwelyn notes that further research would enable a better assessment of whether "regionalism can be a stepping stone or stumbling block for multilateralism".

An interesting point that Pauwelyn highlights in his conclusions on preferential/regional Agreements is that these WTO-plus rules and norms are the "rules of tomorrow" which are created and diffused ultimately by a limited group of countries at the center of the RTA/PTA networks - and is thus an issue of concern for their global legitimacy (more so than the multilateral negotiation process of the WTO). On the other hand, Adlung and Miroudot have found that in the case of services, the vast majority of the 66 RTAs studied included GATS-minus commitments (which were lesser standards than the commitments made in the GATS schedules). ${ }^{1517}$ At the 10th Ministerial Conference held in Nairobi in 2015 WTO Members Nairobi adopted a Ministerial Declaration instructing the

\footnotetext{
1512 See https://www.wto.org/english/tratop_e/region_e/region_e.htm.

1513 Carzaniga, Antonia Giulia, Dhillon, Ibadat S., Magdeleine, Joscelyn, Xu, Lihui, International Health Worker Mobility and Trade in Services, WTO Staff Working Paper, No. ERSD-2019-13, World Trade Organization (WTO), Geneva, 2019, p19.

${ }^{1514}$ Mathis, James H, Regulatory Regionalism in the WTO - Are 'Deep Integration' Processes Compatible with the Multilateral Trading System?, August 5, 2013, available at http://ssrn.com/abstract=2345801 and (Forthcoming) in Lester, S. B. Mercurio and L. Bartels Eds., BILATERAL AND REGIONAL TRADE AGREEMENTS: COMMENTARY AND ANALYSIS, Cambridge University Press, 2014.

1515 See further, Krajewski, Markus, Services Liberalisation in Regional Trade Agreements: Lessons for GATS 'Unfinished Business'? and Kwak, Kyung and Gabrielle Marceau, Overlaps and Conflicts of Jurisdiction Between the WTO and RTA's in Bartels L. and Federico Ortino, Eds., REGIONAL TRADE AGREEMENTS AND THE WTO LEGAL SYSTEM Oxford University Press, 2006.

${ }^{1516}$ Pauwelyn, Joost and Wolfgang Alschner, Forget About the WTO: The Network of Relations between PTAs and 'Double PTAs', Graduate Institute, 2014, available online at http:/graduateinstitute.ch/files/ live/sites/iheid/files/sites/ctei/shared/CTEI/people/students/Wolfgang\%20Alschner/Pauwelyn_AlschnerRel ations $\% 20$ between $\% 20$ PTAs.pdf.

1517 Adlung, Rudolf and Sébastien Miroudot, Poison In The Wine? Tracing GATS-Minus Commitments In Regional Trade Agreements, WTO Staff Working Paper ERSD-2012-04, February 2012.
} 
Committee on RTAs to discuss the systemic implications of RTAs for the multilateral system and their relationship with WTO rules. ${ }^{1518}$ The Ministerial Declaration also stressed that RTAs "remain complementary to, not a substitute for, the multilateral trading system". ${ }^{1519}$

In terms of health services and the impact on public health services, it is important to keep track of the implications of the of the RTA exception and the GATS-plus or GATSminus commitments, so that the global trends are identified. Steps to liberalize health services further through GATS-Plus commitments or to restrain steps towards liberalization through GATS-minus could be identified and assessed from the view of whether and how they protect domestic health services - and if they may be used to support a human rights-based approach to public health services. Carzaniga et al note that some RTAs only provide for fully open market access for health care services when they are delivered as part of free charitable work, while market access and national treatment conditions were maintained for foreign service providers and services which were supplied commercially (an example being India's RTA with Japan in relation to Mode 4 provision of medical and dental services). ${ }^{1520}$

It has been commented that Article $\mathrm{V}$ provides opportunities for regional health services trade for developing countries, for example, at one point in the late 1990s Egypt had become an important medical service provider in the Middle East and Cuba has established links for providing medical services with countries in Latin America. ${ }^{1521}$ It would also be easier to remove trade barriers in all modes of supply at the regional level and encourage sharing of facilities and expertise if there are trusted neighbouring States as trading partners. But this could also be done without any form of economic integration agreement or RTA, as that could allow for greater policy space and also allow for a change in policy based on changes in circumstances.

An opt-out from MFN treatment is also available for recognition of standards, licensing and certification requirements of other Members according to Article VII of the GATS. Article VII does not require recognition, but encourages the use of recognition as a means of liberalization, without considering such actions a violation of Article II. ${ }^{1522}$ However, Article VII:3 specifically notes that such granting of recognition shall not be done in a manner that would "constitute a means of discrimination between countries" in its application or be a "disguised restriction on trade in services". Article VII:5 states that "wherever appropriate, recognition should be based on multilaterally agreed criteria" and requires Members to work towards creating such criteria. Alongside this is Article VI:4 of

\footnotetext{
${ }_{1518}$ WTO, Nairobi Ministerial Declaration, WT/MIN(15)/DEC, adopted on 19 December 2015, para.28.

${ }^{1520}$ Carzaniga, Antonia Giulia, Dhillon, Ibadat S., Magdeleine, Joscelyn, Xu, Lihui, International Health Worker Mobility and Trade in Services, WTO Staff Working Paper, No. ERSD-2019-13, World Trade Organization (WTO), Geneva, 2019, p27.

${ }^{1521}$ Butkeviciene, Jolita and David Diaz, GATS Commitments in the Health Services Sector and the Scope for Future Negotiations, UNCTAD-WHO Joint Publication, International Trade in Health Services: A Development Perspective, UNCTAD/ITCD/TSB/5-WHO/TFHE/98.1,1998, p147.

${ }_{1522}$ Krajewski, M., Article VII GATS in Wolfrum, Rudiger, Peter-Tobias Stoll and Clemens Feinaugle Eds., WTO - TRADE IN SERVICES, Max Planck Commentaries on World Trade Law, Martinus Nijhoff Publishers, 2008, p200. Krajewski, M., NATIONAL REGULATION AND TRADE LIBERALIZATION IN SERVICES, Kluwer Law International, 2003, p43; Nicolaides Kalypso, and Joel P. Trachtman, Liberalization, Regulation, and Recognition for Services Trade in Sauvé, Pierre and Robert M. Stern Eds., SERVICES TRADE IN THE WESTERN HEMISPHERE: LIBERALIZATION, INTEGRATION AND REFORM, Brookings Institution Press, 2000, p241, 265.
} 
the GATS (on domestic regulation) which mandates further negotiations to develop disciplines necessary to ensure that "qualification requirements and procedures, technical standards and licensing requirements do not constitute unnecessary barriers to trade in services". Nicolaides points out that non-discriminatory mutual recognition is possible since mutual recognition agreements between Members are based on 'likeness' of regulations, standards, licensing, certification etc., and thus need not necessarily be discriminatory and violations of MFN treatment. ${ }^{1523}$ Nevertheless, there is a provision described as an MFN exception in the GATS for this area. Members thus could retain national policy space for their regulations concerning recognition of standards, licensing and certification. There is an obligation of Members according to Article VIII:4(a) to inform the Council for Trade in Services within 12 months of accession to the WTO of its existing recognition measures based on the types agreements and arrangements described in Article VII:1. If Members are opening negotiations on recognition, then notification is an obligation under Article VII:4(b) of the GATS, which has to be done without undue delay. If there is adoption of new recognition measures or significant modification of existing ones, there must be prompt notification according to Article VIII:4(c) of the GATS.

In terms of providing health services, it is one of the areas which has the most restrictions in terms of recognition of foreign qualifications within a domestic system, as there is a need to maintain high standards in the quality of health services. Switzerland made a notification under Article VII:4 in 2006 that the Federal Office of Public Health would be implementing a measure (Federal Ordinance RS 811.113) .on postgraduate training and the recognition of postgraduate diplomas and qualifications in the medical profession, pursuant to European Community Directives. ${ }^{1524}$ A separate Article VII:4 notification especially concerning the Swiss Canton of Zurich was also made, declaring that the Department of Health of the Canton of Zurich would be implementing an Amendment to the Public Health Act (810.1) concerning the recognition of the professional qualifications of doctors, dentists, veterinary surgeons, inter alia, from the European Union. ${ }^{1525}$ In March 2019, India made a notification under Article VII:4 that the Indian Nursing Council has entered into a Mutual Recognition Agreement with the Singapore Nursing Board. India stated in its notification that under the terms of the Agreement, nurses of one partner country may apply for registration in the other country to be recognized and allowed to practice nursing in accordance with the laws and regulations of the other country. ${ }^{1526}$ Members would usually be ready to recognize qualifications of other Members only after a long-term relationship of mutual trust would have built up with regard to the quality of the services provided, and national accreditation bodies and professional organizations have recommended such a step. Thus, the EU-Switzerland and India-Singapore examples, where the is recognition of mutually held standards for professionals in health services.

\footnotetext{
${ }^{1523}$ Nicolaidis, K., Non-Discriminatory Mutual recognition: An Oxymoron in the New WTO Lexicon? In Cottier, T., and Petros C. Mavroidis Eds., REGULATORY BARRIERS AND THE PRINCIPLE OF NONDISCRIMINATION IN World trade law, University of Michigan Press, 2002, p267.

${ }^{1524}$ Council for Trade in Services, Notification Pursuant to Article VII:4 of the General Agreement on Trade in Services - Switzerland, WTO Do. S/C/N/385, 08 December 2006.

${ }^{1525}$ Council for Trade in Services, Notification pursuant to Article VII:4 of the General Agreement on Trade In services - Switzerland, WTO Do. S/C/N/387, 08 December 2006.

${ }^{1526}$ Council for Trade in Services, Notification pursuant to article VII:4 of the General Agreement on Trade in Services - India, WTO Doc. S/C/N/929, 06 March 2019.
} 
There are exemptions to MFN treatment specifically stated in the GATS, as discussed above. Additionally, Article XIV of the GATS states that exceptions apply to all provisions of the GATS, as noted by the chapeau to Article XIV:

...nothing in this Agreement shall be construed to prevent the adoption or enforcement by any Member of measures [followed by the listed exceptions]

Therefore, Article XIV exceptions, if they pass the several stages of falling within the scope of a paragraph of Article XIV (the nexus test, the necessity test, and the chapeau which are discussed in detail in Chapter 5 of this study), should apply also as an exception to the MFN treatment obligation. The Appellate Body in US-Gasoline referred to the same wording in Article XX of the GATT 1994, and stated that this wording means that the exception also covers MFN treatment, among other WTO obligations. ${ }^{1527}$ Note that in practice the wording included in the chapeau of Article XIV must also be taken into account for an exception to succeed:

Subject to the requirement that such measures are not applied in a manner which would constitute a means of arbitrary or unjustifiable discrimination between countries where like conditions prevail, or a disguised restriction on trade in services...

Thus, as commented by Van den Bossche, the chapeau of Article XIV, also contains "an MFN-like obligation". ${ }^{1528}$ Thus, Article XIV of the GATS provides both a general exception to MFN treatment and at the same time the chapeau adds an 'MFN-like' obligation to the structure and scope of the Article XIV exception, so that the exceptions are not applied without good faith, in an arbitrary and discriminatory manner.

On the other hand, Article XIVbis of the GATS, the security exception, is a clear MFN exception - stating that "Nothing in this Agreement shall be construed" to require members to furnish information or to prevent any action taken for its 'essential security interests" or to prevent:

.... any action in pursuance of its obligations under the United Nations

Charter for the maintenance of international peace and security.

Thus, UN Security Council sanctions which result in MFN treatment violations are justified under the Article XIVbis of the GATS. The only requirement set out by the GATS is that, according to Article IVbis:2 the Council for Trade in Services shall be informed to the "fullest extent possible" of measures taken with regard to any peace and security related matters. The only problematic aspect here is Article XIVbis:1(b)(i), which also has the requirement of informing the Council for Trade in Services. This provision states that nothing in the GATS shall be construed to:

...prevent any Member from taking any action which it considers

necessary for the protection of its essential security interests:

(i) relating to the supply of services as carried out directly or indirectly for the purpose of provisioning a military establishment...

Which sounds fine, if we are focusing on the fact that it is an MFN (and national treatment) exception, but Article XIVbis:2 at first glance appears to also oblige Members to inform the Council of public procurement for military establishments, since it states that:

\footnotetext{
${ }^{1527}$ Appellate Body Report, US-Gasoline, p24.

1528 Van den Bossche and Werner Zdouc, THE LAW AND POLICY OF THE WORLD TRADE ORGANIZATION, Cambridge University Press, Revised $3^{\text {rd }}$ edition, 2013, p335.
} 
2.The Council for Trade in Services shall be informed to the fullest extent possible of measures taken under paragraphs 1(b) and_(c) and of their termination.

However, Article XIVbis should be read with Article IIIbis, which concerns the disclosure of confidential information, and states that nothing in the GATS shall require any Member to:

...provide confidential information, the disclosure of which would impede law enforcement, or otherwise be contrary to public interest...

Since confidentiality in matters of essential security interests will fall within the larger public interest of non-disclosure of confidential information, the requirement of informing the Council on Trade in Services in ArticleXIVbis:2 is moderated by Article IIIbis. These provisions thus do not seem to cause particular domestic services policy implications or have a negative impact on domestic public health services - but tie in the GATS with the obligations under the UN Charter. Article XIVbis of the GATS is discussed in more detail in Section 5.8.2. of Chapter 5 of this study. 


\subsection{ARTICLES XIX, XX AND XXI OF THE GATS - SPECIFIC COMMITMENTS: NEGOTIATION, SCHEDULING, MODIFICATION - THE POLICY SPACE}

These promises are fair, the parties sure, And our induction full of prosperous hope.

- Mortimer,

Shakespeare's Henry IV, Part I.

\subsubsection{Introduction to the Scheduling of Commitments}

The GATS requires each WTO Member to provide what is known as a 'Schedule of Specific Commitments' that sets out which services a Member is agreeing to include under the scope of the Agreement. According to the WTO official website:

A specific commitment in a services schedule is an undertaking to provide market access and national treatment for the service activity in question on the terms and conditions specified in the schedule. When making a commitment a government therefore binds the specified level of market access and national treatment and undertakes not to impose any new measures that would restrict entry into the market or the operation of the service. Specific commitments thus have an effect similar to a tariff binding... 1529

With regard to making specific commitments, it has often been commented that the GATS has a comparatively much more flexible approach for market access and national treatment than the GATT, due to the voluntary nature of scheduling the commitments in these areas in services. Making use of this flexibility, it can be seen that health services are one of the least committed service sectors. The data is that fewer than 50 WTO members (including the EC counting as one Member) have undertaken commitments in at least one mode of supply relating to health services or health-related professional services. ${ }^{1530}$

Mavroidis has pointed out that although the exact phrase "market access" cannot be found anywhere in the GATT, "all of the GATT is about market access". ${ }^{1531}$ National treatment is guaranteed under the GATT 1994, whereas it is subject to the commitments made by Members under the GATS. The relevant provisions on scheduling of services commitments are Articles XIX, XX and XXI of the GATS. Article XX of the GATS (on the Schedule of Commitments) links together the obligations of market access (Article XVI), national treatment (Article XVII), additional commitments (Article XXI) and

\footnotetext{
${ }^{1529}$ WTO, Guide to reading the GATS schedules of specific commitments and the list of Article II (MFN) exemptions, available at http://www.wto.org/english/tratop_e/serv_e/guide1_e.htm, last accessed 21.06.2012.

1530 WTO, Health and social services: Current commitments and exemptions, available online at https://www.wto.org/english/tratop_e/serv_e/health_social_e/health_social_e.htm, last accessed 30.12.2019. ${ }^{1531}$ Mavroidis, Petros C., Market Access in the GATT, Sant'Anna Legal Studies Research Paper 7/2008 (a transcript of lecture held at Sant'Anna School of Advanced Studies, Pisa, 28 May 2006), available online at http://www.stals.sssup.it/ files/stals_Mavroidis.pdf, last accessed 04.06.2014.
} 
domestic regulation (Article VI) of each Member in the schedule. ${ }^{1532}$ It is intended that the schedule would provide transparency and predictability which is needed for smooth functioning of international trade relations. However, the commitments to liberalize entered in the schedule need not be greater than what is currently available in the Member. The expansion of rights/obligations depends on negotiations for progressive liberalization.

The extent of commitments made by a Member can be checked by looking at their schedule, where the Member has the flexibility to make commitments or limitations either 'horizontally' across all service sectors and/or modes of supply or to make commitments or limitations ${ }^{1533}$ by taking each service Sector and/or mode of supply separately deciding in any of the following 3 ways:

1. Full market access and/or national treatment for a particular mode or sector (no restrictions or limitations on liberalization for that mode or sector)

2. Provide market access and/or national treatment, with restrictions listed:

- Market access could have terms, limitations and conditions

- National treatment could have conditions and qualifications

3. No commitment at all on market access and/or national treatment for a particular mode or sector.

It has been observed that the reason why there is such flexibility is that since GATS liberalization influences internal laws and regulation to a much greater extent than GATT where the market access regulation is said to be at the 'at the border' ${ }^{1534}$ thus making it even more important to leave a larger policy space, and that this was a conscious result of the trade negotiations leading up to GATS. The Schedules of Specific Commitments not only identify the service sectors to which market access and national treatment will be applied by Members, it can also include limitations, conditions and qualifications of the commitments that the Member will maintain even in the sectors that are scheduled.

The reference to national policy objectives in the Preamble of the GATS can thus be seen as an expression of recognition of national sovereignty, which is also expressed in the

${ }^{1532}$ Molinuevo, M. Article XX GATS in Wolfrum, Rudiger, Peter-Tobias Stoll and Clemens Feinaugle Eds., WTO - TRADE IN SERVICES, Max Planck Commentaries on World Trade Law, Martinus Nijhoff Publishers, 2008, p446.

${ }^{1533}$ The Appellate Body Report, China-Publications and Audiovisual Products, Footnote 829, commenting on the terminology states that:

Regarding the term "limitations", we note that Article XX:1 of the GATS refers specifically to

"terms, limitations and conditions" to market access, and "conditions and qualifications" to national treatment. This accords with the wording of Articles XVI:2 (on market access), XVII:1 (on national treatment) and XX:1(b) (on schedules of specific commitments). For simplicity, we adopt the term "limitations", which is used in the column headings in China's Schedule (and those of other Members), and throughout the 1993 and 2001 Scheduling Guidelines.

This Chapter follows the same approach.

1534 Cottier, Delimatis and Diebold, Article XIV GATS in Wolfrum, Rudiger, Peter-Tobias Stoll and Clemens Feinaugle Eds., WTO - TRADE IN SERVICES, Max Planck Commentaries on World Trade Law, Martinus Nijhoff Publishers, 2008, p290-291; also Footer, Mary E. and Carol George, The General Agreement on Trade in Services in Macrory, Patrick, Arthur Appleton and Michael Plummer, THE WORLD TRADE ORGANIZATION: LEGAL, ECONOMIC AND POLITICAL ANALYSIS, VOL. I, Springer 2005, p802. 
flexibility of scheduling of commitments. ${ }^{1535}$ Such recognition is not expressed in the preambles of the WTO Agreement and the GATT 1947. At the same time, recitals 2 and 3 of the Preamble of the GATS also makes clear the importance of the concept of progressive liberalization of services in the multilateral negotiations on international trade. It can be said that there is a balancing of progressive liberalization in the words of the Preamble itself as it also accepts that there should be "due respect to national policy objectives" and recognizes "the right of Members to regulate... in order to meet national policy objectives", and "the particular need of developing countries to exercise this right". Article XIX of the GATS, on negotiation of specific commitments states:

The process of liberalization shall take place with due respect for national policy objectives and the level of development of individual Members, both overall and in individual sectors.

Delimatsis has called Article XIX a "development-friendly set of provisions" that are to be read along with Article IV (the latter shall be discussed further in Chapter 5 of this study). ${ }^{1536}$ This section looks into how these objectives relate to each other in the context of the negotiation and scheduling of specific commitments in the GATS, with special regard to national policy on public health services. The relationship can be viewed as one where it could be possible to reconcile conflicting objectives. But for this, a very careful consideration of both national priorities and the benefits of the international trade rules for all Members is needed. An asymmetric accruing of benefits to some trading partners and the loss of national policy space for some others is the result that is sought to be avoided, at least from the view of this author. Article XIX:1 of the GATS also acknowledges that

This process [of negotiation on specific commitments] shall take place with a view to promoting the interests of all participants on a mutually advantageous basis and to securing an overall balance of rights and obligations.

The abovementioned consideration of sometimes conflicting objectives needs to happen during various stages in the negotiation of commitments. These stages are: the initial decisions on scheduling by national policy makers; subsequent bargaining by representatives of Members in services negotiations; and the interpretation of schedule entries (if any) by panels and the Appellate Body.

With regard to the area of health services, national policy makers setting the agenda and methods for protection of public health services must make clear and conscious decisions in the first instance, whether or not to schedule specific commitments of market access and national treatment in sectors and subsectors that would impact public health services. Whether to add specific wording of protection of public services as a limitation to market access and national treatment in an otherwise liberalized private health service market is another possible strategy. These policies, once formulated, need to be carried through by the representatives of Members in the process of services liberalization negotiations. How to respond to subsequent pressure (if any) to achieve the progressive liberalization obligations of the GATS in areas that Members initially refrained from scheduling is the next possible stage - and here there could be both practical and legal difficulties.

\footnotetext{
${ }^{1535}$ Hestermeyer, H., Preamble GATS, Wolfrum, Rudiger., Peter-Tobias Stoll and Clemens Feinaugle Eds., WTO-TRADE IN SERVICES, Max Planck Commentaries on International Trade Law, Martinus Nijhoff Publishers, 2008, p26.

1536 Delimatsis, P., Article XIX of the GATS in Wolfrum, Rudiger, Peter-Tobias Stoll and Clemens Feinaugle Eds., WTO-TRADE IN SERVICES, Max Planck Commentaries on International Trade Law, Martinus Nijhoff Publishers, 2008, p430.
} 
Furthermore, the actual 'protection' in the schedules is ultimately determined through the dispute settlement system, if a dispute arises. Otherwise it is in practice a clarification of the trade and non-trade policy positions taken by a Member, with the expectation that disputes could thereby be avoided.

Although the idea of balancing the interests of trade and national policy has been raised, it may be pertinent to draw attention to the fact that Articles XIX - XXI of the GATS (Scheduling of Specific Commitments) which is Part IV of the Agreement is titled as 'Progressive Liberalization'. This is obviously the main intention of this Part of the Agreement, although it is also promoted as the section that allows for national policy space to be retained. Reading the Articles in the context of Part IV as well as the Preamble can also lead to the conclusion that the emphasis is more on liberalization than national policy space. Molinuevo has observed that the

Schedules of commitments are the instruments provided by the Agreement

to carry out its guiding principle of progressive liberalization. ${ }^{1537}$

Delimatsis notes that the wording implies a dynamic process ${ }^{1538}$ - with increasingly open markets in services. The balancing of interests of liberalization and policy space is not always focused on or acknowledged. Perhaps this is because this concept of balancing is not entirely accepted by most commentators. Whether this is because it is thought of as unnecessary or un-realistic to discuss, is not clear. Perhaps, rather than 'balancing', the process of liberalization itself is being focused on: e.g. is it meant to be restrained or rushed? One view could be that it is meant to initiate a snowballing of liberalization, but perhaps not an uncontrolled avalanche. The aspect of restraint and control maintained over the liberalization process may be why there are also comments, that seem paradoxical, that: "...the Schedules of commitments do not necessarily entail liberalization obligations". ${ }^{1539}$ This may also be because many of the commitments made by Members during the Uruguay Round merely reflected the status quo in services trade at the time, rather than being commitments for more liberalization.

Ultimately, whether there is liberalization of services, and to what extent, depends on what and how much a Member is willing to offer or concede in the negotiation rounds. Part IV of the GATS has been recognized as a landmark agreement in terms of "creating multilateral disciplines in virgin territory", but is also at the same time criticized as a failure in terms of actually generating future liberalization. ${ }^{1540}$ Services negotiations are an 'offer-request approach' and offers have been disappointing, particularly with regard to Modes 3 and 4 - the latter being of particular interest to developing country Members who are rich in human resources. In addition, it has been generally commented that services negotiations are the 'give side' from developing country Members in WTO negotiations, rather than being a 'give-and-take' bargain. The dynamics of current

${ }^{1537}$ Molinuevo, Martin., Article XX of the GATS in Wolfrum, Rudiger., Peter-Tobias Stoll and Clemens Feinaugle Eds., WTO-TRADE IN SERVICES, Max Planck Commentaries on International Trade Law, Martinus Nijhoff Publishers, 2008, p446.

${ }^{1538}$ Delimatsis, P., Article XIX GATS in Wolfrum Rudiger, Peter-Tobias Stoll and C. Feinaugle Eds. WTO TRADE IN SERVICES, Max Planck Commentaries on World Trade Law, Martinus Nijhoff Publishers, 2008, p431.

${ }^{1539}$ Molinuevo, Martin, Article XX GATS in Wolfrum Rudiger., Peter-Tobias Stoll and C. Feinaugle Eds. WTO - TRADE IN SERVICES, Max Planck Commentaries on World Trade Law, Martinus Nijhoff Publishers, 2008, p447.

${ }^{1540}$ Hoekman, Bernard, Assessing the General Agreement on Trade in Services in Martin, W., and L. Alan Winters, Eds., THE URUGUAY ROUND AND DEVELOPING COUNTRIES, Cambridge University Press, World Bank, 1996, p88 
negotiations in the WTO are changing with differing interests presented by newer players and the continuing need for consensus across a number of different areas of international trade. Furthermore, it has been said generally that many of the 'easier issues' were dealt with during the Uruguay Round and other issues were 'papered over' through constructive ambiguity, but current negotiations take place 'in the shadow' of binding dispute settlement, which perhaps means that negotiators are more keenly aware of the risks of leaving gaps and vagueness in the agreed-upon text.

Although there is an obligation for early and progressively more liberalized international trade in services, Members can schedule commitments at levels lower than the status quo or keep them at the same level indefinitely, unless necessary for striking an advantageous bargain with another Member or unless pressured in other factors to take further measures for liberalization. It has been stated that

Commitments made in the Uruguay Round on Services are best described as bound standstill agreements for policies pertaining to specific sectors. ${ }^{1541}$

Roy notes that the commitments do not necessarily reflect the level of actual openness or restrictions of the sector to foreign players, but only the "legal guarantee of a minimum level of access" which can be brought up in a dispute settlement context. ${ }^{1542}$ This is similar to what has been and continues to be practiced with regard to the difference between bound duties and applied duties in the context of trade in goods in the GATT system. Roy classifies an uncommitted services sector as:

...one where economic operators have no security of access, where any type of restrictions can be imposed at any time, across any mode, and at any level.

Roy's observation that the different levels of GATS commitments by WTO Members is

...less about the extent of liberalization or protection, and more about the

political decision to take legally binding commitments or not... ${ }^{1543}$

-is a pertinent one when taking into consideration the discussion in Chapter One on societal values relating to some services and the political processes through which these values are expressed in national systems.

Furthermore, Article XIX:2 of the GATS also recognizes policy space for developing countries in particular, in avoiding scheduling commitments in certain sectors and liberalizing more slowly, stating that:

There shall be appropriate flexibility for individual developing country

Members for opening fewer sectors, liberalizing fewer types of transactions, progressively extending market access in line with their development situation... ${ }^{1544}$

Article XIX:2 also recalls Article IV, the special provisions for developing country Members, which will be focused on in more detail in Chapter Five.

Thus, it seems that Members can assume or avoid obligations to liberalize according to national policy or current economic concerns, and the extent of commitments can vary

\footnotetext{
${ }^{1541}$ Ibid., (Hoekman).

${ }^{1542}$ Roy, Martin, Endowments, Power, And Democracy: Political Economy of Multilateral Commitments on Trade in Services, WTO Economic Research and Statistics Division, Staff Working Paper ERSD-2010-11 (replacing previous Working Paper ERSD-2009-07), p5-6.

${ }^{1543}$ Ibid., (Roy) p8-9.

1544 This is also repeated in para 12 of the WTO Guidelines and Procedures for the Negotiations on Trade in Services, S/L/93, adopted by the Special Session of the Council for Trade in Services on 28 March 2001
} 
widely from Member to Member. Countering the criticism that that policy is dictated by the WTO, this system has been regularly described as one which has a 'bottom-up' approach $^{1545}$ and as the most flexible agreement in the WTO system. ${ }^{1546}$

However, it also depends on what is perceived as a 'bottom-up' approach. A bottom-up approach can be seen as one where a Member government decides whether or not to liberalize a service sector, and to what extent it will do so. Thus, it is also termed a "positive-list" approach, as there is no automatic assumption of liberalization, but only in sectors where a choice has been made to do so. In this sense, it can be argued that scheduling is a hybrid of 'bottom-up' and 'top-down' approaches, as if a sector is scheduled, it is considered as without restrictions unless national treatment and market access restrictions are specified ${ }^{1547}$. On the other hand, a 'bottom-up' approach can be perceived as something much broader - an inclusive democratic process where there is active participation of all groups including the underprivileged and marginalized, in decision making processes. In that sense, there is still a considerable amount of criticism of the world trade system failing to take a truly bottom-up approach, As Vandana Shiva has commented,

A treaty that totally bypasses national democratic decision making and excludes citizen participation can hardly be called "bottom up". To be truly bottom up, the rules and subject matter of GATS need to first be discussed among local communities and regional and national parliaments. They then need to be amended on the basis of democratic feedback. Without such a "democracy round", GATS is not a bottom up but a top down agreement being forced on the people of the world. ${ }^{1548}$

Thus, despite supposed failure of expected liberalization in practice and the recognition of policy space in Article XIX (negotiation of specific commitments), there is still concern about the role and impact of GATS in 'forcing' countries to liberalize services. Critically assessing these expressions of concern, it can be concluded that what is in fact objected is not merely the GATS, which is the result of what has been negotiated by States at the international level - but a criticism of the failures of the democratic process within States at national and sub-national level, where the concerns of the grassroots have not been taken into account. This failure of local democracy can be due to ignorance, intention, the abdication of the responsibility to inform and consult the public or a combination thereof; but it is that failure which has led to the distrust of the GATS.

\footnotetext{
1545 Van den Bossche, Peter, THE LAW AND POLICY OF THE WORLD TRADE ORGANIZATION: TEXT, CASES AND MATERIALS, Cambridge University Press, $2^{\text {nd }}$ Edition, 2008, p480.

${ }^{1546}$ Bollyky, Thomas J. and Petros C. Mavroidis, Trade, Social Preferences and Regulatory Cooperation: The New WTO-Think, Journal of International Economic Law (2017) 20 (1): 1-30.

1547 Feketekuty, Geza, Assessing And Improving The Architecture Of Gats in Sauvé, Pierre And Stern, Robert M. Eds., Gats 2000, NEW DIRECTIONS IN SERVICES TRADE LIBERALIZATION, Brookings Institution Press, 2000, p 97-98, also noting that a "hotly debated issue" during negotiations was whether a bottom-up or top-down approach is to be followed, with those reluctant to liberalize preferring the bottomsup approach.

See also Footer, Mary E. and Carol George, The General Agreement on Trade in Services in Macrory, Patrick, Arthur Appleton and Michael Plummer, THE WORLD TRADE ORGANIZATION: LEGAL, ECONOMIC AND POLITICAL ANALYSIS, Vol. I, Springer 2005 p856-857; Krajewski, M., NATIONAL REGULATION AND TRADE LIBERALIZATION IN SERVICES, Kluwer Law International, 2003, p74; Mattoo, Aaditya, Robert Stern and Gianni M., Zanini, Eds., A HANDBOOK OF INTERNATIONAL TRADE IN SERVICES, Oxford University Press, 2008, p253.

1548 Shiva, Vandana, GATS/WTO: The Auctioning of Vital Resources and Essential Services, March 26, 2001, available online at http://www.urfig.org/sup-eng-gats-shiva-pt.htm, retrieved $24^{\text {th }}$ June 2009.
} 


\subsubsection{The Process of Scheduling of Commitments}

There is a view that GATS obligations are flexible and non-coercive, as Members decide on whether or not to schedule commitments. This is often presented as effectively countering the criticism that national economic policy is dictated by the WTO. The system of scheduling of commitments has led to the GATS being regularly described as being the 'most flexible' agreement in the WTO system as Members supposedly can assume or avoid obligations to liberalize according to national policy and that even when obligations are undertaken, the extent of commitments can vary widely from Member to Member. In reality, when a sector is scheduled, it is considered as without restrictions unless national treatment and market access restrictions are specified. Therefore, although disputes could theoretically be avoided by intelligent scheduling, there will be situations where errors and oversights or differences in interpretation in dispute settlement context could still happen. Thus, the actual availability of policy space and real choice in this process of liberalization needs to be looked at both critically and realistically.

The schedules of commitments are more complex documents than the lists for MFN exemptions discussed earlier in this Chapter. Each Member must identify the service sectors to which it will apply the market access and national treatment obligations of the GATS and any exceptions from those obligations it wishes to maintain. The commitments and limitations are in every case entered with respect to each of the four modes of supply which constitute the definition of trade in services in Article I of the GATS: these are cross-border supply; consumption abroad; commercial presence; and presence of natural persons. There is a standard format to which all the Members must comply which includes columns for the limitations, if any, in the following manner:

1. Each service sector and/or sub-sector (Usually the sectoral entries have references to the Central Product Classification system of the United Nations, so as to be clear as possible on the scope of the commitment).

2. Whether there are limitations on market access (The mode of supply must be included, and if a Member so chooses, the six categories of restriction listed in Article XVI:2 of the GATS).

3. Whether there are limitations on national treatment

4. Whether there are any additional commitments which are not subject to scheduling under market access or national treatment (this is for positive obligations that are not market access or national treatment e.g. qualifications, standards and licensing matters - and not for additional limitations)

The sectoral classification has twelve main sectors:

1. Business

2. Communication

3. Construction and Engineering

4. Distribution

5. Education

6. Environment

7. Financial

8. Health

9. Tourism and Travel

10. Recreation, Cultural, and Sporting

11. Transport

12. "Other" 
Schedules are also usually divided into two main parts, one of which is the 'horizontal' commitments section. This has the limitations that apply to all sectors (which can be with regard to a particular mode of supply, usually Mode 3 (commercial presence) and Mode 4 (movement of natural persons)). This part is usually at the beginning of the Schedule, with sector specific commitments following afterwards. Thus, to understand the commitments for a particular sector, the horizontal commitments section must also be looked at. Therefore, if there is an entry reading "NONE" in a specific sector - which means that there are no limitations on the commitment - the horizontal commitments also need to be looked at since there may be a relevant horizontal limitation that applies for all sectors.

If a Member wishes to maintain complete freedom and flexibility in a particular mode of supply or service sector, the term "unbound" should be entered in the relevant column. ${ }^{1549}$ It is argued that a Member can indefinitely postpone liberalization by choosing not to make commitment in a particular sector. In the alternative, a member can make and retain bindings below existing status quo for sectors they wish to protect, such as health services. It is often stated that nothing in the Agreement itself prevents such a position being held as long as they wish; however, this is counterbalanced by the obligation to "progressively liberalize" according to Article XIX of the GATS. ${ }^{1550}$ Realistically speaking, the pressures from stronger trading partners upon weaker countries (particularly developing and least developed members) to open their economies further should also not be discounted. It has been commented that the process of liberalization of services has been historically driven by US and European corporate interests in search of access to markets, and as long as this agenda is sustained, the real-world political pressures also remain. ${ }^{1551}$

${ }^{1549}$ As mentioned before in Chapter 2, this term interestingly recalls the Ulysses-story view of WTO law: meaning that Members have not 'bound' themselves to 'the mast' and are free to get lured onto the rocks of 'inefficient' economic decision-making by rent-seeking, protectionist Sirens. From an Antigone-story view of WTO law, Members are free to follow the ancient dictates and laws of the Gods and their conscience, even if it is not a 'pro-market' decision. Less emotively, it means that there is definitely more policy space for Members with regard to market access and national treatment in a particular sector or sub-sector if they have indicated "unbound" in their schedule.

${ }^{1550}$ Article XIX of GATS (Negotiation of Specific Commitments) is under Part IV of the Agreement, titled: Progressive Liberalization.

The WTO publication, GATS: FACT AND FICTION, WTO, 2001, page 5 states that:

There is agreement among all Governments that in the new round of negotiations the

freedom to decide whether to liberalize any given service and the principle of progressive liberalization will be maintained

(This publication is available at www.wto.org/english/tratop_e/serv_e/gatsfacts1004_e.pdf.)

But as noted by Marwell;

...in light of the progressive liberalization objective of GATS, one cannot read liberalization out of the treaty...

(Marwell, J., Trade and Morality: The WTO Public Morals Exception after Gambling 81 NYU Law Review 802, p817.)

1551 Hoekman, Bernard, Aaditya Mattoo and André Sapir, The Political Economy of Services Trade Liberalization: A Case For International Regulatory Cooperation?, Oxford Review of Economic Policy 2007 23(3):367, p1; also pointing out that these 'corporate demandeurs' have been mostly absent in the Doha Round, as opposed to the Uruguay Round, as negotiations have been dominated by demands from developing nations (in particular, India) for market access for agricultural products. Also see Hoekman et al for discussion on why the market access for agricultural products in return for services liberalization has not been successfully proposed as a bargaining method in the negotiations. See further Footer, Mary E. and Carol George, The General Agreement on Trade in Services in Macrory, Patrick, Arthur Appleton and Michael Plummer, THE WORLD TRADE ORGANIZATION: LEGAL, ECONOMIC AND POLITICAL 
Although governments cannot technically be prevented from completely opting out of liberalization obligations for a wide range of sectors during their scheduling process, the relevant WTO Guidelines (S/L/93) note that:

There shall be no a priori exclusion of any service sector or mode of supply. ${ }^{1552}$

This tries to puts a damper on Members wishing to protect certain domestically sensitive sectors such as health, education, and cultural services. It does not recognize that a Member may see a particular sector such as health services, as not suitable for commodification. It does not appear that justifications for not opening up a particular sector for the conceivable future, would be generally accepted as a possible for all Members. As commented by the Panel in US-Gambling, the notion of progressive liberalization, finds expression in the Preamble and in Article XIX:1 and XIX:3 of the GATS and that progressive liberalization:

...entails including more sectors in Members' schedules and reduction or elimination of limitations, terms, conditions and qualifications on market access and national treatment through successive rounds of negotiations [emphasis added]. ${ }^{1553}$

But this does not apply to all Members in the same manner, since there are some flexibilities for developing countries and LDC Members under the GATS. Article XIX:2 of the GATS (read with Article IV on increased participation of developing countries) recognizes "appropriate flexibility" for developing countries to open fewer sectors. With regard to LDCs, the Modalities for the special treatment for least-developed country members in the negotiations on trade in services (2003), recognizes that:

The importance of trade in services for LDCs goes beyond pure economic significance due to the major role services play for achieving social and development objectives and as a means of addressing poverty, upgrading welfare, improving universal availability and access to basic services, and in ensuring sustainable development, including its social dimension. ${ }^{1554}$

It can also be argued that since Article XIX:2 of the GATS recognizes "due respect for national policy objectives and the level of development of individual Members", this flexibility is not necessarily limited only to Members having lower economic development levels, but that the allowable flexibility is on a sliding scale based on needs of development.

Thus, development needs are not totally ignored. The same paragraph of the WTO Guidelines (S/L/93) mentioned above goes on to add that:

Special attention shall be given to sectors and modes of supply of export interest to developing countries.

But this only suggests a promise (and mere one of "special attention") from developed countries to liberalize sectors and modes of supply where developing countries were hoping for trading opportunities. LDCs (and some developing countries as well) have made it clear that liberalization of Mode 4 is the most important area for them, and the

ANALYSIS, Vol. I, Springer 2005, p804-805 on the role of the United States, EC, Japan, Canada, Nordic Countries and the OECD in general in proposing and supporting the inclusion of a services round.

${ }^{1552}$ WTO, Guidelines and Procedures for the Negotiations on Trade in Services, S/L/93, adopted by the Special Session of the Council for Trade in Services on 28 March 2001, para.5.

${ }^{1553}$ Panel Report, US-Gambling, para.6.313

${ }^{1554}$ WTO, Council for Trade in Services, Modalities for the special treatment for least-developed country members in the negotiations on trade in services, adopted by the special session of the council for trade in services on 3 September 2003. 
other Members have promised access in Mode $4 .{ }^{1555}$ The Guidelines and Modalities on negotiations do not explicitly recognize that any Member could/should be free to completely exclude commitments to liberalize any particular service sector. The obligation to progressively liberalize trade in services remains, but "serious difficulties" faced by LDCs are recognized and it is agreed that Members shall "exercise restraint in seeking commitments" and "ensure maximum flexibility" for LDCs. ${ }^{1556}$

When it comes to LDCs, the Modalities for Negotiations (T/N/S/13) which are specific to LDCs are clearly more considerate of the development status than the Guidelines (S/L/93), and use similar language to Article XIX:2 of the GATS, stating that:

There shall be flexibility for LDCs for opening fewer sectors, liberalizing fewer types of transactions, and progressively extending market access in line with their development situation. LDCs shall not be expected to offer full national treatment, nor are they expected to undertake additional commitments under Article XVIII of the GATS on regulatory issues which may go beyond their institutional, regulatory, and administrative capacities. In response to requests, LDCs may make commitments compatible with their development, trade and financial needs and which are limited in terms of sectors, modes of supply and scope. ${ }^{1557}$

In contrast, the Guidelines (S/L/93) and Recommendations of the Council for Trade in Services (WT/L/579) ${ }^{1558}$ contradict the concern for developing countries and the possibility of liberalizing fewer sectors, with an insistence on "no a priori exclusion of any service sector or mode of supply". The Hong Kong Ministerial Declaration of 2005 (WT/MIN(05)/DEC) also stresses on progressive liberalization "with a view to expanding the sectoral and modal coverage of commitments". ${ }^{1559}$ Article XIX:3 and XIX:4 of the GATS refer to both the negotiating guidelines and procedures as well as the acknowledgement of developing country and least developed country needs expressed in Article IV of the GATS (as discussed further in Chapter 6).

As can be seen, this process of liberalization is to be conducted either through successive rounds of trade negotiations or autonomously by the Members and can be carried out on

1555 WTO, Council for Trade in Services, Modalities for the special treatment for least-developed country members in the negotiations on trade in services, adopted by the special session of the council for trade in services on 3 September 2003, TN/S/13, 5 September 2003, para.6:

LDCs should indicate those sectors and modes of supply that represent priority in their development policies, so that Members take these priorities into account in the negotiations.

Further at para 9:

LDCs have indicated that this is one of the most important means of supplying services internationally. Members shall to the extent possible, and consistently with Article XIX of the GATS, consider undertaking commitments to provide access in mode 4, taking into account all categories of natural persons identified by LDCs in their requests.

${ }^{1556}$ WTO, Council for Trade in Services, Modalities for the special treatment for least-developed country members in the negotiations on trade in services, adopted by the special session of the council for trade in services on 3 September 2003, TN/S/13, 5 September 2003, para 1-5.

${ }^{1557}$ Ibid., (T/N/S/13), para.5. Also see WTO, Hong Kong Ministerial Declaration, Doha Work Programme, WT/MIN(05)/DEC, 22 December 2005, adopted on 18 December 2005, para.26 which acknowledges that LDCs "are not expected to undertake new commitments".

1558 WTO, Text of the 'July package' - the General Council's post-Cancun decision, WT/L/579, 2 August 2004, Annex C, Recommendations of the Special Session of the Council for Trade in Services, Paragraph (d).

1559 WTO, Hong Kong Ministerial Declaration, Doha Work Programme, WT/MIN(05)/DEC, 22 December 2005, adopted on 18 December 2005, paras.26 and 27. 
parallel multilateral and/or bilateral tracks. It is important to understand this process to assess the implications of the GATS. The multilateral negotiations are focused on establishing and developing rules and disciplines and the bilateral negotiations in GATS are related mostly to creating market access opportunities. The obligations concerning market access and extension of national treatment to foreign services and service suppliers depend on the commitments undertaken by WTO Members either autonomously or pursuant to bilateral negotiations with other members. It should not be forgotten that bilateral negotiations in the context of the request-and-offer process of GATS negotiations will become automatically multilateralized and as a result the MFN treatment obligation under Article II: 1 of the GATS would apply, so Members must take as much care in their bilateral negotiations as they do in multilateral negotiations.

A Member is also free to differentiate between sub-sectors during the process of making commitments and thereby have different limitations with regard to national treatment and market access for specifically defined sub-sectors. The model usually followed is the classification system prepared by the WTO Secretariat, the Services Sectoral Classification List (W/120), which is based on the Central Product Classification (CPC) System of the United Nations. Taking the example of health services, it is classified under both "Business Services" and "Health Related and Social Services". ${ }^{1560}$ Commitments can also be limited according to mode of supply in the defined sub-sector ${ }^{1561}$.

In addition to this, specific reservations can be made to commitments, which reflect national policy choices and priorities, including the needs of a Member to allow for adaptation of the domestic market and regulatory systems to competition from foreign services ${ }^{1562}$. WTO Members thus have the opportunity to take steps to protect their services-related values and interests when they schedule their commitments. However, some authors have questioned whether the use of schedules for protection of public services in a particular sector is legitimate, although it has been done by some Members. David Luff criticises certain countries (Poland, Slovenia, Malaysia and Mexico) for excluding public health services sub-sectors (hospitals, sanatoriums), stating that in principle exclusions cannot be based on ownership or the public or private nature of a service, but a service in itself has to be either open to international trade or not open. ${ }^{1563}$

1560 See further Luff, David, Regulation of Health Services and International Trade Law, in Mattoo, Aaditya and Sauvé, Pierre, Eds. DOMESTIC REGULATION AND SERVICE TRADE LIBERALIZATION, World Bank Publications, 2003, p199.

${ }^{1561}$ For example Sauvé refers to a limitation on access for foreign gymnastics instructors - a Mode 4 (movement of natural persons) issue - being specified under gymnastics education, a sub-sector of sports education under post-secondary education (Sauvé, Pierre, Trade, Education and the GATS: What's In, What's Out, What's All the Fuss About?, Paper prepared for the OECD/US Forum on Trade in Educational Services, May 2002). Such limitations can be similarly applied to limitations on foreign health services personnel under mode 4 in health services. Other than access limitations, national treatment limitations can also be included so that for example, foreign doctors do not get the same incentives and benefits that a government can grant its local doctors (e.g. tax exemption and social security benefits).

${ }_{1562}$ For example, limitations on the extent of foreign investment in a sector can allow the domestic suppliers more time to become competitive or allow for the proper regulatory mechanisms to be put in place that can deal with the legal challenges of foreign investment being introduced into that sector. Continuing on the example of FDI, it is also possible for member states to have limitations applicable to all sectors (what is referred to as horizontal limitations) with regard to FDI above a certain value, in order to protect domestic interests.

${ }^{1563}$ Luff, David, Regulation of Health Services and International Trade Law, in Mattoo, Aaditya and Sauvé, Pierre, Eds. DOMESTIC REGULATION AND SERVICE TRADE LIBERALIZATION, World Bank Publications, 2003, p200. sense" - the explicit exclusion from the scope of commitments is of obvious importance to the national health policy of the relevant members. 
While Luff says this "does not make sense" - the explicit exclusion from the scope of commitments is of obvious importance to the national health policy of the relevant members.

The effectiveness of protection through scheduling is dependent on the extent of the expertise and foresight of the Member's officials involved in the scheduling process as well as the subsequent interpretation of the language employed. The experience of the United States in US-Gambling, where it later appeared that they had not made an exception for gambling from the scope of national treatment and market access, may leave less-able states with even less faith in their ability get the best out of this system for protection. Therefore, although disputes could theoretically be avoided by intelligent scheduling, in the future there could be situations where errors, oversights, position changes and appeal to evolving social values not covered by existing protections, could result in failure to protect via scheduling and end up in reliance on the general exceptions of the GATS.

\subsubsection{The Services Sectoral Classification System and National Health Policy}

One of the issues that arise in the context of health services under the GATS is the classification of health services. Health services are spread across the services sectoral classification system of the GATS set out in document MTN.GNS/W/120 (hereinafter W/120), which follows the UN provisional Central Products Classification system and comprises of 12 core service sectors which further subdivided into a total of some 160 sub-sectors. The W/120 has a positive list approach wherein any service sector may be included in a Member's schedule of commitments with specific market access and national treatment obligations. This classification itself already indicates a problem of fracturing of health services policy planning, since health services as a whole are spread across different sectors and sub-sectors in the Services Sectoral Classification List.

Arnold and Terrie commenting on the Services Sectoral Classification List approach to separating health services into a number of different sectors and subsectors, give the example of the difficulties that could be faced by the United States in future health services reform. They note that the US has made commitments regarding health insurance and hospital services and services of other health facilities and that these commitments would have a chilling effect on any future ability to adopt a plan for comprehensive universal public health insurance and furthermore Article VIII:4 and Article XVI of the GATS would limit such a public monopoly. ${ }^{1564}$ The Appellate Body in US-Gambling has stated that sectors and sub-sectors are mutually exclusive, and that a service can only fall within one service category. ${ }^{1565}$ Furthermore, it was added that when a 'sector' is committed, that means that all subsectors within are also committed. ${ }^{1566}$ The Panel in EUEnergy Package citing the previous Appellate Body Report in US-Gambling, also noted that there is a "principle of mutual exclusivity of sectors and sub-sectors" and that

\footnotetext{
${ }^{1564}$ Arnold, Patricia J. and Terrie C. Reeves, Global Trade and the Future of National Health Care Reform Accounting Forum, Volume 30, Issue 4, December 2006, p325-340. At present the authors note that the health insurance market in the US has few foreign suppliers, but as a commitment has been scheduled, there are limitations on a new system being introduced or the commitments should be renegotiated.

1565 Appellate Body Report, US-Gambling, para. 180.

1566 Ibid.
} 
therefore "a given service cannot fall under two different sectors or subsectors at the same time". ${ }^{1567}$

The possibility of developing and applying a holistic national policy for health as a social service and human right appears to be undermined by this classification in the Services Sectoral Classification List of the GATS (W/120) where health services are already partly divided up into at least three of the core sectors - social services, ${ }^{1568}$ business services (health workers) and financial services (health insurance).

Health Related and Social Services

- Hospital Services

- Other Human Health Services

- Social Services and Others

Business Services

A. Professional Services

- Medical and dental services

- Services provided by midwives, nurses and paramedics

C. Research and Development Services

Financial Services
A. All Insurance and Insurance Related Services
- Life, Accident and Health Insurance Services

While W/120 is not mandatory for Members to use, it has been generally accepted by Members as 'supplementary means of interpretation' under Article 32 of the VCLT. This matter was mentioned by the Appellate Body in US-Gambling, which deferred to the practice of the parties to consider both W/120 and the 1993 Scheduling Guidelines as supplementary, reversing the earlier finding of the Panel that they were 'context' under Article 31.2 of the VCLT. ${ }^{1569}$

According to W/120, 'Health Related and Social Services' includes hospital and other services not covered by professional services. Medical and dental services, as well as services provided by midwives, nurses, physiotherapists and para-medical personnel fall under Business Services Part A - 'professional services'. Health related R\&D could fall under Business Services Part C - 'research and development services'. Life, accident and health insurance services fall under Financial Services Part A - 'all insurance and insurance-related services'. The Committee on Specific Commitments has noted that there are some questions regarding the classification of education, health, tourism, recreational and cultural services, but comments and discussion on the topics are still ongoing. ${ }^{1570}$ An informal note prepared by the Secretariat on classification issues in health services (for the Members only and not yet public), has been circulated. ${ }^{1571}$ It is unknown whether the issue of coherence of health policy planning has arisen in the context of the Committee's work and discussions, but it is something that should get the attention of health policy-makers, even if most trade policy-makers have not noticed its

1567 Panel Report, EU - Energy Package, para.7.273 citing in support Appellate Body Report, USGambling, para. 172; and also see para.7.274.

${ }^{1568}$ If public health services are exempted by Article I:3 of the GATS, then this would only include profitoriented health services.

${ }^{1569}$ Appellate Body Report, US-Gambling, paras.196-197.

${ }^{1570}$ WTO, Note by The Secretariat, Committee on Specific Commitments: Report of the Meeting held on 29 October 2013, S/CSC/M/68, 25 November 2013

${ }^{1571}$ WTO, Committee on Specific Commitments - Classification issues in health services, JOB /SERV/158, 18 September 2013. 
significance thus far. However, the 1998 WTO Secretariat Background Note on Health and Social Services has noted that the definition of health-related and social services does not include medical and other services which have been classified under Professional Services. The note states that this separation is "not entirely convincing" even from an economic and trade perspective, use criteria for allocation to the different categories that "do not seem to be fully consistent" and "disregards the strong complementarities" between professional and hospital services. ${ }^{1572}$

From the point of view of trade, it is a practical and effective classification; and it is the ease of international trade not the national-level effects and policy coherence which are relevant. It is not that the GATS sectoral classification in itself causes problems for national health policy planning, but it reflects an attitude in international trade law that is in contrary to the national and international approach to national health policy. It creates another hurdle for a coherent right to health approach to health services provision from the viewpoint of national health policy-makers, since it requires them to be aware of and able to competently assess the inter-relations of their policy with GATS.

Bloiun et al commenting on the issue of policy coherence at the interface between trade policy and health services refer to an example of Pakistan's initial offer in services negotiations during 2005. Pakistan is described as having engaged in a broad-based and long term stakeholder consultation with various associations representing health professionals in the formulation of trade policy relevant to health, and consulting officials in the Ministry of Health, although WTO policy is undertaken by the Ministry of Commerce. ${ }^{1573}$ Blouin comments that it was this long term effort that achieved some policy coherence and resulted in Pakistan making an offer on professional services in the health sector that included a public-services "carve-out". ${ }^{1574}$ This is described by Blouin as an exclusion of health services provided by public institutions in order to:

...ensure future regulatory flexibility to improve accessibility to health services, either through subsidies, universal services obligations or other measures. $^{1575}$

Blouin identifies 5 conditions to ensure policy coherence that protects the right to health: (i) Dialogue and joint fact-finding (ii) Leadership by health ministries (iii) Institutional mechanisms of collaboration (iv) Engaging stakeholders (v) Getting the evidence right. ${ }^{1576}$

The WHO clearly supports the concept of national health policies, strategies, and plans:

National health policies, strategies, and plans play an essential role in defining a country's vision, priorities, budgetary decisions and course of action for improving and maintaining the health of its people. Most

\footnotetext{
1572 WTO, Secretariat Background Note, Health and Social Services, S/C/W/50, 18 September 1998, para.6. 1573 Blouin, Chantal, Jody Heymann, Nick Drager, TRADE AND HEALTH: SEEKING COMMON GROUND, McGill-Queen's Press - MQUP, 2007, p268-271; Blouin, Chantal, Trade policy and health: from conflicting interests to policy coherence, Bulletin of the World Health Organization 85 (2007): 169173.

1574 Blouin, Chantal, Jody Heymann, Nick Drager, TRADE AND HEALTH: SEEKING COMMON GROUND, McGill-Queen's Press - MQUP, 2007, p268-271; Blouin, Chantal, Trade policy and health: from conflicting interests to policy coherence, Bulletin of the World Health Organization 85 (2007): 169173.

1575 Blouin, Chantal, Trade policy and health: from conflicting interests to policy coherence, Bulletin of the World Health Organization 85 (2007): 169-173.

${ }^{1576}$.Ibid. (Blouin, WHO Bulletin).
} 
countries have been using the development of national health policies, strategies, and plans for decades to give direction and coherence to their efforts to improve health. ${ }^{1577}$

The WHO approach to strengthening health systems also highlights the concepts of people-centred primary care, moving towards universal coverage and putting health in all policies. ${ }^{1578}$ The importance of linking up public and private healthcare providers in order to develop an integrated and coherent model of health governance is also identified. The "renewed interest" in developing regulatory capacity and national health policies in light of the "fragmented" systems of public and private providers is also recognized. ${ }^{1579}$ The WHO emphasizes that "more could be done to ensure comprehensive, coherent, and balanced" national planning for health in national health strategies. ${ }^{1580}$ The official webpage of the WHO goes on to comment that:

The disconnect between programme planning efforts and national planning processes leads to imbalance, lack of coherence, and subsequent problems with implementation. The causes are complex and include: programme planning conducted by different actors with different planning cycles often delinked from the national planning cycle...

As an example from a special area of health rights, General Comment No. 14 of the CESCR on the Right to Health identifies as a core obligation the obligation to "adopt and implement a national public health strategy and plan of action". ${ }^{1581}$ With regard to the special area of women's health, it is highlighted that there is a need for a

...comprehensive national strategy for promoting women's right to health

throughout their lifespan', including 'policies to provide access to a full range of high quality and affordable healthcare. ${ }^{1582}$

National implementation of the right to health requires a national strategy and possibly framework legislation and national monitoring mechanisms. ${ }^{1583}$

1577 WHO, National health policies, strategies, and plans, available online at http://www.who.int/ nationalpolicies/en/, last accessed 05.05.2014.

${ }^{1578}$ WHO, Report by the Secretariat, Health system strengthening: Current trends and challenges, SixtyFourth World Health Assembly, A64/13, 7 April 2011, paras.2 and 3. Further, with reference to the 'peoplecentred primary care' and 'health in all policies' approach, the original document cites the Commission on Social Determinants of Health, Closing the gap in a generation: health equity through action on the social determinants of health. Geneva, World Health Organization, 2008; "The Nairobi Call to Action for Closing the Implementation Gap in Health Promotion", Seventh Global Conference on Health Promotion (Nairobi, 26-30 October 2009); "Adelaide Statement on Health in All Policies: moving towards a shared governance for health and well-being", Health in All Policies International Meeting (Adelaide, Australia, 12-15 April 2010); "The Tallinn Charter: Health Systems for Health and Wealth", WHO European Ministerial Conference on Health Systems: Health Systems, Health and Wealth (Tallinn, 25-27 June 2008).

1579 WHO, Report by the Secretariat, Health system strengthening: Current trends and challenges, SixtyFourth World Health Assembly, A64/13, 7 April 2011, para.13:

Many Member States are attempting to rationalize and bring coherence to fragmented systems with multiple stakeholders, public, private-not-for-profit, private-for-profit firms and corporations. As a consequence, there has been a renewed interest in developing regulatory capacity and strengthening policy instruments to develop, negotiate and implement more robust national health policies, strategies and plans [footnotes omitted].

$1580 \mathrm{WHO}$, National health policies, strategies, and plans, available online at http://www.who.int/ nationalpolicies/ processes/comprehensive/en/, last accessed 05.05.2014.

${ }^{1581}$ UN CESCR, General Comment No. 14, The right to the highest attainable standard of health, U.N. Doc. E/C.12/2000/4, 2000, $11^{\text {th }}$ August 2000, para.43(f) (core obligations).

1582 Ibid., para.21 (women and the right to health).

1583 Ibid., (General Comment 14), paras.53-56. 
In the European context, Guillod has noted that the Council of the European Union had declared the duty of the State to promote health in all its sectoral policies. ${ }^{1584}$ Article 152(1) EC also requires that health protection is to be part of all Community activities and policies. This is in accordance with Article 11 and 13 of the Revised European Social Charter (1996) which recognize that:

Everyone has the right to benefit from any measures enabling him to enjoy the highest possible standard of health attainable [and] Anyone without adequate resources has the right to social and medical assistance.

Developing countries in particular need cross-sectoral national plans and strategies to deal with issues such as malnutrition, malaria, tuberculosis, polio and other immunization plans, and in the case of some countries, the HIV epidemic. These are not issues that piecemeal profit-seeking private sector healthcare business can successfully tackle, even in the unlikely scenario that they would wish to do so. Thus the manner of sectoral classification and its contradiction with holistic and cross-sectoral national planning on health suggests that the structuring of liberalization of trade in services may be for 'cream skimming' of profits in the health sector leaving the public health systems of Members to continue to deal with the national health issues in the same manner as before. ${ }^{1585}$

Furthermore, from a national health policy point of view, their entry into the health services sector in specific areas where there could be profit should be very carefully regulated, so as not to negatively affect affordability of health services by transferring key public responsibilities to profit-seeking entities e.g. immunization, maternal and child health, nutritional supplements for undernourished children. Therefore, while allowing for case-by-case entry into the market in very specific sub-sectors, a broad sweep of market access and national treatment for health services has not been a popular policy choice for most WTO Members. Furthermore, while there should be international co-operation, particularly through UN agencies, in assisting developing countries eradicate preventable diseases, developing autonomous national strategies and action by the public sector should obviously be preferred to continued dependency upon aid and charity by international agencies. The importance of 'ownership' of national development strategies has been recognized by the Paris Declaration on Aid Effectiveness (of 2005, also see the Accra Agenda for Action 2008) and also by the WHO for health system strengthening in particular. ${ }^{1586}$ As a country becomes more developed, the needs can shift to other causes

\footnotetext{
1584 Resolution of the Council of the European Union of December 20, 1995, on the integration requirements of health protection in EU policies, JOCE 350, p2 - cited in Guillod, Olivier, Market Integration in a Small Federal State (Switzerland): The Role of Public Health in Cottier, Thomas and Petros C. Mavroidis Eds., REGULATORY BARRIERS AND THE PRINCIPLE OF NONDISCRIMINATION IN WORLD TRADE LAW, University of Michigan Press, 2000, p225.

${ }^{1585}$ See WTO, Secretariat Background Note, Health and Social Services, S/C/W/50, 18 September 1998, para.29, which specifically refers to 'cream skimming' by private health insurers, without necessarily contributing to "quality and/or efficiency gains for all population segments and interested groups... leaving the basic public system, often funded through the general budget, with low-income and high-risk members".

${ }^{1586}$ See WHO, Report by the Secretariat, Health system strengthening: Current trends and challenges, Sixty-Fourth World Health Assembly, A64/13, 7 April 2011. An earlier version of this report was considered by the Executive Board at its 128th session in January 2011, document EB128/2011/REC/2, para.14:
}

The principles of the Paris Declaration on Aid Effectiveness, of country ownership, harmonization, alignment, results and mutual accountability are now well established. Robust national health policies, strategies and plans, and the policy dialogue that underpins them, have thus become critical to improve aid effectiveness as well as domestic health system strengthening.... Firstly, and most importantly, a number of 
of morbidity such as diabetes, high blood pressure, heart disease, cancer and so on... which may also need new national strategies.

In addition to the scheduling of GATS commitments under this sectoral classification, there is another additional 'flexibility' to limit commitments to only certain modes of supply. This classification of services in the GATS according to modes of supply is based on the physical location of the supplier and consumer and pursuant to Article I:2 of the GATS, and covers services supplied in the following 'modes' or means of delivering services:

Mode 1 - Cross-border trade ('telemedicine');

Mode 2 - Consumption abroad ('health tourism');

Mode 3 - Commercial presence (establishment foreign-owned health services supplier such as a hospital or clinic); and

Mode 4 - Presence of natural persons (e.g. physical movement of health service personnel across borders). ${ }^{1587}$

The benefits to certain sectors of the economy through international trade in health services in these four modes is not denied. The problem is if these opportunities for international trade could at the same be to the detriment of the more vulnerable sections of the domestic public and create two-tier systems with different levels of quality and affordability (see comments on the four modes of supply earlier in Chapter 3 of this study). ${ }^{1588}$ In such situations, the WTO Member ought to wear its other hat, so to speak, as a State which is the primary duty bearer in terms of human rights, and implement measures to reduce the inequities.

Mode 4, which provides for temporary movement of natural persons is one area where developing countries have felt that there would be opportunities for employment and training of their health personnel. However, perusal of the developed country Members schedules shows that there has not been liberalization of Mode 4. Opportunities exist for developing country health professionals to work and train in developed countries without Mode 4 commitments being made. But while there are benefits of this, on the other hand, the implications are that Mode 4 could exacerbate the problem of 'brain-drain' of health professionals from poorer countries, which would negatively impact health services and human development indicators in those countries. For example, doctors from developing countries who get placements abroad for temporary employment or for specialist training are usually the best from their home countries, and can get longer term employment contracts and the possibility of emigration at the conclusion of their training period, if there is a market for highly skilled specialist doctors in the developed country. Thus, issues such as liberalization of Mode 4 must be balanced with domestic or bilateral codes

developing countries have set up their own structures and processes to obtain alignment of the inputs of development partners behind their priorities.

More than 100 signatories (donor countries, developing-countries, multilateral donor agencies, regional development banks and international agencies) have endorsed the Paris Declaration. The first of the five principle of the Declaration is 'Ownership': that managing their own national development policies and strategies is essential for developing countries to achieve real sustainable development.

${ }^{1587}$ See the previous reference to the modes of supply in Section 3.3.2 of Chapter 3.

1588 See also the observation by the Special Rapporteur on the Right to Health that if increased trade in services were to lead to substandard health facilities, goods and services, this would prima facie be inconsistent with the right to health (UN Economic and Social Council, Commission on Human Rights, Report of the Special Rapporteur Paul Hunt, The right of everyone to the enjoyment of the highest attainable standard of physical and mental health, Addendum, Mission to the World Trade Organization, E/CN.4/2004/49/Add.1, 1 March 2004, para.49). 
or guidelines or voluntary action that takes responsibility for and attempts to minimize such negative downstream effects of liberalization. ${ }^{1589}$

The objective of GATS in achieving progressively higher levels of liberalization of trade in services is not necessarily linked with improvement of national health systems as a whole nor is there a necessary link between increased international trade in health services and greater availability, accessibility, acceptability and quality of health services. ${ }^{1590}$ Even trade experts have noted that that liberalization of services may lead to marginalization of the poor ${ }^{1591}$ - without other separate governmental policy and action to ensure that there is social equity.

Furthermore, it is often only the trade and commerce sections of government that are involved in the preparation and negotiation processes under the GATS and other relevant bodies, such as e.g. Ministries of Health with regard to health services issues, are usually insufficiently involved, if at all. The level to which the marginalized sections of society, who would suffer most if essential health services are cut down, withdrawn or left undeveloped, have a voice in the negotiating process is doubtful. It is true that this is a domestic governance issue and public participation as a prerequisite for the legitimacy of Member decision-making at either domestic or international level is not a concept that international trade law concerns itself with.

However, it is worth noting that this is not the case in all international law regimes. Other areas of international law, particularly human rights and environmental governance, have reasonably well articulated principles on this point. For example, Principle 10 of the Rio Declaration on Environment and Development (1992) describe the three pillars that are considered to form a 'right to participation' as access to information, participation in decision-making, and access to justice (administrative or judicial recourse, redress and remedy) in environmental matters. ${ }^{1592}$ At the 11th Special Session of UNEP's Governing

\footnotetext{
1589 See the adoption of the WHO Global Code of Practice on the International Recruitment of Health Personnel Resolution, WHA63.16., May 2010, accompanied by the development of guidelines for monitoring implementation of the Code by Member States and other stakeholders. Note also that 2006-2015 is the WHO "Health Workforce Decade".

See further The World Health Assembly Resolution, 2004 towards mitigation of the negative effects of health care migration (an issue raised by African health Ministers continuously since then) and the WHO Health Worker Migration Policy Initiative, 2007 which has led to technical Working Groups and an Advisory Council for the promotion of assistance for developing national guidelines or voluntary codes, international guidelines and bilateral agreements and/or a multilateral framework for health worker migration. In early 2008, the World Health Organization (WHO) accepted on principle a resolution submitted by Sri Lanka to restrict brain drain from developing countries to developed countries as the phenomena has caused negative repercussions in the third world. On 1 September 2008, the WHO Secretariat published the first draft of the code for consideration and comment by WHO Member States and other stakeholders. See for an example of international and national codes: The Commonwealth Code of Practice for International Recruitment of Health Workers 2003 and the United Kingdom Department of Health, Code of Practice for the International Recruitment of Health Professionals, 2004.

1590 The four elements of the right to health identified by the General Comment on Article 12 of the ICESCR, discussed earlier (availability, accessibility, acceptability and quality).

${ }^{1591}$ Footer, Mary E. and Carol George, The General Agreement on Trade in Services in Macrory, Patrick, Arthur Appleton and Michael Plummer, THE WORLD TRADE ORGANIZATION: LEGAL, ECONOMIC AND POLITICAL ANALYSIS, VOL. I, Springer 2005, p.727: referring to the reports of the UN High Commission for Human Rights.

${ }^{1592}$ See further, Duvic, Paoli, Leslie-Anne, The Status of the Right to Public Participation in International Environmental Law: An Analysis of the Jurisprudence, Yearbook of International Environmental Law (2013) 23 (1): 80-105; McIntyre, Owen, The role of the public and the human right to water in Public
} 
Council/Global Ministerial Environmental Forum in Bali, Indonesia in 2010, governments adopted the Guidelines for the Development of National Legislation on Access to Information, Public Participation and Access to Justice in Environmental Matters (Bali Guidelines). Regionally, there is a European convention on public participation in environmental matters (the Aarhus Convention on Access to Information, Public Participation in Decision-Making and Access to Justice in Environmental Matters, 1998). In the human rights regime, there is Article 25 of the ICCPR which defines the obligations of States parties in connection with the individual human right to take part in the conduct of public affairs, directly or through chosen representatives. Other international human rights instruments and regional conventions contain similar provisions. Thus, the same governments recognize and value public participation from environmental or human rights angles in certain multilateral contexts, but do not acknowledge similar principles in a different forum.

Coming back to trade in services, it could be said that the voices of the public have not been entirely silenced in ongoing services negotiations and commitments. Currently, the health sector remains one of the least committed areas in WTO Members' services schedules. This can be due to the public pressure for retaining these areas as areas of national policy competence and taking time to freely develop the policies and measures that would be beneficial for both the general economy and the health rights of the population. A glance at the communications of Members on GATS Schedules of Specific Commitments show that out of 356 communications made up to 2016 (the only addition was the EU in 2019), and only 35 were made after the Doha Round was officially launched in November 2001.

\subsubsection{Interpretation of a Services Schedule}

The interpretation of the services schedules is generally accepted as being far more complex than that of goods schedules for a number of reasons. The schedules are vital since "their interpretation defines the scope of the explicit commitments made". ${ }^{1593}$ The scope of commitments is something that the Members themselves are not fully in charge of, although they may try to do this as best as they can when making entries in their schedule and including limitations, because the interpretation is not in their hands. This is due to the fact that although the commitments are entered by the Members concerned, other Members can have a different opinion of the breadth of their commitment and the panels and/or Appellate Body decide on the final interpretation, during which they may or may not accept the arguments and explanations of how that particular Member intended that their entry would be interpreted. The Member which made the commitment can tell other Members what they think the scope of the commitment is, but if the other Member disagrees, this could be the basis of a dispute. The result of US-Gambling has shown that even expert negotiators have "misjudged the scope and depth of their own Schedule of Commitments". 1594

Participation and Water Resources Management: Where Do We Stand in International Law?, UNESCO, 2015.

${ }^{1593}$ Van Damme. Isabelle, TREATY INTERPRETATION BY THE WTO APPELLATE BODY, Oxford University Press, 2009, p95.

${ }^{1594}$ Molinuevo, M. Article XX GATS in Wolfrum, Rudiger, Peter-Tobias Stoll and Clemens Feinaugle Eds., WTO - TRADE IN SERVICES, Max Planck Commentaries on World Trade Law, Martinus Nijhoff Publishers, 2008, p463. 
The status of the Schedules as an integral part of the agreement is not a contentious matter as Article XX:3 of the GATS clearly states that:

Schedules of specific commitments shall be annexed to this Agreement and shall form an integral part thereof.

This has been recognized in the dispute settlement context, by the Appellate Body in USGambling and more recently by the Panel in China-Publications and Audiovisual Products. ${ }^{1595}$ This methodology was discussed by the Appellate Body in US-Gambling, in the following manner:

[T] he task of identifying the meaning of a concession in a GATS Schedule, like the task of interpreting any other treaty text, involves identifying the common intention of Members... [and the meaning] must be determined according to the rules codified in Article 31 and, to the extent appropriate, Article 32 of the Vienna Convention [emphasis added]. ${ }^{1596}$

This makes it clear that the interpretation of schedules should be done in the same way as interpretation of the text of the treaty, that is, by recourse to the Vienna Convention rules. Furthermore, a Member cannot argue a unilateral interpretation of its own schedule, but a holistic 'text-context-object and purpose' approach would be adopted in interpretation of the text of the Schedule by panels and the Appellate Body. This approach can be criticized since it can be argued that Schedules are in fact a mixture of both unilateral and multilateral acts during the process of the negotiation of the GATS. ${ }^{1597}$

We have three GATS disputes in which the services schedules were interpreted, US Gambling and China-Publications and Audiovisual Products and China-Electronic Payment Services. As mentioned above, in the first of these disputes, the Appellate Body in US-Gambling, following the VCLT approach, agreed that the schedules must be seen as the "common agreement among all Members" and interpreted as one would interpret the text of the treaty, even if this may be contrary to the intention of the Member when making the commitment. ${ }^{1598}$ The justification given for this is that

...there are no provisions in the WTO Agreement that would allow a

Member's intentions to be probed and determined, except as reflected in the treaty language. ${ }^{1599}$

Therefore, supposedly objective tools would be resorted to for the interpretation of a Member's schedule and not the undertaking of an investigation into the subjective intent at the time of making the commitment. Perhaps this is due to the fact that the schedule would be a public document and the intention of a Member in entering a commitment is

${ }^{1595}$ Panel Report, China-Publications and Audiovisual Products, para.7.922:

We recognize that GATS schedules are an integral part of the GATS, and are thus legally part of the WTO Agreement [footnote omitted]

Also see Appellate Body Report, US-Gambling, para.182.

1596 Appellate Body Report, US-Gambling, para.160. This statement in US-Gambling was also cited subsequently in the Panel Report, China-Publications and Audiovisual Products, para.7.922

1597 See e.g. Van Damme, Isabelle, The Interpretation of Schedules of Commitments, Journal of World Trade 41(1), 2007, 1-52, p21. See further, Krajewski, M., Playing by the Rules of the Game? Specific Commitments after US-Gambling and Betting and the Current GATS Negotiations, Legal Issues of Economic Integration, 32 (4), 2005, 417-447.

1598 Appellate Body Report, US-Gambling, para.159. See also the Panel Report, US-Gambling, para.6.135 where the Panel acknowledges the US submission that interpreting a commitment on gambling services into the US schedule would be a surprising interpretation considering the numerous bans, restrictions and strict controls that the Member has otherwise placed upon gambling and betting.

${ }^{1599}$ Panel Report, US-Gambling, para.6.137. 
not necessarily obvious and clear to other Members and service suppliers in their respective jurisdictions. Furthermore, the original subjective intention of a Member making a commitment could be quite complex; it is possible that what led to the original commitment was a combination of policy contradictions and compromises. On one hand, it can be commented that ignoring the intent of Members making a commitment suggests a vaguely antagonistic framework of international cross-border trade, rather than a cooperative and open one where there is a prior investigation of the domestic legal system and the expressed policy of a Member with regard to international trade commitments. On the other hand, there is a suggestion of lack of good faith and transparency, and as a result, unawareness of the precise legal rights of service suppliers, if the commitments are vague and to be interpreted subjectively. Whether or not any of these factors actually played a part in the background of the gambling dispute, the path chosen by the Appellate Body is an objective approach to interpreting the schedules.

W/120 and the 1993 Scheduling Guidelines are tools used in such an approach. It has been said by the Panel in US-Gambling that these documents:

...were agreed upon by Members with a view to using such documents, not only in the negotiation of their specific commitments, but as interpretative tools in the interpretation and application of Members' scheduled commitments. ${ }^{1600}$

Antigua's view was in alignment with this, also stating that it was "inappropriate" to interpret a schedule entry on the basis of "divergent dictionary definitions" and that it was:

...more appropriate to examine the term in the light of other classifications, such as W/120, the CPC, other classification systems, and other WTO Members' GATS Schedules [emphasis added] ${ }^{1601}$

The panel agreed that W/120 and the 1993 Scheduling Guidelines comprise the "context" of GATS Schedules, within the meaning of Article 31 of the VCLT and could be used for the purpose of interpreting the GATS and the GATS schedules of Members. ${ }^{1602}$ At the same time, as the Panel rightly acknowledged that use of other Members' Schedules as context must be tempered by the recognition that: "[e]ach Schedule has its own intrinsic logic, which is different from the US Schedule". ${ }^{1603}$

The Appellate Body identified two main difficulties with the Panel's for characterization of these documents as context: there was no convincing evidence that the documents (i) constitute an agreement made between all the parties or that they were an instrument made between some parties and accepted by the others, or (ii) that there was a common understanding among Members that specific commitments are to be interpreted in light of those documents. ${ }^{1604}$ However, while rejecting the panel's position that W/120 and the 1993 Scheduling Guidelines were context under Article 31 of the VCLT, the Appellate Body said that since recourse to Article 31 did not yield a clear meaning as to the scope of the commitment made by the United States, these documents could be taken into account for supplemental means of interpretation identified in Article 32 of the VCLT. ${ }^{165}$

\footnotetext{
${ }^{1600}$ Panel Report, US-Gambling, para 6.82. See further paras.6.77 - 6.82.

${ }^{1601}$ Appellate Body Report, US-Gambling, para.48.

1602 Panel Report, US-Gambling, para.6.82.

${ }^{1603}$ Appellate Body Report, US-Gambling, para.182 citing the Panel Report, US-Gambling, para.6.98.

${ }^{1604}$ Appellate Body Report, US-Gambling, para.174 and 194. See generally for the arguments of the panel and the response of the Appellate Body paras.174-18

1605 Appellate Body Report, US-Gambling, para.178 and 197
} 
However the Appellate Body also noted that W/120 does not contain any explicit indication of how W/120 relates to the GATS Schedules of individual Members. ${ }^{1606}$

The Appellate Body used other Members' schedules as supplemental means of interpretation to note that several Members specifically used the words "gambling and betting services" or something similar, to make exclusions in their Schedules. Therefore the Appellate Body noted that the absence of such specific exclusions in the US Schedule was seem as something that "undercut" the US assertion of its intent to exclude gambling and betting services in its commitment. ${ }^{1607}$ Other Members who did not use the terms "gambling and betting services" in their Schedules were cited as having referred to the CPC codes and stating that the services falling within the category "sporting services" in their schedules did not include gambling and betting services. ${ }^{1608}$ The fact that the United States did not take similar steps became interpreted unfavourably.

The Appellate Body in China-Publications and Audiovisual Products discussed the approach of the Panel on China's schedule entry 'sound recording distribution services'. ${ }^{169}$ The issue was whether 'Sound recording distribution services' covered the distribution of sound recordings in electronic, non-physical form, through technologies such as the Internet or mobile telephone networks. The process used by the Panel in this case was:

1 Checking dictionary definitions for "sound recording" and "distribution services"

2. Examining the context in which the relevant entry is situated, specifically:

i. the immediate context provided by the heading of, as well as various other entries within, sector 2.D (Audiovisual Services) of China's GATS Schedule;

ii. the context provided by China's commitment on distribution services in sector 4 (Distribution Services) of its GATS Schedule;

iii. certain provisions of the GATS itself (Articles I and XXVIII(b));

iv. certain GATS Schedules of other Members.

As a result, the Panel found that some of the examined contexts suggest that sound recordings in electronic form are covered, while the others are "consistent with", do not "address" or do not "contradict" this conclusion. ${ }^{1610}$ The Panel did not address the 'object and purpose' further, as should be done in a holistic interpretive exercise, but did say that they found that the above interpretation was consistent with the object and purpose of the GATS, as reflected in the Preamble of that Agreement. ${ }^{1611}$

\footnotetext{
${ }^{1606}$ Appellate Body Report, US-Gambling, para. 199.

${ }^{1607}$ Appellate Body Report, US-Gambling, para.184. At this point, the original footnote in the Report states: In most instances, the words appear to be used to exclude these services from the scope of the commitment. See the Schedules of Austria (GATS/SC/7); Bulgaria (GATS/SC/122); Croatia (GATS/SC/130); the European Communities (GATS/SC/31); Finland (GATS/SC/33); Lithuania (GATS/SC/133); Slovenia (GATS/SC/99); and Sweden (GATS/SC/82). In two cases, however, the words appear to be used to make a limited specific commitment. See the Schedules of Peru (GATS/SC/69) and Senegal (GATS/SC/75).

${ }^{1608}$ At this point, the original footnote in the Report states: See the Schedules of Australia (GATS/SC/6); Japan (GATS/SC/46); Liechtenstein (GATS/SC/83A); Switzerland (GATS/SC/83); and Thailand (GATS/SC/85).

${ }^{1609}$ See Appellate Body Report, China-Publications and Audiovisual Products, paras.343-345.

${ }^{1610}$ Appellate Body Report, China-Publications and Audiovisual Products, para.344.

1611 See further Panel Report, China-Publications and Audiovisual Products, para.7.1219.
} 
The Panel went on to a review the situation under Article 32 of the Vienna Convention: certain items it identified as preparatory work and certain circumstances and concluded that these too were consistent with its analysis under Article 31. These were:

- The Services Sectoral Classification List (W/120)

- The 1993 Explanatory Note on Scheduling of Initial Commitments in Trade in Services (the "1993 Scheduling Guidelines") and

- The 1991 United Nations Provisional Central Product Classification list is also mentioned along with the services Sectoral Classification List as 'having potential value in assisting the interpretation of GATS schedules'. ${ }^{1612}$

- Certain circumstances surrounding the conclusion of China's Accession Protocol and GATS Schedule.

The Panel in China-Publications and Audiovisual Products also acknowledged that the Appellate Body in US-Gambling had identified the Services Sectoral Classification List and the 1993 Guidelines as supplementary means of interpretation within the meaning of Article 32 of the Vienna Convention although they are not binding on WTO Members. ${ }^{1613}$

In responding to China's challenge of the Panel analysis, the Appellate Body, citing the previous comments in US-Gambling, agreed that Schedules of other Members are relevant for context, but that their use will depend on each Schedule being interpreted and its own "intrinsic logic". ${ }^{1614}$ Therefore it was concluded that other Members' Schedules may ultimately be of "limited utility" and not necessarily a "central feature" of analysis, although "inferences" could be legitimately drawn from such an analysis and confirmation of the interpretive results of other elements of 'context'. ${ }^{1615}$ Thus, it does not seem that an interpretation of terms in a WTO Agreements based only on the views of one Member is possible - even in interpreting a Members' own Schedule of Commitments. In fact, the Panel in US-Gambling clearly states that "...the scope of a specific commitment cannot depend upon what a Member intended or did not intend to do". 1616 Instead, schedules are considered to contain what is seen as the 'common agreement' of Members ${ }^{1617}$ and the context of the practices of other Members are more easily relied upon than submissions on the intentions of a particular Members when they were making their commitments.

The supposed 'flexibility' provided for by the ability to schedule commitments in market access and national treatment is thus constrained by the expertise and foresight of Members' negotiators and legal advisors. Furthermore, although a general intention to exclude may be found if assessing information from outside of the text and the VCLT approach, a post-facto analysis of the commitments may result in a very different interpretation than what is claimed as the Members original intention. Thus, Members have to avoid using vague wording, since the interpretation of the words in their schedule will most likely based on a literal approach and vague wording may therefore not be sufficient to protect their interests. If there is a lack of clarity on whether a limitation has

\footnotetext{
1612 Panel Report, China-Publications and Audiovisual Products, para.7.923

1613 Ibid, referring to Appellate Body Report, US-Gambling, para.196.

1614 Appellate Body Report, China-Publications and Audiovisual Products, paras.3.82-3.83, citing Appellate Body Report, US-Gambling, para.182 and Panel Report, US-Gambling, para.6.98.

1615 Appellate Body Report, China-Publications and Audiovisual Products, paras.3.84-3.85.

${ }^{1616}$ Panel Report, US-Gambling, para.6.136.

${ }^{1617}$ See with regard to GATT schedules, Appellate Body Report, EC-Computer Equipment, para. 109 and 93 - cited with approval by the Appellate Body Report, EC-Chicken Cuts, paras.265-266. For GATS schedules, see Appellate Body Report, US-Gambling, para160.
} 
actually been entered as intended, ${ }^{1618}$ the alleged intention of Members can be easily overridden and it "risks being bound to commitments against its will". ${ }^{1619}$ This is seen in both the services disputes discussed above as well as in China-Electronic Payment Services. ${ }^{1620}$ The fact that even Members such as the United States and China have found that they were unable to rely on what they had assumed where protections and exclusions in their Schedules, does not bode well for less capable Members. This may also be a reason why there are less commitments than expected.

Commitments are set in stone - or are they? As part of the arguments in support of the retention of policy space and flexibility in the GATS, it is pointed out that Members are not prevented from making changes to their Schedules. If an error in scheduling is noted or a change in policy requires a change, Article XXI of the GATS allows for a modification of commitments. The extent to which this provision can be relied upon for maintaining policy space is discussed in the next section of this Chapter.

1618 See Appellate Body Report, US-Gambling, para. 202; WTO, Scheduling of Initial Commitments in Trade in Services: Explanatory Note, MTN.GNS/W/164, 3 Sep. 1993, para.15-16, on the importance of avoiding ambiguity in such entries.

${ }_{1619}$ Prevost, Denise, Services and Public Policy Regulation in WTO Law: the Example of the US-Gambling Case in van de Gronden, Johan Ed., EU AND WTO LAW ON SERVICES: LIMITS TO THE REALIZATION OF GENERAL INTEREST POLICIES WITHIN THE SERVICES MARKETS, Kluwer, 2008, p228.

${ }^{1620}$ See further the Panel Report, China-Electronic Payment Services, paras.7.520 and 7.624 for more on the difficulties in making schedule entries and in reading and interpreting them. China was held to have violated its obligations under Article XVI:2(a) of the GATS in this dispute for not clearly maintaining the relevant limitation in its Schedule. The complicated cross-subsectoral and cross-modal nature of some transactions and thus the difficulty of entering in all the required limitations, was apparent in this dispute. 


\subsubsection{Article XXI of the GATS: Modification of Schedules of Commitments}

'It's too late to correct it', said the Red Queen:

'when you've once said a thing, that fixes it, and you must take the consequences.'

\section{From Lewis Carroll's Through the Looking Glass}

There can be many reasons that could form the basis of a Member's wish to modify ${ }^{1621}$ or withdraw a commitment that has already been made. The 2002 Report on the Liberalization of Trade in Services and Human Rights points out one such reason, that:

Modification of schedules might be necessary to protect against the unforeseen consequences of commitments to liberalize which can disproportionately affect the poor or vulnerable - in particular where proper assessment of the potential effects of liberalization was not undertaken. ${ }^{1622}$

The Report acknowledges in the same paragraph, the balancing line that ought to be taken between the ideals of transparency and predictability in the trading system and the human rights perspective on the need for more flexibility to modify or withdraw commitments;

...where experience demonstrates that a commitment constrains or limits the enjoyment of human rights...

The Report also stresses what this study asserts, that this flexibility is particularly important for developing countries, where the pace of liberalization ought to be able to "fluctuate" according to the needs of development.

How flexible is the GATS when it comes to modification of the Schedules? Are Members really straight-jacketed into a position taken by a previous government - or can there be adjustments when domestic socio-political developments call for a pro-human rights change in trade policy? Krajewski asserts that the schedules are "not set in stone" as they can be withdrawn, modified and are subject to further negotiations. ${ }^{1623}$ However, Articles XIX, XX and XXI are all within Part IV of the GATS, titled 'Progressive Liberalization' and according to Article XIX:1(a), negotiations must be carried out "with a view to achieving a progressively higher level of liberalization". Thus, liberalization cannot be read out of the Agreement. If Article XXI on the modification of Schedules is to be read in this context, it is a context of moving forward on liberalization and not apparently, of moving back or moving away.

Krajewski expands his comment on the nature of commitments in the GATS by adding later on, that the possibility to withdraw;

\footnotetext{
${ }^{1621}$ For the purposes of this Chapter, 'modify' will be used in the sense of reduction of a concession, although it can technically also signify an extention or expansion. The latter is dealt with under different procedures than Article XXI, as is mentioned further on in this same section.

${ }^{1622}$ UN Economic and Social Council, Commission on Human Rights, Report of the High Commissioner, Liberalization of trade in services and human rights, E/CN.4/Sub.2/2002/9, 25 June 2002, Executive Summary, p4 and para.64.

${ }^{1623}$ Krajewski, Marcus, NATIONAL REGULATION AND TRADE LIBERALIZATION IN SERVICES: THE LEGAL IMPACT OF THE GENERAL AGREEMENT ON TRADE IN SERVICES (GATS) ON NATIONAL REGULATORY AUTONOMY, Kluwer Law International, 2003, p80.
} 
...should not hide the fact that the general dynamic of the GATS points into the opposite direction. ${ }^{1624}$

He also admits that the degree of flexibility is related to how (un)problematic the modification of schedules would be.

\subsubsection{Overview of Requirements/Procedure of Article XXI of the GATS}

According to Article XXI of the GATS, the Schedules can be modified, subject to the requirements and procedures set out in that Article. Article XXI, paragraphs 2, 3 and 4, also apply in the case of Article V:5 (Economic Integration Agreements). The first Article $\mathrm{XXI}$ issue was in relation to the EC and new members to the EC which joined after the Uruguay Round - an Article V matter, which was raised in 2003-4. Since then there have been 36 communications concerning both Article V and XXI matters, including a communication from Bolivia in 2008 which apparently indicated that they wished to withdraw their commitment in health services. ${ }^{1625}$

There are a number of limitations spelt out in Article XXI, on the space and flexibility that is available to a Member who wishes to modify or withdraw a commitment. Additionally, Article XXI:5 states that the Council for Trade in Services shall establish procedures for rectification or modification of Schedules, that must be followed by the Members who wish to take such action. Between 1995 and 1999, the process was an ad hoc certification system, with the relevant procedures coming into effect only in late 1999.

The 1999 Procedures for the Implementation of Article XXI of the GATS - Modification of Schedules ${ }^{1626}$ sets out further details of the procedure that must be followed in the case of an Article XXI situation. This is supplemented by the 2000 Procedures for the Certification of Rectifications or Improvements to Schedules of Specific Commitments ${ }^{1627}$ that offer an easier method of changing the schedule if the action consists of

i. new commitments,

ii. improvements to existing ones, or

iii. rectifications or changes of a purely technical character that do not alter the scope or the substance of the existing commitments. ${ }^{1628}$

In such cases, these modifications can take place through 'certification' by the WTO Secretariat. These modifications are deemed not to be under Article XXI and the 1999 Procedures, unless objections are raised by any other Member. If, the required

1624 Ibid. (Krajewski).

1625 Council for Trade in Services, Notification from Bolivia pursuant to Article XXI of the GATS, S/SECRET/12 (11 November 2008). The document itself is not public, but it was reported in news sources, for example, an article in The Guardian reported that:

In keeping with their constitutional law, Bolivia asked the WTO for permission to withdraw the previous government's commitment to open up its hospitals and healthcare sector to foreign corporations...the Bush administration objected.

(Weisbrot, Mark, Can the US and Bolivia get along? Guardian, 25 February 2009, available online at https://www.theguardian.com/commentisfree/cifamerica/2009/feb/25/bolivia-us-obama-bush and also at Huffington Post http://www.huffingtonpost.com/mark-weisbrot/the-united-states-and-bol_b_170006.html )

1626 Council for Trade in Services, Procedures for the Implementation of Article XXX $\bar{I}$ of the GATS Modification of Schedules, S/L/80 (19 $9^{\text {th }}$ July 1999).

${ }^{1627}$ Council for Trade in Services, Procedures for the Certification of Rectifications or Improvements to Schedules of Specific Commitments, S/L/84 (18 ${ }^{\text {th }}$ April 2000).

1628 Ibid., para. 1. 
consultations do not reach a satisfactory result and there is no agreed upon change nor withdrawal of either the modifications or objections, the Article XXI process must be initiated. This Article XXI process begins with the notification to the Council for Trade in Services.

According to Article XXI of the GATS, a modification or withdrawal cannot be done at will, informing the system and other Members after such a decision is made. According to Article XXI:1(a) the modifications or withdrawals cannot be done within the first three years of a commitment entering into force. This is probably for the purpose of balancing between stability and predictability of the system and allowing for flexibility in between rounds of negotiations. ${ }^{1629}$ There was additional flexibility given under Article X:2 of Emergency Safeguard Measures, that allowed for modification or withdrawal after one year and within three years of the entering into force of the GATS; but this provision is no longer in force. After the required passage of time, Article XXI:1(b) adds another limitation, that the Member must give at least three months' notice to the Council for Trade in Services, of the intention to implement a proposed modification or withdrawal. According to the 1999 Procedures, the information given must include the relevant specific commitment and describe exactly what the Member intends to change, as well as the date for implementing the change. The other Members that may be specifically affected must also be indicated. ${ }^{1630}$

The greatest restriction is that which is put into place to protect the benefits that may have accrued to other Members. If other Members make no request for negotiations on any agreement or compensatory adjustment for the possible future losses, a Member can freely go ahead with their modification or withdrawal. However, if a request is made, changes to the Schedule cannot be implemented by the Member who wishes to do so, until a result is achieved or the matter is dropped. Furthermore, as spelt out in Article XXI:2(a) of the GATS, the Member must maintain the general level of commitments made during negotiations. The status quo can be maintained without change or market access in other service sectors could be given to compensate for the withdrawal of market access in the sector at issue for a further imprecise period of time. The 1999 Procedures, paragraph 4, specifies an initial period of three months for reaching agreement, but this can be extended by the negotiating Members by mutual agreement. The negotiations relating to the first Article XXI matter initiated by the EC in 2003-4 were completed only in $2006 .{ }^{1631}$

If negotiations are unsuccessful with regard to coming to an agreement or concerning the "compensatory adjustment", Article XXI:3(a) states that the affected Member may take the matter to arbitration. Article XXI:3(b) states that the modifying Member shall be free to implement the proposed modification or withdrawal if no affected Member has requested arbitration. But the second sentence of Article XXI:3(a) also states that:

\footnotetext{
${ }^{1629}$ See Nartova, Olga, Article XXI GATS in Wolfrum, Rudiger, Peter-Tobias Stoll and Clemens Feinaugle Eds., WTO-TRADE IN SERVICES, Max Planck Commentaries on International Trade Law, Martinus Nijhoff Publishers, 2008Eds. WTO - TRADE IN SERVICES, 2008, p468.

1630 Council for Trade in Services, Procedures for the Implementation of Article XXI of the GATS Modification of Schedules, S/L/80 (19 ${ }^{\text {th }}$ July 1999), para.1.

${ }^{1631}$ Nartova, Olga, Article XXI GATS in Wolfrum, Rudiger, Peter-Tobias Stoll and Clemens Feinaugle Eds., WTO - TRADE IN SERVICES, Max Planck Commentaries on World Trade Law, Martinus Nijhoff Publishers, 2008, p476-77.
} 
Any affected Member that wishes to enforce a right that it may have to compensation must participate in the arbitration.

Furthermore, Article XXI:4. (a) states that:

...the modifying Member may not modify or withdraw its commitment until it has made compensatory adjustments in conformity with the findings of the arbitration.

Article XXI:2(b) clarifies that the compensatory adjustments must be made on an MFN basis, so the obligation to compensate is applicable to all Members.

Article XXI:4(b) adds that if a modifying Member implements its proposed change to the schedules without complying with the findings of the arbitration,

....any affected Member that participated in the arbitration may modify or withdraw substantially equivalent benefits in conformity with those findings [emphasis added].

It is also added that this response by any affected Member against a modifying or withdrawing Member will not be considered in violation of MFN obligations of Article II of the GATS. Thus, a Member considering modifying and/or withdrawing a commitment must be aware that consequences of their decision could involve compensation or commensurate loss of trade benefits from other Members.

The freedom to change the commitments depends mostly on the inclinations of other affected Members and their determination to defend the concessions gained under the scheduled commitments. This determination of other affected Members is in the end determined by the players in the affected sector, their strength in the market and as contributors (more likely) or a vote-base (a possibility) in their domestic context and thus their ability to influence their government to take up the matter in negotiations, arbitration and withdrawal or modification of benefits, if both these mechanisms fail. Thus, this is clearly a very limited freedom as the decision may depend, and the consequences actually depend on the actions of others rather than the actions of the Member itself. It is the freedom of a prisoner, who having unfortunately chained himself, either hopes others around him will look away and be silent while he acts to free himself, although doing so may be to their detriment - or finds himself being coerced to bribing them for the costly key to his freedom. If the schedules are an integral part of the Agreement, it does seem as if it is suggested that a Member 'buys' a treaty amendment by offering another commitment of equivalent value. ${ }^{1632}$ This suggests an inherent inequality in the world trade system, as much as one would see an inherent inequality in a domestic system where it is possible to buy a change in the law that applies to oneself, by negotiating a new, different legal obligation. It is only those with the capacity to 'buy off' everyone who claims they are affected, who can take the risk of making a change. While the WTO system is one of law, this particular situation unfortunately suggests, similar to many domestic legal (dis)orders, a reality of a different system than that of 'equal protection of the law'.

The argument in support of the 'buy off' (offering a commitment of equal value) being fair is that other Members have made commitments in the services negotiations in return for the commitments made by the modifying Member and that there should be a balance between the various Members in what they give and what they receive. If one Member wishes to subsequently withdraw a commitment made, they may do so but in order to be

1632 See, a similar comment with regard to Article XXVIII of the GATT 1994 (on renegotiation and compensation relating to changes in schedules of tariff concessions); Van Damme, Isabelle, TREATY INTERRETATION BY THE WTO APPELLATE BODY, Oxford University Press, 2009, p98. 
fair, they should maintain the negotiated balance by offering market access in another sector. Since the WTO system prefers to at least maintain the levels of liberalization, the balance is retained by the substitution of another commitment. In contrast, if other Members respond by the withdrawal of equivalent commitments, the levels of overall liberalization would decrease. Thus, primacy is given to the protection of a negotiated balance.

On the matter of the compensatory adjustment, this costly key to freedom, Article XXI does not specify what it should be nor how it is to be calculated: it is a matter left for negotiation by the modifying and affected Members. Neither has there been an interpretation or criteria yet for "substantially equivalent benefits" in Article XXI:4(b) of the GATS, which is what can be withdrawn from the modifying Member who fails to compensate, and thus is related to the level of "compensatory adjustment". In the first Article XXI matter with regard to the EC and expansion of its members, the negotiations with the United States, Brazil, Japan and 14 other Members resulted in a compensation package that provided new commitments and benefits for service suppliers to the European services market in a number of sectors including telecommunications and financial services. ${ }^{1633}$ This was in return for the extending the horizontal restriction on market access concerning public utilities and national treatment restrictions concerning subsidies. ${ }^{1634}$ These are some of the same issues that are also a matter of concern in the context of this study.

An additional issue is that while it is usually reasonable to demand a compensatory adjustment in the context of a commercial contractual situation, the WTO agreements have a far greater importance and effect than a mere commercial contract. In this context, from a human rights approach, the obligation of compensation can be seen as an unfair burden, if the modification or withdrawal is for reasons of protecting and promoting human rights obligations. The 2002 Report on the Liberalization of Trade in Services and Human Rights questions whether compensation to affected Members is appropriate in all cases:

Moreover... a human rights approach would question whether States should be sanctioned for taking action to protect human rights. In particular, the requirement of paying compensation might act to discourage States from action which, in turn, could reinforce the status quo or even exacerbate existing problems. ${ }^{1635}$

However, a human rights approach to the interpretation of Article XXI cannot circumvent the possibility of compensatory adjustment, if it is pursued by an 'affected Member' through negotiations, agreement or arbitration. A small space may be available to developing country Members, since if a developing country Member is a party to an arbitration under Article XXI, paragraph 10 of the 1999 Scheduling Procedures includes the ability of such a Member to request for the inclusion of at least one arbitrator from a developing country. This may allow for developing country concerns to be taken into

\footnotetext{
${ }^{1633}$ Nartova, Olga, Article XXI GATS in Wolfrum, Rudiger, Peter-Tobias Stoll and Clemens Feinaugle Eds., WTO - TRADE IN SERVICES, Max Planck Commentaries on World Trade Law, Martinus Nijhoff Publishers, 2008, p476-77.

${ }^{1634}$ Krajewski, Marcus, NATIONAL REGULATION AND TRADE LIBERALIZATION IN SERVICES: THE LEGAL IMPACT OF THE GENERAL AGREEMENT ON TRADE IN SERVICES (GATS) ON NATIONAL REGULATORY AUTONOMY, Kluwer Law International, 2003, p80.

${ }^{1635}$ UN Economic and Social Council, Commission on Human Rights, Report of the High Commissioner, Liberalization of trade in services and human rights, E/CN.4/Sub.2/2002/9, 25 June 2002, Executive Summary, p4 and para. 64.
} 
account in the arbitration process and the final award. However, it does not suggest a possibility to avoid all manner of compensatory adjustments. Unless, that is, there is an Amendment that states that compensatory adjustment to affected Members is not required if the withdrawal or modification of commitments was necessary for the protection and promotion of a human rights obligation e.g. the right to health.

Until such an amendment, as suggested above, is in place, perhaps Article XIV(a) and (b) of the GATS, the general exception provisions on public morals, life and health might be able to balance between commercial imperatives and predictability of the system on one hand and protecting human rights and promoting human development on the other.

In the context of exceptions, which will be discussed in further detail in Chapter 5, it is relevant to note that the United States, following their lack of success in recourse to Article XIV in the US-Gambling dispute in 2005, turned to the Article XXI procedure in 2007. Meanwhile, Antigua and Barbuda, the complainant in that case, requested authorization from the DSB under Article 22.2 of the DSU, to suspend GATS and TRIPS concessions to the United States. The DSB referred the matter for arbitration as required under Article 22.6 of the DSU, resulting in Antigua being authorized later in January 2013, to use counter-measures "at a level not exceeding US\$21 million annually". ${ }^{1636}$ The U.S. through its Article XXI procedures has reached agreements all affected WTO members who requested compensation (Canada, the EU and Japan) other than Antigua. ${ }^{1637}$ The other affected Members, in their compensation package gained liberalized markets for warehousing services (excluding services supplied at ports and airports), private technical testing services, private research and development services, and postal services relating to outbound international letters. ${ }^{1638}$ Even the United States, with all the expertise and resources available to it, found the error in scheduling of commitments a costly mistake, and ultimately could not rely on Article XIV exceptions. It appears on the surface as if this particular dispute was a David vs Goliath victory, but it also raises some worries about the possible difficulties in protecting societal values and modifying or withdrawing commitments.

\footnotetext{
${ }^{1636}$ See current status of dispute, available at: http://www.wto.org/english/tratop_e/dispu_e/cases_e/ds285_e.htm.

${ }_{1637}$ See Report of the Arbitrator, United States - Measures Affecting the Cross-Border Supply of Gambling and Betting Services, WT/DS285/ARB, 21 December 2007; Office of the United States Trade Representative, Statement on Internet Gambling, available at http://www.ustr.gov/about-us/pressoffice/press-releases/archives/2007/december /statement-internet-gambling, last accessed 05.05.2014.

1638 Office of the United States Trade Representative, Statement on Internet Gambling, available at http://www.ustr.gov/about-us/press-office/press-releases/archives/2007/december/statement-internetgambling, last accessed 05.05.2014
} 


\subsubsection{Additional Commitments - Article XVIII of the GATS}

Love sought is good, but given unsought better.

\section{From Shakespeare's Twelfth Night}

It should also be noted that Members can make commitments beyond the scope of Articles XVI and XVII with the general aim of progressive liberalization of services. Article XVIII of the GATS states as follows:

Members may negotiate commitments with respect to measures affecting trade in services not subject to scheduling under Article XVI or XVII, including those regarding qualifications, standards or licensing matters.

Such commitments shall be inscribed in a Member's Schedule.

These additional commitments, which can be made in any given sector, are commitments that are not market access or national treatment (Article XVI or XVII). Such commitments can include, but are not limited to, undertakings with respect to qualifications, technical standards, licensing requirements or procedures. The examples mentioned suggest a connection to the subject matter covered by Article VI of the GATS, which are domestic regulation measures. Article VI:4 of the GATS refers to measures "relating to qualification requirements and procedures, technical standards and licensing requirements".

Therefore, while these additional commitments are not those related to measures which are discriminatory (related to Article II or XVII of the GATS) or market restrictive measures falling under Article XVI of the GATS, it is possible that future disciplines on domestic regulation could involve scheduling under Article XVIII of the GATS. The Guidelines for the Scheduling of Specific Commitments under the GATS also directly refers to the fact that additional commitments can include Article VI undertakings, but that Article XVIII is wider than Article VI in scope. ${ }^{1639}$ This view was also supported by the Panel in Mexico-Telecoms which noted that additional commitments need not be restricted to domestic regulation but can also cover cross-border supply. ${ }^{1640}$

The Scheduling Guidelines highlight that Article XVIII only refers to commitments, and that such additional commitments are expressed in the form of undertakings, not limitations. ${ }^{1641}$ In the schedule, the Additional Commitments column would only include entries where specific commitments are being undertaken, and need not include those modes of supply where there are no commitments undertaken or any entries at all where no Article XVIII undertakings are made. However, the Panel in Mexico-Telecoms commented that limitations in either of the columns of scheduled commitments can, depending on how they are entered, also limit the applicability of the additional commitments. ${ }^{1642}$ What this means is that, if some additional commitments build upon the existing commitments in market access and national treatment, although they are not

\footnotetext{
1639 WTO, Guidelines for the Scheduling of Specific Commitments under The General Agreement on Trade in Services (GATS), adopted by the Council for Trade in Services on 23 March 2001, S/L/92, para. 19.

${ }^{1640}$ Panel Report, Mexico-Telecoms, paras.7.98-7.144.

${ }^{1641}$ WTO, Guidelines for the Scheduling of Specific Commitments under The General Agreement on Trade in Services (GATS), adopted by the Council for Trade in Services on 23 March 2001, S/L/92, para.19.

${ }^{1642}$ Panel Report, Mexico-Telecoms, para.7.94 citing commitments taken "on the basis of the specific commitments undertaken". Also see comments by Krajewski, M, Article XVIII of the GATS in Wolfrum, Rudiger, Peter-Tobias Stoll and Clemens Feinaugle Eds., WTO - TRADE IN SERVICES, Max Planck Commentaries on World Trade Law, Martinus Nijhoff Publishers, 2008, p422.
} 
themselves market access or national treatment commitments, the existing limitations can be extended to the additional commitments also.

Read together with the observation of the Panel in Mexico-Telecoms this makes clear that additional commitments must be an expansion of or addition to existing commitments. For example, it could even be a narrow additional commitment such as expanding to one mode of supply only. A Member must be cautious when initially making commitments under Article XVI and XVII, as Article XVIII commitments cannot draw back on the commitments made earlier under the entries for market access and national treatment when initial commitments made. Thus, the additional commitments can only move a Member forward on the path of progressive liberalization and cannot be used to add limitations and avoid consequences of the 'lock-in' that had been conceded earlier.

This may be the reason behind why it has been generally noted that the level of additional commitments has been low overall. Most of the existing commitments have been made in the telecommunications sector. This is probably due to the fact that services negotiations resulted in what is known as the Reference Paper on Basic Telecommunications, which Members have used as an aid in making additional commitments in the telecommunications sector, as well as other guidance for scheduling. ${ }^{1643}$ These additional commitments concern cross-subsidization, which is considered an anti-competitive practice under Paragraph 1.2(a) of the Reference Paper. Thus, it is possible to say that cross-subsidization, especially in the situation of public monopolies, can be a matter to be included under additional commitments in other sectors - if Members so desire or if there are negotiations that result in similar sectoral outcomes in the future.

The additional commitments column can be used in different ways by Members as there appears to be no commonly agreed system for how to use the fourth column of a services schedule, wherein additional commitments are usually entered. This column can be used for clarifying and supporting existing obligations. It is also possible that the use of the additional commitments column could be the result of confusion or error in scheduling. As the Scheduling Guidelines note that the additional commitments column need only be used for entries of commitments undertaken, ${ }^{1644}$ it would be best that Members who wish to make such entries enter very narrow and specific additional commitments with sector and mode of supply stated clearly, keeping in mind that additional limitations cannot be included. If in doubt about the extent of what is being committed, it is best that the fourth

${ }^{1643}$ For example, the Negotiating Group on Basic Telecommunications documents: Informal Note by the Secretariat, Draft Model Schedule of Commitments on Basic Telecommunications, Attachment 7 to S/L/92 and Annex to Job No. 1311, 12 April 1995; Chairman Note on Revision: Note for Scheduling Basic Telecom Services Commitments, S/GBT/W/2/Rev.1, dated 16 January 1997; Chairman's Note, Market Access Limitations on Spectrum Availability, S/GBT/W/3, 3 February 1997; and

Similarly, in the context of Financial Services, which also has a separate sectoral Annex, the following Informal Note provide scheduling assistance: Informal Notes by the Secretariat for the Committee on Trade in Financial Services, The Distinction between Modes 1 and 2, (Also included in document S/FIN/W/14), 24 June 1997. Also see the Informal Note by the Chairman of the Working Party on Professional Services, Discussion of matters relating to Articles XVI and XVII of the GATS in connection with the disciplines on domestic regulation in the accountancy sector, (also included in document S/WPPS/4, dated 10 December 1998), Job No. 6496, dated 25 November 1998.

The fact that these Annexures and Notes provide more detailed information on these sectors may mean that Members are more clearly able to identify what would be included in the Schedules and in particular what may or may not be included in column four, under additional commitments.

${ }^{1644}$ WTO, Guidelines for the Scheduling of Specific Commitments under The General Agreement on Trade in Services (GATS), adopted by the Council for Trade in Services on 23 March 2001, S/L/92, para.19. 
Chapter 4

column be left alone until there is further clarification by the WTO (meaning the agreement of Members on the expectations regarding Article XVIII as well as perhaps clearer guidance by the Secretariat) on the structure and form for making such entries. 


\subsection{NATIONAL TREATMENT AND MARKET ACCESS}

\subsubsection{Introduction to National Treatment and Market Access}

The earlier part of this Chapter dealt with the so-called 'flexible' procedure for liberalization in the GATS: the ability to schedule commitments. This procedure applies to the two pillars of the world trading system that are not general obligations in the GATS - national treatment and market access. There is further flexibility available to schedule according to the different modes of supply of services, and to avoid scheduling in sensitive sectors. Limitations can be included under both national treatment and market access, but as discussed earlier, cannot be included anew under additional commitments. In addition to this, there can also be horizontal limitations included, which are limitations that apply to all of the sectors included in the schedule. To clarify further, the Schedules should appear in the following manner: ${ }^{1645}$

\begin{tabular}{|c|c|c|c|}
\hline $\begin{array}{l}\text { Sector or } \\
\text { Sub-Sector }\end{array}$ & $\begin{array}{l}\text { Limitations on } \\
\text { Market Access }\end{array}$ & $\begin{array}{c}\text { Limitations on } \\
\text { National Treatment }\end{array}$ & $\begin{array}{c}\text { Additional } \\
\text { Commitments }\end{array}$ \\
\hline \begin{tabular}{l}
\multicolumn{1}{c}{ Part I } \\
Horizontal \\
Commitments \\
for All Sectors \\
in the Schedule
\end{tabular} & $\begin{array}{l}\text { 1.Cross-border supply } \\
\text { 2. Consumption abroad } \\
\text { 3. Commercial presence } \\
\text { 4. Presence of natural } \\
\text { persons }\end{array}$ & $\begin{array}{l}\text { 1.Cross-border supply } \\
\text { 2. Consumption abroad } \\
\text { 3. Commercial presence } \\
\text { 4. Presence of natural } \\
\text { persons }\end{array}$ & \\
\hline $\begin{array}{l}\quad \text { Part II } \\
\text { Sector-Specific } \\
\text { Commitments }\end{array}$ & $\begin{array}{l}\text { 1.Cross-border supply } \\
\text { 2. Consumption abroad } \\
\text { 3. Commercial presence } \\
\text { 4. Presence of natural } \\
\text { persons }\end{array}$ & $\begin{array}{l}\text { 1.Cross-border supply } \\
\text { 2. Consumption abroad } \\
\text { 3. Commercial presence } \\
\text { 4. Presence of natural } \\
\text { persons }\end{array}$ & \\
\hline
\end{tabular}

The market access obligation is contained in Article XVI of the GATS and national treatment is in Article XVII of the GATS, but the following sections of the Chapter will not follow this order. It ought to be reminded that market access is an 'odd-one-out' in terms of not being about the principle of non-discrimination in the same manner as MFN and national treatment in the GATS. Krajewski notes that the phrase 'no less favourable treatment' in Article XVI is not a non-discrimination standard (as between different services or service suppliers), but refers to the comparison of the commitment in the schedule and the actual treatment. ${ }^{1646}$ Therefore, the sections immediately following this one will discuss the scope of Article XVII and the concept of 'likeness' that is found in

${ }^{1645}$ As suggested by the WTO, Guidelines for the Scheduling of Specific Commitments under The General Agreement on Trade in Services (GATS), adopted by the Council for Trade in Services on 23 March 2001, S/L/92 and WTO Secretariat, A HANDBOOK ON THE GATS AGREEMENT, WTO and Cambridge University Press, 2005, p19.

${ }^{1646}$ Krajewski, M., NATIONAL REGULATION AND LIBERALIZATION OF SERVICES: The Legal Impact of The General Agreement on Trade in Services (GATS) on National Regulatory Autonomy, Kluwer Law International, 2003, p82.

See also OECD, INTERNATIONAL INVESTMENT LAW: UNDERSTANDING CONCEPTS AND TRACKING INNOVATIONS: A Companion Volume to International Investment Perspectives, OECD Publishing, 2008, p328:

"Liberalization" in the context of Services is measures through non-discriminatory treatment (national treatment, MFN) and/or the concept of "market access" (as defined in the Agreement). 
Chapter 4

both Article II and Article XVII of the GATS - and then move on to market access. However, despite other differences, all three of these concepts - MFN treatment, national treatment and market access - are concerned with the extent of flexibility and national policy space. In addition to discussing the scope and applications of these three concepts through the relevant provisions, comments will also be made regarding their interrelationship. 


\subsubsection{Article XVII of the GATS: National Treatment}

'...flamingoes and mustard both bite.

And the moral of that is - Birds of a feather flock together.'

'Only mustard isn't a bird,' Alice remarked.

From Lewis Carroll's Alice in Wonderland

\subsubsection{Introduction and Comparison with comparable GATT 1994 and TBT Provisions}

The principle of national treatment with regard to services in WTO law is contained in Article XVII of the GATS. This provision is as follows:

Article XVII - National Treatment

1. In the sectors inscribed in its Schedule, and subject to any conditions and qualifications set out therein, each Member shall accord to services and service suppliers of any other Member, in respect of all measures affecting the supply of services, treatment no less favourable than that it accords to its own like services and service suppliers [at this point, original Footnote 10]

2. A Member may meet the requirement of paragraph 1 by according to services and service suppliers of any other Member, either formally identical treatment or formally different treatment to that it accords to its own like services and service suppliers.

3. Formally identical or formally different treatment shall be considered to be less favourable if it modifies the conditions of competition in favour of services or service suppliers of the Member compared to like services or service suppliers of any other Member.

\section{Original Footnote 10:}

Specific commitments assumed under this Article shall not be construed to require any Member to compensate for any inherent competitive disadvantages which result from the foreign character of the relevant services or service suppliers.

The aim of this Article has been described as intending to create equal conditions of competition for foreign and domestic services and service suppliers with regard to the sectors inscribed in the Schedule. The impact of this provision of public health services would therefore depend on whether Members have made commitments in the health sector or other related sectors such as professional services and financial services (health insurance).

If Members have made commitments, then the national treatment principle would require that the foreign service suppliers should be treated the same as domestic suppliers, when it comes to commercial and trade opportunities in the committed sector and mode of supply. National treatment with regard to hospital services could mean that foreign corporate for-profit hospital chains should be treated the same as domestic public hospitals. This could be considered an undesirable contraction of national policy space for protecting domestic public health services; therefore, it is advisable that Members who wish to retain that space do not make national treatment commitments for health. If 
Members do make commitments, it is important to have foresight and include limitations that protect both current and future health policy. A common example that is given is a requirement that foreign private hospitals set aside a certain amount of free hospital services or free hospital beds as a contribution towards improving equity in access to health services in the country in which they are established in. However, the limitations in schedules cannot foresee the future policy space for public health services that would be needed by government in years to come.

The other health-related sectors should not be forgotten either. Crawford notes how Canada, which has a public health system, has made commitments in financial services and has been seeking reciprocal commitments in insurance and banking and "failed to anticipate the possible repercussions" of private health insurance on the existing public system. ${ }^{1647}$ The Government of Canada appears to have assumed that the commitment in financial services relates only to supplemental private health insurance, and that the commitment would not affect the public system. The argument is that since public health services or 'medicare' in Canada is provided by the government, it is not "in competition" with other service suppliers - thus being SSEGA and not subject to the GATS. Another argument could be that public health services funded by the government are technically not the same 'financial services' or 'health insurance' as private health insurance purchased on the market (they are not 'like' services or 'like' service suppliers). Yet this would ultimately depend on interpretation; and it is possible that a Member that has already scheduled a GATS commitment, and experiments with including private health insurance parallel to or within their public system, but subsequently wish to return to the status quo ante, may face disputes based on the GATS commitments which could result in compensation or retaliation.

The voluntary nature of the national treatment obligation in the GATS is different from the obligations in other WTO Agreements such as the GATT 1994 and the TBT Agreement. In the interpretation of Article XVII of the GATS dispute settlement bodies can take into account the prior interpretations of Article III of the GATT $1994 .{ }^{1648}$ It has also been noted that Article XVII of the GATS was modelled on Article III of the GATT, especially Article III:4 and that it also codifies some features of prior GATT dispute practice. ${ }^{1649}$ But a difference is that Article XVII of the GATS applies to all measures affecting the supply of services covered by the GATS (meaning service sectors that have been included in the schedule of commitments) and Article III of the GATT 1994 is titled "national treatment on internal taxation and regulation" and prohibits discrimination against imported products.

The Appellate Body has identified the fundamental purposes of Article III of the GATT 1994 as avoiding protectionism and ensuring equality of competitive conditions. ${ }^{1650}$ There have been a number of disputes on Article III of the GATT 1994, and clarifications on the 'national treatment tests' for internal taxation and internal regulation may be useful for

\footnotetext{
${ }^{1647}$ Crawford, Mark, Interactions: trade policy and healthcare reform after Chaoulli v. Quebec: is it time for Canada to acknowledge the fragile boundary between health and trade policies and strengthen the separation between private and public health insurance?, Healthcare Policy 1.2 (2006): 90.

${ }^{1648}$ Appellate Body Report, EC-Bananas III, para.231.

1649 Krajewski, M. and Maika Engelke, Article XVII GATS in Wolfrum, Rudiger, Peter-Tobias Stoll and Clemens Feinaugle Eds., WTO - TRADE IN SERVICES, Max Planck Commentaries on World Trade Law, Martinus Nijhoff Publishers, 2008, p398.

${ }^{1650}$ Appellate Body Report, Korea-Alcoholic Beverages, p120; Appellate Body, Canada-Periodicals, p464.
} 
the purposes of the GATS. The relevant concepts used in the national treatment test for internal taxation include 'direct substitution or competitiveness', not being 'similarly taxed' and 'applied so as to afford protection to domestic production'. ${ }^{1651}$ The national treatment test for internal regulation refers to the following elements: that the domestic and imported products are 'like products', that the measure at issue is a "law, regulation or requirement affecting the internal sale, offering for sale, purchase, transportation, distribution or use" and that the imported products are accorded "less favourable treatment' than the domestic product. ${ }^{1652}$

The underlying matter of the competitive relationship between the imported and domestic product in both the GATT 1994 and TBT contexts is decided through four main criteria comparing the characteristics, end-use, consumer tastes and habits and tariff classification of the products, as well as any other factor which can cast light upon the nature of the competitive relationship between the imported and domestic products at issue. ${ }^{1653}$ What is important from a policy flexibility point of view is that the Appellate Body in US-Clove Cigarettes clarified that:

...regulatory concerns underlying technical regulations may play a role in the determination of 'likeness' to the extent that they influence the competitive relationship [between the compared products]. ${ }^{1654}$

This clarification refers to underlying 'regulatory concerns' and does not explicitly refer to the legitimacy of regulatory goals with regard to determining 'likeness'. It can be argued that the legitimacy of regulatory goals should play a role, and that it can be even more important in the area of trade in services, and should be made part of the determination of 'likeness' in the services context. This would make particular value for the health services context, where attaining the highest standard of health under the right to health, could be seen as not merely an underlying regulatory concern, but as a very important and legitimate regulatory goal which could be taken into account.

Article III of the GATT 1994 and Article 2.1 of the TBT Agreement use similar language for the national treatment provision, and they are interconnected, since the TBT also deals with trade in goods and furthering the objectives of the GATT. Therefore, a discussion of the interpretation of Article 2.1 of the TBT Agreement is interesting to look at further.

Article 2: Preparation, Adoption and Application of Technical Regulations by Central Government Bodies

With respect to their central government bodies:

2.1 Members shall ensure that in respect of technical regulations, products imported from the territory of any Member shall be accorded treatment no less favourable than that accorded to like products of national origin and to like products originating in any other country.

\footnotetext{
${ }^{1651}$ Appellate Body Report, Korea-Alcoholic Beverages, p116; Appellate Body, Canada-Periodicals, p2325 .

1652 Appellate Body Report, Korea-Various Measures on Beef, para.133; See also Van den Bossche, Peter, THE LAW AND POLICY OF THE WORLD TRADE ORGANIZATION: TEXT, CASES AND MATERIALS, Cambridge University Press, $2^{\text {nd }}$ Edition, 2008, p368.

1653 Appellate Body Report, Korea-Various Measures on Beef, para 104, 113. Also see Appellate Body Report, EC-Asbestos, para.101.

${ }^{1654}$ Appellate Body Report, US-Clove Cigarettes, para.120. Also see at para.175 and 182, the discussion on 'legitimate regulatory distinction'. See further for discussion on this dispute as well as two other disputes clarifying Article 2.1 TBT (US-Tuna (Mexico) and US-COOL), Epps, Tracy and Michael J. Trebilcock, RESEARCH HANDBOOK ON THE WTO AND TECHNICAL BARRIERS TO TRADE, Edward Elgar Publishing, 2013.
} 
Explaining the above provision, the Appellate Body in US-Clove Cigarettes commented that:

The definition of technical regulations as documents laying down product characteristics gives an indication that, under the TBT Agreement, measures making distinctions based on product characteristics are in principle permitted. However, the fact that a technical regulation defines a product's characteristics with a view to fulfilling a legitimate policy objective does not mean that it may do so by treating imported products less favourably than like domestic products [emphasis added]. ${ }^{1655}$

Thus, a regulatory distinction based on a legitimate policy objective is possible as long as the national treatment principle is not violated. It should be noted that the provisions of the TBT are to be interpreted in light of the principles and exceptions included in Recitals 6 of the Preamble to the TBT, which include "measures necessary for the protection of human, animal, plant life or health". ${ }^{1656}$

Furthermore, the Appellate Body has interpreted the national treatment principle in Article 2.1 of the TBT Agreement, and came up with three requirements. In US-Clove Cigarettes, the Appellate Body stated that a violation of national treatment under Article 2.1 of the TBT includes (i) an examination of whether the measure at issue is a technical regulation within the meaning of the Agreement, (ii) that the domestic and imported product must be 'like' products and (iii) that the imported products must have been treated less favourably. ${ }^{1657}$

As mentioned above, the Appellate Body in US-Clove Cigarettes also commented on the likeness criterion, stating that it must be "based on the nature and extent of their competitive relationship". ${ }^{1658}$ The Panel in US-Tuna II (Mexico) also interpreted the term "like products" in Article 2.1 of the TBT Agreement in accordance with Article III:4 of the GATT 1994 and its related jurisprudence. The Panel noted that the meaning of the term "like products" could be interpreted more narrowly or broadly depending on the context; but focused on the aspects of it relating to "the nature and extent of a competitive relationship" between and among products, citing as pertinent, the previous statement of the Appellate Body in EC-Asbestos on the nature of Article III:4 of the GATT 1994, that it was:

...fundamentally, a determination about the nature and extent of a competitive relationship between and among products. ${ }^{1659}$

This analysis emphasizes the examination of 'like products' but gives less importance to the analysis of the terms "less favourably".

In contrast, the Panel in US-Clove Cigarettes took a somewhat different approach, in the light of the public health context of that dispute, stating that:

"[W]e do not believe that the interpretation of Article 2.1 of the TBT

Agreement, in the circumstances of this case where we are dealing with a technical regulation which has a legitimate public health objective, should

\footnotetext{
${ }^{1655}$ Appellate Body Report, US-Clove Cigarettes, para.98.

1656 See further, Appellate Body Report, US-Clove Cigarettes, paras. 89, 91-95

1657 Appellate Body Report, US-Clove Cigarettes, para.87.

1658 Appellate Body Report, US-Clove Cigarettes, para.194

1659 Panel Report, US-Tuna II (Mexico), paras. 7.223-7.225, citing the Appellate Body Report, ECAsbestos, para. 99
} 


\section{be approached primarily from a competition perspective [emphasis} added]. ${ }^{1660}$

The Panel went on to comment that the significance of the legitimate health protection objective of reducing smoking in youth should: (a) influence the weighing of the evidence relating to the likeness criteria (ii) that certain features of the relevant products, their enduses as well as the perception consumers have about them, must be evaluated in light of that objective (iii) permeate and inform the likeness analysis (iv) be considered particularly relevant in the consideration of the physical characteristics of flavoured cigarettes as well as the consumer tastes and habits criterion, and that (v) consumer perception can only be assessed with reference to the health protection objective of the technical regulation at issue. ${ }^{1661}$ Thus, the Panel upheld Indonesia's claim, finding that clove cigarettes and menthol cigarettes are "like products" for the purpose of Article 2.1 of the TBT Agreement, by giving more attention to the legitimate objective of the regulation and to 'no less favourable' treatment, as compared to the competitiveness criterion in the 'likeness' of the products.

This emphasis on the legitimate public health objective in the assessment of 'less favourable" under Article 2.1 which was done by the Panel in US-Clove Cigarettes thus takes away the focus on competitiveness between products and re-focuses onto the purpose of the government regulations at issue. It is less about whether clove and menthol cigarettes are actually in competition for the same consumer market, but whether the public health protection which is targeted towards the youth segment of consumers could be applied to both products, but only targets the foreign product. Thus, the question whether this TBT measure was a protectionist regulation or an actual public health measure can be properly assessed only if the public health objective permeates the analysis of 'likeness' and 'no less favourable'. The Appellate Body in US-Clove Cigarettes confirmed this by stating that:

... the object and purpose of the TBT Agreement is to strike a balance between, on the one hand, the objective of trade liberalization and, on the other hand, Members' right to regulate. This object and purpose therefore suggests that Article 2.1 should not be interpreted as prohibiting any detrimental impact on competitive opportunities for imports in cases where such detrimental impact on imports stems exclusively from legitimate regulatory distinctions. ${ }^{1662}$

Thus, in the context of a dispute, the panel and/or Appellate Body must analyze whether the detrimental impact on imports stems exclusively from a legitimate regulatory distinction on products, which applies without discrimination to both domestic and foreign products, or whether it reflects discrimination against imported products.

Can the Appellate Body's approach in the interpretation of the terms 'likeness' and 'no less favourable' in the context of trade in goods and technical barriers to trade be useful for a future interpretations of GATS provisions on national treatment? Zleptnig has commented that the TBT Agreement in general, including Article 2.1, represent a "positive approach" to non-economic justifications which includes the non-economic justification rights from the outset in the assessment of the substantive rules; and is thus different from the GATT and GATS "negative approach" which show a hierarchy in the

\footnotetext{
${ }^{1660}$ Panel Report, US -Clove Cigarettes, para. 7.119.

${ }^{1661}$ Panel Report, US -Clove Cigarettes,

1662 Appellate Body Report, US-Clove Cigarettes, para.174 - cited later by the Appellate Body Report of US-Tuna II (Mexico), paras.215-216 and US-COOL, para. 272.
} 
rules-exception relationship. ${ }^{1663}$ Thus, while the TBT Article 2.1 interpretation would no doubt be useful from the perspective of emphasizing a health objective of services regulations, it may be more difficult in the context of the national treatment provision of the GATS.

The comparable provision is Article XVII:3 of the GATS. Which states as follows: Formally identical or formally different treatment shall be considered to be less favourable if it modifies the conditions of competition in favour of services or service suppliers of the Member compared to the like services and service suppliers of any other Member [emphasis added].

It appears that the comparable provision in the GATS emphasizes the competition perspective. The Panel in China-Publications and Audiovisual Products stated with regard to 'less favourable treatment' that there must be a careful analysis of the measure and its implications in the marketplace, but also added that "the examination need not be based on the actual effects of the contested measure in the marketplace". ${ }^{164}$ The panel also stated that prohibiting a foreign service supplier while even conditionally allowing a domestic supplier "modifies conditions of competition in the most radical way, by eliminating all competition with respect to the service at issue". ${ }^{1665}$

What are the criteria for a 'national treatment test' in the services context? According to the Panel in China-Publications and Audiovisual Products, the elements that need to be addressed in the context of obligations under Article XVII of the GATS are:

1. Whether the services at issue are inscribed in the respondent Members' Schedule

2. The extent of the national treatment commitments, including any conditions or qualifications entered in its Schedule in either:

a. the national treatment column by the relevant services sector and covering the mode of supply

b. horizontal national treatment limitations

3. Whether the measures at issue affect the supply of these services;

4. Whether these measures accord less favourable treatment to service suppliers of other Members, in comparison with like domestic suppliers ${ }^{1666}$

Thus, it appears that there is policy space available for Members, as they need not apply the same treatment to national and foreign service suppliers if they have not made specific commitments, and even when they have made commitments, the extent of the obligation would depend on if they were any limitations added to the commitments made. As stated earlier, Members generally follow the Scheduling Guidelines (WTO Document $2001 / \mathrm{S} / \mathrm{L} / 92$ ) in scheduling of specific commitments and in practice it is often so that any deviations from the guidelines are stated clearly.

The WTO has published an illustrative list of national treatment limitations; which include excluding eligibility for national subsidies or tax privileges, nationality and

1663 Zleptnig, Stefan, NON-ECONOMIC OBJECTIVES IN WTO LAW: JUSTIFICATION PROVISIONS OF GATT, GATS, SPS AND TBT AGREEMENTS, Nijhoff International Trade Law Series, 2010, p120121.

1664 Panel Report, China-Publications and Audiovisual Products, paras.7.1130-7.1131, drawing on the previous jurisprudence on Article III:4 of the GATT 1994 in Appellate Body Report, US-FSC (Article 21.5-EC), the Appellate Body Report on Japan-Alcoholic Beverages II, at p110 and the Appellate Body Report, Korea-Various Measures on Beef, para. 142.

${ }^{1665}$ Panel Report, China-Publications and Audiovisual Products, para.7.979.

${ }^{1666}$ Panel Report, China-Publications and Audiovisual Products, paras.7.944 and 7.950. 
residency requirements, technology transfer requirements, requirements that a foreign companies must have registered office on site, the requirement of central bank approval of loans to non-residents, local service requirements, requirements to invest a certain amount of assets in local currency, differential capital requirements, special operational limits and restrictions on property ownership. ${ }^{1667}$ Adlung, commenting in 2008 on the policy coverage of the GATS, notes that six Members have included a national treatment limitation under mode 3 in the horizontal section of their schedule and various Members have limitations allowing them to give subsidies and grants only to domestic service suppliers. ${ }^{1668}$

Thus, it is apparent that there is a difference from the WTO goods regime, where the national treatment obligation cannot be opted out of. There are two ways in which to look at the availability of this opt-out in the GATS. One view is that the opt-out is only a temporary space or flexibility, if it is read with the progressive liberalization obligations of Part IV of the GATS (specifically Article XIX and Article XX on the scheduling of specific commitments). The other view is that the progressive liberalization obligation does not require that all services must eventually be fully liberalized under the GATS, but that the space for Members' policy choices is respected within the framework of the Agreement.

In addition to not being a general obligation and only subject to scheduling, there are other provisions of the GATS that refer to specific exemptions (e.g. Article XIII:1 on government procurement) and exceptions (Article XIV(d) on imposition or collection of direct taxes) from the national treatment obligation. The national treatment obligation has a much longer history than the GATS, and it has long been referred to as "a cornerstone of the world trading system that is served by the WTO", and it has also been said that "the significance of the national treatment obligation can hardly be overstated". ${ }^{669}$ These statements were made in the context of the national treatment provision in the GATT regime. Article III of the GATT 1994 prohibits Members from taking discriminatory measures (taxation or other regulations) against imported products, in order to protect domestic products. The Appellate Body in Korea-Alcoholic Beverages stated that the aim of Article III is to avoid protectionism and protect the expectations and conditions of equal competitive conditions. ${ }^{1670}$

It has also been commented by Stoll that the principle of national treatment has purposes beyond that of non-discriminatory treatment in individual cases and that it "basically calls

\footnotetext{
1667 WTO, Trade in Services, Guidelines for the Scheduling of Specific Commitments under the GATS adopted by the Council for Trade in Services on 23 March 2001, Document 2001/S/L/92 (the Scheduling Guidelines), Attachment 1. Also see Van den Bossche, Peter, THE LAW AND POLICY OF THE WORLD TRADE ORGANIZATION: TEXT, CASES AND MATERIALS, Cambridge University Press, $2^{\text {nd }}$ Edition, 2008, p391.

1668 Adlung, R., Bilateralism in Services Trade: Is There Fire Behind the (Bit-)Smoke?, Journal of International Economic Law, Vol. 11, No. 2, p.365-409, Vol. 11, No. 2, 2008, p. 365-409, p12 and see footnote 43. Adlung also notes the inconsistency that

...the same [Members/States] have promoted BITs with unrestricted post-establishment national treatment provisions; three have even assumed national treatment obligations pre-establishment as well.

${ }^{1669}$ Appellate Body Report, US-Section 211 Appropriations Act, paras. 168 and 241.

1670 Appellate Body Report, Korea-Alcoholic Beverages, para.120. Also see the Appellate Body Report, Japan Alcoholic Beverages II, p16 and 109.
} 
for de-nationalization of the internal market."1671 If this same objective applies broadly for services, and considering the sensitivities that would be raised domestically regarding certain public services, it is no surprise that the negotiations in trade in services resulted in a more flexible arrangement for the GATS than what is in the GATT.

Therefore, despite this significance and this objective of the national treatment principle, there are a number of ways to avoid the national treatment obligation in the GATS. Due to this it can be argued, and it often is, that the GATS allows for sufficient policy space to take measures for the protection of domestic service suppliers, even within the progressive liberalization framework. This protection is not automatic - the actual results will depend on the skill of the Member government to negotiate its way through the complexities of the GATS, while keeping in mind the best policies for national economic development. If used "wisely and cautiously", Article XVII of the GATS could allow for the reconciliation of trade liberalization and national regulatory autonomy. 1672

\subsubsection{Further Comments on the interpretation of Article XVII of the GATS}

As discussed above, national treatment in the GATS depends on the extent and manner in which sectors and modes of supply have been inscribed in the Schedule and whether there are horizontal national treatment limitations included or not. But with regard to the elements that have to be looked at in the Article XVII obligation, it can be seen that there are several phrases and approaches that are important.

This section will briefly discuss the following:

1. The analytical approach to Article XVII of the GATS

2. The relationship between GATT and GATS principles of national treatment

3. The relationship between Article I:1 and Article XVII of the GATS

4. The interpretation of Footnote 10 of Article XVII of the GATS ('inherent competitive disadvantage' and 'modifying the conditions of competition')

5. Less favourable treatment

There are various ways in which the elements of the national treatment obligation of Article XVII of the GATS have been analyzed. A quick overview of Article XVII could be that "the 3 paragraphs of Article XVII form a single and uniform obligation" 1673 but on closer inspection it can be said that:

- paragraph 1 sets out the general standard of the obligation of no less favourable treatment

- paragraph 2 adds a definition of no less favourable treatment

- paragraph 3 clarifies that the decisive aspect of less favourable treatment is modification of conditions of competition in favour of national services and service suppliers 1674

But in order to determine whether there is a violation of the national treatment obligation, a three-part test consisting of the following would be needed:

1671 Stoll, Peter, The Meaning and Function of National Treatment in Stoll, Peter-Tobias and Frank Schorkopf Eds., WTO: WORLD ECONOMIC ORDER, WORLD TRADE LAW, Volume 1, Max Planck Commentaries on World Trade Law, Martinus Nijhoff Publishers, 2006, p54.

1672 Krajewski, M. and Maika Engelke, Article XVII GATS in Wolfrum, Rudiger., Peter-Tobias Stoll and Clemens Feinaugle Eds., WTO-TRADE IN SERVICES, Max Planck Commentaries on International Trade Law, Martinus Nijhoff Publishers, 2008Eds. WTO - TRADE IN SERVICES, 2008, p400.

1673 Ibid.

1674 Ibid. 
1. The scope of Article XVII.

2. Determination of 'like' services" and 'like' service suppliers.

3. Determination of less favourable treatment and detrimental modification of conditions of competition.

The Appellate Body in China-Publications and Audiovisual Products found it appropriate to follow the same analytical approach and three-part test applied by the Panel in the same dispute to assess whether a Member's measure is inconsistent with Article XVII. ${ }^{1675}$ The Appellate Body stated that a complaining party needs to establish all of the following three elements:

i) When a commitment has been made with regard to national treatment in the relevant sector and mode of supply, whether any conditions and qualifications, or limitations are set out in the Member's Schedule;

(ii) Whether the measures are "measures affecting the supply of services" in the relevant sector and mode of supply; and

(iii) Whether measures taken by the Member accord to services or service suppliers of any other Member treatment less favourable than that Member accords to its own like services and service suppliers. ${ }^{1676}$

It can be pointed out that "all measures affecting the supply of services" in Article XVII of the GATS is different from the phrase and "measures by Members affecting trade in services" in Article I:1 of the GATS, which is the general scope of the Agreement and Article I:2 of the GATS on mode of supply, which refers to "...trade in services is defined as the supply of a service". A comparison of the three provisions and their interpretation, as provided in Article XXVIII of the GATS is given below.

\begin{tabular}{|c|c|c|}
\hline $\begin{array}{l}\text { Article I: } 1 \text { of the GATS } \\
\text { "This Agreement applies to measures by } \\
\text { Members affecting trade in services" } \\
\text { Interpretation: Article XXVIII(c) } \\
\text { "measures by Members affecting trade in } \\
\text { services" include measures in respect of: } \\
\text { (i) the purchase, payment or use of a } \\
\text { service; } \\
\text { (ii) the access to and use of, in } \\
\text { connection with the supply of a service, } \\
\text { services which are required by those } \\
\text { Members to be offered to the public } \\
\text { generally; } \\
\text { (iii) the presence, including commercial } \\
\text { presence, of persons of a Member for the } \\
\text { supply of a service in the territory of } \\
\text { another Member. }\end{array}$ & $\begin{array}{l}\text { Interpretation: } \\
\text { Article XXVIII(b) } \\
\text { "supply of a service" } \\
\text { includes the production, } \\
\text { distribution, marketing, } \\
\text { sale and delivery of a } \\
\text { service }\end{array}$ & $\begin{array}{l}\frac{\text { Article XVII: } 1 \text { of the }}{\text { GATS }} \\
\text { No less favourable } \\
\text { treatment } \\
\text { shall be accorded in } \\
\text { respect of "all measures } \\
\text { affecting the supply of } \\
\text { services } \\
\text { Interpretation: } \\
\text { Article XXVIII(b) } \\
\text { "supply of a service" } \\
\text { includes the production, } \\
\text { distribution, marketing, } \\
\text { sale and delivery of a } \\
\text { service }\end{array}$ \\
\hline
\end{tabular}

1675 Appellate Body Report, China-Publications and Audiovisual Products, para.7.641. The original Footnote 827 to this paragraph also states:

The panel in China-Publications and Audiovisual Products at one point in its report distinguished four elements. But elsewhere in its report, the panel combined two of the four elements into one, thus effectively applying a three-part test. See Panel Report, China-Publications and Audiovisual Products, paras.7.1272, 7.942 and 7.956.

${ }^{1676}$ Appellate Body Report, China-Publications and Audiovisual Products, para.7.641. 
Measures "affecting supply of services" seems narrower than "affecting trade in services", and as discussed in Chapter 3, the latter does not have a clearly demarcated scope and definition. WTO dispute settlement appears to have recognized that Article I is broader and analyzing and applying the facts to Article I: 1 is a first, necessary step before assessing the application of Article XVII obligations.

The Appellate Body in Canada-Autos highlighted the drawbacks of the Panel analysis of Article I:1 and Article XVII of the GATS. In that dispute, one question was whether the measure at issue was something that 'affects' wholesale trade of motor vehicles as services, or 'affects' the suppliers in their capacity as service suppliers. ${ }^{1677}$ The Appellate Body literally reversed the approach of the Panel in Canada-Autos, stating that scope of Article I ("affecting trade in services") must be analyzed first, before determining "less favourable treatment' ("affecting supply of services") under Article XVII (or Article II). ${ }^{1678}$ The Appellate Body also stated that the Panel failed to articulate what was required by the Article I:1 term 'affecting' and then failed to analyze the following facts and evidence (they ought not to have made assumptions concerning these):

Facts/evidence which related to the provision of wholesale trade services of motor vehicles in the Canadian market

- including who supplies wholesale trade services of motor vehicles through commercial presence in Canada, and how such services are supplied. ${ }^{1679}$

Thus, the relationship between Article I and Article XVII should not be disregarded as it is a necessary part of the analysis.

Footnote 10 of the GATS emphasizes that when specific commitments in national treatment have been undertaken under Article XVII, this

...shall not be construed to require any Member to compensate for any inherent competitive disadvantages which result from the foreign character of the relevant services or service suppliers.

In Canada-Autos, Canada argued that cross-border supply and consumption abroad (Modes 1 and 2) of the repair and maintenance services at issue were "not technically feasible" and therefore there could be no discrimination against foreign provision of these services and furthermore, their competitive disadvantage was inherent in their foreign character, as stated in footnote 10 to Article XVII. ${ }^{1680}$ The Panel disagreed with the argument presented by Canada, stating that although some services were not technically feasible, all other services listed by the complainants as being affected by measures at issue could be supplied through modes 1 and 2 and further, with regard to inherent disadvantages, that Footnote 10 to Article XVII only exempts Members from having to compensate for disadvantages due to foreign character but it

...does not provide cover for actions which might modify the conditions of

competition against services and service suppliers which are already disadvantaged due to their foreign character. ${ }^{1681}$

This finding was not reviewed by the Appellate Body in Canada-Autos. The reasoning of the Panel on 'inherent competitive disadvantages' appears valid: the Footnote only

\footnotetext{
${ }^{1677}$ Appellate Body Report, Canada-Autos, para.165, 167

1678 Ibid., (AB, Canada-Autos).

${ }^{1679}$ Ibid., (AB, Canada-Autos).

${ }^{1680}$ Panel Report, Canada-Autos, para.10.298.

${ }^{1681}$ Panel Report, Canada-Autos, paras.10.300-10.301.
} 
exempts a Member from taking additional compensatory measures to benefit the foreign service supplier, but does not allow for modifying existing conditions of competition to create additional competitive disadvantages. Thus, Footnote 10 also provides a comparison and contrast between the concepts of inherent competitive disadvantages and detrimental modification of conditions of competition. If the overall objective of the GATS is progressive liberalization, such modifications would be considered steps backward and regarded as inconsistent with the GATS obligations.

As can be seen, Footnote 10 has a limited scope, and Members who have made national treatment commitments remain bound to treat foreign service suppliers 'no less favourably' than domestic suppliers. This goes beyond prohibiting formally different treatment, and includes also formally identical treatment that nevertheless modifies competition against foreign service suppliers. 'Less favourable treatment' that modifies the conditions of competition need not always be apparent in the measure itself, as it can be de facto less favourable. ${ }^{1682}$ In fact, formally different treatment may not always modify conditions of competition unfavourably against foreign service suppliers, as they could even be more favourable to foreign service suppliers (e.g. investment promotion measures that give additional benefits to foreign investors, which could also fall under Mode 3, commercial presence).

\subsubsection{3. 'Likeness' of Services and Service Suppliers for National Treatment}

'I didn't say there was nothing better,' the King replied,

'I said there was nothing like it.'

Which Alice did not venture to deny.

\section{From Lewis Carroll's Alice in Wonderland}

The concepts of 'likeness' and 'no less favourable treatment', as part of the nondiscrimination principle of the WTO, are found in several different provisions across different WTO agreements. As discussed throughout this study, the issue raised with regard to the national treatment obligation is that it is fair not only so far as 'like' services are treated alike, but if Members also have the right to protect the public interest, promote their just societal values and if developing country and LDC Members retain the right to take decisions that increase the effectiveness, competitiveness and equitable distribution of their domestic services supply. Thus, the definition of 'likeness' with regard to national treatment in services may need to be looked at through a wider lens.

In the GATS, 'likeness' is an element in both Article II (MFN treatment - equal treatment of other Members) and Article XVII (national treatment - equal treatment of domestic and foreign suppliers). The concept of 'likeness' was also discussed generally in Section 3.4 of Chapter 3 (in relation to the 'public services exception) as to whether it could play any role in differentiating national 'public services' from foreign commercial services. In this section, the concept will be discussed further with regard to Article XVII of the

${ }^{1682}$ Van den Bossche, Peter, THE LAW AND POLICY OF THE WORLD TRADE ORGANIZATION: TEXT, CASES AND MATERIALS, Cambridge University Press, $2^{\text {nd }}$ Edition, 2008, p395, referring to the Panel Report, EC-Bananas III (Article 21.5-Ecuador), para.6.126.

Note that Article III of the GATT 1994, which has some areas of comparison with Article XVII of the GATS, also covers both de facto and de jure discrimination. 
GATS. It is arguably implied in Article I:3(b) that public services or specifically "services supplied in the exercise of governmental authority" (SSEGA) are not 'like' other services. There could be situations where public services which do not fall within the criteria of Article I:3(c) for SSEGA ("commercial" and "in competition with") could be compared with services provided by private suppliers in a dispute context. In such a case there could be a 'likeness' comparison to be made between public services and the services supplied by private suppliers. In the case of public health services, even when the services provided are comparable, such as immunization, there can be arguments made that they ought not to be considered as 'like' services, as the public character of national immunization programmes cannot be considered the same as the for-profit provision of immunization services, whether or domestic or foreign origin.

Cossy has commented that the negotiating history of the GATS 'likeness' provisions shows that the NAFTA "like circumstances" standard was originally considered, but negotiators finally opted for GATT standard. ${ }^{163}$ The WTO law on 'likeness' has developed in the most part in relation to GATT and trade in goods. The following have been considered as relevant for deciding whether two products are 'like' or not:

1. product properties, nature and quality

2. product end uses in a given market

3. consumer tastes and habits

4. tariff classification

The above is not an exhaustive list, but it shows the links between 'likeness' and both the nature of the products concerned and the significance of their presence in the market from the consumers' perspective. Thus, it is important to point out that 'likeness' is ultimately a determination of the nature and the extent of the competitive relationship between the products concerned. Although the development of 'likeness' was thus developed through goods trade, which in practice appears to show a comparative ease of application of criteria to goods as compared to services, this does not mean that the GATT concept of likeness will be irrelevant for the GATS. ${ }^{1684}$ The aspect of determining the competitive relationship which is useful for 'likeness' of products in the GATT is also useful for the context of 'likeness' of services the GATS. However, there are differences and difficulties in applying similar concepts in both GATT and GATS, due to the intangibility of services as well as because of the different 'modes of supply' in the GATS and the question of whether 'likeness' can be compared across modes. These are issues which are not relevant in the context of the GATT, but have to be tackled for 'likeness' in the GATS context.

What can be learnt from comparison with GATT 1994 jurisprudence on the concept of 'likeness'? Van den Bossche has commented that the GATT disputes which discuss 'like products' can be used as "a useful source of inspiration" for the concepts of 'like services' and 'like service suppliers' in the GATS although there are "more difficult conceptual problems" in services as compared to goods. ${ }^{1685}$ Broadly speaking, the metaphor of the 'accordion' used by the Appellate Body in Japan-Alcoholic Beverages II is generally applicable. The accordion concept with reference to 'likeness' is that the

\footnotetext{
${ }^{1683}$ Cossy, Mirielle, Determining Likeness Under the GATS: Squaring the Circle?, WTO Trade in Services Division, Staff Working Paper No. ERSD-2006-08, September 2006.

1684 Panel Report, US-Gambling, para.3.149: Antigua had expressed the view that 'likeness' was less comparatively less important for services disputes.

${ }^{1685}$ Van den Bossche, Peter, THE LAW AND POLICY OF THE WORLD TRADE ORGANIZATION: TEXT, CASES AND MATERIALS, Cambridge University Press, $2^{\text {nd }}$ Edition, 2008, p340.
} 
scope of the concept of 'likeness' has "no one precise and absolute definition" and depends on the provision, the context and circumstances of the dispute. ${ }^{1686}$

According to the Appellate Body in EC-Asbestos (regarding Article III:4 of the GATT 1994), in tackling the issue of 'likeness', the starting point is obviously the ordinary meaning of 'likeness'. Citing the Shorter Oxford Dictionary 1993, the Appellate Body noted that 'like' means:

Having the same characteristics or qualities as some other ... thing; of

approximately identical shape, size, etc., with something else; similar. ${ }^{1687}$

Thus, the focus in dispute settlement has been on 'likeness' as meaning the same, similar or approximate characteristics of the two things to be compared. What will be assessed is whether the relevant products (or services) share identical or similar characteristics or qualities. ${ }^{1688}$ The Appellate Body accepted that the dictionary definition of 'like' does not resolve the following important issues for assessing 'likeness':

1. It does not indicate which characteristics or qualities are important (in goods these may be "physical properties such as composition, size, shape, texture, and possibly taste and smell, to the end-uses and applications of the product".

2. It provides no guidance in determining the degree or extent to which products must share qualities or characteristics in order to be 'like products' (in reality it can be spectrum of 'very few' to 'many')

3. It does not indicate from whose perspective 'likeness' should be judged - whether ultimate consumers, inventors or producers of those products. ${ }^{1689}$

There are two aspects of EC-Asbestos that may be relevant for the issue of public health services: competitiveness and health risks. The EC had argued in this case that the Panel had erred by adopting "an exclusively 'commercial or market access approach"" to 'like' products, focused too much on 'end-use' and "failed to include consideration of the health 'risk' factors relating to asbestos". ${ }^{1690}$ The Appellate Body agreed with the second issue, that health risks must be included in the concept of 'likeness'. Thus, if there is a difference, such as carcinogenicity or toxicity, this is a defining aspect of the physical properties ${ }^{1691}$ which can lead to the conclusion that there is no 'likeness'. Is it possible to extend that argument to health services? If it is argued that foreign private services being treated the same as domestic public services can result in negative outcomes for the poorer population, it may be possible to stretch a similar concept of risk to the services context. This would have a different result from one focusing on apparent similarities of the service supplied, substitutability (for the wealthier population) and end-user choice and taste. ${ }^{1692}$

\footnotetext{
${ }^{1686}$ Appellate Body, Japan-Alcoholic Beverages II, p114.

1687 Appellate Body, EC-Asbestos, para.90.

1688 Ibid., para.91.

1689 Ibid., para. 92.

${ }^{1690}$ Ibid., para. 104.

${ }^{1691}$ Ibid., para.114:
}

This carcinogenicity, or toxicity, constitutes, as we see it, a defining aspect of the physical properties of chrysotile asbestos fibres. The evidence indicates that PCG fibres, in contrast, do not share these properties, at least to the same extent. We do not see how this highly significant physical difference cannot be a consideration in examining the physical properties of a product as part of a determination of 'likeness' under Article III:4 of the GATT 1994.

See also Panel Report, EC-Asbestos, para. 8.220.

${ }^{1692} \mathrm{An}$ alternative argument is that the 'negative outcomes' were not considered in isolation in the case of asbestos, since 'consumer preferences' affecting the competitive relationship were also considered; then the 
But on competitiveness, EC-Asbestos noted that any interpretation of Article III of the GATT 1994 must reflect the general principle of the Article which was:

... endeavouring to ensure 'equality of competitive conditions' in relation to domestic products. ${ }^{1693}$

So, the relevant characteristics should also be those which reflect the competitive relationship between the foreign and domestic products being compared. The Appellate Body in Argentina-Financial Services, citing the Panel in China-Electronic Payment Services held that Article XVII of the GATS seeks to ensure equal competitive opportunities for like services of other Members, and that "services are therefore "like" when they are in a competitive relationship with each other. ${ }^{1694}$ Therefore a measure would be inconsistent with Article XVII:1 only if the foreign and domestic services at issue are indeed in a competitive relationship, wherein the conditions of competition can be affected by the measures taken by a Member.

For public services, this connects with the arguments raised earlier in Chapter under 'in competition with' in Article I:3(c) of the GATS. What level of importance should be given to the altering of the market where competition is deemed to be occurring? There could be preferential treatment that doesn't actually alter the market or does not alter it significantly. This aspect, which is more part of the 'less favourable treatment' test could affect the 'equality of competitive conditions' that is related with 'likeness'. Free or subsidized health services for those who cannot otherwise afford healthcare or health insurance, would not be actually affecting the equality of competitive conditions, since most of these 'consumers' are actually 'out of the market' and are part of a segment that cannot be 'competed for'. Furthermore, those who can afford private healthcare and yet opt for the free or subsidized health services are not necessarily making decisions based on cost, since there could also be factors such as better quality or availability of specialized expertise in the public health sector, which guides the decision.

Related to this is the idea that substitutability involving cross-elasticity of demand and 'similar purposes' can be used as a 'likeness comparison'. But since these factors are about checking whether price increases of one product/service cause consumers to instead opt for another similar product/service and since judging this requires an existing market with conditions of competition - this cannot be applied to the most relevant situations where there is an existing free/lower priced public service or there is a plan to introduce a free/lower priced public service. For such a comparison there should be the same services in an identifiable market to same group of consumers; and all three of these factors are debatable. Health services are not merely about substitutability. There may be features aside from price, which are factors distinguishing public and private health services and undermining their competitive relationship. An example from the Sri Lankan health services context would be the that the National Institute of Infectious Diseases (formerly known as the Infectious Disease Hospital) and the National Hospital in Colombo (both being free public hospitals), are generally considered to have the best trained and most capable staff to handle cases of Dengue fever, and patients in the Colombo District who have the financial capacity to opt for expensive private hospital

question would be whether public and private health services have different characteristics, and whether the public/private nature affects consumer preferences, thus affecting the competitive relationship.

${ }^{1693}$ Appellate Body Report, EC-Asbestos, para.98.

1694 Appellate Body Report, Argentina-Financial Services, para.6.23, referring to the Panel Report, ChinaElectronic Payment Services, para. 7.700. 
treatment often still show a preference for the public hospitals. This inclination to trust the public health service is supported by study by Rannan-Eliya et al comparing the quality of inpatient care in the public and private sectors in Sri Lanka over a range of indicators including Dengue care, which conclude that the public sector performed significantly better in treatment and management and that quality in the public sector is better than in the private sector in many areas, despite overall public spending being substantially less. ${ }^{1695}$ Patients who can afford the choice will opt for either public or private hospital care due to a number of different preferences which are not necessarily determined by cost of the service, and could be as personal as wanting to consult a particular doctor they are familiar with at a particular hospital.

The Appellate Body in EC-Asbestos also noted that consumer behavior is relevant, since consumers might not treat two products as 'like' based on health aspects such as carcinogenicity or toxicity. ${ }^{1696}$ Of course, consumers need to be aware of carcinogenicity or toxicity for them to have a preference, change in taste and to reduce demand. It is interesting that the Appellate Body in EC-Asbestos placed a high value on consumer tastes and demand and criticized the Panel for declining to examine the criterion of consumer tastes and demands on the basis that it would not provide clear results. ${ }^{1697}$ The Appellate Body went on to comment in the following paragraph that:

....in a case such as this, where the fibres are physically very different, a panel cannot conclude that they are "like products" if it does not examine evidence relating to consumers' tastes and habits. ${ }^{1698}$

It is very doubtful that such an exercise of assessing consumer taste would have added anything of value in this dispute - particular in the context of asbestos, where there is scientific evidence of its inherently hazardous nature as well as the fact that for a long period of time, workers and consumers were not made aware of this evidence. ${ }^{1699}$ In this context, the importance given by Appellate Body to the market forces of consumer

1695 Rannan-Eliya, Ravindra P., Nilmini Wijemanne, Isurujith K Liyanage, Shanti Dalpatadu, Sanil de Alwis, Sarasi Amarasinghe, Shivanthan Shanthikumar, Quality of inpatient care in public and private hospitals in Sri Lanka, Health Policy and Planning, Volume 30, Issue supplement 1, 1 March 2015, Pages i46-i58.

1696 Appellate Body, EC-Asbestos, para.122 and 123.

${ }^{1697}$ Appellate Body, EC-Asbestos, para .120. This was despite the fact that the Appellate Body acknowledged at footnote 101 that Canada expressed its belief during the oral hearings that:

...the parties were in agreement that consideration of consumers' tastes and habits "would add nothing" to the determination of "likeness".

The Appellate Body further commented at para.123 that it did not believe that consumer tastes were "irrelevant" in the context of the relevant regulatory measures, which were for the protection of health, as contended by Canada in the oral hearings.

1698 Appellate Body, EC-Asbestos, para .121.

1699 The harm to human health caused by asbestos was noted as early as 1898 (Deane, Lucy, Report on the health of workers in asbestos and other dusty trades in HM Chief Inspector on Factories and Workshops, Annual report for 1898, p171-2) and definitely by the 1930s (Merewether, Edward, Rowland Alworth, and C. W. Price, Report on Effects of Asbestos Dust on the Lungs and Dust Suppression in the Asbestos Industry. Part I. Occurrence of Pulmonary Fibrosis and Other Pulmonary Affections in Asbestos Workers, 1930). However, workers and consumers were not aware of this risk until much later. See further for the history of the asbestos industry in suppressing evidence and challenging regulations prohibiting the substance - David Gee and Morris Greenberg, Asbestos: from 'magic' to malevolent mineral in Harremoës, Paul, et al. THE PRECAUTIONARY PRINCIPLE IN THE 20TH CENTURY: LATE LESSONS FROM EARLY WARNINGS, Routledge, 2013, p49-63; McCulloch, Jock, Saving the asbestos industry, 1960 to 2006, Public Health Reports 121.5 (2006): 609-614; Tweedale, Geoffrey, and Philip Hansen, Protecting the workers: the medical board and the asbestos industry, 1930s-1960s, Medical History 42.04 (1998): 439 457. 
preference and the manufacturer's acknowledgement of consumer tastes and/or potential civil liability seems excessive and unnecessary. The measure in dispute, the French Decree No. 96-1133, stated in the first sentence of Article 1 that it was "For the purpose of protecting workers". Should the protection of the health of workers in the asbestos industry be subject to the tastes of consumers of the end product? The Appellate Body clearly stated that they do not think that consumers' tastes and habits cease to be relevant where "conditions of competition have been disturbed" by regulatory barriers, ${ }^{1700}$ but perhaps their consideration of the 'likeness' factor should have ignored consumer preference in this type of situation and been more concerned with the comparative harm to the health of workers.

This also leads to the issue of process and production methods (PPMs) as distinguishing features with regard to 'likeness'. A PPM can be described as relating to "the manner in which a product is made and natural resources extracted, grown or harvested". ${ }^{1701}$ A PPM-based measure (e.g. import or export restrictions, labelling, taxes) that is not merely disguised protectionism will address concerns such as human, animal and environmental welfare and be designed to prevent or mitigate harmful effects of PPMs. This continues to be controversial in the GATT context, especially with regard to the post-US-Shrimp implications for PPMs and sustainable development. The continuing need for encouraging environmentally sustainable production, trade and consumerism should not be downplayed, and this is applicable for services as well as goods. ${ }^{1702}$ Arguably, PPMs could be relevant for services and such characteristics can be taken into account; but with regard to services it is more difficult to draw any clear cut line between the process, production and consumption of a service. ${ }^{1703}$ For example, when a clinic provides a basic service of healthcare for infants, there is a specific action that is carried out, which provides the service. This can be carried out by different service providers in a manner that is 'like', except for the following: a public health service providing free immunization to infants and children could be considered as not providing a 'like' service when compared with a private paediatric clinic which charges fees for non-essential services. These two service suppliers could also be said to not be 'like' service suppliers due to the fundamentally different policy considerations behind the manner of their provision of services, although a 'likeness' argument can be made on more superficial grounds.

The Panel in Canada-Autos had stated that to the extent that the service suppliers supply the same service they should be considered 'like'. ${ }^{1704}$ However, the way that 'same service' is defined can result in different conceptions of 'likeness'. Furthermore, so-called 'non-discriminatory treatment' of suppliers of very different types (TNCs, SMEs, public

\footnotetext{
${ }^{1700}$ Appellate Body Report, EC-Asbestos, para.123.

${ }^{1701}$ Bernasconi-Osterwalder, Nathalie (lead author), ENVIRONMENT AND TRADE: A GUIDE TO WTO JURISPRUDENCE Earthscan, 2012, p203.

${ }_{1702}$ See further Pott, Jason, The Legality of PPMs under the GATT: Challenges and Opportunities for Sustainable Trade Policy, International Institute for Sustainable Development, 2008, available online at https://www.iisd.org/pdf/2008/ppms_gatt.pdf.

1703 Conrad, Christiane, R., PROCESSES AND PRODUCTION METHODS (PPMS) IN WTO LAW: INTERFACING TRADE AND SOCIAL GOALS, Cambridge University Press, 2011, p58.

${ }^{1704}$ Panel Report, Canada-Autos, para.10.248.

The Panel in EC-Bananas III, in a finding not reviewed by the Appellate Body, addressed the issue of likeness under Article XVII, which echoes Canada-Autos (Panel Report, EC-Bananas III, para.7.322):

Similarly, in our view, to the extent that entities provide these like services, they are like service suppliers.
} 
and private entities) could be seen as going beyond 'non-discriminatory' treatment into a skewed system of comparison, since these different suppliers can be argued as very 'unlike', even if they are broadly defined as providing the same service. The Panel in China-Electronic Payment Services noted that although a presumption is raised that service suppliers supplying 'like' services are also 'like' service suppliers, this is need not always be the case - and that "a separate inquiry into the 'likeness' of suppliers may be called for" in certain cases. ${ }^{1705}$ Thus domestic public services and foreign TNCs may be differentiated as dissimilar service suppliers, and perhaps also at times as not providing 'like services'. The concepts of non-discrimination in trade law and human rights were also discussed earlier at the beginning of this chapter, which is of relevance to this comparison.

It is also commented widely that there is a general acceptance that 'likeness' is more complicated for services than it is for goods due to the differentiations of supply based in the four modes of supply. After all, the suppliers can be individual contractors or companies; and may or may not be present in the jurisdiction of the Member, since services can also be supplied 'remotely'. The Panel in Canada-Autos has accepted the possibility, in its application of the national treatment principle (Article XVII of the GATS), that 'like' services may be supplied through various different modes ('likeness across modes'). ${ }^{1706}$ However, Panels have so far avoided creating a framework for the analysis of assessing 'likeness' in the GATS. Diebold comments that if 'likeness' is an 'accordion concept' - then it is thus also dependent on the purpose for which the two products and services are compared. ${ }^{1707}$ Diebold suggests generally that if a framework for 'likeness' in the GATS is created, it must assure that where there are national treatment commitments, 'likeness across modes' must be interpreted so as to protect the "competitive opportunities" of all foreign services and service suppliers, regardless of mode of supply. ${ }^{1708}$

Although such an approach would avoid an uneven application of 'likeness', the 'accordion' concept of 'likeness' recognizes that there are different ways of approaching a comparison, and that much can depend on its context etc. Krajewski is of the view that 'likeness across modes' is not a convincing idea as commitments and limitations are included in the GATS schedules on the basis of the four modes of supply, creating an assumption that they are not to be considered 'like' services. ${ }^{1709}$ The idea that Members retain the right discriminate between services supplied through different modes is not only logical in the context of how the GATS was originally negotiated but is also in line with retaining more national policy space and flexibility.

To take an example from health services, can it be said that the national treatment principle can be applied identically for different modes of supply? There is a necessary difference in the way a national regulatory system will look at the cross-border supply of medical advice or medical testing/analysis, the establishment of medical services within

\footnotetext{
${ }_{1705}$ Panel Report, China- Electronic Payment Services, para. 7.705.

${ }^{1706}$ Panel Report, Canada-Autos, para.10.307.

1707 Diebold, Nicholas F., NON-DISCRIMINATION IN INTERNATIONAL TRADE IN SERVICES: 'LIKENESS' IN WTO/GATS, Cambridge University Press, 2014, p102.

1708 Diebold, Nicholas F., NON-DISCRIMINATION IN INTERNATIONAL TRADE IN SERVICES: 'LIKENESS' IN WTO/GATS, Cambridge University Press, 2014, p230.

${ }^{1709}$ Krajewski, M., Article XVII GATS in Wolfrum, Rudiger, Peter-Tobias Stoll and Clemens Feinaugle Eds., WTO - TRADE IN SERVICES, Max Planck Commentaries on World Trade Law, Martinus Nijhoff Publishers, 2008, p405.
} 
the territory, the cross-border movement of patients to and from abroad and the entry of medical professionals into the territory. There are different policy issues with regard to each of these modes, and a 'likeness across modes' clearly is clearly unsatisfactory. Another issue that may be overlooked if assuming that there is cross-modal 'likeness' is that there may not be 'competition across modes' as the nature of service supply and the end users may not be in a full competitive relationship. For example, the cross-border supply of specialized laboratory services under Mode 1 ('telemedicine'); consumption abroad under Mode 2 ('health tourism') and the commercial presence of foreign laboratory services under Mode 3 while all broadly within 'medical services', are not necessarily directly in competition with each other to supply the same service, as there could be differences in availability of a very specific medical test, the human resources expertise offered and significant variations in cost to the patient.

It may also be useful to reflect on the panel and Appellate Body decisions in ArgentinaFinancial Services when discussing 'likeness' with regard to services (under Articles II:1 and XVII:1 of the GATS). Argentina submitted that the characteristics of a good are usually intrinsic to the good itself, while the characteristics of services are often inseparable from the characteristics of the service suppliers and that therefore the criteria for determining "likeness" in trade in services, relating to the service supplier, should include factors such as:

(i) whether the service supplier has particular skills, certifications, or licences;

(ii) the legal form of the service supplier (e.g. whether the service supplier is a natural or juridical person);

(iii) the commercial characteristics of the service supplier (e.g. assets, number of employees, and prior experience supplying the service); and

(iv) the manner and extent to which the service supplier is subject to government regulation and oversight in its supply of the service. ${ }^{1710}$

The Appellate Body did not state that the above criteria were irrelevant, but that they were not persuaded that such 'likeness'-associated criteria displaces the 'presumption of likeness' which is warranted when a measure provides for differential treatment "exclusively on the basis of origin". ${ }^{1711}$ However, it was also stated by the Appellate Body that:

...compared to trade in goods, the scope for such a presumption under the

GATS would be more limited, and establishing 'likeness' based on the presumption may often involve greater complexity in trade in services. ${ }^{1712}$

Furthermore, the Appellate Body found that the Panel erred in its analysis of the term "like services and service suppliers" with respect to Articles II:1 and Article XVII of the GATS; and reversed the Panel's finding that services and service suppliers of "cooperative countries' (countries that Argentina classifies as "countries cooperating for tax transparency purposes") are like services and service suppliers of "non-cooperative

\footnotetext{
${ }^{1710}$ Appellate Body Report, Argentina-Financial Services, footnote 221 (citing Argentina's other appellant's submission, para. 58).

${ }^{1711}$ Appellate Body Report, Argentina-Financial Services, para.6.52:

We have found above that, under Articles II: 1 and XVII: 1 of the GATS, a complainant is not required, in all cases, to establish "likeness" of services and service suppliers on the basis of an assessment of the criteria for establishing "likeness" set out above.

Further, at para.6.34:

...we also note that we are not called upon to pronounce in this appeal on the relevance and weight of specific criteria for determining whether service suppliers and the services provided are "like"

1712 Appellate Body Report, Argentina-Financial Services, para.6.38.
} 
countries". ${ }^{1713}$ The Appellate Body reiterated that the analysis of 'likeness' "serves the same purpose" in the context of both trade in goods and trade in services, namely, to determine whether there is a competitive relationship; although in the services context, the analysis of "likeness" of services and service suppliers "may require additional considerations of whether or how this analysis is affected by the mode(s) of service supply". ${ }^{1714}$ Thus, a general 'likeness' test sourced from the GATT experience cannot be entirely transposed over to the GATS context, ignoring the special features of GATS and the nature of services. Delimatsis and Hoekman raise some criticisms of the ArgentinaFinancial Services view, arguing that a 'likeness' discussion for services is sometimes inappropriate, arguing that "from an economic viewpoint" it would be better if the type of "regulatory concerns" as were raised in the Argentina-Financial Services dispute were considered under the exceptions available under Article XIV GATS, with considerations of 'likeness' retained for situations where the competitive landscape was changed to benefit domestic services and services suppliers. ${ }^{1715}$ It can also be said that regardless of whether there was a change in the overall competitive landscape or not, there could be national policy perspectives that argue against framing the relationship between public and private services in sectors such as health, as suitable for a 'likenesss' analysis or as a competitive relationship generally. Ultimately, the attention given to the similarities and differences is also a question of perspectives on the role of services, and public services in particular.

1713 Appellate Body Report, Argentina-Financial Services, para.7.1.

${ }^{1714}$ Appellate Body Report, Argentina-Financial Services, paras.6.33-6.34.

1715 Delimatsis, P. and Bernard Hoekman, National Tax Regulation, International Standards and the GATS: Argentina-Financial Services, EUI Working Papers, RSCAS 2017/42, Robert Schuman Centre for Advanced Studies Global Governance Programme-276. Also available as Delimatsis, P. and Bernard Hoekman, National Tax Regulation, Voluntary International Standards, and the GATS: ArgentinaFinancial Services, World Trade Review 17.2 (2018): 265-290. 


\subsubsection{Article XVI of the GATS: Market Access}

'I didn't know I was to have a party at all,' said Alice;

'but if there is to be one, I think $I$ ought to invite the guests'.

'We gave you the opportunity of doing it,'

the Red Queen remarked:

'but I daresay you've not had many lessons in manners yet?'

\section{From Lewis Carroll's Through the Looking Glass}

When a Member schedules a specific commitment on market access this generally means that all other WTO Members are given the opportunity to make use of entering the market of the Member who is making the specific commitment, in the sectors and according to the Modes which have been liberalized and subject to any limitations that may have been included in the schedule. Since the level of complexity of national regulatory frameworks within Members can vary, and since there can be various other conditions and limitations imposed even if there is a market access commitment made, in reality different Members would have different experiences in accessing a particular market, in a particular sector and mode of supply.

The GATS does not include a definition of the concept of market access for the purposes of the Agreement. Since health is a sector identified in the GATS, there is an overall assumption of the existence of a 'market' in health, which is contradictory to the more value-laden concept of public health services discussed in this study. The general understanding is that a market access barrier must be identified for a dispute and also whether relevant market access commitments were made. In defining 'market access', the Panel in US Gambling observed that:

The concept of "market access" was fundamental to GATT law and practice; it is still so under the WTO Agreement. In the Dictionary of Trade Policy Terms, "market access" is defined as:

"[O]ne of the most basic concepts in international trade. It describes the extent to which a good or a service can compete with locallymade products in another market. In the WTO framework it as [sic] a legalistic term outlining the government-imposed conditions under which a product may enter a country under non-discrimination conditions". ${ }^{1716}$

This definition refers to non-discrimination conditions of market access. ${ }^{1717}$ Although the relationship between national treatment and market access in the GATS is such that, if they are both read together along with the general MFN obligation, they could result in non-discriminatory access to a market; market access in the GATS is not limited to nondiscrimination. The scope of the market access obligation under Article XVI includes both discriminatory measures and non-discriminatory measures; since it could still include WTO-consistent measures which may also be discriminatory according to the

\footnotetext{
${ }^{1716}$ Panel Report, US-Gambling, para.6.274, citing the DICTIONARY OF TRADE POLICY TERMS, $2^{\text {nd }}$ Edition, Walter Goode, 1998, p176.

${ }^{1717}$ See also Panel Report, China-Publications and Audiovisual Products, para.7.1353 also stressed upon the "no less favourable treatment" nature of market access commitments, while also stating that the commitments can be less than status quo.
} 
national treatment standard of Article XVII of the GATS. ${ }^{1718}$ Thus market access commitments could be both discriminatory and non-discriminatory, depending on how they have been scheduled.

Mavroidis has referred to the above US-Gambling definition as 'unfortunate' and further comments that the relationship between Article XVI and XVII of the GATS needs to clarified. He suggests that there can be an understanding that Article XVI (market access) is a 'sub-set' of Article XVII of the GATS (national treatment) ${ }^{1719}$ Yet there is nothing in the text of the GATS to suggest such an interpretation of the relationship between Article XVI and XVII. But to add further to the confusion on the relationship between these two provisions, Article XX:2 of the GATS also states that:

Measures inconsistent with both Articles XVI and XVII shall be inscribed

in the column relating to Article XVI. In this case the inscription will be considered to provide a condition or qualification to Article XVII as well.

Thus, there could be an erroneous assumption that a measure inconsistent with market access is considered as inconsistent with national treatment as well. However, a measure can be inconsistent with one and not with the other obligation.

Article XVI of the GATS is the provision on market access, and it reads as follows: Article XVI: Market Access

1. With respect to market access through the modes of supply identified in Article I, each Member shall accord services and service suppliers of any other Member treatment no less favourable than that provided for under the terms, limitations and conditions agreed and specified in its Schedule. [at this point, original Footnote 8]

2. In sectors where market-access commitments are undertaken, the measures which a Member shall not maintain or adopt either on the basis of a regional subdivision or on the basis of its entire territory, unless otherwise specified in its Schedule, are defined as:

(a) limitations on the number of service suppliers whether in the form of numerical quotas, monopolies, exclusive service suppliers or the requirements of an economic needs test;

(b) limitations on the total value of service transactions or assets in the form of numerical quotas or the requirement of an economic needs test;

(c) limitations on the total number of service operations or on the total quantity of service output expressed in terms of designated numerical units in the form of quotas or the requirement of an economic needs test; [at this point original Footnote 9]

(d) limitations on the total number of natural persons that may be employed in a particular service sector or that a service supplier may employ and who are necessary for, and directly related to, the supply of a specific service in the form of numerical quotas or the requirement of an economic needs test;

\footnotetext{
1718 WTO, Guidelines for the Scheduling of Specific Commitments under The General Agreement on Trade in Services (GATS), adopted by the Council for Trade in Services on 23 March 2001, S/L/92, para.8.

1719 See Mavroidis, Petros C., Highway XVI Re-visited: The Road from Non-Discrimination to Market Access, World Trade Review, 2007, 6(1), p1-23.
} 
Original Footnote 8:

(e) measures which restrict or require specific types of legal entity or joint venture through which a service supplier may supply a service; and

(f) limitations on the participation of foreign capital in terms of maximum percentage limit on foreign shareholding or the total value of individual or aggregate foreign investment.

If a Member undertakes a market-access commitment in relation to the supply of a service through the mode of supply referred to in subparagraph 2(a) of Article I and if the cross-border movement of capital is an essential part of the service itself, that Member is thereby committed to allow such movement of capital. If a Member undertakes a market-access commitment in relation to the supply of a service through the mode of supply referred to in subparagraph 2(c) of Article I it is thereby committed to allow related transfers of Original Footnote 9: capital into its territory.

Subparagraph 2(c) does not cover measures of a Member which limit inputs for the supply of services.

There is no definition for the concept of market access as such in Article XVI and the scope is not defined nor explained separately from the list of market access barriers and the structure of the schedule of commitments. Thus market access is not presented as a general concept like the national treatment provision (Article XVII of the GATS). ${ }^{1720}$ Instead, market access obligations of a Member are identified through an exhaustive list of six types of measures ${ }^{1721}$ that a Member cannot maintain or adopt, if, and to the extent, market access commitments are undertaken.

These limitations are, in brief:

(a) limitations on the number of service suppliers

(b) limitations on the total value of service transactions or assets

(c) limitations on the total number of service operations or output

(d) limitations on the total number of natural persons that may be employed

(e) measures which restrict or require specific types of legal entity or joint venture through which a service supplier may supply a service; and limitations on the participation of foreign capital.

According to Nielson, in relation to health services, these six limitations cover measures which cannot be taken (unless properly included in the schedule) with regard to limiting the following: the number of hospitals, the amount of assets of foreign private clinics, the number of surgical operations or hospital beds, the number of doctors and nurses employed, requirements that a foreign private clinic must enter into a joint venture with a local clinic to enter the market, and limiting the percentage of the equity that can be

\footnotetext{
${ }^{1720}$ Delimatsis, P. and Martin Molinuevo, Article XVI of the GATS in Wolfrum, Rudiger., Peter-Tobias Stoll and Clemens Feinaugle Eds., WTO-TRADE IN SERVICES, Max Planck Commentaries on International Trade Law, Martinus Nijhoff Publishers, 2008, p369.

${ }^{1721}$ See Panel Report, China-Publications and Audiovisual Products, para. 7.1353: The six types of measures form a closed or exhaustive list, as indicated by the wording of the chapeau to paragraph 2 ("the measures ... are defined as").
} 
foreign-owned in a newly established private clinic. ${ }^{1722}$ Unless scheduling of commitments in health are avoided or a certain level of policy space is retained through clear wording to that effect in a commitment, the above would restrict the policy space for designing and applying measures relating to national health services law and policy of a Member.

This list does not define the scope of market access generally and does not link with nor specify what is meant by "effective market access" - which is an objective of the negotiations on specific commitments according to Article XIX:1 of the GATS. ${ }^{1723}$ It can be stated that "effective market access" may not be on the shoulders of Article XVI alone, but perhaps depends on the interaction of various different GATS obligations including MFN, national treatment, market access, domestic regulation and recognition. Other measures related to but not part of the GATS including competition policy and investment promotion may also figure. Thus, it may be said that Article XVI on market access is only one aspect of "effective market access" and it would be wrong to state that Article XVI covers all measures that impede market access.

The market access obligations under the Article XVI of the GATS depend upon the commitments scheduled by Members, and the terms, limitations and conditions specified in a Member's schedule. The Members' Schedules will set out the minimum standard that they must adhere to, and if wished, Members can treat foreign services and service suppliers more favourably than suggested by the Schedules. ${ }^{1724}$ Therefore, leaving sectors 'unbound' or scheduling commitments to standards less than actual status quo would allow for more flexibility for a Member, since if they have made commitments at a certain standard (even if only a 'standstill' or status quo position), they cannot fall below it without giving cause for a dispute. Article XVI does not mention the modes of supply, so unless there is an explicit limitation in the Members' schedule, a market access commitment in a particular sector applies to all modes of supply in all sub-sectors of that particular sector. ${ }^{1725}$

The Scheduling Guidelines (WTO document 2001/S/L/92) comment further on the nature of the six types of measures listed in Article XVI of the GATS. Paragraph 8 describes the list as consisting of:

1. Four types of quantitative restrictions (sub-paragraphs a-d)

2. Limitations on forms of legal entity (sub-paragraph e)

3. Limitations on foreign equity participation (sub-paragraph f).

The list is exhaustive and includes measures which may also be discriminatory according to the national treatment standard (Article XVII). Paragraph 10 adds that

Approval procedures or licensing and qualification requirements, such as

financial soundness or membership in a professional organization, are

\footnotetext{
${ }^{1722}$ Nielson, Julia, Ten Steps to consider before making commitments in health services under the GATS in Blouin, Chantal, Nick Drager and Richard Smith Eds., INTERNATIONAL TRADE IN HEALTH SERVICES AND THE GATS: CURRENT ISSUES AND DEBATES, World Bank, 2006, p115.

1723 Krajewski, M. Krajewski, Marcus, NATIONAL REGULATION AND TRADE LIBERALIZATION IN SERVICES: THE LEGAL IMPACT OF THE GENERAL AGREEMENT ON TRADE IN SERVICES (GATS) ON NATIONAL REGULATORY AUTONOMY, Kluwer Law International, 2003, p83.

${ }^{1724}$ See Panel Report, para.7.1353:

Under Article XVI, a Member undertakes a minimum standard of treatment, and is thus free to maintain a market access regime less restrictive than set out in its schedule, as confirmed in paragraph 1 which refers to a standard of "no less favourable" treatment.

${ }^{1725}$ See Panel Report, US-Gambling, para.6.285.
} 
frequently stipulated as conditions to obtain a licence..., if such approval procedures or licensing and qualification requirements are discriminatory, they should be scheduled as national treatment limitations [emphasis added].

The Scheduling Guidelines also list examples of limitations on market access drawn from the schedules of specific commitments. In this regard, paragraph 39 of the Scheduling of Limitations is also relevant.

(a) Limitations on the number of service suppliers:

- $\quad$ Licence for a new restaurant based on an economic needs test.

- $\quad$ Annually established quotas for foreign medical practitioners.

- Government or privately owned monopoly for labour exchange agency services.

- $\quad$ Nationality requirements for suppliers of services (equivalent to zero quota).

(b) Limitations on the total value of transaction or assets:

- $\quad$ Foreign bank subsidiaries limited to $\mathrm{x}$ percent of total domestic assets of all banks.

(c) Limitations on the total number of service operations or quantity of service output:

- $\quad$ Restrictions on broadcasting time available for foreign films.

(d) Limitations on the total number of natural persons:

- $\quad$ Foreign labour should not exceed $\mathrm{x}$ percent and/or wages $\mathrm{xy}$ percent of total.

(e) Restrictions or requirements regarding type of legal entity or joint venture:

- $\quad$ Commercial presence excludes representative offices.

- $\quad$ Foreign companies required to establish subsidiaries.

- In sector $\mathrm{x}$, commercial presence must take the form of a partnership.

(f) Limitations on the participation of foreign capital:

- $\quad$ Foreign equity ceiling of $\mathrm{x}$ percent for a particular form of commercial presence.

Members have generally taken care to limit their commitments in health in the different modes of supply, and if they do make commitments there would usually be some form of limitation included. Since it would be already an accepted national policy position, the phrasing of the limitations used by Members are generally similar or identical for both the GATS and for other forms of economic integration agreements. For example, a Background Note by the WTO Secretariat listed several examples where Members have used similar limitations in the GATS and in other agreements. ${ }^{1726}$ It was noted that Germany has a condition of nationality for doctors and dentists, which can be waived on "an exceptional basis in cases of public health interest" and a zero quota for midwives. The UK uses a limitation stating that "establishment for doctors under the National Health Service is subject to medical manpower planning". Singapore generally has a limitation in its trade agreements that only persons registered with the Singapore Medical Council and resident in Singapore can provide medical services. This latter kind of limitation has an effect of barring trade in services in this sector, since this appears to be

\footnotetext{
${ }^{1726}$ The examples are taken from the following document: WTO, Council for Trade in Services, $L D C$ services waiver - Background note by the Secretariat - Measures notified under Articles III:3 and VII:4, and economic integration agreements notified under Article V:7 of the GATS, S/C/W/355, 17 June 2014, paras.3.74 and 3.136.
} 
more in the nature of a permanent settling in the country and does not suggest a temporary movement of service providers. ${ }^{1727}$

With regard to the measures which a Member shall not maintain if market access commitments are made, the disputes on services have made certain clarifications. The disputes have focused on Article XVI:2 of the GATS, where panels and the Appellate Body have noted that a complaining party must do two things in order to establish a prima facie violation:

1. Establish that a responding party has undertaken relevant market access commitments in its GATS Schedule.

2. Identify with supporting evidence, how the challenged laws constitute impermissible limitations falling within the meaning of one of the subparagraphs of Article XVI:2. ${ }^{1728}$

In US-Gambling, the Panel reasoned that measures that prohibit the supply of certain services were a "zero quota" and thus a violation of Article XVI(a) and (c) of the GATS, stating also that if general prohibitions on foreign service suppliers which were not expressed in numbers were to be considered outside the scope of Article XVI this would be an absurd result. ${ }^{1729}$ The United States argued that although the prohibition at issue may have had the effect of a zero numerical quota, it was a regulation limiting services having particular characteristics and was not in the form of a quota - thus not a measure that fell within Article XVI:2(a) and (c) of the GATS. ${ }^{1730}$ The Appellate Body decided otherwise, after looking at the Scheduling Guidelines, which regards measures that include the example of "nationality requirements for suppliers of services (equivalent to a zero quota)" as falling within Article XVI:2(a). ${ }^{1731}$ The Appellate Body also considered the meaning of the terms "monopoly" and "exclusive service suppliers" that appear in Article XVI:2(a) and stated that this should be read to "include limitations that are in form or in effect", monopolies or exclusive service suppliers. ${ }^{1732}$

The Panel in China-Electronic Payment Services also addressed the arguments concerning the scope of Article XVI:2(a) in US-Gambling and whether it covers measures that impose quantitative or quantitative-type limitations. The Panel concluded that they must focus not on whether there was a formal or explicit institution of a monopoly, but

\footnotetext{
${ }^{1727}$ Butkeviciene Jolita and David Diaz, GATS Commitments in the Health Services Sector and the Scope for Future Negotiations, UNCTAD-WHO Joint Publication, International Trade in Health Services: A Development Perspective, UNCTAD/ITCD/TSB/5-WHO/TFHE/98.1,1998, p147.

${ }^{1728}$ Panel Report, China-Electronic Payment Services, paras 7.511-7.512 - citing the former decisions of the Appellate Body Report, US-Gambling, para.143 and the Panel Report, China-Publications and Audiovisual Products, para.7.1354.

${ }^{1729}$ Panel Report, US-Gambling, para.6.332.

Delimatsis and Molinuevo refer to the whole of Part III of the GATS (Articles XVI, XVII and XVIII) as aiming to limit certain quantitative restrictions - Delimatsis P. and M. Molinuevo, Article XVI GATS in Wolfrum, Rudiger, Peter-Tobias Stoll and Clemens Feinaugle Eds., WTO - TRADE IN SERVICES, Max Planck Commentaries on World Trade Law, Martinus Nijhoff Publishers, 2008, p369.

See further Pauwelyn, J., Rien ne Va Plus? Distinguishing Domestic Regulation from Market Access in GATT and GATS, World Trade Review,4 (2) (2005): 131-170, p167, who agrees that the measure was a quality regulation which had the effect of becoming a zero quota on foreign suppliers supplying crossborder gambling, rather than a measure aimed at zero foreign supply while protecting domestic suppliers of the same service.

${ }^{1730}$ Appellate Body Report, US-Gambling, para.25.

${ }^{1731}$ Appellate Body Report, US-Gambling, para.237 citing para.6 of the Scheduling Guidelines S/L/92.

${ }^{1732}$ Appellate Body Report, US-Gambling, para.230.
} 
whether measures at issue would "constitute a limitation that is numerical and quantitative in nature" and limit suppliers to one, or a small number. ${ }^{1733}$ Thus, with regard to protection of sensitive public services, if Members do not enter specific limitations regarding these services, there could be a number of regulatory measures that could be interpreted as violating the obligations under Article XVI.

Article XVI can still be identified as a provision that allows for flexibility, since Members can choose if, when and how they make commitments in market access. Therefore, the GATS does not oblige a Member to open its market fully to foreign service providers, although negotiations between Members at formal or informal level may involve requests, encouragement and/or pressurization for greater liberalization and open markets.

Since market access is voluntary, it is important for Members who have not initially made commitments in health or health-related sectors to carefully consider the policy implications before taking any steps. It has been suggested that Members interested in opening their health sector to foreign health service providers should consider 'experimenting' with unilateral and non-binding liberalization outside of GATS, to gather evidence for the positive outcomes of such market access, (retaining the possibility of returning to status quo ante) before making GATS commitments. ${ }^{1734}$ With regard to health services, Smith et al state that "the central questions facing policymakers...[are] actually very simple, and very stark". ${ }^{1735}$ They list the following questions, that policy makers should avoid making commitments if the answer is 'no' or if there is any doubt:

1. Will increased trade in these services lead to better health outcomes?

2. Will increased liberalization of trade (more competition from foreign private health care companies) lead to better health outcomes?

3. Will making a GATS commitment in these sectors offer any additional advantage that will lead to better health outcomes?

It is also possible that there can be pressure from trading partners to make additional commitments, which can be negotiated under Article XVIII of the GATS. Van den Bossche commenting on the process of market access negotiations draws attention to the obligation of "due respect" for national policy objectives and the level of development of individual Members in Article XIX:2 of the GATS and that 'full reciprocity' in market access should not be expected from developing countries. ${ }^{1736}$ Thus, there may be some space retained in the GATS text, but the Member concerned must be strong in defending its policy position during negotiation with trade partners.

As a final point, it is relevant, as Delimatsis notes, that Article XVI and XVII being negotiable commitments has "considerably weakened the potential 'bite' of the

\footnotetext{
${ }^{1733}$ Panel Report, China-Electronic Payment Services, para.7.593.

${ }^{1734}$ Smith, Richard, Chantal Blouin, Nick Drager, Trade in Health Services and the GATS: Introduction and Summary in Blouin, Chantal, Nick Drager and Richard Smith Eds., INTERNATIONAL TRADE IN HEALTH SERVICES AND THE GATS: CURRENT ISSUES AND DEBATES, The World Bank, 2006, p13; also reiterated in another chapter of the same volume - Fidler, David P., Nick Drager, Carlos Correa, Obijiofor Aginam, Making Commitments in Health Services under the GATS: Legal Dimensions, p141.

${ }^{1735}$ Smith, Richard, Chantal Blouin, Nick Drager, Trade in Health Services and the GATS: Introduction and Summary in Blouin, Chantal, Nick Drager and Richard Smith Eds., INTERNATIONAL TRADE IN HEALTH SERVICES AND THE GATS: CURRENT ISSUES AND DEBATES, The World Bank, 2006, p13.

${ }^{1736}$ Van den Bossche, Peter, THE LAW AND POLICY OF THE WORLD TRADE ORGANIZATION:

TEXT, CASES AND MATERIALS, Cambridge University Press, $2^{\text {nd }}$ Edition, 2008,
} 
GATS". ${ }^{1737}$ This was part of the compromise over the resistance to the inclusion of disciplines on trade in services in WTO law. Article VI of the GATS had been adopted to deal with these types of domestic regulations, but has been left unfinished, with Members agreeing to develop disciplines in the area through the GATS Working Parties set up through the Council for Trade in Services. Currently (since 1999) the work is being carried out by the Working Party on Domestic Regulation (WPDR). ${ }^{1738}$ The last section of this Chapter discusses the implications of Article VI of the GATS in further depth.

1737 Delimatsis, P., Towards a horizontal necessity test for services: Completing the GATS Article VI:4 mandate in Panizzon, Marion, Nicole Pohl and Pierre Sauvé Eds., GATS AND THE REGULATION OF INTERNATIONAL TRADE IN SERVICES, Cambridge University Press, 2008, p370.

${ }^{1738}$ Earlier, the task was for the Working Party of Professional Services (from 1995-1999) - as the domestic regulation provisions and mandate closely affected professional services. For example, the Working Party on Professional Services submitted a Report (S/WPPS/4, 10 December 1998,) to the Council for Trade in Services on Disciplines on Domestic Regulation in the Accountancy Sector, including the informal note by the Chairman entitled "Discussion of Matters Relating to Articles XVI and XVII of the GATS in Connection with the Disciplines on Domestic Regulation in the Accountancy Sector". 


\subsection{ARTICLE VI OF THE GATS: DOMESTIC REGULATION}

'Are they bound?' he enquired.

'No, we aren't,' said Bruno, who thought himself quite able to answer this question.

The Professor shook his head sadly. 'Not even half-bound?'

'Why would we be half-bound?' said Bruno. 'We're not prisoners!'

From Lewis Carroll's Sylvie and Bruno

\subsubsection{The Relationship between Article VI and other GATS Provisions}

The relationship between Article VI and other GATS provisions is a matter of debate. With regard to the relationship between Article VI and Articles XVI and XVII of the GATS, which are specific commitments, it is unclear whether there is overlap and if so, to what extent. Delimatsis even says that the relationship between Articles VI, XVI and XVII is "the thorniest issue in the GATS today". ${ }^{1739}$ Article VI does not apply only to specific commitments but also has aspects of general obligations. Since paragraphs 1 to 3 of Article VI deal with general requirements for review of administrative decisions, and as it appears to have a general due process and good governance objective, it may appear at first that Article VI does not have specific problematic implications for public health services. However, paragraphs 4 and 5 of Article VI which provide for the negotiating mandate for future domestic regulation disciplines raise some concerns.

It can be argued that potential domestic regulation disciplines in services can be more intrusive on national policy space than regulation of trade in goods. ${ }^{1740}$ Delimatsis comments that since it is more difficult to control intangible services 'at the border' than it is for goods, and since domestic regulation can play a 'protectionist' role for domestic services, domestic regulation disciplines are more important for services. ${ }^{1741}$ However various legitimate policy objectives dealing with issues such as equitable access to essential services, consumer protection, environmental and human rights protection, as well as tackling market failure in general is carried out through such domestic regulation. How are these different positive and negative strands of regulation to be untangled? Would the WTO GATS disciplines alone provide the required framework? Andrew Lang has noted that a core criticism of WTO is the perception that it has "expanded unduly

1739 Delimatsis, P., INTERNATIONAL TRADE IN SERVICES AND DOMESTIC REGULATIONS: NECESSITY, TRANSPARENCY, AND REGULATORY DIVERSITY, Oxford University Press, 2007, p86.

${ }^{1740}$ WTO, Secretariat, Trade in Services Division, Background Note, Disciplines on Domestic Regulation Pursuant to GATS Article VI.4: Background and Current State of Play, June 2011, para.11:

Nonetheless, even in sectors where full market access and national treatment has been committed, foreign suppliers may still find it difficult under prevailing regulations to provide services in a host market. The existence of restrictive regulatory effects is more likely in services than in merchandise trade, given the defining role of regulation for products that are intangible by nature and the intrinsically close relationship between product and supplier.

${ }^{1741}$ Delimatsis, P., Due Process and 'Good' Regulation Embedded in the GATS - Disciplining Regulatory Behaviour in Services through Article VI of the GATS, Journal of International Economic Law, 10 (1) 1350, 2006, p16-17. 
beyond its core 'trade' mandate and become too intrusive of domestic regulatory autonomy". ${ }^{1742}$

Furthermore, liberalization of services requires some changes in domestic regulation and what these changes will be is something that can vary. Mattoo and Sauvé comment that the quality of domestic regulation may influence socio-economic effects of trade liberalization and issues such as universal access requirements and maintaining licensing standards for medical professionals. ${ }^{1743}$ This is also recognized by 2011 WTO Secretariat Background Note, which stated that:

A government may also be convinced that certain services, even if provided by private commercial entities, like education or health services, need to be available to all citizens at equitable conditions, no matter their location or income. ${ }^{1744}$

It is further added that:

...the opening of a hitherto restricted market may need to be accompanied by the introduction of licensing mechanisms and public service obligations for quality and social policy reasons. ${ }^{1745}$

This is particularly relevant for public health services, especially where there is a national health service that does not currently offer opportunities for competition (internal or external to the public health system) and entry of international service suppliers, but where there may be plans for potentially opening up some or all of the previously restricted market. It should also be noted with regard to licensing standards that General Comment No 14 on the right to health describes the obligation to protect right to health under Article 12 of the ICESCR as including:

...the duties of States to adopt legislation or to take other measures

ensuring ...that medical practitioners and other health professionals meet

appropriate standards of education, skill and ethical codes of conduct. ${ }^{1746}$

Thus, governmental decisions on regulation of medical and other health professionals are also part of the right to health obligations of the State, and not merely a trade issue concerning competitiveness and liberalization of trade in health services.

Box 1 of the Background Note identifies several 'examples of services-specific regulation to pursue public policy objectives'. The first item recognizes that 'basic equity objectives' would lead to governments ensuring that "all citizens have access to education and essential healthcare at low or zero cost". The measures identified under this are:

Cross-subsidization schemes to ensure that revenues in profitable areas are reinvested in favor of underdeveloped regions or persons in financial

1742 Lang, Andrew, Conclusion: After Neoliberalism in WORLD TRADE LAW AFTER NEOLIBERALISM: RE-IMAGINING THE GLOBAL ECONOMIC ORDER, Oxford University Press, 2011, p313.

${ }^{1743}$ Mattoo, Aaditya and Pierre Sauvé, Domestic Regulation and Trade in Services: Key Issues in Mattoo, Aaditya and Pierre Sauvé Eds., DOMESTIC REGULATION AND SERVICES TRADE LIBERALIZATION, World Bank and Oxford University Press, 2003.

${ }^{1744}$ WTO, Secretariat, Trade in Services Division, Background Note, Disciplines on Domestic Regulation Pursuant to GATS Article VI.4: Background and Current State of Play, June 2011, para.4.

1745 Ibid., para.5.

${ }^{1746}$ UN, CESCR (Committee on Economic, Social and Cultural Rights), General Comment 14, The Right to the highest attainable standard of health (Twenty-second session, 2000), U.N. Doc. E/C.12/2000/4 (2000), para.35. 
need; licensing conditions which include 'universal service obligations'

(for example, commercial hospitals are required to treat a certain percentage of patients free of charge).

Licensing conditions for a minimum percentage of free services that apply equally to domestic and foreign private suppliers are not likely to be violations of national treatment or market access under Article XVI and XVII - however it could be argued that the manner in which they are applied is arbitrary and unduly burdensome and thus in violation of Article VI:4 and VI:5 of the GATS since licensing conditions clearly fall within the scope of domestic regulation. The interesting issue is the mention of crosssubsidization schemes in the context of licensing conditions (as domestic regulation measures), suggesting that such cross-subsidization-related licencing conditions can be looked at under these disciplines in addition to Article XV Subsidies negotiations. Crosssubsidization is also seen elsewhere in the WTO context as something that should not be permitted. While not being a direct violation of market access or national treatment, cross-subsidization within public services, especially those with major market share, can discourage new foreign entrants to the domestic market and be seen as undermining commitments under Articles XVI and XVII. If Members wish to exclude such crosssubsidization-related licensing conditions that are designed to promote equity and social policy in public services delivery (or subsidize private service suppliers who would carry out these otherwise 'public' functions), it appears that they would have to cover a number of fronts including making sure it is protected in the scheduling of commitments and the application of domestic regulation - and not be limited only to the subsidies negotiations.

Immediately following the examples of public policy objectives in Box.1, Paragraph 7 of the Background Note comments that trade negotiations focus on removing 'trade barriers' - and that with regard to rules or regulations, including those mentioned in Box 1, these are not captured even in sectors and modes for which a Member has scheduled commitments on market access and national treatment without limitations. If this was presented as recognition of domestic policy space and regulatory autonomy as envisioned in the Preamble of the GATS, then that would have been fine and no concerns would be raised. However, the Note adds at Paragraph 8-9 that

It is important to ensure that benefits arising from existing commitments are not significantly curtailed by ineffective or inconsistent regulation. Many regulatory regimes have evolved in response to immediate problems and challenges, without much thought being given to trade and efficiency considerations...

The GATS does not interfere with WTO Member's regulatory objectives and concerns, but it recognises that certain measures could restrict trade. Thus, in addition to market access and national treatment, it contains a mandate to develop disciplines to ensure that measures relating to licensing requirements and procedures, qualification requirements and procedures, and technical standards do not constitute unnecessary barriers to trade in services.

The suggestion seems to be that despite the reiteration of non-interference with regulatory objectives and concerns based on public policy, measures such as those listed earlier on equity and social policy may yet be seen as "ineffective or inconsistent" measures that restrict trade and "trade and efficiency considerations". Thus, it is possible that the WTO disciplines would tackle what is thought to be "ineffective or inconsistent" social policy measures. 
This can be supported by arguments which have been made that Article VI:5 of the GATS also represents a non-violation nullification or impairment clause for the regulation of domestic services. The text of Article VI:4 read with Article VI:5 seems to support this view. This has been discussed by a number of scholars including Krajewski, who calls it both a codification of non-violation nullification and impairment as well as a "mixture ("mingling") of the concepts of non-violation and violation". ${ }^{174}$

This appears to make some serious inroads into domestic regulatory autonomy relating to technical standards, licensing and qualification requirements and appears to overweigh the balancing scales on the side of 'efficiency'. Considering that 'efficiency' in economic theory usually focuses on rational self-interest and wealth maximization as against 'irrational', 'altruistic' social policy choices and regulation, - the outcomes may not protect equity measures. The alternative view is that domestic regulation disciplines as mentioned in Article VI:4 only require objective and transparent criteria, not being more burdensome than necessary and that a licensing system should not form a trade barrier in itself; therefore, it would not be too intrusive or restrictive of domestic policy space.

Recognizing that there is a difference between the treatment of market access restrictions and domestic regulation (that of market access restrictions being stricter - a prohibition; whereas there appears to be more deference for domestic regulation per se), Pauwelyn argues that a domestic regulation should not be treated as a market access restriction simply because it has the effect of banning certain imports, as this would seriously undermine the regulatory autonomy of WTO Members. ${ }^{1748} \mathrm{He}$ is of the view that the internet gambling measures at issue in the US-Gambling dispute should not have been seen as market access restrictions but as domestic regulation subject to Articles VI and XVII of the GATS, and as technical standards. ${ }^{1749}$ The Panel in US-Gambling stated that the measures must either fall under Article XVI or Article VI and specifically that:

Thus, Article VI:4 and VI:5 on the one hand and XVI on the other hand are mutually exclusive. ${ }^{1750}$

The Panel did not give a clear basis for the conclusion and it was not an issue in the appeal and therefore was not clarified further. There is also nothing specific mentioned about the relationship between domestic regulation and Article XVII of the GATS on

\footnotetext{
${ }^{1747}$ Krajewski, M., Article VI GATS in Wolfrum, Rudiger, Peter-Tobias Stoll and Clemens Feinaugle Eds., WTO - TRADE IN SERVICES, Max Planck Commentaries on World Trade Law, Martinus Nijhoff Publishers, 2008, p193. See also support by Trachtman, Joel P., Lessons for the GATS from Existing WTO Rules on Domestic Regulation in Mattoo, Aaditya and Pierre Sauvé Eds., DOMESTIC REGULATION AND SERVICES TRADE LIBERALIZATION, World Bank and Oxford University Press, 2003, p67; Kim, Dae-Won, NON-VIOLATION COMPLAINTS IN WTO LAW: THEORY AND PRACTICE, Peter Lang, 2006, p57. See also arguments both for and against Article VI:5 being a non-violation provision by Delimatsis; who is more supportive of the interpretation that it is concerned with violations - Delimatsis, P., INTERNATIONAL TRADE IN SERVICES AND DOMESTIC REGULATIONS: NECESSITY, TRANSPARENCY, AND REGULATORY DIVERSITY, Oxford University Press, 2007, p122-127.

${ }^{1748}$ Pauwelyn, Joost, Rien ne Va Plus? - Distinguishing domestic regulation from market access in GATT and GATS, World Trade Review (2005), 4: 2, 131-170.

${ }^{1749}$ Krajewski, M., Article VI GATS in Wolfrum, Rudiger, Peter-Tobias Stoll and Clemens Feinaugle Eds., WTO - TRADE IN SERVICES, Max Planck Commentaries on World Trade Law, Martinus Nijhoff Publishers, 2008, p176: notes that TBT and SPS regulatory measures were used as examples/templates in the context of Article VI:4 of the GATS. But does this mean that a measure in services can be both domestic regulation and technical standards in services?

${ }^{1750}$ Panel Report, US-Gambling, para 6.305.
} 
national treatment. The position of the Panel has been criticized by Krajewski ${ }^{1751}$ stating that there is a simultaneous and cumulative application of Article VI and specific commitments. Contrary to this position, the Article VI:4 disciplines in accountancy services specifically exclude measures subject to scheduling under Articles XVI and XVII of the GATS from Article VI:4 disciplines, stating that:

Such measures are addressed in the GATS through the negotiation and scheduling of specific commitments. ${ }^{1752}$

This does not necessarily mean that future disciplines will follow the same position as the accountancy disciplines, although it would be problematic if the confusion on the application of the provisions and the classification of the relevant measures affecting services, continues.

Pauwelyn comments that the US-Gambling dispute highlighted the importance of correct classification of policy instruments under WTO law. He adds that:

The classification is crucial also for ongoing negotiations on disciplines for domestic regulation under Article VI:4 of GATS. Essentially, if the scope of market access restrictions under Article XVI of GATS were defined too broadly, as risks being the case after US-Gambling, scores of domestic regulations would already be prohibited and the ongoing negotiations would lose much of their purpose. ${ }^{1753}$

Article VI:4 of the GATS is probably the most debatable of the paragraphs of Article VI, as shall be discussed further in this section.

Article VI of the GATS is a mix of procedural and substantive obligations concerning domestic regulation that supplement the obligations of MFN (Article II of the GATS), national treatment (Article XVII) and market access (Article XVI). The way in which Article VI supplements these other provisions is by dealing with certain domestic regulations that are not inconsistent with the non-discrimination provisions of Articles II and XVII of the GATS, are compliant with market access obligations, but are still "burdensome" or too costly and therefore undermine non-discrimination or market access. Mattoo and Sauvé say that Article VI is the third prong of a three-pronged approach to effective access to services markets (the other two being Articles XVI and XVII of the GATS). ${ }^{1754}$

Article VI of the GATS is a lengthy and apparently rather complicated provision:

Article VI: Domestic Regulation

1. In sectors where specific commitments are undertaken, each Member shall ensure that all measures of general application affecting trade in services are administered in a reasonable, objective and impartial manner.

2. (a) Each Member shall maintain or institute as soon as practicable judicial, arbitral or administrative tribunals or procedures which provide, at

\footnotetext{
${ }^{1751}$ Krajewski, Wolfrum, Rudiger, Peter-Tobias Stoll and Clemens Feinaugle Eds., WTO - TRADE IN SERVICES, Max Planck Commentaries on World Trade Law, Martinus Nijhoff Publishers, 2008, p195196.

${ }^{1752}$ WTO, Council for Trade in Services, Disciplines on Domestic Regulation in the Accountancy Sector, S/L/64, 17 December 1998, adopted by the Council for Trade in Services on 14 December 1998, para.1.

${ }^{1753}$ Pauwelyn, Joost, Rien ne Va Plus? - Distinguishing domestic regulation from market access in GATT and GATS, World Trade Review (2005), 4: 2, 131-170, p133.

${ }^{1754}$ See also Mattoo, Aaditya and Pierre Sauvé, Domestic Regulation and Trade in Services: Key Issues in Mattoo, Aaditya and Pierre Sauvé Eds., DOMESTIC REGULATION AND SERVICES TRADE LIBERALIZATION, World Bank and Oxford University Press, 2003, p3.
} 
the request of an affected service supplier, for the prompt review of, and where justified, appropriate remedies for, administrative decisions affecting trade in services. Where such procedures are not independent of the agency entrusted with the administrative decision concerned, the Member shall ensure that the procedures in fact provide for an objective and impartial review.

(b) The provisions of subparagraph (a) shall not be construed to require a Member to institute such tribunals or procedures where this would be inconsistent with its constitutional structure or the nature of its legal system.

3. Where authorization is required for the supply of a service on which a specific commitment has been made, the competent authorities of a Member shall, within a reasonable period of time after the submission of an application considered complete under domestic laws and regulations, inform the applicant of the decision concerning the application. At the request of the applicant, the competent authorities of the Member shall provide, without undue delay, information concerning the status of the application.

4. With a view to ensuring that measures relating to qualification requirements and procedures, technical standards and licensing requirements do not constitute unnecessary barriers to trade in services, the Council for Trade in Services shall, through appropriate bodies it may establish, develop any necessary disciplines. Such disciplines shall aim to ensure that such requirements are, inter alia:

(a) based on objective and transparent criteria, such as competence and the ability to supply the service;

(b) not more burdensome than necessary to ensure the quality of the service;

(c) in the case of licensing procedures, not in themselves a restriction on the supply of the service.

5. (a) In sectors in which a Member has undertaken specific commitments, pending the entry into force of disciplines developed in these sectors pursuant to paragraph 4, the Member shall not apply licensing and qualification requirements and technical standards that nullify or impair such specific commitments in a manner which:

(i) does not comply with the criteria outlined in subparagraphs 4(a), (b) or (c); and

(ii) could not reasonably have been expected of that Member at the time the specific commitments in those sectors were made.

(b) In determining whether a Member is in conformity with the obligation under paragraph 5(a), account shall be taken of international standards of relevant international organizations (3) applied by that Member.

(original footnote) 3: The term "relevant international organizations" refers to international bodies whose membership is open to the relevant bodies of at least all Members of the WTO.

6. In sectors where specific commitments regarding professional services are undertaken, each Member shall provide for adequate procedures to verify the competence of professionals of any other Member. 
As can be seen, there are some aspects of Article VI which apply only if commitments are scheduled and others that apply upon all WTO Members regardless of scheduling. Articles VI:1, VI:2, VI:3 and VI:6 consist of procedural obligations. Article VI:1, VI:3, VI:5 and VI:6 apply only if commitments have been made whereas Article VI:2 is a general obligation on general administrative procedures.

The provisions abovementioned focus on the standards to be followed when administering and reviewing a measure and it has been commented that this places the provisions in the wider context of the transparency obligations of Article III of the GATS. ${ }^{1755}$ The Panel in US-Gambling noted specifically with regard to Article VI:3 of the GATS, that it "imposed transparency and due process obligations". ${ }^{1756}$ Krajewski also refers to the due process objective and compares Article VI of the GATS with Article $\mathrm{X}: 3(\mathrm{~b})$ and (c) of the GATT and reference to the latter in EC-Selected Customs Matters. ${ }^{1757}$ The provisions of Article VI set standards regarding administrative review that may impose an additional administrative burden and cost upon Members, especially in the case of developing country and LDC Members. ${ }^{1758}$ It is also commented that there is an 'internationalization' of domestic administrative decision-making since Members must now also take non-domestic stakeholder interests into account in setting up administrative review processes.

With regard to policy flexibility, Article VI:2(b) is important as it allows Members to deviate from the Article VI:2 standards for constitutional reasons. As noted earlier in the Introduction to this study, this is an explicit exception from the general rule that applies for the relationship between international and domestic law - and which is codified in Article 27 of the VCLT - that domestic law cannot be used as a justification or excuse for the non-fulfillment of international treaty obligations.

Where commitments have been undertaken, these provisions require that all measures of general application affecting trade in services shall be administered in a reasonable and objective and impartial manner. Therefore, VI:1, 3 and 6 would apply to public health services only if such public services are identified as falling within the scope of the GATS and health services are scheduled without a public services exception included as a limitation in national treatment (or if that scheduled limitation is not accepted as an allowable limitation). So, at first glance Article VI appears to be mostly irrelevant for sectors where commitments have not been made.

It may also be relevant to the understanding of "domestic regulation" that the Appellate Body in Argentina-Financial Services compared the Article VI of the GATS with paragraph 2(a) of the Annex on Financial Services. The Appellate Body did this in the

\footnotetext{
${ }^{1755}$ Krajewski, M., Article VI GATS in Wolfrum, Rudiger, Peter-Tobias Stoll and Clemens Feinaugle Eds., WTO - TRADE IN SERVICES, Max Planck Commentaries on World Trade Law, Martinus Nijhoff Publishers, 2008, p168 citing Delimatsis, Article III GATS in the same volume. Krajewski also cites the WPDR p190-191.

${ }^{1756}$ Panel Report, US-Gambling, para.6.432.

${ }^{1757}$ Krajewski, M, Article VI GATS in Wolfrum, Rudiger, Peter-Tobias Stoll and Clemens Feinaugle Eds., WTO - TRADE IN SERVICES, Max Planck Commentaries on World Trade Law, Martinus Nijhoff Publishers, 2008, p173, citing EC-Selected Customs Matters, para.302.

1758 See further, South Centre Analytical Note, Background Note: Article VI (Domestic Regulation) with Emphasis on Paragraph 4 and the EU and Japanese Proposals, SC/TADP/AN/SV/4, December 2003, especially para.20, which suggests that the administrative burden may require special and differential treatment to be applied.
} 
context of Argentina's defence that the measures at issue in that dispute were justified by the exceptions in Articles XIV(c) and XIV(d) of the GATS and Paragraph 2(a) of the GATS Annex on Financial Services. Paragraph of the 2(a) Annex on Financial Services, is sometimes referred to as the 'prudential exception' since it is an exception for 'prudential reasons' - to ensure the integrity and stability of the financial system. The Appellate Body noted that the title of paragraph 2(a) of the Annex on Financial Services was "Domestic Regulation" and made the observation that neither the Annex on Financial Services nor the GATS itself contains a definition of the term "domestic regulation". ${ }^{1759}$ It was stated that the Appellate body was of the view that:

... the meaning and function to be attributed to the title should be consistent with a proper interpretation of paragraph 2(a) itself. In this respect, we note that the Appellate Body has, in prior cases, referred to the title of a provision to reinforce its interpretation of the text of that provision. ${ }^{1760}$... [and] the context provided by Article VI of the GATS, which is also entitled "Domestic Regulation", may shed some light on the meaning and function of the title of paragraph 2(a).

However, the Appellate Body came to the conclusion that both Article VI and paragraph 2(a) of the Annex on Financial Services indicated that measures falling under these provisions should be "construed in a broad sense and should not serve the function of restricting the types of measures" which would fall under that provision. ${ }^{1761}$ The Appellate Body did not disagree with the Panel, which has stated that paragraph 2(a) was not an 'escape valve' limited to domestic regulations which violated Article VI but also applied to those measures which may be covered by other provisions of the GATS (such as those relating to market access, national treatment or MFN treatment). ${ }^{1762}$ Thus, in terms of financial services, the measures covered by the prudential exception do not need to be confined to the type of measures envisaged in Article VI of the GATS, which is also entitled 'Domestic Regulation'.

\subsubsection{Article VI:4 and VI:5 of the GATS}

Article VI:4 and VI:5 are the more complicated provisions in Article VI of the GATS. Both Article VI:4 and VI:5 are substantive obligations - but Article VI:5 contains provisional measures which are applicable until the necessary disciplines to be negotiated under Article VI:4 are developed. Article VI:4 is a negotiating mandate for domestic regulations disciplines on qualification requirements and procedures, technical standards and licensing requirements. Its scope is as yet unclear. Article VI:5 appears to apply only to sectors that have been scheduled, but also has a close relationship with Article VI:4, as VI:5 applies pending the entry into force of disciplines under the Article VI:4 negotiating mandate.

It is argued whether Article VI:4 applies only to sectors which have been scheduled or is generally applicable even if sectors have not been scheduled. Krajewski says that the text of Article VI:4 neither confirms or specifically disallows the interpretation that it applies only to sectors which have been scheduled, but that there is a 'suggestion' of

\footnotetext{
${ }^{1759}$ Appellate Body Report, Argentina-Financial Services, para. 6.257.

${ }^{1760}$ Ibid., The original footnote cited and explained the Appellate Body Report, US - Carbon Steel, para. 67

${ }^{1761}$ Appellate Body Report, Argentina-Financial Services, para.6.258.

1762 Appellate Body Report, Argentina-Financial Services, para.6.268, citing the Panel Report, ArgentinaFinancial Services, para. 7.848.
} 
general/horizontal applicability. ${ }^{1763}$ An argument in favour of general applicability is that it is under Part II of the GATS (General Obligations and Disciplines) and not Part III (Specific Commitments), and thus, unless specifically mentioned that it applies only to sectors where specific commitments are undertaken (Article VI:1, VI:3, VI:5 and VI:6), it can be assumed to be a general obligation. The only other sub-section of Article VI that does not mention specific commitments as the basis for its operation is VI:2 which obliges a Member to maintain or institute "judicial, arbitral or administrative tribunals or procedures" for review and remedies for administrative decisions affecting trade in services. The broad disciplines for qualifications, licensing, standards etc. in Article VI:4 appear to be similarly general obligations not dependent on the commitment of a service sector. The difference is that tribunals and procedures are of course not sector specific in nature, while there may be sector specific features and requirements for qualifications etc.

Ultimately the interpretation and application of Article VI of the GATS depends also on what is assumed to be its purpose. If it is to ensure that market access and national treatment commitments are not made meaningless due to qualification, licensing, standards etc., then Article VI:4 is limited to scheduled sectors. If the purpose is for harmonization of such licensing, standards etc. ${ }^{1764}$, then Article VI:4, if put in effect, would involve extensive involvement in what are ordinarily areas of national regulatory sovereignty. This would go counter to the proposition that the GATS allows for the greatest extent of policy space in comparison with other WTO agreements - and instead turns it into the most intrusive. Such an interpretation of Article VI:4 would also be in effect an extension of the whole scope of the GATS into details of domestic regulatory matters. Article VI:4 merely provides for the possibility to negotiate such rules in the future and does not automatically, as of now, have this impact on GATS Members. Yet Article VI:4 also explicitly refers to ensuring that the measures covered by the provision would not remain "unnecessary barriers to trade in services". Until such disciplines come into place, Article VI:5 is applicable to services where specific commitments have been made and it currently already imposes on licensing and qualification requirements and technical standards.

Probably in response to some of the concerns expressed by Members on the impact of Article VI:4, an unofficial briefing Note prepared by the WTO Secretariat notes that: Importantly, the Article VI:4 mandate is not intended to launch a deregulatory process, but rather promote a programme for better regulation to realize any of the policy objectives a Member may seek to achieve [original emphasis]. ${ }^{1765}$

However, Article VI:4 gives the Council for Trade in Services a broad mandate to develop multilateral disciplines in this area. Krajweski notes that:

The term disciplines refers to norms which restrict (i.e. discipline) governmental and administrative discretion. By choosing this term, the

\footnotetext{
${ }^{1763}$ Krajewski, M., Article VI GATS in Wolfrum, Rudiger, Peter-Tobias Stoll and Clemens Feinaugle Eds., WTO - TRADE IN SERVICES, Max Planck Commentaries on World Trade Law, Martinus Nijhoff Publishers, 2008, p1843-184.

1764 This could be considered one of the aims of the Art VI:4 negotiations (for unscheduled sectors) whereas the Article VI:4 disciplines applied to scheduled sectors via Article VI:5 prevent nullification or impairment of such specific commitments through qualification requirements, standards and licencing.

${ }^{1765}$ WTO, Trade in Services Division, Briefing Document: Disciplines on Domestic Regulation Pursuant to GATS Article VI.4 - Background and Current State of Play, June 2011, para.15. Note that this is not an official record of the negotiations.
} 
GATS drafters indicated that the norms to be developed under Article

VI:4 aim at the limitation of domestic regulatory autonomy. ${ }^{1766}$

The Article VI:4 mandate for work on developing disciplines in domestic regulation concern ensuring that the following types of measures "do not constitute unnecessary barriers to trade in services":

1. qualification requirements

2. qualification procedures,

3. technical standards

4. licensing requirements and

5. licensing procedures.

These are the 5 types of measures that are being discussed under Article VI:4 in the Working Party on Domestic Regulation. ${ }^{1767}$ According to Article VI:4, the disciplines shall aim to ensure that such requirements as mentioned above are:

(a) based on objective and transparent criteria, such as competence and the ability to supply the service;

(b) not more burdensome than necessary to ensure the quality of the service;

(c) in the case of licensing procedures, not in themselves a restriction on the supply of the service.

Article VI:5(a) is connected to VI:4 because it states that pending disciplines under VI:4, Members who have made specific commitments shall not apply licensing and qualification requirements and technical standards that "nullify or impair such specific commitments" in a manner that does not comply with (a), (b) and (c) above and which "could not have been reasonably expected of that Member at the time the specific commitments in those sectors were made".

Article VI:5(b) adds that "international standards of relevant international organizations" $" 1768$ shall be taken into account when determining the conformity of a Member under VI:5(a). Thus, it appears that Article VI:5 of the GATS is an opportunity for other international standards to enter into the WTO context. However, the footnote to Article VI:5 (Footnote 3 of the GATS) suggests that this does not include regional standard-setting bodies as it refers to bodies whose membership is open to at least all WTO Members. An example of what may not be covered is something like the Basel Committee on Banking Supervision, which plays an important role is financial services regulation in many countries but its membership is technically open only to G10 countries. $^{1769}$

${ }^{1766}$ Krajewski, M., Article VI GATS in Wolfrum, Rudiger, Peter-Tobias Stoll and Clemens Feinaugle Eds., WTO - TRADE IN SERVICES, Max Planck Commentaries on World Trade Law, Martinus Nijhoff Publishers, 2008, p178.

${ }^{1767}$ WTO, Trade in Services Division, Briefing Document: Disciplines on Domestic Regulation Pursuant to GATS Article VI.4 - Background and Current State of Play, June 2011, para.15. Note that this is not an official record of the negotiations

1768 Footnote 3 of the GATS defines "relevant international organizations" as those bodies whose membership is open to the relevant bodies of all WTO Members, so this excludes regional standard setting organizations or other forms of exclusive standard setting.

1769 Kaufman, Christine and Rolf. H. Weber, Reconciling Liberalized Trade in Financial Services and Domestic Regulation in Alexander, Kern and Mads Andenas Eds., THE WORLD TRADE ORGANIZATION AND TRADE IN SERVICES, BRILL, 2008, p416, 417, 423. The authors argue that the BCBS standards represent the state of the art in banking supervision and should be taken into account. Thus, they argue that this footnote (Footnote 3 of the GATS - to "relevant international organizations" in Article VI:5) does not apply to paragraph 2(a) of the Annex on Financial Services (the "prudential carveout'). But they add that in case of doubt, that the exception in Article XIV(a) of the GATS could be resorted to. 
Even if Article VI:5(b) was not analyzed in the Argentina-Financial Services dispute, it is notable that Argentina in its WTO dispute with Panama, cited the standards of the 'Global Forum' of the Organization for Economic Co-operation and Development (OECD), the 2012 Financial Action Task Force (FATF) Recommendations ${ }^{1770}$ and G20 standards in defending its measures under Article XIV(c) of the GATS. ${ }^{1711}$ Argentina submitted that, while the measures at issue seek to ensure compliance with Argentine laws or regulations, these are, in turn, in line with the international instruments. ${ }^{1772}$ The Global Forum has 144 members, and no restrictions on applying except an annual fee (minimum EUR 15 $300)^{1773}$ but FATF has a set of criteria to be applied before considering a country as a potential candidate for FATF membership. ${ }^{1774}$ The inter-governmental network of FATF members include countries in all continents. Argentina is member of both FATF and the Financial Action Task Force of Latin America (GAFILAT - formerly known as GAFISUD: Financial Action Task Force of South America). Panama is a member of GAFILAT. According to the limitation in Footnote 3 of the GATS, the standards of FATF and GAFILAT could not apply as "relevant standards". Thus, it is clear that there can be international standards which are important in a particular service sector and which Members may take into account in formulating policy and domestic regulation and even be referred to in disputes as the basis for measures; but which do not fall within Article VI:5 and Footnote 3 of the GATS.

For the health services sector, important international standards include the WHO International Health Regulations (WHO-IHR), as revised and approved by the World Health Assembly in 2005. ${ }^{1775}$ The IHR (2005) are binding upon member States of the WHO, as per the WHO Constitution and requires steps to be taken to strengthen public health regulatory power and the capacity to respond well and quickly to a public health event of international concern. The IHR (2005) broadens the obligations and expands the scope of application from previous WHO regulations to include new obligations for Member States to develop and maintain core capacities for disease surveillance and response. ${ }^{1776}$ Article 3 of the IHR (2005) include the principle that:

States have, in accordance with the Charter of the United Nations and the principles of international law, the sovereign right to legislate and to implement legislation in pursuance of their health policies. In doing so, they should uphold the purpose of these Regulations [emphasis added].

It has been commented that the effects of the IHR (2005) has been to make new demands on public policy and national and global governance structures, including new legislation and has created a "greater impetus for intervention (and ownership) by central

\footnotetext{
${ }^{1770}$ Financial Action Task Force (FATF) Recommendations, International Standards on Combating Money Laundering and the Financing of Terrorism and Proliferation (February 2012)

1771 Panel Report, Argentina-Measures Relating to Trade in Goods and Services, paras.7.673-7.676; Appellate Body Report, Argentina-Financial Services, section 5.2 and footnote 468.

${ }_{1772}$ Panel Report, Argentina Financial Service, para. 7.597.

1773 See further http://www.oecd.org/tax/transparency/about-the-global-forum/members/.

1774 See further, http://www.fatf-gafi.org/about/membersandobservers/fatfmembershippolicy.html, which lists the quantitative, qualitative and additional factors for membership, as well as the criteria of enhancing 'geographic balance'.

1775 This was built on the first International Sanitary Convention of 1892, which later became the International Sanitary Regulations. WHO Member States adopted this convention in 1951 The regulations were revised and renamed the International Health Regulations (IHR) in 1969

${ }^{1776}$ Katz, Rebecca, and Sarah Kornblet, Comparative Analysis of National Legislation in Support of the Revised International Health Regulations: Potential Models for Implementation in the United States, American Journal of Public Health 100.12 (2010): 2347-2353.
} 
governments in health care services". ${ }^{1777}$ It is fair to say that health policy is increasingly being both internationalized as well as centralized at the national level, since coordinated responses are needed for both global and national public health issues as well as for general preparedness and institutional capacity of by public health authorities. This is not only in the case of epidemic and pandemic infectious disease focused on by the IHR, but also in the case of widespread chronic non-communicable disease.

The WTO has been identified as a key partner for the WHO in implementing the IHR (2005) in a 2007 document on implementation of the IHR, but there is no elaboration on this point. ${ }^{1778}$ There has also been no reference to international health standards in the context of ongoing WTO negotiations. However, the WTO-WHO joint study on WTO Agreements and public health in 2002 discussed the IHR and its proposed revision (still pending at that time) as being one that should have a "consensus among health and trade interests" and make sure that there is "minimum disruption" caused to world trade by temporary and well-aimed measures based on the needs and risks. ${ }^{1779}$ There is no mention of the WTO needing to take such international regulatory standards into account in the context of trade law. Standards in the context of the IHR have been usually discussed in the context of the SPS Agreement, but infectious disease responses could also have a services implication as the IHR deals mostly with diseases spread by humans (not only food and plant material which would be covered by SPS measures) and which would sometimes require restrictions in cross-border travel of human beings or regulations concerning the manner in which various services are provided.

The Council for Trade in Services is given the responsibility to develop the necessary disciplines, under Article VI:4, through any appropriate bodies it may establish. As yet, negotiated domestic regulation disciplines exist only for accountancy, ${ }^{1780}$ and this was created during the time that the matter was dealt with under the former Working Party on Professional Services, which was later replaced by the Working Party on Domestic Regulation in 1999. It is not yet binding and it was decided that it would only be binding if specific commitments in the accountancy sector had been undertaken. ${ }^{1781}$ It is not clear whether this would be the model for future disciplines. The Working Party on Domestic Regulation has met a number of times, but a public draft including general or sectoral proposals on areas such as health have not been forthcoming.

One of the most recent WTO briefing documents on disciplines in domestic regulations (released in 2011), notes that in the WPDR reveals that Members have been negotiating on a set of horizontal disciplines on domestic regulation, which do not preclude the possibility of future work on sectoral disciplines. ${ }^{1782}$ Because of the sensitive nature of certain services, such as health, education, cultural services etc., perhaps it is more

\footnotetext{
1777 Kamradt-Scott, Adam, Changing Perceptions: of Pandemic Influenza and Public Health Responses, American Journal of Public Health 102.1 (2012): 90-98.

1778 WHO, International Health Regulations (2005): Areas of work for implementation, WHO/CDS/EPR/IHR/2007.1, June 2007, p18, http://www.who.int/ ihr/finalversion9Nov07.pdf.

1779 WTO/WHO, The WTO Agreements and Public Health: A Joint Study by the WHO and WTO Secretariat, authored by Drager, N. and Miguel Rodríguez Mendoza et al., 2002, p106 and p100.

${ }^{1780}$ WTO, Council for Trade in Services, Working Party on Professional Services, Disciplines on Domestic Regulation in the Accountancy Sector, S/L/64, 17 December 1998.

${ }^{1781}$ Ibid., (S/L/63).

1782 WTO, Trade in Services Division, Briefing Document: Disciplines on Domestic Regulation Pursuant to GATS Article VI.4 - Background and Current State of Play, June 2011, para.18. Note that this is not an official record of the negotiations
} 
suitable to develop sectoral disciplines. However, no results have yet been forthcoming, perhaps due to these sensitivities and reluctance of Members to allow for more intrusion into the domestic regulation framework of such services.

In 2013, the Working Party on Domestic Regulation requested that the Secretariat prepare a Note on regulatory issues in the health services sector. This Note is dated $30^{\text {th }}$ April 2013 and was originally marked "restricted". The Note makes significant general observations on the necessity of regulation and the objectives of health systems, including acceptance that:

The vast majority of health systems share similar objectives, namely universal access, equitable provision, quality services and efficient use of resources

...regulation is necessary to ensure that health personnel and facilities comply with certain quality, safety and ethical standards, to name a few. ${ }^{1783}$

However, the Note appears to approach health services from primarily a developed country, private provider perspective, focusing on issues such as oversupply of healthcare, aging populations and non-communicable diseases needing long and expensive treatments - and the responses to these issues such as measures to control and contain treatment costs. ${ }^{1784}$

The Note of 2013 does mention "universal access to health care, in particular to remote or poor areas"; but this is not mentioned in the context of public health services, but in saying that capital investment is high and returns are low, and discussing financial incentives, apparently for the private sector to make these investments. ${ }^{1785}$ The same paragraph in the Note identifies these financial incentives to include:

...government loans at low interest, government guarantees for borrowing on private markets, tax waivers and exemptions, direct government subsidies or bonuses to operate in underserved areas.

There is no suggestion in the Note of whether public health services are placed in a better position for ensuring universal access (including affordability) for the poor and for those in remote areas. However, the Note concludes that there are questions which could be further discussed with respect to the regulation of the health sector, including further information on Members regulatory practices in the health services sector or on specific segments - and the GATS implications. ${ }^{1786}$ This could be an opportunity for Members with successful public health services to share the effectiveness of their systems, particularly in light of the fact that health services to the poor and rural health services are not areas where private investors can get good returns on their investments unless public money is funneled into the said investments as incentives. There is no knowing whether this information exchange and discussion will occur and under what circumstances. Questions for further discussion with respect to health services is raised in the Note in the context of "the most significant problems from a trade perspective and how might disciplines under VI:4 help to address them? [emphasis added]". ${ }^{1787}$

\footnotetext{
1783 Working Party on Domestic Regulation, Note by the Secretariat: Regulatory issues in sectors and modes of supply (Addendum), RESTRICTED, S/WPDR/W/48/Add.1, 30 April 2013, paras.2.1 and 2.2.

${ }^{1784}$ Ibid., paras.2.3 and 2.4.

${ }^{1785}$ Ibid., para.2.18.

${ }^{1786}$ Ibid., para.2.23.

${ }^{1787}$ Ibid., para.2.23.
} 
While the negotiations on domestic regulation are still on-going, Members' proposals and several versions of a Chairman's text reflecting drafting suggestions, have been produced. ${ }^{1788}$ The most recent steps were taken when a group of 25 Members led by the EU and Australia co-sponsored a proposal ${ }^{1789}$ at the 11th WTO Ministerial Conference in December 2017. This proposal covered clarifications on issues including enhanced transparency mechanisms, establishment of enquiry points, acceptance of electronic applications, a necessity test, and a new section on 'development' (particularly focused on 'trade assistance'), apparently inspired by the principles governing the Trade Facilitation Agreement which had entered into force in February 2017. There was a mention of health in a footnote in this document in relation to ensuring objective and transparent criteria for developing measures relating to authorization for the supply of a service. The footnote stated as follows:

For greater certainty, such criteria may include, inter alia, competence and the ability to supply a service, including to do so in a manner consistent with a Member's regulatory requirements, such as health and environmental requirements. Competent authorities may assess the weight to be given to each criterion [emphasis added]. ${ }^{1790}$

No consensus was achieved at the Ministerial, but there was a Joint Ministerial Statement made by 58 Members that reaffirmed the commitment to "advancing negotiations on the basis of recent proposals...related discussions in the WPDR and future contributions by Members to deliver a multilateral outcome". ${ }^{1791}$ India (which was not one of the WTO Members involved in the above proposals) made a formal request in relation to the WPDR discussions in 2018 (with regard to Mode 4 - professional services sector) and in 2019 on a Members' "right to regulate...to meet national policy objectives", with special emphasis on developing country needs in this regard. ${ }^{1792}$ Thus, in recent years there appears to be a certain amount of emphasis on retaining policy space for domestic regulation for health services, also taking the development asymmetries between Members into account.

While much of the details of the negotiations are not public, it was noted that consideration has been given to the following regulatory principles: transparency, legal certainty, impartiality and objectivity, relevance of foreign qualifications and experience (including agreements to accept the equivalence of qualifications or unilaterally

${ }^{1788}$ Drafts include the Chairman's March 2009 text which was discussed further together with alternative proposals during the DDA negotiations during March 2011.

1789 WTO, JOB/SERV/272/Rev.1, released on 7 November 2017 and the final updated version JOB/SERV/272/Rev. 2, 24 November 2017. See also as WT/MIN(17)/7/Rev.2, 13 December 2017.

${ }^{1790} \mathrm{WT} / \mathrm{MIN}(17) / 7 /$ Rev.2, para.6.1, footnote 8 .

1791 WTO, Joint Ministerial Statement on Services Domestic Regulations, WT/MIN(17)/61, 13 December 2017.

1792 WTO, Communication from India: GATS Article VI:4: Disciplines for supply of a service through the presence of a natural person of a member in the territory of another member: Draft for Discussion, S/WPDR/W/61/Rev.1, 8 March 2019, para.2:

Members recognize the right to regulate, and to introduce new regulations, on the supply of services within their territories in order to meet national policy objectives and, given asymmetries existing with respect to the degree of development of services regulations in different countries, the particular need of developing countries to exercise this right. These disciplines should not be construed to prescribe or impose particular regulatory approaches or any particular regulatory provisions in domestic regulation. 
recognition of equivalence), ${ }^{1793}$ standard-setting at the international level for evaluation of professional qualifications and necessity. It is this last principle that has gained most attention.

\subsubsection{A 'Necessity Test' for Domestic Regulation?}

Article XX of the GATT 1994, Articles XIV and VI:4 of the GATS, Article 2.2 of the TBT Agreement and Article 5.6 of the SPS Agreement all refer to the term 'necessity' and there has also been a background note prepared by the WTO Secretariat on this concept. ${ }^{1794}$ 'Necessity' can be used as both a balancing mechanism (in GATT and GATS exceptions) as well as a positive obligation (in the TBT and SPS). ${ }^{1795}$ There is still academic debate as to whether disciplines developed under Article VI:4 of the GATS need a specific necessity test. ${ }^{1796}$ Article VI:4 refers to ensuring that qualification requirements etc., do not "constitute unnecessary barriers to trade" and that according to VI:4(b) that these are "not more burdensome than necessary". The scope of such a necessity test for domestic regulation is important from two points of view. One view is that a necessity test restricts domestic regulation itself, and the other is that such a test for Article VI could be a way to balance national policy objectives and trade goals in domestic regulation.

With regard to developing domestic regulation disciplines for services, the link between necessity and legitimate public policy restrictions - "...the importance of domestic regulation in pursuing national policy objectives" - was recognized by the Council for Trade in Services in the Preamble of the 1999 Decision on Domestic Regulation. The unofficial 2011 briefing paper on domestic regulation in services also notes that the same objective is in the Preamble to the GATS. ${ }^{1797}$ Examples of such policy objectives noted in the briefing paper include concerns about the equitable provision of education or health services (when mainly being provided by private commercial entities) which may require cross-subsidization schemes in aid of access to education and essential health care at low or zero costs and licensing conditions which include 'universal service obligations' as well as additional public service obligations for quality and social policy reasons. ${ }^{1798}$ Article VI may possibly be going further than needed for the objective of expansion of trade (as stated in Recital 2 of the Preamble of the GATS) into areas of complex public policy.

\footnotetext{
1793 GATS Article VII allows for recognition measures as long as there are adequate provisions for other Members to negotiate accession and/or achieve recognition of their requirements and certificates, and the measures do not constitute a means of discrimination or a disguised restriction on trade

${ }^{1794}$ WTO, Secretariat Background Note, "Necessity Tests" in the WTO, S/WPDR/W/27/Add.1 and Corr.1.

1795 Krajewski, M., Article VI GATS in Wolfrum, Rudiger, Peter-Tobias Stoll and Clemens Feinaugle Eds., WTO - TRADE IN SERVICES, Max Planck Commentaries on World Trade Law, Martinus Nijhoff Publishers, 2008, p186.

${ }^{1796}$ Delimatsis supports a necessity test strongly, stating that not to do so would be against the legal mandate of Article VI:4 (Delimatsis, P., Who's afraid of Necessity? And Why it Matters in Lim, A.H. and Bart de Meester Eds., WTO DOMESTIC REGULATION AND SERVICES TRADE: PUTTING PRINCIPLES INTO PRACTICE, Cambridge University Press, 2014, p108)

${ }^{1797}$ WTO, Trade in Services Division, Disciplines on Domestic Regulation Pursuant to GATS Article VI.4Background and Current State of Play, June 2011, para.3.

${ }^{1798}$ Ibid, see para.4 - 5 and para.6, Box 1.
} 
The 2011 briefing paper states that "necessity tests" focus on: ...whether a legitimate objective chosen by a WTO Member could equally be achieved by means of a reasonably available alternative that is less trade-restrictive. ${ }^{1799}$

The disciplines on domestic regulation in the accountancy sector also included this important feature regarding standards on domestic measures: that the measures are subject to a 'necessity test' shall not be "more trade restrictive than necessary to fulfill legitimate objectives". Paragraph 2 of the accountancy document ${ }^{1800}$ has an illustrative list of legitimate objectives that include consumer protection, quality of the services and professional competence and integrity of the profession. Paragraph 26 adds that in determining whether a measure is in conformity with the obligations under Paragraph 2, account shall be taken of internationally recognized standards of relevant international organizations applied by that Member. ${ }^{1801}$ This is defined in the exact same way as footnote 3 to Article VI:5(b) of the GATS, as

The term "relevant international organizations" refers to international bodies whose membership is open to the relevant bodies of at least all Members of the WTO.

If this pattern is followed for sectoral domestic regulation disciplines, it could be a way of introducing human rights standards into the disciplines of sectors such as health, education, water and sanitation (environmental) services etc. However, since Article $\mathrm{VI}: 5(\mathrm{~b})$ does not mention actual participation in such standard setting processes, and considering the difficulties and costs that developing and LDC Members face with participation in such international bodies, there is also some concern that this could also be a way of imposing standards by some Members or organizations, on other Members. The consequences of not abiding by such standards could be non-violation complaint under Article VI:5(a).

Delimatisis argues that Members will not fulfil the mandate of Article VI unless they create a necessity test for drawing the line between legitimate regulation and protectionism - preferably a horizontal necessity test. ${ }^{1802}$ It can also be argued both pro and con whether such a horizontal necessity test will compromise or retain the quality of national policy flexibility, but a conclusion on this cannot be drawn without a draft or finalized text on domestic regulation being available. The drawbacks of such a horizontal necessity test are that on the one hand, such a horizontal necessity test would have to be so generalized as being of little practical worth, and on the other hand, such an approach would be ignoring the nature and diversity of services within and between Members and their particular regulatory needs. ${ }^{1803}$ Sectoral disciplines could "address specific regulatory needs" 1804 in sensitive areas such as health services.

\footnotetext{
1799 Ibid., para.18(f).

${ }^{1800}$ WTO, Trade in Services Division, Disciplines on Domestic Regulation in the Accountancy Sector, 17 December 1998, S/L/64.

${ }^{1801}$ Ibid., original footnote to paragraph 26.

1802 Delimatsis, P., Towards a horizontal necessity test for services: Completing the GATS Article VI:4 mandate in Panizzon, Marion, Nicole Pohl and Pierre Sauvé Eds., GATS AND THE REGULATION OF INTERNATIONAL TRADE IN SERVICES, Cambridge University Press, 2008, p371.

1803 South Centre Analytical Note, Background Note: Article VI (Domestic Regulation) with Emphasis on Paragraph 4 and the EU and Japanese Proposals, SC/TADP/AN/SV/4, December 2003, Para 5:

${ }^{1804}$ Krajewski, M., Article VI GATS in Wolfrum, Rudiger, Peter-Tobias Stoll and Clemens Feinaugle Eds., WTO - TRADE IN SERVICES, Max Planck Commentaries on World Trade Law, Martinus Nijhoff Publishers, 2008, p183.
} 
The deadlock in WPDR and the fact that the only success in domestic regulation disciplines was when it tackled a specific sector (accountancy) can suggest that it may be more efficient to deal with domestic regulation in a sector-specific manner. This can assist Members to include their specific concerns for each sector, avoid the generalization of horizontal necessity tests that are obviously not an attractive proposition for some Members and cause concern for civil society and ultimately actually move forward on domestic regulation and liberalization while allowing for sector specific concerns and legitimate protection to take place. So far there have been proposals for sector specific domestic regulations disciplines for legal services, engineering and telecommunications sectors, but otherwise the focus, when there is focus, has been on horizontal disciplines.

The 2011 briefing paper highlights that the Article-VI:4 mandate does not intend deregulation, but to promote "better regulation...based on objective and transparent criteria". ${ }^{1805}$ But designing and implementing 'better regulation' may be a costly exercise, especially for developing countries and LDCs who may have other essential needs and priorities to be addressed in development plans and programmes. Necessity tests in other WTO contexts and in dispute settlement do not specifically acknowledge the issue of higher budgetary costs as a factor that ought to be given weight, but the concept of "undue burden" is recognized, and such costs can be considered under such a concept. Developing countries and LDCs in particular need to raise this matter in WPDR discussions, as a criterion for any future necessity test for domestic regulation. Administrative difficulties due to lack of expertise or trained human resources is also another relevant factor. There is no specific mention of taking into account developing and LDC Members' difficulties in Article VI of the GATS, but the fact that it is a part of the negotiating process under Articles IV and XIX, as well as the Preamble to the GATS, should provide a basis for the inclusion of such differential treatment into future domestic regulation disciplines.

As a final point, it may be relevant to mention some issues regarding health services and domestic regulations. In the case of international trade in health services, non-recognition of foreign degrees, diplomas and certification is seen an added barrier for trade in health services in mode 4. However, there are valid limitations on recognition of foreign credentials in health services. It may be necessary to require a re-training or added training and experience where the foreign training has not included necessary components of education and training relating to the needs of the patients in the jurisdiction where the health personnel will be serving. For example, a tropical country can require health service personnel to be competent in the treatment of tropical infectious and endemic diseases and parasites or venomous bites that are common in that country but which were unnecessary to learn in the country granting the qualifications, which could be a European country.

Thus, non-recognition may have some very important reason relating to the quality and appropriateness of health services within a particular Member. Article VII of the GATS on recognition of standards or criteria for authorization, licensing or certification of service suppliers promotes multilaterally agreed criteria for international standards

\footnotetext{
${ }^{1805}$ WTO, Trade in Services Division, Disciplines on Domestic Regulation Pursuant to GATS Article VI.4Background and Current State of Play, June 2011, paras.15-16. See also Mattoo, Aaditya and Pierre Sauvé, Domestic Regulation and Trade in Services in Mattoo, Aaditya and Pierre Sauvé Eds., DOMESTIC REGULATION AND SERVICES TRADE LIBERALIZATION, World Bank and Oxford University Press, 2003, p1.
} 
(Article VII:5), but also acknowledges bilateral and autonomous agreements (VII:1). Article VII:2 states that where Members accord recognition autonomously, other Members must be given the opportunity to demonstrate that the "education, experience, licenses, certifications or requirements" of their service suppliers should also be recognized. These provisions suggest that the recognition accorded shall not be applied in a discriminatory manner or as disguised restriction on trade in services (VII:3), and that the GATS-compatible criteria would be expected to be objective and non-arbitrary.

But there is another problem which requires careful policy formulation which is related to mode 4 mobility: the brain-drain and the negative impact of 'poaching' of trained professionals from developing countries, which requires an added dimension of effective policies for both developing and retaining services capacity of developing country. Brain drain, or skills drain as it is sometimes referred to, in the area of the health sector in particular, has been a matter of concern for the WHO since the late 1960's.

There are a few points on which there is very little disagreement in the literature:

- The flow of migration of health professionals (medical doctors, nurses, dentists, psychiatrists, pharmacists etc.) is overwhelmingly from poorer countries to better economies and not the other direction; with a significant pattern of Anglophone countries receiving health professional from former British colonies/occupied territories in South Asia, South-East Asia and Africa.

- These source countries have shortages of health professionals for their domestic health services sector (either caused or exacerbated by these migrations), which has a direct impact on the ability to provide required health services to their populations and on their ability to progressively achieve the right to health in their country according to their international human rights law obligations.

- Increased migration and emigration of health professionals (whether due to GATS mode 4 liberalization which could increase temporary movement of natural persons or a combination of other factors) will further exacerbate the problems if there are no steps taken to mitigate them.

In effect, poorer countries are subsidizing the health systems of wealthier countries by funding the education and training of a significant proportion of the health professionals of developed countries, and this is also at the at the cost of the poorer country's own healthcare system.

There has been policy dialogue on this issue of 'brain drain' at international level in the past decade, with the WHO stating that it is a priority area and declaring in the 2004 World Health Assembly Resolution that there must be mitigation of the negative effects of the migration of health care professionals. ${ }^{1806}$ In 2004 and 2005, Paul Hunt, the former Special Rapporteur on the Right to Health, drew attention to the right to health implications of GATS, particularly the 'brain drain' of health professionals from developing countries which should be kept in mind when negotiating Mode 4 issues. ${ }^{1807}$ Furthermore 2006-2015 was also named as the WHO 'Health Workforce Decade'. In

\footnotetext{
${ }^{1806}$ World Health Organization, 57 $7^{\text {th }}$ World Health Assembly, International Migration of Health Personnel: A Challenge for Health Systems in Developing Countries, Res.WHA.57.19, May 22, 2004.

${ }^{1807}$ UN General Assembly, Report of the Special Rapporteur of the Commission on Human Rights, Paul Hunt on the right of everyone to the enjoyment of the highest attainable standard of physical and mental health, UN.Doc.A/60/348, 12 September 2005, para.63. See also UN, ECOSOC, Report of the Special Rapporteur, Paul Hunt, The right of everyone to the enjoyment of the highest attainable standard of physical and mental health: Addendum - Mission to the World Trade Organization, E/CN.4/2004/49/Add.1, 1 March 2004, para.48.
} 
2007 a WHO Health Worker Migration Policy Initiative was established, which led to technical Working Groups and an Advisory Council on the promotion of assistance for development of national guidelines, voluntary codes, international guidelines and bilateral agreements, and hopefully a multilateral framework for health worker migration. So far, the mechanisms which have been created have been based on ethics, not binding legal obligations $^{1808}$ - and these have to be balanced with the development of GATS rules on Mode 4.

In general, domestic regulation can balance some of the possible negative socio-economic effects of trade liberalization. Negotiating domestic regulation disciplines involves the difficulties of identifying and drawing the line that needs to be drawn between retaining space for such legitimate public policy while 're-regulating' for the benefit of international trade that can effectively deliver economic growth and developmental outcomes.

\footnotetext{
1808 See for example: U.K. Department of Health, Code of Practice for the International Recruitment of Healthcare Professionals, December 2004 (revised); Commonwealth Health Ministers, Commonwealth Code of Practice for the International Recruitment of Health Workers, May 2003; A Code of Practice for the International Recruitment of Health Care Professionals: The Melbourne Manifesto, adopted at 5th WONCA World Rural Health Conference Melbourne Australia, May 3, 2002; the International Council of Nurses, ICN position statement on ethical nurse recruitment (2001); the American Public Health Association, Ethical Restrictions on International Recruitment of Health Professionals to the United States, 2006.
} 


\subsection{CONCLUSIONS ON CHAPTER 4}

The general obligations and specific commitments of the GATS discussed in this Chapter combine an underlying 'non-discrimination' ideal of trade law ('do not discriminate between trading partners or between foreign and domestic services and services suppliers') with the flexibility of allowing Members to choose the extent and pacing of their commitments in national treatment and market access. The area of domestic regulation in services under Article VI is a combination of commitments and a mandate to negotiate multilateral disciplines on domestic regulation under Article VI:4. Although these multilateral disciplines on domestic regulation have not yet come into being, there is some concern that they could in the future produce rules which are intrusive into domestic policy space particularly paragraphs 4 and 5 .

Policy space that actually allows for a Member to make development-friendly decisions should allow for the flexibility to make one's own domestic policy while identifying and taking into account the differences in the needs of domestic economic and social development as well as the differences in political and economic power in multilateral negotiations. The non-discrimination provisions of the GATS should thus allow for space for Members that already have, wish to develop or wish to introduce public health services to have the freedom to advance the interests of their citizens, and thereby contribute to the overall quality of life and level of national development.

The general obligation of transparency does not appear to be problematic, except that there is concern with regard to matters such as private health information in the context of health services. This is an area for further research and exploration of the interfaces it may have with various other iterations of privacy and information exchange in the context of trade as well as human rights, which is beyond the scope of this study.

The general obligation of MFN treatment is considered a pillar of the WTO system, with the objective of prohibiting different treatment among 'like' products, services and service suppliers originating in or destined for different countries. It is expected to be used to extend negotiated, reciprocal concessions to all other WTO Members. Section 4.3.2. of this Chapter discussed the history of the MFN treatment principle and Article II of the GATS, the provision which covers the MFN treatment obligation for services in the WTO context. The section also discussed Article II:2 and the Annex on Article II exemptions, since this study is concerned with assessing the extent of policy space that is available to a WTO Member.

So, in what manner are exemptions from MFN treatment a useful flexibility and how do they contribute to development policy space in areas such as health services? MFN treatment exemptions that have been listed by Members include bilateral Agreements for provision of medical services in other countries to citizens in situations where such services are not available in the Members jurisdiction; reciprocal granting of social security, health benefits, public medical insurance, subsidization and compensation plans; and reciprocal treatment and mutual recognition of health professionals, administrators and laboratory services. ${ }^{1809}$ These exemptions can be connected to the right to health and

${ }^{1809}$ Mashayekhi, Mina, Martine Julsaint and Elizabeth Tuerk, Strategic Considerations for Developing Countries: The Case of GATS and Health Services in Blouin, Chantal, Nick Drager and Richard Smith Eds., INTERNATIONAL TRADE IN HEALTH SERVICES AND THE GATS: CURRENT ISSUES AND DEBATES, The World Bank, 2006, p25-27. 
promotion of access to public health services, but the national health policies and the current ground situation of the Members need to be carefully looked at in order to clarify the situation.

Another point is, supposing they can be used for the purpose of protecting public health services, there is nothing in the GATS that recognizes the differences in the ability of Members to process the information and make decisions on MFN exemptions or MFNinconsistent measures (although the 2001 Guidelines and Procedures for Negotiations in Trade in Services refers to 'appropriate flexibility' in the context of negotiations on MFN exemptions). ${ }^{1810}$ MFN Exemptions shall be subject to negotiation according to paragraph 6 of the Annex on Article II (MFN) Exemptions. In such negotiations, appropriate flexibility shall be accorded to individual developing country Members. This is of no help to countries who did not ascertain the need for an exemption either at the entry into force of the WTO and GATS or at the date of their country's accession. Adlung and Carzaniga point out in 2009 , that:

It is telling in this context that of the 49 WTO Members that have not listed MFN exemptions, 48 are developing or least-developed countries. ${ }^{1811}$

Without the expertise and advice on how to use the exemption for their benefit, developing country and least developed country Members have not been able to use even the existing flexibility for their economic and/or social development needs. Article II:2 was probably a missed opportunity for these Members when joining the WTO, and recourse to exceptions to Article II: 1 in the form of Article V, XIV and XIVbis also need a high level of legal expertise.

The section also briefly discusses the other MFN exemption available in Article II:3 of the GATS. Article V of the GATS relating to RTAs is relevant for right to health and protection of public health services so far as it is important to keep track the GATS-plus or GATS-minus commitments in RTAs. It is not merely the provisions of the GATS itself, but the implications of MFN treatment in relation to GATS-Plus commitments that Members and citizens concerned with the impacts on public health services should be mindful of, since it may constrict national policy space. The fact that RTAs are usually not an open multilateral process and that certain Members may be more influential in RTA-creating networks is also a matter of interest, since the policy approach to public services held by such Members could influence the outcome and nature of the commitments in RTAs - and thereby the national policy of less powerful Members who are participating.

With regard to Article VII of the GATS - it allows for a certain amount of policy space with regard to recognition of standards, licensing and certification requirements of other Members. An MFN exemption is available for recognition of standards, licensing and certification requirements of other Members according to Article VII of the GATS.

\footnotetext{
1810 WTO, Guidelines and Procedures for the Negotiations on Trade in Services, S/L/93, adopted by the Special Session of the Council for Trade in Services on 28 March 2001, para.6. They were adopted by the Council for Trade in Services, in Special Session, on 28 March 2001 (WTO document S/L/93 of 29 March 2001) and later incorporated into the wider context of the DDA (see para.15 of the Doha Ministerial Declaration (WTO document WT/MIN(01)/DEC/1 of 20 November 2001). See also Adlung, Rudolf and Antonia Carzaniga, MFN Exemptions Under the General Agreement on Trade in Services: Grandfathers Striving for Immortality?, Journal of International Economic Law, 12(2), 2009, 357-392, p365 for further discussion on this point.

${ }^{1811}$ Ibid., (Adlung and Carzaniga), p365 and Table.2.
} 
Health services is an area that has high level of restrictions in terms of recognition of foreign qualifications. Members are required to make notifications to the Council for Trade in Services if they wish to retain national policy space for their regulations concerning recognition of standards, licensing and certification in the context of the liberalization of health services. While the restrictions are expected to be nondiscriminatory some Members have also notified of Mutual Recognition Agreements, which are arguably based on similarity of the standards etc. Article VII also encourages Members to work towards "multilaterally agreed criteria" and thus may be connected with the negotiating mandate under Article VI:4 of the GATS (on domestic regulation) for development of disciplines necessary to ensure that qualification and licensing requirement etc., do not constitute unnecessary barriers to trade in services.

It seems that overall that MFN treatment exemptions are more extensive than what initially appears. For Members who have been unable to make an exemption under the Annex on Article II exemptions at the time of entry into force of the WTO and GATS, it is still possible to avoid the MFN treatment obligations by seeking a waiver according to Article IX:3 of the WTO Agreement. Other than that, there are other specific methods to avoid MFN treatment obligations as discussed above and in the last resort there can be reliance upon the exceptions in Article XIV and XIVbis - which have to be justified - if a Member wishes to introduce a measure which is not compatible with their MFN treatment obligations. The Article XIV and XIVbis exceptions will be discussed later in more detail in the Chapter 5.

With regard to the MFN obligation, although it is such a fundamental feature of the world trade system, there is a certain retention of national policy space in the GATS, which could be used for protecting public health services, if Members are keen on doing so. Perusal of some of the notifications by Members show that there have been steps taken by some Members in this regard, and it is recommended that Members entering into negotiations for RTAs, multilateral creation of standards, and disciplines relating to domestic regulations continue to be aware of and use the possibilities of exempting health services or including exceptions, so that a more scope for national policy is retained.

If the GATS is truly the most flexible of WTO agreements as well as an effective tool for achieving economic growth and raising the standard of living - the expected liberalization level and outcomes should be higher. It appears that developing country Members, when they do liberalize, would prefer to do so without taking on binding obligations that could become the basis of WTO disputes. It appears that in practice there may be different approaches: sector-by-sector liberalization, or non-mandatory 'understandings' on specific sectors or policies, which may provide greater levels of liberalization than in GATS commitments. The drawback of this is that there would be a lack of information and transparency, which may affect other Members, particularly other developing country or LDC Members with limited capacity in terms of trade law expertise, from benefiting from such de facto openness. It can be said that the importance that is laid on following the GATS liberalization procedures is connected to the importance laid on transparency and predictability in the long run.

According to the logic that liberalization leads to better outcomes for all, there should be greater enthusiasm for making commitments from developing country Members (rather than opposition). The argument is that more funds will become available for allocation to needs such as developing the public health sector and improving health indicators, if 
developing country and LDC Members become more transparent and open by liberalizing services, resulting in a greater volume of trade and investment. Opening the health sector would also arguably result in more service providers entering the market with overall gains for the population. Yet, there is concern that liberalization is a double-edged sword where on one side the economic elites (private service suppliers, health professionals, urban upper economic classes) would benefit but the other side is that the disadvantaged face even more difficulty in receiving the public health services they require. Thus, refraining from undertaking specific commitments can also be seen in a positive light, since the flexibility provided by the GATS includes the possibility to refrain from making specific commitments, and yet still choosing to liberalize in the manner most suitable to domestic conditions or to protect particular service sectors such as health services and to maintain policies that promote equity without having to be anxious about causing trade disputes.

As can be seen, the reluctance to voluntarily make commitments in sensitive areas by some Members, even while opening up their markets to international trade, can be justified and perhaps can even be said to be advisable. Although referred to as being the 'most flexible' of WTO agreements due to the option of scheduling commitments, the GATS may in fact offer very little flexibility in terms of real policy choice in managing liberalization, unless in terms of avoidance of obligations. Thus, if commitments have been made - and also in the case of general obligations - Members which have allegedly taken measures that are inconsistent with these obligations must rely on the general exceptions available under Article XIV of the GATS. It is this provision that will be discussed in the next Chapter that follows. 


\section{CHAPTER 5}

\section{THE GENERAL AND SECURITY EXCEPTIONS TO OBLIGATIONS UNDER THE GATS:}

\section{ARTICLE XIV AND ARTICLE XIVBIS}

It is the purpose that makes strong the vow;

But vows to every purpose must not hold...

Cassandra, Shakespeare's Troilus and Cressida

Let us once lose our oaths to find ourselves, Or else we lose ourselves to keep our oaths

Biron, Shakespeare's Loves' Labour Lost 
Chapter 5 


\section{CHAPTER 5}

\section{GENERAL AND SECURITY EXCEPTIONS TO OBLIGATIONS UNDER THE GATS}

\subsection{INTRODUCTION TO CHAPTER 5}

When it comes to the general obligations and scheduled commitments as discussed in the previous Chapter, the possibility of disputes in sensitive areas such as liberalization obligations undertaken in the health sector will ultimately link back with societal values of Members. Even if GATS obligations exist, how keen would a Member be to 'rock the boat' by pursuing private commercial interests at the cost of what may be the public interest in maintaining a good public health service? Some Members have not been shy to shoulder private corporate interests in dispute settlement, which other Members have seen as causing severe risk and damage to public morals, human health, animal and plant life or health or the environment generally. Therefore, public health services may not always be subject to a tacit understanding of being a 'hands-off' area when it comes to disputes. The line between what ought to be regarded as 'legitimate' and 'protectionist' measures may be seen differently in the WTO context by some WTO Members than it could be seen in other international law regimes such as human rights, animal welfare and plant protection or environmental protection or cultural heritage protection. In this context, the importance of 'bilingualism' or the understanding that there are two languages of human rights and trade, and that there needs to be a competent translation of the values between the regimes can be highlighted. It would be interesting to see if such 'bilingual competence' of diplomats and trade negotiators would be useful to prevent issues relating to sensitive service sectors such as health from going to the level of needing to be sorted through a WTO panel; but could instead be resolved at the consultations phase or even earlier at diplomatic level.

The first section of this Chapter introduces the general exception provision of the GATS: Article XIV, discusses the key jurisprudence (the panel and Appellate Body reports in US-Gambling and Argentina-Financial Services) and the relevance of the disputes which referred to Article XX of the GATT, which is the equivalent exceptions provision for trade in goods. This section also introduces the approach that has been taken in the analysis of exceptions provisions, which is in two parts: firstly, whether the relevant measure falls within the scope of the provision and meets the nexus requirement; and secondly, whether the requirements of the chapeau have been fulfilled.

The next section of this chapter discusses in more detail the interests protected and justified under Article XIV. Since this study is with special reference to public health services, greater attention will be given to paragraphs (a), (b) and (c) of Article XIV of the GATS, as they appear to be the most likely to be used, if at all, with regard to a future dispute on health services. ${ }^{1812}$ These three paragraphs are structured in a similar manner,

\footnotetext{
${ }^{1812}$ Note that it has also been commented by Harris and Moon, that in the comparable provisions in GATT, Articles XX(a), (b) and (c) of the GATT 1994, are the three areas "likely to be directly relevant to human rights measures in general" (Harris, Rachel and Gillian Moon, GATT Article XX and Human Rights: What Do We Know From The First 20 Years?, 2015, Melbourne Journal of International Law, Vol.16, 1, p20, citing Moon, Gillian, Double Agents, Discrimination, Duress and Doha: A Review of Trade and Human Rights since the China-Publications and Audiovisuals Decision, (2011) 19 African Journal of International and Comparative Law 283, p284).
} 
having a nexus of "necessity" with regard to the interest protected and being subject to the chapeau of Article XIV. Conclusions on paragraphs (a), (b) and (c) of Article XIV, the necessity test and the chapeau will follow, before going on to briefly comment on the other general exceptions provisions of Articles XIV(d) and (e) and Article XIVbis is the 'security exception'. Article XIV(d) and (e) are the exceptions relating to direct tax and double taxation. Article XIVbis of the GATS, is the provision on security exceptions. The structure of Article XIVbis is different from Article XIV and is comparable to Article XXI of the GATT 1994. A brief comment on Article XIVbis of the GATS is the penultimate section before the conclusion to this Chapter. The chapter will include general comments on the use of a human rights approach to exceptions clauses, in particular the relevance of the right to health.

\subsection{ARTICLE XIV OF THE GATS}

Article XIV of the GATS is the provision on the general exceptions to the obligations of the GATS. It can be resorted to in a dispute context by a Member responding to a complaint by another Member or several Members of a measure that is in violation of the GATS obligations.

The text of Article XIV is as follows:

Subject to the requirement that such measures are not applied in a manner which would constitute a means of arbitrary or unjustifiable discrimination between countries where like conditions prevail, or a disguised restriction on trade in services, nothing in this Agreement shall be construed to prevent the adoption or enforcement by any Member of measures:

(a) necessary to protect public morals or to maintain public order ${ }^{1813}$

(b) necessary to protect human, animal or plant life or health;

(c) necessary to secure compliance with laws or regulations which are not inconsistent with the provisions of this Agreement including those relating to:

i. the prevention of deceptive and fraudulent practices or to deal with the effects of a default on services contracts;

ii. the protection of the privacy of individuals in relation to the processing and dissemination of personal data and the protection of confidentiality of individual records and accounts;

iii. safety;

(d) inconsistent with Article XVII, provided that the difference in treatment is aimed at ensuring the equitable or effective ${ }^{1814}$ imposition

${ }^{1813}$ At this point, the original footnote 5 in GATS reads:

The public order exception may be invoked only where a genuine and sufficiently serious threat is posed to one of the fundamental interests of society.

${ }^{1814}$ At this point, the original footnote 6 in GATS:

Measures that are aimed at ensuring the equitable or effective imposition or collection of direct taxes include measures taken by a Member under its taxation system which:

(i) apply to non-resident service suppliers in recognition of the fact that the tax obligation of non-residents is determined with respect to taxable items sourced or located in the Member's territory; or

(ii) apply to non-residents in order to ensure the imposition or collection of taxes in the Member's territory; or

(iii) apply to non-residents or residents in order to prevent the avoidance or evasion of taxes, including compliance measures; or 
or collection of direct taxes in respect of services or service suppliers of other Members;

(e) inconsistent with Article II, provided that the difference in treatment is the result of an agreement on the avoidance of double taxation in any other international agreement or arrangement by which the member is bound

Taking into consideration all the other available options, Article XIV of the GATS Agreement can perhaps best be described as a measure of last resort ${ }^{1815}$ with regard to the protection of societal values. Article XIV allows for the possibility for Members of the WTO to take legitimate trade-restrictive measures that would otherwise be in violation of other terms of the Agreement. It can also be described as a 'general override' provision or 'escape clause' that Members can fall back on in situations where they do not wish to comply with obligations under the Agreement, giving preference instead to a contradictory policy goal aimed at (supposedly) a non-trade value. There are conditions that such measures must not be discriminatory nor disguised trade protectionism. As discussed earlier, this is a space for expression of national sovereignty and therefore, retention of the power of the state to regulate on matters in the public interest. ${ }^{1816}$

This is of particular importance with regard to public services, where there is much concern that public health services should be protected as they have a special role in providing for the poor in society, who would not have the means to avail themselves of the health services they need in a wholly free market system. Furthermore, if health services are mainly or only provided by profit-oriented private suppliers and/or if private industry acquisition of existing public responsibilities occurs, there is a possibility that this system will have inadequate self-regulation and thereby have an impact on health and quality of life. ${ }^{1817}$ The Appellate Body has also recognized the importance of health, for example in the concluding paragraph of US-Gasoline it was by stated that Article XX of

(iv) apply to consumers of services supplied in or from the territory of another Member in order to ensure the imposition or collection of taxes on such consumers derived from sources in the Member's territory; or

(v)distinguish service suppliers subject to tax on worldwide taxable items from other service suppliers, in recognition of the difference in the nature of the tax base between them; or

(vi) determine, allocate or apportion income, profit, gain, loss, deduction or credit of resident persons or branches, or between related persons or branches of the same person, in order to safeguard the Member's tax base.

Tax terms or concepts in paragraph (d) of Article XIV and in this footnote are determined according to tax definitions and concepts, or equivalent or similar definitions and concepts, under the domestic law of the Member taking the measure.

1815 Even from a human rights perspective, the exception clauses have been seen as a last resort for reconciliation of human rights norms with trade. See OHCHR, Human Rights and World Trade Agreements: Using General Exception Clauses to Protect Human Rights, HR/PUB/05/5, 2005 (prepared by James Harrison and assisted by Steve Charnovitz, Robert Howse and Gabrielle Marceau), http://www.ohchr.org/Documents/Publications/WTOen.pdf.

${ }^{1816}$ Pauwelyn, Joost, CONFLICT OF NORMS IN PUBLIC INTERNATIONAL LAW: HOW WTO LAW RELATES TO OTHER RULES OF INTERNATIONAL LAW, Cambridge University Press, 2003 p33:

The WTO is not a construct detached from the sovereignty or self-interest of its members.

Pauwelyn argues further that that WTO law is founded on the sovereign and self-interested decisions of states to regulate for their own economic development. The consequences of this exercise of sovereignty, is paradoxically (as in most modern international law) the limitation of sovereignty - also in the self-interest. ${ }_{1817}$ See Barfield, Claude E. FREE TRADE, SOVEREIGNTY, DEMOCRACY: THE FUTURE OF THE WORLD TRADE ORGANIZATION, AEI Press, 2001, p91, on the need to regulate private action in the public interest, to prevent the occurrence of major public problems. 
the GATT (the exceptions provision for trade in goods, similar to Article XIV of the GATS):

...contains provisions designed to permit important state interests -

including the protections of human health...to find expression.

With regard to the right to health, the normative content of the right to health includes the availability of functioning public health facilities in sufficient quantity ${ }^{1818}$ and

...ensuring that these services, whether privately or publicly provided, are

affordable for all, including socially disadvantaged groups. ${ }^{1819}$

The specific legal obligations of states in this regard have been elaborated on in the General Comment on the right to health, as including provision of an environment that facilitates the discharge of the responsibilities regarding the realization of the right to health by intergovernmental organizations and the private business sector. ${ }^{1820}$

However, resorting to Article XIV of the GATS in order for a Member to realize these and other similar obligations and responsibilities is not as easy as it may appear at first glance. Article XIV consists of a chapeau or heading, which places limitations on the application of the measures provisionally justified by the subsequent five paragraphs which specify the exceptions. The scope of each of the paragraphs themselves are discussed in further detail in this chapter. Furthermore, although it is identified as an exception to the general thrust of the Agreement, the balancing role that is played by Article XIV between the rights of a Member invoking the exception and that Members duties towards other Members should be taken into account in assessing the role and importance of Article XIV. ${ }^{1821}$

\subsubsection{The Relevance of GATT Article XX Jurisprudence}

In the context of the scarcity of case law relating to GATS exceptions, we are fortunate to have the WTO case US-Gambling where Article XIV, in particular paragraphs (a) and (c) are discussed. Since US-Gambling there has also been Argentina-Financial Services, where Article XIV, paragraphs (c) and (d) were raised. However, both the Panel and the Appellate Body refrained from ruling on Article XIV(d) in Argentina-Financial Services since the measures were deemed not inconsistent with Article XVII, and reliance on the exception was not needed. As there is not much GATS jurisprudence to rely on, the interpretive guidance available for a Panel with regard to the issue is very limited. However, Article XIV of GATS was preceded by Article XX of GATT 1947 (subsequently Article XX of GATT 1994). The differences in the wording of the chapeau and paragraphs (a) and (b) of both Articles, and paragraph (c) of Article XIV of the GATS compared with paragraph (d) of Article XX of the GATT 1994, are negligible. ${ }^{1822}$

\footnotetext{
1818 UN, CESCR, General Comment No. 14, The Right to The Highest Attainable Standard of Health, E/C.12/2000/4., $11^{\text {th }}$ August 2000, para.12(a). This is the most important soft law instrument discussing in detail the responsibilities of states with regard to the right to health.

${ }^{1819}$ Ibid para.12(b)

${ }^{1820}$ Ibid para.42

${ }^{1821}$ See for comparison, the Appellate Body approach to Article XX of the GATT 1994 in US-Shrimp, in paras. 156 and 159 (specifically in the context of the role of the chapeau):

[A] balance must be struck between the right of a Member to invoke an exception under Article XX and the duty of that same Member to respect the treaty rights of the other Members.

${ }^{1822}$ See e.g. Panel Report, US-Gambling, para.3.207:
} 
Therefore, GATT decisions are of importance as there is opportunity for comparison in this regard. This position was recognized by the Panel in US-Gambling as in line with former decisions, ${ }^{1823}$ stating further that:

... [g]iven the textual similarity between Article XX of the GATT 1994 and Article XIV of the GATS, and the similar purposes that both Articles are designed to serve, we consider that GATT/WTO jurisprudence in relation to the former may be relevant and useful in the interpretation of the latter. ${ }^{1824}$

This does not necessarily mean that the meanings of the two Articles must be interpreted identically if there is relevant prior jurisprudence. But it is possible to do so. Following US-Gambling, panels and the Appellate Body interpreting Article XX of the GATT 1994 have also referred to Article XIV of the GATS in the analysis of certain terms and phrases used in common e.g. in EC-Seal Products and Colombia-Textiles with regard to "public morals". ${ }^{1825}$ Other than the differences between trade in goods and trade in services and the difference in structure of the GATT and the GATS as separate agreements, there is also the fact that Article XX of the GATT and Article XIV of the GATS are not identical, but only similar in some aspects. GATT has ten paragraphs as opposed to five in GATS, and each of the paragraphs offers space for different legitimate policy objectives, and even specifies different requirements with regard to the relationship between the objective and the measure at issue.

Three examples of interests excluded from Article XIV of the GATS although available in Article XX of the GATT, would leave anyone with doubts and confusion as to why this had been done. Article XX of the GATT includes exceptions for measures:

(e) relating to the products of prison labour;

(f) imposed for the protection of national treasures of artistic, historic or archaeological value;

(g) relating to the conservation of exhaustible natural resources if such measures are made effective in conjunction with restrictions on domestic production or consumption...

However, if an evolutionary interpretation of "public morals" is applied (as discussed further in this Chapter), it may be that these GATT exceptions can be considered as part of Article XIV(a) of the GATS, even if not explicitly included in the GATS as separate paragraphs. ${ }^{1826}$ The exclusion is still strange, since services can also, and actually do,

\footnotetext{
The operative language in the opening phrases of Article XIV(c) of the GATS is virtually identical to Article XX(d) of the GATT 1994

${ }^{1823}$ Panel Report, US- Gambling, para.6.447:

...in EC-Bananas III the Appellate Body confirmed [at para. 231] that jurisprudence under the GATT 1994 could be relevant for the interpretation of analogous provisions contained in the GATS.

${ }^{1824}$ Ibid., (US-Gambling).

1825 Appellate Body Report, EC-Seal Products, para.5.179:

The Panel also recalled that it had relied on past WTO jurisprudence on the scope of "public morals" under Article XX(a) of the GATT 1994 and Article XIV(a) of the GATS in identifying the objective of the EU Seal Regime.

The Appellate Body in Colombia-Textiles, at footnote 156, referred to the GATS disputes of ArgentinaFinancial Services and US-Gambling, noting that while Article XX of the GATT 1994 is relevant for the analysis under Article XIV of the GATS. "[w] consider that the reverse is also true".

${ }^{1826}$ See e.g. for the argument that prison labour evolved into a 'public morals' exception: Walker, Simon, $A$ Human Rights Approach to WTO TRIPS in Abbott, Frederick M., Christine Kaufmann and Thomas Cottier Eds., INTERNATIONAL TRADE AND HUMAN RIGHTS: FOUNDATIONS AND CONCEPTUAL
} 
have connection with prison labour, national treasures and exhaustible natural resources. These exceptions also have human rights and environmental relevance. Paragraph (g) will be looked at in more detail under the discussion on Article XIV(b) of the GATS, but a brief mention of paragraphs (e) and (f) will be made here.

The common argument concerning paragraph (e) has been to deny that the prison labour exception has anything to do with human rights or labour standards and that it is related to preventing unfair competition through cheap production of goods. Thus, that while Members are free to produce goods through prison labour, they can justify measures taken against the prison-produced goods of other Members. One example of this view is that of the EEC in the unadopted GATT Panel Report of US-Tuna (EEC) comments thus on Article XX(e):

...the exception in paragraph (e) on the products of prison labour was not intended to combat prison labour practices in other contracting parties...Contracting parties simply wanted to be able, if necessary, to protect themselves against the "unfair competition" resulting from the low-cost labour employed in the production of prison goods. ${ }^{1827}$

While this argument could be accepted if it is to be believed that the negotiators of the GATT 1947 had such limited points of view on this matter, it is difficult to fully agree with that view objectively and in face of some contrary evidence. Reference to the Havana Charter of 1948, also referred to as the draft Charter for an International Trade Organization (ITO), indicates that the drafting of trade rules did not occur in wilful ignorance (in the sense of not knowing and of ignoring) of the developments in human rights and labour fields. The drafters and negotiators of the GATT and the Havana Charter of 1948, were often the same individuals ${ }^{1828}$ - and moreover, Article XXIX of the GATT 1947 deals with the relationship between it and the Havana Charter wherein contracting parties undertook to

Observe to the fullest extent of their executive authority the general principles of Chapters I to VI inclusive, and of Chapter IX [of the Havana Charter] pending their acceptance of it...

Article 7 of the Havana Charter of 1948 was titled "Fair Labour Standards", clearly stating that

Members recognize that measures relating to employment must take fully into account the rights of workers under inter-governmental declarations, conventions and agreements...

Members which are also members of the International Labour Organization shall co-operate with that organization in giving effect to this undertaking.

Van Daele has called this provision -

... a radical new post-World War II approach to international trade and labour. ${ }^{1829}$

Even if the withdrawal of the United States from the ITO in face of opposition from US Congress put an end to the hopes for the ITO, how can it be said that the negotiations for the creation of the WTO have completely wiped the slate clean on all the previous

ISSUES, Studies In International Economics Vol. 5, World Trade Forum, University of Michigan Press, 2006, p201-202.

${ }^{1827}$ GATT Panel Report, US-Tuna (EEC), para.3.35

1828 Jackson, John H., THE JURISPRUDENCE OF GATT AND THE WTO: INSIGHTS ON TREATY LAW AND ECONOMIC RELATIONS, Cambridge University Press, 2000 (Reprint), p23.

${ }^{1829}$ Van Daele, Arne, INTERNATIONAL LABOUR RIGHTS AND THE SOCIAL CLAUSE: FRIENDS OR FOES, Cameron May, 2005, p392. 
progress made? Even if this is argued on the basis of gaps in the GATT 1947 and WTO agreements - and the connection with the drafting of the ITO is said to be severed ${ }^{1830}$ - it is difficult to see how and why the negotiators of the GATS text would continue to have such a restrictive view on the trade-labour-human rights linkage or why they could not see the relevance of prison labour for services, which clearly became an issue prior to the conclusion of the Uruguay Round. A quick perusal of recent news and publications would make plain the extent and the problems of prison labour in services trade (call centers) and the privatization of prison labour, definitely something known to Members and used by many major transnational corporations. ${ }^{1831}$ It is at the very least 'anti-competitive' in that it drives down cost and an 'unfair trade practice' in trade-speak, even if the other violations of international standards are disregarded. Considering the large prison population in countries like the United States, India and China, it is not an insignificant distortion of 'normal' trade in services.

With regard to the post-World War II human rights standards, Article 8 of the ICCPR (on slavery and forced labour) excludes under paragraph (3) any "hard labour" or "work or service" in prison or detention that has been ordered by a competent court (as well as military services, national service or service in situations of emergency or general public obligations). However, Article 7 of the ICESCR recognizes

...the right of everyone to the enjoyment of just and favourable conditions

of work [emphasis added].

This Article goes on to specify the manner in which the right can be enjoyed. This includes fair wages and equal remuneration for work of equal value, safe and healthy working conditions and rest, leisure and reasonable limitation of working hours. These can be used as a restriction on the manner in which even the 'forced labour exceptions' in

\footnotetext{
${ }^{1830}$ To the contrary, see Jackson (op cit., THE JURISPRUDENCE OF GATT AND THE WTO), who has a referred (at p22) to the bond between the Havana Charter and the GATT 1947, noting the relevance of the preparatory work as:

...much of the GATT was taken verbatim from the draft of the ITO Charter...the General

Agreement was expressly tied to the prospective ITO [footnotes omitted]

But adding that it was a complex issue, Jackson further elaborates (at p23), that the "stricter view" is that there has to be a tracing of ITO preparatory work as a source of specific GATT language for the relevance to be considered.

1831 On call-centers operating in US and Indian prisons, see Overby, Stephanie, Prison Labor: Outsourcing's "Best Kept Secret", May 27th 2010, available at: http://www.cio.com/article/595304 /Prison_Labor_Outsourcing_s_Best_Kept_Secret_, last accessed 21.05.2014.

Also see Sullivan, Laura, Prison Call Centers put squeeze on service sector, February 23, 2005, available online at: http://www.npr.org /templates/story/story.php?storyId=4505278, last accessed 21.05.2014.; MSNBC staff, Inside the secret industry of inmate-staffed call centers, Jan 12, 2012, available online at http://usnews.nbcnews.com/_news/2012/01/12/10140493-inside-the-secret-industry-of-inmate-staffed-callcenters, last accessed 21.05.2014.

On the negative outcomes of prison privatization on conditions for inmates and the activities of large US corporations in the sector, see Hinkes-Jones, Llewellyn, Privatized Prisons: A Human Marketplace, The Los Angeles Review of Books, January 10th, 2013, available online at: http://areviewofbooks.org/ essay/privatized-prisons-a-human-marketplace.

See also, for work on the impact of commercialization and/or privatization of US Prisons: The National Prison Project of the American Civil Liberties Union Foundation, information available at https://www.aclu.org/prisoners-rights and Coyle, Andrew, Allison Campbell and Rodney Neufeld, CAPITALIST PUNISHMENT: PRISON PRIVATIZATION AND HUMAN RIGHTS, Clarity Press, 2003. Giving a positive view of the involvement of major multinational companies with both public and private US prisons, see: Barret, Victoria, Silicon Valley's Prison Call Center, $6^{\text {th }}$ October 2010, available at http://www.forbes.com/forbes/2010/0628/companies-televerde-hitachi-netapp-cisco-salvation-atcenter.html, last accessed 21.05.2014.
} 
the ICCPR are carried out. ${ }^{1832}$ Furthermore, the ILO Core Convention 29 - Concerning Forced or Compulsory Labour, which entered into force in 1932, requires under Article $4(1)$ that even when a competent authority can lawfully impose forced or compulsory labour as punishment for a crime etc., it shall not be "for the benefit of private individuals, companies or associations". ${ }^{1833}$ The ILO Convention 29 has been ratified by 177 countries. The only significant countries who have not ratified it are the United States and China; not coincidentally, these are the two countries that have gained the attention of human rights and labour groups for the extent, manner and conditions of their prison labour. Why the matter had not also gained the specific attention of the drafters of the GATS, is an interesting puzzle. ${ }^{1834}$

Article $X X(f)$ in the GATT on the protection of culture has also not been reproduced for the GATS. Perhaps this was based on the assumption of cultural services being irrelevant for services trade and "national treasures of artistic, historic or archaeological value" being seen as relating only to goods. However, this ignores the connection between tangible and intangible cultural heritage. The international law and policy concerning intangible culture is relatively new; the 2003 UNESCO Convention for the Safeguarding of the Intangible Cultural Heritage came into force in 2006. But 159 States have become parties to this Convention as of 2014. According to the definitions in Article 2 of the Convention,

The "intangible cultural heritage" means the practices, representations, expressions, knowledge, skills - as well as the instruments, objects, artefacts and cultural spaces associated therewith ... [and] is manifested through: (a) oral traditions and expressions, including language as a vehicle of the intangible cultural heritage; (b) performing arts; (c) social practices, rituals and festive events; (d) knowledge and practices concerning nature and the universe; (e) traditional craftsmanship.

Several items in this definition embody the interface between tangible and intangible cultural heritage. According to Article 13 of the UNESCO Convention, the State parties have the obligation for the safeguarding, development and promotion of the intangible cultural heritage present in its territory and shall endeavour to

...adopt a general policy aimed at promoting the function of the intangible cultural heritage in society, and at integrating the safeguarding of such heritage into planning programmes;

${ }^{1832}$ See further for analysis of current ICESCR approach to prison labour: Saul, Ben, David Kinley and Jaqueline Mowbray, THE INTERNATIONAL COVENANT ON ECONOMIC, SOCIAL AND CULTURAL RIGHTS: CASES, MATERIALS, AND COMMENTARY, Oxford University Press, 2014, p336-339.

${ }^{1833}$ Also see Article 2(c) (the term 'forced or compulsory labour' shall not include...):

... any work or service exacted from any person as a consequence of a conviction in a court of law, provided that the said work or service is carried out under the supervision and control of a public authority and that the said person is not hired to or placed at the disposal of private individuals, companies or associations [emphasis added]

Article 5(1), which seems to tie in with GATT states that,

No concession granted to private individuals, companies or associations shall involve any form of forced or compulsory labour for the production or the collection of products which such private individuals, companies or associations utilise or in which they trade.

${ }^{1834}$ Also note the exception clause Article XXIII:2 in the Revised GPA (plurilateral) discussed earlier in Chapter 3.5.2 of this study includes an exception:

... relating to the products or services of handicapped persons, of philanthropic institutions or of prison labour. 
It is notable that in Europe, within which there is also concern about the impact of GATS on culture, the European Parliament has a Resolution on cultural diversity that recognizes the UNESCO Convention in its Preamble (Recital 6) that ${ }^{1835}$

UNESCO Universal Declaration on Cultural Diversity, which stresses 'the specificity of cultural goods and services which, as vectors of identity, values and meaning, must not be treated as mere commodities or consumer goods' (Article 8) and states that 'market forces alone cannot guarantee the preservation and promotion of cultural diversity, which is the key to sustainable human development' (Article 11) [emphasis added].

It is quite possible that this obligation under Article 13 of the UNESCO Convention on Intangible Cultural Heritage, read with the UNESCO Declaration on Cultural Diversity, may come into conflict with obligations and commitments under the GATS. This is particularly so as it is possible that there could be cultural limitations on liberalization of that sector (commercialization) and on access to persons outside of that community.

For example it is possible that there may be a performance art, skill set or knowledge that is used for both indigenous customary rituals as well as for cultural tourism purposes, but which excludes participation in the production and performance by those outside a particular sub-group in the community, unless specific permission is given by that subgroup. ${ }^{1836}$ These norms would have been protected by local custom, but may need other national protective measures as it becomes exposed to the larger world. This is therefore not an area that can/should be liberalized for tourism services. But tourism is a sector with commitments made by many WTO Members, more than any other sector. If a Member has made commitments in the tourism sector (under "Other" in the Tourism classification), and this performance art, skill set or knowledge becomes increasingly popular and profitable, the exclusion of foreign participation under the four Modes will be technically be difficult to justify under the GATS. ${ }^{1837}$

The situation can get even more complicated if some of the indigenous cultural rituals, practices and knowledge relate to indigenous medicine, having as their objectives, physical, mental and spiritual health and healing. For example, there are tourism packages promoted by local and national governments that include indigenous medical care e.g. ayurveda services in Kerala (a State in South-West India) and both ayurveda and Sinhala

1835 European Parliament, Resolution on the General Agreement on Trade in Services (GATS) within the WTO, including cultural diversity, P5_TA(2003)0087, 12 March 2003, available online at http://trade.ec.europa.eu/doclib/ docs/2004/april/tradoc_116478.pdf. The Resolution also refers to Article 22 of the EU Charter of Fundamental Rights, which states that "the Union shall respect cultural, religious and linguistic diversity".

${ }^{1836}$ For example, the ancient folk healing ceremonies still used in Sri Lanka that combine rituals for psycho-social and spiritual healing with creative art forms including costume, sculpture and woodcarving and performances that include dance, song, spoken verse, drumming and drama. These ceremonies are referred to as Bali-Thovil, Suniyam Kepim and Shanthikarma ceremonies. Elements of the rituals are being taught and performed outside of the traditional context, including for tourism goods and services.

See for further information:

http://www.gammeddehewa.addr.com/thovil.htm;

http://www.ceylontoday.lk/97-60913-news-detail-bali-thovil-and-shanthi-karma.html.

1837 This kind of issue can also be arguably under "Entertainment Service" or "Other" in "Recreational, Cultural or Sporting Services" in the Services Sectoral Classification List but is being discussed under Tourism Services because that is where it is profitable and attractive for foreign participation. 
wedakam in Sri Lanka, which have implications for Mode 2 and 3. ${ }^{1838}$ These two countries are also examples which were mentioned earlier in Chapter 2 for 'snapshots' on societal values concerning 'modern' universal public health services and high standards of health indicators and human development despite low income and economic growth. In Sri Lanka indigenous medicine is practiced by families which have passed down the knowledge for generations and also conducted by the government in a parallel (to allopathic or western medicine) public health system of government indigenous medicine clinics, hospitals, medicine production and supported by government degree granting university courses. Indigenous medicine has recently become part of the services offered by the tourism industry and there could be a sense of resistance to the foreign provision of the same or similar medico-cultural services by commercial presence in Mode 3, as it is an area of cultural expression with a different context and background than other services.

There is no specific protection for intangible culture in services trade other than Article $\mathrm{XIV}$ (a) ("public morals"). But although there is no doubt that intangible culture-related services are culturally sensitive and important in many domestic contexts, it may not be possible to fit the whole range of cultural interests which might need protection under "public morals". However, Members such as the EU have avoided the issue as much as possible by not making commitments in sectors that are deemed culturally sensitive. Canada has included a horizontal limitation on Mode 3, requiring approval for any acquisition or establishment of a business that is "related to Canada's cultural heritage or national identity", but that is limited to the audio-visual sector. ${ }^{1839}$ The United States and China also have national treatment limitations for subsidies to the audiovisual sector. ${ }^{1840}$ Currently this issue in WTO jurisprudence is under-developed, with even the interface of tangible and intangible products and services not tackled explicitly in either of the most

1838 'Sinhala Wedakam' or 'Hela wedakama' is a term used in Sri Lanka to refer to indigenous medicine which is specific to Sri Lankan traditional medicine and which is not also shared with the common South Asian practices of Ayurveda.

See official website of the Department of Tourism, Government of Kerala (which also notes that Ayurveda centers get official accreditation) https://www.keralatourism.org/ayurveda/:

...Ayurveda, the science of life and longevity, is the oldest healthcare system in the world and it combines the profound thoughts of medicine and philosophy...Kerala possesses an unbroken tradition of Ayurveda that has surpassed the many invasions and intrusions both foreign and native. For hundreds of years the Ayurveda Vaidyas (traditional practitioners of Ayurveda) were almost the only access for people seeking healing from every kind of disease in Kerala. The legendary eight families of Vaidyas (Ashta vaidyas) and their successors treated the entire state for centuries. Unlike the other Indian states the status of Ayurveda in Kerala is not alternative but mainstream.

See also further information: Official Sri Lanka Government news portal: High-end tourists looking at Sri Lanka's Ayurveda, $18^{\text {th }}$ May 2014: http://www.news.lk/news/sri-lanka/item/795-high-end-tourists-lookingat-sri-lanka-s-ayurveda. The news item noted the success of the 2014 AROGYA (health trade fair) and INTRAD (international exhibition and trade fair) introduced by the National Chamber of Commerce of Sri Lanka, Minister of Industry and Commerce and Ministry of Economic Development in partnership with the Ministry of Health, which also featured indigenous medicinal products and services. The Sri Lanka Export Development Board highlighted the current rapid growth and further potential for medical tourism in both the indigenous and non-indigenous medical services sectors. See further, Sri Lankan Financial Times online: Double-digit growth in tourist arrivals persists June 10, 2014, http://www.ft.lk/2014/06/10/doubledigit-growth-in-tourist-arrivals-persists/ and Sri Lanka's Ayurveda industry's healthy potential for growth on show, July 13, 2013, http://www.ft.lk/2013/07/13/sri-lankas-ayurveda-industrys-healthy-potential-forgrowth-on-show/ (on the Ayurveda Expo 2013 which was supported by the Ministry of Indigenous Medicine, Ministry of Commerce and the Sri Lanka Export Development Board). Sri Lanka also has the practitioners of Unani and Siddha medicine.

${ }^{1839}$ Canada: GATS/SC/16.

${ }^{1840}$ United States: GATS/SC/90 and China: WT/ACC/CHN/49/Add.2 (2001). 
relevant disputes, Canada-Periodicals or China-Publications and Audiovisual Products. ${ }^{1841}$ However, Delimatsis has noted that China-Publications and Audiovisual Products "demonstrates that goods incorporating services (such as most publications and audiovisual products)" must comply with the unqualified non-discrimination obligation under the GATT and therefore need to rely on Article XX GATT to justify any WTO inconsistent measures. ${ }^{1842}$ China in that dispute relied on the public morals exception of Article XX(a) - a matter discussed in more detail later in this Chapter.

Article XX of the GATT uses different terms as the nexus for interests to be protected, such as "necessary", "relating to", "imposed" "involving" "in pursuance of" and "essential". Article XIV of the GATS uses "necessary" and "inconsistent with...provided that". The Appellate Body in US-Gasoline has pointed out that it is not reasonable to suppose that the intention was to require in every case

...the same kind or degree of connection or relationship between the measure under appraisal and the stated interest or policy... ${ }^{1843}$

Furthermore, even in the case of identical wording in both Agreements, such as "necessary to protect human, animal or plant life or health" in both Article XX(b) of the GATT and Article XIV(b) of the GATS it does not follow that the paragraphs both represent the same meaning as the context of the entirely of the exceptions provision needs to be taken into account. This is a point will be discussed further on in this Chapter under the sections on Article XIV(b) of the GATS.

The jurisprudence on Article XX of the GATT is also relevant for the purpose of identifying the role and importance of Article XIV within the GATS framework. Earlier GATT panels, as WTO Panels have generally accepted that exceptions must be construed narrowly. The views of the adopted GATT Panel Reports US-Malt Beverages and Canada-Ice cream and Yogurt, as well as the unadopted US-Tuna (EEC), were followed by the WTO Panel in US-Underwear; making it clear that exceptions are expected to be interpreted narrowly. ${ }^{1844}$ The Appellate Body in US-Shirts and Blouses also stressed that the exceptions are limited, affirmative defences and "not positive rules establishing obligations in themselves" 1845 - thus they are unlike the other provisions in the Agreements that impose such positive obligations upon Members. This is also the view of commentators such as Klabbers ${ }^{1846}$ (commenting in 1992 with regard to GATT 1948) with Ortino ${ }^{1847}$ going even further and stating that the structure of the WTO agreements reflects a "ranking of values", with the exception clauses as "secondary" to the "primary norms" and "fundamental policy" of trade liberalization.

\footnotetext{
1841 See for further discussion, Vadi, Valentina, CULTURAL HERITAGE IN INTERNATIONAL INVESTMENT LAW AND ARBITRATION, Cambridge University Press, 2014, p191-194.

${ }^{1842}$ Delimatsis, P., Protecting Public Morals in a Digital Age: Revisiting the WTO Rulings on US-Gambling and China- Publications and Audiovisual Products, Journal of International Economic Law 14(2), 257293, p280-281.

1843 Appellate Body Report, US-Gasoline, p17.

${ }^{1844}$ GATT Panel Reports: US-Malt Beverages para.5.41, Canada-Ice cream and Yogurt, para.59, US-Tuna (EEC), para.5.26 and Panel Report, US-Underwear, para.7.21.

1845 Appellate Body Report, US-Shirts and Blouses, p16.

1846 Klabbers, J., Jurisprudence in International Trade Law: Article XX of the GATT, Journal of World Trade, 1992, 88, stating that a broad interpretation of the Article XX exception would "run counter to the object and purpose of the GATT"

1847 Ortino, F., From 'Non-Discrimination' to 'Reasonableness': a Paradigm Shift in International Economic Law?, Jean Monet Working Paper 01/05 2005, p54 and Ortino F., Treaty Interpretation and the WTO Appellate Body Report US-Gambling: A Critique, Journal of International Economic Law 2006, p145.
} 
However, other writers have played down such an emphasis on hierarchy, by focusing instead upon the idea of a balancing between conflicting interests. These writers include Pauwelyn ${ }^{1848}$ and Trachtman ${ }^{1849}$ who suggest that these conflicts may have to be worked out on a case by case basis in the absence of other clear interpretive guidelines. The Appellate Body in US-Shrimp and US-Gasoline have taken the approach that the role of the general exceptions provision is that of balancing between "competing rights" 1850 and acknowledging a Member's autonomy for "coordinating policies". ${ }^{1851}$ The view that the general exceptions provisions represent secondary or subordinate interests ought not to be maintained in light of the use of language by the Appellate Body recognizing their role in finding a balance between conflicting rights and obligations.

The path suggested by those in the human rights regime seems to see the exceptions as an opportunity for human rights to enter into the interpretation of trade obligations, but at the same time perceives a hierarchy and admits some frustration as to the status quo. The 2002 Report of the High Commissioner on the Liberalization of trade in services and human rights states the general position with regard to WTO obligations that:

The fundamental nature of these entitlements as rights requires an approach that sets the promotion and protection of human rights as objectives of trade liberalization, not as exceptions. ${ }^{1852}$

With regard to the GATS, the Report states as follows

While a human rights approach would place the promotion of human rights at the centre of the objectives of GATS rather than as permitted exceptions, these links nonetheless provide an entry point for a human rights approach to liberalization and a means of ensuring that the essentially commercial objectives of GATS can be implemented with respect for human rights [emphasis added]

This link could also be relevant in determining the appropriate sources of international law relevant to the interpretation of the provisions of GATS in future rulings by the WTO Dispute Settlement Body or the Appellate Body. ${ }^{1853}$

...Any eventual interpretation of the scope of the general exceptions in

GATS to protect public morals, life and health might be important in

\footnotetext{
${ }^{1848}$ Pauwelyn, Joost, CONFLICT OF NORMS IN PUBLIC INTERNATIONAL LAW: HOW WTO LAW RELATES TO OTHER RULES OF INTERNATIONAL LAW, Cambridge University Press, 2003.

1849 Trachtman, J., Trade and...Problems, Cost Benefit Analysis and Subsidiarity, European Journal of International Law, Vol.9(1), 1998, 32-85.

${ }^{1850}$ Appellate Body Report, US-Shrimp, para.159. See further, same paragraph of the report, referring to the "balance of rights and obligations constructed by the Members themselves in that Agreement".

${ }^{1851}$ Appellate Body Report, US-Gasoline, p.30-31, referring also to the Preamble to the WTO Agreement and the Decision on Trade and Environment (Adopted by Ministers at the Meeting of the Trade Negotiations Committee in Marrakesh on 14 April 1994).

${ }^{1852}$ UN Economic and Social Council, Commission on Human Rights, Report of the High Commissioner, Liberalization of trade in services and human rights, E/CN.4/Sub.2/2002/9, 25 June 2002, para.7: which further continued with special reference to human rights and the TRIPS Agreement and the Report of the High Commissioner on the TRIPS Agreement (E/CN.4/Sub.2/2001/13), which had drawn the contrast as follows:
}

... a human rights approach would place the promotion and protection of human rights at the heart of the objectives of intellectual property protection, rather than only as permitted exceptions that are subordinated to the other provisions in the TRIPS Agreement.

${ }^{1853}$ Ibid., (Liberalization of trade in services and human rights), para.63. 
resolving the potential tension between ensuring transparency and commercial predictability and protecting human rights. ${ }^{1854}$

It is thus submitted that while the framework of WTO agreements such as the GATS is not ideal with regard to the desired position and role of human rights, such as the right to health, the exceptions provisions such as Article XIV of the GATS provide an opportunity for balancing of competing interests, depending on how the provisions are interpreted by panels or Appellate Body. However, it is not likely that the interpretive path chosen by the panels or Appellate Body would lead to the placing of 'other' concerns in the heart of the covered agreements as some proponents of human rights (or the environment) would hope. It is possible that a certain 'taking into account' of other international obligations, or even a human rights approach in certain circumstances, could be referred to and acknowledged in the balancing process or in the coordinating of national policies. This Chapter further discusses the extent to which such interpretation is feasible in the context of the VCLT path with regard to the interpretation of WTO exceptions, focusing on the possibilities for the GATS in particular.

\subsubsection{Comparing Article XIV of the GATS with Exceptions Provisions}

It may also be useful to assess the general exceptions provisions in the GATS in comparison with similar wording in multilateral trade agreements other than the GATS. Regional agreements also incorporated similar exception clauses to the GATT and GATS. Article 36 of the EC Treaty ${ }^{1855}$ is a significant example, being very similar in wording and Article 2101 of NAFTA explicitly incorporates Article XX of GATT (1947) ${ }^{1856}$. However, it is cautioned that the

${ }^{1854}$ Ibid., (Liberalization of trade in services and human rights), para.64.

${ }^{1855}$ Free Movement of Goods: Article 36 (ex Article 30 TEC):

The provisions of Articles 34 and 35 shall not preclude prohibitions or restrictions on imports, exports or goods in transit justified on grounds of public morality, public policy or public security; the protection of health and life of humans, animals or plants; the protection of national treasures possessing artistic, historic or archaeological value; or the protection of industrial and commercial property. Such prohibitions or restrictions shall not, however, constitute a means of arbitrary discrimination or a disguised restriction on trade between Member States.

- Consolidated versions of the Treaty on European Union and the Treaty on the Functioning of the European Union, Official Journal C 115 of 9 May 2008

${ }^{1856}$ Article 2101 of NAFTA: General Exceptions -

1. For purposes of: (a) Part Two (Trade in Goods), except to the extent that a provision of that Part applies to services or investment, and (b) Part Three (Technical Barriers to Trade), except to the extent that a provision of that Part applies to services, GATT Article $\mathrm{XX}$ and its interpretative notes, or any equivalent provision of a successor agreement to which all Parties are party, are incorporated into and made part of this Agreement.

The Parties understand that the measures referred to in GATT Article XX(b) include environmental measures necessary to protect human, animal or plant life or health, and that GATT Article XX(g) applies to measures relating to the conservation of living and non-living exhaustible natural resources.

2. Provided that such measures are not applied in a manner that would constitute a means of arbitrary or unjustifiable discrimination between countries where the same conditions prevail or a disguised restriction on trade between the Parties, nothing in: (a) Part Two (Trade in Goods), to the extent that a provision of that Part applies to services, (b) Part Three (Technical Barriers to Trade), to the extent that a provision of that Part applies to services, (c) Chapter Twelve (Cross-Border Trade in Services), and (d) Chapter Thirteen (Telecommunications), shall be construed to prevent the adoption or enforcement by any Party of measures necessary to secure compliance with laws or regulations that are not 
...parallels that exist in this regard between different trade agreements should not camouflage the fact that ...other systems of trade and trade integration vary considerably in their basic legal structures and underlying principles $^{1857}$.

Therefore, while it is not recommended that interpretations of the same or similar words and phrases are transposed to the GATS, it is also not recommended that developments in other contexts are ignored. Such developments may assist in clarifying concepts, even if only to the extent that the concepts are identified as being on a different basis.

This also applies with even greater relevance to certain developments in non-trade contexts in international law, such as human rights and environmental law and policy. The WTO system is a specialized system focusing on international trade law as codified in the relevant WTO agreements, but it is part of the wider area of international law and has considerable overlap with and consequences for other aspects of international law. The debatable nature of the relationship between these other areas of international law (especially international human rights law) and WTO law was discussed in more detail in the earlier Chapters. But as stated by former WTO Director General Pascal Lamy:

...how could the WTO, created in 1994 by an international legal instrument, be immune to the rules of the general international law from which it derives its mission and its very existence? ${ }^{1858}$

In this he also recognizes the trend that has already begun in the dispute settlement context of the WTO. As mentioned earlier in Chapter 1 of this study, the Appellate Body has clearly stated that there is recognition that WTO law is

...not to be read in clinical isolation from public international law. ${ }^{1859}$

This statement has led to much speculation on the possibilities for interactions between WTO law and other areas in public international law in general, although the focus is usually more on the process than of the implications of introducing other substantive nonWTO law into the WTO through such interpretation. ${ }^{1860}$ This will be explored further in this chapter in the context of Article XIV of GATS.

In the WTO context, the TRIPS Agreement also has reference to exceptions in several Articles, especially Article 27.2. ${ }^{1861}$ However, this Article follows a different rationale as it is concerned with identifying patentable subject matter, although it can be argued that there is a similarity with the GATT and GATS in the sense of allowing for policy

inconsistent with the provisions of this Agreement, including those relating to health and safety and consumer protection.

1857 Wolfrum, R., Article XX GATT 1994 in Wolfrum, Rudiger, Stoll and Seibert-Fohr Eds., WTO TECHNICAL BARRIERS AND SPS MEASURES, Max Planck Commentaries on World Trade Law, Martinus Nijhoff Publishers, 2007, p63.

${ }^{1858}$ Lamy, P., Speech given at the University of Geneva, 5 June 2009, Lamy: Globalization and trade opening can promote human rights, http//: www.wto.org/english/news_e/sppl_e/sppl128_e.htm, last accessed 05.06.2009.

${ }^{1859}$ Appellate Body Report, US -Gasoline, para.16.

1860 See Ehlermann, C-D., Six Years on the Bench of the "World Trade Court", in Ortino, Federico and Petersmann, Ernst-Ulrich Eds. THE WTO DISPUTE SETTLEMENT SYSTEM 1995-2003, Kluwer Law International, 2004, p510.

${ }^{1861}$ Patentable subject matter, Article 27(2):

Members may exclude from patentability inventions, the prevention within their territory of the commercial exploitation of which is necessary to protect ordre public or morality, including to protect human, animal or plant life or health or to avoid serious prejudice to the environment, provided that such exclusion is not made merely because the exploitation is prohibited by their law. 
diversity. Members can argue for exclusion of certain subject matter from patentability and thus their exclusion from "commercial exploitation - based on

...ordre public or morality, including to protect human, animal or plant

life or health or to avoid serious prejudice to the environment...

However, there is a proviso that

...such exclusion is not made merely because the exploitation is prohibited by their law.

This suggests that an additional justification is necessary than the mere fact that such subject matter has not so far been recognized as patentable in that domestic jurisdiction or that it has been specifically excluded thus far. The status quo is questioned and relevant domestic authorities should be alert to the possibility of their laws being challenged; and they should be prepared to clarify the linkages of the existing law to ordre public, morality, protection of human, animal or plant life or health or avoidance of serious prejudice to the environment. Controversies relating to Article 27.2-type exclusions include the addition of microbiological or biotechnological processes and products including genes and gene sequences. It is left to Members to make the necessary arguments; either that the exclusion is justified or that if patents are granted, the monopolistic control by corporations of such knowledge and opportunities to conduct further research in those areas has the future health and wellbeing of the global population at stake. ${ }^{1862}$ The consequences of their decision could affect medicine, vaccines, medical treatment and food production, as well as health services and health insurance. The moral dimension of corporate ownership of microbiological products, processes and genes or gene sequences is another serious matter by itself, which can and should be considered as an issue of ordre public or morality regarding the protection human health and there is still some national policy space for public ownership and control. ${ }^{1863}$

Article 8.1 of the TRIPS recognizes the rights of Members to take measures to protect public health and recognizes its importance as a public policy objective. ${ }^{1864}$ It states as follows:

Members may, in formulating or amending their laws and regulations, adopt measures necessary to protect public health and nutrition, and to promote the public interest in sectors of vital importance to their socioeconomic and technological development, provided that such measures are consistent with the provisions of this Agreement

However, it is pointed out that Article 8, which is titled 'Principles', does not set out any legal obligations as such but merely clarifies how concessions are to be made during negotiations, taking into account public policy issues such as public health. ${ }^{1865}$ In this sense, it cannot be seen as a limitation on the intellectual property rights themselves nor

\footnotetext{
${ }^{1862}$ Kuanpoth, Jakkrit, Intellectual Property Protection after TRIPS: An Asian Experience in Malbon, Justin and Charles Lawson Eds., INTERPRETING AND IMPLEMENTING THE TRIPS: IS IT FAIR?, Edward Elgar Publishing, 2008, p75-76.

${ }^{1863}$ See for an example with regard to the global legal framework for pathogens: Abbott, Frederick M., An International Legal Framework for the Sharing of Pathogens: Issues and Challenges, ICTSD Programme on IPRs and Sustainable Development, No. 30, October 2010/FSU College of Law, Public Law Research Paper No. 467; Wickramage, Kolitha, State Sovereignty over Deadly Pathogens: Ensuring Global Health Security, Sri Lanka Journal of International Law, Volume 25, 2016-2017, p50.

1864 Musungu, Sisule F., TRIPS and Public Health, in Correa, Carlos M. and Abdulqawi Yusuf Eds., INTELLECTUAL PROPERTY AND INTERNATIONAL TRADE: THE TRIPS AGREEMENT, Kluwer Law International, 2008 p431-432.

1865 De Carvalho, Nuno Pires, THE TRIPS REGIME OF PATENT RIGHTS, Kluwer Law International, 2010, p223-226.
} 
as exceptions to the rights. ${ }^{1866}$ This is supported by the fact that even the "measures necessary to protect public health" have the proviso that "such measures are consistent with the provisions of this agreement [emphasis added]". It is further confirmed by the Panel in EC-Trademarks and Geographical Indications, stating that there was no general exceptions provision in the TRIPS Agreement added that Members are granted the ...freedom to pursue legitimate public policy objectives since many measures to attain those public policy objectives lie outside the scope of intellectual property rights and do not require an exception under the TRIPS Agreement [emphasis added]. ${ }^{1867}$

The exceptions in the TRIPS Agreement are clearly identified as "limited exceptions" under Article 30 of the TRIPS that allow for a modicum of flexibility, provided that there is not no "unreasonable conflict with the normal exploitation of the patent" [emphasis added] or "unreasonably prejudice the legitimate interests of the patent holder". ${ }^{1868}$

Overall it appears that what may be sometimes presented as exceptions or flexibilities are merely a general indication to Members that there are measures that they can take, and should take if they wish to protect these vital concerns such as health, which do not encroach too far on the rights in the intellectual property regime. The Preamble to the TRIPS Agreement states that there is recognition for

...the underlying public policy objectives of national systems for the protection of intellectual property, including developmental and technological objectives; ....also the special needs of the least-developed country Members in respect of maximum flexibility in the domestic implementation of laws and regulations in order to enable them to create a sound and viable technological base...

This can also be read with Articles 8.1 and 27.2 but while it can add something to the interpretation of patentable subject matter, which has a close link with public health, right to health and access to medicines, it cannot be said that it sufficiently supports those policy aims. That Members took the position that there was inadequate policy space for the protection of public health is clear, as the Doha Declaration on Public Health ${ }^{1869}$ and the Amendment to the TRIPS ${ }^{1870}$ were seen as needed, in the first instance to make the political commitment to public health clearer in terms of TRIPS policy through the Doha Declaration and in the second, to attempt to make it a matter of legal obligation through an Amendment to the text. The Doha Declaration did not directly address exemptions from patentability but raised interpretation in light of objectives and principles of the TRIPS, further support for the special and differential treatment for least developing country Members (including technology transfer and assistance for developing their pharmaceutical manufacturing capacity) and the granting of compulsory licencing as flexibilities which Members can use to protect public health and access to medicines. This

\footnotetext{
1866 Ibid., (de Carvalho) p223.

${ }^{1867}$ Panel Report, EC-Trademarks and Geographical Indications (US), para.7.210 and Panel Report, ECTrademarks and Geographical Indications (Australia), para.7.246.

1868 See further for the in-depth interpretation of Article 30 of the TRIPS; the Panel Report in CanadaPharmaceutical Patents.

${ }^{1869}$ WTO Ministerial Conference, The Declaration on the TRIPS Agreement and Public Health. Adopted on 14 November 2001, Ministerial Conference, Fourth Session, Doha, 9-14 November 2001, $\mathrm{WT} / \mathrm{MIN}(01) / \mathrm{DEC} /$.

1870 WTO General Council, Implementation of Paragraph 6 of the Doha Declaration on the TRIPS Agreement and Public Health, Decision of 30 August 2003, WT/L/540 which led to the WTO General Council Amendment of the TRIPS Agreement Decision of 6 December 2005, WT/L/641 (which would enter into force upon receipt of the required ratifications).
} 
was followed by the 2003 and 2005 decisions of WTO Members concerning production of generic medicines under compulsory licencing. The Amendment incorporating a provision on compulsory licensing (Article 31bis) came into effect in 2017 after the Protocol to the TRIPS was accepted by two-thirds of the Members.

The GATS does not have such a provision on 'principles' which mentions this recognition of public health or public interest in formulating or amending laws or as suggested, as a basis for negotiating concessions during 'progressive liberalization'. Does this make the GATS weaker than the TRIPS with regard to acknowledging the seriousness and vital importance of public health - in the services aspect? It seems that this is so, and that, even more than for the TRIPS Agreement, there could be a need for a 'Declaration on Public Health for GATS' and a related Amendment to the Agreement (for example an Article Ibis to actually 'ring-fence' public health services) ${ }^{1871}$ or an Annex on Public Health Services that gives a legal basis for 'flexibility' that goes beyond 'exceptions' ... and perhaps one that goes beyond the TRIPS Agreement amendment as well, to put the right to health at the heart of the GATS.

Until then, according significance to public health in dispute settlement remains in the hands of panels and the Appellate Body - but only if raised in the arguments of a party to a dispute. This matter was discussed in the Appellate Body Report, US-Gambling. ${ }^{1872}$ Antigua argued that the Panel had acted inconsistently with its obligations under Article 11 of the DSU by 'constructing' the Article XIV(a) defence on behalf of the United States by adding interests such as public health. The Appellate Body stated (citing Appellate Body Report, EC-Hormones) that

...nothing in the DSU limits the faculty of a panel freely to use arguments submitted by any of the parties - or to develop its own legal reasoning - to support its own findings and conclusions on the matter under its consideration. ${ }^{1873}$

However, this was qualified by the comment that panels or the Appellate Body only enjoys such discretion:

...with respect to specific claims that are properly before it, for otherwise it would be considering a matter not within its jurisdiction. Moreover, when a panel rules on a claim in the absence of evidence and supporting arguments, it acts inconsistently with its obligations under Article 11 of the DSU [emphasis added]. ${ }^{1874}$

The Appellate Body further suggested that the interests and concerns raised ought not to be "inventions" of the panels. ${ }^{1875}$

This suggests, quite rightly, that while the 'legal reasoning' can be developed independently, the evidence and arguments concerning specific interests cannot be introduced by the panels. In this dispute Antigua's objections were dismissed since the

\footnotetext{
${ }^{1871}$ See the discussion on Article I of the GATS at Section 3.4 of this study, especially at 3.4.1, 3.4.4 and 3.4.5.

${ }^{1872}$ See Appellate Body Report, US-Gambling, paras.278-285

${ }^{1873}$ Appellate Body Report, US-Gambling para.280 citing Appellate Body Report, EC Hormones, para.156. The Appellate Body Report, US-Certain EC Products, para.123 was also referred to in the footnote.

1874 Appellate Body Report, US-Gambling, para.280 citing Appellate Body Report, Chile-Price Band System, para. 173.

${ }^{1875}$ Appellate Body Report, US-Gambling, para.284, commenting that in this situation there was evidence that the interests were "not an invention of the Panel" [emphasis added].
} 
Appellate Body found that the United States had included references to the interests of public health in its first and second submissions to the Panel although subsequently there were no further explicit references to public health in the context of their argument relating to Article XIV(a). ${ }^{1876}$ It was stated that the Panel was not precluded from considering public health as part of its Article XIV(a) analysis. ${ }^{1877}$

Thus, the primary responsibility is on the part of Members, to bring out public health arguments or go even further and draw attention to their international and domestic obligations to protect the right to health (if this is the case for their jurisdiction - it is obviously not so for the United States). On the other hand, panels have a right to seek information and technical advice under Article 13 of the DSU. Article 13.2 specifically states that "panels may seek information from any relevant source and may consult experts to obtain their opinion...". The Appellate Body in US-Shrimp confirmed that panels can "seek information" from any expert or non-governmental body, and use that information in its reasoning if it so wishes; but additionally, took a creative interpretive step in considering that Article 13 also allowed a panel to accept and consider unsolicited information (amicus curiae briefs). ${ }^{1878}$ This is an important entry point for unsolicited health-related information to enter into consideration, and could be used by health advocacy groups, associations of health professionals, scientists with relevant information on health issues and other organizations with relevant expertise.

It is notable that in US-Clove Cigarettes the Appellate Body declined an offer of technical assistance from the WHO. The Appellate Body stated that they made this decision in light of the fact that the parties had placed a considerable amount of materials regarding WHO legal instruments and the WHO's work in the area of tobacco control on the Panel record, and thus it was not deemed necessary to request assistance from the WHO. ${ }^{1879}$ Unlike the detailed comments of the Panel, the Appellate body makes no further mention of the WHO or its documents or instruments. In not including more detailed response, the Appellate Body was exercising its discretion under Article 13 of the DSU. However, this can be seen as a lost opportunity for including the expertise of the WHO into trade and health discussions at the WTO dispute settlement level.

\subsubsection{The two-tiered approach to the analysis of Article XIV of the GATS}

The first step in interpreting Article XIV of the GATS is to point out the well-trodden path, rather than suggest a short/new cut through the woods of words and technicalities. Despite the differences between the two general exceptions Articles in the GATT and the GATS, there are some aspects of the interpretive path to analyzing these particular exceptions that are non-controversial. The two-tiered approach in the application of Article XX of GATT 1994, which has been followed since US-Gasoline, ${ }^{1880}$ has been

\footnotetext{
1876 The Appellate Body at footnotes 339-340 cited the United States' first written submission to the Panel as stating "supply of gambling into private homes, workplaces, and other environments creates additional health risks" and the second written submission referring to "remote gambling poses a greater and broader threat to human health".

${ }^{1877}$ Appellate Body Report, US-Gambling, para.284.

1878 Appellate Body Report, US-Shrimp, para.104-110. See further, Donaldson, Victoria, The Appellate Body: Institutional and Procedural Aspects in Appleton, Arthur E. and Michael G. Plummer Eds., THE WORLD TRADE ORGANIZATION: LEGAL, ECONOMIC AND POLITICAL ANALYSIS, Springer, 2007 p1259-1261.

1879 Appellate Body Report, US-Clove Cigarettes, para. 11.
} 
approved in the context of Article XIV of the GATS in US-Gambling ${ }^{1881}$ and ArgentinaFinancial Services. ${ }^{1882}$

According to the Panel and Appellate Body in US-Gambling, when Article XIV of the GATS is being raised in a dispute, it must be established whether the measure at the heart of the dispute:

1. falls within the scope of one of the recognized exceptions set out in paragraphs (a) to (e) of Article XIV in order to enjoy provisional justification; and

2. meets the requirements of the introductory clause of Article XIV, the socalled 'chapeau'. ${ }^{1883}$

In US-Shrimp the Appellate Body criticized the Panel which had reversed the sequence, and stated that:

[t]he sequence of steps... reflects, not inadvertence or random choice, but

rather the fundamental structure and logic of Article XX. ${ }^{1884}$

However, more recently, in Indonesia-Import Licencing Regimes, the Panel in their analysis examined the chapeau first, and then rejected the Article XX defence without considering the applicability of the specific paragraphs, but the Appellate Body was not convinced that a deviation from the normal sequence of analysis was "for that reason alone" a reversible legal error by the Panel. ${ }^{1885}$

Article XIV of the GATS, like Article XX of GATT 1994, contemplates a similar analysis of a measure that a Member seeks to justify under that provision. The Member relying upon Article XIV should be able to defend the position that firstly, the challenged measure falls within at least one of the specified exceptions and secondly, that the application of the measure complies with the requirements of the chapeau.

The first step of the abovementioned sequence - whether the challenged measure falls within the scope of a paragraph of Article XIV - includes a demonstration of the existence of a sufficient connection between the measure and the interest protected. The Appellate Body in US-Gambling clarified with regard to the first step that:

This requires that the challenged measure address the particular interest specified in that paragraph and that there be a sufficient nexus between the measure and the interest protected. The required nexus - or "degree of connection" between the measure and the interest is specified in the language of the paragraphs themselves [emphasis added]. ${ }^{1886}$

This aspect is also referred to as the necessity test, when the nexus is the term "necessary", as in the case of the first three paragraphs of Article XIV. This test is in

\footnotetext{
${ }^{1881}$ Panel Report, US-Gambling, para.6.449, citing the Appellate Body Report, US-Gasoline, p22 and the subsequent approval by the Appellate Body in Korea-Various Measures on Beef, para 156 and in the Appellate Body Report US -Shrimp, paras.115-119.

1882 Panel Report, Argentina-Financial Services, para.7.586.

${ }_{1883}$ Panel Report, US-Gambling, para.6.449 and Appellate Body Report, US-Gambling, para.292.

1884 Appellate Body Report, US-Shrimp, paras.119-120.

1885 Appellate Body Report, Indonesia-Import Licensing Regimes, paras.0.69 and 1.7. The Appellate Body noted at para.1.8 that even if they acceded to Indonesia's request, the findings of the Panel would remain undisturbed. Therefore, they declined to rule on Indonesia's claim on appeal under Article XX of the GATT 1994, but declared that "the Panel's finding that 'Indonesia ha[d] failed to demonstrate that Measures 9 through 17 are justified under Articles XX(a), (b) or (d) of the GATT 1994, as appropriate', in paragraph 7.830 of the Panel Report, moot and of no legal effect".

${ }_{1886}$ Appellate Body Report, US-Gambling, para.292.
} 
conjunction with the definition and scope of the relevant objective of the paragraphs of Article XIV and will be discussed in further detail in the subsequent section of this chapter.

Thus, the first part of the Chapter will analyze and the scope of the exceptions in paragraphs (a), (b) and (c) in Article XIV of the GATS: "public morals and public order", "human, animal or plant life or health", "compliance with laws or regulations which are not inconsistent with the provisions of this Agreement" - which all have the nexus of 'necessity'. A discussion on the necessity test will then follow. It should be noted that the current GATS jurisprudence is related to paragraphs (a) and (c) in particular, which use the nexus "necessary". Paragraphs (a) and (b) on public morals and human life or health would perhaps have the most direct connection with health services, the special emphasis of this research. Finally, the application of the measure is also analyzed under the second part of the two-tiered approach, the requirements of the chapeau to Article XIV. 


\subsection{ARTICLE XIV(A) OF THE GATS: "NECESSARY TO PUBLIC MORALS OR TO MAINTAIN PUBLIC ORDER"}

In discussing the first paragraph of Article XIV, the interests of public morals and public order, the structure of the paragraph as understood by the Panel in US-Gambling will be followed, that is, the Panel believed that "public morals" and "public order" are "two distinct concepts" where some overlap may exist as they seek to protect "largely similar values". ${ }^{1887}$ Thus the two phrases will be looked at separately, but the similarities and possible overlap will also be discussed.

In terms of interpretation of the terms "public morals" and "public order", the analysis will include but not be limited to the VCLT 'text-context-object and purpose' approach. The VCLT approach would limit an interpretation of a term to the ordinary meaning in light of context and object and purpose. Ordinary meaning is often sought through reference to dictionaries and glossaries, as will be discussed in more detail in this Section 5.3. Examination of the relevant context in disputes has included reference to the Schedule of the Member (including the structure of the Schedule, other relevant elements of the subsector at issue, sectoral headings in the sector concerned, market access and national treatment commitments, as well as commitments scheduled under another related sector), the substantive provisions of the GATS, the provisions of covered agreements other than the GATS and the GATS Schedules of other Members. ${ }^{1888}$

In looking at object and purpose, the panels and Appellate Body have referred to the objectives in the Preamble of the GATS, but acknowledged that it may not be useful in all instances, since the Preamble may not always have a term or phrase that provides specific 'object and purpose' guidance for the other GATS term or phrase being interpreted in a dispute. ${ }^{1889}$ As can be seen, the reliance on the VCLT method may not be conclusive in interpreting the phrase "public morals" - it being quite ambiguous and its scope possibly being quite broad to capture within this 'formula'.

Therefore, "public morals" and "public order" will also be discussed in terms of general societal values and the contribution that could be made by a human rights-based approach that a 'bilingual' scholar (as referred to in Section 2.3 of this study) could apply to the understanding of the terms. The discussion of "public morals" and "public order" will be discussed in light of the societal values concerning public health services that were raised in the previous Chapters.

\footnotetext{
1887 See Panel Report, US-Gambling, paras.6.465 -6.469.

1888 Panel Report, EU-Energy Package, para.7.314 citing Appellate Body Report, US-Gambling, paras. 7.102 and 179; and China-Publications and Audiovisual Products, paras. 361-372; and Panel Report, China-Electronic Payment Services, para. 7.104).

${ }^{1889}$ See Panel Report, EU-Energy Package, para.7.336, referring to Appellate Body Report, US-Gambling, para.188-189, where the Appellate Body found that the purpose of transparency contained in the preamble to the GATS supported the need for precision and clarity in scheduling GATS commitments but also observed that the objectives contained in the preamble of the GATS did not provide specific guidance as to the correct interpretation of GATS Schedules. See also the Appellate Body Report, China-Publications and Audiovisual Products, para. 393, supporting the latter point made Appellate Body Report, US-Gambling.
} 


\subsubsection{Introduction to "Public morals" in the GATS}

'Tut, tut, child!' said the Duchess.

'Everything's got a moral, if only you can find it.'

From Lewis Carroll's Alice in Wonderland

When any ordinary person thinks of 'morality', various personal views as well as views imposed by society or spiritual and political authority, may come to mind. The issue can be seen from many different angles and the connotations of the phrase are coloured by personal experience. There are many stories that can be told, but this particular story focuses on the modern legal understanding of 'morality' - and thus also of 'values'. In the broadest terms, any law can be considered a:

...social judgment about right and wrong, thus falling within a broad contextual definition of public morals. ${ }^{1890}$

If that was the standard, then any law inconsistent with the GATS could be provisionally protected by the public morals exception. Using such a broad definition would mean that the test of the nexus between the interest and the measure ("necessary") and the chapeau would be the deciding factors in whether a WTO Member can legitimately rely upon a GATS-inconsistent measure "necessary to protect public morals", while maintaining the integrity of the system as a whole.

Furthermore, other subsections, including Article XIV(b) ("measures necessary to protect human, animal or plant life or health") could become redundant as those interests could easily be included within the scope of Article XIV(a) if such a broad definition is applied. It can be argued therefore, by those who support the view that the exceptions should be interpreted narrowly, that the scope of the general exceptions clause should limited, not only by application of the chapeau and "nexus test", but also by the definition of the substantive paragraphs. But the questions of how and by whom interests such as the term "public morals" are to be defined and the extent of the scope of protection need to be further clarified. It has been stated by the Panel in China-Publications and Audiovisual Products that:

...it is undoubtedly the case that the protection of public morals ranks among the most important values or interests pursued by Members as a matter of public policy. ${ }^{1891}$

The importance and the potential of this provision to balance other non-WTO values and interests with WTO obligations is apparent, but it cannot be of any use without resort to it by Members in a dispute and a progressive interpretation by panels and the Appellate Body.

Fortunately, the first step in this direction has been taken and there is finally an authoritative source to turn to in the issue of defining public morals for GATS, and for international trade law: the WTO case of US-Gambling. The Appellate Body observed that this case:

\footnotetext{
${ }^{1890}$ Marwell, Jeremy C., Trade and Morality: The WTO Public Morals Exception after Gambling, 81 NYU Law Review 2006, p817

${ }^{1891}$ Panel Report, China-Publications and Audiovisual Products, para.7.817 (referring to Article XX(a) of the GATT 1994)
} 
.... is not only the first where the Appellate Body is called upon to address the General exception provision of the GATS, but also the first under any of the covered agreements where the Appellate Body is requested to address exception relating to "public morals ${ }^{1892}$.

The succinct result of the Gambling case appears to be that the term is to be defined textually, with acknowledgement of domestic definition, as well with reference to international practice. To what extent this is or could be a reliable guide for application in future disputes is a matter that needs further discussion.

Considering the fact that the interpretation of this phrase in the GATS took six decades since the GATT 1947 provision was first agreed upon ${ }^{1893}$, it is fortunate that there is finally the US-Gambling report to look at. But even in this occasion, the term arose in a traditional public morals issue of gambling. It remains to be seen if and how the interpretation will develop for an issue such as protection of public health services as a matter of public morals.

In the context of Article XX(a) of the GATT 1994, both the Panel and Appellate Body in the Colombia-Textiles dispute considered that Colombia, had:

...presented sufficient evidence to demonstrate the existence of $a$ real and present concern in Colombia with regard to money laundering, as well as with regard to the way in which money laundering is linked with drug trafficking and other criminal activities and with Colombia's internal armed conflict [emphasis added]. ${ }^{1894}$

The documents submitted by Colombia as evidence included the National Development Plan 2010-2014, the National Anti-Drug Policy and the National Policy against Money Laundering and the Financing of Terrorism. Although the Panel recognized the relationship between the national policies and public morals in general, it concluded "the design, architecture, and revealing structure" of the measure at issue (a compound tariff) was such that they could not conclude that there was a relationship between it and the declared policy objective of combating money laundering. ${ }^{1895}$ The Appellate Body in its analysis of the same matter stated that there are two steps in establishing whether a measure is justified under Article XX(a) of the GATT. This could apply similarly for Article XIV(a) of the GATS. A "real and present concern" which has sufficient evidence of national policy, such as a public health services policy, could be accepted prima facie by the WTO dispute settlement bodies, but there are certain requirements in the analysis in addition to this. The two steps described by the Appellate Body are as follows:

First, the measure must be "designed" to protect public morals...

Second, the measure must be "necessary" to protect such public morals. ${ }^{1896}$

The Appellate Body made it clear that the analysis of the "design" of a measure "to protect public morals" requires a "threshold examination" (including content, structure,

\footnotetext{
${ }^{1892}$ Appellate Body Report, US-Gambling, footnote 351. See also Marwell, Jeremy C., Trade and Morality: The WTO Public Morals Exception after Gambling, 81 NYU Law Review, 2006, p811 (also footnote 36 and 37) states that of the more than 250 regional and bilateral trade agreements registered at the WTO, "...over 100 contain public morals exceptions similar or identical to GATS Article XIV(a)".

1893 Note that provision on public morals in the General Exceptions was not debated in detail or modified/re-negotiated from the GATT position in the Uruguay Round for either the GATT or the GATS.

1894 Appellate Body Report, Colombia-Textiles, para.5.50, referring to Panel Report, Colombia-Textiles, para.7.335.

1895 Panel Report, Colombia-Textiles, paras.7.400-7.401, and cited in Appellate Body Report, ColombiaTextiles, para.5.58.

${ }^{1896}$ Appellate Body Report, Colombia-Textiles, para.5.67.
} 
and expected operation of the measure) in order to determine whether there is a relationship between the measure and the protection of public morals; and if this examination "reveals that the measure is incapable of protecting public morals", then the requirements of the "design" step are not met and the there is no further need to examine the necessity of the measure. ${ }^{1897}$ The Appellate Body in Colombia-Textiles did not agree with the conclusions of the Panel in the matter of design of the measure, but came to the same finding on necessity, although on a slightly different analytical path.

While the "design" and "necessity" steps were seen as "conceptually distinct, yet related" and having overlap in terms of analyzing the same evidence and considerations, the Appellate Body in Colombia-Textiles noted that this examination of "design" was not "a particularly demanding step" in contrast with the "more in-depth, holistic analysis" required for an assessment of necessity. ${ }^{1898}$ If a similar two-step process is applied in relation to an Article XIV(a) of the GATS exception raised in connection with a measure that is for protecting public health services, it could be assumed that a threshold examination of "design" of the measure and the relationship with public morals could be more easily determined than "necessity". The necessity test will be discussed further in Section 5.6 of this Chapter.

The scope of public morals under Article XX(a) of the GATT has been extended to newer areas, such as concerns with the health and welfare of animals. The Appellate Body in EC-Seal Products upheld the Panel's earlier finding that the EU Seal Regime is "necessary to protect public morals" within the meaning of Article XX(a) of the GATT 1994. The EU had claimed that the EU Seal Regime is "aimed at addressing public moral concerns on the welfare of seals" (Article XX(a) of the GATT 1994) and the health of seals (Article XX(b) of the GATT 1994) and not merely based on general conservation concerns. ${ }^{1899}$ The Panel and Appellate Body accepted that the policy objective pursued by the EU was an important value or interest covered by the public morals exception. ${ }^{1900}$ However, both the Panel and Appellate Body in EC-Seal Products ultimately found that the measures in dispute were not justified because they failed to meet the requirements under the chapeau of Article XX. If the health and welfare of animals could be considered a matter of public morals, then the welfare of human beings and their needs and human rights in relation to public health services, ought to be accepted as public morals concerns, if the matter is ever raised.

If we turn to the 2002 Report of the High Commissioner on Human Rights on the Liberalization of Trade and Human Rights mentioned earlier, it is stated in the Report that

The protection of public morals, life and privacy are familiar themes to human rights law and their inclusion in GATS could be seen as a link to the promotion and protection of human rights, such as the right to life, the right to health and aspects of the right to privacy. ${ }^{1901}$

\footnotetext{
${ }^{1897}$ Appellate Body Report, Colombia-Textiles, paras.5.68-5.69 (also see 5.126).

1898 Appellate Body Report, Colombia-Textiles, paras.5.70 and 5.76.

${ }^{1899}$ Panel report, EC-Seal products, para.7.3.

1900 Panel report, EC-Seal products, paras.7.631-7.632, citing the Panel report, China-Publications and Audiovisual Products, para. 7.817.

${ }^{1901}$ UN Economic and Social Council, Commission on Human Rights, Report of the High Commissioner, Liberalization of trade in services and human rights, E/CN.4/Sub.2/2002/9, 25 June 2002, para.63.
} 
As can be seen, "public morals" is a term used in the human rights context as well, in particular in the context of the right to health, and this could have relevance for the interpretation of the term "public morals" in the WTO context.

\subsection{2. "Public Morals" and Human Rights}

The idea has been put forward that both international human rights and environmental law and policy can be incorporated through the public morals clauses in the WTO Agreements, as many of these concepts are (arguably) a firm part of the "prevailing notions" of public morals and thus part of the "ordinary meaning" of the term. In an oftquoted statement made a few years prior to the US-Gambling Report, Howse has noted that, in light of modern developments:

...the very idea of public morality has become inseparable from the concern for human personhood, dignity and capacity reflected in fundamental rights. A conception of public morals or morality that excluded notions of fundamental rights would simply be contrary to the ordinary contemporary meaning of the word [emphasis added]. ${ }^{1902}$

Following the US-Gambling Report, there was another Report by the High Commissioner on Human Rights in 2005 subtitled as Using General Exception Clauses to Protect Human Rights, (where Howse was one of the reviewers) ${ }^{1903}$ which quotes the above statement and adds that:

...under the ordinary meaning of the terms, the full range of human rights norms and principles that are codified in international legal instruments could come within the ambit of the term "public morals" [emphasis added ]. ${ }^{1904}$

That seems like a large weight for a small term to bear, but human rights proponents have seen this provision and its ordinary meaning as an opportunity to bring in the entire human rights regime in, and to balance it with the trade regime. ${ }^{1905}$

However, on closer inspection, the relationship between human rights and public morals cannot be deemed identical to the relationship between trade liberalization and the public morals exception. It cannot be said to be a situation where public morals merely refer to a larger category that includes human rights concerns (public morals $=$ human rights $+X+$ $Y$ ). Public morals are raised in the human rights context where "public morals" and "public order" are legitimate limitations or derogations from some human rights, where derogations are allowable. ${ }^{1906}$ This is true across different texts on human rights, from the

1902 Howse, Robert, Back to Court after Shrimp/Turtle? Almost but not quite yet: India's short-lived challenge to labour and environmental exceptions in the European Unions generalized system of preferences, American University International Law Review Vol. 18, No. 6, 2003, 1333 at p1368.

${ }^{1903}$ UN, Office of the High Commissioner on Human Rights, Human Rights and World Trade Agreements: Using General Exception Clauses to Protect Human Rights, HR/PUB/O5/5, 2005 (Prepared by James Harrison and reviewed by Steve Charnovitz, Robert Howse and Gabrielle Marceau).

1904 Ibid., p12.

1905 See further UN Commission on Human Rights, Mainstreaming the Right to Development into International Trade Law and Policy at the World Trade Organization, (Paper prepared by Robert Howse), UN.Doc E/CN.4/Sub.2/2004/17, June 9 2004; UN, Office of the High Commissioner on Human Rights, Human Rights and World Trade Agreements: Using General Exception Clauses to Protect Human Rights, (prepared by James Harrison and assisted by Steve Charnovitz, Robert Howse and Gabrielle Marceau), HR/PUB/O5/5, 2005.

${ }^{1906}$ Limitations to rights apply in ordinary day-to-day situations, but derogations are temporary suspensions of rights that apply only during emergency situations (natural or man-made) that affect the security of the 
international covenants including the ICCPR and regional treaties such as the European Convention on Human Rights to fundamental rights in national constitutions. The role of public morals in these contexts is to limit the application of human rights (of the individual, or of groups) for purposes also related to human rights (of other individuals, groups or of the collective).

This is clear even in the Universal Declaration on Human Rights (UDHR, 1948): UDHR, Article 29(2):

In the exercise of his rights and freedoms, everyone shall be subject only to such limitations as are determined by law solely for the purpose of securing due recognition and respect for the rights and freedoms of others and of meeting the just requirements of morality, public order and the general welfare in a democratic society [emphasis added].

The ICCPR and the ICESCR provide the opportunity for States to accept as binding obligations, the principles set out in the UDHR. The ICCPR does not have a general limitation clause, but tackles limitations on each right separately. For example, Article 12(3) of the ICCPR limits the freedom of movement if there are restrictions ...provided by law, are necessary to protect national security, public order (ordre public), public health or morals or the rights and freedoms of others, and are consistent with the other rights recognized in the present Covenant [emphasis added].

There is however, a general clause on derogations in the ICCPR, which is Article 4, setting out the criteria for derogations from rights in the Covenant.

Limitations are tackled in a general clause in the ICESCR, where Article 4 of the ICCPR states:

The State may subject such rights only to such limitations as are determined by law only in so far as this may be compatible with the nature of these rights and solely for the purpose of promoting the general welfare in a democratic society [emphasis added]

The limitations or derogations (there are not termed 'exceptions' in human rights law) are not for the purpose of undermining the rights of individuals, but to balance the rights at hand with competing rights and the general welfare of democratic societies.

nation. The freedom of expression can be limited generally by laws on 'hate speech' or 'incitement to violence' that could come under Article 19(3)b ICCPR limitations:

For the protection of national security or of public order (ordre public), or of public health or morals

The right to a public hearing (Article 14 ICCPR) can be limited in the following way:

The press and the public may be excluded from all or part of a trial for reasons of morals, public order (ordre public) or national security in a democratic society, or ...

Derogations during the time of emergency are possible for Article 9 and 10 of the ICCPR (liberty and security of the person and deprivation of liberty). Article 61 of the Siracusa Principles on the Limitation and Derogation Provisions in the ICCPR (see below) states clearly that:

Derogation from rights recognized under international law in order to respond to a threat to the life of the nation is not exercised in a legal vacuum. It is authorized by law and as such it is subject to several legal principles of general application.

Some rights cannot be limited or derogated from; for example, no limitations or derogations even in times of emergency are allowed in the international human rights regime from the right to life, the freedom of thought and conscience and the right not to be subjected to torture and slavery. See further, Alston, Phillip and Ryan Goodman, INTERNATIONAL HUMAN RIGHTS, Oxford University Press, 2012, p394. See also UN, Economic and Social Council, Siracusa Principles on the Limitation and Derogation Provisions in the International Covenant on Civil and Political Rights, U.N. Doc. E/CN.4/1985/4, Annex (1985). 
It can be argued that this balancing role carried out by "public morals" limitation in international covenants and conventions between a human right and another societal value is similar to the role of "public morals" in Article XIV(a) in context of trade and other societal values. However, there are important differences. One of these is that in the human rights regime, there is greater acknowledgement of the relationship between public morals and human rights, even when it is a limitation on rights. In the trade context, 'public morals' are used for providing an exception to the trade rules, but at the same time 'public morals' are also presented by some critics as a way in which human rights can enter into the trade regime. However, the relationship between trade rules and human rights is not elaborated further. As discussed earlier in Chapter 1 of this study, WTO proponents usually seem to focus on trade rights as human rights and do not delve further into the details and complexities. The complicated relationship between "public morals" and human rights is something perhaps to be tackled when as and when such an issue arises. But it has so far been avoided and has not been raised by responding Members even when disputes have touched on matters that could be human rights-related.

Therefore, the situation in the WTO context could be presented as follows:

$$
\text { GATS public morals }=\{\text { (human rights /balanced by public morals limitations })+x+y\}
$$

Thus, the suggestion that 'public morals' in the WTO can include all human rights concerns and facilitate a human rights-friendly interpretation of WTO exceptions - while being a possibility under one method of interpretation - faces an obstacle in that "public morals in human rights treaties are also restrictions on human rights. Morijn notes that 'public morality' (and public policy, public security etc.) "conceptually different from fundamental rights" and thus:

$\ldots$ it is hard to see how fundamental rights can be properly integrated into trade agreements through a legal concept that serves as an exception to their own application. This essentially amounts to suggesting a legal avenue to invoke fundamental rights in a trade context through their own exception, and thus to a legal contradiction from a fundamental rights viewpoint [emphasis in original]. ${ }^{1907}$

Thus, some serious doubts exist concerning the usefulness of a human rights approach to interpreting 'public morals'. It could be argued that the only reason to push for it is if all other avenues are unrealistic; such as an amendment to the WTO Agreement or an amendment to the GATS including a new balancing or exceptions provision that explicitly allows for human rights to be taken into account. On the other hand, the mere fact of being a complex concept, does not mean that the application of a formula such as the one suggested above should be rejected, when it can be used to clarify 'public morals' for the GATS context. Despite the complexity of the suggested formula for taking human rights into account, it could be a useful method for the panels and Appellate Body to employ.

The recourse to the public morals exception of Article XX(a) by China in the ChinaPublications and Audiovisual Products dispute for 'content review', and the response by the Panel and the Appellate Body is illustrative of the challenges in trying to include

1907 Morijn, John, Conflicts between Fundamental Rights or Conflicting Fundamental Rights Vocabularies?: An Analysis of Diverging Uses of 'Fundamental Rights' in the Context of International and European Trade Law in Brems Eva Ed., CONFLICTS BETWEEN FUNDAMENTAL RIGHTS, Intersentia 2008, p21-22. 
human rights in the public morals exception. China relied on public morals as a justification for a measure that was both a limitation on trade and a censorship on freedom of information. China did not succeed in its attempt to rely on the exception, but the issue of whether the measures were within the definition of 'public morals' remained an assumption that was not analyzed. The Panel avoided stating whether the Chinese measures were covered by the public morals exception, made an assumption that they were and went directly to tackle the necessity test. ${ }^{1908}$ The Panel only stated that they accepted:

...the fact that the protection of public morals is a highly important governmental interest and that China has adopted a high level of protection of public morals within its territory. ${ }^{1909}$

A Members' reliance on 'public morals' justifications thus appears to be approached rather deferentially, leaving it to the Member to define the public morals in its territory as long as it is supported by evidence that such morals are actually held. The Appellate Body observed, of course, that:

...reliance upon an assumption arguendo...may not always provide a solid foundation upon which to rest legal conclusions ... [and] may detract from a clear enunciation of the relevant WTO law and create difficulties for implementation. ${ }^{1910}$

Therefore, the Appellate Body decided to address themselves the issue of applicability of Article XX(a) of the GATT to the dispute (whether it was a defence to a violation of paragraph 5.1 of China's Accession Protocol). Thus, neither the Panel nor the Appellate Body in this case made any statements on whether 'content review' (or censorship) was a 'public morals' issue and therefore provisionally justified, since it was ultimately held that Art XX was not applicable. This is in contrast with US-Gambling where there was evidence presented and analysed as to whether gambling was a public morals issue. This was the first dispute that could have analysed the scope and meaning of public morals in Article XX(a) of the GATT 1994.

For some, this was a lost opportunity for the WTO to protect and enhance (through trade) human rights such as the freedom of speech and expression and the right to information in China, a country well known for its censorship policies. Since in this case the violations of the human rights were in effect also trade restrictions, this was a situation where the protection of human rights and the interests of trade coincided. Panizzon (in 2008) believed that:

...the WTO should regard the effect of certain human rights violations

[such as freedom of speech] as a restriction on multilateral trade liberalization

- and that it was "questionable" whether China could justify its internet censorship (which was also "a restriction of human rights") under Article XIV of the GATS. ${ }^{1911}$ Uyen P. Le, also referring to internet censorship, said in 2012 that:

1908 This sort of 'skipping the steps' and going straight to the necessity test had also been used, according to the Panel, by the Appellate Body in US-Shrimp (Thailand) / US-Customs Bond Directive with regard to Article XX(d) of the GATT (referred to in Footnote 411 of the Appellate Body Report, China-Publications and Audiovisual Products).

1909 Panel Report, China-Publications and Audiovisual Products, para.7.828. Also repeated in paras.7.863, 7.860, and 7.836.

${ }^{1910}$ Appellate Body Report, China-Publications and Audiovisual Products, para.213.

1911 Panizzon, Marion, How Human Rights violations nullify and impair GATS Commitments in Panizzon, Marion, Nicole Pohl and Pierre Sauvé Eds., GATS AND THE REGULATION OF INTERNATIONAL TRADE IN SERVICES, Cambridge University Press, 2008, see especially p534 and p555. 
... interpretive incorporation of the human rights jurisprudence on "public morals" concerning Internet censorship... would bring about positive results for both international trade and human rights ${ }^{1912}$

However, 'public morals' is a limitation on the freedom of speech and expression and the right to receive information in the ICCPR, just as 'public morals' is a limitation on the trade rules of the WTO. Thus, to seek to enhance a right through its own limitation is obviously a challenge in terms of interpretation. Delimatsis, commenting on the ChinaPublications and Audiovisual Products dispute noted that even a WTO-consistent action by China would enhance neither freedom of expression nor democracy in China, but a "less democratic regime in China" 1913 and further that:

[i]n other words, the WTO judiciary advanced the view that a more democracy-impairing measure would be a less trade-restrictive measure [emphasis in original]. ${ }^{1914}$

This is not only discouraging for human rights activists with special interest in China, but unfortunately supports the negative view of the WTO as insensitive to wider concerns of human rights and democracy and having some kind of 'trade-blinders' or 'trade tunnel vision'. Giving the Appellate Body the benefit of the doubt, it is not that they were unaware of these implications, but it could be that they are aware that the mechanism of bringing in such human rights concerns and human rights treaty obligations into WTO law would be more controversial than a decision that focused entirely on strictly interpreting the relevant WTO provisions. In the particular context of China, where there are various parties interested in political freedoms and/or trade opportunities, it can be argued in their favour that the Appellate Body focused on interpreting WTO law and justifiably avoided extending their role. It could be said that the individuals in the panels and Appellate Body are basically expert mechanics making sure an SUV runs as smoothly as it is designed to do (the SUV being a WTO Member complying with WTO law), but that they are not involved in creating motor traffic regulations, licences, compulsory insurance, seatbelt laws, speed limits, criminalization of hit-and-run or driving under the influence of alcohol or drugs etc. (all other national and international law and their enforcement), and neither are they the traffic police or judiciary enforcing such laws.

Delimatsis made an interesting reference to the Petersmann-Alston/Howse debate, where he identified Petersmann as being in favour of "a broader mission" for the WTO:

... which would encompass the interpretation of WTO law in conformity with universally recognized human rights

- and that this (broader mission) was "contested by several scholars, most notably Robert Howse and Phillip Alston". ${ }^{1915}$ To suggest that Alston and Howse support a narrower view than Petersmann for human rights is quite mistaken. They were challenging Petersmann with regard to his definition and understanding of 'human rights' as not being aligned with the definition and understanding of human rights developed in the human rights regime through human rights instruments. As mentioned earlier in this study, the debate was not on whether the WTO could/should have a broader mission with regard to

\footnotetext{
${ }^{1912}$ Le, Uyen P., Online and Linked In: "Public Morals" in the Human Rights and Trade Networks, 38 North Carolina Journal of International Law and Commercial Regulation, 2012,107, p150.

1913 Delimatsis, P., Protecting Public Morals in a Digital Age: Revisiting the WTO Rulings on US-Gambling and China- Publications and Audiovisual Products, Journal of International Economic Law 14(2), 2011, 257-293, p286, also see p283

${ }^{1914}$ Ibid., (Delimatsis), p292.

1915 Ibid., (Delimatsis) p287 and footnote 165.
} 
human rights, but that human rights vocabulary should not be misused for the purpose of promoting narrow trade concerns. ${ }^{1916}$ Even in the context of China-Publications and Audiovisual Products, the inclusion of human rights concerns seems more about denying China recourse to the exception, than a general promotion and defence of human rights concerns.

Delimatsis also comments that the ECJ did not interpret the 'public morals' exception narrowly, when they should have done so with a view to supporting rules on free movement: for example when it was applied it in the case of Karner. ${ }^{1917}$ However, one cannot agree with Delimatsis since in that case, the ECJ was faced with a conflict between freedom of expression as protected by Article 10 of the European Convention on Human Rights (ECHR) and the aim of consumer protection, ${ }^{1918}$ the latter of which they upheld in the public interest, with the support of the public morals exception to freedom of speech. To have done otherwise would have been to allow for commercial interests to override consumer protection. The WTO system notably does not have a consumer protection regime for similar balancing, and would have to rely on only the exception in case of a conflict between trade and non-trade interests. Furthermore, Karner was about the "commercial use of freedom of expression" in the context of advertising, ${ }^{1919}$ it was not an issue of human dignity and rights, even if the ECJ has recognised the right for corporations to lodge applications with the Court under Article 34 of the ECHR. The ECJ and European Court of Human Rights have a close relationship with regard to the interpretation and application of the ECHR; and the European Court of Human Rights has taken an article-by-article approach to the ECHR in deciding whether corporations have a particular right. ${ }^{1920}$ Similarly, domestic jurisdictions can allow for constitutional fundamental rights applications from corporations for certain rights.

\footnotetext{
1916 Alston as describes this as an opportunistic attempt at co-opting a language with great moral force for narrow instrumentalist reasons (Alston, P., Resisting the Merger and Acquisition of Human Rights by Trade Law: A Reply to Petersmann, 13(4) European Journal of International Law, 2002, 815-844.

${ }^{1917}$ Delimatsis, P., Protecting Public Morals in a Digital Age: Revisiting the WTO Rulings on US-Gambling and China- Publications and Audiovisual Products, Journal of International Economic Law 14(2), 2011, 257-293; discussing Karner, ECJ, Case C-71/02; [2004] ECR I-3025, paras.50-51.

1918 Wood, David, Searching Questions: Freedom of expression, competition and search engines, Competition Law Insight, 12 June 2012, http:/www.gibsondunn.com/publications/Documents/WoodSearchingquestions.pdf.

${ }^{1919}$ Karner, ECJ Case C-71/02, ECR I-3025, 2004, paras.50-51 (also quoted more fully in Delimatsis, Ibid, p290):
}

Whilst the principle of freedom of expression is expressly recognised by Article 10 ECHR and constitutes one of the fundamental pillars of a democratic society, it nevertheless follows from the wording of Article10(2) that freedom of expression is also subject to certain limitations justified by objectives in the public interest, in so far as those derogations are in accordance with the law, motivated by one or more of the legitimate aims under that provision and necessary in a democratic society, that is to say justified by a pressing social need and, in particular, proportionate to the legitimate aim pursued ... When the exercise of the freedom does not contribute to a discussion of public interest and, in addition, arises in a context in which the [Member State] have a certain amount of discretion, review is limited to an examination of the reasonableness and proportionality of the interference. This holds true for the commercial use of freedom of expression, particularly in a field as complex and fluctuating as advertising [emphasis added].

${ }^{1920}$ Van den Muijsenbergh, Winfried H.A.M. and Sam Rezai, Corporations and the European Convention on Human Rights, Paper presented at the University of the Pacific, McGeorge School of Law, Symposium on The Global Impact and Implementation of Human Rights Norms in March 2011, available online at http://www.mcgeorge.edu/ Documents/Conferences/ GlobeJune2012_Corporationsandthe.pdf, p50-52: 
Thus (reminding of the bilingualism argument of Section 2.3 of this study), if WTO law is to gain anything positive from including human rights concerns, there must not be a misunderstanding on the scope and definition of human rights and how it can be related to public morals. WTO experts need to have a clearer understanding of human rights law and the public morals limitations in the human rights law context before discussing the linkages and possibilities for inclusion of human rights language in the WTO public morals context. Similarly, Human rights experts need to understand how public morals is dealt with in the WTO context. If an argument is to be presented that human rights are part of public morals for the purposes of Article XX(a) of the GATT 1994 and Article XIV(a) of the GATS, then the fact that the scope of some human rights are limited by the public morals should also be remembered. For example, in international human rights law, the freedom of expression is limited by protection of national security or of public order, or of public health or morals, and the limitation itself must be "understood in the light of universality of human rights" and be non-discriminatory. ${ }^{1921}$

As writer and philosopher Iris Murdoch has said:

We learn through attending to contexts, vocabulary develops through close attention to objects, and we can only understand others if we to some extent, share their context. (often, we cannot) ...This dependence of language upon contexts has consequences...If the common object is lacking, Communication may break down and the same words may occasion different results in different hearers... We develop language in the context of looking... [emphasis added] ${ }^{1922}$

\footnotetext{
A large number of the Convention's provisions (some with more difficulty than others) have thus already been deemed applicable to corporations. There is, however, also a group of Convention provisions which is explicitly and widely (one is almost tempted to say unanimously) considered unable to, in any way, expand its scope to include corporations. Certain Convention provisions are deemed exclusively applicable to human beings and remain inaccessible for corporations. The artificial and essentially inhuman nature of corporations impedes their inclusion within the protective confines of these provisions which seek to protect individuals of flesh and blood....

To hold otherwise could equate corporations with human beings on a level which borders the incredible....

The Court's acceptance of corporations as beneficiaries of human rights has not escaped criticism...the criticism ranges from conceptual incompatibilities (human rights can only be extended to human beings and not to corporations), to practical horror scenarios (the Court will be flooded by a tsunami of corporate applicants), to quid pro quo assertions (if companies refuse to accept human rights obligations, they should not be able to benefit from their protection)

[emphasis added].
}

This paper cites further sources for criticisms of the extention of human rights to corporations: Grear, Anna, Challenging Corporate 'Humanity': Legal Disembodiment, Embodiment and Human Rights, 7 Human Rights Law Review, 2007,511, 515-17; Emberland, Marius, THE HUMAN RIGHTS OF COMPANIES: EXPLORING THE STRUCTURE OF ECHR PROTECTION, Oxford University Press, 2006.

${ }^{1921}$ See ICCPR, General Comment no. 34, Article 19: Freedoms of opinion and expression CCPR/C/GC/34 12 September 2011, para.29 ("The second legitimate ground [of limitation on Article 19 of the ICCPR] is that of protection of national security or of public order (ordre public), or of public health or morals"); and para.32 ("Any such limitations [for protecting public morals] must be understood in the light of universality of human rights and the principle of non-discrimination").

1922 Murdoch, Iris, THE SOVEREIGNTY OF GOOD, Routledge 2013 (reprint), p31.

A reference to Iris Murdoch's writing in Del Mar, Maksymilian T. and Oche Onazi, The Moral Quality of Work in International Economic Institutions: Resisting Complacency, International Journal of Law in Context, Vol. 4, No 4, 2008, 337-377, led to a search for the original text. 
Even the VCLT Rule of interpretation refers to 'text-context-object and purpose' as a holistic rule. When trade experts refer to human rights language or to terms in human rights treaties in a trade context, they must also realise that such terms in human rights have their own historical-legal context in which they have developed and their own 'culture' of interpretation.

It may be helpful for trade lawyers to consider also for guidance in order to further develop the notion of public morals (if needed), the contribution of the Siracusa Principles on the Limitation and Derogation of Provisions in the ICCPR, the Limburg Principles on the Implementation of the ICESCR and the 2005 Report of the High Commissioner on Human Rights - Human Rights and World Trade Agreements: Using General Exception Clauses to Protect Human Rights. These documents refer specifically to the ICCPR 'public morals exceptions' to human rights - but if linkages are to be made, the scope and context of the exception in the human rights regime needs to be understood more clearly.

Paragraphs 27 and 28 of the Siracusa Principles sets out the interpretive principles for the term "public morals" when used as a limitation clause in human rights contexts. Paragraph 27 recognizes that "public morality varies over time and from one culture to another" and therefore a State is allowed "a certain margin of appreciation", but it also

...shall demonstrate that the limitation [on the human rights] in question is essential to the maintenance of respect for fundamental values of the community. ${ }^{1923}$

Thus, while recognizing that a human right can be limited by "public morals", both are placed in the larger context of "fundamental values of the community". Especially in hard cases, the association between a particular value that is generally speaking one that is of "public morals" and the underlying structure of fundamental values that a community should maintain, comes into play. Paragraph 28 affirms that the margin of appreciation for the recognition of public morals does not apply to the principle of nondiscrimination as defined in the Covenant, which continues to apply. ${ }^{1924}$ In a sense, it can be argued that this concept is also reflected in the WTO exception provisions, where in both the GATT and the GATS, the exception cannot be applied arbitrarily, although there is some deference to the policy choices of Members. The difference is of course, the difference which was discussed earlier in Chapter 2, on the understanding of nondiscrimination in the WTO system and in human rights.

The discussion on the subjects of the principle or right of non-discrimination can be elaborated further by reference to the Limburg Principles on the Implementation of the

${ }^{1923}$ UN, Economic and Social Council, Siracusa Principles on the Limitation and Derogation Provisions in the International Covenant on Civil and Political Rights, U.N. Doc. E/CN.4/1985/4, Annex (1985).

${ }^{1924}$ Furthermore, the Limburg Principles (United Nations, Limburg Principles on the Implementation of the ICESCR Doc. E/CN.4/1984/4, 28 September 1984) add the following paragraphs:

49. Laws imposing limitations on the exercise of economic, social and cultural rights shall not be arbitrary or unreasonable or discriminatory

51. Adequate safeguards and effective remedies shall be provided by law against illegal or abusive imposition on application of limitations on economic, social and cultural rights.

The Limburg Principles were drafted by a group of experts in international law who met in Maastricht on 2-6 June 1986 to consider the nature and scope of the obligations of States parties to the ICESCR. This document was adopted by the UN and referred to in the General Comments of the Committee on Economic, Social and Cultural Rights in the interpretation of ICESCR rights. 
ICESCR ${ }^{1925}$ which specifically focus on the implantation of economic, social and cultural rights. The ICESCR does not have a public morals limitation unlike the ICCPR, but the Limburg Principles discuss limitations in terms of the phrases in Article 4 of the ICESCR: "determined by law", "promoting the general welfare", "in a democratic society" and "compatible with the nature of these rights". Referring to the limitations on ICESCR provided for in Article 4 of the Covenant, the Limburg Principles affirm that:

Article 4 was primarily intended to be protective of the rights of individuals ... [and] was not meant to introduce limitations on rights affecting the subsistence or survival of the individual or integrity of the person [emphasis added]. ${ }^{1926}$

This point should be reiterated, that the international human rights regime deals with rights and dignity of individual persons (and flowing from an individual right, the rights of communities of real persons, such as trade unions ${ }^{1927}$ ) and not legal persons such as corporations or other similar legal entities. The latter also can have 'rights' in law, and do of course have 'rights' specified in commercial and trade law, but legal persons do not have 'human rights'. The fact that some trade unions may have legal personality in some jurisdictions for the purpose of collective bargaining or legal standing before courts and tribunals does not change the fact that they came into existence to protect human rights and labour standards and conditions on behalf of their individual members. The origins of trade unions and the labour rights movement of course pre-date the modern UN human rights system, and their importance cannot be ignored in the context of their role in defending and promoting economic rights and freedoms. Other types of legal persons such as corporations or co-operative societies obviously do not have such a direct connection with representing rights which are also defined as human rights of individuals, but rather have been created for the purpose of individual shareholder or member benefit. In the case of e.g. incorporated companies, these benefits can also be protected as legal rights through a company's articles of association, supported by the relevant company law statute. Human rights on the other hand are not merely rights created through contract or agreement, but have been articulated and recognized in national constitutions and international human rights treaties and declarations, are described as inalienable and inherent in all human beings.

Thus, it is important to remember that 'public morals' in the human rights context are a limitation to the human rights of individual human beings, and flowing on from an individual right, to the rights of communities of real persons. 'Public morals' in the WTO context are an exception used by some Members to limit the rights of other Members and

${ }^{1925}$ Ibid., (Limburg Principles).

${ }^{1926}$ Ibid., (Limburg Principles), para.46-47. Also note that para.69 states as follows:

69. The scope of the rights and freedoms of others that may act as a limitation upon rights in the Covenant extends beyond the rights and freedoms recognized in the Covenant.

Note that the Limburg Principles 48-51 are derived from the Siracusa Principles 15-18.

${ }^{1927}$ Article 8(1) of the ICESCR:

The States Parties to the present Covenant undertake to ensure:

(a) The right of everyone to form trade unions and join the trade union of his choice...

(b) The right of trade unions to establish national federations or confederations and the right of the latter to form or join international trade-union organizations;

(c) The right of trade unions to function freely subject to no limitations other than those prescribed by law and which are necessary in a democratic society in the interests of national security or public order or for the protection of the rights and freedoms of others; (d) The right to strike, provided that it is exercised in conformity with the laws of the particular country. 
the legal persons whose interests are being represented in a dispute, and in both instances the actions of the Members may also flow on at some point to individuals who can benefit personally from the trade rule or its exception. Thus, the term 'public morals' is not transposable in the two contexts, but a certain equivalency can be reached, if the translator/interpreter remains aware of the conceptual differences.

In approaching the challenge of interpreting "public morals" (and "public order"), the Panel in US-Gambling repeatedly highlighted the "sensitivities" involved and the need to tread carefully in this area. ${ }^{1928}$ The Panel was cautious, even reluctant, in its approach to defining the concepts and consciously avoided controversy in its approach and interpretation. The analysis of the decision below appears to support this conclusion. The Panel begins by clarifying the provisional legal standard that needs to be met under Article XIV (a):

- the measure must be one designed to "protect public morals" or to "maintain public order"; and

- the measure for which justification is claimed must be "necessary" to protect public morals or to maintain public order.

The necessity standard will be discussed in more depth later in this chapter, but the focus in this section will be on the definition of "public morals".

Following the framework-setting of the VCLT rule, the Panel then states that it "will interpret Article XIV(a) of the GATS in accordance with the ordinary meaning of the words when read in their context and in light of the object and purpose of the GATS and the WTO Agreement" 1929

\subsubsection{US-Gambling: The Dictionary Approach to "ordinary meaning of the words"}

The term "ordinary meaning of the words" by itself could either be interpreted narrowly or be seen as very broad in scope and have countless meanings, ${ }^{1930}$ depending on how value-laden one wishes to make it. As writer and philosopher Iris Murdoch has stated:

There are two senses of 'knowing what a word means' one connected with ordinary language and the other very much less so. Knowledge of a value concept is something to be understood, as it were, in depth, and not in terms of switching on to some given impersonal network. ${ }^{1931}$

\footnotetext{
${ }^{1928}$ Panel Report, US-Gambling, para.6.461:

We are well aware that there may be sensitivities associated with the interpretation of the terms "public morals" and "public order" in the context of Article XIV.

And also at para.6.462:

...despite the inherent difficulties and sensitivities associated with interpretation ....we must nonetheless give meaning to these terms in order to apply them to the facts of in this case. Indeed, the principle of effective treaty interpretation requires us to do so.

1929 Ibid, (US-Gambling), para.6.459. Also see, Panel Report, US-Upland Cotton, para.7.311, stating at footnote 432 that this approach of looking at the:

... "ordinary meaning of the words read in their context and in light of the object and purpose" of the relevant agreement is "[i]n accordance with the general rule of interpretation in Article 31(1) of the Vienna Convention on the Law of Treaties".

${ }^{1930}$ Feddersen, Christoph T. Focusing on Substantive Law in International Economic Relations: The Public Morals of GATT's Article XX(a) and "Conventional” Rules of Interpretation, 7 Minn. J. Global Trade 75, 1998, p106

${ }^{1931}$ Murdoch, Iris, THE SOVEREIGNTY OF GOOD, Routledge 2013 (reprint), p28.
} 
But the task of interpretation in WTO dispute settlement seems to be such an 'impersonal' one, basing the legitimacy of its decisions on the VCLT Rule of Interpretation.

Ordinary meaning in the WTO context can be seen as usually a textual/literal meaning and associated with the 'literal rule of interpretation'. It can also mean much more than that and reflecting contemporary norms and concerns, can even include human rights, as discussed earlier. The US-Gambling Panel specifically refers to:

...ordinary meaning of the words when read in their context and in light of

the object and purpose of the GATS and the WTO Agreement. ${ }^{1932}$

What this means in the context of the public morals exception in the GATS will be discussed further below.

As pointed out by several commentators, the search for "ordinary meaning" is most often commenced with reference to a dictionary meaning for the purposes of the WTO Panels and Appellate Body. ${ }^{1933}$ It must be kept in mind that identifying the dictionary meaning is not the end of the interpretative exercise since remains incomplete without consideration of the context and the object and purpose of the relevant Agreement. The search for "ordinary meaning" in the US-Gambling dispute is begun by reference to the Shorter Oxford English Dictionary (2002). The results of this perusal are that:

1. Public: "Of or pertaining to the people as a whole; belonging to, affecting, or concerning the community or nation";

2. Morals: "habits of life with regard to right and wrong conduct":

- with the conclusion that "public morals" denotes "standards of right and wrong conduct maintained by or on behalf of a community or nation" and that the measure sought to be justified must be aimed at protecting the interests of the people within a community or a nation as a whole ${ }^{1934}$.

It is interesting to note that although the Appellate Body criticized the Panel in USGambling for limiting itself to dictionary definitions as too mechanical and not taking the range of meaning into account in the context of the word "sporting" in relation to the United States' scheduled commitments; ${ }^{1935}$ there is no criticism by the Appellate Body in China-Publications and Audiovisual Products of the fact of the reliance on a dictionary by the Panel in that instance. This situation of dependency on dictionary definitions

Part of Murdoch's quote above was referred to in Del Mar, Maksymilian T. and Oche Onazi, The Moral Quality of Work in International Economic Institutions: Resisting Complacency, International Journal of Law in Context, Vol. 4, No 4, 2008, 337-377, which led to a search for the original text.

1932 Panel Report, US-Gambling, footnote 639 (citing Appellate Body Report, Japan-Alcoholic Beverages, p14):

Throughout this report, we have based our analysis on the ordinary meaning to be given to the terms of the provisions under examination in their context and in the light of their object and purpose.

${ }^{1933}$ McRae, Donald, Treaty Interpretation and the Development of International Trade Law by the WTO Appellate Body in Giorgio Sacerdoti, Alan Yanovich, Ja Bohanes, THE WTO AT TEN: THE CONTRIBUTION OF THE DISPUTE SETTLEMENT SYSTEM, Cambridge University Press, 2006, p364.

${ }_{1934}$ Panel Report, US -Gambling, 6.463-6.465.

1935 Appellate Body Report, US-Gambling, paras.164-167. At para.166:

First, to the extent that the Panel's reasoning simply equates the "ordinary meaning" with the meaning of words as defined in dictionaries, this is, in our view, too mechanical an approach...

The 13 different dictionary definitions consulted by the Panel are set out in paras.6.55 - 6.59 of the Panel Report. Some of the definitions appear to contradict one another. 
recalls the comment by Irwin and Weiler who note that "the 'battle of the dictionaries', which so frequently characterizes arguments before the $A B$ " 'impoverishes' the legal discourse of the WTO dispute settlement. ${ }^{1936}$ The Appellate Body Report in US-Gambling does recognize that dictionaries "typically aim to catalogue all meanings of words"1937 and added that some dictionary definitions of "sporting" also appear to contradict one another ${ }^{1938}$ And adds further that the range of meanings of the word "sporting" included both the meaning claimed by Antigua and the meaning claimed by the United States. ${ }^{1939}$ The Panel Report had noted ${ }^{1940}$ previous Appellate Body Reports that recognized that dictionary definitions do not necessarily provide a final answer and "leave many interpretive questions open" 1941 and that:

...dictionaries are important guides to, not dispositive statements of, definitions of words appearing in agreements and legal documents. ${ }^{1942}$

Of course, it is clear that a dictionary meaning can be often be found to support any meaning one prefers.

Why the Shorter Oxford Dictionary has to be the standard is so heavily relied on is not clearly explained at any point - it just seems to be a WTO custom, and there is nothing to criticise in using a dictionary that is generally recognized of high quality. But comments by scholars that "the Shorter Oxford Dictionary has become one of the covered agreements " 1943 do not seem to be exaggerated in the context of the heavy reliance placed upon it. The Panel in US-Gambling also referred to other seemingly random dictionary sources to support the Shorter Oxford Dictionary, including online sources. ${ }^{1944}$ Perhaps reflecting the more recent trends for referring to online sources, the EU relied on the Oxford English Dictionary Online (www.oed.com) for the definition of "service" in $E U$ Energy Package; whereas Russia's reference to dictionaries in that dispute (with regard to "supply") was to the much-cited Shorter Oxford English Dictionary (2002) . ${ }^{1945}$ The Panel in EU-Energy Package, itself began its analysis on the ordinary meaning of the term "pipeline transport" by reference to the Shorter Oxford English Dictionary (2007),

\footnotetext{
${ }^{1936}$ Irwin, Douglas A. and Joseph Weiler, Measures Affecting the Cross-Border Supply of Gambling and Betting Services (DS 285), World Trade Review 7: 1, 2008, 71-113, p95.

${ }^{1937}$ Appellate Body Report, US - Gambling, para.165-7.

1938 Appellate Body Report, US-Gambling, footnote 193

${ }^{1939}$ See also comments by Prevost, Denise, Services and Public Policy Regulation in the WTO: the example of the US-Gambling Case in van de Gronden Johan, Ed., EU AND WTO LAW ON SERVICES - THE LIMITS TO THE REALIZATION OF GENERAL INTEREST POLICIES WITHIN SERVICES MARKETS, Kluwer Law International, 2009 and Ortino, F., See, Ortino, Federico, Treaty Interpretation and the WTO Appellate Body Report in US-Gambling: A Critique, Journal of International Economic Law 9(1), 117-148, 2006, p7.

${ }_{1940}$ Panel Report, US-Gambling, para.6.67

1941 Appellate Body Reports on Canada-Aircraft, para.153 and in EC-Asbestos, para.92.

1942 Appellate Body Report on US-Offset Act (Byrd Amendment), para.248.

1943 Petersmann, Ernst-Ulrich, WTO Dispute Settlement Practice 1995-2005: Lessons from the Past and Future Challenges in Taniguchi, Yasuhei, Yanovich, Alan and Bohanes, Jan. Eds. WTO IN THE $21^{\text {st }}$ CENTURY, Cambridge University Press, 2007, p48, stating that this is a criticism of some observers.

1944 The Oxford English Dictionary (1938), The Supplement to the Oxford English Dictionary (1986), Collier's Dictionary (1977), Webster New Encyclopaedic Dictionary (1993), New Little Oxford Dictionary (1989), The American Heritage Dictionary Online (2003), Chambers Online Reference (2003), MerriamWebster Dictionary Online (2003).

${ }^{1945}$ See e.g. Panel report, EU-Energy Package, footnotes 598 and 601 citing European Union's first written submission, paras.65-66 (referring to Oxford English Dictionary Online) and Russia's first written submission, para. 101, (referring to Shorter Oxford English Dictionary, W. Trumble and A. Stevenson (eds) Oxford University Press, 2002).
} 
1946 before moving on to Schedules of Croatia, Hungary and Lithuania and other dictionaries cited by the parties to the dispute.

In US-Gambling, the United States submitted that "a stack of dictionaries would seem to contradict" the assertion of the EC that "sporting" is not commonly used to refer to gambling and therefore cannot be considered 'ordinary meaning'. ${ }^{1947}$ According to the EC Submission, the US referred to the $10^{\text {th }}$ edition of the Merriam-Webster's Collegiate Dictionary, but as the EC could not get their hands on it, they referred to the $3^{\text {rd }}$ College Edition of Webster's New World Dictionary of American English; which clearly states that the definition of "sporting" as meaning "intéresse in or having to do with games, races, etc., characterized by gambling or betting" was an Americanism and not therefore a definition that can be part of the search for an 'ordinary meaning'. ${ }^{1948}$ The United States argued, quite reasonably that:

...all linguistic prejudices aside, no rule of treaty interpretation provides that the "ordinary meaning" of a word in the English language cannot originate in the United States. Indeed, the fact that the schedule at issue is that of the United States makes it all the more absurd to exclude any meaning a priori on the basis that one dictionary calls it an "Americanism"1949

Thus, according to the United States, the sub-sector 10.D of the schedule which states "other recreational services (except sporting)" should exclude gambling - as in the US, according to a number of US dictionaries, one 'ordinary meaning' of the word "sporting" is games etc "characterized by gambling". But the EC responded that it was only a "special meaning", which according Article 31(4) of the Vienna Convention, shall be given to that term then, only "if it is established that the parties so intended" - with the burden of proof being on the party asserting that special meaning. ${ }^{1950}$ But this was not addressed by either the Panel or the Appellate Body in this dispute.

It may be useful to look at the summing up of the issue by the Panel in China-Intellectual Property Rights. The Panel noted the previous approach of the Appellate Body in ECChicken Cuts and US-Softwood Lumber IV:

The Appellate Body has observed that dictionaries are a 'useful starting point' for the analysis of 'ordinary meaning' of a treaty term, but they are not necessarily dispositive. The ordinary meaning of a treaty term must be ascertained according to the particular circumstances of each case. Importantly, the ordinary meaning of a treaty term must be seen in the light of the intention of the parties 'as expressed in the words used by them against the light of the surrounding circumstances' [emphasis added]. ${ }^{1951}$

As the Schedules are an integral part of the GATS, this argument would cover the interpretation of the Schedules as well. Thus, if there is a 'local' meaning that is noted in

\footnotetext{
${ }^{1946}$ Panel Report, EU-Energy Package, para.7.302 citing Shorter Oxford English Dictionary, 6th edn, A. Stevenson (ed.) (Oxford University Press, 2007), Vol. 2.

${ }^{1947}$ Panel Report, US-Gambling, para.3.64.

${ }_{1948}$ Panel Report, US-Gambling, para.4.22 and footnote 537.

${ }^{1949}$ Panel Report, US-Gambling, para.3.64

1950 Panel Report, footnote 539.

${ }^{1951}$ Panel Report, China-Intellectual Property Rights, para.7.559, citing the following at footnote 537: Appellate Body Report in EC-Chicken Cuts, para.175 quoting the Appellate Body Report in US-Softwood Lumber IV, para.59; and referring to Appellate Body Reports in USOffset Act (Byrd Amendment), para.248, and US-Gambling, para.166; and also quoting McNair, The Law of Treaties (Oxford, Clarendon Press, 1961), p365.
} 
dictionaries and a Member argues that this meaning was the one they intended to use in their entry, this ought to have some weight. Of course, other factors that contradict such an assertion should also be taken into account. One major argument is that allowing such 'local' meaning would undermine legal certainty as other negotiators would not have insight into what a particular Member 'intended' with a term. In terms of the principles and purpose underlying treaty interpretation, it could be argued that it is a search for the 'common intent' of negotiators as reflected in the treaty provisions, rather than the particular intent of one Member.

The Appellate Body in US-Gambling noted that the Panel failed to have due regard to the fact that its recourse to dictionaries revealed that gambling and betting can, at least in some contexts, be one of the meanings of the word "sporting". ${ }^{1952}$ It was also noted that the Panel failed to explain the basis for its recourse to the meanings of the Spanish and French words "deportivos" and "sportifs" (although not stated specifically, this seems to be in response to the US objection to the Panel comparing definitions in other languages while ignoring the "Americanism"). ${ }^{1953}$ Yet the final result is that Appellate Body upheld the Panel finding on the inclusion of gambling in the US schedule, although on different legal reasoning. There are also colloquial, regional and technical or legal meanings of words - but which is the 'ordinary meaning'? Trade law itself has many technical meanings that would not be found in ordinary language dictionaries. For example, the Panel in US-Gambling referred to the 'Dictionary of Trade Policy Terms (1998)' for the definition of "market access". ${ }^{1954}$ There can also be special terms or interpretations of terms used by particular industries. Russia referred to "A Dictionary for the Oil and Gas Industry (2011)' for the term "supply" in EU-Energy Package. ${ }^{1955}$ In assessing the relevance of such specialized dictionaries from industry sources for ascertaining "ordinary meaning" of terms relating to pipeline transport, the Panel in EU-Energy Package referred back to the cautioning of the Panel in China-Electronic Payment Services, that:

...panels must be mindful of the limitations, such as self-interest, that industry sources may present and should govern their interpretive task accordingly. ${ }^{1956}$

In EU-Energy Package, the Panel did not agree with Russia's interpretation and made its "own assessment based on dictionary definitions, industry sources and other specialized glossaries" which were provided by Russia. ${ }^{1957}$

\footnotetext{
1952 Appellate Body Report, US-Gambling, para.162: thus seemingly rejecting Antigua's argument (noted in para 3.65 of the Panel Report, that:

Even if it is true that dictionaries mention all these divergent meanings, the term

"sporting" cannot simultaneously have all of these different meanings in a document if it is used just once.

1953 Appellate Body Report, US-Gambling, para.162, seemingly in response to United States' appellant's submission, para. 51, noted in earlier in the Report at para.15:

The Panel in Chile-Price Bands System when referring to the dictionary meaning of "ordinary", included its French and Spanish versions (Panel Report on Chile-Price Bands System, para.7.51). It suggests that other language versions of a word can be checked in this manner, but the reasons for doing so ought to be made clear.

${ }^{1954}$ Panel Report, US-Gambling, para.6.274.

${ }^{1955}$ Panel Report, EU-Energy Package, para.7.268. and footnote 602.

1956 Panel Report, EU-Energy Package, para.7.306 and footnote 660, citing the Panel Report, ChinaElectronic Payment Services, para.7.89.

${ }^{1957}$ Panel report, EU-Energy Package, 7.309. This assessment included the following glossaries provided as exhibits by Russia: the Illustrated Glossary for Transport Statistics, 4th edn (UNECE 2009); H. R. Williams
} 
It can be noted that although dictionary approaches are heavily relied on, sources other than dictionaries were used by the Panel in US-Gambling either as supplemental means of interpretation or as examples for gambling being considered as a public morals or public order issue. These range from a quotation from the separate opinion of Judge Lauterpacht in the Guardianship of Infants Case ${ }^{1958}$ for support that the scope of "public order" includes the protection of minors - to the understanding of "public morals" of Members such as Israel and Philippines, as reflected in their WTO Trade Policy Reviews. The Panel also referred to questions raised relating to restrictions of imports of lottery tickets during the proceedings of the International Conference for the Abolition of Import and Export Prohibitions and Restrictions convened by the League of Nations in 1928. ${ }^{1959}$ However, this was without any framework-setting as to why these other sources are relevant, nor was there any addition of express normative guidelines regarding the choice of supplementary sources.

But although it seems that there is a great deal of reliance on dictionaries in the WTO context and it would be good if some guidelines were developed about their use, this practice should not be seen in isolation from the other tools of interpretation and the context. ${ }^{1960}$ McRae notes how dictionary definitions are "a-contextual" abstractions of possible meanings. ${ }^{1961}$ Terms can have different meanings in a different legal context, with regard to specialized areas of law, in different branches of law and in different legal jurisdictions. ${ }^{1962}$ For example the term "condition" can have an ordinary meaning or several meanings found in a dictionary of language and further specialized meanings in the fields of medicine, psychology and contract law and the consequences can also differ according to English contract law or South African contract law. In the context of assessing public morals, in English common law, 'ordinary meaning' is something decided by the jury or by the judge with reference to the 'the reasonable man' - a legal fiction that assists in setting an objective standard. ${ }^{1963}$ But is there an objective 'reasonable man' test for understanding terms and concepts such as 'public morals' in WTO law? And if so, where does the 'reasonable' person live and how does he/she understand "public morals"? These questions are interesting in their implications, but in

and C. J. Myers (eds.), the Manual of Oil and Gas Terms, 15th edn (LexisNexis, 2012)and a number of online reports - see footnotes 661-666 of the Panel Report.

1958 Case Concerning the Application of the Convention of 1902 Governing the Guardianship of Infants (Netherlands v. Sweden), 1958 I.C.J. 55.

${ }^{1959}$ Panel Report, US-Gambling, para.6.4.72, citing the International Conference for the Abolition of Import and Export Prohibitions and Restrictions, Proceedings of the Conference, (1928), League of Nations Doc. C.21.M.12. 1928 II.7, p.110

${ }^{1960}$ See the proposal by Lo, Chang-Fa, for eight rules for the good faith use of dictionaries in interpreting the WTO covered agreements (Good Faith Use of Dictionary in the Search of Ordinary Meaning under the WTO Dispute Settlement Understanding, Journal of International Dispute Settlement, 2010, 1 (2), p431445). Van damme responding to this article cautioned against focusing too much on developing rules for dictionaries in treaty interpretation in isolation from an appreciation of the function of other interpretive elements recognized under customary principles of treaty interpretation (Van Damme, Isabelle, On Good Faith Use of Dictionary in the Search of Ordinary Meaning under the WTO Dispute Settlement Understanding'- A Reply to Professor Chang-Fa Lo, Volume 2, Issue 1 p231-239)

${ }^{1961}$ McRae, Donald M, The WTO in International Law: Tradition Continued or New Frontier, Journal of International Economic Law, 2000, 27-41.

1962 See Cao, Deborah, TRANSLATING LAW, Multilingual Matters, 2007, p67-70

1963 Finnis, J. M., Developments in Judicial Jurisprudence, Adelaide Law Review, 1962; 1(3): 317-338 this paper specially noted the famous English case of Shaw v DPP (1962 AC 220) where 'ordinary meaning' was said to be what is decided by jury or by an objective 'reasonable man' test. 
WTO law, for better or worse, there is no fictional human viewpoint of a 'reasonable' person, even as the language of these rules impact on the lives of human beings.

\subsection{4. 'Standards of right and wrong conduct......maintained by or on behalf of a community or nation"}

\subsubsection{1. "Standards..."}

Dictionary and other definitions can help define the scope of what public morals are, but do not say much about the contents in a specific situation. In the Panel's view, the content of these concepts for Members can vary in time and space, depending upon a range of factors, including prevailing social, cultural, ethical and religious values. ${ }^{1964}$ Thus, these standards referred to are most likely national standards, but could also be regional or limited to particular sub-groups in a country. Of course, standards and methods of interpretation in domestic law are not to be applied in the same way in a supranational legal dispute, where specific rules of interpretation and definitions may have arisen through international institutions and processes. In the context of 'public morals', the 'ordinary meaning' of public morals as understood in a local sense may be more relevant to understanding the reasons and justifications for the measure than recourse to standards common to other countries. It can be argued that such understandings of public morals, if given recognition as exceptions, could have the potential to undermine the negotiated trade agreements to an extent that the system becomes unworkable. So, would it be left open to any particular community to define for itself what it considers as 'public morals'? This could result in a very wide range of meanings. Could such a unilateral definition be capable of being externally judged? And would it be suitable to attempt to do so in an international forum? The Appellate Body in EC-Seal Products touched on these matters when it recognized the European Union's invocation of public morals (Article XX(a) of GATT 1994) in the context of animal welfare, specifically seal hunting, and left the matter of the level of protection and the choice of regulating different areas of animal welfare up to the discretion of the Members concerned. ${ }^{1965}$ In light of this decision,

\footnotetext{
1964 Panel Report, US-Gambling, para.6.461. Similar language used by the Panel in China-Publications and Audiovisual Products at para. 7.763 with regard to Article XX(a) of the GATT and cited approvingly by the Panel in Australia-Plain Packaging, at para.7.2673.

1965 See Appellate Body Report, EC-Seal Products, paras.5.194-5.203, especially see para.5.200.

It is interesting to note that the Appellate Body Report mentions amicus curiae submissions from animal welfare groups and industry representation by the International Fur Federation (see para.1.15 of the Appellate Body Report and footnote 30 and 31), but Harris and Moon note that the moral content of the indigenous exception was not submitted to or considered by either the panel or Appellate Body. Harris and Moon note that this was a lost opportunity for referring to:

...international instruments recognising indigenous rights and exhorting the international community to respect and protect them - instruments falling within the broad scope of international human rights law...

(Harris, Rachel and Gillian Moon, GATT Article XX and Human Rights: What Do We Know from The First 20 Years?, 2015, Melbourne Journal of International Law, Vol.16, 1, p20, p22).

The issue of "subsistence of the Inuit and the preservation of their cultural identity" is mentioned in passing the Reports, but the impact on communities in closing the market to seal products, one of the few resources they have access to, is not really discussed (see further, Appellate Body Report, EC-Seal Products, para.2.159 and also paras.5.321-5.324, citing Panel Report, paras.7.275 and 7.294). Although the EC mentioned that "the IC exception is "based on a broad recognition of the unique interests of Inuit and other indigenous communities"” (Appellate Body Report, EC-Seal Products, para.2.1.48), the discussion never looks at economic, social and cultural rights of indigenous people. The closest it comes to addressing the indigenous rights aspect of public morals in seal hunting is at para.2.164 of the Appellate Body Report,
} 
Howse comments that since there is no requirement of rationality for the collective preferences of a particular society, and that "the WTO adjudicator has no business second-guessing" these collective preferences. ${ }^{1966}$

It is interesting to note what sources were considered important in judging whether gambling was an issue that fell within the scope of public morals in US-Gambling. The references made in the submissions of the United States noted a large variety of domestic sources and international sources supporting prevailing values. ${ }^{1967}$ Mark Wu comments that neither the Panel nor the Appellate Body specified what must be done to establish that a value is "prevailing" one. ${ }^{1968} \mathrm{Wu}$ draws attention to the assumption that a Member government's actions reflect the will of the people, even without opinion polls and public consultations on that particular issue. ${ }^{1969}$ This was also the submission of the European Union in EC-Seal Products, stating that the panel erred in inferring concerns of EU citizens exclusively from opinion polls and a public consultation, submitting that:

....i]t is...the task of legislators and regulators to translate the broader moral concerns of the public into precise requirements, by relying on their superior knowledge of the specific factual circumstances. [footnotes omitted] ${ }^{1970}$

Of course, the protection of some important societal values may be implicit in the mandate of a particular Member's government (such as free public education and free public health services in Sri Lanka, as discussed in Chapter 2) - others may be part of a detailed election manifesto that both the government and public refer back to during the term of office. There may be some issues that do not fall directly within such mandates and manifestos, but can be justifiably assumed. If there is a habit or requirement of referring to polls, plebiscites or public consultations within the domestic system, a Member can bring that data to the attention of the panel or the Appellate Body. It is probably not up to the dispute settlement bodies to make providing such data a requirement of evidence for "prevailing values", if carrying out such polls and surveys is not common in that jurisdiction and there are other ways to provide evidence for a broadly accepted and generally uncontested public morals basis for policy, laws or regulations.

where the EU refers to polls where " $90 \%$ of respondents agreed with the statement that "the killing of wild animals is acceptable if a person's survival or livelihood depends on it'".

1966 Howse Robert, The World Trade Organization 20 Years On: Global Governance by Judiciary, EJIL (2016), Vol. 27 No. 1, 9-77, p63.

1967 The domestic sources included US sources such as the Internet Gambling Prohibition Act, Senate Report No. 106-121(1999), the Detailed Study by United States National Gambling Impact Study Commission (1999), the Financial Action Task Force, the Report on Money Laundering Typologies 20002001 and the US Supreme Court statement that - "gambling . . . falls into a category of 'vice' activity that could be, and frequently has been, banned altogether" in United States v. Edge Broadcasting Co., 509 U.S. 418, 426 (1993). Also evidence from US institutions including Congressional hearing testimony, the Federal Trade Commission ("FTC"), the Racketeering Records Analysis Unit of the Federal Bureau of Investigation, The Council on Compulsive Gambling, the Harvard Medical School's Division on Addictive Studies, the American Psychiatric Association APA Advisory on Internet Gambling (2001) and more than a dozen religious organizations and churches.

${ }_{1968}$ Wu, Mark, Free Trade and Public Morals, The Yale Journal of International Law, Vol. 33, 2008, 215 , p233.

1969 Ibid., (Wu), p234, also commenting that:

Is the WTO implicitly endorsing a theory of democratic legitimacy, that is, assuming that any legislative [or executive] action reflects the will and mores of the majority of citizens?

${ }^{1970}$ Appellate Body Report, EC-Seal Products, para.2.157. 
$\mathrm{Wu}$ also suggests that there should be a global 'near-consensus' or a 'near-universal agreement ${ }^{\prime 1971}$ as to the public morality issue at the heart of a dispute. Although this could align with using a universal human rights approach to public morals, that approach is questionable as it also limits the recognition of national policy space, mentioned in the Preamble of the GATS. Furthermore, it could be commented that the successful reliance on the public morals exception would depend on how one would judge the achievement of the level of global consensus or agreement suggested by Wu. While a Member could provide information regarding the global state of acceptance of the public morals issue, there is nothing in the GATS that suggests that the protection of public morals under Article XIV(a) must be the protection of universal rather than national, public morals. Since the measure is decided within a national jurisdiction, the first step is to confirm that it is a public moral for that jurisdiction, and the fact that it also has support outside that jurisdiction is an additional matter, which may be of relevance but need not be required.

Regarding the inclusion of international human rights within the concept of "standards" relating to public morals, the Siracusa Principles (ICCPR) ${ }^{\mathbf{1 9 7 2}}$ discussed earlier in this Chapter, have some relevant comments with regard to public morals arguments. The Limburg Principles (ICESCR) do not specifically refer to public morals as a permissible limitation to economic, social and cultural rights, although "public order" is mentioned. There is a comparison that can be drawn between the public morals limitation in human rights and the way that the exceptions are limited by the chapeau in Article XIV of the GATS (which prohibits arbitrary or unjustifiable discrimination in the application of the measure concerned) - in that the non-discrimination principle in human rights continues to apply even when a limitation is allowed. However, the rule of non-discrimination in the ICCPR and ICCPR is different from the ways in which it is presented in the GATS (the chapeau and also MFN, and if scheduled, national treatment) - as discussed earlier in Chapter 4 of this study.

It is to be seen that even in the case of judging whether an issue was within the scope local/national public morals, the Panel in US-Gambling cited and relied upon the international standards against gambling in the submissions of the United States and not on the domestic US sources. These international standards included a draft Convention of the Economic Committee of the League of Nations (1928), two cases of the European Court of Justice, as well as a publication called the Internet Gambling Report. ${ }^{1973}$ Marwell emphasizes that the legitimacy of the view that gambling was an issue of public morality was based "primarily" on evidence that many countries in addition to the United States held this view. ${ }^{1974}$ But while the Trade Policy Reviews of two other Members,

${ }^{1971}$ Wu, Mark, Free Trade and Public Morals, The Yale Journal of International Law, Vol. 33, 2008, 215, p233-234.

${ }^{1972}$ UN, Economic and Social Council, Siracusa Principles on the Limitation and Derogation of Provisions in the International Covenant on Civil and Political Rights, U.N. Sub-Commission on Prevention of Discrimination and Protection of Minorities, Annex, UN Doc E/CN.4/1984/4, 1984.

${ }^{1973}$ WTO, Report by the Secretariat, Trade Policy Review - Israel, WT/TPR/S/58, table III.8 (1999), WTO, Report by the Secretariat, Trade Policy Review - The Philippines, WT/TPR/S/59, table III.11; Economic Committee of the League of Nations, International Conference for the Abolition of Import and Export Prohibitions and Restrictions, Proceedings of the Conference, p. 110, League of Nations Doc. C.21.M.12. 1928 II.7, p. 110 (1928); ECJ Case C-275/92, Her Majesty's Customs and Excise v. Gerhart Schindler and Jörg Schindler, 24 March 1994; ECJ Case C-6/01 - Associação Nacional de Operadores de Máquinas Recreativas (Anomar) and Others, 11 September 2003; and Balestra Mark Ed., INTERNET GAMBLING REPORT- $6^{\text {th }}$ Edition, The River City Group, United States, 2003.

1974 Marwell, Jeremy C., Trade and Morality: The WTO Public Morals Exception After Gambling, 81 N.Y.U. Law Review, 2006, p806, citing the Panel Report, US-Gambling, paras. 6.471-74. 
Israel and Philippines were cited, at no point does the Panel explain its choices and the methodology for choosing these particular sources for what should have been a determination of public morals in the US domestic framework.

The approach of the Panel in EC-Seal Products is more nuanced, with the Panel observing that:

International doctrines and measures of a similar nature in other WTO

Members, while not necessarily relevant to identifying the European

Union's chosen objective, illustrate that animal welfare is a matter of ethical responsibility for human beings in general. ${ }^{1975}$

This approach gives importance to the fact that the Member's views are generally accepted elsewhere while avoiding the problem of "imposing universal values" upon a Member mentioned by Marwell, especially since the public morals exception is likely to be used where there is a difference of moral standard with regard to services provided by other Members. ${ }^{1976}$ The view that a Member should be able to define public morals 'unilaterally', but should also provide evidence that the issue is indeed a public morals issue within that Member, seems preferable if wishing to retain greater policy space to a Member. Gareth Davies comments that the key to the legitimacy of values or morals claimed in a trade context is:

...whether it is genuine and consistent...[and] in fact an authentic reflection of moral views within that jurisdiction. ${ }^{1977}$

The Appellate Body in EC-Seal Products has noted that a measure's contribution to the objective pursued under Article XX of the GATT 1994 must be seen in the light whether there is a "genuine relationship of ends and means between the objective pursued and the measure at issue". ${ }^{1978}$ On the matter of consistency, this matter was also an issue in $E C$ Seal Products, as questions were raised as to whether the different treatment of seal hunts under animal welfare concerns as compared to 'terrestrial wildlife hunts' and slaughterhouses indicated a lack of consistency in application of standards of public morality. ${ }^{1979}$ However, the Appellate Body stated that a Member "may set different levels of protection even when responding to similar interests of moral concern". ${ }^{1980}$ A domestic system is in a better position to assess and present evidence for whether an issue is a public morals issue for that society, than a foreign government and their trade experts although a judge on an international body may be called upon to objectively assess the evidence presented. It has also been commented widely that if a Member has noted its public morals concerns in their own Trade Policy Reviews, ${ }^{1981}$ that can also be taken as

\footnotetext{
1975 Panel Report, EC-Seals, para.7.409.

1976 Op cit., (Marwell), p821.

1977 Davies, Gareth, Morality Clauses and Decision-Making in Situations of Scientific Uncertainty: The Case of GMOs, Research Paper No. 10-06, International Law Forum of the Hebrew University of Jerusalem Law Faculty, presented at a Roundtable on "GMOs and International Trade" held at the Hebrew University of Jerusalem, 1 August 2006, p21 - available online at www.ssrn.com/abstractid=920754. See also

1978 Appellate Body Report, EC-Seal Products, para.5.180 citing Panel Report, EC-Seal Products, para. 7.633 (which in turn referred to the Appellate Body Report, Brazil-Retreaded Tyres, paras. 145-157).

${ }^{1979}$ See Appellate Body Report, EC-Seal Products, paras.5.194-5.201.

1980 Appellate Body Report, EC-Seal Products, para.5.200, citing Panel Report, US-Gambling, para.6.461 (which had referred to Appellate Body Report, Korea-Various Measures on Beef, para.176 and ECAsbestos, para.168).

1981 See for example Wu, Mark, Free Trade and Public Morals, Yale Journal of International Law, Vol. 33, 2008, 215, Appendix I: which lists a number of TPRs. The public morals issues noted include noncontroversial issues such as child pornography, drugs and narcotics, counterfeit money and goods as well as a number of issues related to religious sensitivities (usually Islamic; such as swine and swine products and alcohol)
} 
evidence for their own public morals (unlike the use of other Members TPRs by the dispute settlement bodies in US-Gambling).

On the one hand, the references to other international law and principles can be looked at optimistically from the view of those who would like to see more references of other international law and principles in WTO disputes and perhaps greater domestic policy choice. On the other hand, such references might be useful to prevent abuse or overbreadth of the exceptions due to reliance on national/unilateral definitions. The way that material and examples were cited by the Panel in US-Gambling was that only Lauterpacht's definition of public order was actually referred to as "supplementary means of interpretation". ${ }^{1982}$ The other paragraphs that followed for the notions of public morals appear to have just been 'examples' of gambling used in public morals or public order contexts and not used as interpretative aids as such. However, it was on the latter basis that the Panel came to its conclusion that policies prohibiting gambling and betting services could fall within the scope of Article XIV(a) of the GATS. Thus, the Panel in the US-Gambling dispute has not referred to any international human rights sources for defining public morals (and public order).

What about evolving international standards? As discussed earlier in this study, an evolutionary approach to terms and phrases in the WTO Agreements is possible. The evidence relied upon by the Appellate Body in US-Shrimp included international legal developments - and the approach can be similar for other evolving values. Howse and Marwell have agreed that

This reasoning [in US-Shrimp] would apply with equal or greater force to "public morals", a standard whose plain meaning necessitates an evolution to match contemporary beliefs and norms ${ }^{1983}$

It can be agreed that public morals are highly subjective. A Member's 'public morals' may or may not be aligned with evolving international standards and this should not be a criterion for judging whether it can fall within a public morals exception. But if indeed, the Member's public morals standards are aligned with the international standards, the Member can draw attention to this fact and it should be acknowledged by the dispute settlement bodies, since WTO law should not proceed in a manner isolated from and ignoring standards in other international regimes. A Member should be free to apply their internal standards ${ }^{1984}$ - whether aligned to international standards or not - the focus should on a careful scrutiny on how far the regulatory measure at issue fits with the goal claimed by the Member.

1982 Panel Report, US-Gambling, para 6.410 citing the ICJ, Case Concerning the Application of the Convention of 1902 Governing the Guardianship of Infants (Netherlands v. Sweden), 1958 I.C.J. 55, 90, Judgment of 28 November (separate opinion of Judge Lauterpacht).

1983 Marwell, Jeremy C., Trade and Morality: The WTO Public Morals Exception After Gambling, 81 N.Y.U. Law Review, 2006, p820 citing for support: Robert The World Trade Organization and the Protection of Workers' Rights, 3 Journal of Small and Emerging Business 131, 1999, p142: "[T]he interpretation of public morals should not be frozen in time ...". Howse, Robert, Back to Court After Shrimp/Turtle? Almost But Not Quite Yet: India's Short-Lived Challenge to Labor and Environmental Exceptions in the European Union's Generalized System of Preferences, 18 American University International Law Review, 2003, 1333, p1368 n.145:

$[\mathrm{R}]$ esponsible and representative governments clearly have to be accountable to the values and interests of the citizens of today-and tomorrow-not those of yesteryear.

1984 See Panel Report, US-Gambling, para.6.461: emphasizing the Members' scope to define and apply these concepts according to their own systems and scales of values. See also the Panel Report in ArgentinaFinancial Services, para,7.713 and 7.715-7.716 on the importance given by Argentina domestically for the fight against harmful tax practices, which is also a value aligned with international standards. 


\subsubsection{2. "Maintained on behalf of a Community or Nation"}

The Appellate Body Report in EC-Seal Products brings out this issue, particularly with regard to the arguments of the European Union. It was argued that the relevant "standards" need not be proved to be held by a majority of the people in the relevant community or grounded in the concerns of citizens but that they:

...can be set by a Member's authorities on behalf of a community, in accordance with that Member's own system of government [emphasis in original]. ${ }^{1985}$

Thus the European Union argued that if a concern and an exception to a concern were 'moral in nature' and if evidence existed of there being a 'well established moral doctrine grounding these concerns', it can fall within the scope of the exception. ${ }^{1986}$ Earlier, the Panel in EC-Seal Products had referred to the scope given to Members to define and apply the concept of 'public morals' for themselves but recognized the difficulties of providing evidence which makes an explicit link, although there was considered to be evidence that sufficiently demonstrated the link. ${ }^{1987}$ The Appellate Body in EC-Seal Products noted that in assessing the objective of a measure, the Panel must take into account of all evidence put before it including statutes, legislative history, and other evidence regarding the structure and operation of the measure at issue. ${ }^{1988}$ Furthermore, the Appellate Body has stated on several occasions that Members, in applying similar societal concepts, have the right to determine the level of protection that they consider appropriate. ${ }^{1989}$

The WTO dispute settlement bodies do not make a value judgement on the public morals concerned, or identify what would be considered legitimate and non-legitimate moral interests in light of e.g. international human rights. Thus, it is an unfortunate possibility that the dispute settlement bodies could acknowledge as public morals, issues that are contested, highly controversial or dubious in other contexts and/or are matters of moral relativism or a present a conflict of different public morals. This is an interesting issue that can be discussed further, and may result in further complications for international trade law in the future. There is already a discussion earlier in this chapter concerning China-Publications and Audiovisual Products and the defence of measures under China's restrictive content review (censorship) laws as public morals issues from the viewpoint of the Chinese government. The EC-Seal Products decision draws attention to what could be described as either the relativism of public morals or as the conflict between two types of public morals: the economic and social interests of Inuit communities traditionally engaged in the hunting of seals and seal welfare concerns of the EU public. ${ }^{1990}$

\footnotetext{
1985 Appellate Body Report, EC-Seal Products, para.2.157.

1986 Appellate Body Report, EC-Seal Products, para.2.158 referring to the European Union's other appellant's submission, paras.107-111 and opening statement at the oral hearing.

1987 Panel Report, EC-Seal Products, para.7.409 citing the Panel Report, US-Gambling, para.6.461.

1988 Appellate Body Report, EC-Seal Products, para.5.144.

1989 See Appellate Body Reports on Korea-Various Measures on Beef, para.176 and EC-Asbestos, para.168. Also, Van den Bossche, P., Looking for Proportionality in WTO Law in Legal Issues of Economic Integration, 35(3), 2008, 283-294 at p.293:

The Appellate Body in US-Gambling found yet another occasion to reiterate that the level of protection was sacrosanct.

1990 See Appellate Body Report, EC-Seal Products, paras.2.56-257 referring to Norway's appellant's submission; paras.2.260-2.261 which refer to Iceland's concerns and para.188, which also cites the EU Commission Proposal on the issue.
} 
The position taken on the relativism of morals can also be linked with the position that a Member may take with regard to the (good faith) extra-territorial application of public morals. Should the exception be applied only for internal measures or can it be extended to extraterritorial application? It is arguable whether other international law obligations direct states towards using such provisions for the promotion of certain non-trade values through trade measures in other jurisdictions. It can be argued that the exception applies to public morals exceptions that apply only within own borders and relate to the morals of one's own people e.g. gambling, alcohol, drugs, child pornography. But there can be situations where the measure intends to cover one's own people as well as the protection of rights of people of other countries or relates to international environmental concerns e.g. turtles, atmosphere or is a matter that is directly connected with the production of trade in goods or services e.g. sex tourism or child/prison labour. But it seems less likely that the exception ought to cover actions of another Member which are offensive to ones' own morals and are not directly related to trade in goods and services such as general human rights violations in 'unfriendly regimes'.

The use of human rights protection objectives in all these contexts, from local protection to global application remains controversial even from a human rights perspective since it may cloak narrow protectionist aims while reducing trade opportunities in poorer countries and worsening that human rights situation. The reduction of trade barriers may have the potential to engage with 'unfriendly regimes' which are systematically violating human rights and generally promote the welfare of those populations - thus trade could have a human rights promotion role.

Extraterritoriality was an issue raised in the GATT dispute of US-Tuna (EEC), when the United States argued that there was no territorial or jurisdictional limitation to the application of Article XX(g) of the GATT. ${ }^{1991}$ The EEC and the Netherlands disagreed with the United States stating that a contextual examination of paragraphs (g) and (b) of Article XX, as well as paragraph (a) supported a 'within national borders' jurisdictional limitation and also disagreed that Soering was evidence of routine extraterritorial interpretation of treaty provisions. ${ }^{1992} \mathrm{~A}$ connection between Article XX(g) and Article $\mathrm{XX}(\mathrm{a})$ of the GATT could have been made, under environmental ethics and animal welfare concerns. But A specific reasoning on extraterritorial application or whether there was an implied jurisdictional limitation of the exceptions was avoided in US-Shrimp and also in EC-Seals. ${ }^{1993}$

The jurisdictional limitation can also be raised on logical reasoning on its non-relevance to a particular measure. In EC-Tariff Preferences, India raised the issue of whether there was any connection between the EC Drug Arrangements and Article XX(b), which was raised as a defence by the EC. India argued that the necessity of the Drug Arrangements, either as a measure for protection of human life and health in the EC (from the effects of illegal drug imports) or for more favourable treatment for developing countries (to encourage reduction or elimination of drug production and trafficking) was "logically contradictory and based on several flawed assumptions". ${ }^{1994}$ The panel considered whether providing improved market access through tariff preferences to certain countries

\footnotetext{
${ }^{1991}$ GATT Panel Report, US-Tuna (EEC), paras.3.16

1992 GATT Panel Report, US-Tuna (EEC), paras.3.35.

1993 Appellate Body Report, EC-Seal Products, para.5.173.

${ }^{1994}$ Panel Report, EC-Tariff Preferences, para.7.19.
} 
was aimed at protecting human life or health in the drug importing countries or merely to help them to move to sustainable development alternatives - and decided that the evidence presented suggested the latter. ${ }^{1995}$ However, despite seeming to agree that there could be some positive extraterritorial impact of the measure, the panel found that since the Drug Arrangements were not "designed for the purpose of protecting human life or health in the European Communities", the measures could not be justified under Article XX(b) of GATT 1994. This issue was not appealed, and the outcome of EC-Tariff Preference suggests that the primary focus of a measure under an exception ought to be protection of public morals, human life or health etc., within the domestic jurisdiction.

Gareth Davies gives an interesting example of how the extraterritorial morality argument can be extended, with regard to GM crops. He argues that a nation or continent can have a legitimate interest in GM crops grown elsewhere, since "the environment and the global gene-pool are to some extent collective goods" and GM crops may entail "the taking of an immoral environmental risk" which does ultimately threaten that nation or continent. ${ }^{1996}$ If a society has expressed a moral position on such an issue, the nonapplication of the principle to imports, suggesting 'its ok' for it to happen elsewhere, is described by Davies as "hypocritical". Indeed, international environmental law sets standards that prevent or limit the passing off of such risks to weaker regulatory regimes, for example the Basel Convention on the control of transboundary movements of hazardous wastes and their disposal of 1992, the Bamako Convention on the ban on the import into Africa and the control of transboundary movement and management of hazardous wastes within Africa of 1998, and the Rotterdam Convention on the prior informed consent procedure for certain hazardous chemicals and pesticides in international trade of 2004.

In terms of health services, it should be noted that the international human rights regime does not limit State obligations to the domestic sphere, but instead clarifies the role that must be taken for the extraterritorial protection of the right to health. The CESCR General Comment on the Right to Health notes that:

To comply with their international obligations in relation to article 12, States parties have to respect the enjoyment of the right to health in other countries, and to prevent third parties from violating the right in other countries, if they are able to influence these third parties by way of legal or political means, in accordance with the Charter of the United Nations and applicable international law [emphasis added]. ${ }^{1997}$

The obligation is not limited to a "do no harm" principle but also extends to active support of the right to health in other countries. The sentence immediately following the above quotation (also in the same paragraph) states that:

Depending on the availability of resources, States should facilitate access to essential health facilities, goods and services in other countries, wherever possible, and provide the necessary aid when required.

\footnotetext{
1995 Panel Report, EC-Tariff Preferences, para.7.207.

1996 Davies, Gareth, Morality Clauses and Decision-Making in Situations of Scientific Uncertainty: The Case of GMOs, Research Paper No. 10-06, the International Law Forum of the Hebrew University of Jerusalem Law Faculty, presented at a Roundtable on "GMOs and International Trade" held at the Hebrew University of Jerusalem, August 1, 2006, available online at www.ssrn.com/abstractid=920754, p16.

1997 UN, CESCR, General Comment No. 14, The Right to The Highest Attainable Standard of Health, E/C.12/2000/4., $11^{\text {th }}$ August 2000, para 39.
} 
The above sentence has a footnote (footnote 27) which states that it must be read with paragraph 45 of the General Comment, which identifies a "core obligation" of State Parties to provide "international assistance and cooperation, especially economic and technical", which enables State Parties which are developing countries to fulfil their own obligations. Thus, the moral obligation to consider the extraterritorial consequences is transformed into a core legal obligation under international human rights law. This discussion of the avoidance of passing off of risk and the sharing of resources and expertise leads to an interesting question whether an identification of risk is relevant for public morals in the GATS, as it is usually not used in this context, but instead in connection with the establishment of a health risk under Art XIV(b) of the GATS.

\subsubsection{Identification of 'Risk' needed in order to "Protect" Public Morals?}

In the Appellate Body Report in EC-Seal Products (relating to Article XX(a) of the GATT 1994), the appellant Canada highlighted the phrase "to protect" and argued that it includes identification of a "risk". This phrase was not dealt with in US-Gambling, which focused on 'designed to protect', falling within the scope of protection, the level of protection and the necessity of the protection - but not what "to protect" means. Referring to the relevance of the comments of the Panel in EC-Asbestos on Article $\mathrm{XX}(\mathrm{b})$ of the GATT (which also used the same phrase), Canada inferred that "to protect" implies a test including three elements:

(i) identification of a public moral;

(ii) identification of a risk to that public moral; and

(iii) establishing that a nexus exists between the challenged measure and the protection of the public moral against that risk in the sense that the measure is capable of making a contribution to the protection of that public moral ${ }^{1998}$

Canada argued that the Panel in EC-Seal Products failed to consider whether the risks associated with commercial seal hunts -

...exceeded the accepted level of risk of compromised animal welfare, as

reflected in the EU's policies and practices in this field. ${ }^{1999}$

This argument of Canada has some merit as in order to promote good faith efforts protect public morals (and give effect to the chapeau), some submission should be made as to a possible realistic risk to the public morals that are claimed. Basically, this includes an assessment of what the damage is to public morals caused by the slaughter of seals as opposed to the slaughter of any other animal, wild or domesticated, whose 'products' are sold commercially - that would justify a measure based on protection of public morals? The European Union had a different view, arguing that in order for a measure to fall within the scope of Article $\mathrm{XX}(\mathrm{a})$, all that is needed is to show that the measure is designed to protect public morals. ${ }^{2000}$ It does not need to elaborate on the risk as part of the term 'to protect', but only if there is such a 'public morals' that needs to be protected.

The response of the Appellate Body favoured the EC view, stating that:

...the notion of risk in the context of Article XX(b) is difficult to reconcile with the subject matter of protection under Article XX(a), namely, public morals. While the focus on the dangers or risks to human, animal, or plant

\footnotetext{
${ }^{1998}$ Appellate Body, EC-Seal Products, citing Canada's appellant's submission, para. 390.

1999 Appellate Body, EC-Seal Products, citing Canada's appellant's submission, para.397.

${ }^{2000}$ Appellate Body, EC-Seal Products, citing the European Union's appellee's submission, paras.343 and 344 (referring to Appellate Body Report, Korea - Various Measures on Beef, para.157).
} 
life or health in the context of Article XX(b) may lend itself to scientific or other methods of inquiry, such risk-assessment methods do not appear to be of much assistance or relevance in identifying and assessing public morals [emphasis added]

But interestingly at one point the Report, the Appellate Body refers to the fact that the Panel

...gave detailed reasons for its findings on the uniqueness and distinctiveness of the welfare risks associated with seal hunts. ${ }^{2001}$

Similarly, it could be argued that Article XIV(a) of the GATS also has no connection with identification or assessment of risk. However, such an argument can be made, if we do not limit ourselves to risks based on 'science' but consider unconscionable risks or risks that should not be taken as they are inconsistent with public morals. Gareth Davies has an interesting response to the GMO issue and EC-Approval and Marketing of Biotech Products, where he argues that the EC could have taken up the Article XX(a) exception rather than the Article $\mathrm{XX}(\mathrm{b})$ of the GATT in a situation like GMO regulation, where there is no scientific certainty of the outcome. As there are some similarities between these two exception Articles of the GATT and the exceptions in Article XIV(a) and (b) of the GATS, Davies' comments are worth looking into.

The lack of scientific certainty does not rule out the application of the precautionary principle of international environmental law - but in the WTO context, the doubts as to the binding nature of the principle meant that it could not add sufficient weight to the Article XX(b) 'life and health' exception raised by the EC in EC-Approval and Marketing of Biotech Products. Davies criticizes the reliance on scientific arguments, (albeit uncertain science) as 'silly', 'childish' and 'cowardly'; when the EC could have brought out the "set of deeply culturally specific responses to uncertainty". ${ }^{2002}$ Davies argues that the "best description" of the EC-Approval and Marketing of Biotech Products dispute, which is a disagreement about "when and why it is justified to take risks" - "is in terms of morality" rather than scientific certainty. ${ }^{2003}$ He points out that:

It is not just the risk, or degree of risk, that is the issue in GMO debates

but the absence of sufficiently good reasons for taking the risk. This is

where the moral reasoning enters [footnotes omitted] ${ }^{2004}$

He adds that such a decision "...depends on the value that we assign to various harms and benefits" ${ }^{2005}$ It need not be seen as a situation of arbitrary and fickle measures, but as a legitimate set of values and preferences about a view on risks that can be proved as "genuine and rooted and consistent" 2006 The risk assessment does not have to be

\footnotetext{
2001 Appellate Body, EC-Seal Products, para.5.195.

${ }^{2002}$ Davies, Gareth, Morality Clauses and Decision-Making in Situations of Scientific Uncertainty: The Case of GMOs, Research Paper No. 10-06, the International Law Forum of the Hebrew University of Jerusalem Law Faculty, presented at a Roundtable on "GMOs and International Trade" held at the Hebrew University of Jerusalem, August 1, 2006, available online at www.ssrn.com/abstractid=920754 [conclusion p19]

${ }^{2003}$ Ibid., p3.

2004 Ibid., p9. The footnotes cited by Davies for this point were: Pildes R., and C. Sunstein Experts, Economists and Democrats in Sunstein, C., Ed., FREE MARKETS AND SOCIAL JUSTICE, OUP, 1997; Cranor, C., REGULATING TOXIC SUBSTANCES: A PHILOSOPHY OF SCIENCE AND THE LAW, OUP, 1997 p127; Howse, R., Democracy, Science, and Free Trade: Risk Regulation on Trial at the World Trade Organization, 98 Mich.L.Rev. 2329, p2351; Scott, Nadine, Nature/Culture Clash: The Transnational Trade Dispute over GMOs', Hauser Global Law Working Paper 06/05 p33. ${ }^{2005}$ Ibid., p8.

2006 Ibid., p19.
} 
'scientific' as usually assumed with reference to Article XX(b) of the GATT or Article XIV(b) of the GATS, but can be evidence of social values/public morals. This would make it easier to fulfill the requirements of falling within the scope of an exception.

Following this line of argument, public health and right to health measures for services can come under public morals instead of protection of human life or health, if a genuine societal value concerning not taking risks with regard to the life and health of the population can be shown to be a part of public morals.

\subsubsection{Measures Necessary to Protect Public Order}

The Panel in US-Gambling did not invest much effort in the definition of "public order". It was quick to suggest that the dictionary definition relied upon by them read with the description in footnote 5 to Article XIV(a) of the GATS ${ }^{2007}$ suggest that "public order" refers to the "preservation of the fundamental interests of a society, as reflected in public policy and law" and that these fundamental interests can relate "to standards of law, security and morality". ${ }^{2008}$ The Appellate Body in US-Gambling agreed that the definition of public order includes the standard in footnote 5 and commented further that panels are however not required to make "a separate, explicit determination" that the standard of footnote 5 has been met". 2009

The full explanation of the Panel in US-Gambling with regard to the definition of "public order" is as follows:

The dictionary definition of the word "order" that appears to be relevant in the context of Article XIV(a) reads as follows:

"A condition in which the laws regulating the public conduct of members of a community are maintained and observed; the rule of law or constituted authority; absence of violence or violent crimes."

We recall that drafters of the GATS clarified in footnote 5 that "[t]he public order exception may be invoked only where a genuine and sufficiently serious threat is posed to one of the fundamental interests of society". Hence, in our view, the dictionary definition of the word "order", read together with footnote 5, suggests that "public order" refers to the preservation of the fundamental interests of a society, as reflected in public policy and law. These fundamental interests can relate, inter alia, to standards of law, security and morality. ${ }^{2010}$

It can be noted that morality may be referring to or connected with the first part of $\mathrm{XIV}(\mathrm{a})$, that is, the protection of "public morals" and security concerns may be covered by Article XIVbis. The Panel in US-Gambling makes no comment on possible overlap between security and order concerns in the context of Article XIVbis, which is a separate

\footnotetext{
2007 The footnote to Article XIV(a) adds that:

The public order exception may be invoked only where a genuine and sufficiently serious threat is posed to one of the fundamental interests of society.

${ }^{2008}$ Panel Report, US-Gambling, para.6.467.

${ }^{2009}$ Appellate Body Report, US-Gambling, para. 298, cited also by the Panel Report, EU-Energy Package, para. 7.1144

${ }^{2010}$ Panel Report, US-Gambling, paras.6.466-6.467. As to be expected, the dictionary referred to is The Shorter Oxford English Dictionary, 2002.
} 
provision - but with regard to the parts of Article XIV (a), a general statement is made. The Panel stated that while they believe that:

... "public morals" and "public order" are two distinct concepts under Article XI(a) GATS. Nevertheless, to the extent that both concepts seek to protect largely similar values, some overlap may exist [emphasis added]. ${ }^{2011}$

Neither the abovementioned distinction nor the similarities are clarified further. Until a need arises for such further clarification in subsequent disputes, the exact nature of relationship between these concepts in the WTO GATS context will remain subject to conjecture.

However, it may be useful to discuss the definition of public order and some of the possible approaches to its relationship with public morals and security in further detail.

The elements to be thus discussed would be:

1. "preservation of the fundamental interests of a society as reflected in public policy and law"

2. "These fundamental interests can relate, inter alia, to standards of law, security and morality"

The second element can be discussed in more detail under the following subdivisions:

1. Fundamental interests relating to "standards of law..."

2. Fundamental interests relating to "...security" - overlap with Article XIVbis?

3. Fundamental interests relating to "...morality" - overlap with "public morals"?

There is also a further clarification for public order, in that the Panel in ChinaPublications and Audiovisual Products also noted that, similar to "public morals" "public order" also must be aimed at protecting the interests of the people within a community or nation as a whole. ${ }^{2012}$ The reason given by the Panel is that both concepts share a word in common: "public".

For "preservation of the fundamental interests of a society": following the Panel methodology, a reference to dictionaries could be used in an attempt to further clarify the key words in the definition "fundamental" and "interests" and then declare the scope of "fundamental interests". Perhaps that will not cast too much light, as it will only lead to further terms such as primary, basic, deep-rooted, radical and so on, that can also be defined again with recourse to dictionaries. Perhaps this is also a futile exercise in the sense that the Panel statement has already resulted in the following scope:

Fundamental interests $>$ standards of law, security and morality

- and this is a sufficient formula until there a need arises in a dispute context, to clarify it further.

In EU-Energy Supply, the European Union raised the issue of public order and the standard in footnote 5 to Article XIV(a) of the GATS in defence of a measure that was

2011 Panel Report, US-Gambling, para.6.468

2012 Panel Report, US-Gambling, para.6.463

The Panel believes that a measure that is sought to be justified under Article XIV(a) must be aimed at protecting the interests of the people within a community or a nation as a whole. This is the case whether the measure is asserted to be necessary to "protect public morals" or to "maintain public order" since both terms contain the word "public" [emphasis added]. 
deemed necessary to ensure the European Union's security of energy supply and hence to maintain public order. The European Union argued that security of energy supply is a "fundamental interest of society" and that foreign control of a natural gas transmission system or transmission system operator may in some circumstances pose a "genuine and sufficiently serious threat" to this interest. ${ }^{2013}$ In presenting the defence, the EU energy described energy as being "one of the most basic necessities of modern societies" and "disruptions in supply potentially having severe social, economic and, ultimately, political consequences". ${ }^{2014}$ This line of argument could also be applied to health and health services, that public health services in particular are a 'fundamental interest and basic necessity of society' that needs to be protected from 'genuine and sufficiently serious threats', allowing for it to fall under "public order" as well as "public morals".

The Panel in EU-Energy Supply, generally agreed with the submission of Russia that the scope of a "fundamental interest" can vary between Members "given the difference in values between societies"; and that the responding party must make a prima facie case that it based its measures on "an interest which lies at the core of a society and which that society constantly strives to achieve and maintain". ${ }^{2015}$ It was further agreed that even if there is some variation "given the difference in values between societies". However, the Panel disagreed with Russia that the fundamental interest concerned must be "specific" and "easily identified". ${ }^{2016}$

It is possible to discuss the implications of the above panel references. The idea of fundamental interests of society is not one that is unfamiliar to legal philosophy. Theoretical discussions on the fundamental interests of society as relating to the ordering of the state and its relation with citizens, comes to mind. We can turn to Hobbes and the idea that fundamental and rational self-interest - the preservation of life, securing the good of those close to us and the aim of acquiring a commodious life - leads people to create political institutions including an effective sovereign, and enter into the social contract. ${ }^{2017}$ This idea is further developed in the Social Contract theories of John Locke, Hume and Rousseau.

Summing up Rousseau, Rawls identifies four assumptions of the Rousseau's social contract, to describe the features of a polity within which human beings strive for. The first is co-operation to advance common fundamental interest to promote human potential. Such persons co-operating must advance their interests under conditions of social interdependence with others - which is the second assumption. The third assumption is the equal capacity and interest in our own freedom and the fourth is equal capacity for a political sense of justice and interest in acting accordingly. The social

\footnotetext{
2013 Panel Report, EU-Energy Package, para. 7.1143, citing the European Union's first written submission, paras. 480, 507-509 and 507-526 generally and the European Union's second written submission, paras. 189 and 197-198.

${ }^{2014}$ Panel Report, EU-Energy Package, para. 7.1145, citing the European Union's first written submission, para. 485.

2015 Panel Report, EU-Energy Package, paras.7.1148-7.1152, citing Russia's second written submission, para. 304:

[A] "fundamental interest" must be considered an interest which lies at the core of a society and which that society constantly strives to achieve and maintain. As such, it will be "specific" and easily identified by other parties

${ }^{2016}$ Panel Report, EU-Energy Package, para.7.1152.

${ }^{2017}$ Rawls, John, Lectures on Hobbes in Rawls, John and Samuel Richard Freeman ed., LECTURES ON THE HISTORY OF POLITICAL PHILOSOPHY, Harvard University Press, 2007, p33 and p160.
} 
contract is the solution to the problem of uniting to fulfil our fundamental interests without sacrificing freedom. ${ }^{2018}$ The determination of fundamental interest is further clarified as being determined by the normative conception of the human person as abovementioned. ${ }^{2019}$ It is possible that this conception of fundamental interests can be interwoven with the conception of public order in the WTO - as the scope of "public order" ought not to be one where justifications/exceptions to trade rules can be made to maintain measures that protect the interests of an undemocratic 'police state'.

From a human rights perspective, the Siracusa Principles have defined "public order" as: ...the sum of rules which ensure the functioning of society or the set of fundamental principles on which society is founded ${ }^{2020}$.

The Limburg Principles on ESCR add that: public)

Respect for economic, social and cultural rights is part of public order (ordre

Thus, the right to health can also be identified as part of "public order" if looking at the interpretation in the human rights context. The relationship between public order and human rights is further described as follows:

Respect for human rights is part of public order (ordre public) ... Public order (ordre public) shall be interpreted in the context of the purpose of the particular human right which is limited on this ground. ${ }^{2021}$

In other words, public order both includes human rights concerns and limits the breadth of human rights in favour of public order - a dual relationship, one that embraces and one that chastises. Perhaps it can also be described as a balancing process, so that important interconnected concerns of society are kept within reasonable boundaries, and the interests of both individuals and society is balanced.

The State organs or agents resorting to "public order" actions, either for the promotion or limitation of human rights, are expected not to act without a basis in law and in violation the concept of balance of state power. The Siracusa and Limburg Principles both elaborate that:

State organs or agents responsible for the maintenance of public order (ordre public) shall be subject to controls in the exercise of their power through the parliament, courts, or other competent independent bodies. ${ }^{2022}$

Where there are shortcomings in the domestic system, there are different procedural avenues in the international human rights framework, that can impose legal and diplomatic pressure to balance over-breadth of public order laws and regulations.

The WTO system does not have such a system of control or balancing within its system in the context of the public order exception. But it can be argued that if WTO law is not in fact isolated and immune from developments in international law including international human rights norms - WTO provisions should not be interpreted in a manner that contradicts the understanding of 'public order' and its limitations in the wider normative framework.

\footnotetext{
${ }^{2018}$ Ibid., (Rawls), Lectures on Rousseau, p218-220.

2019 Ibid., (Rawls), p225-226.

2020 Principle 22 of the Siracusa Principles on the Limitation and Derogation of Provisions in the ICCPR, 1984 and Principle 66 of Limburg Principles on the Implementation of the ICESCR, is derived from the abovementioned Siracusa Principles.

${ }^{2021}$ Ibid., (Siracusa Principles), Principles 22 and 23; and Limburg Principles, Principle 67.

2022 Ibid., (Siracusa Principles), Principle 24 and Limburg Principles, Principle 68.
} 
With regard to the concept of fundamental interests relating to "standards of law...", the discussion under "public morals" applies equally to "public order". The fundamental interests and the standards of law that are referred to are domestic laws, but especially where there is customary international law or a State has ratified other international agreements such as those on human rights or environmental law (e.g. climate change) and made these part of domestic law - these interests should be covered by the exception.

This issue of "fundamental interests of...morality" seems to have been already covered by the phrase "public morals". This can seem confusing and lead to a question whether public order - since it includes "morality" - is a concept that includes "public morals" within its definition. Some commentators have seen the Panel statement on the relationship of public morals and public order as not only an assertion demonstrating that public morals are included in public order but that public order is:

...a catch-all term [which] includes all other legitimate objectives identified under Article XIV [emphasis in original]. ${ }^{2023}$

Cottier, Delimatsis and Diebold have commented that the reference in US-Gambling to "the protection of the interests of minors" as falling within the notion of public order means that prevention of under-age gambling (and other dangers of gambling such as addiction) can be equally deemed issues of public order as well as public morals. ${ }^{2024}$ This assumption seems to stem from the view that "morality" and "public morals" are to be considered as identical terms.

But if public morals are something that is part of public order (public order $>$ public morals since public morals $=$ morality) then it suggests that there are superfluous words in the Agreement. The ut res maxim of interpretation (ut res magis valeat quam pereat 'suppose every word to have some effect or use') and the principle of effectiveness in treaty interpretation ${ }^{2025}$ recognize that there cannot be superfluous words in a legal document, each ought to mean something. This has been accepted in the WTO cases of Japan-Alcoholic Beverages, US-Gasoline and US-Continued Zeroing as a part of the General Rule of Interpretation crystallized in Article 31 of the VCLT. ${ }^{2026}$

\footnotetext{
${ }^{2023}$ Cottier, T., P. Delimatsis and N. Diebold, Article XIV GATS in Wolfrum, Rudiger., Peter-Tobias Stoll and Clemens Feinaugle Eds., WTO-TRADE IN SERVICES, Max Planck Commentaries on International Trade Law, Martinus Nijhoff Publishers, 2008, p300.

${ }^{2024}$ Ibid., (Cottier et al) citing the Panel Report, US-Gambling, paras.6.469 and 6.470.

2025 The Principle of Effectiveness based on the ut res maxim was the fourth of six principles that Sir Gerald FitzMaurice derived from the practice of the PCIJ and ICJ - which in fact followed earlier interpretive domestic practice (FitzMaurice, G., Treaty Interpretation and Other Treaty Points 1951-54, British Yearbook of International Law, 33, 1957, 203-293). Earlier English Common Law using the principle include the cases of Ditcher $v$ Denison, 1857, 11 Moore P.C. 325 (it must be assumed at the outset that every word has effect and superfluity should not be imputed without necessity or sound reason) and Cargo ex Argos 1873 LR 5 PC 134 (where the meaning is ambiguous, the rule is to adopt a construction that will give effect to the words rather than give none).

Note however, that English Common Law practice is that a court of law can reject words as surplusage "if it appears that by attempting to give meaning to every word, we should have to make the Act of Parliament insensible" - $R$ v East Ardsley (Inhabitants) 185014 QB 793, p801.

2026 See further the analysis by Fitzmaurice, M. and Panos Merkouris, Canons of Treaty Interpretation: Selected Case Studies from the World Trade Organization and the North American Free Trade Agreement in Fitzmaurice, M., Olufemi A. Elias and Panos Merkouris Eds., TREATY INTERPRETATION AND THE VCLT; 30 YEARS ON, BRILL, 2010, 153, p179-189.
} 
Footnote 5 of the GATS, states with reference to Article XIV(a) that:

The public order exception may be invoked only where a genuine and sufficiently serious threat is posed to one of the fundamental interests of society [emphasis added].

Thus, Cottier et al have explained that the term "public morality" being referred to within 'public order' is not being used in a superfluous manner, by reference to the fact that it is not limited by the Footnote unlike "public order" and can be invoked in situations that are not necessarily considered a "serious threat" to the fundamental interests of society. ${ }^{2027}$ However, a common sense interpretation would presume that it would still need to be "genuine" and that a public order ground must reach the threshold of being both genuine and sufficiently serious. This would make "public morals" a ground that Members are freer to define and apply - and thus broader in scope than "public order" and the "morality" provision under public order, which must be accord to the restrictions of Footnote 5. Thus, in the final analysis, from the point of view of a Member relying upon Article XIV(a), "public morals" is after all the ground with the widest scope because the lack of the "genuine and sufficiently serious threat" as a requirement for public morals means that the actual situation is:

$$
\text { public morals }>\text { (public order }+ \text { 'genuine and sufficiently serious threat })+\ldots \text { morality } .
$$

Of course, Members and the dispute settlement bodies could continue with this line of argument and clarify the relationship in further in future disputes.

The interpretation of "genuine and sufficiently serious threat" was not addressed in disputes until EU-Energy Package. The Panel in approved of the position of the parties (EU and Russia) that "genuine" and "sufficiently serious have distinct meanings. ${ }^{2028}$ However the Panel also cautioned that it may always be appropriate to analyze the terms "in complete isolation from one another" and that a "more holistic approach" may be required in some situations. The Panel began by referring to interpretation given by both the parties with regard to the two terms and noted that they had submitted that:

...the term "genuine" speaks to the "degree of likelihood" of a threat materializing and that the term "sufficiently serious" speaks to the "potential consequences" or the "potential gravity of the effects" of a threat materializing [footnotes omitted]. ${ }^{2029}$

Although the Panel had commenced their interpretation by referring to the principles of treaty interpretation in Article 31 of the Vienna Convention and the dictionary approach of using the Shorter Oxford Dictionary (2007), the Panel generally agreed with the understanding of the parties. The Panel was of the view that the standard under this provision was closer to the EU suggestion than Russia's, and decided that the review must include whether there was "a real, true and authentic possibility" rather than "an imaginary or very remote risk invoked in order to escape the obligations imposed by the GATS". ${ }^{2030}$ The Panel also approved of the EU's argument that these terms "provide

\footnotetext{
${ }^{2027}$ Cottier, T., P. Delimatsis and N. Diebold, Article XIV GATS in Wolfrum, Rudiger., Peter-Tobias Stoll and Clemens Feinaugle Eds., WTO-TRADE IN SERVICES, Max Planck Commentaries on International Trade Law, Martinus Nijhoff Publishers, 2008, p300.

${ }^{2028}$ Panel Report, EU-Energy Package, paras.7.1158- 7.1159.

${ }^{2029}$ Ibid., (EU-Energy Package), para.7.1158, citing European Union's response to Panel question No. 207, para. 192 and No. 207, para.191 - and Russia's response to Panel question No. 207(a), para. 261 and No. 207(b), para. 264.

${ }^{2030}$ Ibid., (EU-Energy Package), paras.7.1157-7.1168, in particular para.7.1168 (citing European Union's response to Panel question No. 207, para.190).
} 
context for the interpretation of each other" and that "the degree of likelihood necessary to regard a threat as 'genuine' must take into account the seriousness of the threat". ${ }^{2031}$

In terms of whether there can be a public health services-related public order exception, it is possible if health sector or health-related sector commitments have been made under the GATS but there are genuine and sufficiently serious threats to fundamental interests of society, which require a restriction on services trade in sectors and measures to protect public services. Such situations could occur in contexts of natural disasters, armed conflicts, epidemics and other health emergencies which require a focus on public health services delivery. The WHO tracked 1483 epidemic events in 172 countries in the period 2011-2018, including severe acute respiratory syndrome (SARS), Middle East respiratory syndrome (MERS), Ebola, and Zika. ${ }^{2032}$ It may be possible for a Member who wishes to implement policy measures to strengthen their health services system in order to withstand the occurrence of such serious threats to resort to the public order exception. It could be said that there is a responsibility for WHO member States to develop their public health services as part of preparedness for emergencies. As identified by the WHO in its 2019 Annual Report on Global Preparedness for Health Emergencies:

Any country without basic primary health care, public health services, health infrastructure and effective infection control mechanisms faces the greatest losses, including death, displacement and economic devastation..$^{2033}$

Since outbreaks of infectious disease, whether in the context of conflict-affected countries or otherwise, could become global pandemics if they spread, they can become an issue affecting global health security. The WHO defines global health security as:

The activities required, both proactive and reactive, to minimize vulnerability to acute public health events that endanger the collective health of populations living across geographical regions and international boundaries. $^{2034}$

The International Health Regulations (IHR) of 2005 provides a legal framework to address prevention, detection, surveillance and response for diseases that could cause public health emergencies of international concern, and authorizes the Director-General of the WHO to declare an international public health emergency and to make recommendations regarding steps Member States should take. Interestingly, Article 2 of the IHR states:

The purpose and scope of these (IHR) Regulations are to prevent, protect against, control and provide a public health response to the international spread of disease in ways that are commensurate with and restricted to public health risks, and which avoid unnecessary interference with international traffic and trade [emphasis added].

Therefore, it can be said that the IHR balances with WTO obligations. If the traderestrictive measures taken are "necessary", then there is possibility to resort to the exception under public order. ${ }^{2035}$

\footnotetext{
${ }^{2031}$ Ibid., (EU-Energy Package), para.7.1169, citing European Union's response to Panel question No. 207, para. 192.

${ }^{2032}$ WHO, Global Preparedness Monitoring Board, A WORLD AT RISK: ANNUAL REPORT ON GLOBAL PREPAREDNESS FOR HEALTH EMERGENCIES, 2019, p2.

${ }^{2033}$ Ibid, (WHO, 2019), p3.

${ }^{2034}$ WHO, THE WORLD HEALTH REPORT 2007 - A Safer Future: Global Public Health Security in the 21st Century, 2007. http:/www.who.int/whr/2007/en/.

${ }^{2035}$ See other references to the IHR in this study, at Sections 4.6.2 and 5.4.2.
} 
In terms of future interpretive challenges, there is another possibility - that "public order" could be raised by a Member as able to be read together with Article XIVbis (Security Exceptions), particularly paragraphs (b) and (c) of XIVbis. This raises a question whether fundamental interests relating to "security" overlap with Article XIVbis? The relevant text of Article XIVbis, is as follows:

1. Nothing in this Agreement shall be construed:

(b) to prevent any Member from taking any action which it considers necessary for the protection of its essential security interests:

(i) relating to the supply of services as carried out directly or indirectly for the purpose of provisioning a military establishment;

(ii) relating to fissionable and fusionable materials or the materials from which they are derived;

(iii) taken in time of war or other emergency in international relations; or

(c) to prevent any Member from taking any action in pursuance of its obligations under the United Nations Charter for the maintenance of international peace and security.

The possibility of linkage between Articles XIV(a) and XIVbis of the GATS is categorically denied by Cottier et al, who state that it is a:

misapprehension that the public order exception also covers national security interests [which are] exclusively subject to Art, XIVbis, whereby only societal interests fall under Article XIV (a)"2036.

In support of this view reference is made to the supplementary means of interpretation referred to by the Panel in US-Gambling which places the concept of public order in civil law and conflict of laws situations. However, in the actual Panel decision, it is arguable that it is merely presented as a repetition of a submission by the United States ${ }^{2037}$. The Panel goes on to cite, as a supplementary means of interpretation for "public order", Judge Lauterpacht's separate opinion in the ICJ Guardianship of Infants case. ${ }^{2038}$ This is an interesting source to refer to, not being directly related to gambling, as in the case of the other material referred to, but is a reliance on the comment that "the protection of the interest of minors ... falls naturally within the notion of ordre public". ${ }^{2039}$ This is even more interesting as the Panel had just stated in the preceding paragraph that the prevention of underage gambling was arguably related to public morals, and it was not considered necessary (the Panel did not think so) to identify whether a particular policy consideration fell under "public morals" or "public order".

Two cases from the European Court of Justice, interpreting Article 30 of the EC Treaty are cited in Footnote 914 of the US-Gambling Panel Report. Article 30 of the EC

2036 Ibid., (Cottier et al), p299, citing Krajewski, M., NATIONAL REGULATION AND TRADE LIBERALIZATION IN SERVICES: THE LEGAL IMPACT OF THE GENERAL AGREEMENT ON TRADE IN SERVICES (GATS) ON NATIONAL REGULATORY AUTONOMY, Kluwer Law International, 2003, p158

2037 The United States argues that the term "public order" refers to the familiar civil law concept denoted in French by the expression "ordre public" and its functional counterpart in common law systems, the concept of "public policy". (cited as footnote 903 - United States' second written submission, para.108.)

2038 ICJ, Case Concerning the Application of the Convention of 1902 Governing the Guardianship of Infants (Netherlands v. Sweden), 1958 I.C.J. 55, p90 (Judgment of 28 November): public order had been described as the "fundamental national conceptions of law, decency and morality."

${ }^{2039}$ Ibid., cited in Panel Report, US-Gambling, para.6.470. 
Treaty ${ }^{2040}$ is very similar to Article XIV of GATS, ${ }^{2041}$ but uses the terms "public morality, public policy and public security" and not "public order". However, these cases discuss the regulation of lotteries in light of maintaining order in society ${ }^{2042}$ and regulation of gambling in casinos as part of consumer protection and maintenance of order in society $^{2043}$. It is not the definition and scope of "public order", but the relevance to a discussion of gambling that appear to be the reason for choosing the said cases. Other available European jurisprudence, especially the available case law on "public morals"2044 is significantly omitted as a source that may shed some light on the interpretation of the exception. It is possible that this was not an oversight, but a conscious decision not to use European law to interpret the text of the GATS - but we cannot speculate on what the Panel members may have been thinking. Nevertheless, it is important to note that despite similarities in terms of promoting free markets, it has also been commented that the two regimes of WTO and EC are based on different foundations and are therefore not comparable, even if similar wording is used in exceptions in both.

From a human rights perspective, national security can also be used at times as a restriction on human rights similar to public morals and public order. The possible limitation of rights in the Covenants seems narrower than the exceptions in Article XIVbis:1(b) and (c), as both the Siracusa and Limburg Principles state that the restriction can be invoked to protect "territorial integrity or political independence against force or threat of force" 2045 and "an emergency in international relations" does not necessarily reach the threshold of "force or threat of force", since it could also refer to "trade wars' or tensions between States which have not reached the threshold of "force". Yet the limitations in the Covenants are similar to Article XIVbis in that the security interests of Article XIVbis must be related to "war or other emergency in international relations" and the Siracusa and Limburg Principles also note that the restrictions cannot be invoked merely to prevent "local or relatively isolated threats to law and order". 2046

\footnotetext{
${ }^{2040}$ Note that Article 30 of the Treaty establishing the European Community (Nice consolidated version) is Article 36 of the EC Treaty (Maastricht consolidated version).

${ }^{2041}$ Article 30 of the EC Treaty states:

The provisions of Article 28 [prohibition of quantitative restrictions on imports] and Article 29 [prohibition on restrictions of exports] shall not preclude prohibitions or restrictions on imports, exports or goods in transit on grounds of public morality, public policy or public security...such prohibitions shall not, however, constitute a means of arbitrary discrimination or disguised restriction on trade between member states.
}

This provision has been relied upon in several instances, including in R.v Henn and Darby (1979) ECR 3795 and Conegate v. Customs and Excise Commissioners (1986) ECR 1007, both involving pornography. ${ }^{2042}$ Case C-275/92, Her Majesty's Customs and Excise v. Gerhart Schindler and Jörg Schindler, (24 March 1994)

${ }^{2043}$ Case C-6/01 - Associação Nacional de Operadores de Máquinas Recreativas (Anomar) and Others (11 September 2003)

${ }^{2044}$ The 'public morals' provision has been relied upon in several instances, including $R$. $v$ Henn and Darby (1979) ECR 3795 and Conegate v, Customs and Excise Commissioners (1986) ECR 1007, both involving pornography.

${ }^{2045}$ Principle 29 of the Siracusa Principles and Principle 62 of the Limburg Principles read as follows: National security may be invoked to justify measures limiting certain rights only when they are taken to protect the existence of the nation or its territorial integrity or political independence against force or threat of force.

${ }^{2046}$ Principle 30 of the Siracusa Principles and Principle 63 of the Limburg Principles read as follows: National security cannot be invoked as a reason for imposing limitations to prevent merely local or relatively isolated threats to law and order. 
Similar to the limitation imposed by the chapeau in Article XIV of the GATS, but missing from Article XIVbis, both the Siracusa and Limburg Principles restrain the security exceptions by reference to non-arbitrariness and furthermore places security exceptions within a system that requires balancing of the rights and the restrictions, stating that:

National security cannot be used as a pretext for imposing vague or arbitrary limitations and may only be invoked when there exists adequate safeguards and effective remedies against abuse. ${ }^{2047}$

There does not appear to be a similar and sufficient balancing of trade liberalization and security within the Article XIVbis of the GATS. Of course, the delicate and difficult three-way balancing of human rights, trade and security is also not acknowledged, unless the reference to the "obligations under the Charter of the United Nations for the maintenance of international peace and security" in Article XIVbis(1)(c) can be seen as an entry point for such a balancing within the GATS. Article XIVbis(1)(c) is an overlooked provision, but which has a broad scope as it allows for Members to take any actions in pursuance of the aforesaid obligation under the Charter of the United Nations.

It should be recalled that human rights protection is fundamental to the UN Charter framework and specifically mentioned as an objective in the second Recital of the Preamble to the UN Charter:

to reaffirm faith in fundamental human rights, in the dignity and worth of the human person, in the equal rights of men and women and of nations large and small...

The Siracusa and Limburg Principles recognize the interconnection of these three areas, particularly Principle 65 of the Limburg Principles which states that:

The systematic violation of economic, social and cultural rights undermines true national security and may jeopardize international peace and security. A State responsible for such violation shall not invoke national security as a justification for measures aimed at suppressing opposition to such violation or at perpetrating repressive practices against its population. ${ }^{2048}$

This recognizes a broader framework than what is usually defined as a war, conflict or national security situation, in that "systematic violation of economic, social and cultural rights undermines true national security and may jeopardize international peace and security" can be applied generally to social inequalities and failure to achieve the basic human rights standards. There is a possibility that interpretations of Article XIVbis, particularly XIVbis(1)(b)(iii) and XIVbis(1)(c) could in fact make room for a broader understanding of national and international security and how it is violated, so as to include human rights as "obligations under the Charter" and systematic human rights violations as 'an emergency in international relations' for which trade obligations can be (temporarily) set aside.

Therefore, it can be argued that just as trade liberalization measures that violate State obligations regarding the right to health is problematic - security exceptions to trade liberalization measures such as trade embargoes or sanctions also should not violate the right to health. Thus, even if security interests call for trade sanctions and embargoes, the result of these on the economic and social rights of people of the country against which

\footnotetext{
${ }^{2047}$ Principle 31 of the Siracusa Principles and Principle 64 of the Limburg Principles.

2048 The Siracusa Principles state "violation of human rights" instead of "violation of economic, social and cultural rights".
} 
sanctions are imposed should be part of the decision-making process. Unfortunately this does not happen as it should - even in the purely human rights context, the legality of such trade sanctions and embargoes is a disputed matter - as was seen the welldocumented example of the terrible damage to Iraq's health system and the most vulnerable parts of its population. ${ }^{2049}$ But this argument is definitely easier to make in the context of international human rights, but seems a strange and convoluted argument from a trade law perspective, since economic and social rights such as the right to health lacks explicit acceptance in the latter context. Furthermore, it seems very unlikely that Members would initiate or accept an investigation of the socio-economic impact of their security measures within the trade law regime.

How would "security", either under public order or under Article XIVbis, be used to benefit public health services? It would depend how broadly the concept is defined, and what kind of links are drawn to domestic law concepts or other non-trade concepts. There could be a humanitarian law perspective on the matter of as well. It can be maintained that the responsibility to provide medical care to the wounded and sick has been a fundamental principle of civilization since ancient times and it is clearly a part of international treaty law since the first Geneva Convention of 1864 . Henri Dunant's proposal to for an independent organization of volunteers to care for wounded soldiers was one of the foundations that the Geneva Convention of 1864 and the International Committee of the Red Cross (ICRC) was built upon. It has been noted that in the years following World War I, there was an ideological power struggle by national Red Cross societies over the role of the ICRC, with unsuccessful attempts to move it from its traditional role during armed conflict to the role of "assisting public health services in

2049 The Iraqi sanctions were and still remain a topic of academic and social commentary on the unconscionableness of trade sanctions. See the work by the Center for Economic and Social Rights on Iraq available online at http://cesr.org/section.php?id=23, in particular the study Unsanctioned Suffering: A Human Rights Assessment Of United Nations Sanctions On Iraq, Center for Economic and Social Rights, May 1996, available online at http://cesr.org/downloads/ Unsanctioned\%20Suffering \%201996.pdf; also see Health and Welfare in Iraq After The Gulf Crisis: An In-Depth Assessment, October 1991, available online at http://cesr.org/downloads/Health\%20and\%20Welfare $\% 20 \mathrm{in} \% 20 \mathrm{Iraq} \% 20$ after $\% 20$ the $\% 20 \mathrm{Gulf} \% 20 \mathrm{Crisis}$ \%201991.pdf, last accessed 07.06.2014.

Also see UNICEF, Iraq surveys show 'humanitarian emergency', available online at http:/www.unicef.org/newsline/99pr29.htm, 12 August 1999; Kandela, Peter, Iraq measures the health effects of sanctions, The Lancet, June 28, 1997 Vol. 349 No. 9069, p1896; Ronsmans, Carine, Oona Campbell, Mary C. Smith Fawzi, Sarah Zaidi, David H. Spodick, Omar A. Obeid and others, Sanctions against Iraq, The Lancet, January 20, 1996 Vol. 347 No. 8995, p198-200.

Garfield, Richard, The Impact of Economic Sanctions on Health and Well-being, Relief and Rehabilitation Network Paper 31, November 1999 - reviews the impact of trade embargoes on health, health services and food security drawing on data available from Cuba, Haiti and Iraq, noting that they: ...cause macroeconomic shocks and economic and social disruption on a scale that cannot be mitigated by humanitarian aid, and which affects the well-being of a population beyond their state of health.

Rieff, David, Were Sanctions Right? New York Times, July 27, 2003 available online at http://www.nytimes.com/2003/07/27/magazine/27SANCTIONS.html, last accessed 07.06.2014:

Sanctions, their opponents insist, transformed a country that in the 1980's was the envy of the developing world in terms of investments in health, education and physical infrastructure into a place where everyone (except the half-million or so members of Saddam Hussein's Baath Party and their families and cronies) was dependent on United Nations food aid, where infant mortality rates had skyrocketed, educational outcomes had collapsed and diseases that had disappeared were reappearing, sometimes at epidemic levels. 
peacetime". ${ }^{2050}$ The right to health in the context of conflict is gaining more attention recently. There is an ongoing ICRC-led project on 'Health Care in Danger' (2012-2015) focusing on how to protect health care and make health service delivery more efficient, effective and impartial during conflict and other emergency and humanitarian situations. ${ }^{2051}$ Health care in these situations is clearly cast within the access rights of the right to health by the ICRC. ${ }^{2052}$ While the ICRC and other humanitarian organizations play specific roles in the provision of health care in conflict and other emergencies, the healthcare framework of the countries facing the humanitarian crisis is also important, as a country lacking basic public services to begin with or not having sufficient public facilities during a humanitarian crisis will only exacerbate the suffering of sick and wounded persons. The attitude towards the right to health and the extent of public facilities in domestic systems is part of the current studies by the ICRC and its partners on this area; and it is something that assesses public health services and right to health even when there is no ongoing armed conflict. ${ }^{2053}$ The protection of public health services by using trade restrictions can be connected with humanitarian law, in so far as a government's responsibilities to strengthen their legal, administrative and infrastructural support for public health services is arguably considered part of their humanitarian law obligations, even in the time of peace. The use of trade sanctions would be balanced by the humanitarian law and human rights law obligations to ensure that the basic rights of the people affected are not violated. This relationship is something that could be the basis of further study.

\footnotetext{
${ }^{2050}$ Jones, Colin, Paul Weindling, Charles Rosenberg, INTERNATIONAL HEALTH ORGANISATIONS AND MOVEMENTS, 1918-1939, Cambridge University Press, 1995, p17.

2051 See the official website on the Health Care in Danger Project: http://www.icrc.org/eng/what-wedo/safeguarding-health-care/solution/2013-04-26-hcid-health-care-in-danger-project.htm, last accessed 06.07.2014.

2052 See e.g. ICRC Press Release, Yemen conference: right to health care must be respected, 18 December 2012, available online at http://www.icrc.org/eng/resources/documents/interview/2012/12-18-yemenhealth-care-in-danger-conference.htm, last accessed 07.06.2014.

2053 The author co-ordinated the preliminary Sri Lanka country report on Health Care in Danger for the ICRC in Sri Lanka and the National IHL Committee during June-December 2013.
} 


\title{
5.4. ARTICLE XIV(B) OF THE GATS: MEASURES NECESSARY TO PROTECT HUMAN, ANIMAL OR PLANT LIFE OR HEALTH
}

\author{
...for on his choice depends \\ The safety and health of this whole state, \\ And therefore must his choice be cirumscrib'd \\ Unto the voice and yielding of the body \\ Whereof he is the head.
}

From Shakespeare's' Hamlet

Article XIV(b) of the GATS is as follows:

Subject to the requirement that such measures are not applied in a manner which would constitute a means of arbitrary or unjustifiable discrimination between countries where like conditions prevail, or a disguised restriction on trade in services, nothing in this Agreement shall be construed to prevent the adoption or enforcement by any Member of measures:

(b) necessary to protect human, animal or plant life or health [emphasis added];

This provision seems to be the most direct and relevant in the GATS for the justification of measures that promote health-related policies. Fidler et al were of the view that:

From a health policy perspective, the most important exception is Article

$\mathrm{XIV}(\mathrm{b})$, the general exception for measures related to the protection of health. ${ }^{2054}$

A Member who has undertaken commitments on health could argue that since Article $\mathrm{XIV}(\mathrm{b})$ provides an exception for policies related to the protection of health, considering the role of national public health services for the protection of health, measures taken to protect such public health services would also fall within the exception. However, as can be seen, a measure has to first fall within the scope of "to protect human ... life or health" as well as to clear the hurdles of 'necessity' and the chapeau.

This section discusses the probability of success of a measure seeking to protect health services - and if any relevant role can be played by a 'human right to health approach'. As described earlier in this study, the right to health is defined in Article 25 of the UDHR and in Article 12 of the ICESCR and further interpreted by the General Comment 14. There is also a UN 'Common Understanding' of a human rights-based approach across all UN agencies for programming practices and the WHO applies this understanding for a human rights-based approach to health. ${ }^{2055}$ The WHO programme of work, including

\footnotetext{
2054 Fidler, David P., Nick Drager, Carlos Correa and Obijior Aginam, Making Commitments in Health Services under the GATS: Legal Dimensions in Blouin, Chantal, Nick Drager and Richard Smith Eds., INTERNATIONAL TRADE IN HEALTH SERVICES AND THE GATS: CURRENT ISSUES AND DEBATES, The World Bank, 2006, p261.

2055 WHO, The Work of WHO on Health and Human Rights, 2009, http://www.who.int/entity/hhr/ HHRETH_activities.pdf. For further information on the 'Common Understanding' applicable across UN agencies, see: UN, The Human Rights Based Approach to Development Cooperation Towards a Common Understanding Among UN Agencies, 2003:
} 
the agenda-setting for WHO Member States and its country cooperation strategies, are developed on the basis of this approach. Thus, there are State responsibilities as WHO Member States towards the provision of health services from a human rights-based approach at the same time as there are GATS obligations as WTO Member States. The exception in Article XIV(b) of the GATS may provide a balancing mechanism for States who have made GATS commitments in health to cover both sets of their obligations in the course of policy planning.

\subsubsection{Reviewing the Journey from GATT to GATS in light of the Right to Health}

Article XIV(b) of the GATS clearly acknowledges that there can be a conflict between trade freedoms protected by the WTO system and the sovereign rights and responsibilities of Members to regulate on health and environmental matters. The history of this type of exception in a trade agreement pre-dates the WTO and even the GATT system. Charnovitz has traced the wording "protect human, animal or plant life or health" to US bilateral trade agreements prior to the World War II. ${ }^{2056}$ These agreements pre-date the human right to health encapsulated in the UN human rights documents and human rights approach applied by UN agencies.

Article XIV(b) of the GATS is identical to Article XX (b) of the GATT 1994, and therefore, the interpretation and application of the phrase in the GATT context becomes very significant for any interpretation of the same phrase used in the GATS. Although Article XX(b) has been raised by Members in the GATT context, many of these instances did not result in dispute settlement through GATT Panels. It was understood in many situations that unilateral actions needed to be taken in crisis situations to protect life or health - and these actions therefore did not become the basis for GATT disputes. Zleptnig gives the examples of restrictions of imports during various crises such as a cholera outbreak in Peru, beef import restrictions during a foot and mouth outbreak in Europe and actions against a number of East European Countries after the Chernobyl nuclear accident. ${ }^{2057}$ When it comes to disputes which resulted in the establishment of panels, Article XX(b) of the GATT was referred to in the unadopted GATT Panel Reports USTuna (Mexico) and US-Tuna (EEC) (dolphin life and health) and in the WTO disputes of US-Gasoline, EC-Asbestos, Brazil-Retreaded Tyres and Thailand-Cigarettes(Philippines) (human life and health). While the measures were deemed to fall within the scope of Article $\mathrm{XX}(\mathrm{b})$ in these disputes, the measures were either not deemed justifiable as "necessary" measures or failed the standard of the chapeau of Article XX and thus were not considered GATT-consistent.

In the first WTO dispute which referred to Article XX(b), the Panel in US-Gasoline accepted the argument that air pollution caused by gasoline use was a risk to human, animal or plant life or health. This analysis on Article XX(b) was not reviewed by the Appellate Body, since this matter was not appealed, but the Panel's analysis on Article

https://unsdg.un.org/sites/default/files/6959The_Human_Rights_Based_Approach_to_Development_Coope ration_Towards_a_Common_Understanding_among_UN.pudf.

${ }^{2056}$ Charnovitz, S., Exploring Environmental Exceptions in GATT Article XX, 5 Journal of World Trade 1991, 37.

2057 See Zleptnig, Stefan, NON-ECONOMIC OBJECTIVES IN WTO LAW: JUSTIFICATION PROVISIONS OF GATT, GATS, SPS AND TBT AGREEMENTS, Martinus Nijhoff Publishers, 2010, p152. 
$\mathrm{XX}(\mathrm{g})$ was an issue before the Appellate Body and the interpretation of "conservation of exhaustible natural resources" was modified. However, ultimately the recourse to the exception failed on the hurdle of the chapeau. The EC-Asbestos dispute concerned a French ban on chrysotile asbestos fibres as a risk to human health, which was challenged by Canada. Article XX(b) was raised in EC-Asbestos to defend the measure and Appellate Body recognized that "[t]he value pursued is both vital and important in the highest degree. ${ }^{2058}$ But this did not play a role in the result of the dispute, and can only be considered obiter dicta, since it was found that there was no violation of Article III:4 of the GATT and therefore there was eventually no need to consider recourse to Article XX GATT. Wolfrum, commenting on the low success rate of the resort to the Article has raised the question whether this is due to the excessive severity of the Article XX(b) test; and whether either the provision or its interpretation should be amended. ${ }^{2059}$

The general view of commentators seems to be that the controversy is not about what a policy aims to protect (e.g. health), but whether that protection can be achieved by a different method than what was chosen by the responding Member (since many measures were prohibitions of imports). Most measures would succeed in the first threshold (subject matter), since what it is designed to protect is usually non-controversial, but could fail the other hurdles. In 'WTO-speak', there has to be a weighing and balancing of the trade restrictiveness of the measure, its contribution to its objective and the importance of the objective being pursued. Finally, it must be determined if there is an alternative, less trade restrictive measure available to achieve the desired protection. In coming to a decision, the nature of the particular product and the risks raised by it would also need to be assessed under the necessity test. The measure also has to clear the hurdle of the chapeau.

In Brazil-Retreaded Tyres, where the issue was an import ban on retreaded tyres, the Panel and Appellate Body accepted the health and environmental concerns raised by waste tyres (including breeding of mosquitoes that could spread dengue and malaria) and repeated that health was a value that was "vital and important in the highest degree". But the recognition of the importance of the protection of health does not conclude the analysis under an exception. In this dispute the final result was that, although the measure was justified under paragraph (b) of Article XX, it failed to be justified under the requirements of the chapeau. Fontanelli comments that when the value is human health (as in EC-Asbestos and Brazil-Retreaded Tyres), the dispute settlement bodies have generally accepted a 'zero risk' or 'maximum possible enhancement' level of protection, whereas when the issue concerns other values, the matter has been "routinely toned down". ${ }^{2060}$ Howse's evaluation of the relevant disputes is also that a government could generally seek to achieve a risk of zero and that this is a rejection of a proportionality

\footnotetext{
2058 Appellate Body Report, EC-Asbestos, para.172. Also see Footer, Mary and Saman Zia-Zarifi, ECAsbestos: The World Trade Organization on Trial for its Handling of Occupational Health and Safety Issues, Melbourne Journal of International Law, Vol. 3, 2002, p140-141

2059 Wolfrum Rudiger, in Rüdiger Wolfrum, Peter-Tobias Stoll, Anja Seibert-Fohr Eds., WTO: TECHNICAL BARRIERS AND SPS MEASURES, Max Planck Commentaries on World Trade Law, Martinus Nijhoff Publishers, 2007 at p98.

${ }^{2060}$ Fontanelli, Filippo, Necessity Killed the GATT - Art XX GATT and the Misleading Rhetoric about 'Weighing and Balancing', European Journal of Legal Studies, Volume 5, Issue 2, 2012/13, p36-56, comparing EC-Asbestos and Brazil-Retreaded Tyres with Korea - Various Measures on Beef and Dominican Republic-Import and Sale of Cigarettes, as well as the SPS cases of Japan-Apples and Australia-Apples.
} 
notion in the evaluation of the relationship between means and ends. ${ }^{2061}$ Michael Min Du has commented generally that decisions under Article XX have "demonstrated inconsistencies" as to when WTO Members' right to set any level of protection that they deem appropriate will be respected. ${ }^{2062}$ However, Van den Bossche and Prevost also emphasize that in all cases (not just human health) the level of protection remains the discretion of the regulating Member under WTO law, and that what is challenged is whether the measure used to achieve the chosen level of protection complies with the necessity test. ${ }^{2063}$

It could be assumed that the importance of the value being protected (e.g. human health) would play a part in the weighing and balancing aspect; and that the more vital the value, and the greater the contribution of the measure to its protection, the more likely it is that a very trade restrictive measure will be justified. However, there is no specific acknowledgment of a greater importance of human health and the related levels of protection for human health, as compared to the level of protection for any other interests or values. The GATT disputes which dealt with matters of human health should be looked at in further detail to assess the approach of the WTO dispute settlement bodies to human health and the right to health.

The first dispute which will be considered is Thailand-Cigarettes (Philippines), which broadly concerned the serious health risks of cigarette smoking, a public health matter. Cigarette smoking is an issue that can ultimately be a burden to the health services system and national economy, as smoking has clear causal connections with a number of serious diseases which then require healthcare intervention. ${ }^{2064}$ It has been repeatedly pointed out that tobacco consumption is one of leading causes of preventable deaths - however, it also is a major industry, source of jobs and revenue, and treating tobacco-related ill health can be a source of income in a profit-oriented healthcare system. As a result of the increasing scientific knowledge on the harm caused by tobacco use, global rules have been negotiated by States for its control, the most important being the 2005 WHO Framework Convention on Tobacco Control (FCTC). This was the first time the WHO has used its constitutional authority under Article 19 of the WHO Constitution, to develop a legal instrument on global population health. ${ }^{2065}$ As of 2019 , there are a 181 State

${ }^{2061}$ Howse Robert, The World Trade Organization 20 Years On: Global Governance by Judiciary, EJIL (2016), Vol. 27 No. 1, 9-77, p61.

2062 Michael Ming Du, Autonomy in Setting Appropriate Level of Protection under the WTO Law: Rhetoric or Reality?, Journal of International Economic Law, Volume 13, Issue 4, December 2010, Pages $1077-$ 1102.

2063 Van den Bossche, Peter and Denise Prévost, ESSENTIALS OF WTO LAW, Cambridge University Press, 2016, p94.

2064 See Shibuya, Kenji, et al, WHO Framework Convention on Tobacco Control: development of an evidence based global public health treaty, BMJ, 19 July 2003; 327(7407): 154-157. Taylor A.L. and D.W. Bettcher, WHO Framework Convention on Tobacco Control: a global "good" for public health, Bulletin of the World Health Organization, 2000;78: 920-9.

2065 The FCTC was adopted by consensus by the WHO's 192 member states on May 21, 2003, been signed by 168 states and is now binding for the 181 States that have also ratified it. For the background and history of the FCTC see Taylor A.L., Making the World Health Organization work: a legal framework for universal access to the conditions for health, American Journal of Law and Medicine,1992;18:301-346; Taylor A.L., An international regulatory strategy for global tobacco control, Yale Journal of International Law, 1996;21(2):257-304; Roemer, Ruth, Allyn Taylor and J. Lariviere, Origins of the WHO Framework Convention on Tobacco Control, Am J Public Health. 2005 June; 95(6): 936-938. See further, Eckhardt J, Holden C, Callard CD, Tobacco control and the World Trade Organization: mapping member states' positions after the Framework Convention on Tobacco Control, published online 19 November 2015. 
parties to the FCTC and a Protocol to Eliminate Illicit Trade in Tobacco Products has successfully gathered the 40 ratifications needed for its entry into force. ${ }^{2066}$

Earlier in 2000, the CESCR General Comment on the Right to Health had identified that States are under obligation to discourage the use of tobacco according to Article 12.2 (b) of the ICESCR (the right to healthy natural and workplace environments). ${ }^{2067}$ The General Comment also specified that "the failure to discourage production, marketing and consumption of tobacco" was a violation of the of the obligation to protect (under a State's obligation to take "all necessary measures to safeguard persons within their jurisdiction from infringements of the right to health by third parties"). ${ }^{2068}$ The CESCR (Committee) has explicitly welcomed ratification of the FCTC and linked the obligations under it to the obligations under Article 12 of the ICESCR in the periodic review of some State party reports. ${ }^{2069}$ The CEDAW Committee has also commented on tobacco control in light of the obligation to implement Article 12 of the CEDAW (women's right to health) in certain State party periodic reviews. ${ }^{2070}$ It is also well documented that there is a link between human rights and the tobacco control discourse which is used to support regulatory measures and judicial enforcement of tobacco control. ${ }^{2071}$ Cabrera and Gostin convincingly argue that tobacco control measures in the FCTC and human rights are mutually reinforcing and decry the "weakness and duplicity" of the tobacco industry efforts to use human rights rhetoric as a resistance to tobacco control laws and regulations. ${ }^{2072}$

States around the world have resorted to various unilateral measures to implement the obligation under both the FCTC and the ICESCR to reduce the supply and demand for tobacco products, including tobacco taxes, bans or restrictions on advertising, health warnings on packaging, product regulations and restrictions on use of tobacco in public places. ${ }^{2073}$ The reasons for adopting unilateral measures with regard to tobacco control are

${ }^{2066}$ WHO, 2018 GLOBAL PROGRESS REPORT on Implementation of the WHO Framework Convention on Tobacco Control, 2018, available online at https://www.who.int/fctc/reporting/WHO-FCTC-2018 global_progress_report.pdf.

${ }^{2067}$ UN, CESCR, General Comment No. 14, The Right to The Highest Attainable Standard of Health, E/C.12/2000/4., $11^{\text {th }}$ August 2000, para.15.

2068 Ibid., (General Comment No. 14), para.51.

2069 CESCR (Committee on Economic, Social and Cultural Rights), Concluding Observations: Brazil, E/C.12/BRA/CO/2, 12 June 2009; CESCR, Concluding observations on the fourth periodic report of Argentina E/C.12/ARG/CO/4, 1 November 2018, para.51 and 52. See also Cabrera, Oscar A., and Alejandro Madrazo, Human rights as a tool for tobacco control in Latin America, Salud Pública De México 52 (2010): S288-S297.

${ }^{2070}$ Committee on the Elimination of Discrimination against Women, Concluding Observations on the seventh periodic report of Argentina, CEDAW/C/ARG/CO/7, 25 November 2016.

${ }^{2071}$ See Reubi, who gives an overview of 10 years of documented linkage made by actors in what he terms "the human rights and tobacco control community" (Reubi, David, Constructing Tobacco Control as a Human Rights Issue: Smoking, Lawyers and the Judicialization of the right to Health in Mold, Alex and David Reubi Eds., ASSEMBLING HEALTH RIGHTS IN GLOBAL CONTEXT: GENEALOGIES AND ANTHROPOLOGIES, Routledge, 2013. See also: Cabrera, Oscar A., and Lawrence O. Gostin, Human rights and the framework convention on tobacco control: mutually reinforcing systems, International Journal of Law in Context, 7.3 (2011): 285-303; Dresler, Carolyn, Harry Lando, Nick Schneider, and Hitakshi Sehgal, Human rights-based approach to tobacco control, Tobacco Control 21, no. 2 (2012): 208211.

${ }^{2072}$ Cabrera, Oscar, A., and Lawrence O. Gostin, Global Tobacco Control: A Vital Component of the Right to Health in Zuniga, José M., Stephen P. Marks and Lawrence O. Gostin Eds., ADVANCING THE HUMAN RIGHT TO HEALTH, Oxford University Press, 2013, 261-274, p262.

2073 Mackey, Tim K., Bryan A. Liang, and Thomas E. Novotny, Evolution of Tobacco Labelling and Packaging: International Legal Considerations and Health Governance, American Journal of Public 
correlated with the resistance against the pressures of the powerful tobacco lobby (sometimes acting through other Member governments) which also acts as a dissuasion for engaging in international-level negotiations that could result in watered-down enforcement mechanisms. Zleptnig notes that the Framework Convention emphasises cooperation rather than unilateral measures, and that this may have implications for a WTO dispute, when such disputes come before a panel or the Appellate Body. ${ }^{2074}$ However, the Appellate Body has recognized that unilaterally prescribed measures may be "to some degree, be a common aspect of measures falling within the scope of one or another of the exceptions (a) to (j) of Article XX [of the GAT]". ${ }^{2075}$ Governments often find themselves struggling to actually implement the required policies and measures, since the powerful tobacco lobby launches both national and international legal challenges against such restrictions, including under the WTO and other trade and investment agreements. ${ }^{2076}$ Eckhard et al, in their study on tobacco-related disputes in the WTO concluded that recent opposition within the WTO to stronger tobacco regulations coming from developing countries is consistent with a relative shift of transnational tobacco companies' lobbying efforts from developed to developing countries. ${ }^{2077}$

The measures taken by Thailand in the context of the Thailand-Cigarettes (Philippines) dispute were found discriminatory against foreign tobacco products in terms of higher taxes than local products, additional administrative requirements and violation of obligations concerning customs valuation. The actual extent to which the Thai measures were based on health protection is doubtful, especially since there is scant reference to public health objectives in the Panel report. There were a few statements made by Thailand which were included in the Panel report, that the Thai Tobacco Monopoly was a government revenue collection entity which monitors Thailand's public health objectives and that the cigarette taxes fed into a health promotion fund. ${ }^{2078}$ The Philippines identified Thailand's health tax as being implemented under the Health Promotion and Foundation Act, B.E. 2544 (2001) and added that the Thai policies and regulations were not at issue in the dispute, including any health related measures on tobacco labelling and advertising

Health 103.4 (2013): e39-e43. PMC. Web. 20 Mar. 2017; Hiilamo, Heikki, Eric Crosbie, and Stanton A. Glantz, The evolution of health warning labels on cigarette packs: the role of precedents, and tobacco industry strategies to block diffusion, Tobacco control 23.1 (2014).

${ }^{2074}$ Zleptnig, Stefan, NON-ECONOMIC OBJECTIVES IN WTO LAW: JUSTIFICATION PROVISIONS OF GATT, GATS, SPS AND TBT AGREEMENTS, Nijhoff International Trade Law Series, 2010, p157.

2075 Appellate Body Report, US-Shrimp, footnote 24, para. 121. Recalled by the Appellate Body in USShrimp (Article 21.5 - Malaysia), para.137.

2076 See Dominican Republic-Import and Sale of Cigarettes, where the Appellate Body found that the stamp requirement imposed on cigarettes by the Dominican Republic is not justified under the exception of Article XX(d) of the GATT 1994 - and the Appellate Body Report, Australia-Tobacco Plain Packaging, para.7.396, where Article 11 and Article 13 of the FCTC Guidelines, which Australia claimed constituted a 'standard' for tobacco plain packaging were not accepted by the Appellate Body as constituting "a 'document' containing a 'standard' within the meaning of the definition of 'standard' in Annex 1.2 of the TBT Agreement".

See also Ottersen, O.P. J. Dasgupta J, C. Blouin et al, The Political Origins of Health Inequity: Prospects for Change (Final Report of The Lancet-University of Oslo Commission on Global Governance for Health), The Lancet, Volume 382, Issue 9917, 15 February 2014

2077 Eckhardt J., Holden C., Callard C.D., Tobacco control and the World Trade Organization: mapping member states' positions after the framework convention on tobacco control, Tobacco Control 2016; 25: 692-698.

${ }^{2078}$ See Panel Report, Thailand-Cigarettes (Philippines), paras.4.57, 7.465, 7.640. Also, at para.7.915 of the Panel report, reference is made to the fact that "TTM's activities are consistent with Thai public health policy (TTM Board includes an individual of the Ministry of Health" (citing at footnote 1564: "Thailand's second written submission, para. 200, footnote 175; response to Panel question No. 75.”). 
restrictions; only that the manner health taxes were administered failed to be uniform, reasonable and impartial. ${ }^{2079}$ There was no mention of public health objectives in the Appellate Body report. However, behind the scenes, the role of the tobacco company Phillip Morris, which had made a considerable investment in the Philippines and was targeting the Thai market can be noted. ${ }^{2080}$

The role of tobacco companies is also clear in the WTO disputes brought against the Australian plain packaging legislation for tobacco products by Honduras, the Dominican Republic, Cuba and Indonesia (and Ukraine which later suspended its complaint). There was also a case brought jointly by British American Tobacco, Imperial Tobacco, Japan Tobacco and Philip Morris in the High Court of Australia and an investment challenge by Philip Morris Asia under the Hong Kong-Australia bilateral investment treaty on the same plain packaging legislation. ${ }^{2081}$ The media reports of May 2017 stated that a confidential interim document given to the parties suggests that Australia has been deemed as having taken a legitimate public health measure. ${ }^{2082}$ The WTO Panel report, Australia-Tobacco Plain Packaging, was made public in June 2018 and did not find Australia's measures concerning trademarks and geographical indications and other plain packing requirements for sale of tobacco products to be in violation of its WTO TRIPS obligations. It is relevant that Australia submitted amicus curiae submissions provided by the World Health Organization (WHO) and the WHO Framework Convention on Tobacco Control (FCTC) Secretariat, and the Panel had invited the WHO and the FCTC Secretariat to provide factual information concerning the FCTC provisions relevant for the dispute. The Panel did not find it necessary in its analysis to address Australia's arguments that the measures are justified under Article XX(b) of the GATT 1994, for the purposes of coming to its conclusions. However, the Panel stated that Article 8.1 and Article 20 of the TRIPS express the intention of drafters of the TRIPS Agreement to preserve the right and ability for WTO Members to pursue certain legitimate societal interests and adopt measures for their protection, and specifically identified public health as such a legitimate societal interest. ${ }^{2083}$

It is important to point out that the GATT/goods-related disputes of Thailand-Cigarettes (Philippines), EC-Asbestos, EC-Hormones and Brazil-Retreaded Tyres all referred to public health and health in as a value or objective but avoided the terminology of rights and did not refer to a right to health. This is also true of EC-Hormones, an SPS dispute and US-Clove Cigarettes, a TBT dispute and Australia-Tobacco Plain Packaging, a TBT and TRIPS dispute - which concern measures addressing risks to health and public health concerns. In contrast, within domestic jurisdictions, health can be directly identified as a right in legislation or in constitutional fundamental rights chapters; or it could be inferred through judicial interpretation, as a part of other rights (such as right to equality or right

\footnotetext{
${ }^{2079}$ Panel Report, Thailand-Cigarettes (Philippines), paras.2.2(d) and 4.3 and 3.1(d).

${ }^{2080}$ See Appellate Body Upholds Ruling against Thailand in Philippines Cigarette Dispute, Bridges Volume 15 - Number 23, 22 June 2011, available online at http://www.ictsd.org/bridges-news/bridges/news/ appellate-body-upholds-ruling-against-thailand-in-philippines-cigarette - referring to the Thai Tobacco Monopoly accounting for 80 percent of the Thai tobacco market, whereas Philip Morris Philippines Manufacturing Inc. supplied $90 \%$ of the Philippine market and had made considerable investments in a Philippine production factory in 2000.

2081 WHO, FCTC Secretariat, Australia's plain packaging laws at the WTO, http://untobaccocontrol.org /kh/legal-challenges/australias-plain-packaging-laws-wto/.

${ }^{2082}$ Miles, Tom and Martine Geller, Australia wins landmark WTO tobacco packaging case, Bloomberg, Friday May $5^{\text {th }}$ 2017, http://www.reuters.com/article/us-wto-tobacco-australia-idUSKBN1801S9.

${ }^{2083}$ Panel report, Australia-Tobacco Plain Packaging, paras.7.2404, 7.2429 and 7.2504.
} 
to life). Thus, it is possible that certain domestic courts could have a very different task of balancing conflicting interests, since the issues are weighted differently in the domestic law compared with the WTO dispute settlement context. If health is given weight as a legal right of each individual human being within a domestic legal system, which the State has an obligation to protect, that can more effectively balance the States' conflicting obligations under trade law, than if it were merely a value that could be taken into account. The following paragraphs highlight the outcomes of such a rights-based approach in domestic legal systems, and how it can guide State policy on health and health financing.

There are many domestic jurisdictions with constitutional provisions on the right to health - and this often translates into the ability to take tangible steps to improve health for the populations concerned. ${ }^{2084}$ In 2006 Hogerzeil et al analyzed 71 court cases from 12 countries and concluded that in 59 cases on access to essential medicines was enforced through the courts as part of the right to health. ${ }^{2085}$ A well-known example is the South African case of Minister of Health v Treatment Action Campaign (2002), ${ }^{2086}$ a successful constitutional challenge to restrictions on the provision of anti-retroviral drugs to HIV positive pregnant women by public health facilities; an outcome which is estimated to have saved tens of thousands of lives by preventing mother-to-child transmission of HIV. Sungkyoung et al in 2018 examined the constitutional provisions on the right to health in the Western Pacific region countries and concluded that countries without clear provisions usually recorded low achievement scores with regard to health. ${ }^{2087}$ However, it can be commented generally that countries without constitutional protections, but still having high achievement, would still need to reconsider their lack of constitutional protections in light of having protection against retrogressive measures. ${ }^{2088}$ For example, although embedded in national policy, neither the United Kingdom nor Canada have a constitutional right to health, only statutes providing for a national health service. In 2012 the governments of both countries took steps that were considered detrimental to the right to health. The impact of the UK Health and Social Care Act 2012 on the NHS is mentioned at other points in this study. The Order Respecting the Interim Federal Health Program, SI/2012-26 of the Canadian Federal Government has apparently 'de-listed' asylum seekers from certain countries from healthcare services coverage. ${ }^{2089}$

Paul Hunt, former UN Rapporteur on the Right to Health, has referred to the importance of "transformative constitutionalism", especially in Latin America and South Africa, which explicitly included constitutionally justiciable right to health and resulted in case

${ }^{2084}$ Kinney E., and B. Clark, Provisions for health and health care in the constitutions of the countries of the world, Cornell Int Law J 2004; 37: 285-355. See also UN Economic and Social Council, Commission on Human Rights, Report of the Special Rapporteur Paul Hunt, The right of everyone to the enjoyment of the highest attainable standard of physical and mental health, Addendum, Mission to the World Trade Organization, E/CN.4/2004/49/Add.1, 1 March 2004, para.15.

${ }^{2085}$ Hogerzeil H.V., Samson M, Vidal Casanovas J, Rahmani L., Access to essential medicines as part of the fulfilment of the right to health - is it enforceable through the courts?, Lancet 2006; 368: 305-1.

${ }^{2086}$ Constitutional Court of South Africa, Minister of Health v Treatment Action Campaign, (2002) 5 SA 721 (CC).

2087 Sungkyoung Choi, Sanghyun Park, So Yoon Kim, A Comparative Study on the Constitutional Right to Health in the Western Pacific Region Countries, Asia Pacific Journal on Public health, Vol 30, Issue 5, 2018.

${ }^{2088}$ Hunt P., Interpreting the International Right to Health in a Human Rights-Based Approach to Health, Health Hum Rights. 2016;18(2):109-130.

2089 Flood, Colleen, and Aeyal Gross, eds., THE RIGHT TO HEALTH AT THE PUBLIC/PRIVATE DIVIDE: A GLOBAL COMPARATIVE STUDY, Cambridge University Press, 2014, p458. 
law, as a way for human rights to challenge the detrimental impact of neoliberal economic policies on health-related services. ${ }^{2090}$ Even University of Chicago Professor Cass Sunstein who was originally a key constitutional theorist standing against the constitutionalization of economic and social rights, arguing that this would have a detrimental impact on developing market-based economies and should be beyond the powers of the judiciary, ${ }^{2091}$ slightly altered his position on the non-justiciability of such rights following the decisions of the experience of the South African Constitutional Court. $^{2092}$

There are increasing numbers of cases in domestic jurisdictions assessing the nature of the State's obligation to provide health services, usually under the relevant constitutional provisions on the right to health or right to life. ${ }^{2093}$ In an example from Uganda in 2015, the civil society group Centre for Health, Human Rights and Development (CEHURD) and others argued that the non-provision or inadequate provision of basic indispensable maternal health-related commodities and services in government health facilities is inconsistent with the Ugandan Constitution and a violation of its right to health obligations. $^{2094}$ The Constitutional Court upheld a preliminary objection on the courts incapacity to interpret the matter before it because of the 'political question doctrine', but the Ugandan Supreme Court overturned this decision, and held that it was the duty of the court "to interpret what amounts to 'taking all practical measures' to ensure the provision of basic medical services". ${ }^{2095}$ Health rights activists also initiated a similar case in Nepal on reproductive health services for women, on the basis that under Article 20(2) of the Interim Constitution of Nepal 2063 (2017), every woman in Nepal had the fundamental

\footnotetext{
${ }^{2090}$ Hunt P., Interpreting the International Right to Health in a Human Rights-Based Approach to Health, Health Hum. Rights 2016;18(2):109-130.

2091 Sunstein, Cass R., Against positive rights: Why Social and economic rights Don't belong in the Constitutions of Post-Communist Europe, E. Eur. Const. Rev. 2 1993: 35.

Sunstein was supported by others such as Seymour J. Rubin, Helen Hershkoff and Frank B. Cross (Rubin, Seymour J., Economic and Social Human Rights and the New International Economic Order, Am. UJ Int'l L. \& Pol'y1 1986, 67; Hershkoff, Helen, Positive rights and state constitutions: The limits of federal rationality review, Harv. L. Rev. 112, 1998, 1131; Cross, Frank B., The error of positive rights, UCLA L. Rev. 48 (2000): 857).

Mark Tushnet and Herman Schwartz challenged this neo-liberal vision (Schwartz, Herman, In defense of aiming high: why economic and social rights do not belong in Post-Communist Constitutions of Europe, E. Eur. Const. Rev. 25 1993; Schwartz, Herman, Do economic and social rights belong in a constitution?, Am. UJ Int'l L. \& Pol'y 10 (1994): 1233; Tushnet, Mark, Civil Rights and Social Rights: The Future of the Reconstruction Amendments, 1992, 25 Loy. L.A. L. REV. 1207, 1213-18; Tushnet, Mark, Social welfare rights and the forms of judicial review, Tex. L. Rev. 82, 200: 1895; Tushnet, Mark, State Action, Social Welfare Rights, and the Judicial Role: Some Comparative Observations, Chi. J. Int'l L.3, 2002, 435).

2092 Sunstein, Cass R., Social and Economic Rights? Lessons from South Africa, (John M. Olin Program in Law and Economics Working Paper No. 124, (2001) and Const. F. 11 (1999): 123. The landmark case in this context is Soobramooney v. Minister of Health Kwa Zulu Natal (1998 (1) SA 765 (CC) a decision of the South African Constitutional Court, which looked at the State obligations under section 27(3) of the Constitution of South Africa, guaranteeing the right to emergency medical treatment, in light of budgetary constraints of the State authorities.

${ }^{2093}$ Cases can also be based on domestic statutes. For detailed country studies see generally: Zuniga, Jose, M., Stephen P. Marks and Lawrence O. Gostin, ADVANCING THE HUMAN RIGHT TO HEALTH, Oxford University Press, 2013; Flood, Colleen, and Aeyal Gross, THE RIGHT TO HEALTH AT THE PUBLIC/PRIVATE DIVIDE: A GLOBAL COMPARATIVE STUDY, Cambridge University Press, 2014. ${ }^{2094}$ Centre for Health, Human Rights and Development and Three Others v. Attorney General of Uganda, Supreme Court of Uganda at Kampala, 2015 - Constitutional Appeal No. 01 of 2013.

2095 Ibid., p22-23.
} 
right to reproductive health. ${ }^{2096}$ The Supreme Court of Nepal emphasized that the realization of economic and social rights is protected under the constitution and under international human rights law, and requires positive action by the State (including physical facilities and legal, institutional, procedural and result-oriented infrastructure) and therefore ordered the Government and several government agencies to hold a consultation, draft a bill, and prepare social programmes aimed at addressing the issue raised in the case (effective health services addressing uterine prolapse).

If right to health can be interpreted through the lens of another right, such as the right to life, then it can also be read into areas where there was no specific mention of the right to health. An example that was highlighted in one of the Reports of the Special Rapporteur on the Right to Health was the case before the Supreme Court of Bangladesh; Dr. Mohiuddin Farooque v. Bangladesh (1996). In this case the Court stated that the right to life under Article 32 of the Constitution of Bangladesh of 1972 was violated when authorities did not take effective action with regard to imported milk powder products which were allegedly contaminated with radioactive material. ${ }^{2097}$ The Court also linked the right to life and the State responsibility to improve the quality of health and nutrition under Article 18 of the Constitution of Bangladesh, interpreting the right to life to include, among others, the "protection of health and normal longevity of an ordinary human being". ${ }^{2098}$ The Indian Supreme Court also expanded the interpretation of the right to life as guaranteed under Article 21 of the Constitution of India in a case reported in 1996, cited as: Paschim Banga Khet Mazdoor Samity v State of West Bengal. ${ }^{2099}$ This case was specifically on health services and the Supreme Court of India declared that denial of emergency medical treatment necessary to preserve human life in governmentowned hospitals is a violation of the right to life. ${ }^{2100}$ Since the facts were that the petitioner had been refused emergency treatment at six successive State hospitals because the hospitals claimed inadequate medical facilities (for the required neuro surgery) or lack of a vacant hospital bed, the Supreme Court also directed the government authorities to develop a primary health care policy to address such problems. It was also pointed out that as there is a joint obligation of the Centre as well as the States to provide medical services, it was expected that the Center would "render the necessary assistance in the improvement of the medical services in the country on those lines" and that the case report would be widely shared among health authorities of all the Indian states. ${ }^{2101}$ Another example linking right to life with right to health in the context of health services can be found in the Indian case of Sandesh Bansal v. Union of India (2012): ${ }^{2102}$ which was concerned with the high Maternal Mortality Ratio in Madhya Pradesh. In this case, which was decided by the High Court of Madhya Pradesh (Jabalpur), it was stated by the

\footnotetext{
2096 Advocate Prakash Mani Sharma v. Government of Nepal and Others, Writ No.064 WO 0230 (SC), 1999, paras.20 and 22.

${ }^{2097}$ Dr. Mohiuddin Farooque v. Bangladesh, 48 DLR, 1996, HCD 438. Dr. Farooque brought the case to Court alleging failure of the Bangladeshi authorities to take action. The case was cited in the following report: UNGA, Human Rights Council, Implementation of General Assembly Resolution 60/251 Of 15 March 2006 , Report of the Special Rapporteur on the right of everyone to the enjoyment of the highest attainable standard of physical and mental health, Paul Hunt, A/HRC/4/28, 17 January 2007, para.75. ${ }^{2098}$ Ibid. (Farooque).

${ }^{2099}$ Paschim Banga Khet Mazdoor Samity and others $v$ State of West Bengaland another, (1996) AIR SC 2426.

${ }^{2100}$ Ibid. (Paschim...), para.9.

${ }^{2101}$ Ibid. (Paschim...), para.16-19.

2102 Sandesh Bansal and others v. Union of India and others, Writ Petition No. 9061/2008, decided on 06 February 2012.
} 
court that the government of the State of Madhya Pradesh was under legal obligation to implement the relevant national policy measures (the National Rural Health Mission, 2005) for improving overall health services provision and providing adequate public health facilities for pregnant woman and mothers in order to protect their right to life.

It is interesting to note that in international human rights law, the "inherent right to life" is included as Article 6 the ICCPR and is not found in the ICESCR (where the right to health is found as Article 12). However, this differentiation has not been relevant for expansive interpretations of the right to life in domestic constitutional law, as can be seen from the above examples. Furthermore, in recent years, the differentiations between the rights of the two Covenants have been gradually eroded and the rights in the Covenants have become more interconnected due to the interpretation of the obligations by human rights bodies. The Human Rights Committee issued a new General Comment No.36 (2018) on the right to life, (which replaced the earlier General Comments No. 6 (1982) and No.14 (1984)), wherein it was clearly declared that the right to life "should not be interpreted narrowly". ${ }^{2103}$ General Comment No.36 also specifically acknowledged the role of the State in taking measures for healthcare and health services, stating that:

The duty to protect life also implies that States parties should take appropriate measures to address the general conditions in society that may give rise to direct threats to life or prevent individuals from enjoying their right to life with dignity. ... The measures called for addressing adequate conditions for protecting the right to life include, where necessary, measures designed to ensure access without delay by individuals to essential goods and services such as ...health-care... bolstering of effective emergency health services... States parties should also develop strategic plans for advancing the enjoyment of the right to life, which may comprise measures... for improving access to medical examinations and treatments designed to reduce maternal and infant mortality [emphasis added]. ${ }^{2104}$

The Human Rights Committee in 2018 also addressed the relationship between the right to life and the right to health in an opinion given under the individual complaints procedure of the ICCPR (Toussaint $v$. Canada), stating that:

....as a minimum, States parties have the obligation to provide access to existing health-care services that are reasonably available and accessible when lack of access to the health care would expose a person to a reasonably foreseeable risk that can result in loss of life. ${ }^{2105}$

It is significant that this individual complaint was brought against Canada, which has a good public health system, but the key issue was the denial of access to health insurance and health care to an irregular migrant, ${ }^{2106}$ highlighting the progress made in terms of

\footnotetext{
${ }^{2103}$ Human Rights Committee, General Comment No. 36 (2018) on Article 6 of the International Covenant on Civil and Political Rights, on the right to life, CCPR/C/GC/36, 30 October 2018, para.3.

${ }^{2104}$ Ibid., (General Comment No.36), para.26. The General Comment also identified the provision of reproductive health services, particularly safe access and aftercare relating to voluntary termination of pregnancy, and the right to health of persons in detention, as part of the right to life obligations of the State in paras. 8 and 25. These two aspects are also right to health-related expansions of the scope of the right to life.

2105 HRC, Views adopted by the Committee under Article 5 (4) of the Optional Protocol, concerning communication No. 2348/2014 (Toussaint v. Canada), CCPR/C/123/D/2348/2014, 30 August 2018, para.11.3.

2106 The Committee concluded that the denial of health-care coverage to an undocumented migrant under the Interim Federal Health Program for immigrants violated the migrant's right to life (Article 6 of the
} 
non-discrimination in the human rights regime. In terms of Article XIV(b) of the GATS, 'human health' is already in the provision, but the connotation of 'human rights' and the States wide-ranging obligations under the international human rights regime to "address the general conditions in society" that could prevent a right to life with dignity and to implement measures relating to health services, is of course, absent.

Judging by the trends of the past two decades of WTO law, the panels and Appellate Body are very unlikely to infer through their interpretation of WTO law, a new right (especially a human right), which is not explicitly included in the text, nor an activist expansion of an existing right, in the manner done by the human rights bodies or domestic courts. Furthermore, such a step can be seen as contradictory to Article 3.2 of the DSU, since it does not "preserve" the rights and obligations of Members, but could be seen as extending them much further from what was assumed at the time the text was agreed upon. If there was a trade dispute on imports of contaminated products, 'health as value' in exceptions provisions - "necessary to protect human...life or health" - could play a comparable role in WTO law as the right to life and/or right to health would play in domestic jurisdictions, but the prioritization, the weight given in each circumstance, is clearly different.

As a final point in this section, it would be good to assess the extent to which Article XX of the GATT and Article XIV of the GATS are similar with regard to the exception on human, animal or plant life or health. The interpretive path taken by any Panel or the Appellate Body in possible future disputes wherein this provision is raised needs to take into account the fact that the GATT also has an additional provision, Article $X X(g)$ "relating to the conservation of exhaustible natural resources". The relationship between these two paragraphs has been raised in the context of environmental protection measures and is something that is not available to a dispute under the GATS. The suggestion is that GATS measures on human life and health may be similar to the GATT and therefore, similar analysis as in GATT disputes could be applied. However, in the case of protection of the environment, it seems that the protection under the GATS may be narrower because of the absence of a provision equivalent to Article XX(g) GATT. Members would need to argue that their conservation efforts are either Article XIV(a) issues under public morals or a combination of Article XIV(a) and Article XIV(b) on human, animal, plant life or health. Thus, it may be the case that restrictions on services trade that are based on environmental concerns may be more difficult to maintain. This means that there may be a need for a specific exception for environmental protection and climate change mitigation measures to be introduced into the GATS, in order for Members to be encouraged to take measures promoting matters such as services connected with renewable energy, carbon emission reduction and other natural resources uses that can have services implications.

It may seem at first that these environmental matters are not necessarily connected with right to health and public health services; however, that issue is being assessed now in light of the forecasts of health impacts of environmental damage and climate change and the responses that are required. For example, Frumkin et al, representing institutions such as the National Center for Environmental Health, US Centers for Disease Control and Prevention, proposed in 2008 that climate change impacts on human health require

ICCPR) and reminded Canada of its obligations, including by "reviewing its national legislation to ensure that irregular migrants enjoyed access to essential health care to prevent a reasonably foreseeable risk that could result in loss of life" (Ibid., Toussaint v. Canada, para.13) 
effective public health responses through essential public health services. ${ }^{2107}$ The Lancet and University College London Institute for Global Health Commission Report in 2009 on Managing the health effects of climate change cites Frumkin et al and discusses the policy implications of climate change for health and other services sectors, including both adaptation and mitigation measures, as well as a achieving development objectives and MDGs. ${ }^{2108}$ The Report also notes that "The effects of climate change on health are inextricably linked to global development policy and concerns for health equity". Thus, it is difficult to discuss the role of public health services while ignoring wider issues in services provision, when the health impacts created by environmental damage eventually need responses and adaptation from the public health services, especially in the cases of the most socially marginalized who would bear the brunt of these impacts.

The fact that these environmental and health concerns are also framed as human rights issues should not be ignored either. In 2012, the UN Human Rights Council established a mandate on human rights and the environment and appointed an 'independent expert' (later named as 'special rapporteur') on 'human rights obligations relating to the enjoyment of a safe, clean, healthy and sustainable environment". ${ }^{2109}$ A number of resolutions on the topic were passed by the Human Rights Council, the most recent in $2016{ }^{2110}$ The UNFCCC Secretariat has also noted the human rights implications of climate change and has requested input from the OHCHR, particularly in relation to health and social welfare systems, which was received by them in $2016 .{ }^{2111}$

The Appellate Body decision in Canada-Renewable Energy/Canada-Feed-in Tariff Program also brings to mind that there may be a need for a specific exception to be introduced to the GATS that covers resource conservation and environmental protection measures for services. In this dispute, which related to obligations under GATT 1994, SCM and TRIMS, the complainants, the EU and Japan, were against what they identified as 'protectionist' measures in a booming renewable energy industry and Canada was unable to justify their measures. It is no doubt an area where the balancing line between public policy and trade rules needs to be carefully drawn. An additional specific exception for both goods and services may be useful in this context. Moreover, there has been no specific pronouncement so far on whether a Member can or cannot take measures, not merely extraterritorially, but with regard to 'global commons' issues such as environmental protection and climate change mitigation, which can ultimately have negative impacts on human health, and require responses and adaptation from health services. The Appellate Body in US-Shrimp did not settle this issue, since there was

${ }^{2107}$ Frumkin, H., Jeremy Hess, George Luber, Josephine Malilay, Michael McGeehin, Climate Change: The Public Health Response, American Journal of Public Health 98, no. 3 (March 1, 2008): pp. 435-445.

${ }^{2108}$ Costello, Anthony, et al., Managing the health effects of climate change, The Lancet 373.9676 (2009): 1693-1733.

${ }^{2109}$ See further for activities. reports and concept notes of the special rapporteur, Mr. John Knox: http://www.ohchr.org/EN/Issues/Environment/SREnvironment/Pages/SRenvironmentIndex.aspxhttp://www .ohchr.org/EN/Issues/Environment/SREnvironment/Pages/Activities.aspx.

See further the documents available at http://ap.ohchr.org/documents/dpage_e.aspx?m=199, including the Reports of the Special Rapporteur.

${ }^{2110}$ See e.g. UN Human Rights Council Resolution, Human rights and climate change, A/HRC/RES/32/33 on 18 July 2016.

2111 See Office of the United Nations High Commissioner for Human Rights, Response to UNFCCC Secretariat request for submissions on: Nairobi Work Programme on impacts, vulnerability and adaptation to climate change - health impacts, including occupational health, safety and social protectionFCCC/SBSTA/2016/2, para 15(a) (i), 29 August 2016, available online at https://unfccc.int/ files/ parties_observers/submissions_from_observers/application/pdf/676.pdf. 
discussion of whether the migratory turtles could be found for part of the time in US waters. $^{2112}$

Article XIV(b) of the GATS has not been invoked in a dispute context so far, although there was a reference to health concerns in US-Gambling in the context of "pathological gambling" or addiction as a health concern. The US raised the health issue in its submissions, but did not cite XIV(b) but seemed to raise it generally as another reason to protect society from the ill-effects of gambling and betting. Antigua challenged the Panel including the health concerns under the Article XIV(a) analysis, when it was not explicitly raised in the context of XIV(a) arguments by the US. The Appellate Body did not think this was a sufficient reason to deny the Panel the right to refer to health concerns and stated that it could be brought in from the overall US submissions. ${ }^{2113}$ There is a passing reference in the US submission to the Harvard Medical School's Division on Addictive Studies and the American Psychiatric Association APA Advisory on Internet Gambling (2001), that is cited by the Panel in its report. These seem to be seen as sufficient evidence of a health risk caused by internet gambling, but the matter was not gone into in further depth by either the panel or Appellate Body in that dispute. Therefore, health has been only brought in by a side-wind in this case and is unlikely to be of value for guidance in future disputes where Article XIV(b) of the GATS is actually invoked.

\subsection{2. "Health" in TRIPS, SPS, TBT (and WHO) contexts}

In the search for definitions and context for "life and health" in terms of Article XIV(b) of the GATS, would it be useful to consider the TRIPS and SPS context? What implications are there for GATS in the use of the term "health" in other WTO Agreements?

The phrase used in the TRIPS text is also the same as GATT and GATS: "to protect human, animal or plant life or health" (in Article 27.2 of the TRIPS: exclusion from patentability). There has been no interpretation of this so far in the TRIPS context. Article 8.1 of TRIPS also recognizes as a general principle that a Member may "adopt measures necessary to protect public health and nutrition". In EC-Trademarks and Geographical Indications, the Panel described Article 8.1 ('Principles') as a granting of "negative right" of Members, which gives them the "freedom to pursue legitimate public policy objectives" and which is in place of general exceptions (which the TRIPS does not have). ${ }^{2114}$ However there has been elaboration of 'health', 'public health' and certainly not of a 'right to health' in TRIPS disputes. The closest entryway is in the Panel report in the Canada-Pharmaceutical Patents disputes, where the Panel discussed the term "legitimate interests" in Article 30 of the TRIPS and provided a definition:

To make sense of the term 'legitimate interests' in this context, that term must be defined in the way that it is often used in legal discourse - as a normative claim calling for protection of interests that are 'justifiable' in

\footnotetext{
2112 UNCTAD, World Trade Law and Renewable Energy: The Case of Non-Tariff Barriers, (authored by Robert Howse), UNCTAD/DITC/TED/2008/5, United Nations, 2009, p8.

${ }^{2113}$ Appellate Body Report, US-Gambling, para.284.

2114 Panel Reports, EC-Trademarks and Geographical Indications (US) para. 7.210 and EC-Trademarks and Geographical Indications (Australia), para.7.246.
} 
the sense that they are supported by relevant public policies or other social norms. ${ }^{2115}$

This is a very broad definition which could include health and the right to health. Paragraphs 5(a) and 19 of the Doha Declaration on the TRIPS Agreement and Public Health, 2001, also refer to the principles of Article 8 of the TRIPS in the context of interpretation of the TRIPS and guidance for the work of the TRIPS Council.

There has been no use of human rights language in any of the WTO agreements or in the findings of the dispute settlement system, and human rights concerns have made inroads into the WTO only via the terminology of 'public health' used in Article 8 and the TRIPS-related Doha Declaration on TRIPS and Public Health, 2001, the latter of which stated that:

We agree that the TRIPS Agreement does not and should not prevent members from taking measures to protect public health. Accordingly, while reiterating our commitment to the TRIPS Agreement, we affirm that the Agreement can and should be interpreted and implemented in a manner supportive of WTO members' right to protect public health and, in particular, to promote access to medicines for all. ${ }^{2116}$

Members remain free to take measures necessary to protect public health provided that such measures are consistent with the TRIPS Agreement. There are exceptions including parallel importation and compulsory licensing.

In recent years, there has been extensive commentary on the topic of patents and access to medicines, and also on the underlying debate regarding the relationship of intellectual property and human rights involving both public health activist organizations ${ }^{2117}$ and organizations within the UN (human rights) framework such as the WHO. This led to the adoption of the Doha Declaration on TRIPS and Public Health by the Ministerial Conference of the WTO in November 2001. ${ }^{2118}$ In light of the serious public health problems, especially those affecting developing country and LDC Members, the Doha Declaration recognizes that the TRIPS Agreement can and should be interpreted and implemented in a manner supportive of Members' right to take measures to protect public health and, particularly, promote access to medicines for all. ${ }^{2119}$ In Australia-Tobacco Plain Packaging, the Panel found that the 2001 Doha Declaration on TRIPS and Public Health is a subsequent agreement to the TRIPS Agreement under Article 31(3)(a) of the Vienna Convention on the Law of Treaties. ${ }^{2120}$ The Doha Declaration of 2001 wherein Paragraph 6 clearly allowed for States to export pharmaceuticals under compulsory license to countries where such pharmaceuticals are needed to protect public health, led to the Waiver of 2003 and finally to an amendment of the TRIPS Agreement in 2005. The Amendment of the TRIPS Agreement is the new Article 31bis, which is in force since

\footnotetext{
2115 Panel Report, Canada-Pharmaceutical Patents, paras. 7.69, also see para.7.71

2116 WTO Doha Declaration on the TRIPS Agreement and public health, WT/MIN(01)/DEC/2, adopted on 14 November 2001 during the Doha Ministerial Conference, Ministerial Conference, Fourth Session, Doha, 9-14 November 2001, WT/MIN(01)/DEC/2, Paragraph 4.

2117 See for example, the activism for essential medicines by Health Action International, Médecins Sans Frontières, Oxfam International, Treatment Action Campaign in South Africa and India's Peoples Health Movement.

2118 WTO Ministerial Conference (2001) Doha Declaration on the TRIPS Agreement and Public Health, adopted on 14 November 2001, Ministerial Conference, Fourth Session, Doha, 9-14 November 2001, $\mathrm{WT} / \mathrm{MIN}(01) / \mathrm{DEC} / 2$

${ }^{2119}$ Ibid. (Doha Declaration on the TRIPS Agreement and Public Health), paras. 1 and 4.

${ }^{2120}$ Panel Report, Australia-Tobacco Plain Packaging, para.7.2409.
} 
2017. ${ }^{2121}$ These developments are promising. Although the Doha Declaration does not explicitly make use of the human rights language it does clearly confirm that developing countries have a right to use the TRIPS flexibilities to the full extent in dealing with public health issues, and the legitimate interests which they can protect under this can include the right to health.

A human rights analysis of the TRIPS Agreement was carried out by the Office of the High Commissioner on Human Rights as early as 2001. ${ }^{2122}$ The WHO, WTO, UNAIDS and WIPO were consulted in the preparation of the Report. The Report emphasizes the balancing of private and public interests in the TRIPS and that the latter can be entry points for a human rights approach to the TRIPS. However, there are number of reasons why there are difficulties in a human rights approach to the interpretation of TRIPS obligations. These include the fact that in TRIPS, public health is an exception, whereas human rights should be central and not an exception to private intellectual property rights (IPR). Furthermore, the rights in the Agreement are clearly weighted towards the interests of IPR holders. Simon Walker notes the "misinterpretations" of trade lawyers making broad statements that intellectual property rights are human rights, in ignorance of the fundamentals of human rights law ${ }^{2123}$ - which adds another layer of confusion to the issue of a human rights approach. Even if there is a human right of intellectual property, the common-sense interpretation is that such a right was/is in the context of the intellectual property rights of individual human beings to claim moral rights as the authors, creators or users of that intellectual property, and not of the rights of corporations to profit financially from what is essentially an anti-free trade restriction on the sharing of knowledge. Walker's research on the drafting of the UDHR provision on intellectual property rights also supports this view. ${ }^{2124}$ A similarity can be drawn with the positioning of Article XIV(b) pf the GATS as an exception, thus making the inclusion of a right to health approach an exception to the rules on trade in services, and not something that can be read into or with the provisions of the GATS itself.

The term "health" has not been defined in the context of the SPS Agreement, although it is mentioned several times in the text of the Agreement, including in Recital 2 of the Preamble, which states that Members have agreed to the provisions of this Agreement:

Desiring to improve the human health, animal health and phytosanitary situation in all Members...

\footnotetext{
${ }^{2121}$ WTO General Council (2003) Implementation of Paragraph 6 of the Doha Declaration on the TRIPS Agreement and Public Health. Decision of 30 August 2003, WT/L/540. This decision was then formalized in an amendment to the TRIPS Agreement, the WTO General Council (2005) Amendment of the TRIPS Agreement. Decision of 6 December 2005, WT/L/641.

${ }^{2122}$ UN High Commissioner for Human Rights, The impact of the Agreement on Trade-Related Aspects of Intellectual Property Rights on human rights, E/CN.4/Sub.2/2001/13, 27 June 2001.

${ }^{2123}$ Walker, Simon, A Human Rights Approach to WTO TRIPS in Abbott, Frederick M., Christine Kaufmann and Thomas Cottier Eds., INTERNATIONAL TRADE AND HUMAN RIGHTS: FOUNDATIONS AND CONCEPTUAL ISSUES, Studies In International Economics Vol. 5, World Trade Forum, University of Michigan Press, 2006, p177.

${ }^{2124}$ Article 27 of the UDHR states

1. Everyone has the right freely to participate in the cultural life of the community, to enjoy the arts and to share in scientific advancement and its benefits.

2. Everyone has the right to the protection of the moral and material interests resulting from any scientific, literary or artistic production of which he is the author.

Although some have interpreted this to apply to 'legal persons', the UDHR referred to the protection of the intellectual property rights of individual human beings, read in conjunction with the right to 'share in scientific advancement and its benefits'.
} 
The desire to improve human health is an explicit objective of the application of the SPS Agreement. Despite health services being a matter of such importance to human life and health, the GATS does not address any specific objective of protecting health in the context of trade in services, but only mentions it in the exception in Article XIV(b). In contrast, the term health is mentioned 20 times in the SPS Agreement; in recital 1,2 and 6 of the Preamble and in Articles 2.1, 2.2 ('Basic rights and obligations'), 3.2 ('Harmonization'), 5.1., 5.3, 5.5 ('Assessment of risk and determination of the appropriate level of SPS protection'), as well as in Annex A ('definitions') and Annex B ('Transparency'). This is of course due to the SPS having the specific objective of balancing trade and health and therefore covering the issue of human and animal life and health in greater detail. But health itself is not defined in the SPS, instead, the protection of health is related to the right to take measures to protect human health through SPS measures, provided that it is 'necessary' and based on scientific principles as far as possible. The SPS agreement only covers SPS measures, which it defined in Annex A.1 as measures aiming at a limited category of health risks: food safety risks or risks from pests and diseases of plants and animals. Carrying out of a risk assessment is part of this process of decision-making by a government and this will be discussed separately in the section that follows this discussion on the definition and context of 'health'.

There is another point in the SPS Agreement which is the recognition of the special role of international standards under the SPS Agreement. Under Annex A ('Definitions'), "International standards, guidelines and recommendations" are defined in four different ways, for (i) animal health, (ii) plant health (iii) "food safety", which suggests 'human health', and also (iv) 'other matters'. Of these paragraphs, there are two which are directly relevant for human health, although they do not provide a definition of "health": Paragraph 3(a) of Annex A

for food safety, the standards, guidelines and recommendations established by the Codex Alimentarius Commission relating to food additives, veterinary drug and pesticide residues, contaminants, methods of analysis and sampling, and codes and guidelines of hygienic practice;

Paragraph 3(d) of Annex A:

for matters not covered by the above organizations, appropriate standards, guidelines and recommendations promulgated by other relevant international organizations open for membership to all Members, as identified by the Committee.

The Appellate Body in US-Continued Suspension/Canada-Continued Suspension commented that:

International standards are given a prominent role under the SPS Agreement, particularly in furthering the objective of promoting the harmonization of sanitary and phytosanitary standards between WTO Members. This is to be achieved by encouraging WTO Members to base their SPS measures on international standards, guidelines or recommendations, where they exist. There is a rebuttable presumption that SPS measures that conform to international standards, guidelines or recommendations are "necessary to protect human, animal or plant life or health, and ... [are] consistent with the relevant provisions of this Agreement and of the GATT 1994" [emphasis added] ${ }^{2125}$

\footnotetext{
${ }^{2125}$ Appellate Body Report, US-Continued Suspension / Canada-Continued Suspension, para. 532.
} 
This is an explicit recognition that if Members' domestic SPS measures are in conformity with relevant international standards, and that evidence has to be presented that they are inconsistent with the GATT 1994 and the SPS Agreement. ${ }^{2126}$ SPS measures not based on international standards could still be allowed if they are based on a risk assessment.

Article 2.4 of the TBT Agreement also recognizes that Members may base their technical regulations on relevant international standards. According to Article 2.2, the technical regulations concerned could be those which are based on the "legitimate objectives" of the "protection of human health or safety". "human health" has not been defined as such, but there has been elaboration in the dispute settlement context on the definition of "standard" and "international standard". Annex 1.2 to the TBT Agreement defines a "standard" as follows:

Document approved by a recognized body, that provides, for common and repeated use, rules, guidelines or characteristics for products or related processes and production methods, with which compliance is not mandatory. It may also include or deal exclusively with terminology, symbols, packaging, marking or labelling requirements as they apply to a product, process or production method. ${ }^{2127}$

The dispute settlement bodies have also identified a three-step analysis for Article 2.4, developed by Panel and the Appellate Body in EC-Sardines and affirmed by the Panel in US- Tuna II (Mexico):

(i) the existence or imminent completion of a relevant international standard;

(ii) whether the international standard has been used as a basis for the technical regulation; and

(iii) whether the international standard is an ineffective or inappropriate means for the fulfilment of the legitimate objectives pursued, taking into account fundamental climatic or geographical factors or fundamental technological problems. ${ }^{2128}$

The best example with regard to international standards is one which is related to health protection. The WTO has observer status in the WHO and was part of the WHO InterAgency Task Force on Tobacco Control. WTO Members, as State Members of the WHO, participated in the negotiation of the Framework Convention on Tobacco Control (FCTC), an international standard which was identified by Australia in the AustraliaTobacco Plain Packaging dispute as a relevant international standard under Article 2.4 of the TBT Agreement. Unsurprisingly, the Panel Report acknowledged that Australia had:

...pursued its relevant domestic public health objective in line with the emerging multilateral public health policies in the area of tobacco control as reflected in the FCTC and the work under its auspices. ${ }^{2129}$

The fact that the WHO had taken steps to ensure that the WTO as an organization had been having close links with the process of developing these standards, is a significant aspect of international cooperation and the WHO's global health policy strategy.

\footnotetext{
${ }^{2126}$ See Appellate Body Report, EC-Hormones, para. 170.

${ }^{2127}$ See also, the discussion on "standard" and "international standard" by the Panel in Australia-Tobacco Plain Packaging at paras.7.281-7.286.

${ }^{2128}$ Panel Report, US-Tuna II (Mexico), para.7.627 - referring to Panel Report, EC-Sardines, paras.7.617.139 and Appellate Body Report, EC-Sardines, paras.217-291.

${ }^{2129}$ Panel Report, Australia-Tobacco Plain Packaging para.7.2604.
} 
The GATS does not have a specific provision referring to harmonization of domestic standards in services with international standards or a rebuttable presumption of conformity with the GATS similar to the SPS and TBT contexts. While international standards are recognized in some WTO contexts, such as recognizing the standards, guidelines and recommendations established by the Codex Alimentarius Commission, reference to similar international standards, guidelines and recommendations have not been done for the services context. Health services delivery does have relevant international standards prepared by the WHO and ISO, which could be, but have not been, linked with the GATS. ${ }^{2130}$ These standards need implementation and regulation by governments and public health systems and could also be used by private health services providers. But references to universal service provision, equitable and nondiscriminatory access, affordability, public welfare and the right to health with regard to health services has been avoided thus far in the services context. The only explicit reference to 'universal service' is in the Telecommunication Services Reference Paper of 1996, which some Members have appended to their Services Schedules. Paragraph 3 of the Reference Paper refers to the right of Members to define the kind of universal service obligation it wishes to maintain, which will not be considered anti-competitive so long as it is "transparent, non-discriminatory and competitively neutral manner and are not more burdensome than necessary". ${ }^{2131}$

Could international standards be applied and be useful for an interpretation of "health" in Article XIV(b) of the GATS? As the Appellate Body has referred to international environmental conventions in the context of defining "exhaustible natural resources" under Article XX(g) of GATT 1994, ${ }^{2132}$ it can be argued that there is a possibility of similarly resorting to relevant international conventions for interpretation of "health" in the context of Article XX(b) of GATT 1994 - and similarly to measures for the protection of health services when resorting to Article XIV(b) of GATS.

The first place to look at for a definition is the 'right to health' as expressed in Article 12 of the ICESCR, as discussed in earlier Chapters of this study, particularly Section 2.4 of Chapter 2. It should be reiterated that unlike the right to health in the ICESCR, the ICCPR only refers to health in relation to public health measures being an allowable restriction to the freedoms of speech, movement, assembly, association and the freedom to manifest one's religion - and not in the context of a right. But neither of the Covenants include a specific definition for "health"; and the one often used by health professionals and even by human rights activists is the definition from the Preamble to the Constitution of the World Health Organization (WHO). The WHO is a specialized agency of the UN

\footnotetext{
2130 The WHO, has a large number of standard setting documents and agreements, including: the International Health Regulations, or IHR (2005), an agreement for global health security between 196 countries including all WHO Member States; a series of guidelines on health systems (see https:/www.who.int/publications/guidelines/health_systems/en/); public health emergencies (see https:/www.who.int/publications/guidelines/health-emergencies/en/) and many more on specific responses to treatment of diseases, conditions or health situations (see https://www.who.int/publications/ guidelines/year/en/). See further, ISO AND HEALTH, 2 ${ }^{\text {nd }}$ Edition, 2016, available online at https://www.iso.org/publication/PUB100343.html, which refers to 1300 standards that focus on health, and which also cover quality and safety standards in health services delivery. As described in their website, https://www.iso.org/about-us.html, ISO is an "independent, non-governmental international organization with a membership of over 164 national standards bodies" with a central secretariat in Geneva.

2131 Telecommunication Services Reference Paper (1996), https://www.wto.org/english/tratop_e/serv_e/ telecom_e/tel23_e.htm.

2132 Appellate Body Report, US-Shrimp, paras.129-34.
} 
established in 1948, which has defined the vision of ideal health in the Preamble to its Constitution as:

Health is a state of complete physical, mental and social well-being and not merely the absence of disease or infirmity. ${ }^{2133}$

Making a connection with human rights and health, this Preamble further states that: The enjoyment of the highest attainable standard of health is one of the fundamental rights of every human being without distinction of race, religion, political belief, economic or social condition [emphasis added]. ${ }^{2134}$

The WHO has been for the past six decades, the coordinating authority on health within the UN system. The current definition of 'public health' used by the WHO also has an individual rights approach:

Public health law concerns the legal powers and duties of the state to assure the conditions for people to be healthy (e.g., to identify, prevent, and ameliorate risks to health in the population) and the limitations on the power of the state to constrain the autonomy, privacy, liberty, proprietary, or other legally protected interests of individuals for the protection or promotion of community health. ${ }^{2135}$

This may give a broader understanding of health than the science-risk-focused and physical health-based approach under the SPS Agreement. Due to the nature of the debate on access to medicines and public health, the discourse surrounding TRIPS can be said to be more in line with right to health and individual human rights, but as discussed above, the text and the interpretation of the text have not addressed health.

It can be argued that the aspects of social and mental health, as well as the right to health and individual autonomy can be brought into the GATT and GATS context by reference to the WHO definitions. It can also be mentioned that mental health, social well-being and community health which is part of the definitions presented above do not need to be limited to scientific proof of negative effects on physical health which appears to be required for 'health risk' in the SPS context, but can be applied in a much broader manner. ${ }^{2136}$ The passing reference to the health impacts of internet gambling addiction in US-Gambling shows that such arguments can be raised in the services context and that there could be space for further development of both the public health and right to health approaches in WTO law. The understanding of the basis for measures for the protection of health in the context of services would be supported by reference to international standards, guidelines and recommendations, including those specific ones made by the WHO and ISO. Such references may be used to broaden the policy space for the protection for public health services under the GATS. An inclusion of the role of risk in the analysis of measures for the protection of a service, may play a role as a restricting factor on non-trade concerns such as health, depending on how narrowly or broadly 'risk'

\footnotetext{
2133 The WHO Constitution, adopted by the representatives of 61 States during the International Health Conference, New York, 22 July 1946, entered into force on 7 April 1948. Amendments adopted by the Twenty-sixth (1977), Twenty-ninth (1984), Thirty-ninth (1994) and Fifty-first (2005) World Health Assemblies are incorporated in the present text.

${ }^{2134}$ Ibid. See further the WHO official webpage on health and human rights: http://www.who.int/hhr/en/

${ }^{2135}$ From the WHO official webpage on health and human rights and specially focusing on 'health law': http://www.who.int/hhr/health_law/en/, citing public health expert and Georgetown University professor, Lawrence Gostin (Gostin, L., PUBLIC HEALTH LAW: POWER, DUTY, RESTRAINT, 1st Edition, 2000).

${ }^{2136}$ See Button, Catherine, THE POWER TO PROTECT: TRADE, HEALTH AND UNCERTAINTY IN THE WTO, Hart Publishing, 2004, p25-27.
} 
is interpreted. However, although scientific proof of a risk to health has been referred to in the Art XX(b) GATT case law, it is less likely that a requirement of a risk assessment such as used in the SPS context could be read into the GATS.

\subsection{3. 'Risk', evidence and precaution: SPS and TBT approaches and implications for GATS}

The GATT 1994 and the GATS both have health in exception clauses to the obligations of the Agreements. The rights and obligations of the GATT 1994 are applied alongside the more specific rules in the SPS and TBT Agreements which allow governments to take action in order to protect human, animal or plant life or health when trading in goods. The SPS and TBT Agreements, which both recognize that Members can take regulatory action based on international standards in order to protect health as a legitimate policy objective. The SPS Agreement names the FAO/WHO Codex Alimentarius as the relevant standardsetting organization for food safety and the WHO has an important role as observer in the SPS and TBT Committees. Furthermore, the Codex Alimentarius standards can also be used as a basis for trade measures such as labelling, which are covered by the TBT Agreement. Specific provisions in both the SPS and TBT Agreements make a linkage between the measures to protect health and the risks that would be prevented by taking action as well as the risks of failing to take action. This section assesses the references to international standards and the nature of 'risk' that is to be taken into account for such measures relating to the protection of health under the SPS and TBT Agreements, and considers there is any relevance for protection of public health services under the GATS.

The GATS does not have similar provisions explicitly requiring a risk assessment for services trade. Yet it is possible that the 'necessity' test and the level of protection ('zero risk'), which is discussed in the next section of this Chapter, may bring in the aspect of risk assessment with regard to 'necessity'. Cottier et al have noted that in the GATT, the aim of the policy measure being for the purpose of the protection of health would not be disputed as much as whether there was in fact a risk that the measure could prevent. ${ }^{2137}$ If a similar analysis is applied for Article XIV of the GATS, especially for Article XIV(b), one could make an argument for the consideration of the risk to human life and health, and to include an aspect of risk assessment. However, this kind of risk assessment has not been required under the comparable Article XX(b) of the GATT so far, therefore it seems unlikely that it would become part of the analysis of Article XIV(b) of the GATS. The following discussion on risk, evidence and precaution is thus an assessment of the SPS and TBT approaches and broad general observations on how similar science and riskbased arguments could be raised to justify health-related measures in the GATS.

Article 2 of the TBT is on "Preparation, Adoption and Application of Technical Regulations (by Central Government Bodies". Article 2.2 of the TBT Agreement provides that:

Members shall ensure that technical regulations are not prepared, adopted or applied with a view to or with the effect of creating unnecessary obstacles to international trade. For this purpose, technical regulations shall not be more trade-restrictive than necessary to fulfil a legitimate objective, taking account of the risks non-fulfilment would create. Such

\footnotetext{
${ }^{2137}$ Cottier, T, P, Delimatsis and N. Diebold, Article XIV GATS in Wolfrum, Rudiger, Peter-Tobias Stoll and Clemens Feinaugle Eds., WTO - TRADE IN SERVICES, Max Planck Commentaries on World Trade Law, Martinus Nijhoff Publishers, 2008, p303-304.
} 
legitimate objectives are, inter alia: national security requirements; the prevention of deceptive practices; protection of human health or safety, animal or plant life or health, or the environment. In assessing such risks, relevant elements of consideration are, inter alia: available scientific and technical information, related processing technology or intended end-uses of products [emphasis added].

According to the Appellate Body in US-Tuna II (Mexico), in the context of a dispute where there is a claim made under Article 2.2 of the TBT Agreement, a panel must first assess what a Member seeks to achieve by means of the technical regulation, taking into account "the texts of statutes, legislative history, and other evidence regarding the structure and operation of the measure". ${ }^{2138}$ With regard to protection of human health, health-related measures are often easily accepted as 'legitimate objectives'. In US-Clove Cigarettes, the Panel stated that it was "self-evident that measures to reduce youth smoking are aimed the protection of human health". ${ }^{2139}$ This is also because of the large amount of evidence gathered by researchers over the years on the impacts of tobacco and on the marketing of tobacco and tobacco products. This led to the drafting of the WHO Framework Convention on Tobacco Control (FCTC) as an "evidence-based treaty"; ${ }^{2140}$ and also to references made by the Panel and the parties in the Australia-Tobacco Plain Packaging dispute to evidence-based policy positions taken by Australia as a State party to the FCTC.

Research can also warn of the consequences of inaction, whether it is tobacco control, climate change mitigation or the inadequacy or high cost of health services. The Appellate Body Report in US-Tuna II (Mexico) stated that the nature of the risks at issue and the gravity of consequences that would arise from non-fulfilment of the objective(s) pursued by the Member through the measure, are part of the assessment under Article 2.2 of the TBT. ${ }^{2141}$ This was also the view of the Panel in Australia-Tobacco Plain Packaging, which commented further on the "the gravity of the consequences of nonfulfilment", observing that a Panel's assessment of the risks of non-fulfillment should begin with identifying the nature and gravity of such risks (and not with a comparison of the measure taken with possible alternative measures). ${ }^{2142}$ Referring to the context of tobacco control the Panel also noted that there can be situations when a single measure is an integral part of a larger comprehensive policy containing many elements, which has been created to tackle a "multifaceted problem", the entirety of the policy and its objectives should be looked at. ${ }^{2143}$ If such an approach can be argued and accepted in the health services context, as part of Article XIV(b) of the GATS, it would strengthen the position of a Member who has a comprehensive national policy on protection of public health services.

The SPS Agreement also has risk and evidence-related provisions that support a Members

\footnotetext{
${ }^{2138}$ Appellate Body Report, US-Tuna II (Mexico), para. 314. See also Appellate Body Reports, US-COOL, paras. $371-372$.

2139 Panel Report, US-Clove Cigarettes, para. 7.347

2140 This is how the FCTC is described on its official webpage: https://www.who.int/fctc/cop/about/en/. Furthermore, a quick search of the PubMed site using the search terms 'evidence-based' and 'tobacco' results in 19175 publications in biomedical literature and 468 publications when using the search terms 'FCTC' and 'evidence-based'.

${ }^{2141}$ Appellate Body Report, US-Tuna II (Mexico), para. 322.

2142 Panel Report, Australia-Tobacco Plain Packaging (Cuba), para. 7.1321.

${ }^{2143}$ Panel Report, Australia-Tobacco Plain Packaging (Cuba), para. 7.1528.
} 
consideration of human health when taking SPS measures. According to Article 2.1 SPS Agreement:

Members have the right to take sanitary and phytosanitary measures necessary for the protection of human, animal or plant life or health, provided that such measures are not inconsistent with the provisions of this Agreement.

Article 5.1 of the SPS Agreement provides that:

Members shall ensure that their sanitary or phytosanitary measures are based on an assessment, as appropriate to the circumstances, of the risks to human, animal or plant life or health, taking into account risk assessment techniques developed by the relevant international organizations [emphasis added].

The importance of these provisions was explained by the Appellate Body in $E C$ -

Hormones as being:

...essential for the maintenance of the delicate and carefully negotiated balance in the SPS Agreement between the shared, but sometimes competing, interests of promoting international trade and of protecting the life and health of human beings. ${ }^{2144}$

With regard to the protection of health in the context of the SPS Agreement, the concept of risk assessment is defined in Annex A ('Definitions'), paragraph 4, as provided below:

Risk assessment - The evaluation of the likelihood of entry, establishment or spread of a pest or disease within the territory of an importing Member according to the sanitary or phytosanitary measures which might be applied, and of the associated potential biological and economic consequences; or the evaluation of the potential for adverse effects on human or animal health arising from the presence of additives, contaminants, toxins or disease-causing organisms in food, beverages or feedstuffs [emphasis added].

A note to paragraph 5 of Annex A adds that many Members also refer to the "appropriate level" of SPS protection or the "level deemed appropriate" by the Member establishing the SPS measure as the "acceptable level of risk". Thus, the appropriate level of protection is linked with the level of risk which a member is prepared to accept, and measures will be taken to prevent or limit the possibility of harm beyond that acceptable level of risk.

The Panel in EC-Asbestos has stated that the existence of a risk is necessary for 'protection' of health and looked at "whether there was sufficient scientific evidence" as per Article 2.2 of the SPS Agreement to conclude that there exists a risk for human life or health. ${ }^{2145}$ Article 2.2 of the SPS Agreement refers to a Members' obligation to:

...ensure that any sanitary or phytosanitary measure is applied only to the extent necessary to protect human, animal or plant life or health, is based on scientific principles and is not maintained without sufficient scientific evidence, except as provided for in paragraph 7 of Article 5.

Article 5.7 of the SPS states as follows:

In cases where relevant scientific evidence is insufficient, a Member may provisionally adopt sanitary or phytosanitary measures on the basis of available pertinent information, including that from the relevant

\footnotetext{
2144 Appellate Body Report, EC-Hormones, para. 177.

${ }^{2145}$ Panel Report, EC-Asbestos, para.8.170 and para.8182.
} 
international organizations as well as from sanitary or phytosanitary measures applied by other Members. In such circumstances, Members shall seek to obtain the additional information necessary for a more objective assessment of risk and review the sanitary or phytosanitary measure accordingly within a reasonable period of time.

Article 5.7 has been identified by the Appellate Body as reflecting the precautionary principle, ${ }^{2146}$ but that it is limited to emergencies and as a "temporary 'safety valve'. ${ }^{2147}$ The ordinary method of looking at risk is to ascertain whether there is sufficient scientific evidence.

What does "sufficient" scientific evidence mean in this context? This is elaborated with regard to the SPS by the Appellate Body in US-Continued Suspension/CanadaContinued Suspension, where it was stated, in line with previous Appellate Body decisions, that relevant scientific evidence will be considered "insufficient" for purposes of Article 5.7:

...if the body of available scientific evidence does not allow, in quantitative or qualitative terms, the performance of an adequate assessment of risks as required under Article 5.1 and as defined in Annex A to the SPS Agreement. ${ }^{2148}$

The Appellate Body went on to clarify that this means that when there is sufficient relevant scientific evidence to perform a risk assessment, a Member may take an SPS measure on that basis under Article 5.1 and Article 2.2. of the SPS; but if there is insufficient relevant scientific evidence to perform a risk assessment, a Member may take a provisional SPS measure under Article 5.7. ${ }^{2149}$ In EC-Hormones the EC had argued that the concept of risk in the SPS Agreement was qualitative, not quantitative, and therefore any identified increase in risk was sufficient for a Member to take action:

A risk evaluated to be one in a million is sufficient justification. If there is a potential for adverse effects (no matter how small), then there is, according to the European Communities, a risk. ${ }^{2150}$

The position taken with regard to carcinogenic risk was consistent in both EC-Asbestos and EC-Hormones. However, it is relevant to note that the Appellate Body stated that the scientific evidence presented cannot be too 'general' with regard to the risk of cancer caused by asbestos and growth hormones but have to directly focus on and address the specific risk at stake. ${ }^{2151}$ It was stated in the EC-Hormones dispute and approved in later Appellate Body reports, that the scientific evidence as to the risk must be precise and concern the harm caused by the specific substance in the specific manner for the specific purpose: with regard to the carcinogenic risk of residues of the specific hormones at issue (particularly oestradiol-17 $\beta$ ) in bovine meat for human consumption and not the carcinogenic risk of the relevant hormones in general or of a whole category of hormones. ${ }^{2152}$ It appears that the Appellate Body has agreed that a risk may be assessed quantitatively or qualitatively.

\footnotetext{
${ }^{2146}$ See Appellate Body Report, EC-Hormones, paras. 123-125 and Appellate Body Reports, US-Continued Suspension/Canada-Continued Suspension, para.680.

${ }^{2147}$ Appellate Body Reports, US-Continued Suspension/Canada-Continued Suspension, para.680 and 678.

2148 Appellate Body Report, US-Continued Suspension / Canada-Continued Suspension, para.674.

2149 Appellate Body Report, US-Continued Suspension / Canada-Continued Suspension, para.674.

${ }^{2150}$ Appellate Body Report, EC-Hormones, para.29.

${ }^{2151}$ Appellate Body Report, EC-Hormones, para.200 and Panel Report, EC-Asbestos, para.8.170 -8.182.

2152 Appellate Body Report, EC-Hormones, para. 199; cited also in Appellate Body Report, Japan-Apples, para. 202 and Footnote 372; Appellate Body Report and US-Continued Suspension / Canada-Continued Suspension, paras. 559, 562-563.
} 
It is questionable whether this position is in touch with the realities of the availability of specific scientific research with regard to the risks of practices in these industries. One issue is that scientific research to the level of specificity that has been required by the Appellate Body appears to be a higher standard than the level of evidence that would compel a State to act according to other norms and standards of responsible governance. In reality, while science may give a basis for health policy measures by governments, actions are not taken on only such a basis. This is particularly true of health services, where societal values play a larger role in policy creation that evidence-based health research. While science can provide a risk assessment and suggest measures, the governmental responses with regard to the acceptability of the risk are often political choices. Even if the decisions ought to primarily take into account the estimated seriousness of the possible consequences and the importance of taking precautionary measures, corporate lobbying and political campaign funding, and the extent of public awareness of the risks and whether it could be translated into political pressure, play a significant role. In the context of WTO law, Members are free to choose their level of protection, and may take into account non-science factors in choosing this level and the measure to achieve it. These aspects of regulation are commonly known as risk management and are subject to more flexible disciplines than risk assessment in Art 5, and while the SPS agreement does not explicitly use this term (as noted by the Appellate Body in EC-Hormones) it does have separate disciplines for these matters.

In the end, the response to scientific evidence can be said to be a matter of policy and willingness to face the possible risks. It is relevant that the Panel in EC-Hormones observed that an assessment of risk is, at least with respect to risks to human life and health, a scientific examination of data and factual studies and not " $a$ 'policy' exercise involving social value judgments made by political bodies". ${ }^{2153}$ The Panel differentiated such policy matters as pertaining to 'risk management' and stated that it was a different exercise from a 'scientific' examination of data and factual studies which would be done in a 'risk assessment'. However, the Appellate Body disagreed with this, stating that there is no reference to the term "risk management" in the SPS Agreement, only to "risk assessment" and that:

...the Panel's distinction, which it apparently employs to achieve or support what appears to be a restrictive notion of risk assessment, has no textual basis. ${ }^{2154}$

This was approved by the Appellate Body in US-Continued Suspension / CanadaContinued Suspension, which identified the distinction made by the Panel in ECHormones as too rigid and as a more restrictive interpretation of 'risk assessment' than can be justified in light of the use of this phrase in the SPS Agreement. ${ }^{2155}$ However, the Appellate Body in US-Continued Suspension / Canada-Continued Suspension, also acknowledged that the Codex ${ }^{2156}$ draws a distinction between "risk management" and "risk assessment". The Codex defines risk assessment as a "scientifically based process" and 'risk management' as:

\footnotetext{
${ }^{2153}$ Appellate Body Report, EC-Hormones, para.181, citing the Panel Report.

2154 Appellate Body Report, EC-Hormones, para. 181, approved in Appellate Body Reports, US-Continued Suspension/Canada-Continued Suspension, paras.541-542.

${ }^{2155}$ Appellate Body Reports, US-Continued Suspension/Canada-Continued Suspension, para. 535.

${ }^{2156}$ See reference in previous section of this chapter to Paragraph 3(a) of Annex A (food safety standards, guidelines and recommendations established by the Codex Alimentarius Commission).
} 
The process, distinct from risk assessment, of weighing policy alternatives, in consultation with all interested parties considering risk assessment and other factors relevant for the health protection of consumers and for the promotion of fair trade practices, and, if needed, selecting appropriate prevention and control options. ${ }^{2157}$

The view of the Appellate Body was not to give a narrow interpretation of the term "risk assessment" in the SPS Agreement by reference to Codex definitions of a term not included in the SPS Agreement, without a textual basis in the SPS Agreement itself that would support such an interpretation.

The Appellate Body in EC-Hormones also recognized that risk assessment may be made in a situation where there are different, even contradictory, scientific opinions with regard to the relevant risks; and thus, the Appellate Body took a different approach from that of the panel, stating that in the context of Article XX(b) of the GATT 1994 that:

...responsible and representative governments may act in good faith on the basis of what, at a given time, may be a divergent opinion coming from qualified and respected sources. ${ }^{2158}$

As can be seen, the Appellate Body has indicated that even a minority scientific view can be the basis for an SPS measure. The Appellate Body in EC-Asbestos has restated this, adding that:

A Member is not obliged, in setting health policy, automatically to follow what, at a given time, may constitute a majority scientific opinion. ${ }^{2159}$

This is useful in a situation such as GMO use, where there is still uncertainty in terms of scientific evidence of the risk to human, animal or plant life or health; and a minority scientific view that precautions should be taken could become the basis for national policy. The Panel in EC-Approval and Marketing of Biotech Products explained this in the following manner, in the context of SPS measures, which are consistent with Article 5.1 of the SPS Agreement.

Thus, there may conceivably be cases where a Member which follows a precautionary approach, and which confronts a risk assessment that identifies uncertainties or constraints, would be justified in applying (i) an SPS measure even though another Member might not decide to apply any SPS measure on the basis of the same risk assessment, or (ii) an SPS measure which is stricter than the SPS measure applied by another Member to address the same risk [footnotes omitted]. ${ }^{2160}$

The Panel adds that SPS measures following such a precautionary approach must be based on a risk assessment a risk assessment consistent with the requirements of Article 5.1 of the SPS Agreement.

While the above statements can be read as the Appellate Body showing deference to national policy based on minority scientific opinion when the scientific data and research is still at an early stage, it could be questioned whether there is also a danger in the approach. Such a position can also be analyzed as one that gives credence to arguments in

\footnotetext{
${ }^{2157}$ Cited in Appellate Body Reports, US-Continued Suspension/ Canada-Continued Suspension, para. 535, but this reference in the Appellate Body Report had not included the phrase "in consultation with all interested parties", which is part of the full Codex definition.

${ }^{2158}$ Appellate Body Report, EC-Hormones, para. 194

${ }^{2159}$ Appellate Body Report, EC-Asbestos, para.178 (also citing in the same paragraph, the above reference; Appellate Body Report, EC- Hormones, para.194).

${ }^{2160}$ Appellate Body Report, EC-Approval and Marketing of Biotech Products, para 7.3065.
} 
favour of minority scientific views that are in the process of being discredited and do not accept the majority scientific opinion on the risks of, for example, asbestos or anthropogenic climate change. ${ }^{2161}$ Similarly, in the context of services, despite right to health-based health economics providing evidence that a single payer, universal coverage public health system provides a better option for health services delivery, the trade regime could still lean more towards a liberalization of health services based on encouraging reduced public involvement, more private competition, and the corporatization and marketization of health services.

The WTO dispute settlement bodies should be a neutral forum that is not pre-tilted towards any position held by the parties to a dispute, but to weigh the available evidence objectively but fairly. A fairer balance may be achieved in policy-making which relies on scientific data if the dispute settlement bodies were more favourable towards the precautionary principle (which was invoked by the European Communities in ECHormones). Although the Appellate Body accepted that the precautionary principle had crystallized into a "general principle of customary international environmental law" they stated that it was "unnecessary, and probably imprudent" to take a position on its general customary international law nature. ${ }^{2162}$ While activists on health and environmental issues may have been disappointed that the WTO had been so cautious in matters of such serious nature, some legal scholars have argued that there is insufficient legal foundation for the precautionary principle to be used as suggested by the EC, in the WTO context. ${ }^{2163}$ Even the majority of the ICJ judges have avoided reliance on the precautionary principle; and have done so even in the case of the impacts of nuclear testing (!). ${ }^{2164}$ So the caution of the WTO dispute settlement bodies in using it as reflected in the text before them (e.g. within the parameters of Article 5.7. of the SPS) and not to make any broader conclusions, is understandable.

${ }^{2161}$ On the scientific evidence and policy linkage concerning asbestos see for example; Ogunseitan, Oladele A., The asbestos paradox: global gaps in the translational science of disease prevention, Bulletin of the World Health Organization 93.5 (2015): 359-360; Baur, Xavier, et al. Collegium Ramazzini: Comments on the 2014 Helsinki consensus report on asbestos, American Journal of Industrial Medicine 59.7 (2016): 591594; Terracini, Benedetto, et al., Comments on the causation of malignant mesothelioma: Rebutting the false concept that recent exposures to asbestos do not contribute to causation of mesothelioma, American Journal of Industrial Medicine 59.6 (2016): 506-507; Ruff, Kathleen, and John Calvert, Rejecting sciencebased evidence and international co-operation: Canada's foreign policy on asbestos under the Harper government, Canadian Foreign Policy Journal 20.2 (2014): 131-145.

On climate change see; Oreskes, Naomi, The scientific consensus on climate change, Science 306.5702 (2004): 1686-1686 - concluding that there is "robust consensus", "overwhelming agreement" and "clear and persuasive evidence" that anthropogenic global climate change is occurring. See further; Lewandowsky, Stephan, Gilles E. Gignac, and Samuel Vaughan, The pivotal role of perceived scientific consensus in acceptance of science, Nature Climate Change 3.4 (2013): 399-404; Lewandowsky, Stephan, et al., Seepage: Climate change denial and its effect on the scientific community, Global environmental change 33 (2015): 1-13.

2162 Appellate Body Report on EC-Hormones, para.123.

${ }^{2163}$ See further Priess, Hans-Joachim, and Christian Pitschas, Protection of public health and the role of the precautionary principle under WTO law: a trojan horse before Geneva's walls, Fordham International Law Journal 24 (2000), 519: arguing that the legal basis for reliance on the precautionary principle must be first clarified, in order for a proper dialogue to be undertaken between Members on the content and scope of the precautionary principle in the context of WTO law.

${ }_{2164}$ ICJ, Request for an Examination of the Situation in Accordance with Paragraph 63 of the Court's Judgment of 20 December 1974 in the Nuclear Tests (New Zealand v. France) Case, 1995, ICJ, 288. See further, Atapattu, Sumudu A., EMERGING PRINCIPLES OF INTERNATIONAL ENVIRONMENTAL LAW, Transnational Publishers, 2006, p242-272; commenting on the dissenting opinions of Judge Christopher Weeramantry and Judge Sir Geoffrey Palmer in the Nuclear Weapons Case (ICJ, Legality of the Use by a State of Nuclear Weapons in armed Conflict, Advisory Opinion, 1996 I.C.J. 66) at p244-249. 
In EC-Hormones, the EC repeatedly commented that the Panel had distorted of relevant scientific evidence in its reasoning - a contention which was not accepted by the Appellate Body. ${ }^{2165}$ However, the asbestos, GMO and the beef industry are powerful industries that may be actually able to distort scientific research and findings, as well as legal and policy measures. For example, recent reports discussing the role of asbestos in cancer noted that powerful figures in the asbestos industry have been influencing scientific studies on risk assessment and regional and international standardization and law-making on asbestos and even pressurizing the WHO to withdraw its call for a ban. ${ }^{2166}$ There have also been discussions concerning the barriers created by the GMO industry in the development of research on the harmful effects of GMOs and conducting adequate risk assessments; particularly of the creation of a popular opinion that there is scientific consensus that GMOs are not harmful. ${ }^{2167}$ The barriers for scientific study of risks include the fact that since these food safety issues are entwined with industry-held intellectual property, there is no public access for independent researchers to conduct the necessary research or for the existing research to be made publicly available. ${ }^{2168}$

In the EC-Hormones situation, Canada and the United States, although having conducted risk assessments containing scientific evidence and information, refused to make them public claiming that the studies were "proprietary and confidential in nature". ${ }^{2169}$ Yet it can be recalled that the Panel in Argentina-Textiles and Apparel had commented that although the common law procedure of 'discovery' of documents is not available in international courts and tribunals,

...the idea of peaceful settlement of disputes before international tribunals is largely based on the premise of co-operation of the litigating parties. In this context, the most important result of the rule of collaboration appears to be that the adversary is obligated to provide the tribunal with relevant documents which are in its sole possession... parties do have a duty to collaborate in doing their best to submit to the adjudicatory body all the evidence in their possession. ${ }^{2170}$

The EC further commented that they believed that the Panel had "fundamentally erred in law" when they basically condoned in this action of allowing information to be withheld

\footnotetext{
${ }^{2165}$ Appellate Body Report on EC-Hormones, para.141.

${ }^{2166}$ WHO/International Agency on Research on Cancer (IARC), WORLD CANCER REPORT 2014 (edited by Stewart, Bernard W. and Christopher P. Wild), WHO, 2014. This Report is also available online for download at http://www.iarc.fr/en/publications/books/wcr/index.php. See also Holmes, David, IARC in the dock over ties with asbestos industry, The Lancet, Volume 381, Issue 9864, 359 - 361, 2 February 2013.

${ }^{2167}$ Krimsky, Sheldon, An illusory consensus behind GMO health assessment, Science, Technology, \& Human Values 40.6 (2015): 883-914, comments on the role that politics and corporate interests have had in "distorting an honest inquiry into the health effects of GMO crops". Hilbeck, Angelika, et al, No scientific consensus on GMO safety, Environmental Sciences Europe 27.1 (2015): 4, "concludes that the scarcity and contradictory nature of the scientific evidence published to date prevents conclusive claims of safety, or of lack of safety, of GMOs. Claims of consensus on the safety of GMOs are not supported by an objective analysis of the refereed literature.".

2168 See Antoniou M.N. and C.J. Robinson, Cornell Alliance for Science Evaluation of Consensus on Genetically Modified Food Safety: Weaknesses in Study Design, Frontiers in Public Health 2017; 5:79 which noted that "vital industry proprietary biosafety data on GM crops and associated pesticides are not publicly available and is thus cannot inform this project [reviewing scientific abstracts supporting GMO safety]".

2169 Appellate Body Report, EC-Hormones, para.12 and para.201.

${ }^{2170}$ Panel Report on Argentina-Textiles and Apparel, paras.6.40 and 6.58. This finding was not re-assessed by the Appellate Body in that same dispute.
} 
in EC-Hormones. ${ }^{2171}$ There is nothing that may have prevented the Panel from calling for this information. In fact, the Panel has a right to seek information under Article 13 of the Dispute Settlement Understanding (DSU) and Article 11.2 of the SPS Agreement, including confidential information and scientific data. Furthermore, Article 18 of the DSU provides for the protection of confidential information submitted by a Member. Of course, it is absurd that information as to the nature and risks of products to be consumed by the public would be identified as "proprietary and confidential" information which could be withheld from the public.

Comparing EC-Hormones and EC-Asbestos, it has been claimed that the latter case went some way towards redressing the perception of trade-bias in comparison to a non-trade concern. However, the carcinogenic nature of asbestos has been known for decades, even if a total ban is still elusive. Thus, Mary Footer comments with regard to the outcome of EC-Asbestos that:

Ironically, the high scientific understanding of the hazards of asbestos use may make it difficult to justify zero-risk-tolerance policies toward products whose hazardous nature is less well understood. ${ }^{2172}$

As science and technology keep advancing at a rapid pace, the idea that a risk ought to be confirmed by repeated scientific research over several decades in order for it not to be considered merely “a 'policy' exercise involving social value judgments made by political bodies" and that a policy exercise is an unacceptable basis (as stated by the panel in EC-Hormones) - is far too high standard. The Appellate Body in EC-Hormones recognized that risk is:

not only risk ascertainable in a science laboratory...but is also risk in human societies [and] adverse effects on human health in the real world... ${ }^{2173}$

As clarified by the Appellate Body in US-Continued Suspension, the task of a panel is to determine whether the risk assessment is "objectively justifiable" and based on "legitimate science". ${ }^{2174}$ It is not the role of the panels or Appellate Body to make a decision on whether the science or the risk assessment is correct or to make a definitive pronouncement on what a government policy on the issue should be, but to evaluate whether the stance taken has been reasoned, is objective and is based on scientific evidence. $^{2175}$ In addition, an acceptance of the broader role of public interest, right to health, the precautionary principle and general administrative and governance responsibilities towards regulating and managing risk could lead to a more well-balanced assessment of trade and non-trade conflicts within the WTO context.

How precise would the standards of scientific evidence be with regard to services and what should be the standard for all public health and safety? Research in health services has a number of evolving definitions, some very broad and some more specific, but always linked to policy choices. For example, Health Services Research has been defined as "a multidisciplinary field of inquiry, that examines the use, costs, quality, accessibility,

\footnotetext{
2171 Appellate Body, EC-Hormones, para.12 and para.201.

${ }^{2172}$ Footer, Mary and Saman Zia-Zarifi, EC-Asbestos: The World Trade Organization on Trial for its Handling of Occupational Health and Safety Issues, Melbourne Journal of International Law, Vol. 3, 2002, p142.

${ }^{2173}$ Appellate Body Report, EC-Hormones, para. 187.

2174 Appellate Body Report, US-Continued Suspension, paras.590-592.

2175 See further, Trebilcock, M., Robert Howse and Antonia Eliason, THE REGULATION OF INTERNATIONAL TRADE, $4^{\text {th }}$ edition, Routledge, 2013, p300-302.
} 
delivery, organization, financing, and outcomes of health care services". ${ }^{2176}$ Meanwhile, the even more policy-oriented multidisciplinary approach of Health policy and systems research is defined as research that:

...seeks to understand and improve how societies organize themselves in achieving collective health goals, and how different actors interact in the policy and implementation processes to contribute to policy outcomes... [and how] health policies can shape - and be shaped by - health systems and the broader determinants of health. ${ }^{2177}$

Similarly, research on public health services can be defined as research on the organization, financing and delivery of public health services their impact on health. ${ }^{2178}$ With regard to research relating to risk assessments for measures for the protection and promotion of public health services, there is increasing research drawing links and providing evidence. It is clear that "health research has high value to society" and that it affects "important societal interests". ${ }^{2179}$ It remains to be seen whether the health services research would be used or be considered relevant in a GATS context. It certainly could underlie national policy positions in current services negotiations with regard to the liberalization of health services, but the extent to which such research on the role and impact of public health services would be given prominence would depend on the submissions and arguments presented by representatives of the Members.

\footnotetext{
${ }^{2176}$ US Institute of Medicine, Health services research: Work force and educational issues, National Academy Press; 1995. See also Lohr K.N and D.M. Steinwachs, Health Services Research: An Evolving Definition of the Field, Health Services Research, 2002;37(1):15-17. See further, Remme J.H.F., T. Adam , F.Becerra-Posada, C. D'Arcangues, M. Devlin, et al. Defining Research to Improve Health Systems, PLoS Med 7(11), 2010:

The term health services research suggests research that focuses on the service component of the health system, but it is often defined more broadly and used interchangeably with health systems research.

2177 WHO-Alliance for Health Policy and Systems Research, What is Health Policy and Systems Research (HPSR)?, available at http://www.who.int/alliance-hpsr/about/hpsr/en/. See further, Mills A., Gilson L., Hanson K, Palmer N., Lagarde M., What do we mean by rigorous health-systems research? (2008) Lancet 372: $1527-1529$.

${ }^{2178}$ Based on a consensus definition reached by the US Academy Health PHSR Special Interest Group and often cited in US health systems research.

2179 Nass S.J., Levit L.A., Gostin LO, Eds, The Value, Importance, and Oversight of Health Research in BEYOND THE HIPAA PRIVACY RULE: ENHANCING PRIVACY, IMPROVING HEALTH THROUGH RESEARCH, Institute of Medicine (US) Committee on Health Research and the Privacy of Health Information: The HIPAA Privacy Rule Washington, National Academies Press (US), 2009, available online at https://www.ncbi.nlm.nih.gov/books/NBK9571/.
} 


\subsection{ARTICLE XIV(C) - MEASURES NECESSARY TO SECURE COMPLIANCE WITH LAWS OR REGULATIONS WHICH ARE NOT INCONSISTENT WITH THE PROVISIONS OF THE GATS}

Article XIV(c) concerns the following type of measures, those which are:

Necessary to secure compliance with laws or regulations which are not inconsistent with the provisions of this Agreement including those relating to:

i. the prevention of deceptive and fraudulent practices or to deal with the effects of a default on services contracts;

ii. the protection of the privacy of individuals in relation to the processing and dissemination of personal data and the protection of confidentiality of individual records and accounts;

iii. safety.

The parts of this provision which appear at first to be most relevant for the issue of public health services could be measures relating to privacy and safety, but any measure necessary to secure compliance with laws or regulations which are not inconsistent with the GATS, and are for the protection of health, can fall under this provision.

\subsubsection{Introduction to Article XIV(c)}

In order to benefit from the Article XIV(c) exception, the member relying upon it must fulfill the requirements that the disputed measures are "necessary to secure compliance" with "laws and regulations" that are "not inconsistent" with the GATS.

The "necessity test" discussed in further detail later in this chapter is applicable in this instance as a method of restricting the exception. But before a necessity analysis can commence, a Member relying upon Article XIV(c) must show that the measure falls within the scope of the provision. This is the aspect which will be discussed in further detail in this section of the chapter. The terms "laws and regulations" and "secures compliance with" have been clarified in disputes, as discussed further below, as has the requirements of consistency with the GATS. The relationship between the disputed measures and how they "secure compliance with laws and regulations" has also been clarified further in dispute settlement.

The legal standard under Article XIV(c) was identified by the Panel in US-Gambling as having three elements (it can also be referred to as a three-tier test):

1. the measure for which justification is claimed must "secure compliance" with other laws or regulations;

2. those other "laws or regulations" must not be inconsistent with the relevant WTO Agreement, in this instance with the GATS; and

3. the measure for which justification is claimed must be "necessary" to secure compliance with those other laws or regulations. ${ }^{2180}$

In the footnote to the paragraph identifying these three elements, the Panel recalled the analysis of the Appellate Body in Korea-Various Measures on Beef, which dealt with the similarly worded Article XX(d) of the GATT $1994 .^{2181}$

${ }^{2180}$ Panel Report, US-Gambling, para.6.536. 
Article XX(d) of GATT refers to measures...:

Necessary to secure compliance with laws or regulations which are not inconsistent with the provisions of this Agreement, including those relating to customs enforcement, the enforcement of monopolies operated under paragraph 4 of Article II and Article XVII, the protection of patents, trademarks and copyrights, and the prevention of deceptive practices.

As can be seen, both Article XIV(c) of the GATS and Article XX(d) of GATT refer to measures "necessary to secure compliance with laws or regulations which are not inconsistent with the provisions of this Agreement". But Article XX(d) of the GATT is not identical to Article XIV(c) of the GATS, as the listed interests in the two articles are different, with the only common feature being the prevention of deceptive practices. However, GATT panels, WTO panels and the Appellate Body have clarified the interpretation of Article XX(d) of the GATT and there are sufficient similarities for these interpretations to be relevant for the GATS. The Panel in US-Gambling ${ }^{2182}$ discussing Article XIV(c) of the GATS explicitly stated that the two Articles are texturally very similar $^{2183}$ and prior GATT cases were relied on to the extent applicable, confirming the position that such interpretation is relevant for the understanding of Article XIV(c) of the GATS. ${ }^{2184}$

The requirements that have to be fulfilled for a justification under Article $\mathrm{XX}(\mathrm{d})$ of GATT or Article XIV(c) of the GATS are the same, as can be seen by the reference by the Panel in US-Gambling to the Korea-Various Measures on Beef analysis. The Appellate Body in that instance had referred to two elements ${ }^{2185}$ of the justification, but the Panel in US-Gambling merely divided the first element referred to by the Appellate Body into two separate elements and referred to three. It is useful to note that the Panel in Canada-Wheat Exports and Grain Imports had earlier also referred to the same three elements in the context of analyzing Article XX(d) of GATT. ${ }^{2186}$ All these elements have to be fulfilled in order for the measure to be justified under the relevant exception ${ }^{2187}$.

${ }^{2181}$ Panel Report, US-Gambling, Footnote 990.

2182 In US-Gambling, the defence was under Article XIV(a) and (c) of GATS. Although the Panel considered paragraph (c), the analysis by the Appellate Body was concerned with Article XIV(a) and it was not considered necessary to complete the analysis on Article XIV(c) once it was accepted that a provisional justification under Article XIV(a) existed (Appellate Body Report, US-Gambling, para.337). See generally on judicial economy in dispute settlement contexts; Alvarez-Jiménez, Alberto, The WTO Appellate Body's Exercise of Judicial Economy, Journal of International Economic Law 2009 12(2):393-415

2183 Panel Report, US-Gambling, para.6.537

2184 Additionally, it may also be useful to compare NAFTA Arbitral Panel reports concerning Article 2101 (General Exceptions) as this is similar to Article XX(g) of GATT and Article XIV(c) of GATS. Article 2101 of NAFTA is entitled "General Exceptions," and provides in paragraph 2:

Provided that such measures are not applied in a manner that would constitute a means of arbitrary or unjustifiable discrimination between countries where the same conditions prevail or a disguised restriction on trade between the Parties, nothing in... Chapter Twelve (Cross-Border Trade in Services)... shall be construed to prevent the adoption or enforcement by any Party of measures necessary to secure compliance with laws or regulations that are not inconsistent with the provisions of this Agreement, including those relating to health and safety and consumer protection [emphasis added]."

2185 Appellate Body Report, Korea-Various Measures on Beef, para.157, referring to the earlier Appellate Body Report of US-Gasoline.

${ }^{2186}$ Panel Report, Canada-Wheat Exports and Grain Imports, para.6.218

${ }^{2187}$ See also GATT Panel Report, US - Section 337 Tariff Act, para.5.23- The conditions attached to the use of Article XX(d):

...each of these conditions must be met if an inconsistency with another GATT provision is to be justifiable under Article XX(d). A measure which does not meet any one of these conditions, for 
For the purposes of understanding Article XIV(c) of GATS, it is also possible to subdivide the elements identified by the Panel in US-Gambling, for purposes of further clarity, into:

1. Determining the scope of "measures" for the purposes of this Article

2. Identifying the measure for which justification is claimed

3. Determining the parameters of "laws and regulations"

4. A subsequent identification of the "laws and regulations" relevant to the dispute

5. An examination of the consistency of the identified "laws and regulations" with the GATS.

While "measures" are at the heart of all the disputes where the general exceptions would be raised, "measures" relating to Article XIV(c) are linked to compliance with laws and regulations, and in order to avoid a confusion between "measures" and the "laws and regulations" at issue, a preliminary step of determining the scope of and clearly identifying these two aspects would make the next step of the test easier. For this reason, there will be a discussion of "measures" under this part of the chapter. The next steps would then be to;

6. Assess whether the measure was aimed at or designed towards "securing compliance" with the laws and regulations identified above.

The above step shows the linkage between the different aspects and if taken as a whole, is one part of a two-stage test for Article XIV(c). The second part of such a two-stage test would be: the application of the Necessity Test

This two-stage approach is what was identified by the Appellate Body in Korea-Various Measures on Beef $f^{2188}$ and the Panel in US-Gasoline ${ }^{2189}$ as the requirements for the disputed measure to be provisionally justified. Following this justification, the requirements of the chapeau of Article XIV would also have to be fulfilled in order for the defence to succeed. In this section, the six elements abovementioned will be discussed. The necessity test will be discussed separately in Part 3 of this Chapter.

\subsubsection{The requirements of Article XIV(c) of the GATS}

The scope and definition of the term "measures" was discussed in detail in Chapter 3 of this study and therefore does not require repetition at this point. The process of identifying the measure for which justification is claimed will also not be discussed in this section but the analysis will focus on the "laws or regulations" and the listed interests.

\subsubsection{1. "Laws or regulations" and the listed interests}

The term "laws and regulations" specifically referred to in Article XIV(c) include those relating to the three listed interests under Article XIV(c); prevention of deceptive and fraudulent practices or to deal with the effects of a default on services contracts, protection of privacy and confidentiality and safety. The provision is an open-ended one

example the condition that it must be "necessary to secure compliance" with a law consistent with the GATT, cannot be justified under Article XX(d).

${ }^{2188}$ Appellate Body report, Korea-Various Measures on Beef, para.157.

${ }^{2189}$ Panel report, US-Gasoline, para.6.31. 
and the list is merely illustrative, as evident by the fact that this list is preceded by the terms "including those relating to". It was noted by the Panel in US-Gambling that "...Article XIV(c) provides a non-exhaustive list of laws or regulations...Accordingly, measures other than those that fall within the list may be relied upon in justifying a GATS-inconsistent measure under Article XIV(c) provided that those measures aim to secure compliance with laws and regulations are WTO-consistent". ${ }^{2190}$

Thus, the measures which fall within the scope of this exception could include measures aiming to secure compliance with laws and regulations for the protection and promotion of the right to health through public health services. However, this connection has not been raised in discussions on the policy space in the GATS.

The interests raised in disputes are also evidence for the fact that the relevant measures are not limited to the listed interests. It has been commented that in cases where Article $\mathrm{XX}(\mathrm{d})$ of the GATT, the equivalent of Article XIV(c) of the GATS, has been raised as a defence, panels and the Appellate Body have not involved themselves too much in assessing whether the protected interest is one of those listed or whether it is a legitimate policy objective in itself, but in whether the measure at issue relates to compliance with laws and regulations that are otherwise consistent with GATT. ${ }^{2191}$ The issue of the relative importance of the common interest or values that are to be protected, is an issue that is usually considered under the necessity test, as discussed further on in this chapter, and not under this stage of the provisional justification.

The interests that have been at issue where Article XX(d) of GATT has been raised as the defence have been varied. Thus far they have included issues of a procedure banning entry of allegedly patent infringing goods ${ }^{2192}$, compliance with tax laws, ${ }^{2193}$ circumvention of tariffs ${ }^{2194}$ and anti-dumping duties, ${ }^{2195}$ under-invoicing and smuggling, ${ }^{2196}$ and the prevention of deceptive practices and protection of consumer interests in the retail of goods. ${ }^{2197}$ Thus while the issues may have some similarities to the listed interests, there does not necessarily have to be a connection between the list and the type of interests. It can be seen that as disputes on Article XX(d) of GATT have not been limited by the listed interests, the relevance of the listed interests is not of the greatest importance. Therefore, a wide variety of interests and policy objectives could also be justified under both Article XX(d) of GATT and therefore also under Article $\mathrm{XIV}(\mathrm{c})$ the GATS, as long as the other legal requirements are met.

\footnotetext{
${ }^{2190}$ Panel Report, US-Gambling, para.6.540.

${ }^{2191}$ See also Krajewski, M., NATIONAL REGULATION AND TRADE LIBERALIZATION IN SERVICES, Kluwer Law International, 2003, p158-159

${ }^{2192}$ GATT Panel Report, US - Section 337 of the Tariff Act of 1930

${ }^{2193}$ Panel Report, Argentina-Hides and Leather, paras. 11.290-11.308

${ }^{2194}$ Panel Report, China-Auto Parts; circumvention of tariff provisions for motor vehicles: Appellate Body Report, Dominican Republic-Import and Sale of Cigarettes; tax evasion and smuggling of cigarettes.

${ }^{2195}$ EEC-Parts and Components (a GATT panel case) and Appellate Body Report, US - Customs Bond / US - Shrimp (Thailand), ensuring the final collection of anti-dumping or countervailing duties in the event of default by importers with regarding to dumping of shrimp

${ }^{2196}$ Panel Report, Colombia- Ports of Entry.

2197 Appellate Body Report, Korea-Various Measures on Beef: a dual retail system for domestic and imported beef, Panel Report, Canada-Wheat Exports and Grain Imports: additional regulatory requirements for foreign wheat
} 
Article XX(d) of the GATT has also been raised together with other paragraphs of Article $\mathrm{XX}$, where it seems that its importance is usually seen as secondary to the other interest. In Brazil-Retreaded Tyres, the measure was a ban on import of retreaded tyres due to health and environmental concerns, ${ }^{2198}$ and the focus was seemingly more on Article XX(b) than Article XX(d). Article XX(a) and Article XX(d) of the GATT were raised together in Colombia-Textiles, which concerned a compound tariff that was argued as 'designed' to combat money laundering (a public morals issue) and also designed to secure compliance with Article 323 of Colombia's Criminal Code. Similarly, Article XIV(c) of the GATS has only been raised twice, together with Article XIV(a), in the context of US-Gambling and Argentina-Financial Services.

As mentioned earlier, the analysis in US-Gambling at the Appellate Body level was focused more on Article XIV(a). Argentina-Financial Services dealt with Article XIV(c) of the GATS, but did not go into a 'public morals' discussion, although societal values were in the backdrop of the dispute. The Panel accepted that Argentina's measures were designed to secure compliance with its Constitution and domestic law as well as international obligations, and recognized that the objectives were extremely important, noting in particular that:

...the protection of its tax collection system and the fight against harmful tax practices and money laundering are objectives, interests or values of the utmost importance for Argentina. ${ }^{2199}$

The Appellate Body in Colombia-Textiles, which also dealt with disincentives against money laundering, compared the legal standards under Article XX(a) and Article XX(d) noting that while there are several similarities, the differences lay in the fact that the societal interest or value must fall within the scope of "public morals" for Article XX(a) while the interests and values reflected in the "laws or regulations" under Article XX(d) "are not limited in a similar way". ${ }^{2200}$ The Appellate Body also added in the same paragraph of the Report, that specific rules, obligations, or requirements of laws or regulations raised in connection with the Article XX(d) exception must not themselves GATT-inconsistent, while that is not a requirement of the "public morals" raised in connection with Article XX(a).

It will be interesting to see what inter-relations and developments could occur in the future if/when Article XIV(c) is raised together with one of the other sub-paragraphs, such as public morals and public order, or health. For example, a possible overlap between paragraphs could occur between public morals under Article XIV(a) of the GATS and Article XIV(c) generally or the areas of protection of human or animal or plant life or health under Article XIV(b) of the GATS and standards of safety in services provision under Article XIV(c)iii. This concerns measures that relate to safety, that are necessary in order to comply with laws and regulations which are not inconsistent with the provisions of the GATS. Safety can also be seen as interconnected with public morals. For example in a recent UK House of Lords report on cross-border health services in the European Union, the common values and principles of social protection, social cohesion, social justice, sustainable development, universality, access to good quality care, equity,

\footnotetext{
2198 Appellate Body Report, Brazil-Retreaded Tyres, paras.7.101-7.102.

2199 Panel Report, Argentina-Financial Services, para.7.682. See also, para.7.681, para.7.655 and paras.7.664-7.671.

${ }^{2200}$ Appellate Body Report, Colombia-Textiles, para.5.126.
} 
and solidarity are stressed. ${ }^{2201}$ One of the "operating principles" under these overarching values is identified as "safety", in the sense of patient safety including "monitoring of risk factors and adequate training for health professionals, and protection against misleading advertising of health products and treatments."2202

It is also possible however, that for the sake of judicial economy, the dispute settlement bodies would avoid elaborating on the overlap or interconnections, as determining that the measure is justified under one of the exceptions of Article XIV will be sufficient. Taking this into account, the listed interests themselves will only be discussed briefly at this time and the issues of overlap will be referred to where necessary.

The first listed interest under Article XIV(c) - deceptive and fraudulent practices. "The prevention of deceptive and fraudulent practices or to deal with the effects of a default on services contracts" may include for example, consumer protection measures. In Korea-Various Measures on Beef, for example, Korea's argued that the dual retail system which prohibited retail sales of domestic and imported beef products by the same retail outlets and imposed other limitations on the methods of sale of imported beef was designed to secure compliance with the Korean Unfair Competition Act and prevent fraudulent practices of Korean traders in misrepresenting imported beef as higher value domestic beef. Therefore, although the dual retail system was in violation of the national treatment requirement of Article III:4, ${ }^{2203}$ Korea argued that it was nevertheless justified by Article XX(d). The Panel accepted that the system was put in place "at least in part, in order to secure compliance with the Korean legislation against deceptive practices". ${ }^{204}$ Ultimately, Korea did not succeed in this instance, as the Appellate Body, agreeing with the Panel, stated that the necessity requirement had not been fulfilled.

In the context of the past GATS disputes, Article XIV(c) was relied upon by the United States in US-Gambling. The United States argued that the internet gambling prohibition was required to effectively implement domestic laws that included legislation to combat organized crime, money laundering and fraud. Although the analysis was mostly on the public morals and public order aspects of internet gambling, it was also recognised that the measures taken by the United States were connected with securing compliance of a number of domestic laws, at both Federal and State level, including prevention of fraud.

The second listed interest is of privacy, relating to personal data, records and accounts. Privacy issues are of particular interest for electronic services including banking and other financial services, telecommunications and telemedicine. The issue of privacy in electronic financial services has been considered briefly, in relation to computer and related services. The relevant note by the WTO Secretariat mentions that government policies and practices are significant for the sector and that as on-line supply of services become more common, issues such as "authentification, encryption, protection of

\footnotetext{
${ }^{2201}$ House of Lords, European Union Committee, 8th Report of Session 2006-07, CROSS BORDER HEALTH SERVICES IN THE EUROPEAN UNION, published 28 February 2007.

${ }^{2202}$ Ibid (CROSS BORDER HEALTH SERVICES IN THE EUROPEAN UNION), p10.

2203 Article III(4) of GATT 1994:

The products of the territory of any contracting party imported into the territory of any other contracting party shall be accorded treatment no less favourable than that accorded to like products of national origin in respect of all laws, regulations and requirements affecting their internal sale, offering for sale, purchase, transportation, distribution or use...

${ }^{2204}$ Panel Report, Korea - Various Measures on Beef, para.658.
} 
individual privacy, and protection of the consumer" assume ever greater importance. ${ }^{2205}$ The Note also adds that

"[i]t is probably true that efforts to improve global market access for computer and related services will hinge less on traditional trade or regulatory barriers, than on consideration of a diverse range of public policy issues." 2206

Themes for further consideration in this area were identified as the restrictive effects of Article XIV and the underlying policy objectives of measures under Article XIV which could include privacy and content regulation. ${ }^{2207}$

Although submissions made by Members with regard to post-Doha services negotiations have not addressed e-commerce, WTO members have been expressing interest in discussing in public policy issues relating to privacy and consumer interests in this area of e-commerce. The European Communities submitted that a list of regulatory objectives "for example, consumers' protection, universal service, and security of the transactions, as well as those covered by Article XIV of the GATS" could be established in this area, which could justify specific domestic regulation. ${ }^{2208}$ However, little progress has been made in this area under the Doha Agenda, wherein there is also as yet no specific agreement to negotiate or a negotiating group on e-commerce despite the launch of a work programme in 1998 , although there remains a possibility that the issues can arise under the general services negotiations. ${ }^{2209}$ It definitely should be an issue for health data of individuals in the context of trade in health services.

The issue of privacy may however be balanced by morality and security concerns and content regulation could relate to both privacy and public morals and public order issues, so the underlying policy objectives for regulation could have different foundations. For example, in the United States, the Privacy Act of 1974, ${ }^{2210}$ covers records in the possession and control of Federal agencies, one of which is the Department of Health and Human Services, which has its own specific Privacy Act Regulations. These Privacy Regulations $^{2211}$ balance individual privacy with "responsibilities of the Department for disclosing records which the general public is entitled to have under the Freedom of Information $A c t^{2212}$ and Part 5 of this title". Privacy with regard to health insurance information is another area where there could be domestic regulation that involves public morals and health protection with potential service liberalization impacts.

\footnotetext{
2205 WTO, The Council for Trade in Services, Note by the Secretariat, Work Programme on Electronic Commerce, $\mathrm{S} / \mathrm{C} / \mathrm{W} / 68,16^{\text {th }}$ November 1998 , para. 27.

${ }^{2206}$ Ibid., (S/C/W/68).

2207 Ibid para.39.

2208 GATS Council, Communication from The European Communities and their Member States, Work Programme on Electronic Commerce, S/C/W/98 (23 Feb. 1999). See also GATS Council, Submission from the United States, Work Programme on Electronic Commerce, WT/GC/W/493/Rev. 1 (8 July 2003) at paras. 3 and 17-18: the United States submission relating to the Cancun Ministerial stresses that measures taken consistent with Article XIV of the GATS should not constitute a means of arbitrary or unjustifiable discrimination between countries or serve as a disguised restriction on trade. A report of dedicated discussions in the GC on e-commerce is found in $\mathrm{WT} / \mathrm{GC} / \mathrm{W} / 676$

${ }^{2209}$ See further, Wunsch-Vincent Sacha in Joanna McIntosh Ed., E-COMMERCE, AND INFORMATION TECHNOLOGIES: FROM THE URUGUAY ROUND THROUGH THE DOHA DEVELOPMENT AGENDA, A Report for the UN ICT Task Force, author, Markle Foundation, 2004

${ }^{2210}$ As amended at 5 U.S.C. $552 \mathrm{a}$

221145 Code of Federal Regulations 5b.3

22125 U.S.C. 552.
} 
The third listed interest, safety, has already been mentioned briefly above. This interest may cover a variety of national regulations and standards for service suppliers. It is suggested that it may also overlap with Article VI of the GATS (domestic regulation) on the quality of service suppliers ${ }^{2213}$. Subsections 4, 5 and 6 of Article VI, relating to qualification requirements and procedures and licensing can be particularly relevant here and there can also be an overlap in this context with the prevention of "deceptive and fraudulent practices" in Article XIV(c)i. However, Article VI does not provide an exception from GATS disciplines but instead contains a limited discipline for domestic regulation of services.

From a human rights perspective, the Siracusa Principles have noted for the ICCPR context that:

Public safety means protection against danger to the safety of persons, to their life or physical integrity, or serious damage to their property.

The need to protect public safety can justify limitations provided by law. It cannot be used for imposing vague or arbitrary limitations and may only be invoked when there exist adequate safeguards and effective remedies against abuse. .214 $^{2}$

Thus, even if a human rights view of safety is brought into the concept of safety in the GATS, through comparison of the use of the same term in the ICCPR, vague or arbitrary measures are considered to be unjustifiable.

\subsubsection{The Scope and Definition of "Laws or Regulations"}

Coming to the issue of the scope and definition of "laws and regulations" in Article XIV(c) of the GATS, we need again to look at the GATT 1994 context. The Appellate Body in Mexico-Taxes on Soft Drinks considered in detail the meaning of "laws and regulations" in the context of Article XX(d) of the GATT. The conclusion is that "laws and regulations" refer to rules that form part of the domestic legal system of a WTO member. Such rules include rules deriving from international agreements that have been incorporated into the domestic legal system of a WTO member or have direct effect according to that WTO Members' legal system - but it does not extend to obligations of another Member under an international agreement. ${ }^{2215}$

The reasoning of the Appellate Body began with the comment that the terms "laws or regulations" are generally used to refer to domestic laws or regulations and that this is the common understanding. ${ }^{2216}$ The Appellate Body also took notice of the fact that the parties to the dispute, Mexico and the United States, had noted that previous GATT and WTO disputes in which Article XX(d) had been invoked as a defence involved domestic measures. $^{2217}$ It was further added that "one does not immediately think about

\footnotetext{
2213 Cottier, Delimatsis and Diebold, Article XIV GATS in Wolfrum, Rudiger., Peter-Tobias Stoll and Clemens Feinaugle Eds., WTO-TRADE IN SERVICES, Max Planck Commentaries on International Trade Law, Martinus Nijhoff Publishers, 2008, p.309

2214 Siracusa Principles, Principles 33-34.

2215 Appellate Body Report, Mexico-Soft Drinks, para.69-71. See generally for analysis of the characterization of national law in the WTO dispute settlement context - Bhuiyan, Sharif, NATIONAL LAW IN WTO LAW: EFFECTIVENESS AND GOOD GOVERNANCE IN THE WORLD TRADING SYSTEM, Cambridge University Press, 2007

${ }^{2216}$ Ibid., (Mexico-Soft Drinks), para.69

${ }^{2217}$ Ibid., para. 69.
} 
international law when confronted with the term "laws" in the plural". ${ }^{2218}$ The illustrative list of "laws and regulations" provided in Article XX(d) was also seen as supporting this conclusion as they were "typically the subject of domestic laws or regulations". ${ }^{2219}$ The use of the term "enforcement" in the listed interests - which are "customs enforcement, the enforcement of monopolies operated under paragraph 4 of Article II and Article XVII of the GATT (the protection of patents, trademarks and copyrights, and the prevention of deceptive practices) - were also seen as indicating that there was a requirement of governmental enforcement of domestic law in the understanding of the terms "laws and regulations". Although the term enforcement is not used in the GATS, the argument that domestic law is what is meant, can be similarly extended for the prevention of fraudulent and deceptive practices, effects of default on service contracts, privacy, confidentiality and safety interests listed under Article XIV (c) of the GATS.

The Appellate Body in Mexico-Taxes on Soft Drinks further added that the consequences of including other international agreements such as NAFTA under "laws and regulations" would be to put the WTO panels and Appellate Body in a position of having to determine whether there is a violation of the relevant international agreement and thereby to "become adjudicators of non-WTO disputes", something that is not part of the function of the WTO dispute settlement bodies, as envisaged by the DSU. ${ }^{2220}$ The relevant paragraph of the DSU cited in support of this position was Article 3.2, the Appellate Body highlighting that the dispute settlement system of the WTO

...serves to preserve the rights and obligations of Members under the covered agreements, and to clarify the existing provisions of those agreements [emphasis in original DS Report]. ${ }^{221}$

That a Member acted in accordance with its obligations under a different international agreement that is not inconsistent with the WTO agreements, is not considered a relevant fact for the purposes of ascertaining a Members' obligations under WTO Agreements.

It was however accepted by the Appellate Body in that in the domestic legal systems of some WTO members, international rules can have direct effect and therefore become part of the domestic law of that member. ${ }^{2222}$ This is further clarified as; when an international agreement can be invoked and enforced against individuals, it can then be regarded as an integral part of the domestic legal order, ${ }^{2223}$ which again stresses upon the enforcement role of governmental authorities. Of course, in dualist systems that do not have direct effect as in a monist system, the international obligation is only justiciable within the domestic system if it has been incorporated through enabling legislation or if customary international law exists which is not in conflict with domestic law. The Panel in MexicoTaxes on Soft Drinks, commenting further on the aspect of enforcement, noted that there is no "systemic problem" in concluding that when enforcement action is directed to the right target within a Member's legal system that such the target will be achieved because "the State by its very nature is usually in a position to achieve that enforcement, through the use of coercion, if necessary". ${ }^{2224}$ Contrasting this position with international relations, the Panel stated that achieving the goal of changing the behavior of the United

\footnotetext{
${ }^{2218}$ Ibid., para.69.

${ }^{2219}$ Ibid., para.70.

${ }^{2220}$ Ibid., (Appellate Body Report, Mexico-Soft Drinks), para.78

${ }^{2221}$ Ibid., footnote 173.

${ }^{2222}$ Ibid., footnote 148 .

${ }^{2223}$ Ibid Footnote 149, citing the third party submission of the European Communities, para.41

${ }^{2224}$ Panel Report, Mexico- Taxes on Soft Drinks, para.8.185
} 
States through the Mexican tax measures at issue and making United States comply with its obligations under NAFTA is "inescapably uncertain". 2225

This highlights the connection between the definition of "laws and regulations" and the requirement that the measures at issue must "secure compliance with" the said laws and regulations. Therefore, "laws and regulations" must be such as a Member can secure compliance with - and this suggests domestic law (and international law as incorporated into domestic law either directly or through enabling legislation) and not securing another Member's compliance with another non-WTO international obligation. The enforcement aspect of this compliance requirement will be discussed again further on, but the connection between the interpretations - the dependence of the interpretation of "laws and regulations" as excluding international obligations on the interpretation of "compliance" as "enforcement" - is evident.

It was recognized by the Appellate Body that the interests listed under Article XX(d) of GATT may in addition to being domestic matters, also be the subject of international agreements. However, as the terms "laws or regulations" are qualified by the requirement that they must not be "inconsistent" with the GATT 1994, this was seen as further support for the position that the reference is to domestic and not international law. This is due to the fact that the Appellate Body was convinced by the submission of the United States, that the word "inconsistent" is used in connection with domestic measures, whereas the word "conflict" is used in the WTO agreements when referring to treaty obligations. ${ }^{2226}$ Furthermore, the argument that when international obligations or international agreements are intended, that they are specifically identified as such and not left to inference, was also seen as a convincing one. Article $\mathrm{XX}(\mathrm{h})$ of GATT, which specifically refers to "obligations under any intergovernmental commodity agreement" and Article X:1, which makes a distinction between "laws and regulations" and international agreements, was cited as support for this argument. ${ }^{2227}$ However, it was added in a footnote that there are situations where the term "regulations" are used where the context makes it clear that the regulations are "international in character". 2228 The examples mentioned were "regulations" in the context of Article VI of the WTO Agreement, "financial regulations" in the context of Article VII, the reference, generally, to "regulations" of the GATT 1947 and "regulations" in the context of rules applied by free trade areas or customs unions in Article XXIV of the GATT 1994.

The extension of this approach would mean that a Member would not be able to rely directly upon the existence of an obligation under an international agreement if they rely on paragraph (d) of Article XX of the GATT, but only if that obligation has been incorporated into "laws and regulations" in the domestic legal system. If, as is often the case, the Member raising the defence has coupled or combined their defence with other paragraphs of the general exceptions provision; international agreements may be shown as evidence of a public morals, public order or health or environmental interest. This means that the defence, when relating to Article XX(d) of the GATT 1994 or Article

\footnotetext{
2225 Ibid.

${ }^{2226}$ Appellate Body Report, Mexico-Taxes on Soft Drinks, footnote 152, citing the submission of the United States, para.33.

${ }^{2227}$ Ibid., (AB, Mexico-Taxes on Soft Drinks) para. 71

${ }_{2228}$ Ibid., (AB, Mexico-Taxes on Soft Drinks) at footnote 156, citing the Panel Report (footnotes 423 and 424 to para. 8.195) and the third party submission of Japan (paras.17-19).
} 
XIV(c) of the GATS must be related to incorporated domestic laws and not directly to an international agreement.

The immediate reaction to the abovementioned position may be - "but what about the reliance on international obligations referred to in US-Shrimp?" This was indeed the position of Mexico in Mexico-Taxes on Soft Drinks. However, the attempt of Mexico to use the Appellate Body rulings in US-Shrimp and US-Shrimp (Article 21.5-Malaysia) as support for the interpretation that it could refer to the obligations of the United States under NAFTA as "laws and regulations" under Article XX(d) of GATT was rejected. ${ }^{2229}$ The Appellate Body pointed out that in the abovementioned disputes, the United States had sought to justify its measures, which were domestic laws and regulations, under Article XX(g) of the GATT 1994 and not Article XX(d). Furthermore, the reference to the Inter-American Convention for the Protection and Conservation of Sea Turtles was made in the context of the chapeau of Article XX, and not that the measures were intended to secure compliance with the obligations of another Member under the said Inter-American Convention. As this was under Article XX $(\mathrm{g})$ of GATT, there was no need for the United States to prove that the measure was designed to secure compliance with any particular domestic law or regulation. However, Mexico raised the NAFTA obligations of the United States as a justification for its measure under paragraph (d) and this is where they were unsuccessful.

The importance of correctly identifying domestic "laws and regulations" was an issue in China-Auto Parts. The Panel in this instance noted that China had made references "interchangeably" to China's customs laws and regulations including its tariff provisions for motor vehicles, China's tariff schedule, the interpretation of tariff provisions for motor vehicles provided in China's tariff schedule and to duties, as the relevant "laws and regulations", without making a clear identification. ${ }^{2230}$ The Panel came to the conclusion that the laws and regulations at issue are:

China's tariff provisions, including those for motor vehicles, are contained in and are thus part of China's domestic tariff schedule, which reproduces China's commitments in China's Schedule of Concessions with respect to goods from other member countries. ${ }^{2231}$

As concessions are part of China's accession protocol and an integral part of the WTO Agreement under Part I, Article 1.2 of the Accession Protocol, this meant that China was claiming that its measures were in order to comply with its obligations under the WTO as interpreted by domestic Chinese law since China had taken the position that its own interpretation of its concessions with respect to motor vehicles was, by itself, a part of China's tariff schedule. This meant in effect that "a WTO Member's own interpretation of a treaty term is considered as constituting part of such a treaty itself" - something which the panel found an "absurd situation". ${ }^{2232}$ Thus, the dispute settlement bodies would not rely upon a Member's interpretation of a treaty term, but will look at existing evidence in international law, apply the VCLT rules on treaty interpretation and come to their own conclusion. This would of course be much easier and more valid in the context of interpreting WTO agreements and their related protocols or documents, where the interpreters are familiar with the language of trade; but there should be acknowledgement that if terms in non-trade agreements such as those related to human rights or the

\footnotetext{
${ }^{2229}$ Ibid., para.76. Also see Panel Report, Mexico-Taxes on Soft Drinks, para.8.179.

${ }^{2230}$ Panel Report, China- Auto Parts, para.7.290

${ }^{2231}$ Ibid, para.7.295

${ }^{2232}$ Ibid, para.7.295
} 
environment are at issue, it is advisable to consider and accept the interpretations of other relevant international bodies, which are familiar with that non-trade language and their specialized traditions of interpretation.

Thus it can be seen that within the WTO dispute settlement context, the terms "laws and regulations" in Article XX(d) of the GATT 1994 cannot be interpreted according to the wishes of a party to a dispute or as relating to policy measures in general, but "has to be understood in a technical, legal manner" 2233 relating to identifiable "laws and regulations" presented so as to be interpretable by the dispute settlement bodies. This reasoning can also be applied to Article XIV(c) of the GATS. If the Member is relying on other paragraphs of the general exceptions excluding paragraph (d) or (c) referred to above, which do not have the term "laws and regulations" - the measure could be a based on a national policy that is an implementation of an obligation under an international agreement or perhaps even (as discussed in the preceding sections of this chapter), inspired by or supported by an international normative principle.

The identification of the relevant "laws and regulations" is a requirement of the exception and the party invoking an exception as an affirmative defence bears the burden of proof to make a prima facie case. What kind of evidence is needed for this proof can vary from case to case. On the matter of what a dispute settlement body ought to take into account when deciding on the identity of the laws and regulations relevant to an Article XX(d) of the GATT defence, the Panel in Colombia-Ports of Entry, citing the prior Appellate Body case of US-Shrimp (Thailand) recalled that "a wide array of provisions cited by either of the parties in determining the relevant laws and regulations" may be considered and that a panel is free to use any of these to objectively assess which are relevant for the defence. ${ }^{2234}$ However, the panel must not overstep its boundaries in making this assessment as it was noted in US-Gambling, that:

[a] panel may not take upon itself to rebut the claim (or defence) where

the responding party (or complaining party) itself has not done so. ${ }^{2235}$

Therefore, the decision with regard to this requirement must be limited to whether the laws and regulations have been correctly identified for the purposes of the relevant dispute and not overstep into the area of provisionally justifying the defence, which has several other requirements that must be first determined before such a justification is possible.

\subsubsection{3. "Not inconsistent with the provisions of this Agreement"}

In a goods context, EC-Trademarks and Geographical Indications, the relevant Regulation, the EC Council Regulation EEC No 2081/92, was found to be inconsistent

\footnotetext{
${ }^{2233}$ Reyes-Knocke and Arend, Article XX(d) GAT 1994, in Wolfrum Rudiger, in Rüdiger Wolfrum, PeterTobias Stoll, Anja Seibert-Fohr Eds., WTO: TECHNICAL BARRIERS AND SPS MEASURES, Max Planck Commentaries on World Trade Law, Martinus Nijhoff Publishers, 2007, p126.

${ }^{2234}$ Panel Report, Colombia-Ports of Entry, footnote 849; citing in support the Appellate Body Report, US Shrimp (Thailand), para. 302:

In our view, the Panel was free to use the arguments made and provisions cited by all the parties - including Thailand and India - in order to assess objectively which laws and regulations were relevant to the United States' defence. We do not believe that, in doing so, the Panel exceeded its jurisdiction.

2235 Appellate Body Report on US - Gambling, para. 282; cited with added emphasis in the Panel Report, China-Auto Parts, footnote 533.
} 
with the national treatment provisions of the GATT 1994. ${ }^{2236}$ Therefore, even if the disputed measures secured compliance with the Regulation, the defence raised by the EC failed as it was not demonstrated that the said Regulation was "not inconsistent" with the provisions of the relevant Agreement. A similar conclusion was reached by the Panel in China-Auto Parts, that even if it were to accept China's interpretation that the applicable "law or regulation" was its tariff provisions for motor vehicles, these tariff provisions were inconsistent with China's commitment under its Schedule of Concessions, resulting in a failure to justify its measures under Article XX(d) of GATT. ${ }^{2237}$ Thailand's defence under Article XX(d) of the GATT 1994 was rejected by the Panel in Thailand-Cigarettes (Philippines), but the Appellate Body found that the Panel had erred in how it came to that decision, and reversed one part of the Panel's findings. That is, the Appellate Body accepted Thailand's argument that the panel should have looked first at whether the relevant laws were otherwise consistent with the GATT 1994, before looking at whether the measures (the additional administrative requirements for re-sales of imported cigarettes) were inconsistent with Article III:4 of the GATT 1994. ${ }^{238}$ Ultimately Thailand's reliance on an Article XX(d) defence was not successful, but the process of how such a defence should be analyzed was clarified in this dispute.

In a dispute, a measure "as such" can be challenged, or the application of a measure in a WTO inconsistent manner, can also be challenged. ${ }^{2239}$ In US-Oil Country Tubular Goods Sunset Reviews, the Appellate Body in discussing challenges to measures "as such" as being inconsistent with obligations under the WTO, stated that these measures would be scrutinized in various deliberative processes under municipal law to ensure their consistency with international obligations, and therefore that consistency can be assumed, (unless proven otherwise). ${ }^{2240}$ It is added that:

[t]he presumption that WTO Members act in good faith in the implementation of their WTO commitments is particularly apt in the context of measures challenged 'as such'. ${ }^{2241}$

As the Appellate Body specifically refers to "enactment" of such measures and to "deliberative processes", it is also possible this reasoning can be extended to the types of "laws and regulations" that require WTO consistency under Article XIV(c) of the GATS, as these are likely to be legislation or regulations that have also undergone similar scrutiny in the domestic legal system, or as in the case of European countries, has been scrutinized at the European level, by relevant institutions. If that is the case, then both the legal basis for the WTO-inconsistency of the specific municipal measure (which could itself be "laws or regulations") $)^{2242}$ - and the WTO-inconsistency of the "laws and regulations" upon which the measures are based should be claimed unambiguously ${ }^{2243}$ as the responding member's law will be treated as WTO-consistent until proven otherwise,

\footnotetext{
${ }^{2236}$ Panel Report, EC-Trademarks and Geographical Indications (Australia), para.7.332; Panel Report, ECTrademarks and Geographical Indications (US), para.7.297.

${ }^{2237}$ Panel report, China-Auto Parts, para.7.296

${ }^{2238}$ Appellate Body Report, Thailand-Cigarettes (Philippines), paras.163-171, reversing the finding in para.7.758 of the Panel Report

${ }^{2239}$ Appellate Body Report, US- Carbon Steel, para.156.

${ }^{2240}$ Appellate Body Report, US- Oil Country Tubular Goods Sunset Reviews, paras.172-173

${ }^{2241}$ Appellate Body Report, US-Oil Country Tubular Goods Sunset Reviews, paras.172-173

${ }^{2242}$ Appellate Body Report, US-1916 Act, paras.60-61, observed the fact that it was well-settled under the GATT 1947 that a challenge to legislation as such could be brought before a Panel and this has been followed subsequently by WTO Panels.

${ }^{2243}$ Appellate Body in US-Oil Country Tubular Goods Sunset Reviews, paras.172-173
} 
with the burden of proof being on the complainant. ${ }^{2244}$ Once a prima facie case of WTOinconsistency is proven, the burden shifts back to the respondent. However, it has been stated that it is not that each and every provision of the disputed "laws and regulations" or the relevant "laws and regulations" as a whole must be proven WTO-consistent by the respondent, but only the relevant provisions for the purpose of the dispute. ${ }^{245}$

According to the Appellate Body in US-Carbon Steel, which discussed the issue of burden of proof with regard to the WTO-inconsistency of domestic regulation, the nature and extent of evidence required to satisfy this burden can include "the text of the relevant legislation or legal instruments, which may be supported, as appropriate, by evidence of the consistent application of such laws, the pronouncements of domestic courts on the meaning of such laws, the opinions of legal experts and the writings of recognized scholars" and this evidence will of course vary depending on each dispute. ${ }^{2246}$ In the case of an Article XX(d) of the GATT 1994 or Article XIV(c) of the GATS defence, the respondent must be equally clear in identifying the relevant laws and regulations on which the disputed measures are based because evidence regarding WTO-inconsistency of "measures" or "laws and regulations" that were not presented or wrongly presented by the complainant can be clarified in their (i.e. the respondents') favour.

The Panel in US-Gambling also discussed the issue of proving WTO consistency in some detail, but with regard to the claim of WTO-inconsistency raised by Antigua and not specifically to the Article XIV(c) defence. ${ }^{2247}$ However, the Panel noted that the United States, in its defence under Article XIV(c) of the GATS relies on the state gambling laws challenged by Antigua in its Panel request, without specifically identifying all the state laws that would justify the measures and providing the Panel a specific discussion of why and how the various state laws are WTO-consistent. The Panel did not believe that WTOconsistency can be presumed merely because the complainant party failed to make out a prima facie case of inconsistency and that the United States' had failed to fulfill its obligation to demonstrate that it complied with the requirements of Article XIV(c). Another reason against making that presumption was the fact that during the proceedings before the Panel, four of the state laws in question (those of Louisiana, Massachusetts, South Dakota and Utah) were actually found to be prima facie inconsistent with the WTO obligations for market access under Mode 1 (cross-border supply). Therefore, it was concluded that the United States was not entitled to rely upon state gambling laws in its defence.

However, with regard to other criminal laws and regulations relating to organized crime $^{2248}$ that the disputed measures were allegedly enforcing, the Panel stated that since Antigua had not questioned their WTO-consistency, a presumption was allowable, citing the Appellate Body on US-Carbon Steel in this regard. ${ }^{2249}$ Subsequently, taking into account Antigua's submission that the United States had not submitted sufficient information on these laws, the Panel noted that the Racketeer Influenced and Corrupt

\footnotetext{
${ }^{2244}$ Appellate Body Report, US- Carbon Steel, para.156, citing as example the Appellate Body Report, USWool Shirts and Blouses, para.335.

${ }^{2245}$ Panel Report, Colombia-Ports of Entry, para.7.529

2246 Appellate Body Report, US- Carbon Steel, para.157, approved in the Appellate Body Report, USGambling, para 138.

${ }^{2247}$ Panel Report, US-Gambling, para 6.547-6.551

2248 The Racketeer Influenced and Corrupt Organizations statute ("RICO statute"), the Organized Crime Control Act of 1970 and the Attorney General Order 1386-89.

${ }^{2249}$ Appellate Body Report, US-Carbon Steel, para.115
} 
Organizations (RICO) statute was named, explained and the text containing the relevant provisions had been provided, ${ }^{2250}$ and that the attention of the Panel would be limited to the RICO statute in considering the defence under Article XIV(c). The Organized Crime Control Act of 1970 and Attorney General Order 1386-89 would be referred to only where necessary for the definition of organized crime. Antigua claimed on appeal that the Panel had improperly constructed the defence for the United States by taking the RICO statute into account as it had not been sufficiently identified for the purposes of the Article XIV(c) defence. ${ }^{251}$ However, this issue was not decided by the Appellate Body, which chose instead to confine its analysis to $\operatorname{Article} \operatorname{XIV}(a) .{ }^{2252}$

In the next GATS dispute, Argentina-Financial Services, the Panel recalled that a Member's legislation shall be presumed WTO-consistent until proven otherwise; and also went on to state that even if some provisions of the laws or regulations at issue were found to be inconsistent, other provisions could be consistent. ${ }^{2253}$ Yet curiously the Panel stated in the next sentence of the report that it was "therefore not necessary to undertake a detailed examination of the instruments and/or provision". ${ }^{2254}$ This was critiqued by the Appellate Body, stating justifiably that:

$[\mathrm{T}]$ there may be circumstances in which the GATS-inconsistency of certain provisions of a legal instrument could affect or taint the GATSconsistency of other parts of the same instrument or of the instrument as a whole. $^{2255}$

\subsubsection{Aimed or Designed towards "Securing compliance with"}

The terms "securing compliance with" in the legal context can have a variety of meanings, ranging from strategies used by enforcement agencies (whether punitive, coercive or co-operative) to discussions of why target groups conform to regulatory processes and standards. ${ }^{2256}$ In this sense, it is important to distinguish whether the discussion should be on measures aiming at securing compliance with the relevant laws and regulations or whether compliance must actually be secured or guaranteed to be secured by the measure at issue. If it is a new measure that has just been introduced or if there is otherwise a difficulty in obtaining empirical data, the difference between the standard of aiming and actually securing or guaranteeing an outcome can be significant when it comes to fulfilling the requirements of Article XIV(c).

The Panel in Mexico-Taxes on Soft Drinks firstly took a "dictionary approach", citing The New Shorter Oxford English Dictionary. The result of this approach was that "to secure compliance" means "ensuring an outcome by acting in accordance with". ${ }^{2257}$ The context

\footnotetext{
${ }^{2250}$ The United States submitted this information as reply to Panel question No. 45

2251 Appellate Body Report, US-Gambling, para.290.

2252 Ibid., (US-Gambling).

${ }^{2253}$ Panel Report, Argentina-Financial Services, para. 7.625.

2254 Ibid.

2255 Appellate Body Report, Argentina-Financial Services, para. 6.201.

2256 See generally, OECD, REDUCING THE RISK OF POLICY FAILURE: CHALLENGES FOR REGULATORY COMPLIANCE, OECD Publishing, Paris 2000.

${ }^{2257}$ Panel Report, Mexico - Taxes on Soft Drinks, para.8.174: “The word 'compliance' may be defined as 'the action of complying with a request, command, etc.', while in that sense to 'comply' with is to 'act in accordance with'. In turn, to 'secure' may be defined as to 'make (something) certain or dependable. Now [especially] ensure (a situation, outcome, result, etc.)'." The source is The New Shorter Oxford English Dictionary (Clarendon Press, 1993), Vol. I, p. 461 and Vol. II, p2754
} 
of "laws and regulations", which suggest obligations that can be enforced by authorities, and a consideration of the travaux préparatoires of GATT 1947 were also used to strengthen support for the view that "to secure compliance" is to be read as meaning to enforce compliance. ${ }^{258}$ The argument that the context of "laws and regulations" support an interpretation of "enforcement" was based on the reference to the use of the terms "enforcement", "protection" and "prevention" of the listed interests or illustrations of Article $\mathrm{XX}(\mathrm{d})$ of the GATT, all of which terms were seen as concerning the same concept. The terms "prevention" and "protection" are used in sub-paragraphs (i) and (ii) of Article XIV(c) of the GATS, but not "enforcement" - and no such term is placed before the interest of "safety".

It can also be pointed out that the term "enforcement" is actually used in Article XIV of the GATS only in the context of the chapeau, and the reference is to "adoption or enforcement by any member of measures (emphasis added)" and not in relation to "laws and regulations" under subsection (c). Furthermore, Article XX(d) of GATT 1994 does not have separate subparagraphs, but is a single sentence. Whether these points will have any relevance for interpretation of measure under one of the sub-paragraphs, especially "safety", cannot be guessed at this stage, but it may be possible to argue for a different standard for "safety" based on this logic as the phrase

"adoption and enforcement...of measures...necessary to secure compliance with laws or regulations... relating to...safety"

- does not inevitably lead to the conclusion that enforcement of laws and regulations relating to safety is the only intended interpretation. But it may be that future dispute settlement bodies will not find the reference to the terms connecting the illustrations as significant as the Panel in Mexico-Taxes on Soft Drinks did, and other justifications for the interpretation of "enforcement" can easily be made, as this has already been the position in a line of earlier disputes.

In the WTO dispute settlement context, the matter of "securing compliance" was first looked at in the GATT panel context in EEC-Parts and Components. The Panel in this dispute suggested that "securing compliance with laws and regulations" in Article XX(d) of GATT "covers only measure relating to the enforcement of obligations (emphasis added)",2259 or in other words, measures relating to actions that would be illegal under such laws and regulations and not to the "substantially broader" goal of securing the objectives underlying such laws and regulations ${ }^{2260}$. Therefore, regulations that create a legal framework for regulatory authorities, but does not establish obligations that require enforcement are not covered under the Article XX(d) exception.

The Panel in US-Gasoline followed this standard, stating that the United States could not justify its measures in that instance as necessary to "secure compliance" as the measures at issue in this dispute were not an enforcement mechanism relating to specific "laws and regulations" but were only rules for determining baseline establishment methods for

${ }^{2258}$ Panel Report, Mexico-Taxes on Soft Drinks, paras.8.175-8.176. It was further added at para.8.177 that this interpretation is also confirmed by the Appellate Body's use of the expression enforcement instrument" when referring to measures covered by paragraph (d) (citing the Appellate Body Report, Korea-Various Measures on Beef, paras.162-163; the Panel Report, US-Gasoline, para. 6.33; and the GATT Panel Report, EEC-Parts and Components, paras.5.17-5.18).

${ }^{2259}$ GATT Panel Report, EEC-Parts and Components, Para 5.18.

${ }^{2260}$ GATT Panel Report, EEC-Parts and Components, para 515-518. Also see Panel Report, ColombiaPorts of Entry, para. 7.538; Panel Report, Canada-Periodicals, para. 5.9; Panel Report, Mexico-Taxes on Soft Drinks, para. 8.175. 
imported and domestic gasoline. Therefore, the Panel concluded that these were "not the type of measures with which Article XX(d) was concerned". ${ }^{2261}$

The Panel in US-Gambling also referred back to earlier jurisprudence and stressed that measures must enforce legal obligations rather than "merely ensure the attainment of the objectives of those laws and regulations" but also added that measures need not be exclusively for the purpose of securing compliance - it is sufficient if it is part of the reason that the measure was put into place. ${ }^{2262}$ More recently, the Appellate Body in Argentina-Financial Services emphasized that there was no justification under Article $\mathrm{XIV}(\mathrm{c})$ of the GATS for a measure that was not designed to secure compliance with a Members' laws and regulations, adding that the analyses of the necessity test may overlap in the sense that some considerations may be relevant to both "securing compliance" and "necessary". 2263 The Appellate Body in Colombia-Textiles also addressed a similar issue as to whether the relevant measure (a compound tariff) was "designed" to secure compliance with domestic laws or regulations that were a "disincentive' for money laundering (particularly Article 323 of Colombia's Criminal Code); and found that the measure was within the meaning of Article XX(d) of the GATT 1994. ${ }^{2264}$ However, the Appellate Body went on to find that a proper weighing and balancing that could lead to a conclusion that the measure was "necessary" could not be conducted due to the "lack of sufficient clarity" as to "the degree of contribution of the measure at issue to securing compliance" with the relevant domestic law, and "the degree of trade-restrictiveness of the measure". 2265

The GATT Panel in EEC-Parts and Components abovementioned, reasoned that to include the enforcement of underlying policy objectives would mean that whenever the objectives of an otherwise (GATT) consistent law cannot be achieved by enforcing the obligations already specified under that law, that new obligations could then be imposed through additional measures and justified under Article $\mathrm{XX}(\mathrm{d})$, and that this could not have been the intention. It could be argued in counter to this position that if the purpose of the exception is indeed to allow for national policy flexibility, this interpretation would be an additional limitation of intended policy space, rather than an unwanted expansion to unintended consequences.

It was highlighted by the Appellate Body in Mexico-Taxes on Soft Drinks, "the terms "to secure compliance' circumscribe the scope of Article XX(d)" 2266 and are not meant to be used to broaden the scope of "laws and regulations". But in this particular instance, the Appellate Body was specifically referring to whether international countermeasures should be recognized under "laws and regulations" and that the inclusion of the objective of securing compliance with international obligations is tied up with the expansion of scope of the term "laws and regulations". It is interesting that the Appellate Body also adds that accepting such an interpretation will have consequences for securing compliance with WTO obligations as well, as they are also "international obligations". If the same logic used by Mexico in this dispute is used, the Appellate Body states,

\footnotetext{
${ }^{2261}$ Panel Report, US-Gasoline, para. 6.33

${ }^{2262}$ Panel report, US-Gambling, Para 6.538- 6.539

${ }^{2263}$ Appellate Body Report, Argentina-Financial Services, paras.6.203-6.204.

${ }^{2264}$ Appellate Body Report, Colombia-Textiles paras.6.8-6.9, reversing the Panel's finding in para.7.519 of the Panel Report.

${ }^{2265}$ Appellate Body Report, Colombia-Textiles para.6.10.

${ }^{2266}$ Appellate Body Report, Mexico-Taxes on Soft Drinks, para 71
} 
members would be able to use unilateral countermeasures justified by the general exceptions instead of complying with the rules under Articles 22 and 23 of the DSU and Article XXIII:2 of the GATT 1994 (or Article XXIII:2 of the GATS). ${ }^{2267}$

However, it should be noted that the Appellate Body in Mexico-Taxes on Soft Drinks disagreed with the emphasis of the Panel on coercion and certainty in the context of the interpretation of "secure compliance with" - which were also means of circumscribing the scope of the exception. The Panel in Mexico-Soft Drinks had, in addition to its analysis on "laws and regulations" as excluding international agreements, had also based its rejection of countermeasures as a justifiable measure based on the interpretation of "secure compliance" as "enforcement". The Panel noted that the Draft Articles on Responsibility of States for Internationally Wrongful Acts adopted by the International Law Commission do not speak of enforcement when addressing the use of countermeasures in draft Article 49 (1) but to the term "induce". ${ }^{268}$ Further, the possibility of countermeasures to persuade other states is, according to the Panel, "itself an acknowledgement of the absence of any international body with enforcement powers". ${ }^{2269}$ This was seen as a sufficient indication that countermeasures cannot "secure compliance with" anything, only "induce" certain behaviour. As inducement did not involve coercion, the measure therefore did not fall within the scope "to secure compliance with" of Article XX(d) of GATT. The Appellate Body, although agreeing with the analysis on "laws and regulations", did not agree that coercion was a necessary feature of securing compliance. ${ }^{2270}$

The Appellate Body in Mexico-Taxes on Soft Drinks also disagreed on the issue of certainty, as mentioned above. The submissions of the European Communities that "even within the domestic legal order of WTO Members, enforcement of laws and regulations may not simply be taken for granted, but may depend on numerous factors" 2271 was taken into account in this regard. It was also stated by the Appellate Body that the Panel's reliance on US-Gambling in this matter was incorrect, ${ }^{2272}$ as the context in US-Gambling was with regard to the "necessity" analysis under Article XIV(a) and not related to the term "to secure compliance with" in Article XIV(c) ${ }^{2273}$ It was clarified that a measure not suitable for or not capable of securing compliance will not meet the requirement of "necessary".

According to the Appellate Body in Mexico-Taxes on Soft Drinks, the discussion on securing compliance also relates to the design of the measures sought to be justified under

\footnotetext{
${ }^{2267}$ Ibid., para 77.

${ }^{2268}$ Panel Report, Mexico-Taxes on Soft Drinks, para 8.180

${ }^{2269}$ Panel Report, Mexico-Taxes on Soft Drinks, para 8.178

${ }^{2270}$ Appellate Body Report, Mexico-Taxes on Soft Drinks, para 74-75.

${ }^{2271}$ Ibid footnote 165 - the European Communities' third participant's submission, para. 28

2272 Panel Report, Mexico-Taxes on Soft Drinks, paras.8.187-8.188 (referring to Appellate Body Report, US

- Gambling, para. 317). Panel Report, Mexico-Taxes on Soft Drinks, para 8.197: ... on the facts of the case, because of the uncertainty of their consequences, the challenged measures are not designed "to secure compliance with laws or regulations which are not inconsistent with the provisions" of GATT 1994 [emphasis added]

2273 Appellate Body Report, Mexico-Taxes on Soft Drinks, para.74. It was further stated that the Appellate Body had previously explained that: ... 'contribution made by the compliance measure to the enforcement of the law or regulation at issue' is one of the factors that must be weighed and balanced to determine whether a measure is "necessary" within the meaning of Article XX(d).

- Appellate Body Report, Korea - Various Measures on Beef, para.164.
} 
the relevant exception, adding that there is no justification under Article $\mathrm{XX}(\mathrm{d})$ for a measure that is not designed 'to secure compliance' with a Member's laws or regulations. ${ }^{2274}$ This analysis was examined by the Panel in China-Auto Parts, which cited it as support for dividing the requirement of "to secure compliance", into two parts:

1. Whether the challenged measure is "designed" to secure compliance with the law or regulation concerned; and

2. Whether the measure in fact "secures compliance with" the law or regulation. ${ }^{2275}$

Thus, it appears that the Appellate Body focused more on whether the measure was designed to secure compliance and whether there was some evidence of it being capable to do so, rather than whether the measure was 'certain' to secure compliance. This appears to be in line with the requirements under Article XX(d) of the GATT as stated in Korea-Various Measures on Beef which also uses the term "designed" in its breakdown of the elements. ${ }^{2276}$

With regard to how a measure is to be determined as "designed" to secure compliance with the law or regulation concerned, in Colombia-Ports of Entry, the Panel agreed that Colombia had demonstrated that the preambles and relevant provisions of laws and regulations at issue and the evidence presented on the circumstances surrounding the implementation of the disputed ports of entry measure (including data on and various steps taken to combat the problems of contraband goods and under-invoicing) demonstrated that the measure had been "designed to secure compliance..." as required by the legal standard. ${ }^{2277}$ Therefore it can be assumed that both evidence in the form of the relevant laws and regulations as well as other factual evidence demonstrating the circumstances, can be taken into account. If "design", which is not a term used in the texts of the exceptions (Article XX(d) of the GATT and Article XIV(c) of the GATS), is a requirement, does a Member raising either of the exceptions as a defence have to provide evidence of intention to achieve particular results? Or can the intention be determined prima facie from the existence and nature of the measure? If a Member cannot provide evidence that there was an intention to achieve a particular result and is thus unable to prove "design", would the Member be in a position of being found to have violated its WTO obligations as an unintentional result of the measure or measures taken by them? Can a Member attempt to justify both intentional violations with regard to these

2274 Appellate Body Report, Mexico-Taxes on Soft Drinks, para.72. The Panel in Mexico-Taxes on Soft Drinks also noted this:

The question of whether the measure identified by Mexico is designed to secure compliance is therefore one that must be addressed by the Panel. "The considerations that influenced the Panel in reaching a conclusion regarding the phrase "to secure compliance" ... are also relevant to answering this question [emphasis in original]

- Panel Report, para 8.184. Also cited were - the Appellate Body Report, Korea-Various Measures on Beef, para.157 and the Panel Report, Korea - Various Measures on Beef, paras.655-658.

${ }^{2275}$ Panel Report, China-Auto Parts, para. 7.299. The Panel in this instance, referred to this issue of design of measures as something that had been analyzed in several prior disputes mentioning the Panel Report on EC - Tariff Preferences, para. 7.200; and in footnote 550 to the Appellate Body Report on Japan Alcoholic Beverages II, page 29, Argentina - Textiles and Apparel, para.55 and US-Shrimp, para. 137. The Panel in China-Auto Parts believed that these references were relevant although the context was not 'measures securing compliance with laws and regulations not inconsistent with WTO obligations', but measures under different exceptions.

2276 Appellate Body Report, Korea-Various Measures on Beef, para.157:

First, the measure must be one designed to "secure compliance" with laws or regulations that are not themselves inconsistent with some provision of the GATT 1994.

${ }^{2277}$ Panel Report, Colombia -Ports of Entry, para.7.536- 7.543 
particular exceptions, as well as to justify accidental ones made through measures that were not carefully thought out (unless a clever ex post facto rationalization is made)?

It appears that there is a preference for a limitation of the scope of the exception in the "secure compliance with laws and regulations" provision, which has the potential to become quite broad, and the interpretation of it as "enforcement" is seen as a method of limitation. ${ }^{2278}$ But clearly, there are "laws and regulations" in normal domestic law that are not related to enforcing compliance, but merely create institutions for policy planning of a particular matter or for co-ordination purposes or as information clearing-houses, grant certain policy-making powers to persons or institutions, create broad guidelines for the use and management of resources and incorporate international standards of normative nature into domestic law. Measures that secure compliance of domestic and foreign service suppliers with such laws and regulations by laying down obligations to follow procedures and recommendations, will naturally be related to underlying objectives. It is very possible that these situations could involve objectives related to good governance, human rights and environment issues. In the context of Article XIV(c) of the GATS, Argentina explained to the Panel in Argentina-Financial Services that, while the measures at issue seek to ensure compliance with Argentine laws or regulations, these are, in turn, in line with the international instruments of the Global Forum and the Financial Action Task Force (FATF) Recommendations, International Standards on Combating Money Laundering and the Financing of Terrorism and Proliferation $(2012){ }^{2279}$

Even if these sorts of measures are prima facie not inconsistent with the WTO agreements and the GATS, the resort to Article XIV(c) in such situations may in practice be secondary to the defence under Article XIV(a) or Article XIV(b) of the GATS. It could also be that when Article XX(d) of the GATT 1994 or Article XIV(c) of the GATS is raised together with another exception, such as public morals, public order or human, animal, plant life or health, it is more likely to be provisionally justified under the alternate exception, which could have less requirements to fulfill under its legal standard and possibly, a broader scope.

In EU-Energy Package, Article XIV(c) of the GATS could have been interpreted, but since the complainant, Russia, did not demonstrate to the Panel that one of the measures in the dispute (the public body measure in the national implementing laws of Croatia, Hungary and Lithuania) was inconsistent with Article XVII of the GATS, the Panel did not consider it necessary to rule on the European Union's relevant defence under Article $\mathrm{XIV}(\mathrm{c})$ of the GATS. The European Union also raised Article XIV(c) together with Article XIV $(a)$ of the GATS (with regard to public order - the security of energy supply), in the context of a defence for the unbundling measure in the national implementing laws of Croatia, Hungary and Lithuania. However, the Panel stated that since Russia has not demonstrated that the GATS-inconsistency (relating to Article XVI:2 of the GATS) of the unbundling measure, the Panel again did not consider it necessary to rule on the defences of Articles XIV(a) and (c) of the GATS.

\footnotetext{
${ }^{2278}$ See further, Ortino, Federico, BASIC LEGAL INSTRUMENTS FOR THE LIBERALISATION OF TRADE: A COMPARATIVE ANALYSIS OF EC AND WTO LAW, Hart Publishing, 2004, p199-201 commenting that compliance does not have to be interpreted exclusively as "to enforce".

${ }^{2279}$ Panel Report, Argentina-Financial Services, para.7.534; Appellate Body Report, Argentina-Financial Services, para.1.4.
} 
A dispute relating to public health which could resort to the exceptions of public morals and human health may also include Article XIV(c) in its defence, if the measures are laws and regulations which are otherwise not inconsistent with the GATS. If such a dispute occurs, the relevant jurisprudence on Article XIV(c) could become useful, unless other paragraphs of Article XIV are sufficient as a defence and the dispute settlement bodies decide on judicial economy, or like EU-Energy Package, there is no need to raise a defence due to the lack of GATS inconsistency of the measure. Thus, while most proponents of policy space for health or protection of public health services refer to paragraphs (a) and (b) of Article XIV of the GATS, it is possible that there could be role for paragraph (c) to play. 


\subsection{THE NEXUS - INCLUDING "THE NECESSITY TEST"}

...she decided on going into the garden at once; but, alas for poor Alice! when she got to the door, she found she had forgotten the little golden key, and when she went back to the table for it, she found she could not possibly reach it...

From Lewis Carroll's Alice in Wonderland

\subsubsection{The Existence of a Sufficient Nexus between the Measure and the Interest Protected.}

\subsubsection{Introduction to "the Necessity Test" in WTO Law}

The use of one word, 'necessary', was a slender reed indeed on which to hang such an extensive and complex set of obligations. ${ }^{2280}$

The reference to "The Necessity Test" when glancing at WTO-related literature can give an impression that there is one common concept of 'Necessity Test', but this is a bit misleading. There are in fact a number of different provisions in WTO agreements that refer to a necessity requirement. These include Articles XX and XI of the GATT; Articles XIV, VI:4 and Article XII:2(d) of the GATS; Section 5(e) of the Annex on Telecommunications; Articles 2.2 and 2.5 of the TBT Agreement; Articles 2.2 and 5.6 of the SPS Agreement; Articles 3.2, 8.1 and 27.2 of the TRIPS Agreement; and Article 23.2 of the Agreement on Government Procurement. Overall, a 'necessity test' emphasises that Members understand that their obligations "should not be deviated from lightly". ${ }^{2281}$ But at the same time it should be able to balance policy flexibility and autonomy with adherence to substantive and procedural obligations undertaken.

It is possible that there may be differences in the way the term 'necessity' is interpreted in the different WTO agreements and documents, as in each instance it is not only the literal or dictionary definition of necessary, but the context and object-and-purpose of each agreement and document that has to be taken into account in a holistic exercise. Therefore, it should be kept in mind that

...in spite of similarities between the wording of necessity tests in different WTO provisions, an interpretation developed in the context of one case cannot be automatically transposable to other provisions. 2282

\footnotetext{
${ }^{2280}$ Panel Report, US-Shrimp, para.3.225.

${ }^{2281}$ Delimatsis, P., Who's afraid of Necessity? And Why it Matters in Lim, A.H. and Bart de Meester Eds., WTO DOMESTIC REGULATION AND SERVICES TRADE: PUTTING PRINCIPLES INTO PRACTICE, Cambridge University Press, 2014, p104.

${ }^{2282}$ WTO, Note by the Secretariat, Working Party on Domestic Regulation, "Necessity Tests" In The WTO, $\mathrm{S} / \mathrm{WPDR} / \mathrm{W} / 27,2$ December 2003, para.4. This document is based on an earlier document, WTO, Note by the Secretariat, Application of the Necessity Test: Issues for Consideration, Job No. 5929, dated 8 October 1999.

See for a contrary view, Delimatsis, P., Who's afraid of Necessity? And Why it Matters in Lim, A.H. and Bart de Meester Eds., WTO DOMESTIC REGULATION AND SERVICES TRADE: PUTTING PRINCIPLES INTO PRACTICE, Cambridge University Press, 2014, p96-97 - who argues that the concept of necessity in GATT/WTO interpretation has "converged across WTO Agreements" and "become a universal concept" and has "virtually acquired constitutional value".
} 
However, it can be assumed that there would be a similar interpretation for the term 'necessary' in the three different paragraphs of Article XIV that use the same term. This approach is supported by the fact that the interpretation of the term "necessary" in Article XX(d) of the GATT 1994 in Korea-Various Measures on Beef was referred to by the Appellate Body when it interpreted Article XX(b) of the GATT 1994 in ECAsbestos. ${ }^{2283}$ This supports the position that the Appellate Body's analysis in KoreaVarious Measures on Beef does not exclusively apply to Article XX(d) of the GATT 1994 but is likely to apply by analogy to all similar necessity tests in Article XX of the GATT 1994.

As there are structural similarities between Article XX of the GATT 1994 and Article XIV of the GATS as mentioned earlier in this Chapter, the necessity test that has been developed for the most part by the Appellate Body in prior GATT 1994 decisions of Korea-Various Measures on Beef and US-Gasoline has been adopted in the context of Article XIV of the GATS in US-Gambling.

\subsubsection{The Two-tiered Approach Revisited}

As mentioned earlier in Section 5.2.1 of the introductory section to this Chapter, the twotiered approach in the application of Article XIV of the GATS must analyse the measure at the heart of the dispute the following manner.

1. Does the measure concerned:

i. Fall within the scope of one of the recognized interests set out in paragraphs (a) to (e) of Article XIV in order to enjoy provisional justification;

ii. Demonstrate the existence of a sufficient nexus (relationship or connection) between the measure and the interest protected; and

2. Does the measure meet the requirements of the introductory provisions of Article XIV, the so-called "chapeau"? 2284

The first step of this approach requires that the Member must establish whether the disputed measure was designed to pursue a certain policy objective which falls within the scope of one of the recognized exceptions set out in paragraphs (a) to (e) of Article XIV in order to enjoy provisional justification. Paragraphs (a), (b) and (c) of Article XIV were discussed in the preceding sections of this Chapter. This first step of analysis also includes a demonstration of the existence of a sufficient nexus (relationship or connection) between the measure and the interest protected. It is at this point of considering the nexus between the measure and the value or interest that many national measures face their strictest test. The WTO disputes concluded thus far show that although the majority of respondents had succeeded in proving that their measure fell within the scope of the exception, most then failed at the hurdle of the nexus.

The need for the measure at issue in a dispute is questioned through the terms used as the nexus. For Article XIV (a), (b) and (c) of the GATS, this term is "necessary, for Article $\mathrm{XIV}(\mathrm{d})$ of the GATS the term is "aimed at" and Article XIV(e) has "the result of" as the relevant term.

In US-Gasoline, where the two-tiered approach to determining an exception clause was first presented, the Appellate Body also looked into the matter of the different terms used

\footnotetext{
${ }^{2283}$ Appellate Body Report on EC - Asbestos, paras. 171-172. Also see Panel Report, US-Gambling Panel para. 3.256.

${ }^{2284}$ See Panel Report, US-Gambling, para.6.449.
} 
as the nexus between the interests protected by paragraphs (a) to (i) of Article XX of the GATT 1994 and the disputed measure. It was observed that

Article XX uses different terms in respect of different categories:

'necessary' - in paragraphs (a), (b) and (d); 'essential' - in paragraph (j); 'relating to' - in paragraphs (c), (e) and (g); 'for the protection of' - in paragraph (f); 'in pursuance of' - in paragraph (h); and 'involving' - in paragraph (i).

It does not seem reasonable to suppose that the WTO Members intended to require, in respect of each and every category, the same kind or degree of connection or relationship between the measure under appraisal and the state interest or policy sought to be promoted or realized. ${ }^{2285}$

However, not all the types of nexus abovementioned have been subject to interpretation. Furthermore, similarity of wording does not by itself lead to similarity in interpretation. It has been noted by the WTO Secretariat that, in spite of the similarity in wording, an interpretation developed in the context of one case with regard to one such provision cannot be automatically transposable to other provisions, as each provision has to be read in light of the object and purpose of the Agreement of which it is part ${ }^{2286}$.

\subsection{2. "Necessary" in Article XIV(a), (b) and (c) of the GATS}

\subsubsection{Introduction}

There are three different types of nexus in the sub-sections of Article XIV of the GATS. There are:

1. "necessary" in Article XIV(a), (b) and (c)

2. "aimed at" in Article XIV(d)

3. "the result of" in Article XIV(e)

Articles XIV(d) and (e) which relate to direct taxation and double taxation measures have not been given much attention in the literature, as there are not usually identified as controversial areas. There is also no mention of these provisions in disputes except for a brief mention of Article XIV(d) being raised as a defence, but without any detailed analysis by the panel or Appellate Body, in Argentina-Financial Services. The terms "aimed at" and "the result of", which appear to be much less complicated than "necessity", have also not been interpreted. Both phrases can be interpreted according to their ordinary meaning:

Aim. 1. A thing aimed at... 6. An end aimed at, an objective, design, intention, purpose...

Result. 4. The effect, consequence, issue or outcome of some action, process or design. ${ }^{2287}$

The term "necessary" on the other hand has been one of the most important and perhaps also one of the most controversial in the dispute settlement context.

The Panel in US-Gambling, in considering the term "necessary" under Article XIV(a) of the GATS looked to the parameters set out by the Appellate Body in Korea-Various Measures on Beef when determining whether a measure was "necessary" within the

\footnotetext{
2285 Appellate Body Report, US-Gasoline, para.804

${ }^{2286}$ WTO, Secretariat, Note to the Working Party on Domestic Regulation, Necessity Tests in the WTO, S/WPDR/W/27, 2 December 2003, para.4.

2287 Brown, Lesley, Ed., THE NEW SHORTER OXFORD ENGLISH DICTIONARY Vol. 1 \& 2, Clarendon Press, 1993.
} 
meaning of Article XX(d) of the GATT $1994 .{ }^{2288}$ The US-Gambling Panel cited the Appellate Body statement in Korea-Various Measures on Beef that:

[T] he reach of the word 'necessary' is not limited to that which is 'indispensable' or 'of absolute necessity' or 'inevitable'...As used in Article $\mathrm{XX}(\mathrm{d})$, the term 'necessary' refers, in our view, to a range of degrees of necessity. At one end of this continuum lies 'necessary' understood as 'indispensable'; at the other end, is 'necessary' taken to mean as 'making a contribution to'. We consider that a 'necessary' measure is, in this continuum, located significantly closer to the pole of 'indispensable' than to the opposite pole of simply 'making a contribution to' [original footnote omitted]. ${ }^{2289}$

The Panel in US-Gambling was of the view that these statements are equally applicable in the context of Article XIV of the GATS, including Article XIV(a), which is what was relied upon in that dispute. ${ }^{2290}$ Therefore the Panel in US-Gambling, continuing to follow the Korea-Various Measures on Beef standard stated that the term "necessary" refers to "a range of degrees of necessity" and that a "necessary measure" in this context is significantly closer to "indispensable" than to "making a contribution to". 2291

The Panel in Mexico-Telecoms also examined the meaning of the term "necessary" in a services context, but it was not in relation to Article XIV of the GATS, but to paragraph 5(e) of the Annex on Telecommunications. This paragraph states as follows:

(e) Each Member shall ensure that no condition is imposed on access to and use of public telecommunications transport networks and services other than as necessary:

(i) to safeguard the public service responsibilities of suppliers of public telecommunications transport networks and services, in particular their ability to make their networks or services available to the public generally;

(ii) to protect the technical integrity of public telecommunications transport networks or services; or

(iii) to ensure that service suppliers of any other Member do not supply services unless permitted pursuant to commitments in the Member's Schedule.

It was noted that the meaning of "necessary" could range from a measure that is "indispensable" to achieving a policy goal, to one that is merely "making a contribution" to that policy goal. ${ }^{2292}$ This echoes the Korea-Various Measures on Beef reference to the "range of degrees of necessity". ${ }^{2293}$ But as the context of Section 5(e) was interpreted as to also require fulfillment of the standard of "reasonable" terms in Section 5(a); and the Panel found that "necessary" in Section 5(e) was closer to "making a contribution" to a policy goal. ${ }^{2294}$ The reference to policy goals in Mexico-Telecoms draws attention to the issue of the importance of the policy goal for the interpretation of 'necessary', which is one of the factors which a panel or Appellate Body would take into account in assessing 'necessary'.

\footnotetext{
${ }^{2288}$ Article XX(d) of the GATT 1994 is textually analogous to Article XIV(c) of the GATS.

${ }^{2289}$ Appellate Body Report on Korea - Various Measures on Beef, para. 161.

${ }^{2290}$ Panel Report, US-Gambling, para.6.575

${ }^{2291}$ Panel Report, US-Gambling, para.6.475.

${ }_{2292}$ Panel Report, Mexico-Telecoms, para.7.338.

2293 Appellate Body Report, Korea-Various Measures on Beef, para.161.

${ }^{2294}$ Panel Report, Mexico-Telecoms, para.7.341-7.342.
} 
The developments in recent disputes show that the determination of necessity requires an assessment of a number of factors. The Panel and Appellate Body in Argentina-Financial Services referred to and relied upon the Appellate Body reports in US-Gambling and ECSeal Products with regard the proper analysis of 'necessity' in the general exceptions provisions. It was stated that:

... a necessity analysis involves a process of "weighing and balancing" a series of factors, including the importance of the objective, the contribution of the measure to that objective, and the trade-restrictiveness of the measure.[and] in most cases, a comparison between the challenged measure and possible alternatives should then be undertaken.

As the Appellate Body [in EC-Seal Products] has stated, "[i]t is on the basis of this 'weighing and balancing' and comparison of measures, taking into account the interests or values at stake, that a panel determines whether a measure is 'necessary' or, alternatively, whether another, WTOconsistent measure is "reasonably available". Such an analysis, the Appellate Body has observed, involves a "holistic" weighing and balancing exercise "that involves putting all the variables of the equation together and evaluating them in relation to each other after having examined them individually, in order to reach an overall judgement". 2295

This clarifies the nature of the process of analysis (a holistic 'weighing and balancing' exercise with regard to the importance of the policy objective pursued) and the factors which should be analyzed.

The factors, as identified in WTO jurisprudence, ${ }^{2296}$ and discussed by commentators, are as listed below:

1. The importance of the policy objective (the greater the importance of the interest that the challenged measure is intended to protect, the more likely it would be considered to be 'necessary');

2. The contribution of the measure to the achievement of the objective pursued by the policy (the greater the extent of the contribution of the challenged measure to the realization of the end pursued by that measure, the more likely it would to be 'necessary');

3. The trade-restrictiveness of the measure (the more slight the trade impact, the more likely it is to be 'necessary').

4. And in most cases, there would also be a consideration of:

(i) a comparison between the challenged measure and possible alternatives should then be undertaken;

(ii) the consideration of whether there is a less trade restrictive alternative measure which could have been taken.

(If a reasonably available WTO-consistent alternative measure exists that achieves the same objective and the trade impact of that measure is less

\footnotetext{
${ }^{2295}$ Appellate Body, Argentina Financial Services, para. 6.182, citing Panel Report, Argentina Financial Services, paras. 7.658-7.661 (referring to Appellate Body Reports, US-Gambling, para. 304; and EC-Seal Products, paras. 5.169 and 5.214).

${ }^{2296}$ Panel Report, US-Gambling, para.6.476-6.477, citing the earlier decisions of the Appellate Body in Korea-Various Measures on Beef and EC-Asbestos - in particular, the Appellate Body Report, KoreaVarious Measures on Beef, paras.162, 163 and 166. Also, the Appellate Body Report, US-Gambling, para.306.
} 
than the challenged measure, the measure at issue may be considered as not 'necessary').

These factors are discussed in more detail in the following sections.

\subsubsection{The Importance of the Policy Objective}

It would be beneficial for Members defending measures that are deemed by them as 'necessary' for protecting and promoting a vital societal value, if the importance of the policy goal is taken into account.

In Korea-Various Measures on Beef (and affirmed in US-Gambling), the Appellate Body has suggested that if the value or interest pursued is considered important, it is more likely that the measure is "necessary". 2297 Panel and Appellate Body reports have generally acknowledged certain objectives as important, for example, that the objective of combating money laundering was deemed to reflect "societal interests that can be described as vital and important in the highest degree" (in Argentina-Financial Services and Colombia-Textiles). ${ }^{2298}$

This kind of recognition of importance of the policy objective was also confirmed by the Appellate Body in EC-Asbestos in the context of the protection of human life or health from the effects of asbestos: emphasizing that the protection of health was "both vital and important in the highest degree". ${ }^{2299}$ Several later dispute settlement reports also affirmed this position of the vital importance of health, including by the Panel in AustraliaTobacco Plain Packaging ${ }^{2300}$ and the Appellate Body in Brazil-Retreaded Tyres, which stated that "few interests are more 'vital' and 'important' than protecting human beings from health risk". ${ }^{2301}$ Protecting the human right to health, especially the affordability, accessibility and quality of public health services would certainly fall within the conception of important, so raising such an argument could be part of an necessity analysis. Public health by itself, without reference to the human right to health is already considered important in the WTO context.

The importance of a policy goal was also raised by China in China-Publications and Audiovisual Products, arguing that the importance of the value pursued by the measures at issue was for them a matter of public morality which was "a value of vital importance for China ... [and] there are few values of such importance" - and adding that it was "a crucial policy issue in virtually all States and forms a central element of social cohesion and the ability of communities to live together". ${ }^{2302}$ The context of this dispute, that the

\footnotetext{
${ }^{2297}$ Appellate Body Report, Korea - Various Measures on Beef, para.162 in the context of Article XX(d) of the GATT 1994; also cited by Panel in US-Gambling at para.3.389, in the context of Article XIV(a) of the GATS:

The more vital those common interests or values are [that the law or regulation is enforced to protect], the easier it would be to accept as "necessary" a measure designed as an enforcement instrument.

2298 Panel Report, US-Gambling, paras.6.492 and 6.493; Panel Report, Argentina-Financial Services, para.7.682 and paras.7.664-7.671; Appellate Body Report, Argentina-Financial Services, paras.6.1916.192; Appellate Body Report, Colombia Textiles, para.5.105.

2299 Appellate Body Report, EC-Asbestos, para.172.

${ }^{2300}$ Panel Report, Australia-Tobacco Plain Packaging, para.7.2587, para7.247 (referencing EC-Asbestos and in relation to the TBT and TRIPS provisions on health as a legitimate objective of regulatory measures).

${ }^{2301}$ Appellate Body Report, Brazil-Retreaded Tyres, para. 144.

2302 Panel Report, China-Publications and Audiovisual Products, para.7.794
} 
selection of import entities is "necessary" to protect public morals (under Article XX(a) of the GATT) within China is a matter that other Members may see as censorship and suppression of freedom of expression in addition to being a restriction on trade. So, this begs the question whether the importance of the measure is decided solely by the Member? Yet is a Panel or the Appellate Body the suitable body to evaluate the importance of a national policy goal? Moreover, there has been no rationale or methodology developed (and perhaps there should not be one) for accepting or rejecting what a Member may claim as important. Some authors argue that perhaps there should be a criterion of commonality of interests required for 'importance' but admit there is no basis in Article XX of the GATT 1994 (or Article XIV of the GATS) for such a requirement. ${ }^{2303}$

Other international law could be cited for evidence if commonality of interests would be considered as relevant; and in the situation of censorship it could be discussed in light of international human rights norms and obligations. Freedom of expression and the right to information which is in Article 19 of the ICCPR states that:

Article19(2). Everyone shall have the right to freedom of expression; this right shall include freedom to seek, receive and impart information and ideas of all kinds, regardless of frontiers, either orally, in writing or in print, in the form of art, or through any other media of his choice [emphasis added].

General Comment No.34 emphasizes that this right includes cultural and artistic expression and all forms of audio-visual expression and the means for their dissemination. ${ }^{2304}$ Article 19 is itself limited by protection for public health, public morals, national security or public order according to Article 19(3). The limits of the application of Article 19(3) is described in the General Comment as follows:

...when a State party imposes restrictions on the exercise of freedom of expression, these may not put in jeopardy the right itself. The Committee recalls that the relation between right and restriction and between norm and exception must not be reversed... and they must conform to the strict tests of necessity and proportionality... A law may not confer unfettered discretion for the restriction of freedom of expression on those charged with its execution. ${ }^{2305}$

Regarding limitations to freedom of expression and right to information which are based on public morals justifications, the General Comment notes that such limitations "must be understood in the light of universality of human rights and the principle of nondiscrimination"; thus, a China-specific set of morals or different application to domestic and foreign audio-visual media could not have been justified under public morals in a human rights context. If these standards were applied to China's public morals arguments, a more in-depth look at the justifications for the limitation of audio-visual

\footnotetext{
2303 McGrady, Benn, Necessity Exceptions in WTO Law: Retreaded Tyres, Regulatory Purpose and Cumulative Regulatory Measures, Journal of International Economic Law 2009 12(1):153-173, footnote 41 citing Charnovitz, Steve, An Analysis of Pascal Lamy's Proposal on Collective Preferences, Journal of International Economic Law, 8(2), 2005, 449, p468.

${ }^{2304}$ UN Human Rights Committee, General Comment No. 34 - Article 19: Freedoms of opinion and expression, CCPR/C/GC/34, 12 September 2011, para 11 and 12.

${ }^{2305}$ UN Human Rights Committee, General Comment No. 34 - Article 19: Freedoms of opinion and expression, CCPR/C/GC/34, 12 September 201, para.21, 22 and 25, cross referencing General Comment No. 27 and HRC Communication No. 1022/2001, Velichkin v. Belarus, views adopted on 20 October 2005. See also para 33-36.
} 
products and the methods used for doing so could have occurred. However, the use of human rights standards has not been brought into WTO dispute settlement thus far.

One aspect of EC-Tariff Preferences concerned the life or health objective in Article XX(b) of the GATT 1994. The Panel also referred back to Korea-Various Measures on Beef when it considered the necessity nexus between the EC Drug Arrangements that linked GSP benefits with action against illicit drugs and the stated health objective of reduction of illicit drugs trafficked into the EC. The Panel noted, among other relevant points, that since some drug-producing countries were outside of the scheme, the Drug Arrangements are not contributing sufficiently to the reduction of drug supply to the EC's market. The Panel also concluded that the measure was not necessary to achieving the health objective stated by the EC as:

The whole design of the EC Regulation does not support the European Communities' contention that it is 'necessary' to the protection of human life and health in the European Communities, because such design of the measure does not contribute sufficiently to the achievement of the health objective [emphasis added]. ${ }^{2306}$

Thus, the nexus of "necessary" must 'contribute sufficiently' to the achievement of the stated objective - being closer to 'indispensable' than merely 'contributes to' the stated policy goal. Delimatsis comments that the common feature of the concept of 'necessity' across WTO agreements is that it includes the idea of the justiciability of means (measures) and not ends (policy objectives). ${ }^{2307}$

In the Brazil-Retreaded Tyres dispute, the value that the measure sought to protect was also health under Article XX(b). Although the measure failed at the chapeau, with regard to the necessity test, the result was that it can be deemed acceptable to evaluate the contribution of the measure taking into account the cumulative (and 'future' impact) of the measure taken together with other policy measures. The qualitative approach taken by the Panel and Appellate Body in this dispute also appears to be not as strict with regard to the evidence of scientific risk assessment of alleged health protection measures. A more common-sense approach to evidence of risk appears to have been taken with regard to this situation of the disposal of waste tyres. This may also be due to the fact that the EC, the complainant, did not dispute the scientific evidence submitted by Brazil. ${ }^{2308}$ The risk in this case was linked to the necessity of an import ban on retreaded tyres instead of any other alternative measure, with the health risks being easily accepted as being caused by waste tyres. The Appellate Body agreed that the landfilling of waste tyres may pose risks of "instability of sites that will affect future land reclamation, long-term leaching of toxic substances, and the risk of tyre fires and mosquito-borne diseases" and both stockpiling and incineration pose risks to human, animal, plant life or health. ${ }^{2309}$ The Appellate Body concluded that waste tyres carry "risks for public health and the environment" which

\footnotetext{
${ }^{2306}$ Panel Report, EC-Tariff Preferences, para.7.211.

2307 Delimatsis, Panagiotis., Who's afraid of Necessity? And Why it Matters in Lim, A.H. and Bart de Meester Eds., WTO DOMESTIC REGULATION AND SERVICES TRADE: PUTTING PRINCIPLES INTO PRACTICE, Cambridge University Press, 2014, p96.

2308 Appellate Body Report, Brazil Tyres, para.11: the EC emphasising "this is not a case involving scientific uncertainty about the existence of risks" but about contribution of the measure to the aim.

The evidence presented by Brazil is referred to in the Panel Report, paras. 7.188, 7.189 and 7.192 and footnotes 1330-1331 and 1339-1342; as well as footnotes 382-385 of the Appellate Body Report.

${ }^{2309}$ Appellate Body Report, Brazil Tyres, para.163, citing the Panel Report, para 7.183. Also see paras.170 and 174 and the specific mention of "risks of dengue fever and malaria" in para.179 (presumably referring to the possibility of waste tyres becoming mosquito breeding sites).
} 
governments can legitimately take action to minimize, including import bans for retreaded tyres, especially since that would be a measure that would not involve "prohibitive costs or substantial technical difficulties". ${ }^{2310}$

Thus, it does not appear that there is any problem in recognizing that health is an important policy goal for WTO Members, whether under Article XX(b) of GATT 1994 or other similar exception provisions which allow for health considerations such as Article XIV(b) of the GATS, or as legitimate policy allowed under TBT or SPS Agreement. However, the measures taken for the health should be WTO-consistent in so far as it can fall within the scope of the available exceptions. In terms of GATT 1994 and the GATS, the necessity test is used to decide whether the national policies can stand within the requirements of WTO law. If a Member fails in this aspect, it is not meant to reflect negatively on the importance of health as a policy goal. The Panel in US-Clove Cigarettes declined to rule on whether the US measure at issue was justified under Article XX(b) of the GATT 1994, however, the Panel began its analysis emphasizing that:

...measures to protect public health are of the utmost importance, and that the WTO Agreements fully recognize and respect the sovereign right of Members to regulate in response to legitimate public health concerns. ${ }^{2311}$

In the context of the above comments, the Panel referred to the Doha Declaration on Public Health, 2001 in general - and with regard to the issue of tobacco control in the specific dispute, the WHO Framework Convention on Tobacco Control (WHO-FCTC) and its related WHO Partial Guidelines. ${ }^{2312}$ Although the ICESCR or regional conventions which include the right to health have not been raised in WTO dispute settlement contexts, it could be noted that the Preamble of WHO FCTC referred to by the Panel and Appellate Body in the above cases, begins by stating that State Parties are "[d]etermined to give priority to their right to protect public health" and also recalls Article 12 of the International Covenant on Economic, Social and Cultural Rights (the right to health).

\subsubsection{Reasonably Available Alternative Measures and the Level of Protection}

Necessity does not equate to 'zero alternatives' in the WTO dispute settlement context, ${ }^{2313}$ but there needs to be consideration by the panel of what kind of alternatives to a measure exist, in order to decide on the necessity of the measure at issue. Once the analysis by the panel yields a preliminary conclusion that the measure is necessary:

... this result must be confirmed by comparing the measure with its possible alternatives, which may be less trade restrictive while providing an equivalent contribution to the achievement of the objective pursued. ${ }^{2314}$

The balance that that must be achieved in determining whether alternative measures are available can be represented by the terms 'less trade restrictive' on one side and 'equivalent contribution to achievement of objectives' on the other side. The Panel and Appellate Body in Brazil-Retreaded Tyres both agreed that an alternative measure has to

\footnotetext{
${ }^{2310}$ Ibid., at para. 171.

${ }^{2311}$ Panel Report, US-Clove Cigarettes, para.7.2. Also see paras.7.3-7.6, citing the Appellate Body Report, EC-Asbestos, para. 172 and the Appellate Body Report, Brazil-Retreaded Tyres, para. 144.

${ }^{2312}$ Ibid, paras.7.3-7.6.

2313 See Appellate Body Report, US-Gambling para.309:

A member does not have to "show, in the first instance, that there are no reasonably available alternatives to achieve its objectives" [original emphasis].

${ }^{2314}$ Appellate Body Report, Brazil-Retreaded Tyres, para.156.
} 
be a substitute and not a complementary measure to the measure being challenged in dispute settlement. ${ }^{2315}$ In addition to being an alternative measure that achieves this balance to the satisfaction of the panel (or Appellate Body), the aforesaid alternative measure should also be reasonably available to the responding Member.

It is important that the 'level of protection' that the Member wishes to maintain, could be maintained by an alternative measure. It has been often stated that a Member has the right to choose the level of protection it wishes ${ }^{2316}$ and the WTO dispute settlement has been said to have shown a "highly deferential approach"2317 to the level of protection a Member has chosen to achieve a particular objective. The Appellate Body in USGambling has clearly stated that:

...a "reasonably available" alternative measure must be a measure that would preserve for the responding Member its right to achieve its desired level of protection with respect to the objective pursued under the relevant paragraph of Article XIV. ${ }^{2318}$

However, the intense scrutiny of the relationship between the objective and the measure in question has usually meant that the level of protection is a part of that analysis of the factors in the necessity test. Analyzing the level of protection of a measure is included in the question as to whether there is a reasonably available alternative measure to achieve the objective pursued. If the level of protection the Member wishes to achieve is not considered in that analysis, there cannot be an effective evaluation of whether reasonably available alternative which achieve the same level of protection are available. Thus, while there is policy space to decide the level of protection, the specific measure is still questioned through the analysis of whether a Member has considered reasonably available alternatives, which achieve the same level of protection but are less trade restrictive than the chosen measure.

The Appellate Body in US-Gambling has emphasized this point, stating that if an alternative measure proposed by a complainant does not allow a Member to achieve the same level of protection, it is not a "genuine" alternative. ${ }^{2319}$ The Appellate Body has also stated that it is up to the complaining Member to identify possible alternatives that could have taken, and furthermore that these alternatives should be ones capable of being implemented and not "merely theoretical" alternatives. ${ }^{2320}$ The Panel in EC-Asbestos, dealing with an exception under Article XX(b) of the GATT for the protection of human

\footnotetext{
2315 Ibid. See also Zleptnig, Stefan, NON-ECONOMIC OBJECTIVES IN WTO LAW: JUSTIFICATION PROVISIONS OF GATT, GATS, SPS AND TBT AGREEMENTS, Nijhoff International Trade Law Series, 2010, p242-243.

${ }^{2316}$ For example, zero risk policy for asbestos related health risks (Appellate Body EC-Asbestos, para. 168); zero tolerance for cigarette tax collection and smuggling (Panel Report, Dominican Republic-Import and Sale of Cigarettes, para.7.228)

2317 Zleptnig, Stefan, NON-ECONOMIC OBJECTIVES IN WTO LAW: JUSTIFICATION PROVISIONS OF GATT, GATS, SPS AND TBT AGREEMENTS, Nijhoff International Trade Law Series, 2010, p228

2318 Appellate Body Report, US-Gambling, para.307, citing Appellate Body Report, EC-Asbestos, paras. 172-174 and Appellate Body Report, Korea-Various Measures on Beef, para. 180. See also Van den Bossche, Peter, Looking for Proportionality in WTO Law, Legal Issues of Economic Integration, 35(3), 283-294, 2008, p293:

The Appellate Body in US-Gambling found yet another occasion to reiterate that the level of protection was sacrosanct.

${ }^{2319}$ Appellate Body Report, US -Gambling, para.308 and para.311.

${ }^{2320}$ Appellate Body Report, US-Gambling, para.156, 311.Also see paras.307 and 316.
} 
health, highlighted that the "availability of a measure should not be examined theoretically or in absolute terms [emphasis added]". ${ }^{2321}$

If there is another measure that was reasonably available, that could have been adopted and could have contributed sufficiently to the stated policy goal, and would be less trade restrictive, WTO law would question the necessity of the original measure. This analysis was originally used in GATT jurisprudence and later became part of the WTO. The GATT Panel case US-Section 337 Tariff Act, in the context of Article XX(d) of the GATT, clarified this aspect of 'necessity', stating that:

... a contracting party is bound to use, among the measures reasonably available to it, that which entails the least degree of inconsistency with other GATT provisions [emphasis added]. ${ }^{2322}$

Thus, the policy space for a Member does not appear at first to take into account other factors that may have made the challenged measure seem suitable to the Member (e.g. easier to implement, less costly, does not need extra training of personnel, more environmentally friendly, more acceptable to the general public etc.) if there is a reasonably available alternative measure that is WTO consistent and had the least 'negative' impact on trade obligations.

Zleptnig comments that the earlier elaboration of reasonably available alternative measure and trade restrictiveness under GATT in the US-Section 337 Tariff Act and Thailand-Cigarettes disputes can be seen as 'rigid' and that moreover they been criticized for imposing too many constraints on a Member's right to regulate. ${ }^{2323}$ In the trade context this original terminology of 'least trade restrictive' measure has been replaced as is now referred to in WTO law as a 'reasonably available alternative measure, ${ }^{2324}$ Thus the terminology of 'least trade restrictive alternative' has given way in WTO dispute settlement to the concept that if there is a less trade restrictive alternative than the challenged measure, the measure could be considered as not 'necessary'. ${ }^{2325}$ This shift of emphasis in terminology suggests a little more policy space,

\footnotetext{
${ }^{2321}$ Panel Report, EC-Asbestos, Para.8.207.

2322 GATT Panel Report, US-Section 337 Tariff Act, para.5.26.
}

The Panel in US-Gambling at para.6.496 also referred to the well-established analysis of both the Appellate Body in Korea - Various Measures on Beef, para.165 and the GATT Panel in US-Section 337 Tariff Act, para. 5.26.

${ }^{2323}$ Zleptnig, Stefan, NON-ECONOMIC OBJECTIVES IN THE IN WTO LAW: JUSTIFICATION PROVISIONS OF THE GATT, GATS, SPS AND TBT AGREEMENTS, Martinus Nijhoff Publishers, $2010, \mathrm{p} 231$.

${ }^{2324}$ Sykes notes that the term "least restrictive means" originated in American law and is found in US Constitutional law in Dormant Commerce Clause Cases and in NAFTA as well the WTO (Sykes, Alan O., The Least Restrictive Means, University of Chicago Law Review, Vol. 70, No. 1, Centennial Tribute Essays, Winter, 2003, pp. 403-419, p403-404). It would be interesting to see if the apparent hierarchy of trade suggested by the strict 'least trade restrictive' standard of US-Section 337 Tariff Act and followed in some later GATT cases also originates with US-trained professionals. However, Fontanelli traces the introduction of the least trade restrictive measure test in US-Section 337 Tariff Act to suggestions by the EC to the Panel and the fact that Pierre Pescatore, "a former judge at the European Court of Justice and passionate advocate of the process of European integration" was on the Panel (Fontanelli Filippo, Necessity Killed the GATT - Art XX GATT and the Misleading Rhetoric about 'Weighing and Balancing', European Journal of Legal Studies, Volume 5, Issue 2, Autumn/Winter 2012/13, p36-56). The US and European conceptions of least restrictive would be based upon the experience of their own systems and not necessarily identical in scope.

${ }^{2325}$ The WTO Secretariat has also noted this transformation from 'least' to 'less' trade restrictive in WTO, Note by the Secretariat, GATT/WTO Dispute Settlement Practice Relating to GATT Article XX, paragraphs (b), (d) and (g), WT/CTE/W/203, 8 March 2002, para.42. 
as the insistence on choosing the least trade-restrictive measure (as stated in US-Section 337 Tariff Act) appears to have been removed.

In US-Gasoline, the first WTO disputes to deal with necessity tests and 'alternative measures' under the WTO system, the Panel considered whether there were less inconsistent measures which could reasonably achieve the same alternative. ${ }^{2326}$ KoreaVarious Measures on Beef laid the basis for the current approach that carries out a weighing and balancing of the relevant factors of the 'necessity test' and also a consideration of whether there is a less trade restrictive alternative measure that could have reasonably been taken. The issue of reasonably available alternatives was analyzed in detail by the Appellate Body in Brazil-Retreaded Tyres and both this and the approach to weighing and balancing test as a whole was confirmed in EC-Seal Products. ${ }^{2327}$

Delimatsis has analyzed that WTO jurisprudence has only recognized that a measure would not be a reasonably available alternative if:

1. It is merely theoretical and the Member is not capable of implementing it,

2. It is an undue burden e.g. prohibitive costs or substantial technical or administrative difficulties,

3. It would not preserve the right to maintain the desired level of protection ${ }^{2328}$ According to the analysis of Delimatisis it would appear that both feasibility of alternatives and the achievement of the policy objective will be considered. Points 1 and 3 mentioned by Delimatsis have already been discussed above, but a brief mention of Point 2 above, should be added here. The aspect of 'undue burden' was specifically mentioned in the Appellate Body report in US-Gambling as including "prohibitive cost or substantial technical difficulties". ${ }^{2329}$ As can be seen, the mere fact of higher cost will not necessarily be considered relevant, but prohibitive cost that could be seen as an undue burden and would be relevant. Technical or administrative difficulties of implementation per se would not be relevant, but substantial difficulties of implementation would be. In sum, if the other criteria of necessity have been fulfilled (importance of the objective, contribution of the measure to its achievement - and trade restrictiveness also considered) but the same ends could be achieved with an alternative measure, but with only a 'moderate' increase in difficulty, the Member could be questioned as to why they did not adopt the alternative measure. ${ }^{2330}$

The Panel in EC-Asbestos noted that one measure being easier to implement does not mean that another measure is not reasonably available. ${ }^{2331}$ The Panel made particular reference to France being a country with "advanced labour legislation and specialized administrative services" which would be expected to be prepared to "deploy

\footnotetext{
${ }^{2326}$ Panel Report, US-Gasoline, paras.624-626.

${ }^{2327}$ Appellate Body Report, EC-Seals, para.5.214.

${ }^{2328}$ Delimatsis, Panagiotis, Determining the Necessity of Domestic Regulations in Services: The Best is Yet to Come, The European Journal of International Law Vol. 19, No. 2, p365-408.

${ }^{2329}$ Appellate Body Report, US-Gambling, para.307.

${ }^{2330}$ Panel Report, US-Gasoline, paras.6.26 and 6.28 (is reasonably available even if administrative difficulties); Panel Report, EC-Asbestos, paras.8.207-8.216; Appellate Body Report, EC-Asbestos, para.174 (not reasonably available if implementation difficulties, administrative burden, costly, technical difficulties and lack of expertise) Panel Report, Canada-Wheat Exports and Grain Imports, para.6.226; Appellate Body Report, Dominican Republic-Import and Sale of Cigarettes, para.70; Appellate Body Report, USGambling, para. 308; Appellate Body Report, Brazil-Retreaded Tyres, paras.156, 171, 174, 175 and 211 (confirmed earlier case law and clarified the criteria further)

${ }^{2331}$ Panel Report, EC-Asbestos, Para.8.207.
} 
administrative resources proportionate to its public health objectives" and to "incur the necessary expenditure". ${ }^{2332}$ It is possible that although France was identified as a developed country with these features in place, a more lenient view may be taken of difficulties faced by developing countries. However, there is nothing explicit in the GATS for taking developing country or LDC implementation issues into account in a dispute, other than the jurisprudence on the alternative being 'reasonable' and not being an undue burden. The Panel in EC-Asbestos referred to assessing the existence of a reasonably available alternative measure "in light of economic and administrative realities" but also added that "the State must provide itself with the means of implementing its policies". ${ }^{2333}$ It may be argued that it is unfair to demand a Member to spend more public money (not 'prohibitive', but still a higher expenditure and more administrative costs) on a measure which it could just as easily achieve with less expenditure.

Another important feature of the alternative measures reasoning was added in BrazilRetreaded Tyres, and later recognized by the Appellate Body in EC-Seal Products. This feature was the recognition of the fact that measures can be part of a comprehensive and cumulative set of multiple interacting policies, particularly with regard to public health and the environment. ${ }^{234}$ Thus a holistic weighing and balancing exercise to determine "necessary" will look at a number of factors including the level of material contribution to the objective, the potential alternative measures, and the nature, quantity, and quality of evidence without any pre-determined threshold level with regard to contribution. ${ }^{2335}$ It is possible that such a holistic analysis would lead to an understanding of "necessary" that would balance trade and non-trade concerns. If the panels and Appellate Body also take into consideration the other non-WTO State obligations under international law, this could add more weight to the side of non-trade values in the holistic analysis.

Desierto also supports this view, commenting that the WTO dispute settlement bodies should not preclude themselves from considering ICESCR compliance with regard to the holistic weighing and balancing required for the public morals exceptions in Articles XX(a) of the GATT 1994 and Article XIV(a) of the GATS. ${ }^{2336}$ Desierto mentions that a State's obligations under Article 12 of the ICESCR (the right to health) is relevant for Article XX(b) of the GATT 1994 and Article XIV(b) of the GATS; and could "substantiate the evidentiary characterization" of the challenged measures objective, as well to "scrutinize the actual contribution of the challenged measure to the objective".2337 She also states that ICESCR obligations could be relevant for scrutinising reasonableness and good faith (under the chapeaux of the exceptions) with regard to a policy objective. ${ }^{2338}$ However, it can be submitted that Article 12 could be applicable for both "public morals" as well as "human life... or health". Its relevance for the chapeau of Article XIV of the GATS can be discussed further in Section 5.7, which follows this Section 5.6.

\footnotetext{
2332 Panel Report, EC-Asbestos, Para.8.207.

2333 Panel Report, EC-Asbestos, Para.8.207.

${ }^{2334}$ Appellate Body Report, EC-Seal Products, para.5.213 citing Appellate Body Report, Brazil-Retreaded Tyres, para. 150-151.

2335 Appellate Body Report, EC-Seal Products, paras.5.214 and 5.215.

2336 Desierto, Diane A., PUBLIC POLICY IN INTERNATIONAL ECONOMIC LAW: THE ICESCR IN TRADE, FINANCE, AND INVESTMENT, Oxford University Press, 2015, p194

${ }^{2337}$ Ibid. (Desierto).

${ }^{2338}$ Ibid. (Desierto), p204.
} 


\subsubsection{A Brief Comment on International Co-operation}

As discussed earlier, the Panel in US-Gambling concluded that a key element of the application of the necessity test in this dispute is whether the United States has "explored and exhausted reasonably available WTO-consistent alternatives... that would ensure the same level of protection" 2339 as the prohibition or restriction applied by them. The Panel relied on the Appellate Body report in US - Shrimp (Article 21.5-Malaysia), and on USTuna (Mexico) ${ }^{2340}$ - the latter being an un-adopted Panel report. ${ }^{2341}$ The Panel's view on necessity is an interesting one, as it seems to be pointing towards a co-operative approach in international affairs rather than a more formal legalistic approach. The WTO-consistent alternatives expected of the United States appear to involve greater diplomatic efforts under existing alternate mechanisms. However, it should be noted that the Appellate Body in US-Shrimp was referring to international cooperation in the context of the chapeau, and not in the context of the necessity test - so there are some doubts as to the Panel's analysis for the purposes of the necessity test.

Antigua in its submissions in US-Gambling had pointed out that the positive and objective assessments of Antigua's regulatory and other measures by the Financial Action Task Force on Money Laundering - established by the G-7, of which the is US also a member - should have been taken into account. This is particularly relevant as Antigua had been tackling the very issues that were raised by the US as the problems that US legislation was designed to address. Antigua further stated that the US could have involved itself in any needed law reform in Antigua through the existing bilateral treaty relating to assistance for law reform. ${ }^{2342}$ Antigua also claimed that the United States' refusal to engage in consultations [through a Mutual Legal Assistance Treaty that exists between the two countries] is contrary to Article XIV of the GATS.

Whereas it was not explicitly stated that these factors influenced the Panel, ${ }^{2343}$ it is possible to make that inference, as it was stated that the United States had:

.... an obligation to consult with Antigua before and while imposing its prohibition on the cross-border supply of gambling and betting services. $^{2344}$

The lack of consultations or negotiations led to the conclusion by the Panel that necessity was not established since the United States had failed to undertake a course of action in good faith which may have led to a WTO-consistent, reasonably available, alternative

\footnotetext{
${ }^{2339}$ Panel Report, US-Gambling, para.6.528.

${ }^{2340}$ Ibid para.6.526. The Appellate Body in US-Shrimp (at paras.166-169) discussed the importance of international cooperation. But what the Panel in US-Gambling referred to was the Appellate Body in US Shrimp (Article 21.5 - Malaysia), where the Appellate Body appeared to recognize unilateral measures under Article XX of the GATT 1994, but it also indicate that although a multilateral agreement is not required under the Article XX chapeau, it may be "preferred". In US-Tuna II (Mexico) it was stated that the US had not exhausted all options reasonably available for WTO-consistent dolphin protection measures, in particular through negotiation of international co-operative agreements. Such agreements were said to be especially desirable as dolphins roam international waters and cross national maritime boundaries.

${ }^{2341}$ The reference to an unadopted Panel report is justified by citing the Appellate Body in Japan-Alcoholic Beverages at p13 - that reasoning from such sources can be useful and relevant and that although adopted panel reports do not carry precedential weight, they do carry some weight for subsequent Panel as part of the "GATT aquis".

${ }^{2342}$ Panel Report, US-Gambling, para 6.523.

2343 Ibid., para 6.522 .

${ }^{2344}$ Ibid., para 6.531 and 6.534
} 
measure. ${ }^{2345}$ The Panel in this instance has brought in an additional good faith requirement into the necessity test although good faith is explicitly mentioned in the text only in the chapeau of Article XIV of the GATS in the context of non-arbitrary and nondiscriminatory treatment. This attempt by the Panel perhaps ought not to be seen as an unwelcome attempt, since a good faith aspect to necessity and alternative measures would be a tool that could benefit both complainant and respondent and assist to come to a balanced decision.

However, the Panel's conclusions on the necessity test in US-Gambling were subsequently rejected by the Appellate Body. It stated that the Panel's necessity analysis of the Panel was flawed, as engaging in consultations with a view to arriving at a negotiated settlement that achieves the same objectives as legislation, was not a reasonably available or appropriate alternative:

... because consultations are by definition a process, the results of which are uncertain and therefore not capable of comparison with the measures at issue in this case. ${ }^{2346}$

In this the Appellate Body appeared to agree with the submissions of the United States before the Panel that there was no way of knowing whether such consultations would have been fruitful. And while the Panel pointed out that one cannot prejudge that the situation will remain unchanged in the future, it is possible that un-co-operative actions of parties in the past may be given weight.

The effect of this is that alternative good faith cooperation in international negotiations and consultations may be relevant to a complainant, but they need not necessarily cause the respondent to 'fail' the necessity test. Antigua only raised this one issue of consultations as an alternative measure (as it is the responsibility of the complainant to do so). Although not considered a reasonably available alternative in this dispute, it is possible that it could be considered such in another dispute, although a complainant is advised to suggest more than just this alternative. While the Appellate Body decision in this instance is justified, international cooperation can still be considered in the analysis under the chapeau, so it is hoped that the WTO as a system could avoid the charge of creating a general effect of only encouraging adversarial approaches as opposed to cooperative ones in the international arena.

\subsubsection{5. 'Trade Restrictiveness' and 'Trade Impacts'}

It is possible that the most important hurdle of the exceptions provision may be the consideration of the element of trade impact. It may be that the assessment of the trade impact of their measures may play a role in compelling Members to make a particular choice of measures in order to be compliant with WTO law. ${ }^{2347}$

It has been noted by the WTO Secretariat that the necessity tests:

...reflect the balance in WTO agreements between two important goals: preserving the freedom of Members to set and achieve regulatory objectives through measures of their own choosing, and discouraging

\footnotetext{
2345 Ibid., para. 6.531 .

2346 Appellate Body Report, US-Gambling, para.317 and 321.

${ }^{2347}$ Fontanelli Filippo, Necessity Killed the GATT - Art XX GATT and the Misleading Rhetoric about 'Weighing and Balancing', European Journal of Legal Studies, Volume 5, Issue 2, Autumn/Winter 2012/13, p36-56.
} 
Members from adopting or maintaining measures that unduly restrict trade [emphasis added] ${ }^{2348}$

This concept of trade impacts or trade-restrictiveness of a measure was included as part of the weighing and balancing process described by the Appellate Body Report in KoreaVarious Measures on Beef and used in subsequent disputes. ${ }^{2349}$ The Appellate Body in Argentina-Financial Services adds that, similar to the duty of a panel to assess, "in a qualitative or quantitative manner", a measure's contribution to the end pursued, and that:

[t]he same is true with respect to a measure's trade-restrictiveness - a panel must seek to assess the degree of a measure's trade-restrictiveness, rather than merely ascertaining whether or not the measure involves some restriction on trade. ${ }^{2350}$

The response of the dispute settlement bodies to the degree of trade restrictiveness could be assumed as being more in favour of measures that have less of an impact on trade. Thus, it is not unexpected that the Appellate Body could state as follows, with the weight on the trade impact rather than the contribution towards the non-trade objective:

[f]or example, a measure making a limited contribution to protecting public morals may be justified under Article XX(a) in circumstances where the measure has only a very low trade-restrictive impact, taking into account the importance of the specific interest or value at stake; similarly, it may be that a measure making a significant contribution is not justified under Article XX(a) if that measure is highly trade restrictive [emphasis added]. ${ }^{2351}$

The above was stated by the Appellate Body in Colombia-Textiles, in the context of a finding that there was a relationship between the design of the measure at issue and the protection of public morals (reversing the Panel on this point), but that there was insufficient basis for a finding that the measure was "necessary". The Panel in that dispute had found that the compound tariff at issue was "less restrictive on international trade than an import ban"; 2352 however, the Appellate Body, in going into more detail on the matter, was of the view that the Panel was "unable to determine the degree of traderestrictiveness of the measure" and that in the end it was not demonstrated the measure was necessary to protect public morals. ${ }^{2353}$

It can be noted that only 'trade impacts ${ }^{2354}$ of a measure are specifically noted as being taken into account in dispute settlement for the purposes of 'weighing and balancing' of the 'relative importance' of the value protected. Non-trade interests or values can be considered in assessing the legitimacy of the objectives of the measure or measures being challenged in dispute settlement. However, the non-trade impacts of not having that measure are not considered. Thus, 'health' can be an interest or value which is a justifiable policy objective, but information concerning the impact of 'negatively

\footnotetext{
${ }^{2348}$ WTO, Note by the Secretariat, Working Party on Domestic Regulation, "Necessity Tests" In The WTO, S/WPDR/W/27, 2 December 2003, para 4. This document builds upon the earlier document, WTO, Note by the Secretariat, Application of the Necessity Test: Issues for Consideration, Job No. 5929, dated 8 October 1999.

2349 Appellate Body Report, Korea-Various Measures on Beef, paras.162, 163 and 166.

${ }^{2350}$ Appellate Body Report, Argentina-Financial Services, para. 6.234.

${ }^{2351}$ Appellate Body Report, Colombia-Textiles, para.5.77.

2352 Panel Report, Colombia-Textiles para. 7.444.

${ }^{2353}$ Appellate Body Report, Colombia-Textiles, paras.5.111-5.117.

2354 The Appellate Body in US-Gambling also uses the term "international commerce" instead of trade (para.306).
} 
affecting the right to health' if the measure is not implemented, is not taken into account, as this is not the form of analysis which takes place in the GATS. ${ }^{2355}$

How 'trade impacts' are defined and limited is not included in the analysis by panel and the Appellate Body, so it is not clear whether it can be interpreted very broadly to include a concept of trade in the context of development (sustainable/human development) with an interconnection with economic social rights impact and other human rights or environment-related impacts. Such an understanding could lead to consideration of the impacts of measures in greater breadth and depth. But the suggestion is that 'trade' is to be equated with 'commerce' - since the latter term is used interchangeably when referring to this factor. The Appellate Body in US-Gambling confirmed that the 'weighing and balancing' would include "the restrictive impact of the measure on international commerce". 2356

Thus, while a broad concept of 'trade as part of development' may be widely beneficial for different participants in international trade, the WTO focus on 'trade as commerce', suggests a more limited view. Such a limited concept of 'trade impacts' is set on the opposite scale to the other important interests or values that the measure at issue is supposed to protect in this so-called 'weighing and balancing' exercise. It may be a more well-rounded balancing process if the value to be protected, the contribution to the aim and the impacts are not cast as value vs. trade impact, but in a more holistic manner as trade and non-trade values in the context of economic and social development. Because this is what governments are expected to do and what the WTO should assist governments in doing, rather than governments and the WTO casting a dispute in terms of values that conflict with trade. It can be noted that there is an alternate view, that the inclusion of the 'contribution of the measure to its objective' (the extent to which a measure achieves protection of health or other objectives in Article XIV) as part of the weighing and balancing test would entail an examination of the non-trade impact of the measure and would therefore be a balancing of the impacts of the measure as a whole. The question is whether this aspect provides sufficient weightage in the balancing exercise, and can bring in the space and flexibility that reflects the range of factors that the government of a Member must consider in its policy planning.

More factors relating to significant impact of a measure could be taken into account in balancing the rights and obligations of Members and their regulatory flexibility. Some of these factors could be obligations under other international law. It can be argued that the VCLT aims at promoting coherence in different areas of international law and encourages mutually supportive reading of treaties. Marceau suggests that the:

The WTO Agreement, as with any other treaty, should be interpreted taking into account other relevant and applicable rules of international law, including human rights. ${ }^{2357}$

So far there has not been a specific methodology developed for applying such an approach in WTO law. Although it is not specifically included in a VCLT approach to

\footnotetext{
${ }^{2355}$ It may be useful to note that in comparison, the necessity obligation in Art 2.2 of the TBT Agreement explicitly requires 'taking into account the risks of non-fulfilment' of the objective of the regulation.

2356 Appellate Body Report, US-Gambling, paras.306-307.

${ }^{2357}$ Marceau, G., WTO Dispute Settlement and Human Rights in Abbott, Frederick M., Christine BreiningKaufmann and Thomas Cottier Eds., INTERNATIONAL TRADE AND HUMAN RIGHTS: FOUNDATIONS AND CONCEPTUAL ISSUES, Studies in International Economics, University of Michigan Press, 2006, p202.
} 
interpretation, it is possible to include a model of 'taking into account' human rights in the WTO context, that would guide and inform the balancing process of assessing both trade and non-trade impacts.

This would mean that the other side of the coin would also have to be taken into account, the negative impacts of trade on development and rights - and thus the corresponding responsibility to take measures that may have 'trade (restrictive) impacts' but otherwise beneficial outcomes. It can be argued that beneficial outcomes of the measure would already be considered in the current weighing and balancing exercise under the factor of 'the contribution of the measures at issue to the policy objective pursued'. But such weighing and balancing in the WTO context does not extend to an explicit recognition of how the measure at issue may be part of a wider State policy of progressively realizing an international human right or of pursuing a national constitutional, legislative or policy objective which has the same objective. The panels and Appellate Body generally cease their analysis for the purposes of WTO law at the point of accepting that there is a legitimate policy objective to which the measure in question is contributing towards. If there is a more in-depth assessment being done of the beneficial non-trade impacts of a measure falling under WTO rules, these would be done, if at all, either by national governments in the formulation of such policies and measures or by non-governmental organizations, international experts or specialized bodies.

The former Special Rapporteur on the Right to Health, Paul Hunt, in his report on the mission to the WTO has discussed the human rights approach to trade impacts, and particularly trade in services, as well. Although there can be an increase in trade through liberalization, it is emphasized that such increases may have potential 'losers' who need protection by additional policies (e.g. reduction in rural primary health care, reduced access for the poor because of user-fees or spread of substandard health facilities, goods and services, which would be prima facie inconsistent with the right to health). ${ }^{2358}$ It is recommended that policies are monitored in this light and appropriate policy adjustments are made. ${ }^{2359}$ Hunt notes that despite the fact that a detailed methodology had not yet been developed, he had:

... found wide support for the general notion of human rights or right to health assessments of trade rules and policies. ${ }^{2360}$

While it is true that there is no strong rejection of the "general notion" of human rights assessments, there is no explicitly identified mechanism of implementing human rights assessments of trade rules within the WTO in general or within the GATS provisions in particular. Article XIX of the GATS is also mentioned in the same paragraph by Hunt which is referred to above, as support for the view that the Council for Trade in Services is responsible for carrying out assessments of trade in services. A glance at Article XIX:3 of the GATS shows that the responsibility of the Council for Trade in services is in the context of progressive liberalization and negotiation of specific commitments, and refers to overall and sectoral assessment of trade in services "with reference to the objectives of this Agreement [including Article IV:1]". There is nothing in this provision that suggests taking human rights into account in assessment of trade in services, so it is doubtful that it could be interpreted as a basis for human rights assessments. Furthermore, even if

${ }^{2358} \mathrm{UN}$ CHR, The right of everyone to the enjoyment of the highest attainable standard of physical and mental health, Report of the Special Rapporteur, Paul Hunt, Addendum, Mission to the World Trade Organization, E/CN.4/2004/49/Add.1, 1 March 2004, para.49.

${ }^{2359}$ Ibid., para 25.

${ }^{2360}$ Ibid., para. 53 . 
human rights assessments can be included as part of the assessments on trade in services (through an expansive interpretation of "national policy objectives" in the preamble of the GATS as including their human rights obligations) - Article XIX:3 makes no mention of using such assessments in a dispute settlement context. So, while human rights assessments could be undertaken by States and various organizations, there is no explicit basis for the use of such assessments in the GATS dispute settlement context.

While the methodology of using human rights assessment remains unclear, there is nothing to explicitly prohibit a broader 'human rights and development impact assessment' being used in either negotiations or dispute settlement context. If assessment of the "the restrictive impact of the measure on international commerce" can be read into a 'balancing' process of the 'necessity test' - which is after all supposed to be part a justification provision for exceptions from the GATS - there is nothing to prohibit the inclusion of the impact of the absence of that measure (the impact of implementing the trade rules fully without an exception) in it as well. This could be part of 'the importance of the value' at stake and the contribution of the measure to the protection of that value. Thus, human rights approaches or assessment of human rights legitimacy of a measure can be used also as a balancing mechanism that looks at both the goal and the limit to be placed on a social regulation from a human rights perspective. ${ }^{2361}$ However, Members have clearly opted not to phrase the importance of a value in terms of human rights and it is unlikely that they may do so in the future. The panels and Appellate Body would definitely not bring in such a new and controversial factor on their own either.

It can also be argued in counter to this proposition, that the WTO is not the forum to conduct such a broad balancing, since its mandate is focused on a narrower version of trade and commerce. However, the WTO also claims to be about 'sustainable development', as evident in the Preamble to the WTO Agreement and the rhetoric of the Doha Development round of negotiations. It is also in fact the only forum that can presently engage in such an activity with regard to the impacts of and impact on, trade rules of the WTO system. So, can the WTO continue to ignore these interconnections? Perhaps dispute settlement in its current state is not the best forum for this - but instead the negotiating context. However even there the Members have avoided explicitly addressing these interconnections with human rights, particularly economic and social rights, thus isolating the discussions and negotiations in the WTO from the other major multilateral negotiations, international policy formulations and agreements As Paul Hunt has stated:

Any modern policy maker, unless purely driven by ideology, will wish to consider, in a balanced, objective and rational manner, the likely impact of a proposed new policy, especially on those living in poverty... Right to health impact assessments are an aid to equitable, inclusive, robust and sustainable policy-making. ${ }^{2362}$

If the WTO wishes to be or even just to appear more neutral in terms of ideology, the opportunities for balancing trade and non-trade interests and policies must be utilized better, and at all available opportunities.

2361 See also Schefer, K.N., SOCIAL REGULATION AND THE WTO: TRADE POLICY AND INTERNATIONAL LEGAL DEVELOPMENT, Edward Elgar Publishing, 2010, who suggests that the interpretation of exceptions is one way of pursuing social goals with trade regulations.

${ }^{2362} \mathrm{UN}$ CHR, The right of everyone to the enjoyment of the highest attainable standard of physical and mental health, Report of the Special Rapporteur, Paul Hunt, Addendum, Mission to the World Trade Organization, E/CN.4/2004/49/Add.1, 1 March 2004, para.56. 


\subsubsection{Assessing the 'Pass-Mark' for the Necessity Test}

Delimatsis says that the necessity tests, from GATT 1947 onwards, have "provided flexibility and 'breathing space' to regulators" and drawn "the dividing line among competing values". ${ }^{2363}$ But the balancing exercise appears to be weighted to trade if one judges by the results of dispute settlement, since respondents have overwhelmingly been on the losing side. This may give an impression that the hurdle of necessity is designed to be difficult to get over. But there may be another reason for the failure rate - perhaps WTO dispute settlement being costly and time-consuming, it would not be pursued by Members unless they feel that they have an extremely good chance of success. It could also suggest that the interpretations of the necessity tests by experts and dispute settlement bodies have given most Members an idea of how to design their measures to be WTO-compatible, and that the weighing of competing values has already occurred at domestic level in most situations.

Necessity tests are also used in other contexts than the WTO. Perhaps reference to how it is used elsewhere would be useful. It is interesting to refer to the Limburg Principles discussed earlier in this Chapter, which in the context of the term "necessary", is used to as an additional limitation to the restriction on trade union rights (a double protection for the human right). What occurs in the context of Article XIV of the GATS and Article XX of the GATT 1994 is that 'necessity' becomes a limit of the regulatory autonomy on Members in pursuit of societal objectives, and the stricter and more intrusive a necessity test becomes, the more it could undermine public policy regulations. This is different from the human rights regime where necessity is used to restrict the limitations on a human right, and as a result has the effect of strengthening the right.

Paragraph 60 of the Limburg Principles discusses the phrase 'necessary in a democratic society':

In addition to the interpretative principles listed under Article 4 concerning the phrase "in a democratic society", Article 8 [of the ICESCR, on trade union rights] imposes a greater restraint upon a State party which is exercising limitations on trade union rights. It requires that such a limitation is indeed necessary. The term "necessary" implies that the limitation:

(a) responds to a pressing public or social need;

(b) pursues a legitimate aim; and

(c) is proportional to that aim

[emphasis added].

Paragraph 61 adds that: "[a]ny assessment as to the necessity of a limitation shall be based upon objective considerations". This use of "necessary" as additional criteria for State action to be considered legitimate is for the purpose of protecting labour rights in general as well as the rights under the ILO Convention No 87, Concerning Freedom of Association and the Right to Organize (1948). There has not been a General Comment further elaborating the rights under Article 8 of the ICESCR, but it appears that the basic

2363 Delimatsis, P., Who's afraid of Necessity? and Why it Matters in Lim, A.H. and Bart de Meester Eds., WTO DOMESTIC REGULATION AND SERVICES TRADE: PUTTING PRINCIPLES INTO PRACTICE, Cambridge University Press, 2014, p95. 
underlying premise of much of modern labour law - the inequality of bargaining power has been taken into account, in adding a "greater restraint" in the form of a type of necessity test for limitations on trade union rights. Is this specific set of criteria in another regime relevant for comparison with the WTO GATS context? Perhaps it can be useful.

Comparing the criteria in this non-trade necessity test with the WTO necessity test standards, it appears that it is similar with regard to the requirement of pursuing a legitimate aim. The requirement of responding to a pressing public or social need, if applied to a WTO perspective, would mean that the WTO-type necessity which limits WTO Members' rights should also have an ascertainable and clearly expressed link to public needs (perhaps a more in-depth analysis of the importance of the policy objective that the measure contributes to) in the weighing and balancing exercise and not overemphasize the wants of private pressure groups or private industries when tackling the element of trade restrictiveness of a measure. This latter aspect appears not to have the similar importance in the trade context as the human rights contexts, as the demarcation between public and private needs in the trade context has been blurred and conceptually muddied. Furthermore, the needs of important private industries are often cast as public needs in the trade context, due to the income and/or jobs they bring to a national economy. Thus, the contrasting basis upon which necessity is perceived (limiting national policy or strengthening human rights-based policy) and the problem of definition of the concept of 'public' makes it difficult to compare the Limburg criteria to a WTO necessity test.

The WTO necessity test is also not linked directly to what is "necessary in a democratic society" in the way necessity is linked in all the human rights and constitutional rights regimes and frameworks. Human rights are not merely a utopian dream of poets and philosophers, but a way of creating the type of societies we each wish to live in by creating a network of rights, freedoms and restrictions. Perhaps this seemingly minor point sheds light on one of the major issues that critics of the WTO system raise: the issue of democratic accountability of decisions taken by policy-makers to their societies and to global society - which is really a national level problem; and the 'taking into account' of democratic values in an international judicial context. There is really no space for the latter in the current WTO framework, as it considers matters of public accountability of Members an issue that is a domestic matter and not relevant to the WTO. What is the 'society' envisioned by the WTO system? Is it an international trade system that is a 'collection of democratic societies' with all the complications of balancing and protecting various rights and which consists of smaller component parts of Members, who are also in turn democratic societies? Technically, the system of governance plays no part in the application of trade rules and the smooth functioning of the international trade system. It is irrelevant for the success of the system, as Membership could be a collection of fascist dictatorships, communist single party States, absolute monarchies, theocracies and oligarchies, as long as they abide by the trade rules of the WTO (and indeed, some Members have some of these characteristics). An aspect that would play a significant part in a human rights and democracy analysis of policy and legal measures is thus absent in the WTO context. It could be said that the system is the poorer for it. On the other hand, there is an opposite argument, that leaving issues of governance out of the WTO means Members cannot misuse and abuse 'human rights and democracy concerns' as a basis for violations of MFN treatment, as extraterritorial public morals arguments or as methods to pressurize other Members. Some Members would 
welcome the lack of these pressures in trade negotiations, and view this as creating a fairer playing field.

Another principle or tool that is used in judicial review in both domestic administrative and constitutional law as well as in human rights is 'proportionality' and although this is something that can be discussed in greater depth, only a brief comment on proportionality will be made here. The requirement of 'proportionality' is not as explicit and is more debatable in the context of the necessity test in WTO law ${ }^{2364}$ than it is in the ICCPR Human Right Committee, the ECHR and in the EC Law context. ${ }^{2365}$ Andenas and Zleptnig comment that while there are different "nuances and functions" in different areas of international and European law

Generally, proportionality in international law is about the limits of unilateral state action necessary to pursue a legitimate objective.

-and the principle of proportionality plays a sophisticated role in "the balancing of competing values and interests in the WTO". ${ }^{2366}$ It is also suggested by Andenas and Zleptnig that having a well-structured test for weighing and balancing (including a structured test for the proportionality element) may be more favourable to Members pursuing legitimate policy choices than tests that are not defined clearly and leave more room than necessary for further 'judicial norm creation' (although the proportionality principle itself originated as a judicially created norm). ${ }^{2367}$

Ultimately, the clearer the obligations and the tests for determining violations are, the more trust a WTO Member, and members of the public, can place in the system. There are no official expert committees to assist in interpretation and clarification of the obligations, unlike in the human rights context, and lesser numbers of cases than in e.g. the domestic and European context for these tests to be developed and applied. At the same time, the consequences of WTO disputes are far reaching. Thus, it could be said that it is even more important in this context to have clear steps that can successfully balance the competing interests of trade and other non-trade values without suggesting any inbuilt preference in the weighing scales. Yet in turn, because such clarifications themselves could have far reaching consequences, WTO Members are unlikely to agree

2364 Van den Bossche, Peter, Looking for Proportionality in WTO Law, Legal Issues of Economic Integration, 35, Issue 3, 2008, p283-294; Andenas, Mads and Stefan Zleptnig, Proportionality: WTO Law: In Comparative Perspective, Texas International Law Journal Vol. 42, 2007, 371, p384 also noting that the principle of proportionality is not used as openly in WTO as it is in EC law. Andenas and Zleptnig (at p380381) refer to the use of proportionality in the Appellate Body Report, US-Line Pipe, paras.256-260 and Appellate Body Report, US-Cotton Yarn, para.120, in the context of international countermeasures.

See also Desmedt, Axel, Proportionality in WTO Law, Journal of International Economic Law, 4 441-480 2001 , p478 commenting that there is no that "overarching proportionality principle" in WTO law as there is in EC law.

2365 Proportionality could be used in the ICESCR in a similar manner to the ICCPR, since the Optional Protocol to the ICESCR is in force since May 5, 2013, The Optional Protocol to the ICESCR allows for a complaints procedure similar to the HRC under the ICCPR, thus there can now be 'case law' based on the ICESCR.

See further for existing HRC and ECHR case law referring to proportionality: Ben Saul, Ben, David Kinley and Jaqueline Mowbray Eds., THE INTERNATIONAL COVENANT ON ECONOMIC, SOCIAL AND CULTURAL RIGHTS: CASES, MATERIALS, AND COMMENTARY, Oxford University Press, 2014, p256.

${ }^{2366}$ Andenas, Mads and Stefan Zleptnig, Proportionality: WTO Law: In Comparative Perspective, Texas International Law Journal Vol. 42, 2007, 371, p373-374.

${ }^{2367}$ Ibid., p421-423, also citing Cass, Deborah, The "Constitutionalization” of International Trade Law: Judicial Norm-Generation as the Engine of Constitutional Development in International Trade, European Journal of International Law, 12, 39, 2001, 42. 
on this matter. In the human rights context, the experts, special rapporteurs, expert committees and treaty bodies which undertake clarifications are given their mandate by the respective the human rights treaties or UN bodies (in the case of the CESCR, by ECOSOC $)^{2368}$ - and base their clarifications on State party practice and State party submissions and Reports. There is no comparable mechanism in the WTO context for clarification of obligations and a multilateral, decision-by-consensus approach is both cumbersome and unlikely to be initiated by Members. While a range of factors for determining 'necessity' may be more useful for a better determination, than a limited number of factors, some authors have commented that the trends in this regard have not added to the clarity around the 'necessity test', but perhaps further obscured it, causing more legal uncertainty. ${ }^{2369}$ In response it could be argued that since the necessity test must be applied on a case-by-case basis, and the factors will always vary in each case, there will always be an element of uncertainty.

\footnotetext{
2368 See Section 2.4.2. in Chapter 2 for a discussion of the status of General Comments with special reference to the CESCR.

${ }^{2369}$ Fontanelli, Filippo, Necessity Killed the GATT - Article XX GATT and the Misleading Rhetoric about 'Weighing and Balancing', European Journal of Legal Studies, Volume 5, Issue 2, Autumn/Winter 2012/13, p 36-56; Kapterian, Gisele, A Critique of the WTO Jurisprudence on 'Necessity', 59 ICLQ 89, 2010.
} 


\subsection{THE CHAPEAU OF ARTICLE XIV}

'The Eighth Square at last!', she cried ...

'Oh how glad I am to get here!'

'And what is this on my head?' she exclaimed in a tone of dismay, as she put her hands up to something very heavy, that fitted tight all around her head.

\section{from Lewis Carroll's Through the Looking Glass}

\subsubsection{Introduction to the 'Chapeau'}

In addition to the necessity requirement applied to the nexus between the measure and the claimed objective, the application of the specific exceptions under Article XIV are also limited by the chapeau, which further limits the potential abuse or misuse of the exceptions ${ }^{2370}$ and restrains the application of the General Exceptions.

The chapeau of Article XIV of the GATS is as follows:

Subject to the requirement that such measures are not applied in a manner which would constitute a means of arbitrary or unjustifiable discrimination between countries where like conditions prevail, or a disguised restriction on trade in services, nothing in this Agreement shall be construed to prevent the adoption or enforcement by any Member of measures...

As mentioned earlier in this Chapter, jurisprudence on Article XX of the GATT is of relevance in interpreting the chapeau in GATS since the phrases used are identical. In Argentina-Financial Services, the Panel specifically noted that the chapeau of Article XIV of the GATS is drafted in terms very similar to the chapeau of Article XX of the GATT $1994 .{ }^{2371}$ This was also confirmed more recently by the Panel in EU-EnergyPackage. ${ }^{2372}$ Therefore, dispute settlement reports discussing Article XX of the GATT 1994 are of relevance to understanding the chapeau of Article XIV of the GATS.

As pointed out in the dispute settlement context, the chapeau is less concerned about the measure at the center of the dispute and its contents as with the manner in which that measure is applied. ${ }^{2373}$ If the manner of application of the measure are arbitrary and unjustifiable discrimination and disguised protectionism lacking in good faith and reasonableness, then recourse to the exception cannot be allowed to succeed. The Appellate Body has noted that in complying with the chapeau, the burden is "a heavier

\footnotetext{
${ }^{2370}$ Appellate Body Report, EC-Seal Products, para. 5.297 indicated that:

The function of the chapeau of Article XX of the GATT 1994 is to prevent the abuse or misuse of a Member's right to invoke the exceptions contained in the subparagraphs of that Article.

${ }^{2371}$ Panel Report, Argentina-Financial Services, paras.7.745-7.746, referring to the following Appellate Body Reports, US-Gasoline, US-Shrimp, US-Gambling, and Brazil-Retreaded Tyres; and to the following Panel Reports, US-Gambling, EC-Tariff Preferences, EC-Asbestos and Brazil-Retreaded Tyres.

${ }^{2372}$ Panel Report, EU-Energy Package, para. 7.1244.

${ }^{2373}$ Appellate Body Report, US-Gasoline, p22, citing the GATT Panel Report, US-Spring Assemblies, BISD 30S/107, para.56.
} 
task" than that of proving an exception covers the measure at issue. ${ }^{2374}$ In both situations, the burden lies upon the Member invoking the exception. ${ }^{2375}$ The reasoning that that is used for this purpose will be discussed in this section.

The consideration of the chapeau would logically follow the provisional justification of the disputed measure under the relevant paragraphs of the exception clause. ${ }^{2376}$ To take an example; there can be acceptance of the objective design and nexus to public morals (Article XIV(a) of the GATS), but this does not make a measure immune from scrutiny under WTO law, for its application.

It can also be said that Panels and the Appellate Body can avoid questioning too closely whether the claimed issue is in fact a public morals issue in that jurisdiction, and the exception usually stands or fails on the tests of both necessity and the chapeau. In the case of US-Gambling, the Appellate Body held against the United States on the grounds that they had not demonstrated that the prohibitions on remote gambling applied to both foreign and domestic service suppliers, in a manner that did not constitute arbitrary and unjustifiable discrimination' within the meaning of the chapeau. Similarly, the Appellate Body in EC-Seal Products completed the analysis of the Panel and found that the EU Seal Regime, in particular the exception for seal products obtained from seals hunted by Inuit or other indigenous communities (the IC exception), was not designed and applied so as to fulfill the requirements of the chapeau of Article XX of the GATT $1994 .^{2377}$

The Appellate Body in US-Gasoline, referring to the drafting history of Article XX and its object and purpose, stated that the while the exceptions "may be invoked as a matter of legal right";

...they should not be so applied as to frustrate or defeat the legal obligations of the holder of the right under the substantive rules of the General Agreement. ${ }^{2378}$

McRae has critically commented that the Appellate Body in US-Gasoline appears to view the exceptions (in Article XX of the GATT 1994) as measures that take away treaty rights rather than "measures that are in themselves treaty rights". ${ }^{2379}$ Zleptnig comments that, in contrast to earlier GATT Panels, it can be argued that the WTO Appellate Body has applied a hierarchical attitude placing substantive rights over exceptions. ${ }^{2380}$ While

\footnotetext{
${ }^{2374}$ Appellate Body Report, US-Gasoline, p. 23; also see Appellate Body Report, EC-Seal Products, para.5.297. This was approved in the Panel Report, Argentina-Financial Services, para.7.743.

${ }^{2375}$ Appellate Body Report, US-Gasoline, pp. 22-23.

${ }^{2376}$ Appellate Body Report, US-Shrimp, para.119, referring to the chapeau of Article XX of GATT 1994, which is almost identical to the chapeau of Article XIV of the GATS.

2377 Appellate Body Report, EC-Seal Products, para.6.1(d).

The Panel in EC-Seal Products found that the European Union failed to make a prima facie case that their measures were justified under Article XX(b) of the GATT 1994, so it is also possible that the reliance on an exception can fail at the outset. The European Union appealed this finding and the reasoning given by the panel - but Norway submitted that the EU Seal Regime could not be justified under Article XX(b) since the EU Seal Regime does not as a whole provide for seal welfare (seal life and health) since it allows for discriminatory market access to seal products from Greenlandic hunts.

${ }^{2378}$ Appellate Body Report, US-Gasoline, p22 referring to document EPCT/C.11/50, p7.

${ }^{2379}$ McRae, C., GATT Article XX and the WTO Appellate Body in Bronckers, Marco and Reinhard Quick Eds., NEW DIRECTIONS IN INTERNATIONAL ECONOMIC LAW: ESSAYS IN HONOR OF JOHN H. JACKSON, Kluwer Law International, 2000, p232.

${ }^{2380}$ Zleptnig, Stefan, NON-ECONOMIC OBJECTIVES IN WTO LAW: JUSTIFICATION PROVISIONS OF GATT, GATS, SPS AND TBT AGREEMENTS, Nijhoff International Trade Law Series, 2010, footnote 233 .
} 
the Appellate Body in US-Shrimp explicitly recognizes that an exception is a right in the treaty, at the same time exceptions are contrasted with other "substantive treaty rights". ${ }^{2381}$ It is also stated in US-Shrimp, that:

...the negotiating history of Article XX confirms that the paragraphs of

Article XX set forth limited and conditional exceptions from the obligations

of the substantive provisions of the GATT [emphasis in original]. ${ }^{2382}$

The WTO dispute settlement bodies clearly have a delicate task to discover the balance between the substantive obligations and the exceptions in the GATT and GATS. ${ }^{2383}$

The general exception clause as a whole has also been described as a tool for balancing the rights of a member state to pursue its national policy objectives with the duty to respect the treaty rights of other members, and the chapeau plays a vital role in this process of balancing the rights and duties of WTO Members. ${ }^{2384}$ Achieving this delicate balance is not an easy task for panels or the Appellate Body to oversee and guide. As explained by the Appellate Body in US-Shrimp (which has analyzed the chapeau extensively):

The task of interpreting and applying the chapeau is, hence, essentially the delicate one of locating and marking out a line of equilibrium between the right of a Member to invoke an exception under Article XX and the rights of the other Members under varying substantive provisions (e.g., Article XI) of the GATT 1994, so that neither of the competing rights will cancel out the other and thereby distort and nullify or impair the balance of rights and obligations constructed by the Members themselves in that Agreement [emphasis added]. ${ }^{2385}$

This line of equilibrium, according to the Appellate Body, is "not fixed and unchanging", but one that moves according to the variations of the facts in specific cases and the measures at stake. ${ }^{2386}$

${ }^{2381}$ Appellate Body Report, US-Shrimp, para. 156: refers to "the right of a Member to an exception under Article XX" and then contrasts that with "the substantive rights of the other Members under the GATT 1994, on the other hand". These rights need to be balanced by the Appellate Body in the context of a dispute.

2382 Appellate Body Report, US-Shrimp, para. 157.

2383 See Appellate Body Report, US-Shrimp, paras.156, 157 and 159 referring to the balance that the chapeau is expected to achieve.

${ }^{2384}$ Appellate Body Report, US-Shrimp, para.156:

To permit one Member to abuse or misuse its right to invoke an exception would be effectively to allow that Member to degrade its own treaty obligations as well as to devalue the treaty rights of other Members...The chapeau was installed at the head of the list of "General Exceptions" in Article XX to prevent such far-reaching consequences.

Also note the Appellate Body Report, US-Shrimp, para.157, which stated that the chapeau of Article XX of the GATT 1994 is a "fundamental part of the balance of rights and obligations struck by the original framers of GATT 1947”.

${ }^{2385}$ Appellate Body Report, US-Shrimp, para.159.

2386 Appellate Body Report, US-Shrimp, para.159, also recalled by the Appellate Body Report, EC-Seal Products, paras.5.297 and 5.301. Also see Appellate Body Report, US-Shrimp, para.120 commenting that the "actual contours and contents" of the standards of what is 'arbitrary', 'unjustifiable' or a 'disguised restriction' could vary depending on the different measure, and thus the standard is decided case-by-case.

See also Wolfrum, R., Article XX GATT 1994 in Wolfrum, Rüdiger, Peter-Tobias Stoll, Anja Seibert-Fohr Eds., WTO: TECHNICAL BARRIERS AND SPS MEASURES, Martinus Nijhoff Publishers, 2007, p65, for comments on the analysis of the Appellate Body in US-Gasoline that the standards established in the chapeau are broad and will vary as the justification varies - for example, 'arbitrary discrimination' may have different meaning for 'necessary to protect public morals" and 'relating to products of prison labour'. 
As can be seen, this suggests not only the difficult task of balancing (competing/conflicting interests) on a high wire (line of equilibrium), but on a high wire whose location also changes. Thus, each step forward needs to be taken with extreme caution. It has been commented by Trachtman that in conflicts between trade and other social values, it is not that either of them are to be pre-eminent, but that it is a choice between "the extent to which each value is to be implemented: i.e. we must make tradeoffs among these values". ${ }^{2387}$ These trade-offs will be decided through legislative and adjudicative processes both at domestic and international level. Thus, it can be argued that to keep going forward on this high wire act, each side needs to compromise to achieve both balance and momentum.

The conditions of the chapeau are that the measure should not, in the manner of application, be an "arbitrary or unjustifiable discrimination between countries where like conditions prevail, or a disguised restriction on trade in services". This position was reiterated by the Panel in US-Gambling, summing up the earlier GATT jurisprudence of US-Gasoline and US-Shrimp. ${ }^{2388}$ The Appellate Body in Brazil-Retreaded Tyres noted that the requirements of the chapeau are two-fold: that is, not to be (i) arbitrary or unjustifiable treatment, or (ii) disguised restriction on trade. ${ }^{2389}$ Although the public health measures taken by Brazil were provisionally justified under Article XX(b) of the GATT, they were not found to succeed on the requirement of the chapeau due to the exemption of MERCOSUR countries from the import ban on retreaded tyres.

The Appellate Body in US-Shrimp put it slightly differently and identified three standards contained in the chapeau, by splitting the first into two parts:

1. Arbitrary discrimination between countries where the same conditions prevail;

2. Unjustifiable discrimination between countries where the same conditions prevail;

3. A disguised restriction on international trade. ${ }^{2390}$

The Panel in Argentina-Financial Services these three types of situations with regard to application of measures and added that 1 and 2 above were usually considered together. ${ }^{2391}$ The Panel also cited Appellate Body in EC-Seal Products, that:

... whether a measure is applied in a particular manner can most often

be discerned from the design, the architecture, and the revealing structure of a measure" [original emphasis]. ${ }^{2392}$

This analysis ultimately led the Panel to the finding that the application of some of the disputed measures by Argentina had been 'arbitrary and unjustifiable'.

Bartels, commenting on the function of the chapeau to Article XX of the GATT 1994, has said that the chapeau comprises "a distinct and secondary subsystem of discrimination obligations" that are based, not on the purpose of the measure itself: ...but rather on the purpose of the non-application of the measure in certain cases [emphasis added]. ${ }^{2393}$

\footnotetext{
${ }^{2387}$ Trachtman, Joel P., Trade and...Problems, Cost-benefit Analysis and Subsidiarity, European Journal of International Law 9, 1998, 32-85, p33.

2388 Panel Report, US-Gambling, paras.3.257-3.259.

${ }^{2389}$ Appellate Body, Brazil-Retreaded Tyres, para.226.

${ }^{2390}$ Appellate Body Report, US-Shrimp, para.150.

${ }^{2391}$ Panel Report, Argentina-Financial Services, paras. 7.745-7.746

2392 Panel Report, Argentina-Financial Services, para. 7.748, referring to Appellate Body Report, EC-Seal Products, para. 5.302.

2393 Bartels, Lorand, comments in Desierto, Diane, The Right to Regulate for Public Morals Upheld (Somewhat): The WTO Panel Report in EC-Seal Products, EJILTalk! Blog, January 27, 2014, available
} 
The Appellate Body in Brazil-Retreaded Tyres, stated that earlier Appellate Body reports of US-Gasoline and US-Shrimp have shown that:

...the analysis of whether the application of a measure results in arbitrary

or unjustifiable discrimination should focus on the cause of the

discrimination, or the rationale put forward to explain its existence. ${ }^{2394}$

Thus, the purpose of the chapeau is to prevent any other unfair exceptions being included as part of the primary exception measure allowed by the relevant Agreement (in other words, regulating the exceptions in the exception). In practical terms, this means looking into the reason or justification for the discrimination and evaluating it. If the exception is to fulfill all the requirements of Article XX of the GATT or Article XIV of the GATS, the actual application of the exception measure must be justifiable as well, and not only the purpose of the measure and the way it is supposed to operate, which may be "otherwise fair and just on its face" ${ }^{2395}$ Thus, before discussing the three standards referred to above, the concept of good faith that is part of the chapeau, should be mentioned.

\subsubsection{The Good Faith Requirement}

In the words of the Appellate Body in US-Shrimp (with regard to Article XX of the GATT 1994):

The chapeau ...is, in fact, but one expression of the principle of good faith [and] must be exercised bona fide, that is to say, reasonably. ${ }^{2396}$

Article 31(1) of the VCLT also requires that interpretation of treaties shall be done in good faith, so the concept plays a dual role in the WTO exceptions provisions in both GATT and GATS.

It is intended that this balancing process undertaken through the chapeau would lead to avoidance of abuse of the exceptions, and limit its use to authentic situations of conflicting non-trade values. For example, in the Colombia-Ports of Entry dispute, Colombia stated that the measure in question was in good faith for customs enforcement but Panama argued that the design of the measure revealed its "true purpose" was to "protect fragile domestic industries and not to enforce customs laws". ${ }^{2397}$ Thus, as part of the their analysis, panels and the Appellate Body must assess the aspect of 'good faith' as a requirement of the chapeau, and ascertain whether or not the measure is a "disguised restriction" or not.

Furthermore, the Appellate Body adds that it is possible to seek "additional interpretative guidance, as appropriate, from the general principles of international law" since good faith is "at once a general principle of law and a general principle of international law". ${ }^{2398}$ Article $38(1)$ of the Statute of the International Court of Justice, which is generally referred to as "the most authoritative and complete statement as to the sources

online at http://www.ejiltalk.org/the-right-to-regulate-for-public-morals-upheld-somewhat-the-wto-panelreport-in-ec-seal-products/.

2394 Appellate Body, Brazil-Retreaded Tyres, para.226, referring to analysis in previous disputes of USGasoline, US-Shrimp, and US-Shrimp (Article 21.5-Malaysia).

${ }^{2395}$ Appellate Body Report, US-Shrimp, para. 160.

${ }^{2396}$ Appellate Body Report in US-Shrimp, para.158, also cited in Appellate Body, Brazil Retreaded Tires, para. 224

${ }^{2397}$ Panel Report, Colombia-Ports of Entry, paras.7.495-7.496

${ }^{2398}$ Appellate Body Report in US-Shrimp, para.158. 
of international law"2399 includes "general principles of law" as one of the sources. The principle of good faith is one of the most important of the general principles, which has been included in the UN Charter Article 2(2) and further elaborated in the Declaration on Friendly Relations (General Assembly Resolution 2623, 1970) as well as by the ICJ. What the ICJ had to say about the principle of good faith may be relevant for the WTO context. The ICJ in the Nuclear Tests case and the Border and Transborder Armed Action Case refers to good faith as:

One of the basic principles governing the creation and performance of legal obligations, whatever their source. ${ }^{2400} \ldots$ [but it is] not in itself a source of obligation where none would otherwise exist. ${ }^{2401}$

The ICJ in the Nuclear Tests case also notes in the context of the good faith principle that:

Trust and confidence are inherent in international co-operation, in particular in an age when co-operation in many fields is becoming increasingly essential. ${ }^{2402}$

This connection of good faith with international co-operation suggests that bilateral and/or multilateral consultation can also be seen as part of good faith requirement instead of being brought in through the necessity test (as part of judging the necessity of the measure).

Both US-Shrimp and US-Gambling discussed the importance of alternatives such as diplomatic measures or regional and international co-operation through other binding agreements that should be taken before taking trade-restrictive measures such as import prohibitions. ${ }^{2403}$ The lack of 'serious efforts' for alternative solutions can be seen as a point against the appellant in these cases. Situations where there were serious negotiations with some Members and not with others have been seen by the Appellate Body as having an effect that is "plainly discriminatory and... unjustifiable". ${ }^{2404}$ Evidence of international consensus on the co-operative approach to solving international problems can be found in the language used in the Rio Declaration on the Environment and Development, ${ }^{2405}$ as well as (obviously) the UN Charter and other human rights conventions. Perhaps the lack of trust and confidence between States is what leads to discrimination in the application of exceptions even in situations where similar conditions exist in both States.

\subsection{3. "Arbitrary or unjustifiable discrimination between countries"}

The chapeau of Article XIV of the GATS refers to "arbitrary or unjustifiable discrimination between countries where like conditions prevail". What each of these

\footnotetext{
${ }^{2399}$ Shaw, Malcolm N., INTERNATIONAL LAW, 6 ${ }^{\text {th }}$ Edition, Cambridge University Press, 2008, p70 (citing Brownlie and Oppenheim).

${ }^{2400}$ ICJ, Nuclear Tests Case, (New Zealand v France), 1974 ICJ Reports, p253, p267.

${ }^{2401}$ ICJ, Border and Transborder Armed Action case, (Nicaragua v Honduras), 1988, ICJ Reports 69, p105.

2402 ICJ, Nuclear Tests Case, (New Zealand v France), 1974 ICJ Reports, p253, p267.

2403 Appellate Body Report, US-Shrimp, para.171, calls import prohibitions "the heaviest "weapon" in a Member's armoury of trade measures", and thus suggests it is a measure of last resort rather than the first response to a problem.

${ }^{2404}$ Appellate Body Report, US-Shrimp, para.172.

2405 The United Nations Conference on Environment and Development, Rio Declaration on Environment and Development 1992, Annex 1, U.N. Doc. A/CONF.151/ 26/Rev.1, June 14, 1992, Preamble: States shall cooperate in a spirit of global partnership to conserve, protect and restore the health and integrity of the Earth's ecosystem.
} 
words and phrases mean has been looked at in a number of WTO cases including USShrimp, in the context of Article XX of the GATT 1994. The Appellate Body in USShrimp, following some of the reasoning in the earlier dispute of US-Gasoline, identified three elements for identifying discrimination under the chapeau:

1. The application of the measure must result in discrimination (the nature and quality of which is different from the discrimination already found under other substantive provisions of the Agreement.

2. The discrimination must be arbitrary or unjustifiable in character

3. The discrimination must occur between countries where the same conditions prevail (both MFN and national treatment will be considered in a GATT context, national treatment will depend on scheduling of commitments in a GATS context) ${ }^{2406}$

Thus, not every incidence of discrimination will be covered by the chapeau. Discrimination must be arbitrary or unjustifiable thus non-arbitrary and justifiable discrimination will presumably not fail to clear the hurdle of the chapeau.

It is clear that arbitrariness in its common meaning and as recognized by the Panel in $E C$ Tariff Preferences, refers to the idea that no objective criteria were applied in a process of differentiation or selection. ${ }^{2407}$ The Panel in Brazil-Retreated Tyres found that action which was not "capricious" or "random" action would not be considered arbitrary, but this was not the reasoning of the Appellate Body in the same dispute, which stated that the "cause or rationale" for the discrimination is what must be assessed. ${ }^{2408}$

In Argentina-Financial Services, Argentina sought to defend six of its measure under Article XIV(c) of the GATS, but did not succeed because the Panel found that it granted 'cooperative country status' to countries with which it does not have an agreement that allows effective exchange of such information. Thus, there was arbitrariness in the manner in which Argentina designates cooperative and non-cooperative countries in relation to its measures and as a result it did not comply with the chapeau of Article XIV. ${ }^{2409}$ The parties did not appeal the Panel's analysis, so the Appellate Body did not have to consider the matter any further.

One of the characteristics of arbitrariness discussed in US-Shrimp was "rigidity and inflexibility" in how the appellant Member's officials make determinations without taking into account the conditions prevailing in other Members. ${ }^{2410}$ An example of unjustifiability was given as the "intended and coercive effect" on other governments to "adopt essentially the same policy" as the Member taking the measure. ${ }^{2411}$ It was also commented:

...discrimination exists...when the application of the measure at issue does not allow for any inquiry into the appropriateness of the regulatory programme for the conditions prevailing in those exporting countries. ${ }^{2412}$

\footnotetext{
${ }^{2406}$ Appellate Body Report, US-Shrimp, para.150 citing Appellate Body Report, US-Gasoline, p23-24.

${ }^{2407}$ Panel Report, EC-Tariff Preferences, paras. 7.228-7.229, 7.232 and 7.234.

2408 Appellate Body, Brazil-Retreaded Tyres, para.246 referring to the Panel Report, Brazil-Retreaded Tyres, para.7.294.

${ }^{2409}$ Panel Report, Argentina-Financial Services, para. 8.2.d. See also para.7.764.

${ }^{2410}$ Appellate Body Report, US-Shrimp, para. 177.

${ }^{2411}$ Ibid., para. 161.

${ }^{2412}$ Ibid., paras. 164-165
} 
These are interesting comments, since if the same approach is applied to a WTO agreement or the multilateral trade system itself as whole, it may be argued that the WTO agreements and the System also have some arbitrary and unjustifiable elements - if there is coercion from other Members and there isn't sufficient policy space allowed for what is appropriate to a particular country! Thus, if the same rationale of the interpretation of chapeau is applied generally - it is not only the framing of the measure itself but it could also be the implementation that measure which can be seen as incompatible with GATS obligations. If what is applied to GATS-incompatible measures can also be extended to the implementation of GATS obligations; one could argue that it is arbitrary and unjustifiable to be rigid and inflexible, to ignore the conditions in different Members and to take coercive action to pressure them to "adopt essentially the same policy". Chapter 6 which follows this Chapter, deals with some of these issues in more depth, focusing on the needs of developing and LDC Members.

\subsection{4. "Disguised restriction on trade"}

Unlike the other two standards in the chapeau, the concept of "disguised restriction on trade" has not often been explicitly discussed in disputes. This is either because the preliminary justification was rejected, as in Colombia-Ports of Entry, ${ }^{2413}$ or if the other two criteria of the chapeau were not fulfilled, wherefore making explicit statements on the issue of 'disguised restriction' on trade can then be avoided, as was stated by the Appellate Body in US-Shrimp. ${ }^{2414}$

According to the Appellate Body in US-Gasoline, the concept of disguised restriction encompasses both arbitrary and unjustifiable discrimination, but may also cover other factors. ${ }^{2415}$ This suggests that there could be non-discriminatory measures that are nevertheless 'disguised restrictions on trade'. As highlighted by the Appellate Body in Brazil-Retreaded Tyres, a measure is arbitrary or unjustifiable discrimination within the chapeau if it:

...bears no relationship to the accomplishment of the objective that falls within the purview of one of the paragraphs of Article XX, or goes against this objective. ${ }^{2416}$

It was found in this dispute that the import ban on retreaded tyres was being applied in a manner that constitutes a disguised restriction on international trade imports of used tyres since imports were taking place "in significant amounts under court injunctions to the benefit of the domestic retreading industry". ${ }^{2417}$ At the same time it was seen that

2413 The parties in Colombia-Ports of Entry did raise the issue of disguised restriction (Panel Report, Colombia-Ports of Entry, paras.4.89, 4.141, 4.176 and 7.490-7.496). But as Colombia had raised Article $\mathrm{XX}(\mathrm{d})$ of the GATT as a defence, which was rejected as not preliminarily justified, the Panel did not proceed to examine the requirements of the chapeau.

${ }^{2414}$ Appellate Body Report, US-Shrimp, para.184:

We find, accordingly, that the United States measure is applied in a manner which amounts to a means not just of "unjustifiable discrimination", but also of "arbitrary discrimination" between countries where the same conditions prevail, contrary to the requirements of the chapeau of Article XX. The measure, therefore, is not entitled to the justifying protection of Article XX of the GATT 1994. Having made this finding, it is not necessary for us to examine also whether the United States measure is applied in a manner that constitutes a "disguised restriction on international trade" under the chapeau of Article XX [emphasis added].

2415 Appellate Body Report, US-Gasoline, p25.

${ }^{2416}$ Appellate Body Report, Brazil-Retreaded Tyres, para.246.

2417 Appellate Body Report, Brazil-Retreaded Tyres, para.248, citing Panel Report, para.7.349. 
competitors from non-MERCOSUR countries had been kept out of the Brazilian market. ${ }^{2418}$ Thus a hidden agenda - or what is known as 'disguised protectionism' or 'disguised restriction on trade' - should not be able to be protected by the general exceptions provision of an Agreement. Howse comments that the differentiation between MERCOSUR and non-MERCOCUR Members was due to the fact that Brazil lost its case in the MERCOSUR regional forum for its tyre scheme, and thus had to stop applying the import ban to MERCOSUR member states. ${ }^{2419}$ This could be explained as a reason for differentiation, and that it was arguably not an arbitrary differentiation, but it remains difficult to justify this action under the chapeau. Tancredi has commented that this result exemplifies the fact that the Appellate Body does not "facilitate compliance" for WTO Members with regard to obligations arising under other international agreements and that such other obligations "do not constitute exceptions to the regular application of WTO law". ${ }^{2420}$ It could still be seen as a situation where non-MERCOSUR countries were still 'unjustifiably' discriminated, even if it was not an 'arbitrary' discrimination.

The Appellate Body in US-Gasoline has commented on the relationship between the requirements of the chapeau and held that the concepts of "arbitrary or unjustifiable discrimination" and "disguised restriction on international trade" were interconnected. The Appellate body in US-Gasoline stated that in that particular dispute, the measures violated WTO obligations since they constituted "unjustifiable discrimination" and a "disguised restriction on international trade", even if they were not explicitly recognized as "arbitrary discrimination". The factors that could be taken into account for one criterion could be relevant for the other criteria as well. Furthermore, unlike in the earlier adopted GATT Panel disputes of US-Tuna and US-Spring Assemblies, it is still possible to include a measure that is not publicly announced but nevertheless implemented. ${ }^{2421}$ The analysis of the Appellate Body can be summed up as follows:

Disguised restriction $=$

disguised discrimination $+/$ - concealed (restriction or discrimination) $+/$ unannounced (restriction or discrimination) $+/$ - arbitrary discrimination $+/-$ unjustifiable discrimination $+/-\mathrm{X}$ (another factor). ${ }^{2422}$

\footnotetext{
${ }^{2418}$ Appellate Body Report, Brazil-Retreaded Tyres, para.248, citing Panel Report, para.7.348. (footnote omitted).

${ }^{2419}$ Howse Robert, The World Trade Organization 20 Years On: Global Governance by Judiciary, EJIL (2016), Vol. 27 No. 1, 9-77, p73.

${ }^{2420}$ Tancredi, Antonello, Trade and Inter-Legality in Klabbers, Jan. and Gianluigi Palombella Eds., THE CHALLENGE OF INTER-LEGALITY, ASIL Studies in International Legal Theory, Cambridge University Press, 2019, p185.

${ }^{2421}$ See for discussion of the analysis of "disguised restriction" in these two GATT Panel disputes: Appleton, Arthur E. and Michael G. Plummer, THE WORLD TRADE ORGANIZATION: LEGAL, ECONOMIC AND POLITICAL ANALYSIS, Volume I, Springer Science \& Business Media, 2007, p156157.

${ }^{2422}$ Appellate Body Report, US-Gasoline, p25:

"Arbitrary discrimination", "unjustifiable discrimination" and "disguised restriction" on international trade may, accordingly, be read side-by-side; they impart meaning to one another. It is clear to us that "disguised restriction" includes disguised discrimination in international trade. It is equally clear that concealed or unannounced restriction or discrimination in international trade does not exhaust the meaning of "disguised restriction." We consider that "disguised restriction", whatever else it covers, may properly be read as embracing restrictions amounting to arbitrary or unjustifiable discrimination in international trade taken under the guise of a measure formally within the terms of an exception listed in Article XX. Put in a somewhat different manner, the kinds of considerations pertinent in deciding whether the application of a particular measure amounts to "arbitrary or unjustifiable discrimination", may also be taken into account in
} 
Thus, with regard to the chapeaux of both Articles XX of the GATT and Article XIV of the GATS, the panels and Appellate Body have considered whether the measures at issue, even if otherwise appearing to be unproblematic, were applied in such a manner as to constitute a disguised restriction. 


\subsection{BRIEF COMMENTS ON OTHER EXCEPTIONS}

Since the special emphasis of this study is on public health services, greater attention has been focused on the exceptions which may be useful for the purposes of justifying measure protecting such services. Moreover, the interests protected in paragraphs (a), (b) and (c) of Article XIV are the ones which are more likely to be used in dispute settlement, as well as the ones which have been given more academic attention. However, as it is relevant to make a few comments on the nature of the exceptions in Article XIV(d) and (e) and Article XIVbis of the GATS, as well as their implications in the context of health. These implications are not as clear and direct as in the case of measures which can be justified under paragraphs (a), (b) and (c) of Article XIV of the GATS, but they are nevertheless issues that should be touched upon. The next two parts of this Chapter asses these provisions and conclude the discussion on exceptions.

\subsubsection{Article XIV(d) and (e) - Direct and Double Taxation}

As mentioned at the beginning of this Chapter, greater attention was focused in this study on the first three paragraphs of Article XIV of the GATS. The academic commentary available on Articles XIV(d) and (e) is limited, as these two exceptions are often quickly dismissed by authors as limited in scope and practical application. ${ }^{2423}$ There also does not seem to be at first glance, any direct relevance with the area of public health services, the area of special emphasis in this study. However, particularly since another GATS dispute, namely Argentina-Financial Services, has been decided, and since it relates to taxation matters, a brief comment on the issues involved and the connections that can be made to broader themes will be discussed below.

The Appellate Body in Argentina-Financial Services noted that Articles (d) and (e) do not have an equivalent in GATT 1994 and describes these GATS exceptions in the following manner:

In particular, Article XIV(d) allows for derogation from the national treatment obligation in Article XVII of the GATS, while Article XIV(e) allows for derogation from the most-favoured-nation obligation in Article II of the GATS. ${ }^{2424}$

The core issue raised by Panama, the complainant in that dispute, was that there was differential treatment towards services and service suppliers located in WTO Member countries designated as 'non-cooperative jurisdictions' by Argentina, which violated both the national treatment obligation and the MFN treatment obligation under Articles II:1 and XVII of the GATS.

However, Argentina focused on the exception provided for in Article XIV(c) as did the analysis by both the Panel and Appellate Body. Argentina invoked Article XIV(d) as an alternative or additional defence with respect to three of the measures challenged by Panama in that dispute. The Panel exercised judicial economy with respect to Argentina's

\footnotetext{
${ }^{2423}$ Not discussed (only mentioned) by Zleptnig, Stefan, NON-ECONOMIC OBJECTIVES IN WTO LAW: JUSTIFICATION PROVISIONS OF GATT, GATS, SPS AND TBT AGREEMENTS, Nijhoff International Trade Law Series, 2010, p181) and only very briefly discussed by Cottier et al, Article XIV GATS in Wolfrum, Rudiger, Peter-Tobias Stoll and Clemens Feinaugle Eds., WTO - TRADE IN SERVICES, Max Planck Commentaries on World Trade Law, Martinus Nijhoff Publishers, 2008.

${ }^{2424}$ Appellate Body Report, Argentina-Financial Services, para.6.113 and footnote 311.
} 
defence under Article XIV(d) of the GATS because measure 2 (presumption of unjustified increase in wealth), measure 3 (transaction valuation based on transfer prices) and measure 4 (payment received rule for the allocation of expenditure) were found not to be inconsistent with Article XVII of the GATS. Paragraph (e) was not discussed in the dispute.

There was more attention paid in the dispute to what is called the 'prudential exception' or 'prudential carve-out ${ }^{2425}$ (paragraph 2(a) of the Annex on Financial Services) - and Argentina's argument that paragraph 2(a) was an exception to any violation of GATS provisions. ${ }^{2426}$ Argentina's defence was primarily on the exception in Article XIV(c) and paragraph 2(a) of the Annex on Financial Services, ${ }^{2427}$ and the Panel and Appellate Body exercised judicial economy by not analyzing Article XIV(d), since it was found that the relevant measures for which this exception was relied upon were not inconsistent with GATS obligations under Article XVII. ${ }^{2428}$ Thus, although there has been a GATS dispute on taxation matters, the exceptions in Article XIV(d) and (e) were not given much attention. This is also the case in commentary on taxation and GATS exceptions in general; for example, Grynberg and Chilala comment that defensive measures against harmful tax practices can be looked at under "prevention of deceptive practices" in Article XIV(c)(i) of the GATS, rather than looking at Article XIV(d) and the related interest (iii) of Footnote 6 of the GATS ("avoidance or evasion of taxes, including compliance measures"). ${ }^{2429}$

The brief comment on the 'tax exceptions' in this section will refer to the definition, scope and the possibilities for policy space. Approaching the issue from a broad trade perspective, taxation, even if it is an internal measure, can be related or connected to tariffs, non-tariff border measures and export subsidies - since they can have similar economic effects and may either deter or encourage cross-border capital and labour flows. In this way, taxation can be seen as relevant to measures in investment (FDI generally as well as TRIMS), subsidies and countervailing measures (SCM Agreement), the Agreement on Agriculture and the GATS. ${ }^{2430}$ At some points there may be overlap between these Agreements, in relation to which types of taxation measures are consistent

\footnotetext{
2425 Appellate Body Report, Argentina-Financial Services, footnote 592 noted that the Panel in this dispute uses the term 'prudential exception', and the parties use 'prudential exception' or 'prudential carve-out' but state that although the Appellate Body would use the terminology in the context of referring to the submissions of parties, they are not "adopting" this terminology.

${ }^{2426}$ Panel Report, Argentina-Financial Services, paras.7.781-7.7.82. See further the entire section 7.3.7 of the Panel report, titled 'Argentina's defence under paragraph 2(a) of the Annex on Financial Services ("prudential exception")'.

${ }^{2427}$ Paragraph 2(a) of the Annex on Financial Services provides:

2. Domestic Regulation

(a) Notwithstanding any other provisions of the Agreement, a Member shall not be prevented from taking measures for prudential reasons, including for the protection of investors, depositors, policy holders or persons to whom a fiduciary duty is owed by a financial service supplier, or to ensure the integrity and stability of the financial system. Where such measures do not conform with the provisions of the Agreement, they shall not be used as a means of avoiding the Member's commitments or obligations under the Agreement.

2428 See Panel Report, Argentina-Financial Services, paras.7.779-7.780 and Appellate Body Report, Argentina-Financial Services, para.1.6 and footnote 123.

${ }^{2429}$ Grynberg, Roman and Bridget Chilala, WTO Compatibility of the OECD Defensive Measures against Harmful Tax Practices in R. Biswas Ed., INTERNATIONAL TAX COMPETITION: GLOBALIZATION AND FISCAL SOVEREIGNTY, Commonwealth Secretariat 2002, p159.

${ }^{2430}$ Daly, Michael Eds., THE WTO AND DIRECT TAXATION: WTO DISCUSSION PAPERS, 2005.
} 
or inconsistent with WTO obligations. Taking a further step back and looking at taxation from the point of view of its role in sustainable development, human rights and public services is also possible, although these policy implications are usually avoided in the discussions on the more specific and technical trade rules. ${ }^{2431}$

The 'tax exceptions' in Article XIV(d) and (e) of the GATS that will be briefly mentioned in this section relate to two types of taxation: direct taxation and double taxation.

Direct taxation comes under Article $\mathrm{XIV}(\mathrm{d})$ but the term itself is defined in Article XXVIII(o) of the GATS as:

"Direct taxes" comprise all taxes on total income, on total capital or on elements of income or of capital, including taxes on gains from the alienation of property, taxes on estates, inheritances and gifts, and taxes on the total amounts of wages or salaries paid by enterprises, as well as taxes on capital appreciation. ${ }^{2432}$

According to Article XIV(d), a Member can, if the measure is for the purposes of "equitable and effective imposition or collection of direct taxes", have recourse to this exception from the application of the national treatment obligation of Article XVII of the GATS. This means that even if direct taxation as defined in Articles XIV(d) and XXVIII(o) was not specifically included as a limitation on national treatment in the Schedule, a Member may still be able to justify such a measure as not inconsistent with their WTO obligations. However, the MFN obligation continues to apply to direct taxation unless specifically listed under the Article II (MFN) exemptions. ${ }^{2433}$ Even then, the chapeau of Article XIV limits the possibility of 'arbitrary and unjustifiable discrimination' between Members.

The relevant provision on direct taxation (including the chapeau of Article XIV) is as follows:

Subject to the requirement that such measures are not applied in a manner which would constitute a means of arbitrary or unjustifiable discrimination between countries where like conditions prevail, or a disguised restriction on trade in services, nothing in this Agreement shall be construed to prevent the adoption or enforcement by any Member of measures:

d) inconsistent with Article XVII, provided that the difference in treatment is aimed at ensuring the equitable or effective [at this point original Footnote 6] imposition or collection of direct taxes in respect of services or service suppliers of other Members.

Since what is 'equitable' or 'effective' can be subject to debate, Footnote 6 of the GATS specifies an exhaustive list of six types of measures that are included in the scope of "equitable and effective":

\footnotetext{
${ }^{2431}$ See Mendis, Nishara, A Comment on the Interface of Harmful Tax Practices, Human Rights and WTO Law, in Light of the Panama Papers Scandal and Argentina-Financial Services Case, Indian J. Int'l Econ. L. 9 (2018): 19.

${ }^{2432}$ Comparison with Footnote 58 of the SCM Agreement:

For the purpose of this Agreement:

The term "direct taxes" shall mean taxes on wages, profits, interests, rents, royalties, and all other forms of income, and taxes on the ownership of real property.

${ }^{2433}$ It has been noted that some Members e.g. the United States, have clearly included direct taxation in their MFN exemptions list, whereas the coverage of other Members e.g. EC is not as thorough (Cappadona, Gerlando, National Report: Italy in Lang, Michael, Judith Herdin, Ines Hofbauer Eds., WTO AND DIRECT TAXATION, Kluwer Law International, 2005 p434.
} 
(i) apply to non-resident service suppliers in recognition of the fact that the tax obligation of non-residents is determined with respect to taxable items sourced or located in the Member's territory; or

(ii) apply to non-residents in order to ensure the imposition or collection of taxes in the Member's territory; or

(iii) apply to non-residents or residents in order to prevent the avoidance or evasion of taxes, including compliance measures; or

(iv) apply to consumers of services supplied in or from the territory of another Member in order to ensure the imposition or collection of taxes on such consumers derived from sources in the Member's territory; or

(v) distinguish service suppliers subject to tax on worldwide taxable items from other service suppliers, in recognition of the difference in the nature of the tax base between them; or

(vi) determine, allocate or apportion income, profit, gain, loss, deduction or credit of resident persons or branches, or between related persons or branches of the same person, in order to safeguard the Member's tax base.

The fact that it is an exhaustive list may suggest that the interpretation of "equitable" and "effective" will be rather limited, but the wording is fairly broad and furthermore, the Footnote also adds that:

Tax terms or concepts in paragraph (d) of Article XIV and in this footnote, are determined according to tax definitions and concepts, or equivalent or similar definitions and concepts, under the domestic law of the Member taking the measure [emphasis added].

Cottier et al have commented that this allows for a national tax measure with similar functions to the types listed in Footnote 6 to be included as "important flexibility" that would allow the WTO dispute settlement bodies to expand the scope of coverage of Article XIV(d), if relevant national measures have similar functions and objectives to those listed. ${ }^{2434}$ This can be contrasted with how the term "foreign-source income" in the context of double taxation exception in the SCM Agreement was analyzed by the Appellate Body in US-FSC(Article 21.5 - EC) with reference to "widely recognized" international legal principles found in bilateral and multilateral tax agreements, even if it was also acknowledged that there are variations in the application of such rules among States. $^{2435}$

Although (iii) of Footnote 6 of the GATS referred specifically to prevention of tax evasion and compliance measures, which were at the heart of the Argentina-Financial

${ }^{2434}$ Cottier et al, Article XIV GATS in Wolfrum, Rudiger, Peter-Tobias Stoll and Clemens Feinaugle Eds., WTO - TRADE IN SERVICES, Max Planck Commentaries on World Trade Law, Martinus Nijhoff Publishers, 2008, p311-321.

${ }^{2435}$ Appellate Body Report, US-FSC (Article 21.5 - EC), paras.141-143:

Although there is no universally agreed meaning for the term 'foreign-source income' in international tax law, we observe that many States have adopted bilateral or multilateral treaties to address double taxation...

Although these instruments do not define 'foreign-source income' uniformly, it appears to us that certain widely recognized principles of taxation emerge from them...

We recognize, of course, that the detailed rules on taxation of non-residents differ considerably from State-to-State, with some States applying rules which may be more likely to tax the income of non-residents than the rules applied by other States. However, despite the differences, there seems to us to be a widely accepted common element to these rules. 
Services dispute, Article XIV(d) was not considered in much detail by the panel or Appellate Body. Argentina's claim was that certain of its defensive tax measures ${ }^{2436}$ in respect of Panama's national treatment claims under Article XVII of the GATS are justified, alternatively, under Article XIV(d) of the GATS. ${ }^{2437}$ Argentina maintained that these defensive tax measures were for the protection of Argentina's tax base and also to prevent concealment and laundering of money of criminal origin; ${ }^{2438}$ and furthermore, these measure were stated as being in line with recommendations of the Global Forum on Transparency and Exchange of Information for Tax Purposes (Global Forum) and the framework of the Financial Action Task Force (FATF). ${ }^{2439}$ But, as mentioned earlier, since it was found that the these measures were not inconsistent with Argentina's obligations under Article XVII of the GATS, the Panel refrained from ruling on whether these measures are covered by the exception provided for in Article XIV(d) of the GATS.

It is pertinent to comment that abovementioned international obligations with regard to financial and tax laws and policies may relate to both tax evasion, which entails criminal penalties in the domestic law of many countries, as well as tax avoidance which may not be illegal per se. The terms 'tax abuse' and 'illicit financial flows' are also used in this regard, but the terms are difficult to define, and therefore are generally remain a grey area in domestic and international law. The Panel in Argentina-Financial Services, declared that "the expression "harmful tax practices" covers tax evasion, avoidance and fraud". ${ }^{2440}$

According to a recent United Nations Human Rights Council study, a broad definition of these terms is preferable, identifying 'illicit financial flows' to include both illegal tax evasion and legally questionable tax avoidance and covering all funds that "circumvent the spirit of the law" through legal loopholes and other artificial arrangements. ${ }^{2441}$ The human rights regime has recently started paying attention to harmful tax practices and their impact on human rights. In 2016, the negative effects of harmful tax practices on human rights were highlighted by the UN Human Rights Council Resolution No. 31 and in the Study of the Independent Expert on the Impact of Illicit Financial Flows on Human Rights. ${ }^{242}$ The Study on Illicit Financial Flows emphasized the connections between harmful tax practices and corruption, obstacles to sustainable development and the

2436 Identified in the dispute as measures 2, 3 and 4. Measure 2 related to presumption of unjustified increase in wealth; measure 3 on transaction valuation based on transfer price; and measure 4 was a 'payment received rule' for the allocation of expenditure.

${ }^{2437}$ Panel Report, Argentina-Financial Services, para.7.765 and paras.7.779-7.780.

${ }^{2438}$ See Panel Report, Financial Services, para.7.681:

... there can be no doubt that combating money laundering, which fits in with the fight against drug trafficking and terrorism, is a priority for the international community and thus also for Argentina

${ }^{2439}$ Appellate Body report, Argentina-Financial Services, para.1.4 citing Panel Report, Argentina-Financial Services, paras.7.527, 7.534, 7.786 and 7.789.

${ }^{2440}$ Panel Report, Argentina - Financial Services, footnote 867.

${ }^{2441}$ Human Rights Council, Final study on illicit financial flows, human rights and the 2030 Agenda for Sustainable Development of the Independent Expert on the effects of foreign debt and other related international financial obligations of States on the full enjoyment of all human rights, particularly economic, social and cultural rights, UN Doc. A/HRC/31/61, 15th January 2016, paras.6-7.

${ }^{2442}$ Human Rights Council Resolution No. 31, The negative impact of the non-repatriation of funds of illicit origin to the countries of origin on the enjoyment of human rights, and the importance of improving international cooperation, UN Doc. A/HRC/31/L.24/Rev.1 (Mar. 23, 2016); Human Rights Council, Final study on illicit financial flows, human rights and the 2030 Agenda for Sustainable Development of the Independent Expert on the effects of foreign debt and other related international financial obligations of States on the full enjoyment of all human rights, particularly economic, social and cultural rights, UN Doc. A/HRC/31/61, 15 January 2016. 
international human rights principles of equality and non-discrimination, in particular, economic inequality, and highlighted the negative impact on the right to health due to reduction of revenue which could have been used for public health services. ${ }^{2443}$ This links is made explicit in a number of other recent human rights reports including in the description of the normative framework of the Report of the Special Rapporteur on Extreme Poverty and Human rights, where it is stated that the Report:

...examines how a State's use of its revenue-raising power has a direct impact on its ability to comply with international human rights obligations, in particular relating to the economic, social and cultural rights of people living in poverty. ${ }^{2444}$

The policy and regulatory measures with regard to financial and tax law and policy have been seen in the human rights context as connected to the State responsibility to progressively realize the economic and social rights of their people, by preventing tax avoidance, using tax revenue for social welfare and cooperating with other States and international organizations towards making those rights a reality in other jurisdictions as well. ${ }^{2445}$

The issue of defensive tax measures is not considered from the viewpoint of human rights obligations in Argentina-Financial Services, but the Panel in Argentina-Financial Goods and Services accepted that Argentina's measures were designed to secure compliance with its Constitution and domestic law as well as international obligations ${ }^{2446}$ and recognized that the underlying "objectives, interests and values were of the utmost importance". ${ }^{247}$ Furthermore, the Panel pointed out that the previous GATS dispute of US-Gambling also emphasized that protecting society against the threat of money laundering is an interest that is important in the highest degree. ${ }^{2448}$ The Panel further added that:

In any country, tax collection is an indispensable source of revenue to ensure the functioning of the State and the various government services to citizens. Protection of the national tax base guarantees the viability of a country's public finances and, by extension, its economy and financial system. The risks posed by harmful tax practices are even more important for developing countries because they deprive their public finances of financial resources vital to promoting their economic development and implementing their domestic policies [emphasis added]. ${ }^{2449}$

\footnotetext{
${ }^{2443}$ Ibid (Study on Illicit Financial Flows, 2016), para.21.

${ }^{2444}$ UN Human Rights Council, The Report of the Special Rapporteur on extreme poverty and human rights, Magdalena Sepúlveda Carmona, A/HRC/26/28, $22^{\text {nd }}$ May 2014, p5.

${ }^{2445}$ See further: Committee on Economic, Social and Cultural Rights, Concluding observations on the sixth periodic report of the United Kingdom of Great Britain and Northern Ireland, E/C.12/GBR/CO/6, 24 June 2016, para 16; Committee on the Rights of the Child, Concluding observations on Georgia, U.N. Doc. No. CRC/C/15/Add.124 (2000) paras.18-19; The Lima Declaration on Tax Justice and Human Rights, "Advancing Tax Justice through Human Rights", Lima, Peru in 2015, convened by the Center for Economic and Social Rights, the Global Alliance for Tax Justice, Oxfam, Red Latinoamericana sobre Deuda, Desarrollo y Derechos (LatinDADD), Red de Justicia Fiscal de América Latina y el Caribe and the Tax Justice Network.

${ }^{2446}$ Panel Report, Argentina -Financial Services, para.7.655

${ }^{2447}$ Panel Report, Argentina- Financial Services, para.7.682. See also paras.7.664-7.671.

${ }^{2448}$ Panel Report, US-Gambling, paras. 6.492 and 6.493.

${ }^{2449}$ Panel Report, Financial Services, paras. 7.681.
} 
The Appellate Body did not disagree with the Panel's view on these issues, and although not citing the above paragraphs specifically, did refer to the Panel finding the objectives as being "of vital importance" and being in conformity with international priorities. ${ }^{2450}$

Thus, Article XIV(d) can be looked at in terms of protection of public health services, although indirectly, since measures for the protection of the tax base, if good governance is followed, could be expected to lead to better financing for public health services and better outcomes in terms of realizing the right to health. The impact of tax practices on social inequity, the growing gap between the rich and the poor and the violation of human rights, is a link being highlighted by human rights experts, UN bodies, intergovernmental and non-governmental groups.

Creating a more transparent and accountable global tax system is part of the responsibility of government to both their own citizens and to those in other States, with regard to collecting and using public revenue for public goods and services. Inaction on the above matters is gradually being accepted as a failure to fulfill a States' obligations regarding achievement of human rights and development - both their own domestic obligations as well as impacting the ability of other States affected by their actions or inactions, to fulfill their obligations.

The exception in Article XIV(e) allows for the non-application of the general MFN obligation, even if there is discriminatory treatment, if such treatment is based on an Agreement relating to the avoidance of double taxation. There is no definition of double taxation in the GATS, but reference can be made to the definition given by the Appellate Body in US-FSC, that:

...double taxation "occurs when the same income, in the hands of the same taxpayer, is liable to tax in different States. ${ }^{2451}$

Basically, double taxation refers to situations where the producer or service supplier is taxed in the country where the goods or services originate as well as the country to which they are exported. In the context of GATS, the four different modes of supply would also need to be taken into account. Farell comments that the text of Article XIV(e) does not offer any clear parameters for what falls within or outside the provision, but could broadly cover "non-standard tax policy" where Members attempt to avoid MFN treatment obligations in a tax treaty (and does so in an 'arbitrary or unjustifiable' manner, inconsistent with the standard in the chapeau). ${ }^{2452}$

Moreover, there are also other relevant provisions on double taxation in the GATS. Article XXII:3 of the GATS (the obligation on consultation) exempts double taxation from national treatment and the consultation and dispute settlement before WTO dispute settlement:

A Member may not invoke Article XVII, either under this Article or Article XXIII [dispute settlement and enforcement], with respect to a measure of another Member that falls within the scope of an international agreement between them relating to the avoidance of double taxation. In case of disagreement between Members as to whether a measure falls

\footnotetext{
${ }^{2450}$ Appellate Body Report, Argentina-Financial Services, paras.6.191-6.192.

${ }^{2451}$ Appellate Body Report, US-FSC (Article 21.5 - EC), para.137.

${ }^{2452}$ Farell, Jennifer E., THE INTERFACE OF INTERNATIONAL TRADE LAW AND TAXATION, IBFD, 2013, p187.
} 
within the scope of such an agreement between them, it shall be open to either Member to bring this matter before the Council for Trade in Services [at this point, the original Footnote 11]. The Council shall refer the matter to arbitration. The decision of the arbitrator shall be final and binding on the Members.

The original Footnote 11 to Article XXII:3 states that:

With respect to agreements on the avoidance of double taxation which exist on the date of entry into force of the WTO Agreement, such a matter may be brought before the Council for Trade in Services only with the consent of both parties to such an agreement.

Appendix 2 to the DSU also acknowledges the special procedure for arbitration under Article XXII:3.

Thus, double taxation is an area with a lot of policy space, as there is a national treatment exemption as well as an MFN exception from the application of the GATS - and an additional exemption from the usual dispute settlement system established by the WTO DSU. It is to be wondered at why it was decided that double taxation would be exempt from national treatment, but only an exception would be granted for MFN treatment, as bilateral treaties on double taxation can cover both these types of obligations.

Thus far, there have been no GATS cases double taxation which relied upon Article $X I V(e)$, but reference can be made to the analysis of the double taxation exception (Footnote 59) of the SCM Agreement by the Panel and Appellate Body in US-FSC and US-FSC (Article 21.5 - EC). Footnote 59 to Paragraph (e) ${ }^{2453}$ of the Illustrative List of Export Subsidies in Annex I to the SCM Agreement includes the statement that:

Paragraph (e) is not intended to limit a Member from taking measures to avoid the double taxation of foreign-source income earned by its enterprises or the enterprises of another Member.

The Appellate Body in US-FSC has stated that in the WTO framework, Members retain the discretion to avoid double taxation, even in the absence of Footnote 59.2454 Furthermore in US-FSC (Article 21.5-EC), noting that although Members retain the right to determine their rules of taxation, Footnote 59 did not give Members an unfettered discretion to avoid double taxation of "foreign-source income" through the grant of export subsidies as they must comply with any other relevant WTO obligations. ${ }^{2455}$

Due to the connection of tax measures with subsidies, the possibilities and limitations for taxation measures relating to trade in services would be interesting to go into further depth. However, there has not been much attention given to these tax provisions in the GATS context, unlike in the GATT and SCM context, where we have panel and Appellate Body Reports that analyze some of the terms and provisions relating to taxation. Furthermore, subsidies disciplines still remain a negotiating mandate in the GATS.

\footnotetext{
${ }^{2453}$ Paragraph (e) referred to above states:

The full or partial exemption remission, or deferral specifically related to exports, of direct taxes [original footnote 58] or social welfare charges paid or payable by industrial or commercial enterprises [original footnote 59].

${ }^{2454}$ Appellate Body Report, US-FSC, para.98

${ }^{2455}$ Appellate Body Report, US-FSC (Article 21.5-EC), paras.139-140.
} 
However, it can be seen that the negotiations should also take into account the relationship between subsidies and taxation. As tariff reductions would reduce government revenue, even if it may have other benefits for the economy, this may be particularly relevant for public services funded from national treasuries - looking at the situation from a very broad point of view. For example, it has been commented that Botswana has one of the highest levels of reliance on trade taxes in the world but they are still one of the fastest growing economies in Africa, ${ }^{2456}$ and they have also implemented one of the best public health services in that continent. Taxes relating to cross-border trade may be seen as a more equitable tax system, as well as able to raise more revenue, than other taxation such as VAT, which can be identified as disproportionately burdening the poorer sections of society. ${ }^{2457}$

Although not directly an issue of exceptions under Article XIV(d) and (e), the broader issues related to taxation and human rights are interesting to consider. It can be argued that one of the policy justifications for the direct tax exceptions is the necessity and duty of a State to maintain its tax base. The role of public services, especially universal health service provision which is free at the point of delivery, could depend upon on the attitude and practice of a society towards creating and maintaining a tax base that will allocate costs and benefits within that society. ${ }^{2458}$ Equitably sharing the costs of such a public service through the tax system is as important as equitably distributing the benefits. It can be argued that a Member should have a certain amount of discretion to take measures in relation to its tax policy that are directed towards this objective. However, as pointed out by Daly, tax policies and measures of Members are being monitored and evaluated through the Trade Policy Review Mechanism and even if they do not relate to WTO obligations or negatively affect trade partners, there may still be encouragement for unilateral liberalization of tax policy by removing or modifying existing measures. ${ }^{2459}$

In this context, the international co-operation for the development of guidelines in the area of tax justice occurring parallel to the WTO, are of great importance, and hopefully balance out and harmonize the trade objectives focused on in the WTO context (liberalization of services, MFN treatment and national treatment) with the non-trade objectives (ethics, values, principles of justice, equity and human rights) relating to public services, especially public health services with universal coverage, funded through general taxation and free at the point of delivery. ${ }^{2460}$

${ }^{2456}$ OECD and African Development Bank, African Economic Outlook 2010, Special theme: Public Resource Mobilisation and Aid, 2010, p93.

${ }^{2457}$ Although there is a general IMF and trade policy theory put forward that replacing trade taxes with other methods such as VAT is better for the economy as a whole, IMF studies have also shown that low income countries will find it more difficult to collect from other methods, the same level of government revenue lost through trade liberalization reforms that reduced import taxes/customs revenues - Baunsgaard T. and M. Keen, Tax Revenue and (or?) Trade Liberalisation, IMF Working Paper WP/05/112, June 2005.

${ }^{2458}$ Nielson, Julia, Ten Steps to Consider Before Making Commitments in Health Services Under the GATS in Blouin, Chantal, Nick Drager and Richard Smith Eds., INTERNATIONAL TRADE IN HEALTH SERVICES AND THE GATS: CURRENT ISSUES AND DEBATES, The World Bank, 2006, p131. ${ }^{2459}$ Daly, Michael, WTO and Direct Taxation, WTO Discussion Paper no. 9, p2 and 8, available online at http://www.wto.org/english/res_e/booksp_e/discussion_papers9_e.pdf.

2460 See further: UN General Assembly Resolution 63/239, Doha Declaration on Financing for Development, Annex, para. 16. See also para.25. This is an Outcome Document of the Follow-up International Conference on Financing for Development to Review the Implementation of the Monterrey Consensus, held in Doha in 2008; Inaugural 2016 Report of the Inter-agency Task Force on Financing for Development - Addis Ababa Action Agenda: Monitoring commitments and actions, Chapter II.A Domestic public resources, p33-34, available online at http://www.un.org/esa/ffd/wp-content/uploads/2016/03/2016- 


\subsubsection{Article XIVbis - The Security Exceptions}

The protection of national sovereignty in the sense of retaining decision-making power at the national level for protecting the national interest - which underpins all the exceptions to the general obligations of the WTO - becomes even more apparent in the context of the security exceptions provisions. While international trade brings economic benefits, it also has the drawback that:

...trade means that states must cooperate in ways that expose them to potential economic and security threats. ${ }^{2461}$

Therefore, there must be some means for balancing the benefits and threats - the economic threats by methods such as balance-of-payments and emergency safeguard measures and the security threats by security exceptions.

It is also generally commented that the WTO involves a 'shift towards legalism' as Members had to sacrifice a larger share of sovereignty than previously under the GATT 1947 , for greater stability and predictability in the world trade order. ${ }^{2462}$ If there is a greater sacrifice of sovereignty in the GATS, it ought to follow that the available exceptions would gain more attention. It is possible therefore that this security exception would increase in importance.

As discussed earlier under the section on "public order", there appears to be some overlap between the Article XIV and Article XIVbis exceptions, and therefore there will only be a brief discussion of this area. Although the spill-over of (international/defensive) security issues and (domestic) public order is a possibility, there is also a counter-view in support of a limited definition of "public order" which is not inclusive of such 'security' concerns. It should be noted that Article XIVbis can be seen as a broader exception, not only in terms of its' scope and definition, but since it is not limited by the same necessity and chapeau requirements that the Article XIV exceptions are subject to.

The security exception in trade law has been described as "a virtually unlimited escape clause" 2463 and "an Achilles heel of international law", ${ }^{2464}$ especially as it is not subject to

IATF-Chapter2A.pdf; See also, Advance unedited draft of 2017 report of the Inter-agency Task Force on Financing for Development - Progress and prospects, available online at http://www.un.org/esa/ffd/wpcontent/uploads/2017/03/2017-IATF-Report_AUV_30-Mar-2017.pdf; OECD, The OECD's Project on Harmful Tax Practices: the 2004 Progress Report, http://www.oecd.org/tax/harmful/30901115.pdf; IMF, OECD, UN, World Bank, Supporting the Development of More Effective Tax Systems: A Report to the G20 Development Working Group (2011), http:// www.oecd.org/ctp/48993634.pdf; See also the July 2016 report which analyzed how support for developing tax capacity can be improved, and provided the following recommendations - IMF, OECD, UN and World Bank Enhancing the Effectiveness of External Support in Building Tax Capacity in Developing Countries (2016), available at: http://www.oecd.org/tax/enhancingtheeffectiveness-of-external-support-in-building-tax-capacity-in-developing-countries.pdf.

${ }^{2461}$ Shell, G. Richard, Trade Legalism and International Relations Theory: An Analysis of the World Trade Organization, Duke Law Journal, Vol.44, No. 5, March 1995, p856.

2462 See Abbott, Kenneth W., Robert O. Keohane, Andrew Moravcsik, Anne-Marie Slaughter and Duncan Snidal, The Concept of Legalization, 54(3) International Organization, 2000; Shell, G. Richard, Trade Legalism and International Relations Theory: An Analysis of the World Trade Organization, Duke Law Journal, Vol.44, No. 5, March 1995.

${ }^{2463}$ Cottier T., and Delimatsis P., Article XIV bis GATS: Security Exceptions in Wolfrum, Rudiger., PeterTobias Stoll and Clemens Feinaugle Eds., WTO - TRADE IN SERVICES, Max Planck Commentaries on International Trade Law, Martinus Nijhoff Publishers, 2008, p331, referring also to Article XXI of the GATT 1994 and Article 73 of the TRIPS and citing Hahn, M., Vital Interests and the Law of the GATT: An Analysis of GATT's Security Exception, Michigan Journal of International Law 12, 1991, 558, p559. 
the same balancing process as Article XIV through the chapeau of Article XIV and the limitations of the nexus on the interests expressed in the subparagraphs. Although security interests may suggest purely non-economic concerns, in reality the line between security or political interests and economic ones are often blurred. As the means to the political ends are often economic, some see a risk that this exception can be used to undermine the entire WTO system. ${ }^{2465}$

There has not been an opportunity so far to create parameters for Article XIVbis of the GATS, and the scope of application is still a matter of speculation. Parallels to Article XIVbis GATS in the other WTO agreements are found in Article XXI of GATT 1947/1994 and Article 73 of TRIPS. The Article 3 of the TRIMS Agreement incorporates Article XXI of the GATT. The EC Treaty, Article 296 and Article 30 (with regard to "public security") and NAFTA Article 2101 also have similar provisions. As discussed earlier under "public order", national security and 'emergency situations' are grounds for restriction of most rights and freedoms in the context of human rights treaties as well. The ICCPR and the ECHR both include security as a limitation on rights such as public trial, freedom of expression and freedom of association and assembly. It is suggested by Akande and Williams that a comparative examination of how national security issues are treated in other international tribunals may be of guidance. ${ }^{2466}$

Article XXI of GATT 1947/1994 is particularly relevant as it existed for a long period of time, and some guidance ought perhaps to be found in the context of its use. However, the security exception of the GATT 1947 was rarely resorted to. There are several possible reasons for this including mutual deterrence, restraint and interest in compliance. The possibilities for political and security tensions among GATT 1947 parties and trading partners was limited as the tensions in that period were mostly focused on Cold War rivalries and not between GATT parties. When sanctions were undertaken, it was usually against Cold War rivals and such measures were rarely taken against other GATT Members. $^{2467}$

Another factor is that there was no obligation to notify recourse to security exceptions under Article XXI of the GATT until the GATT contracting parties adopted a Decision Concerning Article XXI (BISD 29S/23) following the Falkland Islands conflict in December 1982. ${ }^{2468}$ Paragraph 2 of Article XIVbis requires that the Council for Trade in Services shall be informed "to the fullest extent possible" of measures taken under the security exception.

\footnotetext{
${ }^{2464}$ Schloemann H., and S. Ohrloff, "Constitutionalization" and Dispute Settlement in the WTO: National Security as Issue of Competence, 93, American Journal of International Law, 1999, 424, p426.

2465 Cottier T., and Delimatsis P., Article XIV bis GATS: Security Exceptions, Wolfrum, Rudiger, PeterTobias Stoll and Clemens Feinaugle Eds., WTO-TRADE IN SERVICES, Max Planck Commentaries on International Trade Law, Martinus Nijhoff Publishers, 2008Eds. WTO - TRADE IN SERVICES, 2008, p331.

2466 Akande, Dapo and Williams, Sope, International Adjudication on National Security Issues: What role for the WTO?, Vol. 43 Vanderbilt Journal of International Law, 2002-2003, 365 at 371

${ }^{2467}$ Cold War period issues have also spilled over to the WTO context, as seen in the dispute US-Helms Burton in 1996 (the Cuban Liberty and Democratic Solidarity Act also known as the Helms-Burton Act, which imposed trade sanctions against foreign companies who traded with Cuba). However, this dispute did not however result in a ruling by the Panel.

${ }^{2468}$ Cottier T., and Delimatsis P., Article XIV bis GATS: Security Exceptions, Wolfrum, Rudiger., PeterTobias Stoll and Clemens Feinaugle Eds., WTO-TRADE IN SERVICES, Max Planck Commentaries on International Trade Law, Martinus Nijhoff Publishers, 2008, p333 and 347.
} 
The changes in world politics since then have led some authors to state that security is now a far more important matter under the WTO than GATT $1947 .{ }^{2469}$ However, some of the persisting security issues involving countries such as Iran and North Korea continue in much the same manner as they are not currently WTO members either. There have been several serious GATT-era disputes that did not result in panels, relating to e.g. Falklands and Yugoslavia conflicts. ${ }^{2470}$ In the context of the tensions between the United States and Nicaragua in the 1980s and the import prohibition on Nicaraguan goods and services in 1985, a panel was established, but its terms of reference excluded GATT Article XXI and ultimately it did not result in an adopted report. ${ }^{2471}$

It has also been argued that the GATT system was an inappropriate forum for dealing with security issues. Does this argument not apply with equal force to the WTO? In relation to the EU challenge to the 'Helms-Burton Act' of the United States ${ }^{2472}$ it was thought that the United States may perhaps invoke Article XXI of GATT 1994 as a justification for the US measures. But the actual position taken by the US suggested that they questioned the jurisdictional competency of the WTO dispute settlement system to adjudicate on the matter. The dispute was eventually settled between the EC and the US and did not result in a Panel decision, so it was not clarified in that dispute whether the WTO panels or Appellate Body can or ought to decide on such issues.

Russia and most former Soviet states have recently joined the WTO, and during the Ukrainian crisis in July 2014 trade sanctions imposed by the US and EU countries and counter-sanctions by Russia were discussed in terms of WTO violations. In 2015 Ukraine initiated a WTO complaint against Russia on embargoes on traffic in transit from Ukraine through Russia and Russia made a complaint against the Ukraine sanctions in $2017 .{ }^{2473}$ While the Ukraine did not specifically or obliquely refer to the 2014 tensions in their request for consultations, Russia specifically referred to restrictions and prohibitions adopted since 2014, in the two opening paragraphs in their request for consultations. Russia took the position that the measures were necessary for the protection of its essential security interests and invoked the provisions of Article XXI(b)(iii) of the GATT 1994. In April 2019, the Panel report of Russia-Traffic in Transit was adopted. This is the first dispute where a Panel was asked to interpret Article XXI of the GATT 1994. The Panel rejected Russia's argument that Article XXI(b)(iii) was "self-judging" and that the Panel therefore did not have jurisdiction over the matter. ${ }^{2474}$ The Panel recognized the discretion of every Member to define what is an "essential security interest" and to decide for itself on the necessity of its actions. ${ }^{2475}$ However, the Panel stated that Article

\footnotetext{
${ }^{2469}$ Schloemann H.L. and S. Ohrloff, "Constitutionalization” and Dispute Settlement in the WTO: National Security as an Issue of Competence, 93 American Journal of International Law, 1999, 424, p425.

${ }^{2470}$ European Economic Community banned imports from Argentina in 1982 and took trade measures against Yugoslavia in 1991. See further Trapp, Kimberly N., STATE RESPONSIBILITY FOR INTERNATIONAL TERRORISM, Oxford University Press, 2011, p211-213.

${ }^{2471}$ Article XXI Proposal by Nicaragua, MTN.GNG/NG7/W/48, 29 June 1988; GATT Panel Report, USNicaraguan Trade, L/6053 (unadopted).

${ }^{2472}$ Cuban Liberty and Democratic Solidarity (Libertad) Act of 1996, also known as the Helms-Burton Act relates to the US embargo against Cuba, and also has affects foreign States who may provide assistance to Cuba and foreign companies which may trade with Cuba.

${ }^{2473}$ Russian Federation-Measures Concerning Traffic in Transit (Russia-Traffic in Transit), consultations requested on 14 September 2016 (panel composed) and Ukraine-Measures relating to Trade in Goods and Services, consultations requested on 19 May 2017 (in consultations).

${ }^{2474}$ Panel Report, Russia-Traffic in Transit, paras. 7.102-7.104.

2475 Panel Report, Russia-Traffic in Transit, paras.7.130-7.131 and paras.7.146-7.147.
} 
XXI(b)(iii) must be interpreted and applied in good faith and that the Panel can review if the measures were "not implausible". 2476

Recently the United States has used Section 232 of the Trade Expansion Act of 1962 in order to impose increased tariffs on imports of certain steel and aluminum products, with the result that several WTO Members including China, the European Union, Canada and Russia, have initiated dispute settlement proceedings against the United States. The panel was composed in January 2019 for US-Steel and Aluminium Products (China). The United States' response is that the domestic steel and aluminum industries are vital for its essential security interests and that therefore the tariffs are necessary and have cited the security exception in GATT Article XXI. However, a direct link between the measures and national security has been difficult to justify. The United States also stated that the WTO dispute settlement system cannot review a Member's invocation of Article XXI, and had supported Russia's position as a third party in Russia-Traffic in Transit - but this argument is unlikely to be supported by the current Panel, subsequent to the earlier decision of the Panel in Russia-Traffic in Transit, that a review of whether there is a good faith application of the provision is possible.

Another aspect that could be relevant in the context of GATS is that the emergency safeguard measures for services for economic emergencies have not yet been finalized under the Article X (GATS) negotiating mandate, unlike the GATT 1994, which has its emergency safeguard measures in place. This may cause a blurring of the lines between economic and security concerns and lead to the security exceptions being used for protection in place of economic safeguards (whether legitimate or not). It has been commented that the lack of an emergency safeguard mechanism for services:

...creates an obvious disequilibrium and therefore the possibilities of extensive misuse of Article XIV (notably of the ordre public exception) or Article XIVbis (especially of international emergency) are considerably higher [original emphasis]. ${ }^{2477}$

Thus, it can be argued that security exceptions may gain more prominence in both GATT 1994 and GATS contexts in the near future.

These matters of unilateral definition and jurisdiction have not yet come up under GATS. In 2000, Honduras and Colombia initiated consultations ${ }^{2478}$ on the matter of tax measures by Nicaragua, which considered that its measures were consistent with both Article XXI of the GATT 1994 and Article XIVbis of the GATS. However, the panels were never composed in this situation. There is a possibility that the recent complaint by Qatar against the United Arab Emirates could refer to GATS Article XIVbis. The United Arab Emirates and other countries in the region such as Bahrain, Saudi Arabia and Egypt took economic measures against Qatar which they justified as necessary due to Qatar's alleged funding of terrorist organizations. Qatar denies that there is a national security justification and alleges that the measures are merely commercial. A Panel was

\footnotetext{
2476 Panel Report, Russia-Traffic in Transit, paras. 7.132-7.135 and 7.138-7.139.

2477 Cottier T., and Delimatsis P., Article XIV bis GATS: Security Exceptions, Wolfrum, Rudiger., PeterTobias Stoll and Clemens Feinaugle Eds., WTO-TRADE IN SERVICES, Max Planck Commentaries on International Trade Law, Martinus Nijhoff Publishers, 2008, p338.

${ }^{2478}$ Request for the establishment of a panel by Colombia, Nicaragua-Measures Affecting Imports from Honduras and Colombia, WT/DS188/2, p. 1; and Dispute Settlement Body, Minutes of Meeting held on 7 April 2000, WT/DSB/M/78. Request to Join Consultations, Nicaragua-Measures Affecting Imports from Honduras and Colombia - Communication from the European Communities, WT/DS201/2, 22 June 2000.
} 
established in April 2019, for United Arab Emirates-Goods, Services and IP rights. Assuming that this dispute would make reference to and carry out an interpretation of Article XIVbis of the GATS; what would be the terms which would be focused on, and would they have any relevance for a health context?

The text of the relevant security exception, Article XIVbis of the GATS, is as follows:

1. Nothing in this Agreement shall be construed:

(a) to require any Member to furnish any information, the disclosure of which it considers contrary to its essential security interests; or

(b) to prevent any Member from taking any action which it considers necessary for the protection of its essential security interests:

(i) relating to the supply of services as carried out directly or indirectly for the purpose of provisioning a military establishment;

(ii) relating to fissionable and fusionable materials or the materials from which they are derived;

(iii) taken in time of war or other emergency in international relations; or

(c) to prevent any Member from taking any action in pursuance of its obligations under the United Nations Charter for the maintenance of international peace and security.

2. The Council for Trade in Services shall be informed to the fullest extent possible of measures taken under paragraphs 1 (b) and (c) and of their termination.

From the terms "necessary" "essential" and "emergency" an overall impression is created that paragraphs 1(a) and (c) of this Article are not to be used lightly, and possibly pertain to a standard higher than normal "important" security interests. Objective criteria for defining the terms "necessary" "essential" and "emergency" have been proposed. But the Member seemingly has discretion to decide on "disclosure [...] which it considers contrary" to and "action which it considers necessary for the protection" of its essential security interests. Potential threats as well as actual, and perhaps even broader threats to global or regional security not specific to the internal security of the member may be advanced as within the definition. Would a public health crisis be considered within these terms, and how serious would it have to be to fall within this exception?

With regard to whether there is a connection with health issues, the most relevant phrase could be:

...necessary for the protection of its essential security interests: ... taken in time of war or other emergency in international relations

"Other emergency in international relations" could refer to a public health crisis, but it may be limited to that of such a serious level where the impacts are seen beyond national borders. In the context of Article 73(b)(iii) of the TRIPS Agreement, which has the same phrase as Article XIVbis(1)(iii) of GATS extracted above, Ping Xiong has commented that the security exception would be applicable only to a situation that presents a threat or risk of "regional or world disorder" (or threat to "order and peace") - and even then only 
to the extent that it would be necessary to respond to such a situation. ${ }^{2479}$ Ping Xiong cites Cann as support for the idea that epidemics such as HIV/AIDS can create a situation serious enough that it can threaten a nation's security and even regional security and cites Correa in stating that a health crisis may justify invocation of the Article 73 exception in TRIPS. ${ }^{2480}$ It should be noted that unlike the GATS, the TRIPS Agreement also has in addition to Article 73, the flexibilities provided for in Article 31, the Doha Declaration on TRIPS and Public Health and now, since 2017, a new Article 31bis. These together specifically address a Members' right to determine, in the context of public health, what constitutes a "national emergency or other circumstances of extreme emergency", and provides an alternate set of flexibility measures for access to essential medicines. A comparable specific flexibility is not there for the protection of health services in the GATS, which has only the general security exception in Article XIVbis.

Security can be said to be ultimately a matter that can be decided only by the state itself, as no other entity can have equal authority or interest to protect and advance the security of that state - but not all agree with this view. The idea that this grants unfettered discretion does not sit well with some commentators, one of them pointing out that:

"[p]ermitting unilateral interpretation without recourse to multilateral

overview... would allow the exception to emasculate the rules of a liberal trade order" ${ }^{2481}$

This appears linked with the philosophical underpinnings of neo-liberal economic theory which questions the scope of sovereign decision-making even in the case of a governmental function such as protection of national security, which was traditionally given considerable leeway in liberal economic theory. ${ }^{2482}$

This issue of unilaterally determining whether there was a security threat was also raised in the context of the GATT Panel Report US-Nicaraguan Trade, ${ }^{2483}$ dealing with Article XXI of GATT 1947. The Panel was unable to rule on the issues due to limited terms of reference, but asked several pertinent questions including: how was abuse to be avoided if the interpretation was exclusively by the invoking party and how could the complainant then have the complaint examined if the Panel cannot examine whether the recourse to the security exception was justified?

2479 Xiong, Ping AN INTERNATIONAL LAW PERSPECTIVE ON THE PROTECTION OF HUMAN RIGHTS IN THE TRIPS AGREEMENT: AN INTERPRETATION OF THE TRIPS AGREEMENT IN RELATION TO THE RIGHT TO HEALTH, Martinus Nijhoff Publishers, 2012, p238.

${ }^{2480}$ Ibid., (Xiong), p237-238 citing Cann Jr, Wesley A., On the Relationship between Intellectual Property Rights and the Need of Less-Developed Countries for Access to Pharmaceuticals: Creating a Legal Duty to Supply under a Theory of Progressive Global Constitutionalism, U. Pa. J. Int'l Econ. L. 25 (2004): 755, p827-828; Correa, Carlos, TRADE RELATED ASPECTS OF INTELLECTUAL PROPERTY RIGHTS: A COMMENTARY ON THE TRIPS AGREEMENT, Oxford University Press, 2007, p520.

${ }^{2481}$ Knoll, David D. The Impacts of Security Concerns upon International Economic Law, 11 Syracuse Journal of International Law and Commerce, 1984, 567, p587, referring to the GATT security exception.

2482 Jackson, John H., THE WORLD TRADING SYSTEM: LAW AND POLICY OF INTERNATIONAL ECONOMIC RELATIONS, MIT Press, 1997, p229:

One exception to liberal trade policies that has always been recognized by economic theorists and statesmen is that of national security.

Jackson also cites Adam Smith ("defence is more than opulence") at p21 for national security being a justifiable departure from liberal trade policies. But Jackson adds at p230 that Article XXI of the GATT is worded in "language so broad, self-judging and ambiguous" that it is open for abuse.

${ }^{2483}$ GATT Panel Report, US-Nicaraguan Trade, L/6053, para.5.17. 
Cottier and Delimatsis comment that the exception must be subject to the legal disciplines of the WTO and evidence of necessity for protection of security interests and evidence that the information sought falls within security interests must be provided. ${ }^{2484}$ Perhaps there is a possibility that 'unclassified' material that is already within the public right to information can be produced that will sufficiently proof. But Article XIVbis:1(a) clearly protects a Member from being compelled to provide information that it decides not to disclose.

There is an obviously wider margin of appreciation for Article XIVbis compared with Article XIV in general. Cottier and Delimatsis draw attention to the principle of good faith as both a general principle of law and a principle of general international law, being the balancing mechanism, even if it was not explicitly included in the text as per the proposal by Nicaragua in the Uruguay Round. ${ }^{2485}$ This suggestion underscores that, despite the supposed shift towards legalism and demand for stability and predictability mentioned earlier, trading partners still need to rely upon comity and diplomacy for the smooth flow of international trade.

The co-operation for international security concerns - as opposed to purely internal security matters - is raised in paragraph 1(c). The "action in pursuance of ...obligations under the United Nations Charter for maintenance of international peace and security" suggest action under Chapter VII (Security Council), VIII (regional security arrangements) or Article 51 (self-defence). Such action would include economic sanctions authorized by Security Council Resolutions in binding terms - which would create an obligation of compliance by UN member States. It should be noted that in such instances there is a role for a human rights approach. In the case of the right to health, the General Comment notes that:

States parties should refrain at all times from imposing embargoes or similar measures restricting the supply of another State with adequate medicines and medical equipment. Restrictions on such goods should never be used as an instrument of political and economic pressure. ${ }^{2486}$

The restriction on such goods would have an impact on the quality of the health services that can be provided in the country facing economic sanctions. This issue was also discussed earlier in the Chapter with regard to the overlap between the public order and security exceptions and the sanctions upon Iraq after the first Gulf War.

It should be noted in the context of the collective/United Nations procedures for identifying a security threat, that there are number of instances where health crises have been identified as security issues. The Security Council has in the period 2011-2017 looked at a number of problems as both security-related and as "health crises". These include risk of famine in Yemen, Somalia, South Sudan, and North-East Nigeria (2017), Meetings on famine in conflict areas (2017), Council briefings and debates on Ebola as a security threat (2014-15), and the global impact of HIV/AIDS (2011). In 2014 the UN

\footnotetext{
${ }^{2484}$ Cottier T., and Delimatsis P., Article XIV bis GATS: Security Exceptions, Wolfrum, Rudiger., PeterTobias Stoll and Clemens Feinaugle Eds., WTO-TRADE IN SERVICES, Max Planck Commentaries on International Trade Law, Martinus Nijhoff Publishers, 2008, p335.

${ }^{2485}$ Nicaragua had suggested that as a requirement of good faith, security exceptions should be resorted to only after failure of bilateral and $\mathrm{UN}$ or other inter-governmental negotiations.

${ }^{2486}$ UN CESCR, General Comment No. 14, The right to the highest attainable standard of health, U.N. Doc. E/C.12/2000/4, 2000, para.41. In the same paragraph of the Comment the CESCR recalls its position, stated in General Comment No. 8, on the relationship between economic sanctions and respect for economic, social and cultural rights.
} 
Security Council adopted Resolution 2177, characterizing the Ebola epidemic as a threat to international peace and security and calling in its operative paragraphs on all Member States to provide international assistance and co-operation. ${ }^{2487}$ There were also Resolutions on Ebola in the Democratic Republic of Congo more recently in 2018 (S/RES/2439) and earlier Resolutions on HIV AIDS in 2000 and 2011 (S/RES/1308 and $\mathrm{S} / \mathrm{RES} / 1983)$. It has been observed that the expansion of the Security Council role to such non-military sources of instability may have interesting implications for the WTO security exceptions clauses. ${ }^{2488}$

However, the Security Council has not acknowledged the right to health in its debates or resolutions. Even the General Assembly reports on health crises $^{2489}$ neglect the phrase 'right to health', but there are references to the importance of ensuring the continuation of essential health services and building up the capacity of health systems for universal health coverage. The report of the Director-General of the WHO on responses to global health crises (focusing on Ebola and Zika responses) also avoided the language of rights but acknowledged that:

... the bedrock of outbreak and emergency preparedness and response is a functioning, resilient national health system - with service delivery, financing, human resources, infrastructure, information and supply management systems capable of detecting and responding to public health events at the national and subnational levels [emphasis added]. ${ }^{2490}$

There is currently a Global Health Crises Task Force established by the UN SecretaryGeneral to support and monitor the implementation of the recommendations of these reports, which were issued by the Secretary-General and by the High-level Panel on the Global Response to Health Crises. The UN Security Council and General Assembly have brought 'health crises' under security matters, and this may support Members who wish to take measures to protect their essential health services in times of crisis, but the lack of a human rights approach to universal access and essential health services is matter of concern, since it can undermine the normative value and role played by the right to health in such security measures.

Thus, it can be seen that the security exception under Article XIVbis is a broader type of exception than Article XIV of the GATS. The protection of national security interests and international peace that is allowed under this provision is naturally extensive It also links directly with wider international law obligations and procedures under the UN Charter.

\footnotetext{
${ }^{2487}$ See for a critique of this Resolution as a widening of the Security Council's competence under Chapter VII of the UN Charter, beyond inter-state military conflict to non-military crisis including social and 'humanitarian' issues: Steinoth, Charlotte, The Security Council's Response to the Ebola Crisis: A Step Forward or Backwards in the Realization of the Right to Health?, March 2, 2017, https://www.ejiltalk.org/ the-security-councils-response-to-the-ebola-crisis-a-step-forward-or-backwards-in-the-realization-of-theright-to-health/.

${ }^{2488}$ Yoo, Ji Yeong and Dukgeun Ahn, Security Exceptions in the WTO System: Bridge or Bottle-Neck for Trade and Security?, Journal of International Economic Law, 2016, 19, 417-444, p441.

${ }^{2489}$ UN GA, Report of the High-level Panel on the Global Response to Health Crises, Protecting humanity from future health crises, A/70/723, 9 February 2016; UN GA, Report of the Secretary-General, Strengthening the global health architecture: implementation of the recommendations of the High-level Panel on the Global Response to Health Crises, A/70/824, 8 April 2016.

${ }^{2490}$ UN GA, Note by the Secretary-General on Global health and foreign policy, Report of the DirectorGeneral of the World Health Organization on the lessons learned in the public health emergency response to and management of previous international crises with health consequences (pursuant to General Assembly resolution 70/183), A/71/601, 4 November 2016, para.5.
} 
Problems about the protection of interests such as health that fall within the context of general public international law processes thus also apply to the assessment of this provision of the GATS. It is unfortunate that the original roots of trade rules, to promote trade and economic co-operation as a means of preventing war, is not reflected within this provision - nor the overlap of human rights concerns as both a reason for and reason to limit security-based limitations. It is an area where further work (suggestions, proposals, interpretations, amendments) could perhaps be done to introduce a clearer balance between defensive or offensive security action and cooperative/preventive and peaceful action through trade and human rights protection. 


\subsection{CONCLUSIONS ON CHAPTER 5}

In theory, the general exceptions in the GATS can protect national sovereignty and allow for protection of national interests in the prescribed situations. But a narrow construction of the scope of these provisions would allow for very little maneuverability. However, the policy space cannot be so broad as to threaten the international trading system that is attempting to create a clear, multilateral structure for trade that does not allow for trade protectionism or arbitrary or discriminatory treatment among trading partners. Examination of the status of an exception can be therefore be described as:

....an attempt to navigate between the Scylla and Charabdis ... of desired

national sovereignty and required international uniformity. ${ }^{2491}$

In this risky navigation, Members often find themselves floundering, even if the national policy objective that was the basis of their disputed measure is recognized as extremely important.

In determining the availability of a general exception, several questions need to be answered in the positive by panels and/or the Appellate Body, including whether the measure falls within the scope of the specific exception and if the standard of the nexus, (e.g. necessary, aimed at) is satisfied. In this process the importance of the interests or values at stake, reasonable available alternatives and trade impacts are also considered. Once the 'necessity test' is passed, there is another hurdle in the chapeau requirements. In a vast majority of the WTO disputes where exceptions have been raised, the respondent has not been successful. While a few cases could not prove that the measure fell within the scope of the exception, and some failed on the requirements of the chapeau, a majority of the cases could not overcome the nexus or 'necessity test'. In fact, it is possible to say that many disputes are really decided by the analysis of the nexus and the chapeau, and the question of whether the defence raised by the respondent Member falls within one of the interests in the exceptions is addressed only superficially.

This study is carried out in the context of the importance of public health services and in light of the idea that the human right to health that can also support national policy measures on public health services. Therefore, the main thrust of this Chapter concerned exceptions that are more likely to be relied on if a health-related matter arose in dispute settlement. As a result, a significant part of this concluding section will be focusing on a set of common conclusions on the paragraphs of Article XIV, (a), (b) and (c) of the GATS, 'necessary' and the chapeau.

It has been already suggested by commentators that the public morals exception has potential as an entry point for human rights concerns. However, there are difficulties in bringing human rights into the GATS through the exceptions at both technical and conceptual levels, as discussed in this Chapter. Despite these difficulties, a human rights approach can still be used, particularly with regard to assessing the scope of the interests/societal values protected in the exceptions and in the discussion of the necessity of measures.

\footnotetext{
${ }^{2491}$ Feddersen Christoph T., Focusing on Substantive Law in International Economic Relations: The Public Morals of GATT's Article XX(a) and "Conventional" Rules of Interpretation, 7 Minn. J. Global Trade 75, 1998, p78.
} 
An analysis of the interpretation of Article XIV(a) of the GATS in US-Gambling and the sources used would probably involve more about what was not said, than what was actually said and how it can guide future dispute settlement bodies in cases of general exceptions of the GATS. Thus, much of the commentary will have to be speculative and based on the very few available dispute settlement decisions, including those based on other WTO Agreements, especially cases based on Article XX(a) of the GATT 1994, such as EC-Seal Products. The Appellate Body, like any judicial body dealing with conflicting norms, must make a choice while attempt to strike a balance, and provide a convincing legal justification for its decision. In the context of US-Gambling, which was a traditional "public morals" situation of gambling (that has long been recognized as such although in the more modern context of trans-boundary internet gambling) - the interpretative approach was non-controversial. There was no need to interpret the scope of "public morals and public order" as provided in Article XIV(a) of the GATS in more detail than was needed for the dispute at hand. EC-Seal Products, dealing with the comparable provision in Article XX(a) of GATT 1994 recognized that animal welfare is a matter of ethical responsibility for human beings in general.

But there still has not been an opportunity for reference to human rights as a moral and ethical responsibility. Economic and social rights play a role in economic decisionmaking relating to services such as health services, and there is a balancing process carried out in the domestic sphere of many States, but this is not yet as clearly reflected in the GATS. But as the interpretation for "public morals or public order" is very broad, there is still potential for this exception in the GATS to be interpreted more expansively in the future.

Human rights has a complicated relationship with public morals and public order, as the latter are legitimate derogations from (some) human rights and can also play a balancing role between different rights or between a human right and another societal value. Although there have been many suggestions to introduce human rights concerns and approaches through the general exception clauses there are both benefits and drawbacks in doing so. A human rights approach could have a positive impact in several areas, such as in giving more specific definition to terms. Human rights treaties with broad membership could also be valid tools to interpret the scope of public morals, public order, human life or health. An evolutionary approach and 'non-isolated' view of WTO law could support human rights at heart of 'public morals' and as relevant to public order and right to health as at the heart of the protection of human life or health.

Yet human rights are risky tools, that can also be subverted for either protectionist or neoliberal goals that may be otherwise in conflict with economic and social rights. Perhaps if the scope and use of human rights approaches would be assessed according to the interpretations accepted in international human rights jurisprudence and expert bodies, non-genuine claims with regard human rights-related exception measures can be weeded out. However, the status of such interpretive guidance in international law generally and what status they could have within the WTO if the panels and Appellate Body refer to and rely on them, remain to be seen. It could be noted that if the interpretations and analysis made by human rights experts appointed by relevant human rights bodies for that specific purpose would be used by panels and the Appellate Body as intended by those human rights bodies, it would also be a response to the assertion that the WTO dispute settlement bodies are not suitable, capacity-wise to decide on any human-rights related matters since they would not be trying to re-invent the wheel on relevant human rights-related 
matters but relying on the existing expert interpretations. It also addresses the contention that decision-making and balancing human rights in the WTO context is a clearly and fundamentally different exercise than if it occurred in a human rights forum, which is familiar with the particular connotations of the historical and jurisprudential development of the rights at issue. Whether the WTO engages or does not engage with these issues, such engagement is not prohibited by the text of the GATS, and requires only the will to implement. The lack of such will on the part of the organization, the Members and the dispute settlement bodies, rather than the prohibition of such action in the WTO agreements appears to be the main reason why such a step is not being taken.

The extensive body of human rights jurisprudence can also be used as a different kind of limit upon a free-reign of public morals justifications in WTO exceptions which could be used as disguised protectionism. This could happen by suggesting that a trade restriction, even one inspired by human rights, should not be used to harm the socio-economic conditions of a population - and thus deny them their socio-economic rights. ${ }^{2492}$ It is important to note that in reality, developing countries often fear the use and abuse of 'human rights' reasoning by developed countries. Developing countries governments can view the strict standards of the exceptions as protecting their interests in cases of arbitrary extraterritorial application of human rights-based measures. This is clear from the commentary on the controversies over the granting of GSP and GSP-plus and the often-arbitrary imposition (or threats to do so) of economic sanction measures by some countries, based upon political reasons but related to allegations of civil and political rights violations. The 2005 Report of the High Commissioner on Human Rights (Human Rights and World Trade Agreements: Using General Exception Clauses to Protect Human Rights mentioned earlier in this Chapter) included the question whether the measure concerned is "imposed for authentic human rights purposes" or not - and how that could possibly be ascertained. ${ }^{2493}$ The Report has implied that one way in which the difficulty in distinguishing between "authentic" measures and disguised protectionism (which achieves neither trade nor human rights objectives) could be handled is: if a greater space will be allowed for Members to use the general exceptions to protect human rights "at home" than to use extraterritorial measures against foreign services and service suppliers. 2494

Of course, it can also be argued that the distrust of the extraterritorial application of human rights measures is born of a need to protect business and economic interests in the developing country at the expense of the rights of a large majority of the population. But there is also evidence presented that the non-implementation of core human rights (as

\footnotetext{
${ }^{2492}$ UN, Office of the High Commissioner on Human Rights, Human Rights and World Trade Agreements: Using General Exception Clauses to Protect Human Rights, (prepared by James Harrison and assisted by Steve Charnovitz, Robert Howse and Gabrielle Marceau), HR/PUB/05/5, 2005, http://www.ohchr.org/Documents/Publications/WTOen.pdf, also states this.

Also see Cassimatis, who concludes that further empirical and political assessments are needed to "fully understand the potential and the dangers of human rights related trade measures" - Cassimatis, Anthony, HUMAN RIGHTS RELATED TRADE MEASURES UNDER INTERNATIONAL LAW: THE LEGALITY OF TRADE MEASURES IMPOSED IN RESPONSE TO VIOLATIONS OF HUMAN RIGHTS OBLIGATIONS UNDER GENERAL INTERNATIONAL LAW, Martinus Nijhoff Publishers, 2007, p437.

${ }^{2493}$ UN, Office of the High Commissioner on Human Rights, Human Rights and World Trade Agreements: Using General Exception Clauses to Protect Human Rights, (prepared by James Harrison and assisted by Steve Charnovitz, Robert Howse and Gabrielle Marceau), HR/PUB/O5/5, 2005., p15-16 ${ }^{2494}$ Ibid., p17.
} 
well as core labour standards and environmental protection obligations) in some developing countries is for the purposes of attracting investors and to be more 'competitive' in international trade. ${ }^{2495}$ Ironically these investors are usually from some of the same countries whose governments use 'human rights diplomacy' to critique developing country societies on their democratic credentials or their implementation of certain civil and political rights.

Article XIV(b) of the GATS, the provision on the protection of life and health, may hold the most promise for the protection of public health services if there is an eventual dispute on the matter. A Member may have to show evidence of the health risks of not taking that protective measure. As this may deal with economic and social policy or social science assessments rather than scientific risk assessment followed in GATT 1994 and SPS disputes (although it may include statistics or data), it will be interesting to see how risk is calculated or assessed for the GATS. It is possible that the dispute settlement bodies could follow the same sort of analysis that was followed with regard to 'risk' in public morals in the recent EC-Seal Products case, in place of the 'SPS-type scientific assessment'.

The extent to which the dispute settlement bodies will take the right to health into account is doubtful, considering that so far, they have only applied a concept of 'public health' as a legitimate interest. This is probably because the Members themselves have avoided the use of such 'rights-language'. If a Member promotes a right to health approach, the dispute settlement bodies may have to justify its rejection, and to actually do so appears to be somewhat irrational. The right to health is inextricably linked with the type of healthcare system that a country wishes to create and maintain, and ignoring this concept ought not to be done, if an opportunity for introducing it occurs. The right to health could be considered as supporting and strengthening the foundation for the measures that could end up relying on Article XIV(b) of the GATS. A measure necessary for the protection of human life or health ought to be discussed in light of the right of human beings to health, since the right of a Member to take such protective measures is not for an abstract objective, but for the benefit of human beings. Other measures to protect human life and health pale into insignificance beside the necessity to have a good health service that progressively realizes the right to health of the population as individuals and as a whole.

With regard to the term "laws and regulations", measures covered by the exception in Article XIV(c) of the GATS include, but are not limited to the listed interests; prevention of deceptive and fraudulent practices or to deal with the effects of a default on services contracts, protection of privacy and confidentiality and safety. "Laws and regulations" in this context refer to rules passed by the legislative or executive, that form part of the domestic legal system of a WTO member, which including rules deriving from international agreements that have been incorporated into the domestic legal system of a WTO member or have direct effect according to that WTO Members legal system but does not extend to obligations of another Member under an international agreement. Article XIV(c) cannot be interpreted according to the wishes of the domestic legal system of a party to a dispute or be regarded as relating to policy measures in general. "Laws and regulations" must be correctly identified for the purposes of the dispute - but a panel is

${ }^{2495}$ This has been commented on especially in the area of labour standards; see Davies, Ronald B., and K.C. Vadlamannati, A Race to the Bottom in Labour standards: An Empirical Investigation, Vol.103, Journal of Development Economics, July 2013, p1-14. 
free to use any provisions referred to by any of the parties in the dispute and to then make a choice as to which provisions are relevant to assess for the purposes of the defence.

Consistency of the relevant laws and regulations with the provisions of the relevant Agreement is generally presumed until prima facie evidence of inconsistency is presented by the claimant, whereupon the burden shifts to the respondent. If raised for the first time under an affirmative defence, the burden - that there is no WTO-inconsistency - is upon the respondent. And with regard to "to secure compliance", the term is to be read as meaning to enforce compliance and does not refer to compliance with general objectives. Enforcement does not need to mean coercion or that the outcome is certain, but that the measure should be designed with compliance specifically in mind. Compliance with public health objectives or right to health obligations clearly can be a basis for laws and regulations which are not incompatible with WTO obligations.

Thus, while is it possible that a human rights approach to the interpretation of Article XIV and its subsections, especially paragraph (a) and (b), has promise; and while it is possible to agree that:

The use of human rights discourse can orient international economic institutions to recognising new and vital contexts of moral attention...2496

...there remains the necessity of a broad understanding of human rights law and its effects and outcomes, and not a piecemeal patching up where it seems suitable in the opinion of some countries or interest groups for a particular short-term goal. This is where the value of a 'bilingual approach' to human rights and trade is evident, since the translation of human rights language and discourse into trade law can be done more systematically and with a greater understanding of the limitations inherent in such an attempt at translation.

A human rights-based approach to trade policy, in order to ensure that trade is targeted towards equitable outcomes, appears to be a better pathway than using human rights as an exception to trade and thus casting the entire relationship into an adversarial one. The abovementioned 2005 Report of the High Commissioner on Human Rights also highlights the concern with human rights being "associated too closely with trade restrictions" because it enters the scene through the exceptions clauses. It is recognized that the use of human rights to legitimize trade restrictions:

...could work against wider objectives of human rights approaches to trade and development, which places the realization of human rights among the objectives of trade rules ${ }^{2497}$

If human rights come into the discussion only as exceptions and restrictions to trade, which have to be justified by the Member raising the exception, this can cause a certain level of distrust regarding the role of human rights or other related values in the context of trade. Even for proponents of human rights approaches to trade, the goal is not to use them merely as exceptions - that is a last resort - but preferably to attempt to bring human rights into the trade system as an inbuilt balance against the possibility of harm.

There is some overlap between the different sub-paragraphs of Article XIV, especially as a broad concept of public morals and public order possibly overlaps with the other

\footnotetext{
2496 Del Mar, Maksymilian and Oche Onazi The Moral Quality of Work in International Economic Institutions: Resisting Complacency, International Journal of Law in Context, 4, 337-372, 2009, p358.

${ }^{2497}$ OHCHR, Human Rights and World Trade Agreements: Using General Exception Clauses to Protect Human Rights, HR/PUB/05/5, 2005 (prepared by James Harrison and assisted by Steve Charnovitz, Robert Howse and Gabrielle Marceau), http://www.ohchr.org/Documents/Publications/WTOen.pdf, p15.
} 
paragraphs of Article XIV and public order possibly overlaps with Article XIVbis (which is discussed separately in Section 5.9 of this study). It is possible that a measure for the protection of public health services could be justified under Articles XIV(a), (b) and (c) public morals, human life or health and measures securing compliance with laws and regulations which are not inconsistent with the GATS. Whether the view is that each clause is mutually exclusive or that a single measure can be related to more than one subparagraph, it is advisable for respondents in GATS disputes to rely on more than one subparagraph, as has been in the context of GATT, where in US-Shrimp, Article XX(b) and (g) of the GATT were invoked. Only one of the exceptions needs to be proven, but a party can always invoke more than one in the alternative.

The following summary can be made of the steps to be taken by a dispute settlement body with regard to the necessity test for the exceptions of Articles XIV(a), (b) and (c). It would first be assessed whether this measure is "necessary" - and in defining "necessary" the term means something closer to "indispensable" than "contributing to". Originally it was stated that this measure should be the least trade restrictive alternative. However now the requirement is that there should be no reasonably available alternative measure that is less trade restrictive. The current approach is that the panel and/or Appellate Body must carry out a holistic weighing and balancing of the importance of the policy objective pursued, the trade restrictiveness of the measure at issue and the contribution of the measure made to the achievement of the policy objective pursued - with in most cases also a consideration of whether there is a less trade restrictive alternative measure that could have reasonably been taken. The idea of a holistic weighing and balancing exercise has been emphasized in more recent WTO jurisprudence. It can be stated that the necessity test exists to makes sure that Members properly assess the linkage of the policy consideration or value to the measure in question.

However, it is difficult for a Member to know beforehand whether their measure would be considered 'necessary' or not by the WTO dispute settlement bodies. What happens in dispute settlement is that there is a case-by-case assessment of particular measures, to confirm either the position of the complaining Member or the position of the responding Member. In practice, the necessity test has a very high failure rate and this is sometimes explained as due to the excessive strictness of the necessity test. However, another explanation can also be given, that this failure is perhaps because it is more likely that Members would pursue a dispute only if they are quite confident of the measure being inconsistent with WTO obligations. For those who succeed in the getting over the hurdle of the necessity test, there is still the final requirement of the chapeau of Article XIV of the GATS to face.

The chapeau to the general exceptions provision is an additional safeguard that the exceptions will not be abused for protectionist purposes. It is a balancing mechanism that carries out a case by case assessment of the justification for the WTO-inconsistent measure. This intention is laudable, especially as it encourages honest, good faith dealing between WTO Members. Yet ultimately, in the few instances where respondents succeeded in overcoming both the preliminary hurdles (the scope of the exception and the nexus) in the Article XIV exception, they more often than not failed at the final hurdle of the chapeau. From a respondent Members' point of view, they are far more 
likely to fail in their recourse to the general exceptions, than succeed in justifying their actions. $^{2498}$

This results, as well as analysis of the argumentation in the disputes, has led to comments that the WTO panels and Appellate Body have been "endlessly creative" in finding reasons to deny the general exceptions the reach that they could have had, if the interpretation was not so restrictive. ${ }^{2499}$ This seems a rather harsh judgement, and it can be said that it is the case that almost all the GATS disputes are ones where the complainants were just very sure of the merits of their case and the other Member refused to settle the matter during diplomatic negotiations or WTO consultations. But it remains true in terms of the outcomes of dispute settlement that the standards of the chapeau will curtail any attempts at applying WTO-inconsistent measures, even if they adhere to public morals, health protection or any other justification and are deemed to have complied with the standard of the nexus. A more detailed socio-political study on the extent to which there is evidence that each of the measures that failed the chapeau was in fact introduced as a protectionist measure for the benefit of certain producers or suppliers, would perhaps cast more light on the matter., if the legal consequences faced by the measure are more clearly seen as restricting an unfair attempt at protectionism than being, as is often portrayed to the public, the use of legal technicalities to prevent important social objectives being implemented, such studies would also be a successful response to public criticisms of the panels and Appellate Body.

Paragraphs (d) and (e) of Article XIV of the GATS do not at first glance seem to have relevance for the protection of public health services. However, when looking at a fairly broad canvas of the role of taxation from the point of view of its role in sustainable development, human rights and public services it is possible to link policy and regulatory measures with regard to financial and tax law and policy to the State responsibility to progressively realize the the right to health by using tax revenue for the development of public health services.

It can be argued that the WTO system forces Members to assess their non-trade measures which also restrict trade, fully and in depth, and that this is a useful contribution even towards domestic accountability as well international responsibility with regard to both the trade system and other obligations. The legal and policy regime for international human rights as a whole as well as for the right to health (and the special regimes for environment, labour and other non-trade matters) usually encourage critiques of the systems from within; including clarification of aims and concepts, and the good faith aspects of methods of implementation and remedies resorted to. ${ }^{2500}$ There ought to be no

\footnotetext{
2498 Stone Sweet, Alec and Thomas L. Brunell, Trustee Courts and the Judicialization of International Regimes: The Politics of Majoritarian Action in the ECHR, the EU and the WTO, Yale Law School Faculty Scholarship, 1-1-2013, p83. The authors make an interesting point that the likelihood of success will be higher if the measures are established practice in industry suggesting that any measures that disturb the status quo or practice of industry would be less likely to succeed (at p.83-85).

${ }^{2499}$ Hernandez-Truyol, B.E. and S.J. Powell, JUST TRADE: A NEW COVENANT LINKING TRADE AND HUMAN RIGHTS, NYU Press, 2009, p95.

${ }^{2500}$ See e.g. Kennedy, David, Reassessing International Humanitarianism: The Dark Side in Orford Anne, Ed., INTERNATIONAL LAW AND ITS OTHERS, Cambridge University Press, 2009; Tomuschat, Christian, HUMAN RIGHTS: BETWEEN IDEALISM AND REALISM, Oxford University Press, 2014; Douzinas, Costas, HUMAN RIGHTS AND EMPIRE: THE POLITICAL PHILOSOPHY OF COSMOPOLITANISM, Routledge, 2007; Ignatieff, Michael, HUMAN RIGHTS AS POLITICS AND IDOLATRY, Princeton University Press, 2003; Beitz, Charles R., THE IDEA OF HUMAN RIGHTS,
} 
objection to an assessment within the WTO, of whether or not non-trade measures are merely being used as a smoke-screen for unfair protectionism for the benefit of a few. What is interesting is that a similar kind of scrutiny is also by-and-large lacking within the WTO system, by its proponents, towards the concepts, aims, use of and effects of trade law. The exceptions may have been seen at one point by some observers, as an opportunity to engage in such a scrutiny. It remains an excellent area for further exercise of 'bilingualism' by international lawyers and anyone else who is interested in the interface between WTO obligations and other non-trade concerns. However, the interpretation and implementation of the exceptions has thus far been such that this potential has come to be seen as much more limited than earlier expectations.

Oxford University Press, 2011; Thomas Pogge, WORLD POVERTY AND HUMAN RIGHTS: COSMOPOLITAN RESPONSIBILITIES AND REFORMS, 2nd ed., Polity Press, 2008. 


\section{CHAPTER 6}

\section{EXTRA POLICY SPACE FOR DEVELOPING AND LEAST DEVELOPED COUNTRY MEMBERS?}

It's a great huge game of chess that's being played - all over the world - if this is the world at all, you know.

Oh, what fun it is! How I wish I was one of them!

I wouldn't mind being a Pawn, if only I might join

- though of course I should like to be a Queen, best.

From Lewis Carroll's Through the Looking Glass

Have I not here the best cards for the game, To win this easy match play'd for a crown? And shall I now give o'er the yielded set?...

From Shakespeare's King John 
Chapter 6 


\section{CHAPTER 6 \\ 'EXTRA' POLICY SPACE FOR DEVELOPING COUNTRY AND LDC MEMBERS?}

\subsection{INTRODUCTION TO CHAPTER 6}

This Chapter will assess the extent of extra policy space that a Member may or may not have under the GATS framework, if they are a developing or least developed country Member. Although this Chapter does not focus on developed countries, it is not ignored that there can be inequalities and inequities in health services provision within developed countries. ${ }^{2501}$ The evidence from research is that the greater the disparities are within a society in terms of income differences, the poorer the health consequences will be. ${ }^{2502}$ However, developing and especially least developed countries (LDCs) are, in the normal course of events, likely to face more serious challenges from extreme poverty, lack of basic infrastructure, lack of access to clean drinking water and sanitation, epidemic disease including HIV/AIDS, armed conflict and displacement, natural disasters and climate change; all of which negatively impact development and the right to health. ${ }^{2503}$

Therefore, it is important to assess whether there is any extra policy space for developing and LDC Members to take measures for protecting and improving their domestic health services, particularly public health services which should be providing universal access in dealing with the most serious and widespread health problems. The policy formulation for solutions to these health challenges should come from other fields than international trade. However, WTO law, and in the case of services, the GATS, could also play a significant role in defining certain trade-related boundaries of the policy framework within which developing and LDC Members must act.

There are several mentions of developing country or LDC needs in the GATS that suggest that there is flexibility allowed for a positive differentiation of Members who are in less favourable economic position compared to other Members. The negotiators in the Uruguay Round were no doubt aware of the GATT experience of including the Enabling Clause and GSP system in an attempt to redress the inequalities in goods trade, but a similar mechanism was not followed for trade in services. This Chapter will analyze the provisions that were instead included in the GATS and their usefulness in terms of maintaining national policy space for development-linked societal values. As in the previous Chapters, health services policy will be highlighted.

The first part of this Chapter introduces the background to the provisions of the GATS which are relevant for the discussion of whether there is 'extra' policy space for developing countries and LDC Members. The second part discusses the available

\footnotetext{
2501 See Van Doorslaer, Eddy, et al., Inequalities in access to medical care by income in developed countries, Canadian Medical Association Journal 174.2 (2006): 177-183 - this research on the use of doctors in 21 OECD countries in year 2000 showed that the degree of pro-rich inequity in doctor use is highest in the United States and Mexico, followed by Finland and Portugal - reinforced where there is more private insurance and private options - but in most OECD countries the social arrangements benefit the poor.

${ }^{2502}$ Pickett, Kate E. and Richard G. Wilkinson, Income inequality and health: A causal review, Social Science \& Medicine, Volume 128, March 2015, Pages 316-326.

${ }^{2503}$ The legal framework of the international human right to health was discussed in detail in Section 2.4 of Chapter 2 of this study.
} 
definitions for 'developing country' and 'LDC', which is not expressly defined within the texts of the WTO Agreements. The special provisions for developing country and LDC Members are analyzed in more detail in the next part of the chapter, which also has a section on the role of subsidies in development policy before concluding.

\subsection{BACKGROUND AND RELEVANT PROVISIONS}

Discussions on developing countries, least developed countries (LDCs) and trade in services often commence with a reference to the reluctance of developing countries to include services in the WTO 'package'. It is widely accepted that the push for liberalization of services originated from certain US service sectors, which influenced the stand of the US negotiators in the GATT Tokyo Round (1973-1979) ${ }^{2504}$ and that some developing countries continued to oppose the inclusion of services right up to the conclusion of the Uruguay Round. ${ }^{2505}$ The developing countries who openly opposed the inclusion of services were usually led by India and Brazil, as well as Argentina. A commentary on the negotiating history states that:

The decision to formally undertake work on trade in services by the GATT was subject to heated debate between the United States and developing countries...The United States threatened to abandon the GATT if trade in services was not placed on the negotiating table. ${ }^{2506}$

So it was that services were included in the negotiations and ultimately became part of the WTO system as a compromise in order to take the negotiations forward. ${ }^{2507}$ The wording of the Ministerial Declaration of $20^{\text {th }}$ September 1986 (the Punta del Este Declaration) reflects this compromise, referring as it does to the expansion of trade under conditions of:

...progressive liberalization and as a means of promoting economic growth of all trading partners and the development of developing countries.

Developing countries initially submitted proposals for specific measures to be included in the draft of GATS, such as infant industry protection. ${ }^{2508}$ But subsequent deadlock in services and the final tough negotiations in other areas such as agricultural subsidies meant that few of these proposals became provisions by the time of the final package. Instead, Article IV of the GATS, titled "Increased Participation of Developing Countries" reiterated the framework for progressive liberalization of trade in services through negotiated commitments, allowing for some acknowledgement of different development status of developing countries and LDCs. However, the original objective of the development of developing countries is retained in second and fifth recitals of the Preamble to the GATS, as well as specific mention of the "serious difficulty" faced by LDCs in the sixth and final recital of the Preamble.

\footnotetext{
${ }^{2504}$ Stewart, Terence P. Ed., THE GATT URUGUAY ROUND: A NEGOTIATING HISTORY (19861992), Volume II, Kluwer Law and Taxation, 1993, p2343.

${ }^{2505}$ Hoekman, Bernard, Developing Countries and the Uruguay Round: Negotiating on Services, World Bank Policy Research Working Paper No.1220, 1993, p4; Marchetti Juan A. and Petros C. Mavroidis, The Genesis of the GATS (General Agreement on Trade in Services), European Journal of International Law, 2011, 22 (3), p689-721.

${ }^{2506}$ Stewart, Terence P. Ed., THE GATT URUGUAY ROUND: A NEGOTIATING HISTORY (19861992), Volume II, Kluwer Law and Taxation, 1993, p2354.

${ }^{2507}$ Footer, Mary E. and Carol George, The General Agreement on Trade in Services in Macrory, Patrick, Arthur Appleton and Michael Plummer, THE WORLD TRADE ORGANIZATION: LEGAL, ECONOMIC AND POLITICAL ANALYSIS, VOL. I, Springer 2005, p817.

${ }^{2508}$ Ibid., (Footer and George), p818.
} 
While a specific provision on infant industry protection was not included in the final draft of the GATS, developing countries succeeded in resisting the pressure for inclusion of a national treatment obligation of general application, such as is included in the GATT. This may be due not merely to the inflexibility of developing countries, but to the fact that the EC also resisted inclusion of both national treatment and market access provisions in the GATS as general obligations. ${ }^{2509}$ It has been commonly stated that developing countries made a bad bargain during the negotiations that led to the WTO, by merely increasing the burdens on themselves without proportional benefits, something that would be termed in Sri Lankan idiom as 'exchanging ginger for pepper'. Scott and Wilkinson commenting on the lack of capacity of trade delegations of low-income countries, noted that negotiators have later admitted they did not fully understand at the time of the Uruguay Round what they could have bargained for and what they had given away. $^{2510}$

MFN treatment in the GATS is a general obligation (although conditional, being subject to Article II exemptions) and when the WTO came into force, GATS lacked the type of special and differential treatment that was already available under the GATT 1994 Generalized System of Preferences (GSP), It was only later that an institutionalized process for developed countries to grant special and differential benefits for least developed countries in trade in services was introduced through the through the 2011 LDC Services Waiver which was 'operationalized' by the 2013 Bali Ministerial Conference decision. ${ }^{2511}$ It has been commented by Chadha that the reason for there to originally be less preferential treatment for developing countries in the GATS as compared to the GATT 1994 is because:

The GATS is based on the argument that if the national governments have concern for economic efficiency, the optimal policies would be the same for both developed and developing countries. ${ }^{2512}$

So, it is unsurprising that there are some who will argue against an assumption that additional policy space is necessary for developing economies in the area of trade in services. It can be argued that the telos of progressive liberalization in the GATS includes the development of developing countries and LDCs - and increased international trade in services can be causally linked to the efficiency and competitiveness of domestic services in such countries, just as much as in industrialized, developed countries.

It can also be argued that there is no need for fear of lack of policy space as the GATS is the most flexible of the WTO agreements, due in particular to the system of negotiating and scheduling specific commitments on market access and national treatment. This flexibility is common to all WTO members regardless of economic development level. However, it is often pointed out that there is, in reality, a disadvantage for developing country members, as they are firstly, subject to greater constraints in terms of expertise and capacity for negotiating and scheduling these commitments and secondly, subject to

\footnotetext{
${ }^{2509}$ Ibid., (Footer and George), p818.

${ }^{2510}$ Scott, James and Rorden Wilkinson, Changing of the Guard: expert knowledge and 'common sense' in the Doha Development Agenda, BWPI Working Paper 166, Brooks World Poverty Institute, 2012, p15.

${ }^{2511}$ Ministerial Conference, Decision of 17 December 2011, Preferential Treatment to Services and Service Suppliers of Least-Developed Countries, WT/L/847, dated 19 December 2011. This Waiver Decision was 'operationalized' by the 2013 Bali Decision on LDC Services. It was reported that by 2015 and 2016, a number of developed countries had notified preferential measures in support of LDC services.

2512 Chadha, Rajesh, GATS and Developing Countries: A Case Study of India in. Stern, Robert M. Ed., SERVICES IN THE INTERNATIONAL ECONOMY, University of Michigan Press, 2001, p249.
} 
pressures to commit from stronger players that they are often not in a position to resist. ${ }^{2513}$ It has been suggested that the best practical strategy for negotiating is formation of developing country blocs for greater bargaining power ${ }^{2514}$ but this suggestion includes the assumption that developing countries have more in common than they actually do and that least developed country concerns can and will be taken into account by leading developing countries in such negotiations.

The rise of the BRICs and other important developing economies (e.g. the G20) are affecting the balance of global economic power, or at the very least, the perception of the sources of power. This should have an impact on the directions the WTO and the postDoha negotiations will take. Scott and Wilkinson comment that these developing economies do not yet have the power to be the "dominant voices" in the negotiations in the way the US and EU are, nor is it conceivable that they could do anything similar to what the US has done to protect its domestic interests (e.g. amendments relating to the 'green box' of subsidies to the Agreement on Agriculture). ${ }^{2515}$ However, Scott and Wilkinson note an important shift of vision away from the "Western-dominated narratives" of trade liberalization with the rise of developing countries such as India and China, which they describe as:

...the rekindling of interest in more interventionist models of development...[and] the role that the state can play in the development process... 2516

This importance of the role of the State means that there should be policy space for measures that promote national development - especially in the case of developing and least developed countries.

The role of the State with regard to strengthening public services as part of its development obligation, has been discussed extensively in light of the State obligations under Article 12 (right to health) of the ICESCR. Similarly, the failure of the State has implications for development and for the delivery of public services and the right to health. The current UN Special Rapporteur on the right to health, Dainius Puras' submitted a Report in 2017 on the "devastating effect" that corruption can have on "good governance, the rule of law, development and the equitable enjoyment of all human

\footnotetext{
${ }^{2513}$ For example, Gregory Schaffer notes:

We can roughly categorize these challenges [to developing countries] as constraints of legal knowledge, financial endowment, and political power, or, more simply, of law, money and politics.
}

- Shaffer, Gregory, The Challenges of WTO Law: Strategies for Developing Country Adaptation (a version of the paper published in the World Trade Review July 2006), available at http://www.worldtradelaw.net/ articles/shafferdc.pdf, last accessed on 25.05.2010.

2514 See Mashayekhi, Mina, Martine Julsaint and Elizabeth Tuerk, Strategic Considerations for Developing Countries: the case of GATS and Health Services in Blouin, Chantal, Nick Drager and Richard Smith Eds. INTERNATIONAL TRADE IN HEALTH SERVICES AND THE GATS: CURRENT ISSUES AND DEBATES, World Bank, 2006, p17.

${ }^{2515}$ Scott, James and Rorden Wilkinson, Changing of the Guard: expert knowledge and 'common sense' in the Doha Development Agenda, BWPI Working Paper 166, Brooks World Poverty Institute, 2012, p11.

${ }^{2516}$ Ibid., (Scott and Wilkinson)., p12, noting also that this "idea of the developmental state" came into the mainstream through the World Bank World Development Report 1997 which argued that the State should play a facilitator role:

...development requires an effective state that plays a facilitator role in encouraging and complementing the activities of private businesses and individuals.

(from the World Development Report 1997: The State in a Changing World, World Bank, piii). 
rights, including the right to health", particularly in how it "reinforces ineffective and harmful policymaking and health services provision". ${ }^{2517}$ He noted that:

The right to health requires that States take action, including policy, legislative, and budgetary action, to prevent corruption from impeding the available, accessible, acceptable and good-quality health care. ${ }^{2518}$

There is increasing correlation being made between public financing, good governance, development and human rights. ${ }^{2519}$ There has also been extensive work over the past several decades at the UN level on developing a global political commitment to promote health and reduce health inequities by addressing social determinants, particularly through strengthening public health service provision. ${ }^{2520}$

It can be argued that the GATS actually has this policy space for measures that promote national development, including health services, and that it is the misunderstanding of the existence and extent of the space that is the problem and not the lack of it. This Chapter looks into this assertion in further depth.

There are several key statements and provisions in the GATS that refer specifically to developing countries and/or least developed countries (LDC's):

- Article XIX (Progressive Liberalization - Negotiation of Specific Commitments) allows for fewer commitments by developing countries, giving them some (temporary) leeway.

- Article XIX:3 cross-refers to Article IV:1 and IV:3.

- The Preamble of the WTO Agreement and the Preamble of the GATS, read with Article $I V$ (Increasing Participation of Developing Countries) and Article $X V: 1$ (Subsidies) provide for special consideration and may provide for 'extra' policy space for developing and least developed countries.

- In addition, Article $X X V$ on technical cooperation also refers specifically to least developed countries in cross reference to Article IV:2.

The above provisions will be focused on for the purposes of this Chapter, but other relevant provisions will be referred to briefly below. Not all are 'rights' of Members under the Agreement. Article III:4 of the GATS (Transparency) allows for "appropriate flexibility" for the time-limits for establishment of the enquiry points required by this provision. But this is not a general right of developing country and LDC Members for extra time, but a flexibility that "may be agreed upon for individual developing country Members".

\footnotetext{
2517 UNGA and HRC, Report of the Special Rapporteur Dainius Puras, on the right of everyone to the enjoyment of the highest attainable standard of physical and mental health, A/72/137, 14 July 2017, summary, p2 and conclusions, para.84.

${ }^{2518}$ Ibid (Puras, 2017), para.36.

${ }^{2519}$ See for example: Joseph E Stiglitz and Mark Pieth commenting on how the anti-corruption and human rights instruments moved closer together (Stiglitz Joseph E., and Mark Pieth, Overcoming the Shadow Economy (Friedrich-Ebert Stiftung, November 2016), available online at https://www.documentcloud.org/ documents/3219549-Stiglitz-and-Pieth-Overcoming-the-Shadow-Economy.html, last accessed 20.04.2017) ${ }^{2520}$ See the WHO, The Ottawa Charter for Health Promotion, adopted 21 November 1986 at the First International Conference on Health Promotion; WHO, Closing the gap in a generation: health equity through action on the social determinants of health, Final report of the Commission on Social Determinants of Health, Geneva, 2008; the Rio Political Declaration on Social Determinants of Health, 2011; Goal 3 of the Sustainable Development Goals adopted by the General Assembly in 2015.
} 
There are other provisions in the GATS that developing countries in particular may wish to take advantage of, including the flexibility for developing countries included in Article $\mathrm{X}$ (Emergency Safeguard Mechanism), Article V:3 (Economic Integration Agreements) and Article XII (Restrictions to Safeguard the Balance of Payments). But the emergency safeguard measures provision in Article $\mathrm{X}$ is only a negotiating mandate and needs further multilateral negotiations before it can become the basis of any action.

Economic integration agreements (EIA) also apply only to situations where such agreements have been negotiated by Members and apply to any Member that has done so - and there is acknowledgement of the needs of developing countries in such a context. Article V:3 of the GATS states that there are two types of flexibilities available for developing countries entering into an EIA:

1. Article $\mathrm{V}: 3(\mathrm{a})$ - Flexibility regarding the conditions of substantial sectoral coverage ${ }^{2521}$ and national treatment set out in V:1, "in accordance with the level of development of the countries concerned, both overall and in individual sectors and subsectors" -

2. Article V:3(b) - Flexibility in situations where an EIA involves only developing countries (sometimes referred to as South-South EIAs), MFN may be granted to "juridical persons owned or controlled by natural persons of the parties to such an agreement". This allows for an additional flexibility notwithstanding V:6, which would otherwise entitle a service supplier of any other Member not party to the EIA, to also benefit from the same treatment (provided that it is "a juridical person constituted under the laws of a party to the EIA and "engages in substantive business operations in the territory of the parties to such agreement").

At first glance, it appears that Article V:3(a) is worded, not so much as a right of developing countries, but as a possibility in negotiation with trading partners. The extent of flexibility in Article V:3(b) is also unclear. Comparing the GATT Enabling Clause with Article V:3(b) of the GATS could be useful for trying to identify the extent of flexibility which is for developing countries. In addition to GSP, the GATT Enabling Clause also provides the legal basis for the Global System of Trade Preferences (GSTP) and for regional arrangements under which developing countries exchange trade concessions among themselves. It has been commented by Sieber-Gasser that that there are several different ways (from narrow to broad) that Article V:3 could be interpreted in light of differences between it and the GATT system and the lack of GATS jurisprudence on the matter. ${ }^{2522}$ Sieber-Gasser also notes that few developing countries have taken advantage of Article V:3(b) and that thus far it seems to be of limited practical relevance. ${ }^{2523}$ The provision, if used, could perhaps allow for EIAs to make exclusions concerning the protection of certain services such as health services, or to retain

\footnotetext{
${ }^{2521}$ Article V:1 of the GATS requires "substantial sectoral coverage", which is described in Footnote 1 of the GATS as:

This condition is understood in terms of number of sectors, volume of trade affected and modes of supply. In order to meet this condition, agreements should not provide for the $a$ priori exclusion of any mode of supply.

2522 See further, Sieber-Gasser, Charlotte, Part III:1: The Legal Scope for Flexibilities for South-South Preferential Services Trade in DEVELOPING COUNTRIES AND PREFERENTIAL SERVICES TRADE, Cambridge University Press, 2015, p202.

2523 Sieber-Gasser, Charlotte, Part III:1: The Legal Scope for Flexibilities for South-South Preferential Services Trade in DEVELOPING COUNTRIES AND PREFERENTIAL SERVICES TRADE, Cambridge University Press, 2015, p213.
} 
restrictions in access for certain modes of supply. However, it should be noted that the Panel in Canada-Autos stated generally that:

...the purpose of Article $\mathrm{V}$ is to allow for ambitious liberalization to take place at a regional level, while at the same time guarding against undermining the MFN obligation by engaging in minor preferential arrangements [emphasis added]. ${ }^{2524}$

The Appellate Body did not address this point, but there is doubt as to whether Article V could be used in the future by developing countries for flexibility that reins in liberalization for a specific sector or modes within a sector.

Article XII, as well as what is likely for the emergency safeguard measures under Article $\mathrm{X}$ - would cover only special and temporary circumstances and would apply not to a general state of a member's economy over a long period of time (as long as it is 'developing'). Developing countries could use these provisions (including what may be negotiated under Article X), but the extent of the benefit to be gained remains to be seen and could only assist in situations of economic difficulty. Therefore, these provisions would not be useful for a Member wanting to take protective measures concerning its public health system in the normal course of its affairs, with a normal level of economic growth and stability.

Article XII:1 of the GATS on balance-of-payments restrictions does not require further negotiations (as required the emergency safeguard measures) or a separate agreement such as an EIA for its application. It applies to any Member facing "serious balance-ofpayments and external financial difficulties or threat thereof". Article XII:1 states that:

...particular pressures on the balance of payments of a Member in the process of economic development or economic transition may necessitate the use of restrictions.

Thus, developing country needs are taken into account. But, keeping in mind our focus on public health services, it should be noted that there is no flexibility to protect a service sector or type of service, although certain restrictions on trade in services (where commitments have been undertaken) "including on payments or transfers for transactions relating to such commitments", can be made. According to Article XII:3, it is expressly stated that Members may prioritize the supply of services which are more essential to their economic or development programmes when determining the incidence of restrictions, but no restrictions can be adopted or maintained "for the purpose of protecting a particular service sector".

Although there is no dispute settlement finding relating to Article XII of the GATS, the Appellate Body report in India-Quantitative Restrictions on measures under Article XVIII:11 of GATT 1994 to safeguard the balance-of-payments with regard to trade in goods is interesting to refer to. The Appellate Body upheld the Panel finding that such import restriction measures (in this instance it was import restrictions on agricultural and industrial goods and textiles) were not justified in that dispute. What is significant is that the Appellate Body also rejected India's claim that a 'Principle of Institutional Balance' between judicial and political organs exists in the WTO, which requires that Panels refrain from reviewing the justification of balance-of-payments restrictions under Article XVIII:B. ${ }^{2525}$ India's claim that this assessment by the Panel was dependent on an IMF

${ }^{2524}$ Panel Report, Canada-Autos, para.10.272.

${ }^{2525}$ Appellate Body Report, India-Quantitative Restrictions, para.105. 
analysis, and was a wrongful delegation of the duty to make an objective assessment of the matter in accordance with Article 11 of the DSU, was also rejected by the Appellate Body. ${ }^{2526}$ Panels can decide on whether measures taken by Members to safeguard balance-of-payments are justified or not, but is expected to make an objective decision on the matter. However, this decision can be influenced by an IMF conclusion that the import restrictions were not necessary. This is in keeping with Article XII:5(e) of the GATS which states that IMF findings on statistics and facts relating to an IMF Member who is in consultations regarding a dispute on a balance of payments should be accepted.

Although this appears to affect the sovereign authority of a State to make economic and development policy decisions, ${ }^{2527}$ it was explained by both the Panel and Appellate Body that this does not mean that a Member is required to change its development policy. This position accepts the views of the complainant (the United States) and the IMF, the latter's views being specifically cited by both the Panel and Appellate Body. ${ }^{2528}$ The Appellate Body summed up its position, thus:

We believe structural measures are different from macroeconomic instruments with respect to their relationship to development policy. If India were asked to implement agricultural reform or to scale back reservations on certain products for small-scale units as indispensable policy changes in order to overcome its balance-of-payments difficulties, such a requirement would probably have involved a change in India's development policy. ${ }^{2529}$

It has been commented by both Howse and Joseph that the Appellate Body decision can be seen as presenting a dismemberment of 'development policy' from macro-economic and trade policy, whereas a holistic view of development would see them as entwined. ${ }^{2530}$ Howse states that a different understanding of 'development policy' and a broader human-rights-based approach to development may have been understood if UNCTAD and UNDP had been consulted in addition to the IMF. To Howse, it "would be obvious" that macro-economic policies which effect the reserves of currency needed for fulfilment of economic and social rights (through purchase of goods and services) are part of 'development policy'. ${ }^{2531}$ Joseph adds that this dispute highlights the fact that there is an

${ }^{2526}$ Ibid., (India-Quantitative Restrictions), para.149, stating that the Panel did not simply accept the views of the IMF (which is allowed under Article 13 of the DSU), but critically assessed it and also considered other data and opinions in reaching its conclusions. India's argument was that the Panel relied on "unverifiable views" from the IMF and not "facts and an expert opinion" (see para.50).

${ }^{2527}$ See Ibid., (India-Quantitative Restrictions), para.35, India's submission that:

It is up to each Member to choose among those policy instruments, taking into account, not only the economic efficiency considerations on which the IMF bases its policy advice, but also its structural, institutional and political constraints.

${ }^{2528}$ See Ibid., (India-Quantitative Restrictions), paras.125-126, citing the IMF view which was accepted in para.5.220 of the Panel Report. Also see the US view, in para.68 of the Appellate Body report:

Furthermore, macroeconomic policy instruments with respect to a Member's external financial situation, like its commercial trade policy, are not instruments of "development policy" within the meaning of the proviso to Article XVIII: 11.

${ }^{2529}$ Appellate Body Report, India-Quantitative Restrictions, para.128

${ }^{2530}$ UN Commission on Human Rights, (Paper prepared by Robert Howse), Mainstreaming the Right to Development into International Trade Law and Policy at the World Trade Organization, UN.Doc E/CN.4/Sub.2/2004/17, June 92004 paras.46-49, for critique of this aspect of the decision. See also Joseph, Sarah, BLAME IT ON THE WTO: A HUMAN RIGHTS CRITIQUE, Oxford University Press 2013, p66 and 171 .

${ }^{2531}$ UN Commission on Human Rights, (Paper prepared by Robert Howse), Mainstreaming the Right to Development into International Trade Law and Policy at the World Trade Organization, UN.Doc E/CN.4/Sub.2/2004/17, June 9 2004, para.48. 
inclination of the WTO dispute settlement to defer to "technocrats of international financial institutions" but to ignore the equally relevant work of "international institutions concerned with social justice". ${ }^{2532}$ Desierto also agrees with Howse and Joseph comments more specifically that a WTO Member who is also a State Party to the ICESCR could make its case for import restrictions to either address balance of payments emergencies or ensure "adequate" reserves for economic development programmes by referring to its ICESCR obligations, especially the minimum core obligations which must be met regardless of economic difficulties. ${ }^{2533}$ Desierto also notes that it is not a well-balanced analysis to leave out this aspect of a Members' economic development obligations, and to rely primarily on the IMF assessment of needs, which ignores such human rights and human development evaluations.

The suggestion in India-Quantitative Restrictions is that only specific and temporary restrictions would be covered by the proviso to Article XVIII:11 of GATT 1994 and that restrictions that are 'macro-level' and which would not be limited to a specific period of time may fall outside the scope. Similarly, Article XII of the GATS refers to "particular pressures...in the process of economic development or economic transition" and ensuring financial reserves "adequate for the implementation of its programme of economic development or economic transition". Thus, in light of India-Quantitative Restrictions, it is possible to say that the policy space that may be available under the comparable provision in the GATS will also be very limited.

However, 'macro-economic development policy', as raised by India in India-Quantitative Restrictions, is not a concept that is applied specifically to a particular period of transition only and could even be used by all Members at all times, and not just economies in transition, developing countries and LDCs. Howse has commented that a right to development approach would not separate development from macro-economic policies, as well as the fact that other expert opinion on development policy from agencies such as the UNCTAD were ignored in favour of the monetarist views of the IMF. ${ }^{2534}$ Of course, the recourse to the IMF can be easily justified as the IMF is referred to specifically in the provisions for balance-of-payments in the WTO, (including Article XII of the GATS), and other organizations and agencies in the field of development such as UNCTAD are not specifically mentioned in the texts in that specific context.

The approach taken in this chapter to the question of whether there is really more policy space for developing countries in the GATS, is to focus on the legal interpretation of the Preamble and provisions of the Agreement that can be of use to all developing and least developing country Members in all situations and at all times, not just for Members entering into economic integration agreements, facing balance of payments issues or wanting to benefit from emergency safeguard measures.

\footnotetext{
${ }^{2532}$ Joseph, Sarah, BLAME IT ON THE WTO: A HUMAN RIGHTS CRITIQUE, Oxford University Press 2013, p67.

${ }^{2533}$ Desierto, Diane A., PUBLIC POLICY IN INTERNATIONAL ECONOMIC LAW: THE ICESCR IN TRADE, FINANCE, AND INVESTMENT, Oxford University Press, 2015 p210.

${ }^{2534}$ Ibid., (India-Quantitative Restrictions), para.126.

Also see Scheuermann, Philipp, NORMATIVE CONDITIONS TO MAKE WTO LAW MORE RESPONSIVE TO THE NEEDS OF DEVELOPING COUNTRIES, Volume 73 of Europaisches und Internationales Recht, Herbert Utz Verlag, 2010, p90-91.
} 
This legal focus of this Chapter does not intend to ignore the geopolitical and socioeconomic realities faced by developing and least developed countries, but attempts to focus the analysis how far the legal space can be extended. The hope is that thereby developing country Members would be assisted in playing a better game with the cards that have been dealt. It is often argued that there are sufficient GATS provisions which take special account of the needs of developing and least developed countries. Yet these provisions should be clarified further, in order for these members to know where they stand and to what extent the provisions can be used. But before analyzing these terms and provisions, it may be necessary to look at how developing and least developed countries are identified and defined in the WTO system. 


\subsection{WHAT IS A DEVELOPING COUNTRY OR LEAST DEVELOPED COUNTRY IN WTO LAW?}

The miserable Hatter dropped his teacup and bread-and-butter, and went down on one knee.

'I'm a poor man, your Majesty,' he began.

\section{From Lewis Carroll's Alice in Wonderland}

The WTO system does not have a legal definition of 'developing country' nor does it set out, in any of its covered agreements and annexes, a guideline on how to make an attempt at definition. This can be considered odd as a majority of WTO members are developing countries and since there are several special provisions that apply to such countries. On one hand, this preliminary difficulty can be looked at as another useful flexibility, as 'developing country' can be self-defined. On the other hand, it can be seen as a preliminary stumbling block in the application of the available special treatment as it can be a useful flexibility for other Members rejecting such self-definition and wishing to deny benefits that may accrue to a 'developing country' whose economy is showing signs of fast growth and increased international competitiveness. A few years ago, a group of Members formed themselves as an "Asian Group of Developing Members", ${ }^{2535}$ as a forum for sharing views among its Members and for them to work with other Members towards common objectives where their views are convergent. This group is the only official communication listing a self-defined group of "developing Members", although there is a separate definition for least developed countries (LDCs), as will be discussed in more detail in this section.

In the case of the GATS, there is no attempt or hint at a definition for 'developing country'. However, Article XVIII:1 of the GATT 1994 (Governmental Assistance to Economic Development) refers to:

...those contracting parties the economies of which can only support low standards of living and are in the early stages of development.

Furthermore, Article XXXVI of the GATT 1994 (under Part IV, Trade and Development), reminding the contracting parties of the objectives and principles of the Agreement, refers to lower standards of living ${ }^{2536}$, lower export earnings and a less diversified economy in relation to "less developed contracting parties".

These criteria may be useful for identifying developing country status, but it is not precise and its applicability, even in the GATT 1994, is uncertain. Nor can we turn to the dispute settlement system of the WTO, as there has not so far been any definition of developing country status. The panels and the Appellate Body usually merely refer to the self-

\footnotetext{
2535 Communication from Pakistan, Communique- Formation of Asian Group of Developing Members, Document WT/GC/COM/6 of 27 March 2012. The listed WTO members (31):

Bahrain, Kingdom of, Bangladesh, Brunei Darussalam, Cambodia, China, Chinese Taipei, Hong Kong, China, India, Indonesia, Jordan, Korea, Republic of, Kuwait, the State of, Kyrgyz Republic, Lao People's Democratic Republic, Macao, China, Malaysia, Maldives, Mongolia, Myanmar, Nepal, Oman, Pakistan, Philippines, Qatar, Saudi Arabia, Kingdom of, Singapore, Sri Lanka, Thailand, Turkey, United Arab Emirates, Viet Nam

${ }^{2536}$ See especially, Article XXXVI(c) ...noting, that there is a wide gap between standards of living in less-developed countries and in other countries...
} 
identification of countries as developing countries in their submissions and if there is no opposition from the other party or parties, the issue remains non-controversial.

Thus, it is often reiterated that developing country status is self-defined in the WTO. ${ }^{2537}$ This seems on one hand, an easy way to avoid a prolonged discussion on legal technicalities. However, this does not mean that developing country status cannot be questioned or challenged or has never been a matter of contention. In its first dispute as a complainant in the WTO dispute settlement system, US-Steel Safeguards, ${ }^{2538}$ China claimed that as a developing country member, Article 9:1 of the Agreement on Safeguards should be applicable to them. China's claim was based on its self-definition, which the United States objected to, but could not bring any legal arguments against. ${ }^{2539}$ The Panel and Appellate Body declined to decide on the matter, citing judicial economy. ${ }^{2540}$

If we look at the GATT criteria of standards of living, export earnings and diversification of the economy mentioned above, it is still difficult to categorize certain countries. Take for example, the case of China: there are some doubts as to the exact data on the Chinese economy, but it is generally agreed that it is in a strong economic position globally. World Bank data claims that China's GDP per capita was USD 9770 for 2018 and its GNI per capita was USD 9460. ${ }^{2541}$ Earlier studies referred to China's Gini coefficient (a measure of inequality) as having risen during the past 30 years to place it among the countries with the worst inequality in 2008. ${ }^{2542}$ According to World Bank data, the richpoor gap and the discrepancy in economic development and income between provinces and between urban and rural households had been increasing during this period. However, most recent World Bank data such as the national poverty headcount ratio (the percentage of the population living below the national poverty lines) shows a steep decline in poverty from 17.2 in 2010 to 3.1 in $2017 .^{2543}$

China noted in its preliminary assessment on the opening up of trade in services in 2002 that the imbalance of economic development between regions is likely to be further widened as a result of GATS, as foreign investors in services target Beijing and coastal cities of already more developed eastern China. ${ }^{2544}$ Thus while China has a high economic growth rate and export earnings, in other aspects China was seen as a developing country. China used similar statistics to argue for developing country status during negotiations for accession to the WTO in 2001, pointing out that even though

${ }^{2537}$ Grote, Rainer, Article IV GATS in Wolfrum, R., Peter-Tobias Stoll and Clemens Feinaugle Eds., WTOTRADE IN SERVICES, Max Planck Commentaries on International Trade Law, Martinus Nijhoff Publishers, 2008, p118.

${ }^{2538}$ Panel Report, US- Steel Safeguards, and Appellate Body Report, US- Steel Safeguards.

2539 See Panel Report, US-Steel Safeguards, para.7.1882: and Appellate Body Report US-Steel Safeguards paras.234-235 and para.260.

${ }^{2540}$ Panel Report, US-Steel Safeguards, para.10.714 and Appellate Body Report US - Steel Safeguards, para.508.

2541 World Bank, https://data.worldbank.org/indicator/NY.GDP.PCAP.CD?locations=CN, last accessed 28.12.2019.

${ }^{2542}$ Sicular, Terry, The Challenge of High Inequality in China, Inequality in Focus Series, Poverty Reduction and Equity Department, World Bank, Vol. 2, Number 2. August 2013, available at http:/www.worldbank.org/content/ dam/ Worldbank/document/Poverty\%20documents/Inequality-InFocus-0813.pdf, last accessed 27.07.2014.

${ }^{2543}$ World Bank, https://data.worldbank.org/country/china?view=chart, last accessed 28.12.2019.

${ }^{2544}$ Communication from the People's Republic of China - Assessment of Trade in Services, TN/S/W/9, 19 December 2002, para.26. 
exports from China stood at approximately USD 195 billion, the difference between urban and rural income was approximately USD 655 to USD $260 .{ }^{2545}$ Therefore it was stated that, "although important achievements have been made in its economic development, China was still a developing country" 2546 and should be regarded as such under the WTO. With regard to improving public health services and covering 200 million citizens without medical insurance, new policy plans unveiled by Central Committee of the Chinese Communist Party and the State Council in in 2009, "for the first time clearly defines basic health care as a public service provided to all Chinese citizens" based on the "People-first principle" and pledged a health care system providing "safe, effective, convenient and affordable" public health care services financed jointly by the central and local governments for both urban and rural residents and all citizens without medical insurance. ${ }^{2547}$ Having achieved massive overall gains in economic growth in the past few decades, China has now also put in place a national policy framework for public health services coverage and delivery, with extensive public subsidies and financing and ambitious targets.

China's growth rate in the past two decades has been unprecedented and shows signs of continuing in the same vein, making China an economic power while still being a "developing country". This naturally leads to dissatisfaction of other trading partners with its self-definition, as seen above; and their reluctance to see China make full use of the special and more favourable treatment available to developing country members under the WTO agreements. Extensively citing economic growth statistics, ${ }^{2548}$ the United States has recently complained that "self-declared developing countries" cause "unpredictable and illogical results" in the operation and implementation of existing special and differential provisions in WTO agreements, clearly indicating China as the most problematic case in their view, but also referring to other Members such as Singapore, Hong Kong, China, Macao, Israel, India, Kuwait, the Republic of Korea, United Arab Emirates, Brunei Darussalam, Kazakhstan, Colombia, Thailand, Turkey, Chile, Argentina, the Kingdom of Saudi Arabia and Qatar. ${ }^{2549}$ In this 45-page communication, the United States notes that new factual circumstances require reconsideration of the currently used UNDP, IMF and World bank classifications and the overall WTO approach to definition of Members as developing countries, particularly the lack of establishment of gradations among developing Members within the WTO system.

\footnotetext{
${ }^{2545}$ WTO, Working Party on the Accession of China, Report of the Working Party on the Accession of China, WT/ACC/CHN/49, October 1, 2001, para.7.

${ }^{2546}$ Ibid, para. 8 .

${ }^{2547}$ Zhao, Litao, and Yanjie Huang, China's blueprint for health care reform, East Asian Policy 2.1 (2010): 51-9.

${ }^{2548}$ WTO, General Council, Communication from The United States - An Undifferentiated WTO: selfdeclared development status risks institutional irrelevance, WT/GC/W/757, 16 January 2019. The statistics covered were: GDP per capita total exports, high-technology intellectual property royalties, foreign direct investment, corporate size, supercomputers, space, defense spending. Some of the significant statistics were that GDP per capita for Brunei Darussalam $(\$ 76,870)$, the State of Kuwait $(\$ 74,109)$, the Kingdom of Saudi Arabia $(\$ 51,329)$, and the United Arab Emirates $(\$ 68,121)$ had figures "well above the average for OECD Members" (para.2.8) and that "China's exports in the ATP [advanced technology products] categories jumped 3400 per cent in value terms between 1995 and 2016, exceeding the exports of the United States; Japan; Germany; the UK; and France combined ( original emphasis, para.2.17).

${ }^{2549}$ WTO, General Council, Communication from The United States - An Undifferentiated WTO: selfdeclared development status risks institutional irrelevance, WT/GC/W/757, 16 January 2019, particularly paras.1.8-1.9, 2.3-2.7 and 4.4.
} 
It has been commented with regard to self-definition as a developing country in the GATS, that other countries:

...remain free to challenge this self-definition [as a developing country] and to refuse to negotiate any commitments...under Article IV ${ }^{2550}$.

If such refusals to accept a self-definition as a developing country occur under GATS, whether with regard to such negotiations or relating to the general recognition of the possibility of additional policy flexibility, there may be a basis for a dispute in the future. In such a case, the dispute settlement system may still be at a loss for a method of formulating a suitable legal definition - and may consider it, quite reasonably, not to be their task. However, it will be a very awkward situation if a country is considered as a developing country by some WTO members and not as a developing country by some other WTO members - thereby facing a restriction of their rights under the relevant agreement that the dispute settlement system cannot do anything about. This was pointed out by China in its submissions in US - Steel Safeguards (before the Panel):

Further in China's view, it is not possible that a single Member be considered a developing country by, say, the United States and not the European Communities and others in respect of the same dispute or the same provision. To proceed otherwise would deprive WTO developing country Members from all legal certainty as far as their rights and obligations under WTO Agreements are concerned. To proceed otherwise would also be in contradiction with the need for a multilateral approach of the "special and differential treatment" provisions within the WTO. ${ }^{2551}$

One commentator noted that developing country Members face many economic and political pressures from different developed countries with regard to claiming developing country status under different agreements, which "ultimately results in a patchwork of differential application". ${ }^{2552}$ However, the actual extent of these pressures are probably overstated, since for most countries, the claiming of developing country status by another country would not be an issue which would be given any attention.

Yet it can be said that attention was paid to developing country status and special and differential treatment with regard to China in its accession process. "Some members of the Working Party [to China's Accession Protocol]" put forward the idea of a "pragmatic approach' with regard to China's use of differential and more favourable treatment provisions in the WTO agreements - and that "(e)ach agreement and China's situation should be carefully considered and specifically addressed". ${ }^{253}$ The issue of "tradedistorting subsidies" 2554 was particularly focused on although there were still many unresolved issues regarding agricultural subsidies of developed countries. It was stated that it was:

\footnotetext{
${ }^{2550}$ Grote, Rainer, Article IV GATS in Wolfrum, Rudiger, Peter-Tobias Stoll and Clemens Feinaugle Eds., WTO-TRADE IN SERVICES, Max Planck Commentaries on International Trade Law, Martinus Nijhoff Publishers, 2008, p118.

${ }^{2551}$ Panel Report, US-Steel Safeguards, para.7.1863:

2552 Broude, Tomer, The Rule(S) of Trade and the Rhetos of Development: Reflections on the Functional and Aspirational Legitimacy of the WTO, 27(4) Columbia Journal of Transnational Law, November, 2006 also available online at http://www.worldtradelaw.net/articles/broudelegitimacy.pdf, accessed on 25.10 .2010

${ }^{2553}$ WTO, Working Party on the Accession of China, Report of the Working Party on the Accession of China, WT/ACC/CHN/49, October 1, 2001, para. 9.

${ }^{2554}$ Ibid, para. 171.
} 
...inappropriate for China to benefit from certain provisions of Article 27 [of the SCM Agreement]. ${ }^{2555}$

Article 27 of the SCM Agreement deals with Special and Differential Treatment of Developing Country Members. China submitted to the pressure and conceded that they would not seek to invoke Articles 27.8, 27.9 and 27.13 of the SCM Agreement, but reserved the right to benefit from Articles 27.10, 27.11, 27.12 and 27.15. ${ }^{2556}$

It can be argued that China is a special case, considering its growing economic power and the special Accession Protocol; but if a similar 'pragmatic approach' is extended to ongoing negotiations/rounds with other developing countries showing strong economic growth under different regimes in the WTO, and the 'patchwork' effect becomes more and more acceptable, it is to the detriment of developing countries' ability to claim special treatment under the available provisions. This is more so for small developing economies, whose voices are not heard in the Ministerial Conferences and whose fate is usually decided by concessions acceded to or proposals rejected by larger developing economies, in particular the 'emerging powers'.

On the other hand, a 'pragmatic approach' focusing on treating the more successful developing economies more like developed members than developing members, may at times give benefits to smaller and slower developing economies if this means that they can more easily access the special treatment available under the WTO agreements. So, this could be welcomed by some developing countries in certain contexts. But it has to be admitted that such an approach probably results in developing countries as a whole losing the little extra support given by the agreements to buttress the comparatively lesser bargaining power that they have in ongoing rounds - rather than some small developing economies maintaining or managing to get more flexibility than they would otherwise have got.

Another possibility with an application of developing country status depending on different agreements or sectors of the economy is that some countries with strong economies may find it useful to be covered by the developing country definition in some situations. If powerful economies decide to redefine themselves as developing based on the comparative strength of the industry or sector at issue, that would be another complication if a dispute arises as it can be argued that an unfair advantage would be taken. States like Israel, which are considered developed by some standards and are members of the OECD and listed as an advanced economy by the IMF, are still are referred to as developing countries in other circumstances. According to United Nations statistical categorization of economic groupings, Israel is still considered a developing country. ${ }^{2557}$ This may be due to inequality statistics or perhaps other political reasons. Israel certainly saw its interests as being on the side of developed countries, when it supported the US proposal for the establishment of a working party on trade in services in the face of opposition by developing countries. ${ }^{2558}$ All the other GATT contracting parties

\footnotetext{
2555 Ibid.

2556 Ibid.

${ }^{2557}$ United Nations Statistical Division data:

There is no established convention for the designation of "developed" and "developing" countries or areas in the United Nations system ...In international trade statistics, the Southern African Customs Union is also treated as a developed region and Israel as a developed country; countries emerging from the former Yugoslavia are treated as developing countries (http://unstats.un.org/unsd/methods/m49m49regin.htm\#developed).

${ }^{2558}$ GATT, Minutes of Meeting, GATT Doc. No. C/M/183, p41.
} 
in support of the US proposal were clearly developed countries - with Israel was the only arguable case, in terms of developed or developing categorization.

Perhaps it can be said that the GATS commitments are already a patchwork, if in the sense that members can chose in which sectors and which modes to liberalize. It is possible that this may yet become a feature of the system if countries maneuver and compromise according to the best possible advantages that can be gained with regard to a particular negotiation at the particular time. This may be seen as fair and reasonable depending on the circumstances, as there is an obviously wide gap between e.g. Mexico and Papua New Guinea, beyond that of mere geography, although they will both be broadly classified as developing countries. It can be suggested to have a more subtle gradation for treatment of developing countries at various different levels of development. Such a proposal can be criticized as leading to even more fracturing among developing countries and intra-competitiveness that may be disadvantageous if real negotiating power would be based on common positions as negotiating blocs. However, even in the current situation, developing country Members as a large grouping have few common interests and often find it difficult to agree on common positions. However, whether such a proposal gains support among WTO Members or not, the fact remains that both the process within the WTO for such a 'graduation' of developing countries and the criteria for such a categorization are problematic.

Therefore, it can be argued that status as developing country ought to be clear and stable for the application (or not) of special provisions for developing countries - not only under the GATS, but across the different WTO agreements. Although it has happened with China already, in its Accession Protocol, the variation of status depending on the agreement or with regard to different provisions or even sub-sections of the same Article could cause a great deal of confusion in application if it happens with a number of countries. Of course, all other Members do not have to contend with the sort of Accession Protocol that China agreed to, but in the absence of a definition, there is nothing to say that a self-defined 'developing status' can be maintained if it is challenged by the other party in negotiations or a dispute.

Other than China's accession, there is already a differentiated special and differential treatment regime for developing countries under the GATT Enabling Clause and Generalized System of Preferences (GSP). Under GSP schemes, developed countries may decide which countries to give tariff preferences to and they may decide to withdraw preferences from developing countries who they see as no longer in need of them. Writing on the history of the relationship of developing countries and the GATT/WTO, Hudec notes that this policy of 'graduation' was an idea advanced by developed countries, mainly the United States, in the 1970s as a "counter-reaction" to the special and differential treatment (or from a developed country point of view "preferential and non-reciprocal' treatment) under the GSP. ${ }^{2559}$ It is possible that, according to the classification of developed members who have such GSP schemes, some developing countries could be given special treatment above others who may be positioned in similar

2559 Hudec, Robert E., (first edition), Joel P. Trachtman and Chantal Thomas (ed.), DEVELOPING COUNTRIES IN THE GATT/WTO LEGAL SYSTEM, Rowman \& Littlefield /Cordell Hull Institute and Gower Publishing, (First Edition 1987 - revised Edition 2009), p17, 67-68. 
circumstances. Developing countries recognized this and have officially, collectively objected to this graduation policy which is based on developed country discretion. ${ }^{2560}$

The Appellate Body in EC-Tariff Preferences has also recognized that different treatment between different developing countries can happen according to developed country assessment of development needs; and the legitimacy of the criteria used in such an assessment was not really questioned. ${ }^{2561}$ This is pointed out by one commentator as being a flaw that could be corrected with insights from the understanding of equality and differential treatment in human rights law. ${ }^{2562}$ An affirmative action measure in human rights can only be justified if criteria for the identification of the group are 'reasonable and objective' and it is in furtherance of a legitimate objective. ${ }^{2563}$ Is it possible for the WTO to develop 'reasonable and objective' criteria for classification of developing countries with recognition of the range of different levels of development among them?

It is questionable whether the WTO is willing to deal with developing criteria for defining development or non-development and also whether this goes beyond its mandate. So far, no WTO body has defined development, although there are certain rights which are granted based upon this concept: which suggests unwillingness to change the current scenario of self-definition by the Members. Yet if the agreements are concerned with attainment of 'development' (and not merely 'economic growth') the issue needs to tackled at some point and not continuously avoided. The WTO does not have to accept the criteria or methodology of other international organizations, but the Ministerial Declaration of $20^{\text {th }}$ September 1986, under the GATT (1947) states in Part II (Negotiations on Trade in Services) that:

[The multilateral framework of principles and rules for trade in services]

shall respect the policy objectives of national laws and regulations applying to services and shall take into account the work of relevant international organizations. (emphasis added) $)^{2564}$

The WTO webpage on defining developing and least developed countries ${ }^{2565}$ refers to the United Nations Conference on Trade and Development (UNCTAD) website for

${ }^{2560}$ Ibid., (Hudec), footnote 34, citing the text of the Arusha Program of February 1979, adopted by the Group of 77 :

The Group of 77 rejects the concept of "graduation" sought to be introduced by developed countries in the trading system, which would, inter alia, allow developed countries to discriminate among developing countries in a unilateral and arbitrary manner.

(Arusha Program for Collective Self-Reliance and Framework for Negotiations, United Nations Document TD/236 (1979) p. 35, reprinted in Proceedings of the United Nations Conference on Trade and Development, Fifth Session (Manila), United Nations Document TD/269, Vol.1, 1981, p.145).

2561 Appellate Body Report, EC-Tariff Preferences (GSP Case), paras.157-174. It is also repeatedly suggested that GSP schemes are more related to developed country social, political and economic needs and agendas than assessment of developing country needs. For a more detailed discussion, see Gregory Shaffer and Yvonne A. Mensah, Law and Politics of Rights: Who Decides the Conditions for Trade Preferences: Institutional Choice in the General System of Preferences Case, 39(5) Journal of World Trade, 2005, p977.

${ }^{2562}$ Moon, Gillian, Trade and Equality: A Relationship to Discover, Journal of International Economic Law 12(3) 618 at p633.

${ }^{2563}$ Ibid; also see the UN Human Rights Committee, General Comment No. 18 (Non-Discrimination), U.N. Doc. HRI/GEN/1/Rev.1, 1994, para.13. The relevant paragraph states that:

...the Committee observes that not every differentiation of treatment will constitute discrimination, if the criteria for such differentiation are reasonable and objective and if the aim is to achieve a purpose which is legitimate under the Covenant [ICCPR].

2564 GENERAL AGREEMENT ON TARIFFS AND TRADE (GATT), Ministerial Declaration of 20 September 1986 (Punta Del Este Declaration)

${ }^{2565}$ See WTO, http://www.wto.org/english/tratop_e/devel_e/d1who_e.htm, accessed 02.06.2010 
information on GSP and LDCs. But the UNCTAD does not have its own definition of developing countries, although it deals with data and recommendations, and it adopts the $\mathrm{UN}$ list of LDCs that will be discussed further on.

Although the WTO does not seem to have any guidelines on criteria for developing country status, the two other 'Bretton Woods' Institutions do. The IMF, for the purposes of its World Economic Outlook reports and databases categorizes world economies into advanced and emerging (or developing) economies based on a number of factors, based mainly on:

(1) Average per capita income level over a number of years (to take account of volatility of markets)

(2) Export diversification (economies principally based on oil exports and have high per capita GDP could thereby be excluded from the advanced category)

(3) Degree of integration into the global financial system. ${ }^{2566}$

However, it is stressed that meaningful analysis of the currently available data is the goal and not a rigid classification based on economic or other criteria.

The World Bank classifies 186 countries into four income groups, low income, middle income (consisting of two categories, lower middle and upper middle) or high income, with middle and lower income countries generally being referred to as developing economies. ${ }^{2567}$ The classification is based on per capita gross national income (GNI earlier referred to in World publications as gross national product or GNP) ${ }^{2568}$. However, these income categories are related to the operational practices of the Bank with regards to lending and it is made clear that "[c]lassification by income does not necessarily reflect development status" 2569 .

Another, very different way of classifying countries according to the level of development is the Human Development Index (HDI) used by the United Nations Development Program's Human Development Report (HD Report). The HD reports have been issued almost annually since 1990. The index is a comparative measure of a number of criteria including population, life expectancy, birth and death rates, Gross Domestic Product in purchasing power parity (GDP in PPP) per capita, the national unemployment rate, adult literacy and population per doctor - that measure quality of life rather than economic growth per se. The most recent indices issued by the Human Development Report Office consist of five composite indices: the Human Development Index (HDI), the Inequality-Adjusted Human Development Index (IHDI), the Gender Development Index (GDI), the Gender Inequality Index (GII), and the Multidimensional Poverty Index (MPI).

\footnotetext{
${ }^{2566}$ See IMF, http://www.imf.org/external/pubs/ft/weo/faq.htm\#q4b.

2567 See for 2010 classifications World Bank, http://data.worldbank.org/about/country-classifications, accessed 26.05.2010. The groups are: low income, $\$ 975$ or less; lower middle income, $\$ 976$ - $\$ 3,855$; upper middle income, $\$ 3,856$ - \$11,905; and high income, $\$ 11,906$ or more. For 2020, see https://datahelpdesk.worldbank.org/knowledgebase/articles/906519, accessed 28.12.2019: low-income economies are those with GNI per capita of $\$ 1,025$ or less in 2018; lower middle-income economies are those between $\$ 1,026-\$ 3,995$; upper middle-income economies are those between $\$ 3,996-\$ 12,375$ and high-income economies are those with $\$ 12,376$ or more.

2568 See http://data.worldbank.org/about/data-overview/methodologies, regarding this change in the terminology.

${ }^{2569} \mathrm{http}$ ///data.worldbank.org/about/country-classifications, accessed 26.05.2010.
} 
Each HD Report has a thematic approach, with the first HD Report being titled "Concept and Measurement of Human Development" (1990) and the most recent being titled "Beyond income, beyond averages, beyond today: Inequalities in human development in the 21st century" (2019). The HD Report of 2010, was the '20 $0^{\text {th }}$ Anniversary report' and was titled "The Real Wealth of Nations: Pathways to Human Development". It featured introductory reflections by Amartya Sen, who worked with series founder Mahbub ul Haq on the conception of the first Human Development Report and affirmed the conceptual basis of the capabilities approach and the role of human rights, peace and democracy for development. The Report also emphasized that the data continued to confirm the central contentions of the first HD reports, that human development is different from economic growth and that substantial progress in non-income dimensions of human development can be achieved even when "decoupled" from economic growth. ${ }^{2570}$

The HD Reports often reflected an explicit human rights-based approach. For example, the HD Report of 2000 was titled "Human Rights and Human Development" and looked at human rights as an intrinsic part of development and at development as a means to realizing human rights. The report argued that a decent standard of living, adequate nutrition, healthcare and education were human rights, not merely development goals. The 2016 HD Report was titled "Human Development for Everyone" and its overall outlook was that universalism is at the core of the human development approach and that this was the same spirit which is shared by the United Nations 2030 Agenda and the Sustainable Development Goals. The 2016 HD report was clear in its position that "[h]uman rights are the bedrock of human development" and that human development needs strong national human rights institutions and mechanisms, supportive domestic legal reforms and stronger international action. ${ }^{2571}$ The report further states that:

Human rights provide principles, vocabularies and tools for defending the rights, help reshape political dynamics and open space for social change. $^{2572}$

In line with the importance given to human rights standards for achieving human development, Table 15 of the Report detailed the ratification/accession status of countries with regard to fundamental human rights treaties. Furthermore, the Report specifically critiqued the WTO (under the section "Structural challenges in global institutions"), in terms of how its rules "affect national space to define public policies", particularly, the use of trade policy to support sectoral or industrial development or social policy. ${ }^{2573}$ The HD Report of 2019 specifically refers to human rights such as Article 25 of the Universal Declaration of Human Rights (the right to a basic standard of living) and even in more challenging areas such as the right to water or human rights-based approach to access to the internet. ${ }^{2574}$ With regard to the right to health, the Report notes that:

\footnotetext{
2570 UNDP, HUMAN DEVELOPMENT REPORT 2010: THE REAL WEALTH OF NATIONS: PATHWAYS TO HUMAN DEVELOPMENT, p5 and $\mathrm{p} 49$.

${ }^{2571}$ UNDP, HUMAN DEVELOPMENT REPORT 2016: HUMAN DEVELOPMENT FOR EVERYONE, p8 and p16. See also p85-86, p130.

2572 Ibid., (UNDP, 2016), p130.

2573 Ibid., (UNDP, 2016), p142: These comments were not related to services policy, but agriculture, specifically the example given in Box 5.3 of the Report, which referred to the issue of agriculture subsidies and the right to food approach of India's National Food Security Act of 2013.

${ }^{2574}$ UNDP, HUMAN DEVELOPMENT REPORT 2019: BEYOND INCOME, BEYOND AVERAGES, BEYOND TODAY: INEQUALITIES IN HUMAN DEVELOPMENT IN THE 21ST CENTURY, p37, p191 and p233.
} 
Health inequalities can be a clear manifestation of social injustice ...[and]

also reflect shortcomings in meeting basic human rights...2575

The reflections on redistribution and financing of public services (including universal health services coverage) are founded on reduction of social inequalities, but there is barely any mention on the WTO or trade rules in that context. What is directly relevant for this section of the study is the conceptual basis of categorizing countries according to their development, but the inclusion of a human rights-based approach for development which is promoted in the HD Reports also deserves attention in this context.

The categories of countries in the HD Reports refer to levels of human development calculated according to the composite indices and are: 1) Very High HD 2) High HD 3) Medium HD and 4) Low HD - with the latter three groups understood to comprise of developing countries. It is interesting that there are 38 countries with "Very High HD" according to the 2009 HD Report and that list includes Barbados, Qatar, Israel, Hong Kong (China), Andorra, Brunei Darussalam and Kuwait, countries or territories that may not all be considered 'developed' countries according to different classifications which emphasize indices of social inequality, gender inequality and political freedoms. ${ }^{2576}$ The 2013 HD Report includes the United Arab Emirates in the list of "Very High HD countries'; and the 2019 report, where the countries with "Very High HD" have increased to 62, includes Saudi Arabia but not China (which is still in the next category of "High HD”). Interestingly, the 2013 HD Report adds as one of its highlighted findings, that:

There is a clear correlation between past public investment in social and physical infrastructure and progress on the Human Development Index. ${ }^{2577}$

The report particularly mentions that "people-friendly" States have expanded basic public services including health and education, and that this is an "integral part" and not merely an "appendage" of growth. ${ }^{2578}$ This reiterates the difference between HDI and its link to a broader concept of development than the economic growth and GDP indicators. The 2013 HD Report, aptly titled "The Rise of the South: Human Progress in a Diverse World" also projects that by 2020 the combined economic output of Brazil, India and China, driven by South-South partnership, will surpass the combined output of Canada, France, Germany, Italy, the United Kingdom and the United States. ${ }^{2579}$

The consequences of different criteria for classification are most apparent in an example such as Equatorial Guinea, a State which is currently a WTO observer. According to the HD Report 2013, the highest average annual growth in income per capita between 1990 and 2012 (over 9\%) was recorded in China and Equatorial Guinea. ${ }^{2580}$ Equatorial Guinea had a Gross Domestic Product in purchasing power parity (GDP in PPP) per capita of over USD 30,000 due to oil, gold, diamond and other mineral revenues in 2004 (more than that of Japan or the United Kingdom) which dropped to USD 18,000 in 2009 and was calculated at GNI (PPP) at 21,715 in 2012. ${ }^{2581}$ The World Bank data for 2018 shows the GDP per capita dropping to USD 10,261. The 2019 HD Report shows that Equatorial

\footnotetext{
2575 Ibid., (UNDP, 2019), p37.

2576 UNDP, HUMAN DEVELOPMENT REPORT 2009: OVERCOMING BARRIERS: HUMAN MOBILITY AND DEVELOPMENT.

${ }^{2577}$ UNDP, HUMAN DEVELOPMENT REPORT 2013: THE RISE OF THE SOUTH - HUMAN PROGRESS IN A DIVERSE WORLD, p22-23.

${ }^{2578}$ Ibid., (UNDP, 2013), p4.

${ }^{2579}$ Ibid., (UNDP, 2013), piv (foreword).

${ }^{2580}$ Ibid., (UNDP, 2013), p25.

${ }^{2581}$ International Monetary Fund (IMF) World Economic Outlook database, available online at http://www.imf.org/external/pubs/ft/weo/2010/01/weodata/index.aspx.
} 
Guinea has retained a high GNI per capita of 17,796, which is the GNI generally seen in countries in the High and Very High HD ranking.

Despite the inclusion of this data in the calculation of HDI, Equatorial Guinea ranked 118 out of 182 countries in the 2009 HD Report, behind the Occupied Palestinian Territories (no. 110) and fell further to 136 in the 2013 HD Report, behind Iraq (no.131) and equal to India which only has a GNI (PPP) of USD 3285. In 2018 (according to the 2019 HD Report), the ranking had fallen further to 144. According to data analyzed by the WHO, the World Bank, Human Rights Watch and the Center for Economic and Social Rights, despite high income from mineral wealth, a majority of the population of Equatorial Guinea live below the poverty line on USD 1 per day and basic development indicators of the country, such as child nutrition and primary school enrollment, are below some of their poorer African neighbors. Governmental expenditure on health and education is also estimated as lower than the Sub-Saharan African average. Total health expenditure as a percentage of GDP has been erratic, being estimated as $4.0 \%$ in 1996, 1.6\% in 2005 and $4.7 \%$ in 2013 . But it is estimated as less than $1 \%$ of the government budget. The lack of an organized health system means that there is usually insufficient data to prepare comprehensive health indicators for the country, but the estimated life expectancy at birth was a mere 52.6 years in 2012 and barely rising to 58.4 in 2018, which is less than e.g. Tanzania, another LDC, where it was 61 years in 2012 and 65 years in $2018 .^{2582}$

The apparent regression in the provision of basic health and education was raised by a number other countries during Equatorial Guinea's Universal Periodic Review (UPR) before the Human Rights Council in 2009, where they recommended budgetary prioritization of health and education in order to comply with its obligations to progressively realize economic and social rights. ${ }^{2583}$ The 2019 UPR process continues to emphasize the country's responsibilities concerning health and education services, from basic policy planning to resource allocation. ${ }^{2584}$ A World Bank Public Expenditure Review carried out in 2010 also recommended "a re-allocation of resources towards human development, especially education and health". ${ }^{2585}$ And yet, based only upon the increase in GNI per capita, the Committee for Development Policy recommended to the UN Economic and Social Council (ECOSOC) that Equatorial Guinea be 'graduated' from its current least developed country status in terms of UN categorization (which is discussed in further detail below). ${ }^{2586}$ On the $4^{\text {th }}$ of June 2017, Equatorial Guinea graduated from the LDC category. The income-only graduation according to the most recent review of the Committee for Development Policy (2018) was only USD 2,460. While Equatorial Guinea far exceeding that income threshold, the 2018 UN Triennial

\footnotetext{
${ }^{2582} \mathrm{http} / / /$ www.unicef.org/infobycountry/equatorialguinea statistics.html, last accessed 27.07.2014.

2583 UN, Human Rights Council, Report of the Working Group on the Universal Periodic Review: Equatorial Guinea, Sixth session, 11 December 2009, UN Doc. A/HRC/WG.6/6/L.15 or A/HRC/13/16.

${ }^{2584}$ UN, Human Rights Council, Equatorial Guinea: Third Review, Session 33, List of recommendations contained in Section II of the Report of the Working Group A/HRC/42/13, https://www.uprinfo.org/sites/default/files/document/equatorial_guinea/session_33_-may_2019/2rps_equatorial_guinea.pdf, accessed 28.12.2019.

${ }^{2585} \mathrm{http}$ //Www.worldbank.org/en/country/equatorialguinea/overview, last accessed 27.07.2014.

${ }^{2586} \mathrm{ECOSOC}$ has endorsed this recommendation and forwarded it to the UN General Assembly. The most recent document on the issue is the Report of the Committee for Development Policy,12 June 2014, E/2014/L.15. Only a small number of countries have been able to 'graduate' from LDC status since the concept was implemented in the early 1970s. The countries which have managed to do so are Botswana (1994), Cape Verde (2007), Maldives (2011) and Samoa (2014).
} 
Review of LDC's clearly showed that it was far below the graduation thresholds for the Human Assets Index and Economic Vulnerability Index (discussed below in more detail).

The problem with countries such as Equatorial Guinea is the lack of good governance, particularly in terms of governance for equitable socio-economic development. In this aspect, concerning the quality of the lives lived by its population as a whole, it clearly remains an LDC, even if it has mineral wealth which gives it a high GDP or GNI. For the purposes of the WTO, the LDC status is related to the granting of trade preferences and also has relevance for certain flexibilities (e.g. delay in patent protection) and assistance in consideration of capacity constraints. The granting of trade preferences may not necessarily result in improving the health and education standards for the general population, since it is up to national authorities to use the increased trade revenue it may have received from the preferences and direct it towards social services spending. The expectation is that the benefits would be redistributed fairly among the population and not rest in the hands of only a few beneficiaries.

Although there is lack of clarity with regard to the definition of developing countries, it seems that the WTO system has accepted a definition of 'least developed country' in accordance with a general United Nations classification system. ${ }^{2587}$ This classification is the one adopted for statistical purposes at the UN following the UN Resolution 2768 (XXVI) of 18 November 1971 - and it is used to compile the UN Statistical Yearbook; and takes care to point out that there is no common agreement in the United Nations system concerning the terms "developed" and "developing" or the stage of development reached by a country and its classification. ${ }^{2588}$ The Yearbook itself merely following "conventional practice" 2589 and following this practice Canada, the United States Japan, Australia, New Zealand and are developed countries, European countries are also developed, while all others are by and large treated as "developing" with special consideration for least developed countries, landlocked developing countries and small island developing countries and transition countries ${ }^{2590}$.

The criteria for LDC's, reviewed every three years by the Committee for Development Policy (CDP), a subsidiary body of the UN Economic and Social Council (ECOSOC), are calculated based on:

1. Low Income:

In the 2012 review: A three-year average GNI per capita of less than USD 905 with a threshold of USD1086 for graduation from LDC status.

In the 2015 review: USD 1,035 for inclusion, above USD 1,242 for graduation.

\footnotetext{
2587 WTO, http://www.wto.org/english/tratop_e/devel_e/d1who_e.htm, accessed 02.06.2010; also see Van den Bossche, Peter, THE LAW AND POLICY OF THE WORLD TRADE ORGANIZATION: TEXTS, CASES AND MATERIALS, $2^{\text {nd }} E d ., 2008$, p105.

$2588 \mathrm{http} / /$ unstats.un.org/unsd/methods/m49/m49regin.htm\#least (last revised 01.04.2010) accessed 25.05.2010. Also see current UN Statistical yearbook, 52 $2^{\text {nd }}$ issue, p3 - available at http://unstats.un.org/unsd/syb/syb52.pdf, accessed on 25.05.2010:

In international trade statistics, the Southern African Customs Union is also treated as a developed region and Israel as a developed country; countries emerging from the former Yugoslavia are treated as developing countries; and countries of eastern Europe and of the Commonwealth of Independent States (code 172) in Europe are not included under either 2589 Ibid developed or developing regions.

2590 See Office of the High Representative for the Least-Developed Countries, Landlocked Developing Countries and Small Island Developing States, online at http://www.unohrlls.org/
} 
In the 2018 review:

2. Human assets weakness: A Human Assets Index (HAI) based on indicators of (a) nutrition: percentage of population undernourished; (b) health: mortality rate for children aged five years or under; (c) education: the gross secondary school enrolment ratio; and (d) adult literacy rate; and

3. Economic Vulnerability: an Economic Vulnerability Index (EVI) based on (a) population size; (b) remoteness; (c) merchandise export concentration; (d) share of agriculture, forestry and fisheries in gross domestic product; (e) homelessness owing to natural disasters; (f) instability of agricultural production; and (g) instability of exports of goods and services. The 2015 review added another criterion: share of population in low elevated coastal zones. The 2018 review defined EVI as "as an indicator of structural vulnerability to exogenous shocks". 2591

Furthermore, large economies and populations (exceeding 75 million) are excluded from the category. A government of a country has to accept LDC status to be added to the list. A country will be eligible for 'graduation' from the LDC list if it meets the graduation threshold for at least two of the three criteria mentioned above. But, as mentioned earlier, a country can also 'graduate' based only on GNI regardless of the other two criteria. ${ }^{2592}$ This GNI-based graduation may not always correctly reflect the economic and developmental ground realities in terms of human development and domestic services capacity. It is submitted that one way that the development status of a country can be judged is by evaluating its domestic services capacity, particularly in areas such as health services. An LDC could thus be identified by the general quality of life of its citizens, and not by wealth that could be concentrated in the hands of a few. It is curious that even the ECOSOC may not take into consideration the socio-economic disparities and inequities within a country, in determining its development status.

A country must be found eligible at two successive triennial reviews by the CDP in order to be recommended for 'graduation' and only does so three years after the UN General Assembly takes note of the ECOSOC endorsement of the CDP recommendation. This UN system as of 2017 recognizes 48 LDCs and 36 of these are WTO members, with a further 8 negotiating to join the WTO, and who are currently WTO observers. ${ }^{2593}$ The LDC WTO observer category included Cape Verde and the Maldives which 'graduated' from the LDC list in 2007 and 2011 respectively; and Equatorial Guinea, which also 'graduated' from the LDC list in 2017 following the 2012 recommendation by the Committee for Development Policy, which reviews LDC status. ${ }^{2594}$ Nepal was considered as having met the eligibility criteria for graduation from the LDC list for the first time in the 2015

\footnotetext{
${ }^{2591} \mathrm{https}$ //www.un.org/ldcportal/the-2018-triennial-review-of-the-ldc-category/

2592 UNCTAD, THE LEAST DEVELOPED COUNTRIES REPORT, 2009, p4; UN, LDC Identification Criteria and Indicators, available online at https://www.un.org/development/desa/dpad/least-developedcountry-category/ldc-criteria.html.

${ }^{2593}$ LDC's recognized by the WTO : Afghanistan, Angola, Bangladesh, Benin, Burkina Faso, Burundi, Cambodia, Central African Republic, Chad, Congo, Democratic Republic of the Djibouti, Gambia, Guinea, Guinea Bissau, Haiti, Laos, Lesotho, Liberia, Madagascar, Malawi, Maldives, Mali, Mauritania, Mozambique, Myanmar, Nepal, Niger, Rwanda, Senegal, Sierra Leone, Solomon Islands, Tanzania, Togo, Uganda, Vanuatu, Yemen, Zambia. 8 more least-developed countries are negotiating to join the WTO: they are Bhutan, Comoros, Ethiopia, Sao Tomé \& Principe, Somalia, Sudan, South Sudan and Timor-Leste. Equatorial Guinea which was also in this list has "graduated" from LDC status in 2017.

The most recent updated UN LDC list is available online at: https://www.un.org/development/desa/dpad/wp-content/uploads /sites/45/publication/ldc_list.pdf. For the list of LDC WTO Members see http://www.wto.org/english/thewto_e/whatis_e/tif_e/org7_e.htm. ${ }^{2594} \mathrm{See}$ http://unohrlls.org/about-ldcs/criteria-for-ldcs/.
} 
review but is still listed as an LDC by December 2018, with the decision deferred for the the 2021 triennial review. ${ }^{2595}$

The WTO acceptance of this UN LDC classification means that there is some stability and certainty with regard to classification of LDCs in the WTO system. However, the other methods used for classification of a country as low in development, do not always line up with this LDC list. According to the 2010 UNDP HDI, there are 41 Low HD countries $^{2596}$ as opposed to the abovementioned 48 LDCs, and the list does not neatly overlap. The UNDP HDI also has another calculation after 2010, when the Human Development Report introduced the Inequality-adjusted Human Development Index (IHDI). In the comparison for the 2013 HDI report, there are 24 Low HD countries and there is overlap only in the case of 20 countries which fall into the lowest grouping according to both the current UN/WTO LDC classification and the Low HD classification. ${ }^{2597}$ According to the 2016 HD report, there are 41 Low HD countries and there is overlap in terms of 34 countries. ${ }^{2598}$ The 2019 HD Report has 32 countries listed as Low HD countries ( 6 countries and territories including Somalia and North Korea are not ranked), with 47 countries currently on the UN LDC list and overlap in terms of only 27 countries. Significantly, the Syrian Arab Republic, which is facing prolonged armed conflict, has currently fallen to the level of a Low HD country; and Nigeria which is rich in natural resources but high in corruption is also ranked as a Low HD country.

The variety of factors taken into account and the variations in the calculations for HDI could explain the fluctuations in the list of countries identified as Low HD, whereas the UN LDC list is more stable and only has triennial reviews of status. It is unlikely that the WTO would change its current method of classification of LDCs, but having different methods with country lists that overlap but do not entirely match may cause difficulties for the countries considered LDCs in another measurement, but not in the one used by the WTO.

For the purposes of the GATS, measuring the overall level of development can also be viewed from an analysis based on outcomes in an essential service sector such as health, instead of on general economic criteria or criteria connected to overall results of all economic policy such as the HDI. This may give a clearer picture of the actual standard of development and quality of life enjoyed by the public, and also identifies the needs of the relevant sector in the economy of the developing member. In the health sector, there is considerable work done by the World Health Organization (WHO) in collecting and analyzing health indicators and statistics and tracking the financing ${ }^{2599}$ and human

\footnotetext{
2595 http://unohrlls.org/about-ldcs/criteria-for-ldcs/ and www.wto.org/english/tratop_e/dda_e/negotiating group s_e.pdf , accessed 20.4.2017 and https://www.un.org/development/desa/dpad/least-developedcountry-category/ldcs-at-a-glance.html accessed 28.12.2019.

${ }^{2596} \mathrm{http} / /$ hdr.undp.org/en/composite/HDI: this HDI calculation does not include D.R. Korea, the Marshall Islands, Nauru, Tuvalu, Monaco, San Marino and Somalia.

2597 Afghanistan, Benin, Burkina Faso, Burundi, Central African Republic, Chad, DR Congo, Ethiopia, Gambia, Guinea, Guinea-Bissau, Malawi, Mali, Mozambique, Niger, Rwanda, Senegal, Sierra Leone, Togo, Zambia.

2598 Afghanistan, Angola, Benin, Bhutan, Burkina Faso, Burundi, Central African Republic, Chad, Comoros, D.R. Congo, Djibouti, Eritrea , Ethiopia, Gambia, Guinea, Guinea-Bissau, Haiti, Lesotho, Liberia, Madagascar, Malawi, Mali, Mauritania, Mozambique, Niger, Rwanda, Sao Tome \& Principe, Senegal, South Sudan, Sudan' Tanzania, Togo, Uganda, Yemen.

2599 See National Health Accounts: http://www.who.int/whosis/indicators/2007 NationalHealthAccounts2 /en/ index.html.
} 
resources capacity ${ }^{2600}$ as indicators of the strength of national health systems. Continuing the earlier example of Equatorial Guinea, the 2010 World Health Report states that basic indicators of health services such as percentage of 1-year-olds immunized against measles (MDG4) and ante-natal care coverage [MDG5] had gone down drastically in the period of 1990-2008, when the oil revenue-based GDP and per capita income ballooned.

Thus, the preparedness or competitiveness of the national health sector for international trade in services cannot be linked necessarily to national income levels. It is possible to take the reference in Article XIX:2 to "due respect for ...the level of development of individual Members, both overall and in individual sectors" [emphasis added] as support for also looking sector by sector at the level of development in the case of a self-defined developing country. However, this is not an entitlement to special and differential treatment. Furthermore, this approach in negotiations can go against developing country interests as well, if a particular sector is considered as successful, but may also be beneficial if some economic data do not give a realistic picture of the state of the vulnerability of the particular sector.

The classification of LDCs does not appear to be particularly problematic since the UN classification system is being used by the WTO. However, 'developing country' status within the WTO is somewhat unclear. As long as the application of developing status is not at issue in a dispute or can be avoided by the dispute settlement panels or the Appellate Body (whether by using the ever-handy 'judicial economy' justification or otherwise), the issue of classification will remain unresolved. There are both positive and negative views of this situation. The positive aspect is that developing a rigid classification may be seen detrimental to their interests by some developing economies, who may disagree with the criteria and methods chosen by the WTO and would prefer the current vagueness, so far as it benefits them. The negative aspect is that there is a lack of clarity with regards to the application of such special provisions in the cases of some members and that a lack of classification can encourage the patchwork application of these provisions.

Do we want a system where a Member's status is not clearly classified and can be in some circumstances considered a developing country, but not for some agreements and annexes; only for one set of provisions but not for this subparagraph? Is this a 'good' flexibility to include or is this more likely to cause further unnecessary complexity and unfairness in the international trading regime? Another argument against a strict set of clear criteria is that there may be a disincentive to develop or at least a disincentive to publish accurate development statistics in order for some countries to get benefits as developing or least developed members. But this is based on the assumption that there are tangible benefits under GATS for developing and least developed members. There are clear possibilities for benefits for developing members under the GATT 1994 for GSP concessions, but are there really any special benefits for developing countries under the GATS? If there are no tangible benefits - a whole different debate - then there would be no point in being concerned about the classification and gaining of special and differential treatment. The next sections of this Chapter will discuss what is on offer under the GATS provisions for developing country and LDC Members.

\footnotetext{
2600 See Human Resources for Health, http://www.who.int/whosis/indicators/2007HumanResources ForHealth /en/index.html.
} 


\subsection{SPECIAL PROVISIONS FOR DEVELOPING AND LEAST DEVELOPED MEMBERS FOR TRADE IN SERVICES}

'The provision I am most anxious about is this.'

He unrolled a large parchment scroll, and read aloud the words

'item, that we will be kind to the poor'...

'I suppose, now, that word 'item' has some deep legal meaning?'

From Lewis Carroll's Sylvie and Bruno

\subsubsection{The Role of Preambles in Interpretation}

The issue of the legal status of Preambles should be briefly evaluated before moving on to their possible interpretation and application. This is also because there still some differences of opinion with regard to the status of preambles. Some writers, such as Hestermeyer, have commented that preambles are not of legally binding nature - meaning that they do not create obligations independent of the terms of a treaty. ${ }^{2601}$ There are also statements to the contrary, supporting the view that preambles can create legally binding obligations. Kelsen has noted that the Preamble to UN Charter "has virtually the same legal validity, that is to say, the same binding force as other parts of the Charter". ${ }^{2602}$ Note that Kelsen does not say that the Preamble to the UN Charter has the same legal validity as the other parts, but "virtually" the same validity. His view was that contents of a treaty have binding force "only if it has normative character [emphasis added]", in establishing an obligation, either by itself or in connection with other contents of the treaty. According to Kelsen, a recital of a preamble can have such normative, obligation-creating character, adding also that:

A statement has normative character even if it may be used only for the purpose of interpreting other statements having the character of true norms ${ }^{2603}$

However, with regard to the Preamble of the UN Charter, he also notes that there are recitals which are statements of "political ideals" and of "ideological [rather than] legal, importance" and he doubts whether such statements can even be used for interpretation, since they refer to objects which are regulated differently or not mentioned at all within other parts of the Charter. ${ }^{2604}$ Thus Kelsen identifies as "empty phrases" in the Preamble (since they are not mentioned in other parts of the Charter), the phrases "equal rights of men and women", dignity and worth of the human person" and "to practice tolerance". ${ }^{2605}$ He identifies this as a failure of drafting, since the recitals on fundamental human rights were intended by the drafters to be the parts which would not only make their way into the hearts of common people and awaken their imagination, but be in harmony with the other provisions of the Charter. ${ }^{2606}$

\footnotetext{
${ }^{2601}$ Hestermeyer, H., Preamble, General Agreement on Trade in Services in Wolfrum, Rudiger, PeterTobias Stoll and Clemens Feinaugle Eds., WTO - TRADE IN SERVICES, Max Planck Commentaries on World Trade Law, Martinus Nijhoff Publishers, 2008, p19, citing Simma B., Ed., THE CHARTER OF THE UNITED NATIONS: A COMMENTARY, Vol. I, $2^{\text {nd }}$ Edition, 2002, para. 13 etc.

2602 Kelsen, Hans, THE LAW OF THE UNITED NATIONS: A CRITICAL ANALYSIS OF ITS FUNDAMENTAL PROBLEMS, Law Book Exchange, 1950, p9.

${ }^{2603}$ Kelsen, Ibid, p.9.

${ }^{2604}$ Kelsen, Ibid, p.9-10.

${ }^{2605}$ Kelsen, Ibid., p1 1-12 and concluding paragraph of Footnote 4.

2606 Kelsen, Ibid., p.11, footnote 4: citing the Report of Subcommittee 1/1/A of the San Francisco Conference, UNCIO Doc.785, I/I/27, p1.
} 
Similarly, in the Rights of Nationals of the United States of America in Morocco (1952) the International Court of Justice stated that a principle embodied in the relevant preamble "was intended to be of a binding character and not merely an empty phrase". ${ }^{2607}$ However, later in the same Case this statement is qualified, stating that the interpretation of a preamble should not go so far as to imply any fundamental changes in the character of the existing treaty rights. ${ }^{2608}$ This appears to be an example of compromising and including both views on the intended impact of the preamble - or it could be a case of being restrained due to the lack of clear drafting of the treaty text. More generally it has been noted that words in a preamble are not superfluous. ${ }^{2609}$ Even if accepting the argument that words of a Preamble do not have equal status with the operative part of an Agreement - the Articles that set out the rights and obligations of the parties - this does not mean that a preamble does not have any influence over the interpretation of the Articles of the treaty, since they can be of normative character when read with the operative provisions.

A moderate view would be that the Preamble cannot be the basis of a claim of violation of rights, but can support a particular interpretation of the language of the treaty. The Appellate Body in US-Shrimp has expressed this as follows:

As this preambular language reflects the intentions of negotiators of the WTO Agreement, we believe it must add colour, texture and shading to our interpretation of the agreements annexed to the WTO Agreement... 2610 (emphasis added).

Since there is no official travaux preparatoire for the WTO, it is not possible to confirm the intention of the negotiators by what they actually discussed during the negotiations and it is also questionable whether a time-bound intention is the best approach for a dynamic trading system. But it is clear that the preamble is part of the context-object-andpurpose for the standard treaty interpretation approach contained in Article 31 of the Vienna Convention on the Law of Treaties (VCLT).

There are several statements (recitals) and provisions in the GATS covering developing and least developed members. This Chapter will focus on the Preamble, Articles IV, $\mathrm{XV}: 1, \mathrm{XIX}: 2, \mathrm{XIX}: 3$ and XV:1 of the GATS and related provisions such as Article XXV, as they contain specific mention of developing and/or least developed countries. At the outset, it appears questionable how the above recitals and provisions can be used and how far they can be and will be used in the real world, as opposed to remaining as empty rhetoric. There has so far been no WTO jurisprudence relating on or relevant to the developing country and LDC provisions in Articles IV, XIX, XV or XXV of the GATS, although in some instances, these provisions are referred to in the work that is being

\footnotetext{
${ }^{2607}$ Rights of Nationals of the United States of America in Morocco, (France v United States of America), 1952 ICJ Reports 176, at p184. Note that in that case, the relevant principle in the Preamble (an MFN-type principle which was termed "economic liberty without any inequality" in the Act of Algeciras of 1906) was also expressly applied by another Article in the Act to the public services in Morocco, which was then a French Protectorate.

${ }^{2608}$ Ibid., (US Nationals in Morocco case), p198.

${ }^{2609}$ Schwarzenberger, George, INTERNATIONAL LAW, Vol.1, 3rd Edition, Stevens 1937, p526: As every word and part of a treaty is presumed to have a meaning and produce some legal effects, no inherent reason exists for discrimination against the preamble as compared with the operative articles of the treaty

${ }^{2610}$ Appellate Body Report, US-Shrimp, para.153.
} 
carried out through WTO Committees, through bilateral relations or other development or funding agencies and procedures.

There are several questions that need to be asked:

1. Do the special provisions in reality translate into extra policy space for developing and least developed country Members or are they merely limited to expressions of intent without any concrete outcomes?

2. Do the special provisions empower developing and least developed country Members to protect the interests of their domestic services or are the provisions entirely dependent on the goodwill and political will of developed country Members?

The position of this Chapter is that the GATS framework ought to empower developing countries themselves to be able to present their case of being in an economically disadvantageous position vis-à-vis the developed countries and that as a result, corrective measures can be sought and applied to level the playing field to the extent possible under the Agreement.

Before introducing these sections, a brief mention of the context of the GATS as one of the covered agreements under the WTO is relevant, as the Preamble of the WTO Agreement may have some significance in interpreting the relevant GATS provisions. If the Preambles of the WTO Agreement and the GATS have legal effect and influence upon the interpretation of the relevant provisions of the GATS, this would mean that the recitals would have an important part to play in the balancing process between competing values with regards to trade in services that must be umpired by the interpretation of the GATS by panels and the Appellate Body. It should be noted that the Preamble of GATS has implications beyond the additional policy space for developing countries, as the "due respect for national policy objectives" is to be applied generally to all Members.

\subsubsection{The Preamble of the WTO Agreement establishing the WTO}

The Preamble of the WTO Agreement identifies some of the basic principles and objectives underlying the multilateral trading system:

Recognizing that their relations in the field of trade and economic endeavour should be conducted with a view to raising standards of living, ensuring full employment and a large and steadily growing volume of real income and effective demand, and expanding the production of and trade in goods and services, while allowing for the optimal use of the world's resources in accordance with the objective of sustainable development, seeking both to protect and preserve the environment and to enhance the means for doing so in a manner consistent with their respective needs and concerns at different levels of economic development,

Recognizing further that there is need for positive efforts designed to ensure that developing countries, and especially the least developed among them, secure a share in the growth in international trade commensurate with the needs of their economic development... [emphasis added]

As mentioned before, the preamble of course does not lay down binding obligations but sets out the object and purpose of an agreement. According to Art 31(2) of the VCLT) is part of the context for the purpose of the interpretation of a treaty, and it is on that basis that it should be taken into account. The often-cited comment by the Appellate Body's in US-Shrimp, that a Preamble would only add "colour, texture and shading" to an 
interpretation can be reminded here as well. The statements in the Preamble of the WTO Agreement, if given this legal effect, could support the following propositions.

\subsubsection{An interpretation that trade is targeted towards raising standards of living and ensuring full employment within the Members.}

Any provisions in the WTO agreements on national policy flexibility or regulatory sovereignty can be supported by this part of the Preamble, if the policy targets raising domestic standards of living and creating jobs. The Preamble also gives equal weight to trade as a means of creating a "steadily growing volume of real income and effective demand, and expanding the production of and trade in goods and services". It can be presumed that these sets of objectives would go hand in hand, but it is also quite possible that developing country Members would restrict the expansion of foreign goods and services in their domestic market in order to improve their domestic industries and increase standards of living and employment for their own citizens. This type of protectionism is exactly what the WTO hopes to dismantle and yet, it is said that there is space for WTO Members to postpone market access and national treatment - and also repeated reassurance for developing and least developed WTO Members that they have additional time and space to make commitments in these areas.

\subsubsection{An interpretation supportive of environmentally friendly trade - that avoids ecological damage and harm to human, animal and plant life and health.}

The term "sustainable development" is specifically mentioned and the understanding of this phrase now extends to macro and cross-sectoral policy making beyond what was traditionally seen as environmental issues. ${ }^{2611}$ Paragraph 6 of the Doha Ministerial Declaration of 2001 "strongly reaffirms [the] commitment to sustainable development" in the Preamble, but also reaffirms that policy space in this regard is limited by the available exceptions and other rules of the WTO framework ${ }^{2612}$. The Doha Ministerial Declaration of 2001 also referred to the World Summit on Sustainable Development (WSSD) which was known at the time to have been scheduled to be held in September 2002. It is interesting to point out that the WSSD has been described by critical sections of civil

${ }^{2611}$ For example, the 2005 World Summit outcome document, GA Res/60/1, $24^{\text {th }}$ October 2005 , refers to ...the integration of the three components of sustainable development - economic development, social development and environmental protection - as interdependent and mutually reinforcing pillars...

(at para.48, under the heading of "Sustainable development: Managing and protecting our common environment").

2612 WTO, Doha Ministerial Declaration 2001, WT/Min.(01)/Dec/1, 20 November 2001 (adopted on 14 November 2001), para.6:

We recognize that under WTO rules no country should be prevented from taking measures for the protection of human, animal or plant life or health, or of the environment at the levels it considers appropriate, subject to the requirement that they are not applied in a manner which would constitute a means of arbitrary or unjustifiable discrimination between countries where the same conditions prevail, or a disguised restriction on international trade, and are otherwise in accordance with the provisions of the WTO Agreements.

Also see press statement by WTO Director-General Mike Moore:

The Doha Development Agenda and trade will also play an important role in the upcoming Johannesburg conference on Sustainable Development

(WTO press release $29^{\text {th }}$ April 2002, http://www.wto.org/english/news_e/pres02_e/pr290_e.htm., accessed $2^{\text {nd }}$ June 2010. 
society as having become Doha+10 months instead of the Rio $+10^{2613}$ that it was supposed to be. ${ }^{2614}$ This was due to the statements in the Johannesburg Declaration, and the Plan of Implementation, which were the outcome documents of the WSSD 2002, which appeared to redefine sustainable development in a more trade-oriented manner and mentions (more than 25 times) that action for sustainable development should be achieved in the framework of either the WTO, the Doha Agenda, the Doha Work Programme or the Monterey Consensus. ${ }^{2615}$ This emphasis did not appear to provide sufficient recognition to the need to take non-trade concerns into account and to align the identified trade concerns and obligations with these other development objectives, such as those described in paragraph 7(c) of the Plan of Implementation of the WSSD to:

Develop national programmes for sustainable development and local and community development, where appropriate within country-owned poverty reduction strategies, to promote the empowerment of people living in poverty and their organizations. These programmes should reflect their priorities and enable them to increase access to productive resources, public services and institutions, in particular land, water, employment opportunities, credit, education and health... ${ }^{2616}$

And more specifically with regard to health, in paragraph 54 of the Plan of Implementation, to:

Strengthen the capacity of health-care systems to deliver basic health services to all in an efficient, accessible and affordable manner ....in conformity with human rights and fundamental freedoms and consistent

2613 The World Summit on Sustainable Development also known as the Third Earth Summit and the Johannesburg Conference, held 10 years after the United Nations Conference on Environment and Development held in Rio de Janeiro 1992, also known as the Earth Summit, Rio Summit or Rio Conference. It was also held shortly after the WTO Doha Ministerial Conference.

${ }^{2614}$ Kelsey, Jane, The Road from Doha to Cancun via Johannesburg, $2^{\text {nd }}$ October 2002, available at http://www.arena.org.nz/janewssd.htm, last accessed 02.06.2010. See also UN Department of Public Information Press Release, Non-Governmental Organization Press Conference on State of Summit, 30 August 2002, available online at http://www.un.org/events/wssd/pressconf/020830conf5.htm where it is stated that:

Non-governmental organization (NGO) representatives expressed alarm at an afternoon press conference today over what they described as the "hijacking" of the sustainable development process by the World Trade Organization (WTO) agenda.

The NGOs referred to included Friends of the Earth International, Third World Network and Greenpeace and Oxfam.

${ }^{2615}$ See Plan of Implementation of the World Summit on Sustainable Development, 2002, available online at: http://www.un.org/esa/sustdev/documents/WSSD POI PD/English/WSSD PlanImpl.pdf, para.99:

Complement and support the Doha Ministerial Declaration and the Monterrey Consensus by undertaking further action at the national, regional and international levels, including through public/private partnerships, to enhance the benefits, in particular for developing countries as well as for countries with economies in transition, of trade liberalization, through, inter alia, actions at all levels to: (a) Establish and strengthen existing trade and cooperation agreements, consistent with the multilateral trading system, with a view to achieving sustainable development...

See also UN GA, WSSD, Johannesburg Declaration on Sustainable Development, A/CONF.199/20, para.9 (available online at http://www.un-documents.net/jburgdec.htm):

Between Rio and Johannesburg, the world's nations have met in several major conferences under the auspices of the United Nations, including the International Conference on Financing for Development, as well as the Doha Ministerial Conference. These conferences defined for the world a comprehensive vision for the future of humanity [footnotes omitted; emphasis added].

2616 Plan of Implementation of the World Summit on Sustainable Development, 2002, available online at: http://www.un.org/esa/sustdev/documents/WSSD_POI_PD/English/WSSD_PlanImpl.pdf. 
with national laws and cultural and religious values, and taking into account the reports of relevant United Nations conferences and summits and of special sessions of the General Assembly. This would include actions at all levels to:

(a) Integrate the health concerns, including those of the most vulnerable populations, into strategies, policies and programmes for poverty eradication and sustainable development;

(b) Promote equitable and improved access to affordable and efficient health -care services, including prevention, at all levels of the health system...

Thus, there was a great deal of controversy over the change in the emphasis of plans and means to achieve sustainable development from Rio to Rio+10. However, perhaps as response to the criticisms and acknowledgement of the shortcomings in the earlier plan, the outcome document of Rio +20 held in 2012 readjusted the approach on sustainable development.

The outcome document of the Rio+20 WSSD, 2012 (titled The Future We Want) focuses more clearly on placing sustainable development within the existing framework of human rights and environmental law. It also has a separate section on 'Health and Population' where access to medicines and the Doha Declaration on the TRIPS Agreement and Public Health and the role of the WHO in strengthening health systems is specifically mentioned, but not GATS and health services. ${ }^{2617}$ Paragraphs 138-139 of the outcome document also state:

138. We recognize that health is a precondition for and an outcome and indicator of all three dimensions of sustainable development...We call for the full realization of the right to the enjoyment of the highest attainable standard of physical and mental health.

139. We also recognize the importance of universal health coverage to enhancing health, social cohesion and sustainable human and economic development. We pledge to strengthen health systems towards the provision of equitable universal coverage.

Thus, there is clearly space for discussion on provisions of health services, the role of the public sector/government in providing health services and engagement with the trade aspect of GATS. However, health services are neglected in favour of focusing attention on the TRIPS issue of access to medicines.

Trade is mentioned last in the 2012 The Future We Want document and sustainable development is no longer cast as something subject to the priorities of international trade law and WTO law, as suggested in the 2002 WSSD Plan of Implementation. Paragraphs 281 and 282 of The Future We Want reaffirms that international trade is "an engine for development" and urges a "development-oriented conclusion to the Doha Development Agenda. This understanding of sustainable development and the revision of emphasis regarding the role played by trade had been promoted by and is duly noted in the context of civil society engagement with sustainability, development studies, human rights and environmental law and law and policy. Countries participating in these sustainable development Summits are also WTO Members, although the actual specialized work in these areas is mostly likely carried out by different subject experts. If it is also

2617 See UN GA, WSSD, The Future We Want, A/RES/66/288, paras.142-143 (available online at http://rio20.net/wp-content/uploads/2012/06/N1238164.pdf). 
independently acknowledged in the WTO context, by Members and officials carrying out functions for the relevant WTO bodies, that trade is but a 'tool' or 'engine' for the goal of sustainable development, it ought to be the case that greater account is taken of the work in other specialised areas and of other useful documents outlining policy and governmental responsibilities.

There are both challenges and opportunities for developing country Members in taking sustainable development into account in the WTO. One of the challenges is to address the fears of developing country Members that the principle of sustainable development (focusing on environmental protection) will not be used against them for trade protectionist measures by developed country Members. The Doha Ministerial Declaration acknowledges the concerns of developing and least developed Members in this regard in paragraphs 31-33 of the Declaration. Paragraph 78 of The Future We Want document also underscores the cooperative efforts that could be carried out by the UN system, international financial agencies and the WTO, to "integrate the three dimensions of sustainable development (economic, social and environmental)" within their respective mandates.

The objective of sustainable development has been recognized by the Appellate Body in US-Shrimp - but it was not in the context of 'development' or developing countries. The Preamble to the WTO Agreement was used in the interpretation of the term "exhaustible natural resources" in Article XX(g) of the GATT 1994. Although Article XX(g) was originally a part of GATT 1947, the Appellate Body noted at paragraph 129, that;

While Article XX was not modified in the Uruguay Round, the preamble attached to the WTO Agreement shows that the signatories to that Agreement were, in 1994, fully aware of the importance and legitimacy of environmental protection as a goal of national and international policy. The preamble of the WTO Agreement - which informs not only the GATT 1994, but also the other covered agreements - explicitly acknowledges "the objective of sustainable development" ... [footnote omitted]

The Appellate Body in US-Gasoline had also noted the:

...specific acknowledgement to be found about coordinating policies of trade and the environment... ${ }^{2618}$

- that is found in the Preamble to the WTO Agreement and the Decision on Trade and Environment. However, the Appellate Body in US-Gasoline stated that WTO Members' autonomy in this regard is "circumscribed" by the need to "respect" the WTO agreements. ${ }^{2619}$ It has been commented that these decisions (together with US-Tuna II (Mexico) has:

... opened the WTO's door to environmental protection, engaging in a process of balancing the goals of facilitation of international trade with those of protecting the environment. ${ }^{2620}$

Yet the decisions refer to 'sustainable development' in a limited way as merely "environmental protection" since the facts of the dispute did not require a more holistic approach. As mentioned earlier, the understanding of principle of sustainable development has progressed beyond merely "environmental protection" in both public

\footnotetext{
2618 Appellate Body Report, US-Gasoline, p.30.

${ }^{2619}$ Ibid.

${ }^{2620}$ Gomula, Joanna, Environmental Disputes in the WTO in Fitzmaurice, Malagosia, David M. Ong and Panos Merkouris Eds., RESEARCH HANDBOOK ON INTERNATIONAL ENVIRONMENTAL LAW, Edward Elgar Publishing, 2010, p411.
} 
international and domestic law, to become a holistic concept and an 'umbrella' term which integrates the economic, social, cultural and environmental components of development. $^{2621}$

\subsubsection{Differential treatment for developing country Members}

Differential treatment for developing country Members maybe suggested by economic endeavour being conducted "in a manner consistent with their respective needs and concerns at different levels of economic development".

However, it is also possible to read this part of the recital as referring only to environmental protection and sustainable development (in use of natural resources aspect only) to be "in a manner consistent with..." and not with reading all provisions of WTO agreements to be read consistently with the needs and concerns of developing countries. That would make this reference in the Preamble of little use beyond an acknowledgement of the common but differentiated responsibilities principle of international environmental law.

The next recital confirms differential treatment as an objective, stating that there is a "need for positive efforts designed to ensure that developing countries, and especially the least developed among them, secure a share in the growth in international trade commensurate with the needs of their economic development". This part can be read as supportive for any text in the WTO agreements referring to positive efforts by the Members or by the organization. It can also be read as encouraging the organization and its Members to design positive efforts outside of the terms of the agreements, but in line with the objectives and principles of the organization. The Doha Ministerial Declaration of 2001 recalls the Preamble and reiterates the need to make positive efforts such as "enhanced market access, balanced rules, and well targeted, sustainably financed technical assistance and capacity-building programmes"2622 for developing and least developed members.

The Doha Ministerial Declaration is interesting in that it takes over the language of propoor development and absorbs it into the WTO regime. The same paragraph mentioned above also wraps up developing country needs and interests with words highlighting care and concern for developing country Members:

The majority of WTO members are developing countries. We seek to place their needs and interests at the heart of the Work Programme adopted in this Declaration [emphasis added].

Critics point out that the ensuing naming of post-Doha negotiations as the "Development Round or "Development Agenda" furthered the developing member-friendly image to an undeserved degree. ${ }^{2623}$ The July Framework Package ${ }^{2624}$ for future negotiations which

${ }^{2621}$ See French, Duncan, Sustainable Development in Fitzmaurice, Malagosia, David M. Ong and Panos Merkouris Eds., RESEARCH HANDBOOK ON INTERNATIONAL ENVIRONMENTAL LAW, Edward Elgar Publishing, 2010; Atapattu, Sumudu, EMERGING PRINCIPLES OF INTERNATIONAL ENVIRONMENTAL LAW, Transnational Publishers, 2006.

2622 Ibid, para.2.

${ }^{2623}$ See e.g. Stieglitz, Joseph, The Development Round that Wasn't, Project Syndicate, 2005.12.07 available at: http://www.projectsyndicate.org/commentary/stiglitz65, last accessed on 02.06.2010:

Both as it was conceived, and even more as it has evolved, today's Development Round does not deserve its name. Many of the issues that it has addressed should never have 
followed in 2004 reiterated many of the same statements as the Doha Ministerial Declaration, but also confirmed processes such as the request-offer approach for GATS, which is seen as subjecting developing countries to increased bilateral pressure. There was also additional pressure created by calling for moving the process forward faster despite the acknowledgment that developing and least developed countries do not have the same capacity to respond quickly to offers and develop their negotiating positions. ${ }^{2625}$ On one hand, it can be seen as necessary to gently or firmly prod developing countries to progressively liberalize, but on the other hand, does this not go counter to the claims that the GATS, even more than other WTO agreements, allows for developing country Members to liberalize services at 'their own pace'?2626

\subsubsection{Needs of Economic Development - Especially Developing Countries}

The Panels in India-Quantitative Restrictions and Brazil-Aircraft (Article 25.1 Canada $)^{2627}$ recognized the special needs of developing countries as stated in the Preamble of the WTO Agreement. The Appellate Body in EC-Tariff Preferences, regarding GATT 1994 and the Enabling Clause, refers to the preamble to the WTO Agreement for recognition of the possibility of varying the "positive efforts" taken to ensure developing and least developed countries secure a share in the growth of international trade. The Appellate Body focuses on the terms "commensurate [to their needs of economic development]" 2628 and "respective needs and concerns at different levels of economic development" 2629 in order to read Paragraph 3(c) of the Enabling Clause as allowing for different treatment of different developing country beneficiaries under a GSP. ${ }^{2630}$

However, statements of recognition and consideration of special needs in a preamble cannot purely by themselves be translated into concrete additional benefits for developing country Members. The Preamble can be used to more strongly support what is considered by panels or Appellate Body to already be fundamental features of the multilateral

been on the agenda of a genuine development round, and many issues that should have been on the agenda have not been.

${ }^{2624}$ The General Council decision on the Doha Agenda Work Programme (the "July package"), agreed on 1 August 2004, WT/L/579.

2625 See e.g. Oliva, Maria Julia, The Doha Work Programme: Still the Development Agenda?, CIEL Geneva, available at http://www.ciel.org/Publications/Doha_SDI12.pdf, accessed on 02.06.2010.

${ }^{2626}$ See Delimatsis, P., Article XIX GATS in Wolfrum, Rudiger, Peter-Tobias Stoll and Clemens Feinaugle Eds., WTO - TRADE IN SERVICES, Max Planck Commentaries on World Trade Law, Martinus Nijhoff Publishers, 2008, p. 434 referring to Article XIX:2 of the GATS. See also Delimatsis, P., INTERNATIONAL TRADE IN SERVICES AND DOMESTIC REGULATIONS: NECESSITY, TRANSPARENCY, AND REGULATORY DIVERSITY, Oxford University Press, 2007, p32; Stoler, Andrew L., Jim Redden, Lee Ann Jackson, TRADE AND POVERTY REDUCTION IN THE ASIA-PACIFIC REGION: CASE STUDIES AND LESSONS FROM LOW-INCOME COMMUNITIES, Cambridge University Press, 2009, p626.

${ }^{2627}$ India-Quantitative Restrictions (regarding GATT) and Brazil-Aircraft (Article 25.1 Canada, regarding Article 27 of the SCM - commenting that export subsidies may play important role in economic development programmes of developing country members (see footnote 49 and para.6.47).

${ }^{2628}$ Recital 2 of the Preamble to the WTO Agreement.

${ }^{2629}$ Ibid, Recital 1.

2630 Appellate Body Report, EC-Tariff Preferences, paras.161-162. The Appellate Body also refers for support to the Preamble to the 1971 Waiver Decision, which provides that "a principal aim of the contracting parties is promotion of the trade and export earnings of developing countries for the furtherance of their economic development" (1971 Waiver Decision, Preamble, first Recital). 
trading system. For example, the Panel in Turkey-Textiles ${ }^{2631}$ referred to the use of the terms "elimination of discriminatory treatment" in Recital 3 of the Preamble to the WTO Agreement - as support for the view quantitative restrictions to goods cannot be introduced (with regard to Article XXIV of GATT on Customs Unions). The Panel goes on to say that Article XXIV of the GATT:

...cannot be considered to exempt constituent members of a customs

union from the primacy of the WTO rules [emphasis added] ${ }^{2632}$

- with the suggestion that the Preamble confirms these rules.

Therefore, even in the case of phrases such as "sustainable development", although it is considered as a framework for socio-economic policymaking in the wider legal and policy context in the wider world outside of the WTO bubble, it cannot be interpreted in such a way as to exempt Members from the WTO rules, which retain "primacy". The possibilities for the Preamble to the WTO Agreement to be used to foster "sustainable development" goals and apply the recognition of the special needs of developing countries to the interpretation and application of the GATS in a positive manner must occur within the framework of WTO rules. However, the Preamble to the WTO Agreement can still be used to support a sustainable development approach to viewing the 'progressive liberalization' objectives of the GATS - which may require at times, cautious and slow liberalization (if at all) of certain sensitive sectors, led by and regulated by the domestic public sector. On the other hand, developing countries are also wary of the direction that broad interpretations may take, as there can be interpretations that use environmental protection as a way of sustaining the unequal global status quo and disregarding their development priorities. ${ }^{2633}$

\subsubsection{The Preamble to the GATS}

The GATS is situated in the context described in the Preamble of the WTO Agreement, in the same context of economic and social conditions in the world and as one of the agreements in the WTO package. The GATS begins with six recitals that are generally understood to be the Preamble to the Agreement, that are reproduced in full below. The relevant Articles related to developing and least developed country concerns follow.

Recognizing the growing importance of trade in services for the growth and development of the world economy;

Wishing to establish a multilateral framework of principles and rules for trade in services with a view to the expansion of such trade under conditions of transparency and progressive liberalization and as a means of promoting the economic growth of all trading partners and the development of developing countries;

Desiring the early achievement of progressively higher levels of liberalization of trade in services through successive rounds of multilateral negotiations aimed at promoting the interests of all participants on a mutually advantageous

\footnotetext{
${ }^{2631}$ Panel Report, Turkey-Textiles, para.9.163.

2632 Ibid.

2633 See Gonzales, C.G., Beyond Eco-Imperialism: An Environmental Justice Critique of Free Trade, Denver University Law Review, 78(4), 2001, 979-1016.
} 
basis and at securing an overall balance of rights and obligations, while giving due respect to national policy objectives;

Recognizing the right of Members to regulate, and to introduce new regulations, on the supply of services within their territories in order to meet national policy objectives and, given asymmetries existing with respect to the degree of development of services regulations in different countries, the particular need of developing countries to exercise this right;

Desiring to facilitate the increasing participation of developing countries in trade in services and the expansion of their service exports including, inter alia, through the strengthening of their domestic services capacity and its efficiency and competitiveness...

Taking particular account of the serious difficulty of the least-developed countries in view of their special economic situation and their development, trade and financial needs... [emphasis added]

In Chapter 2 of this study, the aspect of due respect for national policy in the Preamble to the GATS was discussed, and the question of the extent to which this objective is represented by the provisions of the GATS is a main thrust of this research. It is also clear under the VCLT approach to interpretation, that preambles generally are part of 'context' for the purposes of interpretation and have also been used as such for the interpretation of Members' GATS obligations, exceptions and schedules of commitments - as discussed in earlier Chapters.

The question of whether the Preamble to the GATS suggests a 'sustainable development telos' was also assessed earlier in Chapter 2, with the conclusion being that it is difficult to argue that such an interpretation has come to replace the existing trade liberalization focus and telos of the Agreement. This section will highlight whether the Preamble of the GATS could support interpretations of GATS obligations with a focus on the needs of development, and the specific needs of developing and least developed country Members.

The statements in the Preamble of the GATS, if given legal effect in terms of interpretation, ${ }^{2634}$ could support:

a. A reading of the GATS that recognizes the importance of trade in services not only for economic growth but also as a means to promote "the development of developing countries". The use of the word "development" in addition to the term economic growth, could allow for an additional dimension to the Agreement, but what 'development' means in the WTO regime may not necessarily be the same as that in another regime of international or domestic law nor a right to development or human rights approach to development. Krajewski also notes that the Preamble of the GATS skips the phrases "raising

\footnotetext{
2634 The Recitals in the Preamble, while they can be useful have also been described as "merely hortatory", in the case of both progressive liberalization (Recital 3) and developing country policy space (Recital 5) Hestermeyer, H., Preamble, General Agreement on Trade in Services in Wolfrum, Rudiger, Peter-Tobias Stoll and Clemens Feinaugle Eds., WTO - TRADE IN SERVICES, Max Planck Commentaries on World Trade Law, Martinus Nijhoff Publishers, 2008, p24 and 27.
} 
standards of living" and "ensuring full employment" which are in the GATT 1994 and the WTO. ${ }^{2635}$

b. Fair trading conditions and a flexible reading of the GATS as suggested by the phrase "promoting the interests of all participants on a mutually advantageous basis and at securing an overall balance of rights and obligations". Any unfair tilting of the system to favour economically and/or politically powerful Members at the expense of weaker Members or pushing of lop-sided bargains when negotiating further Rounds is against the express objectives of the Agreement. Interpretation of the Articles of the GATS should keep in mind this objective when the balancing rights and obligations during a dispute. Although it may seem incongruous to an adversarial procedure, the objective of promoting the interests of all Members in a mutually advantageous manner should be kept to the forefront in both consultations and dispute settlement. The advantages or interests abovementioned ought to be interpreted broadly, to cover public interest and development policy and not be limited to narrow concerns of commerce.

c. The actual impact of showing "due respect to national policy objectives" and "new regulations" introduced to meet the objectives of economic growth and development will turn on interpretation of the extent of "due respect" which would be applied in practice. Paragraph 7 of the Doha Ministerial Declaration reaffirms "the right of members under the General Agreement on Trade in Services to regulate, and to introduce new regulations on, the supply of services". ${ }^{2636}$ This recital can also be read with Article XIX:2 of the GATS and can be said to clearly recognize that national policy objectives on liberalization in trade in services will vary among Members and between different service sectors of a Member. Liberalization of telecommunication services can bring greater gains more quickly for a developing country Member's economy (and benefit consumers of that Member across the income scale). But in sensitive areas such as health and education, the touted benefits of the liberalization process may be looked at with more skepticism and a reluctance to make commitments or make commitments soon.

d. The desire to strengthen developing country domestic services capacity, efficiency and competitiveness is mentioned in the Preamble but it is not apparent that there is anything in the GATS itself that provides specifically for the strengthening of domestic services. It is more likely to be read in through the resort to the available flexibilities by Members. So, this recital in the Preamble is an acknowledgement of the policy space that can be read 'between the lines' of the GATS, and could be used to support an interpretation of broader policy space, if that space can be shown to strengthen domestic services capacity, efficiency and competitiveness. Delaying commitments in market access and national treatment can also be supported by this statement in the Preamble, since, in combinations with other measures, such a delay may allow time for domestic suppliers to improve their capacity etc.

\footnotetext{
${ }^{2635}$ Krajewski, Marcus, NATIONAL REGULATION AND TRADE LIBERALIZATION IN SERVICES: THE LEGAL IMPACT OF THE GENERAL AGREEMENT ON TRADE IN SERVICES (GATS) ON NATIONAL REGULATORY AUTONOMY, Kluwer Law International, 2003 at p56-57

2636 WTO, Doha Ministerial Declaration 2001, WT/Min.(01)/Dec/1, 20 November 2001 (adopted on 14 November 2001), available online at https://www.wto.org/english/thewto_e/ minist_e/min01_e/ mindecl_e. htm\#services.
} 
e. Increased participation of developing countries in trade in services and the expansion of their service exports is another area where liberalization per se may not bring such results, but a combination of domestic measures and international co-operation and assistance may do so.

f. The particular need of developing countries to exercise the right to regulate according to national policy objectives - is something that can on one hand seem an unnecessary inclusion, since all States should regulate to further national policy objectives (and not, for example, the interests of other States, multinational or domestic corporations or individual entrepreneurs at the expense of domestic public interest) - except where there are common global objectives such as universal human rights norms and environmental protection. However, the international economic and trade system having cast that obvious right and responsibility into doubt, the WTO system needs to specifically mention this right, as has been done in the GATS in this instance. The special right of developing countries that is highlighted here is not merely granted due to the general acceptance of the needs of their economic development, but also due to their insistence during the WTO negotiations on the inclusion of such wording (at least in the Preamble if not as an Article). Many developing countries having gone through being denied the sovereign right to protect their own national interests due to imperialism, colonization, occupation or interference with their sovereign independence, this wording is of special significance to them. ${ }^{2637}$

However, the Preamble also expresses the wish in the second recital "to establish a multilateral framework of principles and rules for trade in services with a view to the expansion of such trade under conditions of ...progressive liberalization" (emphasis added). The promotion of mutually advantageous interests, the balancing of rights and obligations and the "due respect to national policy objectives" is also placed in the context of "early achievement of progressively higher levels of liberalization of trade in services through successive rounds of multilateral negotiations". It is possible that in practice, the objective of expanding trade under conditions of progressive liberalization can override the assurances concerning fair trade, equitable development and respect for national policy objectives aimed at the growth and development of developing country domestic service sectors. Thus, officials and the public must consciously keep these latter issues at the forefront of policy in the context of both domestic governance as well as bilateral or multilateral negotiations on trade in services.

The WTO Secretariat comments in its Background Note on Application of the Necessity Test (WTO Job no. 5929), that there are two potentially conflicting priorities in the WTO: "promoting trade expansion versus protecting the regulatory right of government". ${ }^{2638}$ This conflict is also seen in the Preamble of the GATS. The problem is then how to achieve the balance between those conflicting priorities. However, the Panel in US-

2637 Most developing countries, with rare exceptions, were subject to centuries of partial or complete subjugation to foreign powers and their trade and economic interests. There are developed countries which have also had similar experiences during European wars and shifts of power but they did not face the same kind of pervasive socio-economic devastation as Latin America, Asia and Africa. There are also native peoples who experienced the loss of their sovereignty now living within developed countries such as United States, Canada, Australia and New Zealand.

${ }^{2638}$ WTO Document, Job.No.5929. 
Gambling did not seem to see these as necessarily conflicting priorities which need to be balanced, stating that:

Members regulatory sovereignty is an essential pillar of the progressive liberalization of trade in services, but this sovereignty ends whenever rights of other Members under the GATS are impaired [emphasis added]. ${ }^{2639}$

In that case it could be said that the balancing that identified is actually twofold:

1. A Member must conduct an internal balancing of liberalization and regulation within domestic policy formulation.

2. There also needs to be within the WTO system, on one hand a balancing of one Member's right to regulatory sovereignty and on the other hand their obligations to liberalize and other Members' right to benefit from their liberalization.

The Panel in US-Gambling also cited the Preamble of the GATS in relation to the expression of progressive liberalization, and linked it with Article XIX:1 and XIX:3 (negotiations of specific commitments) as well as Article XVIII (additional commitments|) linked with Article VI:4 (domestic regulation). ${ }^{2640}$ This approach of highlighting the progressive liberalization aspect of the Preamble is in line with the view that such preambular language reinforces the traditional and central telos of trade expansion $^{2641}$ and that national policy flexibility and the sharing of benefits of international trade with developing countries was added as secondary considerations.

Yet the Preamble does not necessarily have to be read with the weight all on the progressive-liberalization-end of the balancing scale. It can be argued that progressive liberalization as the aim and desire of the agreement is toned down to some extent by the other objectives, which also are clearly spelt out. Even the official WTO website appears to acknowledge this, stating that:

Trade expansion is thus not seen as an end in itself, as some critical voices allege, but as an instrument to promote growth and development. The link with development is further reinforced by explicit references in the Preamble to the objective of increasing participation of developing countries in services trade and to the special economic situation and the development, trade and financial needs of the least-developed countries [emphasis added] $]^{2642}$

\footnotetext{
${ }^{2639}$ Panel Report, US-Gambling, para.6.316.

${ }^{2640}$ Ibid, para.6.313:

Apparently,[Article XVIII linked with Article VI:4] are at the heart of the notion of progressive liberalization, which finds expression in the preamble of the GATS and in Article XIX, paragraphs 1 and 3. Progressive liberalization entails including more sectors in Members' schedules and reduction or elimination of limitations, terms, conditions and qualifications on market access and national treatment through successive rounds of negotiations
}

See also the previous discussion under Chapter 4 of this study, particularly 4.4 .6 on additional commitments and 4.6 on domestic regulation.

${ }^{2641}$ Broude, Tomer, The Rule(s) of Trade and the Rhetos of Development: Reflections on the Functional and Aspirational Legitimacy Of The WTO, 27(4) Columbia Journal of Transnational Law, November, 2006 (also available at http://www.worldtradelaw.net/articles/broudelegitimacy.pdf) at p27:

Nevertheless, the rhetos of development that now pervades the trade discourse, inevitably leads to uncertainty and ambiguity in the definition and perception of the WTO's telos.

2642 The WTO, THE GATS - A GENERAL INTRODUCTION, 29 March 2006, Doc.3776.4, available at http://www.wto.org/english/tratop_e/serv_e/gsintr_e.doc, accessed 19.05.2010 
Yet it should be noted that the Preamble by itself has little purpose other than to identify the objectives of the Agreement. In the wider context of international law generally, the International Court of Justice (ICJ) has considered the words of preambles in several cases. The preambles of the of the Havana Convention on Asylum (1928) and the Montevideo Convention on Political Asylum (1933) were referred to in the Asylum Case $(1950)^{2643}$ to determine the objectives of the relevant treaties. This is an innocuous use of the Preamble and not one that that would raise protests of judicial "overstepping". Preambles in such situations are used as simple reminders of object and purpose and to be read with together with the other relevant Articles of the Treaty. The "development objectives" of the Preamble can be used as context for any of the terms and provisions in the agreement - not only with developing and LDC provisions that we are considering. Would that expand the "concern for developing members" to interpretation and application of all parts of GATS? It should be kept in mind that the possibility to use the Preamble in this way is one thing, but the likelihood of that occurring is different matter.

With regard to the intention of the negotiators and drafters of the GATS, there are some sources for finding details of the drafting history. How important can this be for the use of the preamble and the "colour, texture and shading" that it might offer? Is it possible to come to any conclusion based on the fact that the reference to the term "national sovereignty" was deleted from the Preamble in the Draft Final Act (Dunkel Draft)? ${ }^{2644}$ Furthermore, there was a debate as to whether or not Recital 4 should have been included as a draft Article VI:I of the GATS, instead of being included in the Preamble. Hestermeyer suggests that the negotiators may have wanted the statement to be of less legal force. ${ }^{2645}$ Being a recital in the Preamble is clearly less favourable for strengthening national policy/regulatory sovereignty arguments, than if the relevant sentences had been included as an Article of the GATS.

\subsubsection{Using the Preamble of the GATS for interpretation of terms in the GATS}

The Preamble of the GATS was referred to most recently by the Appellate Body in Argentina-Financial Services, in so far as they acknowledged the prior statements of the Panel and the complainant, Panama, that the scope of "national policy objectives" in the third and fourth recitals of the Preamble is "broader than the objectives listed in the exceptions" and that Members can "pursue a wide range of national policy objectives without violating their obligations under the GATS". ${ }^{2646}$ The Appellate Body did not use the Preamble for interpreting terms of the GATS as such, but referred to it in the context of the types of measures which could be taken in the context of measures taken pursuant to paragraph 2(a) of the Annex on Financial Services. The Appellate Body noted that the third and fourth recitals of the Preamble was relevant for ascertaining the object and purpose of the GATS and that an interpretation limiting the types of measures that could

\footnotetext{
${ }^{2643}$ ICJ, Asylum Case (Colombia v. Peru), 1950 I.C.J. 266, p282.

2644 WTO, The Draft Final Act embodying the results of the Uruguay Round of Multilateral Trade Negotiations, MTN.TNC/W/FA, 20 December 1991.

${ }^{2645}$ Hestermeyer, H., Preamble, General Agreement on Trade in Services in Wolfrum, Rudiger, PeterTobias Stoll and Clemens Feinaugle Eds., WTO - TRADE IN SERVICES, Max Planck Commentaries on World Trade Law, Martinus Nijhoff Publishers, 2008, p20.

2646 Appellate Body Report, Argentina-Financial Services, paras.6.114-6.117 referring to Panel Report, Argentina-Financial Services, paras. 7.215-7.217.
} 
potentially fall under paragraph 2(a) "would not be in consonance with the balance of rights and obligations that is expressly recognized in the preamble of the GATS". ${ }^{2647}$

The Preamble of the GATS was also referred to in a broad sense by the Panel in USGambling, noting that: "[t]he GATS explicitly recognizes in its preamble the 'right of Members to regulate' services" and that the objectives of expanding trade under conditions of transparency as mentioned in the Preamble applies to the GATS schedules of specific commitments, which should be "readily understandable". ${ }^{2648}$ The Panel further commented that their conclusion on the US entry in their schedule of commitments is "compatible with the principle of progressive liberalization" embodied in the preamble and Article XIX of the GATS. ${ }^{2649}$

The Preamble of the GATS was also referred to in China-Publications and Audiovisual Products and China-Electronic Payment Services. The unclear status of China - whether it should receive benefits as a developing country - was discussed earlier in this Chapter. In China-Electronic Payment Services, the 'progressive realization' and transparency objectives in the Preamble to the GATS was raised by the complainant, the United States, with regard to China's scheduling practices. In the Panel Report, this submission is discussed with reference to the 'object-and-purpose' component of the VCLT approach to interpretation, and not the 'context'. The Panel accepted the US position that the way in which China had scheduled its' commitments across several sub-sectors were barriers to the achievement of progressive liberalization as well as transparency. Both these objectives, mentioned in the Preamble to the GATS also are supported by express provisions contained the GATS, including Articles III and XIX of the GATS. The Panel accepted that the said objectives were found in the Preamble of the GATS and supported also by the prior decision of the Appellate Body in US-Gambling. ${ }^{2650}$ However, the Panel admitted that the Appellate Body in both US-Gambling and China-Publications and Audiovisual Products had "observed that the objectives of the GATS did not provide specific guidance as to the correct interpretation of the entries at stake" but that it also did not support a constrained (scope and coverage) interpretation of schedule entries. ${ }^{2651}$ This reference to the Preamble of the GATS concerned Schedule entries and not Articles of the GATS, so what could be suggested from the decision is limited. Is it possible to infer that although there is no specific guidance as to how the Preamble would affect the interpretation of Articles of the GATS or specific commitments (which are considered an 'integral part' of the GATS), a widening of the scope and coverage may be more acceptable to panels and the Appellate Body than a narrowing?

The respondent in China-Electronic Payment Services also referred to the Preamble of the GATS, but to different recitals. The Panel mentions China's arguments and acknowledges that:

- They have "the right to regulate, and to introduce new regulations on the supply of services to meet domestic policy objectives" according to the Preamble of the GATS.

\footnotetext{
${ }^{2647}$ Appellate Body Report, Argentina-Financial Services, para.6.260.

${ }^{2648}$ Panel Report, US-Gambling, para.3.188 and para.6.107.

2649 Panel Report, US-Gambling, para.6.109.

${ }^{2650}$ Panel Report, China-Electronic Payment Services, paras. 7.195-7.99 (citing at para.7.196 the Appellate Body Report, US-Gambling, para.188).

2651 Ibid., (China-Electronic Payment Services), para.7.197; citing the Appellate Body Report, ChinaPublications and Audiovisual Products, para. 393 and the Appellate Body Report, US-Gambling, para. 189.
} 
- Articles VI:1 and VI:5 of the GATS further confirm that even in sectors in which a WTO Member has undertaken specific commitments, that WTO Member may, subject to certain disciplines, apply measures of general application affecting trade in services, including e.g. non-discriminatory licensing, qualification and technical requirements.

- That in this specific dispute, paragraph 2(a) of the GATS Annex on Financial Services is relevant and provides that, notwithstanding any other provisions of the GATS, a WTO Member may take measures for prudential reasons, including for the protection of e.g. investors and depositors, or to ensure the integrity and stability of the financial system. ${ }^{2652}$

However, none of these three arguments are dealt with, and are only mentioned once within a single paragraph of the decision. It appears that the liberalization objectives would be considered more decisive in supporting a particular view of the Agreement, but other recitals and provisions that may balance the opposite scales to liberalization, get scant attention.

The Mexico-Telecoms dispute brings in more discussion of similar balancing or limitation, as well the 'developing country' aspect. In Mexico-Telecoms, Mexico argued that commitments made by developing country Members have to be interpreted in the light of recital 5 of the Preamble of the GATS, ${ }^{2653}$ which recognizes the need to "strengthen their domestic services capacity and efficiency and competitiveness" and Article IV of the GATS. ${ }^{2654}$ However, the Panel stated:

... we note that these provisions describe the types of commitments that Members should make with respect to developing country Members; they do not provide an interpretation of commitments already made by those developing country Members [emphasis added]. ${ }^{2655}$

This approach would limit the Preamble to confirming the (temporary) right of a developing member not to make a commitment, but to treat it and the interpretation of its schedule the same as any other member once it does commit a sector.

Related to this point, the Panel also rejects Mexico's arguments that its measures were in accordance with Section 5(g) of the Annex on Telecommunications ${ }^{2656}$. The Panel states that the extra policy space for developing country Members under Section 5(g) is only so far as to recognize "the right of developing countries to inscribe limitations in their schedules for the objectives recognized in Section 5(g)" (original emphasis) and cannot be inconsistent with explicit voluntary commitments. ${ }^{2657}$ If this is the case, and as any Member has the right to inscribe limitations in their schedules as they wish, there does not

${ }^{2652}$ Ibid., (China-Electronic Payment Services), para.7.569.

${ }^{2653}$ Recital 5 of the Preamble to the GATS:

Desiring to facilitate the increasing participation of developing countries in trade in services and the expansion of their service exports including, inter alia, through the strengthening of their domestic services capacity and its efficiency and competitiveness

${ }^{2654}$ Panel Report, Mexico-Telecoms, para.7.214. Also see Mexico's second oral statement, para.81.

${ }^{2655}$ Ibid, para.7.386

${ }^{2656}$ Section 5(g) of the Annex on Telecommunications:

Notwithstanding the preceding paragraphs of this section, a developing country Member may, consistent with its level of development, place reasonable conditions on access to and use of public telecommunications transport networks and services necessary to strengthen its domestic telecommunications infrastructure and service capacity and to increase its participation in international trade in telecommunications services. Such conditions shall be specified in the Member's schedule [emphasis added].

${ }^{2657}$ Panel Report, Mexico-Telecoms, paras.7.386-7.389. 
seem to be any value in the inclusion of an additional rhetorical statement that developing countries may do so to strengthen their domestic infrastructure and service capacity. The Panel emphasizes that they do not believe that section $5(\mathrm{~g})$ can be used as a defence ${ }^{2658}$ and even if read with recital 5 of the Preamble of the GATS, Article IV of the GATS and Article 12.11 of the DSU (taking into account more favourable treatment for developing countries) $)^{2659}$ the schedule of commitments in telecommunications cannot be interpreted differently. It is added that:

...these findings in no way prevent Mexico from actively pursuing the development objectives referred to in these provisions by extending telecommunications networks and services at affordable prices in a manner consistent with its GATS commitments [emphasis added]. ${ }^{2660}$

The Panel also adds (obiter) that even if section $5(\mathrm{~g})$ could be used as a defence for measures inconsistent with specific commitments, the arrangements must be "reasonable and necessary" conditions for enhancing the relevant development objectives. ${ }^{2661}$ From experience it is seen that the necessity of a measure is often the hurdle too high for respondents in many WTO cases. If the approach of the Panel is generally followed, the only use of such developing country provisions in the GATS is as a restatement of the right to make commitments (perhaps more slowly and if not otherwise pressured) and the right to look forward to as yet unclear forms of assistance by the Organization and developed country Members. The very optimistic may perhaps read in a vague 'gentlemanly' promise that developed country Members would refrain from pressure on developing and least developed country Members to liberalize since they have a right to do so at their own pace.

The Appellate Body in US-Gambling referred to the Preamble, but only to state that the object and purpose of GATS as stated in its Preamble was NOT useful for the question at hand. ${ }^{2662}$ The reference to the Preamble was probably to respond to the analysis of the Panel in US-Gambling. The Panel referred to the Preamble in several contexts under the section "ordinary meaning in light of the object and purpose of the treaty". These contexts were as follows, for interpreting:

a) Transparency as an object and purpose of the GATS: the consistency of the 1993 Scheduling Guidelines with the Preamble of the GATS. ${ }^{2663}$

b) The compatibility of the Panel findings (concerning the US schedule) with the objective of progressive liberalization "as embodied in Article XIX and the Preamble of the GATS". 2664

c) The Scope of Article XVI (Market Access) as also confirming progressive liberalization accompanied by "progressive elimination of various restrictions" and the maintenance of market access restrictions only where they have been "explicitly and transparently scheduled". In support of this the Panel cites recitals 3 and 4 of the Preamble of the GATS emphasizing the phrases "successive rounds

\footnotetext{
${ }^{2658}$ Ibid, para.7.388.

${ }^{2659}$ Ibid see conclusions and recommendations para.8.3.

2660 Ibid.

${ }^{2661}$ Ibid, para.7.388.

2662 The issue at hand was whether the reference in Article XVI:2(a) to "limitations on the number of service suppliers ... in the form of numerical quotas" encompasses the type of measure at issue here, namely, a prohibition on the supply of a service in respect of which a specific commitment has been made (see Appellate Body Report, US-Gambling, para.235). Footnote 271 of the Report referred to the use of the Preamble by the Panel.

${ }^{2663}$ Panel Report, US-Gambling, para.6.107.

2664 Ibid., para.6.109.
} 
of multilateral negotiations", "national policy objectives" and "Recognizing the right of Members to regulate". 2665

d) Further on the Panel adds that the Preamble confirms that the purpose of Article $\mathrm{XVI}$ is

"to take an early and significant step towards the progressive liberalization of trade in services, acknowledging that this is to be achieved through successive rounds of negotiations [original emphasis] ... ${ }^{2666}$

As it was the complainant and not the respondent in US-Gambling who is the developing country, the developing country concerns mentioned in the Preamble were not necessary for the analysis. However, the stress upon progressive liberalization as a guide to object and purpose for interpreting the provisions of GATS adds weight to the other side of the scale. Balancing progressive liberalization with not hurrying a developing country into making commitments and letting it decide its own pace is not going to be any easier with this background.

The next GATS case concerned China, the most controversial developing member in terms of acceptance of status. The Appellate Body in China-Publications and Audiovisual Products referred to the Panel's use of the references to progressive liberalization in the Preamble of the GATS for interpreting China's GATS Schedule entry "sound recording distribution services" as extending to electronic distribution of sound recordings. The Appellate Body quite naturally observed that while they did not disagree, "none of the objectives listed in the Preamble of the GATS provides specific guidance as to the correct interpretation". ${ }^{2667}$ The Appellate Body agreed that the scheduling of specific commitments "represents another manifestation of progressive liberalization" and added that, in line with Mexico-Telecoms:

We do not consider, however, that the principle of progressive liberalization lends support to an interpretation that would constrain the scope and coverage of specific commitments that have already been undertaken by Members and by which they are bound. ${ }^{2668}$

The possibility that progressive liberalization can be used to extend the scope and coverage is not ruled out. The interpretative exercise can be viewed neutrally, as aiming to neither constrain nor extend the coverage (Art 3.2 DSU specifically states that rulings or recommendations of dispute settlement bodies cannot add to or diminish rights and obligations provided in the covered agreements); and that the role is to determine the common intention of Members when they negotiated the schedules. However, it is also possible to view the interpretation of the US schedule in the US-Gambling and China's schedule in China-Electronic Payment Services or China-Publications and Audiovisual Products as extending the coverage beyond what the US and China had intended or envisaged at the time of scheduling and that whether there was actual common intention of the Members at the time of scheduling, was not really at issue. Common sense would also note that the population size of China and Mexico means that they are markets that developed Members are interested in breaking into and the tools of interpretation are more likely to lead to a more expansive than a more restrictive interpretation of the breadth of the scope and coverage of a specific commitment.

\footnotetext{
${ }^{2665}$ Ibid., paras.6.314-6.315

${ }^{2666}$ Ibid., para.6.317.

2667 Appellate Body Report, China-Publications and Audiovisual Products, para.392-393

2668 Appellate Body Report, China-Publications and Audiovisual Products, para.394.
} 
It seems clear at present that the special situation of developing country Members is not going to be used to limit the scope and coverage of commitments in a Member's schedule. Especially if they have potential as an emerging market. The limitations on commitments have to be made specifically by developing countries, and they cannot assume that they would be interpreted with deference to their developing country status, giving them an additional flexibility that other Members do not have. If developing country governments make commitments without properly assessing whether there are in the general public interest or make commitments in one area in exchange for receiving other benefits in areas of export interest to them - they cannot later consider themselves less bound by those promises. However, in situations where an unforeseen development in trade in services has come up and the scope of the commitment is not clear, it is possible to argue that an interpretation limiting the scope of the commitment in favour of the developing country could be made.

As far as can be seen, "progressive liberalization" in the Preamble and the GATS provisions will probably continue to be hierarchically superior to "development of developing countries", "national policy objectives" and "special economic situation". Although panels and the Appellate Body and some commentators may see such a hierarchy of objectives, such a view and such interpretive practice is not required by any interpretive approach, and possibly not correct, since the Preamble of the GATS suggests a balancing of these objectives. It may the lack of express provisions in support of "development of developing countries", "national policy objectives" and "special economic situation" within the GATS may contribute towards these objectives having lesser weight than "progressive liberalization", which specifically supports the provisions in Part IV of the Agreement, as well as the overall thrust of the GATS.

This overall liberalization approach may also be seen in how preambles have been used to interpret terms and provisions in other WTO agreements. In the context of trade in goods, it has also been mentioned that there are no guidelines with regard to which objective of the Preamble trumps the other in a conflict, but dispute settlement bodies have referred to the fact that there may be a conflict. In the Appellate Body Reports in US-Continued Suspension and Canada-Continued Suspension, the Preamble to the SPS Agreement was referred to in the context of the right of WTO Members to take measures necessary to protect human, animal or plant life or health. The Appellate Body referred to the first recital of the Preamble in stating that the right to take protective measures must not be inconsistent with obligations of the Agreement and must be justified. Thus, the recitals which were focused on, were those calling on Members to ensure that they shall not arbitrary and justifiable discriminate between Members nor apply SPS measures in a manner which would constitute a disguised restriction on international trade. ${ }^{2669}$

Other disputes in which preambles were referred to include: EC-Sardines, which referred to the Preamble of the TBT; and Argentina-Footwear (EC) and Korea-Dairy, which referred to the Preamble of the Agreement on Safeguards for interpretation. ${ }^{2670}$ ChilePrice Band System is particularly interesting since the Appellate Body refers to the

\footnotetext{
${ }^{2669}$ Appellate Body Report, US-Continued Suspension and Canada-Continued Suspension, paras.522, 532, 692 and footnote 1086.

2670 Appellate Body Report, EC-Sardines, para.215 (note the Appellate Body's reliance on the TBT preamble to carve out space for discriminatory measures if their impact 'stems exclusively from a legitimate regulatory distinction' when interpreting Article 2.1 of the TBT); Appellate Body Report, Argentina-Footwear (EC), para.95 and Appellate Body Report, Korea-Dairy, para. 88 .
} 
Preamble of Agreement on Agriculture, noting that developing countries have an interest in creating and maintaining a fair trading system in agriculture. However, this reference seems to be obiter dicta since it is also stated that since both participants in this dispute are developing country Members, it is not required to apply any of these specialized provisions. ${ }^{2671}$ Moreover, both Chile and Argentina confirmed this view. The Appellate Body in Chile-Price Band System made similar statements to those made by the Appellate Body in EC-Export Subsidies on Sugar. The latter had noted that:

...the third paragraph of the Preamble to the Agreement recognizes that the "long-term objective" of WTO Members, in initiating a reform process to deal with the distortions in the world agricultural markets, is "to provide for substantial progressive reductions in agricultural support and protection". Pursuant to this objective, the fourth paragraph of the Preamble expresses the commitment of the WTO Members "to achieving binding commitments" in the three specified areas, including "export competition". An interpretation that export subsidy commitments must be expressed in a Member's Schedule in terms of both budgetary outlay and quantity commitment levels is more in harmony with the objectives stated in the Preamble to the Agreement than an interpretation that a Member is only obliged to fulfil "whatever commitments" it chooses to specify in its Schedule [as per European Communities' appellant's submission, para.140]. ${ }^{2672}$

Thus, in this instance also, the Appellate Body has used the relevant Preamble to interpret the suitable breadth of a Member's liberalization commitments and had not decided in favour of the Member retaining freedom to decide the scope of the commitments for themselves. This confirms the reality that the commitments are not unilaterally made by the Member but are instead the outcome of negotiations with other Members.

In Canada-Patent Term the Appellate Body had to decide a question of the interpretation and application of Article 70.1 of the TRIPS Agreement (Protection of existing subject matter), especially the possible interpretation of the terms "acts which occurred" before date of application of TRIPS to Canada. In this instance also, the Appellate Body interpretation was to prevent the narrowing of the scope of application of the TRIPS Agreement, not to limit the scope. ${ }^{2673}$ Similarly, in the case of India-Patents (US), addressing the US claim that the Indian legal regime for patent protection for certain products was inconsistent with the TRIPS Agreement, the Appellate Body (and Panel) referred to a part of the Preamble in the interpretation of Article 70.8(a), especially the "the need to promote effective and adequate protection of intellectual property rights". ${ }^{2674}$ However, there was no reference to (and there is still no interpretation for) the following parts of the Preamble of the TRIPS Agreement:

Recognizing the underlying public policy objectives of national systems for the protection of intellectual property, including developmental and technological objectives;

Recognizing also the special needs of the least-developed country Members in respect of maximum flexibility in the domestic implementation of laws and regulations in order to enable them to create a sound and viable technological base;

\footnotetext{
${ }^{2671}$ Appellate Body Report, Chile-Price Band System, para. 199.

2672 Appellate Body Report, EC-Export Subsidies on Sugar, para. 196.

2673 Appellate Body Report, Canada-Patent Term, para.57-60

${ }^{2674}$ Appellate Body Report, India-Patents (US), para.57.
} 
Thus, it seems that there is a pattern in the TRIPS Agreement where Recitals that balance the trade objectives with developing country interests have been generally ignored, but other Recitals promoting a trade objective have been used to the limit policy space that could have been made available to developing country Members.

The seemingly conflicting objectives in the Preambles to the WTO Agreement has not been balanced in dispute settlement, and the TRIPS required an amendment to support public health objectives and access to medicines. This does not bode well for the interpretation of the Preamble of the GATS in the context of the need for flexibility and policy space for developing country and LDC Members. Unless there are specific provisions which can be supported by the Recitals that promote development and 'nontrade' interests, the Recitals cannot stand by themselves. ${ }^{2675}$

The application of developing country interests and the promotion of the basic objectives of the GATT as expressed in the Preamble to the GATT to relevant provisions of the GATT by the Appellate Body in EC-Tariff Preferences, is an interesting example. The Appellate Body interpreted parts of the Enabling Clause which allows for special and differential treatment of developing countries through the GSP procedure. The Appellate Body pointed out that Paragraph 7 of the Enabling Clause provides that the concessions, contributions and obligations assumed thereby should also promote the basic objectives of the GATT 1994, including those embodied in the Preamble to the GATT 1994. ${ }^{2676}$ The second Recital of the Preamble to the WTO Agreement, ${ }^{2677}$ and the Preamble to the 1971 Waiver Decision ${ }^{2678}$ are also mentioned by the Appellate Body in the same paragraph of the decision, as is Paragraph 3(c) of the Enabling Clause, which states that the treatment provided under the Enabling Clause

....shall...be designed and, if necessary, modified, to respond positively to

the development, financial and trade needs of developing countries.

Such "positive efforts" are also called for in the second Recital of the Preamble to the WTO Agreement and in Article XXXVI:3 of the GATT 1994. ${ }^{2679}$ However, there is no such a reference to "positive efforts" or "respond positively" in the Preamble of the GATS and there is no "Enabling Clause 'and GSP-like system except for the 2011 LDC Waiver Decision. It appears that the interpretation of the Preamble of the GATS would have a different story when dealing with the development needs of developing and LDC Members.

\footnotetext{
${ }^{2675}$ However, note there is a difference in the role played by the Preamble to the TBT Agreement, where the wording of Recital 6 is similar to the exceptions in Article XX of the GATT 1994 and Article XIV of the GATS. The Panel in EC-Sardines (at paras.7.119-7.120) note that the Preamble of the TBT plays a similar role to the exceptions abovementioned:

Article 2.2 and this preambular text affirm that it is up to the Members to decide which policy objectives they wish to pursue and the levels at which they wish to pursue them.

See further on the relationship between the Preamble and Articles 2.1. and 2.2 of the TBT Agreement: Panel Report, US-Clove Cigarettes, paras.7.111-7.114, 7.329, 7.359-7.360, 7.370 and Panel Report, USTuna II (Mexico), paras. 7.41, 7.110, 7.225, 7.276, 7.460, 7.467.

${ }^{2676}$ Appellate Body Report, EC-Tariff Preferences, para. 168.

${ }^{2677}$ WTO Agreement, Preamble, second Recital which states that there is a: ...need for positive efforts designed to ensure that developing countries, and especially the least developed among them, secure a share in the growth in international trade commensurate with the needs of their economic development

${ }^{2678} 1971$ Waiver Decision, Preamble, first Recital: ...a principal aim of the CONTRACTING PARTIES is promotion of the trade and export earnings of developing countries for the furtherance of their economic development.

${ }^{2679}$ Referred to also in the Appellate Body Report, EC-Tariff Preferences, para.92.
} 
Are there contradictions or conflicts among the different objectives in the Preamble of the GATS? The recitals do not seem to have been drafted to explicitly support particular provisions, and seem to be have been cast adrift. Can developing country and LDC Members use the recitals for interpretations of the GATS which support national policy catering to their development needs? The following section looks at Article IV of the GATS, which is the GATS version of special and differential treatment.

\subsubsection{Article IV of the GATS: Increasing Participation of Developing Countries}

Article IV of the GATS reads as follows:

1. The increasing participation of developing country Members in world trade shall be facilitated through negotiated specific commitments, by different Members pursuant to Parts III and IV of this Agreement, relating to:

a) the strengthening of their domestic services capacity and its efficiency and competitiveness, inter alia through access to technology on a commercial basis;

b) the improvement of their access to distribution channels and information networks; and

c) the liberalization of market access in sectors and modes of supply of export interest to them.

2. Developed country Members, and to the extent possible other Members, shall establish contact points within two years from the date of entry into force of the WTO Agreement to facilitate the access of developing country Members' service suppliers to information, related to their respective markets, concerning:

(a) commercial and technical aspects of the supply of services;

(b) registration, recognition and obtaining of professional qualifications;

(c) the availability of services technology.

3. Special priority shall be given to the least-developed country Members in the implementation of paragraphs 1 and 2. Particular account shall be taken of the serious difficulty of the least-developed countries in accepting negotiated specific commitments in view of their special economic situation and their development, trade and financial needs.

Article IV of the GATS is titled "Increasing Participation of Developing Countries". Developing countries make up the majority of the WTO membership, and they are participating in the sense of being there and making up the numbers; but developing countries do not have a major share of the world services market, and this has not changed significantly since the creation of the WTO. Nitya Nanda says that the linkage made between the GATS and the possibility of an increased share in global services trade for developing countries compared with the pre-WTO GATS era, "should be taken with a pinch of salt". ${ }^{2680}$ Nanda's analysis is that developing country growth of services trade

2680 Nanda, Nitya, EXPANDING FRONTIERS OF GLOBAL TRADE RULES: THE POLITICAL ECONOMY DYNAMICS OF THE INTERNATIONAL TRADING SYSTEM, Routledge, 2008, p52-53. 
share in the first few years after the establishment of the WTO reflects the services trade growth of Asian countries such as South Korea, Hong Kong (China), Singapore and Taiwan and does not show the stagnation in other developing countries and regions. The gains in the expansion of services trade is generally commented on as being gains flowing to developed country Members who were prepared and have the technology and capital to be able to benefit from new or expanded services markets.

It is also generally commented that most developing countries do not gain much from the liberalization of services trade under Modes 1-3 (cross border supply, consumption abroad and commercial presence) due to obvious constraints of capital and technology, but that Mode 4 (movement of natural persons) is an area where they can benefit, especially if they have a reasonably well educated and trained workforce. Several developing countries find that the remittances from citizens employed abroad are a significant percentage of GDP, for example, it is approximately $10 \%$ of GDP for the Philippines, Sri Lanka, Guatemala and Senegal and even higher for certain countries facing or having recently overcome political instability. ${ }^{2681}$ Overall it has been estimated that remittances are now the second largest source of external financial flows to developing countries, behind foreign direct investment. ${ }^{2682}$ A study in 2014 concluded that remittances have also proven to be:

...a more sustainable source of foreign currency for developing countries than other capital inflows such as foreign direct investment, public debt or official development assistance [emphasis added]. ${ }^{2683}$

The inclusion of Mode 4 was at the insistence of developing country Members, who hoped for greater benefits for themselves in the free movement of persons and this area is of continuing interest for them. Despite the initial hopes, liberalization of this Mode may be the one that has lagged behind the most, since temporary migration from developing to developed countries remains in general the most difficult in terms of having the most restrictions.

The issue of disproportionate benefits to developed country Members under the GATS was raised by a communication by a group of developing country Members quite early on, in $2001,{ }^{2684}$ in connection with the ineffective implementation of Article IV of the GATS, citing both WTO data ${ }^{2685}$ and UNCTAD reporting ${ }^{2686}$ of trade in services growth. The Members Communication included the position that special and differential treatment has in practice two broad "operational elements":

${ }^{2681}$ World Bank, Data on personal remittances received (as \% of GDP), 2009-2013, available online at http://data.worldbank.org/indicator/ BX.TRF.PWKR.DT.GD.ZS.

${ }^{2682}$ World Bank, Migration and Development Brief No 21: Migration and Remittances, 2 October 2013, siteresources.worldbank.org/INTPROSPECTS/Resources/3349341288990760745/MigrationandDevelopme ntBrief21.pdf.

${ }^{2683}$ European Parliament, Directorate-General for External Policies of the Union (author: Karine Manyonga Kamuleta), The Impacts of Remittances on Developing Countries, EXPO/B/DEVE/2013/34, April 2014, available online at http://www.europarl.europa.eu/RegData/etudes/etudes/join/2014/433786/EXPODEVE ET(2014)433786_EN.pdf.

${ }^{2684}$ Communication from Cuba, Pakistan, Senegal, Sri Lanka, Tanzania, Uganda, Zambia And Zimbabwe: Increasing Participation of Developing Countries in International Trade in Services: Effective Implementation of Article IV of GATS, 6 December 2001, S/CSS/W/131, para.1.

2685 WTO, Annual Report 1997, Vol. II and WTO International Trade Statistics, 2000.

${ }^{2686}$ UNCTAD, Positive Agenda and Future Trade Negotiations, 2000, p82:

Experience so far suggests that the structure of the GATS has proven to be of greater utility to developing countries than declarations in their favour, such as GATS Article IV, which have not to date been effectively implemented. 
(2) facilitation of exports, i.e., enhanced and non-reciprocal access for developing country exports to developed country markets;

(3) flexibility and policy discretion to developing countries in respect of their own markets, i.e., right to regulate to pursue developmental objectives, right to maintain some trade barriers and the right to provide appropriate support to their domestic services providers.

- and that Article IV of the GATS "therefore should be interpreted in the context of this broad special and differential treatment paradigm". 2687

However, it is significant that Article IV of the GATS is not titled "special measures for developing countries" or some phrasing that suggests differential treatment, but as "increasing participation of developing countries". It is often highlighted by commentators that the GATS does not actually contain special and preferential treatment for developing countries for the purposes of development policy but that development is to be achieved through liberalization itself. ${ }^{2688}$ This suggests a limitation on alternative national policy measures for development and an indication that the provision is included to incentivize developing country participation through acknowledging a limited flexibility.

Yet the Preamble to the GATS includes the objectives of "[d]esiring to facilitate the increasing participation of developing countries..." (Recital 5) in services exports, as well as "[r]ecognizing the right of Members to regulate...in order to meet national policy objectives..." (Recital 4). Article IV is meant to provide for the former objective, but the latter objective is not explicitly supported by any provisions in the Agreement, other than the flexibility provided for in Article XIX:2 of the GATS with regard to scheduling of commitments. ${ }^{2689}$ It can be argued that the:

....appropriate flexibility for individual developing country Members for

opening fewer sectors, liberalizing fewer types of transactions ... [etc.] ...

...ought to be superfluous, since it should be that no Members are compelled by any other forces or circumstances to make commitments that are against their interests. Is this the provision upon which most of the flexibility of the GATS ultimately relies? Hestermeyer comments that the drafting history of the Preamble of the GATS shows that there was a debate on whether to place Recital 4 (including mention of national economic policy sovereignty) in the text of the Agreement under Article VI (domestic regulations), to give it more legal force. ${ }^{2690}$ However, this was deleted from Article VI in the Dunkel Draft. This suggests that the concept of national policy flexibility was not intended to have broad legal force as a provision that balances the conflicts that could arise between

\footnotetext{
${ }^{2687}$ Op cit., (Communication, S/CSS/W/131), para.2.

${ }^{2688}$ Footer, Mary E. and Carol George, The General Agreement on Trade in Services in Macrory, Patrick, Arthur Appleton and Michael Plummer, THE WORLD TRADE ORGANIZATION: LEGAL, ECONOMIC AND POLITICAL ANALYSIS, VOL. I, Springer 2005, p832; Hestermeyer, H., Preamble, General Agreement on Trade in Services in Wolfrum, Rudiger, Peter-Tobias Stoll and Clemens Feinaugle Eds., WTO - TRADE IN SERVICES, Max Planck Commentaries on World Trade Law, Martinus Nijhoff Publishers, 2008, p28;

${ }^{2689}$ It could also be argued that the general exceptions recognized in Article XIV of the GATS provides for policy space for all Members, but that becomes relevant where the schedule of commitments is determined to not have succeeded in carving out the policy space at the outset. Whether an exception can be seen as an explicit right in itself is another issue, which may be argued differently depending on the specific context and development of the rules and exceptions.

${ }^{2690}$ Hestermeyer, H., Preamble, General Agreement on Trade in Services in Wolfrum, Rudiger, PeterTobias Stoll and Clemens Feinaugle Eds., WTO - TRADE IN SERVICES, Max Planck Commentaries on World Trade Law, Martinus Nijhoff Publishers, 2008, p20.
} 
it and liberalization obligations of the GATS, but only to be connected with the space allowed for the scheduling of commitments.

It can be seen that the focus of Article IV of the GATS is on the negotiation of specific commitments pursuant to Parts III and IV of the GATS, which are respectively, specific commitments and progressive liberalization. The increased participation in international services trade through liberalization, is linked in Article IV with the following:

(a) the strengthening of domestic services capacity and its efficiency and competitiveness, inter alia through access to technology on a commercial basis;

(b) the improvement of access to distribution channels and information networks;

(c) the liberalization of market access in sectors and modes of supply of export interest to developing countries.

Logically, liberalization via specific commitments cannot by itself deliver any of the above. Therefore, it can be assumed that the Article refers to a process of negotiation during which developed country Members would make certain concessions due to the fact that they are negotiating with a developing country Member. It seems that Article IV:1 of the GATS creates a framework identifying the concessions which could be made by developed countries. Following the structure of the paragraph, they can be identified as follows.

1. Specific reference is made to agreements for buying technology from developed country Members on commercial terms, as being among other possibilities for strengthening developing countries services capacity.

2. Greater access to distribution channels and information networks.

3. Voluntary liberalization of market access by developed country Members.

\subsubsection{Agreements for buying technology from developed country Members on commercial terms.}

The Dunkel Draft introduced the "inter alia through access to technology on a commercial basis" section of Article IV of the GATS. It can be said that the specific mention of "commercial basis" rather deflates the idea of improved access to technology for developing country Members, many of whom who cannot afford it anyway, without aid or some further concessions. This phrase does not of course close out other channels of aid. But it does not really support an obligation to take positive measures to ensure access to technology for developing countries and LDCs within the WTO system, as opposed to a mere vague statement which sounds like merely a political commitment.

During the Uruguay Round negotiations in November 1989, Peru made a proposal that market access by developing countries or LDCs should be contingent on transfer of technology, training of national personnel, access to distribution and information channels and investment of a percentage of the earnings of the foreign supplier for improvement of domestic infrastructure and for scientific and technological research. ${ }^{2691}$ The Republic of Korea also noted that GATS should contain provisions for technology transfer and improved market access for developing countries and there were also detailed proposals

2691 Communication from Peru: Elements of a Framework Agreement on Trade in Services, GATT Doc.No.MTN.GNS./W/65, July 20, 1989 at p5, cited in Stewart, Terence P., Ed., THE GATT URUGUAY ROUND: A NEGOTIATING HISTORY (1986-1992), Volume II: Commentary, Kluwer Law and Taxation Publishers, 1993, p2379. 
from a Latin American group of countries. ${ }^{2692}$ These detailed proposals did not become part of the final draft, and according to the GATS, the liberalization offers by developing country and LDC Members are not explicitly linked to methods, processes and conditions for technology transfer from developed country Members. Article XIX of the GATS however, mentions that it is possible

...when making access to their markets available to foreign service suppliers, [developing country Members could decide on] attaching to such access conditions aimed at achieving the objectives referred to in Article IV.

Such access conditions could include training of nationals, investment in the national economy or in R\&D. But since technology transfer on a commercial basis has already been specifically mentioned in Article IV as part of facilitation for liberalization, at first glance it does not seem typical to interpret that technology transfer can simultaneously be considered as an access condition as originally suggested in the Uruguay Round negotiations. This is because 'a commercial basis' does not immediately suggest conditions which would be particularly beneficial from the viewpoint of developing country or LDC Members, but rather, beneficial from the viewpoint of the Members whose citizens or corporations have rights to the relevant technology.

However, as discussed earlier in Chapter 3 of this study, especially section 3.4 .4 and the interpretation of 'commercial basis' in China-Intellectual Property Rights and CanadaRenewable Energy/Canada-Feed-in Tariff Program; WTO law has approached the interpretation of 'commercial' as not merely or even primarily profit-seeking. That interpretation was in a different context of extending the scope of WTO law to cover certain activities: Chinese intellectual property violations carried out on a commercial scale and the commercial nature of a Canadian government programme for encouraging through subsidies and then procuring renewable energy, which was challenged as a national treatment violation. But if it is applied for this situation of technology transfer as well, then access conditions under Article XIX, which are also 'on a commercial basis' according to Article IV, could include conditions that are not based on profit, and are instead beneficial on a 'commercial basis (not limited to profit-seeking)' in a broader sense of assisting developing country and LDC Members obtain technology with transfer conditions that assist in developing their domestic industries to become more productive and competitive.

This means that such deals and bargains can occur in light of the rights and obligations under Article XIX and IV of the GATS, but it does not suggest that they actually occur with the developing country or LDC Member being in a strong position to bargain by making market access contingent on access to these technological benefits. On the contrary, their participation, including the liberalization of market access commitments, shall be facilitated by other Members, who may also grant access to technology on commercial terms if they so wish. It is interesting to note in that China agreed not to apply technology transfer conditions in paragraphs 1.2 and 7.3 of its Accession Protocol and paragraph 203 of its Working Party report. However, in 2018 the EU initiated a WTO dispute over Chinese domestic legislation and measures which impose technology transfer conditions for foreign companies investing in China. The EU (with the United

${ }^{2692}$ Communication from the Republic of Korea on the Structure of the GATS, October 25, 1989 (informal paper) and Communication from Brazil, Chile, Colombia, Cuba, Honduras, Jamaica, Nicaragua, Mexico, Peru, Trinidad and Tobago and Uruguay: Structure of a Multilateral Framework for Trade in Services, GATT Doc. No. MTN.GNS./W/95, February 26, 1989, cited in Stewart (Ibid). 
States, Japan and Chinese Taipei joining the consultations) has complained that the measures concerning the transfer of technology into China are applied in a manner inconsistent with its WTO (GATT 1994 and TRIPS) obligations. ${ }^{2693}$

Another issue is that the granting of such access to technology would not necessarily be related to the priorities and needs of development within the developing country or LDC Member. This is often seen in aid or technology transfer situations where donors or other agencies tie assistance with unnecessary and expensive technology that is not the most suitable or cost-effective in terms of the needs of the developing country or LDC Members. With regard to trade in services, an example from a recent UN DESA Report noted with regard to technical cooperation in telecommunications (specifically based on para. 6(d) of the GATS Annex on Telecommunications, in addition to the Article IV obligation) that the experience, especially that of LDCs, has been that technology transfer was guided by commercial considerations such as profitability and not necessarily by any actual development needs of the country e.g. prioritization of $3 \mathrm{G}$ mobile technology over developing other rural telecommunications systems. ${ }^{2694}$

\subsubsection{Greater access to information networks and distribution channels.}

This access to information is through unspecified means, possibly linked with Article $I V: 2$ and cross-referenced with proposed guidelines and procedures from the Council for Trade in Services under Article XIX. It can also be linked with the general obligations that all Members have under Article III of the GATS (transparency).

Article IV:2 of the GATS concerns contact points for information and clarifies the information that developing members should have access to as concerning the following three areas.

(a) Commercial and technical aspects of the supply of services.

(b) Registration, recognition and obtaining of professional qualifications. (This will be very useful for Mode 4 expansion, but it is almost a reciprocal duty as, developing members must also make information available to "the extent possible".)

(c) The availability of services technology (possibly to encourage developing members to purchase such technology on commercial terms). Article XXV of the GATS on technical cooperation, that is to be read with Article IV:2, is also not a very promising provision. It merely states that:

1. Service suppliers of Members which are in need of such assistance shall have access to the services of contact points referred to in paragraph 2 of Article IV.

2. Technical assistance to developing countries shall be provided at the multilateral level by the Secretariat and shall be decided upon by the Council for Trade in Services.

\footnotetext{
2693 China-Certain Measures on the Transfer of Technology, Request for Consultations by the European Union-Revision, WT/DS594/1/Rev.1, 08.01.2019.

${ }^{2694}$ UN DESA, Trade-related International Support Measures (ISMs) for Least Developed Countries (LDCs): Background document for stakeholder workshops in the Gambia and Uganda January 2014, (REV 1) UN DESA, available online at http://esango.un.org/ldcportal/documents/10179/127657/Trade-related\% 20ISMs\%20for\% 20LDCs_Overview_DRAFT.pdf.
} 
Paragraph 2 at least has some potential for positive action and can be used for demands that the Organization becomes more sensitive to developing country needs, whereas Paragraph 1 appears to be somewhat superfluous.

Negotiating without the information needed to make informed choices and to form positions has been described by one writer as "chasing a black cat in a dark room blindfolded" - and a particular problem for developing country and LDC Members, who clearly have less capacity than developed country Members. ${ }^{2695}$ Would there be an improvement in the situation if Article IV, XIX and XXV are implemented as envisioned? It seems very difficult to hold a Member to account for failure to comply with Article IV only - and it is usually posited that it is the binding dispute settlement system that encourages compliance with WTO obligations. Compliance with Article IV, XIX and XXV requires co-operation and transparency between Members, and ultimately depends on the political will of the Members to make the efforts and necessary investments towards greater access to information.

\subsubsection{Voluntary liberalization of market access by developed country Members.}

This is essentially a promise that developing members get something in return during negotiations with developed members. Market access is of course an area where all WTO Members are supposed to have national policy flexibility and liberalize progressively and not all at once. As developed members are 'more equal' than developing members in the real world political and economic context, and since developing country and LDC Members cannot exert political and economic power of a sufficient level to pressurize developed country Members into making decisions on market access which are favourable to the development needs of developing country and LDC Members, this provision has little real force.

However, read with Article XIX and the relevant Modalities on liberalization, other Members appear to be called upon to act with restraint and allow for the exercise of flexibility by developing country and LDC Members.

\subsubsection{Article XIX and Article IV of the GATS}

Article XIX (Negotiations on Specific Commitments) is to be read with Article IV, to confirm that the process of negotiation should be carried out taking into account developing country Member concerns.

Article XIX:2 of the GATS states that:

The process of liberalization shall take place with due respect for national policy objectives and the level of development of individual Members, both overall and in individual sectors. There shall be appropriate flexibility for individual developing country Members for opening fewer sectors, liberalizing fewer types of transactions, progressively extending market access in line with their development situation and, when making access to their markets available to foreign service suppliers, attaching to such access conditions aimed at achieving the objectives referred to in Article $I V$ [emphasis added].

\footnotetext{
2695 Raghavan, Chakravarthi, Developing Countries and Services Trade: Chasing a Black Cat in a Dark Room, Blindfolded, Third World Network, 2002. See also Kelsey, Jane, SERVING WHOSE INTERESTS?: THE POLITICAL ECONOMY OF TRADE IN SERVICES, Taylor \& Francis, 2008, p10.
} 
As can be seen, Article XIX:2 of the GATS begins with a reiteration of the Preamble of the GATS, adding that the level of development both overall and in individual sectors needs to be taken into account. This could be strengthening the developing country Member's position that their development status must be considered in negotiations; but it can also suggest that tough bargains will be struck in areas where a developing member's service sector is becoming competitive.

Article XIX:3 of the GATS which follows directly after, also refers to assessment of trade in services in overall terms and on a sectoral basis "with reference to the objectives of this agreement, including those set out in paragraph 1 of Article IV". It is also interesting that the greater flexibility suggested by Article XIX:2 is followed by the statement in Article XIX:3 that:

Negotiating guidelines shall establish modalities for the treatment of liberalization undertaken autonomously by Members since previous negotiations.

In 2003, the Council for Trade in Services adopted a document titled Modalities for the Treatment of Autonomous Liberalization (TN/S/6), according to the requirements of Article XIX:3 and supported by paragraph 15 of the Doha Ministerial Declaration (WT/MIN(01)/DEC/1) and paragraph 13 of the Guidelines and Procedures for the Negotiations on Trade in Services (S/L/93). ${ }^{2696}$ Paragraph 3 of the Modalities for Autonomous Liberalization defines the term 'autonomous liberalization' as a measure:

a) subject to scheduling under Part III of the GATS, and/or leading to the termination of an MFN exemption,

b) compatible with the MFN principle,

c) undertaken by the liberalizing Member unilaterally, since previous negotiations, in accordance with Article XIX of the GATS, and

d) applicable to any or all service sectors [footnote omitted].

In a footnote to paragraph (c) above, it is stated that "liberalization measures undertaken as part of economic reform programmes", including IMF and World Bank led economic reforms, should be considered as "autonomous liberalization measures" in so far as they meet the criteria set out in (a)-(d) above.

This can be analyzed in two ways; either that it represents a triple pressure on Members to liberalize (WTO, IMF and World Bank) or that it is an 'incentive' for autonomous liberalization since "economists will argue that unilateral liberalization is usually best way to enhance domestic welfare [emphasis added]". ${ }^{2697}$ The idea of 'incentive' in this

2696 See WTO, Modalities for the Treatment of Autonomous Liberalization, Adopted by the Special Session of the Council for Trade in Services on 6 March 2003, TN/S/6, 10 March 2003.

${ }^{2697}$ Delimatsis, P., Article XIX GATS in Wolfrum, Rudiger, Peter-Tobias Stoll and Clemens Feinaugle Eds., WTO - TRADE IN SERVICES, Max Planck Commentaries on World Trade Law, Martinus Nijhoff Publishers, 2008, p439. Delimatsis adds that this is because voluntary liberalization is connected to the recognition that domestic regulatory reform is also needed. While this may draw attention to the responsibility that developing countries have towards their own development and the need for designing regulatory measures that would benefit them, this does not acknowledge the right and responsibility to choose the most suitable regulatory mechanisms for themselves, rather than 'one-size-fits-all' ones imposed on them. (See further, Steiglitz, Joseph, GLOBALIZATION AND ITS DISCONTENTS, Penguin Books, 2002, p251-252 in support of both the responsibility to regulate and democratic choice in developing countries, instead of policies dictated by others).

See also Ruse - Khan, Henning Grosse, A Comparative Analysis of Policy Space in WTO Law, Max Planck Papers on Intellectual Property, Competition \& Tax Law Research No. 08-02, electronic copy available at: http://ssrn.com/abstract=1309526: noting the economic and social damage caused by e.g. the structural adjustment programmes of the World Bank Group demanding privatization of water and education in 
context as well as the terminology of 'unilateral' liberalization sometimes used by commentators is not necessarily within the framework of the meaning of 'autonomous 'and 'voluntary'. The Shorter Oxford English Dictionary notes the following definitions:

Autonomous: of, pertaining to, or characterized by autonomy; selfgoverning, independent; free of external influence or control.

Voluntary:...without external constraint...done of one's own free will...not constrained, prompted or suggested by another...left to choice, not required or imposed.

Unilateral: spec.in Law Of an obligation entered etc.: entered on by one party, esp. with no reciprocal obligation from any other...

Liberalization under Article XIX of the GATS by developed country Members can easily fall within all these definitions, including allowing for non-reciprocal national treatment and market access as a special and differential treatment for developing or LDC Members. But for developing country and LDC Members, the difference between 'autonomous'/'voluntary' and 'unilateral' is significant, since they are just not in a position to undertake liberalization efforts without making any developmental progress in terms of services capacity. 'Unilateral' liberalization also appears to run counter to the developing country and LDC position of wanting reciprocal and/or special treatment from developed country trading partners, which takes into account their development status and their need (and right) to develop. It has been commented that the realities of power and bargaining leverage create both implicit and explicit pressures on developing countries in negotiations to 'unilaterally' liberalize and that these pressures include dissuasion in taking advantage of flexibilities in Article IV and XIX of the GATS, which may be part of negotiated liberalization. ${ }^{2698}$

It is usually the case that developing countries and LDCs cannot individually take advantage of flexibilities and work the system to their advantage without being part of coalitions or negotiating groups - and even then, their efforts are not always successful. ${ }^{2699}$ Furthermore. since the interests of these coalitions or negotiating groups are often led by the more economically powerful developing countries within the group, and it may rarely be the case that the interests of all developing and LDC Members would coincide. There are also specific interests that countries wish to protect and particular alliances relating to these.

Currently there are a number of different recognized negotiating groups in the WTO including several which are mixed developing country and LDC groups and several

developing countries; the IMF lending activities curtailing the countries' spending on its own people and the unrestricted capital movement which caused severe crisis in Indonesia and Argentina in the late 1990s. See further, UNDP, MAKING GLOBAL TRADE WORK FOR PEOPLE, UNDP and Earthscan, 2003, p249 commenting on IMF imposed investment liberalization measures that were imposed on Thailand after 1998, despite limitations in their schedule.

${ }^{2698}$ UNDP, MAKING GLOBAL TRADE WORK FOR PEOPLE, UNDP and Earthscan, 2003, p262-263.

An alternative argument to the above is that Article XIX:3 and the related modalities are included in the GATS in order to recognize the unilateral liberalization which has already occurred/will occur outside of GATS negotiations and suggests that a trading partner ought therefore to avoid pressurizing and refrain from pursuing its requests for further liberalization in light of the unilateral steps which have been undertaken. However, there is no suggestion within the wording of the provision that such a reduction of pressure to liberalize is intended, merely that unilateral liberalization is encouraged.

${ }^{2699}$ Narlikar, Amrita, INTERNATIONAL TRADE AND DEVELOPING COUNTRIES: BARGAINING COALITIONS IN THE GATT \& WTO, Routledge, 2003; Rolland, Sonia E., Developing Country Coalitions at the WTO: In Search of Legal Support, 48 Harvard International Law Journal (2007), pp. 483551. 
which overlap in terms of Members being in more than one grouping. ${ }^{2700}$ For example, there is the African, Caribbean and Pacific (ACP) group, the African group, the LDC group, the G-90 (ACP, African group and LDCs together), Asian developing members, G-20, G-33, Small, vulnerable economies (SVEs) etc. There are also very small groups such as 'Low-income economies in transition' (which are seeking LDC treatment), Tropical products group, Cotton-4 and 'W/52 sponsors' for geographical indicators. Ecuador for example is in 8 groups including G-20, G-33, Tropical products, SVE and W/52 Sponsors. Sri Lanka, for another example is in Asian Developing group, G-33, SVE and W/52 Sponsors. Benin is an LDC and in 7 groups including Cotton- 4 and ACP. The give-and-take and trade-offs in WTO negotiations means that it is often difficult to achieve smaller economies' interests. ${ }^{2701}$

The modalities under Article XIX and Article IV of the GATS need to be explored further. There have been several proposals, such as the Proposal by the African Group (TN/CTD/W/3/Rev.2) which called for periodic benchmarks set by the Committee on Trade and Development for financial and technical cooperation and other arrangements for special concessions designed to assist domestic services of developing country Members and technology transfer to such Members according to Article IV of the GATS. With regard to LDCs, there are provisions and proposals for separate and special attention to their needs. While there are many of these proposals, including some which have been adopted by the Council on Trade in Services, the actual operationalization thus far remains less than satisfactory. Considering that Article IV of the GATS is titled "Increased Participation of Developing Countries", the benefits seem to be offered as a sugar coating to the carrot of WTO membership for developing countries.

\subsubsection{Special Treatment for Least Developed Countries (LDCs)}

At a 2019 WTO Services Council session focusing on LDCs, it was commented that LDCs account for only $1 \%$ of world services and only $0.3 \%$ of world services exports. ${ }^{2702}$ It has been noted that the first major draft of the GATS, the Chairman's Draft dated December 1990 (MT.GNS/35) included with regard to LDCs that:

In view of the of the weakness of their domestic service capacity, special consideration shall be given to their difficulty in accepting in accepting commitments under Part III and IV of this agreement [they will not be expected to make commitments until their domestic service sector becomes significantly competitive]

\footnotetext{
${ }^{2700}$ WTO, Groups in the WTO, updated 7 April 2017, available online at: https://www.wto.org/english/tratop_e/dda_e/negotiating_groups_e.pdf.

${ }^{2701}$ As compared with services, trade in goods has a longer history of negotiations starting from the GATT era and more attention by Members even currently, The example of cotton subsidies has been commented on extensively for the issues of how small African economies have attempted to negotiate but failed to have WTO law implemented in accordance with their interests. However, Brazil, a major competitor and large economy, managed to successfully challenge the United States in the US-Subsidies on Upland Cotton dispute (US-Upland Cotton). (See further Eagleton-Pierce, Matthew D., The Competing Kings of Cotton: (Re)framing the WTO African Cotton Initiative, New Political Economy 2012, 17:3, p313-337; Lee, Donna and Nicola J. Smith, The Political Economy of Small African States in the WTO, The Commonwealth Journal of International Affairs, 2008, Volume 97, Issue 395, p259-271).

${ }^{2702}$ WTO, News: WTO members review preferences granted to LDCs' service suppliers, Dedicated Session of the WTO Services Council, held on 29-30 October 2019, available online at:

https://www.wto.org/english/news_e/news19_e/serv_30oct19_e.htm.
} 
However, the last part of the sentence above (in brackets) was cut out of the Dunkel Draft of 1991(MTN.TNC/W/FA), which became in effect the basis for the eventual Agreement. ${ }^{2703}$ In a sense this has been partly revived by the 2004 Sutherland Report ${ }^{2704}$ recommendations, especially Paragraphs 306-310 of the Report which discusses WTO membership for LDC's with no-or-few-obligations and the principle of non-reciprocity (although still continuing to including "pressure" to move towards competitive trade regimes and stating that removing all obligations being a "mistake"). ${ }^{2705}$ But the importance of the Sutherland Report is that it advises that new agreements reached in the WTO should go beyond mere political commitments to contractual rights for funding, technical assistance, capacity building and aid for LDC's. Paragraph 27 of the Sutherland Report (in Principal Conclusions and Recommendations of the Consultative Board) repeats the recommendation that the concept of contractual rights should be included in the future. ${ }^{2706}$ However the current framework for special treatment for LDCs in the GATS does not have terminology that suggests an obligation to provide LDCs with assistance or a right for LDCs to be treated differently.

Article IV:3 read with Article XIX:3 of the GATS refers to LDCs separately from the larger category of developing members. However, it can be seen that whatever special treatment can be given is vague and the modalities need to be specified later.

Article IV:3

Special priority shall be given to the least-developed country Members in the implementation of paragraphs 1 and 2. Particular account shall be taken of the serious difficulty of the least-developed countries in accepting negotiated specific commitments in view of their special economic situation and their development, trade and financial needs [emphasis added]

Article XIX:3

Negotiating guidelines shall establish modalities for the treatment of liberalization undertaken autonomously by Members since previous

${ }^{2703}$ See also the Ministerial Decision on Measures in Favour of Least Developed Countries, adopted by the Trade Negotiations Committee on 15 August, 1993, para. 1 which included a general decision that LDCs:

... will only be required to undertake commitments and concessions to the extent consistent with their individual development, financial and trade needs, or their administrative and institutional capabilities.

This only granted LDCs an additional one year from 15 April 1994 to submit their schedules as required by Article XI of the WTO Agreement. There is no special reference to trade in services in this Ministerial Decision other than increasing technical assistance for services exports in Paragraph 2(v). But Paragraph 2(iii) mentions that all WTO rules must be applied in "a flexible and supportive manner" for the LDCs.

${ }^{2704}$ This is a WTO report chaired by former WTO Director-General Peter Sutherland, with the seven other members of the Consultative Board (four academics, three diplomats and one businessperson); Sutherland Peter et al. 2004, The Future of the WTO: Addressing Institutional Challenges in the New Millennium, Report of the Consultative Board to the Director-General Supachai Panitchpakdi, WTO, 2004, (The Sutherland Report).

2705 Sutherland Peter et al, The Future of the WTO: Addressing Institutional Challenges in the New Millennium, Report by the Consultative Board to the Director-General Supachai Panitchpakdi, WTO, 2004, (The Sutherland Report), available online at: http://www.wto.org/English/thewto_e/10anniv_e/future_wto_e.pdf. ${ }^{2706}$ Ibid., (Sutherland Report).

See further, South Center, Special and Differential Treatment Negotiations: State of Play and Proposed Language for WTO's MC8, Analytical Note SC/TDP/AN/MC8/2, November 2011. This paper summarizes the proposals submitted (Council for Trade in Services - Special Session, Proposals) for special and differential treatment in services in paras.14-16. 
negotiations, as well as for the special treatment for least-developed country Members under the provisions of paragraph 3 of Article IV.

The implementation of the LDC modalities has been discussed in the ministerial meetings and conferences, with various methods being suggested, including waiver mechanisms. Despite communications from LDCs to that effect, neither Article XIX:3 nor Article IV:3 of the GATS had been actually interpreted as providing for preferential market access to LDC services or service suppliers during the first 20 years of the WTO. ${ }^{2707}$ The 2011 LDC Services Waiver ${ }^{2708}$ was the first action that could be seen as giving effect to Art IV:3.

Article IV:7 of the WTO Agreement, the section on the structure of the WTO states that the Ministerial Conference shall establish a Committee on Trade and Development and that:

...As part of its functions, the Committee on Trade and Development shall periodically review the special provisions in the Multilateral Trade Agreements in favour of the least-developed country Members and report to the General Council for appropriate action.

Article IV:7 abovementioned also states that membership in the Committees included in that provision "shall be open to representatives of all Members". LDC Members have so far usually made their points of view through Communications and Declarations. Some of these have been noted by other WTO Declarations, for example, Paragraph 42 of the Doha Ministerial Declaration of November 2001, states that:

We acknowledge the seriousness of the concerns expressed by the leastdeveloped countries (LDCs) in the Zanzibar Declaration adopted by their ministers in July $2001 \ldots{ }^{2709}$

The Zanzibar Declaration was the result of a meeting of LDCs that focused on LDC interests in world trade and connected the Integrated Framework agreed upon at the Third UN Conference on LDCs held in May 2001, with the Doha Ministerial, and adding a number of agenda items for implementation in Doha. ${ }^{2710}$ In addition to the Zanzibar Declaration, a separate Declaration (WT/L/424) was issued by the G77 and China in Doha in October 2001, reiterating some of the same positions. Paragraph 7 of this Declaration called for the special and differential treatment provisions in WTO Agreements to be made "legally binding" and "enforceable" instead of remaining merely "best endeavour clauses". However, although the Doha Declaration notes the concerns of LDCs in 21 different paragraphs, the actual outcomes of Doha in terms of concrete changes in favour of LDCs have been described as not meeting "even a fraction of the expectation of the LDCs" 2711 and more expressively by a Third World Network Paper as

\footnotetext{
${ }^{2707}$ See e.g. comment by Delimatsis, P., Article XIX GATS in Wolfrum, Rudiger, Peter-Tobias Stoll and Clemens Feinaugle Eds., WTO - TRADE IN SERVICES, Max Planck Commentaries on World Trade Law, Martinus Nijhoff Publishers, 2008, p439.

${ }^{2708}$ WTO Doc. WT/L/847, Preferential Treatment to Services and Service Suppliers of LDCs Decision, 17 December 2011.

${ }^{2709}$ WTO, Doha Ministerial Declaration, WT/MIN(01)/DEC/1), November 2001.

${ }^{2710}$ Kennedy, Kevin, Special and Differential Treatment of Developing Countries in Macrory, Patrick, Arthur Appleton and Michael Plummer, THE WORLD TRADE ORGANIZATION: LEGAL, ECONOMIC AND POLITICAL ANALYSIS, VOL. II, Springer, 2005, p1562.

${ }^{2711}$ Adhikari, Ratnakar, LDCs in the Multilateral Trading System, in Macrory, Patrick, Arthur Appleton and Michael Plummer, THE WORLD TRADE ORGANIZATION: LEGAL, ECONOMIC AND POLITICAL ANALYSIS, VOL. II, Springer, 2005, p370.
} 
both a "grave affront" and a "slap in the face" for LDCs who had made "concrete and specific demands". ${ }^{2712}$

The focus in the WTO seems to be on LDC participation and liberalization. Even Paragraph 42 of the Doha Declaration abovementioned, includes this focus, stating that:

Accession of LDCs remains a priority for the Membership. We agree to work to facilitate and accelerate negotiations with acceding LDCs.

Paragraph 9 Doha Ministerial Declaration also notes that the WTO Membership will

... attach great importance to concluding accession proceedings as quickly as possible. In particular, we are committed to accelerating the accession of least-developed countries.

Thus, while enforceable pro-LDC measures were not considered a priority in Doha, the accession of LDC was considered a priority - an unfortunate focus on quantity of the membership over the quality of the WTO framework in terms of achieving development for all its Members. Furthermore, some studies have noted that the first LDC accessions in the early 2000s involved difficult conditions imposed by more powerful trading partners (mainly the United States), the lack of acknowledgement of the particular needs of LDCs by Working Parties on Accession and included waivers of transition periods which are allowed to LDCs. ${ }^{2713}$

It can be wondered what benefits the LDCs will gain through accession to the WTO and liberalization, without corresponding assistance and special treatment that is needed to support their development efforts. This is true for trade in goods, agriculture in particular, as for investment, intellectual property and services. Adhikari, citing the UNTAD LDC Report of 2000, notes that even at that time, LDCs had made serious efforts to liberalize, but it was "worrisome" that they were still "being marginalized from the system". ${ }^{2714}$ Presciently, it was also noted that the 2000s "may well become a decade of rhetoric and inaction" with regard to the WTO framework supporting development in LDCs. ${ }^{2715}$

Yet LDCs continued in their efforts to operationalize the special treatment and differential provisions and contributed six more LDC Group Declarations to the Doha Agenda, from the Dhaka Declaration (2003) to the Geneva Declaration (2011). Also of interest is the Framework Agreement on Special and Differential Treatment (WT/GC/W/442) and the Proposal by the LDCs in Doc.TN/CTD/W/4/Add.1 to add under Article IV.3, after the first sentence, another sentence on multilaterally agreed criteria for giving priority to LDC Members and their export interests when developing further disciplines and general

${ }^{2712}$ Hormeku, Tetteh, 'Clean text' for WTO Ministerial, dirty slap in face of Africans, Third World

Network, available online at http://www.twnside.org.sg/title/twr133g.htm, last accessed 12.06.2014.

2713 See further for discussion of particular LDC accession processes, Hawthorne, Helen, LEAST DEVELOPED COUNTRIES AND THE WTO: SPECIAL TREATMENT IN TRADE, Palgrave MacMillan, 2013, p78-83. Hawthorne includes case studies of the accession process of Vanuatu, Nepal, Cambodia, Cape Verde and Samoa, the first five LDCs to accede to the WTO.

Also note that such pressures appear to contradict the guideline in WTO Document WT/L/508, The Guidelines for Accession of Least-Developed Countries, 20 January 2003, that:

WTO Members shall exercise restraint in seeking concessions and commitments on trade in goods and services from acceding LDCs...

....as well as the guideline that all LDCs shall be granted special and differential treatment and transitional periods/arrangements "taking into account individual development, financial and trade needs".

${ }^{2714}$ Adhikari, Ratnakar, LDCs in the Multilateral Trading System, in Macrory, Patrick, Arthur Appleton and Michael Plummer, THE WORLD TRADE ORGANIZATION: LEGAL, ECONOMIC AND POLITICAL ANALYSIS, VOL. II, Springer, 2005, p344.

2715 Ibid., (Adhikari). 
obligations under the Agreement. Of these proposals, most have not yet resulted in concrete changes in process nor in additions or amendments to the text of the GATS, other than the LDC Services Waiver Decision of 2011 and the related Bali Decision to operationalize the Waiver in 2013 allows Members to grant preferential market access for LDC services and service suppliers by waiving the MFN obligation for this purpose. The idea for this waiver originated in the special priority for LDCs in Article IV of the GATS, and was first approved by the Council on Trade in Services in 2011. ${ }^{2716}$ There is still potential for progress in this area as the Doha Development Round negotiations have not been concluded as such. However, there does not seem to be agreement between Members on whether the round of negotiations will continue or not.

There were several attempts between Doha and Bali to encourage establishment and implementation of modalities for the special treatment of LDCs in the services negotiations. A Special Session of the Council for Trade in Services adopted the Modalities for Special treatment for LDCs in 2003, which require members to ensure maximum flexibility in negotiations and to provide effective market access in sectors and modes of supply of export interest to LDCs. ${ }^{2717}$ It was also stated in the 'Modalities' that Members should develop "appropriate mechanisms" to fully implement Article IV:3 and to facilitate the effective market access of LDC services and service suppliers to foreign markets. The Hong Kong Ministerial Declaration ${ }^{2718}$ reaffirmed the objectives of the GATS, the Doha Ministerial Declaration, the 2001 Guidelines and Procedures for the Negotiations on Trade in and the 2003 Modalities and the broad statements in favour of developing countries in Annex C of the "July Package"2719 of 2004. It was critiqued at the time that the Hong Kong Ministerial was "unending rhetoric" without actual implementation and that it confirmed the "comatose state" of development issues mandated in Doha. ${ }^{2720}$ But it was also commented that the positive aspect was the Doha Development Agenda and Round of negotiations kept moving forward, albeit very slowly. ${ }^{2721}$ In July 2008, Members came to a decision that the special treatment for LDCs for services could be implemented through a waiver and a series of consultations led to a draft legal text of a waiver in February 2010. ${ }^{2722}$

${ }^{2716}$ WTO Doc. WT/L/847, Preferential Treatment to Services and Service Suppliers of LDCs Decision, 17 December 2011.

2717 Council for Trade in Services, Special Session, Modalities for the Special Treatment for LeastDeveloped Country Members in the Negotiations on Trade in Services, TN/S/13, 3 September 2003.

2718 WTO, Doha Work Programme, Hong Kong, Ministerial Declaration, WT/MIN(05), adopted on 18 December 2005, paras.25-26, available one at:

https://www.wto.org/english/thewto_e/minist_e/min05_e/final_text_e.htm\#services:

Negotiations shall have regard to the size of economies of individual Members, both overall and in individual sectors. We recognize the particular economic situation of LDCs, including the difficulties they face, and acknowledge that they are not expected to undertake new commitments.

It was also noted at para.27 that during negotiations "particular attention will be given to sectors and modes of supply of export interest to developing countries".

2719 WTO, General Council Decision on the Post-Cancun Doha Agenda Work Programme (The 'July

Package'), WT/L/579, adopted 1 August 2004, available online at

https://www.wto.org/english/tratop e/dda e/draft text gc dg 31july04 e.htm\#annexc.

${ }_{2720}$ Muralidharan, S. Development Deficit Agenda of Doha Round, Economic and Political Weekly, 2005, 40(52), 5450-5453.

2721 Wilkinson, Rorden The WTO in Hong Kong: What it really means for the Doha Development Agenda, New Political Economy, 2006, Vol. 11, Issue 2.

${ }^{2722}$ WTO, Preferential Treatment to Services and Service Suppliers of Least-Developed Countries, Decision of 17 December 2011, WT/L/847. See also Council for Trade in Services, Special Session, Negotiations on Trade in Services, Report by the Chairman, Ambassador Fernando de Mateo, to the Trade 
A decision to implement the LDC waiver mechanism was adopted at the eighth WTO Ministerial Conference in December 2011, and allows Members to grant preferential treatment to service suppliers from LDC members contrary to the MFN obligation. ${ }^{2723}$ The important issues covered by this Waiver are:

1. Waives the MFN treatment obligation (preference can be given to LDCs)

2. Includes an LDC-specific enabling clause for services exports

3. Lasts for 15 years from the date of its adoption (until 11 December 2026)

4. Preferences can be granted immediately and unconditionally to services and service suppliers of services and service suppliers of all LDCs

5. The Waiver should not reduce the benefits of non-LDC members

However, no Member made use of this text and thus an official Decision to 'operationalize' it so that it can be effectively used was made in the next Ministerial Conference in Bali in 2013. ${ }^{2724}$ The Bali decision in 2013 to operationalize the LDC Waiver of 2011 has generally had positive feedback. It can be noted that after the 2013 operationalization of the waiver decision, certain commitments were made by developed Members, including offers concerning preferential access for short term training of services professionals from LDCs. ${ }^{2725}$ In the WTO Annual Report 2016 it is noted that 22 WTO members have submitted notifications granting preferences to LDC services and service suppliers. ${ }^{2726}$ In 2019, it was reported at the dedicated session of the WTO Services Council that 51 WTO Members have notified preferences under the Services Waiver and that number included both developed and developing countries. ${ }^{2727}$

The Waiver has been lauded as a success story for LDCs. But rather than a legally enforceable obligation, much of its implementation still remain dependent on political commitments. WTO members in a position to do so were encouraged at Bali to operationalize the waiver both at Bali and subsequent meetings and Ministerial Conferences. The Waiver was originally to expire in 2026, that is, 15 years from its adoption on 17 December 2011, but it was extended at the WTO Ministerial Conference in Nairobi in December 2015, to be applicable until 2030.

Other than services, relevant mechanisms discussed and adopted at the Bali Ministerial include a monitoring mechanism to review the implementation of all special and differential treatment provisions across all the WTO agreements and duty-free, quota-free

\footnotetext{
Negotiations Committee for the purpose of the TNC stocktaking exercise, TN/S/35, 22 March 2010, paras.16-17.

${ }^{2723}$ See WTO, Negotiations on implementation of LDC modalities, available online at: http://www.wto.org/english/tratop_e/serv_e/ldc_mods_negs_e.htm.

${ }^{2724}$ WTO, Bali Ministerial Decision, Operationalization of the Waiver Concerning Preferential Treatment to Services and Service Suppliers of Least-Developed Countries, WT/MIN(13)/43 - WT/L/918, 11 December 2013. See also WTO, Bali Ministerial Decision, Preferential Rules of Origin for LeastDeveloped Countries, WT/MIN(13)/42, WT/L/917, of 7 December 2013.

2725 See e.g. European Commission, EU offer least developed countries preferential market access for services, High Level Meeting, Geneva, 5 February 2015, available online at: http://Trade.Ec.Europa.Eu/Doclib/Press/Index.Cfm?Id=1256.

${ }^{2726}$ WTO, ANNUAL REPORT 2016, p120-121.

${ }^{2727}$ WTO, News: WTO members review preferences granted to LDCs' service suppliers, Dedicated Session of the WTO Services Council, held on 29-30 October 2019, https://www.wto.org/english/news_e/ news19_e/serv_30oct19_e.htm.
} 
market access for LDCs. ${ }^{2728}$ While services subsidies were not discussed in depth, either at that point or in subsequent years, there was some effort made at Bali to get the ball rolling on the controversial area of cotton subsidies. While the operationalization of the Waiver Decision in Bali and its extension in Nairobi are usually considered unalloyed successes from LDC points of view, the entirety of the developments in this period are more complex and have been thoughtfully analyzed and critiqued in terms of expected outcomes for both developing countries and LDCs. ${ }^{2729}$

In addition to the above Declarations and Proposals, LDCs have also formed core groups and focal points or spokesperson Members on issues that are of concern to them. ${ }^{2730}$ Of the latter, two are particularly relevant for services. The first is the role of Zambia, which as the coordinator and chair of a group of 50 LDCs, has made submissions on behalf of the group on modalities for special treatment with regard to trade in services. ${ }^{2731}$ The second is the role of Bangladesh, which is also a focal point Member for LDC services. After the Bali Ministerial, current WTO Director-General Roberto Azevedo noted the important role taken by Bangladesh in Bali, being the largest economy and largest importer among the LDCs. ${ }^{2732}$

The flexibilities for negotiations which available under Article XIX of the GATS, as discussed above for developing countries, apply to LDC as well - but there may be additional space for LDCs. Article XIX:3 of the GATS states that:

Negotiating guidelines shall establish modalities for the treatment of liberalization undertaken autonomously by Members since previous negotiations, as well as for the special treatment for least-developed country Members under the provisions of paragraph 3 of Article IV [emphasis added].

Despite the pressure or incentives for Members for autonomous liberalization discussed earlier, it can be argued that the Modalities for Autonomous Liberalization (TN/S/6)

\footnotetext{
${ }^{2728}$ WTO, Ministerial Decision, Monitoring Mechanism on Special and Differential Treatment, Ministerial Decision, 7 December 2013, WT/MIN(13)/44, WT/L/920; WTO, Ministerial Decision, Duty-Free and Quota-Free (DFQF) Market Access for Least-Developed Countries, Ministerial Decision, 7 December 2013, WT/MIN(13)/44, WT/L/919.

${ }^{2729}$ See Hoekman, Bernard, The Bali Trade Facilitation Agreement and rulemaking in the WTO: milestone, mistake or mirage? (2014); Narlikar, Amrita, and Shishir Priyadarshi, Empowering the poor? The successes and limitations of the Bali Package for the LDCs, Third World Quarterly 35.6 (2014): 1051-1065; Bellmann, Christophe, The Bali Agreement: Implications for development and the WTO, International Development Policy/Revue internationale de politique de dévelopement, 5.2 (2014); Wilkinson, Rorden, Erin Hannah, and James Scott, The WTO in Bali: What MC9 means for the Doha Development Agenda and why it matters, Third World Quarterly 35.6 (2014): 1032-1050; Wilkinson, Rorden, Erin Hannah, and James Scott, The WTO in Nairobi: the demise of the Doha Development Agenda and the future of the multilateral trading system, Global policy 7.2 (2016): 247-255.

2730 See Hawthorne, Helen, LEAST DEVELOPED COUNTRIES AND THE WTO: SPECIAL TREATMENT IN TRADE, Palgrave MacMillan, 2013, p64 for a full list of core groups and focal point Members.

${ }^{2731}$ WTO documents: LDC Group Request on Mode 4, JOB(06)/155, 24 May 2006; Implementation of the Modalities for the Special treatment for LDC Members in Trade in Services Negotiations, JOB(05)/114, 17 June 2005; Draft Modalities for the Special Treatment for LDC Members in the Negotiations on Trade in Services, JOB(02)/205, 6 December 2002; Draft Modalities for the Special treatment for LDC members in the Negotiations on Trade in Services, Communication from the LDC Group, T/NS/W/13, 7 May 2003; Communication from the Republic of Zambia on behalf of the LDC Group, A Mechanism to Operationalize Article IV:3 of the GATS, TN/S/W/59, 28 March 2006.

${ }^{2732}$ WTO NEWS, Speeches-DG Roberto Azevedo: Azevêdo underlines leadership role of Bangladesh in post-Bali work, 3 June 2014, available online at http://www.wto.org/english/news_e/spra_e/spra21_e.htm
} 
discussed above, read with the Modalities for LDC's (TN/S/13) of 2003 call upon Members to refrain from requesting for autonomous liberalization from LDCs or requesting for credit from them, although LDCs may be given credit for doing so. The relevant paragraphs are as follows:

$\mathrm{TN} / \mathrm{S} / 6$, para.14:

In the application of these modalities, and in recognizing and granting credit pursuant to these modalities, Members shall take fully into account the flexibility provided for individual developing country Members [under the Preamble, Article IV, and Article XIX:2 of the GATS, and in line with paragraph 2 of the Doha Ministerial Declaration], as well as the level of development of developing country Members in relation to other Members. Special consideration shall be given to the least-developed country Members.

$\mathrm{TN} / \mathrm{S} / 13$, para.5:

LDCs shall not be expected ...to undertake additional commitments under Article XVIII of the GATS on regulatory issues which may go beyond their institutional, regulatory, and administrative capacities

$\mathrm{TN} / \mathrm{S} / 13$, para.10:

LDCs shall be granted appropriate credit for their autonomous trade liberalization. In addition, Members shall refrain from requesting credits from LDCs. ${ }^{2733}$

Paragraph 3 of the TN/S/13 also calls for "maximum flexibility for LDCs" and Paragraph 4 states the Members "shall exercise restraint in seeking commitments from LDCs". Paragraph 5 also notes that "LDCs shall not be expected to offer full national treatment" or to undertake additional commitments under Article XVIII of the GATS. Paragraphs 6-9 call upon Members to implement the special provisions for LDCs in Article IV and XIX of the GATS. Paragraph 11 states that specific interests and difficulties of LDCs shall be taken into account in developing any multilateral rules and disciplines (Articles VI:4 (Domestic regulation), X (Emergency safeguard measures), XIII (Government procurement) and XV (Subsidies) of the GATS).

However, one of the most recent UN DESA reports states that, other than some progress on matter of technical assistance and contact points provisions of Article XXV:1 and 2 and Article IV:2 of the GATS, none of these other measures can be said to have been operationalized and that the WTO Secretariat has not been notified of any commitments that have been made pursuant to Article IV:1 or these Modalities. ${ }^{2734}$ With regard to technical assistance for services, a DESA survey of LDC Members revealed that most of the assistance they had received was from multilateral or regional organizations and not bilaterally from their trading partners. Trading partners as such may not necessarily want to see increased capacity and competitiveness from the weakest trading nations, but when acting in their role as members of multilateral and regional organizations they may be more likely to set aside funding for technical assistance in order to carry out the mandate of such organizations. With regard to technical cooperation in telecommunication

2733 WTO Doc. TN/S/13, Modalities for the Special Treatment tor Least-Developed Country Members in the Negotiations on Trade in Services, adopted by the special session of the Council for Trade in Services, 3 September 2003.

${ }^{2734}$ UN DESA, Trade-related International Support Measures (ISMs) for Least Developed Countries (LDCs): Background document for stakeholder workshops in the Gambia and Uganda January 2014, (REV 1) UN DESA, available online at http://esango.un.org/ldcportal/documents/10179/127657/Trade-related\% 20ISMs\%20for\% 20LDCs_Overview_DRAFT.pdf. 
services, ${ }^{2735}$ other developing countries were mentioned in the DESA survey as a main source of assistance, and not developed countries (responses of Uganda, Chad, Madagascar, Mali).

It was also noted in the 2012 Report to the Secretary-General of the UN on the Programme for Action for LDCs, that there was declining official development assistance in the wake of the financial crisis in Europe, but that while net bilateral aid had decreased, overall net aid to LDC's increased in the same period, as had the role played by countries such as Brazil, China, South Africa and Turkey, and private foundations and philanthropists. ${ }^{2736}$ This Report also notes that the biennial technical assistance plans, the Enhanced Integrated Framework ${ }^{2737}$ and the Standards and Trade Development Facility (for SPS capacity building) ${ }^{2738}$ of the WTO had some tangible results and benefits for LDCs. ${ }^{2739}$ The 2016 Review of the Programme for Action for LDCs welcomed the extension of the Enhanced Integrated Framework for trade-related technical assistance to LDCs. ${ }^{2740}$ While the main Review did not focus on WTO obligations for technical and other assistance to LDCs, and health services were not mentioned except in the context of gender and reproductive rights; the Declaration of the civil society forum at the review meeting stated that formulation and implementation of effective policies on the "right to health" had become a development priority for LDCs. ${ }^{2741}$ Furthermore, the civil society forum highlighted that in the context of the WTO, special and differential treatment, policy flexibility for LDCs and the Bali package need to be made operational, while urging "regional cooperation, South-South cooperation and North-South cooperation". 2742

Perhaps the perception of insufficient technical assistance and consideration of developing country or LDCs status during bilateral negotiations can have a positive outcome of guiding LDCs towards more South-South trade cooperation, in place of the dependency on developed country assistance. The positive aspects are of course to be balanced by the fact that the assistance to other developing countries and LDCs from e.g. India, China and Arab countries, while still being South-South co-operation, may come alongside self-interest of donors and political and economic power imbalances and

${ }^{2735}$ According to the GATS Annex on Telecommunications, paragraph 6(d):

$M$ embers shall give special consideration to opportunities for the least-developed countries to encourage foreign suppliers of telecommunications services to assist in the transfer of technology, training and other activities that support the development of their telecommunications infrastructure and expansion of their telecommunications services trade.

${ }^{2736}$ UN GA-ECOSOC, Report of the Secretary-General Implementation of the Programme of Action for the Least Developed Countries for the Decade 2011 to 2020 (Istanbul Programme of Action), ECOSOC Sixtyseventh session, New York 2-27 July 2012, A/67/88-E/2012/75, 17 May 2012, para.5 and 44.

2737 This was originally established in 1997, at the High-Level Meeting on LDCs' Trade Development held at the WTO and has since been extended in 2006 and 2016. The EIF is partnered with the IMF, UNCTAD, UNDP, the World Bank and the International Trade Centre (ITC). See further: www.enhancedid.org.

2738 "The STDF grew out of a joint communiqué issued by the Heads of FAO, OIE, World Bank, WHO and WTO at the Doha Ministerial Conference in November 2001" (http://www.standardsfacility.org/history)

${ }^{2739}$ UN GA-ECOSOC, Report of the Secretary-General Implementation of the Programme of Action for the Least Developed Countries for the Decade 2011 to 2020 (Istanbul Programme of Action), ECOSOC Sixtyseventh session, New York 2-27 July 2012, A/67/88-E/2012/75, 17 May 2012, paras.81-83.

2740 UN GA, Report on the Comprehensive High-level Midterm Review of the Implementation of the Istanbul Programme of Action for the Least Developed Countries for the Decade 2011-2020, Antalya, Turkey, 27-29 May 2016, A/CONF.228/3, 13 July 2016, para.62.

${ }^{2741}$ Ibid, Annex III: Antalya declaration of the least developed country civil society forum, para. 7 .

${ }^{2742}$ Ibid, Annex III: Antalya declaration of the least developed country civil society forum, paras. 8 and 15 . 
tensions. But when considering South-South cooperation, it may also be seen as more suitable to increase trade with other developing countries, who might more clearly understand that:

The importance of trade in services for LDCs goes beyond pure economic significance due to the major role services play for achieving social and development objectives and as a means of addressing poverty, upgrading welfare, improving universal availability and access to basic services, and in ensuring sustainable development, including its social dimension... ${ }^{2743}$

A brighter future for LDC development cooperation may be found by turning to developing countries and learning from their experiences with poverty alleviation, improving services for the poor and gaining higher HDI, particularly in health and education indicators - all on simpler development models and perhaps also with less cost. The 2016 Report of the UN High-level Committee on South-South Cooperation commented that South-South co-operation had become a driver of development and solidarity, which was visible in a number of areas including health services and procurement of essential medicines for the public health sector, where best practices were being shared and new initiatives were being encouraged. ${ }^{2744}$

Economic models which were promoted at one time, such as user fees for primary and secondary education and drinking water, costly and complicated mechanisms for health insurance etc., have already seen falling standards of living in developing and LDC countries and counter-efforts have been taken to eliminate fees and follow public services models instead. ${ }^{2745}$ The mechanisms that LDCs should look at are those that have assisted developing countries to make significant gains in both HDI and GDP per capita. Public services have clearly played an important part in this, as well as the supportive role of private enterprise. It is up to each country to find the optimum balance of public and private investment, infrastructure, manufacturing and service supply that would best suit its own development trajectory.

Scott and Wilkinson have also commented that in the last decade or so there has more prominence of trade intellectuals and organizations such as South Centre, Focus on the Global South and Third World Network who are:

...either sympathetic with the broad plight of developing countries or else organically connected with Southern states... [both disseminating and] producing its own Southern-focused analyses of and commentary on trade issues. $^{2746}$

2743 WTO Doc. TN/S/13, Modalities for the Special Treatment tor Least-Developed Country Members in the Negotiations on Trade in Services, adopted by the special session of the Council for Trade in Services, 3 September 2003, para.2.

${ }^{2744}$ UN GA, Report of the High-level Committee on South-South Cooperation, Nineteenth session, 16-19 May 2016, A/71/39, paras.25, 42 and 44 (https://documents-dds ny.un.org/doc/UNDOC/GEN/N16/161/76/PDF/N1616176.pdf?OpenElement.)

2745 See Bentaouet Kattan, R. and N. Burnett, User Fees in Primary Education, World Bank, 2004, p9, recommending that "Where user fees for basic education are in place, governments should be encouraged to take deliberate steps to replace them with adequate public funding...”. The example of Tanzania's efforts to achieve the Millennium Development Goals for literacy by reversing user fees for education is mentioned in this publication as well as the dramatic reduction of tuberculosis cases after China implemented the WHO recommendation of eliminating user fees for tuberculosis treatment (see p29 and p30).

${ }^{2746}$ Scott, James and Rorden Wilkinson, Changing of the Guard: expert knowledge and 'common sense' in the Doha Development Agenda, BWPI Working Paper 166, Brooks World Poverty Institute, 2012, p14. See also Scott, James and Wilkinson, Rorden, The Poverty of the Doha Round and the Least Developed Countries, Third World Quarterly, 32(4), May 2011. 
Thus, there is now more credible commentary and analysis that runs counter to the 'orthodox' approaches to trade policy than there was in the years before 1995. Such commentary may suggest different models of policy-making and cooperation for the future. Andrew Lang has noted how various social actors and activists in both the North and South have challenged the trade regime using human rights to "contest economic liberalism". ${ }^{2747}$ Steger, noting the changes in the current WTO, as compared with the old GATT system - the transformation in geo-politics and power from the bi-polar US-EUdriven system to the emerging role of BRICS and the vast majority of the WTO membership being developing countries - suggests that the WTO needs "major surgery" (institutional reform) in order to become responsive to modern needs. ${ }^{2748}$ This transformation needs to be driven by the membership of the organization using trade as a tool for development, not merely by the needs of one or two Members wishing to maintain their trade hegemony. More South-South trade cooperation and a greater role by BRICS, developing country groups and LDC groups working for common development goals may hold promise in this context.

2747 Lang, Andrew, WORLD TRADE LAW AFTER NEOLIBERALISM. RE-IMAGINING THE GLOBAL ECONOMIC ORDER, Oxford University Press, 2011, p83. Also see Alessandrini, Donatella, Developing Countries and the Multilateral Trade Regime: The Failure and Promise of the WTO's Development Mission, 3 Trade Law \& Development, 2011, p242.

2748 Steger, Debra P., The Culture of the WTO: Why It Needs to Change, Journal of International Economic Law 2007, 10(3):483-495. 


\subsection{THE ROLE OF SUBSIDIES IN DEVELOPMENT PROGRAMMES}

A brief reiteration of the importance of the topic of subsidies is required when discussing the possible additional policy space for developing and LDC Members. The negotiating mandate for subsidies under Article XV of the GATS was discussed in more detail in Chapter 3 of this study, but for the purposes of this section, attention is drawn to the mention of developing country Members:

Article XV: 1 of the GATS

...Such negotiations shall recognize the role of subsidies in relation to the development programmes of developing countries and take into account the needs of Members, particularly developing country Members, for flexibility in this area...

A draft checklist on possible rules for services subsidies was circulated on 17 March 2003. This Checklist $(\mathrm{JOB}(03) / 57)$, which was also mentioned earlier in Chapter 2, acknowledges:

...the role of subsidies in relation to development, and the needs of developing country Members for flexibility, including special and differential treatment. ${ }^{2749}$

But there is nothing to suggest how this obligation to "take into account" the developing country need for flexibility is to be implemented in the GATS. Another relevant document from September 2003, the Modalities for Special treatment for LDCs (TN/S/13), requires members developing multilateral rules and disciplines under Article $\mathrm{XV}$ to take into account the specific interests and difficulties of LDCs. ${ }^{2750}$ These documents can be seen as encouragement for accepting developing country proposals for more flexibility and policy space during subsidies negotiations. It remains possible to submit proposals for a specific special and differential treatment regime in the future service subsidies agreement.

The Report of the High Commissioner on Human Rights on liberalization of trade in services and human rights connected the right to regulate recognized in both the Preamble of the GATS and in Article 2(3) of the Declaration on the Right to Development with subsidies, stating that subsidies and the obligation to provide universal services, are important forms of governmental regulation in the services sector. ${ }^{2751}$ A human rights approach to the right to regulate regarding subsidies would clarify that the State obligation in this regard in the Declaration on the Right to Development is described as both a right and a duty to regulate for the wellbeing of populations and individuals. Furthermore, the Report of the High Commissioner also notes that if the application of the WTO principle of non-discrimination would have the effect of denying developing countries from "using development tools such as subsidies" (including crosssubsidization) and if this in turn impacts negatively on policies "guaranteed to ensure universal service supply" by causing reduction in quality and quantity and/or raises prices

\footnotetext{
2749 WTO, Note from the Chairperson of Working Party on GATS Rules, Checklist on Subsidies, Negotiations on Subsidies (Article XV of the GATS), JOB(03)/57 17 March 2003.

2750 Council for Trade in Services, Special Session, Modalities for the Special Treatment for LeastDeveloped Country Members in the Negotiations on Trade in Services, TN/S/13, 3 September 2003, para.11. This paragraph also included LDC interests in negotiations under Articles VI:4 (Domestic regulation), X (Emergency safeguard measures), XIII (Government procurement).

${ }^{2751} \mathrm{UN}, \mathrm{OHCHR}$, Liberalization of Trade and Human Rights: Report of the High Commissioner of Human Rights, E/CN.4/Sub.2/2002/9, June 25 2002, para.55.
} 
of services for the poor, this could be considered de facto discrimination under human rights law. ${ }^{2752}$

The High Commissioner on Human Rights has welcomed the specific reference to the needs of developing countries in Article XV of the GATS and has encouraged all WTO Members to acknowledge the connected human rights responsibility of all States. ${ }^{2753}$ With regard to the development, interpretation and application of the concepts of 'tradedistortion' and 'trade restriction', it has been suggested that rules or 'tests' should be developed which acknowledge and protect States' duties concerning human rights in determining or assessing whether or not a measure is trade-distortive or trade restrictive. ${ }^{2754}$ It is also possible to take a different approach by developing and introducing exceptions to the general rules on subsidies in this regard, during the subsidies negotiations. Such exceptions could allow measures that are trade distortive or restrictive, if the measure in question is for the protection of human rights, in particular, universal service supply, accessibility, quality, quantity, affordability of essential services, including healthcare.

The UNDP study "Making Global Trade Work for People" notes that subsidies were essential for countries to gain rapid economic growth; and that in the case of the "Asian Tigers' even helped them "move well beyond the limits of comparative advantage". ${ }^{2755}$ It has been suggested that awareness of this experience could lead to some developing countries opting not to object to the subsidies programmes of other developing countries. Keck and Low state that some developing countries have proposed full flexibility in applying subsidies and expansion of the range of non-actionable specific subsidies seemingly "unconcerned about subsidy competition among themselves" and the "general wisdom" that subsidies can cause distortions that are harmful to the economy and to development. ${ }^{2756}$

Even if a future Subsidies Agreement on Services comes into being with special and differential treatment for developing countries, taking into account their development programmes and the protection of important public services, this would not be the end of the story. In practice, it is not always possible for developing countries to benefit from the special and differential treatment in trade agreements. The UNDP study "Making Global Trade Work for People" also noted that despite the flexibilities made available for developing countries and LDCs through the SCM Agreement, international financial institutions had often prevented their use through conditions in loans to eliminate subsidies, including those not covered by the SCM Agreement. The UNDP study termed this policy of taking away with one hand what was given by the other, as a "lack of coherence in global economic policy making". ${ }^{2757}$ But it can be also questioned whether this was truly unintentional and whether negotiators on subsidies in the trade in services context would also feel free to allow for policy space in one Agreement, that would be

\footnotetext{
2752 Ibid., (OHCHR), para.61.

2753 Ibid., para. 62.

2754 Ibid., paras. 62 and 71.

${ }^{2755}$ UNDP, MAKING GLOBAL TRADE WORK FOR PEOPLE, UNDP and Earthscan, 2003, p.197 and Box 10.1.

${ }^{2756}$ Keck, Alexander and Patrick Low, Special and Differential Treatment in the WTO: Why, When and How? Economic Research and Statistics Division Staff Working Paper, ERSD-2004-03, WTO, May, 2004, p.18.

${ }^{2757}$ UNDP, MAKING GLOBAL TRADE WORK FOR PEOPLE, UNDP and Earthscan, 2003, p197-198.
} 
denied in other ways. These other ways could include RTAs and BITs as well as loan conditionalities placed by international financial institutions.

Taken in light of the approaches linking trade liberalization and human rights, such measures of economic liberalization could be interpreted as violations of human rights. It is States that have the ultimate responsibility to protect and enforce international human rights obligations, and some States are also seen as driving forces behind international trade and financial institutions. Yet behind the actions or inaction of States is the action or inaction of individuals who carry out specific functions. Awareness of both international trade and international human rights obligations may assist such individuals to have a more balanced approach in the WTO context in matters such as subsidies and to understand, interpret and translate the 'two languages' in the ways discussed in Chapter 2 of this study. 


\subsection{CONCLUSIONS ON CHAPTER 6}

'Oh, don't talk about trouble!' said the Duchess.

'I make you a present of everything I've said as yet.'

'A cheap sort of present!' thought Alice.

'I'm glad they don't give birthday presents like that!'

But she did not venture to say it out loud.

\section{From Lewis Carroll's Alice in Wonderland}

In looking at the possibility of extra policy space for developing country and LDC Members, this Chapter has taken the approach of first assessing the concepts of developing country and LDC status as an access gateway to the possible special treatment provisions of the GATS. Secondly, the extent to which the available recitals and provisions that mention developing or LDC Member's interests actually focus on the needs of development have been assessed.

Some of the apparent benefits and flexibilities in the GATS are open to both developing countries and LDCs and some only to LDCs. The definition of LDCs is fairly clear and stable, but 'developing country' has no fixed definition. The issue of definition raises problematic issues with regard to the application of 'extra' benefits and well as to the nature and assessment of 'development' as compared with growth, and of equitable development both within Member jurisdictions and between WTO Members. These latter concepts were also discussed more broadly earlier in Chapter 2, and this Chapter links with those concepts, with special reference to developing country provisions in the GATS.

The Preamble of the GATS could be used to support policy space and flexibility with regard to all the provisions of the GATS, but there is also special reference to developing country and LDC Members in the Preamble. If there is actually only one path of trade liberalization for development of all WTO Members, then all WTO Members should have no problem with identical liberalization strategies and policies for trade in services. The acknowledgement of different needs of developing country and LDC Members with regard to national policy on services suggests that there are valid needs and justifiable reasons for alternate policy choices. However, these recitals and provisions acknowledging such needs for national policy for development do not, by themselves, easily transform into enforceable legal protections or obligations.

It appears from the analysis in this Chapter, that for the GATS, all the recitals and special provisions for developing countries and LDCs either return to the basic issue of negotiation of commitments and the power imbalances therein; or depend on the benevolence of developed countries, other developing countries and the Organization itself for improving access to information, as well as for guidelines for technical assistance for LDC's. ${ }^{2758}$ Overall, the application of the available recitals and provisions for the expansion of policy space for developing country and LDC Members appears to be unsatisfactory, and it is doubtful whether such Members in fact have, on the basis of

${ }^{2758}$ Note that the general idea of the WTO framework is that which was also stated by the Appellate Body Report, EC-Bananas III, para 154: "A Member may yield rights and grant benefits but it cannot diminish its obligations". 
these provisions alone, more policy space to take into account their development status and needs. There are meager opportunities for the recitals supporting developing country policy choice to be used to expand policy space. However, it can still be hoped that the preambular language may be used to balance liberalization and development needs. One positive example is the operationalization of the LDC Waiver; where the objectives of the preamble were used repeatedly over time at successive WTO Ministerial Conference and meetings to build up a series of decisions leading to more concrete implementation of special and differential treatment for LDCs.

The issue of extra policy space can be tackled both on a level of searching for mechanisms for promoting such space, as well as at the conceptual level of supporting the necessity for it. After the launch of the Doha 'Development' Round, the Doha Implementation Decision established through Paragraph 12.1, a work programme on special and differential treatment, which was also endorsed by Paragraph 44 of the Doha Ministerial Declaration. Paragraph 44 of the Doha Ministerial Declaration states that Members agreed that:

... all special and differential treatment provisions shall be reviewed with a view to strengthening them and making them more precise, effective and operational.

Macrory and Stephenson have suggested that there should be a reference paper on special and differential treatment for developing country and LDC Members, which would be binding on developed country Members who chose to adopt it, much like the Telecommunications Reference Paper. ${ }^{2759}$ The nature of such a reference paper and the sufficient 'moral persuasion' on Members to adopt such obligations is a matter for speculation. If ever such a document is drafted with intention to become a part of the GATS, it is possible to think that it may be limited to LDCs or, that it's application would be left as an optional, political decision of the developed country Members. Even the LDC Waiver Decision merely persuades other Members to give preferential treatment and does not grant legal rights to LDCs to demand such an outcome or to enforce it. It is also possible that preferential schemes do not deliver the expected results for developing country and LDC Members, due to a range of other factors, and that looking at such schemes in order to achieve long-term 'sustainable development' may be a case of looking for the right thing in the wrong place. ${ }^{2760}$

\footnotetext{
${ }^{2759}$ Macrory, Patrick F.J. and Sherry Stephenson, MAKING TRADE IN SERVICES SUPPORTIVE OF DEVELOPMENT IN COMMONWELATH SMALL AND LOW-INCOME COUNTRIES, Economic Paper Vol. 93, Commonwealth Secretariat, 2011, p42-43.

${ }^{2760}$ For example Keck, Alexander, Special and Differential Treatment in the WTO: What, When and How?, Staff Working Paper ERSD-2004-03, May 2004, p13-14 (citing Brenton, P. Integrating the Least Developed Countries into the World Trading System: The Current Impact of EU Preferences under Everything But Arms, World Bank Policy Research Working Paper 3018, 2003, World Bank) states that during 2001, when the European 'Everything But Arms' preferential access system was applied for LDCs, there was actually a fall in export values to the EU for the majority of LDCs. This was supposedly due to declining prices for primary exports that could not be compensated for in increased quantity of exports to the EU.

See further, Alessandrini, Donatella, DEVELOPING COUNRIES AND THE MULTILATERAL TRADING REGIMES: THE FAILURE AND PROMISE OF THE WTO'S DEVELOPMENT ROUND, Hart Publishing, 2010, p3; commenting that the failure of the development enterprise dating from GATT 1947 , is related to two assumptions - one more generally concerning the nature of the relationship between trade liberalization and development and the other assumption being that market access for developing countries in developed countries will solve global imbalances and deliver development.
} 
It is also important that any new mechanisms do not set up a framework of dependence on developed country 'hand-outs' or 'handicap cards' - but empower and incentivize developing countries' national policy-making. If developing country or LDC Members want to develop their public health services, it is not advisable that the system become too dependent on international aid, but that the Member itself develops the sector through long term strategic planning for infrastructure and human resources and sustained budgetary choices and allocations that develop an effective and sustainable national health policy.

To apply a metaphor for the above from the arena of sports (limited-over/one-day international (ODI) cricket in particular), developing countries must have the space to develop their own strategies for winning the game. In 1996, when Sri Lanka first made it to the final of the cricket World Cup, the team had not followed the standard path to the final. They had introduced an entirely new method of using an explosive opening pair of batsmen to attack the bowling in the first fifteen overs of the game (instead of the traditional sedate beginnings) and had used the opening fast bowlers to limit the opponents run rate and relied on spinners to take wickets instead of vice versa. When the Captain of the Sri Lankan team won the toss in the final, expert commentators were horrified when he opted to 'chase' instead of batting first. No team had ever won a Cricket World Cup final by chasing, and here the Captain had chosen to chase. However, the Sri Lankan team had correctly assessed the pitch and outfield, the strengths of the team members and the weak points of the opposition. Contrary to the expectations of most cricket experts, Sri Lanka, clearly an underdog and a team that had never even proceeded beyond Group 1 and only won 4 matches in 5 World Cup tournaments, won a resounding victory at the 1996 World Cup final, crowning an unbeaten series of 8 straight wins in the tournament. Following this victory, Sri Lanka went on to achieve cricket world records for the highest team totals in all three forms of the game (Test Cricket, ODI and Twenty20) as well as a number of world records for partnerships and individual performances.

The strategies used by the 1996 Sri Lanka World Cup team changed Sri Lanka's cricketing fortunes and the ODI format forever, leading to the adoption of the same strategies by other teams and ultimately influencing the creation of new rules to accommodate and develop such strategies even further. The cricket example proves that strategies for success can be based on innovative alternative measures and the adaptation of one's own strengths in the space available to innovate. The ability and choice to take such alternative action revolutionized the game and even led to a new feature of the game and new rules in the form of 'power plays' that restrict the fielders and encourage 'big hitting'. Similarly, developing countries in the context of international trade need the space to take innovative measures, and perhaps even to change the features and rules of the international trade game so that those innovative measures may have a chance to become the accepted new form of the game, with the new rules created to encourage such measures, rather than to make them prohibited tactics.

Without an overall ethos of respect for possible alternate paths to development taken by developing countries, any addition or amendment to the GATS will only bring another host of difficulties in interpretation and application. Moreover, although developing countries have special development challenges, the respect for national policy and the application of space and flexibility as a balancing mechanism to counter any flaws in trade liberalization are issues that are relevant for all Members, and ought not to be 
tackled only for and by developing countries. It remains necessary, as Dani Rodrik has said, that:

...in trade, developing nations should push to enshrine the notion of "policy space" in the constitution of the WTO. The goal would be to ensure that developing countries can employ the kind of trade and industrial policies needed to restructure and diversify their economies and set the stage for economic growth... ${ }^{2761}$

But it must be made clear that this reform or reinterpretation of WTO law is not an antitrade or anti-developed country agenda. In fact, such changes may actually assist the global trading regime and make it more relevant to economic and social development across the world, and developed countries should be allies with developing countries if such an endeavour is to be seriously undertaken. As Rodrik commented further:

Developing nations should argue that recognizing these economic and political realities makes the global trade regime not weaker and more susceptible to protectionism, but healthier and more sustainable. ${ }^{2762}$

Unfortunately, it seems that the WTO system has not fully embraced this idea of development within its system and is more in line with neo-liberal ideas on the necessity of limitations on the ability of governments to take measures in relation to trade and economic policy.

${ }^{2761}$ Rodrik, Dani, Let Developing Nations Rule, Project Syndicate, 2008 available online at www.projectsyndicate.org/commentary/rodrik26/English, last accessed 10.08.2013. Rodrik is Professor of International Political Economy at the John F. Kennedy School of Government, Harvard University.

2762 Ibid. 


\section{CHAPTER 7}

\section{CONCLUSIONS}

'Thinking again?' the Duchess asked, with another dig of her sharp little chin.

'I've a right to think,' said Alice sharply, for she was beginning to feel a little worried.

From Lewis Carroll's Alice in Wonderland 
Chapter 7 


\section{CHAPTER 7}

\section{CONCLUSIONS}

The GATS has been described as allowing for national policy space and policy flexibility. If this is true, then important societal values can be protected by WTO Members, without having to face negative consequences for violating the GATS. However, there are serious doubts concerning this assertion that policy space is protected, which appears to have had a 'chilling effect' on the aims of the GATS to increase active participation in the liberalization processes by making and expanding commitments in services and developing new services disciplines. It may also have had a restricting effect on national policy-makers in areas such as protection and expansion of public health services, but the latter is something that is difficult to assess and needs far more research into health policy formulation and implementation in countries across the world.

It can be more helpful to discuss the rules and the flexibility or policy space that may be retained with reference to specific issues valued by Members and the consequences from the view of individual persons who live within such Members' jurisdictions, than to discuss the matter in the abstract. This research was prompted by concern for the retention of policy space for WTO Members to protect a core societal value such as public health services. Country snapshots were used in this study to emphasize the differing roots and growth of public health systems and the practical importance to those societies in terms of eradicating disease, providing basic healthcare and a better standard of life. Throughout this study, there were inclusions on the relevance of the right to health as provided for in Article 12 of the International Covenant on Economic, Social and Cultural Rights (ICESCR), which is the key international human rights law provision on the right to health. This human rights provision, and its objectives of progressively achieving the right to health in countries across the world, cannot be interpreted and implemented without considering the importance of public health services in that endeavour. This study has been in a way a tribute to the continuing relevance and value of the role of public health services, as much as it has been an analysis of the provisions of the GATS which may allow for this value to be protected.

This study is thus also about the issue of balancing: legal balancing between predictability and flexibility of the WTO system - and socio-economic and political balancing with regard to policy choices and the measures that can be taken under them by governments representing their public's interests. If progressive liberalization of services is not a value in itself, but only an instrument of a particular economic policy expressed in the WTO system - a question to be asked is whether this does or does not preclude the broader understanding of human development as a value that can be promoted within the system. Like an artiste on a high wire, WTO Members ought to have the policy space to balance on either side, left and right, the different policies that on the one hand promote trade and entrepreneurship, and on the other hand protect non-trade social values. Putting a Member in a straight-jacket of rules without the required policy-space risks the entire performance - imagine trying to walk a high wire without being able to use your arms for balance or to hold a balance pole. The analysis and discussions in this study have shown that for the Member that is balancing on a high wire, the GATS includes a number of flexibilities for balance (particularly the exemptions and policy space during the making 
or avoiding of commitments) and that the exceptions provide for safety nets in defence of measures taken.

The balancing of both market and government contribution is an essential part of this search for a better future. The special reference to public health services, demonstrates the need for policy space, without denying that some trade rules can be broadly beneficial for economic growth and development. Another aspect of balancing is whether national and international economic concerns can be balanced for the creation of a better standard of living across the world - and most importantly, whether this progress can be shared by the disadvantaged and vulnerable, as well as by the entrepreneurs and investors. Amartya Sen has argued that relying on the market may be "less than effective" with regard to public goods such as public healthcare and communal goods such as healthcare facilities, as it is just an arrangement, the success of which is based on other political and social arrangements. ${ }^{2763}$ As Jeffery Sachs has also concluded, a "naïve free market position" cannot be justified in the context of the increasing complexity of modern life, which requires a more extensive role for government to ensure fairness and sustainability of the market contribution to society. ${ }^{2764}$ The WHO Commission on Macroeconomics and Health chaired by Sachs has also (referring to the 'capabilities approach' introduced by Amartya Sen in Development as Freedom) stated that health is one of the basic capabilities that gives value to human life and that "the wisdom of every culture also teaches that 'health is wealth' in a more instrumental and value-laden sense as well". ${ }^{2765}$

In Buddhism for example, verse 204 of the Dhammapada states 'aarogya paramaa laabha' or that health is the greatest gain or ultimate 'profit' (for an individual human being who wants to develop themselves both physically and spiritually). The provision of health services to those in need of healthcare has intrinsic value but there is also instrumental value, in that being of good health, receiving medical attention for illness, injury, disability or chronic conditions clearly leads to overall gains and flourishing for the individuals concerned and ultimately also for the development of society as a whole. The right to health, including the access to health services and medicines, is also instrumental in the sense of being an important part for an individual human being to have access to the enjoyment of their other human rights, and of course the lack of healthcare due to poverty can clearly lead to serious deprivations and even death. The right to anything at all first requires that a child or adult does not die prematurely for preventable reasons due to the lack of healthcare, which could have been provided if systems of governance had prioritized a public healthcare system.

However, a system that approaches the provision of health services primarily as an opportunity for individuals and companies to make financial profits, distorts and reduces the concept of 'wealth' in the concept of 'health is wealth' to mere money, instead of the value that can be added to the life and lived experience of an individual and the value added to a society which takes care of, protects the dignity of and increases opportunities

\footnotetext{
${ }^{2763}$ Sen, Amartya, DEVELOPMENT AS FREEDOM, Anchor Books, 2000, p128 and p142.

${ }^{2764}$ Sachs, Jeffery, THE PRICE OF CIVILIZATION: REAWAKENING VIRTUE AND PROPSERITY AFTER THE ECONOMIC FALL, Vintage Books, 2012, p44-46. Sachs was also special advisor to the UN Secretary General Ban Ki-Moon on the MDGs.

2765 World Health Organization (WHO), MACROECONOMICS AND HEALTH: INVESTING IN HEALTH FOR ECONOMIC DEVELOPMENT, Report of the Commission on Macroeconomics and Health Chaired by Jeffrey D. Sachs, 2001, p2.

(Available online at http://whqlibdoc.who.int/publications/2001/924154550x.pdf).
} 
for its members. Some critics of public health service systems, using the narrow perspective of 'wealth' as financial profit and as something which should be created through provision of health services, focus on the issues of 'inefficiency' in the use of resources for providing those services. They suggest that a public health system can be improved by the introduction of financial profit-oriented private sector management ideas of cost-efficiency. Objectively, it can be stated that what is necessary for a successful outcome is using the best possible methods to achieve the best goal in terms of human welfare. Sen has described this as including a "synchronous consideration" of the goals of both equity and efficiency. ${ }^{2766}$

The focus of the legal analysis of this study was whether there is space for a balancing of values within the GATS and how far it could be extended in light of the need for the protection of public health services from a perspective of the right to health. The application of the VCLT rules provide a basis for interpreting the provisions of the GATS in search of such a balancing of interests, but the more specific question was also whether a human rights-based approach, specifically a right to health-based approach, would be able to enter into this VCLT method for WTO interpretation. The Chapters of this study assessed the debates surrounding the rights and obligations of WTO Members through a combination of both the classic VCLT approach which is a codification of customary international law on treaty interpretation and the inclusion of human rights approaches. Georges Abi-Saab, former Chairman of the WTO Appellate Body, has commented that: ...interpretation remains an integrated operation, which uses several tools simultaneously to shed light from different angles onto the interpreted text... ${ }^{2767}$

It is hoped that this study succeeded in shedding some further light from different angles on these debates and on the text of the GATS. However, the extent of the weight that can be given to other international rules, principles or norms within the interpretive exercise, is not more than a very limited role, with cautious acknowledgment in very specific situations, usually where there will not be a clash with the interpretation of the WTO texts.

Abi-Saab also highlights that interpretation is art as much as science, and that the toolkit will yield varying results depending on the judicial policy of the institution, its historical background and setting. This is true for both academic and judicial approaches to WTO interpretation. In the domestic judicial context, a handful of individuals have in some domestic jurisdictions changed the prior strict constructivist trends of appellate and constitutional courts and strengthened individual and social rights and benefits through their use of legal interpretation. This study also mentions some of these cases which compelled governments to improve their national health policy. The hope that this could also occur in the WTO system has faced an additional blow with the crisis of the blocking of re-appointments and new appointments of Appellate Body members by the United States, which has attempted to justify its actions with allegations of 'judicial activism' and 'overreach' against the Appellate Body. This contradicts the previous criticism from non-governmental and activist sources that the Appellate Body has been too literal and conservative in its interpretation of WTO Law. The Appellate Body is currently not able

${ }^{2766}$ Sen, Amartya, DEVELOPMENT AS FREEDOM, Anchor Books, 2000, p1 19-120.

${ }^{2767}$ Abi-Saab, G., The Appellate Body and Treaty Interpretation in Fitzmaurice, M., Olufemi A. Elias and Panos Merkouris Eds., TREATY INTERPRETATION AND THE VCLT; 30 YEARS ON, BRILL Publishers, 2010, p105 (reprinted from Sacerdoti et al, Eds., THE WTO AT 10; THE CONTRIBUTION OF THE DISPUTE SETTLEMENT SYSTEM, Cambridge University Press, 2006, p453-64). 
to continue to function, and if WTO Members cannot find a way out of this impasse, ${ }^{2768}$ the future of the entire system itself may be at stake. This situation could also offer an opportunity for Members to reform the procedure of the WTO dispute settlement system, ${ }^{2769}$ and there could be a slight possibility that such reform could be a change for the better.

The panels and the Appellate Body shy away from amorphous concepts of 'justice' and 'equity' in WTO dispute settlement reports, but if the WTO system is indeed an implementation of a new world trade 'constitution', can such concepts be avoided forever in the wider WTO context? Furthermore, the ethos captured in Recitals 4 and 5 of the Preamble of the VCLT itself affirms that disputes concerning treaties should be settled "in conformity with the principles of justice and international law" and that "conditions under which justice and respect for the obligations arising from treaties can be maintained" is intended to be established. ${ }^{2770}$ The WTO is still a young institution, but its future is in doubt. It is hoped that the institution could be given the opportunity and the space to develop further through acknowledging the importance of its role for the creation of a better world order, including explicit support for social safety nets such as public health services, which are necessary for more just and equitable societies.

Chapter 1 of this study presented the backdrop of the underlying concepts and interpretive approaches to the legal analysis. The larger objectives of economic growth and development that the WTO aims to achieve through liberalization of international trade was discussed in light of alternative approaches to human development, the right to development, a human rights-approach, human dignity, and the right to health. The extent to which these values clashed with each other, and whether there could be a point of understanding was discussed, including the inherent difficulties of using a human rights approach. It was recognized that there was a lack of reference to human rights in WTO law or dispute settlement reports and the entryways for such attempts (using the VCLT) were not only difficult but may not be practically used by Members or accepted by the panels or Appellate Body. Trade and human rights were presented as two different languages which also needed translation before a successful interpretation of human rights into GATS provisions could be attempted, and the concept of bilingualism was introduced, meaning that competency in both languages was necessary for the interpretive exercise to be attempted with some measure of success.

Chapter 2 discusses the fears that have been expressed concerning privatization, corporatization and commercialization of public services, particularly health services. A

\footnotetext{
${ }^{2768}$ See the discussion in Pauwelyn, Joost, WTO Dispute Settlement Post 2019: What to Expect?, Journal of International Economic Law, Volume 22, Issue 3, September 2019, p297-321.

${ }^{2769}$ See for example, the varied views of Lo, Chang Fa, A Proper Balance between WTO's Members-Driven Nature and the Appellate Body's Role as an Adjudicator - Careful Exercise of Judicial Activism in Lo, Chang-fa, Junji Nakagawa and Tsai-fang Chen Eds., THE APPELLATE BODY OF THE WTO AND ITS REFORM, Springer, 2019, p125-140; Picker, Colin B., The AB Crisis as symptomatic of the WTOs Foundational Defects or: How I learned to Stop Worrying and Love the AB, in Lo, Chang-fa, Junji Nakagawa and Tsai-fang Chen Eds., THE APPELLATE BODY OF THE WTO AND ITS REFORM, Springer, 2019, p53-65; Babu, R. Rajesh, WTO Appellate Body Overreach and the Crisis in the Making: A View from the South in Lo, Chang-fa, Junji Nakagawa and Tsai-fang Chen Eds., THE APPELLATE BODY OF THE WTO AND ITS REFORM, Springer, 2019, p91-107.

${ }^{2770}$ See further the discussion in Petersmann, E-U., The crown jewel of the WTO has been stolen by US trade diplomats : and they have no intention of giving it back, in Prévost, Denise, Iveta Alexovicova and Jens Hillebrand Pohl Eds., RESTORING TRUST IN TRADE: LIBER AMICORUM IN HONOUR OF PETER VAN DEN BOSSCHE, Hart Publishing, 2018, p105-118, at p110.
} 
Member has the possibility of using the exemption from the scope of the GATS in Article I:3(b) and (c) for exempting "services supplied in the exercise of governmental authority" - which suggests public services. However, the definition is also tied to the interpretation that the dispute settlement bodies may give to the concepts of "commercial" and "in competition with", since having these features would include what may have otherwise been considered a public service under the coverage of the GATS. Thus, even if a 'ringfence' for public services exists in Article I of the GATS, there are contrary views on the breadth or the scope of application and it is not a sufficient protection in terms of being a clear exemption. Moreover, taking a human rights approach to health services and their role in development leads to a different view on whether a public health service can be deemed to be provided in a manner that is "commercial" and "in competition" with private suppliers. Such interpretations have not yet been used in a 'bilingual' manner in GATS discourse, and may not be used in the context of GATS disputes unless a Member with a strong right to health-based policy background finds themselves involved in a services dispute on this point.

Article I and public services also have connections with other GATS provisions on monopolies, and the negotiating mandates for government procurement and subsidies which suggests a GATS system which at its inception would have expected a fully liberalized world trade system on services to be developed in the course of time. The analysis of the above public services-related provisions finds that they do not effectively engage with the situations where public provision is the most successful method of universal service provision - such as national public health services - nor with the human rights dimensions these topics. There is opportunity for more research into these areas, to bring in this viewpoint to the discourse.

If a Member finds that the exemption does not cover their public health services, they are nevertheless still up on the highwire with the flexibility not to make commitments in market access and national treatment and the hope of a safety net to break a fall in terms of the exceptions. The process of the scheduling of commitments is one of the areas where the actual power relations in WTO negotiations can play a part, but at the same time this is also described as an area where Members can retain their policy space by not making commitments or by including limitations which specifically protect their public health services. Members can protect their public health services (although private suppliers could be granted limited rights), by avoiding national treatment and market access obligations for public funded healthcare services. This was discussed in more detail in Chapter 4, which was structured as the chapter on 'general obligations and specific commitments'.

This chapter also analyzed the differences in non-discrimination as a value in trade and human rights, and looked at Article II:2 and the Annex on Article II Exemptions, as well as other MFN Exemptions (Article II:3) and Exceptions (Articles V, VII) concluding that while they may provide more space for Members than initially assumed, that they are once again of limited usefulness unless Members have had and continue to have the legal expertise to expand their trade opportunities and policy space in that context.

If the balance that is sought in the GATS obligations fails for a Member because of commitments made earlier in haste and with insufficient care to limit the commitments, there is recourse to a final safety net in the form of the exceptions under Article XIV of the GATS. The exceptions dealing with public morals and public order, human life and 
health in Article XIV(a) and (b) have a lot of potential in terms of being methods for defending Members' measures in the furtherance of their societal values and interests, and is also an entryway for human rights and the right to health. Article XIV(c) also has potential to be used parallel to the other paragraphs. Article XIVbis and the other paragraphs under Article XIV could also be available as safety nets, but to a more limited extent. Moreover, many disputes are ultimately decided by the analysis of the nexus and the chapeau, and the interests in the exceptions are given deference but treated superficially in terms of analysis. The exceptions are an inbuilt balance but also only a last resort. The analysis in Chapter 5 gives a certain level of positivity, but as discussed, there are also drawbacks in trying to insert concepts from another regime without sufficient 'bilingualism'. These can never be cast-iron guarantees for policy space and flexibility, and neither are they fail-safe safety nets, but merely the acknowledgment of possibilities.

There are also several areas in the GATS that are still negotiating mandates where the process of formulating further disciplines for trade in services is still being carried out. The negotiating mandates have not generated the expected results, with most Members appearing extremely reluctant to proceed and no new multilateral disciplines in services emerging after 25 years. Subsidies under Article XV, government procurement under Article XIII and domestic regulation under Article VI:4 of the GATS are areas which may have far reaching implications for policy autonomy and the protection of public services. The relevance of these areas, with special reference to public health services, have been touched on in this study. While the mandate and procedure of negotiations are matters for legal interpretation, the actual nature and processes of negotiation are the result of political power imbalances, bargaining, compromise and an underlying element of domestic and transnational special interests. The relationship of negotiations on specific commitments and the abovementioned special mandates is something that can only be guessed at through publicly available documents. ${ }^{2771}$

Chapter 6 discussed the issue of whether there is extra policy space for developing country and LDC Members, since they could have a special interest in developing their existing public health services capacity and arguably should have more policy space to carry out their 'progressive realization' steps. The chapter noted that the WTO system does not have a gradation-type classification for developing countries that accurately traces the levels of development achieved and that the even the LDC definition which is used has flaws. Self-definition as a developing country is not problematic except if the countries with real needs for support get overlooked as more economically powerful developing countries take center stage. However, the United States has recently challenged the practice of self-definition, particularly in light of the emergence of China as an economic power. The argument of this study is that there should be improved policy space for public services protection for all Members and additional special assistance for the Members that most need it, and this would probably need more work and reform of some of the ways the WTO works with its Members and how their Members cooperate with each other in implementing the goals of the Preamble to the GATS and Article IV of the GATS.

\footnotetext{
2771 Trebilcock, M., Robert Howse and Antonia Eliason, THE REGULATION OF INTERNATIONAL
} TRADE, $4^{\text {th }}$ edition, Routledge, 2013, p3, also notes that this is a "critical yet under-appreciated issue". 
Clarifications on the scope and definitions of the above-mentioned balancing mechanisms and safety nets can be done with the participation of the Members of the WTO. Authoritative interpretations and amendments to the GATS are theoretically possible, if there is political momentum and leadership from a few Members. Amendments that would be helpful include both general and/or specific provisions into the current text or future disciplines adding that a Member has a right to protect and promote the delivery of services through their national public services, and to take into account, perhaps as an exception to GATS general obligations, whether a measure is designed and implemented so as to promote human dignity in their societies according to a human rights approach to development.

With regard to public health services, an important step could be a WTO Ministerial Declaration recognizing the role of public health services for the right to health and right to development (which would be preferable to terms such as "for health outcomes" or "public health" and "development"), which could be the basis for future Amendments to the GATS exempting public health services entirely under Article I, or specifically under areas such as scheduling under Article XIX to XXI. Areas which are negotiating mandates such as subsidies disciplines under Article XV or domestic regulation under Article VI are also opportunities for bringing up the importance of domestic policy objectives for universal service obligations in health and developing specific exclusions from commodification. Other than public health services, specific amendments with regard to climate change mitigation and environmental protection measures can also be said to be essential, and these are other potential areas for research.

There is more than one specific path to prosperity, and the 'dark side' of modern capitalist economic growth models have long since been made apparent. While engaging in these positive visions of the structures we should build for a better future and the outcomes we want, it is also important to grapple with the negative aspects and outcomes of the systems we want to implement. David Kennedy in a critical appraisal of human rights and humanitarian law and action has commented that:

We have focused on structure - institutions, constitutions - rather than outcomes. We have preferred procedures to substance. ${ }^{2772}$

One could say the same for the WTO - another international regime that promises certain positive contributions to international law and economic development. If a similar honest appraisal of WTO law and its present and potential consequences is done, with an unflinching look at the 'dark sides' to the story, perhaps a better ending can be written and lived.

Not engaging with these criticisms and absorbing the necessary changes in outlook would fix the WTO system in an outdated model of development, which would not be sustainable and may not result in an equitable society. Alternative paths to development are possible, and arguably, few currently developed nations have made gains on the exact same models that are being suggested for currently developing nations. There will always be temporary winners and losers in the trade game, but the best system is probably one that is structured so that there is a possibility for all Members to have a decent shot at the championship league or Test status someday - rather than one in which there is very little chance of ever moving up the ranks. Using another general and mixed sports analogy - a

2772 Kennedy, David, Reassessing International Humanitarianism: The Dark Side in Orford Anne, Ed., INTERNATIONAL LAW AND ITS OTHERS, Cambridge University Press, 2009, p153. 
healthy and fair competition, with a fair chance of winning requires that there are institutions, rules or policies that represent forwards, defenders, goal keepers (or batsmen, bowlers, fielders and wicket keepers) umpires and match referees. A game of only forwards/batsmen (pro-liberalization - and already 'in the batting crease', with scores already up on the board for some teams) and umpires (following only the rule book), can hardly be a kind of game that attracts many enthusiastically cheering fans. The point is that proponents of the WTO system do not need to fear defenders/bowlers/fielders, goal or wicket keepers and match referees ${ }^{2773}$ to balance liberalization with protections, preventions, safety nets and judgements on gentlemanly conduct. In fact, the game may very well be much better off and much more exciting, with them participating in it.

All systems need to evolve and adapt in order to survive in changing circumstances; and those that can take an alternative path to the one envisaged decades ago are more likely to keep growing. Delimatsis has even said that the GATS is now "an artefact of the 90s that struggles to remain a living instrument". ${ }^{2774}$ Trade rules in general and the trade in services framework are already facing issues of adaptation and change due to practical advances in technology, socio-political changes where there are more demands made of governments and private actors to act responsibly, as well as conceptual advances in other regimes of international law, particularly human rights law. It would be useful overall if the understanding and use of the policy space in the GATS can be expanded through interpretation, even at the societal and academic level (since few services disputes arise, giving little opportunity for the dispute settlement bodies to do so), which take into account the developments in economic and social rights societal acceptance of the noneconomic values relating to services provision. This study has hoped to contribute to this endeavour.

International trade in services within the GATS framework, while suggesting a promise of more cooperation, more trade opportunities and cheaper services, remains, like all endeavours, a risk which no attempt at balancing and no safety net can completely cover. There is a risk of failure of the market and reduction in public spending leading to increase in prices, less affordability and quality of services available for the poor. The importance of assessing the balancing mechanisms and safety nets available in the GATS for services is because the risk is mostly likely to be borne by those who are already the most disadvantaged, marginalized and most in need of basic services. The risks are such that the overall assessment of the GATS would be that health services are a type of service which Members should avoid liberalizing and should preferably implement on the basis of careful national policy shaped by a human rights-based approach.

Investing in public services, subsidizing public services, moving to a public model which does not commodify the service provided and targeting results in terms of measurable positive outcomes for members of the public will reap rewards in some service sectors far more than if these sectors were liberalized. Public health services have proven to be an area where such policies have led to high standards in healthcare and in turn contributed towards the development of a country through having a healthy population. A similar area

\footnotetext{
2773 Strangely enough, an unsubstantiated fear of bias or overreach in the match referees (the Appellate Body could be described thus) has led to the United States' recent action to block Appellate Body appointments and this has placed the entire future of the 'sport' in uncertainty.

2774 Delimatsis, P., Trade in services and regulatory flexibility: 20 years of GATS, 20 years of critique, European Yearbook of International Economic Law 2016, 153-173.
} 
is public education, where enrolment, literacy, economic growth and raising human development standards have been positively linked to public investment in education.

If the WTO system cannot acknowledge these factors, there will be problems in terms of the trust, confidence and use of the system, especially in the services context. What would be the result of such a failure of the WTO or the GATS framework? Perhaps some of these results are already being seen, in the lack of progress in negotiations on WTO services disciplines and in the development of alternate GATS-plus bilateral and plurilateral Agreements. Recent years have seen certain WTO Members move towards such alternative options, even if they are not necessarily replacements for the multilateral framework of the GATS. The Transatlantic Trade and Investment Partnership (TTIP - as of April 2019 the negotiating directives are obsolete ${ }^{2775}$ was such an attempt made between the United States and the European Union. The Trade in Services Agreement (TiSA), which is being negotiated by 23 WTO Members, including the EU, is open to all WTO Members, but still has the appearance of a plurilateral. ${ }^{2776}$ The negotiations for the Trans Pacific Partnership (TPP), which was revised and renamed in January 2018 as the

2775 The Transatlantic Trade and Investment Partnership (TTIP) was a comprehensive bilateral agreement being negotiated between the U.S. and EU which intends, among other objectives, to improve market access, develop rules for intellectual-based property and create market-based disciplines that address stateowned enterprises. When the TTIP was being negotiated between the EU and the United States, the European Commission declared that public services will be protected in the text of the TTIP (See European Commission, Protecting Public Services in TTIP and other EU Trade Agreements, 4 July 2014, available online at http://trade.ec.europa.eu/doclib/press/index.cfm?id=1115). Because of the concerns on behalf of highly valued European public services such as healthcare and education services, the European Commission noted that three important guarantees for public services will be implemented: maintaining public monopolies (although private suppliers could be granted exclusive rights), not applying national treatment and market access for public funded healthcare and education for new entrants to the EU market and allowing for national regulation of public services as defined by that EU Member.

2776 Negotiations on the Trade in Services Agreement (TiSA) began formally in March 2013 with participants agreeing on a basic text in September 2013. There has been no negotiation round since 2016. It involves 23 WTO Members including the EU and the United States, the two economies which account for the vast majority of global services exports. The negotiations are alternately chaired by these States as well as by Australia. The 23 WTO members are taking part in the TiSA talks include large, medium and small economies: Australia, Canada, Chile, Chinese Taipei, Colombia, Costa Rica, the EU, Hong Kong China, Iceland, Israel, Japan, Korea, Liechtenstein, Mexico, New Zealand, Norway, Pakistan, Panama, Paraguay, Peru, Switzerland, Turkey and the United States. African Members are not participants and neither are the BRICS as of yet, except for Hong Kong China. China has already asked to become a participant. The presence of smaller Members such as Switzerland, Iceland and Liechtenstein may be due to the interest in financial services. (from http://ec.europa.eu/trade/policy/in-focus/tisa/). Although it currently includes only a small number of WTO Members the TiSA remains open to all WTO members and perhaps could become a replacement for much of the GATS for the participating Members. The intention is that TiSA As this will be negotiated parallel to the WTO Doha Development Round, it may be part of the plan that issues that would not achieve consensus in the WTO could be resolved among the like-minded group of TiSA negotiating countries - which may in turn be a basis for the desired momentum for the WTO negotiations (See European Commission: “..we also hope the TiSA talks will help kick start the stalled multilateral negotiations - the Doha Development Round..."- from http://ec.europa.eu/trade/policy/in-focus/tisa/).

It is expected that TiSA would be based on the same general structure and scope as the GATS but would be a broader version of the WTO GATS agreement which will open up markets for trade in services. In 2016, parties discussed a number of key annexes, including on domestic regulation and Mode 4 - areas which have not progressed in the WTO context - as well as specific Annexes on professional services and stateowned enterprises (see European Commission, Report of the $21^{\text {st }}$ TiSA negotiating round, November 2016, http://rade.ec.europa.eu/doclib/docs/2016/november/tradoc_155095.pdf).

It is noteworthy that Canada has publicly declared that it would not be "offering any commitments that would impact publicly-funded health services" (see Government of Canada, Trade in Services Agreement (TiSA), Myths and Realities, available online at https://www.international.gc.ca/ trade-agreements-accordscommerciaux/topics-domaines/services/tisa-acs.aspx?lang=eng. 
Comprehensive and Progressive Agreement for Trans-Pacific Partnership (CPTPP) is in effect a new 'Free Trade Area of the Asia Pacific'. ${ }^{2777}$ The CPTPP entered into force on 30 December 2018 for the first six countries to ratify it - Canada, Australia, Japan, Mexico, New Zealand, and Singapore; and for Vietnam on 14 January 2019. Malaysia, Brunei, Chile and Peru have signed and are expected to ratify.

As discussed in this study, the scope and definition of trade agreements with regard to services such as health services, should take into account the role of public health services for the right to health and maintain the right and duty of States to develop the best possible health services systems. The problematic areas in the GATS have been highlighted in this study, particularly the lack of clarity on the 'public services exemption', and the same concerns apply to bilateral or plurilateral Agreements on services. It is notable that in the TPP text, the Preamble, Recital 9 is quite comprehensive on national policy space for countries which participate, stating that the parties to the agreement themselves:

Recognise their inherent right to regulate and resolve to preserve the flexibility of the Parties to set legislative and regulatory priorities, safeguard public welfare, and protect legitimate public welfare objectives, such as public health, safety, the environment, the conservation of living or non-living exhaustible natural resources, the integrity and stability of the financial system and public morals... ${ }^{277}$

Furthermore, Recital 10 of the TPP text refers specifically to healthcare systems. It is stated that parties to the Agreement "[r]ecognise further their inherent right to adopt, maintain or modify health care systems". This appears to be a development linked to particular interests of Members to safeguard their policy space for protecting public health services or could be used to that effect. The CPTPP text incorporates, by reference, the provisions from the TPP, and Recital 1 of the CPTPP Preamble reaffirmed the "matters embodied" in the TPP Preamble; with Recital 6 reaffirming "the importance of preserving [the] right to regulate in the public interest". ${ }^{2779}$ However, a more detailed analysis of the text and annexures of the CPTPP is needed, to ascertain if the position declared in the Preamble is reflected in the provisions and annexures.

Whether the CPTPP and the TiSA (if it enters into force) would create a better balance between national policy and liberalization of services than the GATS needs to be researched in much more detail. It is possible that improvements could be suggested to the TiSA, taking into account what has been learned from the analysis of the GATS, but there would also be both new and continuing problems in both the CPTPP and TiSA.

2777 The Trans Pacific Partnership (TPP) refers to the negotiations conducted during 2010 and 2015, between Australia, Brunei, Canada, Chile, Japan, Malaysia, Mexico, New Zealand, Peru, Singapore, the United States, and Vietnam - and to its outcome document. All 12 State parties needed to ratify the TPP text in order for it to come into force; but in 2017 the US formally declared that it will not be ratifying, although the main drive for the creation of the TPP was apparently US business and trade interests. The TPP was is a text of a free trade agreement for eliminating tariffs and non-tariff barriers to goods, services, and agriculture. It also included a section on e-commerce, which is novel for trade agreements. It has now been replaced by the СРTPP and has come into force for the ratifying countries, without the participation of the United States.

${ }^{2778}$ See Office of the US Trade representative, TPP Full Text, available online at https://ustr.gov/tradeagreements/free-trade-agreements/trans-pacific-partnership/tpp-full-text.

Also see Government of Canada, TPP Consolidated Text, https://www.international.gc.ca/tradecommerce /trade-agreements-accords-commerciaux/agr-acc/tpp-ptp/text-texte/00.aspx?lang=eng.

2779 See Government of Canada, CPTPP Text, https://www.international.gc.ca/trade-commerce/tradeagreements-accords-commerciaux/agr-acc/cptpp-ptpgp/text-texte/cptpp-ptpgp.aspx?lang=eng. 
Currently, the GATS remains in place as the most comprehensive agreement on services. If the CPTPP and the ongoing TiSA negotiations also ultimately fail to provide and implement satisfactory solutions to the issues relating to public services and public health care systems, this may further entrench the problems and errors of the GATS in the new trade agreements and their structures as well. A vicious cycle of lack of clarity and trust in international trade frameworks could be repeated.

What can be done to create and support a break away from such a vicious cycle? It can be argued that what is needed now is to strengthen and clarify what Andrew Lang calls the "emerging post-neoliberal legal imagination", ${ }^{2780}$ that is perhaps already being created as an alternative to the legal thinking that is constrained within the neo-liberal aspects of the WTO framework. With regard to health services, the area of special emphasis in this study, it must be stressed that attaching the mere label of 'human right' to a policy should not give it "unqualified value" without also envisioning "human well-being'. ${ }^{2781}$ The GATS exists in the context of human beings, individually and collectively as societies, envisioning the role and form of services and the outcomes of their provision. The efforts which have been devoted to building and maintaining public health services, as social policy and as a vital part of the right to health, are an important example of how such visions for a better society have been realized.

Despite of, or perhaps because of, it now being a quarter of a century since the WTO GATS came into being, there is a need to look a little deeper into the apparent policy space and flexibilities, from the perspective of both those more concerned with societal values protection and those more concerned about increasing the ease with which international trade in services is carried out. The purpose of this study was to make such an objective appraisal with regard to the GATS.

This study has discussed and analyzed the scope of the GATS, its exemptions, the general and specific obligations, as well as the exceptions and special provisions from the angle of the available flexibilities and policy space. The outcome is that there are entryways for such values, but that it is something to argue and struggle for and the support for it is not sufficiently strong. A combination of methods: using MFN exemptions, refraining making commitments in sensitive sectors or scheduling very clear limitations and using the exceptions if commitments have been made - could retain the national policy space for measures taken in light of human development and right to health objectives. The 'red line' running through this study is the position that national decision-makers must be free to make the decisions that it is their duty to make, such as defending public health services.

The focus has been on treaty interpretation, but without ignoring the practical aspects of ideological underpinnings, global power-imbalances and slow-moving negotiations that affect the development and interpretation of the rules. The current crisis with regard to the future of the WTO dispute settlement system (the inability of the Appellate Body to hear and decide new appeals from December $11^{\text {th }} 2019$ onwards) means that the interpretation

2780 Lang, Andrew, Conclusion: After Neoliberalism in WORLD TRADE LAW AFTER NEOLIBERALISM: RE-IMAGINING THE GLOBAL ECONOMIC ORDER, Oxford University Press, $2011, \mathrm{p} 343$.

${ }^{2781}$ Freedman, Lynn P., Reflections on Emerging Frameworks of Health and Human Rights in Mann, Jonathan M., Sofia Gruskin, Michael A. Grodin and George J. Annas Eds., HEALTH AND HUMAN RIGHTS: A READER, Routledge, 1999, p228. 
of the rules may have to depend in the future on diplomatic negotiations, consultations and perhaps mutually agreed solutions assisted by panel findings or based on arbitration or other regional or plurilateral mechanisms, in order to resolve trade disputes in the absence of an Appellate Body. It is to be hoped that the Members can come to an agreement on reforms and practical measures to revive the Appellate Body, but this would be dependent on what developments or regressions in international relations and the international rule of law would occur during 2020.

The overall conclusion following the analysis of the flexibilities or policy space in the GATS in this study, is that the policy space is limited and is apparently most often and best used by non-participation in the opportunities that the GATS offers. Members have been cautious to take further liberalization steps, in terms of commitments or negotiations or clarifying disciplines that were left over from the Uruguay Round. The choice not to test the space and protections can be criticized but also judged more favourably in light of the estimation of the difficulty of interpreting public policy, non-trade objectives, a human rights approach or a right to health-based approach into WTO Law and the GATS.

It is hoped that the legal and policy analysis captured at this point of time in this study can be considered a useful contribution to the current understanding of the both the policy space in the WTO GATS and the societal-values-plus-right-to-health-based view of the role of public services. 


\section{SELECTED BIBLIOGRAPHY}

Abi-Saab, G., The Appellate Body and Treaty Interpretation in Fitzmaurice, M., Olufemi A. Elias and Panos Merkouris Eds., TREATY INTERPRETATION AND THE VCLT; 30 YEARS ON, BRILL Publishers, 2010.

Adlung, R., Bilateralism in Services Trade: Is There Fire Behind the (Bit-)Smoke, Journal of International Economic Law, Vol. 11, No. 2, p. 365-409, Vol. 11, No. 2, 2008, p.365-409.

Adlung, R., Public Services and the GATS, Journal of International Economic Law 9(2), 455-485, 2006.

Adlung, R., Public Services and the GATS, Staff Working Paper ERSD-2005-03, WTO Economic and Statistical Division, 2005.

Adlung, R., Services Liberalization from a WTO/GATS Perspective: In Search of Volunteers, WTO Staff Working Papers, Economic Research and Statistics Division, ERSD-2009-05, February 2009.

Adlung, Rudolf and Antonia Carzaniga, MFN Exemptions Under the General Agreement on Trade in Services: Grandfathers Striving For Immortality? Journal of International Economic Law 12(2), 2009, 357-392.

Adlung, Rudolf and Martin Molinuevo, Bilateralism in Services Trade: is there Fire Behind the (Bit)Smoke, Staff Working Paper ERSD-2008-01, World Trade Organization, Economic Research and Statistics Division, 16 January 2008.

Adlung, Rudolf and Sébastien Miroudot, Poison in The Wine? Tracing GATS-Minus Commitments in Regional Trade Agreements, WTO Staff Working Paper ERSD-2012-04, February 2012.

Akande, Dapo and Williams, Sope, International Adjudication on National Security Issues: What role for the WTO? Vol. 43 Vanderbilt Journal of International Law, 2002-2003.

Aleinikoff, Thomas Alexander and Vincent Chatail Eds., MIGRATION AND INTERNATIONAL LEGAL NORMS, T.M. Asser Press, 2003.

Alessandrini, Donatella, DEVELOPING COUNTRIES AND THE MULTILATERAL TRADING REGIMES: THE FAILURE AND PROMISE OF THE WTO'S DEVELOPMENT ROUND, Hart Publishing, 2010.

Alexander, Kern and Mads Andenas, THE WORLD TRADE ORGANIZATION AND TRADE IN SERVICES, Martinus Nijhoff Publishers, 2008.

Allmand Warren, Preface to Howse, Robert and Makau Mutua, Protecting Human Rights in a Global Economy: Challenges for the World Trade Organization, International Centre for Human Rights and Democratic Development, 2000.

Alston, P., Resisting the Merger and Acquisition of Human Rights by Trade Law: A Reply to Petersmann, 13(4) European Journal of International Law, 2002, 815-844.

Alston, P., Ships Passing in the Night: The Current State of the Human Rights and Development Debate Seen Through the Lens of the Millennium Development Goals, Human Rights Quarterly 27(3), 2005, 755-829.

Alston, Philip and Ryan Goodman, INTERNATIONAL HUMAN RIGHTS, Oxford University Press, 2013.

Alston, Philip, The Historical Origins of 'General Comments' in Human Rights Law in Boisson De Charzournes, Laurence and Vera Gowlland-Debbas Eds., THE INTERNATIONAL LEGAL SYSTEM IN QUEST OF EQUITY AND UNIVERSALITY, 2001.

Alston, Phillip and Ryan Goodman, INTERNATIONAL HUMAN RIGHTS, Oxford University Press, 2012.

Alston, Phillip, Resisting the Merger and Acquisition of Human Rights by Trade Law: A Reply to Petersmann, European Journal of International Law (EJIL), Vol.13, No. 4, 2002.

Aman Jr., Alfred, C., Privatization and Democracy: Resources in Administrative Law in Freeman, Jody and Martha Minow Eds., GOVERNMENT BY CONTRACT, Harvard University Press 2009.

Ameringer, Carl F., THE HEALTHCARE REVOLUTION: FROM MONOPOLY TO MARKET COMPETITION, University of California Press, 2008.

Anand, Sudhir and Martin Ravallion, Human Development in Poor Countries: On the Role of Private Incomes and Public Services, The Journal of Economic Perspectives, Vol. 7, No. 1 (Winter, 1993), 133.

Andenas, Mads and Stefan Zleptnig, Proportionality: WTO Law: In Comparative Perspective, Texas International Law Journal Vol. 42, 2007, 371.

Anderson, Robert D., Claudia Locatelli, Anna Caroline Müller, and Philippe Pelletier, The Relationship Between Services Trade and Government Procurement Commitments: Insights from Relevant WTO Agreements and Recent RTAS, WTO Working Paper ERSD-2014-21, 18 November 2014. 
Annas, George, J., Human Rights and Health: The Universal Declaration of Human Rights at 50 in Gruskin, Sofia, Michale A. Grodin, George J. Annas and Stephen P. Marks (Eds.) PERSEPCTIVES OF HEALTH AND HUMAN RIGHTS, Routledge, 2005.

Appleton, Arthur E. and Michael G. Plummer, THE WORLD TRADE ORGANIZATION: LEGAL, ECONOMIC AND POLITICAL ANALYSIS, Volume I, Springer Science \& Business Media, 2007.

Arato, Julian, Treaty Interpretation and Constitutional Transformation: Informal Change in International Organizations, Yale Journal of International Law, Vol. 38, No.2, 2013.

Arnold, Patricia J. and Terrie C. Reeves, Global Trade and the Future of National Health Care Reform, Accounting Forum, Volume 30, Issue 4, December 2006, p325-340.

Arnold, Patricia J., Disciplining Domestic Regulation: The World Trade Organization and the Market for Professional Services, Accounting, Organizations and Society 30, 2005.

Arrowsmith, Sue and Geo Quinot, PUBLIC PROCUREMENT REGULATION IN AFRICA, Cambridge University Press, 2013.

Arrowsmith, Sue and Robert D. Anderson, Eds., THE WTO REGIME ON GOVERNMENT PROCUREMENT: CHALLENGES AND REFORM, Cambridge University Press, 2011.

Arrowsmith, Sue, GOVERNMENT PROCUREMENT IN THE WTO, Kluwer Law International, 2003.

Atapattu, Sumudu A., EMERGING PRINCIPLES OF INTERNATIONAL ENVIRONMENTAL LAW, Transnational Publishers, 2006.

Atkinson, Sarah, Political Cultures, Health systems and Health Policy, Social Science \& Medicine 55 (2002) 113-124.

Atkinson, Sarah, Regianne Leila Rolim Medeiros, Paulo Henrique, Lima Oliveira and Ricardo Dias de Almeida, Going Down to the Local: Incorporating Social Organization and Political Culture into Assessments of Decentralized Health Care, Social Science \& Medicine 51 (2000) 619.

Bacchi C., The Practice of Affirmative Action Policies: Explaining Resistances and How These Affect Results in Boerefijn, Ingrid, F. Coomans, J. Goldschmidt, R Holtmaat and R. Wollesewinkel Eds., TEMPORARY SPECIAL MEASURES: ACCELERATING DE FACTO EQUALITY OF WOMEN UNDER ARTICLE 4(1) UN CONVENTION ON THE ELIMINATION OF ALL FORMS OF DISCRIMINATION AGAINST WOMEN, Volume 1 of Maastricht Series in Human Rights, Intersentia 2003, p75,79.

Balasubramaniuam, Dr. K., The General Agreement on Trade in Services and Public Health, HAI News, Number 141, April-June 2007.

Baldacci, E., B. Clements, S. Gupta and Qiang Ciu, Social Spending, Human Capital and Growth in Developing Countries, World Development, Vol. 3, issue 6, August 2008.

Bangdiwala, Shrikant I., Tucker, Joseph D., Li, Li-Ming, and K. Srinath Reddy et al, Public Health Education in India and China: History, Opportunities, and Challenges, Public Health Reviews, Vol.33, No. 1, 204-224.

Barfield, Claude E. FREE TRADE, SOVEREIGNTY, DEMOCRACY: THE FUTURE OF THE WORLD TRADE ORGANIZATION, AEI Press, 2001.

Baunsgaard T. and M. Keen, Tax Revenue and (or?) Trade Liberalization, IMF Working Paper WP/05/112, June 2005.

Bayar, Monia, INTENTIONALITY IN TRANSLATION: (WITH A SPECIAL REFERENCE TO ARABIC/ENGLISH TRANSLATION), University of Edinburgh, 1992.

Bayar, Monia, TO MEAN OR NOT TO MEAN, Kadmous Cultural Foundation Khatawat, 2007.

Beitz, Charles R., Cosmopolitanism and Global Justice in Brock, Gillian and Darrel Moellendorf, Eds., CURRENT DEBATES IN GLOBAL JUSTICE, Series: Studies in Global Justice, Vol. 2, 2005 reprinted from 2005, The Journal of Ethics 9:1, Special Volume.

Beitz, Charles R., Justice and International Relations, Philosophy \& Public Affairs Vol. 4, No. 4, Summer, 1975, pp. 360-389.

Benatar, Solomon, and Gillian Brock, GLOBAL HEALTH AND GLOBAL HEALTH ETHICS, Cambridge University Press, 2011.

Benvenisti, Eyal, Margin of Appreciation, Consensus and Universal Standards, International Law and Politics, Vol 31 1999, 843.

Bertrand, Elodie, The Coasean analysis of lighthouse financing: myths and realities, Cambridge Journal of Economics, Volume 30, Issue 3, May 2006, p389-402.

Bhuiyan, Sharif, NATIONAL LAW IN WTO LAW: EFFECTIVENESS AND GOOD GOVERNANCE IN THE WORLD TRADING SYSTEM, Cambridge University Press, 2007.

Bigdeli and Rechsteiner Article VIII GATS in Wolfrum, Rudiger, Peter-Tobias Stoll and Clemens Feinaugle Eds., WTO - TRADE IN SERVICES, Max Planck Commentaries on World Trade Law, Martinus Nijhoff Publishers, 2008. 
Billmeier, Andreas And Tommaso Nannicini, Trade Openness and Growth: Pursuing Empirical Glasnost, IMF Staff Papers 2009: 56.

Binder, Guyora and Robert Weisberg, LITERARY CRITICISMS OF LAW, Chapter Three: Narrative Criticism of Law, Princeton University Press, 2000.

Bjorkman, James Warner, Health Policy and Politics in Sri Lanka: Developments in the South Asian Welfare State, Asian Survey, Vol. 25, No. 5, May, 1985.

Blake, Conway, Normative Instruments in International Human Rights Law: Locating the General Comment, NYU School of Law, Center for Human Rights and Global Justice Working Paper Number 17, 2008 (also available as 50 Harvard International Law Journal Volume 1, No.50, 2009).

Blouin, Chantal, Economic Dimensions and Impact Assessment of GATS to Promote and Protect Health in Chantal Blouin, Nick Drager and Richard Smith eds., INTERNATIONAL TRADE IN HEALTH SERVICES AND THE GATS: CURRENT ISSUES AND DEBATES, The World Bank, 2006.

Blouin, Chantal, Nick Drager and Richard Smith Eds., INTERNATIONAL TRADE IN HEALTH SERVICES AND THE GATS: CURRENT ISSUES AND DEBATES, The World Bank, 2006.

Bollyky, Thomas J. and Petros C. Mavroidis, Trade, Social Preferences and Regulatory Cooperation: The New WTO-Think, Journal of International Economic Law (2017) 20 (1): 1-30.

Boudon, Raymond, THE ORIGIN OF VALUES: SOCIOLOGY AND PHILOSOPHY OF BELIEFS, Transaction Publishers, 2001.

Boyd White, James, Establishing Relations Between Law and Other Forms of Thought and Language, Erasmus Law Review, Vol. 01, Issue 03, 2008.

Brock, Gillian., GLOBAL JUSTICE: A COSMOPOLITAN ACCOUNT, Oxford University Press, 2009.

Broude, Tomer, The Rule(s) of Trade and the Rhetos of Development: Reflections on the Functional and Aspirational Legitimacy Of The WTO, 27(4) Columbia Journal of Transnational Law, 2006.

Buffard, I. and Zemanek K. The 'Object and Purpose' of a Treaty: An Enigma? Australian Review of International and European Law, 311, 1998.

Butkeviciene Jolita and David Diaz, GATS Commitments in the Health Services Sector and the Scope For Future Negotiations, UNCTAD/ITCD/TSB/5-WHO/TFHE/98.1, 1998.

Button, Catherine, THE POWER TO PROTECT: TRADE, HEALTH AND UNCERTAINTY IN THE WTO, Hart Publishing, 2004

Cao, Deborah, TRANSLATING LAW, Multilingual Matters, 2007.

Cappadona, Gerlando, National Report: Italy in Lang, Michael, Judith Herdin, Ines Hofbauer Eds., WTO AND DIRECT TAXATION, Kluwer Law International, 2005 p434.

Cass, Deborah, The "Constitutionalization" of International Trade Law: Judicial Norm-Generation as the Engine of Constitutional Development in International Trade, European Journal of International Law, 12, 39, 2001, 42.

Cass, Deborah, THE CONSTITUTIONALIZATION OF THE WORLD TRADE ORGANIZATION, Oxford University Press, 2005.

Cassimatis, Anthony, HUMAN RIGHTS RELATED TRADE MEASURES UNDER INTERNATIONAL LAW: THE LEGALITY OF TRADE MEASURES IMPOSED IN RESPONSE TO VIOLATIONS OF HUMAN RIGHTS OBLIGATIONS UNDER GENERAL INTERNATIONAL LAW, Martinus Nijhoff Publishers, 2007.

Chadha, Rajesh, GATS and Developing Countries: A Case Study of India in Stern, Robert M. Ed., SERVICES IN THE INTERNATIONAL ECONOMY, University of Michigan Press, 2001.

Chanda, Rupa, Trade in Health Services in TRADE IN HEALTH SERVICES: GLOBAL, REGIONAL AND COUNTRY PERSPECTIVES, Pan American Health Organization, 2002.

Chandra, Rupa, GATS and Its Implications for Developing Countries: Key Issues and Concerns, ST/ESA/2002/DP.25, DESA Discussion Paper of the United Nations Department of Economic and Social Affairs, November 2002.

Chapman, Audrey R., HUMAN RIGHTS, GLOBAL HEALTH, AND NEOLIBERAL POLICIES, Cambridge University Press, 2016.

Charnovitz, Steve, Economic and Social Actors in the World Trade Organization, ILSA Journal of International and Comparative Law, Vol. Spring 2001, Florida.

Charnovitz, Steve, Exploring Environmental Exceptions in GATT Article XX, 5 Journal of World Trade $1991,37$.

Charnovitz, Steve, An Analysis of Pascal Lamy's Proposal on Collective Preferences, Journal of International Economic Law, 8(2), 2005, 449.

Charnovitz, Steve, The WTO and The Rights of Individual, Journal of Intereconomics Vol. March/April 2001, Springer -Verlag, p1- 15. 
Chauffour, Jean-Pierre, THE POWER OF FREEDOM: UNITING HUMAN RIGHTS AND DEVELOPMENT, Cato Institute, 2009.

Chen, Hejing and John Whalley, The WTO Government Procurement Agreement and its Impacts on Trade, National Bureau of Economic Research (NBER) Working Paper 17365, August 2001.

Chesterman, Andrew, MEMES OF TRANSLATION: THE SPREAD OF IDEAS IN TRANSLATION THEORY, Vol. 22 of John Benjamin's Translation Library, John Benjamin's Publishing, 1997.

Chimni, Bhupinder, WTO, Democracy and Development: A View from the South in Lee, Yong-Shik Ed., ECONOMIC DEVELOPMENT THROUGH WORLD TRADE: A DEVELOPING WORLD PERSPECTIVE, Kluwer Law International, 2008.

Cho, Sungjoon. FREE MARKETS AND SOCIAL REGULATION: A REFORM AGENDA OF THE GLOBAL TRADING SYSTEM, Kluwer Law International, 2003.

Choudhury, Barnali, PUBLIC SERVICES AND INTERNATIONAL TRADE LIBERALIZATION: HUMAN RIGHTS AND GENDER IMPLICATIONS, Cambridge University Press, 2012.

Coase, Ronald H., The Lighthouse in Economics, Journal of Law and Economics 17, 1974.

Collins, Christopher S., A General Agreement on Higher Education: GATS, Globalization, and Imperialism, Research in Comparative and International Education, 2(4), pp. 283-296, 2007.

Conrad, Christiane, R., PROCESSES AND PRODUCTION METHODS (PPMS) IN WTO LAW: INTERFACING TRADE AND SOCIAL GOALS, Cambridge University Press, 2011.

Cornford, Andrew, The WTO Negotiations on Financial Services: Current Issues and Future Directions, UNCTAD Discussion Paper, No.172, June 2004.

Cossy M., Water Services at the WTO in Brown Weiss, E., L. Boisson de Chazournes and N. BernasconiOsterwalder Eds., FRESH WATER AND INTERNATIONAL ECONOMIC LAW Oxford University Press, 2005.

Cossy, Mirielle, Determining Likeness Under the GATS: Squaring the Circle? WTO Trade in Services Division, Staff Working Paper No. ERSD-2006-08, September 2006.

Costa, M. Victoria., Human Rights and the Global Original Position Argument in The Law of Peoples, 2005 Journal of Social Philosophy, 36: 49-61.

Cottier T., and Delimatsis P., Article XIVbis GATS: Security Exceptions in Wolfrum, Rudiger., Peter-Tobias Stoll and Clemens Feinaugle Eds., WTO - TRADE IN SERVICES, Max Planck Commentaries on International Trade Law, Martinus Nijhoff Publishers, 2008.

Cottier, T, P, Delimatsis and N. Diebold, Article XIV GATS in Wolfrum, Rudiger, Peter-Tobias Stoll and Clemens Feinaugle Eds., WTO - TRADE IN SERVICES, Max Planck Commentaries on World Trade Law, Martinus Nijhoff Publishers, 2008.

Cottier, Thomas and Martin Molinuevo, Article V GATS in Wolfrum Rudiger, Peter-Tobias Stoll and Clemens Feinaugle Eds., WTO - TRADE IN SERVICES, Max Planck Commentaries on World Trade Law, Martinus Nijhoff Publishers, 2008.

Cottier, Thomas and Petros C. Mavroidis Eds., REGULATORY BARRIERS AND THE PRINCIPLE OF NON-DISCRIMINATION IN WORLD TRADE LAW, World Trade Forum Vol.2, Studies in International Economics, University of Michigan Press, 2000.

Cottier, Thomas, in the preface to Poretti, Pietro, REGULATION OF SUBSIDIES WITHIN THE GENERAL AGREEMENT ON TRADE IN SERVICES, Kluwer Law International 2009.

Cottier, Thomas, Introduction in Cottier, Thomas, Joost Pauwelyn and Elizabeth Burgi Bonanomi Eds., HUMAN RIGHTS AND INTERNATIONAL TRADE, Oxford University Press, 2005.

Coyle, Andrew, Allison Campbell and Rodney Neufeld, CAPITALIST PUNISHMENT: PRISON PRIVATIZATION AND HUMAN RIGHTS, Clarity Press, 2003.

Cranor, C., REGULATING TOXIC SUBSTANCES: A PHILOSOPHY OF SCIENCE AND THE LAW, OUP, 1997.

Croome, John, RESHAPING THE WORLD TRADING SYSTEM: A HISTORY OF THE URUGUAY ROUND, Diane Publishing, 1996 (Also available 2nd (Revised) Edition, from Kluwer Academic Publishers, 1999).

Daly, Michael Eds., THE WTO AND DIRECT TAXATION: WTO DISCUSSION PAPERS, World Trade Organization, 2005.

Daniels, Norman, JUST HEALTH: MEETING HEALTH NEEDS FAIRLY, Cambridge University Press, 2007.

Daniels, Norman, JUST HEALTH CARE, Series: Studies in Philosophy and Health Policy, Cambridge University Press, 1985.

Darcy, Shane and Joseph Powderly Eds., JUDICIAL CREATIVITY AT THE INTERNATIONAL CRIMINAL TRIBUNALS, Oxford University Press, 2010. 
Davey William J., NON-DISCRIMINATION IN THE WORLD TRADE ORGANIZATION: THE RULES AND EXCEPTIONS, Hague Academy of International Law and Martinus Nijhoff Publishers, 2012

Davey, William J., and Joost Pauwelyn, MFN Unconditionality: A Legal Analysis of the Concept in View of its Evolution in the GATT/WTO Jurisprudence with Particular Reference to the Issue of "Like Product" in Cottier, Thomas and Petros C. Mavroidis Eds., REGULATORY BARRIERS AND THE PRINCIPLE OF NON-DISCRIMINATION IN WORLD TRADE LAW, World Trade Forum Vol.2, Studies in International Economics, University of Michigan Press, 2000.

Davies, Gareth, Morality Clauses and Decision-Making in Situations of Scientific Uncertainty: The Case of GMOs, Research Paper No. 10-06, the International Law Forum of the Hebrew University of Jerusalem Law Faculty, presented at a Roundtable on "GMOs and International Trade" held at the Hebrew University of Jerusalem, August 1, 2006

Davis, Jacky and Raymond Tallis, Eds., NHS SOS: HOW THE NHS WAS BETRAYED AND HOW WE CAN SAVE IT, One World Publications, 2013.

De Carvalho, Nuno Pires, THE TRIPS REGIME OF PATENT RIGHTS, Kluwer Law International, 2010.

Declaration on the Human Rights of Individuals Who are Not Nationals of the Country in which They Live, 1985, World Health Assembly Resolution WHA61.17: 7. 'Health of migrants', 2008.

Del Mar, Maksymilian and Oche Onazi The Moral Quality of Work in International Economic Institutions: Resisting Complacency, International Journal of Law in Context, 4, 337-372, 2009, p358.

Delcamp, Alain, Definition and Limits of The Principle of Subsidiarity: Report Prepared for The Steering Committee on Local and Regional Authorities (CDLR), Steering Committee on Local and Regional Authorities, Council of Europe, 1994.

Delgado, Richard, Storytelling for Oppositionists and Others: A Plea for Narrative, Michigan Law Review, Vol. 87, No. 8, Legal Storytelling, August 1989, 2411.

Delimatsis P. and M. Molinuevo, Article XVI GATS in Wolfrum, Rudiger, Peter-Tobias Stoll and Clemens Feinaugle Eds., WTO - TRADE IN SERVICES, Max Planck Commentaries on World Trade Law, Martinus Nijhoff Publishers, 2008.

Delimatsis, P., GATS and Public Healthcare: Reflecting an Uneasy Relationship in Van Calster, Geert and Marie Denise Prévost, Eds., RESEARCH HANDBOOK ON ENVIRONMENT, HEALTH AND THE WTO, Edward Elgar Publishing, 2013

Delimatsis, P. and Martin Molinuevo, Article XVI GATS in Wolfrum, Rudiger., Peter-Tobias Stoll and Clemens Feinaugle Eds., WTO-TRADE IN SERVICES, Max Planck Commentaries on International Trade Law, Martinus Nijhoff Publishers, 2008.

Delimatsis, P. and Bernard Hoekman, National Tax Regulation, International Standards and the GATS: Argentina-Financial Services, EUI Working Papers, RSCAS 2017/42, Robert Schuman Centre for Advanced Studies Global Governance Programme-276).

Delimatsis, P. and Bernard Hoekman. National Tax Regulation, Voluntary International Standards, and the GATS: Argentina-Financial Services." World Trade Review 17.2 (2018): 265-290.

Delimatsis, P., Article XIX GATS in Wolfrum Rudiger, Peter-Tobias Stoll and C. Feinaugle Eds. WTO TRADE IN SERVICES, Max Planck Commentaries on World Trade Law, Martinus Nijhoff Publishers, 2008.

Delimatsis, P., Coherence and Divergence in Agreements on Trade in Services: A Drama in Three Acts, TILEC Discussion Paper, DP 2019-019, 2019, p10.

Delimatsis, P., Due Process and 'Good' Regulation Embedded in the GATS - Disciplining Regulatory Behaviour in Services through Article VI of the GATS, Journal of International Economic Law, 10 (1) $13-50,2006$

Delimatsis, P., INTERNATIONAL TRADE IN SERVICES AND DOMESTIC REGULATIONS: NECESSITY, TRANSPARENCY, AND REGULATORY DIVERSITY, Oxford University Press, 2007.

Delimatsis, P., Protecting Public Morals in a Digital Age: Revisiting The WTO Rulings on US-Gambling and China-Publications and Audiovisual Products, Journal of International Economic Law 14(2), 2011, 257-293, p280-281.

Delimatsis, P., Towards a horizontal necessity test for services: Completing the GATS Article VI:4 mandate in Panizzon, Marion, Nicole Pohl and Pierre Sauve Eds., GATS AND THE REGULATION OF INTERNTIONAL TRADE IN SERVICES, Cambridge University Press, 2008.

Delimatsis, P., Trade in services and regulatory flexibility: 20 years of GATS, 20 years of critique, European Yearbook of International Economic Law 2016, 153-173.

Delimatsis, P., Who's afraid of Necessity? And Why it Matters in Lim, A.H. and Bart de Meester Eds., WTO DOMESTIC REGULATION AND SERVICES TRADE: PUTTING PRINCIPLES INTO PRACTICE, Cambridge University Press, 2014. 
Delimatsis, Panagiotis, Article III GATS: Transparency, WTO - TRADE IN SERVICES, Rüdiger Wolfrum, Peter-Tobias Stoll, Clemens Feinäugle, Eds., Max Planck Commentaries on World Trade Law Vol. 6, Martinus Nijhoff Publishers, 2008.

Delimatsis, Panagiotis, Article IIIbis GATS: Disclosure of Confidential Information in Wolfrum, Rudiger, Peter-Tobias Stoll and Clemens Feinaugle Eds., WTO - TRADE IN SERVICES, Max Planck Commentaries on World Trade Law, Martinus Nijhoff Publishers, 2008.

Delimatsis, Panagiotis, Determining the Necessity of Domestic Regulations in Services: The Best is Yet to Come, The European Journal of International Law Vol. 19, No. 2, p365-408.

Delmas-Marty, Mireille, THE EUROPEAN CONVENTION FOR THE PROTECTION OF HUMAN RIGHTS: INTERNATIONAL PROTECTION VERSUS NATIONAL RESTRICTIONS, Martinus Nijhoff Publishers, 1992.

Desierto, Diane A., PUBLIC POLICY IN INTERNATIONAL ECONOMIC LAW: THE ICESCR IN TRADE, FINANCE, AND INVESTMENT, Oxford University Press, 2015.

Desmedt, Axel, Proportionality in WTO Law, Journal of International Economic Law, 4 2001, 441-480.

Diebold, Nicholas F., NON-DISCRIMINATION IN INTERNATIONAL TRADE IN SERVICES: 'LIKENESS' IN WTO/GATS, Cambridge University Press.

Donaldson, Victoria, The Appellate Body: Institutional and Procedural Aspects Arthur E. and Michael G. Plummer Eds., THE WORLD TRADE ORGANIZATION: LEGAL, ECONOMIC AND POLITICAL ANALYSIS, Springer, 2007 p1259-1261.

Drake, William J and Kalypso Nicolaidis, Ideas, Interests, and Institutionalization: "Trade in Services" and the Uruguay Round, International Organization, Vol. 46, No. 1, Knowledge, Power, and International Policy Coordination (Winter, 1992), p37-100.

Drake, William J. and Kalypso Nicolaidis, Ideas, Interests, and Institutionalization: 'Trade in Services' and the Uruguay Round, International Organization, Vol. 46, No. 1, Winter, 1992, p40.

Duncan, R. Paul, Michael E. Morris and Linda E. MacCarey, Canada (Chapter 4) in James A. Johnson and Carleen Harriet Stoskopf Eds., COMPARATIVE HEALTH SYSTEMS: GLOBAL PERSPECTIVES, Jones \& Bartlett Learning, 2010.

Dunne, Matthew, S. III, Redefining Power Orientation: A Reassessment of Jackson's Paradigm in Light of Asymmetries of Power, Negotiation, and Compliance in the GATT/WTO Dispute Settlement System, Law and Policy in 34 International Business, 2002-2003, 277, p342.

Dunning, John H. Multinational Enterprises and the Growth of Services: Some Conceptual and Theoretical Issues, The Service Industries Journal, Volume 9, Issue 1, 1989, p5-39.

Dworkin, Ronald, SOVEREIGN VIRTUE: THE THEORY AND PRACTICE OF EQUALITY, Harvard University Press 2000

Dworkin, Ronald, What is Equality? Part 1: Equality of Welfare, Philosophy and Public Affairs 10 1981, pp. $185-246$

Dworkin, Ronald, What is Equality? Part 2: Equality of Resources, Philosophy and Public Affairs 101981 , pp. 283-345

Edwards, S., Openness, Trade Liberalization, and Growth in Developing Countries, Journal of Economic Literature, Vol. 31, No. 3, September 1993, p1358.

Ehlermann C-D. and L. Ehring, The Authoritative Interpretation Under Article IX:2 of the Agreement establishing the World Trade Organization: Current Law, Practice and Possible Improvements, 8 JIEL 803, 2005, 81.

Ehlermann, C-D., Six Years on the Bench of the "World Trade Court", in Ortino, Federico and Petersman, Ernst-Ulrich Eds. THE WTO DISPUTE SETTLEMENT SYSTEM 1995-2003, Kluwer Law International, 2004.

Ekins, Paul and Tancredi Voituriez, Overview and General Introduction in Ekins, Paul and Tancredi Voituriez Eds., TRADE, GLOBALIZATION AND SUSTAINABILITY IMPACT ASSESSMENT: A CRITICAL LOOK AT METHODS AND OUTCOMES, Earthscan 2009/ Routledge 2012.

Elster, Jon, ULYSSES AND THE SIRENS: STUDIES IN RATIONALITY AND IRRATIONALITY, Cambridge University Press, 1979.

Elster, Jon, ULYSSES UNBOUND: STUDIES IN RATIONALITY, PRECOMMITMENT, AND CONSTRAINTS, Cambridge University Press, 2000.

Emberland, Marius, THE HUMAN RIGHTS OF COMPANIES; EXPLORING THE STRUCTURE OF ECHR PROTECTION, Oxford University Press, 2006.

Epps, Tracy and Michael J. Trebilcock, RESEARCH HANDBOOK ON THE WTO AND TECHNICAL BARRIERS TO TRADE, Edward Elgar Publishing, 2013. 
Fairclough, Norman, DISCOURSE AND SOCIAL CHANGE, Wiley Blackwell, 1993 p51, citing Foucault, M, The Order of Discourse in Shapiro, Michael J. (Ed.) LANGUAGE AND POLITICS, New York University Press, 1984.

Feddersen Christoph T., Focusing on Substantive Law in International Economic Relations: The Public Morals of GATT's Article XX(a) and "Conventional" Rules of Interpretation, 7 Minn. J. Global Trade 75, 1998, p78.

Feinaugle, C., Article XXVIII GATS in Wolfrum, Rudiger, Peter-Tobias Stoll and Clemens Feinaugle Eds., WTO - TRADE IN SERVICES, Max Planck Commentaries on World Trade Law, Martinus Nijhoff Publishers, 2008.

Feketekuty, Geza, Assessing And Improving The Architecture of GATS in Sauvé, Pierre And Stern, Robert M. Eds., Gats 2000, NEW DIRECTIONS IN SERVICES TRADE LIBERALIZATION, Brookings Institution Press, 2000.

Feketekuty, Geza, INTERNATIONAL TRADE IN SERVICES: AN OVERVIEW AND BLUEPRINT FOR NEGOTIATIONS, Ballinger Publishers and |The American Enterprise Institute, 1988.

Feketekuty, Geza, Trade in Services - Bringing Services in the Multilateral Trading System in Bhagwati, J. and Mathias Hirsch, THE URUGUAY ROUND AND BEYOND, ESSAYS IN HONOUR OF ARTHUR DUNKEL, University of Michigan Press, 1998.

Fidler, David P., Carlos Correa and Obijiofor Aginam, DRAFT LEGAL REVIEW OF THE GENERAL AGREEMENT ON TRADE IN SERVICES (GATS) FROM A HEALTH POLICY PERSPECTIVE, WHO, 2005.

Fidler, David P., Nick Drager, Carlos Correa and Obijior Aginam, Making Commitments in Health Services under the GATS: Legal Dimensions in Blouin, Chantal, Nick Drager and Richard Smith Eds., INTERNATIONAL TRADE IN HEALTH SERVICES AND THE GATS: CURRENT ISSUES AND DEBATES, The World Bank, 2006.

Filmer, Deon, Jeffrey S. Hammer and L. H. Pritchett, Weak Links in the Chain II: A Prescription for Health Policy in Poor Countries, The World Bank Research Observer, Vol. 17, No. 1 (Spring, 2002), p47

Finnis, J. M., Developments in Judicial Jurisprudence, Adelaide Law Review, 1962; 1(3): 317-338.

Fitzmaurice, G., The Law and Procedures of the International Court of Justice: Treaty Interpretation and Certain Other Points (1951) 28 B.Y.I.L. 1.

FitzMaurice, G., Treaty Interpretation and Other Treaty Points 1951-54, British Yearbook of International Law, 33, 1957, 203-293.

Fitzmaurice, M. and Panos Merkouris, Canons of Treaty Interpretation: Selected Case Studies from the World Trade Organization and the North American Free Trade Agreement in Fitzmaurice, M., Olufemi A. Elias and Panos Merkouris Eds., TREATY INTERPRETATION AND THE VCLT; 30 YEARS ON, BRILL, 2010, 153.

Flood, Colleen, and Aeyal Gross, THE RIGHT TO HEALTH AT THE PUBLIC/PRIVATE DIVIDE: A GLOBAL COMPARATIVE STUDY, Cambridge University Press, 2014.

Fontanelli Filippo, Necessity Killed the GATT - Art XX GATT and the Misleading Rhetoric about 'Weighing and Balancing', European Journal of Legal Studies, Volume 5, Issue 2, Autumn/Winter 2012/13, p36-56.

Footer, Mary and Saman Zia-Zarifi, EC-Asbestos: The World Trade Organization on Trial for its Handling of Occupational Health and Safety Issues, Melbourne Journal of International Law, Vol. 3, 2002.

Footer, Mary E. and Carol George, The General Agreement on Trade in Services in Macrory, Patrick F. J, Arthur Edmond Appleton and Michael G. Plummer, Eds., THE WORLD TRADE ORGANIZATION: LEGAL, ECONOMIC AND POLITICAL ANALYSIS, VOL. II, Springer 2005.

Frank, Arthur, W., What's Wrong with Medical Consumerism? in Henderson, Saras, and Petersen, Alan, Eds., CONSUMING HEALTH: THE COMMODIFICATION OF HEALTH CARE, Routledge, 2002, p25.

Frankel, Jeffrey A. and David Romer, Does Trade Cause Growth? The American Economic Review, Vol. 89, No. 3, June 1999, p379

Freedman, Lynn P., Reflections on Emerging Frameworks of Health and Human Rights in Mann, Jonathan M., Sofia Gruskin, Michael A. Grodin and George J. Annas Eds., HEALTH AND HUMAN RIGHTS: A READER, Routledge, 1999.

Freeman, Marsha A., Beate Rudolf and Christine Chinkin Eds., THE UN CONVENTION ON THE ELIMINATION OF ALL FORMS OF DISCRIMINATION AGAINST WOMEN: A COMMENTARY, Oxford University Press, 2012.

French, Duncan, Sustainable Development in Fitzmaurice, Malagosia, David M. Ong and Panos Merkouris Eds., RESEARCH HANDBOOK ON INTERNATIONAL ENVIRONMENTAL LAW, Edward Elgar Publishing, 2010. 
Gao, Henry S., Aggressive Legalism: The East Asian Experience and Lessons for China in Gao, Henry S. and Donald Lewis Eds. CHINA'S PARTICIPATION IN THE WTO, Cameron May, 2005.

Gao, Henry, Annex on Telecommunications in Wolfrum, Rudiger, Peter-Tobias Stoll and Clemens Feinaugle Eds., WTO - TRADE IN SERVICES, Max Planck Commentaries on World Trade Law, Martinus Nijhoff Publishers, 2008.

Gardiner, Richard, TREATY INTERPRETATION, Oxford University Press, 2008.

Garfield, Richard, The Impact of Economic Sanctions on Health and Well-being, Relief and Rehabilitation Network Paper 31, November 1999.

Gazzini, T., Can Authoritative Interpretation Under Article IX: of the Agreement Establishing the WTO Modify the Rights and Obligations of Members?, International and Comparative Law Quarterly 57(1), 2008, 169.

George, Susan, Globalizing Rights? in Gibney, Matthew J., Ed., GLOBALIZING RIGHTS: THE OXFORD AMNESTY LECTURES 1999, Oxford University Press, 2003

Gibbs, Murray and Mina Mashayeki Elements of a Multilateral Framework for Trade in Services, 14 N.C.J. Int'l L. \& Com. Reg. 1, 1989.

Gomula, Joanna, Environmental Disputes in the WTO in Fitzmaurice, Malagosia, David M. Ong and Panos Merkouris Eds., RESEARCH HANDBOOK ON INTERNATIONAL ENVIRONMENTAL LAW, Edward Elgar Publishing, 2010

Gonzales, C.G., Beyond Eco-Imperialism: An Environmental Justice Critique of Free Trade, Denver University Law Review, 78(4), 2001, 979-1016.

Gostin, Lawrence, PUBLIC HEALTH LAW: POWER, DUTY, RESTRAINT, 1st Edition, 2000.

Gostin, Lawrence O., and Devi Sridhar, Global Health and the Law, The New England Journal of Medicine 370;18, May 1, 2014

Grant, Stephanie, Functional Distinction or Bilingualism: Human Rights and Trade - the UN Human rights system in Abbot, Frederick M., Christine Breining-Kaufman and Thomas Cottier (Eds.) INTERNATIONAL TRADE AND HUMAN RIGHTS: FOUNDATIONS AND CONCEPTUAL ISSUES, University of Michigan Press, 2006.

Grear, Anna, Challenging Corporate 'Humanity': Legal Disembodiment, Embodiment and Human Rights, 7 Human Rights Law Review, 2007,511, 515-17; Emberland, Marius, THE HUMAN RIGHTS OF COMPANIES: EXPLORING THE STRUCTURE OF ECHR PROTECTION, Oxford University Press, 2006.

Gregory Shaffer and Yvonne A. Mensah, Law and Politics of Rights: Who Decides the Conditions for Trade Preferences: Institutional Choice in the General System of Preferences Case. Journal of World Trade, 39(5) 2005, p977.

Greig, Don, The Time of Conclusion and the Time of Application of Treaties as Pointsof reference in the Interpretive Process in Craven, Maththew, Malgosia Fitzmaurice and Maria Vogiatzi Eds., TIME, HISTORY AND INTERNATIONAL LAW, Martinus Nijhoff Publishers, 2007.

Grieshaber-Otto, Jim and Scott Sinclair, BAD MEDICINE: TRADE TREATIES, PRIVATIZATION, AND HEALTH CARE REFORM IN CANADA, Canadian Centre for Policy Alternatives, 2004.

Grote, Rainer, Article IV GATS in Wolfrum, Rudiger., Peter-Tobias Stoll and Clemens Feinaugle Eds., WTO-TRADE IN SERVICES, Max Planck Commentaries on International Trade Law, Martinus Nijhoff Publishers, 2008

Guillod, Olivier, Market Integration in a Small Federal State (Switzerland): The Role of Public Health in Cottier, Thomas and Petros C. Mavroidis Eds., REGULATORY BARRIERS AND THE PRINCIPLE OF NON-DISCRIMINATION IN WORLD TRADE LAW, University of Michigan Press, 2000.

Gunatilleke, Godfrey and Aleya El Bindari Hammad, Eds., HEALTH: THE COURAGE TO CARE, WHO/HPD/97.3, WHO, 1997.

Gunatilleke, Godfrey, The Right to Development in Sri Lanka, in Sengupta, Arjun, Archna Negi and Moushumi Basu Eds., REFLECTIONS ON THE RIGHT TO DEVELOPMENT, SAGE Publications India, 2005.

Gupta, S., M. Verhoeven, and E. Tiongson, Public Spending on Health Care and the Poor, Health Economics 2003 12(8): 685-96.

Ham, Chris and Lorraine Hawkins, Implementing Organizational Reforms to Hospitals in the Public Sector in Preker, Alexander S, and April Harding Eds. INNOVATIONS IN HEALTH SERVICES DELIVERY: THE CORPORATIZATION OF PUBLIC HOSPITALS, World Bank, 2003.

Hammonds, Rachel, Gorik Ooms, Moses Mulumba, and Allan Maleche, UHC2030's Contributions to Global Health Governance that Advance the Right to Health Care: A Preliminary Assessment, Health and Human rights Journal, November 21, 2019. 
Harding, April and Alexander S. Preker Eds., PRIVATE PARTICIPATION IN HEALTH SERVICES, World Bank, 2003.

Hauser, Heinz, Foreign Trade Policy and the Function of Rules for Trade Policy Making, in Detlev, Christian D. and Ernst-Ulrich Petersmann Eds., FOREIGN TRADE IN THE PRESENT AND THE NEW INTERNATIONAL ECONOMIC ORDER, Series: Progress and Undercurrents in Public International Law, Vol. 4, University of Fribourg Press, 1988.

Hawthorne, Helen, LEAST DEVELOPED COUNTRIES AND THE WTO: SPECIAL TREATMENT IN TRADE, Palgrave MacMillan, 2013.

Henkin, L, The Mythology of Sovereignty, American Society of International Law Newsletter, March-May 1993.

Hernandez, Gleider, Interpretative Authority and the International Judiciary in Andrea Bianchi, Daniel Peat, Matthew Windsor, Eds., INTERPRETATION IN INTERNATIONAL LAW, Oxford University Press, 2015.

Hernandez-Truyol, B.E. and S.J. Powell, JUST TRADE: A NEW COVENANT LINKING TRADE AND HUMAN RIGHTS, NYU Press, 2009, p95.

Hervey, Tamara, EUROPEAN SOCIAL LAW AND POLICY, Longman, 1998, p8-10.

Hestermeyer, H., Preamble, General Agreement on Trade in Services in Wolfrum, Rudiger, Peter-Tobias Stoll and Clemens Feinaugle Eds., WTO - TRADE IN SERVICES, Max Planck Commentaries on World Trade Law, Martinus Nijhoff Publishers, 2008.

Higgins, Rosalyn, A Babel of Judicial Voices? Ruminations from the Bench, The International and Comparative Law Quarterly, Vol. 55, No. 4, October 2006, p791- 804.

Hobbins, A.J., Rene Cassin and the Daughter of Time: The First Draft of the Universal Declaration of Human Rights, Fontanus Vol. 2 (1989) p7.

Hoekman, Bernard, Aaditya Mattoo and André Sapir, The Political Economy of Services Trade Liberalization: A Case For International Regulatory Cooperation? Oxford Review of Economic Policy 2007 23(3):367.

Hoekman, Bernard, Assessing the General Agreement on Trade in Services in Martin, W., and L. Alan Winters, Eds., The Uruguay Round and Developing Countries, Cambridge University Press, World Bank, 1996.

Hoekman, Bernard, Developing Countries and the Uruguay Round: Negotiating on Services, World Bank Policy Research Working Paper No.1220, 1993.

Hoekman, Bernard, Liberalizing Trade in Service, a Survey, World Bank Policy Research Working Paper 4030, 2006.

Holmes, David, IARC in the dock over ties with asbestos industry, The Lancet, Volume 381, Issue 9864, 359 - 361, 2 February 2013.

Horn, Henrik and Joseph Weiler, European Communities-Trade Description of Sardines: Textualism and its Discontent, in Horn Henrik and Mavroidis Petros C. Eds., THE WTO CASE LAW OF 2002, Cambridge University Press, 2005.

Howse Robert and Kalypso Nicolaidis, Enhancing WTO Legitimacy: Constitutionalization or Global Subsidiarity? in Verweij, Marco and T. Josling Eds., DELIBERATELY DEMOCRATIZING MULTILATERAL ORGANIZATION, special issue of Governance Vol. 16, No. 1, 2003.

Howse Robert, Human Rights in the WTO: Whose Rights, What Humanity?: Comment on Petersmann, Jean Monnet Working Paper No.12/02, Symposium: Trade and Human Rights: An Exchange, 2002.

Howse, Robert and Elizabeth Tuerk, The WTO Impact on Internal Regulation - A case study of Canada-EC Asbestos Dispute in De Burca G., and J. Scott Eds., THE EU AND THE WTO: LEGAL, CONSTITUTIONAL ISSUES, Hart Publishing 2001.

Howse, Robert and Kalypso Nicolaidis, Legitimacy and Global Governance: Why Constitutionalizing the WTO is a Step Too Far in Porter Roger B. et al., Eds., EFFICIENCY, EQUITY, AND LEGITIMACY: THE MULTILATERAL TRADING SYSTEM AT THE MILLENNIUM, Brookings, 2001.

Howse, Robert, Back to Court after Shrimp/Turtle? Almost but not quite yet: India's short-lived challenge to labour and environmental exceptions in the European Unions generalized system of preferences, American University International Law Review Vol. 18, No. 6, 2003, 1333.

Howse, Robert, Democracy, Science, and Free Trade: Risk Regulation on Trial at the World Trade Organization, 98 Michigan Law Review 2329.

Howse, Robert, Human Rights, International Economic Law and Constitutional Justice: A Reply, European Journal of International Law Vol. 19, No. 5, p945.

Howse, Robert, Sovereignty, Lost and Found in Shan, Wenhua, REDEFINING SOVEREIGNTY IN INTERNATIONAL ECONOMIC LAW, Hart Publishing, 2008. 
Howse, Robert, The End of the Globalization Debate in Meredith Kolsky Lewis, Susy Frankel, Eds., INTERNATIONAL ECONOMIC LAW AND NATIONAL AUTONOMY, Cambridge University Press, 2010.

Howse, Robert, The House That Jackson Built: Restructuring the GATT System, Michigan Journal of International Law, 1999, Vol. 20.

Howse, Robert, The Most Dangerous Branch? WTO Appellate Body Jurisprudence on the Nature and Limits of Judicial Power in Cottier, Thomas and Petros Mavroidis Eds. THE ROLE OF THE JUDGE IN INTERNATIONAL TRADE REGULATION - EXPERIENCE AND LESSONS FOR THE WTO, World Trade Forum, IV, 11, 2003.

Howse, Robert, The use and abuse of other "relevant rules of international law" in treaty interpretation: insights from WTO trade/environment litigation, NYU, IILJ Working Paper 2007/1.

Howse, Robert, The WHO/WTO Study on Trade and Public Health: A Critical Assessment, Journal of Risk Analysis, Vol.24, Issue 2, 2004, 501.

Howse, Robert, The WHO/WTO Study on Trade and Public Health: A Critical Assessment, Journal of Risk Analysis, Vol.24, Issue 2, 2004, 501.

Howse, Robert., Adjudicative Legitimacy and Treaty Interpretation in International Trade Law: The Early Years of WTO Jurisprudence, in Weiler, Joseph H. H. Ed, THE EU, THE WTO, AND THE NAFTA: TOWARDS A COMMON LAW OF INTERNATIONAL TRADE?, Oxford University Press, 2000.

Howse, Robert, The World Trade Organization 20 Years On: Global Governance by Judiciary, EJIL (2016), Vol. 27 No. 1, 9-77.

Howse, Robert, Economics for Progressive International Lawyers: A Review Essay, 5 London Review of International Law 2017, 187-196

Hudec, Robert E., (ed. Joel Trachtman) DEVELOPING COUNTRIES IN THE GATT/WTO LEGAL SYSTEM, Rowman \& Littlefield /Cordell Hull Institute and Gower Publishing, 1987.

Hudec, Robert, The GATT Legal System: A Diplomats Jurisprudence, Journal of World Trade 4, 1970, 615, p665

Irem, Dogan, Taking a Gamble on Public Morals: Invoking the Article XIV Exception to GATS, Brooklyn Journal of International Law, 32 Vol 3, 2007, p1131-1156.

Irwin Douglas A., and Joseph Weiler, Measures Affecting the Cross-Border Supply of Gambling and Betting Services (DS 285), 7 World Trade Review, 2008, 71, p94-95.

Ishay, Micheline, THE HISTORY OF HUMAN RIGHTS: FROM ANCIENT TIMES TO THE GLOBALIZATION ERA, University of California Press, 2008.

Jackson, John H., Perspectives on the Jurisprudence of International Trade: Costs and Benefits of Legal Procedures in the United States, Michigan Law Review, 82, 1984, p1570-71

Jackson, John H., Reflections on the Possible Research Agenda for Exploring the Relationship between Human Rights Norms and International Trade Rules in Frederick M. Abbott, Christine BreiningKaufmann and Thomas Cottier Eds., INTERNATIONAL TRADE AND HUMAN RIGHTS: FOUNDATIONS AND CONCEPTUAL ISSUES, Studies in International Economics, University of Michigan Press, 2006.

Jackson, John H., Sovereignty, Subsidiarity and Separation of Powers in Kennedy, Daniel L. and James D. Southwick, THE POLITICAL ECONOMY OF ITNERNATIONAL TRADE LAW: ESSAYS IN HONOR OF ROBERT E. HUDEC, Cambridge University Press, 2002.

Jackson, John H., SOVEREIGNTY, THE WTO AND CHANGING FUNDAMENTALS OF INTERNATIONAL LAW, Cambridge University Press, 2006.

Jackson, John H., THE JURISPRUDENCE OF GATT AND THE WTO: INSIGHTS ON TREATY LAW AND ECONOMIC RELATIONS, Cambridge University Press, 2000 (Reprint).

Jackson, John H., THE WORLD TRADING SYSTEM: LAW AND POLICY OF INTERNATIONAL ECONOMIC RELATIONS, 2nd Edition, 1997.

Jackson, John, H., SOVEREIGNTY, THE WTO AND CHANGING FUNDAMENTALS OF INTERNATIONAL LAW, Cambridge University Press, 2006.

Jackson, John, H., The WTO 'Constitution' and Proposed Reforms: Seven 'Mantras' Revisited, Journal of International Economic Law (2001) 4 (1): 67-78.

Jacobs, F. L., Varieties of Approach to Treaty Interpretation: With Special Reference to the Draft Convention on the Law of Treaties Before the Vienna Diplomatic Conference, 18 ICLQ 318, 1969, p319-320.

Jacobs, Lawrence R. and Theda Skocpol, HEALTH CARE REFORM AND AMERICAN POLITICS: WHAT EVERYONE NEEDS TO KNOW, Oxford University Press, (Revised), 2012. 
James Taylor, Translating Hospitality: Paul Ricoeur's Ethics of Translation, The New Arcadia Review, Vol. $4, \quad 2011$,
http://www.bc.edu/publications/newarcadia/archives/4/translating hospitality/.

Jennings, R. And Watts, A., OPPENHEIM'S INTERNATIONAL LAW, VOL.I, (9th Ed.) Oxford University Press, 2008

Johnson, Debra and Colin Turner, Eds. INTERNATIONAL BUSINESS: THEMES AND ISSUES IN THE MODERN GLOBAL ECONOMY, Routledge, 2003.

Johnston, Ian C, SOPHOCLES' ANTIGONE, Richer Resources Publications, 2007.

Jos Draijer, Netherlands Permanent representative to the EU, speaking at Effective Cross Border Healthcare: Next Generation, EUregio II Conference, 16 November 2011, Maastricht.

Joseph, Sarah, BLAME IT ON THE WTO: A HUMAN RIGHTS CRITIQUE, Oxford University Press 2013.

Joseph, Sarah, Human Rights and International Economic Law, in Bungenberg M., C. Herrmann, M.Krajewski, J. Terhechte. eds., EUROPEAN YEARBOOK OF INTERNATIONAL ECONOMIC LAW, Vol 7., Springer, 2016.

Kapterian, Gisele, A Critique of the WTO Jurisprudence on 'Necessity', 59 ICLQ 89, 2010.

Kaufman, Walter Arnold, TRAGEDY AND PHILOSOPHY, Princeton University Press 1979, reprinted in 1992, p201-202

Kaul Inge, Isabelle Grunberg and Mark A. Stern Eds., GLOBAL PUBLIC GOODS: INTERNATIONAL COOPERATION INTO THE 21ST CENTURY, Oxford University Press and United Nations Development Program,1999.

Keck, Alexander and Patrick Low, Special and Differential Treatment in the WTO: Why, When and How?, Economic Research and Statistics Division Staff Working Paper, ERSD-2004-03, WTO, May, 2004.

Keeler, H. and Leena Grover, General Comments of the Human Rights Committee and their Legacy in Keller, H. and Geir Ulfstein Eds., UN HUMAN RIGHTS TREATY BODIES: LAW AND LEGITIMACY, Cambridge University Press, 2012.

Kelsen, Hans, THE LAW OF THE UNITED NATIONS: A CRITICAL ANALYSIS OF ITS FUNDAMENTAL PROBLEMS, Law Book Exchange, 1950.

Kelsey, Jane, SERVING WHOSE INTEREST: THE POLITICAL ECONOMY OF TRADE IN SERVICES AGREEMENTS, Routledge, 2008.

Kennedy, Daniel L. and James D. Southwick, THE POLITICAL ECONOMY OF INTERNATIONAL TRADE LAW: ESSAYS IN HONOR OF ROBERT E. HUDEC, Cambridge University Press, 2002.

Kennedy, David, Reassessing International Humanitarianism: The Dark Side in Orford Anne, Ed., INTERNATIONAL LAW AND ITS OTHERS, Cambridge University Press, 2009.

Kennedy, David, The International Human Rights Movement: Part of the Problem?, Harvard Human Rights Journal, Volume 14, 2002, 101.

Kennedy, Kevin, Special and Differential Treatment of Developing Countries in Macrory, Patrick, Arthur Appleton and Michael Plummer, THE WORLD TRADE ORGANIZATION: LEGAL, ECONOMIC AND POLITICAL ANALYSIS, VOL. II, Springer, 2005.

Kinley, David, Ed., HUMAN RIGHTS AND CORPORATIONS, Ashgate Press, 2009. Kinney, Eleanor D., The international human right to health: What does this mean for our nation and world, Ind. L. Rev. 34 (2000): 1457

Kinney, Eleanor D. and Brian Alexander Clark, Provisions for health and health care in the constitutions of the countries of the world, Cornell Int'l LJ 37 (2004): 285.

Klabbers, J., Jurisprudence in International Trade Law: Article XX of the GATT, Journal of World Trade, $1992,88$.

Klabbers, Jan, AN INTRODUCTION TO INTERNATIONAL INSTITUTIONAL LAW, Cambridge University Press 2003, p 96.

Knoll, David D. The Impacts of Security Concerns upon International Economic Law, Syracuse Journal of International Law and Commerce, 11, 1984, p587.

Koh, Harold H., How is International Human Rights Law Enforced, Indiana Law Journal, 74:4, 1999, 1397 1417

Koivusalo M. J., World Trade Organization and Trade-Creep in Health Services, Health Services Research and Policy, April 6(2):65-7, 2001

Koskenniemi, M., Report of the ILC Study Group, Fragmentation of International Law: Difficulties Arising from the Diversification and Expansion of International Law. Doc.A/CN.4/L.682 and Add.1. and Corr. 1, 2 May 2006. 
Koskenniemi, M., Study on the Function and Scope of the Lex Specialis Rule and the Question of 'SelfContained Regimes, UN Doc. ILC (LVI)/SG/FIL/CRD.1/Add.1, 2004.

Koskenniemi, M., THE POLITICS OF INTERNATIONAL LAW, Hart Publishing, 2011.

Krajewski, M, Article VI GATS in Wolfrum, Rudiger, Peter-Tobias Stoll and Clemens Feinaugle Eds., WTO - TRADE IN SERVICES, Max Planck Commentaries on World Trade Law, Martinus Nijhoff Publishers, 2008.

Krajewski, M, Article XVIII of the GATS in Wolfrum, Rudiger, Peter-Tobias Stoll and Clemens Feinaugle Eds., WTO - TRADE IN SERVICES, Max Planck Commentaries on World Trade Law, Martinus Nijhoff Publishers, 2008.

Krajewski, M. and Maika Engelke, Article XVII GATS in Wolfrum, Rudiger., Peter-Tobias Stoll and Clemens Feinaugle Eds., WTO-TRADE IN SERVICES, Max Planck Commentaries on International Trade Law, Martinus Nijhoff Publishers, 2008.

Krajewski, M., Article VII GATS in Wolfrum, Rudiger, Peter-Tobias Stoll and Clemens Feinaugle Eds., WTO - TRADE IN SERVICES, Max Planck Commentaries on World Trade Law, Martinus Nijhoff Publishers, 2008.

Krajewski, M., Commodifying and Embedding Services of General Economic Interest in Transnational Contexts -The example of healthcare liberalization in the EU and the WTO in Jorges, Christian and Joseph Falke Eds., KARL POLANYI - GLOBALIZATION AND THE POTENTIAL OF LAW IN TRANSNATIONAL MARKETS, Hart Publishing, 2011.

Krajewski, M., NATIONAL REGULATION AND TRADE LIBERALIZATION IN SERVICES: THE LEGAL IMPACT OF THE GENERAL AGREEMENT ON TRADE IN SERVICES (GATS) ON NATIONAL REGULATORY AUTONOMY, Kluwer Law International, 2003.

Krajewski, M., Playing by the Rules of the Game? Specific Commitments after US-Gambling and Betting and the Current GATS Negotiations, Legal Issues of Economic Integration, 32 (4), 2005, 417-447.

Krajewski, M., Public Services and Trade Liberalization: Mapping the Legal Framework, Journal of International Economic Law, Vol. 6, No. 2, 2003, 341-367.

Krajewski, M., Democratic Legitimacy and Constitutional Perspectives of WTO Law, Journal of World Trade 35, 167, 2001.

Krajewski, Markus, Services Liberalisation in Regional Trade Agreements: Lessons for GATS 'Unfinished Business'? and Kwak, Kyung and Gabrielle Marceau, Overlaps and Conflicts of Jurisdiction Between the WTO and RTA's in Bartels L. and Federico Ortino, Eds., REGIONAL TRADE AGREEMENTS AND THE WTO LEGAL SYSTEM Oxford University Press, 2006.

Krajweski, M., Public Services and the Scope of the General Agreement on Trade in Services (GATS), A Research Paper written for the Center for International Environmental Law (CIEL), 2001 p7-8

Kretzmer D. and E. Klein, Ed., THE CONCEPT OF HUMAN DIGNITY IN HUMAN RIGHTS DISCOURSE, Kluwer Law International, 2002.

Kuanpoth, Jakkrit, Intellectual Property Protection after TRIPS: An Asian Experience in Malbon, Justin and Charles Lawson Eds., INTERPRETING AND IMPLEMENTING THE TRIPS: IS IT FAIR?, Edward Elgar Publishing, 2008

Lal, Deepak and Sarath Rajpatirana, Foreign Trade Regimes and Economic Growth in Developing Countries, World Bank Research Observatory, 1987, 2(2).

Lang, Andrew T. F., Reconstructing Embedded Liberalism: John Gerard Ruggie and Constructivist Approaches to the Study of the International Trade Regime, Journal of International Economic Law, Vol. 9, No. 1, March 2006 pp. 81-116

Lang, Andrew T.F., WORLD TRADE LAW AFTER NEOLIBERALISM: REIMAGINING THE GLOBAL ECONOMIC ORDER, Oxford University Press, 2011.

Lang, Andrew, The GATS and Regulatory Autonomy: A Case Study of Social Regulation of the Water Industry, Journal of International Economic Law, 7, 2004

Larson, Mildred L., MEANING-BASED TRANSLATION: A GUIDE TO CROSS-LANGUAGE EQUIVALENCE, 2nd Edition, University of America Press, 1998

Le, Uyen P., Online and Linked In: "Public Morals" in the Human Rights and Trade Networks, North Carolina Journal of International Law and Commercial Regulation, 2012, 38, 107.

Leader, Sheldon, Trade and Human Rights II in Macrory, Patrick, F. J., Arthur E. Appleton and Michael G. Plummer Eds., The WORLD TRADE ORGANIZATION: LEGAL ECONOMIC AND POLITICAL ANLAYSIS, VOLUME II, Springer, 2005.

Lee, Daniel E., and Elizabeth J. Lee, HUMAN RIGHTS AND THE ETHICS OF GLOBALIZATION, Cambridge University Press, 2010.

Lee, Y.S., Bilateralism under the World Trade Organization, 26 North Western University Journal of International Law and Business, 357, 2006. 
Lennard, Michael, Navigating by the Stars: Interpreting the WTO Agreements, 5(1) Journal of International Economic Law, 17.

Leroux, Eric, What is a 'Service Supplied in the Exercise of Governmental Authority' under Article I:3(b) and (c) of the General Agreement on Trade in Services?, Journal of World Trade, 40, 2006, p345.

Letsas, George, A THEORY OF INTERPRETATION OF THE ECHR, Oxford University Press, 2007.

Letsas, George, Intentionalism and Interpretation of the ECHR in Fitzmaurice, M., Olufemi A. Elias and Panos Merkouris Eds., TREATY INTERPRETATION AND THE VCLT; 30 YEARS ON, BRILL Publications, 2010.

Levenstein, Margaret C., and Valerie Y. Suslow, Private International Cartels and their Effect on Developing Countries, Background paper for the World Bank's World Development Report 2001.

Lianos, Ioannis and Okeoghene Odudu, Eds., REGULATION TRADE IN SERVICES IN THE EU AND WTO: TRUST, DISTRUST AND ECONOMIC INTEGRATION, Cambridge University Press, 2012.

Linarelli John, The WTO Transparency Agenda: Law, Economic and International Relations Theory in Arrowsmith, S. and M. Trybus Eds., PUBLIC PROCUREMENT: THE CONTINUING REVOLUTION, Kluwer Law International, 2003.

Linarelli, John, Margot E. Salomon, M. Sornarajah, Chapter 2: Confronting the Pathologies of International Law: From Neoloberalism to Justice in THE MISERY OF INTERNATIONAL LAW: CONFRONTATIONS WITH INJUSTICE IN THE GLOBAL ECONOMY, Oxford University Press, 2018.

Linderfalk, UIf, ON THE INTERPRETATION OF TREATIES: THE MODERN INTERNATIONAL LAW AS EXPRESSED IN THE 1969 VIENNA CONVENTION ON THE LAW OF TREATIES, Spinger, 2007.

Linderfalk, Ulf, Who are 'The Parties'? - Article 31, Paragraph 3(C), The 1969 Vienna Convention and the 'Principle of Systemic Integration' Revisited, Netherlands International Law Review, Volume 55, Issue 03, December 2008.

Lindroos, Anja and Mehling, Michael, Dispelling the Chimera of 'Self-Contained Regimes', International Law and the WTO, European Journal of International Law 2005 16(5):857-877.

Lloyd, Denis, THE IDEA OF LAW, Penguin Books, first published 1964.

Lo, Chang-Fa, Eight rules for the good faith use of dictionaries in interpreting the WTO covered agreements (Good Faith Use of Dictionary in the Search of Ordinary Meaning under the WTO Dispute Settlement Understanding), Journal of International Dispute Settlement, 2010, 1 (2), p431 445 .

Lo, Chang Fa, A Proper Balance between WTO's Members-Driven Nature and the Appellate Body's Role as an Adjudicator - Careful Exercise of Judicial Activism in Lo, Chang-fa, Junji Nakagawa and Tsai-fang Chen Eds., THE APPELLATE BODY OF THE WTO AND ITS REFORM, Springer, 2019, p125-140

Luff, David, Regulation of Health Services and International Trade Law in Mattoo, A. and P. Sauvé Eds., DOMESTIC REGULATION AND SERVICES TRADE LIBERALISATION, The World Bank/Oxford University Press, 2003

Luja, R. H. C, The WTO Subsidies Regime: Are there Lessons to be Learnt from Recent EC State Aid Issues? in Lang, Michael, Judith Herdin, Ines Hofbauer Eds., WTO AND DIRECT TAXATION, Kluwer Law International, 2005

Macrory, Patrick, Arthur Appleton and Michael Plummer, THE WORLD TRADE ORGANIZATION: LEGAL, ECONOMIC AND POLITICAL ANALYSIS, VOL. II, Springer, 2005.

Macrory, Patrick F.J. and Sherry Stephenson, MAKING TRADE IN SERVICES SUPPORTIVE OF DEVELOPMENT IN COMMONWELATH SMALL AND LOW INCOME COUNTRIES, Economic Paper Vol. 93, Commonwealth Secretariat, 2011.

Maggi, G. and A. Rodriguez-Clare, The Value of Trade Agreements in the Presence of Political Pressures, Journal of Political Economy, 106(3), 1998, 547-601.

Maggiori, Robert, Review of 'Traduire: Defense et illustration du multilinguisme' by François Ost (2009), available online at http://www.presseurop.eu/en/content/article/18351-ost-translation.

Malpas, J. and Norelle Lickis, PERSPECTIVES ON HUMAN DIGNITY: A CONVERSATION, Springer, 2007.

Marceau, Gabrielle, WTO Dispute Settlement and Human Rights in Abbott, Frederick M., Christine Breining-Kaufmann and Thomas Cottier Eds., INTERNATIONAL TRADE AND HUMAN RIGHTS: FOUNDATIONS AND CONCEPTUAL ISSUES, Studies in International Economics, University of Michigan Press, 2006.

Marceau, Gabrielle, Conflicts of Norms and Conflicts of Jurisdictions: The Relationship between the WTO Agreement, MEA's and Other Treaties, Journal of World Trade, 2001, 1130. 
Marceau, Gabrielle, WTO Dispute Settlement and Human Rights, 2002, European Journal of International Law Vol. 13, No.4, p753.

Marchetti, J.A. and Petros C. Mavroidis, The Genesis Of The GATS (General Agreement On Trade In Services), EJIL (2011), Vol. 22 No. 3, 689-721

Marchetti J.A. and Petros C. Mavroidis, The Genesis of The GATS (General Agreement On Trade In Services), European Journal of International Law Vol. 22 No. 3, 2011, 689-721.

Marchetti, Juan A. and Petros C. Mavroidis, What are the Main Challenges for the GATS Framework? Don't Talk about Revolution, European Business Organization Law Review, No. 5, 2004, p511562.

Marks, Stephen P., The Human Right to Development: Between Rhetoric and Reality, Harvard Human Rights Journal, Vol. 17, 2004, 137.

Marks, Stephen P., The Human Rights Framework for Development: Seven Approaches, 2003 and The Human Rights Framework for Development: Five Approaches, 2001, published in the Working Paper Series of the Francois-Xavier Bagnoud Center of the Harvard School of Public Health.

Marmot, M., Social Determinants of Health Inequalities, 365 The Lancet (2005a) 1099.

Marwell, J.,Trade and Morality: The WTO Public Morals Exception after Gambling 81 NYU Law Review 802, 2006, p817.

Mashayekhi, Mina, Martine Julsaint and Elizabeth Tuerk, Strategic Considerations for Developing Countries: The Case of GATS and Health Services in Blouin, Chantal, Nick Drager and Richard Smith Eds., INTERNATIONAL TRADE IN HEALTH SERVICES AND THE GATS: CURRENT SSUES AND DEBATES, The World Bank, 2006.

Matsushita, Mitsuo, Thomas J. Schoenbaum, Petros C. Mavroidis and Michael Hahn, THE WORLD TRADE ORGANIZATION: LAW, PRACTICE, AND POLICY, Oxford University Press, 2015.

Matto, Aaditya and Pierre Sauve, Domestic Regulation and Trade in Services in Matto, Aaditya and Pierre Sauve Eds., DOMESTIC REGULATION AND SERVICES TRADE LIBERALIZATION, World Bank and Oxford University Press, 2003.

Mattoo, Aaditya, Dealing with Monopolies and State Enterprises: WTO Rules for Goods and Services, WTO Research And Analysis, Staff Working Paper No: TISD-98-01, January 1998.

Mattoo, Aaditya, MFN and the GATS in Cottier, Thomas and Petros C. Mavroidis Eds., REGULATORY BARRIERS AND THE PRINCIPLE OF NON-DISCRIMINATION IN WORLD TRADE LAW, World Trade Forum Vol.2, Studies in International Economics, University of Michigan Press, 2000.

Mattoo, Aaditya. Services Globalization in an Age of Insecurity: Rethinking Trade Cooperation, The World Bank, 2018.

Mattoo, Aaditya, Robert M. Stern and Gianni Zanini, Eds., A HANDBOOK OF INTERNATIONAL TRADE IN SERVICES, 2008.

Mavroidis, Petros C., No Outsourcing of Law? WTO Law as Practiced by WTO Courts, American Journal of International Law, 102, 2008, 421.

Mavroidis, Petros C., Highway XVI Re-visited: The Road from Non-Discrimination to Market Access, World Trade Review, 2007, 6(1), p1-23.

Mavroidis, Petros C., Market Access in the GATT, Sant'Anna Legal Studies Research Paper 7/2008.

Mavroidis, Petros C., THE REGULATION OF INTERNATIONAL TRADE: GATT, MIT Press, 2015.

McCarthy, T., On Reconciling Cosmopolitan Unity and National Diversity in de Greiff P. and C. Cronin Eds., GLOBAL JUSTICE AND TRANSNATIONAL GOVERNANCE, The MIT Press, 2002.

McCrudden, Christopher, Human Dignity and Judicial Interpretation of Human Rights, European Journal of International Law 19, 4, 2008.

McDougal, Myers S., H.D. Lasswell and James M. Miller, THE INTERPRETATION OF INTERNATIONAL AGREEMENTS AND WORLD PUBLIC ORDER: PRINCIPLES OF CONTENT AND PROCEDURE, Martinus Nijhoff Publishers, 1994 (Reprint).

McGrady, Benn, Necessity Exceptions in WTO Law: Retreaded Tyres, Regulatory Purpose and Cumulative Regulatory Measures, Journal of International Economic Law 2009 12(1):153-173.

McGuire, James William, WEALTH, HEALTH, AND DEMOCRACY IN EAST ASIA AND LATIN AMERICA, Cambridge University Press, 2010.

Mckenzie, Michael, European Communities - Conditions for The Granting Of Tariff Preferences to Developing Countries, Melbourne Journal of International Law (2005) 6(1) 118.

McLachlan, Campbell, The Principle of Systemic Integration and Article 31(3)(c) of the Vienna Convention, ICLQ 54 (2005) 279.

McRae, C., GATT Article XX and the WTO Appellate Body in Bronckers, Marco and Reinhard Quick Eds., NEW DIRECTIONS IN INTERNTIONAL ECONOMIC LAW: ESSAYS IN HONOR OF JOHN H. JACKSON, Kluwer Law International, 2000. 
McRae, Donald M, The WTO in International Law: Tradition Continued or New Frontier, Journal of International Economic Law, 2000, 27-41.

McRae, Donald, Treaty Interpretation and the Development of International Trade Law by the WTO Appellate Body in Giorgio Sacerdoti, Alan Yanovich, Ja Bohanes, THE WTO AT TEN: THE CONTRIBUTION OF THE DISPUTE SETTLEMENT SYSTEM, Cambridge University Press, 2006.

Mehrach, Mohamed, A TEXT-BASED MODEL FOR TRANSLATION EVALUATION, Ridderkerk: Ridden Print, 1977.

Merkouris, Panagiotis, ARTICLE 31(3)(C) VCLT AND THE PRINCIPLE OF SYSTEMIC INTEGRATION: NORMATIVE SHADOWS IN PLATO'S CAVE, BRILL, 2015.

Mohamadieh, Kinda, Disciplining Non-discriminatory Domestic Regulations in the Services SectorsAnother Plurilateral Track at the WTO, Briefing Paper 103, Third World Network, October 2019.

Mold, Alex and David Reubi Eds., ASSEMBLING HEALTH RIGHTS IN GLOBAL CONTEXT: GENEALOGIES AND ANTHROPOLOGIES, Routledge, 2013.

Molinuevo, M., Article XX GATS in Wolfrum, Rudiger, Peter-Tobias Stoll and Clemens Feinaugle Eds., WTO - TRADE IN SERVICES, Max Planck Commentaries on World Trade Law, Martinus Nijhoff Publishers, 2008.

Montiglio, Silvia, FROM VILLAIN TO HERO: ODYSSEUS IN ANCIENT THOUGHT, University of Michigan Press, 2011.

Moon, Gillian, Trade and Equality: A Relationship to Discover, Journal of International Economic Law 12(3) 618 .

Moore, Mike, A WORLD WITHOUT WALLS - FREEDOM, DEVELOPMENT, FREE TRADE AND GLOBAL GOVERNANCE, Cambridge University Press, 2003.

Morijn, John, Conflicts between Fundamental Rights or Conflicting Fundamental Rights Vocabularies?: An Analysis of Diverging Uses of 'Fundamental Rights' in the Context of International and European Trade Law in Brems Eva Ed., CONFLICTS BETWEEN FUNDAMENTAL RIGHTS, Intersentia 2008.

Morrison, Fred L., Its Elementary, My Dear Abbot, in Kennedy, Daniel L. M. and Southwick, James D. THE POLITICAL ECONOMY OF INTERNATIONAL TRADE LAW, Cambridge University Press, 2002.

Munday, Jeremy, INTRODUCING TRANSLATION STUDIES, THEORIES AND APPLICATIONS, Routledge, 2001.

Munin, Nelie, LEGAL GUIDE TO GATS, Kluwer Law International, 2010.

Murdoch, Iris, THE SOVEREIGNTY OF GOOD, Routledge 2013 (reprint).

Murphy, Sean D., The Relevance of Subsequent Practice, GWU Law School Public Law Research Paper No. 2013-102 and Nolte Ed., TREATIES AND SUBSEQUENT PRACTICE, Cambridge University Press, 2013.

Musungu, Sisule F., TRIPS and Public Health, in Correa, Carlos M. and Abdulqawi Yusuf Eds., INTELLECTUAL PROPERTY AND INTERNATIONAL TRADE: THE TRIPS AGREEMENT, Kluwer Law International, 2008.

Nanda, Nitya, EXPANDING FRONTIERS OF GLOBAL TRADE RULES: THE POLITICAL ECONOMY DYNAMICS OF THE INTERNATIONAL TRADING SYSTEM, Routledge, 2008.

Nartova, Olga, Article XXI GATS in Wolfrum, Rudiger, Peter-Tobias Stoll and Clemens Feinaugle Eds., WTO - TRADE IN SERVICES, Max Planck Commentaries on World Trade Law, Martinus Nijhoff Publishers, 2008.

Natens, Bregt and Jan Wouters, The Scope of GATS and of its Obligations Working Paper 117 - August 2013, Leuven Centre for Global Governance Studies and the Institute for International Law, KU Leuven.

Natens, Bregt, REGULATORY AUTONOMY AND INTERNATIONAL TRADE IN SERVICES: THE EU UNDER GATS AND RTAS, Edward Elgar Publishing, 2016.

Neergard, Ulla, EU Healthcare Law in a Constitutional Light: Distribution of Competences, Notions of 'Solidarity' and 'Social Europe', in J.W. van der Gronden, E. Szyszczak, Ulla Neergard and M. Krajerski Eds., HEALTH CARE AND EU LAW, T.M Asser Press and Springer, 2011.

Nichols, Philip M., Sovereignty and Reform of the World Trade Organization in Shan, Wenhua, Penelope Simon and Dalvinder Singh Eds., REDEFINING SOVEREIGNTY IN INTERNATIONAL ECONOMIC LAW, Hart Publishing, 2008

Nicolaides Kalypso and Joel P. Trachtman, Liberalization, Regulation, and Recognition for Services Trade in Sauve, Pierre and Robert M. Stern Eds., SERVICES TRADE IN THE WESTERN HEMISPHERE: LIBERALIZATION, INTEGRATION AND REFORM, Brookings Institution Press, 2000 
Nicolaides, Phaedon, LIBERALIZING SERVICE TRADE: STRATEGIES FOR SUCCESS, Routledge, 1989

Nicolaidis, K., Non-Discriminatory Mutual recognition: An Oxymoron in the New WTO Lexicon? In Cottier, T., and Petros C. Mavroidis Eds., REGULATORY BARRIERS AND THE PRINCIPLE OF NON-DISCRIMINATION IN World trade law, University of Michigan Press, 2002

Nida, Eugene A., TOWARD A SCIENCE OF TRANSLATING, Brill Publishers, 1964

Nielson Julia, Joint WTO - World Bank Symposium on Movement of Natural Persons (Mode 4) Under The GATS: Current Regimes for Temporary Movement of Service Providers - Labour Mobility in Regional Trade Agreements, Trade Directorate OECD, 2002.

Nielson, Julia, Ten Steps to Consider Before Making Commitments in Health Services Under the GATS in Blouin, Chantal, Nick Drager and Richard Smith Eds., INTERNATIONAL TRADE IN HEALTH SERVICES AND THE GATS: CURRENT ISSUES AND DEBATES, The World Bank, 2006.

Nolte, Georg Second Report for the ILC Study Group on Treaties over Time, in Nolte Ed., TREATIES AND SUBSEQUENT PRACTICE, Cambridge University Press, 2013.

Noordhoek, Willemijn, Human Rights in the Law of the World Trade Organization: The Case of the European Generalized System of Preferences, Maastricht Faculty of Law Working Paper 2010/2.

Nottage H. and T. Sebastian, Giving Legal Effect to the Results of WTO Trade Negotiations: An Analysis of the Methods of Changing WTO Law, 9 JIEL 989, 2006, 1003.

Nusbaumer, J., SERVICES IN THE GLOBAL MARKET, Kluwer Academic Publishers, 1987.

Nussbaum, Martha C., Sophocles; Antigone: Conflict, Vision and Simplification in THE FRAGILITY OF GOODNESS: LUCK AND ETHICS IN GREEK TRAGEDY AND PHILOSOPHY, Revised Edition, Cambridge University Press, 2001.

Nussbaum, Martha Human Rights and Human Capabilities, Harvard Human Rights Journal 21, 2007.

Nygren-Krug, Helena, The Right (s) Road to Universal Health Coverage, Health and Human Rights 21.2, $2019,215$.

Oliva, Maria Julia, The Doha Work Programme: Still the Development Agenda?, CIEL Geneva, available at http://www.ciel.org/Publications/Doha_SDI12.pdf.

Orford, Anne, Trade, Human Rights and the Economy of Sacrifice in Orford, Anne, Ed., INTERNATIONAL LAW AND ITS OTHERS, Cambridge University Press, 2009.

Organization for Economic Co-operation and Development (OECD), GATS, THE CASE FOR OPEN SERVICES MARKETS, OECD Publishing, 2002.

Ortino F., Treaty Interpretation and the WTO Appellate Body Report US-Gambling: A Critique, Journal of International Economic Law 2006.

Ortino, F., From 'Non-Discrimination' to 'Reasonableness': a Paradigm Shift in International Economic Law?, Jean Monnet Working Paper 01/05 2005.

Ortino, Federico, Treaty Interpretation and the WTO appellate Body Report in US-Gambling: a critique, Journal of International Economic Law 9(1), 117-148, 2006.

Ortino, Federico, BASIC LEGAL INSTRUMENTS FOR THE LIBERALISATION OF TRADE: A COMPARATIVE ANALYSIS OF EC AND WTO LAW, Hart Publishing, 2004.

Ottersen, O.P. J. Dasgupta J, C. Blouin et al, The Political Origins of Health Inequity: Prospects for Change (Final Report of The Lancet -University of Oslo Commission on Global Governance for Health), The Lancet, Volume 382, Issue 9917, 15 February 2014.

Panizzon, Marion, How Human Rights violations nullify and impair GATS Commitments in Panizzon, Marion, Nicole Pohl and Pierre Sauve Eds., GATS AND THE REGULATION OF INTERNTIONAL TRADE IN SERVICES, Cambridge University Press, 2008.

Pauwelyn, J., Rien ne Va Plus? Distinguishing Domestic Regulation from Market Access in GATT and GATS, World Trade Review,4 (2) (2005): 131-170.

Pauwelyn, J., CONFLICT OF NORMS IN PUBLIC INTERNATIONAL LAW: HOW WTO LAW RELATES TO OTHER RULES OF INTERNATIONAL LAW, Cambridge University Press, 2003.

Pauwelyn, J., The Nature of WTO Obligations, Jean Monnet Working Paper No. 1/02.

Pauwelyn J., and Isabelle van Damme, The World Trade Organization, in Bowman Michael J., and Dino Kritsiotis Eds., CONCEPTUAL AND CONTEXTUAL PERSPECTIVES ON THE MODERN LAW OF TREATIES, Cambridge University Press, 2018, p109-147.

Pauwelyn, Joost, WTO Dispute Settlement Post 2019: What to Expect?, Journal of International Economic Law, Volume 22, Issue 3, September 2019, p297-321.

Paxson, Christina H. and Norbert Schady, Child Health and Economic Crisis in Peru, World Bank Policy Research Working Paper Series 3260, 2004.

Pekkanen, Saadia M., Aggressive Legalism: The Rules of the WTO and Japan's Emerging Trade Strategy, The World Economy 24, 2001, p707. 
Petersman, Ernst-Ulrich, WTO Dispute Settlement Practice 1995-2005: Lessons from the Past and Future Challenges in Taniguchi, Yasuhei, Yanovich, Alan and Bohanes, Jan. Eds. WTO IN THE 21st CENTURY, Cambridge University Press, 2007.

Petersmann, E-U., The GATT/WTO Dispute Settlement System: International Law, International Organizations and Dispute Settlement, Kluwer Law International, 1997.

Petersmann, Ernst-Ulrich, Reforming Multilevel Governance of Transnational Public Goods through Republican Constitutionalism: Legal Methodology Problems in International Law, Asian J. WTO \& International Health Law \& Policy 12 (2017): 33, p39.

Petersmann, E-U., Constitutionalism and WTO law: From a State Centred Approach towards a Human Rights Approach in International Economic Law in Kennedy, Daniel L. M. and Southwick, James D., THE POLITICAL ECONOMY OF INTERNATIONAL TRADE LAW, Cambridge University Press, 2002

Petersmann, E-U., Human Rights, International Economic Law and Constitutional Justice, EJIL, Vol.19, 2008, 769 .

Petersmann, E-U., Human Rights, International Economic Law and Constitutional Justice: A Rejoinder, EJIL, Vol.19, No.5, 2008, p955.

Petersmann, E-U., Taking Human Dignity, Poverty and Empowerment of Individuals More Seriously: Rejoinder to Alston, EJIL, Vol. 13, No 4, 2002.

Petersmann, E-U., The 'Human Rights Approach' advocated by the UN High Commissioner for Human Rights and by the ILO: Is it Relevant for WTO Law and Policy?, Journal of International Economic Law 2004, 605, Vol. 7, No. 3, p607, 2004.

Petersmann, E-U., The WTO Constitution and Human Rights, Journal of International Economic Law 3 (1), 2000, 19-25.

Petersmann, E-U., The crown jewel of the WTO has been stolen by US trade diplomats : and they have no intention of giving it back, in Denise Prévost, Iveta Alexovicova and Jens Hillebrand Pohl Eds., RESTORING TRUST IN TRADE: LIBER AMICORUM IN HONOUR OF PETER VAN DEN BOSSCHE, Hart Publishing, 2018, p105-118.

Piccard, Ann, The United States' Failure to Ratify the International Covenant on Economic, Social and Cultural Rights: Must the Poor Be Always with Us? Stetson University College of Law Research Paper No. 2011-04

Pildes R., and C. Sunstein, Experts, Economists and Democrats in Sunstein, C., Ed., FREE MARKETS AND SOCIAL JUSTICE, Oxford University Press, 1997.

Pogge, Thomas, Human Flourishing and Universal Justice, in Paul, E.F., F.D., Miller and J. Paul Eds.., HUMAN FLOURISHING, Cambridge University Press, 1999.

Pogge, Thomas, An Egalitarian Law of Peoples, Philosophy \& Public Affairs, 23: 1994, 195-224.

Pogge, Thomas, Moral Universalism and Global Economic Justice, Philosophy, Politics and Economics 1:1, 2002.

Poiares Maduro, Miguel, Interpreting European Law: Judicial Adjudication in a Context of Constitutional Pluralism, European Journal of Legal Studies, Vol.1, Issue 2, 5, December 2007.

Pollock A. M. and D. Price, Rewriting the Regulations: How the World Trade Organization could Accelerate Privatisation in Health-Care Systems, Lancet, 2000; 356: 1995-2000.

Poretti, P., REGULATION OF SUBSIDES WITHIN THE GENERAL AGREEMENT ON TRADE IN SERVICES OF THE WTO: PROBLEMS AND PROSPECTS, Kluwer Law International, 2009.

Poretti, P., Article XV GATS in Wolfrum, Rudiger, Peter-Tobias Stoll and Clemens Feinaugle Eds., WTO TRADE IN SERVICES, Max Planck Commentaries on World Trade Law, Martinus Nijhoff Publishers, 2008.

Poretti, Pietro, 'Waiting for Godot': Subsidy Disciplines in Services Trade, in Marion Panizzon, Nicole Pohl and Pierre Sauve Eds., GATS AND THE REGULATION OF INTERNATIONAL TRADE IN SERVICES, Cambridge University Press, 2008.

Powles, Steven, Joint Criminal Enterprise Criminal Liability by Prosecutorial Ingenuity and Judicial Creativity?, Journal of International Criminal Justice 2004, 2(2), 606-619.

Prechal, Sacha, Fundamental Rights and the Liberalization of Service Markets in van de Gronden, Johan, Ed., EU AND WTO LAW ON SERVICES: LIMITS TO THE REALIZATION OF GENERAL INTEREST POLICIES WITHIN THE SERVICES MARKETS, Kluwer Law International, 2008

Priess, Hans-Joachim, and Christian Pitschas, Protection of public health and the role of the precautionary principle under WTO law: a trojan horse before Geneva's walls, Fordham International Law Journal 24 (2000), 519.

Preker, Alexander S, and April Harding Eds. INNOVATIONS IN HEALTH SERVICES DELIVERY: THE CORPORATIZATION OF PUBLIC HOSPITALS, World Bank, 2003. 
Prévost, Denise, Services and Public Policy Regulation in the WTO: the example of the US-Gambling Case in van de Gronden Johan, Ed., EU AND WTO LAW ON SERVICES - THE LIMITS TO THE REALIZATION OF GENERAL INTEREST POLICIES WITHIN SERVICES MARKETS, Kluwer Law International, 2009.

Prévost, Denise, Opening Pandora's box: the panel's findings in the EC-Biotech products dispute, (2007).

Prévost, Denise, BALANCING TRADE AND HEALTH IN THE SPS AGREEMENT: THE DEVELOPMENT DIMENSION, Wolf Publishers, 2009.

Prévost, Denise, and Peter Van den Bossche, The agreement on the application of sanitary and phytosanitary measures, THE WORLD TRADE ORGANIZATION: LEGAL, ECONOMIC AND POLITICAL ANALYSIS. Springer US, 2005.

Pulkowski, Dirk, THE LAW AND POLITICS OF INTERNATIONAL REGIME CONFLICT, Oxford University Press, 2014.

Qin, Julia Ya, "WTO-Plus" Obligations and Their Implications for the World Trade Organization Legal System: An Appraisal of the China Accession Protocol, Journal of World Trade 37(3): 483-522, 2003.

Qin, Julia Ya, Defining Non-discrimination under the Law of the World Trade Organization, 2005 Boston University International Law Journal Vol. 23:215.

Qin, Julia Ya, WTO Regulation of Subsidies to State-Owned Enterprises (SOEs) - A Critical Appraisal of the China Accession Protocol, Journal of International Economic Law, 7(4), 2004, 863-899.

Qureshi, Asif H., INTERPRETING WTO AGREEMENTS: PROBLEMS AND PERSPECTIVES, Cambridge University Press, 2006.

Qureshi, Asif H., Sovereignty Issues in the WTO Dispute Settlement - A Development Sovereignty Perspective, in Shan, Wenhua, Penelope Simon and Dalvinder Singh Eds., REDEFINING SOVEREIGNTY IN INTERNATIONAL ECONOMIC LAW, Hart Publishing, 2008.

Rabe, Johan, EQUALITY, AFFIRMATIVE ACTION AND JUSTICE, Books on Demand, 2001.

Raghavan, Chakravarthi, Developing Countries and Services Trade: Chasing a Black Cat in a Dark Room, Blindfolded, Third World Network, 2002.

Rannan-Eliya, Ravi P. and Lankani Sikurajapathy, Sri Lanka: 'Good Practice' in Expanding Health Care Coverage, Institute for Health Policy and The World Bank, 2009.

Ratner Steven R., Corporations and Human Rights: A Theory of Legal Responsibility, 111 YALE L.J. 443, 2001.

Rawls, John, Lectures on Hobbes in Rawls, John and Samuel Richard Freeman ed., LECTURES ON THE HISTORY OF POLITICAL PHILOSOPHY, Harvard University Press, 2007.

Rawls, John, THE LAW OF PEOPLES: WITH, THE IDEA OF PUBLIC REASON REVISITED, Harvard University Press, 2001.

Rawls, John., A THEORY OF JUSTICE, Harvard University Press, 1971.

Reyes-Knocke and Arend, Article XX(d) GATT 1994, in Wolfrum Rudiger, in Rüdiger Wolfrum, PeterTobias Stoll, Anja Seibert-Fohr Eds., WTO: TECHNICAL BARRIERS AND SPS MEASURES, Max Planck Commentaries on World Trade Law, Martinus Nijhoff Publishers, 2007.

Richard N. Cooper, Why liberalization meets resistance in J. Michael Finger (ed.), THE URUGUAY ROUND, A HANDBOOK ON THE MULTILATERAL TRADE NEGOTIATIONS, World Bank, November 1987.

Ricoeur, Paul, ON TRANSLATION, translated by Eileen Brennen, Routledge, 2006.

Ricoeur, Paul, REFLECTIONS ON THE JUST, University of Chicago Press, 2007.

Riley, James C., LOW INCOME, SOCIAL GROWTH AND GOOD HEALTH: A HISTORY OF TWELVE COUNTRIES, University of California Press, 2008.

Rintala, Marvin, CREATING THE NHS: ANEURIN BEVAN AND THE MEDICAL LORDS, Routledge, 2003.

Robinson, Mary, The Fifth Annual Grotius Lecture: Shaping Globalization: The Role of Human Rights, American University International Law Review 19, no. 1 (2003): 1-26.

Roemer, John E., EQUALITY OF OPPORTUNITY, Harvard University Press, 1998.

Roemer, Ruth, Allyn Taylor and J. Lariviere, Origins of the WHO Framework Convention on Tobacco Control, Am J Public Health. 2005 June; 95(6): 936-938.

Ronsmans, Carine, Oona Campbell, Mary C. Smith Fawzi, Sarah Zaidi, David H. Spodick, Omar A. Obeid and others, Sanctions against Iraq, The Lancet, January 20, 1996 Vol. 347 No. 8995.

Rosen, George, A HISTORY OF PUBLIC HEALTH, first published 1958, reprinted John Hopkins University Press, 1993.

Rosenne, S., The Position of the International Court of Justice on the Foundations of the Principle of Equity in International Law in Bloed and Van Dijk (Eds) FORTY YEARS OF THE INTERNATIONAL COURT OF JUSTICE, Europa Institute, 1988. 
Roy, Martin, Endowments, Power, And Democracy: Political Economy of Multilateral Commitments On Trade In Services, WTO Economic Research and Statistics Division, Staff Working Paper ERSD2010-11 (replacing previous Working Paper ERSD-2009-07.

Freeman, Jody and Martha Minow, Eds., GOVERNMENT BY CONTRACT: OUTSOURCING AND AMERICAN DEMOCRACY, Harvard University Press, 2009.

Rubin, Edward L., The Possibilities and Limitations of Privatization, Harvard Law Review, Vol. 123, No. 890, 2010 (also available as Vanderbilt Public Law Research Paper No. 11-09; Vanderbilt Law and Economics Research Paper No. 11-14).

Rubini, Luca, THE DEFINITION OF SUBSIDY AND STATE AID: WTO AND EC LAW IN COMPARATIVE PERSPECTIVE, Oxford University Press, 2009.

Ruggie, J., Special Representative of the Secretary-General, Guiding Principles on Business and Human Rights: Implementing the United Nations 'Protect, Respect and Remedy' Framework, U.N. Doc., A/HRC/17/31. March 21, 2011.

Ruse-Khan, Henning Grosse, A Comparative Analysis of Policy Space in WTO Law, Max Planck Papers on Intellectual Property, Competition \& Tax Law Research No. 08-02.

Sachs, Jeffery, THE PRICE OF CIVILIZATION: REAWAKENING VIRTUE AND PROPSERITY AFTER THE ECONOMIC FALL, Vintage Books, 2012.

Sage, William M., Brand New Law! The Need to Market Health Care Reform, University of Pennsylvania Law Review, Vol. 159, 2011; U of Texas Law, Public Law Research Paper No. 190.

Sakr, Rafael Lima, Beyond History and Boundaries: Rethinking the Past in the Present of International Economic Law, Journal of International Economic Law, Volume 22, Issue 1, March 2019, 57-91.

Sampson, Gary P. and Richard H. Snape, Identifying the Issues in Trade in Services, The World Economy 8, June 1985.

Sampson, Gary P., THE WTO AND SUSTAINABLE DEVELOPMENT, United Nations University Press, 2005.

Saul, Ben, David Kinley and Jaqueline Mowbray, THE INTERNATIONAL COVENANT ON ECONOMIC, SOCIAL AND CULTURAL RIGHTS: CASES, MATERIALS, AND COMMENTARY, Oxford University Press, 2014.

Sauvé, Pierre, Completing the GATS Framework: Addressing Uruguay Round Leftovers, Aussenwirtschaft, Vol. 57, No. 3, 2002.

Sauvé, Pierre, To fuse, Not to Fuse, or Simply Confuse? Assessing the Case for Normative Convergence Between Goods and Services Trade Law, Journal of International Economic Law, Volume 22, Issue 3, September 2019, p355-371

Sauvé, Pierre, Trade, Education and the GATS: What's In, What's Out, What's All the Fuss About? Paper prepared for the OECD/US Forum on Trade in Educational Services, May 2002.

Savedoff, William D., and Pablo Gottret, Eds, GOVERNING MANDATORY HEALTH INSURANCE: LEARNING FROM EXPERIENCE, The World Bank, 2008.

Saxena, Shekhar Graham Thornicroft, Martin Knapp, Harvey Whiteford, Resources for mental health: scarcity, inequity, and inefficiency, The Lancet, Volume 370, Issue 9590, 8-14 September 2007, p878-889.

Schefer, K.N., SOCIAL REGULATION AND THE WTO: TRADE POLICY AND INTERNATIONAL LEGAL DEVELOPMENT, Edward Elgar Publishing, 2010.

Scheuermann, Philipp, NORMATIVE CONDITIONS TO MAKE WTO LAW MORE RESPONSIVE TO THE NEEDS OF DEVELOPING COUNTRIES, Volume 73 of Europaisches und Internationales Recht, Herbert Utz Verlag, 2010.

Schloemann H.. and S. Ohrloff, "Constitutionalization" and Dispute Settlement in the WTO: National Security as Issue of Competence, American Journal of International Law, 93, 1999, p426.

Schneiderman, David, Realising Rights in an Era of Economic Globalization in Shan, Wenhua, Penelope Simon and Dalvinder Singh Eds., REDEFINING SOVEREIGNTY IN INTERNATIONAL ECONOMIC LAW, Hart Publishing, 2008.

Schwartz, Warren F. and Eugene W. Harper, Jr., The Regulation of Subsidies Affecting International Trade, Michigan Law Review, Vol. 70, No. 5, April 1972, p842, footnote 11; UNDP, MAKING GLOBAL TRADE WORK FOR PEOPLE, UNDP and Earthscan, 2003.

Schwarzenberger, George, INTERNATIONAL LAW, Vol.1, 3rd Edition, Stevens 1937.

Schwenke, Chloe, RECLAIMING VALUE IN INTERNATIONAL DEVELOPMENT: THE MORAL DIMENSIONS OF DEVELOPMENT POLICY AND PRACTICE IN POOR COUNTRIES, ABCCLIO, 2009.

Scott, James and Rorden Wilkinson, Changing of the Guard: expert knowledge and 'common sense' in the Doha Development Agenda, BWPI Working Paper 166, Brooks World Poverty Institute, 2012. 
Scott, James and Wilkinson, Rorden, The Poverty of the Doha Round and the Least Developed Countries, Third World Quarterly, 32(4), May 2011.

Scott, Nadine, Nature/Culture Clash: The Transnational Trade Dispute over GMOs', Hauser Global Law Working Paper 06/05.

Sellin, J. and N. Mendis, Women's Right to Health and International Trade - Special Reference to the GATS and the TRIPS Agreement in Westendorp, Ingrid Ed., THE WOMEN'S CONVENTION TURNED 30: ACHIEVEMENTS, SETBACKS, AND PROSPECTS, Intersentia, 2012.

Sen, Amartya, INEQUALITY RE-EXAMINED, Harvard University Press, 1995.

Sen, Amartya, Development as Capability Expansion, Journal of Development Planning 19: 41-58.

Sen, Amartya, DEVELOPMENT AS FREEDOM, Anchor Books, 2000.

Sen, Amartya, DEVELOPMENT AS FREEDOM, Oxford University Press, 1999.

Sen, Amartya, Elements of a Theory of Human Rights, Philosophy \& Public Affairs, 32: 2004, 315-356.

Sen, Amartya, Sri Lanka's Achievements: How and When in T. Srinivasan and P. Bardhan Eds. RURAL POVERTY IN SOUTH ASIA, Columbia University Press, 1988.

Sen, Amartya, The Sir John Crawford Memorial Lecture, held in Washington D.C., October 291987.

Sen, Amartya., COMMODITIES AND CAPABILITIES, Oxford University Press, 1985.

Shaffer, Gregory, Manfred Elsig and Sergio Puig, The Extensive (but Fragile) Authority of the WTO Appellate Body, Law and Contemporary Problems, Vol. 79:237, No. 1 2016, p260-261.

Shaffer, Gregory C. and Joel P. Trachtman, Interpretation and Institutional Choice at the WTO, Oñati Socio-Legal Series, Vol. 1, No. 4, 2011.

Shaffer, Gregory, The Challenges of WTO Law: Strategies for Developing Country Adaptation (a version of the paper published in the World Trade Review July 2006), available at http://www.worldtradelaw.net/ articles/shafferdc.pdf last accessed on 25.05.2010.

Shaw, Malcolm N., INTERNATIONAL LAW, 6th Edition, Cambridge University Press, 2008.

Shell, G. Richard, Trade Legalism and International Relations Theory: An Analysis of the World Trade Organization, Duke Law Journal, Vol.44, No. 5, March 1995.

Shelp, Ronald K., Trade in Services, Foreign Policy, No. 65 (Winter, 1986-1987).

Shelp, Ronald, K., BEYOND INDUSTRIALIZATION: ASCENDANCY OF THE GLOBAL SERVICE ECONOMY, Praeger, 1981.

Shibuya, Kenji, et al, WHO Framework Convention on Tobacco Control: development of an evidence based global public health treaty, BMJ, 19 July 2003; 327(7407): 154-157.

Shiva, Vandana, EARTH DEMOCRACY: JUSTICE, SUSTAINABILITY AND PEACE, Zed Books, 2006.

Sicular, Terry, The Challenge of High Inequality in China, Inequality in Focus Series, Poverty Reduction and Equity Department, World Bank, Vol. 2, Number 2. August 2013.

Sinclair, Ian, THE VIENNA CONVENTION ON THE LAW OF TREATIES, 2nd Ed., Manchester University Press, 1984.

Sinclair, Scott, GATS and South Africa's National Health Act: A Cautionary Tale, Canadian Centre Policy Alternatives, 2005.

Slotbloom, Marco, A COMPARISON OF WTO AND EC LAW: DO DIFFERENT OBJECTS AND PURPOSES MATTER FOR TREATY INTERPRETATION? Cameron May, 2006.

Smith R., R. Beaglehole, D. Woodward and N. Drager Eds., GLOBAL PUBLIC GOODS FOR HEALTH: HEALTH ECONOMICS AND PUBLIC HEALTH PERSPECTIVES, Oxford, Oxford University Press, 2003.

Smith, Richard Chantal Blouin, Zafar Mirza, Peter Beyer, Nick Drager Eds., TRADE AND HEALTH: TOWARDS BUILDING A NATIONAL STRATEGY, WHO, 2015.

Smits, Jan M., Redefining Normative Legal Science: Towards an Argumentative Discipline in Fons Coomans, Fred Grunfeld and Menno T. Kamminga Eds., METHODS OF HUMAN RIGHTS RESEARCH, Intersentia, 2009.

Steger, Debra P., The Culture Of The WTO: Why It Needs To Change, Journal Of International Economic Law 2007, 10(3): 483-495.

Steiglitz, Joseph, GLOBALIZATION AND ITS DISCONTENTS, Penguin Books, 2002.

Steve Charnovitz, The WTO and The Rights of Individual, Journal of Intereconomics Vol. March/April 2001, Springer -Verlag, p1-15.

Stewart, Terence P. Ed., THE GATT URUGUAY ROUND: A NEGOTIATING HISTORY (1986-1992), Volume II, Kluwer Law and Taxation, 1993.

Stoll, Peter, The Meaning and Function of National Treatment in Stoll, Peter-Tobias and Frank Schorkopf Eds., WTO: WORLD ECONOMIC ORDER, WORLD TRADE LAW, Volume 1, Max Planck Commentaries on World Trade Law, Martinus Nijhoff Publishers, 2006. 
Stoll, Peter-Tobias and Frank Schorkopf, WTO: WORLD ECONOMIC ORDER, WORLD TRADE LAW, Max Planck Commentaries on World Trade Law, Martinus Nijhoff Publishers, 2006.

Stoll, Peter-Tobias, Article 3 DSU in Wolfrum, Rüdiger, Peter-Tobias Stoll and Karen Kaiser Eds. WTO: INSTITUTIONS AND DISPUTE SETTLEMENT, Max Planck Commentaries on World Trade Law, Brill, 2006.

Stone Sweet, Alec and Thomas L. Brunell, Trustee Courts and the Judicialization of International Regimes: The Politics of Majoritarian Action in the ECHR, the EU and the WTO, Yale Law School Faculty Scholarship, 1-1-2013.

Svitone, Ennio Cufino, Richard Garfield, Maria Ines Vasconcelos and Villane Araujo Craviero, Primary Health Care Lessons From The Northeast Of Brazil: The Agentes De Saúde Program, Rev Panam Salud Publica 2000, Vol.7, N.5 pp. 293-301, 2000.

Sykes, Alan O., Subsidies and Countervailing Measures in Macrory, Patrick F. J, Arthur Edmond Appleton and Michael G. Plummer, THE WORLD TRADE ORGANIZATION: LEGAL, ECONOMIC AND POLITICAL ANALYSIS, Vol. II, Springer, 2005.

Sykes, Alan O., The Least Restrictive Means, University of Chicago Law Review, Vol. 70, No. 1, Centennial Tribute Essays, Winter, 2003, pp. 403-419.

Sykes, Alan O., The Questionable Case for Subsidies Regulation: A Comparative Perspective, Stanford Law and Economics Olin Working Paper No. 380.

Tamanaha, Brian, The Dark Side of the Relationship between the Rule of Law and Liberalism, NYU Journal of Law and Liberty, 33, 2008.

Tancredi, Antonello, Trade and Inter-Legality in Klabbers, Jan. and Gianluigi Palombella Eds., THE CHALLENGE OF INTER-LEGALITY, ASIL Studies in International Legal Theory, Cambridge University Press, 2019.

Taylor A.L. and D.W. Bettcher, WHO Framework Convention on Tobacco Control: a global "good" for public health, Bulletin of the World Health Organization, 2000;78: 920-9.

Taylor A.L., An international regulatory strategy for global tobacco control, Yale Journal of International Law, 1996;21(2):257-304.

Taylor A.L., Making the World Health Organization work: a legal framework for universal access to the conditions for health, American Journal of Law and Medicine,1992;18:301-346.

Tobin, Jennifer L and Marc L. Busch, A BIT Is Better Than a Lot: Bilateral Investment Treaties And Preferential Trade Agreements, World Politics 62, No. 1, January 2010, p30.

Todd Peters, Rebecca, IN SEARCH OF THE GOOD LIFE: THE ETHICS OF GLOBALIZATION, Continuum International Publishing Group, 2006.

Tomuschat, C., HUMAN RIGHTS: BETWEEN IDEALISM AND REALISM, $2^{\text {nd }}$ Edition, Oxford University Press, 2008.

Trachtman, Joel P., The Constitutions of the WTO, The European Journal of International Law Vol. 17 no.3, $2006,623$.

Trachtman, Joel P., Trade and...Problems, Cost-benefit Analysis and Subsidiarity, EJIL, Vol.9(1), 1998, 32-85.

Trachtman, Joel, The Domain of WTO Dispute Resolution, Harvard International Law Journal 40(2) 1999, p360.

Trebilcock, M., Robert Howse and Antonia Eliason, THE REGULATION OF INTERNATIONAL TRADE, 4th edition, Routledge, 2013.

Trejos, Juan Diego, UNRISD Background Paper - Basic Social Services: Achievements and Bottlenecks since 1950, UNRISD, 2008.

Trepte, P., Regulating Procurement: Understanding the Ends and Means of Public Procurement Regulation in Arrowsmith, Sue, J. Linarelli and D. Wallace, REGULATING PUBLIC PROCUREMENT: NATIONAL AND INTERNATIONAL PERSPECTIVES, Kluwer Law International, 2000.

Tulchinsky, Theodore H. and Elena A. Varavikova, THE NEW PUBLIC HEALTH: AN INTRODUCTION FOR THE 21ST CENTURY, 3rd Edition, Academic Press, 2014.

Tung, Ko-Young, Shaping Globalization: The Role of Human Rights - Comment on the Grotius Lecture by Mary Robinson, American University International Law Review 19, no. 1 (2003): 27.

Uragoda, C. G. A HISTORY OF MEDICINE IN SRI LANKA, The Sri Lanka Medical Association, 1987.

Urfan Khaliq and Robin Churchill, The Protection of Economic and Social Rights: A Particular Challenge in Keller, H. and Geir Ulfstein, Eds., UN HUMAN RIGHTS TREATY BODIES: LAW AND LEGITIMACY, Cambridge University Press, 2012.

Vadi, Valentina, CULTURAL HERITAGE IN INTERNATIONAL INVESTMENT LAW AND ARBITRATION, Cambridge University Press, 2014.

Van Daele, Arne, INTERNATIONAL LABOUR RIGHTS AND THE SOCIAL CLAUSE: FRIENDS OR FOES, Cameron May, 2005. 
Van Damme, Isabelle, The Interpretation of Schedules of Commitments, Journal of World Trade 41(1), 2007, 1-52, p21.

Van Damme, Isabelle, TREATY INTERPRETATION BY THE WTO APPELLATE BODY, Oxford University Press, 2009

Van Damme, Isabelle, Treaty Interpretation by the WTO Appellate Body, EJIL, Vol.21, No. 3, 2010, 605.

Van Damme, Isabelle, TREATY INTERPRETATION BY THE WTO APPELLATE BODY, Oxford University Press, 2009.

Van den Bossche, Peter and Werner Zdouc, THE LAW AND POLICY OF THE WORLD TRADE ORGANIZATION, Cambridge University Press, Revised 3rd edition, 2013.

Van den Bossche, Peter, Looking for Proportionality in WTO Law, Legal Issues of Economic Integration, 35(3), 2008, 283-294,

Van den Bossche, Peter, THE LAW AND POLICY OF THE WORLD TRADE ORGANIZATION: TEXT, CASES AND MATERIALS, Cambridge University Press, 2nd Edition, 2008.

Van den Bossche, Peter and Denise Prévost, ESSENTIALS OF WTO LAW, Cambridge University Press, 2016.

Van Duzer, J. Anthony, Health, Education and Social Services in Canada: The Impact of the GATS, Curtis, J.M., and D. Ciuriak, Eds., TRADE POLICY RESEARCH 2004, International Trade Canada, (Independent Report commissioned for the Government of Canada), 2004, p287-518.

Van Zandt, David E., The Lessons of the Lighthouse: 'Government' or 'Private' Provision of Goods, Journal of Legal Studies 22, January p47-72 and October, p357-376, 1993.

Vaughan, Sovereignty and International Economic Law in Shan, Wenhua, Penelope Simon and Dalvinder Singh Eds., REDEFINING SOVEREIGNTY IN INTERNATIONAL ECONOMIC LAW, Hart Publishing, 2008

Voituriez, Tancredi, Why did 'Development' Entrap the Doha Round? in Ekins, Paul and Tancredi Voituriez Eds., TRADE, GLOBALIZATION AND SUSTAINABILITY IMPACT ASSESSMENT: A CRITICAL LOOK AT METHODS AND OUTCOMES, Earthscan 2009/ Routledge 2012.

Walker, Simon, A Human Rights Approach to WTO TRIPS in Abbott, Frederick M., Christine Kaufmann and Thomas Cottier Eds., INTERNATIONAL TRADE AND HUMAN RIGHTS: FOUNDATIONS AND CONCEPTUAL ISSUES, Studies in International Economics Vol. 5, World Trade Forum, University of Michigan Press, 2006.

Walker, Simon, A Human Rights Approach to WTO TRIPS in Abbott, Frederick M., Christine Kaufmann and Thomas Cottier Eds., INTERNATIONAL TRADE AND HUMAN RIGHTS: FOUNDATIONS AND CONCEPTUAL ISSUES, Studies In International Economics Vol. 5, World Trade Forum, University of Michigan Press, 2006.

Walt, Gill, HEALTH POLICY: AN INTRODUCTION TO PROCESS AND POWER, Witwaterstrand University Press, Zed Books, $2^{\text {nd }}$ Edition, 1996.

Waltz, Susan, Reclaiming and Rebuilding the History of the Universal Declaration of Human Rights, Third World Quarterly, 2002, 23:3, 437- 448.

Waluchow, Wil Constitutions as Living Trees: An Idiot Defends in Dyzenhaus David, Sophia Reibetanz Moreau and Arthur Ripstein Eds., LAW AND MORALITY: READINGS IN LEGAL PHILOSOPHY University of Toronto Press, 3rd Edition, 2007.

Waluchow, Wil, A COMMON LAW THEORY OF JUDICIAL REVIEW: THE LIVING TREE, Cambridge University Press, 2007.

Waluchow, Wil, Constitutions as Living Trees: An Idiot Defends Canadian Journal of Law and Jurisprudence, 2005, 18207.

Wang, P., China's Accession to the WTO Government Procurement Agreement - Challenges and The Way Forward, Journal of International Economic Law, 2009, 12 (3): 663-706.

Wang, P., Coverage of the WTO's Agreement on Government Procurement: Challenges of Integrating China and Other Countries with a Large State Sector, Journal of International Economic Law 2007, 10: 887.

Wang, P., Procurement of State Trading Enterprises Under the GATS in Arrowsmith, Sue and Robert D. Anderson Eds., THE WTO REGIME ON GOVERNMENT PROCUREMENT: CHALLENGE AND REFORM, Cambridge University Press, 2011.

Wang, Y., Most-Favoured-Nation Treatment under the General Agreement on Trade in Services and its application in Financial Services, Journal of World Trade, 30, 1996 1, p99.

Weber, Rolf H., Regulatory Autonomy and Privacy Standards Under the GATS, Asian Journal of WTO \& International Health Law and Policy, Vol. 7, No. 1, pp.25-48, March 2012, p31-32.

Webster, Charles, THE NHS: A POLITICAL HISTORY, Oxford University Press, 1998. 
Weinberger, Eliot, Anonymous Sources (on Translators and Translation), in Allen, Esther and Susan Bernofsky Eds., IN TRANSLATION: TRANSLATORS ON THEIR WORK AND WHAT IT MEANS, Columbia University Press, 2013.

Weisstub, David, Honor, Dignity, and the Framing of Multiculturalist Values in Kretzmer D. and E. Klein, Ed., THE CONCEPT OF HUMAN DIGNITY IN HUMAN RIGHTS DISCOURSE, Kluwer Law International, 2002.

Wernicke, Stephan, Services of General Economic Interest in European Law: Solidarity embedded in the Economic Constitution in van der Gronden, Johan, Ed., EU AND WTO LAW ON SERVICES: LIMITS TO THE REALIZATION OF GENERAL INTEREST POLICIES WITHIN THE SERVICES MARKETS, Kluwer Law International, 2008.

Williams, Robert R., TRAGEDY, RECOGNITION AND THE DEATH OF GOD: STUDIES IN HEGEL AND NIETZSCHE, Oxford University Press, 2012.

Wickramage, Kolitha, State Sovereignty over Deadly Pathogens: Ensuring Global Health Security, Sri Lanka J. Int'l L. 25 (2016): 85.

Wolfowitz, Paul D., Foreword to the WORLD DEVELOPMENT REPORT 2006: EQUITY AND DEVELOPMENT, World Bank and Oxford University Press, 2005.

Wolfrum, R., Annex on Article II Exemptions in Wolfrum, Rudiger, Peter-Tobias Stoll and Clemens Feinaugle Eds., WTO - TRADE IN SERVICES, Max Planck Commentaries on World Trade Law, Martinus Nijhoff Publishers, 2008.

Wolfrum, R., Article II GATS: Most-Favoured Nation Treatment in Wolfrum, R., Peter-Tobias Stoll and Clemens Feinaugle Eds., WTO-TRADE IN SERVICES, Max Planck Commentaries on International Trade Law, Martinus Nijhoff Publishers, 2008.

Wolfrum, R., Article XX GATT 1994 in Wolfrum, Rudiger, Stoll and Seibert-Fohr Eds., WTO TECHNICAL BARRIERS AND SPS MEASURES, Max Planck Commentaries on World Trade Law, Martinus Nijhoff Publishers, 2007.

Wolfrum, Rudiger, Peter-Tobias Stoll and Clemens Feinaugle Eds., WTO - TRADE IN SERVICES, Max Planck Commentaries on World Trade Law, Martinus Nijhoff Publishers, 2008.

Wolfrum, Rudiger, Stoll and Seibert-Fohr Eds., WTO - TECHNICAL BARRIERS AND SPS MEASURES, Max Planck Commentaries on World Trade Law, Martinus Nijhoff Publishers, 2007.

Woodward, D., and R. Smith, Global Public Health: Concepts and Issues in Smith R., R. Beaglehole, D.Woodward and N. Drager Eds., GLOBAL PUBLIC GOODS FOR HEALTH: HEALTH ECONOMICS AND PUBLIC HEALTH PERSPECTIVES, Oxford, Oxford University Press, 2003.

Woodward, David, Nick Drager, Robert Beaglehole and Debra Lipson, Globalization, Global Public Goods and Health in TRADE IN HEALTH SERVICES: GLOBAL, REGIONAL AND COUNTRY PERSPECTIVES, Pan American Health Organization, 2002.

Wouters, Jan and Bart De Meester, Safeguarding Coherence in Global Policy-Making on Trade and Health: The EU-WHO-WTO Triangle, International Organizations Law Review, 2, 2005, p295.

Wu, Mark, Free Trade and Public Morals, Yale Journal of International Law, Vol. 33, 2008, 215.

Wunsch-Vincent S. in J. McIntosh Ed., E-COMMERCE, AND INFORMATION TECHNOLOGIES: FROM THE URUGUAY ROUND THROUGH THE DOHA DEVELOPMENT AGENDA, A Report for the UN ICT Task Force, Markle Foundation, 2004.

Xinquan, Tu, Organizational Aspects of China's GPA Accession Negotiation and Their Implications, Indiana University Research Center for Chinese Politics and Business, Working Paper No.6, October 2011

Yokoi-Arai, Mamiko, GATS' Prudential Carve-Out in Financial Services and Its Relation with Prudential Regulation, International and Comparative Law Quarterly, Vol.57, July 2008, p613-614.

Young, Suzanne, Outsourcing in public health: a case study of contract failure and its aftermath, Journal of Health Organization and Management, Vol. 22 Issue: 5, 2008, pp.446464.

Yusuf, Abdulqawi, LEGAL ASPECTS OF TRADE PREFERENCES FOR DEVELOPING STATES: A STUDY IN THE INFLUENCE OF DEVELOPMENT NEEDS ON THE EVOLUTION OF INTERNATIONAL LAW, BRILL, 1982.

Zacharias, Diana, Article XIII GATS in Wolfrum, Rudiger, Peter-Tobias Stoll and Clemens Feinaugle Eds., WTO - TRADE IN SERVICES, Max Planck Commentaries on World Trade Law, Martinus Nijhoff Publishers, 2008.

Zhao, Litao, and Yanjie Huang, China's blueprint for health care reform, East Asian Policy 2.1 (2010): 51 9. 
Zleptnig, Stefan, NON-ECONOMIC OBJECTIVES IN WTO LAW: JUSTIFICATION PROVISIONS OF GATT, GATS, SPS AND TBT AGREEMENTS, Nijhoff International Trade Law Series, 2010.

Zuniga, Jose, M., Stephen P. Marks and Lawrence O. Gostin, ADVANCING THE HUMAN RIGHT TO HEALTH, Oxford University Press, 2013.

\section{Selected WTO Documents}

WTO, Annual Report 1997, Vol. II and WTO International Trade Statistics, 2000.

WTO, Annual Report of the Working Party on GATS Rules to the Council for Trade in Services, S/WPGR/20, 8 November 2010.

WTO, Background Note by the Secretariat, Education Services, S/C/W/49, 23 September 1998.

WTO, Background Note by the Secretariat, Education Services, S/C/W/313, 1 April 2010.

WTO, Background Note by the Secretariat, Education Services, S/C/W/313, 1 April 2010.

WTO, Background Note by the Secretariat, Environmental Services, S/C/W/320, 20 August 2010.

WTO, Background Note by the Secretariat, Financial Services, S/C/W/72, 2 December 1998.

WTO, Background Note by the Secretariat, Health and Social Services, S/C/W/50, 18 September 1998.

WTO, Background Note by the Secretariat, Interpretation of Procurement-Related Provisions in GATT Possible Application to Article XIII of GATS, S/WPGR/W/29, 31 March 1999.

WTO, Background Note by the Secretariat, Legal Services, S/C/W/318 14 June 2010.

WTO, Background Note by the Secretariat, Legal Services, S/C/W/43, 6 July 1998.

WTO, Background Note by the Secretariat, Legal Services, S/C/W/43, 6 July 1998.

WTO, Background Note by the Secretariat, Postal and Courier Services, S/C/W/39 12 June 1998.

WTO, Background Note by the Secretariat, Telecommunications Services, S/C/W/74 8 December 1998.

WTO, Background Note by the Secretariat, Telecommunications Services, S/C/W/29910 June 2009.

WTO, Background Note by the Secretariat, Working Party on GATS Rules, Subsidies for Services Sectors: Information Contained in WTO Trade Policy Reviews, S/WPGR/W/25, 26 January 1998.

WTO, Background Note by the Secretariat, Working Party on GATS Rules, Subsidies for Services Sectors: Information Contained in WTO Trade Policy Reviews, S/WPGR/W/25, 26 January 1998.

WTO, Committee on Specific Commitments, Classification issues in health services, JOB /SERV/158, 18 September 2013.

WTO, Communication from India: GATS Article VI:4: Disciplines for supply of a service through the presence of a natural person of a member in the territory of another member: Draft for Discussion, S/WPDR/W/61/Rev.1, 8 March 2019.

WTO, Communication from the Republic of Zambia on behalf of the LDC Group, A Mechanism to Operationalize Article IV:3 of the GATS, TN/S/W/59, 28 March 2006.

WTO, Council for Trade in Services, Modalities for the special treatment for least-developed country members in the negotiations on trade in services, adopted by the special session of the council for trade in services on 3 September 2003, TN/S/13, 5 September 2003.

WTO, Council for Trade in Services, Procedures for the Certification of Rectifications or Improvements to Schedules of Specific Commitments, S/L/84 (18th April 2000).

WTO, Council for Trade in Services, Procedures for the Implementation of Article XXI of the GATS Modification of Schedules, S/L/80 (19th July 1999).

WTO, Council for Trade in Services, Report by the Chairman to the Trade Negotiations Committee, $\mathrm{TN} / \mathrm{S} / 23,28$ November 2005.

WTO, Council for Trade in Services, Working Party on Professional Services, Disciplines on Domestic Regulation in the Accountancy Sector, S/L/64, 17 December 1998.

WTO, Cyprus, Final List of Article II (MFN) Exemptions, GATS/EL/2515 April 1994.

WTO, Doha Declaration on the TRIPS Agreement and Public Health, WT/MIN(01)/DEC/1, 20 November 2001.

WTO, Doha Ministerial Declaration 2001, WT/MIN(01)/Dec/1, 20 November 2001 (adopted on 14 November 2001).

WTO, Draft Modalities for the Special Treatment for LDC Members in the Negotiations on Trade in Services, JOB(02)/205, 6 December 2002.

WTO, Draft Modalities for the Special treatment for LDC members in the Negotiations on Trade in Services, Communication from the LDC Group, T/NS/W/13, 7 May 2003.

WTO, Duty-Free and Quota-Free (DFQF) Market Access for Least-Developed Countries, Ministerial Decision, WT/MIN(13)/44, WT/L/919, 7 December 2013.

WTO, GATS: FACT AND FICTION, 2001. 
WTO,

GATS: $\quad$ FACT

AND

FICTION,

WTO,

2001,

www.wto.org/english/tratop_e/serv_e/gatsfacts1004_e.pdf.

WTO, General Council, Amendment of the TRIPS Agreement, WT/L/641, 6 December 2005.

WTO, General Council, Implementation of Paragraph 6 of the Doha Declaration on the TRIPS Agreement and Public Health, Decision of 30 August 2003, WT/L/540.

WTO, General Council, Implementation of paragraph 6 of the Doha Declaration on the TRIPS Agreement and public health, Decision of the General Council of 30 August 2003.

WTO, Guide to reading the GATS schedules of specific commitments and the list of article II (MFN) exemptions, available at http://www.wto.org/english/tratop e/serv_e/guide1_e.htm.

WTO, Guidelines and Procedures for the Negotiations on Trade in Services, S/L/93, 28 March 2001.

WTO, Guidelines and Procedures for the Negotiations on Trade in Services, S/L/93, adopted by the Special Session of the Council for Trade in Services on 28 March 2001.

WTO, Guidelines For Accession Of Least-Developed Countries, Document WT/L/508, 20 January 2003.

WTO, Guidelines for the Scheduling of Specific Commitments under The General Agreement on Trade in Services (GATS), adopted by the Council for Trade in Services on 23 March 2001.

WTO, Hong Kong Ministerial Declaration, Doha Work Programme, WT/MIN(05)/DEC, 22 December 2005, adopted on 18 December 2005.

WTO, Implementation of the Modalities for the Special treatment for LDC Members in Trade in Services Negotiations, JOB(05)/114, 17 June 2005.

WTO, Informal Note by the Chairman of the Working Party on Professional Services, Discussion of matters relating to Articles XVI and XVII of the GATS in connection with the disciplines on domestic regulation in the accountancy sector, (also included in document S/WPPS/4, dated 10 December 1998), Job No. 6496, dated 25 November 1998.

WTO, Informal Notes by the Secretariat for the Committee on Trade in Financial Services, The Distinction between Modes 1 and 2, (Also included in document S/FIN/W/14), 24 June 1997.

WTO, JOB/SERV/272/Rev.1, released on 7 November 2017 and the final updated version JOB/SERV/272/Rev. 2, 24 November 2017. See also as WT/MIN(17)/7/Rev.2, 13 December 2017.

WTO, Joint Ministerial Statement on Services Domestic Regulations, WT/MIN(17)/61, 13 December 2017.

WTO, Ministerial Conference, The Declaration on the TRIPS Agreement and Public Health. Adopted on Ministerial Conference, Fourth Session, Doha, 9-14 November 2001, WT/MIN(01)/DEC/,14 November 2001.

WTO, Ministerial Decision of 19 December 2015, WT/MIN(15)/45, WT/L/980.

WTO, Ministerial Decision on General Services, 07 DECEMBER 2013, WT/MIN(13)/37, WT/L/912.

WTO, Ministerial Decision, Duty-Free and Quota-Free (DFQF) Market Access for Least-Developed Countries, Ministerial Decision, 7 December 2013, WT/MIN(13)/44, WT/L/919.

WTO, Ministerial Decision, Monitoring Mechanism on Special and Differential Treatment, 7 December 2013, WT/MIN(13)/45, WT/L/920.

WTO, Ministerial Declaration of 20 September 1986 (Punta Del Este Declaration),GATT Doc No. MIN.DEC.

WTO, Modalities For The Special Treatment For Least-Developed Country Members In The Negotiations On Trade In Services, adopted by the special session of the Council for Trade in Services, $\mathrm{TN} / \mathrm{S} / 13$, 3 September 2003.

WTO, Modalities for the Treatment of Autonomous Liberalization, Adopted by the Special Session of the Council for Trade in Services on 6 March 2003, TN/S/6, 10 March 2003.

WTO, Negotiating Group on Basic Telecommunications documents: Informal Note by the Secretariat, Draft Model Schedule of Commitments on Basic Telecommunications, Attachment 7 to S/L/92 and Annex to Job No. 1311, 12 April 1995.

WTO, Note by the Secretariat, Application of the Necessity Test: Issues for Consideration, Job No. 5929, dated 8 October 1999.

WTO, Note by The Secretariat, Committee on Specific Commitments: Report of the Meeting held on 29 October 2013, S/CSC/M/68, 25 November 2013.

WTO, Note by the Secretariat, Council for Trade in Services, Council Review of MFN Exemptions, Report of the Meeting held ON 5 JULY 2000 S/C/M/45 18 August 2000.

WTO, Note by the Secretariat, Dispute Settlement Practice Relating to GATT Article XX, paragraphs (b), (d) and $(g)$, WT/CTE/W/203, 8 March 2002.

WTO, Note by the Secretariat, Interpretation of Procurement-Related Provisions in GATT - Possible Application to Article XIII of GATS, Background S/WPGR/W/29.

WTO, Note by the Secretariat, Working Party on Domestic Regulation, "Necessity Tests" In The WTO, S/WPDR/W/27, 2 December 2003. 
WTO, Note by the Secretariat, Working Party on GATS Rules, Overview of Government ProcurementRelated Provisions in Economic Integration Agreements, S/WPGR/W/44, 24 June 2003.

WTO, Note by the Secretariat, Working Party on GATS Rules, Report of the Meeting held on 29 October 2013, S/WPGR/M/82, 24 January 2014.

WTO, Note by the Secretariat, Working Party on GATS Rules: Report of the meeting of 23 June 2004, S/WPGR/M/48 2004, 20 July 2004.

WTO, Note from the Chairperson of Working Party on GATS Rules, Checklist on Subsidies, Negotiations on Subsidies (Article XV of the GATS), JOB(03)/57 17 March 2003.

WTO, Operationalization of the Waiver Concerning Preferential Treatment to Services and Service Suppliers of Least-Developed Countries, Ministerial Decision of 7 December 2013.,Docs., WT/MIN(13)/43, WT/L/918.

WTO, Preferential Rules of Origin for Least-Developed Countries, WT/MIN(13)/42, WT/L/917, 7 December 2013.

WTO, Preferential Treatment to Services and Service Suppliers of LDCs Decision, Doc. WT/L/847, 17 December 2011.

WTO, Report by the Chairman of The Council on Trade in Services (Ambassador Fernando De Mateo) to the Trade Negotiations Committee, TN/S/36, 21 April 2011.

WTO, Report by the Chairperson of the Working Party on GATS Rules, Negotiations On Government Procurement, S/WPGR/11, 30 June 2003.

WTO, Report by The Chairperson of The Working Party on GATS Rules, S/WPGR/21, 14 April 2011.

WTO, Request for an Authoritative Interpretation pursuant to Article IX:2 of the Marrakesh Agreement establishing the World Trade Organization: Communication by the European Communities, WT/GC/W/133, 25 January 1999.

WTO, Scheduling of Initial Commitments in Trade in Services: Explanatory Note, MTN.GNS/W/164, 3 Sep. 1993.

WTO, Secretariat, A HANDBOOK ON THE GATS AGREEMENT, WTO and Cambridge University Press, 2005.

WTO, Secretariat, Article II:1(b) of the General Agreement - Additional Note by the Secretariat, Negotiating Group on GATT Articles, MTN.GNG/NG7/W/53, 2 October 1989.

WTO, Secretariat, Definitions in the Draft GATS, Note by the Secretariat, MTN.GNS/W/139, 15 October 1991.

WTO, Secretariat, Definitions in the Draft General Agreement on Trade in Services, Note by the Secretariat, MTN.GNS/W/139, 15 October 1991.

WTO, Secretariat, Trade in Services Division, Background Note, Disciplines on Domestic Regulation Pursuant To GATS Article VI.4: Background and Current State of Play, June 2011.

WTO, Secretariat, Working Group on the Relationship between Trade and Investment, Note by the Secretariat, WT/WGTI/W/109, 27 March 2002.

WTO, Services Sectoral Classification List (document MTN.GNS/W/120 of July 1991, a GATT Secretariat document)

WTO, Sutherland, Peter et al, The Future of the WTO: Addressing the Institutional Challenge in the New Millennium, Report of the Consultative Board to the Director-General Supachai Panitchpakdi (The Sutherland Report), 2005.

WTO, Technical Note by the Secretariat, Accession to the World Trade Organization - Information to be Provided on Policy Measures Affecting Trade in Services, WT/ACC/5, 31 October 1996.

WTO, Text of the 'July package' - the General Council's post-Cancun decision, WT/L/579, 2 August 2004.

WTO, The Council for Trade in Services, Note by the Secretariat, Work Programme on Electronic Commerce, S/C/W/68, 16th November 1998.

WTO, The Draft Final Act Embodying the Results Of The Uruguay Round Of Multilateral Trade Negotiations, MTN.TNC/W/FA, 20 December 1991.

WTO, THE GATS - A GENERAL INTRODUCTION, 29 March 2006, Doc.3776.4

WTO, The General Council Decision on the Doha Agenda Work Programme (The "July package"), $\mathrm{WT} / \mathrm{L} / 579$. as agreed on 1 August 2004.

WTO, Trade in Services Division, Disciplines on Domestic Regulation in the Accountancy Sector, 17 December 1998.

WTO, Trade in Services Division, Disciplines on Domestic Regulation Pursuant to GATS Article VI.4 Background and Current State of Play, June 2011.

WTO, Trade in Services, Guidelines for the Scheduling of Specific Commitments under the GATS adopted by the Council for Trade in Services on 23 March 2001, Document 2001/S/L/92 (the Scheduling Guidelines).

WTO, UNDERSTANDING THE WTO, 5th Edition, July 2011. 
WTO, Uruguay Round, Explanatory Note by the Secretariat, Group of Negotiations on Services, Listing of Article II Exemptions, MTN.GNS/Job.2061, 15 September 1993.

WTO, Working Party on GATS Rules, Background Note by the Secretariat, Subsidies for Services Sectors: Information Contained in WTO Trade Policy Reviews, Concepts and Definitions S/WPGR/W/25, 26 January 1998.

WTO, Working Party on GATS Rules, Background Note by The Secretariat, Subsidies for Services Sectors: Information Contained in WTO Trade Policy Reviews, S/WPGR/W/25/Add.7, 17 April 2014.

WTO, Working Party on the Accession of China, Report of the Working Party on the Accession of China, WT/ACC/CHN/49, October 1, 2001.

WTO/WHO, The WTO Agreements and Public Health: A Joint Study by the WHO and WTO Secretariat, authored by Drager, N. and Miguel Rodríguez Mendoza et al., WTO Secretariat, 2002

United Nations CPC classification List (Statistical Papers, Series M, No.77, 1991) This was superseded by the Central Product Classification (CPC) Version 1.0, published in 1998. The updated Central Product Classification (CPC) Ver.2.1. Series M No. 77, Ver.2.1 - T/ESA/STAT/SER.M/77/Ver.2.1 is dated11 August 2015.

\section{Other Reports and Documents}

OECD and African Development Bank, African Economic Outlook 2010, Special theme: Public Resource Mobilization and Aid, 2010.

OECD Working Party of the Trade Committee (Author: Martin Roy) Trade In Services: A Roadmap To GATS MFN Exemptions, TD/TC/WP (2001)25/FINAL, 29 October 2001.

OECD, Competition Provisions in Regional Trade Agreements, OECD Trade Policy Working Paper No. 31. COM/DAF/TD(2005)3/FINAL, 2006.

OECD, INTERNATIONAL INVESTMENT LAW: UNDERSTANDING CONCEPTS AND TRACKING INNOVATIONS: A Companion Volume to International Investment Perspectives, OECD Publishing, 2008.

OECD, REDUCING THE RISK OF POLICY FAILURE: CHALLENGES FOR REGULATORY COMPLIANCE, OECD Publishing, Paris 2000.

OECD, Transparency in Government Procurement: The Benefits of Efficient Governance, TD/TC/WP/(2002)31/Rev2/14, April 2003.

South Center, Special and Differential Treatment Negotiations: State of Play and Proposed Language for WTO's MC8, Analytical Note SC/TDP/AN/MC8/2, November 2011.

South Centre, Analytical Note, Background Note: Article VI (Domestic Regulation) with Emphasis on Paragraph 4 and the EU and Japanese Proposals, SC/TADP/AN/SV/4, December 2003.

South Centre Analytical Note, Background Note: Article VI (Domestic Regulation) with Emphasis on Paragraph 4 and the EU and Japanese Proposals, SC/TADP/AN/SV/4, December 2003.

UN CESCR, General Comment No. 14: The right to the highest attainable standard of health, U.N. Doc. E/C.12/2000/4, 2000.

UN Economic and Social Council,, Globalization and its Impact on the Full Enjoyment of Human Rights Preliminary report submitted by J. Oloka-Onyango and Deepika Udagama, in accordance with Sub-Commission resolution 1999/8, E/CN.4/Sub.2/2000/13, 15 June 2000.

UN Economic and Social Council, Globalization and its Impact on the Full Enjoyment of Human RightsFinal report submitted by J. Oloka-Onyango and Deepika Udagama, E/CN.4/Sub.2/2001/10.

UN Economic and Social Council, Commission on Human Rights, Report of the Special Rapporteur Paul Hunt, The right of everyone to the enjoyment of the highest attainable standard of physical and mental health, Addendum, Mission to the World Trade Organization, E/CN.4/2004/49/Add.1, 1 March 2004.

UN Economic and Social Council, Mainstreaming the right to development into international trade law and policy at the World Trade Organization, (Paper prepared by Robert Howse), E/CN.4/Sub.2/2004/17, 9 June 2004.

UN Economic and Social Council, Report of the High Commissioner of Human Rights, Liberalization of Trade and Human Rights, E/CN.4/Sub.2/2002/9, June 252002.

UN Economic and Social Council, Report of the High Commissioner, Analytical study of the High Commissioner for Human Rights on the fundamental principle of non-discrimination in the context of globalization E/CN.4/2004/40, 15 January 2004.

UN Economic and Social Council, The Committee on Economic, Social and Cultural Rights, General Comment No. 8 (1997), The Relationship between Economic Sanctions and Respect for Economic, Social and Cultural Rights, E/C.12/1997/8. 
UN Economic and Social Council, The relationship between the enjoyment of human rights, in particular economic, social and cultural rights, and income distribution, Final Report of José Bengoa, Special Rapporteur to the Sub -Commission on Prevention of Discrimination and Protection of Minorities, E/CN.4/Sub.2/1997/9, 30 June 1997.

UN GA, WSSD, Johannesburg Declaration on Sustainable Development, A/CONF.199/20.

UN GA, WSSD, The Future We Want, A/RES/66/288.

UN General Assembly, Declaration on the Right to Development, adopted by Resolution 41/128 of 4 December 1986.

UN General Assembly, Vienna Declaration and Programme of Action, 12 July 1993, A/CONF.157/2, endorsed by General Assembly Resolution 48/121, 20 December 1993.

UN High Commissioner for Human Rights, The impact of the Agreement on Trade-Related Aspects of Intellectual Property Rights on human rights, E/CN.4/Sub.2/2001/13, 27 June 2001.

UN Human Rights Committee, General Comment No. 18 (Non-Discrimination), U.N. Doc. HRI/GEN/1/Rev.1, 1994.

UN Human Rights Council, The Right to Development, Resolution A/HRC/RES/19/34, 11 April 2012.

UN Office of the High Commissioner of Human rights, General Comment 3: The Nature of States parties Obligations (Art. 2, para.1 of the Covenant on Economic Social and Cultural Rights, E/1991/23, $14 / 12 / 90$.

UN Office of the High Commissioner of Human Rights, Human Rights and World Trade Agreements: Using General Exception Clauses to Protect Human Rights, HR/PUB/05/5, 2005 (prepared by James Harrison, assisted by Steve Charnovitz, Robert Howse and Gabrielle Marceau), http://www.ohchr.org/Documents/Publications/WTOen.pdf.

UN Office of the High Representative for the Least-Developed Countries, Landlocked Developing Countries and Small Island Developing States, online at http://www.unohrlls.org/ UNCTAD, THE LEAST DEVELOPED COUNTRIES REPORT, 2009.

UN Siracusa Principles on the Limitation and Derogation of Provisions in the ICCPR, 1984.

UN, Commission on Human Rights, Report of the High Commissioner of Human Rights, Liberalization of Trade and Human Rights: Report of the High Commissioner of Human Rights, E/CN.4/Sub.2/2002/9, June 252002.

UN, Committee on Economic, Social and Cultural Rights, General Comment No. 15 on the Right to Water, 2002, UN.Doc. E/C.12/2002/11.

UN, Copenhagen Declaration for Social Development, A/CONF.166/9, 19 April 1995.

UN, Economic and Social Council and Commission on Human Rights, Report of the Special Rapporteur on the right of everyone to the enjoyment of the highest attainable standard of physical and mental health, Paul Hunt, E/CN.4/2006/48, 3 March 2006.

UN, Economic and Social Council, Siracusa Principles on the Limitation and Derogation Provisions in the International Covenant on Civil and Political Rights, U.N. Doc. E/CN.4/1985/4, Annex (1985).

UN, Human Rights Committee, General Comment No. 17: Article 24 (Rights of the child), Adopted at the Thirty-fifth session of the Human Rights Committee, on 7 April 1989.

UN, Human Rights Council, Implementation of General Assembly Resolution 60/251 Of 15 March 2006 , Report of the Special Rapporteur on the right of everyone to the enjoyment of the highest attainable standard of physical and mental health, Paul Hunt, A/HRC/4/28, 17 January 2007.

UN, Human Rights Council, Report of the Special Rapporteur on the right of everyone to the enjoyment of the highest attainable standard of physical and mental health, Anand Grover, 12 April 2011 $\mathrm{A} / \mathrm{HRC} / 17 / 25$.

UN, Human Rights Council, Report of the United Nations High Commissioner for Human Rights on the role of the public service as an essential component of good governance in the promotion and protection of human rights, A/HRC/25/27, 23 December 2013.

UN, Human Rights Council, Report of the Working Group on the Universal Periodic Review: Equatorial Guinea, Sixth session, 11 December 2009, UN Doc. A/HRC/WG.6/6/L.15 or A/HRC/13/16.

UN, Limburg Principles on the Implementation of the ICESCR, Doc. E/CN.4/1984/4, 28 September 1984.

$\mathrm{UN}$, Norms on the Responsibilities of Transnational Corporations and other Business Enterprises with regard to Human Rights, U.N. Doc. E/CN.4/Sub.2/2003/12/Rev.2 2003 (Approved August 13, 2003, by U.N. Sub-Commission on the Promotion and Protection of Human Rights Resolution 2003/16, U.N. Doc. E/CN.4/Sub.2/2003/L.11).

UN, Office of the High Commissioner on Human Rights, ECONOMIC, SOCIAL AND CULTURAL RIGHTS: HANDBOOK FOR NATIONAL HUMAN RIGHTS INSTITUTIONS, Professional Training Series No. 12, Un, 2005.

UN, Office of the High Commissioner on Human Rights, Human Rights and World Trade Agreements: Using General Exception Clauses to Protect Human Rights, HR/PUB/O5/5, 2005. 
UN, Office of the High Commissioner on Human Rights, Liberalization of Trade and Human Rights: Report of the High Commissioner of Human Rights, E/CN.4/Sub.2/2002/9, June 252002.

$\mathrm{UN}$, Statement made by agencies of the United Nations system and other international organizations in support of policy coherence in the implementation of the right to development, 14 September 2011.

UNCHR Special Rapporteur on the Prevention of Discrimination, Marc Bossuyt, The Concept of Affirmative Action, Final Report, UN.Doc.E/CN.4/Sub2/2002/21.

UNCTAD, Beyond Conventional Wisdom in Development Policy: An Intellectual History of UNCTAD (1964-2004), UNCTAD/EDM/2004/4.

UNCTAD, Competition Provisions in Regional Trade Agreements: How to Assure Development Gains 2005.

UNCTAD, Most-Favoured-Nation Treatment, UNCTAD Series on Issues in International Investment Agreements II, UNCTAD/DIAE/IA/2010/1.

UNCTAD, Positive Agenda and Future Trade Negotiations, 2000.

UNCTAD, World Trade Law and Renewable Energy: The Case of Non-Tariff Barriers, (authored by Robert Howse), UNCTAD/DITC/TED/2008/5, United Nations, 2009.

UNDP, HDR 2009: OVERCOMING BARRIERS: HUMAN MOBILITY AND DEVELOPMENT.

UNDP, HDR 2010: THE REAL WEALTH OF NATIONS: PATHWAYS TO HUMAN DEVELOPMENT.

UNDP, HDR 2013: THE RISE OF THE SOUTH - HUMAN PROGRESS IN A DIVERSE WORLD.

UNDP, HDR 2016: HUMAN DEVELOPMENT FOR EVERYONE.

UNDP, HDR2019: BEYOND INCOME, BEYOND AVERAGES, BEYOND TODAY: INEQUALITIES IN HUMAN DEVELOPMENT IN THE 21ST CENTURY.

UNDP, MAKING GLOBAL TRADE WORK FOR PEOPLE, UNDP and Earthscan, 2003.

UNGA Resolution 2625 of 1970 (Declaration on Principles of International Law Concerning Friendly Relations and Co-operation Among States in accordance with the Charter of the United Nations).

UNGA Resolution, Transforming our world: the 2030 Agenda for Sustainable Development, A/RES/70/1, 21 October 2015.

UNGA, Millennium Declaration, A/RES/55.2 adopted by the UN General Assembly on 8 September 2000.

United Nations Conference on Environment and Development, Rio Declaration on Environment and Development 1992, Annex 1, U.N. Doc. A/CONF.151/ 26/Rev.1, June 14, 1992.

United Nations Economic Commission for Europe, GUIDEBOOK ON PROMOTING GOOD GOVERNANCE IN PUBLIC-PRIVATE PARTNERSHIPS, UNITED NATIONS, UNECE, 2008.

United Nations General Assembly (UNGA), Preparatory Committee for Special Session of the GA on Implementing Copenhagen+5 (2000), Note by the Secretary General, Symposium on States, Markets and Social Services: Roles and Co-operation of the Public and Private Sectors, UN Doc A/AC.253/14 and E/CN.5/2000/5.

United Nations General Assembly (UNGA), The Vienna Declaration and Program of Action adopted by the World Conference on Human Rights on 25th June 1993, A/CONF.157/23.

United Nations General Assembly (UNGA), Universal Health Coverage: Moving together to build healthier world, A/RES/70/1, 21 October 2015. (Adopted September 23, 2019, at the High-Level Meeting on Universal Health Coverage - Resolution adopted by the General Assembly on 25 September 2015).

United Nations Research Institute for Social Development (UNRISD), Chapter 6: Universal Provision of Social Services in COMBATING POVERTY AND INEQUALITY: STRUCTURAL CHANGE, SOCIAL POLICY AND POLITICS, UNRISD, 2010.

United Nations Research Institute for Social Development (UNRISD) Project on Commercialization of Health Care: Global and Local Dynamics and Policy Responses (2001-2004).

WHO, Commission on the Social Determinants of Health, CHALLENGING INEQUITY THROUGH HEALTH SYSTEMS, Final Report Knowledge Network on Health Systems, June 2007.

WHO, Global Code of Practice on the International Recruitment of Health Personnel Resolution, WHA63.16., May 2010.

WHO, International Trade and Health, Report by the WHO Secretariat, EB 116/4, 28th April 2005.

WHO, MACROECONOMICS AND HEALTH: INVESTING IN HEALTH FOR ECONOMIC DEVELOPMENT, Report of the Commission on Macroeconomics and Health Chaired by Jeffrey D. Sachs, 2001.

WHO, Report by the Secretariat, Health system strengthening: Current trends and challenges, Sixty-Fourth World Health Assembly, A64/13, 7 April 2011.

WHO, Social Determinants of Health, Closing the gap in a generation: health equity through action on the social determinants of health. World Health Organization, 2008. 
Selected bibliography

WHO, The Tallinn Charter: Health Systems for Health and Wealth, WHO European Ministerial Conference on Health Systems: Health Systems, Health and Wealth (Tallinn, 25-27 June 2008).

World Bank, GLOBAL ECONOMIC PROSPECTS AND THE DEVELOPING COUNTRIES, World Bank Publications, 2002,

World Bank, THE WORLD DEVELOPMENT REPORT 2004: MAKING SERVICES WORK FOR POOR PEOPLE, World Bank and Oxford University Press, 2003.

World Bank, The World Development Report 2006, EQUITY AND DEVELOPMENT, World Bank and Oxford University Press, 2005. 


\section{SUMMARY}

The WTO GATS introduced a multilateral framework for international trade in services, and is part of the liberalization ethos that has influenced global economic, social and trade policy relating to services for the past quarter of a century. The purpose of this study is to make an objective appraisal into the apparent policy space and flexibilities in the GATS, from the perspective of both those more concerned with increasing the ease with which international trade in services is carried out and those concerned about the protection of core societal values.

The GATS exists in the context of human beings, individually and collectively as societies, envisioning the role and form of services and shaping the outcomes of their provision. The efforts which have been devoted to building and maintaining public health services which are 'universal', 'single payer' and free at the point of delivery, as social policy and as a vital part of the right to health, an important example of how such visions for a better society have been realized. Country snapshots are used in this study to emphasize the differing roots and growth of public health systems and the practical importance to those societies in terms of eradicating disease, providing basic health and a better standard of life. There are also references made to several important cases in domestic jurisdictions which compelled governments to improve their national health policy. This study of the GATS is with special reference to national policy space for the provision of public health services, considering whether such services could be unduly constrained by the trade liberalization obligations. It is difficult to assess and measure the overall constraint that the WTO approach to liberalization of services has had on public health services policy, yet it is important to discuss the GATS in light of public health services and vice versa.

The central question of this thesis is 'how much policy space for the protection of nontrade core societal values is available for a WTO Member under the GATS'? This assessment is done in the light of the State obligation in international law, and also in certain circumstances, according to national law and policy, to fulfill, protect and promote the right to health. The assumption is that there is governmental responsibility, which also aligns with standards of international human rights law, to retain and use as much policy space as possible in order to carry out policies supporting citizens' rights and benefits, with special reference to the chosen area of public health services. The 'red line' running through this study is the position that national decision-makers must be free to make the decisions that it is their duty to make, such as defending public health services. This study has implications beyond the GATS to the consideration of a socio-economic policy framework for supporting public health services in general.

In order to ascertain the extent of policy space in the GATS, one must grapple with the possibilities and limitations of treaty interpretation in situations where there are competing and conflicting interests. Thus, the methodology used is primarily treaty interpretation using the Vienna Convention on the Law of Treaties of 1969 (VCLT) and supplemented by the rulings of panels and the Appellate Body in WTO dispute settlement. The Chapters of this study assess the debates surrounding the rights and obligations of WTO Members through a combination of both the classic VCLT approach which is a codification of customary international law on treaty interpretation and the inclusion of human rights approaches, noting however, that the extent of the weight that can be given to other international rules, principles or norms within the interpretive 
exercise, is limited. There is also a limitation in that there are very few GATS decisions in comparison with GATT jurisprudence; and no dispute reports that shed light on some of the most contentious terms, phrases and issues. It is hoped that this inquiry nevertheless leads to a better understanding of the content of the obligations of the specific provisions of the GATS chosen for analysis.

Throughout this study, there are inclusions on the relevance of the right to health as provided for in Article 12 of the International Covenant on Economic, Social and Cultural Rights (ICESCR), which is the key international human rights law provision on the right to health, the implementation of which also emphasizes the importance of public health services. The two regimes of trade and human rights have been identified at times as two distinct legal languages, therefore this study considers the application of the concept of 'bilingualism' and thus, of 'language translation', in addition to legal interpretation, with the hope that this bring a fresh perspective to the debates and controversies in the area of services, particularly with regard to the issue of the protection of public health services.

In order to answer the research question, an analysis was carried out of specific provisions of the GATS which are most often referred to as the ones allowing for policy space. The exemptions, the general and specific obligations, as well as the exceptions and special provisions are assessed from the angle of the available flexibilities for national policy space. The provisions which discussed in depth in this study include Article 1:3 of the GATS, which is sometimes referred to as a 'public services exemption' but which uses the phrase "services supplied in the exercise of governmental authority"; and Article XIV of the GATS, which is the general exceptions provision and includes "public morals" and "life or health" as policy objectives on which an exception can be argued. The discussion is not limited to these provisions but also included an analysis of provisions on non-discrimination, the scheduling of commitments and domestic regulation and their implication for national policy space. The study also critically discusses the extent of 'extra' policy space that may be available to developing countries and least developed countries in their implementation of the GATS while also developing their public health services using a right to health-based approach. There are also several as in the GATS that are still negotiating mandates where the processes of formulating further disciplines for trade in services but which have not generated the expected results. The negotiating mandates for subsidies under Article XV, government procurement under Article XIII and domestic regulation under Article VI:4 of the GATS, which may have far reaching implications for policy autonomy and the protection of public services, are referred to in this study.

This study comprises six chapters, with the Introduction to the study as Chapter 1 and the overall Conclusions as Chapter 7. The analysis is contained in Chapters 2 to 6.

Chapter 2 introduces the background to the research question, underlying concepts and the methodology, setting the scene for the legal analysis of the provisions of the GATS that is dealt with in the chapters that follow. The basic underlying concepts of the rule of law, liberalization, democratic participation in policy and law-making and human development, are discussed on the premise that these should be recognized as part of the larger picture behind the focused area of trade in services in the foreground. The second part of Chapter 2 deals with the opportunities and limitations of the standard approach to interpretation in the WTO context, based on the General Rule and supplementary rules of the Vienna Convention of the Law of Treaties, which is analyzed together with the 
suggestions for a 'human rights approach' to the interpretation of WTO law. It is recognized that there is a lack of reference to human rights in WTO law or dispute settlement reports and the entryways for such attempts (using the VCLT) are not only difficult but may not be practically used by Members or accepted by the panels or Appellate Body. Bringing human rights into the equation has its own set of challenges. A broad theoretical approach based on language translation theory is suggested as a possible method of bridging the gap between the dichotomies of the trade and human rights regimes, which may not be able to be reconciled through the more conservative interpretative methods. It is also argued that before a successful interpretation of human rights into GATS provisions could be attempted, 'bilingualism', meaning competency in both trade and human rights languages, is necessary for the interpretive exercise to be attempted with some measure of success. The third part of Chapter 2 presents the international human rights framework for the right to health, specifically Article 12 of the International Covenant on Economic, Social and Cultural Rights (1977) and its interpretation through the General Comment No. 14 (2000). This discussion of the understanding of the right to health and its relationship with State responsibilities, including the delivery of public health services, flows into the chapters that follow.

Chapter 3 deals with the scope of the GATS, with particular focus on what is often referred to as the 'public services exemption' in Article I of the GATS. A Member has the possibility of using the exemption from the scope of the GATS in Article I:3(b) and (c) for exempting "services supplied in the exercise of governmental authority" - which suggests public services. However, the definition is also tied to the interpretation that the dispute settlement bodies may give to the concepts of "commercial" and "in competition with". Thus, even if a 'ring-fence' for public services exists in Article I of the GATS, there are contrary views on the breadth or the scope of application and it is not a sufficient protection in terms of being a clear exemption. The broader background of the debates on the protection of public services, particularly discussing the fears that have been expressed concerning privatization, corporatization and commercialization of public health services, also discussed in this Chapter. Since State subsidies of primary importance in the context of protecting public services, a part of this chapter focuses on the state of affairs with regard to rules on subsidies for services. The scope of 'measures' that come under the GATS, the unclear definition for 'trade in services', the GATS approach to monopolies and government procurement are also discussed in this Chapter.

Chapter 4 is structured in three main parts. The first part of Chapter 4 analyzed the differences in non-discrimination as a value in trade and human rights. Nondiscrimination among trading partners in WTO law is concerned with efficiency and prosperity of the world trading system as a whole; but in human rights law, nondiscrimination is concerned with whether individual human beings are protected from negative discrimination, and receive special treatment or positive action if that is necessary in order to redress social injustice. The dissimilarities between these two concepts on non-discrimination are usually underplayed in the trade law context, and thus attention is drawn to this before moving on to the second part of the Chapter; the process of the scheduling of commitments. This is one of the as where negotiating power of Members can play a part, but at the same time determined Members can retain their policy space by not making commitments or by including limitations which specifically protect their public health services by avoiding national treatment and market access obligations for public funded health services. Chapter 4 also looked at Article II:2 and the Annex on Article II Exemptions, as well as other MFN Exemptions (Article II:3) and 
Exceptions (Articles V, VII), concluding that while they may provide more space for Members than initially assumed, that they once again of limited usefulness unless Members have had and continue to have the legal expertise to expand their trade opportunities and policy space. The the obligations regarding transparency and confidentiality in Article III and IIIbis and the Most Favoured Nation Treatment Principle of Article II are also briefly discussed The third part of the Chapter is on the area that is said to be more flexible and which is also referred to as the special feature of GATS; the Scheduling of Commitments by Members for either/both national treatment (Article XVII) and market access (Article XVI) obligations. A brief discussion of Article VI of the GATS, on domestic regulation, is also part of the third part of Chapter 4. The impact of GATS on domestic regulation is often referred to as the a where GATS could be most intrusive with regard to the domestic policy space.

Even in the situation where specific commitments have been undertaken by Members, there is recourse to a final safety net in the form of the general exceptions under Article XIV of the GATS (and probably useful to a lesser extent, Article XIVbis Security Exceptions). The exceptions are analyzed in Chapter 5. Of the available exceptions, the public morals exception in Article XIV(a) of the GATS and the human life and health exception in Article XIV(b) of the GATS are the most obvious points of entry for societal values, human rights and the right to health. Article XIV(c) also has potential to be used parallel to the other paragraphs. Yet most disputes are ultimately decided by the analysis of the nexus and the chapeau, and the interests in the exceptions are given deference but treated superficially in terms of analysis. This discussion in this Chapter takes into account the limitations of the VCLT, the realities of international relations and the challenges of incorporating other international rules, norms and principles such as human rights, particularly the right to health.

Chapter 6 looks at whether there is actually more leeway for developing country Members and least developed country (LDC) Members in the GATS framework, analyzing the relevant provisions as well as the definitions for developing country and least developed country within the WTO context, including the issue of self-definition. This is connected to the special interest such countries may have for developing their existing public health services capacity and implementing their 'progressive realization' steps relating to the right to health. The chapter noted that the WTO system does not have a gradation-type classification for developing countries that accurately traces the levels of development achieved and that the even the LDC definition which is used has flaws. The 'extra space' for developing countries and LDCs requires inter-State cooperation for implementation. It is argued that there should be improved policy space for public services protection for all Members and additional special assistance for the Members that most need it, and this would probably need more work and reform of some of the ways the WTO works with its Members and how their Members cooperate with each other in implementing the goals of the Preamble to the GATS and Article IV of the GATS.

The outcome of this research is that there are entryways for societal values and national policy space to implement them in the GATS, but that it is something to argue and struggle for and the support for it is not sufficiently strong. In terms of what Members could undertake, there could be a combination of methods: using MFN exemptions, refraining making commitments in sensitive sectors or scheduling very clear limitations and using the exceptions if commitments have been made - could retain the national policy space for measures taken in light of human development and right to health 
objectives. Clarifications on the scope and definitions of the above-mentioned balancing mechanisms and safety nets can be done with the participation of the Members of the WTO. Authoritative interpretations and amendments to the GATS are theoretically possible, as would be a WTO Ministerial Declaration recognizing the role of public health services for the right to health and right to development (which would be preferable to terms such as "for health outcomes" or "public health" and "development"), which could be the basis for future Amendments to the GATS exempting public health services and protecting domestic policy objectives for universal service obligations in health. Members have been cautious in taking further services liberalization steps, in terms of GATS commitments or negotiations, however, there are alternatives available in the forms of services-related agreements as bilateral, plurilateral or preferential trade agreements, and attention should shift to the analysis of these agreements

All systems need to evolve and adapt in order to survive in changing circumstances; these include practical advances in technology, socio-political changes, conceptual advances in other regimes of international law, particularly human rights law; and more recently, the need for national policy protective of domestic public services capacity in pandemic situations. In the practical scenario, any hopes that progressive change could also occur in the WTO system has faced an additional blow with the crisis of the blocking of reappointments and new appointments of Appellate Body. This means that the interpretation of the rules may have to depend in the future on diplomatic negotiations, consultations and perhaps mutually agreed solutions assisted by panel findings or based on arbitration or other regional or plurilateral mechanisms, in order to resolve trade disputes in the absence of an Appellate Body. It is to be hoped that the Members can come to an agreement on reforms and practical measures to respond to this situation, but this would be dependent on what developments or regressions in international relations and the international rule of law would occur during 2020.

This study has been in a way a tribute to the continuing relevance and value of the role of public health services, as much as it has been an analysis of the provisions of the GATS which may allow for this value to be protected. The conclusions of this research will be of relevance for those interested in WTO law and the GATS as well as those interested in the role of public health services in achieving higher levels of implementation of the right to health. This discussion of the policy space within the GATS, is also placed in the broader context of protection of socio-economic values and rights in the current framework of international economic law, and hopes to contribute to that wider debate. 


\section{VALORISATION ADDENDUM}

The legal and policy analysis relating to the availability of national policy space in the WTO GATS, encapsulated within this thesis at this point of time (January 2020), can be considered a useful contribution to the discussion of the mechanisms of the liberalization of services in international trade law, with special reference to the role of public health services, from the perspective of societal values and human rights-based approaches.

The discussion supports policy space for States to protect and further develop public health services as an important feature of the interaction of rights and responsibilities of citizen and State, and of members of a modern society to each other. The ongoing Covid19 pandemic situation further drives home the value of national public health services as a fundamental need and human right. This is applicable to developed countries as well as developing countries and least developed countries (LDCs). The Covid-19 crisis has revealed even more clearly that while the negative economic effects of the protective public health measures taken by governments are borne by all countries, the costs in human lives have varied and can at times be correlated in terms of the attitudes towards ethical social responsibility, the implementation of State social welfare and the provision of public health services and the strength of public services in general, within countries.

In the course of assessing the policy space in the GATS, certain provisions which have not yet been authoritatively interpreted and which are of concern with regard to the protection of public health services, were discussed in depth in this thesis, with reference to WTO dispute settlement jurisprudence. This includes Article 1:3 of the GATS, which includes the concept of exemption of "services supplied in the exercise of governmental authority" (understood usually as a "public services exemption') and Article XIV of the GATS, the general exceptions provision of the GATS which includes "public morals" and "life or health" recognized as legitimate policy objectives. The thesis also analyzes provisions on non-discrimination, the scheduling of commitments and domestic regulation and their implications for national policy space and critically discusses whether developing countries and LDCs have any extra leeway under the GATS in light of their special needs.

The target groups of this thesis are primarily legal academics, scholars and students from different legal specializations, but also those in social science specializations, as well as public policy experts and policy makers, political scientists, health economists, medical professionals with an interest in international trade law, and government officials involved with foreign affairs, trade or commerce departments or health ministries.

One of the main underlying motivations for embarking on this research was to attempt to build bridges between those trained primarily in international human rights law and those trained primarily in international economic law, international trade law or WTO law. This book is born from my own need to find in one place, an objective analysis of the interconnections between these two fields, that would assess the details of WTO case law as well as include the broader concepts of human rights and public policy.

There are already many academics who have made significant contributions on specific areas and issues discussed in this research, as demonstrated by the publications cited in this thesis. What this thesis aimed to do in addition, was to bring together the different viewpoints and debates and place them in the context of a detailed analysis of the provisions of the GATS which deal with national policy space and their interpretation, while constantly touching base with the larger picture of socio-economic policy choices, the right to health and practical national approaches. Although it has been suggested by 
previous scholarship that it is possible to harmonize WTO law and human rights concerns, this thesis cautions against overconfidence or oversimplification, and the analysis highlights drawbacks in trying to insert concepts from another regime without sufficient 'bilingualism' in both the fields of human rights law and WTO law. In this aspect, while drawing together existing scholarship and jurisprudence, the thesis includes innovative elements in its framing and discussion of the issues.

Currently being a member of the academic staff of the Department of Public and International Law, Faculty of Law, University of Colombo, Sri Lanka, I am in a position to continue to prepare activities and disseminate my findings to the academic community in Sri Lanka and abroad. I would hope to publish a commercial edition of the book, and continue with seminar and conference presentations and academic articles, based on and inspired by this research. I would also consider greater engagement with blogs and social media networks concerning my research in the future, as a way to publicize my findings and analysis and engage with colleagues interested in this area of research, both regionally and internationally.

During the course of my research for this thesis, I prepared presentations and short papers on my area of study for the University of Colombo and Sri Lanka Law College, as well as conferences and academic sessions at the University of Kelaniya, the Sir General John Kotelawala Defence University (KDU) and the Open University of Sri Lanka. One of these presentations was later published as a paper for the Indian Journal of International Economic Law (Vol.9, 2018). A co-authored chapter on the interconnection between women's right to health and international trade was published by Intersentia in 2012 and is being updated for its second edition in 2020.

The research into the interconnections between economic and social rights and the institutions of economic globalization and international trade has also been very relevant for postgraduate courses, lectures and academic advising I have been involved in, such as the regional Master of Human Rights and Democratization (Asia Pacific) Programme; the LL.M Programme, Faculty of Law, University of Colombo; the Masters in Human Rights, Faculty of Graduate Studies, University of Colombo. In the future, I would hope to engage more closely with colleagues for further lectures and developing course material for new programmes, workshops and lecture series.

As Executive Editor of the Sri Lanka Journal of International Law, I have been on the Editorial Board from 2015-2020, using my training to peer review submissions on areas in my expertise for the journal, and to encourage young researchers in Sri Lanka and India with their queries and research activities in these areas. I hope that with the finalization of my thesis I can continue this trend, and encourage more colleagues and students to engage with and debate the issues raised in this research, as well as with multidisciplinary approaches regarding globalization and trade law topics in general.

I also hope that a much shorter and more layman-friendly version of certain parts of this thesis can be prepared and translated into Sinhala and be published in Sri Lanka, perhaps in monograph form, since there is generally a keen interest in and appreciation of the protection of the public health services system and the implications of globalization and international trade on the part of the Sinhala-speaking university student population and the general public. 


\begin{abstract}
ABOUT THE AUTHOR
Nishara Mendis was born on $25^{\text {th }}$ November 1978 in Colombo, Sri Lanka. She obtained an LL.B (Hons, First Class) from the University of Colombo in 2003 and an LL.M from Yale Law School in 2005. She joined the Faculty of Law, University of Colombo as a permanent academic staff member in 2006, which was also the year she took oaths as an Attorney-at-Law of the Supreme Court of Sri Lanka. From 2008 to 2012 she was a researcher at the Institute for Globalization and International Regulation and a member of the Department of International and European Law, Faculty of Law, Mastricht University, The Netherlands. She is currently a lecturer in the Department of Public and International Law, Faculty of Law, University of Colombo, where she teaches and is a research advisor for international law topics for undergraduates (Public International Law, International Humanitarian Law and Law of the Sea) and is also engaged with human rights, development and globalization-related topics at the diploma and postgraduate level. Ms. Mendis has also been on the Editorial Board of the Sri Lanka Journal of International Law, as Executive Editor since 2015.
\end{abstract}


